\title{
Grundvand
}

\section{Overvågning og Problemer}

\author{
ERIK NYGAARD (RED.)
}
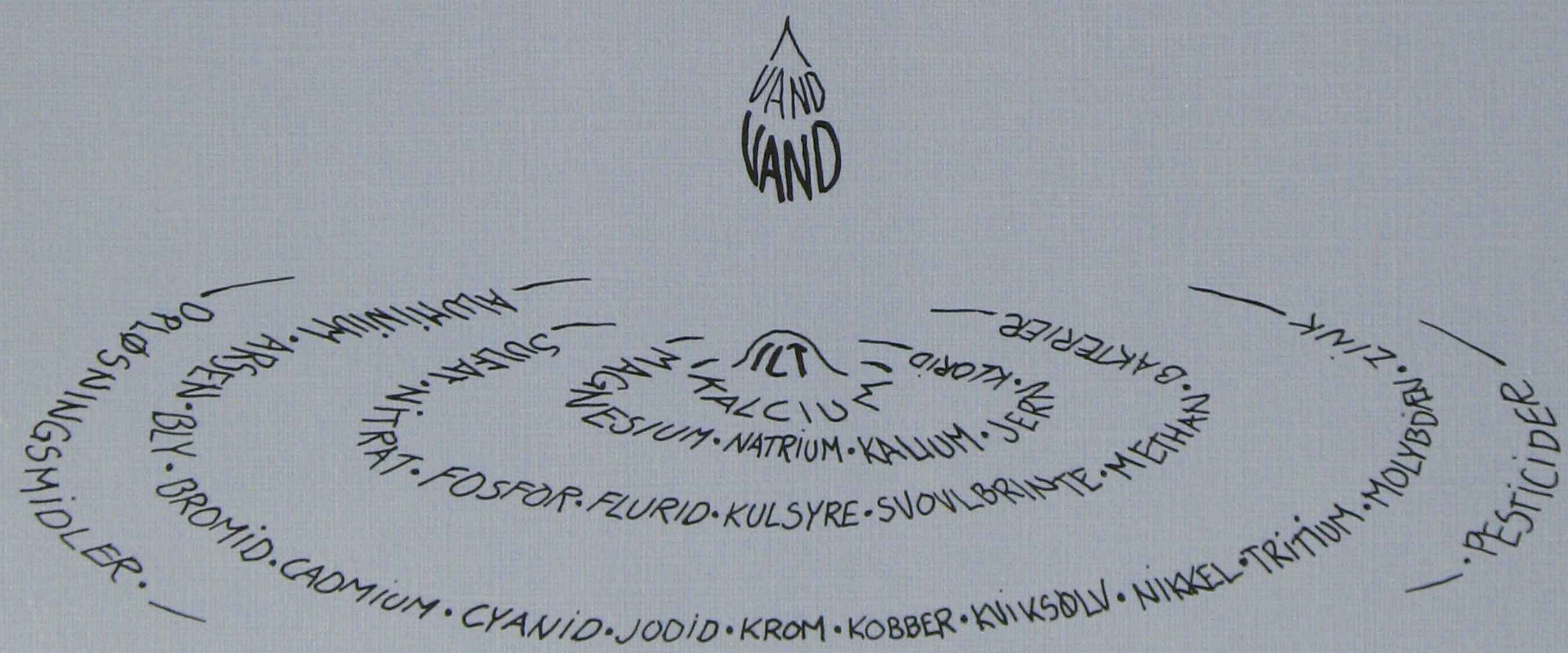


\section{Grundvand}

Overvågning og Problemer

ERIK NYGAARD (RED.) 
DGU Serie D nr. 8

ISBN 87-88640-75-2

ISSN 0900-6257

Oplag: 500

Tryk: DGU

Tegning og repro: Grafisk sektion, DGU

Dato: 29-11-1991

Pris: 378 kr. excl. moms

(c) Danmarks Geologiske Undersøgelse, Thoravej 8, DK-2400 København NV.

I kommission hos:

Geografforlaget ApS

Ekspedition: Faverhøjvej 43, 5464 Brenderup

Telefon: 64441683 , Fax: 64441697 


\section{INDHOLDSFORTEGNELSE}

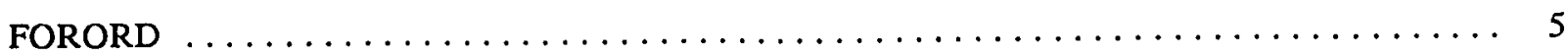

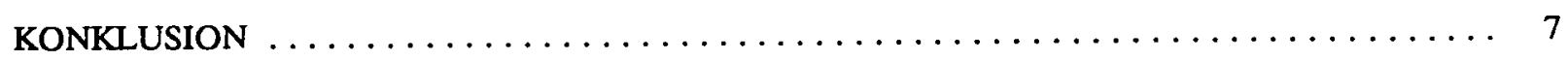

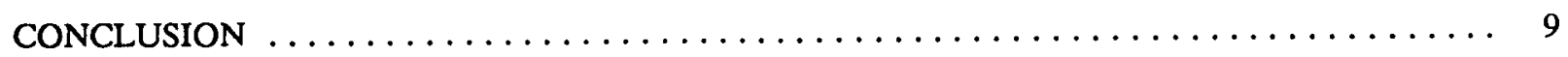

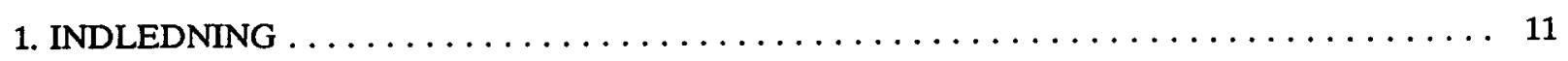

2. GRUNDVANDSOVERVÅGNINGSOMRÅDER (GRUMO) $\ldots \ldots \ldots \ldots \ldots \ldots \ldots \ldots \ldots$

DE ENKELTE OVERVÅGNINGSOMRÅDER $\ldots \ldots \ldots \ldots \ldots \ldots \ldots \ldots \ldots \ldots \ldots \ldots \ldots$

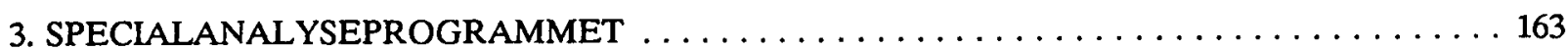

AMTERNES VURDERING AF SPECIALANALYSERNE . . . . . . . . . . . . 169

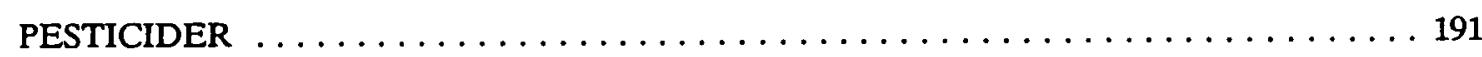

HYDROKEMISK KLASSIFIKATION AF GRUNDVAND $\ldots \ldots \ldots \ldots \ldots \ldots \ldots \ldots$

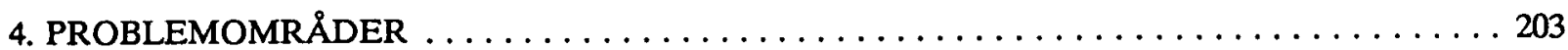

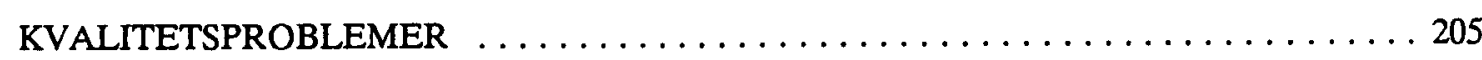

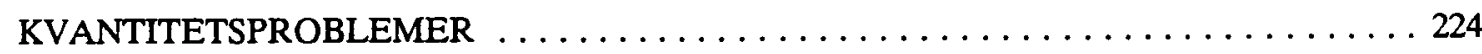

TILTAG FOR AT BEVARE GRUNDVANDSRESSOURCEN $\ldots \ldots \ldots \ldots \ldots \ldots 226$

5. GRUNDVAND I LANDOVERVÅGNINGSOPLANDENE $\ldots \ldots \ldots \ldots \ldots \ldots \ldots \ldots .227$

6. SAMMENFATNING OG DISKUSSION $\ldots \ldots \ldots \ldots \ldots \ldots \ldots \ldots \ldots \ldots \ldots \ldots \ldots \ldots \ldots \ldots \ldots$

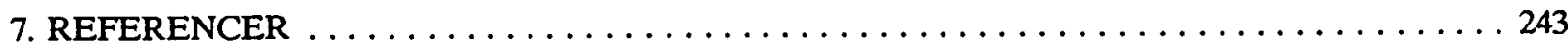

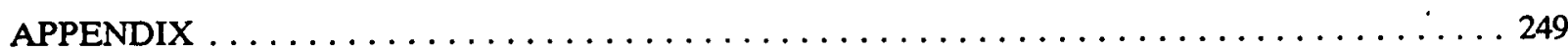




\section{FIGURLISTE}

Figur 1: Placeringen af de 67 grundvandsovervågningsområder. $\ldots \ldots \ldots \ldots \ldots \ldots \ldots \ldots$

Figur 2: Hovedreservoir bjergartstyper i overvågningsområderne. $\ldots \ldots \ldots \ldots \ldots \ldots \ldots \ldots 15$

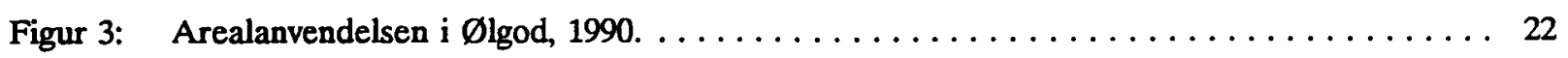

Figur 4: $\quad$ Oxiderede stoffer på Nordsamsø. $\ldots \ldots \ldots \ldots \ldots \ldots \ldots \ldots \ldots \ldots \ldots \ldots \ldots \ldots \ldots \ldots$

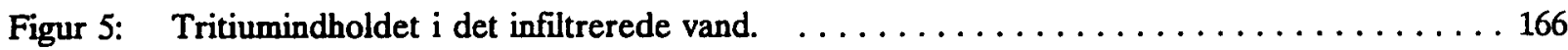

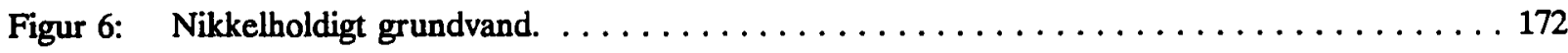

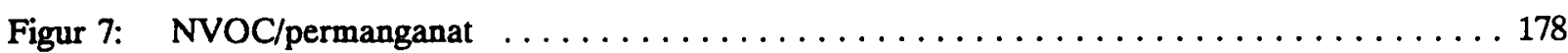

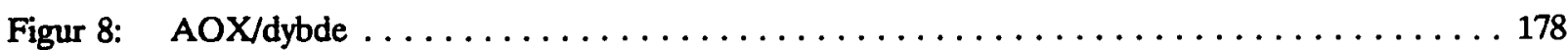

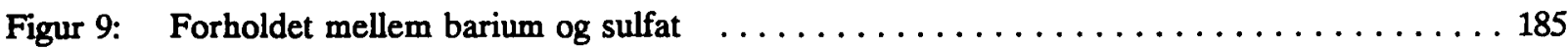

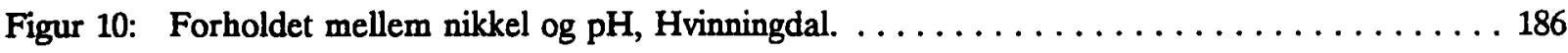

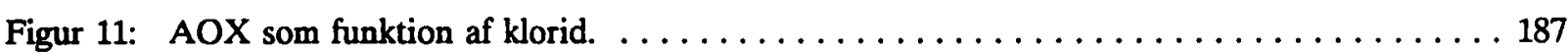

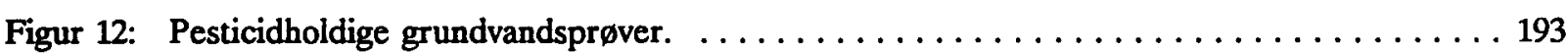

Figur 13: Piper diagrammer for overvågningsområderne Tornby og Råkilde. $\ldots \ldots \ldots \ldots \ldots \ldots 2$

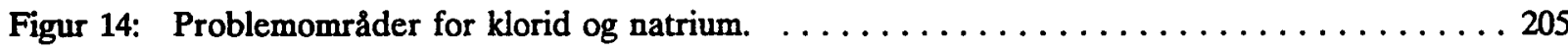

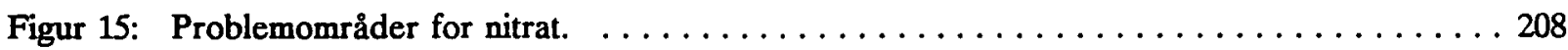

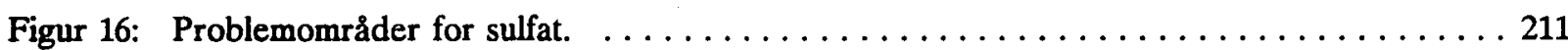

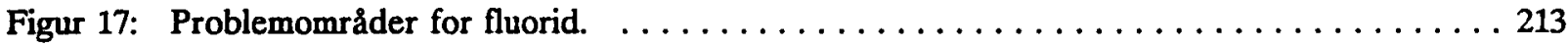

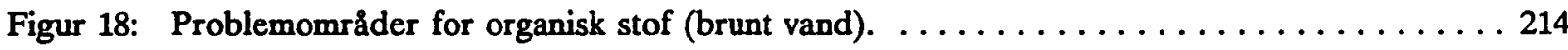

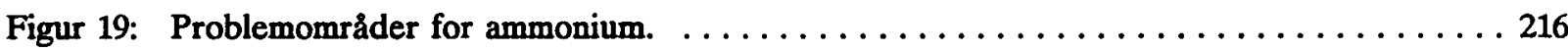

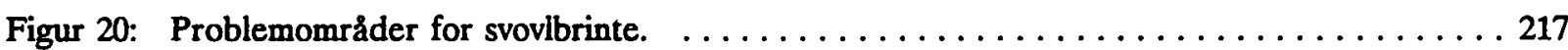

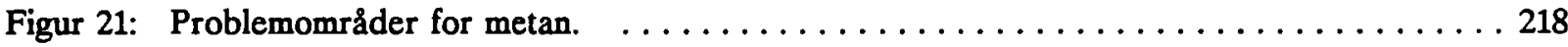

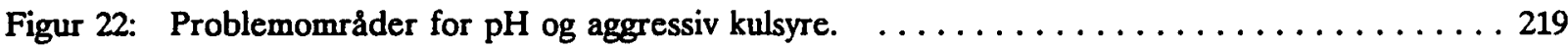

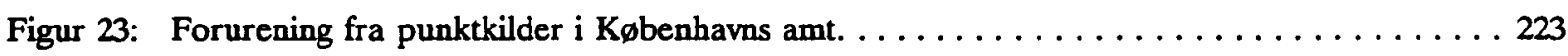

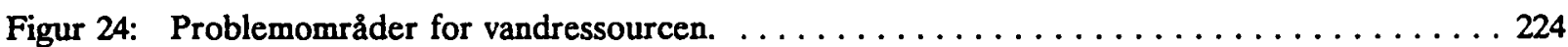

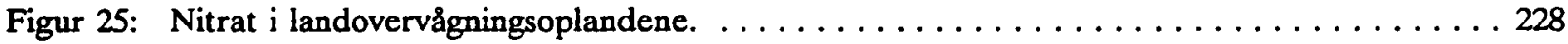

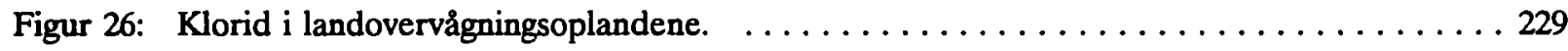

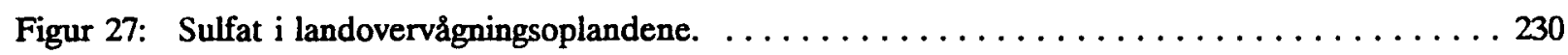

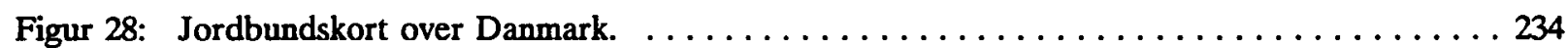

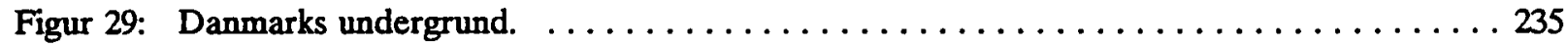

Figur 30: Nitrat i det øverste grundvand. $\ldots \ldots \ldots \ldots \ldots \ldots \ldots \ldots \ldots \ldots \ldots \ldots \ldots \ldots \ldots$ 


\section{FORORD}

Denne rapport om grundvandet er $\mathrm{i}$ hovedsagen baseret på data og rapporter fra amterne og Københavns/ Fredriksberg kommuner. Rapporten er forfattet af en arbejdsgruppe bestående af: Ingrid Salinas, Per Rasmussen, Per Nyegaard, Erik Nygaard, Finn Lykke Nielsen, Poul Merkelsen, Arne Lundsgaard, Henning Kristiansen, Allan Grambo, Tibor Czakó, og Walter Brüsch, alle DGU.

Den meget omfattende sekretærbistand blev ydet af Helle Dybdal Pedersen, Bente Larsson, Conni Steffensen og Maibritt Larving Hvidkjær. Rentegningen er udført af Eva Melskens, Gitte Nicolaisen, Helle Zetterwall og Kirsten Andersen.

Her ud over har andre medarbejdere ved DGU hjulpet med løsning af konkrete problemer for rapporteringen, således at de mange og meget varierende oplysninger har kunnet sammenføjes til en helhed.

En foreløbig version af afsnittene 2, 3, 4 og 7 er blevet kommenteret af amterne, Københavns og Frederiksberg kommuner, og Miljøstyrelsen. Kommentarerne er i stort omfang indarbejdet i rapporten. 


\section{KONKLUSION}

Grundvand er en værdifuld naturlig ressource, der både har stor økologisk og økonomisk betydning, og som er afgørende for opretholdelsen af liv og sundhed. Udnyttelsen af grundvand bør derfor ske på et bæredygtigt grundlag, der sikrer grundvandet mod uoprettelig skade som følge af overudnyttelse og forurening.

Derfor overvåges udviklingen i grundvandet nøje, blandt andet i 67 lokale overvågningsområder, der er fordelt over hele landet og repræsenterer et bredt udsnit af grundvandsforholdene i Danmark. Også vandværkerne gennemfører en jævnlig overvågning af grundvandets kvalitet.

De oplysninger om grundvandet som præsenteres i denne rapport viser, at grundvandet $i$ mange henseender er påvirket af menneskelig aktivitet. En del af denne påvirkning gælder problemerne med blandt andet nitrat, sulfat og klorid, men også en del mere specielle stoffer er påvist i grundvandet.

Nitratbelastningen af det øverste grundvand i overvågningsområderne gør sig gældende i næsten hele landet, men er størst i Midt-, Nord- og Vestjylland. Også det dybereliggende grundvand er nitratpåvirket i en femtedel af områderne.

Generelt er grundvandets nitratindhold et problem for vandforsyningen i et bredt område, der strækker sig fra Djursland over Himmerland til Thy, samt i mange lokale områder i de fleste andre landsdele.

Der er et let forhøjet kloridindhold i det øverste grundvand i næsten alle overvågningsområder. Derimod er et større kloridindhold $\mathrm{i}$ områdernes dybtliggende grundvand i særlig grad et Midt- og Østsjællandsk fænomen. Grundvandets kloridindhold udgør dog et problem for vandforsyningen i talrige lokale områder over det meste af landet.

Sulfatindholdet er forholdsvis højt i det øverste grundvand i overvågningsområderne og aftager med dybden, men der er også enkelte områder, hvor indholdet er stort i det dybtliggende grundvand.

Sulfatindholdet i grundvandet er især et problem for vandforsyningen i dele af Østjylland og Øerne.

Der er fundet mere specielle forurenende stoffer så som pesticider og klorerede kulbrinter, i vandprøver fra steder og i dybder, hvor de ikke var forventet. Udbredelsen af disse stoffer er endnu ufuldstændig kendt og må fortolkes i sammenhæng med de oplysninger, der indsamles i de kommende år.

Overvågningsområderne ligger fortrinsvis i landbrugsområder. Den udbredte nitratbelastning og stedvise forekomst af blandt andet pesticider må derfor hovedsagelig stamme fra landbrugsdrift. Den forurening, der i dag konstateres er imidlertid foregået for år tilbage, fordi grundvand dannes og udskiftes over en længere årrakke. 
Også den tidligere uhensigtsmæssige håndtering af affald og placering af industrigrunde spores i grundvandet. Dette kommer blandt andre til udtryk i en del af de overvågningsområder, der ligger i nærheden af byer. Her kan grundvandet indeholde en lang række miljøfremmede organiske og uorganiske stoffer.

Det er imidlertid oftest et stort indhold af almindelige stoffer så som sulfat og klorid, der begrænser udnyttelsen af grundvandet. Et forhøjet indhold af disse stoffer kan skyldes overudnyttelse af grundvandet og den iltning af svovlkis og organisk materiale, som den kan medføre, eller indtrængning af salt vand fra havet eller dybt salt grundvand.

Grundvandsovervågningens resultater viser, at der fortsat er behov for en indsats til beskyttelse af grundvandet. Det er nødvendigt i fremtiden at reducere forureningsbelastningen fra landbruget og følge udviklingen $\mathrm{i}$ det allerede forurenede grundvand. Det omfattende analyseprogram for specielle stoffer må derfor videreføres.

Selvom dele af grundvandet mange steder er påvirket af overudnyttelse og forurening er der i størstedelen af landet stadig godt og rigeligt grundvand til rådighed. Grundvandsovervågningen skal netop medvirke til, at forsyningen med det livsvigtige drikkevand også i fremtiden kan sikres. 


\section{CONCLUSION}

Groundwater is a valuable natural resource of great ecologic and economic importance, and it is crucial for life and health. Groundwater must therefore be used on a sustainable basis, ensuring it against irreversible damage by over-utilization and pollution.

For these reasons the groundwater is quality inspected, both at wellsites and in 67 local monitoring areas, which are distributed all over Denmark, representing most of the groundwater conditions in the country. Also the waterworks monitor the groundwater regularly.

The latest information on the groundwater, presented in this report, shows that the groundwater in many respects is influenced by human activity. Part of this influence leads to problematic concentrations of nitrate, sulphate and chloride, but also other more rare pollutants are found.

The uppermost groundwater in the monitoring areas is contaminated with nitrate all over the country, but it is most prominent in Mid, North and West Jylland. Also the groundwater at depth is contaminated with nitrate in 13 of the 67 monitoring areas.

Generally the nitrate content of the groundwater is a problem for the freshwater supply within a broad NWSE trending geographic band across northern Jylland as well as in many local areas.

In most of the monitoring areas the uppermost groundwater is slightly enriched in chloride. Contrary to this high chloride content in the deeper seated groundwater is a problem in mid and east Sjælland. The chloride content of the groundwater further poses problems to the freshwater supply in many local areas all over the country.

The sulphate content is generally high relatively in the uppermost groundwater in the monitoring areas and decreases with depth, but there are a few areas, in which the sulphate content is high in the deeper groundwater as well. The sulphate content of the groundwater poses a problem to the fresh water supply in part of eastern Jylland and the isles.

More rarely considered pollutants, such as pesticides and chlorinated hydrocarbons, are found in a number of surprising sites and depths. The distribution of these pollutants is not yet fully understood and has to be interpreted in the context of the information to be gathered during the coming years.

Most of the groundwater monitoring areas are located in agricultural areas. The wide-spread contamination with nitrate and local presence of among others pesticides is therefore likely dominantly to stem from farming. But the pollution discovered today has occurred years ago, since groundwater is recharged and exchanged over a number of years. 
10

Also the former inappropriate handling of waste may be traced in the groundwater. This is especially registered in some monitoring areas located in the vicinity of urban areas. Here the groundwater may contain a large number of alien organic and inorganic constituents.

On the other hand it is most frequently a large content of common constituents such as sulphate and chloride, which limits the use of groundwater. High concentrations of these constituents may be caused by overexploitation leading to oxidation of pyrite or intrusion of saline water.

The monitoring has shown that a continued effort to protect the groundwater is necessary. The release of contaminants in connection with farming must be reduced and the quality of the polluted groundwater must be followed. Therefore the comprehensive program for measuring rare inorganic and organic pollutants must be continued.

Despite part of the groundwater is influenced by overexploitation and pollution at many sites, there is still plenty of good groundwater available in most of the country. The monitoring of the groundwater is intended to contribute to the effort of ensuring that the vital supply of drinking water can continue in the future. 


\section{INDLEDNING}

Grundvands overvågningsprogrammet, der blev iværksat i forbindelse med Vandmiljøplanen i 1987, afrapporteres hermed for anden gang. Som det fremgår, for eksempel af Appendix, er de datamængder, der allerede er til rådighed meget omfattende. Det har derfor været nødvendigt at udvikle et fælles dataudvekslingssystem, STANDAT (Miljøstyrelsen 1990a), som i år for første gang har været taget i brug. Effektiviteten af dataoverførslen i dette nye system afhænger naturligvis af, at der ikke også overføres data i andre formater og, at alle benytter STANDAT på samme måde. Dette års indberetning er i disse henseender kun delvis lykkedes, idet fire amter ikke har været i stand til at benytte STANDAT og, der har været vanskeligheder for flere andre. Overførslen af data er således på nær to undtagelser overført senere end planlagt. Hertil har der også været indkøringsvanskeligheder med modtageprogramellet i Fagdatacentret på Danmarks Geologiske Undersøgelse (DGU). For at rette op på dette med henblik på de fremtidige indberetninger skal de udestående spørgsmål afklares, således at Aftaleudvalget, der består af de involverede myndigheder, kan udsende nye og fyldestgørende retningslinier.

Da datamængden fortsat vil stige er det her valgt, inden for rammerne af det paradigma, der er aftalt med amterne, at beskrive grundvandsovervågningsområderne og udpege de områder hvor der er kendte problemer for udnyttelsen. De årlige rapporter fra Fagdatacentret på DGU vil herefter kunne gøres tematiske, således at muligheder $\mathrm{i}$ og resultater fra udvalgte baser, områder og analyser vil kunne blive behandlet for sig selv, uden at deres sammenhæeng med helheden tabes af syne. 


\section{GRUNDVANDSOVERVÅGNINGSOMRÅDER (GRUMO)}

De 67 grundvands-overvågningsområder, der er etableret i forbindelse med Vandmiljøplanen for at beskrive tilstanden- og de eventuelle ændringer i grundvandets sammensætning, er fordelt nogenlunde jæunt ud over landet, figur 1. De tænkes at repræsentere grundvandet i almindelighed. Områderne, der er på 0,5-50 kvadratkilometer udgør typisk oplandet til et vandværk eller en vandværksboring i et landbrugsområde. Det vil sige, at områderne er begrænset af naturlige og oppumpningsforårsagede vandskel. Inden for et overvågningsområde vil det infiltrerede vand altså i princippet strømme hen mod, og på et eller andet tidspunkt nå frem til vandværksboringen boringen. Eventuelle kvalitetsændringer i grundvandet, for eksempel grundet forurening fra jordoverfladen, kan således følges inden for området.

19 af de 67 overvågningsområder blev etableret af Danmarks Geologiske Undersøgelse med henblik på at udtage meget dybdespecifikke vandprøver fra repræsentative hovedreservoirer og de ovenliggende sekundære reservoirer i Danmark. Dette etableringskoncept for de overfladenære filtre sigtede på at tage prøver af grundvandet på en måde, der hindrede "kortslutning" til hovedreservoiret.

Udvidelsen af grundvandsovervågningen med de 48 områder, som amterne, og Københavns- og Frederiksberg kommuner, har etableret, er sket i forbindelse med en både udvidelse af overvågningen og analyseprogrammet. Denne udvidelse har skærpet kravene til vandprøvernes størrelse og renhed, og i de amtsligt etablerede områder hentes prøverne derfor overvejende fra intervaller med god og vedvarende ydelse fra gruskastede filtre. En betydelig del af de forhold, der endnu volder problemer for analyseprogrammet, skyldes disse ændringer i kravene til vandprøverne, idet det nuværende omfattende analyseprogram er ens for alle områder.

Som det fremgår af det følgende har mange af de tekniske vanskeligheder i overvågningsområderne kunnet overvindes, således at overvågningen i næsten alle områder nu foregår rutinemæssigt.

Overvågningen af grundvandet $\mathrm{i}$ overvågningsområderne omfatter 641 boringer med ialt 1029 filtre, tabel 2 a-i. En trediedel af prøvetagningen foregår i vandværksboringer og private vandforsyningsboringer, etableret før overvågningsprogrammet. Langt de fleste boringer er dog udført specielt med prøvetagning for øje. I disse boringer foregår der således ingen vandindvinding.

Etableringen af prøvetagningssteder blev stort set afsluttet i midten af juni 1990. Københavns, Roskilde og Viborg amter har dog udbygget deres områder med supplerende boringer indtil juni 1991.

Det er tilstrabt at etablere ca. 15 prøvetagningsfiltre i hvert overvågningsområde, disse er fordelt geografisk inden for området (vandværkets eller kildepladsens opland) og er sat $\mathrm{i}$ forskellige dybder, således at de dækker den varierende reservoirforhold. For overvågningsområderne som helhed aftager filterantallet jæunt med dybden ned til $180 \mathrm{~m}$ under terræn. 


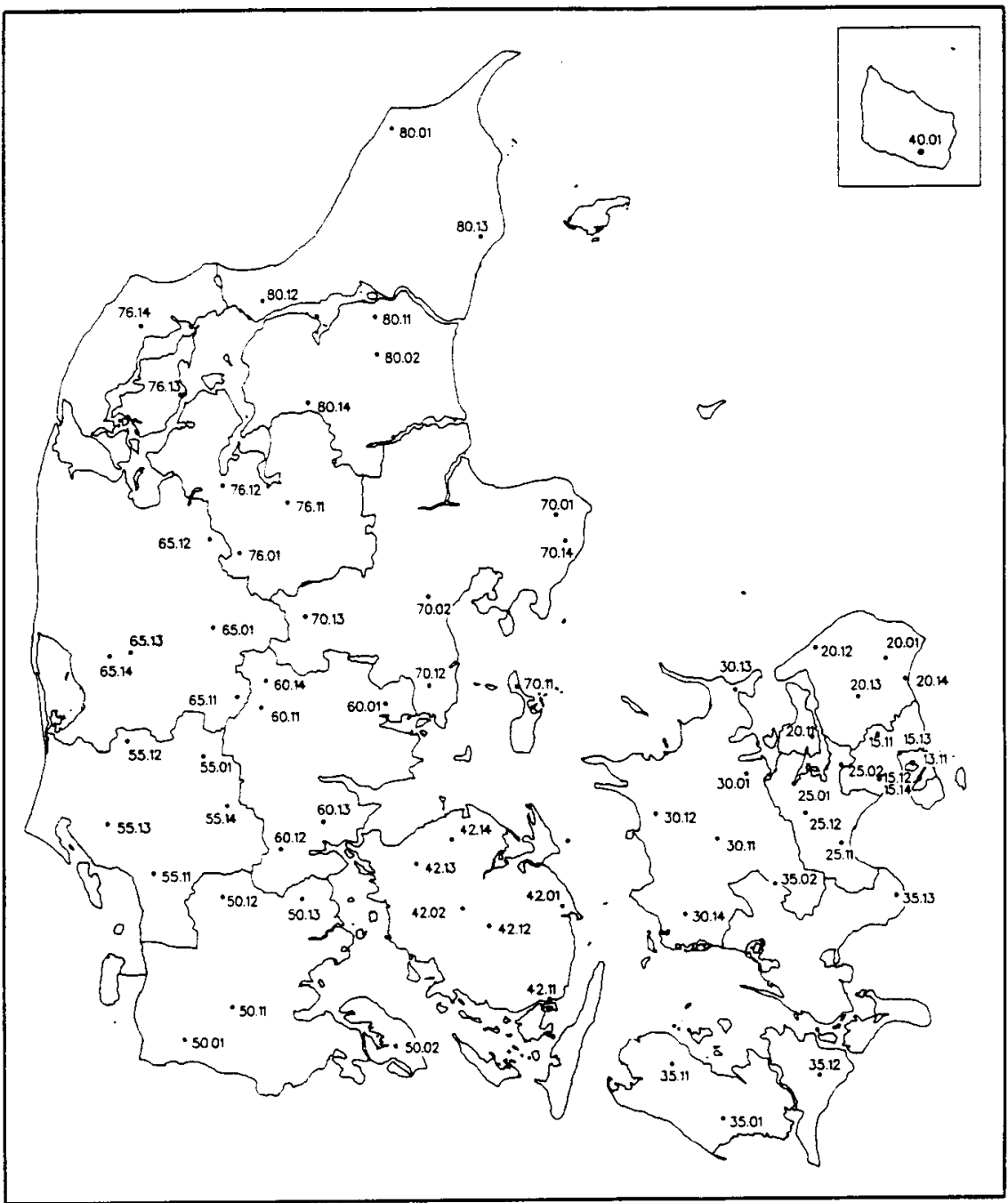

\begin{tabular}{|c|c|c|c|c|c|}
\hline 13.11 & $\begin{array}{l}\text { RDBENHAVN OG } \\
\text { FREDERIRSBERG KOMMUNER } \\
\text { Prederiksberg }\end{array}$ & $\begin{array}{l}35.01 \\
35.02 \\
35.11 \\
35.22 \\
35.13\end{array}$ & $\begin{array}{l}\text { STORSTROM } \\
\text { Holeby } \\
\text { Hjelmsolille } \\
\text { Vesterborg } \\
\text { Sibirien } \\
\text { St. Heddinge }\end{array}$ & $\begin{array}{l}60.01 \\
60.11 \\
60.12 \\
60.13 \\
60.14\end{array}$ & $\begin{array}{l}\text { VELE } \\
\text { Egebjerg } \\
\text { Thyregod } \\
\text { Trudsbro } \\
\text { Follerup } \\
\text { Ejstrupholm }\end{array}$ \\
\hline $\begin{array}{l}15.11 \\
15.12 \\
15.13\end{array}$ & $\begin{array}{l}\text { KOBENHAVN } \\
\text { Sonderse } \\
\text { Ishøj } \\
\text { Gladsaxe }\end{array}$ & 40.01 & $\begin{array}{l}\text { BORNHOLM } \\
\text { Smålyng }\end{array}$ & $\begin{array}{l}65.01 \\
65.11 \\
65.12 \\
65.13 \\
65.14\end{array}$ & $\begin{array}{l}\text { RNGKGBWG } \\
\text { Herning } \\
\text { Brande } \\
\text { Haderup } \\
\text { Herborg } \\
\text { Finderup } \\
\end{array}$ \\
\hline $\begin{array}{l}20.01 \\
20.11 \\
20.12 \\
20.13 \\
20.14\end{array}$ & $\begin{array}{l}\text { FREDERTKSBORG } \\
\text { Endrup } \\
\text { Skuldelev } \\
\text { Asserbo } \\
\text { Anemose } \\
\text { Espergzerde }\end{array}$ & $\begin{array}{l}42.01 \\
42.02 \\
42.11 \\
42.12 \\
42.13 \\
42.14\end{array}$ & $\begin{array}{l}\text { FYN } \\
\text { Nyborg } \\
\text { Borreby } \\
\text { Svendborg } \\
\text { Nr. Saby } \\
\text { Harndrup } \\
\text { Jullerup }\end{array}$ & $\begin{array}{l}70.01 \\
70.02 \\
70.11 \\
70.12 \\
70.13 \\
70.14\end{array}$ & $\begin{array}{l}\text { ARHUS } \\
\text { Kastbjerg } \\
\text { Kasted } \\
\text { Nordsamso } \\
\text { Fillerup } \\
\text { Hvinningdal } \\
\text { Hom! } \\
\end{array}$ \\
\hline $\begin{array}{l}25.01 \\
25.02 \\
25.11 \\
25.12\end{array}$ & $\begin{array}{l}\text { ROStril.DB } \\
\text { Tostilstrup } \\
\text { Brokilde } \\
\text { Asemose } \\
\text { Osted }\end{array}$ & $\begin{array}{l}50.01 \\
50.02 \\
50.11 \\
50.12 \\
50.13\end{array}$ & $\begin{array}{l}\text { SONDERYLLAND } \\
\text { Abild } \\
\text { Mjang Dam } \\
\text { Bedsted } \\
\text { Rodding nord } \\
\text { Christiansfeld }\end{array}$ & $\begin{array}{l}76.01 \\
76.11 \\
76.12 \\
76.13 \\
76.14 \\
\end{array}$ & $\begin{array}{l}\text { VIBORG } \\
\text { Rabis Bek } \\
\text { Viborg N. } \\
\text { Skive } \\
\text { Nytebing M. } \\
\text { Thisted - Baun }\end{array}$ \\
\hline $\begin{array}{l}30.01 \\
30.11 \\
30.12 \\
30.13 \\
30.14\end{array}$ & $\begin{array}{l}\text { VESTSISELLAND } \\
\text { Holbxk } \\
\text { Munke Bjergby } \\
\text { Store Fugjede } \\
\text { Nykobing S. } \\
\text { Eggeslevmagle }\end{array}$ & $\begin{array}{l}55.01 \\
55.11 \\
55.12 \\
55.13 \\
55.14\end{array}$ & $\begin{array}{l}\text { RIRE } \\
\text { Grindsted } \\
\text { Bramming } \\
\text { פlgod } \\
\text { Forumilund } \\
\text { Vorbasse }\end{array}$ & $\begin{array}{l}80.01 \\
80.02 \\
80.11 \\
80.12 \\
80.13 \\
80.14\end{array}$ & $\begin{array}{l}\text { NORDYYLAND } \\
\text { Tomby } \\
\text { R\&kilde-Stevring } \\
\text { Drastrup } \\
\text { Skerping } \\
\text { Albek } \\
\text { Gislum }\end{array}$ \\
\hline
\end{tabular}

Figur 1: Placeringen af de 67 grundvandsovervågningsområder. 


\section{Prøveindsamling}

Overvågningsområderne repræsenterer flertallet af de reservoirmæssige typer i Danmark, og har, som det fremgår af figur 2, hovedvagt på de sandede reservoirer.

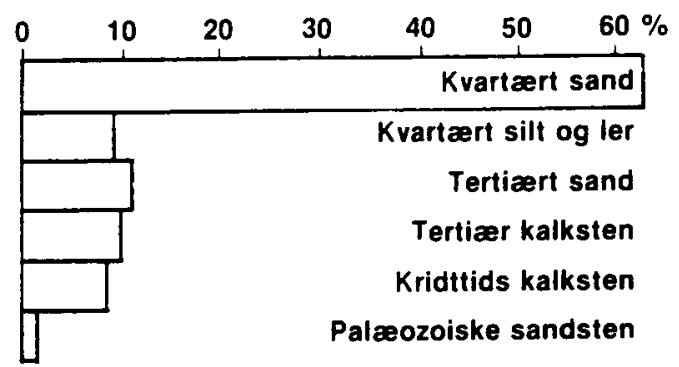

Figur 2: Den procentvise fordeling af hovedreservoir bjergartstyper $i$ gnundvandsovervågningsområderne.

Ca. to trediedel af filtrene, heriblandt dem i allerede eksisterende boringer, er placeret $\mathrm{i}$ hovedreservoirer, mens nye undersøgelsesboringer med flere filtre også overvåger de sekundære reservoirer. Reservoirforholdene i de enkelte overvågningsområder er givet i oversigtsform på side 28-161.

Afhængigt af hvor præcist en vandprøves oprindelse kendes, og hvor stabile analyserne er, godkendes filtrene til prøvetagning med henblik på analyser inden for bestemte "analysepakker": Hovedbestanddele, Bakteriologiske undersøgelser, Uorganiske sporstoffer, Organisk mikroforurening og Pesticider, (Miljøstyreisen, 1990b), og tabel 3. Prøver fra alle benyttede filtre skal undersøges for Hovedbestanddelene, foreløbig 4 gange årligt. De øvrige analysepakker gennemføres én gang i løbet af treårsperioden 89-91 for de godkendte filtre. Status for alle disse analyser fremgår af tabel 2.

Prøvetagningen af niveaubestemte prøver eller blandingsvand fra et filterinterval foregår enten med en permanent monteret montejuspumpe (trykluftpumpe), der er velegnet til niveaukorrekt prøvetagning, eller med dykpumpe. Dykpumper anvendes enten fastmonteret $\mathrm{i}$ vandforsyningsboringer eller til prøvetagning $\mathrm{i}$ undersøgelsesboringer med kort filterinterval, hvor et mobilt udstyr i nogle tilfælde benyttes.

Også sugepumper og jetpumper anvendes i begrænset omfang, og enkelte boringer har seivløb.

Mens vandforsyningsboringer med længere filtre som regel har tilstrækkelig ydelse til analyseformålene, giver undersøgelsesboringer med kort filterinterval ikke altid vand nok. Dette problem er typisk for de øverste filtre, som er placeret $i$ de sekundære reservoirer. Prøvetagning og analyse af vand fra disse øvre filtre er vasentlig da en eventuel forurening, der følger med det nedsivende vand, først vil nå disse niveauer. Skismaet mellem prøvernes kvalitet og analysernes væsentlighed inspirerer $\mathrm{i}$ en del tilfælde til fleksibilitet med hensyn til de ideale krav til prøvetagningen. Montejuspumpeudstyret har været plaget af sikkerhedsproblemer og utætheder. Herudover har en del af boringerne med montejustoppe en så beskeden diameter, at ydelsen altid vil være ringe. Funktionsproblemerne med montejustoppene er nu løst, mens utætheder i rørsystemerne 


\begin{tabular}{|c|c|}
\hline Amt/kommune & Problem \\
\hline $\begin{array}{l}\text { Københavns og } \\
\text { Frederiksberg kom. }\end{array}$ & Utætte montejustoppe. De fleste prøver er grumsede eller kalkholdige. \\
\hline Københavns amt & Utætte montejustoppe. \\
\hline Frederiksborg & Slammede prøver. \\
\hline Roskilde & Slammede prøver. \\
\hline Vestsjælland & Utætte montejustoppe og enkelte uklare vandprøver. \\
\hline Storstrøms & $\begin{array}{l}\text { Utætte montejuspumper. Suspenderet formationsmateriale i prøverne. } \\
\text { Både slam og vandmængdeproblemer er forsvundet i områder hvor } \\
\text { rørene er blevet svejset sammen. Disse problemer findes nu kun i } \\
\text { Holeby, hvor mange filtre sidder i moræneler. }\end{array}$ \\
\hline Bornholm & $\begin{array}{l}\text { Analyser viser at vandudskiftningen i en boring, der ikke kan renpum- } \\
\text { pes, er for ringe. }\end{array}$ \\
\hline Fyn & $\begin{array}{l}\text { Langsom retablering af vandspejl og uklare prøver i de sekundære } \\
\text { reservoirer, samt for små vandmængder. }\end{array}$ \\
\hline Sønderjylland & Uklare vandprøver og lav ydelse i Abild området. \\
\hline Ribe & $\begin{array}{l}\text { Renpumpning med dykpumpe i Vorbasse området tager lang tid. } \\
\text { Overfladenære filtre i Grindsted området er næsten altid tørre og et } \\
\text { stort antal filtre yder urent vand. }\end{array}$ \\
\hline Vejle & Dårlig ydelse og uklare prøver. \\
\hline Ringkøbing & Tvivlsom funktionsdygtighed af 8 filtre i Herning området. \\
\hline Århus & $\begin{array}{l}\text { Urene prøver med stort kalk-, sand- og okker-indhold, især i et af } \\
\text { områderne. }\end{array}$ \\
\hline Viborg & Enkelte boringer yder dårligt vand grundet bentonit og olie. \\
\hline Nordjylland & $\begin{array}{l}\text { Utætte montejustoppe. Uklare vandprøver i Tornby- og Råkilde om- } \\
\text { råderne. }\end{array}$ \\
\hline
\end{tabular}

Tabel 1: $\quad$ Amtemes/kommunemes bemaerkninger om overvågningsområdemes tekniske funktion. 
fortsat reducerer ydelserne og øger kvalstofforbruget i nogle boringer. Vandet fra mange ikke gruskastede filtre, som der især er mange af $i$ de statsligt etablerede områder, indeholder ofte slam eller suspenderet materiale fra reservoiret (for eksempel kalk eller silt) eller fra boringens udbygning (bentonit). Vandprøver fra sådanne filtre kan være langsommelige at filtrere og kun egne sig til analyse af hovedbestanddele. En samlet oversigt over hvilke analyser der kan foretages på vandprøver, afhængig af boringens udbygning og pumpetype, er givet i bilag 2.3, (Miljøstyrelsen, 1990b).

\section{Overvågningstyper.}

Overvågningsboringerne er klassificeret hydrogeologisk efter deres placering $\mathrm{i}$ oplandet, filterdybden og hvad vandprøven repræsenterer (jæunfør Andersen 1987): Vandværksboringer, som har stor ydelse, er volumenovervågende. Linieovervågning foregår de steder i vandværkets opland, hvor filtre er placeret i grundvand, der strømmer hen mod vandværksboringen, der i sig selv kan opfattes som både volumen-og linieovervågende. Linieovervågning kan foregå i flere dybdeintervaller. Punktovervågning foregår i nærheden af vandskel eller andre steder $\mathrm{i}$ oplandet ide øverste lokale grundvandsforekomster, hvorfra grundvandet bevæger sig ned mod hovedreservoiret. Punktovervågning foregår derfor $\mathrm{i}$ de mest overfladenære filtre. Af grundvands-overvågningsområdernes over 1000 filtre er de $10 \%$ volumen-, $60 \%$ linie- og $30 \%$ punktovervågende.

\section{Teknisk funktion}

Amterne har efter de første års drift bedømt den tekniske funktion af filtrene i overvågningsområderne. På landsplan leverer langt den største del af filtrene vandprøver, der er egnede til det fulde analyseprogram, mens der ved ca. $15 \%$ af filtrene er kvalitets- eller vandmængdemæssige grænser for analysemulighederne, tabel 1.

\section{Forbedringsforslag}

Muligheden for at udtage vandprøver, der er egnede til analyseformål, fra de filtre, hvor der i øjeblikket er problemer, kan forbedres, enten ved at filteret renpumpes eller ved at prøvetagningsudstyret forbedres.

Renpumpning har i vidt omfang været gennemført, men kan ikke standse tilførslen af fine partikler $\mathrm{i}$ alle tilfælde. Dette gælder især for de ikke gruskastede filtre. De mange tilfælde af utætte montejustoppe er antagelig nu et historisk problem, idet alle de problematiske toppe er blevet udskiftet (af sikkerhedsmæssige grunde). Utætheder i rørene under jorden kan dog ikke altid afhjælpes. 


\begin{tabular}{|c|c|c|c|c|c|c|c|c|}
\hline \multicolumn{4}{|c|}{ OVERVÅGNINGSSTED } & \multicolumn{5}{|c|}{ MÅLINGER } \\
\hline \multirow[b]{2}{*}{ Amt/Komm. } & \multicolumn{2}{|c|}{ Antal } & \multirow[b]{2}{*}{ GRUMO } & \multirow{2}{*}{$\begin{array}{l}\text { Analyse- } \\
\text { pakker }\end{array}$} & \multirow{2}{*}{$\begin{array}{l}\text { Analyse- } \\
\text { runder }\end{array}$} & \multicolumn{2}{|c|}{ I antal } & \multirow[b]{2}{*}{ Periode } \\
\hline & Bor. & Filtre & & & & Bor. & Filtre & \\
\hline Fr.berg/Kbh.komm. & 10 & 18 & Frederiksberg & $\begin{array}{c}1 \\
3,4,5\end{array}$ & 14 & & & $\begin{array}{c}1989-1991 \\
1990\end{array}$ \\
\hline \multirow[t]{3}{*}{ Københavns amt } & \multirow[t]{3}{*}{25} & \multirow[t]{3}{*}{55} & Søndersø & $\begin{array}{c}1 \\
3,4,5 \\
\text { Tritium }\end{array}$ & $\begin{array}{l}6 \\
1\end{array}$ & $\begin{array}{l}9 \\
9 \\
9\end{array}$ & $\begin{array}{l}19 \\
19 \\
18 \\
\end{array}$ & $\begin{array}{c}1989-1991 \\
1990\end{array}$ \\
\hline & & & Ishøj & $\begin{array}{c}1 \\
1 \\
\text { Tritium } \\
\end{array}$ & $\begin{array}{l}7 \\
2\end{array}$ & $\begin{array}{l}9 \\
2 \\
9 \\
\end{array}$ & $\begin{array}{c}17 \\
3 \\
16 \\
\end{array}$ & $1989-1991$ \\
\hline & & & Gladsaxe & $\begin{array}{c}1 \\
\text { Tritium }\end{array}$ & 6 & $\begin{array}{l}9 \\
8 \\
\end{array}$ & $\begin{array}{l}18 \\
16 \\
\end{array}$ & $1989-1991$ \\
\hline \multirow[t]{5}{*}{ Frederiksborg amt } & \multirow[t]{5}{*}{37} & \multirow[t]{5}{*}{65} & Endrup & $\begin{array}{c}1 \\
4,5 \\
\text { Tritium } \\
\end{array}$ & $3-6$ & 6 & 11 & $1989-1990$ \\
\hline & & & Skuldelev & $\begin{array}{c}1 \\
4,5 \\
\text { Tritium } \\
\end{array}$ & $6-8$ & 8 & 15 & $1989-1990$ \\
\hline & & & Asserbo & $\begin{array}{c}1 \\
4,5 \\
\text { Tritium } \\
\end{array}$ & $6-8$ & 6 & 10 & $1989-1990$ \\
\hline & & & Attermose & $\begin{array}{c}1 \\
4,5 \\
\text { Tritium }\end{array}$ & $6-8$ & 7 & 13 & $1989-1990$ \\
\hline & & & Espergerde & $\begin{array}{c}1 \\
4,5 \\
\text { Tritium } \\
\end{array}$ & $6-8$ & 10 & 16 & $1989-1990$ \\
\hline \multirow[t]{4}{*}{ Roskilde amt } & \multirow[t]{4}{*}{44} & \multirow[t]{4}{*}{$\$ 2$} & Torkilstrup & $\begin{array}{c}1 \\
3,4,5 \\
\text { Tritium } \\
\end{array}$ & 4 & $\begin{array}{l}9 \\
2 \\
7 \\
\end{array}$ & $\begin{array}{c}16 \\
2 \\
13 \\
\end{array}$ & $\begin{array}{c}1989-1990 \\
1991\end{array}$ \\
\hline & & & Brokilde & $\begin{array}{c}1 \\
3,4,5 \\
\text { Tritium } \\
\end{array}$ & 4 & $\begin{array}{l}8 \\
2 \\
7 \\
\end{array}$ & $\begin{array}{c}10 \\
2 \\
9 \\
\end{array}$ & $\begin{array}{c}1989-1990 \\
1991\end{array}$ \\
\hline & & & Asemose & $\begin{array}{c}1 \\
3,4,5 \\
\text { Tritium }\end{array}$ & 4 & $\begin{array}{c}13 \\
3 \\
13 \\
\end{array}$ & $\begin{array}{l}13 \\
13 \\
\end{array}$ & $\begin{array}{c}1989-1990 \\
1991\end{array}$ \\
\hline & & & Osted & $\begin{array}{c}1 \\
3,4,5 \\
\text { Tritium }\end{array}$ & 4 & $\begin{array}{c}12 \\
5 \\
11 \\
\end{array}$ & $\begin{array}{l}14 \\
12 \\
\end{array}$ & $\begin{array}{c}1989-1990 \\
1991\end{array}$ \\
\hline \multirow[t]{5}{*}{ Vestsjæillands amt } & \multirow[t]{5}{*}{30} & \multirow[t]{5}{*}{66} & Holbzek & $\begin{array}{c}1 \\
3,4,5 \\
\text { Tritium }\end{array}$ & 5 & $\begin{array}{l}6 \\
2 \\
6 \\
\end{array}$ & $\begin{array}{l}10 \\
4 \\
9 \\
\end{array}$ & $\begin{array}{c}1989-1990 \\
1990-1991 \\
1990 \\
\end{array}$ \\
\hline & & & Munke Bjergby & $\begin{array}{c}1 \\
3,4,5 \\
\text { Tritium } \\
\end{array}$ & 6 & $\begin{array}{l}6 \\
6 \\
4 \\
\end{array}$ & $\begin{array}{c}14 \\
9 \\
10 \\
\end{array}$ & $\begin{array}{c}1989-1990 \\
1990-1991 \\
1989 \\
\end{array}$ \\
\hline & & & Store Fuglede & $\begin{array}{c}1 \\
3,4,5 \\
\text { Tritium } \\
\end{array}$ & 7 & $\begin{array}{l}5 \\
5 \\
5 \\
\end{array}$ & $\begin{array}{c}10 \\
9 \\
9 \\
\end{array}$ & $\begin{array}{c}1989-1990 \\
1990-1991 \\
1990 \\
\end{array}$ \\
\hline & & & Nykøbing $\mathrm{Sj}$. & $\begin{array}{c}1 \\
3,4,5 \\
\text { Tritium } \\
\end{array}$ & 8 & $\begin{array}{l}5 \\
5 \\
6 \\
\end{array}$ & $\begin{array}{l}12 \\
11 \\
12 \\
\end{array}$ & $\begin{array}{c}1989-1990 \\
1990 \\
\end{array}$ \\
\hline & & & Eggeslevmagle & $\begin{array}{c}1 \\
3,4,5 \\
\text { Tritium }\end{array}$ & 7 & $\begin{array}{l}6 \\
5 \\
6 \\
\end{array}$ & $\begin{array}{l}14 \\
11 \\
11 \\
\end{array}$ & $\begin{array}{c}1989-1990 \\
1991 \\
1990\end{array}$ \\
\hline
\end{tabular}




\begin{tabular}{|c|c|c|c|c|c|c|c|c|}
\hline \multicolumn{4}{|c|}{ OVERVÅGNINGSSTED } & \multicolumn{5}{|c|}{ MÅLINGER } \\
\hline \multirow[b]{2}{*}{ Amt/Komm. } & \multicolumn{2}{|c|}{ Antal } & \multirow[b]{2}{*}{ GRUMO } & \multirow{2}{*}{$\begin{array}{l}\text { Analyse } \\
\text { pakker }\end{array}$} & \multirow{2}{*}{$\begin{array}{l}\text { Analyse- } \\
\text { runder }\end{array}$} & \multicolumn{2}{|c|}{ I antal } & \multirow[b]{2}{*}{ Periode } \\
\hline & Bor. & Filtre & & & & Bor. & Filtre & \\
\hline \multirow[t]{5}{*}{ Storstroms amt } & \multirow[t]{5}{*}{47} & \multirow[t]{5}{*}{78} & Holeby & $\begin{array}{c}1 \\
2 \\
\text { Tritium }\end{array}$ & 4 & $\begin{array}{l}5 \\
1 \\
5\end{array}$ & $\begin{array}{c}16 \\
1 \\
16 \\
\end{array}$ & $\begin{array}{l}1990 \\
1990 \\
1990 \\
\end{array}$ \\
\hline & & & Hjelmsølille & $\begin{array}{c}1 \\
3,4,5 \\
\text { Tritium }\end{array}$ & 5 & $\begin{array}{l}14 \\
4 \\
9 \\
\end{array}$ & $\begin{array}{c}21 \\
4 \\
13 \\
\end{array}$ & $\begin{array}{c}1989-1990 \\
1990 \\
1990\end{array}$ \\
\hline & & & Vesterborg & $\begin{array}{c}1 \\
3,4,5 \\
\text { Tritium }\end{array}$ & $\begin{array}{l}5 \\
1 \\
\end{array}$ & $\begin{array}{l}8 \\
5 \\
8 \\
\end{array}$ & $\begin{array}{c}12 \\
6 \\
12 \\
\end{array}$ & $\begin{array}{c}1989-1990 \\
1990 \\
1990 \\
\end{array}$ \\
\hline & & & Sibirien & $\begin{array}{c}1 \\
\text { Tritium }\end{array}$ & 3 & $\begin{array}{l}6 \\
6\end{array}$ & $\begin{array}{l}14 \\
14\end{array}$ & $\begin{array}{l}1990 \\
1990\end{array}$ \\
\hline & & & St. Heddinge & $\begin{array}{c}1 \\
2,3,4,5 \\
\text { Tritium }\end{array}$ & 4 & $\begin{array}{c}10 \\
7 \\
10 \\
\end{array}$ & $\begin{array}{l}21 \\
12 \\
20 \\
\end{array}$ & $\begin{array}{l}1990 \\
1990 \\
1990 \\
\end{array}$ \\
\hline Bornholms ame & 9 & 15 & Smålyng & $\begin{array}{c}1 \\
3.4,5\end{array}$ & 10 & $\begin{array}{l}9 \\
5\end{array}$ & $\begin{array}{l}15 \\
8\end{array}$ & $\begin{array}{c}1988-1991 \\
1990\end{array}$ \\
\hline \multirow[t]{6}{*}{ Fyns amt } & \multirow[t]{6}{*}{47} & \multirow[t]{6}{*}{89} & Nyborg & $\begin{array}{c}1,2 \\
3,4,5 \\
\text { Tritium } \\
\end{array}$ & $\begin{array}{l}6 \\
1 \\
\end{array}$ & $\begin{array}{l}9 \\
5 \\
9 \\
\end{array}$ & $\begin{array}{c}18 \\
5 \\
15 \\
\end{array}$ & $\begin{array}{c}1989.1990 \\
1990 \\
1989-1990 \\
\end{array}$ \\
\hline & & & Borreby & $\begin{array}{c}1,2 \\
3,4,5 \\
\text { Tritium }\end{array}$ & $\begin{array}{l}6 \\
1 \\
\end{array}$ & $\begin{array}{l}8 \\
3 \\
7 \\
\end{array}$ & $\begin{array}{c}14 \\
3 \\
11 \\
\end{array}$ & $\begin{array}{c}1989-1990 \\
1990 \\
1989-1990 \\
\end{array}$ \\
\hline & & & Svendborg & $\begin{array}{c}1 \\
3,4,5 \\
\text { Tritium }\end{array}$ & $\begin{array}{l}8 \\
1 \\
\end{array}$ & $\begin{array}{l}8 \\
5 \\
8 \\
\end{array}$ & $\begin{array}{c}14 \\
5 \\
14 \\
\end{array}$ & $\begin{array}{c}1989-1990 \\
1990 \\
1989-1990\end{array}$ \\
\hline & & & Nr. Søby & $\begin{array}{c}1,2 \\
3,4,5 \\
\text { Tritium }\end{array}$ & $\begin{array}{l}8 \\
1\end{array}$ & $\begin{array}{l}8 \\
6 \\
8\end{array}$ & $\begin{array}{c}15 \\
6 \\
15\end{array}$ & $\begin{array}{c}1989-1990 \\
1990 \\
1989-1990\end{array}$ \\
\hline & & & Horndrup & $\begin{array}{c}1 \\
3,4,5 \\
\text { Tritium }\end{array}$ & $\begin{array}{l}8 \\
1 \\
\end{array}$ & $\begin{array}{l}6 \\
6 \\
6 \\
\end{array}$ & $\begin{array}{c}16 \\
8 \\
9 \\
\end{array}$ & $\begin{array}{c}1989-1990 \\
1990 \\
1989.1990\end{array}$ \\
\hline & & & Jullerup & $\begin{array}{c}1,2 \\
3,4,5 \\
\text { Tritium }\end{array}$ & $\begin{array}{l}8 \\
1 \\
\end{array}$ & $\begin{array}{l}8 \\
4\end{array}$ & $\begin{array}{l}12 \\
4 \\
9\end{array}$ & $\begin{array}{c}1989-1990 \\
1990 \\
1989-1990\end{array}$ \\
\hline \multirow[t]{5}{*}{ Sønderjyll. amt } & \multirow[t]{5}{*}{40} & \multirow[t]{5}{*}{74} & Abild & $\begin{array}{c}1 \\
3,4,5 \\
\text { Tritium }\end{array}$ & 4 & $\begin{array}{l}7 \\
7\end{array}$ & $\begin{array}{l}16 \\
16 \\
\end{array}$ & $\begin{array}{l}1990 \\
1990\end{array}$ \\
\hline & & & Mjang Dam & $\begin{array}{c}1 \\
3,4,5 \\
\text { Tritium }\end{array}$ & 4 & $\begin{array}{l}6 \\
6 \\
\end{array}$ & $\begin{array}{l}10 \\
10 \\
\end{array}$ & $\begin{array}{l}1990 \\
1990\end{array}$ \\
\hline & & & Bedsted & $\begin{array}{c}1 \\
3.4 .5 \\
\text { Tritium }\end{array}$ & 4 & $\begin{array}{l}9 \\
9\end{array}$ & $\begin{array}{l}21 \\
21 \\
\end{array}$ & $\begin{array}{l}1990 \\
1990\end{array}$ \\
\hline & & & Roddning Nord & $\begin{array}{c}1 \\
3,4,5 \\
\text { Tritium }\end{array}$ & 4 & $\begin{array}{l}7 \\
7 \\
\end{array}$ & $\begin{array}{l}9 \\
9\end{array}$ & $\begin{array}{l}1990 \\
1990\end{array}$ \\
\hline & & & Christiansfeld & $\begin{array}{c}1 \\
3,4,5 \\
\text { Tritium }\end{array}$ & 4 & $\begin{array}{l}13 \\
13 \\
\end{array}$ & $\begin{array}{l}18 \\
18 \\
\end{array}$ & $\begin{array}{l}1990 \\
1990\end{array}$ \\
\hline
\end{tabular}

Tabel 2: Grundvandsanalyser $i$ grundvandsovervågningsprogrammet 1988-1991 (fortssettes). 


\begin{tabular}{|c|c|c|c|c|c|c|c|c|}
\hline \multicolumn{4}{|c|}{ OVERVÅGNINGSSTED } & \multicolumn{5}{|c|}{ MÅLINGER } \\
\hline \multirow[b]{2}{*}{ Amt/Komm. } & \multicolumn{2}{|c|}{ Antal } & \multirow[b]{2}{*}{ GRUMO } & \multirow{2}{*}{$\begin{array}{l}\text { Analyse- } \\
\text { pakker }\end{array}$} & \multirow{2}{*}{$\begin{array}{l}\text { Analyse- } \\
\text { runder }\end{array}$} & \multicolumn{2}{|c|}{ I antal } & \multirow[b]{2}{*}{ Periode } \\
\hline & Bor. & Filtre & & & & Bor. & Filtre & \\
\hline \multirow[t]{5}{*}{ Ribe amt } & \multirow[t]{5}{*}{52} & \multirow[t]{5}{*}{79} & Grindsted & $\begin{array}{c}1 \\
3 \\
4,5 \\
\end{array}$ & $0-6$ & 16 & $\begin{array}{c}25 \\
1\end{array}$ & 1989.1990 \\
\hline & & & Bramming & $\begin{array}{c}1 \\
3 \\
4,5 \\
\text { Tritium }\end{array}$ & $2-8$ & 9 & $\begin{array}{c}12 \\
3 \\
1 \\
4 \\
\end{array}$ & $1989-1990$ \\
\hline & & & Ølgod & $\begin{array}{c}1 \\
3 \\
4,5\end{array}$ & 2.7 & 9 & $\begin{array}{c}12 \\
3 \\
1\end{array}$ & $1989-1990$ \\
\hline & & & Forumiund & $\begin{array}{c}1 \\
3 \\
1,5 \\
\text { Tritium }\end{array}$ & $1-7$ & 10 & $\begin{array}{c}13 \\
4 \\
2 \\
10 \\
\end{array}$ & 1989.1990 \\
\hline & & & Vorbasse & $\begin{array}{c}1 \\
4.5\end{array}$ & 0.7 & 8 & $\begin{array}{c}17 \\
2 \\
\end{array}$ & $1989-1990$ \\
\hline \multirow[t]{5}{*}{ Vejle amt } & \multirow[t]{5}{*}{50} & \multirow[t]{5}{*}{84} & Egebjerg & $\begin{array}{c}1 \\
3,4.5 \\
\text { Tritium }\end{array}$ & 5 & $\begin{array}{l}7 \\
5 \\
5\end{array}$ & $\begin{array}{c}15 \\
5 \\
9 \\
\end{array}$ & $\begin{array}{c}1989-1990 \\
1990 \\
1990 \\
\end{array}$ \\
\hline & & & Thyregod & $\begin{array}{c}1 \\
3,4,5 \\
\text { Tritium }\end{array}$ & 8 & $\begin{array}{l}13 \\
6 \\
4 \\
\end{array}$ & $\begin{array}{c}17 \\
6 \\
4\end{array}$ & $\begin{array}{c}1989-1990 \\
1990 \\
1990 \\
\end{array}$ \\
\hline & & & Trudsbro & $\begin{array}{c}1 \\
3,4,5 \\
\text { Tritium }\end{array}$ & 8 & $\begin{array}{c}11 \\
6 \\
11\end{array}$ & $\begin{array}{c}20 \\
6 \\
15\end{array}$ & $\begin{array}{c}1989-1990 \\
1990 \\
1990\end{array}$ \\
\hline & & & Follerup & $\begin{array}{c}1 \\
3,4,5 \\
\text { Tritium }\end{array}$ & 7 & $\begin{array}{l}8 \\
4 \\
7\end{array}$ & $\begin{array}{l}10 \\
4 \\
7\end{array}$ & $\begin{array}{c}1989-1990 \\
1990 \\
1990\end{array}$ \\
\hline & & & Ejstrupholm & $\begin{array}{c}1 \\
3,4,5 \\
\text { Tritium }\end{array}$ & 5 & $\begin{array}{c}10 \\
4 \\
8\end{array}$ & $\begin{array}{c}22 \\
4 \\
17\end{array}$ & $\begin{array}{c}1989-1990 \\
1990 \\
1990\end{array}$ \\
\hline \multirow[t]{5}{*}{ Ringkøbing amt } & \multirow[t]{5}{*}{31} & \multirow[t]{5}{*}{60} & Herming & $\begin{array}{c}1 \\
3 \\
4 \\
\text { Tritium }\end{array}$ & 34 & $\begin{array}{c}11 \\
2\end{array}$ & $\begin{array}{c}14 \\
2\end{array}$ & $\begin{array}{l}1990 \\
1990\end{array}$ \\
\hline & & & Brande & $\begin{array}{c}1 \\
3 \\
4 \\
\text { Tritium }\end{array}$ & $3-4$ & $\begin{array}{l}5 \\
2 \\
3\end{array}$ & $\begin{array}{c}13 \\
4 \\
7 \\
13 \\
\end{array}$ & $\begin{array}{l}1990 \\
1990 \\
1990 \\
1990\end{array}$ \\
\hline & & & Haderup & $\begin{array}{c}1 \\
3 \\
4 \\
\text { Tritium } \\
\end{array}$ & $3-4$ & $\begin{array}{l}3 \\
1 \\
2\end{array}$ & $\begin{array}{l}8 \\
2 \\
3 \\
8\end{array}$ & $\begin{array}{l}1990 \\
1990 \\
1990 \\
1990\end{array}$ \\
\hline & & & Herborg & $\begin{array}{c}1 \\
3 \\
4 \\
\text { Tritium } \\
\end{array}$ & 34 & $\begin{array}{l}5 \\
1 \\
3\end{array}$ & $\begin{array}{c}11 \\
2 \\
7 \\
11\end{array}$ & $\begin{array}{l}1990 \\
1990 \\
1990 \\
1990\end{array}$ \\
\hline & & & Finderup & $\begin{array}{r}1 \\
3 \\
4 \\
\text { Tritium } \\
\end{array}$ & $3-4$ & $\begin{array}{l}5 \\
6 \\
2\end{array}$ & $\begin{array}{c}14 \\
6 \\
3 \\
14\end{array}$ & $\begin{array}{l}1990 \\
1990 \\
1990 \\
1990\end{array}$ \\
\hline
\end{tabular}

Tabel 2: Grundvandsanalyser i grundvandsovervågningsprogrammet 1988-1991 (fortsattes). 


\begin{tabular}{|c|c|c|c|c|c|c|c|c|}
\hline \multicolumn{4}{|c|}{ OVERVÅGNINGSSTED } & \multicolumn{5}{|c|}{ MÅLINGER } \\
\hline \multirow[b]{2}{*}{ Amt/Komm. } & \multicolumn{2}{|c|}{ Antal } & \multirow[b]{2}{*}{ GRUMO } & \multirow{2}{*}{$\begin{array}{l}\text { Analyse- } \\
\text { pakker }\end{array}$} & \multirow{2}{*}{$\begin{array}{l}\text { Analyse- } \\
\text { runder }\end{array}$} & \multicolumn{2}{|c|}{ I antal } & \multirow[b]{2}{*}{ Periode } \\
\hline & Bor. & Filtre & & & & Bor. & Filtre & \\
\hline \multirow[t]{6}{*}{ Århus amt } & \multirow[t]{6}{*}{100} & \multirow[t]{6}{*}{132} & Kastbjerg & 1 & 2 & 9 & 13 & 1990 \\
\hline & & & Kassted & 1 & 2 & 15 & 19 & 1990 \\
\hline & & & Nordsamsø & $\begin{array}{c}1 \\
3,4,5 \\
\text { Tritium }\end{array}$ & $4-5$ & $\begin{array}{l}22 \\
10\end{array}$ & $\begin{array}{l}24 \\
24\end{array}$ & 1990 \\
\hline & & & Fillerup & $\begin{array}{c}1 \\
3,4,5 \\
\text { Tritium }\end{array}$ & $4-5$ & $\begin{array}{c}18 \\
9\end{array}$ & $\begin{array}{l}21 \\
21\end{array}$ & 1990 \\
\hline & & & Hvinningdal & $\begin{array}{c}1 \\
3,4,5 \\
\text { Tritium }\end{array}$ & $4-5$ & $\begin{array}{l}18 \\
11\end{array}$ & $\begin{array}{l}27 \\
27\end{array}$ & 1990 \\
\hline & & & Homå & 1 & 4 & 17 & 27 & $1990-1991$ \\
\hline \multirow[t]{5}{*}{ Viborg amt } & \multirow[t]{5}{*}{38} & \multirow[t]{5}{*}{179} & Rabis Bæk & 1 & 2 & 8 & 120 & 1990 \\
\hline & & & Viborg $\mathrm{N}$. & $1,3,4,5$ & 4 & 7 & 14 & 1990 \\
\hline & & & Skive & $1,3,4,5$ & $3-4$ & 12 & 15 & 1990 \\
\hline & & & Nykøbing M. & $1,3,4,5$ & 4 & 5 & 14 & 1990 \\
\hline & & & Thisted-Baun & $1,3,4,5$ & 4 & 6 & 16 & 1990 \\
\hline \multirow[t]{6}{*}{ Nordjyllands amt } & \multirow[t]{6}{*}{75} & \multirow[t]{6}{*}{92} & Tornby & $\begin{array}{c}1, \text { Tritium } \\
3,4\end{array}$ & $6-8$ & $\begin{array}{l}6 \\
3\end{array}$ & $\begin{array}{c}11 \\
3\end{array}$ & $1989-1990$ \\
\hline & & & Råkilde-Støvring & $\begin{array}{c}\text { 1,Tritium } \\
3,4\end{array}$ & $6-8$ & $\begin{array}{l}9 \\
4\end{array}$ & $\begin{array}{c}13 \\
5\end{array}$ & $1989-1990$ \\
\hline & & & Drastrup & $\begin{array}{c}\text { 1,Tritium } \\
\mathbf{3 , 4}\end{array}$ & $6-8$ & $\begin{array}{c}18 \\
8\end{array}$ & $\begin{array}{c}22 \\
8\end{array}$ & $1989-1990$ \\
\hline & & & Skerping & $\begin{array}{c}\text { 1,Tritium } \\
3,4\end{array}$ & $6-8$ & $\begin{array}{c}15 \\
5\end{array}$ & $\begin{array}{c}19 \\
5\end{array}$ & $1989-1990$ \\
\hline & & & Albak & $\begin{array}{c}1, \text { Tritium } \\
3,4\end{array}$ & $6-8$ & $\begin{array}{c}10 \\
5\end{array}$ & $\begin{array}{c}14 \\
5\end{array}$ & $1989-1990$ \\
\hline & & & Gislum & $\begin{array}{c}\text { 1,Tritium } \\
3,4\end{array}$ & $6-8$ & $\begin{array}{c}11 \\
4\end{array}$ & $\begin{array}{c}11 \\
4\end{array}$ & $1989-1990$ \\
\hline
\end{tabular}

Tabel 2: $\quad$ Grundvandsanalyser i grundvandsovervågningsprogrammet 1988-1991. 


\section{DE ENKELTE OVERVÅGNINGSOMRÅDER}

De 67 overvågningsområder, der ligger spredt i alle landsdele, er etableret af amter, kommuner og DGU. Hver af disse parter har givet en grundbeskrivelse af de områder, de selv har etableret, endda ofte i flere omgange. Beskrivelserne fylder seks hyldemeter og kun en snæver indviet kreds kan siges at have haft overblik over dette materiale. Det er $\mathrm{i}$ et forsøg på at gøre dette omfattende materiale tilgængeligt for en bredere kreds, at overvågningsområderne i dette afsnit er beskrevet på en standardiseret form.

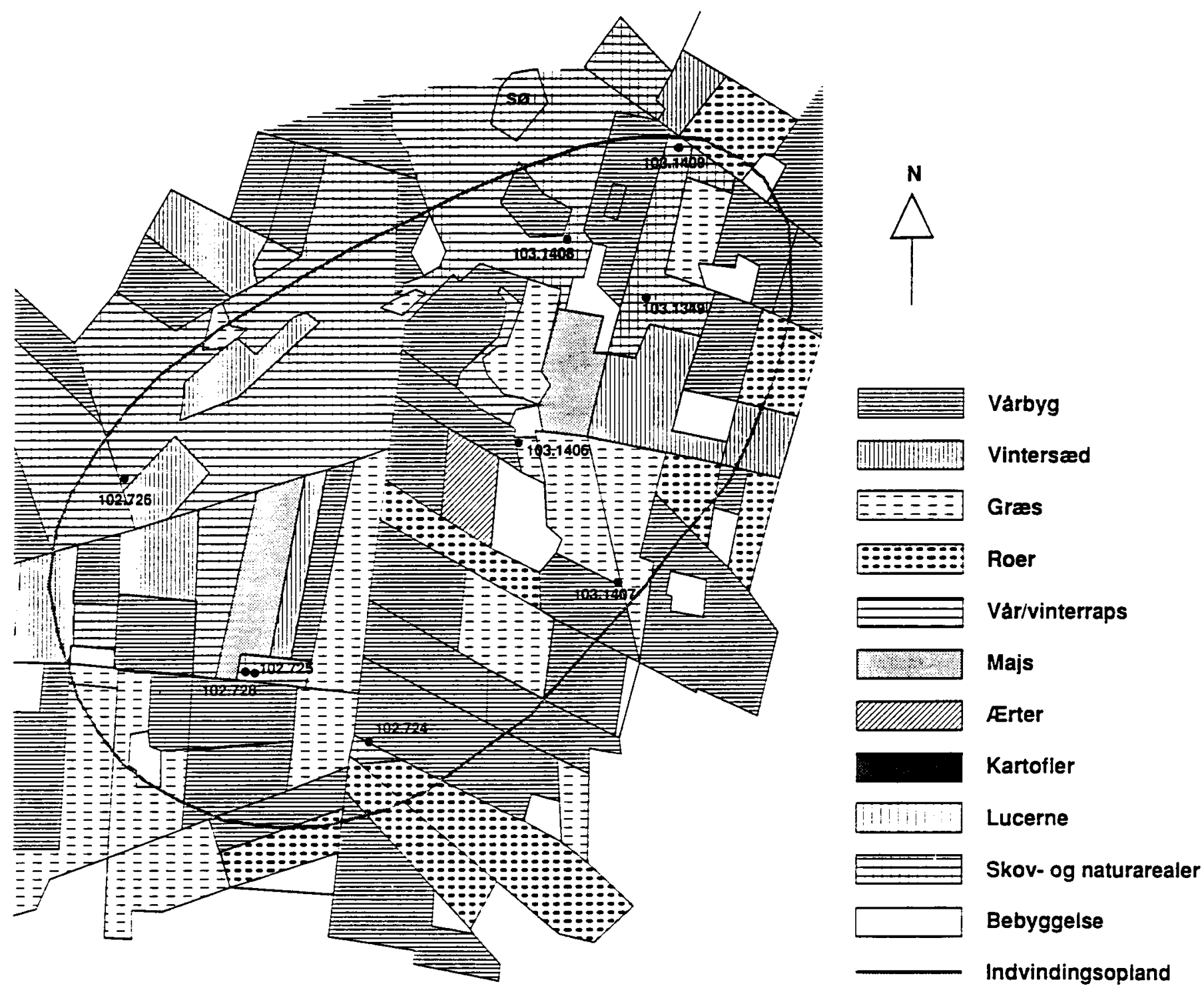

Figur 3: Arealanvendelsen i Ølgod, 1990.

Når områderne præsenteres på denne måde forsvinder en del af den individualitet, der er at finde $\mathrm{i}$ de originale beskrivelser, vurderinger og beretninger. Fordelen ved standardpræsentationen er den store sammenlignelighed, men samtidig indebærer det også at en del værdifulde elementer $\mathrm{i}$ beskrivelsen har måttet udelades i de tilfælde, hvor kun et eller nogle enkelte amter har præsenteret dem. Blandt disse særlige supplerende beskrivelser bør de årlige arealanvendelseskort fra Ribe amt nævnes, figur 3. Som det fremgår 
andetsteds i denne rapport er arealanvendelsen en af de vigtige faktorer for en nøjere fortolkning af den menneskeskabte påvirkning af grundvandet, og oplysninger af denne type er derfor væsentlige, omend kortene også illustrerer, hvor kompliceret fortolkningen i realiteten er. Nordjyllands amt har inkluderet luftfotografier af overvågningsområderne, hvilket også kan give et visuelt indtryk af arealanvendelse og topografi.

På analysesiden er der i flere amter opstillet hydrokemiske sammenhænge og dybderelationer, og der vil på dette område kunne hentes en del yderligere information, blandt andre i rapporterne fra Århus, Vejle, Fyns og Storstrøms amter. Figur 4 viser et eksempel fra det topografisk varierede Nordsamsø. En sammenligning mellem denne figur og dybdeplottene for nitrat og sulfat på side 132 tydeliggør, at der er potentiale i disse data til langt mere vidtgående fortolkninger, end der her har kunnet præsenteres.

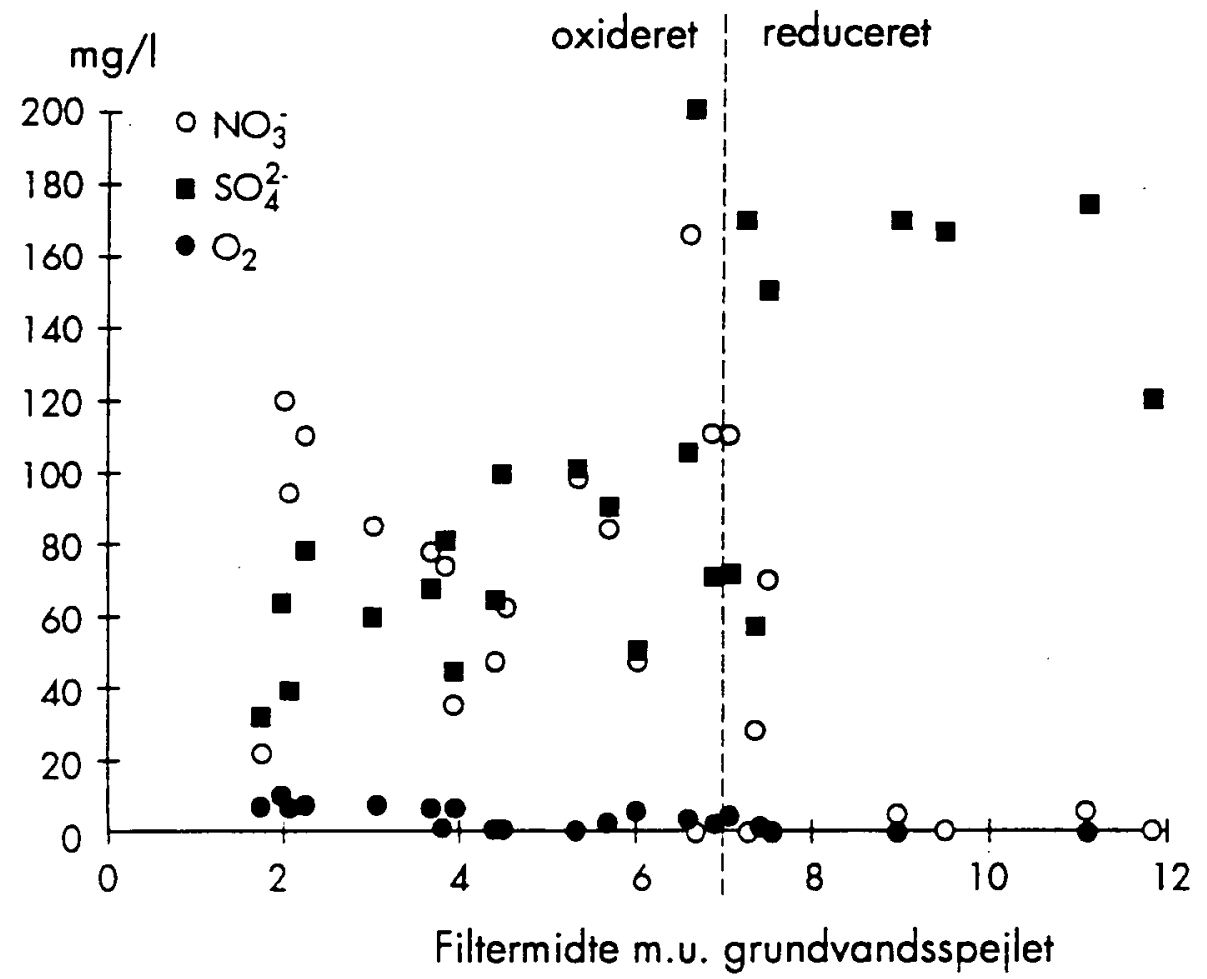

Figur 4: Oxiderede stoffer på Nordsamsø.

\section{Forklaring til områdebeskrivelserne}

Den ensartede beskrivelse af overvågningsområderne omfatter en kort verbal karakteristik af Geologien, Hydrogeolgien og Hydrokemien. Det udnyttelsesmæssigt vigtigste reservoir er kaldt hovedresrvoiret og de mere terrænnære er kaldt sekundære reservoirer. Beskrivelsen er suppleret med kort, profil og grafer, hvis indhold og signaturer forklares $\mathrm{i}$ det føigende. Områdernes beliggenhed fremgår af det indsatte Danmarkskort og figur 1.

\section{Potentiale- og Terrænkort}

Disse kort er tegnet i samme størrelsesforhold, og dette er valgt, således at det overvågede område fylder kortrammen nogenlunde ud. Der er angivet en fælles længdeskala på et af kortene og nord er opad. Både korttemaerne, potentiale- og terrænkurverne samt overvågningsområdets afgrænsning og hvilken overvågningstype, der foregar i loringerne, er cittid at finde på de respektive loort. Oplysninger om 
løbenummerdelen af boringernes DGU-numre, hvilken overvågningstype der foregår i boringen, vandløb og søer samt lokalitetsnavne (der kan findes på et generalstabskort) er anført på det af kortene, hvor der er bedst plads. Kortene og denne præsentation i det hele taget indeholder udelukkende de boringer, der indgår i overvågningen. Overvågningsområderne er hovedsagelig afgrænset for de sekundære reservoirer, mens de kan være betydeligt større for hovedreservoirerne, især de artesiske.

\section{Signaturforklaring til potentiale- og terrænkort}

\begin{tabular}{|c|c|}
\hline & Områdegrænse \\
\hline $20 \longrightarrow$ & Potentiallinie med kote i m \\
\hline$\rightarrow$ & Strømningsretning \\
\hline 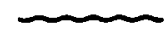 & Grundvandsskel \\
\hline$\longrightarrow-\longrightarrow$ & Hydrologisk negativ grænse \\
\hline $60 \longrightarrow$ & Topografiske kurver med kote i m \\
\hline - & Bakketop \\
\hline+ & Dal \\
\hline & Vandløb \\
\hline & Sø, have \\
\hline$\star$ & By \\
\hline$\square$ & Boring, volumenmoniterende \\
\hline$\square$ & Boring, volumen- og punktmoniterende \\
\hline$\triangle$ & Boring, liniemoniterende \\
\hline$\Delta$ & Boring, linie- og punktmoniterende \\
\hline$\bullet$ & Boring, punktmoniterende \\
\hline 916 & Boring med DGU løbenummer \\
\hline DGU nr. & DGU atlasbladnummer \\
\hline
\end{tabular}

Omkring kortrandene er der i en del tilfælde anført om potentialekortet viser forholdene $\mathrm{i}$ hovedreservoiret eller det sekundære reservoir. Herudover er det vist, hvilket eller hvilke af Kort og Matrikelstyrelsens kortblade i 1:25.000 (4-cm kort) området findes på, områdets omtrentlige areal, den fælles del af DGUnummeret (atlasbladnummeret) og, hvor der forekommer atlasbladgrænser, er disse angivet.

\section{Profilet}

Orienteringen af det geologiske profil er angivet med verdenshjørner og boringerne er identificeret med DGU-løbenummer. Profilets længde kan aflæses af kortene og er tilpasset så det fylder rammen ud. Profilets 
højde fremgår af koterne i profilets sider. Det er tilstræbt at vise placeringen af alle de filtre, der indgår i overvågningen. Dette har på grund af blandt andet boringernes spredte beliggenhed ikke altid kunnet lade sig gøre. I andre tilfælde er boringer ved siden af profillinien indlagt i korrekt dybde uden at de indgår i korrelationen mellem boringerne.

Signaturforklaring til geologisk profil

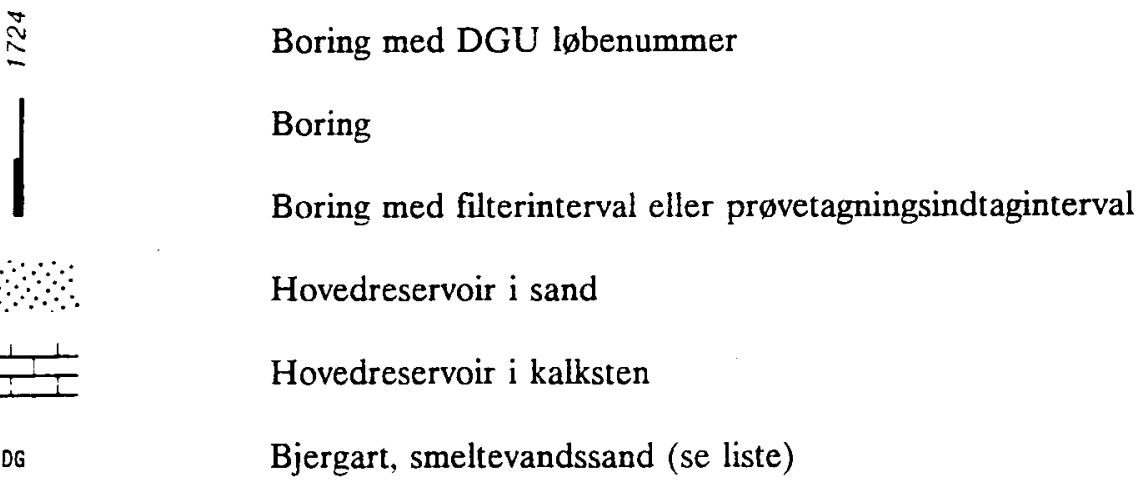

\section{DGU bjergartssymboler}

DGU-symbolerne og deres betydning fremgår af nedenstående alfabetiske liste.

\begin{tabular}{ll} 
SK & Campanien-Maastrichtien skrivekridt \\
BK & Danien bryozokalk, koralkalk \\
ZK & Danien kalk, kalk og flint \\
KK & Danien kalksandskalk \\
LL & Eocæn ler, Lillebæit Ler, plastisk ler \\
RL & Eocæn Røsnæs Ler \\
Z & Flint, sten \\
O & Fyld \\
MG & Glacial morænegrus \\
ML & Glacial moræneler \\
MS & Glacial morænesand \\
DG & Glacial smeltevandsgrus \\
DL & Glacial smeltevandsler \\
DS & Glacial smeltevandssand \\
DI & Glacial smeltevandssilt \\
G & Grus, sand og grus \\
P & Gytje, dynd \\
IG & Interglacial ferskvandsgrus \\
IS & Interglacial ferskvandssand \\
QI & Interglacial saltvandsler \\
\hline
\end{tabular}


QS Interglacial saltvandssand

QI Interglacial saltvandssilt

K Kalk, kridt, kalksten

KQ Kambrium Balka Sandsten

$\mathrm{KJ}$ Kambrium grønne skifre

EQ Kambrium Nexø sandsten

L Ler, mergel

KG Miocæn kvartsgrus

KS Miocæn kvartssand

M Muld

OL Oligocæn ler

OS Oligocæn sand

GC Oligocæn - miocæn - pliocæn brunkul

GL Oligocæn - miocæn - pliocæn glimmerler

GS Oligocæn - miocæn - pliocæn glimmersand

GI Oligocæn - miocæn - pliocæn glimmersilt

FL Postglacial ferskvandsier

FS Postglacial ferskvandssand

FT Postglacial ferskvandstørv

ES Postglacial flyvesand

HG Postglacial saltvandsgrus

HP Postglacial saltvandsgytje

HL Postglacial saltvandsler

HS Postglacial saltvandssand

HI Postglacial saltvandssilt

HT Postglacial saltvandstørv

PA Prækambrium gnejs, granit, pegmatit

$S \quad$ Sand

PK Selandien kalk, palæocæn grønsandskalk

PL Selandien ler, palæocæn ler, Kerteminde Mergel

PS Selandien sand, palæocæn grønsand

YL Senglacial saltvandsler

YS Senglacial saltvandssand

YI Senglacial saltvandssilt

T Tørv

\section{Vandbalancen}

Denne omfatter hovedelementerne Middelnedbør, Fordampning (egentlig middelevapotranspirationen) og Nettonedbør. Under Nettonedbør kan der vare supplerende oplysninger målt i millimeter, mens andre 
supplerende oplysninger er angivet under den lille "vandsøjle". Endelig er der oppumpningens størrelse og vandværket angivet.

\section{Arealanvendelse}

Arealanvendelsen er vist i en procentinddelt cirkel. Der er angivet 5\% intervaller. Procenten af den eller de største arealanvendelser er yderligere noteret og landbrugsarealet er rastet.

\section{Nitrat-, klorid- og sulfatkoncentrationer mod dybden}

Analyseresultaterne for disse stoffer er vist i grafer, hvis skalaer er tilpasset spredningen i måleværdierne og det relevante dybdeinterval. Graferne viser alle data mod dybden under terræn, idet kun denne relation for indeværende kan sammenknyttes for alle de overvågningsområder, hvorfra der er data. I tilfælde hvor graferne $i$ et vist omfang illustrerer detektionsgrænser for felt- og laboratoriemålinger er dette anført med "DG" ud for den pågældende værdi.

Med den valgte præsentationsform er det tilstræbt at give en bred forståelse af de enkelte overvågningsområder og samtidig gøre det let at finde de samme oplysninger for andre områder. Som en gennemgang af disse beskrivelser vil vise mangler der dog endnu basale oplysninger om en del af områderne.

En samlet præsentation af de analysedata, der i skrivende stund findes i databasen findes i Appendix.

På de følgende 67 dobbeltsider (side 28-161) præsenteres hvert enkelt grundvandsovervågningsområde. 
1513 I $S \emptyset$

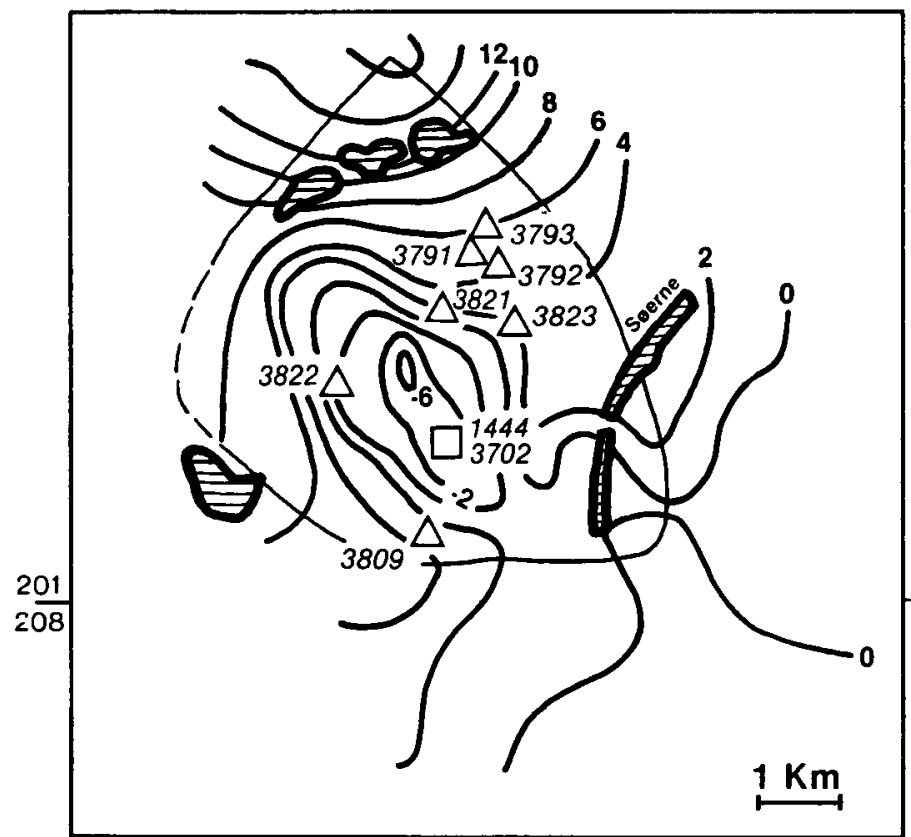

DGU nr. 201 og 208
Terræn

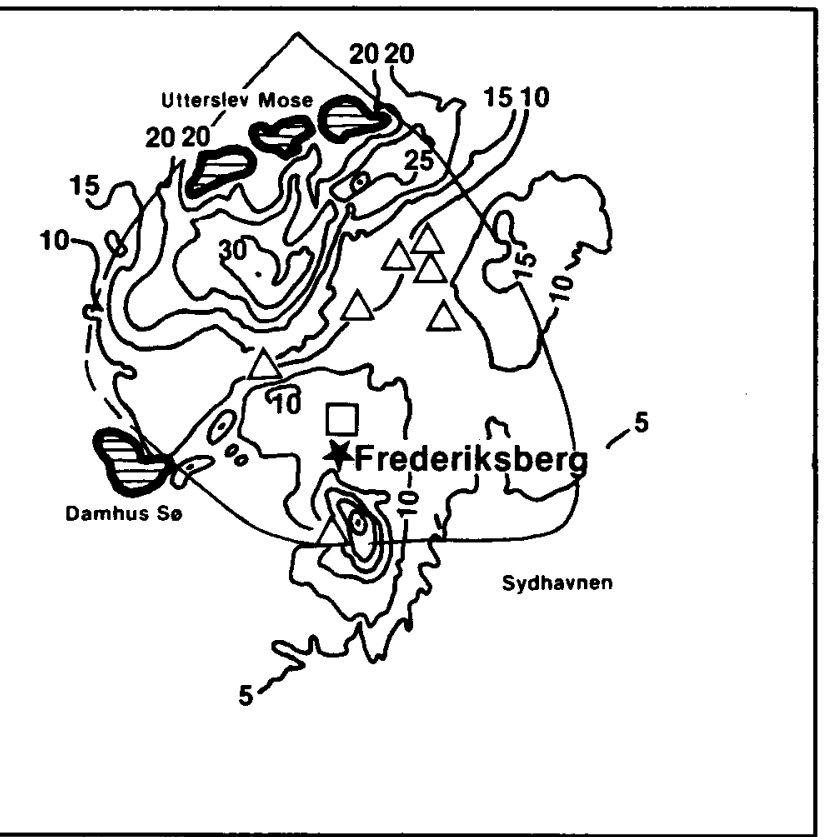

Areal $35 \mathrm{~km}^{2}$

Geologi: De øverste prækvartære lag i området består af bryozo- og kalksandskalk af Danien alder. Stedvis i den østlige del af området er der herover et tyndt dække af grønsandskalk fra Selandien tiden. Området skæres af den nordvest-sydøst forløbende Carlsbergforkastning. Øst for forkastningen ligger kalkoverfladen relativt 90 meter dybere. Den kvartære lagserie over kalken består generelt af to moræner adskilt af smeltevandssedimenter.Nogle steder mangler den nedre moræne. I de østlige kystnære områder findes der stedvis yderligere postglaciale Litorina aflejringer. I en del af området er der fyld.

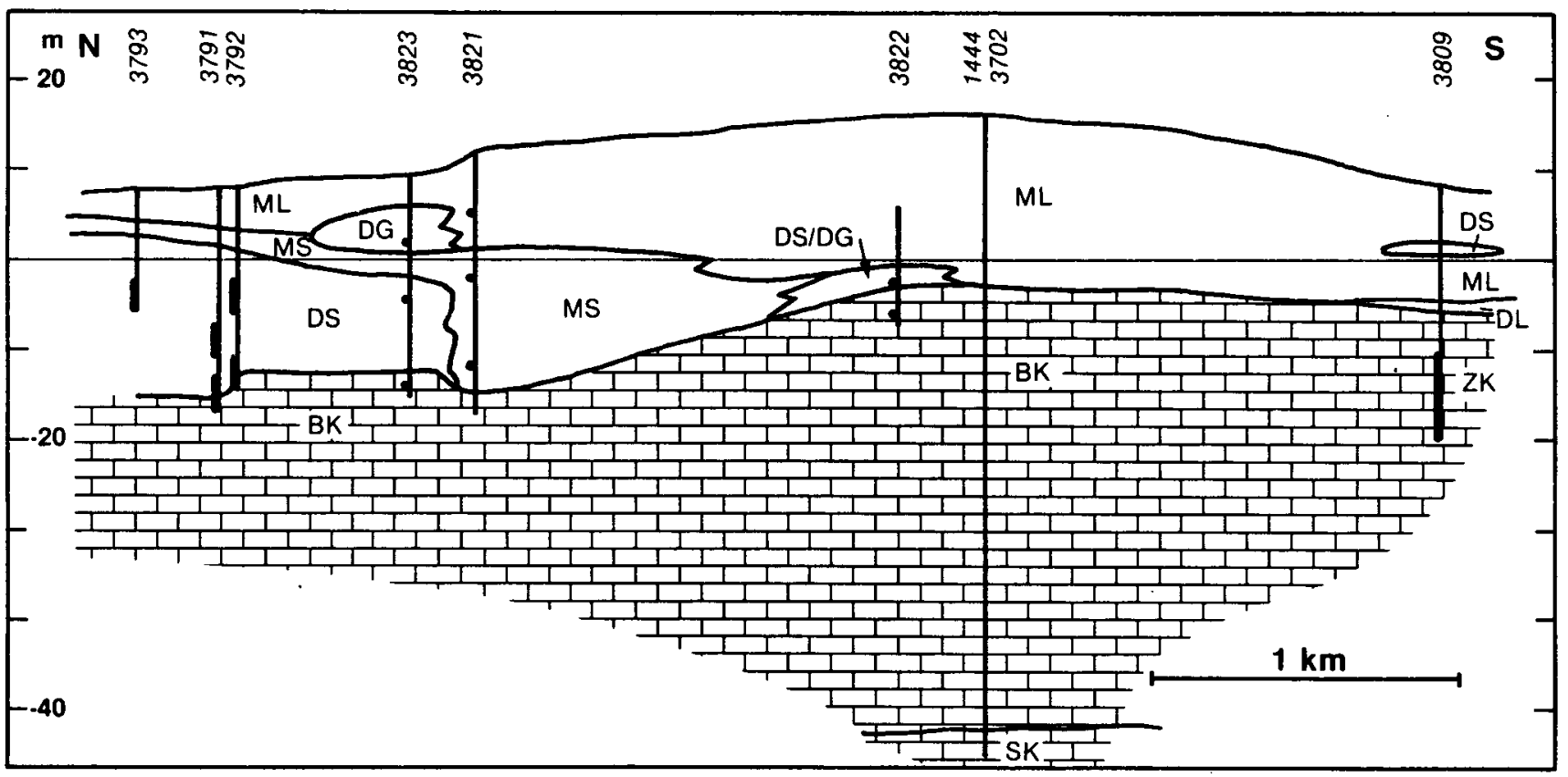


Hydrogeologi: Hovedreservoiret er artesisk og udgøres af Danienkalken og grønsandskalken i fællesskab. Der er sekundære, tildels usammenhængende, grundvandsreservoirer i de kvartære lag. Indvindingsboringerne er placeret i sprækkezoner omkring Carlsbergforkastningen. Overvågningsboringerne er placeret i ældre industrikvarterer.

Kildepladser: Siden $1980^{\prime}$ erne indvindes der ikke grundvand til drikkevandsforsyning i Københavns kommunes del af området. Derimod indvindes der til industri med videre.

Grundvandskemi: Grundvandet er middelhårdt-hårdt. I hovedreservoiret er der forhøjet indhold af klorid/jern og sulfat, samt miljøfremmede stoffer i mindre mængde, som for eksempel trikloretylen. I perioden 1980-91 er sulfatindholdet $i$ hovedreservoiret steget, mens hårdheden er faldet i 1990. Grundvandskemien vairerer en del afhængig af om vandet stammer fra produktionsboringerne i Carlsberg-forkastningszonen eller fra boringer $i$ ældre industrikvarterer.

Vandbalance $\mathbf{m m} / \mathbf{a r r}$ :

Arealanvendelse \%:

Middelnedbør 660

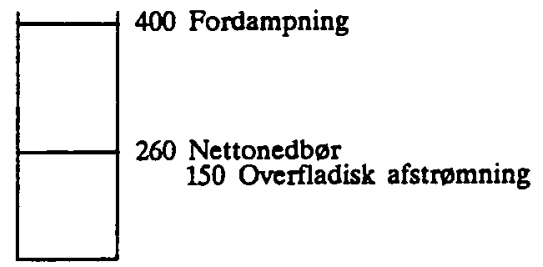

Kildeplads: Frederiksberg kommunale vv, 2.5 mill. m3/âr

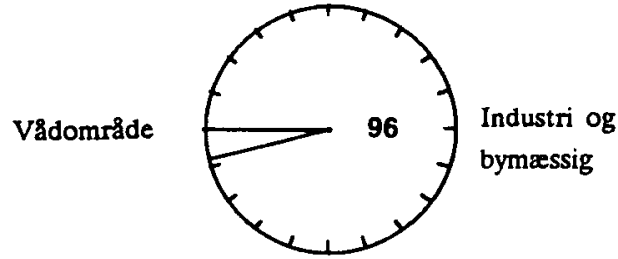

Registrerede depoter, ældre lossepladser $i$ industrikvarterer samt spredt affaldsudlagning.

Koncentrationen af udvalgte stoffer i forhold til dybde under terran.

Graferne viser data fra 1989 og 1990.

Nitrat/Dybde Klorid/Dybde Sulfat/Dybde

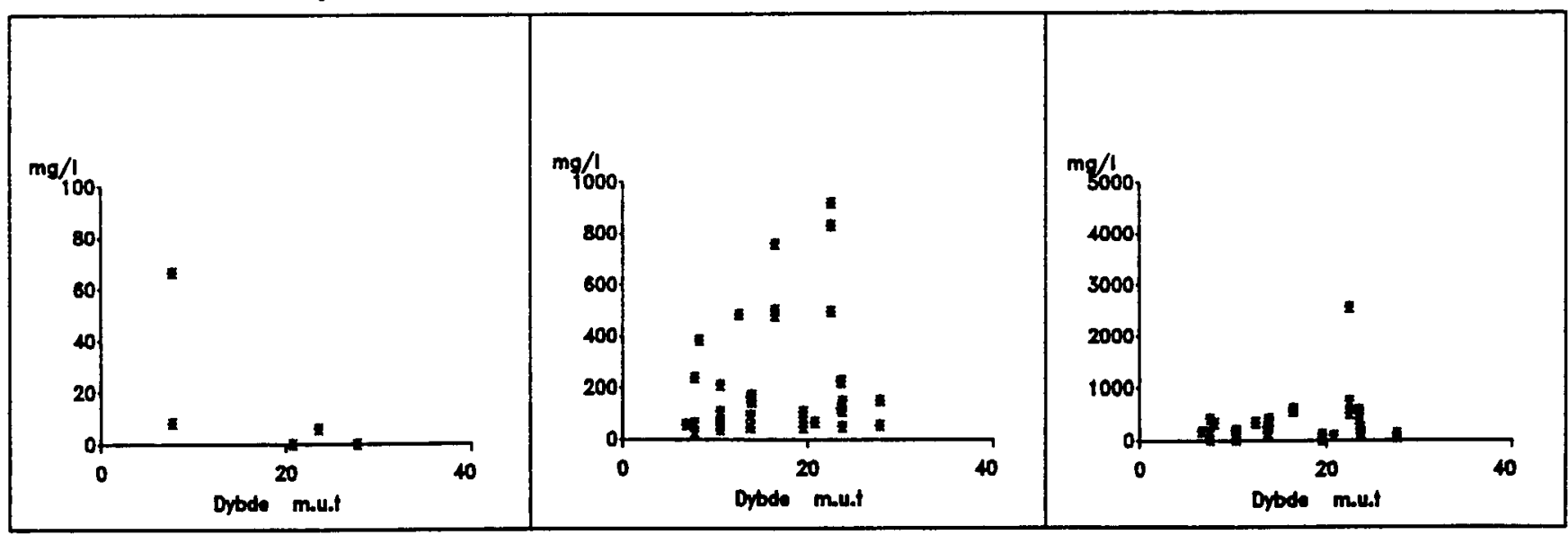




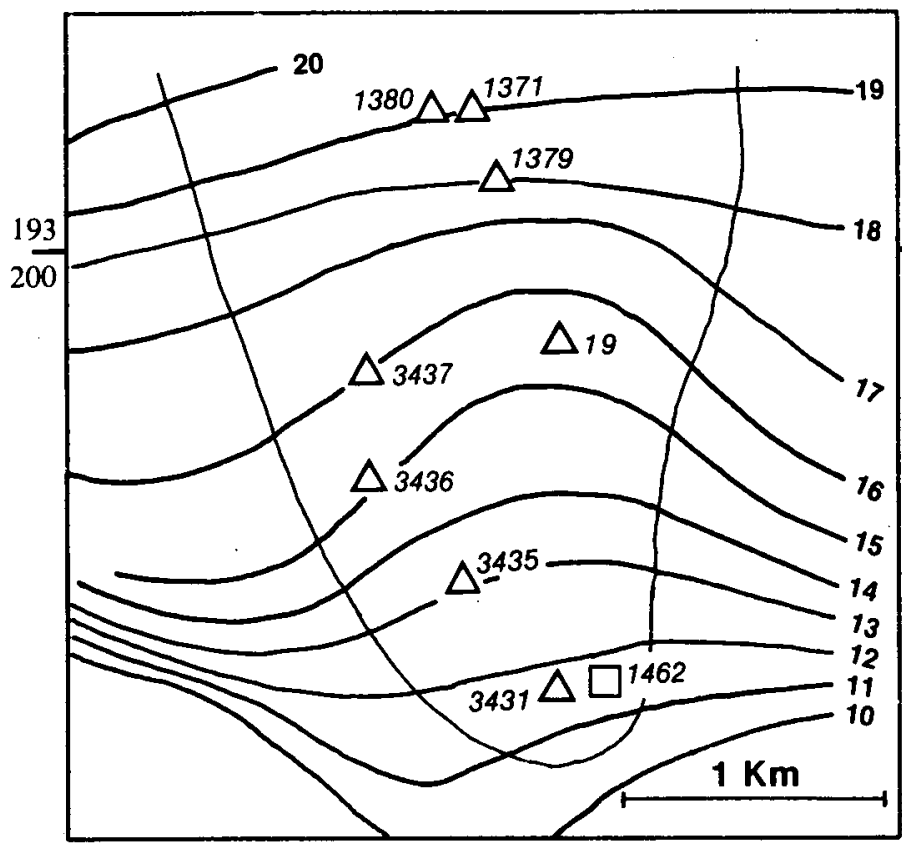

DGU nr. 193. og 200.

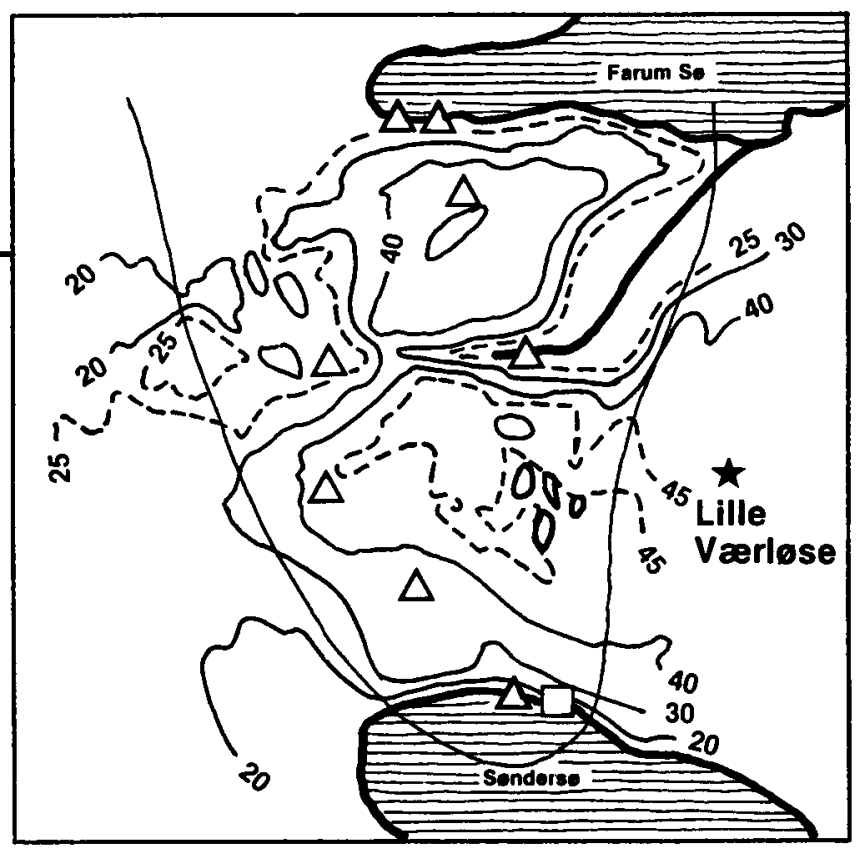

Areal $9 \mathrm{~km}^{2}$

Geologi: De øverste prækvartære lag består af kalksandskalk af Danien alder. Området ligger inden for en tektonisk betinget øst-vestgående dal, som følges fra Øresundskysten til Roskilde Fjord. Dalen har under istiden været en tunneldal og under afsmeltningen en smeltevandsdal, hvor der er blevet aflejret smeltevandssedimenter med tynde lokale indlejrede lag af moræneler. Den glaciale lagserie afsluttes generelt med et morænelerslag, hvorover der ved Farum $S \emptyset$ findes postglaciale tørv og gytje. Landskabet er et storbakket morænelandskab.

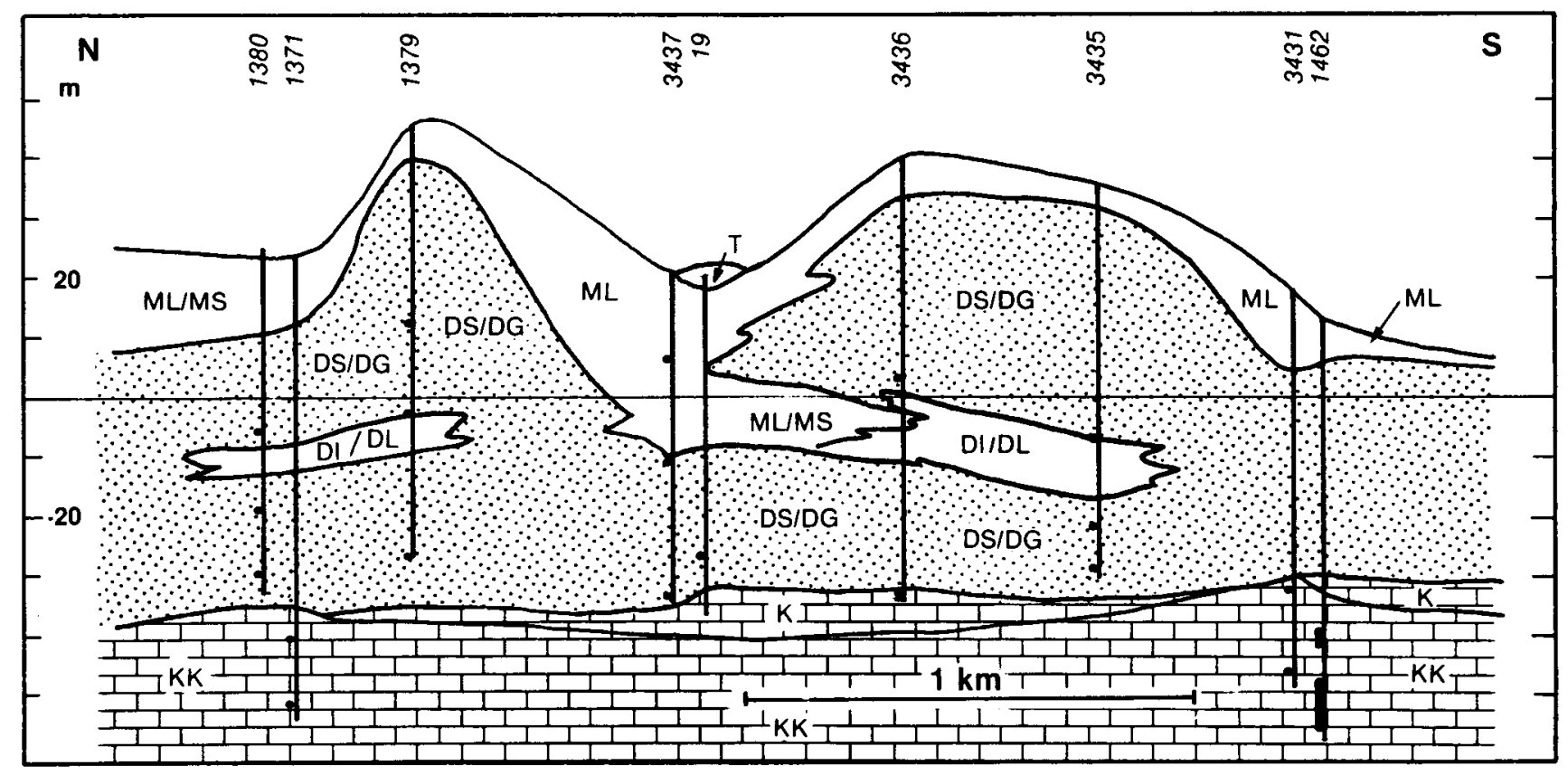


Hydrogeologi: Hovedreservoiret består af Danienkalk og kvartære smeltevandssedimenter der er hydraulisk sammenhangende. I dette reservoir er der de fleste steder frie til semiartesiske forhold, mens det er helt artesisk, hvor kalkoverfladen er dybtliggende. Der findes lokale sekundære smeltevandssand og -grus reservoirer adskilt af moræneler.

Grundvandskemi: Grundvandet er af calcium-bikarbonattypen og har et meget ringe indhold af fosfor og nitrat. I den sydlige del af området er sulfatindholdet relativt højt, hvilket antagelig skyldes den store indvinding, som giver mulighed for iltning af pyrit $i$ aflejringerne.

Vandbalance mm/år:

Koncentrationen af udvalgte stoffer i forhold til dybde under terræn.

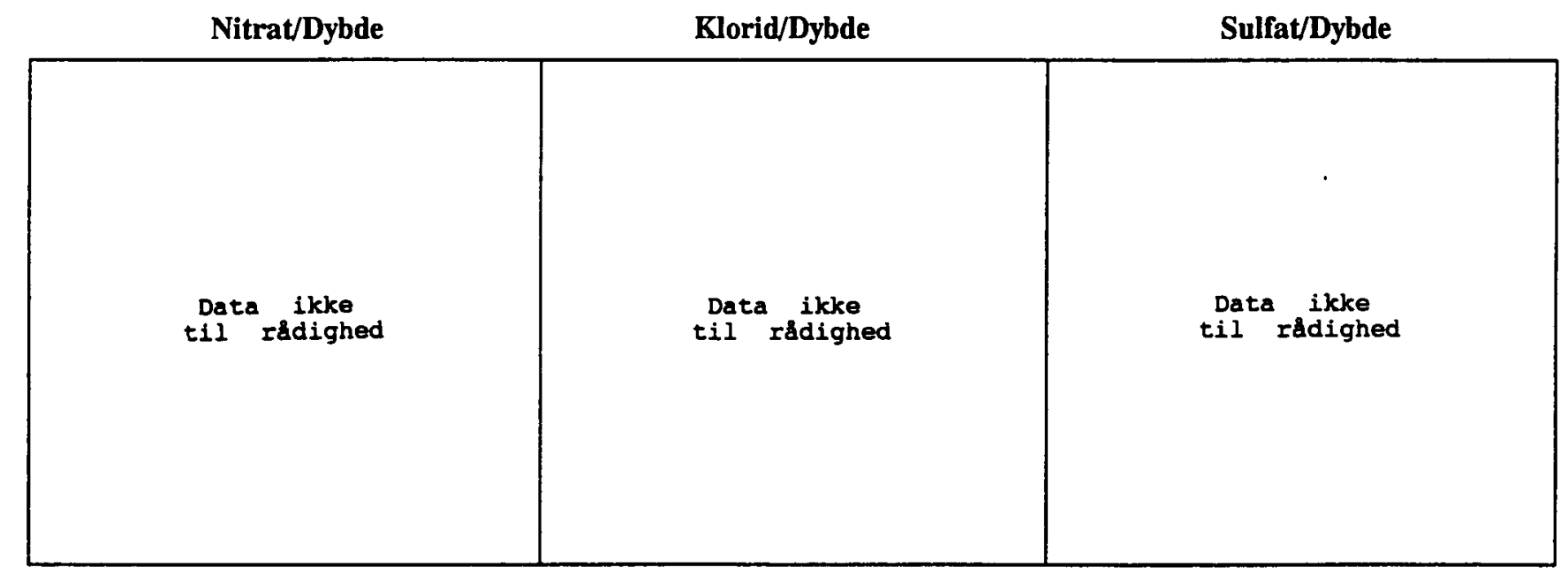




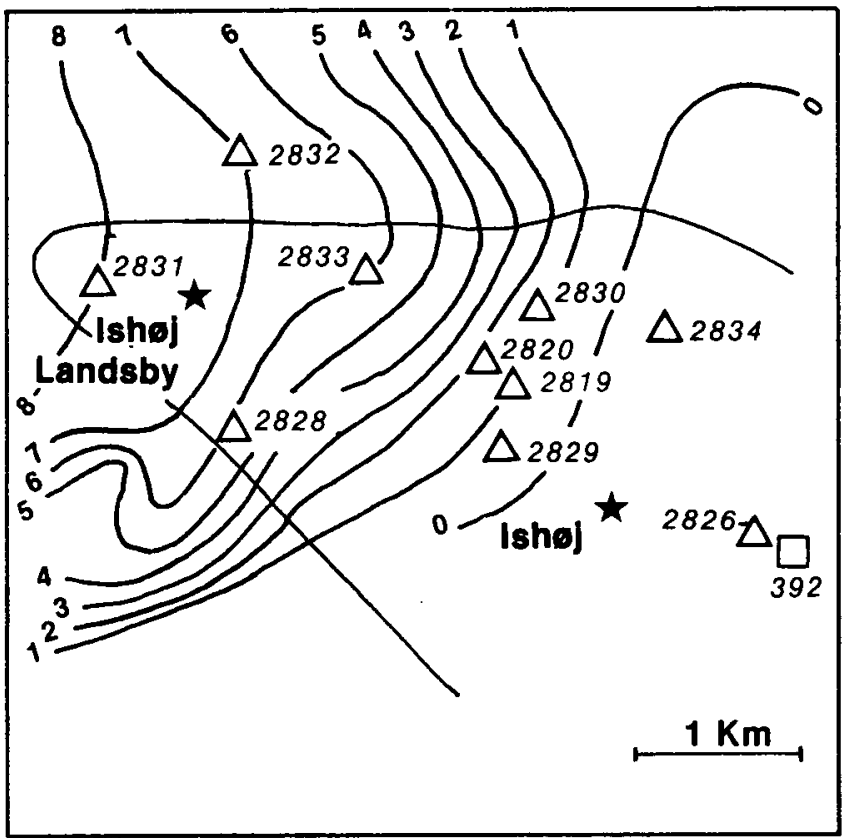

DGU nr. 207

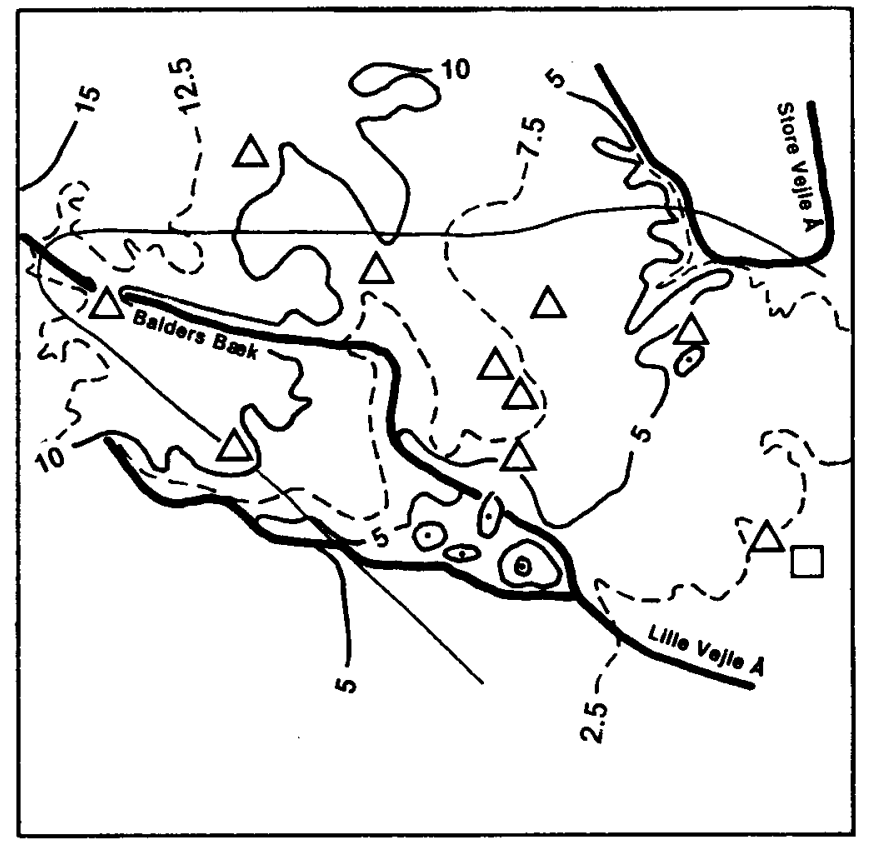

Areal $18 \mathrm{~km}^{2}$

Geologi: Den øverste prækvartære lagserie består af skrivekridt af Senon alder og kalksandskalk, bryozokalk og coccolitkalk af Danien alder. På østsiden af den nord-syd forløbende Køge Bugt-forkastning ligger de kvartære aflejringer direkte ovenpå skrivekridtet. De kvartære aflejringer består af moræneler med indlejrede 0,5-2 meter tykke lag af smeltevandssedimenter. Ved Store Vejleå tynder de kvartære sedimenter helt ud. Området har små niveau forskelle og udgør et bundmorænelandskab.

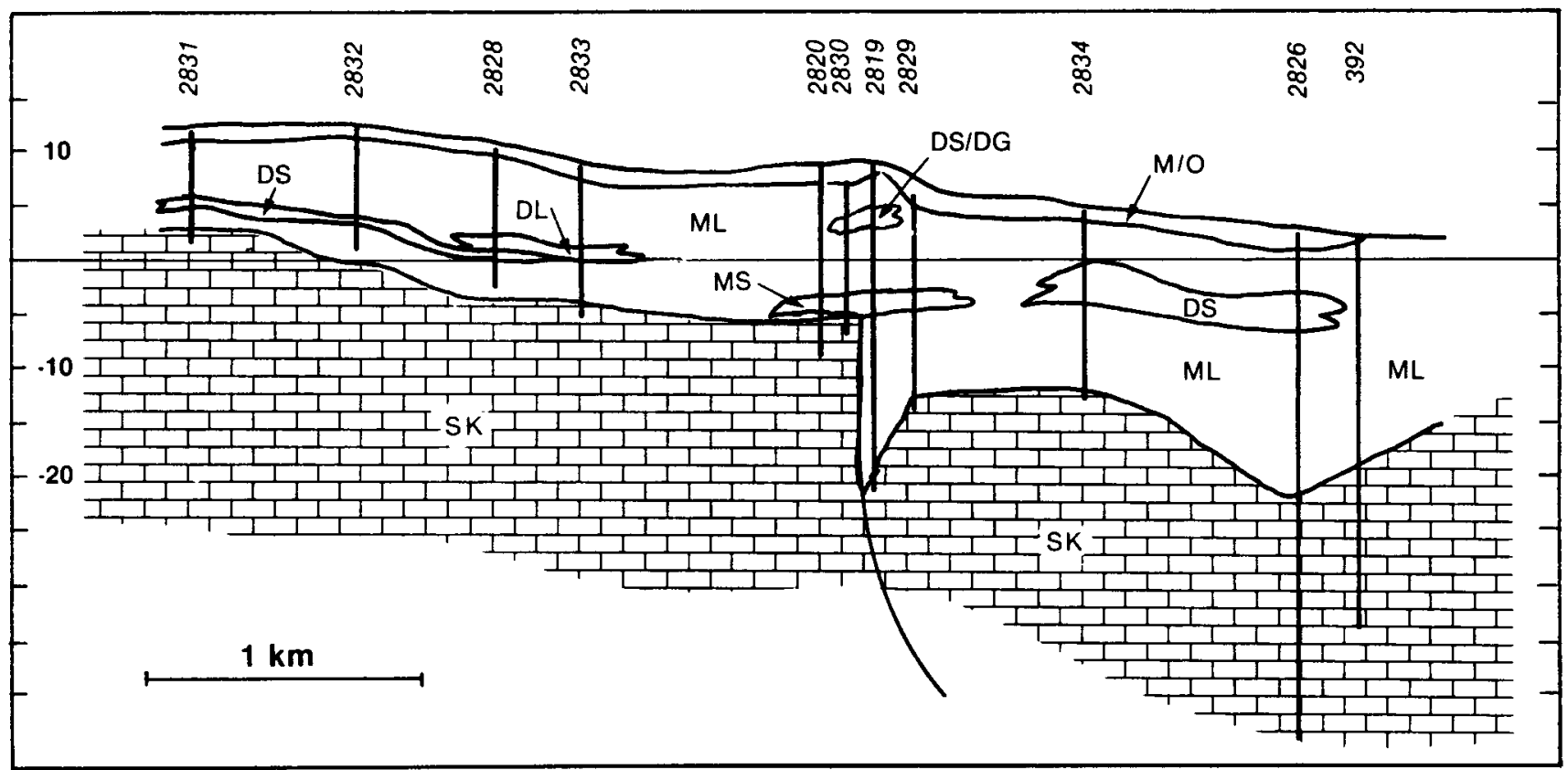


Hydrogeologi: Kalkstenene udgør tilsammen hovedreservoiret, der dels er artesisk, dels frit. På grund af den strukturelle opbygning og den individuelle udbredelse af de enkelte lag andrer de hydrauliske forhold sig over små afstande.

Grundvandskemi: Grundvandet er overvejende af calcium-bikarbonattypen, idet det dog indeholder mere og mere natrium og kalium jo mindre afstanden til Køge Bugt er: Der er altså en gradvis overgang til natriumbikarbonattypen. Det antages, at dette forhold skyldes ionbytning eller at moræneleret er af marin oprindelse. Det store fluoridindhold er proportionalt med natrium og kalium koncentrationen. Tritium analyser viser, at grundvandet er ungt.

Vandbalance $\mathrm{mm} / \mathrm{år}:$

Middelnedbør 650

Kildeplads: Ishøj Strand nord,

\section{Arealanvendelse \%:}

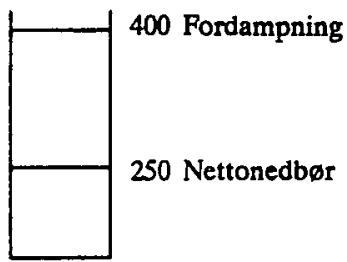

400 Fordampning

Landbrug

og natur

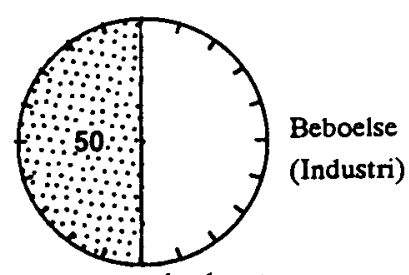

Registrerede depoter. to gamle depoter, et med industriaffald og et med blandet affald.

Koncentrationen af udvalgte stoffer i forhold til dybde under terræn.

Nitrat/Dybde

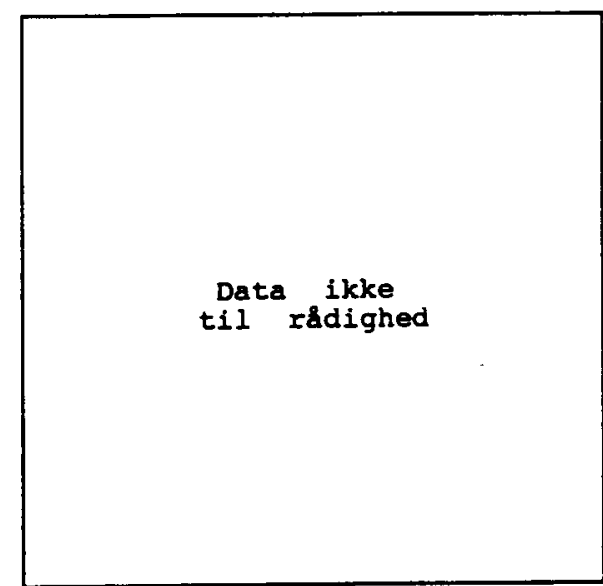

Klorid/Dybde

Sulfat/Dybde

Data ikke

til rodighed
Data ikke
til rådighed 

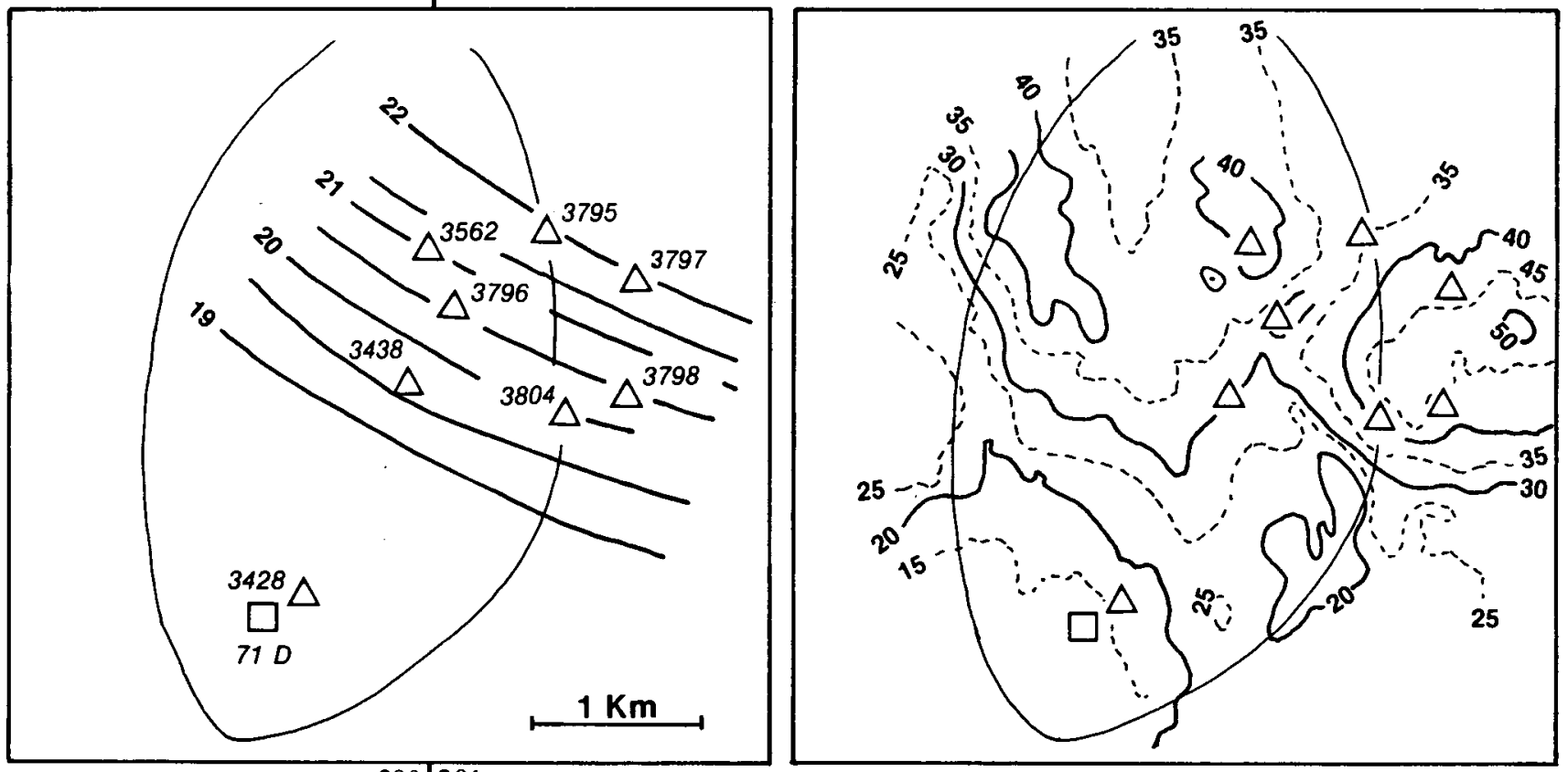

DGU nr. 200/201

Areal $9 \mathrm{~km}^{2}$

Geologi: Danienkalken udgør det øverste prækvartære lag i området. Den øverste del af kalken er i reglen opsprækket. Den kvartære lagserie består af moræneler, hvori der er isolerede lag af moræne- eller smeltevandssand. Moræneleret kiler delvis ud mod sydvest. Herover findes der smeltevandssand og øverst lokalt tørv og gytjeaflejringer. Landskabeligt er området et småbakket morænelandskab med mosehuller.

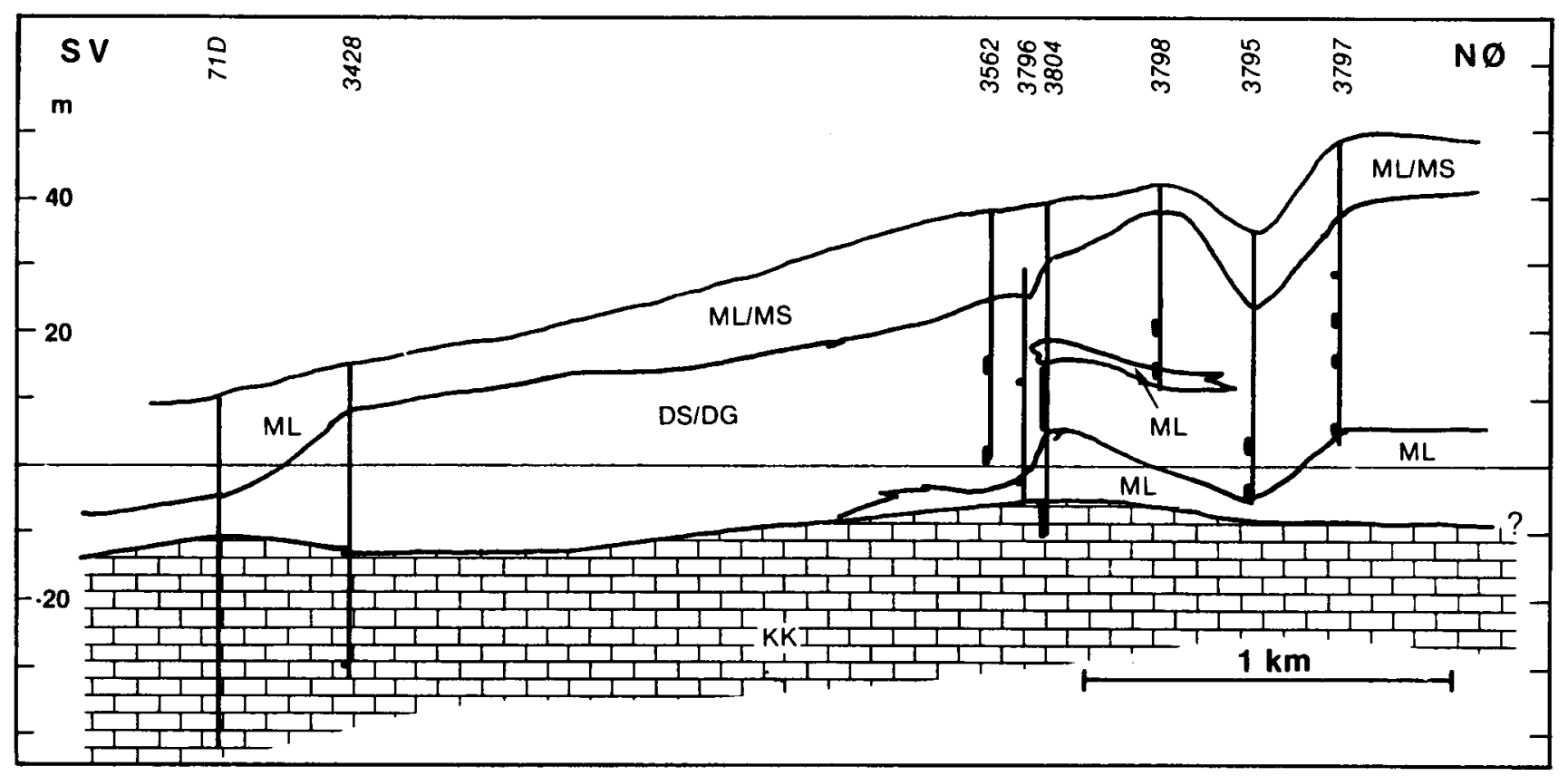


Hydrogeologi: Hovedreservoiret består af Danienkalk og er artesisk. Det sekundære reservoir består af smeltevandssand og har frit grundvandsspejl $i$ den vestlige og artesiske forhold i den østlige del af området. Der er generelt nedadrettet grundvandsstrømning fra det kvartære reservoir til kalkreservoiret og $\mathrm{i}$ den sydvestlige del af området er der direkte hydraulisk forbindelse mellem de to reservoirer. Der er nogen usikkerhed om potentialeforholdene $i$ begge reservoirer, og kortet viser dem $i$ sandreservoiret.

Da overvågningen foregår $\mathrm{i}$ et byområde er det uvist, hvor stor en del af nettonedbøren der bortledes gennem kloakker.

Grundvandskemi: Grundvandet $\mathrm{i}$ området er påvirket af en kraftig forurening fra erhvervskvarteret. Således forurener en losseplads der har ligget på Columbusvej, det sekundære grundvandsreservoir. Gladsaxe kommune har kortlagt arealanvendelsen $i$ et større område (inklusive overvågningsområdet) og hermed

Vandbalance mm/år:

Middelnedbør 680

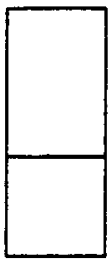

Kildepladser. XIII, KBH vfs.,
Arealanvendelse \%:

400 Fordampning

280 Nettonedbør (50\% erhv.)
Udbygget efter 1940

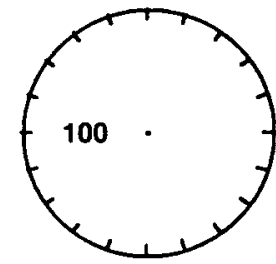

Registrerede depoter: forurening fra kemikaliedepoter og industrigrunde.

bl.a. stedfæstet kemikaliedepoter. Der er herigennem fundet forurenede stoffer $i$ grundvandet $i$ det sekundære reservoir samt et enkelt sted også en lav koncentration af fenoler $i$ hovedreservoiret. Der er iværksat afværgeoppumpning på indtil videre 50 kubrikmeter i timen i det sekundære reservoir for at hindre, at forureningen breder sig til hovedreservoiret.

Koncentrationen af udvalgte stoffer i forhold til dybde under terræn.

\section{Nitrat/Dybde}

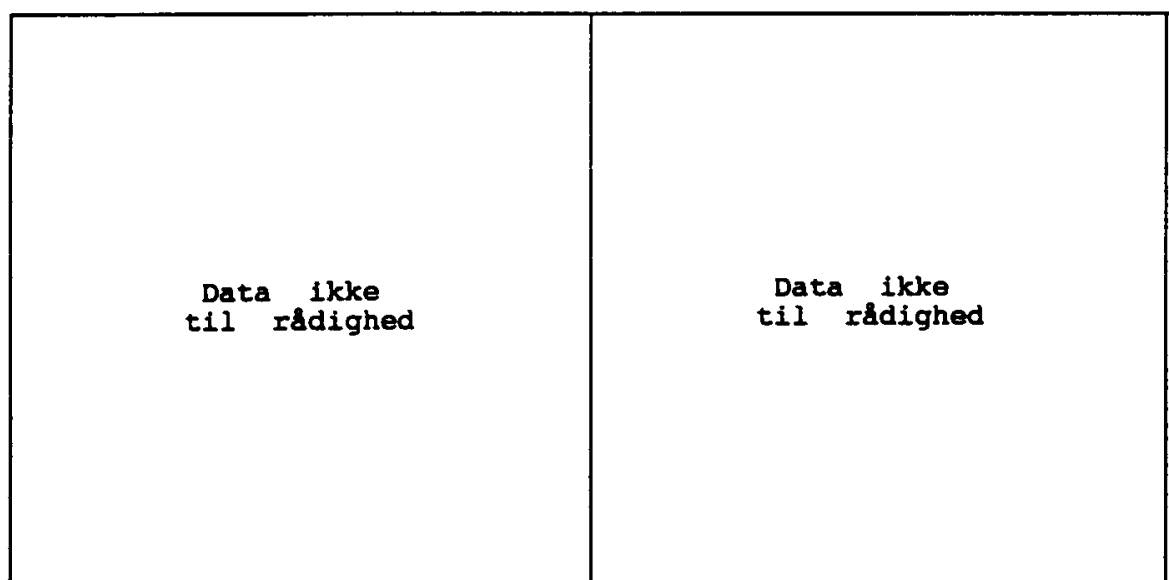

Sulfat/Dybde

Data ikke

til rådighed 

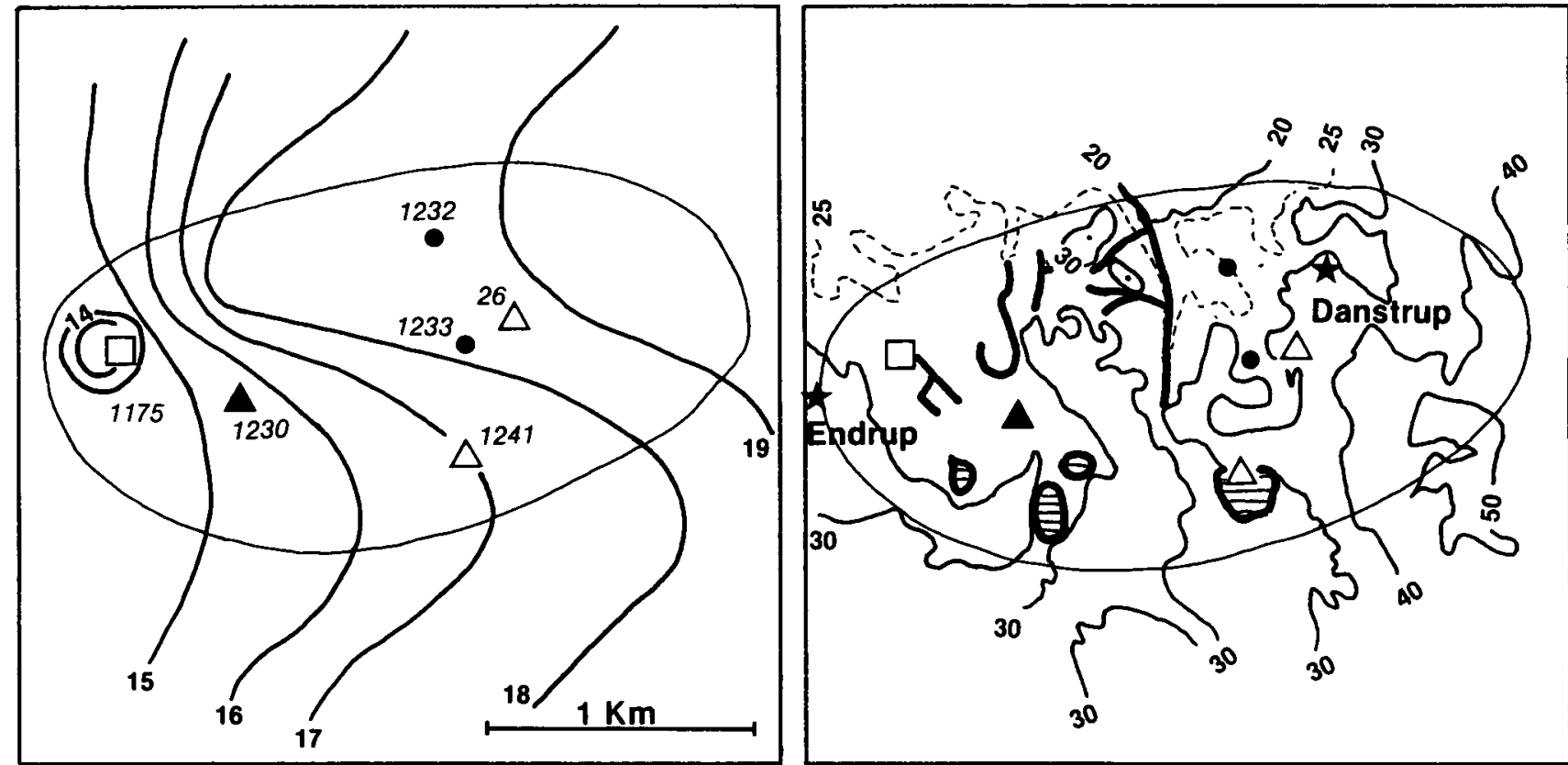

DGU nr. 187

Areal $3 \mathrm{~km}^{2}$

Geologi: Det øverste prækvartære lag i området består af Danienkalk. Den kvartære lagserie består nederst af smeltevandsler. Herover findes det såkaldte Alnarpsand der overlejres af moræneler og/eller smeltevandsler og -silt. Der er indlejret enkelte isolerede lommer af smeltevandsaflejringer i moræneleret.

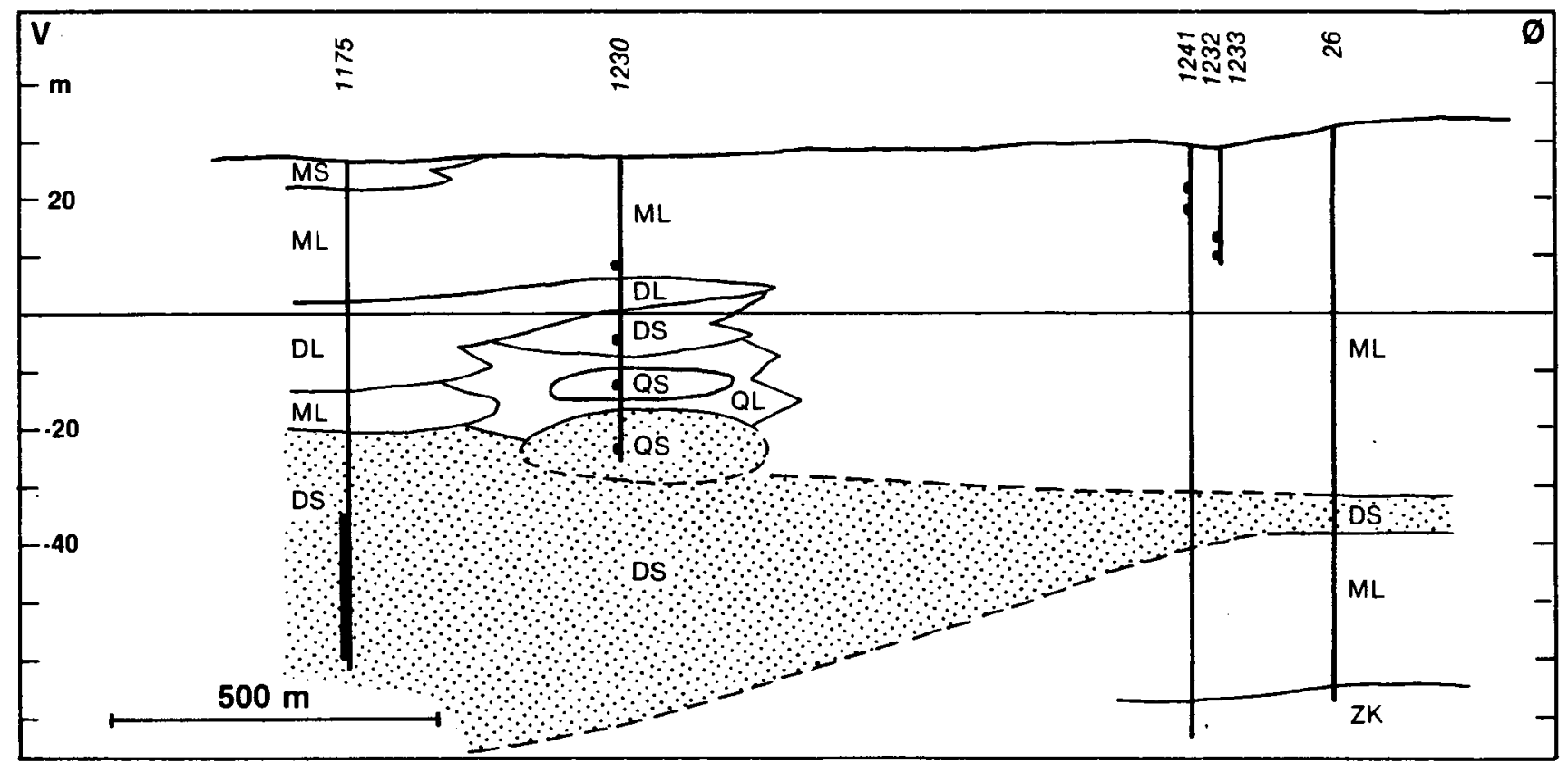


Hydrogeologi: Hovedreservoirerne i området findes i Danienkalken og Alnarpsandet, som antagelig flere steder er hydraulisk forbundne. De sekundære reservoirer findes $\mathrm{i}$ de isolerede smeltevandsaflejringer.

Grundvandskemi: Grundvandet $\mathrm{i}$ området er overvejende af calcium-bikarbonattypen og har et højt jern- og manganindhold. Alle reservoirerne er velbeskyttede mod overfladeforurening. I Alnarpsandet kan dog forekomme ionbyttet grundvand med natriumbikarbonat.

Vandbalance mm/år:

Middelnedbør 740

\section{Arealanvendelse \%:}

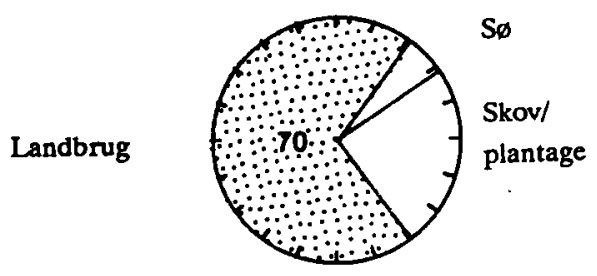

Registrerede depoter: ingen

$\underline{\text { Koncentrationen af udvalgte stoffer } i \text { forhold til dybde under terran. }}$

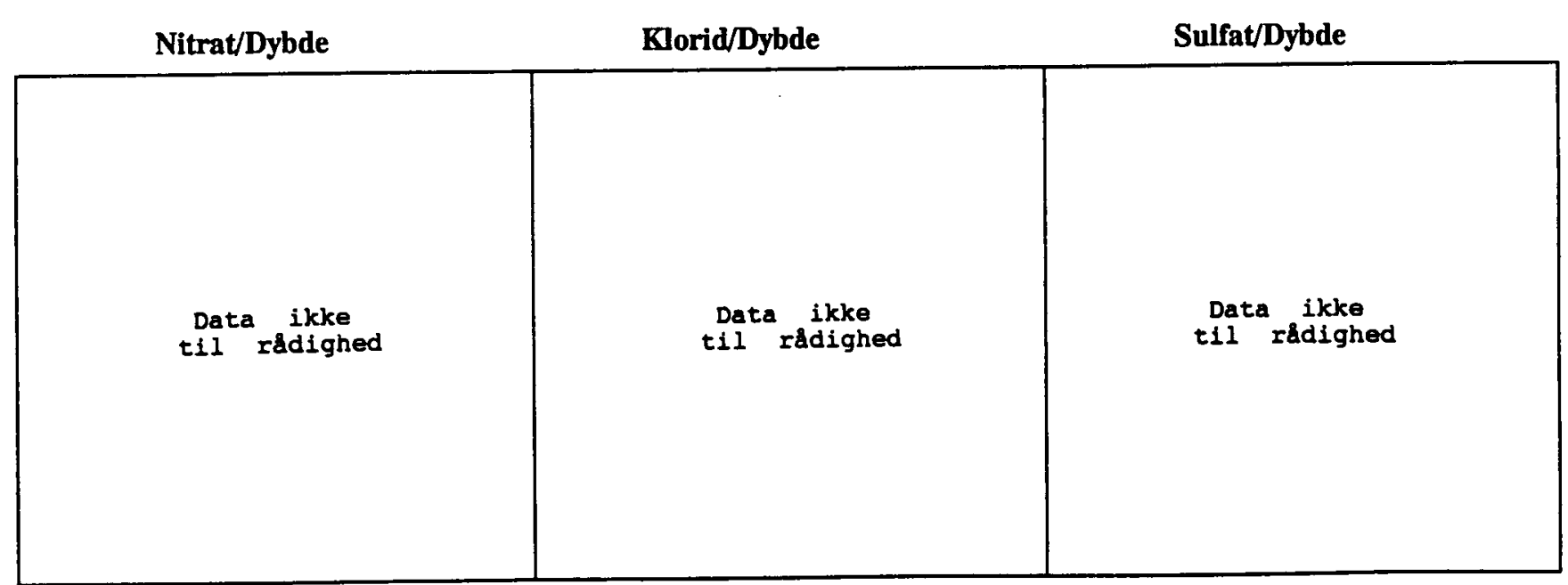



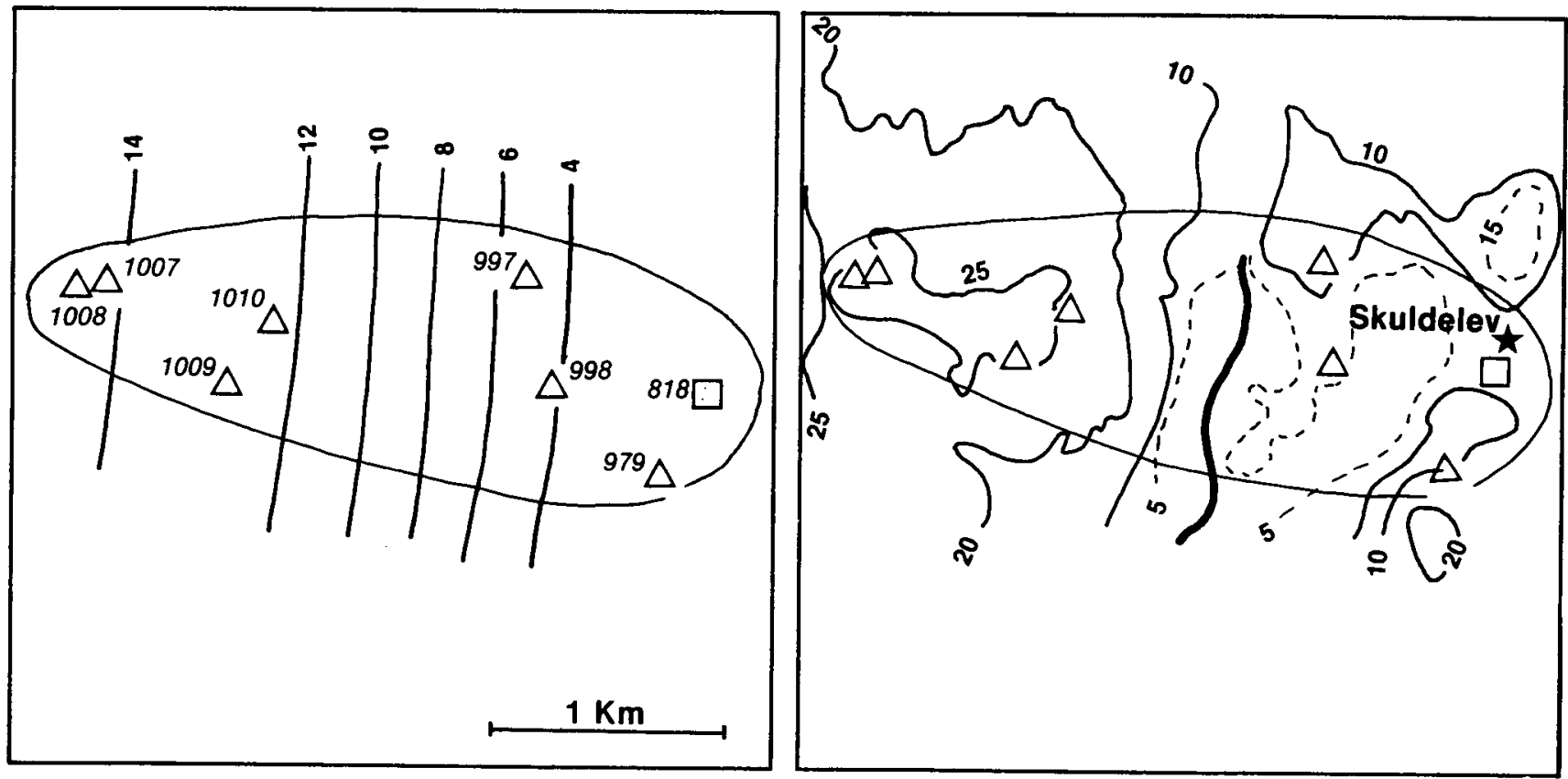

DGU nr. 199

Areal $2 \mathrm{~km}^{2}$

Geologi: De øverste prækvartære lag i området består af Danien kalksandskalk, der enkelte steder overlejres af grønsandskalk fra Selandien. Den kvartære lagserie består nederst af smeltevandssand, hvorover der i den østlige del af området ligger moræneler. I den nordlige del af området afsluttes den kvartære lagserie med smeltevandssand. Topografisk er området et småbakket morænelandskab.

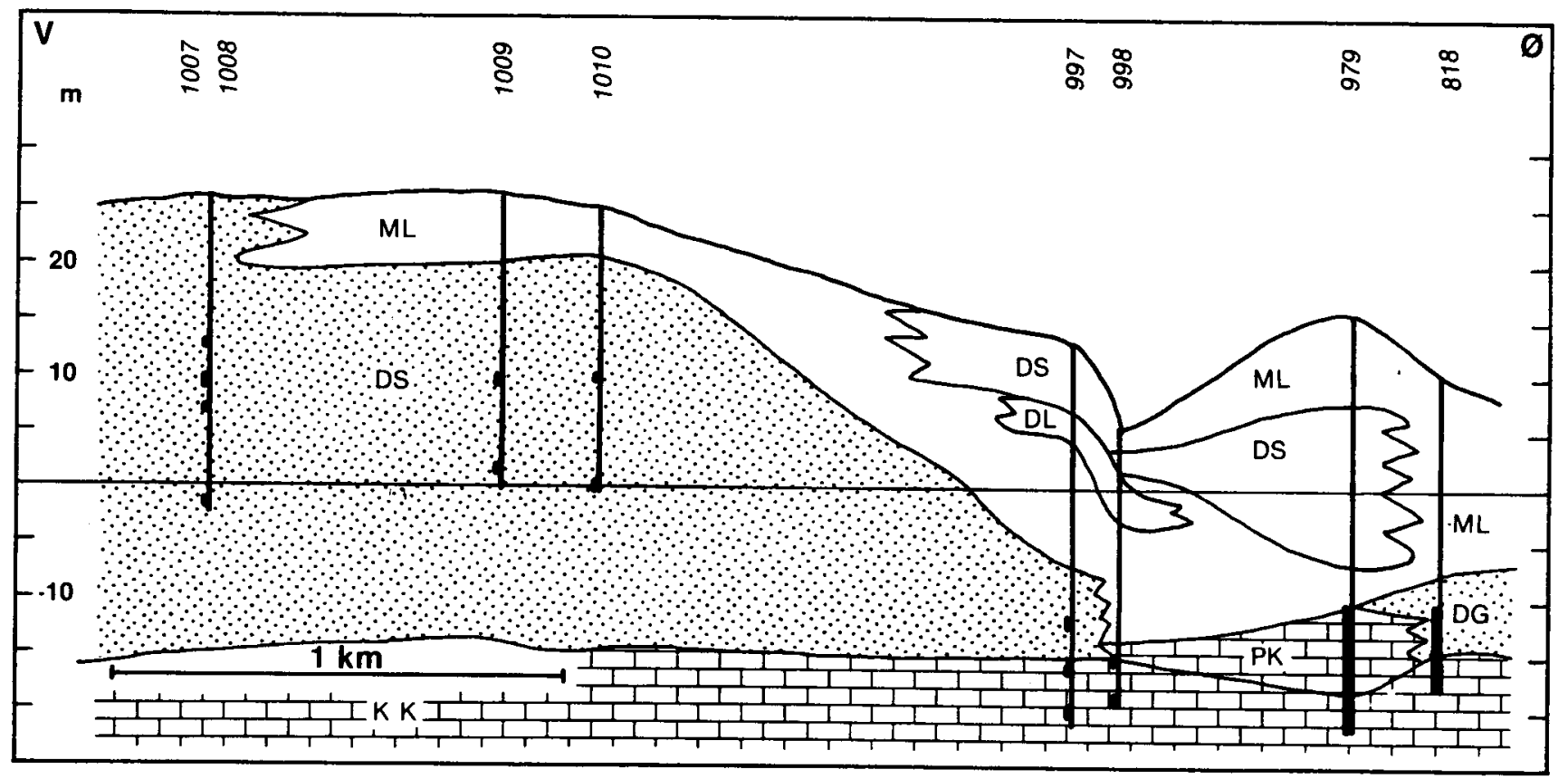


Hydrogeologi: Hovedreservoiret består af både kalksandskalk og grønsandskalk i kombination med de lag af smeltevandssand, hvortil der er hydraulisk forbindelse. Reservoiret har frit grundvandsspejl i den vestlige del af området og artesiske forhold i den østlige. Områdets afgrænsning er usikker.

Grundvandskemi: I hovedreservoiret er grundvandet af calcium-bikarbonattypen og iltret og jernfattigt. I den vestlige del af området, hvor grundvandsspejlet er frit og lerdækket tyndt, er grundvandet nitratholdigt. Grundvandet i den østlige del af området er velbeskyttet og overvejende nitratfrit.

Vandbalance $\mathbf{m m} / \mathbf{a ̊ r}:$

Middelnedbør 680

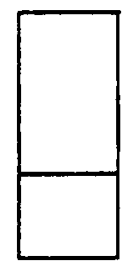

Kildeplads: Skuldelev vv., 0,18 mill. m3/âr

\section{Arealanvendelse \%:}

460 Fordampning

220 Nettonedbør

Landbrug

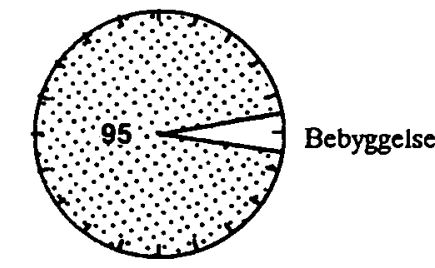

Registrerede depoter: ingen.

Koncentrationen af udvalgte stoffer $i$ forhold til dybde under terran.

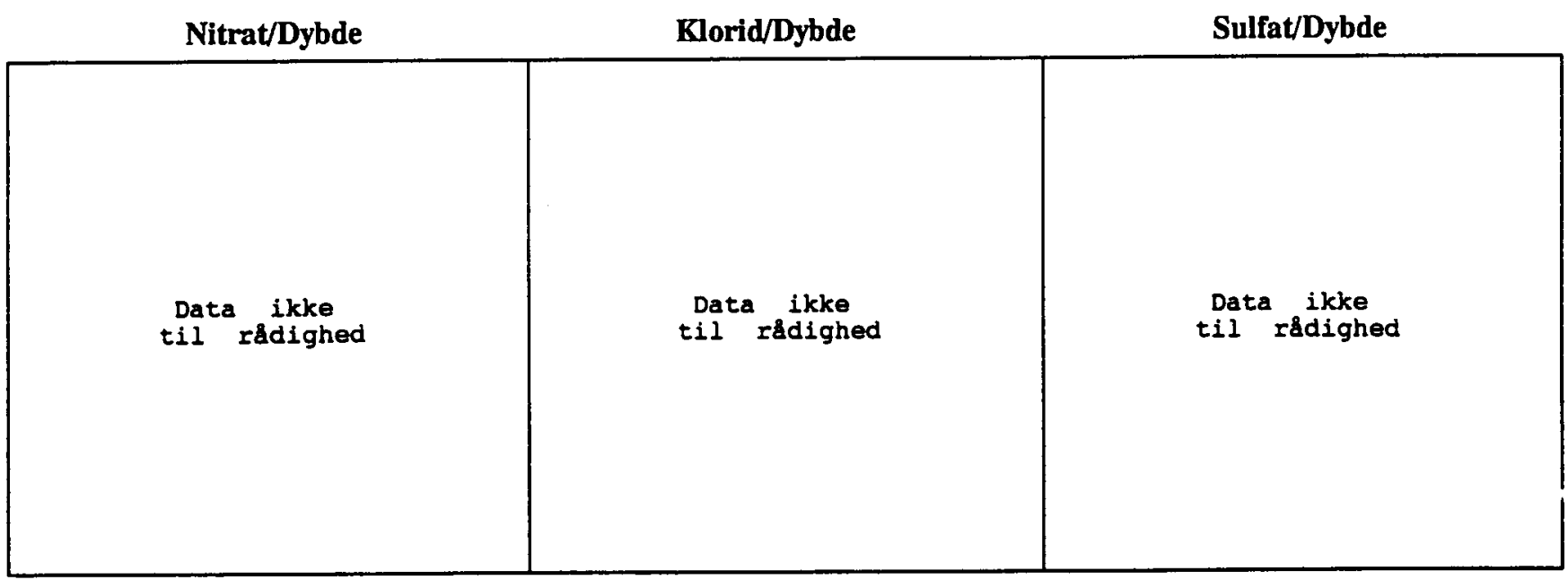




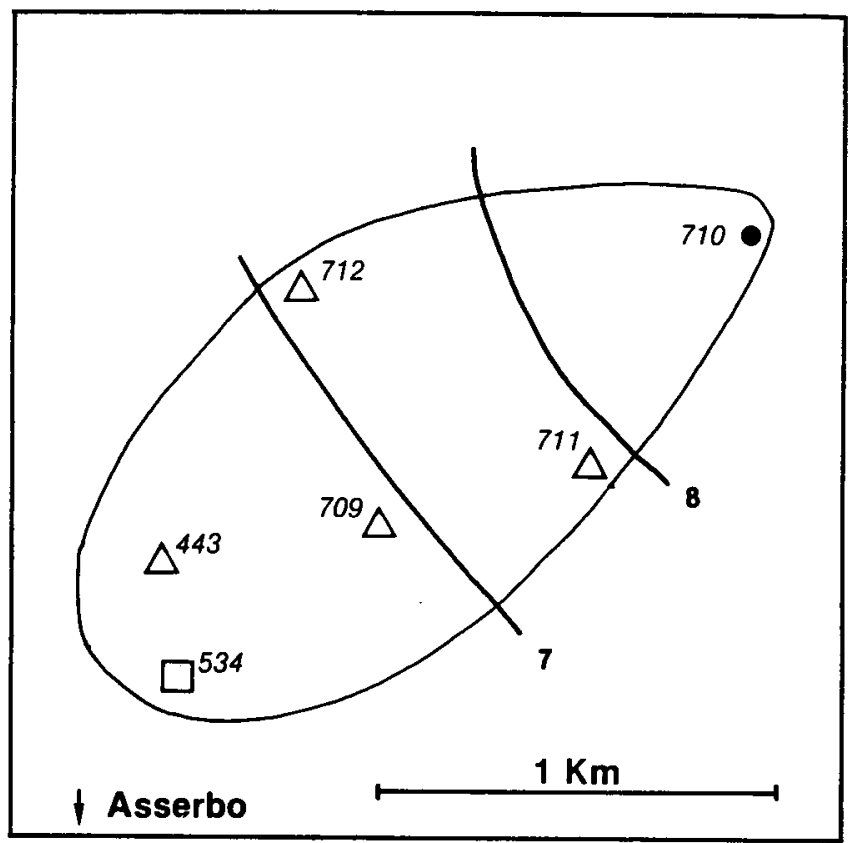

DGU nr. 186

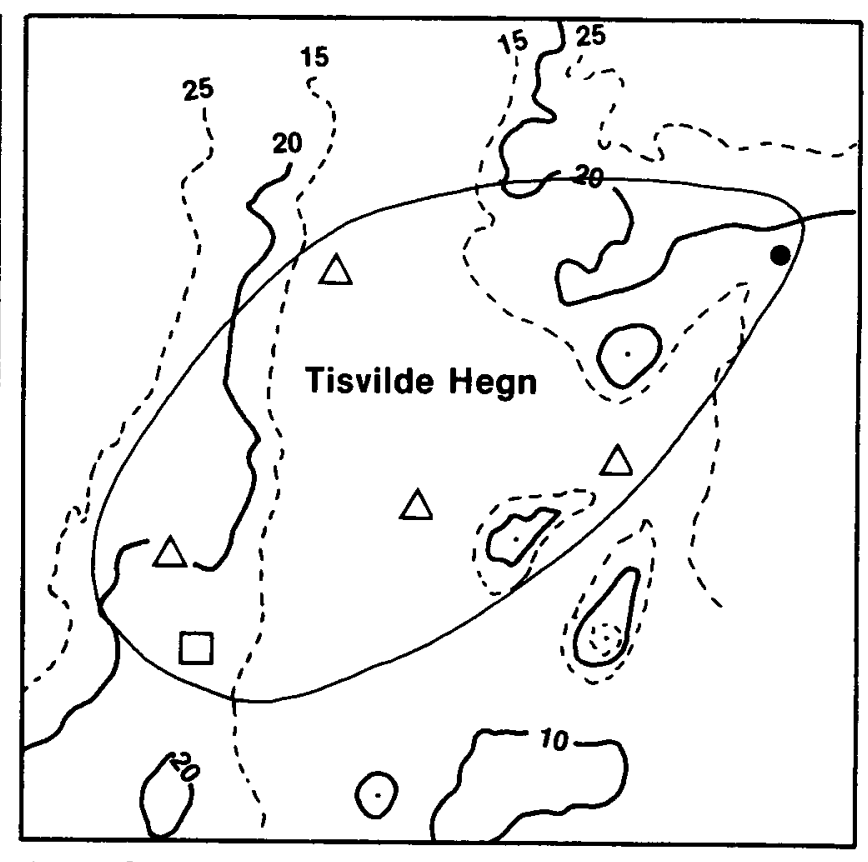

Areal $1,5 \mathrm{~km}^{2}$

Geologi: De øverste prækvartære aflejringer i området består af Danienkalk. Over dette er der moræneler og smeltevandssand. Øverst består lagserien af postglaciale marine og æoliske aflejringer. Området morfologi karakteriseres af en lav litorinaflade med isolerede morænebakkeøer.

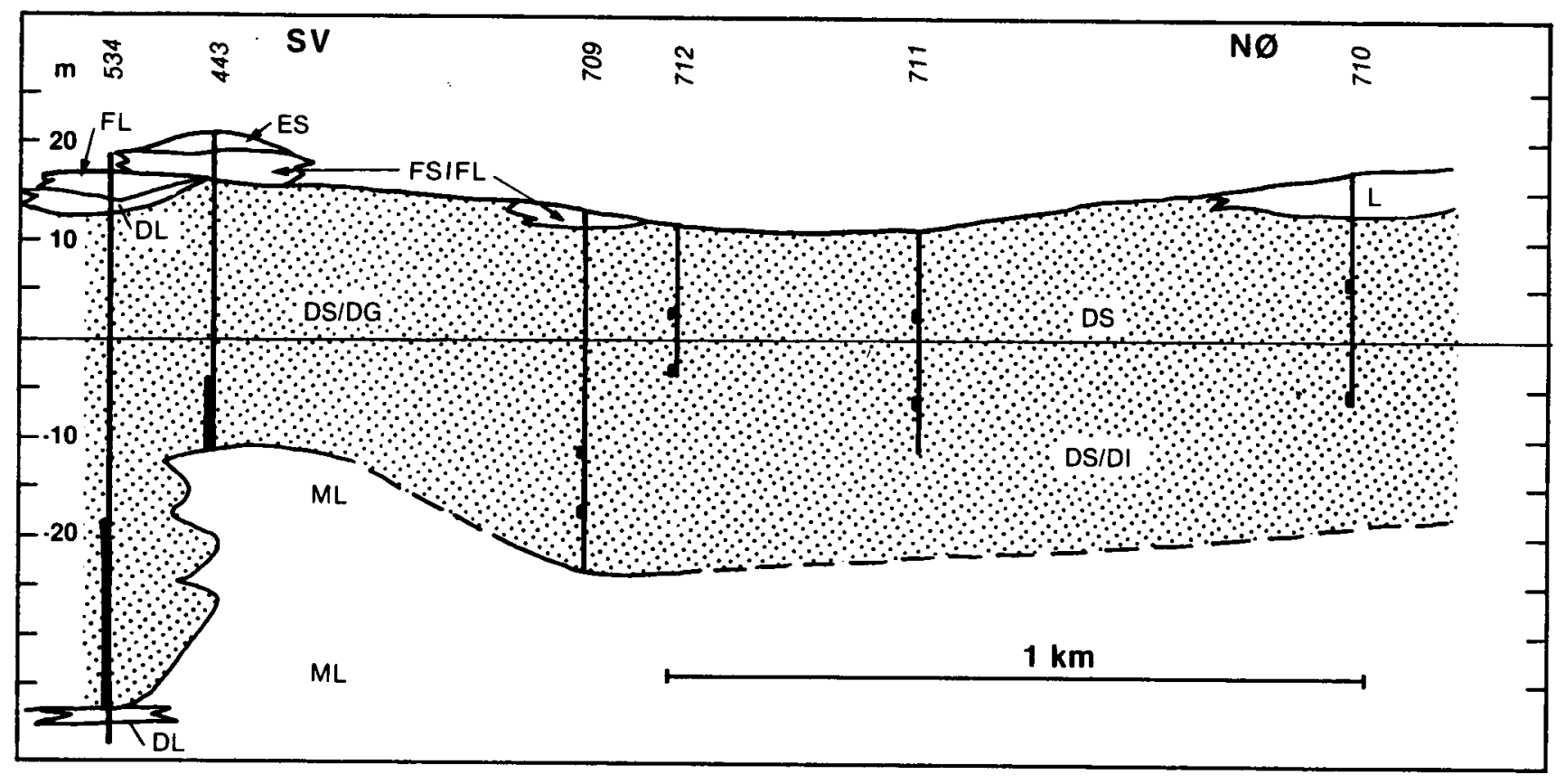


Hydrogeologi: Smeltevandssandet udgør hovedreservoiret, og der er frit grundvandsspejl.

Grundvandskemi: Grundvandet er hovedsagelig af calcium-bikarbonattypen, blødt til temmelig hårdt. Grundvandet er overvejende nitratfrit, men indeholder lidt nitrat ned til 15 meter under terræn. pH varierer meget $(7,1-8,1)$ ned til 25 mețer under terran. I over 25 meters dybde er $\mathrm{pH}$ ret konstant 7,6. Der er ikke nogen tydelig koncentrationsvariation med dybden for sulfat, fosfor og kalium.

Vandbalance $\mathbf{m m} / \mathbf{a} \mathbf{r}$

Middelnedbør 700

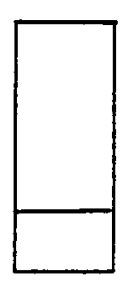

Kildeplads: Asserbo, v.v, 0,17 mill. m3/âr

\section{Arealanvendelse \%}

525 Fordampning

Nåleskov

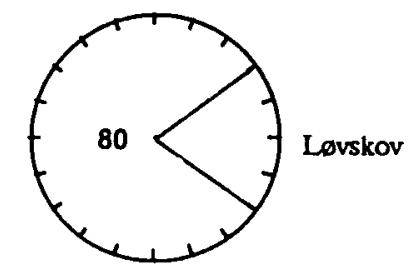

Registrerede depoter. ingen

Koncentrationen af udvalgte stoffer i forhold til dybde under terræn.

Nitrat/Dybde

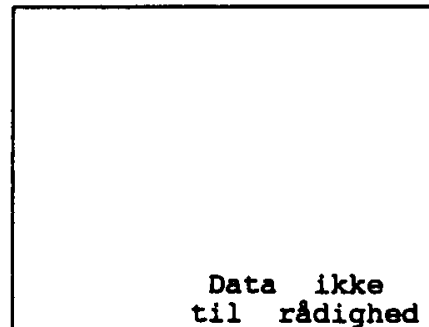

Data ikke
til radighed
Klorid/Dybde

Sulfat/Dybde
Data ikke

til redighed
Data ikke

til radighed 


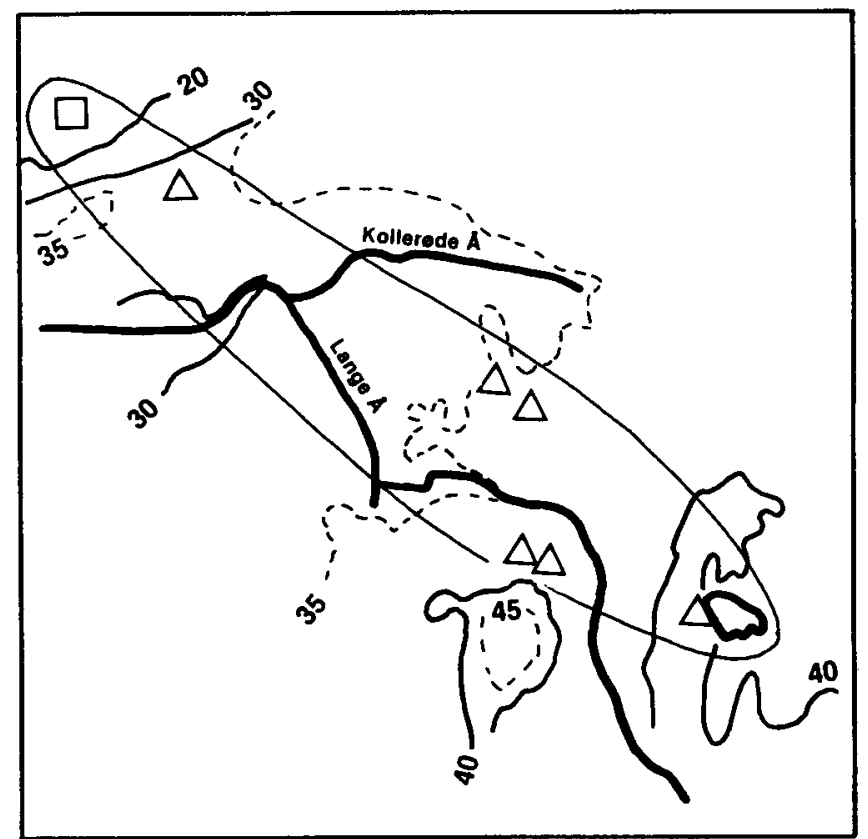

DGU nr. 187

Geologi: Det øverste prækvartære lag i området består af kalksandskalk af Danien alder. Den kvartære lagserie består af smeltevandssand overlejret af moræneler. Topografisk er området et småbakket morænelandskab med et større moseområde $\mathrm{i}$ den vestlige del.

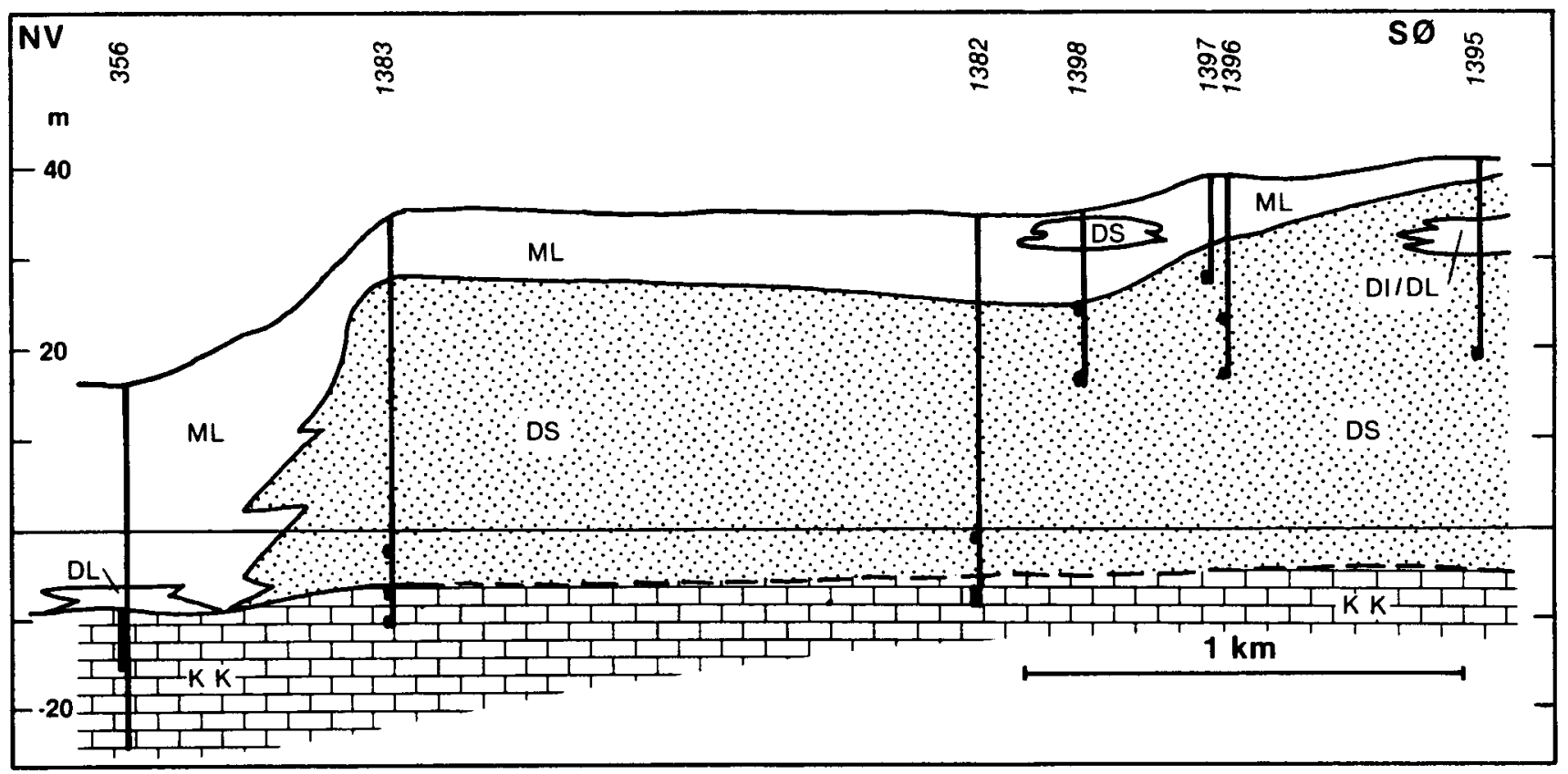


Hydrogeologi: Hovedreservoiret er det højtliggende artesiske kalkreservoir i kombination med det direkte overlejrede smeltevandssand. Grundvandspotentialet nedstrøms Nr. Herlev er tydeligt pávirket af den store indvinding på Attemose kildeplads og det store fald i terrænoverfladen fra morænelandskabet til mosen. Områdets afgrænsning harmonerer ikke med den store oppumpning.

Grundvandskemi: Grundvandet er af kalcium-bikarbonattypen, det er nitratfrit og har et højt indhold af fosfor, der aftager med dybden, og som amtet vurderer er geologisk betinget.

Vandbalance $\mathbf{m m} / \mathbf{a} r$ :

Middelnedbør 730

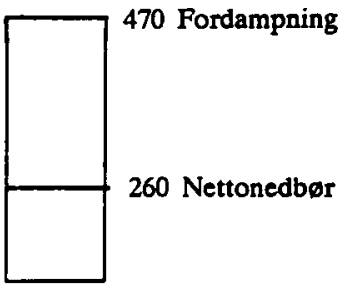

Kildeplads: Attemose, 4,1 mill. m /âr

Østligste del af kildepladsn 0,2 mill. $\mathrm{m} 3 / \mathrm{ar}$.

\section{Arealanvendelse \%:}

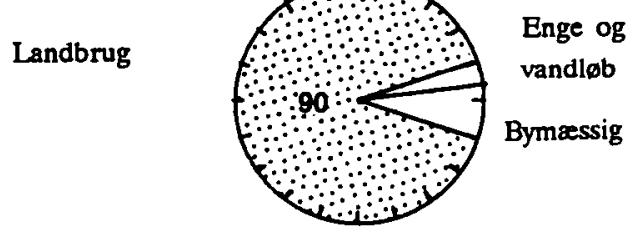

Registrede depoter. ingen

Koncentrationen af udvalgte stoffer i forhold til dybde under terræn.

\begin{tabular}{|l|c|c|}
\hline \multicolumn{2}{|c|}{ Nitrat/Dybde } & Sulfat/Dybde \\
\hline $\begin{array}{c}\text { Data ikke } \\
\text { til radighed }\end{array}$ & $\begin{array}{c}\text { Data ikke } \\
\text { til radighed } \\
\text { Til rádighed }\end{array}$ \\
\hline
\end{tabular}



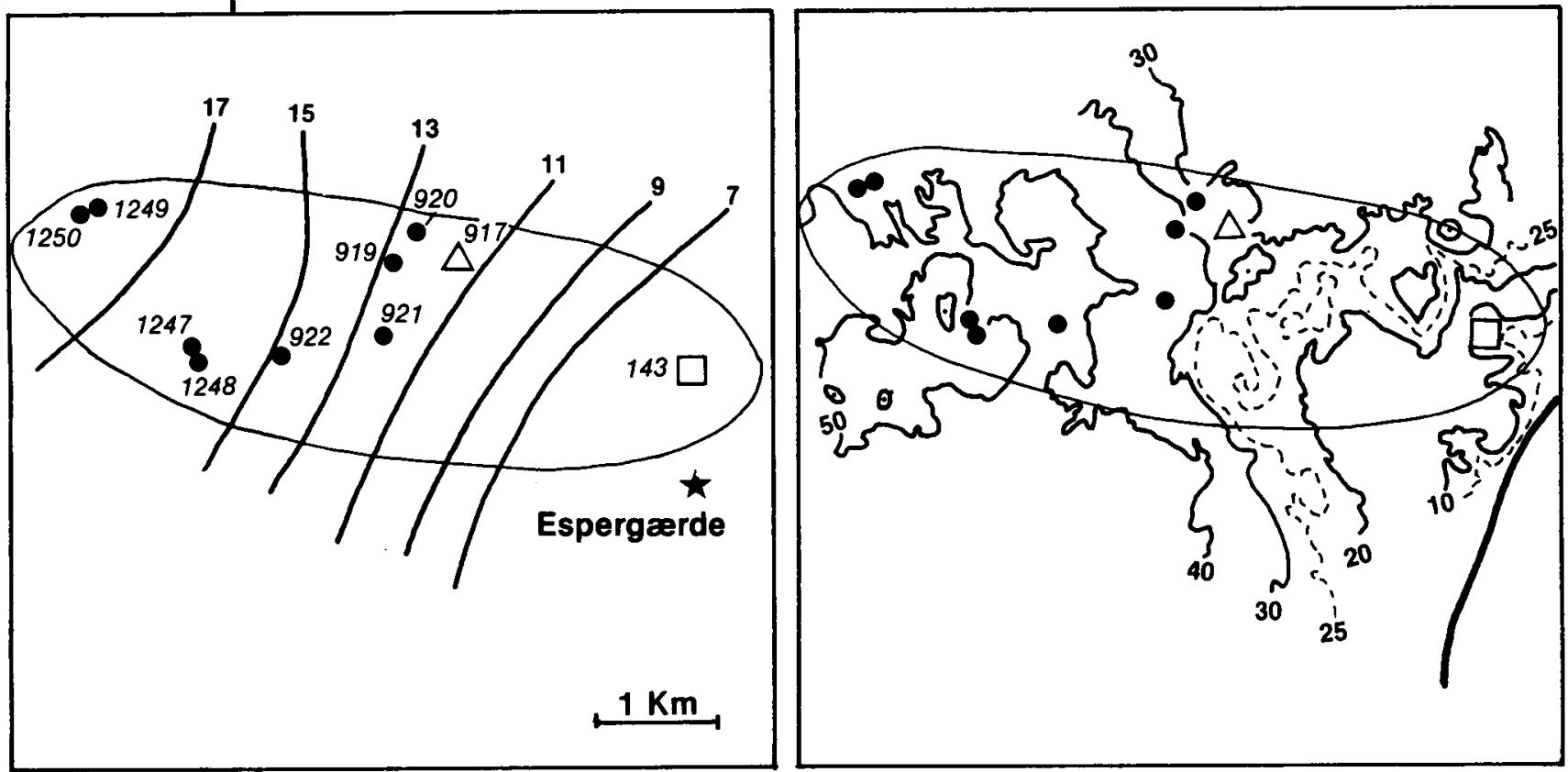

DGU nr.

Areal $11 \mathrm{~km}^{2}$

Geologi: De øverste prækvartære aflejringer består af kalksandskalk af Danien alder. Området er præget af en vestnordvest-østsydøst forløbende tektonisk betinget dal, Alnarpdalen, hvor prækvartæroverfladen er nedforkastet et halvt hundrede meter til kote -60 til -70 meter. Den kvartære lagserie består nederst af en moræneaflejring, herover er der en tyk smeltevandsserie (Alnarpsandet). Alnarpsandet overlejres af et morænelerslag og smeltevandssedimenter. De øverste 5-15 meter består af vekslende lag af moræneler og smeltevandssedimenter. Området kan karakteriseres som et højtliggende småbakket morænelandsskab, der enkelte steder har dødisrelief.

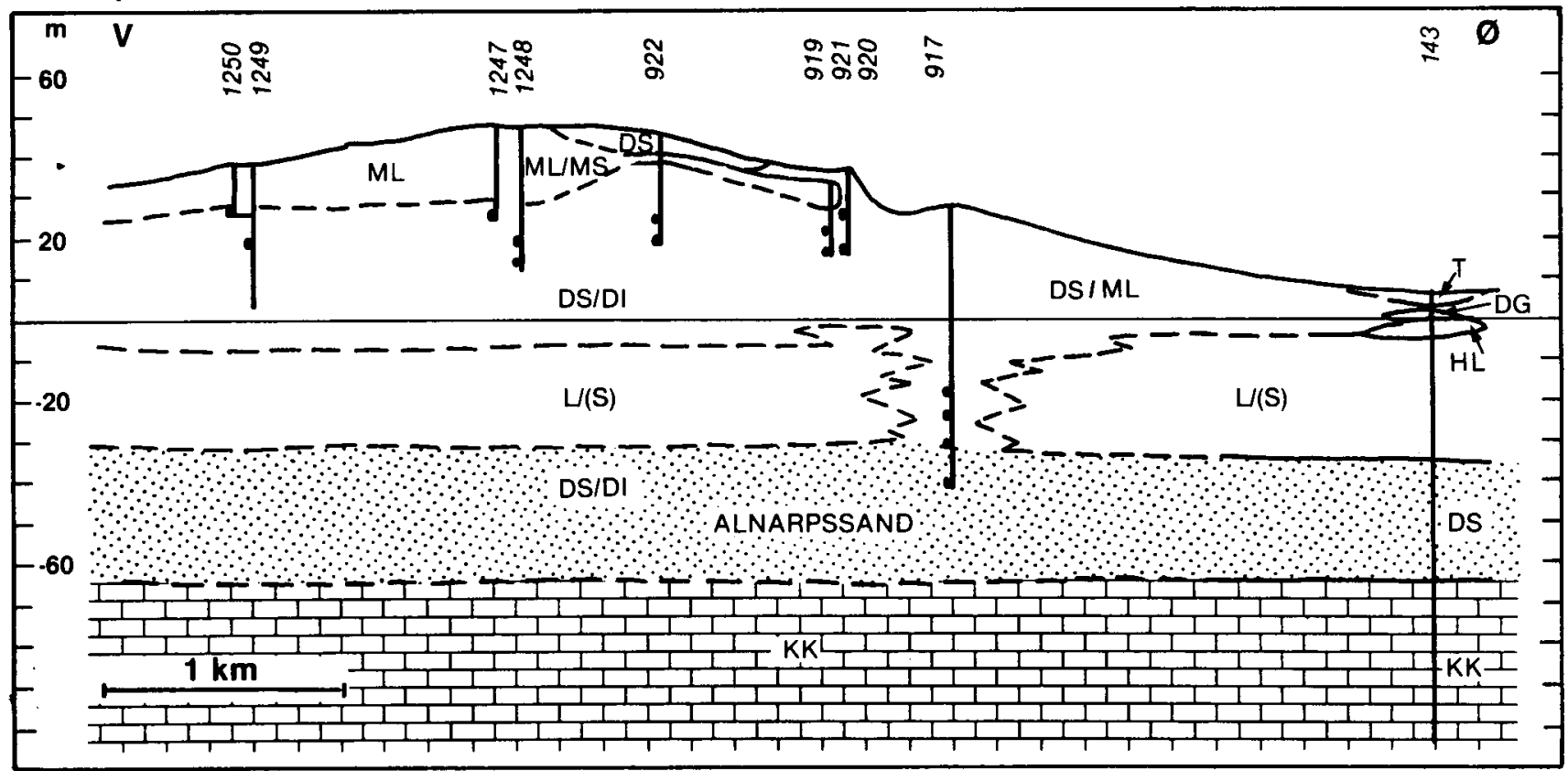


Hydrogeologi: Danienkalken og Alnarpsandet er begge hovedreservoirer. Begge reservoirer er artesiske og stedvis er der hydraulisk forbindelse mellem dem.

I de overlejrende smeltevandssedimenter er der et sekundart reservoir med vekslende artesiske og frie vandspejlsforhold fra sted til sted.

I hovedreservoirerne er potentialeforskellen mellem Danienkalken og Alnarpsandet er lille. I det sekundære reservoir er den hydrauliske gradient på 2-3 promille. Det er dette potentialebillede, der er vist.

Grundvandskemi: Grundvandet er i alle reservoirerne hovedsagelig af calcium-bikarbonattypen, og temmelig hårdt til hårdt. En enkelt boring indeholder vand af natrium-bikarbonattypen. Grundvandet i Danienkalk og

Vandbalance $\mathrm{mm} / \mathrm{år}$ :

Middelnedbør 725

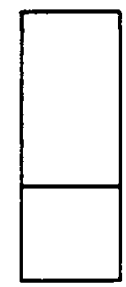

Kildeplads: Espergarde, 1,1 mill. m3/ar

\section{Arealanvendelse\%:}

475 Pordampning

Landbrug

(planter)

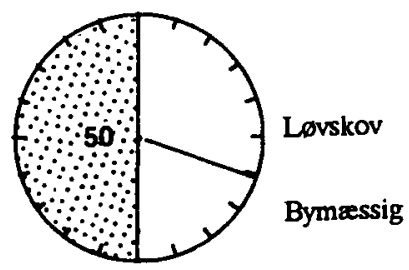

Registrerede depoter: jordfyldt grusgrav ved Nyrup.

Alnarpsand reservoirerne er jernholdigt og nitratfrit. Grundvandet $\mathrm{i}$ det sekundære reservoir indeholder stedvis nitrat (10-55 milligram pr. liter). Tritium analyser viser at grundvandet $\mathrm{i}$ hovedreservoirerne er gammelt og derfor ikke opblandet, og at det derfor antagelig er godt beskyttet, mens det stedvis er ungt og sårbart $\mathrm{i}$ det sekundære reservoir.

Koncentrationen af udvalgte stoffer i forhold til dybde under terræn.

\begin{tabular}{|c|c|c|}
\hline Nitrat/Dybde & Klorid/Dybde & Sulfat/Dybde \\
\hline $\begin{array}{l}\text { Data ikke } \\
\text { til radighed }\end{array}$ & $\begin{array}{l}\text { Data ikke } \\
\text { til rådighed }\end{array}$ & $\begin{array}{l}\text { Data ikke } \\
\text { til rádighed }\end{array}$ \\
\hline
\end{tabular}


1513 IV SV

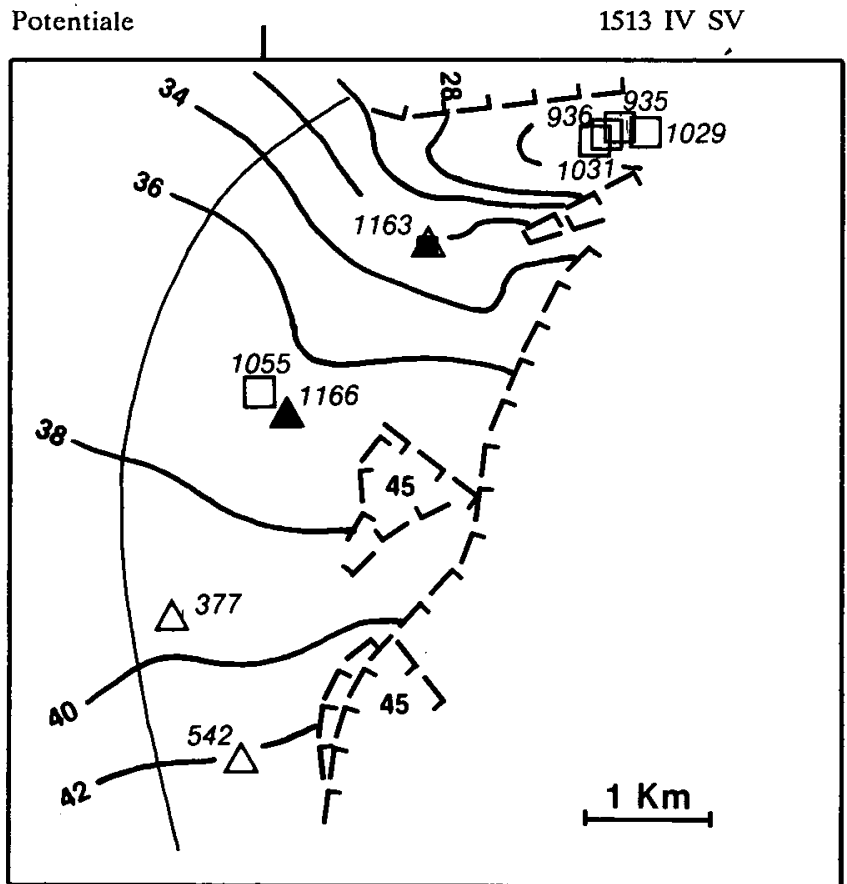

DGU nr. $2 0 5 \longdiv { 2 0 6 }$

Terren

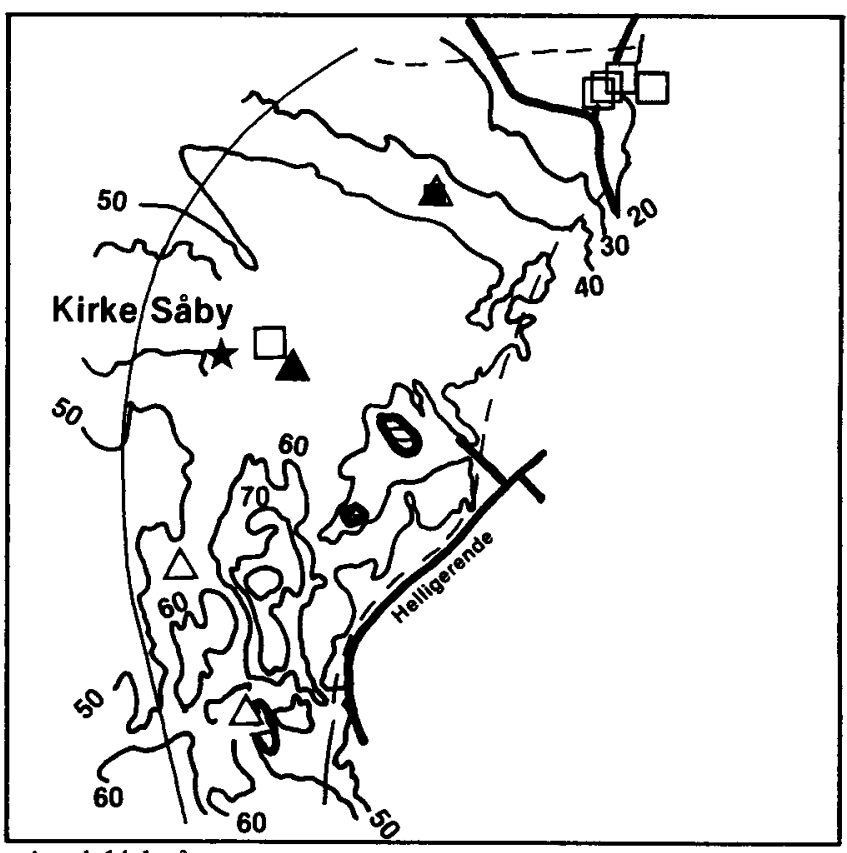

Areal $14 \mathrm{~km}^{2}$

Geologi: De prækvartære aflejringer i området består af Danienkalk overlejret af Selandien grønsandskalk. De kvartære aflejringer udgøres af sandede smeltevandssedimenter, den såkaldte Torkilstrup formation, overlejret af glaciale lerede bjergarter. I den nordlige del af området ligger Torkilstrup formationen direkte oven på grønsandskalken, mens der mod syd er et lag af moræneler mellem sandet og grønsandskalken.

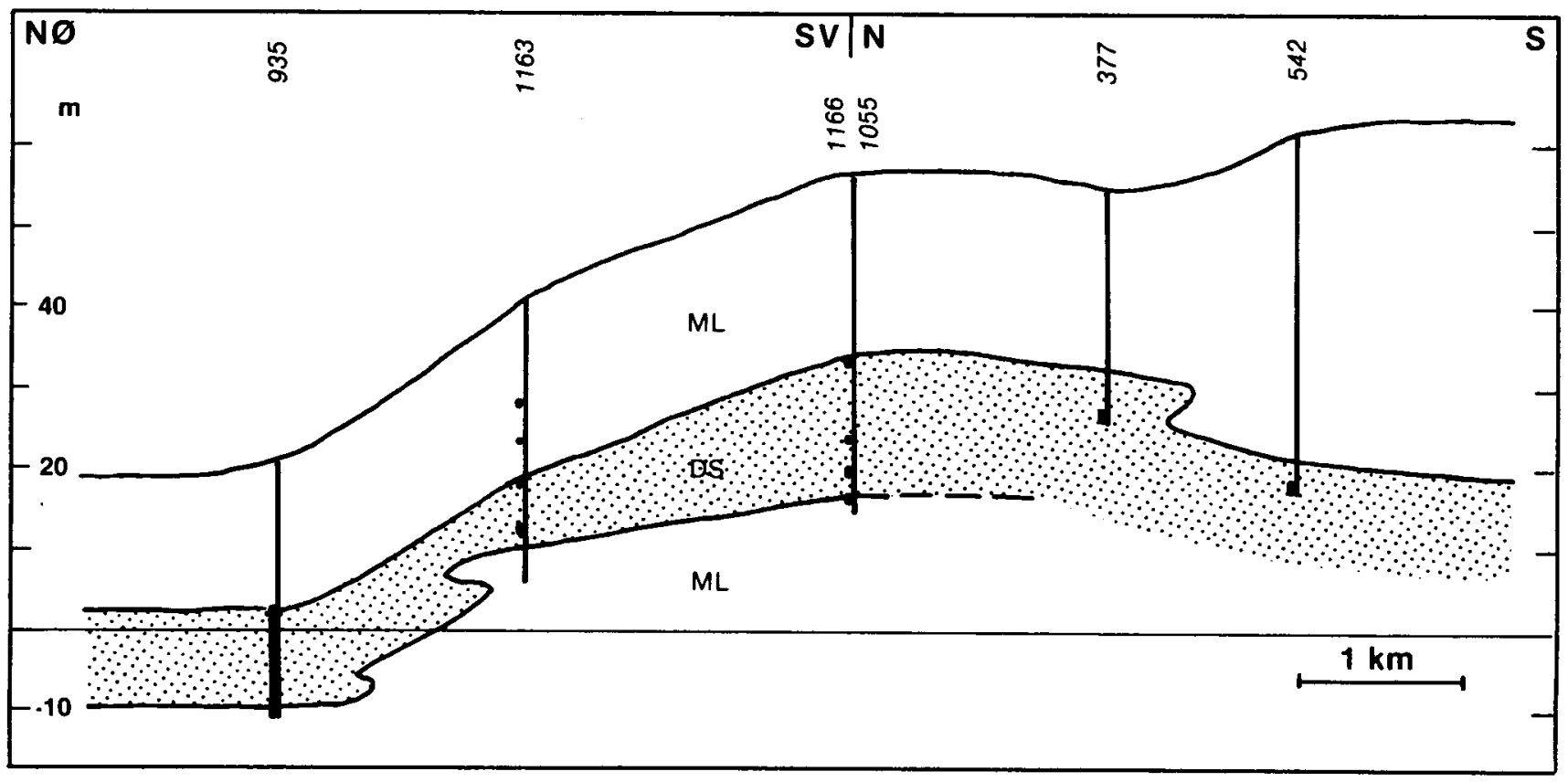


Hydrogeologi: I området er der to hovedreservoirer, der begge er artesiske. Danienkalken udgør sammen med grønsandskalken det ene, og Torkilstrup formationen det andet. Indvindingen foregår hovedsagelig fra Torkilstrup formationen, og overvågningen er begrænset til de kvartære reservoirer. I den nordlige del af området er hovedreservoirerne $\mathrm{i}$ direkte hydraulisk kontakt.

Områdets grænser udgøres mod nord og øst af Torkilstrup formationens udbredelsesgrænse.

Grundvandskemi: Grundvandet er af calcium-bikarbonattypen. Nitratindholdet i nogle af områdets søer er i nærheden af den vejlende værdi for drikkevand.

Vandbalance mm/år:

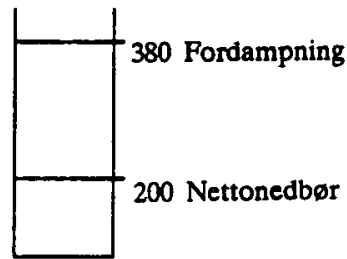

Kildeplads: Borrevejle, 1.7 mill. m3/år

Kirke Såby vv, 0.15 mill. m3/år
Arealanvendelse \%:

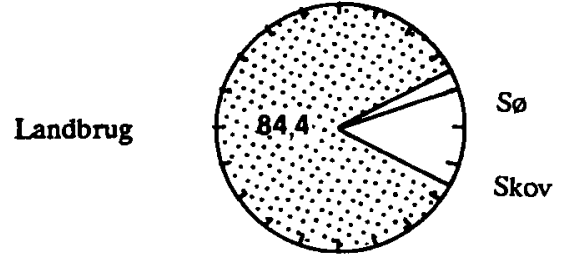

Registrerede depoter: to lossepladser

Koncentrationen af udvalgte stoffer $\mathrm{i}$ forhold til dybde under terran.

Graferne viser data for 1989 og 1990.

Nitrat/Dybde

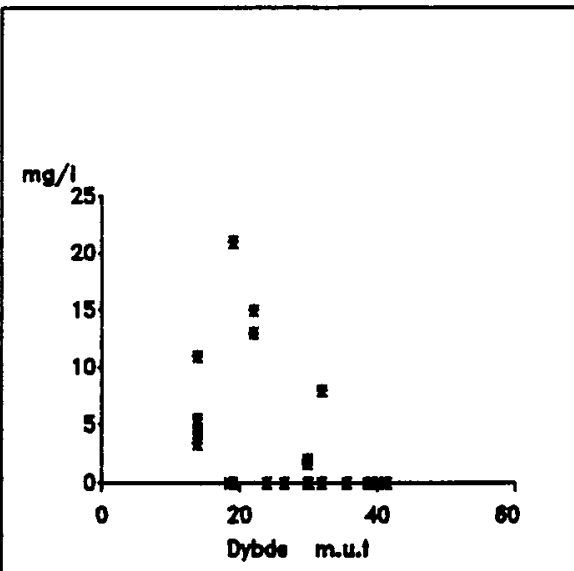

Klorid/Dybde

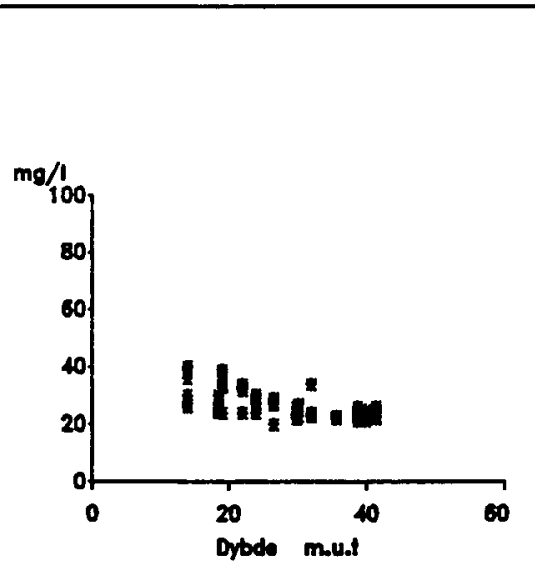

Sulfat/Dybde

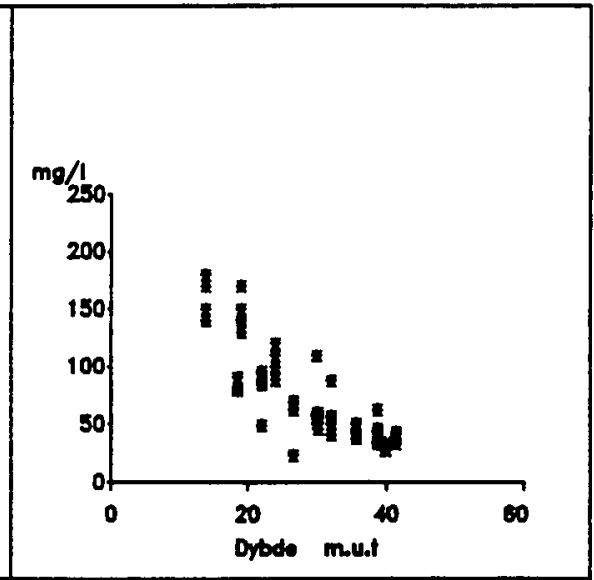


1513 I SV + NV og 1513 II N $\varnothing+\mathrm{S} \emptyset$

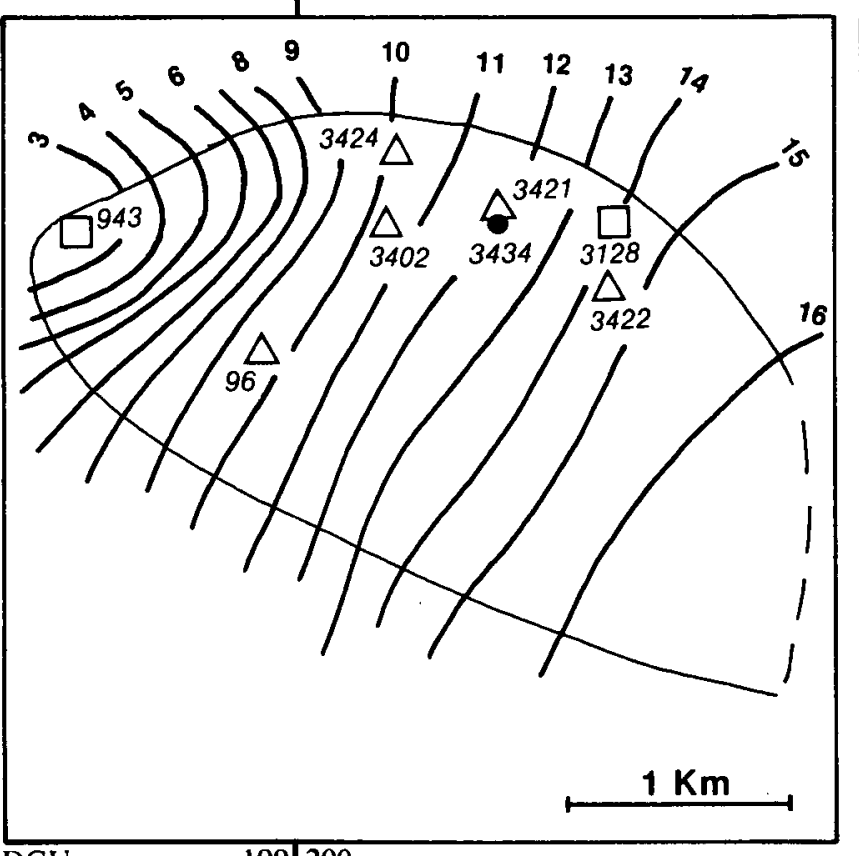

DGU nr.
Terræn

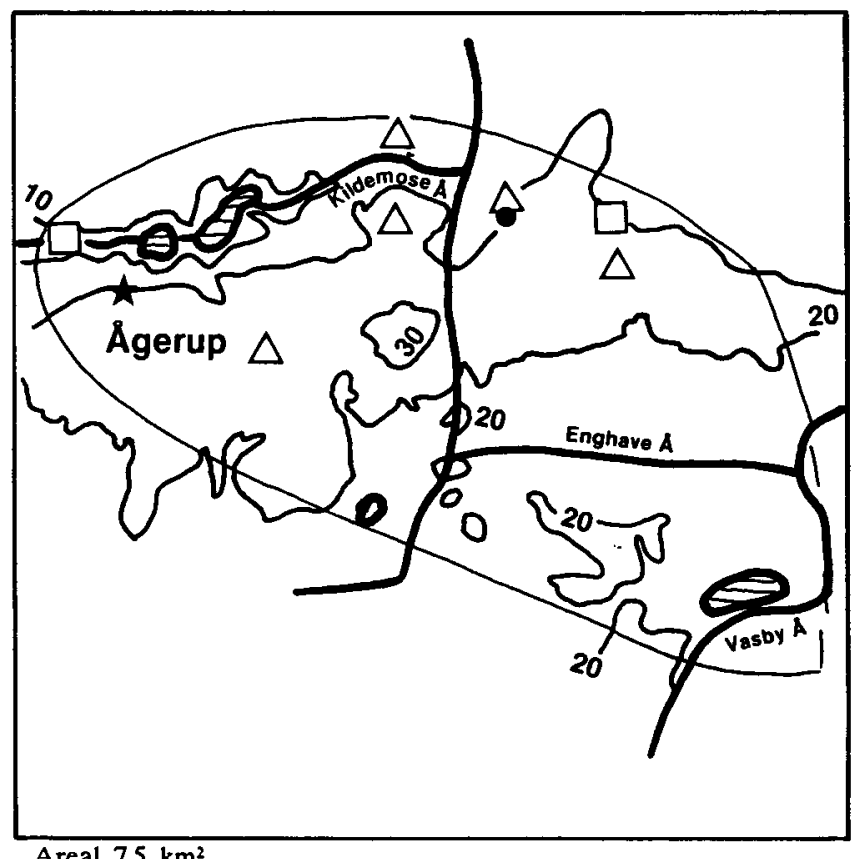

Geologi: De øverste prækvartære aflejringer består af Danienkalk. De kvartære aflejringer domineres af moræneler med mindre indslag af op til 5 meter tykke sandlag. Stedvis ligger der smeltevandssand mellem moræneleret og kalken. Området karakteriseres som et bølget morænelandskab.

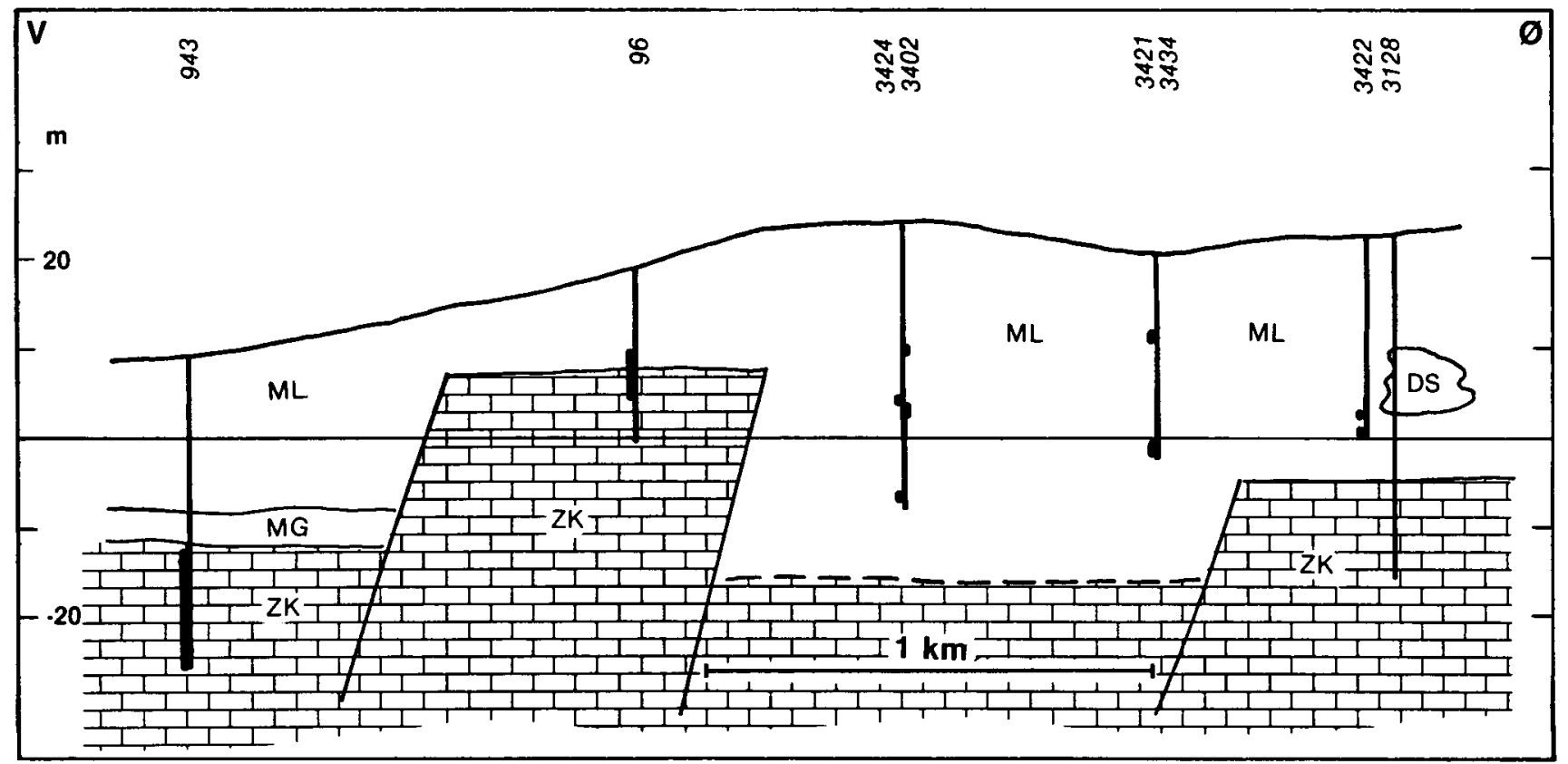


Hydrogeologi: Hovedreservoiret er den højtliggende Danienkalk, der overvejende har frit grundvandsspejl. Smeltevandssandet udgør et usammenhængende sekundært reservoir. Områdeafgrænsningen er baseret på det sekundære reservoir.

Grundvandskemi: Grundvandet er af calcium-bicarbonattypen med varierende mangan og jernindhold. Nitratindholdet er lille. Sulfatindholdet er ret højt på grund af at den store indvinding har sæenket grundvandsstanden i moseområdet, således at sulfatforbindelser er blevet iltet.

Vandbalance mm/år:

Middelnedbør 540

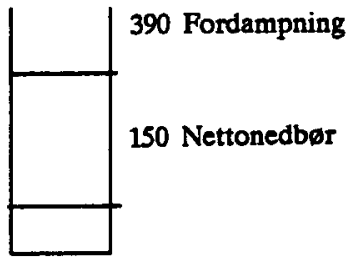

Kildeplads: Brokilde, 3.1 mill. m3/âr, Ågerup, 0.1 mill. m3/ar
Arealanvendelse \%:

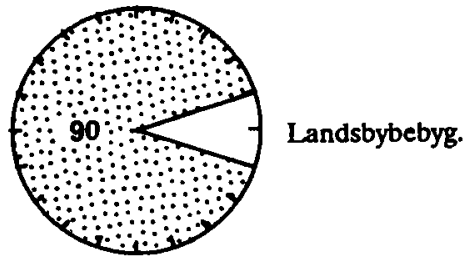

Registrerede depoter: ingen

Koncentrationen af udvalgte stoffer i forhold til dybde under terræn.

Graferne viser data fra 1989 og 1990.

Nitrat/Dybde

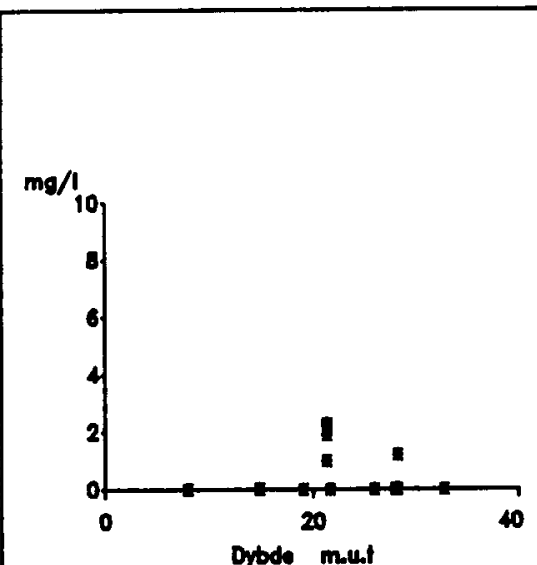

Klorid/Dybde

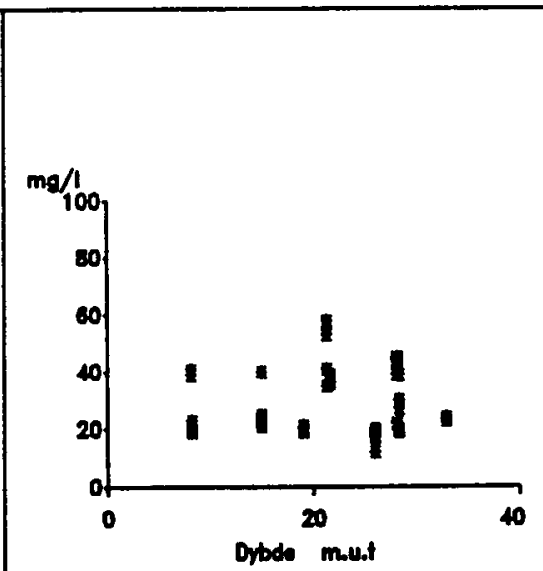

Sulfat/Dybde

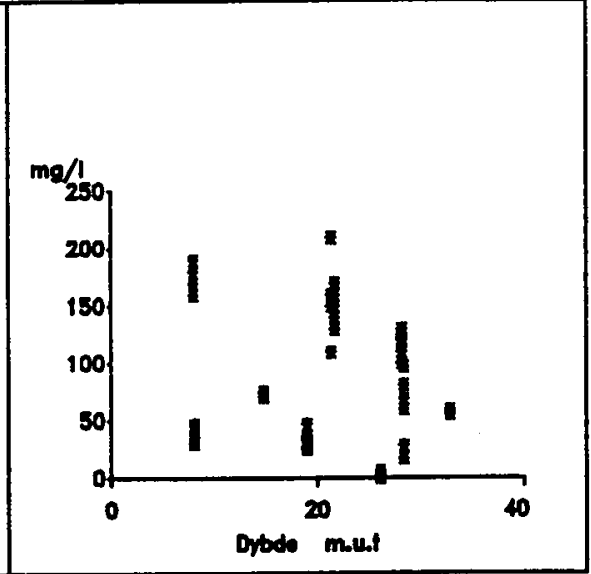




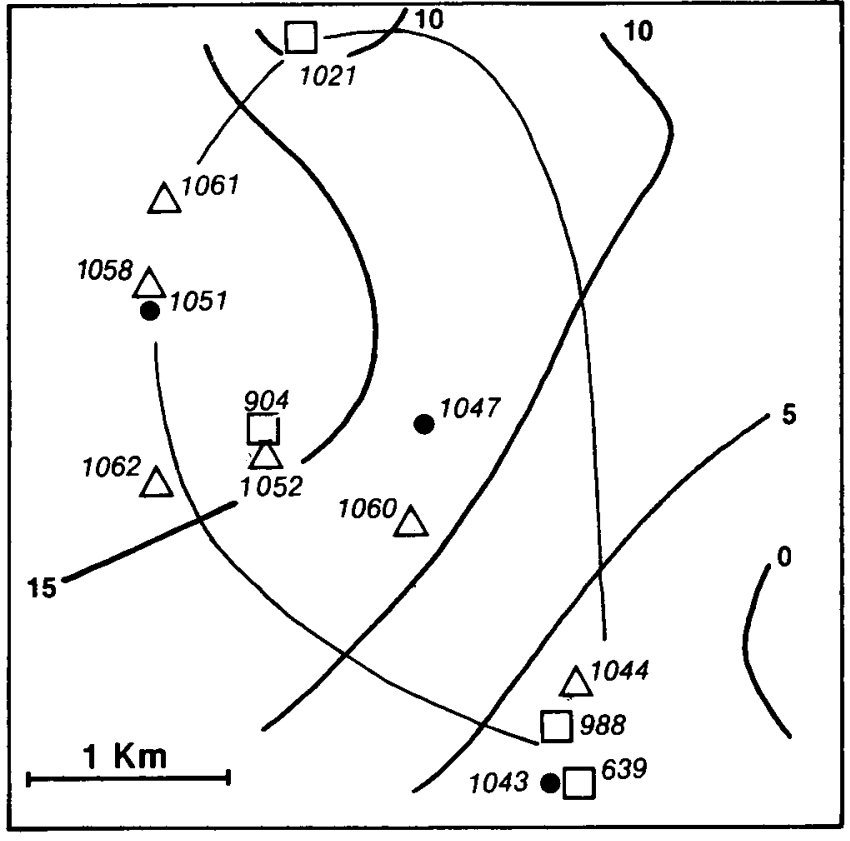

DGU nr. 212

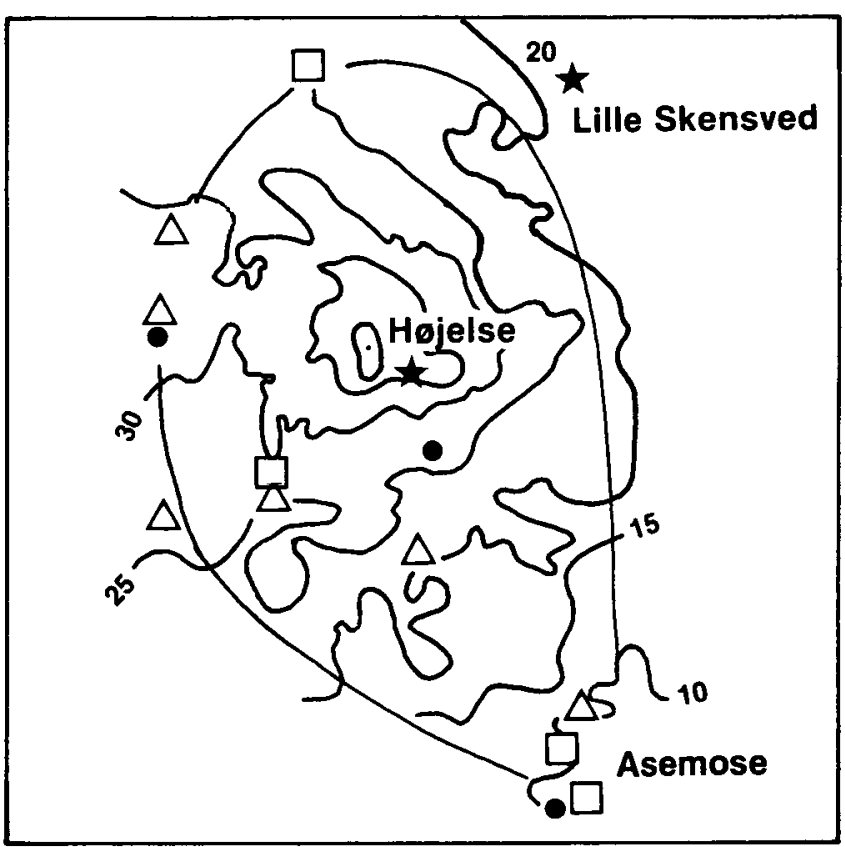

Areal $6 \mathrm{~km}^{2}$

Geologi: De øverste prækvartære lag i området består af kalksandskalk og bryozokalk fra Danien. Kvartæret er 5-15 meter tykt og består hovedsagelig af moræneler. Der er indlejret enkelte sand- og gruslommer $i$ moræneleret. Landskabeligt kan den nordlige del af området karakteriseres som moræneflade og den sydlige del som et dødislandskab.

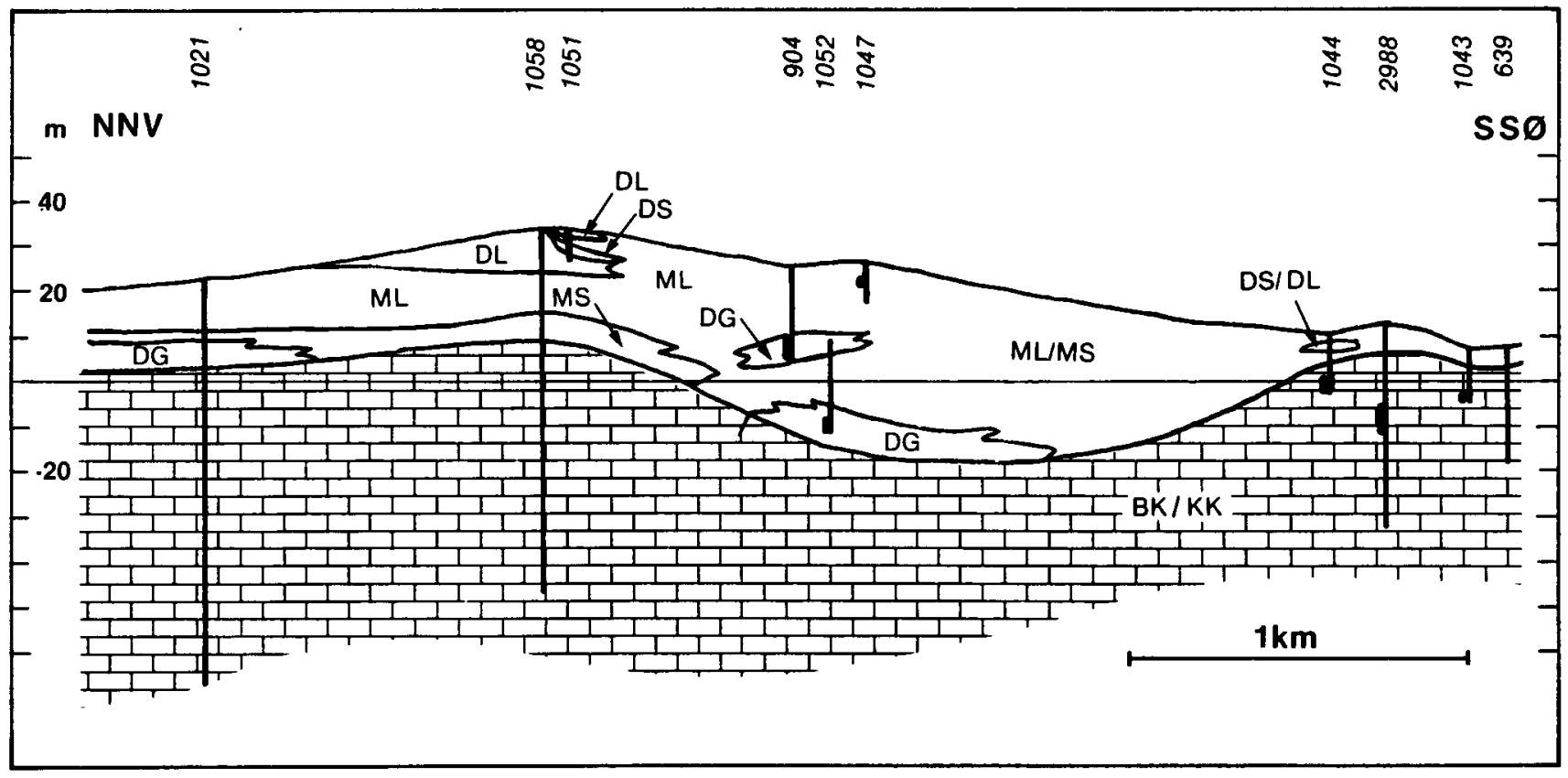


Hydrogeologi: Danienkalken udgør hovedreservoiret. Vandføringen er størst $\mathrm{i}$ den øverste del af kalken, der ofte er opsprækket. Da der er frit grundvandsspejl, og da lerdækket er beskedent, er reservoiret sårbart. Grundvandspotentialet $\mathrm{i}$ det/de sekundære reservoirer er ukendt. Grundvandets strømningsretning foregår p.g.a. andre indvindinger $\mathrm{i}$ området ikke entydigt mod centralboringen.

$\mathrm{På} \mathrm{grund} \mathrm{af} \mathrm{den} \mathrm{store} \mathrm{indvinding} \mathrm{i}$ området er der meget lidt vand til rådighed til afstrømning, hvorfor Køge $\AA ̊$ ofte er tørlagt.

Grundvandskemi: Grundvandet er oxideret. De vejledende grænseværdier, der gælder for drikkevand, er i 1989 overskredet for sulfat, klorid, natrium i enkelte boringer. Det højest tilladte fosforindhold er overskredet adskillige steder. I betragtning af hvor tæt området ligger på Køge Bugt vurderes klorid- og natrium-

Vandbalance mm/år:

Middelnedbør 635

Middelnedbør 635

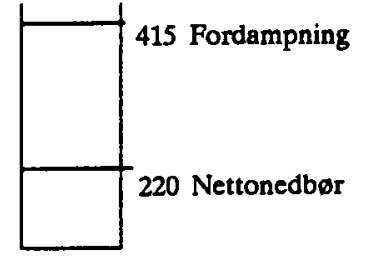

Køge $\AA$ ofte tørlagt

Kildeplads: Asemosevæerket, 0.17 mill. m3/år, andre indvindinger
Arealanvendelse \%:

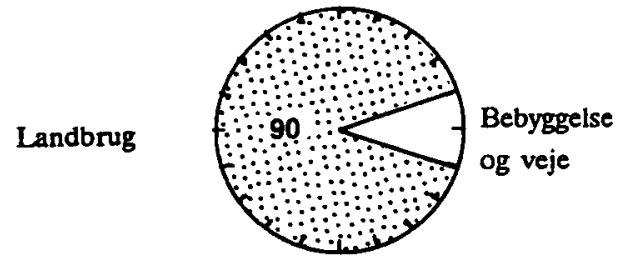

Registrerede depoter. ingen

indholdet ikke at være alarmerende. Det relativt høje fosforindhold, der i 1989 blev konstateret i de sekundære reservoirer genfindes ikke i 1990 dataene og tilskrives forurening under borearbejdet. I hovedreservoiret er der et stigende indhold af nitrat, calcium og sulfat i perioden 1989-1990. Dette hænger muligvis sammen med at indvindingen steg med $7 \%$ i perioden. I enkelte prøver fra overfladenære filtre er der relativt højt kalium- og nitratindhold.

Koncentrationen af udvalgte stoffer i forhold til dybde under terran.

Graferne viser data fra 1989 og 1990.

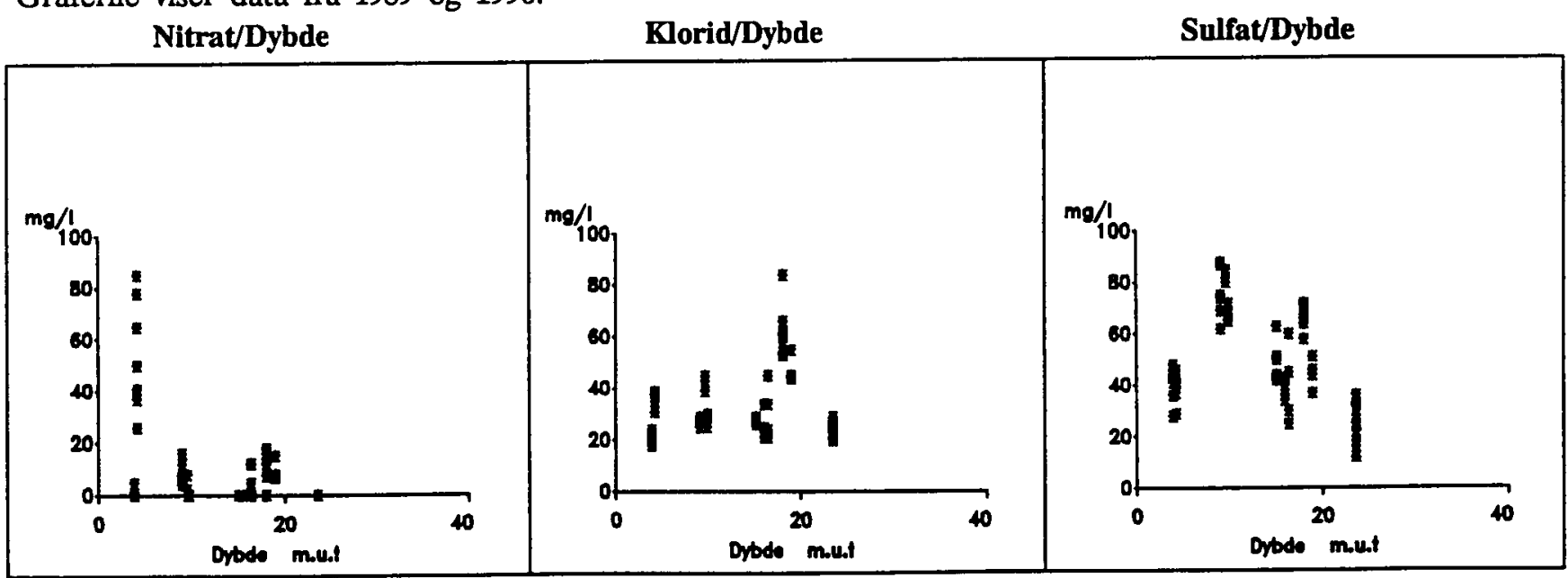


1513 III NØ + NV

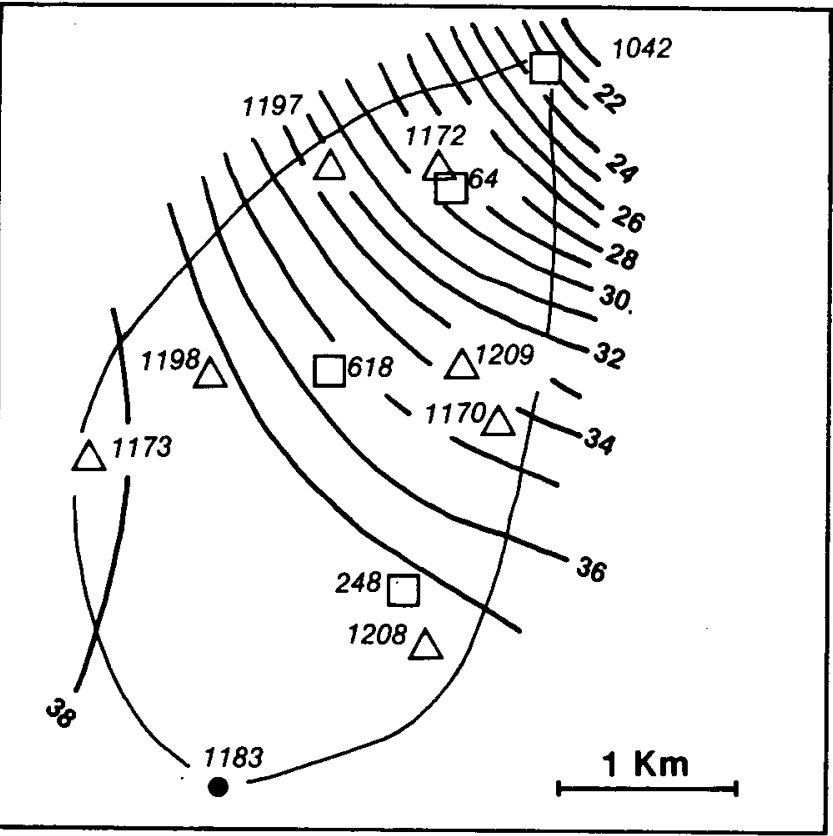

DGU nr. 206

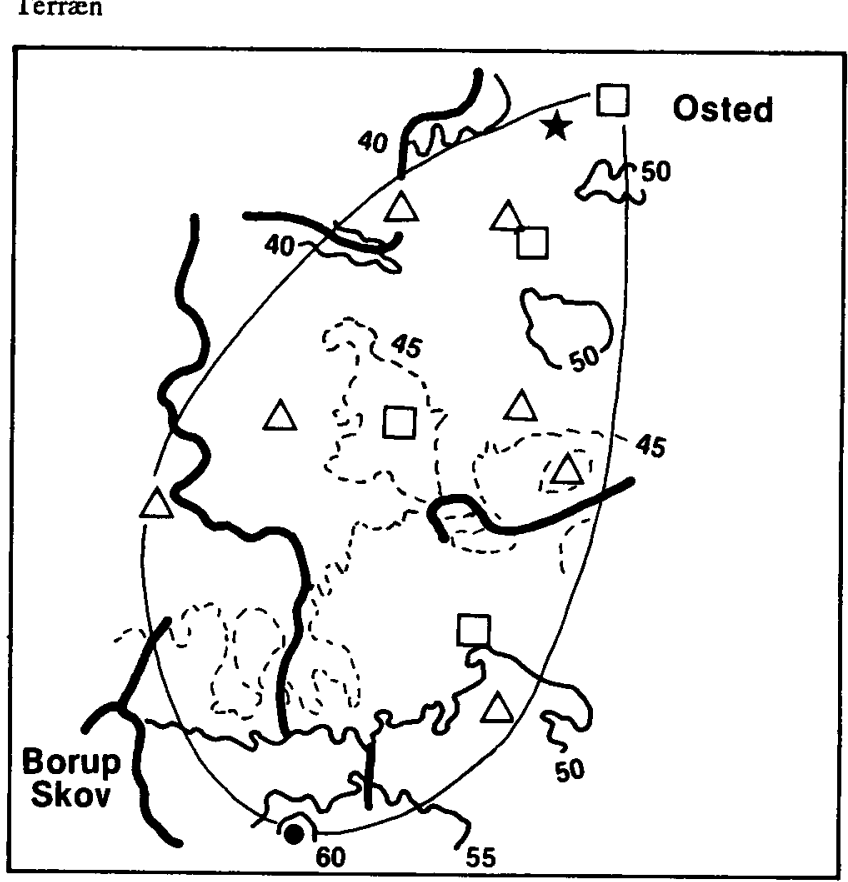

Areal $6 \mathrm{~km}^{2}$

Geologi: Den øverste prækvartære lagserie består af kalksten fra Danientiden overlejret af grønsandskalk fra Selandien. Herover følger en kvartær lagserie af moræneler og smeltevandssedimenter. I den sydlige del af området er der et dødislandskab og mod nord en bølget moræneflade.

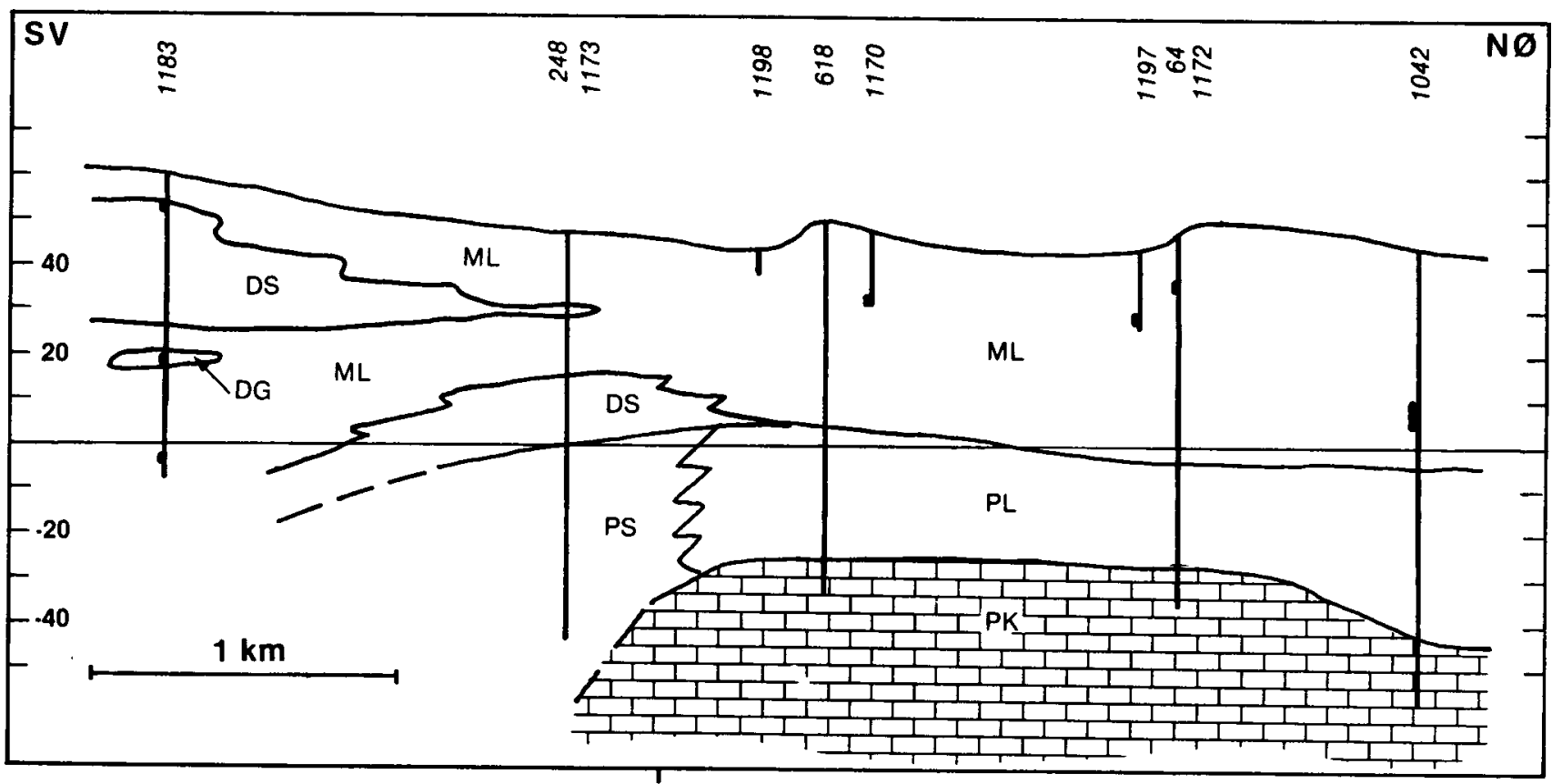


Hydrogeologi: Hovedreservoiret er artesisk og består af den samlede kalkstenssekvens. Grundvandspotentialet i hovedreservoiret er stærkt påvirket fra Københavns Vandforsynings kildepladser og er antagelig større end det omgivne overvågningsområde. Grundvandspotentialet i de sekundære reservoirer er ikke kortlagt.

Grundvandskemi: Det dybtliggende grundvand er stærkt reduceret og indeholder en del ammonium. Reservoiret er velbeskyttet overfor overfladeforurening. Grundvandet i de sekundære reservoirer har et lavt indhold af nitrat og, som følge af de geologiske forhold, et relativt højt sulfatindhold.

Vandbalance $\mathbf{m m} / \mathbf{a ̊ r}:$

Middelnedbør 665

Kildeplads: Osted vv, 1.9 mill. m3/âr anden indvinding, 0.1 mill. $\mathrm{m} 3 / \mathrm{ar}$
Arealanvendelse \%:

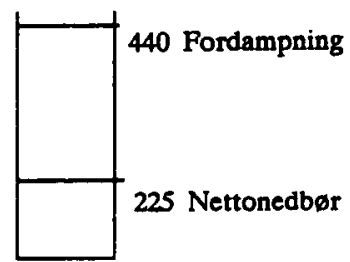

Landbrug

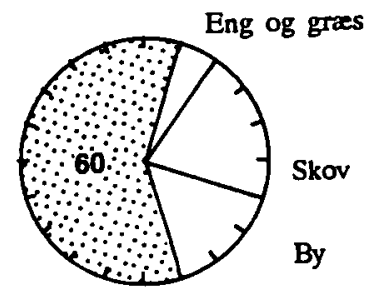

Registrerede depoter. ingen

Koncentrationen af udvalgte stoffer i forhold til dybde under terræn.

Graferne viser data fra 1989 og 1990.

Nitrat/Dybde

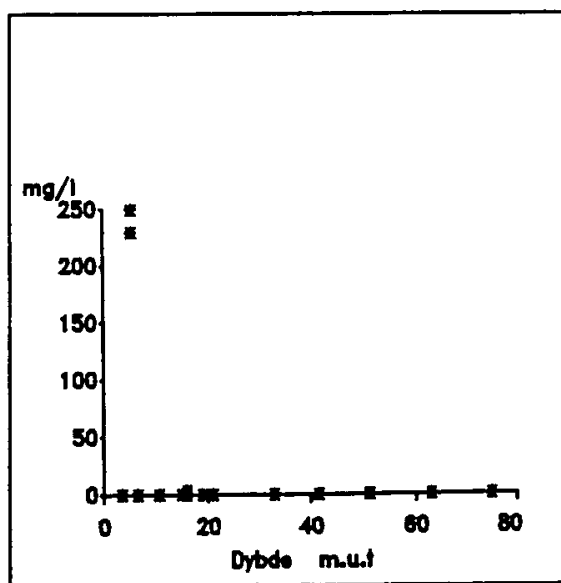

Klorid/Dybde

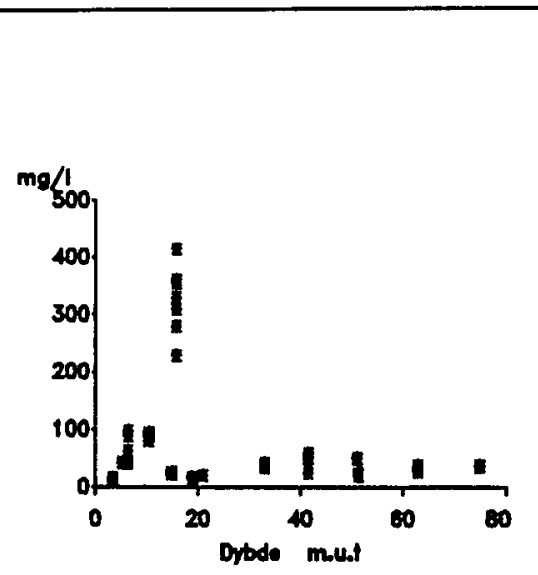

Sulfat/Dybde

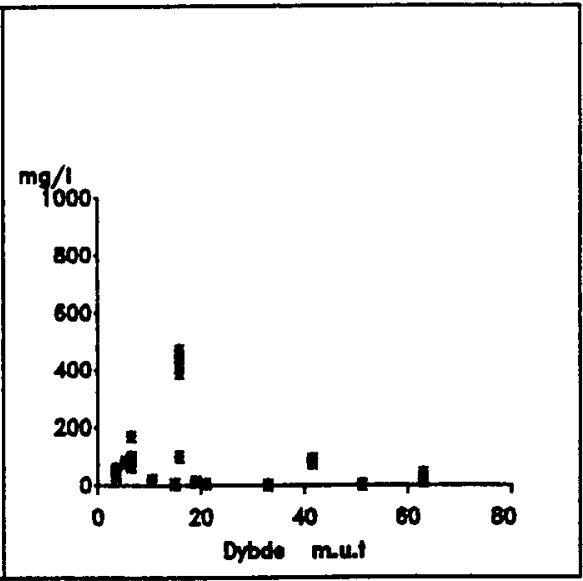




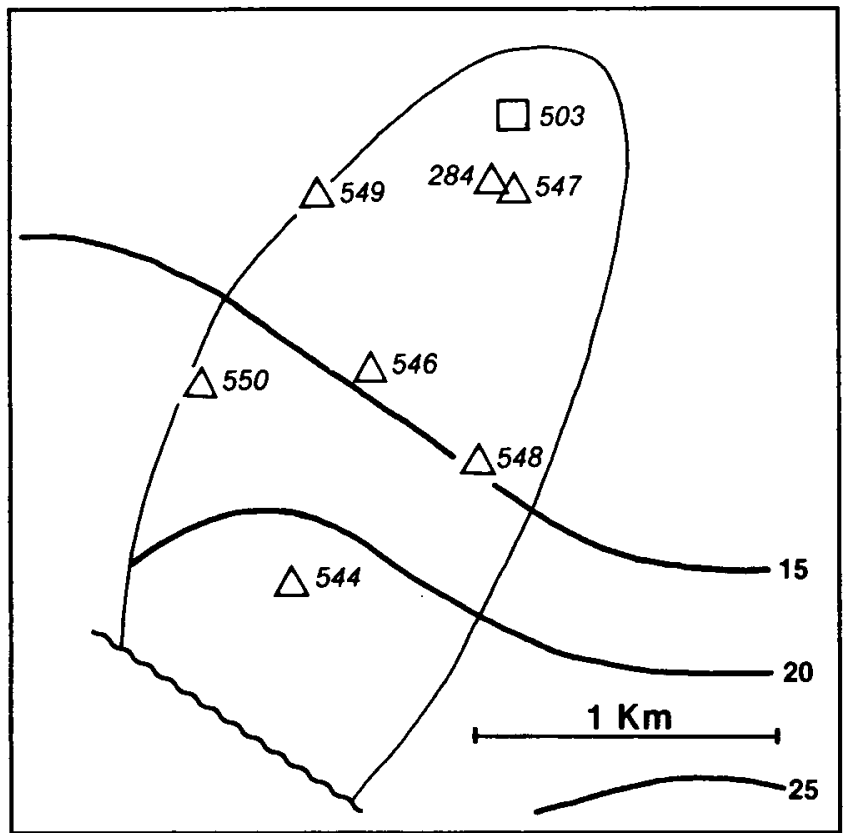

DGU nr. 198
HOLBAEK (30.01)

1413 I $S \varnothing$

Ref. Vestsjællands amt, 1990, 1991 og DGU 1990.

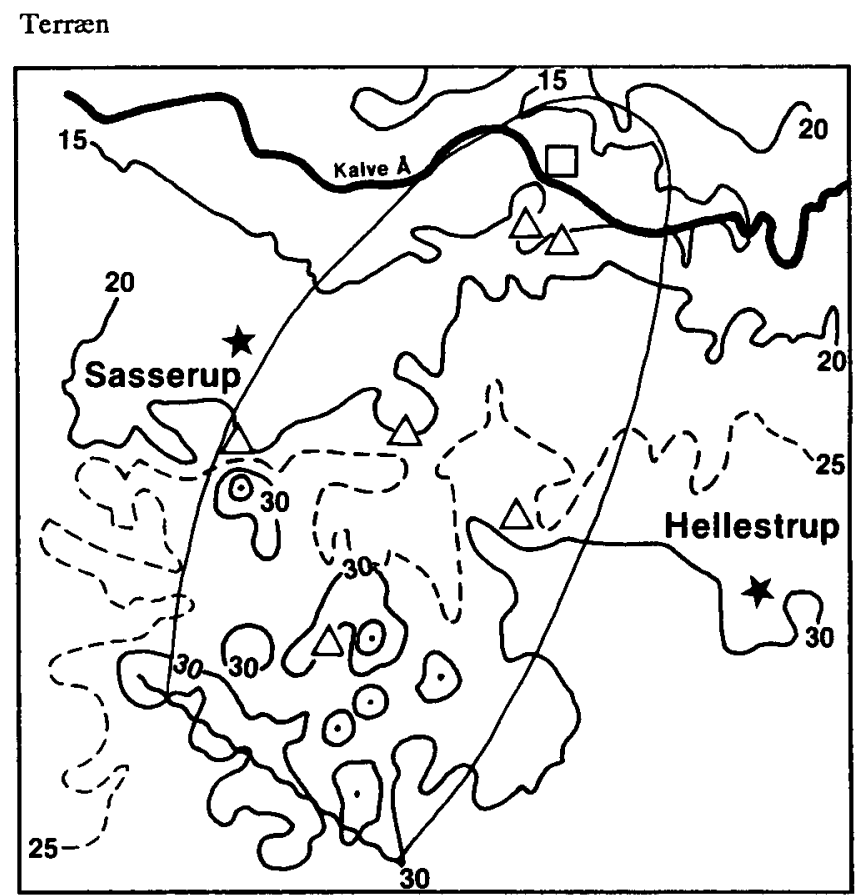

Areal $3 \mathrm{~km}^{2}$

Geologi: I området overlejrer en morænelersdomineret kvartær lagserie lerlag af Selandien alder. Øverst i den kvartære lagserie er der indlejret smeltevandssand i moræneleret. I overfladen er moræneler den dominende jordart.

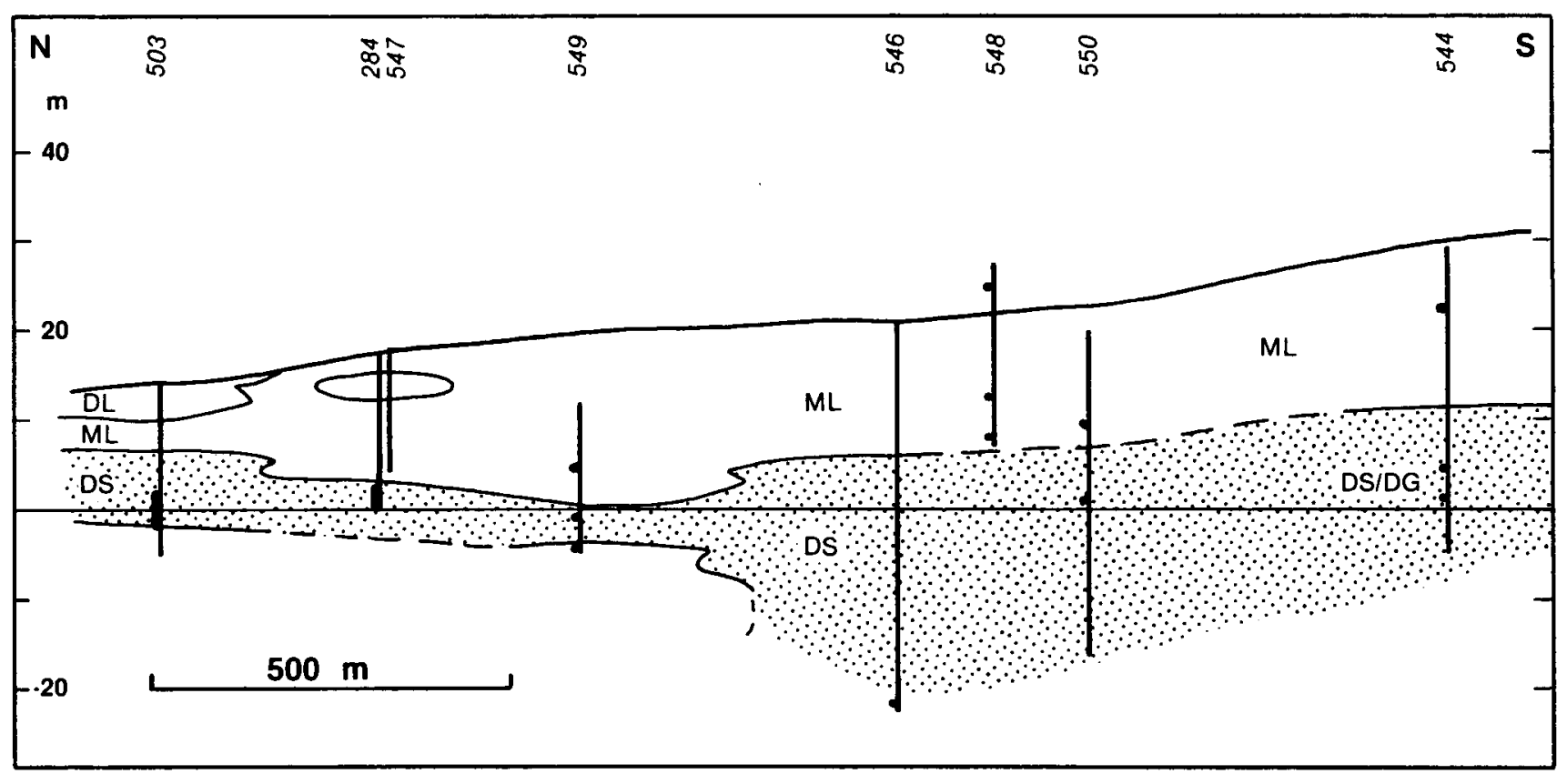


Hydrogeologi: Hovedreservoiret $\mathrm{i}$ området udgøres af smeltevandssandet, hvori der er artesiske forhold. Grundvandet strømmer i nordøstlig retning mod Holbæk fjord.

Grundvandskemi: Grundvandet $\mathrm{i}$ området er af calcium-karbonattypen. Den totale hărdhed er mellem 12 og $19^{\circ} \mathrm{dH}$. Indholdet af opløst jern varierer stærkt fra boring til boring og stiger generelt med dybden. Manganindholdet er gennemgående højt, mens nitratindholdet er lavt. Et enkelt sted, er der dog over 50 milligram nitratm pr. liter samtidig med at jernindholdet er lavt. Fosfatindholdet er gennemgående lavt.

Vandbalance $\mathbf{m m} / \mathbf{a ̊ r}$

Middelnedbør 580

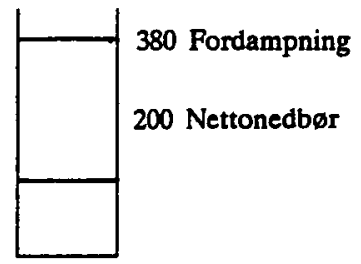

Kildepladser: Sasserup, 0.4 mill. $\mathrm{m} 3 / \mathrm{a} r$

\section{Arealanvendelse \%:}

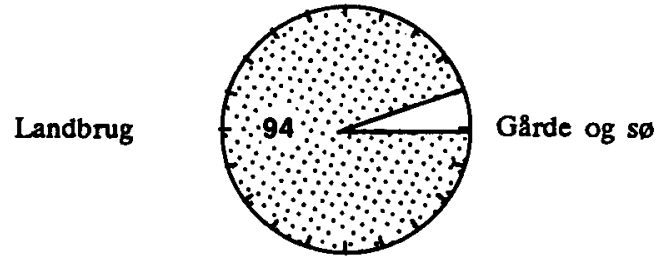

Registrerede depoter.

Koncentrationen af udvalgte stoffer i forhold til dybde under terran.

Graferne viser data fra 1989 og 1990.

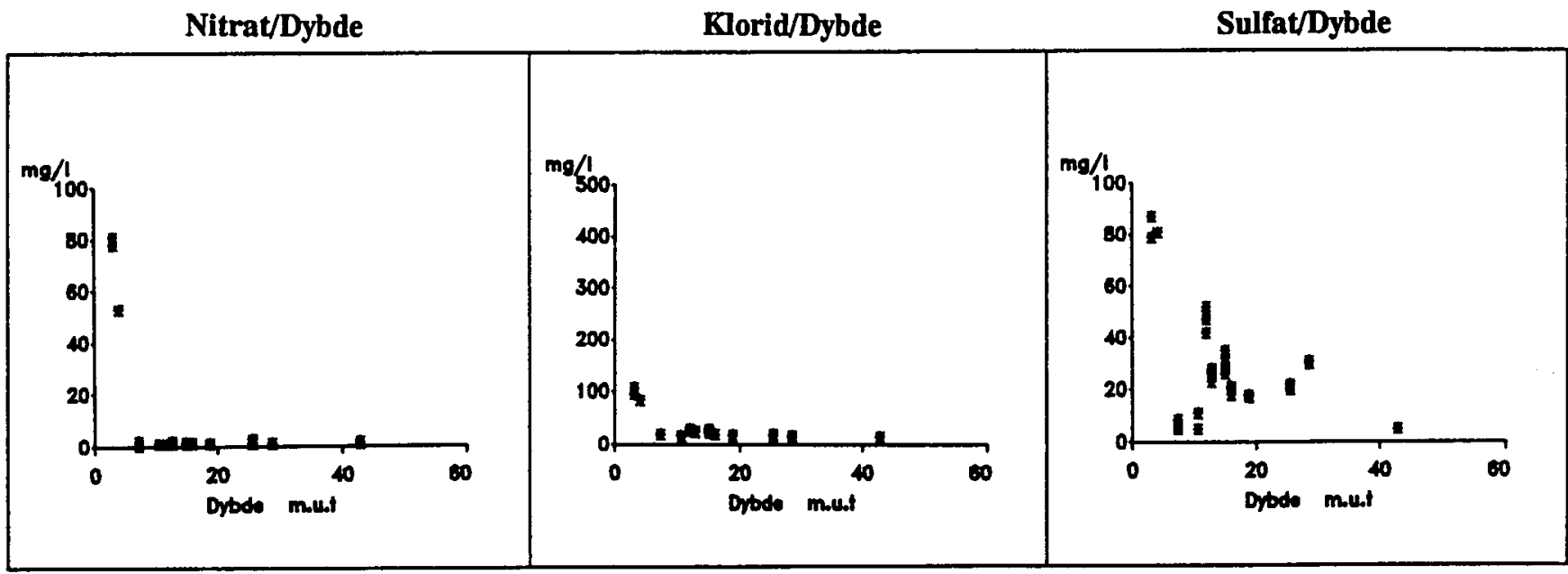




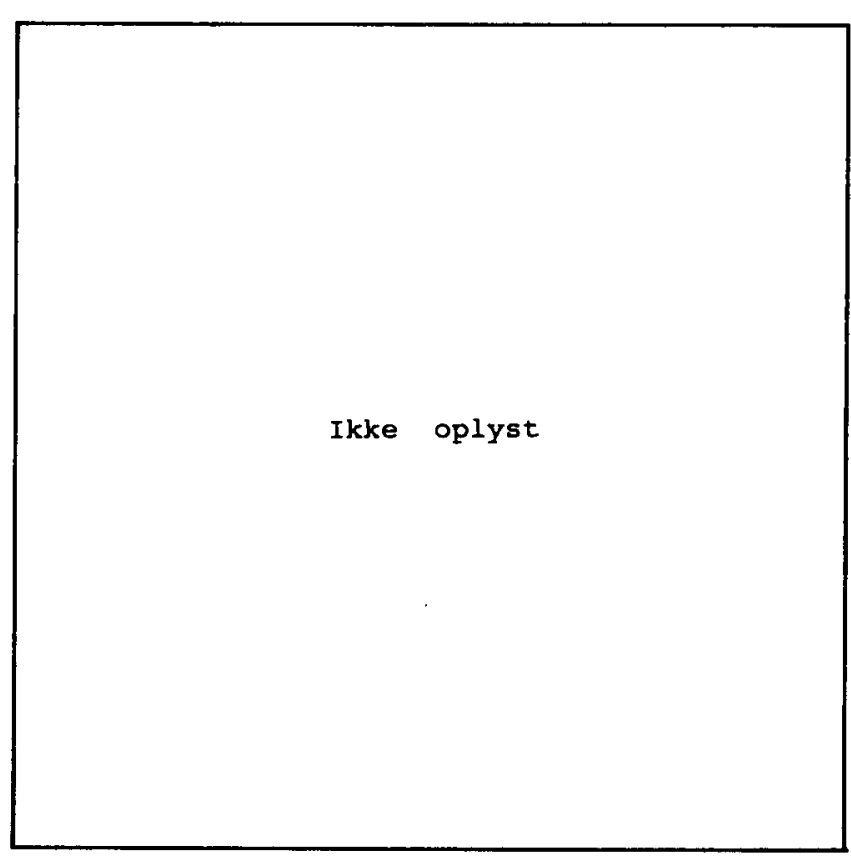

DGU nr. 210

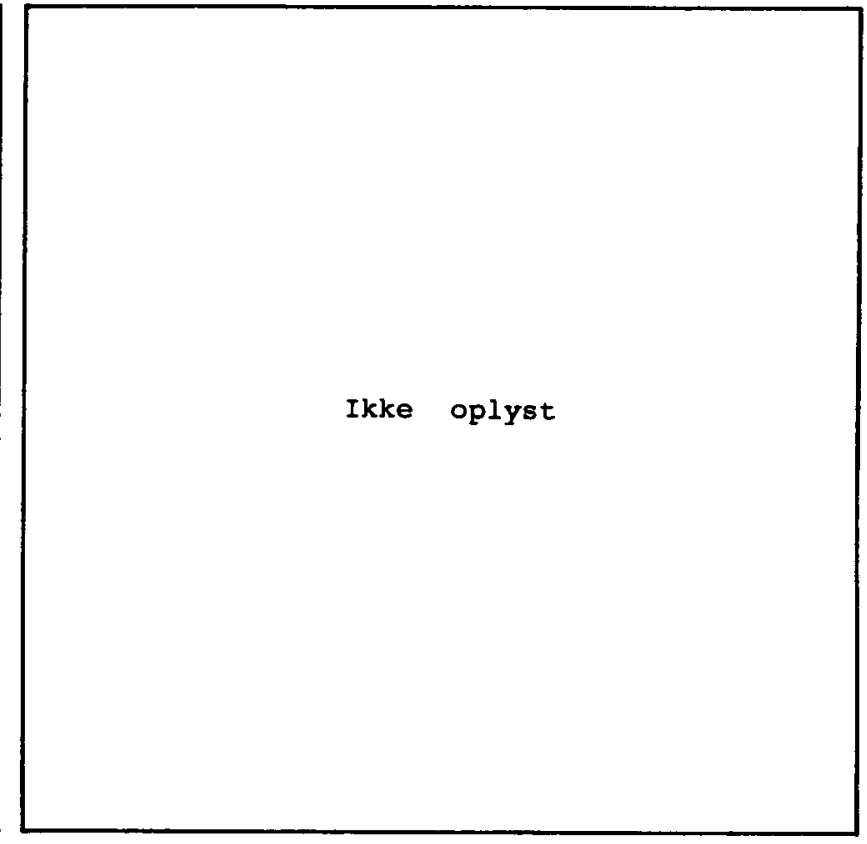

Areal

Geologi: Det øverste prækvartære lag består af ler, der antagelig er af Paleocæn alder. Prækvartæroverfladen er ikke anboret $\mathrm{i}$ eller nær overvågningsområdet, men formodes at ligge dybere end kote -60 meter. I de kvartære aflejringer findes to enheder af smeltevandssand, adskilt af moræeneler. I overfladen er der stedvis ferskvandstørv.

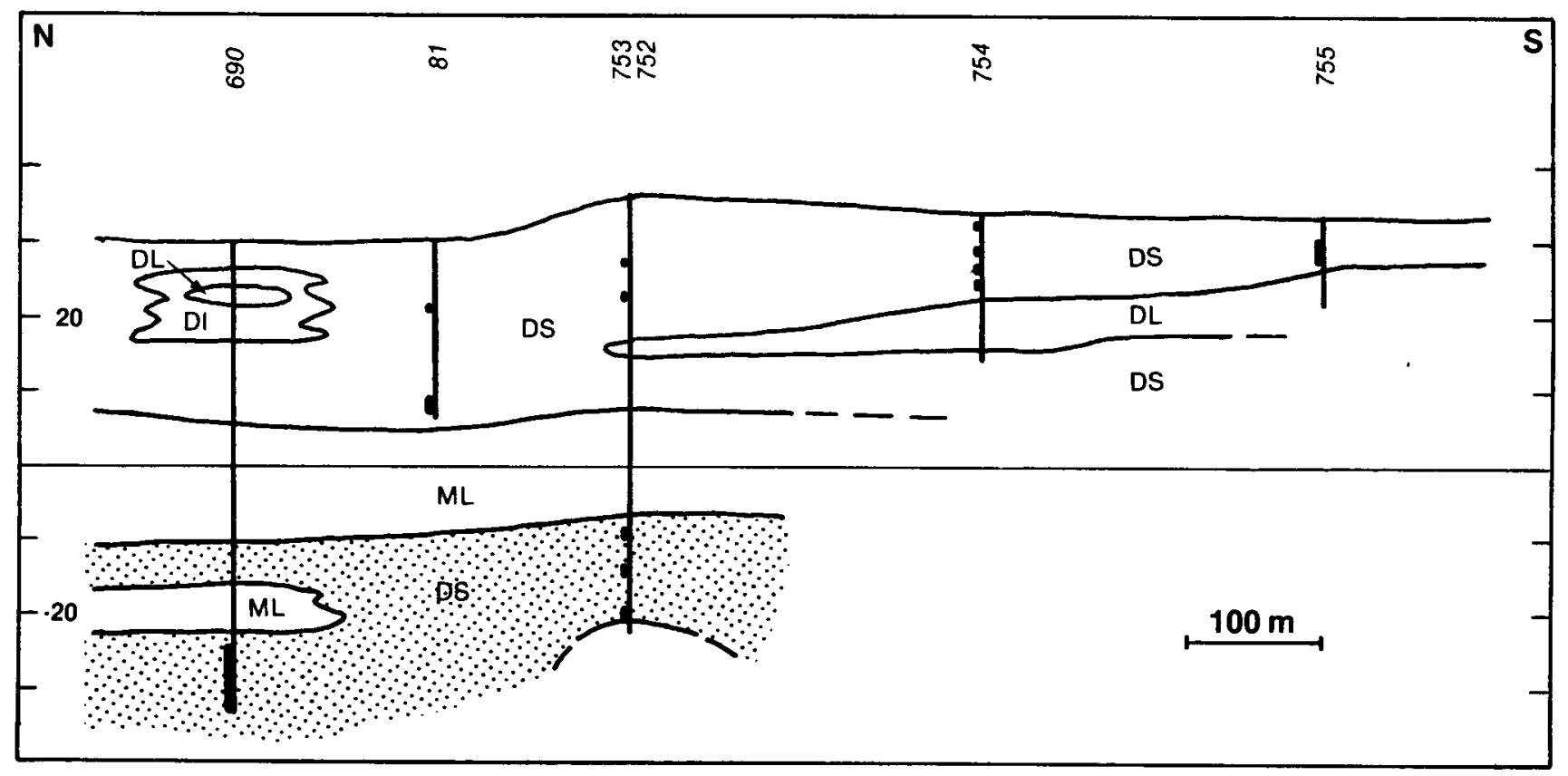


Hydrogeologi: Hovedreservoiret består af det nedre lag af smeltevandssand, der er artesisk og regionalt udbredt. Transmissiviteten er $8,5 \times 10^{3}$ kvadratmeter pr. sekund. Det sekundæere reservoir udgøres af det nedre, glaciale lag af smeltevandssand. Reservoiret har frit grundvandsspejl. Grundvandet strømmer $i$ begge reservoirer mod nordvest. Munke Bjergby vandvark indvinder vand fra begge reservoirer.

Grundvandskemi: Grundvandet i hovedreservoiret er af calcium-bikarbonattypen. Ionkoncentrationen er på 10-13 milliakvivalenter pr. liter.

Grundvandet $\mathrm{i}$ hovedreservoiret er sulfatreduceret og indeholder metan og svovlbrinte og er dermed stærkt reduceret. Grundvandet i det sekundære reservoir er også af calcium-bikarbonattypen. Ionkoncentrationen er på 18-25 milliækvivalenter pr. liter, og reduktionsniveauet er lavt.

Vandbalance mm/år:

Middelnedbør 640

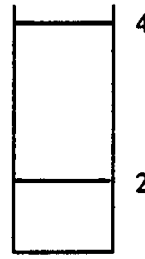

Kildeplads: Munke Bjergby, 0.05 mill. m3/âr

\section{Arealanvendelse \%:}

400 Fordampning

Landbrug

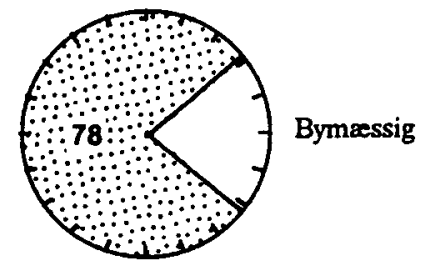

Registrerede depoter:

Dette øverste grundvand er iltholdigt, men kun et sted indeholder det lidt nitrat. Indholdet af opløst jern og jerntotal varierer meget, og jernreduktionen er således ikke forløbet til ende. Grundvandet i det sekundære reservoir er meget hårdt, og sulfatindholdet er relativt højt, antagelig som følge af iltning af pyrit i den ferskvandstørv, som dakker dele af det sekundære reservoir. I forhold til det sekundare reservoir har grundvandet $\mathrm{i}$ hovedreservoiret et lavere indhold af sulfat, klorid og calcium, medens koncentrationen af jern, bikarbonat, ammonium og fosfor er højere.

Koncentrationen af udvalgte stoffer i forhold til dybde under terran.

Graferne viser data fra 1989 og 1990.

Nitrat/Dybde

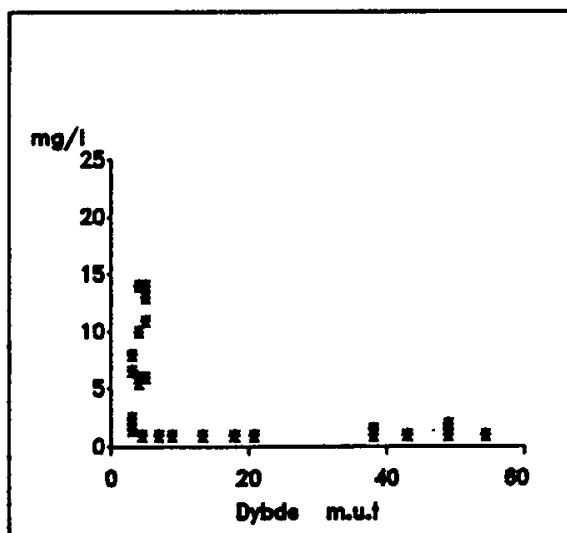

Klorid/Dybde

Sulfat/Dybde

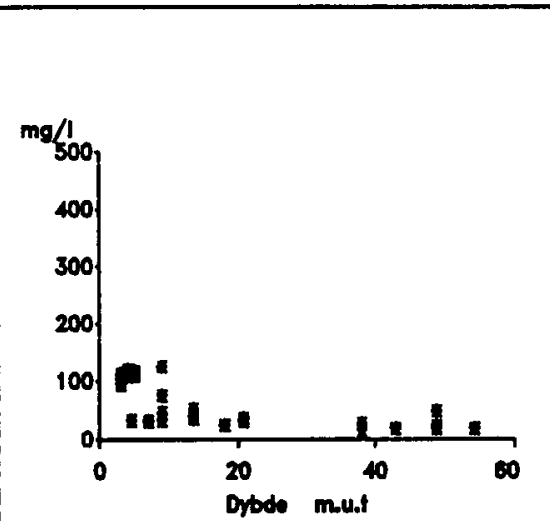

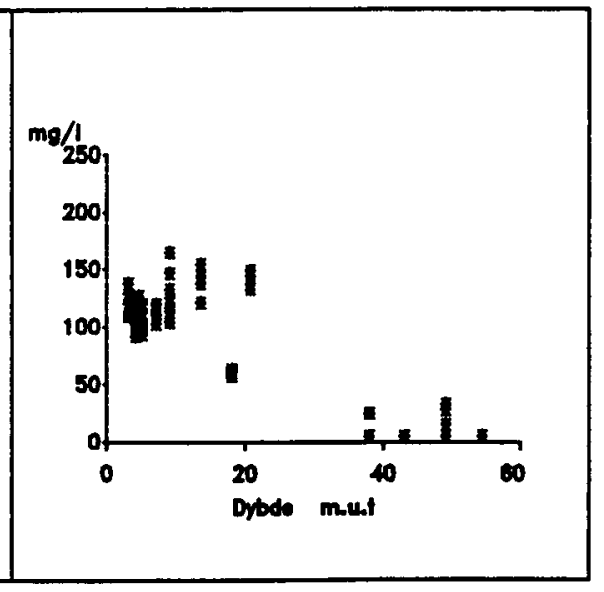




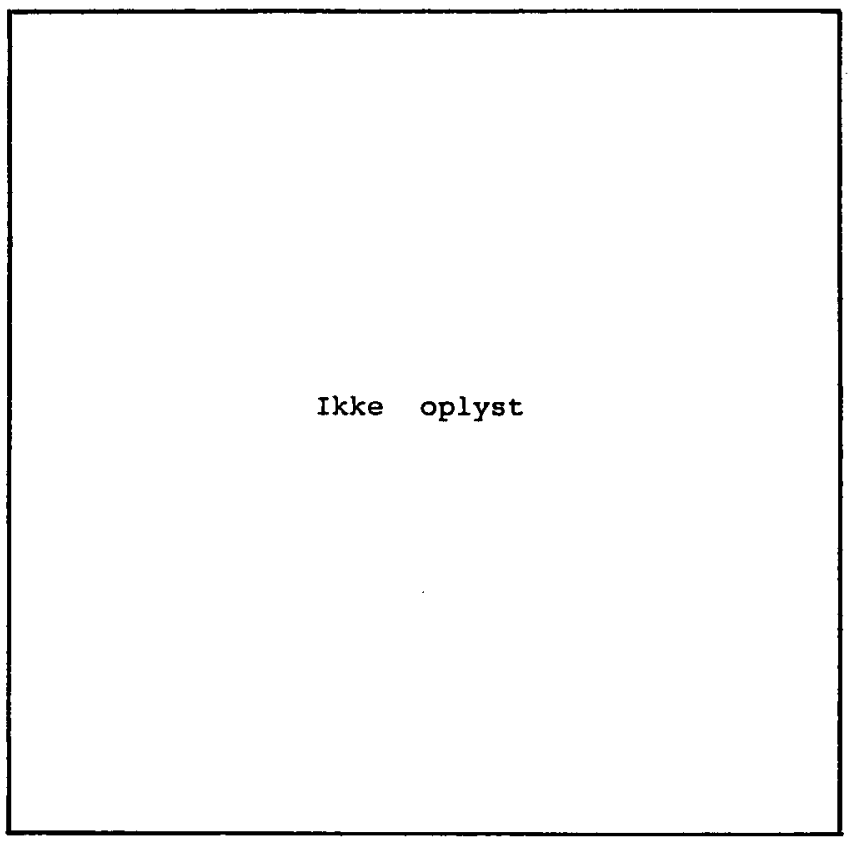

DGU nr. 203

Ikke oplyst

Areal

Geologi: De øverste prækvartære lag består af Røsnæs Ler Formationen eller Lillebælt Ler Formationen, som er af Eocæn alder. Prækvartæroverfladen ligger antagelig dybere end kote -60 meter, men flager af plastisk ler kan findes indlejret $\mathrm{i}$ de overlejrende kvartære lag.

I den kvartære lagfølge er der to enheder af smeltevandssand og -grus adskilt af moræneler.

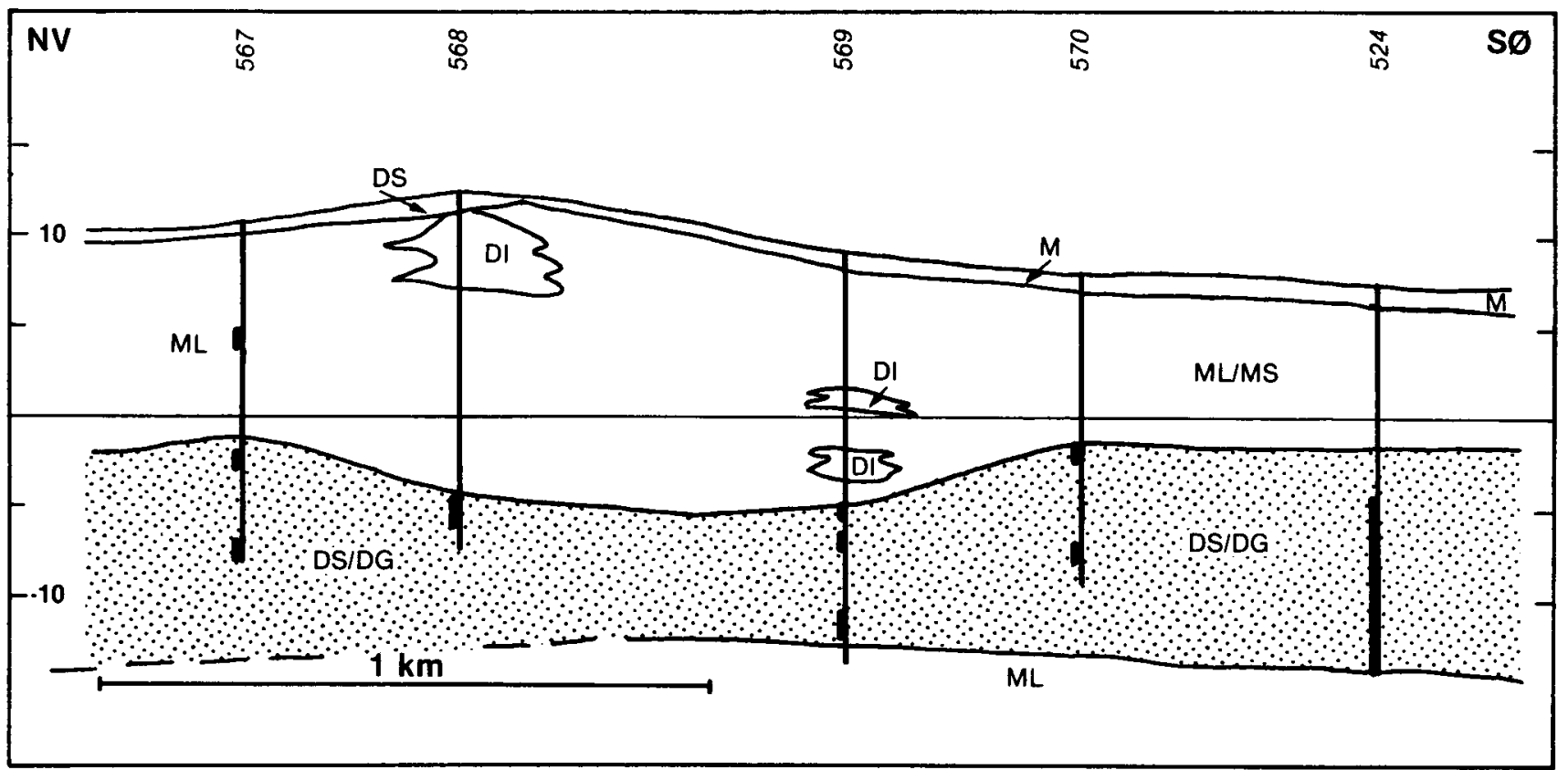


Hydrogeologi: Lagene af smeltevandssand kaldes henholdsvis Store Fuglede og Bjerge Reservoiret. Disse hovedreservoirer er udbredt $\mathrm{i}$ hele området. Bjerge Reservoiret står tilsyneladende ikke $\mathrm{i}$ direkte forbindelse med Tissø.

Store Fuglede Reservoiret har en transmissivitet på ca. 1 × 10 $0^{-2}$ kvadratmeter pr. sekund. Mod sydvest er reservoiret afgrænset af en negativ hydrologisk grænse.

Grundvandskemi: Grundvandet er af calcium-bikarbonattypen. Ionkoncentrationen er på 14-27 milliækvivalenter pr. liter. Forholdene mellem de vigtigste ioner og totalkoncentrationerne er konstante fra filter til filter $\mathrm{i}$ reservoiret. Nitratindholdet er lavt. Ammoniumkoncentrationen er lav men varierer en del fra filter til filter. Der er stigende fosforindhold i grundvandet (total P) ved Store Fuglede kildeplads.

Vandbalance $\mathrm{mm} / \mathrm{år}$ :

Middelnedbør 600

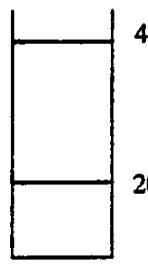

Kildeplads: Store Puglede, 0.62 mill. m3/år

\section{Arealanvendelse \%:}

400 Fordampning

Landbrug

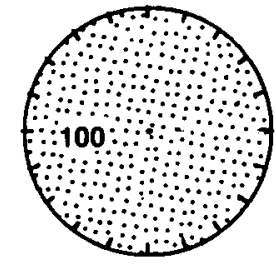

Registrerede depot:

Koncentrationen af udvalgte stoffer i forhold til dybde under terræn.

Graferne viser data fra 1989 og 1990.

Nitrat/Dybde

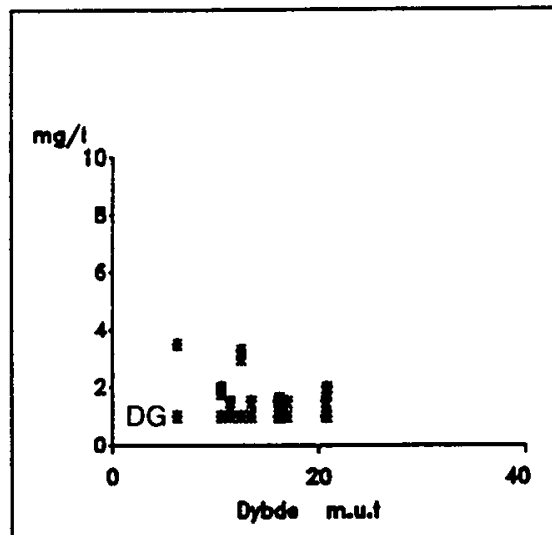

Klorid/Dybde

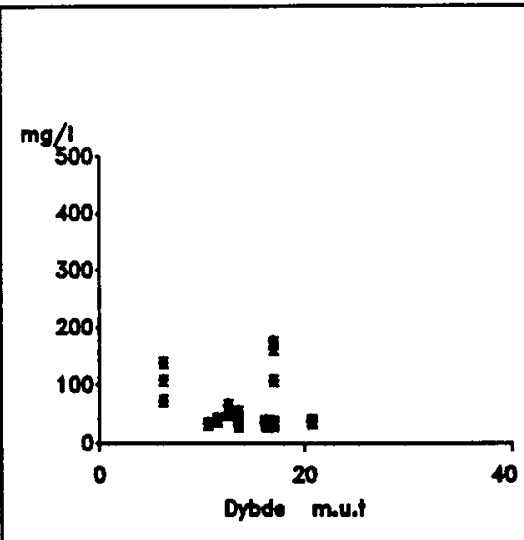

Sulfat/Dybde

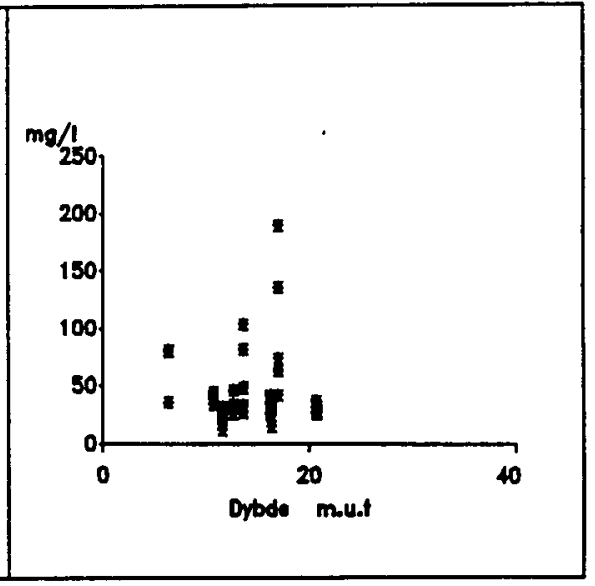




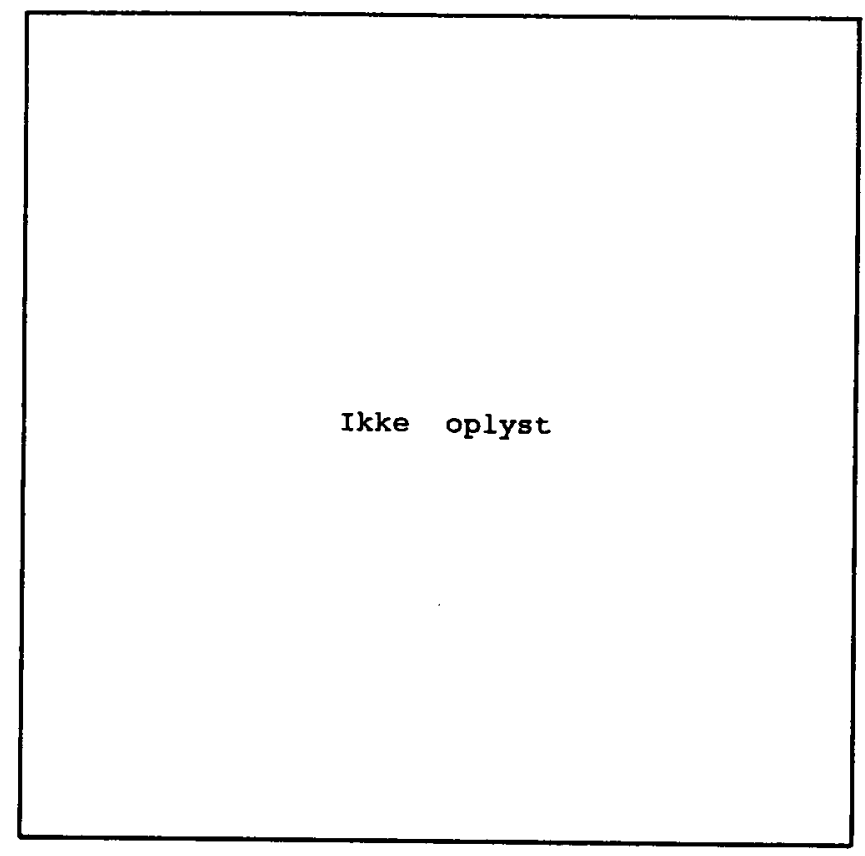

Geologi: De øverste prækvartære lag i området består hovedsagelig af hærdnede lag af kalksandskalk og slamkalk fra Maastrichtien og Danien. Prækvartæroverfladen hælder mod syd og er delt op i blokke af forkastninger, som overvejende har nordøst-sydvestlig retning. De kvartære aflejringer i området består hovedsagelig af moræneler. Ved Rørmosen kildeplads findes dog betydelige indslag af smeltevandssand og grus. Denne lagserie overlejres af postglacialt saltvandsdynd, -ler, -sand og -grus (Litorina aflejringer).

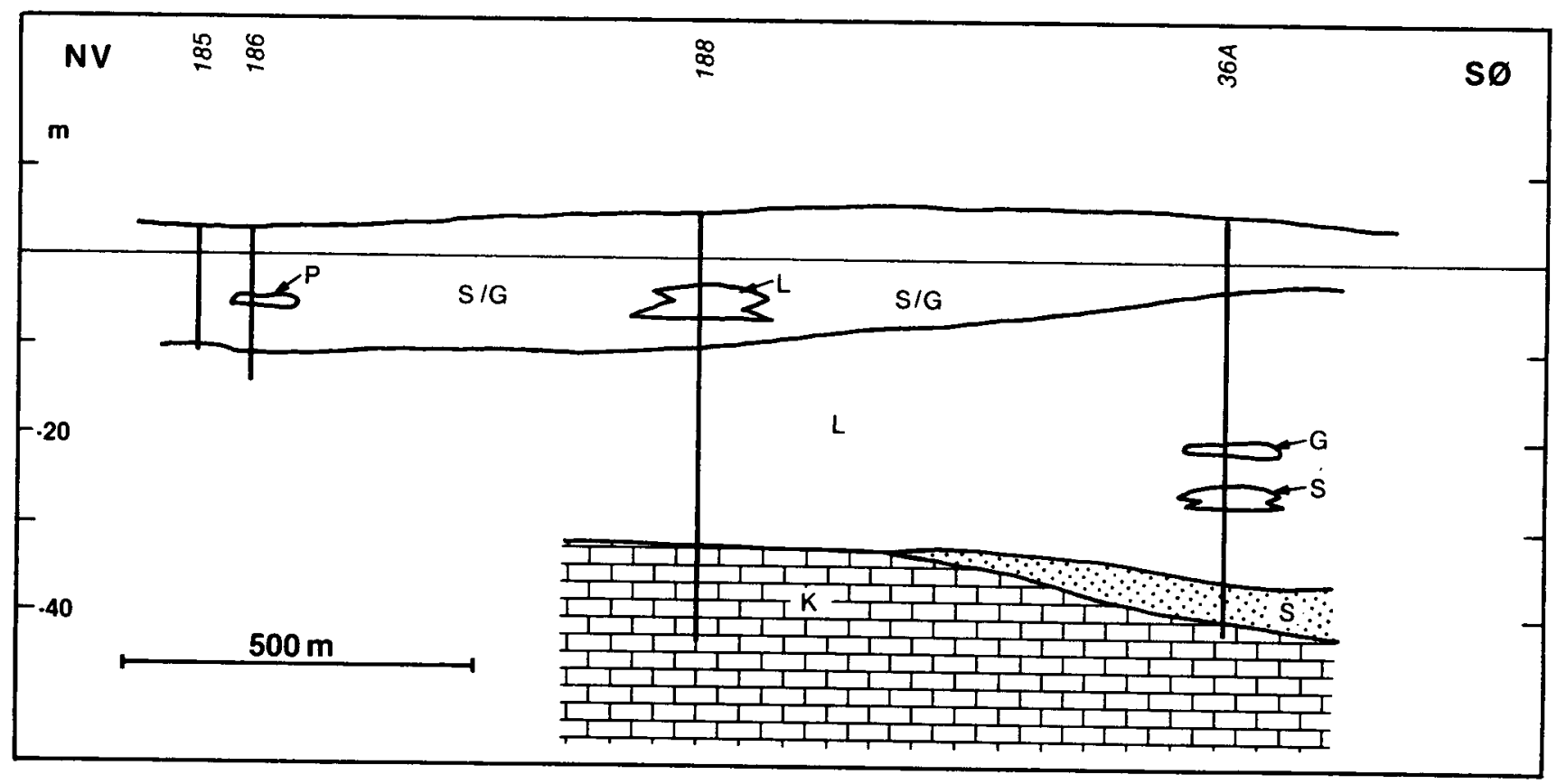


Hydrogeologi: Hovedreservoiret, der er artesisk, består af Danien Kalksten. kalkstenen har en transmissivitet på ca. 4,6 x 10 10 kvadratmeter pr. sekund. Grundvandet strømmer mod syd. Det sekundære reservoir består af postglacialt saltvandssand og -grus.

Grundvandskemi: Grundvandet i området er generelt af calcium-bikarbonattypen og i kalkstens-reservoiret dominerer calciumionen svagt. Grundvandet $i$ hovedreservoiret har $i$ forhold til grundvandet $i$ det sekundære reservoir et højere indhold af magnesium, bikarbonat og ammonium, og et lavere indhold af calcium og sulfat. Iøvrigt er det stærkt reduceret og indeholder metan og svovlbrinte. Grundvandet i det sekundære reservoir er af en calciumtype med en svagt dominerende bikarbonat-ion. Ud mod kysten stiger ionkoncentrationen gradvis fra 12-18 milliækvivalenter pr. liter, hvilket hovedsagelig skyldes en

Vandbalance mm/år:

Middelnedbør 610

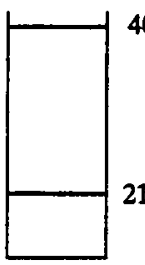

Kildeplads: Rørmosen, 0.6 mill. m3/år

\section{Arealanvendelse \%:}

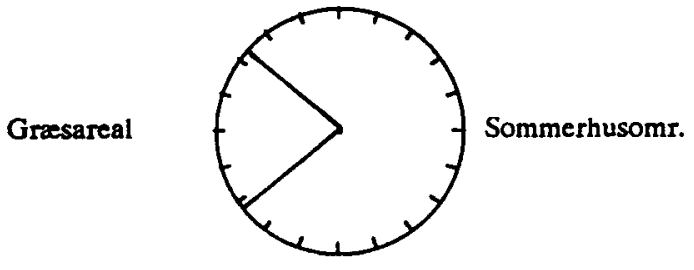

Registrerede depoter:

stigende koncentration af klorid, natrium, og sulfat. Nitratindholdet er under $5 \mathrm{mg} / \mathrm{i}$ begge reservoirer. Enkelte indvindingsboringer på kildepladsen har højt fosforindhold.

Koncentrationen af udvalgte stoffer i forhold til dybde under terran.

Graferne viser data fra 1989 og 1990.

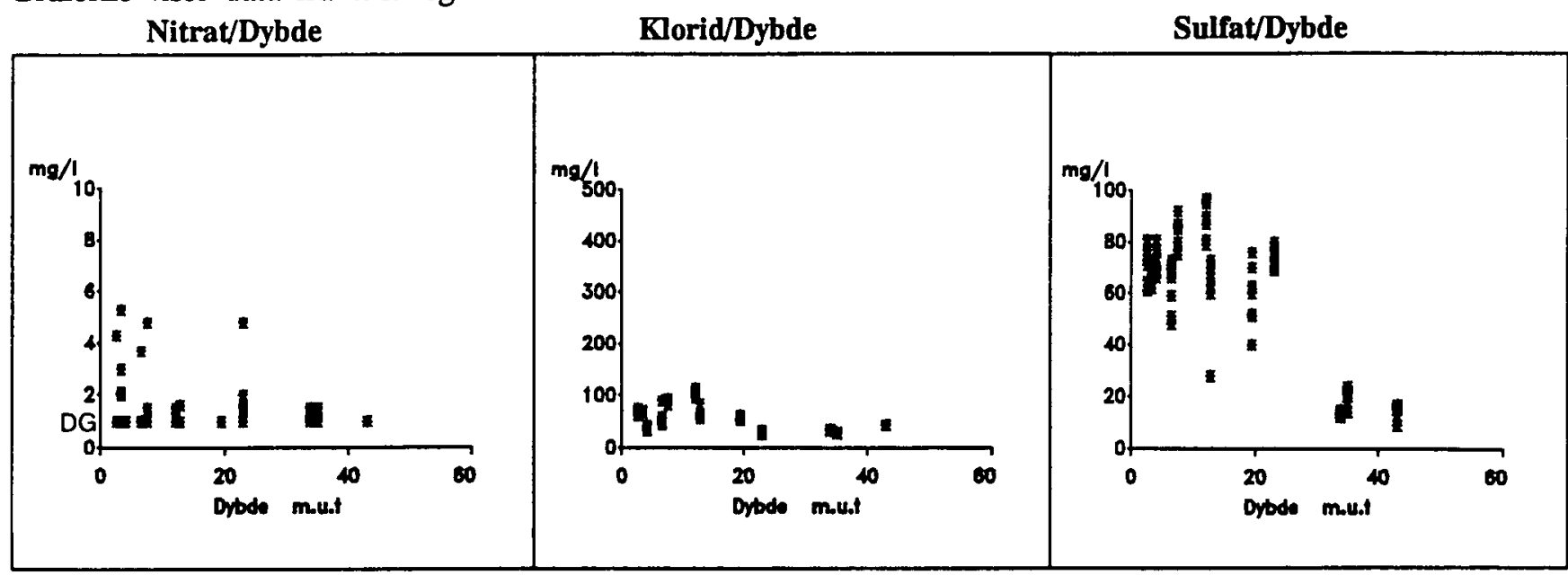




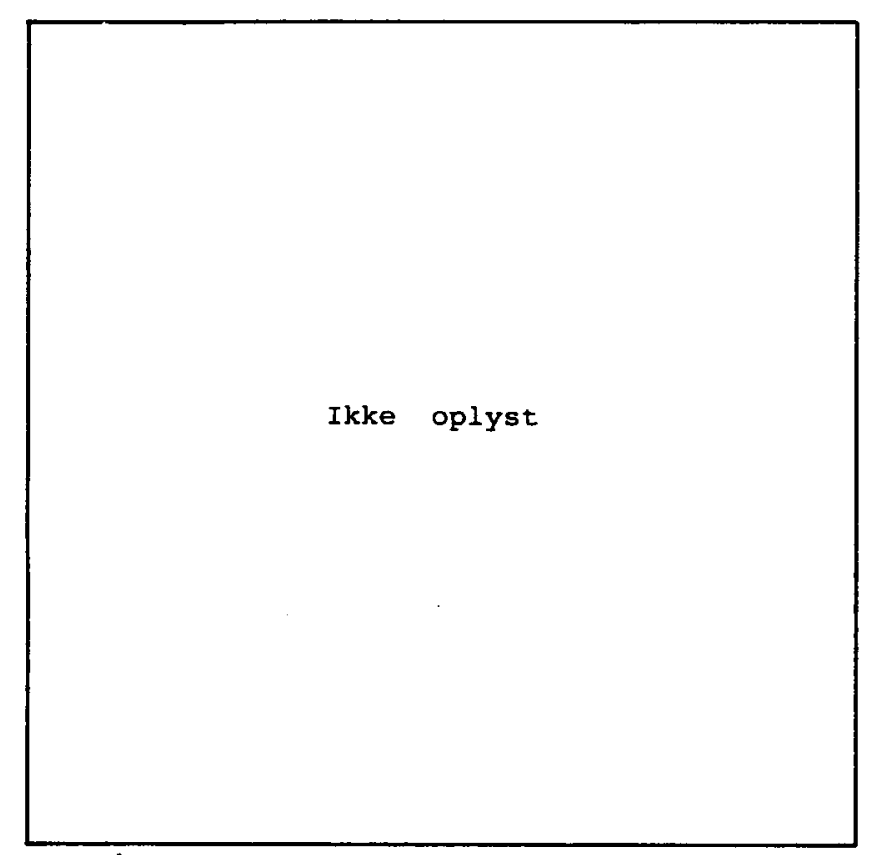

DGU nir. 215

Ikke oplyst

Areal

Geologi: De kvartære aflejringer består af smeltevandssand og moræneler. Smeltevandssandet forekommer i to intervaller og er adskilt af moræneler. I det dybeste morænelerslag er der flager af Eocænt ler.

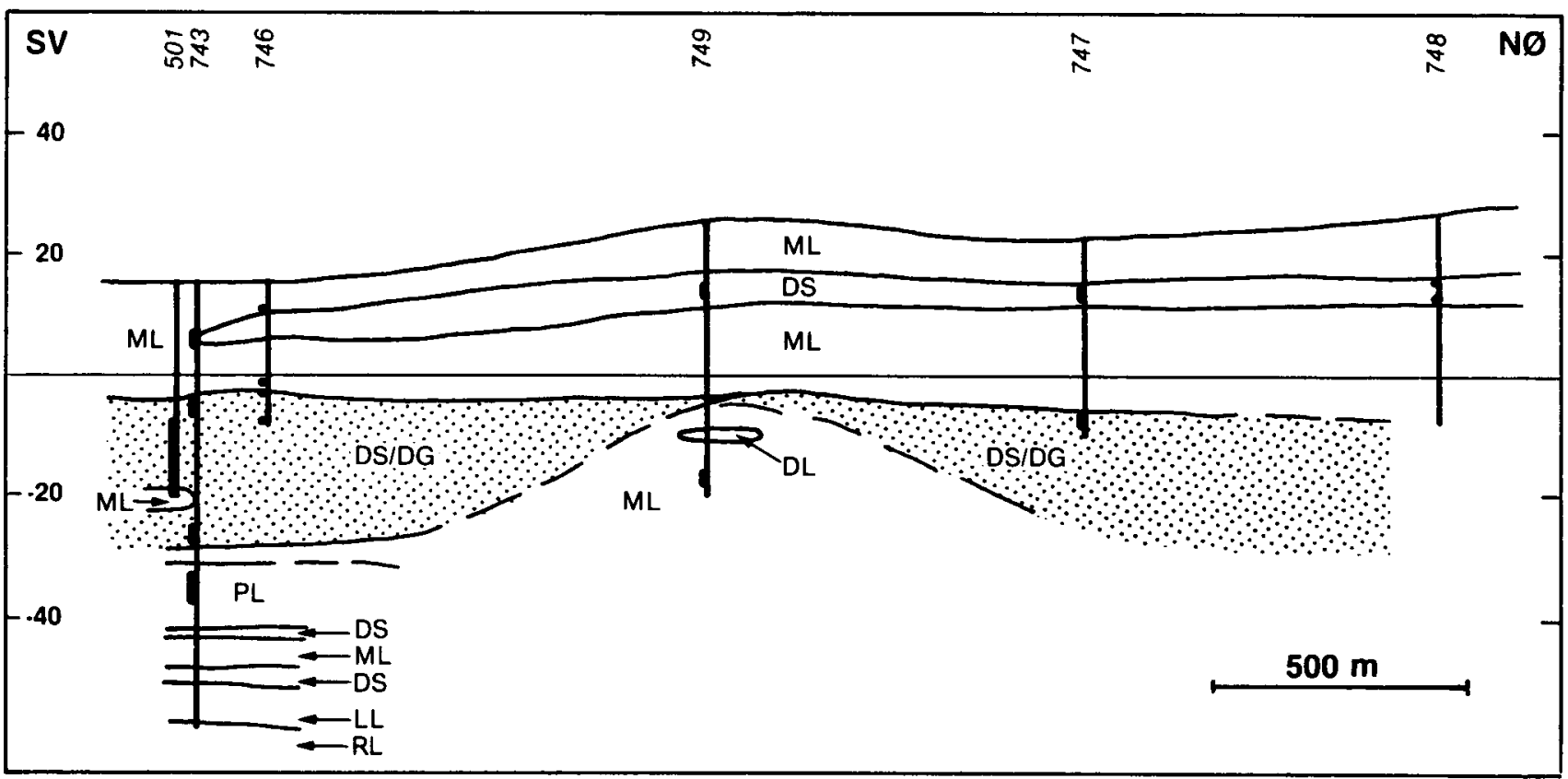


Hydrogeologi: Det dybestliggende lag af smeltevandssand udgør det artesiske hovedreservoiret og kaldes Eggeslevmagle Reservoiret.

Det sekundære reservoir består af et overfladenært lag af smeltevandssand, som synes at være sammenhængende inden for hele overvågningsområdet. Laget er typisk siltet $\mathrm{i}$ den nederste del.

Begge reservoirer er artesiske.

Grundvandskemi: Grundvandet $i$ hovedreservoiret er generelt en blanding mellem en calcium-bikarbonat- og en natrium-kloridtype. Nitratkoncentrationen $i$ hovedreservoiret er genrelt lav. Grundvandet i det sekundære reservoir er af calcium-bikarbonattypen. Ionkoncentrationen $i$ det sekundære reservoir er på ca. 20 milliækvivalenter pr. liter og reduktionsgraden er lav til moderat. Jernreduktionen er generelt ikke

Vandbalance $\mathrm{mm} / \mathrm{år}$ :

Middelnedbør 537

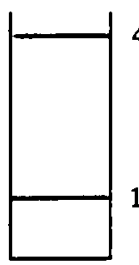

Kildeplads: Flakkebjerg w, 0.6 mill. m3/år

\section{Arealanvendelse \%:}

400 Fordampning

137 Nettonedbør

Landbrug

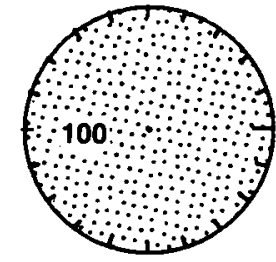

Registrerede depoter:

tilendebragt. Hovedreservoiret har i forhold til det sekundære reservoir højere koncentration af natrium, klorid, bikarbonat og ammonium, mens det har lavere sulfat- og calciumkoncentration. Saltindhold skyldes optrængende mineralvand.

Koncentrationen af udvalgte stoffer i forhold til dybde under terran.

Graferne viser data fra 1989 og 1990.

Nitrat/Dybde

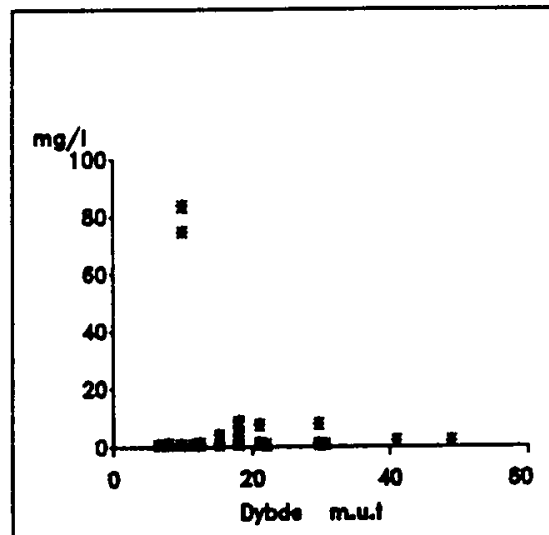

Klorid/Dybde

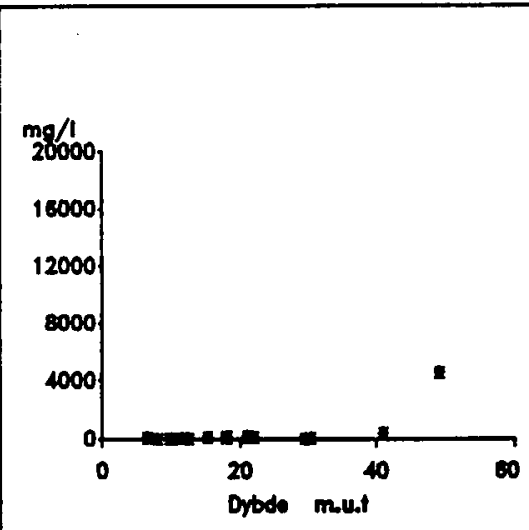

Sulfat/Dybde

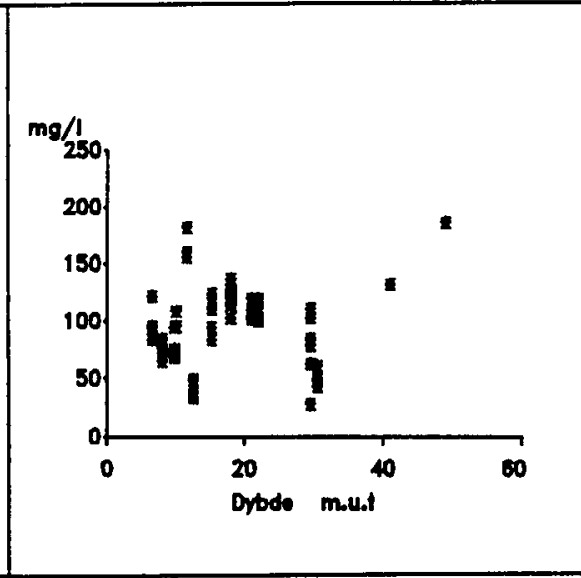


$1411 \mathrm{NV}+\mathrm{N} \emptyset$

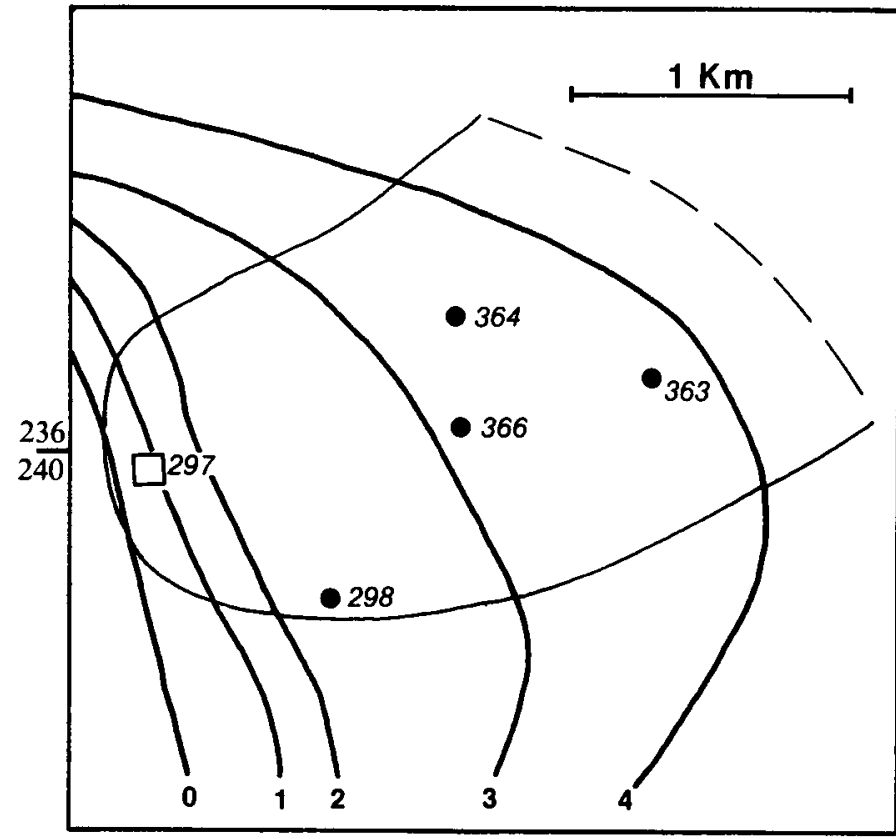

DGU nr. 236. og 240.

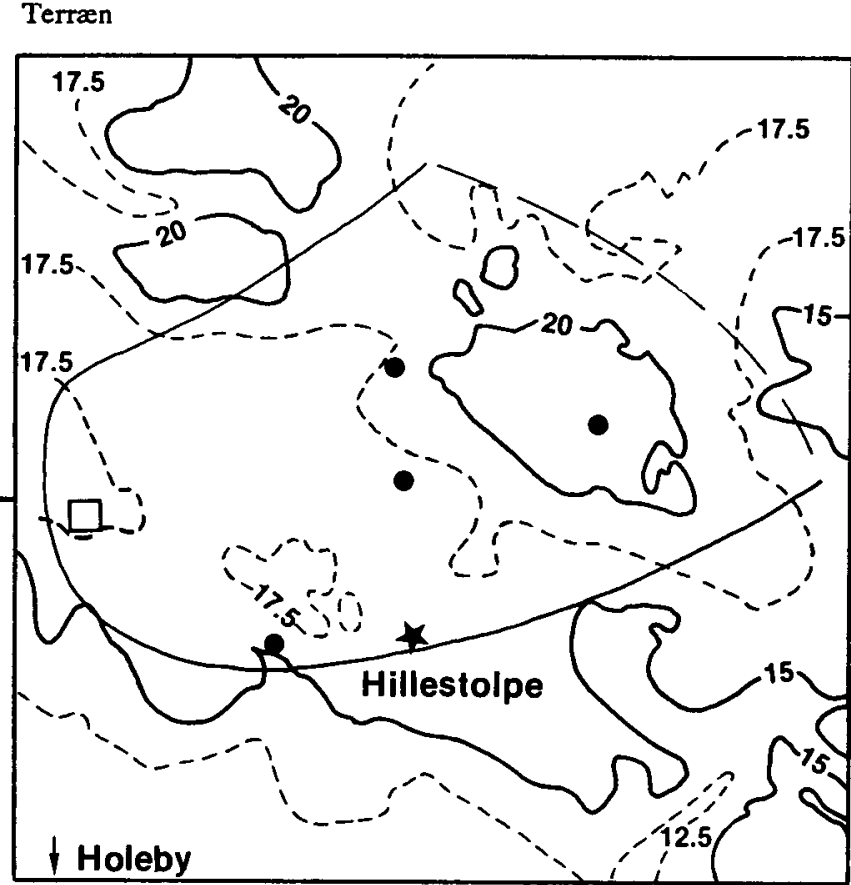

Areal $4 \mathrm{~km}^{2}$

Geologi: De øverste prækvartære lag i området udgøres af skrivekridt af Maastrichtien alder overlejret af plastisk ler (lillebæltsler) fra Eocæn. Den kvartære lagserie består af smeltevandssand og -grus overlejret af moræneler. Smeltevandsaflejringerne findes $\mathrm{i}$ en dalstruktur $\mathrm{i}$ kalkoverfladen. De kvartære lag er ikke gennemboret indenfor området. Landskabeligt er området et morænelandskab med ringe højdeforskel.

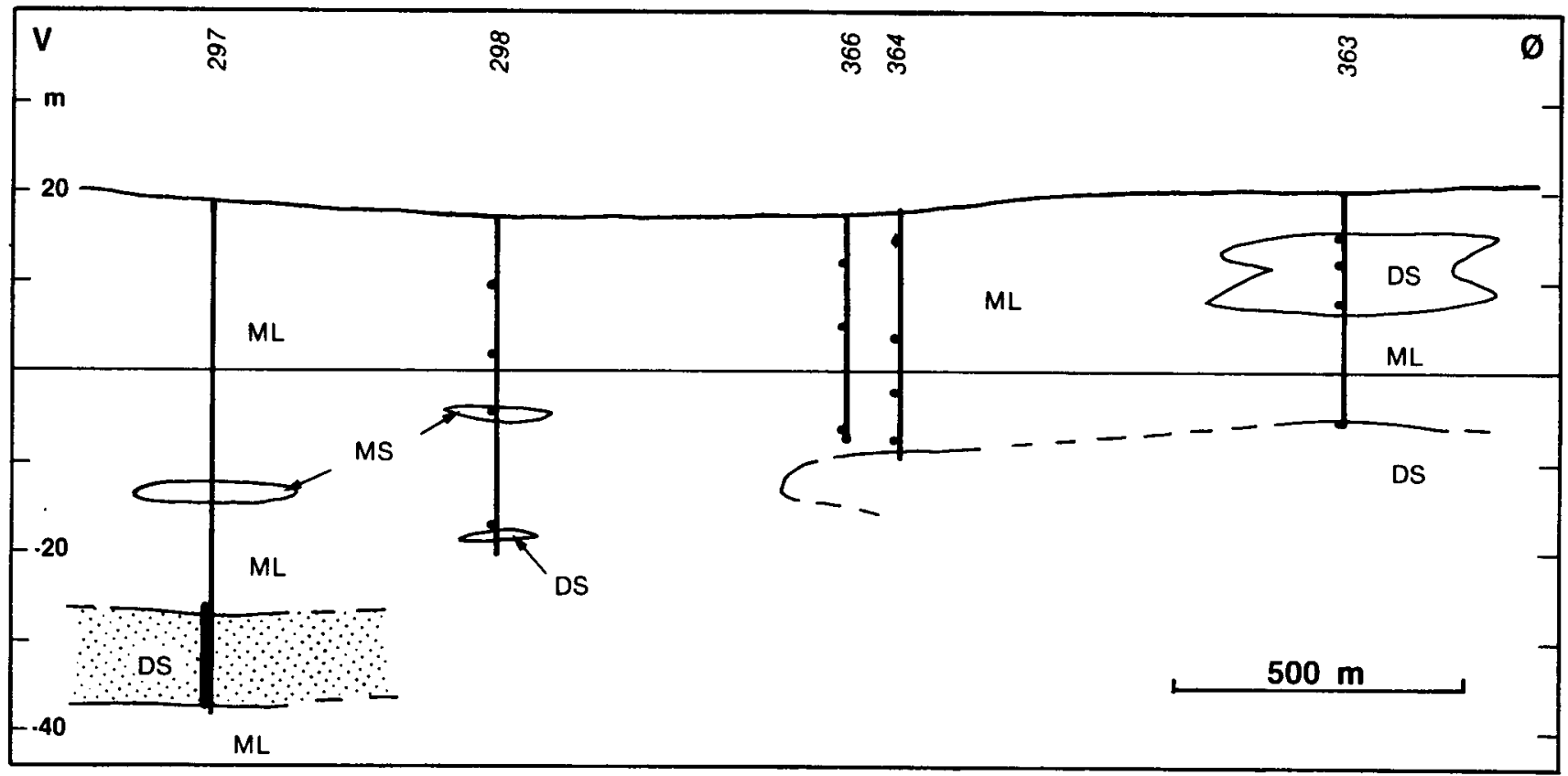


Hydrogeologi: Skrivekridt kan opfattes som det nederste reservoir i området, omend det ikke er anboret, og grundvandskvaliteten er ukendt. Herover findes det artesiske hovedreservoir i smeltevandssedimenterne. Isolerede sekundære artesiske reservoirer forekommer $i$ de sandede smeltevandssedimenter over hovedreservoiret.

Grundvandskemi: Grundvandet er af calcium-bikarbonattypen. Grundvandskvaliteten $\mathrm{i}$ hovedreservoiret er god. Vandet $\mathrm{i}$ de sekundære reservoirer har et relativt højere indhold af opløste salte og enkelte steder højt nitratindhold.

Vandbalance $\mathbf{m m} / \mathbf{a} \mathbf{r}:$

Middelnedbør 700

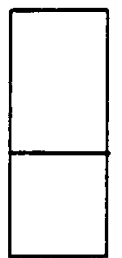

400 Fordampning

300 Nettonedbor

Kildeplads: Holeby og Omegn v, 0.33 mill. m3/år
Arealanvendelse \%:

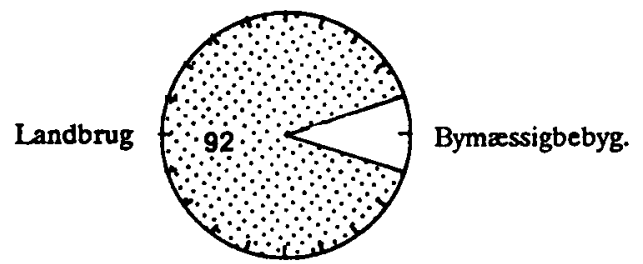

Registrerede depoter. ingen

Koncentrationen af udvalgte stoffer i forhold til dybde under terran.

Graferne viser data fra 1989 og 1990.

Nitrat/Dybde

Klorid/Dybde

Sulfat/Dybde

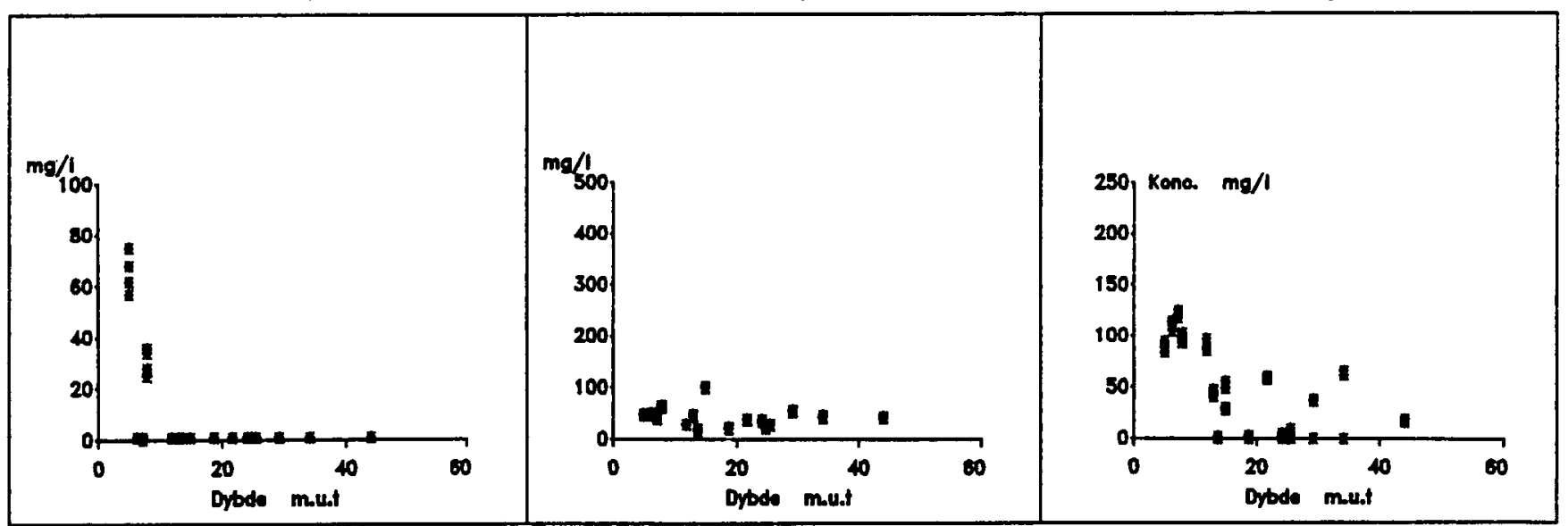


1512 IV NV

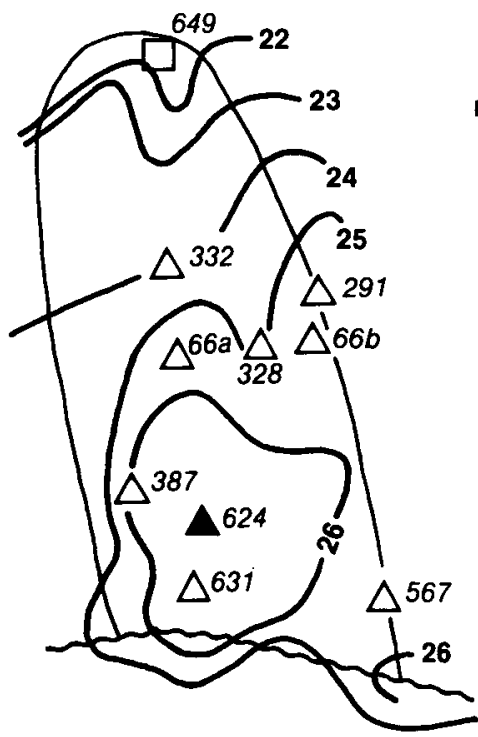

Terran

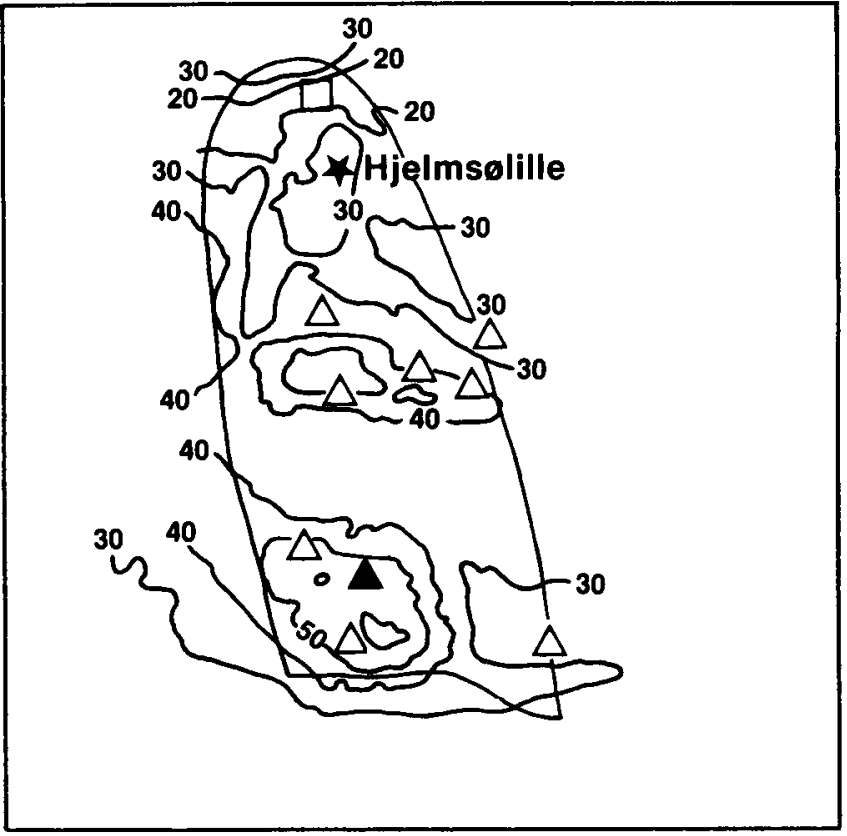

Areal $11 \mathrm{~km}^{2}$

DGU nr. 216

$1 \mathrm{Km}$

Geologi: Den øverste prækvartære lagserie i området udgøres af kalk af Danien alder overlejret af grønsandskalk fra Selandien. Særligt i den nordlige del af området er der dels indlejret grønsandsler i grønsandskalken, dels et lag grønsandsler umiddelbart over kalken. Den kvartære lagserie domineres af moræneler med indlejret smeltevandssand og -ler. I overfladen forekommer der lokalt postglaciale tørv og ferskvandssand, hovedsagelig i ådalene.

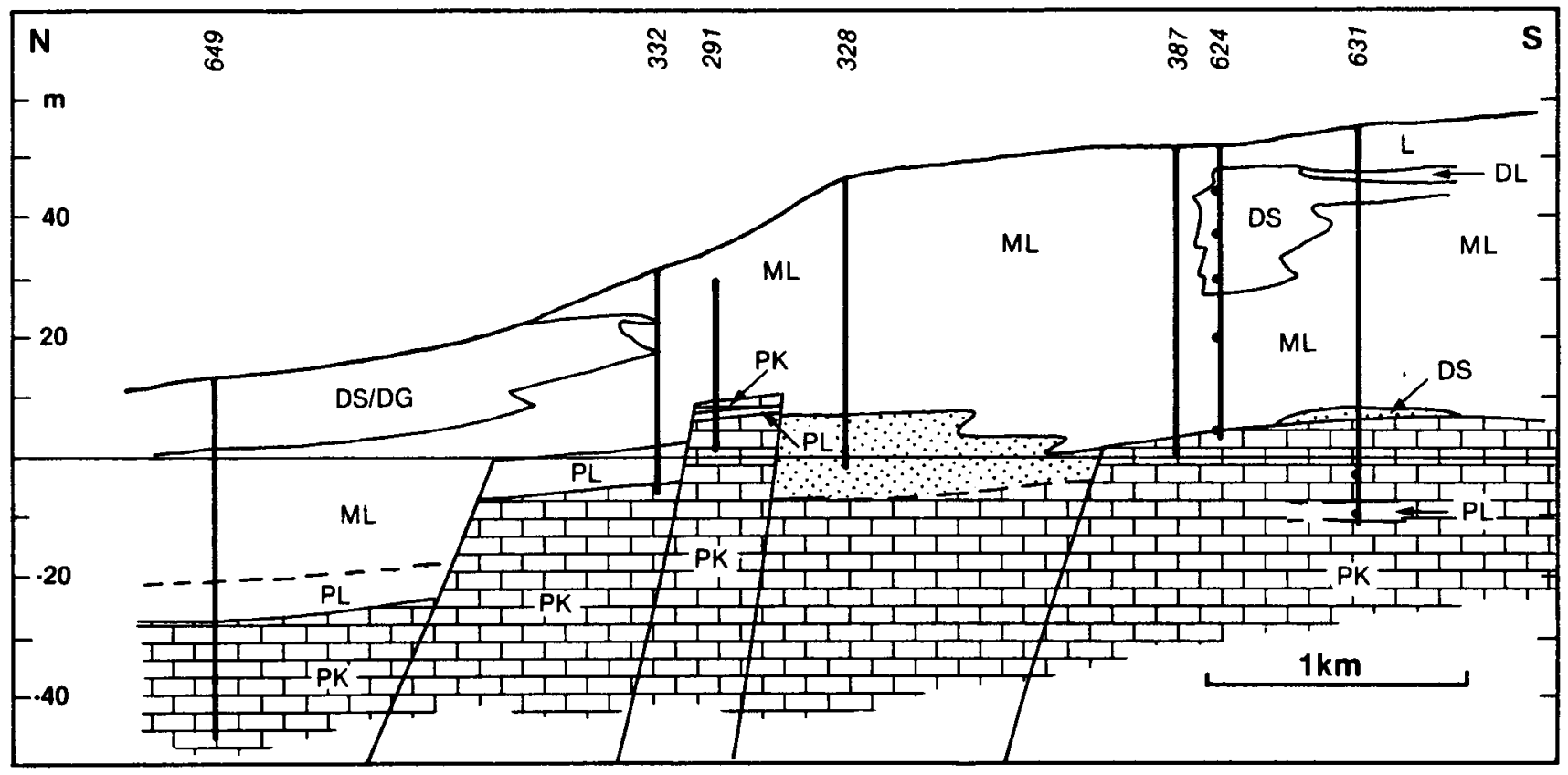


Hydrogeologi: Hovedreservoirerne, der er artesiske, findes i Danien og Selandien kalkstenen. Hvor der forekommer indlejret grønsandsler, er der flere adskilte reservoirer i grønsandskalken. I Susådalen har de udbredte dybereliggende reservoirer et højere potentiale end de øvre reservoirer. De sekundære reservoirer $i$ smeltevandssand og -grus aflejringerne udnyttes kun i ringe udstrækning. Den overordnede strømningsretning for grundvandet foregår mod nord-nordvest, men lokalt er strømningsmønsteret mere kompliceret, jævnfør potentialekortet.

Grundvandskemi: Grundvandet i området er af calcium-bicarbonattypen og har højt ammoniumindhold. Det dybereliggende grundvand indeholder forholdsvis meget klorid og natrium, der stammer fra mineralvand, som trænger op i sprækkezoner. I de sekundære reservoirer er nitratindholdet lavt, mens indholdet af opløst jern er relativt højt.

Vandbalance mm/år:

Middelnedbor 700

Kildeplads: Hjelmsølillevæerket, 2 mill. m3/år, Tybjerg, 00,06 mill. m3/år Tybjerglillebakke 00.05 mill. $\mathrm{m} 3 / \mathrm{a}_{\mathrm{r}}$

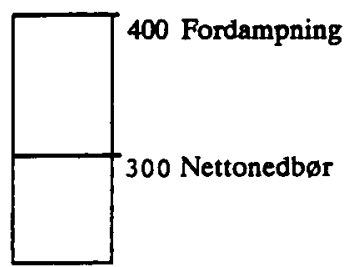

\section{Arealanvendelse \%:}

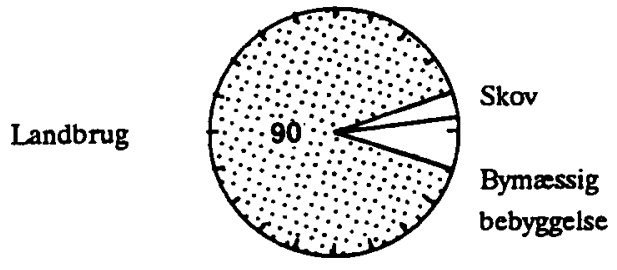

Registrerede depoter: ingen

Koncentrationen af udvalgte stoffer i forhold til dybde under terran.

Graferne viser data fra 1989 og 1990.

Nitrat/Dybde

Klorid/Dybde

Sulfat/Dybde

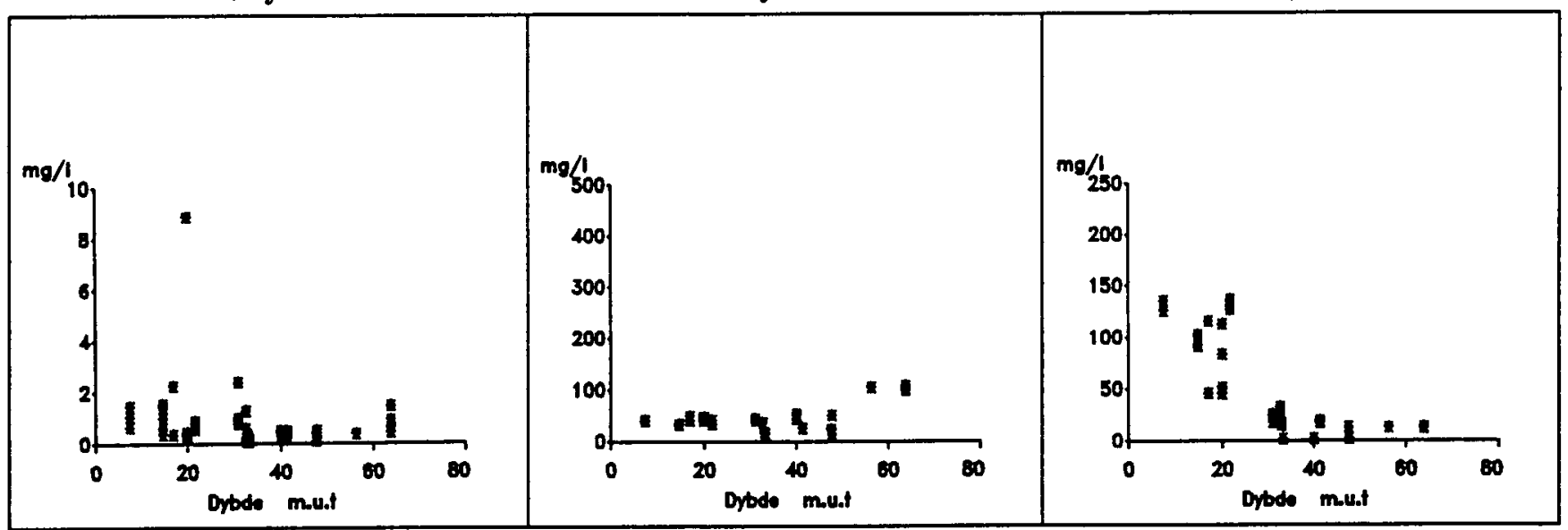




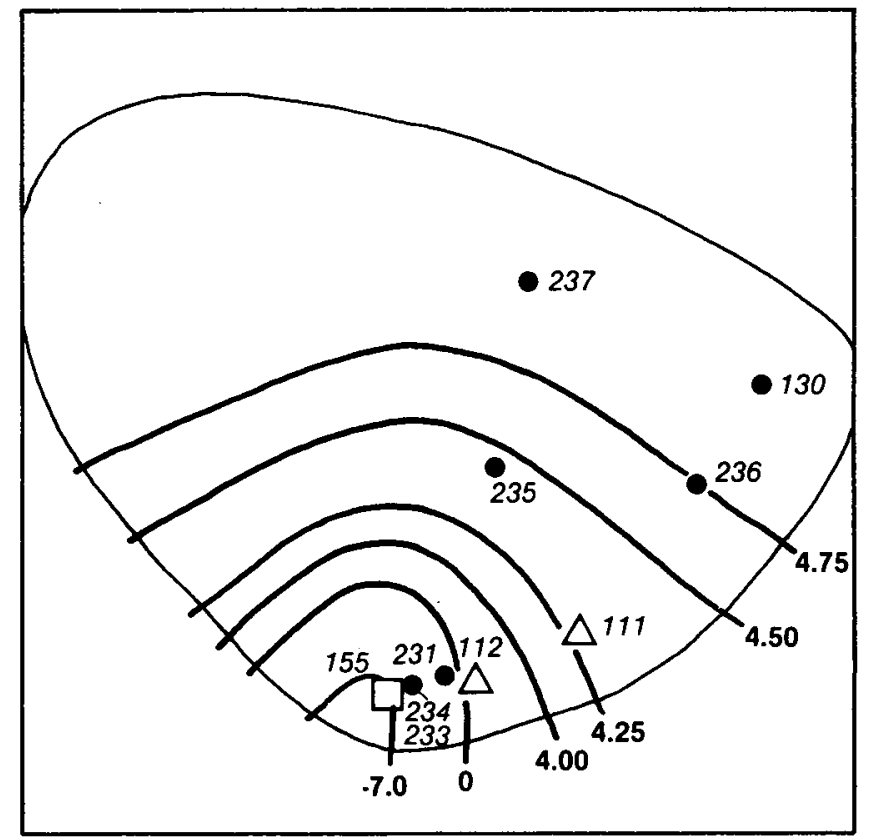

DGU nr. 230

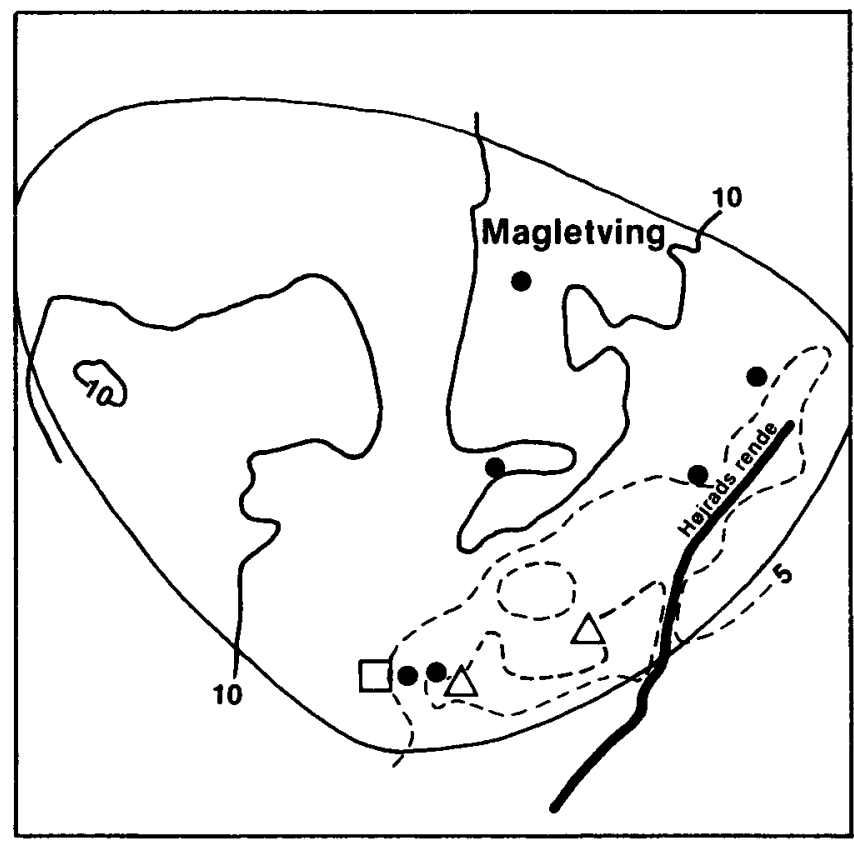

Areal $2.5 \mathrm{~km}^{2}$

Geologi: De фverste prækvartære aflejringer i området består af skrivekridt af Maastrichtien alder. Herover er der vekslende sandede smeltevandssedimenter og moræneler. Det nederste sandlag ligger direkte oven på skrivekridt. I området er der dels morænebakkelandskaber, dels et fladt smeltevandssandsdomineret landskab.

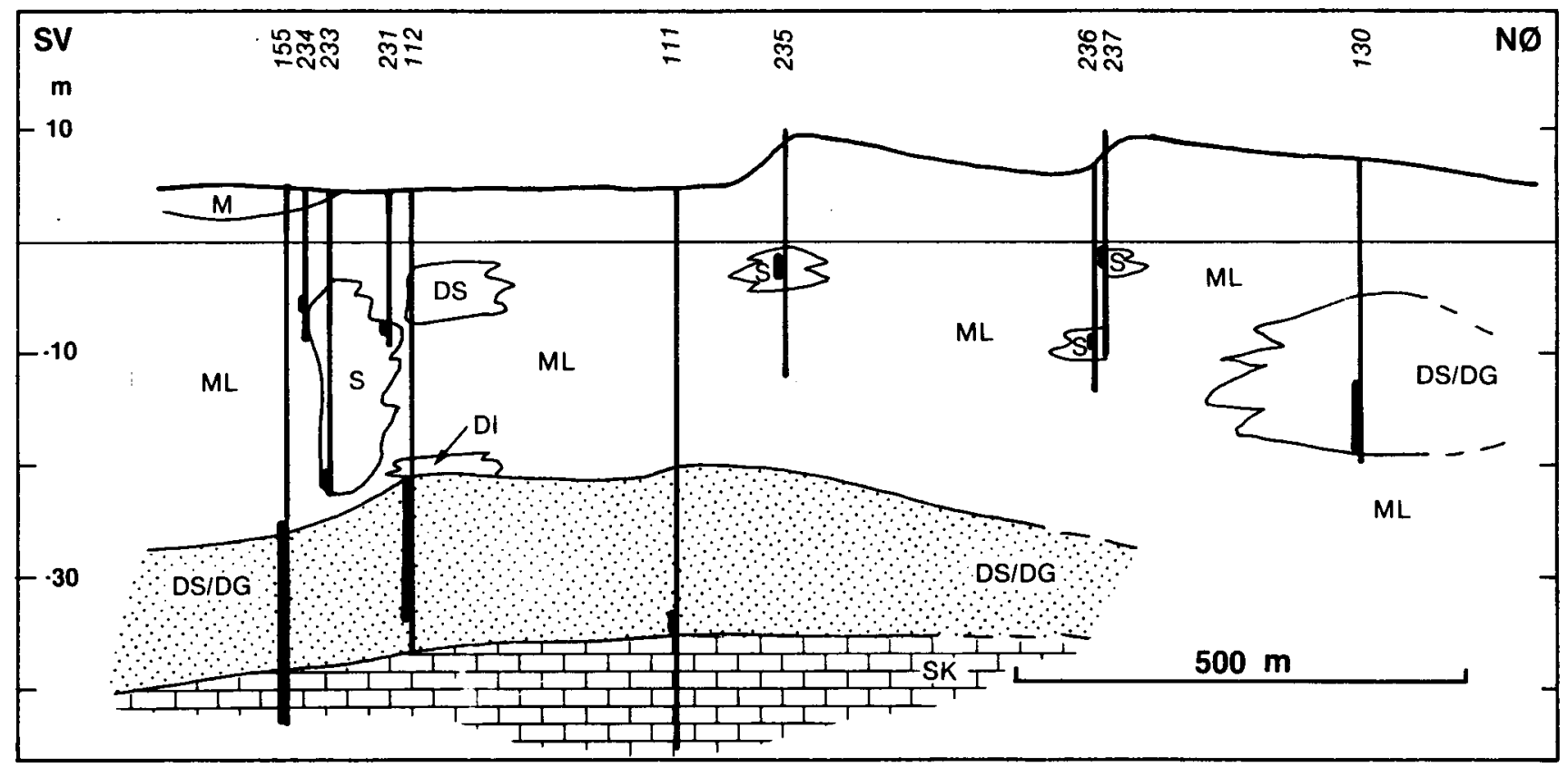


Hydrogeologi: De sandede smeltevandsaflejringer umiddelbart over skrivekridt udgør hovedreservoiret. De sekundære reservoirer består af de sandede smeltevandsaflejringer, der ikke er i direkte forbindelse med skrivekridtet. I begge reservoirtyper er der artesiske forhold.

Grundvandskemi: Grundvandet er af calcium-bikarbonattypen. pH (malt i felten) er mellem 7 og 7,5 i hele området. Sulfatindholdet er forholdsvis højt i grundvandet $\mathrm{i}$ både hovedreservoiret og de sekundære reservoirer. Grundvandet i flere sekundære reservoirer indeholder nitrat.

Vandbalance $\mathrm{mm} / \mathrm{år}$ :

Middelnedbør 700

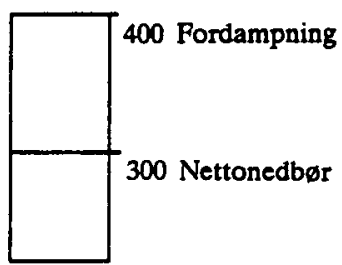

Kildeplads: Regionalvandvarket, 0.25 mill. m3/år

\section{Arealanvendelse \%:}

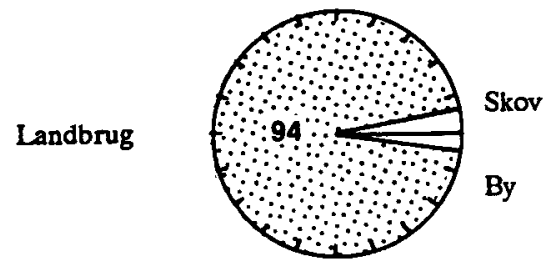

Registrerede depoter: ingen

Koncentrationen af udvalgte stoffer i forhold til dybde under terran.

Graferne viser data fra 1989 og 1990.

Nitrat/Dybde

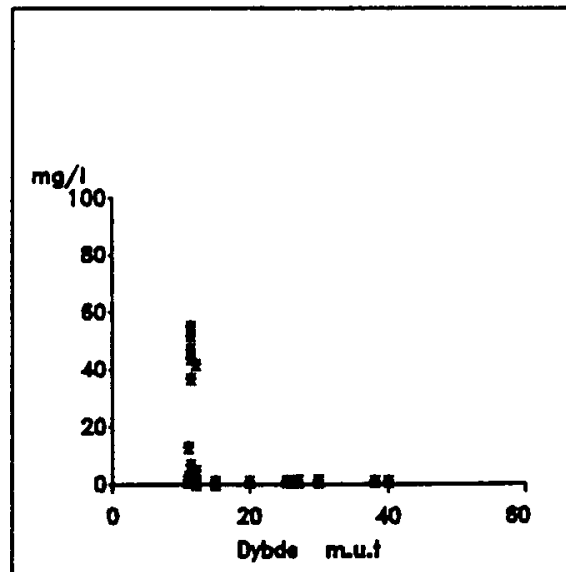

Klorid/Dybde

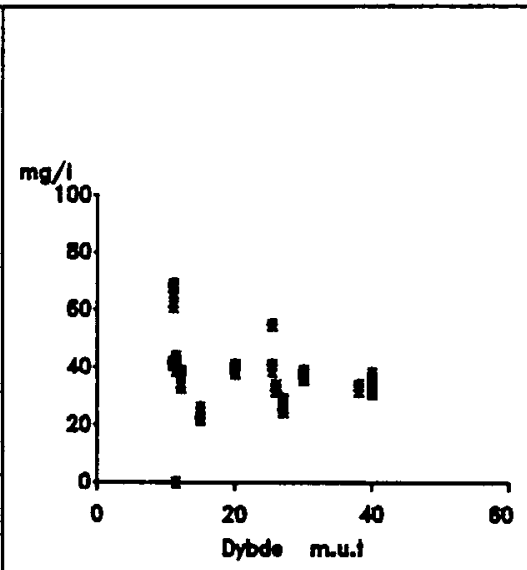

Sulfat/Dybde

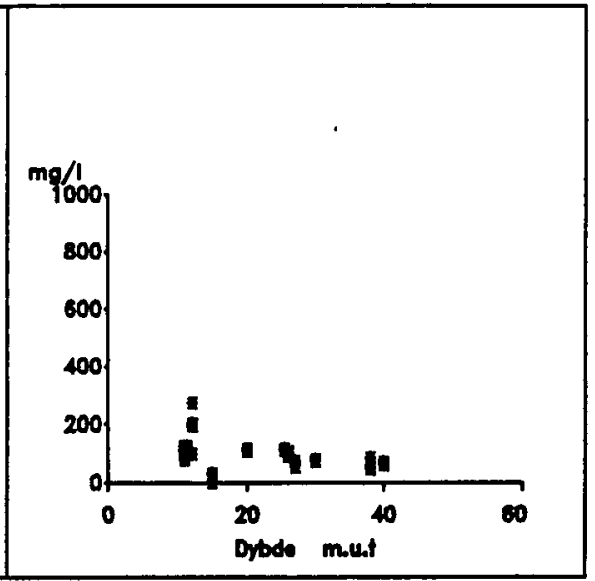



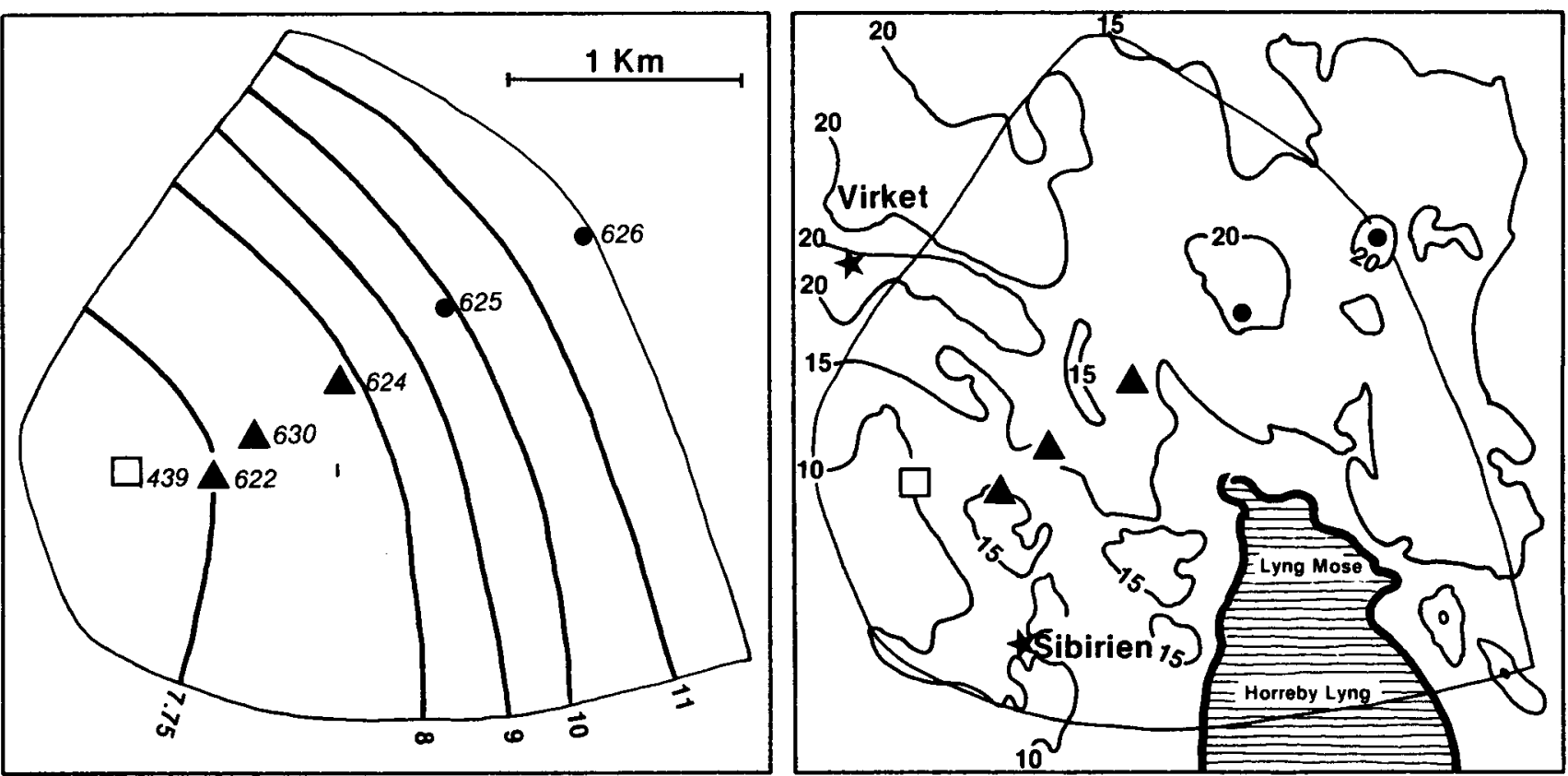

DGU nr. 238

Areal $7 \mathrm{~km}^{2}$

Geologi: De øverste prækvartære lag består af skrivekridt fra Maastrichtien. Herover er der kvartære aflejringer, der nederst består af sandede smeltevandssedimenter, overlejret af moræneler med lommer af smeltevandssand.

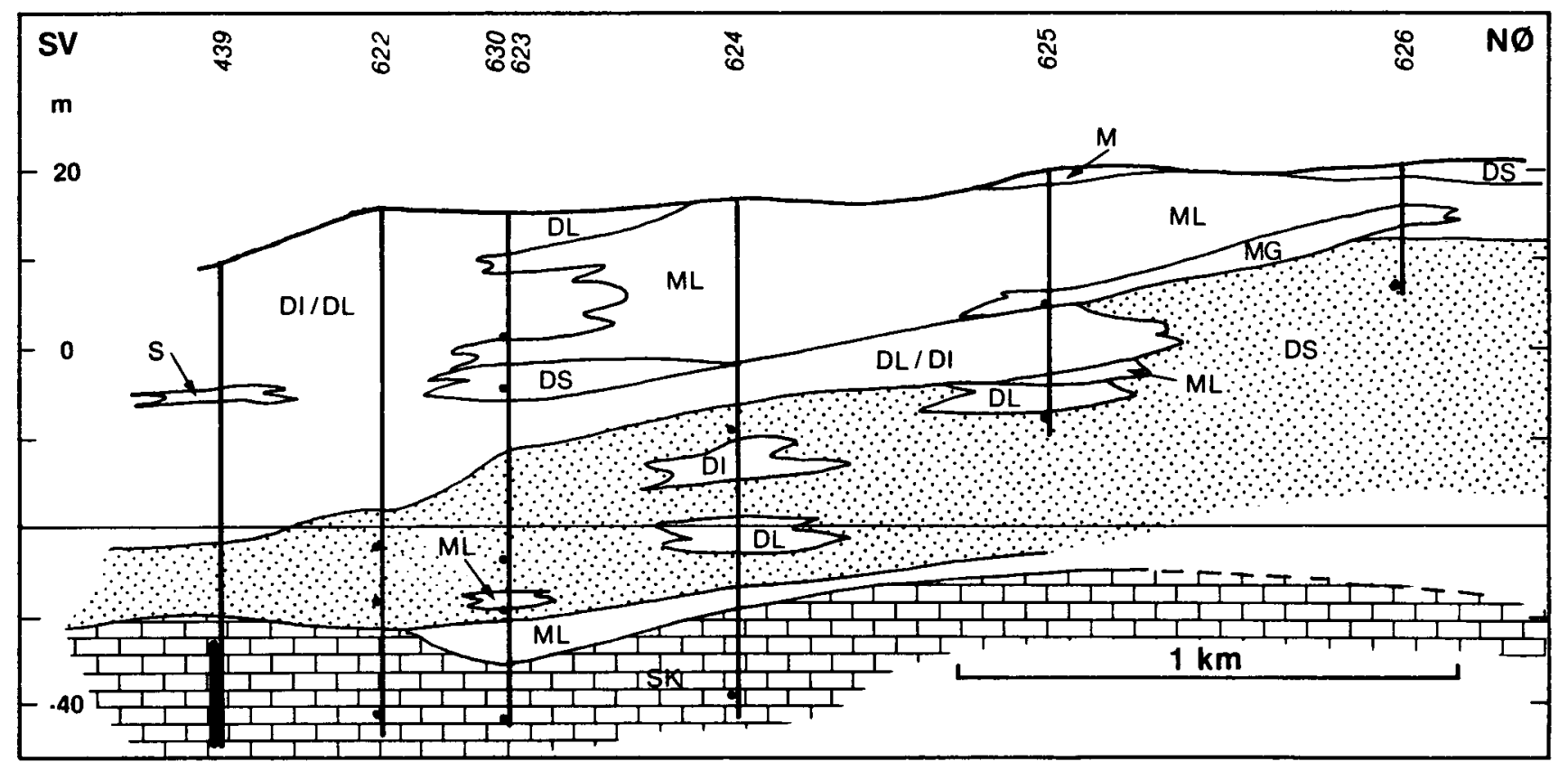


Hydrogeologi: Skrivekridtet og det overlejrende smeltevandssand udgør tilsammen hovedreservoiret. Det sekundære reservoir findes $\mathrm{i}$ de indlejrede smeltevandssedimenter $\mathrm{i}$ moræneleret. I begge reservoirer er der artesiske forhold.

Grundvandskemi: Grundvandet er af calcium-bikarbonattypen. Der er konstateret indhold af klorid, natrium, fosfor, ammonium, jern og mangan samt kaliumpermanganattal over de vejledende værdier $i$ hovedboringen. Saltindholdet $i$ hovedboringen skyldes optrængning af mineralvand $i$ en nærved liggende boring gennem sprækker. Kun nær oplandsgrænsen og $\mathrm{i}$ det sekundære reservoir indeholder grundvandet nitrat.

Vandbalance mm/år:

Middelnedbør 700

Kildeplads: Nykøbing kommunale varker, 0.58 mill. m3/âr

\section{Arealanvendelse \%:}

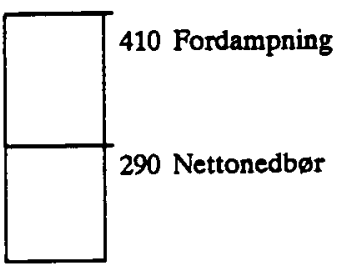

Landbrug

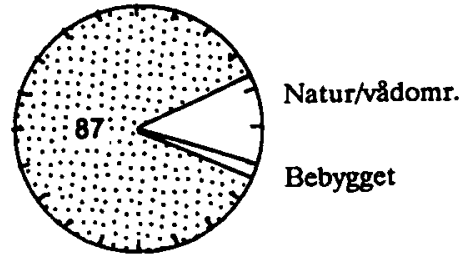

Registrerede depoter.

Koncentrationen af udvalgte stoffer i forhold til dybde under terran.

Graferne viser data fra 1989 og 1990.

$$
\text { Nitrat/Dybde }
$$

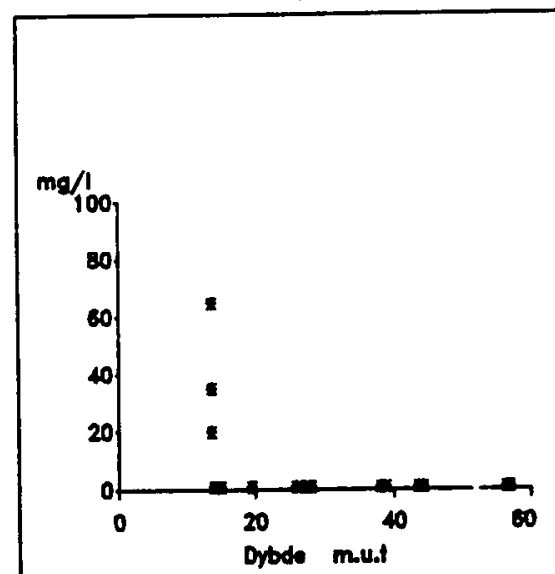

Klorid/Dybde

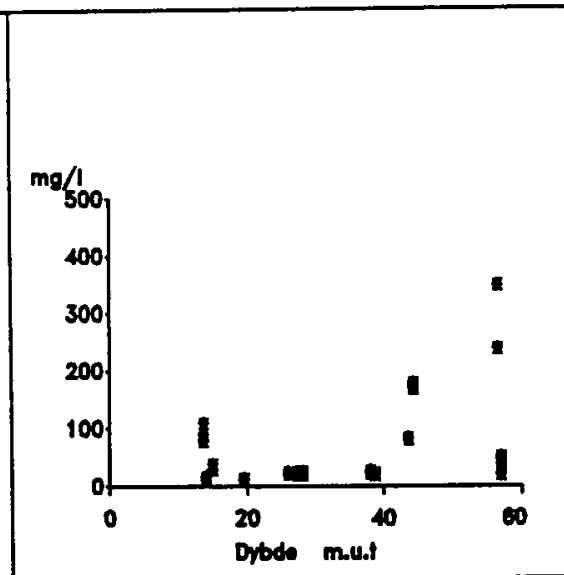

Sulfat/Dybde

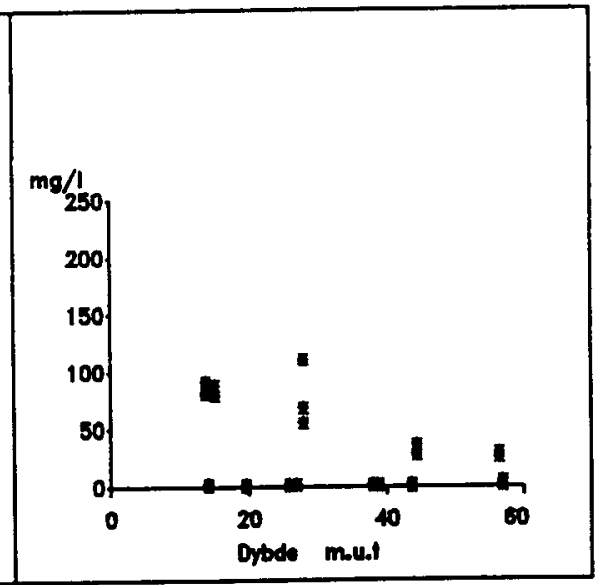


Potentiale

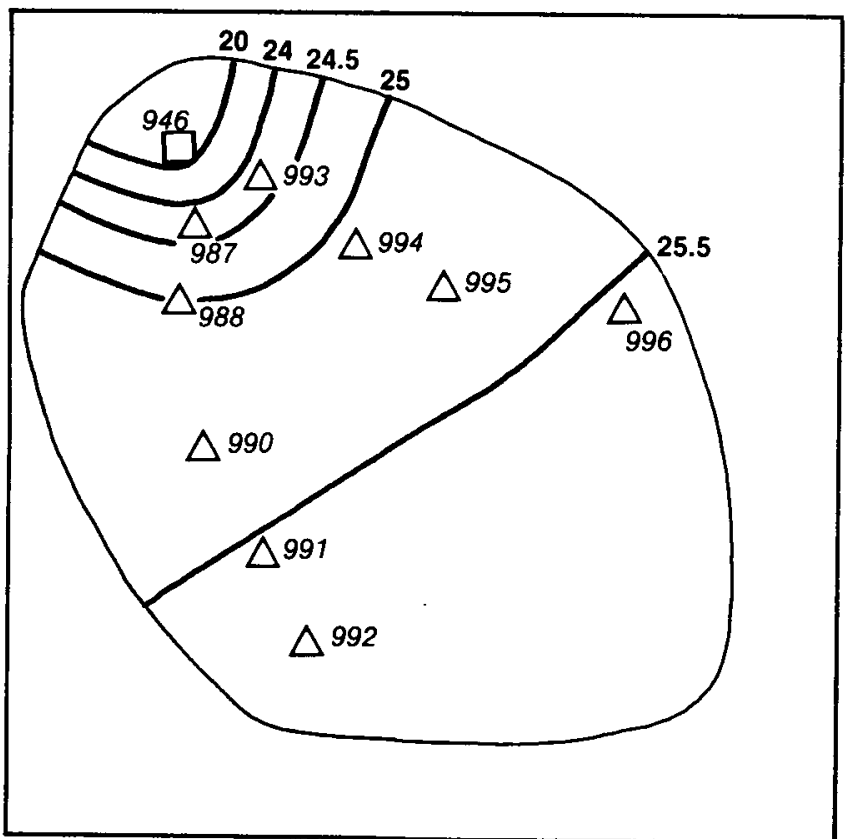

DGU nr. 218
Terræn

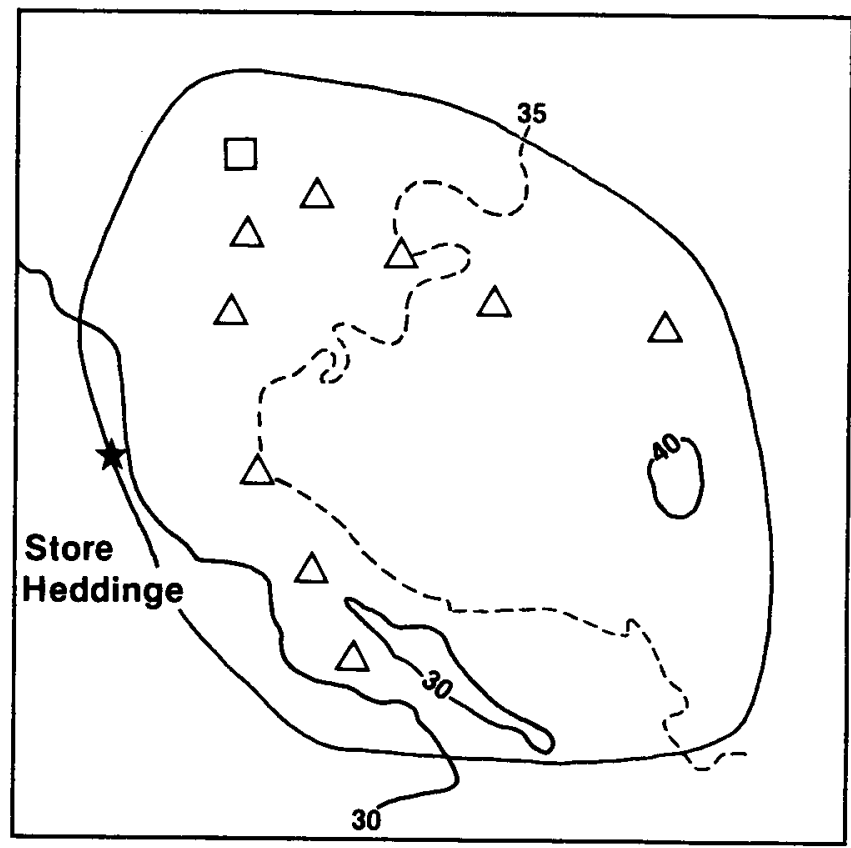

Areal $5,8 \mathrm{~km}^{2}$

Geologi: Den øverste prækvartære lagserie består op til kote 10 af skrivekridt af Maastrichtien alder overlejret af bryozokalk af Danien alder. På grænseovergangen mellem disse lag er der en hærdningshorisont samt stedvis et tyndt lag fiskeler. Prækvartæroverfladen er stærkt opsprækket. De kvartære aflejringer domineres af moræneler. Ikke alle overvågningsområdets filtre er inkluderet $\mathrm{i}$ profilet.

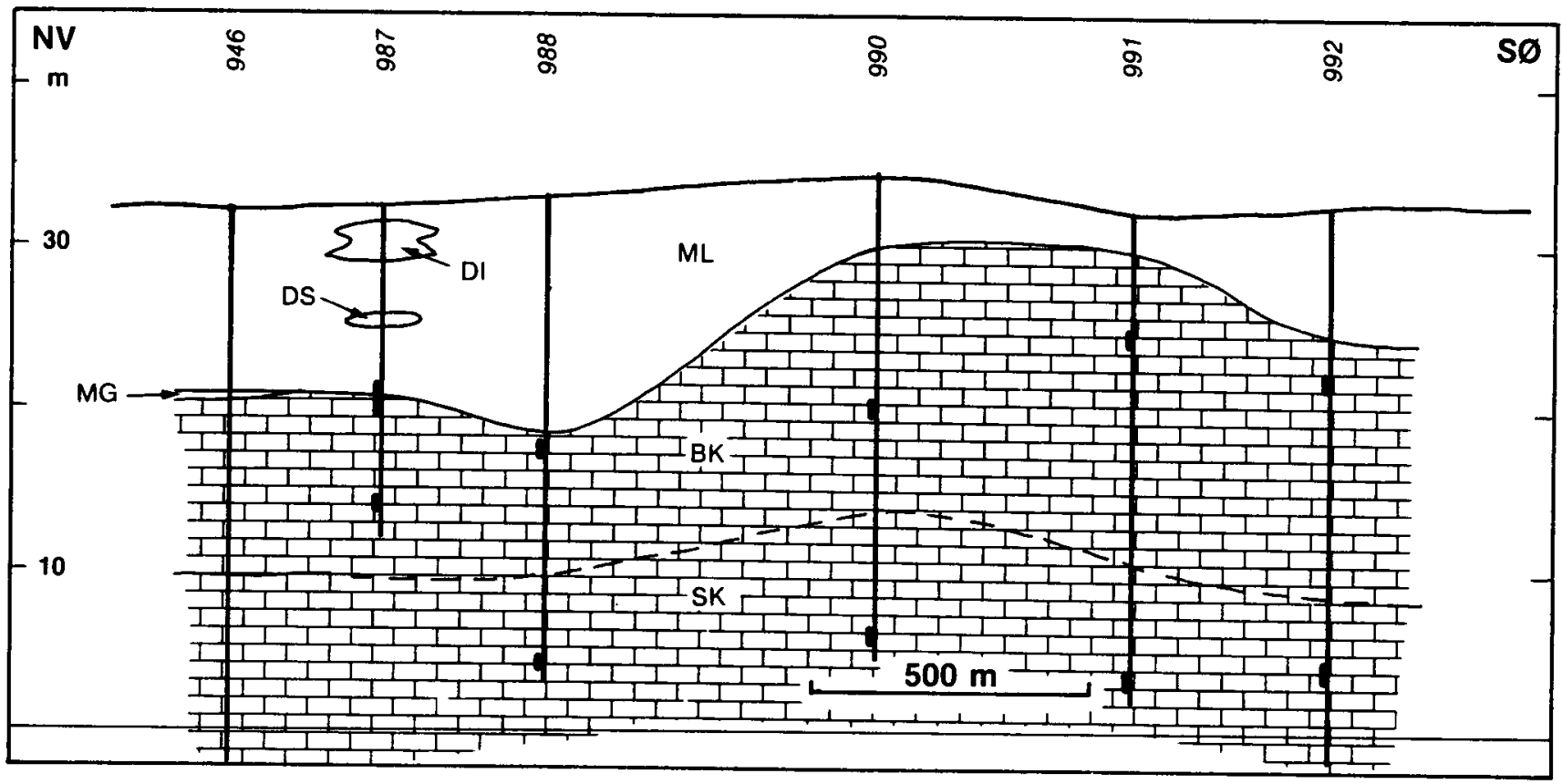


Hydrogeologi: Bryozokalken udgør hovedreservoiret. Skrivekridtet yder ikke tilstrækkelig vand til at kunne udnyttes undtagen i sprækkezoner. Der er vekslende artesiske og frie forhold i hovedreservoiret.

Grundvandskemi: Grundvandet er af calcium-bikarbonattypen. Området er nitratbelastet. I den centrale del af området, hvor der kun er et tyndt morænedække, er der et højt men varierende nitratindhold, idet reduktionskapaciteten er lav. Generelt er reduktionskapaciteten ikke opbrugt i de artesiske dele af reservoiret. I vandet fra de dybere filtre er der høje geologisk betingede indhold af strontium og fluor. Sulfatindholdet er over den vejledende grænseværdi for drikkevand. Dette høje indhold findes i ganske ungt oxideret eller let reduceret grundvand, samt i tilsvarende grundvand med tritiumindhold på 10-20 TU.

Vandbalance $\mathbf{m m} / \mathbf{a ̊ r}$

Middelnedbør 650

Kildeplads: St. Heddinge , 0.4 mill. m3/år, kommunale w

\section{Arealanvendelse \%:}

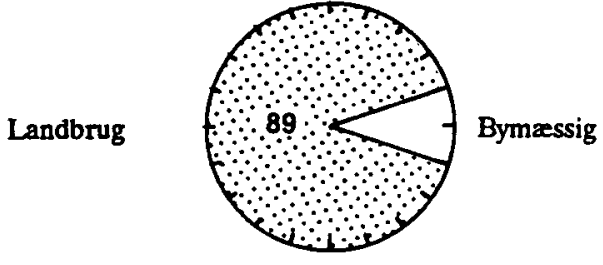

Registrerede depoter. flere industrigrunde, bland andet en gasvarksgrund.

Koncentrationen af udvalgte stoffer i forhold til dybde under terræn.

Graferne viser data fra 1989 og 1990.

Nitrat/Dybde

Klorid/Dybde

Sulfat/Dybde

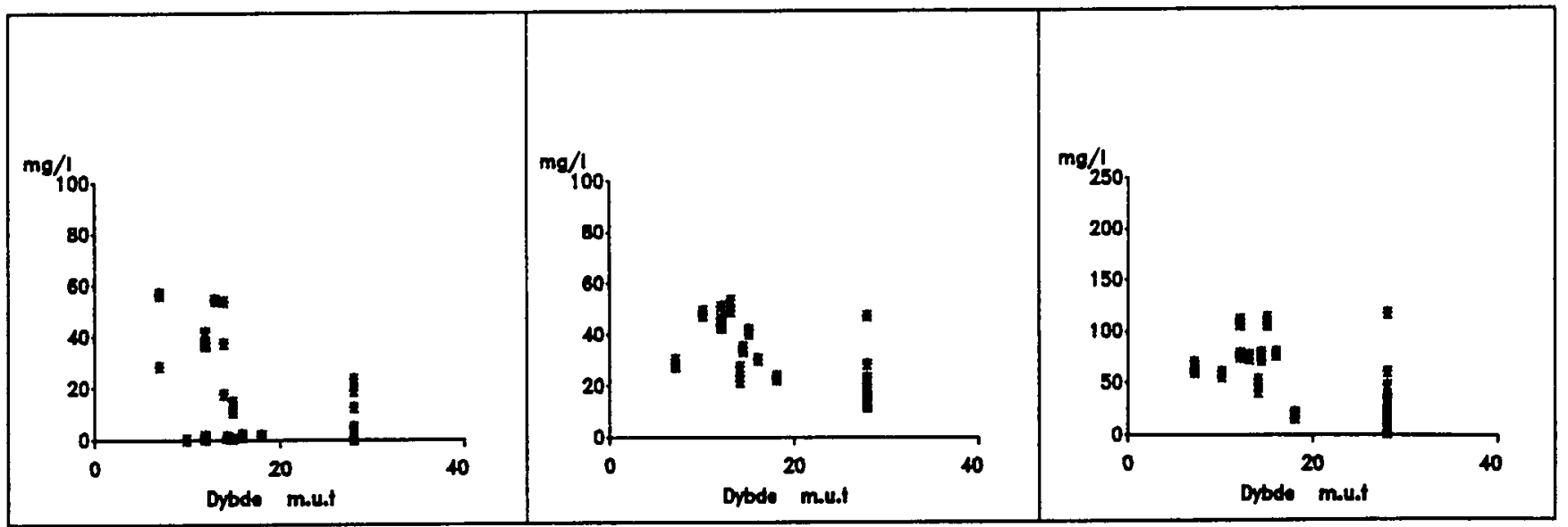




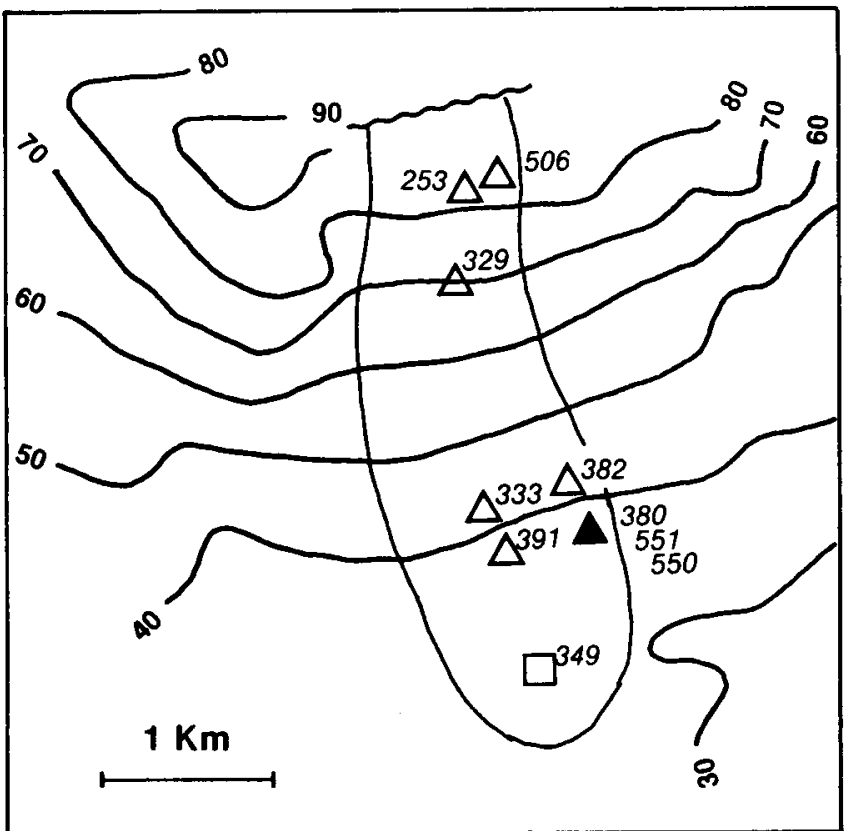

DGU nr. 247

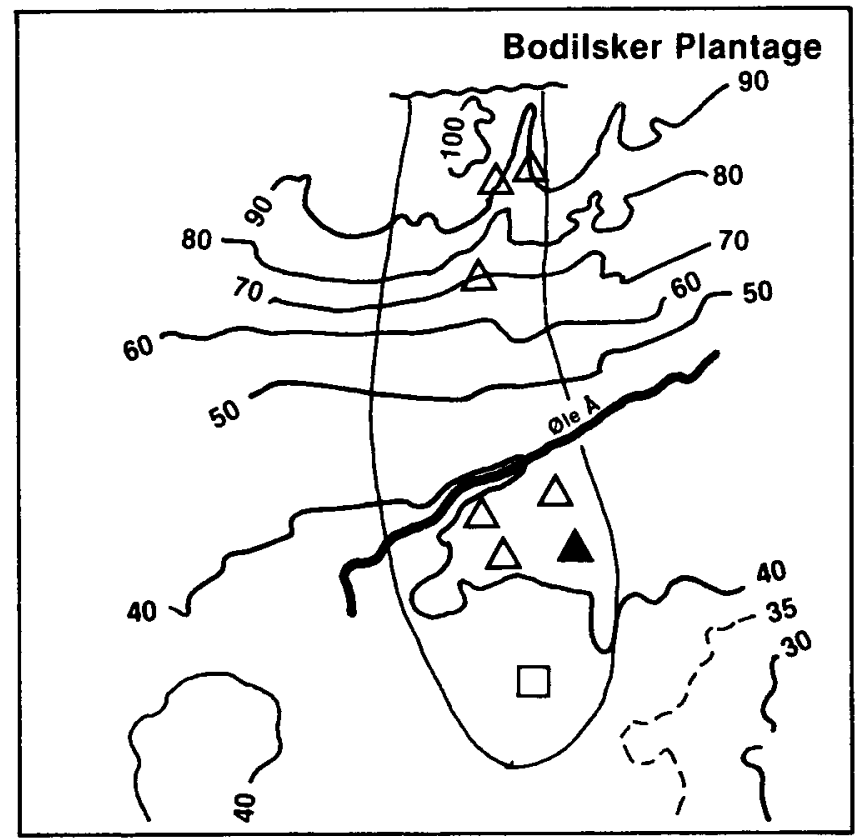

Areal $4,5 \mathrm{~km}^{2}$

Geologi: Bornholm er i geologisk henseende en horst, der er opstået som følge af jordskorpebevægelser. Øen er gennemskåret af forkastninger, der bevirker at den sydlige og vestlige del af øen består af hældende forkastningsblokke. Forkastningerne forløber hovedsagelig parallelt med kysterne. Smålyngen er en del af det Sydbornholmske sandstensområde, hvor sandsten af Nedre Kambrisk alder overlejrer Prækambriske gnejs- og granitbjergarter. De Nedre Kambriske sandsten udgøres af fire formationer, nemlig de tykke lag af Nexø Sandsten, Balka Sandsten og de "Grønne Skifre", som overlejres af et tyndt lag Rispebjerg Sandsten. Den ældste formation, Nexø Sandstenen, i den sydlige del af området. Lagserien hælder $3-4^{\circ}$ mod sydsydøst. De kvartære aflejringer

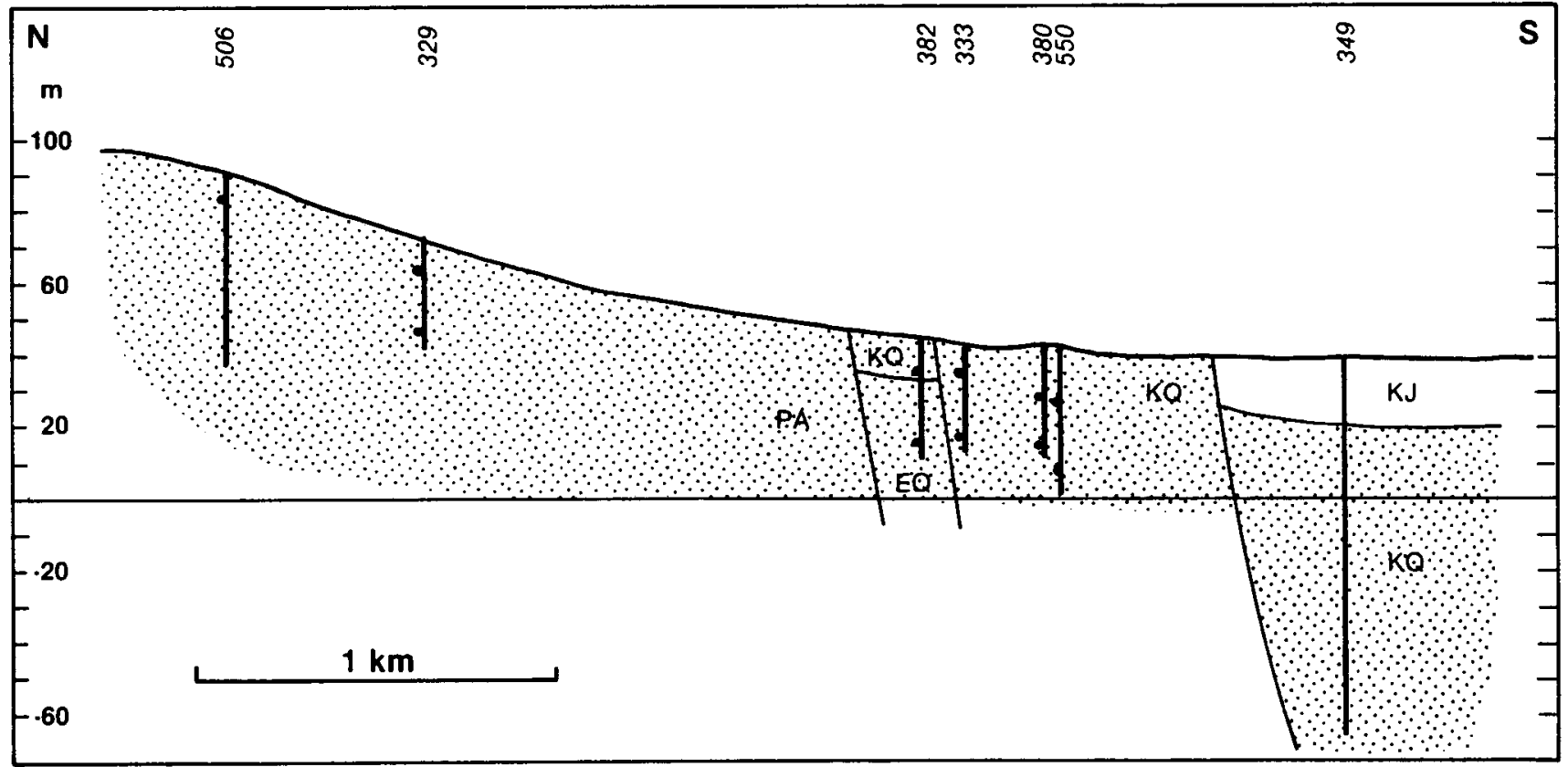


Hydrogeologi: Sammen med sprakkezonerne udgør sandstenene reservoiret $\mathrm{i}$ området, og tilsammen danner de sammenhængende reservoirer, idet sprækkesystemerne er $i$ hovedkontakt med hinanden. Reservoiret har frit grundvandsspejl, og der er således lækage fra de kvartære aflejinger. Amtet vurderer, at der er et hovedresrevoir i Balka Sandsten, og et sekundært i de "Grønne Skifre". Reservoirerne vurderes i fortsættelse heraf at være vekslende artesiske og frie.

Grundvandskemi: Grundvandet er af calcium-bikarbonattypen, det er ret aggressivt og har et relativt højt geologisk betinget sulfatindhold. Indholdet af bikarbonat, sulfat, klorid, calcium, magnesium, natrium og calcium varierer en hel del. I øvrigt er grundvandet renest under skovområderne mod nord og har et større stofindhold under landbrugsområderne.

Vandbalance $\mathbf{m m} / \mathbf{a ̊ r}$

Middelnedbør 600

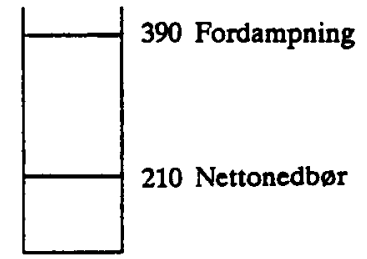

Kildeplads: Smålyng w, 0.56 mill. m3/år

\section{Arealanvendelse \%:}

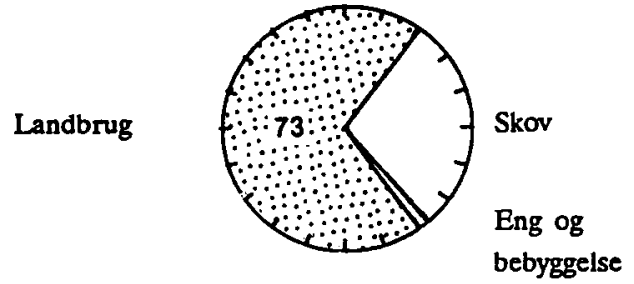

Registrerede depoter: ingen

Koncentrationen af udvalgte stoffer $\mathrm{i}$ forhold til dybde under terran.

Graferne viser data fra 1989 og 1990.

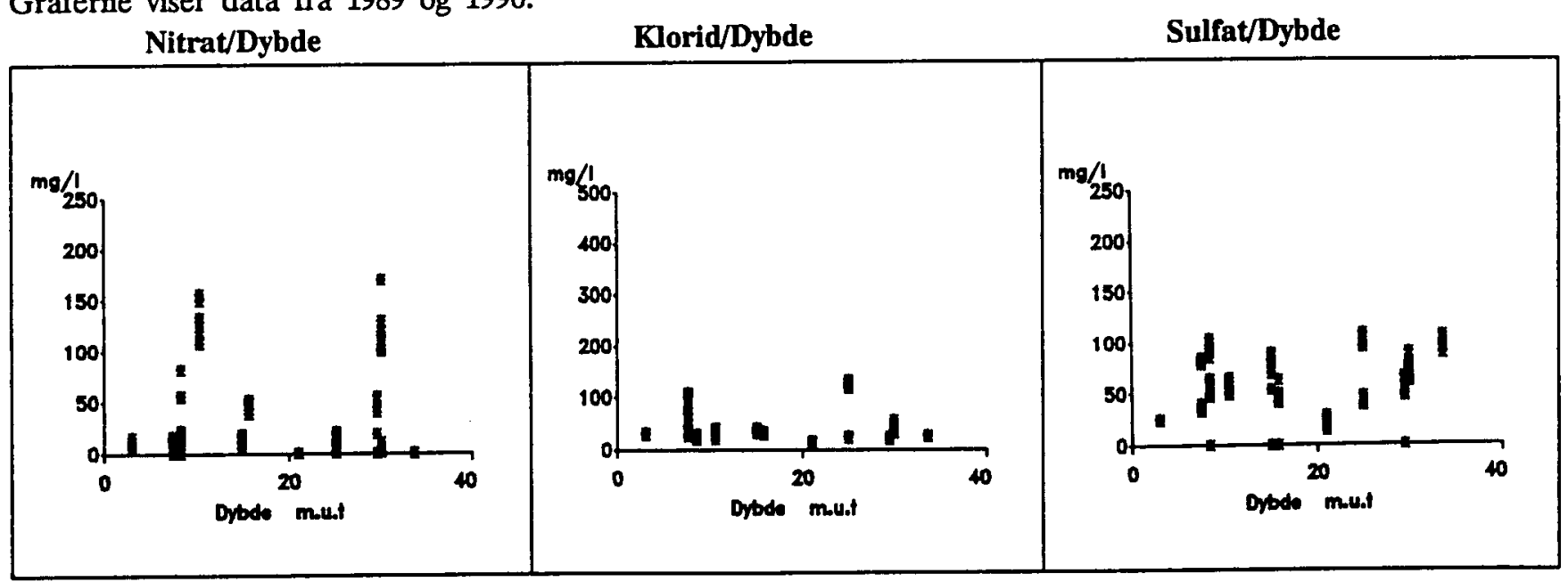



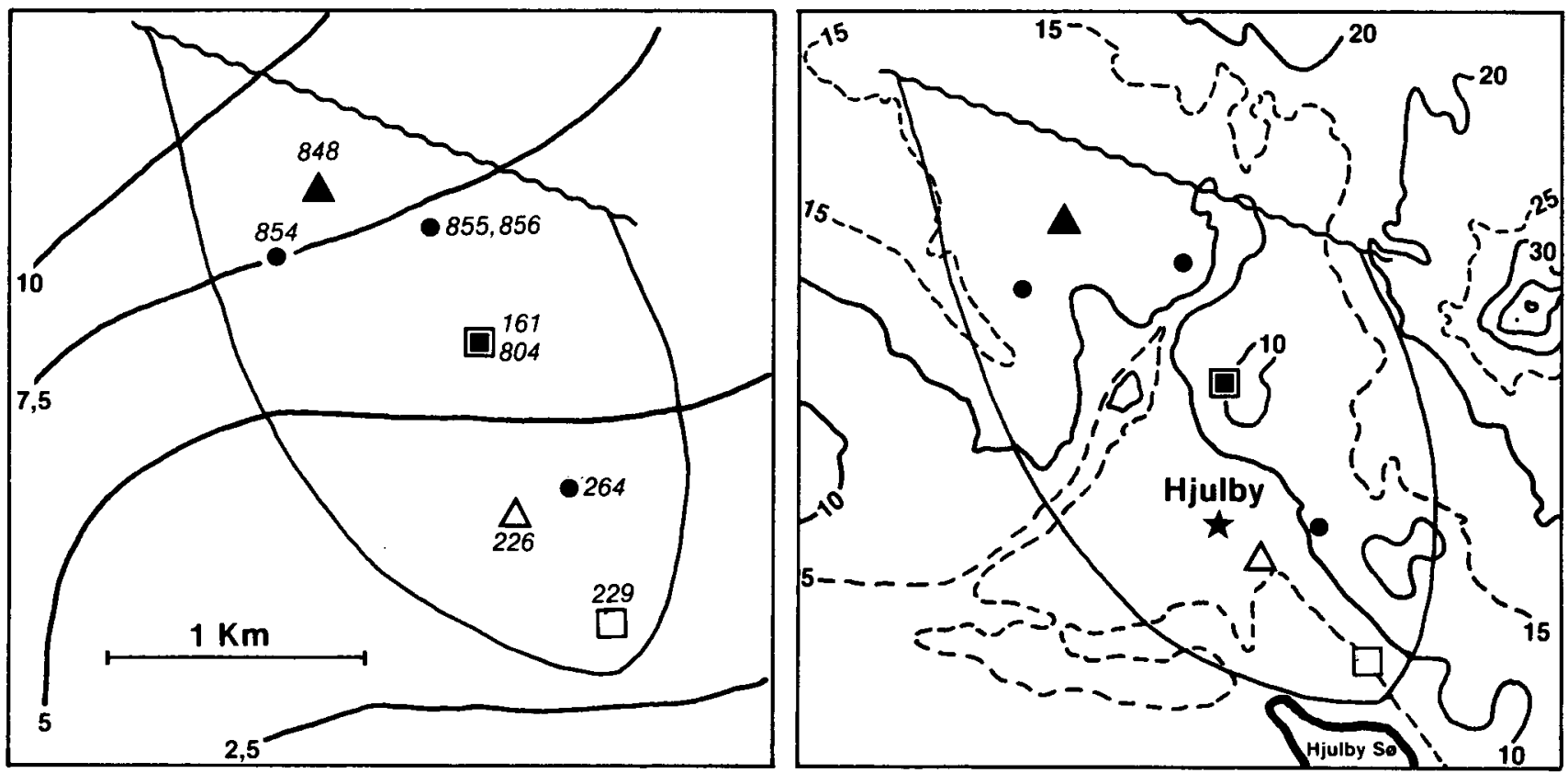

DGU nr. 147

Areal $3 \mathrm{~km}^{2}$

Geologi: De øverste prækvartære aflejringer i området er bryozokalk fra Danien og grønsandskalk fra Selandien. Grønsandskalken udgør prækvartæroverfladen i den nordlige del af området, men den kiler ud mod syd, således at denne overflade her udgøres af bryozokalk. Prækvartæroverfladen hælder mod syd. De kvartære aflejringer består af moræneler samt smeltevandssand og grus. Enkelte steder findes der postglaciale ferskvandsaflejringer af sand, gytje og tørv.

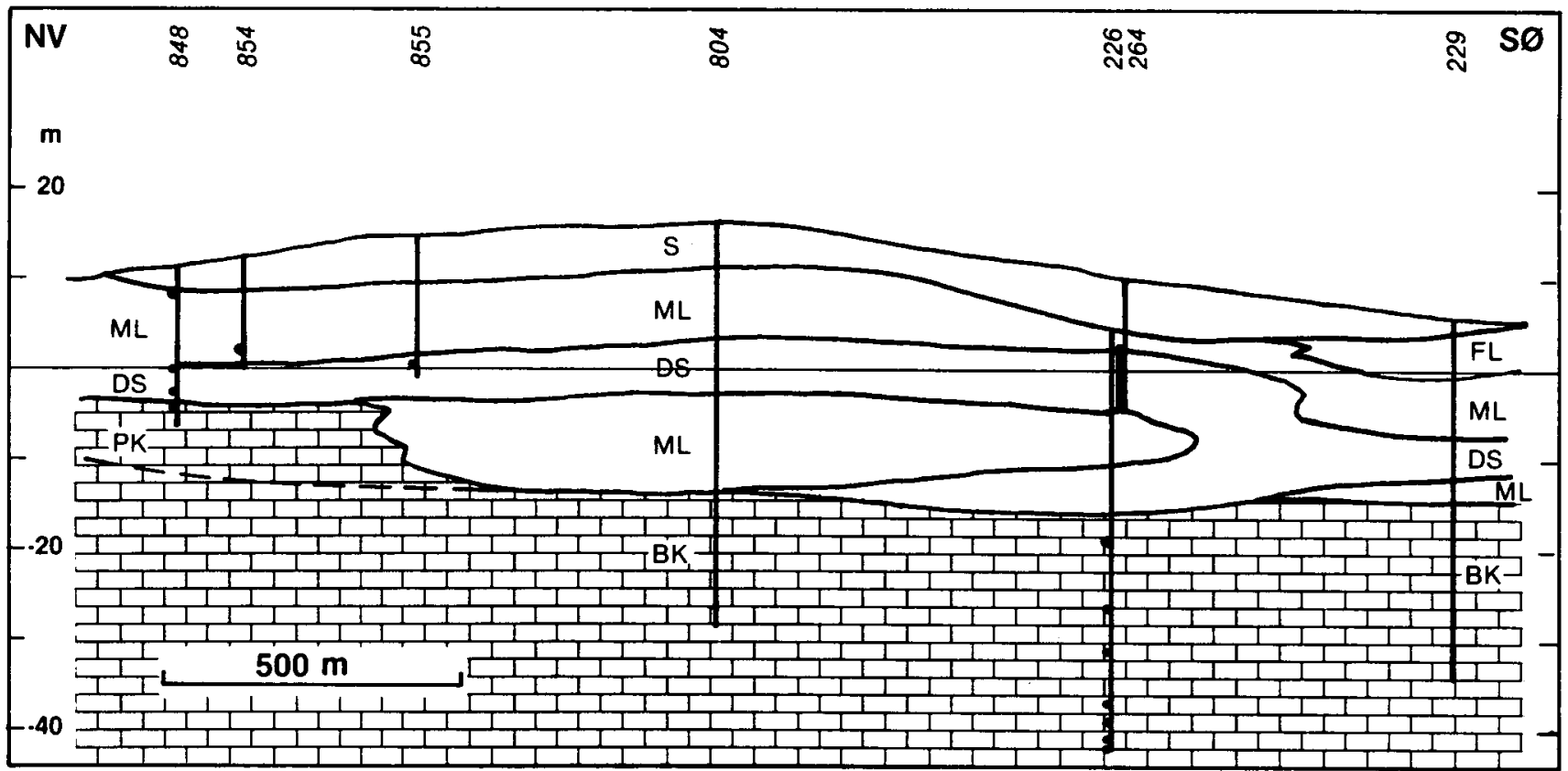


Hydrogeologi: Danien- og Selandienkalken, som er i hydraulisk forbindelse, udgør et samlet artesisk hovedreservoir. Over dette findes et delvis sammenhangende sekundart reservoir i kvartært smeltevandssand. I den sydlige del af området, hvor smeltevandssandet står i direkte forbindelse med Danienkalken, regnes det for en del af hovedreservoiret. I det sekundære reservoir er der ligeledes artesiske forhold og den kvartære lagserie yder derfor en vis beskyttelse af kalkreservoiret.

Oprindelig gik grundvandsstrømmen $\mathrm{i}$ hovedreservoiret mod øst, men som følge af vandindvindingen på Hjuls $\emptyset$ kildeplads er strømningsretningen nu mod sydøst. Potentialet $\mathrm{i}$ det sekundare reservoir falder $\mathrm{i}$ samme retning, men ligger blot en meter højere. Oppumpningen er større end, hvad der svarer til områdeafgrænsningen.

Vandbalance $\mathbf{m m} / \mathbf{a ̊ r}:$

Middelnedbør 640

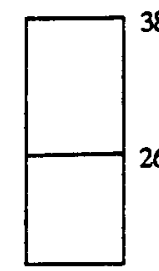

380 Fordampning

260 Nettonedbør 220 Afstrømning

40 Anden infiltration

Kildeplads: Hjulby Bro, 2,3 mill. m3/âr, heraf 0.1 mill. $\mathrm{m} 3 / a ̊$ r $\mathrm{i}$ selve overvågningsområdet.

\section{Arealanvendelse \%:}

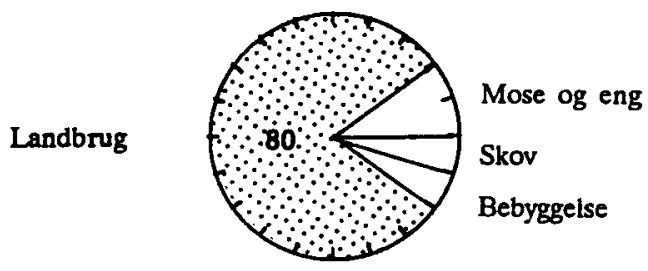

Registrerede depoter: en losseplads

Grundvandskemi: Grundvandet i hovedreservoiret er af calcium-bikarbonattypen med middelhårdt vand, moderat reduceret med lavt indhold af opløst jern og med et typisk sulfatindhold på 20-50 milligram pr. liter. Kloridinholdet skyldes indtrængende havvand eller optrængning af salt og mineralvand.

Koncentrationen af udvalgte stoffer $\mathrm{i}$ forhold til dybde under terran.

Graferne viser data fra 1989 og 1990.

Nitrat/Dybde

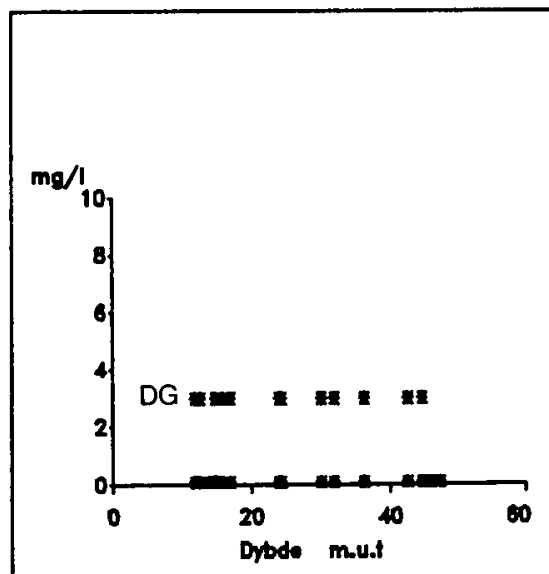

Klorid/Dybde

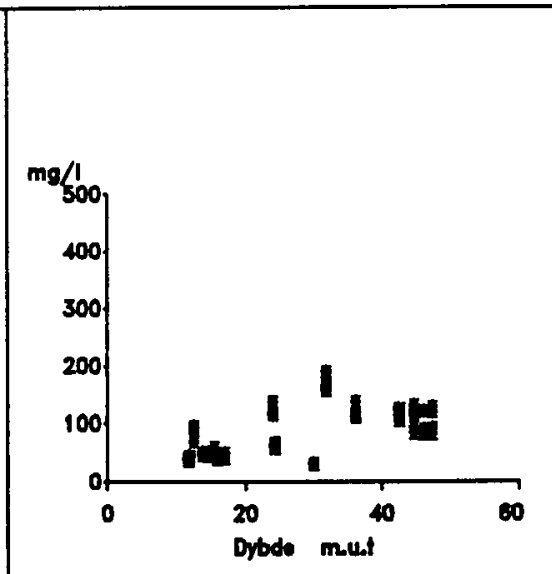

Sulfat/Dybde

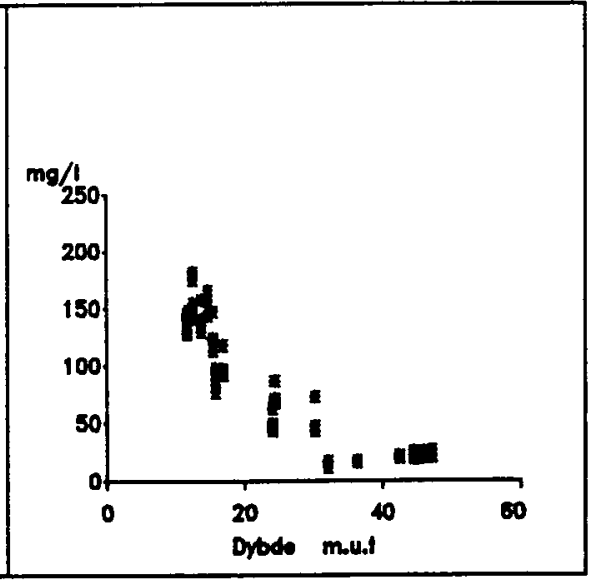



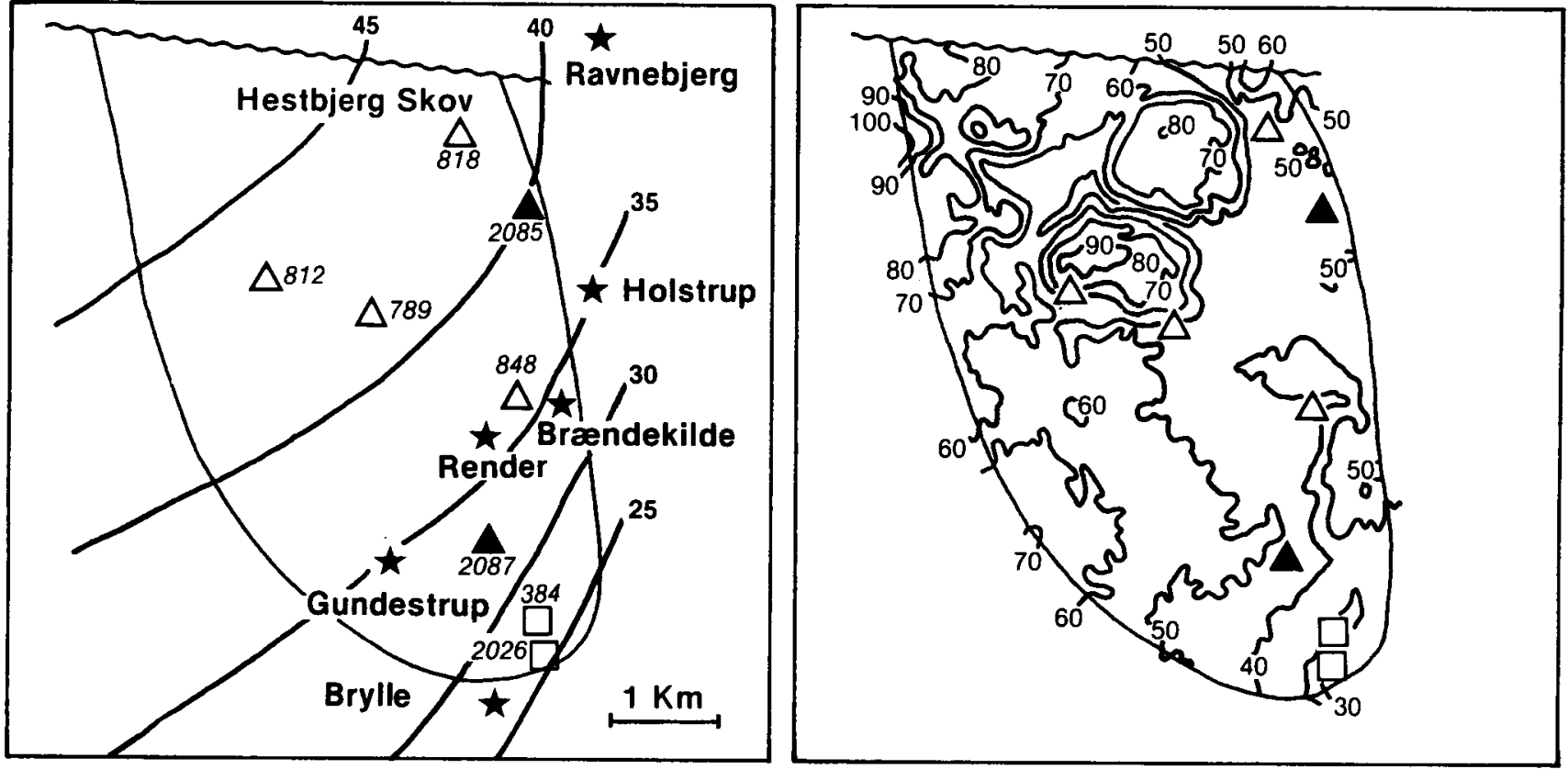

DGU nr. 145

Areal $19 \mathrm{~km}^{2}$

Geologi:Den øverste prækvartære lagserie består af Danienkalk overlejret af ler og skifer fra Selandien tid. De kvartære aflejringer domineres af moræneler. Lag af smeltevandssand og -grus forekommer dog i flere dybdeintervaller. Postglaciale aflejringer i form af ferskvandsgytje forekommer i sødepressioner. Landskabeligt består området af store issøbakker og jæunt kuperet morænelandskab.

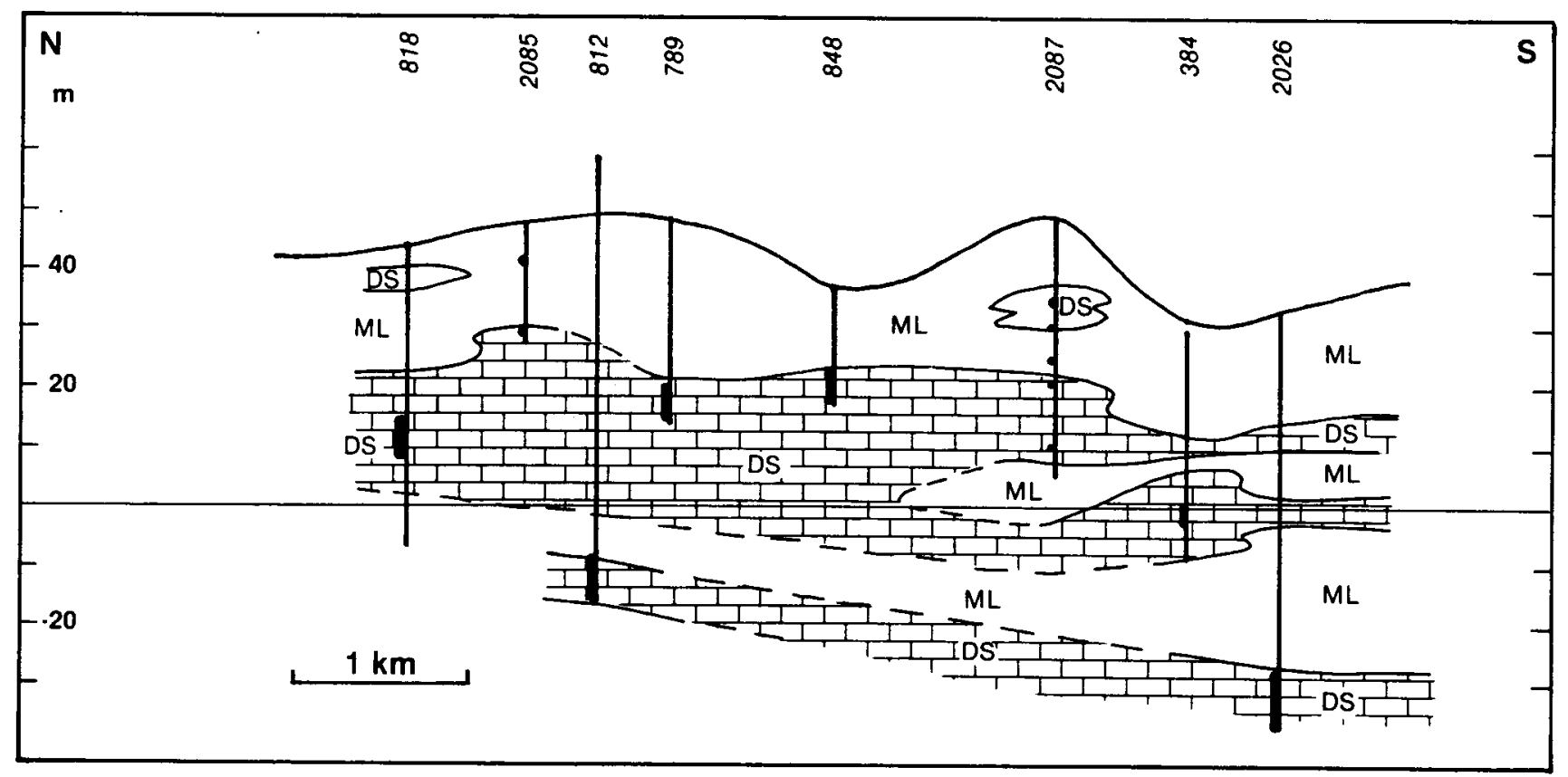


Hydrogeologi: Reservoiret i Danienkalken er artesisk. Hovedreservoiret findes i de sandede kvartære smeltevandsaflejringer. Det er uvist hvorvidt der er hydraulisk forbindelse mellem disse reservoirer.

Grundvandskemi: Grundvandet er af calcium-bikarbonattypen. Hårdheden, sulfat- og $i$ et vist omfang kloridindholdet falder med dybden, mens calciumindholdet stiger. Grundvandets sammensætning har været konstant gennem måleperioden.

Vandbalance mm/år:

Middelnedbør 700

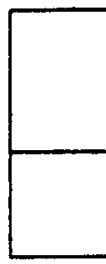

Kildepladser. Borreby varket, 1.6 mill. m3/år anden indvinding, 0.05 mill. $\mathrm{m} 3 / \mathrm{a} r$

\section{Arealanvendelse \%:}

390 Fordampning

250 Nettonedbør

Landbrug

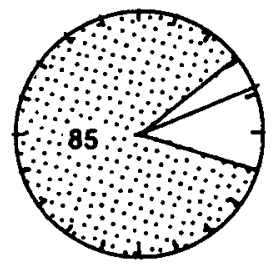

Sø gg eng

Skov/plantage

Koncentrationen af udvalgte stoffer $\mathrm{i}$ forhold til dybde under terræen.

Graferne viser data fra 1989 og 1990.

Nitrat/Dybde

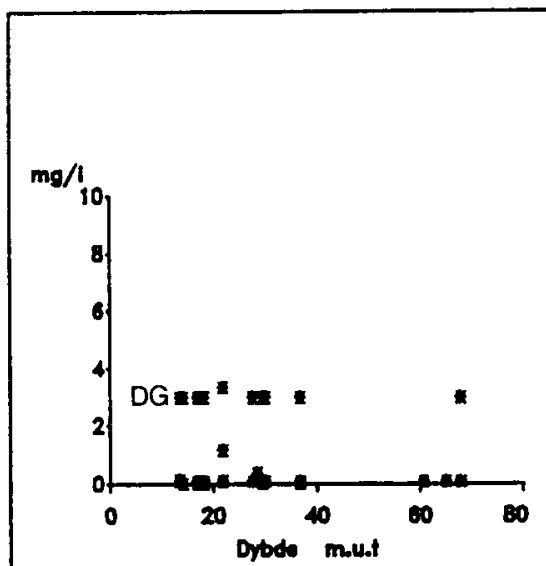

Klorid/Dybde

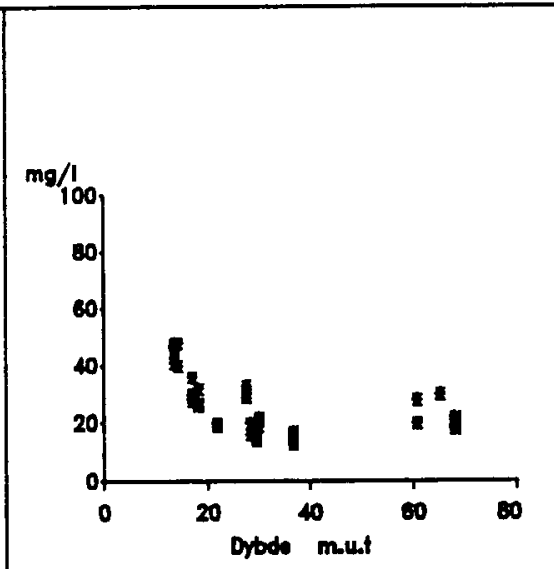

Sulfat/Dybde

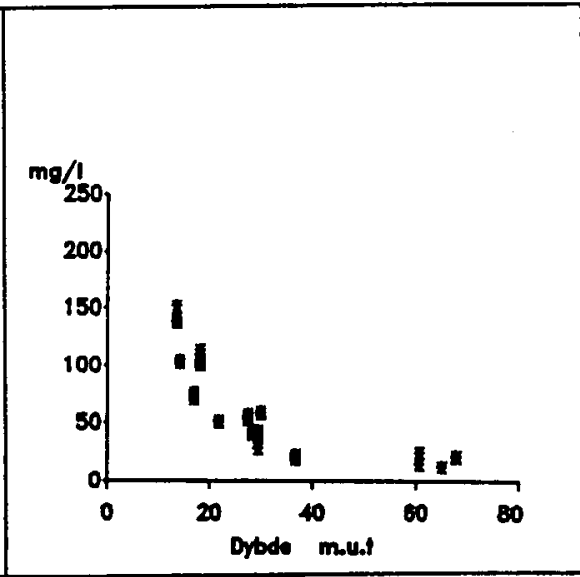


1312 II $S \emptyset+\mathrm{N} \emptyset$

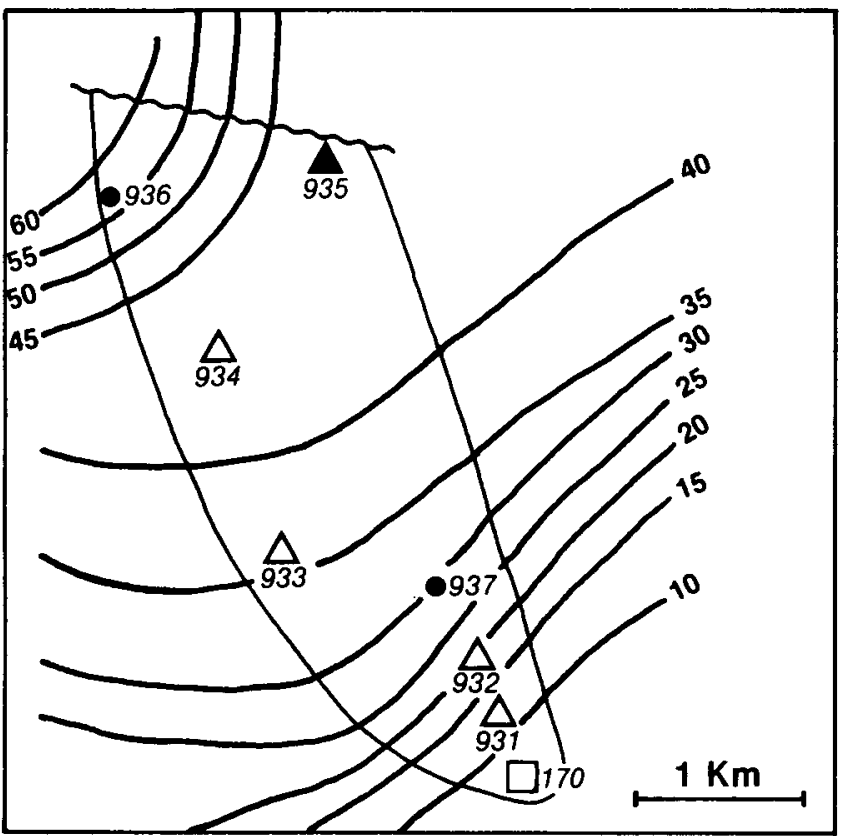

DGU nr. 164 og 165
Terræn

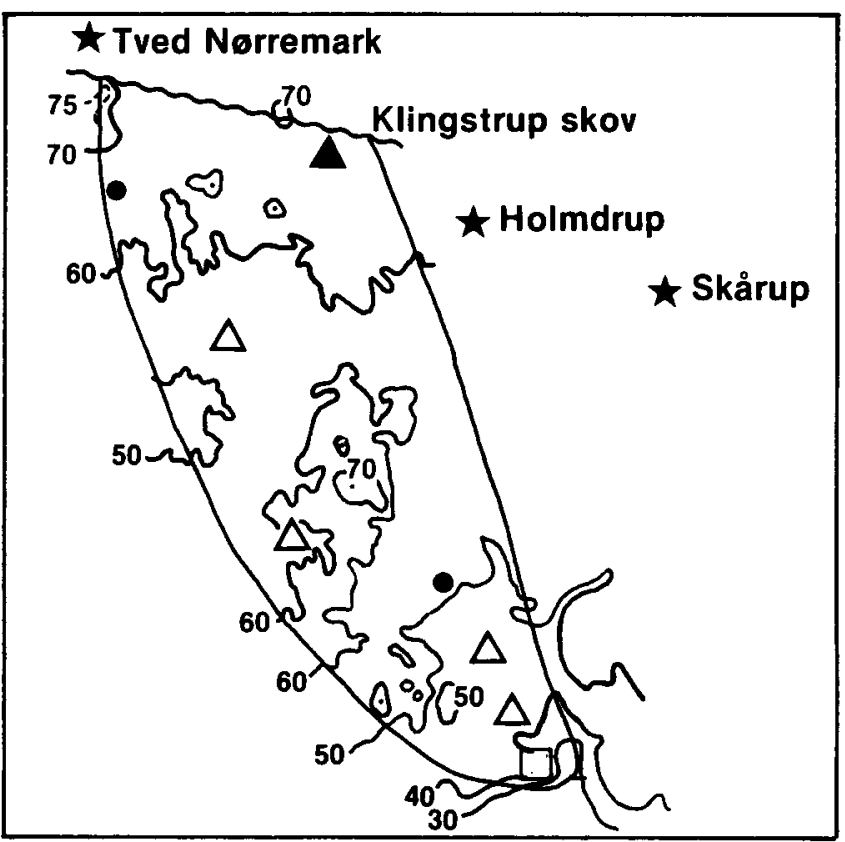

Areal $6,5 \mathrm{~km}^{2}$

Geologi: De øverste prækvartære lag i området er af Selandien alder, og deres overflade dykker mod sydvest. Ovenover dette er der 70-100 meter kvartæraflejinger. Herover er der kvartære aflejringer, der hovedsagelig består af moræneler med indlejret smeltevandssand og -grus samt interglacialt ferskvandssand, "det hvide sand". Et af sandlagene er delvis sammenhængende og dækket af moræneler. Dette sandlag består af smeltevandssand og -grus $\mathrm{i}$ den nordlige del af området, mens det $\mathrm{i}$ den sydlige del af området består af ferskvandssand. I de topografiske lavninger er der postglaciale aflejringer af tørv og gytje. Området har et bølget moræenelandskab.

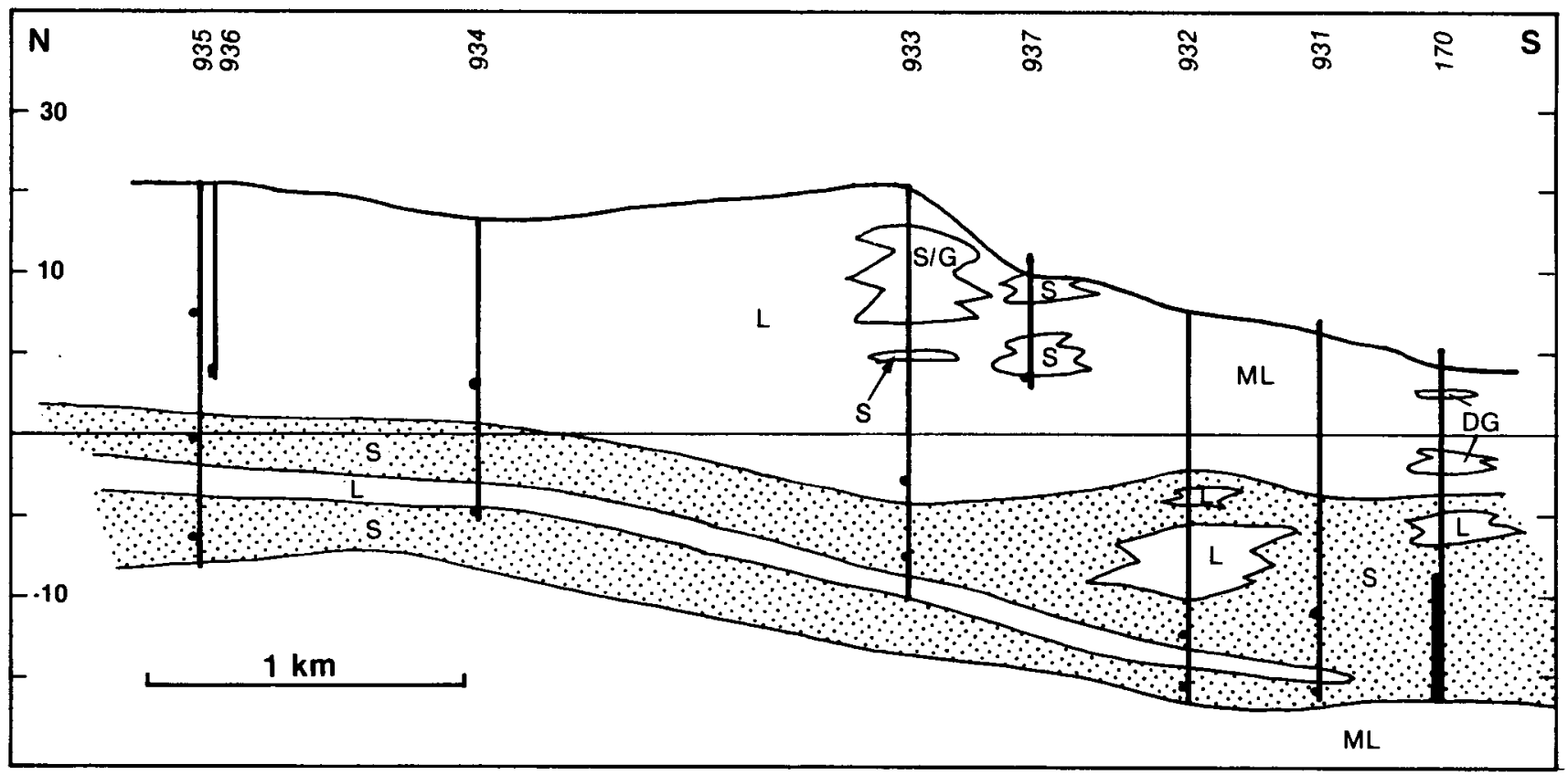


Hydrogeologi: Hovedreservoiret består af smeltevandsaflejringer og interglacialt kvartssand med frit grundvandsspejl ved kildepladsen men ellers artesiske forhold. Reservoiret består af et antal delreservoirer der er adskilt af stejltstillede vandstandsende lag. Indvindingsforholdene er bedst $\mathrm{i}$ den sydlige del af området. I den centrale del af området er der sekundære reservoirer bestående af smeltevandssand, der stedvist når frem til terrænoverfladen. Vandspejlet i disse sekundære reservoirer er stedvis frit, stedvis artesisk. Det stejle potentialegradient $\mathrm{i}$ den centrale del af området viser, at der er ringe hydraulisk kontakt mellem den nordlige og sydlige del af hovedreservoiret. Der er ingen sammenhæeng mellem potentialet $\mathrm{i}$ hovedreservoiret og det sekundære reservoir. Potentialet for de sekundære reservoirer er højere end for hovedreservoiret.

Grundvandskemi: Grundvandet i hovedreservoiret er af calcium-magnesium-bikarbonattypen, og dets kemiske sammensætning varierer med dybden. Dette hænger sammen med, at nogle dele af reservoiret består af smeltevandssand, og andre af interglacialt kvartssand. Calciumindholdet i grundvandet falder med dybden,

Vandbalance $\mathbf{m m} / \mathbf{a ̊ r}$

Middelnedbør 700

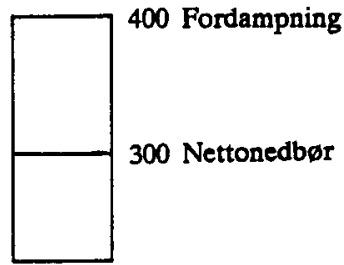

Kildeplads: Skovmøllevarket, 1.1 mill. m3/år, heraf 0.15 mill3/år i selve overvågningsområdet

\section{Arealanvendelse \%:}

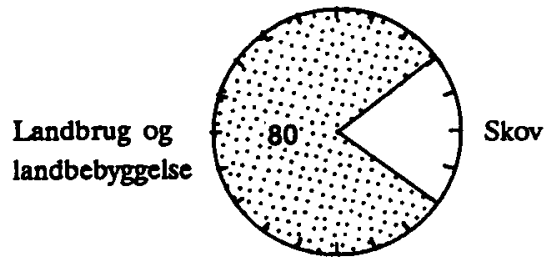

Registrerede depoter: en losseplads, et kemikalieaffaldsdepot

mens natriumindholdet stiger som følge af ionbytning. Grundvandet i den dybere del af hovedreservoiret har på grund af de interglaciale aflejringer, et forhøjet indhold af organisk stof, ammonium, total fosfor og metan. I de sekundære reservoirer er der kun en beskeden variation i grundvandets kemiske sammensæatning. Koncentrationerne af nitrat, klorid, sulfat, natrium og calcium i grundvandet er uændrede i perioden 19891990. Tritiumanalyser viser at grundvand op større dybde end 40 meter under terræn, stammer fra før 1950.

Koncentrationen af udvalgte stoffer i forhold til dybde under terræn.

Graferne viser data fra 1989 og 1990.

Nitrat/Dybde

Klorid/Dybde

Sulfat/Dybde

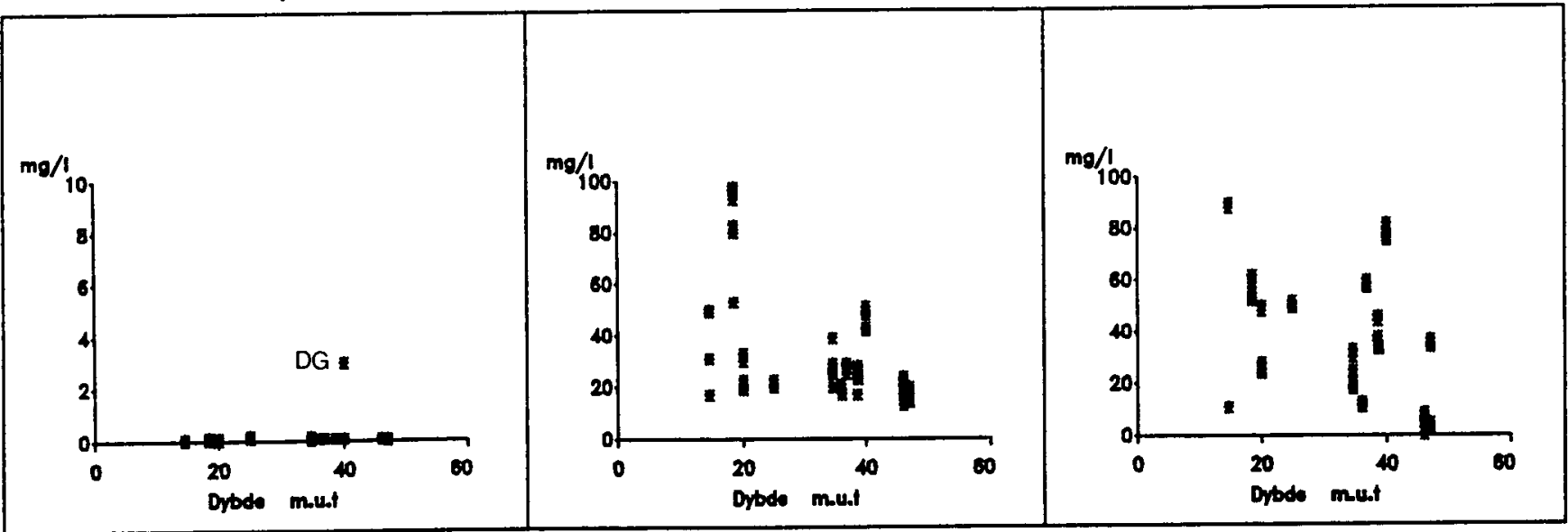




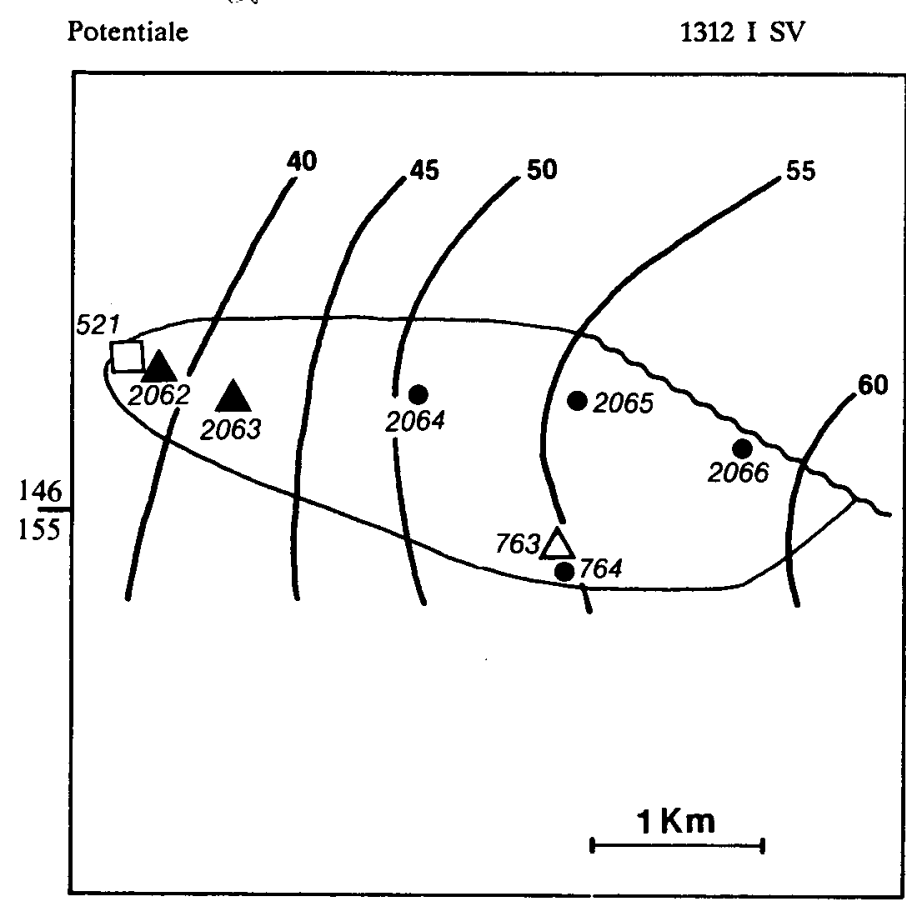

DGU nr. 146. og 155

Terræen

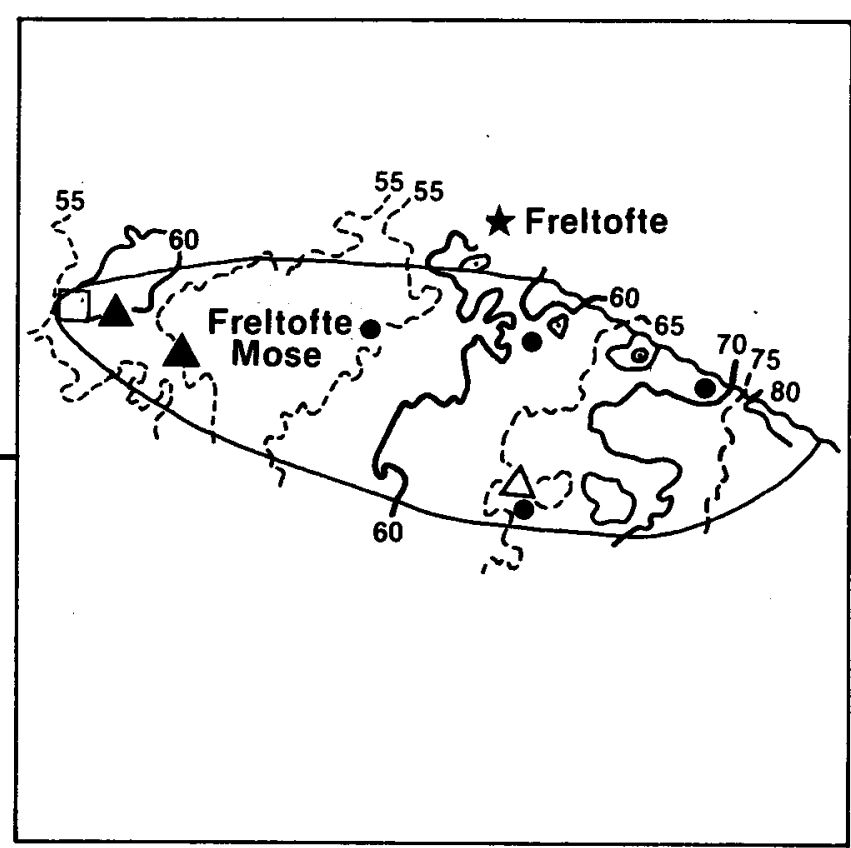

Areal $5 \mathrm{~km}^{2}$

Geologi: De øverste prækvartære lag er af Selandien alder, og deres overflade dykker mod sydvest. Herover er der en 90-120 meter tyk kvartær lagserie bestående af moræne- og smeltevandsaflejringer. Smeltevandsaflejringerne har ofte en betydelig udstrækning. I overfladen forekommer der enkelte steder postglaciale tørve- og gytjeaflejringer. Terrænoverfladen i området er et kombineret dødis- og morænebakkelandskab.

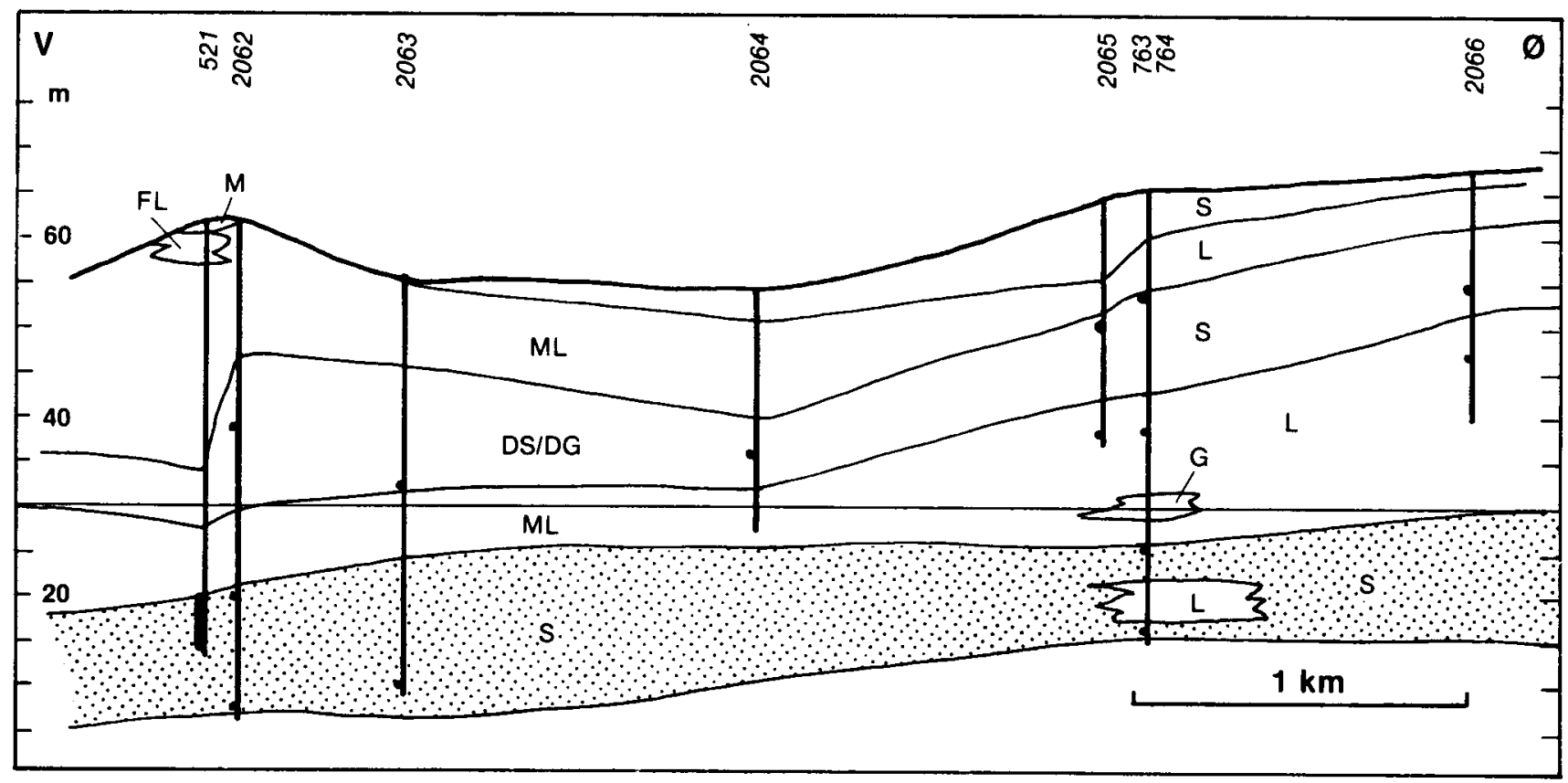


Hydrogeologi: Hovedreservoiret er artesisk og består af et udstrakt lag af smeltevandssand. Dette reservoir er beskyttet af et tykt lag moræneler. Herover ligger det sekundære reservoir, der også er beskyttet, men af et mindre lerlag. I det sekundære reservoir veksler frie og artesiske forhold.

Potentialet $\mathrm{i}$ det sekundære reservoir følger fordelingen $\mathrm{i}$ hovedreservoiret, idet det blot er lidt højere. Potentialeforskellen stiger fra øst mod vest fra 0,1 til 2 meter, idet kildepladsen ligger $i$ den vestlige del af området. Hvor Vindinge $\AA$ udspringer, ved boring 146.2064, er trykniveauet i begge reservoirer over terran.

Grundvandskemi: Grundvandet $i$ begge reservoirer er af calcium-bikarbonattypen, det er moderat reduceret og ensartet såvel $\mathrm{i}$ hele overvågningsområdet som $\mathrm{i}$ begge reservoirer. Vandkvaliteten er god og konstant, og de vejledende grænseværdier for drikkevand overskrides ikke. Det yngste grundvand findes ved kildepladsen, mens det bliver ældre mod øst.

Vandbalance mm/år:

Middelnedbør 700

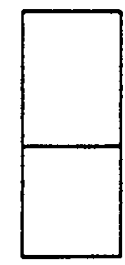

Kildeplads: Nørre Søby w, 0.2 mill. m3/âr

\section{Arealanvendelse \%:}

400 Fordampning

300 Nettonedbør Landbrug

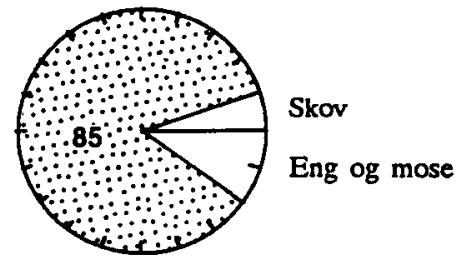

Registrerede depoter: to lossepladser.

Koncentrationen af udvalgte stoffer $i$ forhold til dybde under terræen.

Graferne viser data fra 1989 og 1990.

Nitrat/Dybde

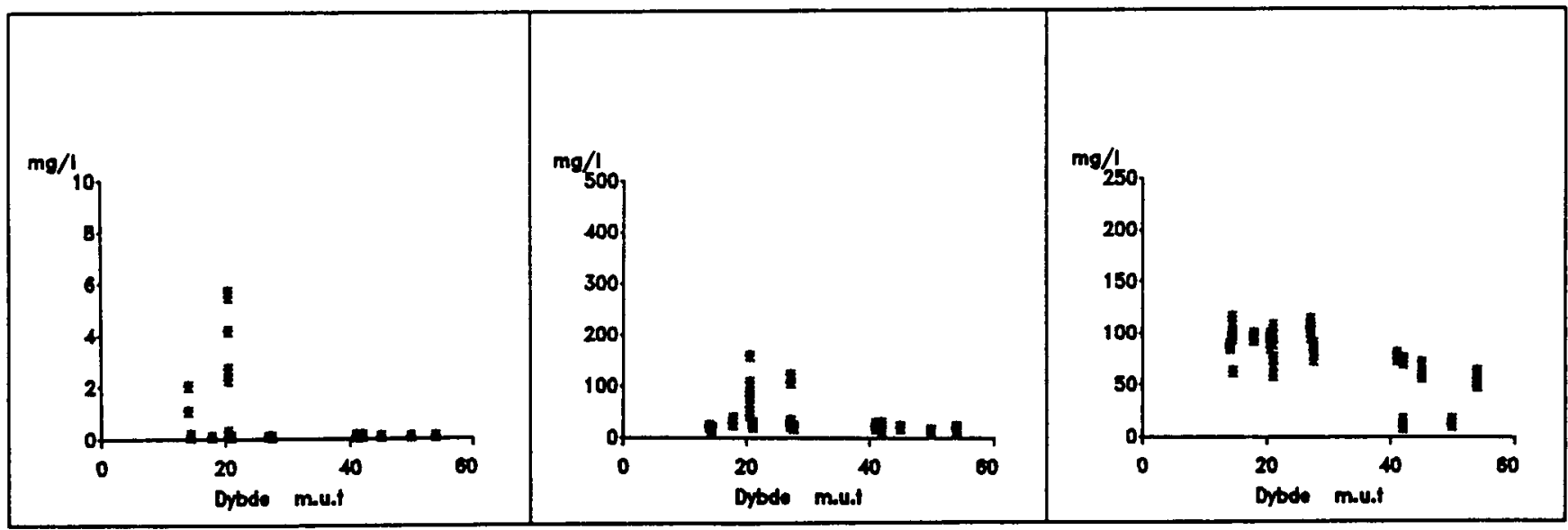


1313 III SV

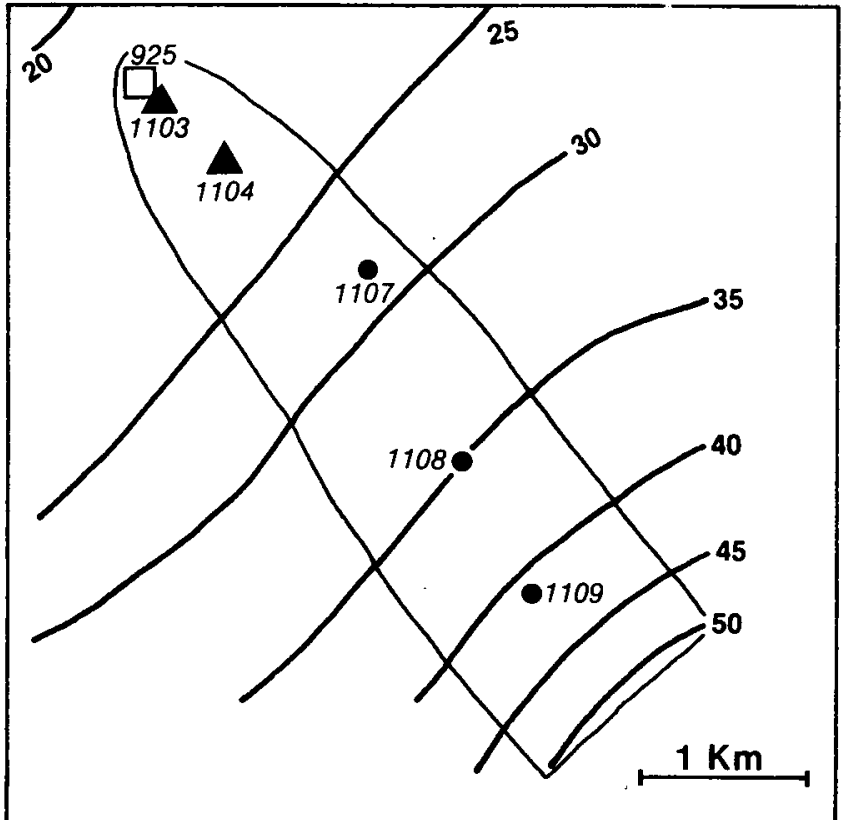

DGU nr. 135
Terran

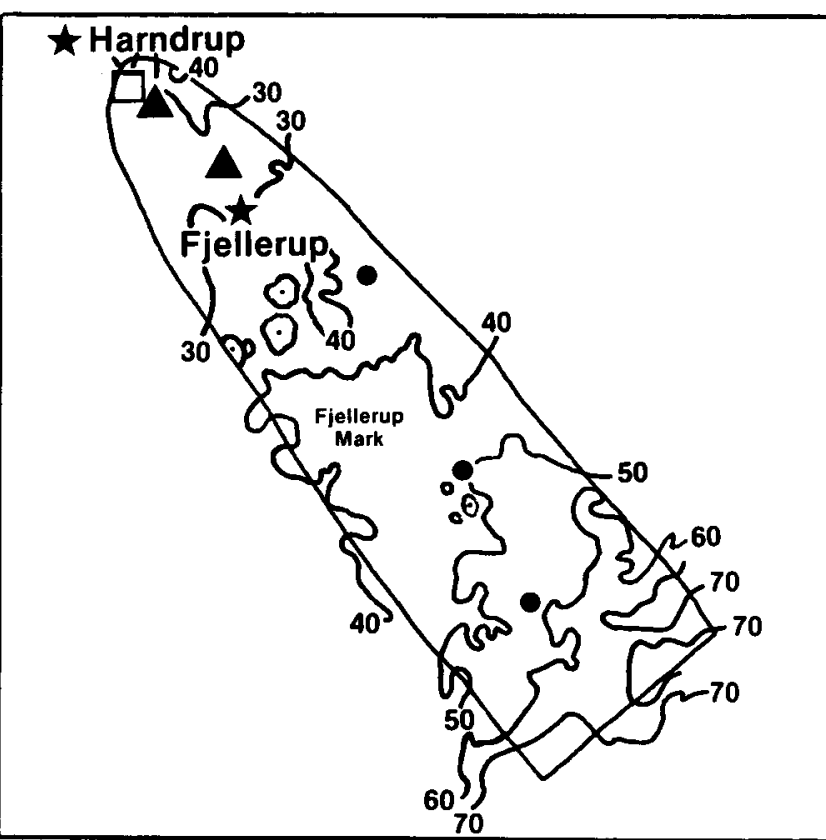

Areal $5,5 \mathrm{~km}^{2}$

Geologi: De øverste prækvartære aflejringer i området findes i kote -70 meter og består af mergel fra Selandien perioden. Prækvartæroverfladen dykker svagt mod vest. Den kvartære lagserie består hovedsagelig af moræne- og smeltevandsaflejringer. Smeltevandssand og grus forekommer dels $\mathrm{i}$ isolerede lommer, dels $\mathrm{i}$ større sammenhængende lag i flere niveauer. I lavninger er der stedvis postglaciale aflejringer, så som tørv, gytje, ler og sand. Området ligger i et dødislandskab.

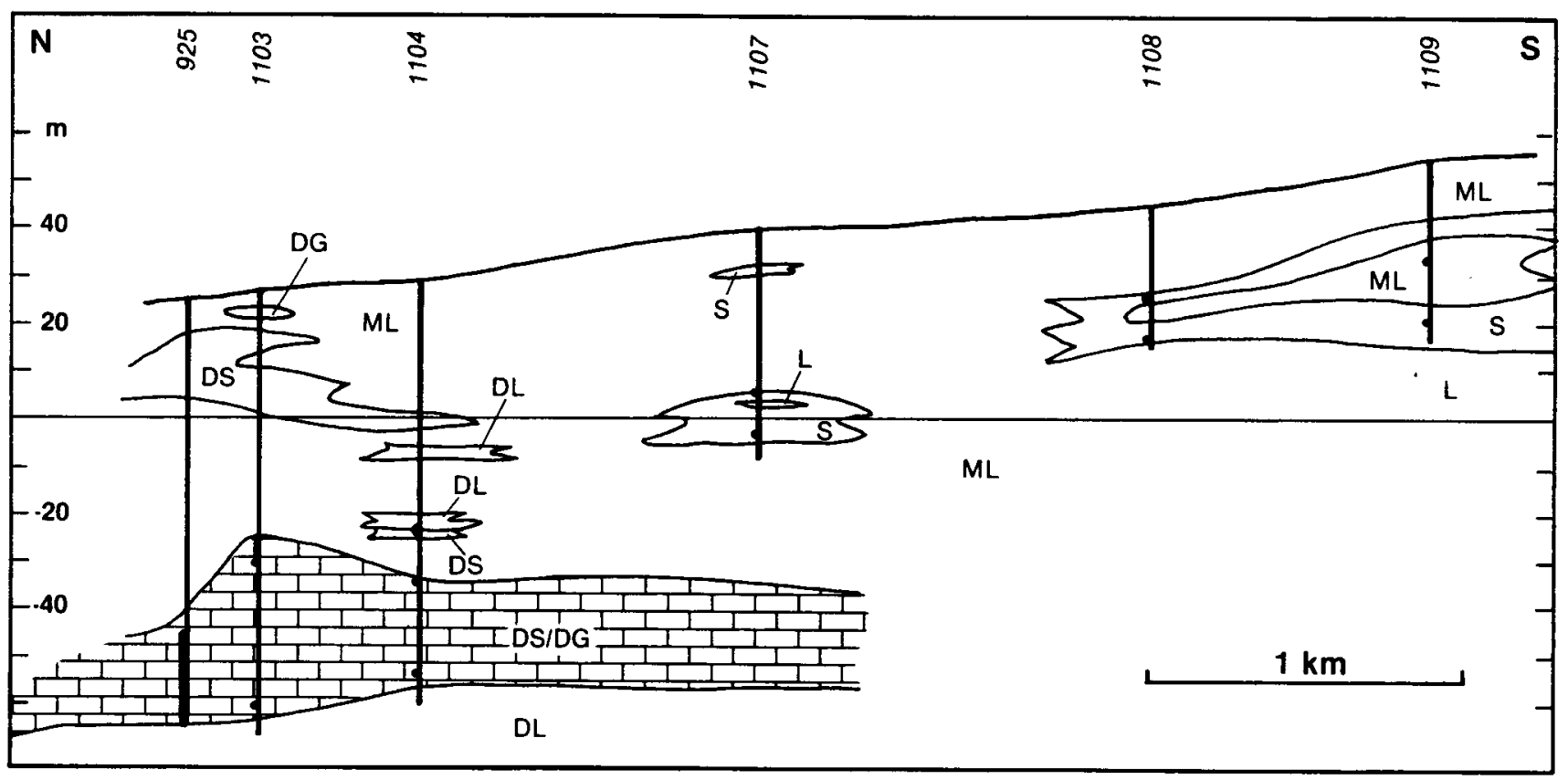


Hydrogeologi: Hovedreservoiret består af smeltevandsaflejringer med artesiske forhold. Reservoiret er 20-30 meter tykt og strækker sig ud over områdets afgrænsning mod nord og sandsynligvis også mod syd. Reservoiret er beskyttet af et tykt lag moræneler. Der er her ud over et større sekundært smeltevandsreservoir med artesiske forhold, som er dækket af moræneler. Især i den nordlige del af området findes der yderligere nogle mindre sekundære smeltevandsreservoirer. Der er ringe hydraulisk forbindelse mellem de sekundære reservoirer.

Grundvandskemi: Grundvandet er af calciummagnesium-bikarbonattypen, og det er relativt ensartet inden for området. Dog aftager koncentrationen af klorid, calcium og sulfat med dybden. Vandkvaliteten i de sekundære reservoirer varierer p.g.a. forureningsbelastning fra overfladen. Indholdet af nitrat, klorid og sulfat har været konstant i perioden 1967-1990. I hovedreservoiret stammer grundvandet fra før 1950.

Vandbalance mm/år: Middelnedbor 750

Midelnedbor 750

Kildeplads Harndrup w, 0.12 mill. m3/ar
Arealanvendelse \%:

400 Fordampaing

350 Nettonedbør

Landbrug

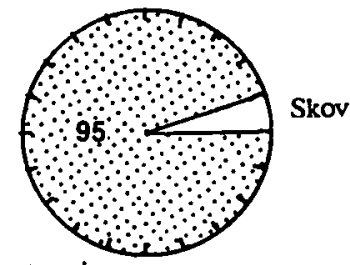

Registrerede depoter: ingen

Koncentrationen af udvalgte stoffer i forbold til dvbde under terran.

Graferne viser data fra 1989 og 1990.

Nitrat/Dybde

Klorid/Dybde

Sulfat/Dybde

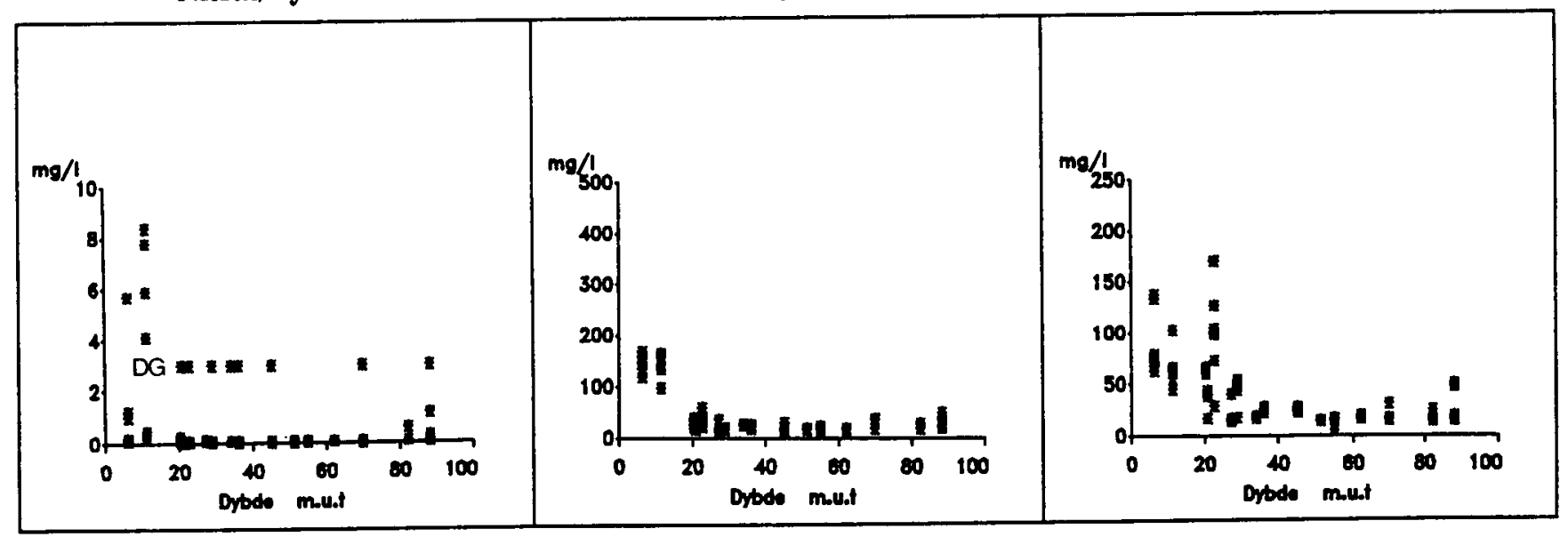



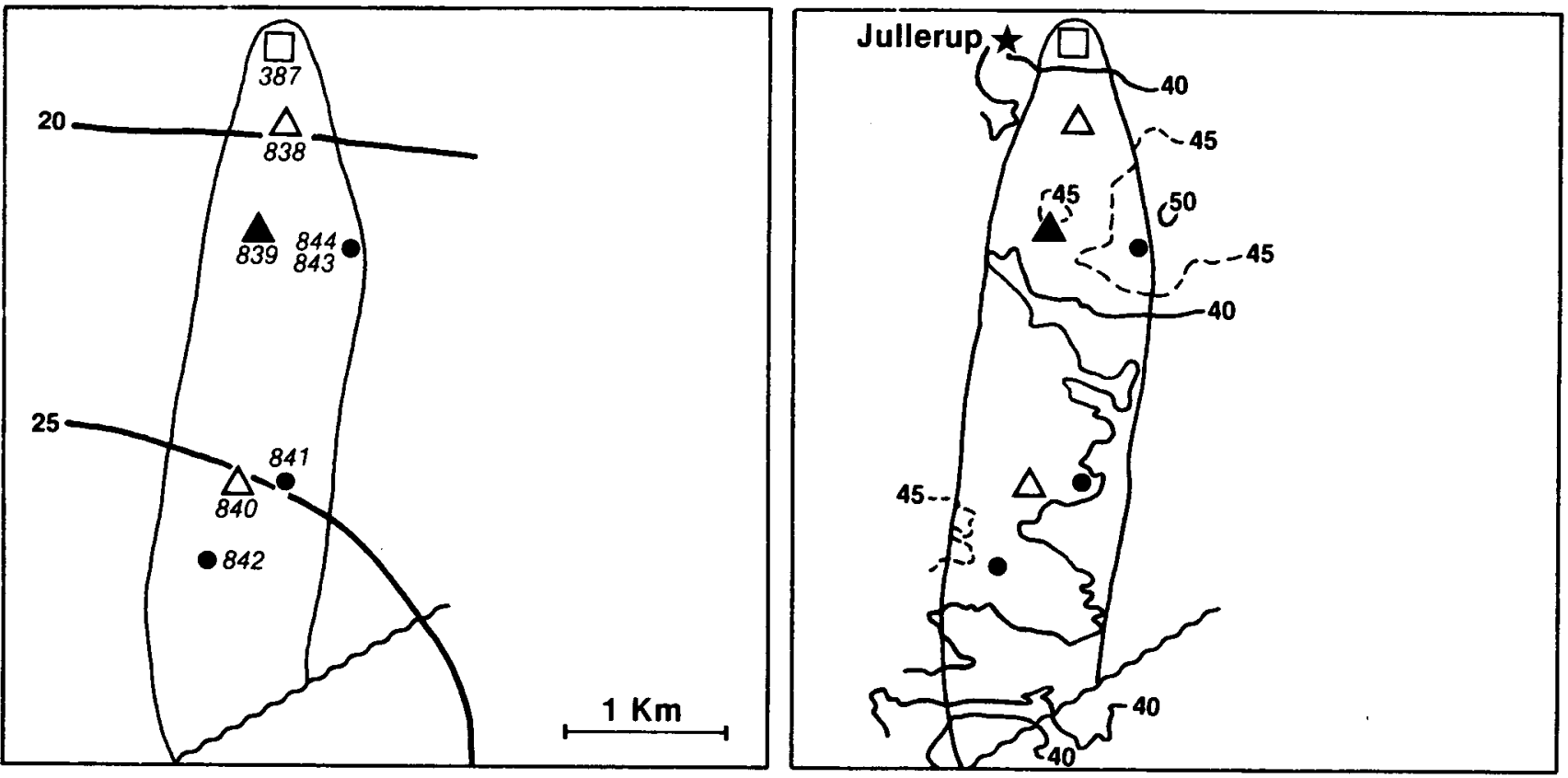

DGU nr. 136

Areal $4,5 \mathrm{~km}^{2}$

Geologi: Den prækvartære overlade består af aflejringer af Selandien alder og dykker mod nord-nordvest. Den kvartære lagserie består af smeltevands- og moræneaflejringer. Smeltevandsaflejringerne udgør dels større sammenhængende lag, dels lommer i moræneleret. Stedvis er morænelerslaget over både hovedreservoiret og de sekundære reservoirer ganske tyndt. Områdets kvartære aflejringer har et sandet præg, hvorfor det er sårbart for overfladeforurening. Landskabeligt udgør området en moræneflade.

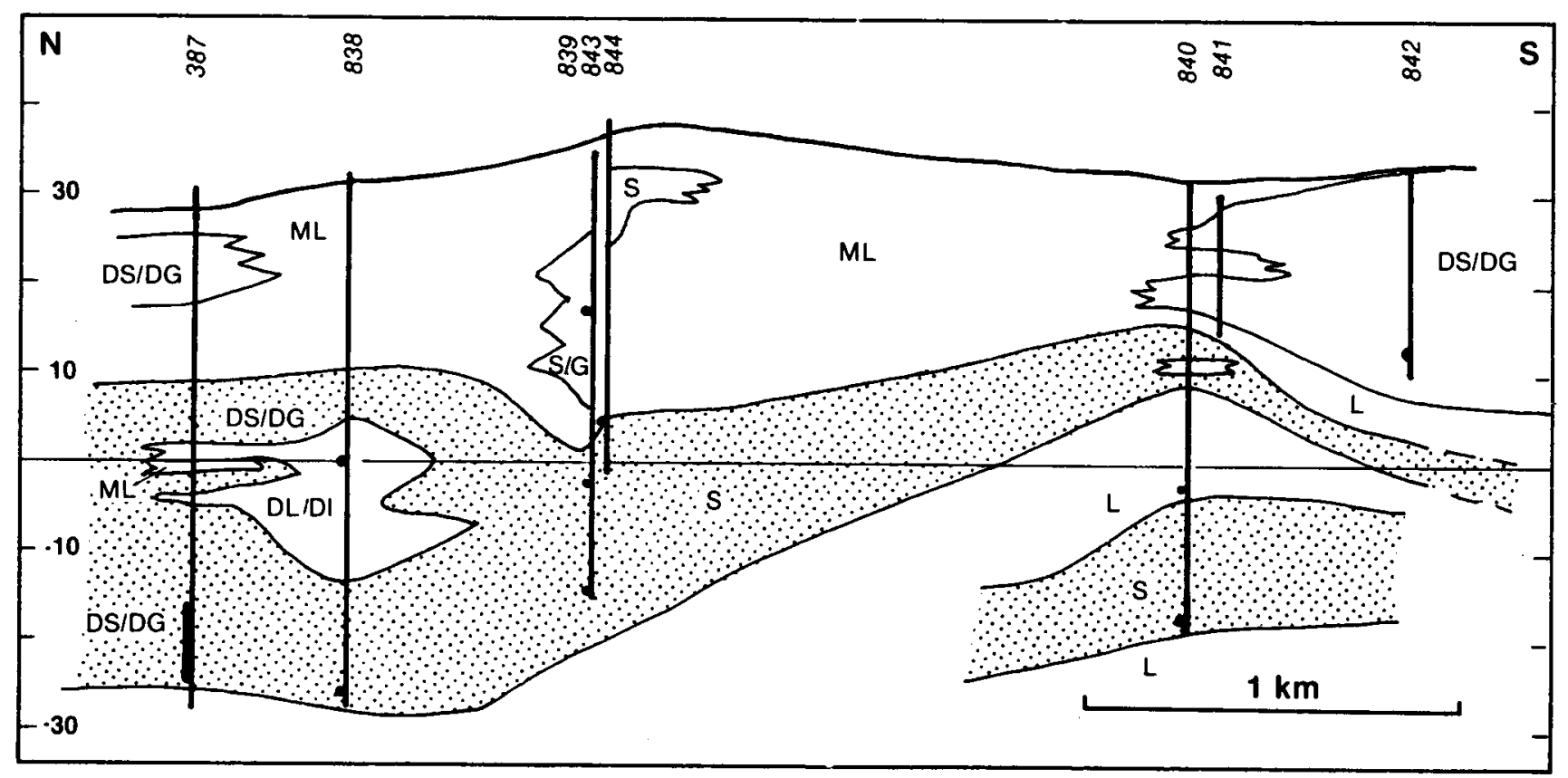


Hydrogeologi: Hovedreservoiret, der strækker sig ud over områdets afgrænsning, er artesisk og består af smeltevandssand. Også de sekundære reservoirer består af smeltevandssand, hvoraf det største har frit grundvandsspejl og et potentiale, der følger potentialet for hovedreservoriet.

Grundvandskemi: Grundvandet $i$ hovedreservoiret er af calcium-bicarbonattypen $i$ hele reservoiret. Der er ikke påvist nitrat, og sulfat- og kloridkoncentrationen har været konstant i perioden 1960-1990. I grundvandet fra det sekundære reservoir er der påvist forhøjet nitrat- og kloridkoncentration, som dokumenterer påvirkning fra overfladen. Grundvand i dybder under 50 meter under terræn stammer fra før 1950.

Vandbalance mm/år:

Middelnedbør 720

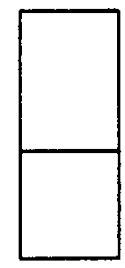

Kildeplads: Jullerup vv, 0.1 mill. m3/år
Arealanvendelse \%:

400 Fordampning

320 Nettonedbgr

spredt

landbebyggelse

Registrerede depoter: ingen

Koncentrationen af udvalgte stoffer i forhold til dybde under terræn.

Graferne viser data fra 1989 og 1990.

Nitrat/Dybde

Klorid/Dybde

Sulfat/Dybde

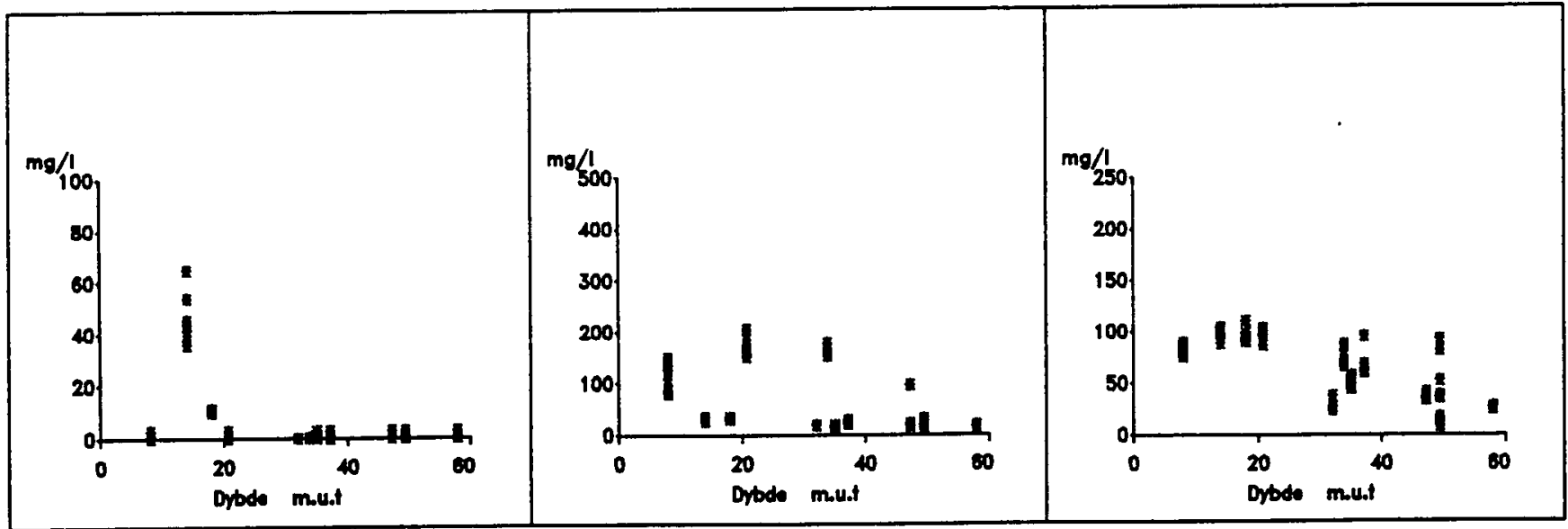




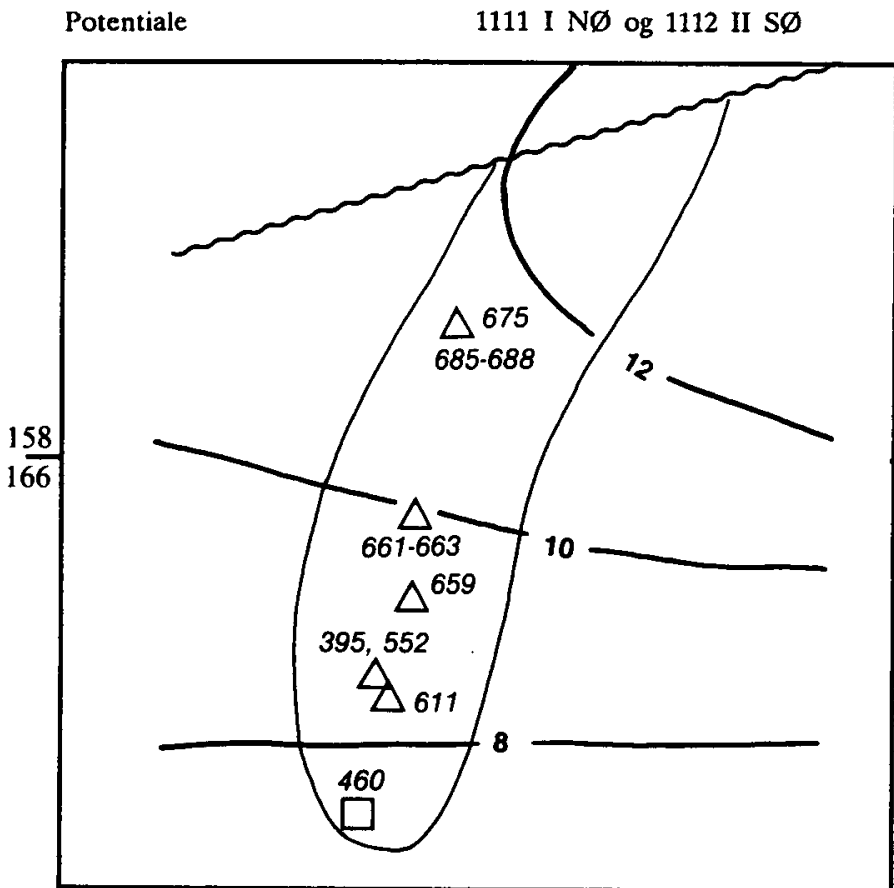

DGU nr. 158 og 166
Terræn

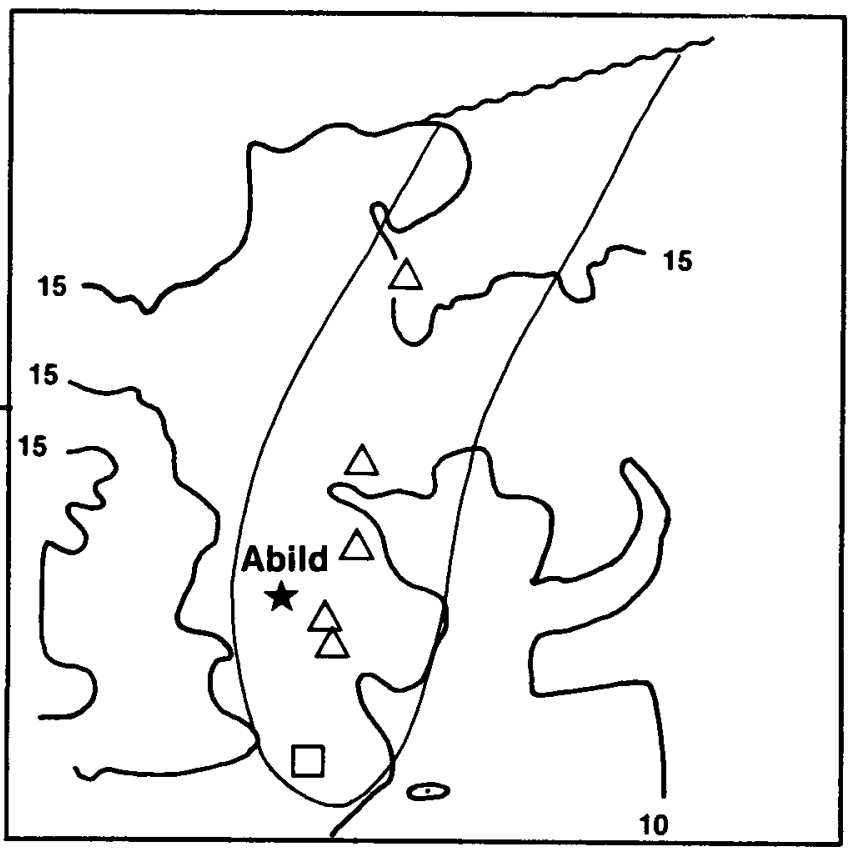

Areal 7 km$^{2}$

Geologi: De øverste prækvartære lag i området består af Miocænt glimmersand og -ler samt kvartssand. Den kvartære lagserie består af moræneler, hvori der $\mathrm{i}$ to niveauer er indlejret smeltevandssand. Disse sandlag har stor udbredelse. I overfladen dominerer moræneaflejringer.

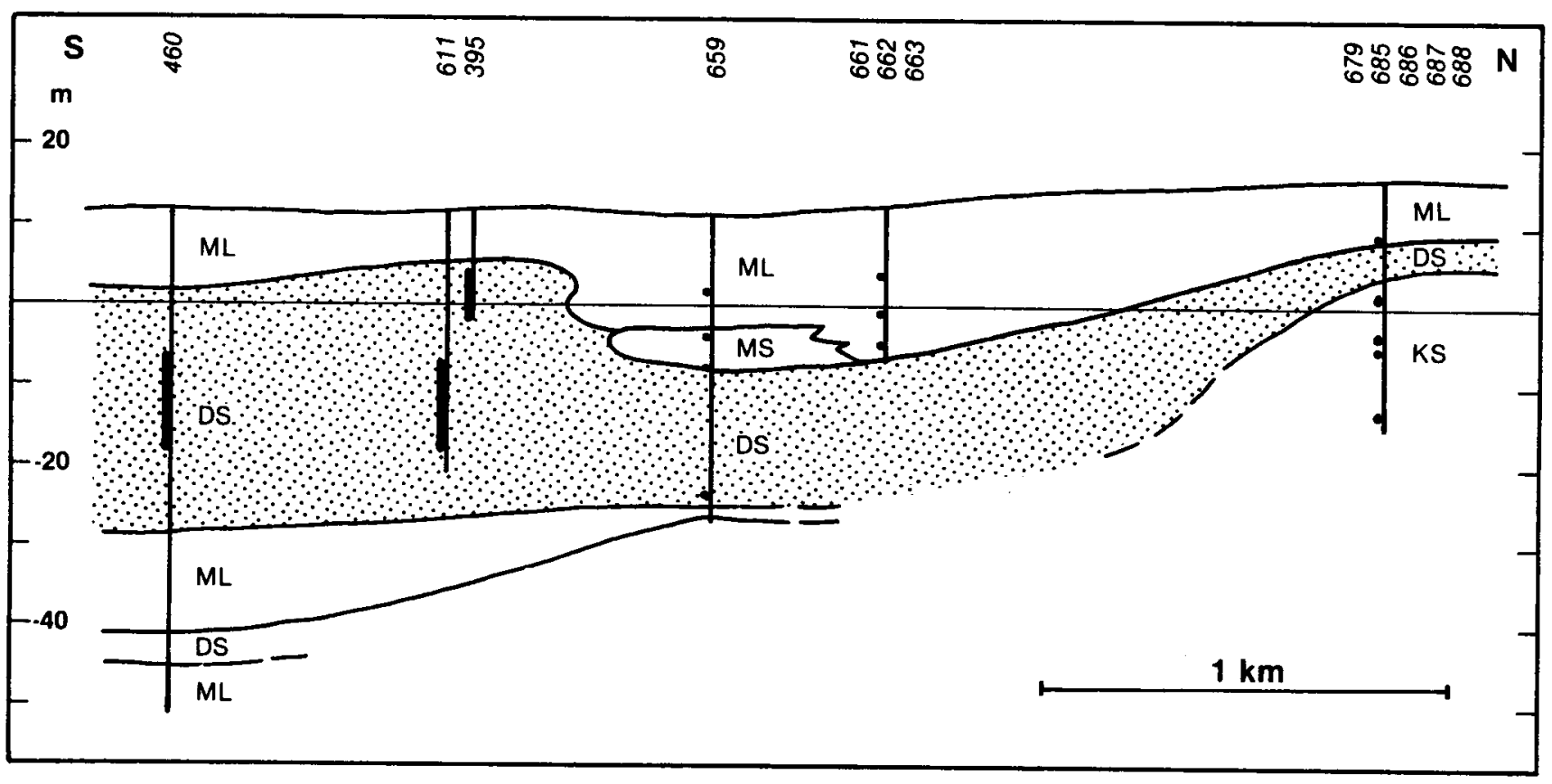


Hydrogeologi: Der er artesiske forhold i begge de kvartære sandlag. Kun det øvre sandreservoir, hvorfra også indvindingen foregår, og kvartssandet indgår i overvågningen, og områdeafgrænsningen gælder dette reservoir.

Grundvandskemi: Grundvandet i området er af calcium-bicarbonattypen. Den totale hårdhed er mellem 7 og $15^{\circ} \mathrm{dH}$. Jern- og manganindholdet, der reduceres ved normal vandbehandling, er meget højere end græenseværdien for drikkevand. Grundvandets nitratindhold er meget lav.

Vandbalance $\mathrm{mm} / \mathrm{a} \mathbf{r}$ :
Arealanvendelse \%:

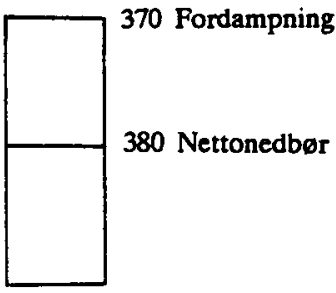

Landbrug

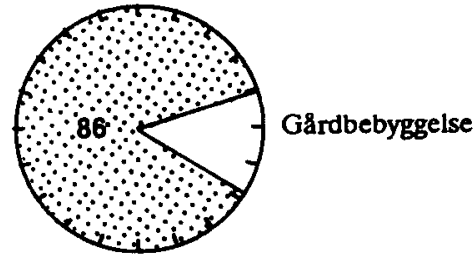

Registrerede depoter. ingen

Koncentrationen af udvalgte stoffer $\mathrm{i}$ forhold til dybde under terræn.

\begin{tabular}{|l|c|c|}
\hline \multicolumn{2}{|c|}{ Kitrat/Dybde } & Sulfat/Dybde \\
\hline $\begin{array}{c}\text { Data ikke } \\
\text { til rådighed }\end{array}$ & $\begin{array}{c}\text { Data ikke } \\
\text { til rádighed }\end{array}$ & $\begin{array}{c}\text { Data ikke } \\
\text { til rådighed }\end{array}$ \\
\hline
\end{tabular}



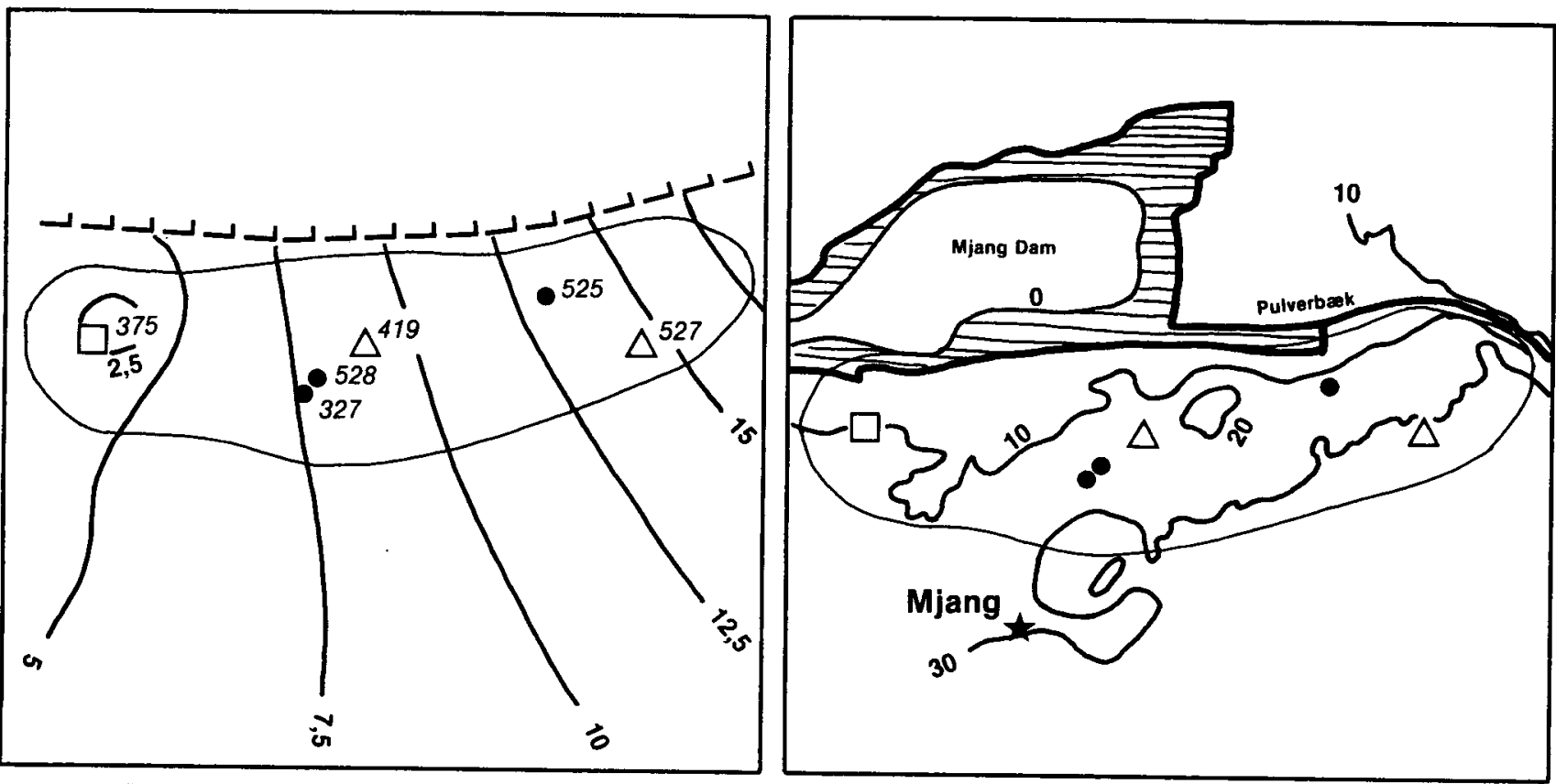

DGU nr. 170

Areal $1,5 \mathrm{~km}^{2}$

Geologi: De prækvartære lag i området består af glimmerler og glimmersand af Miocæn alder. De kvartære aflejringer domineres af moræneler, i hvilket der er aflejret smeltevandssand og -grus, samt interglacialt marint sand. Nord for Mjang Dam består de kvartære aflejringer udelukkende af moræneler. Syd for Mjang Dam er der to sand/grus lag i moræneleret. Det nedre lag har den største sammenhængende udbredelse. Sandlaget har lokalt en stor tilsyneladende tykkelse grundet skråstilling som følge af isdeformation.

Det øvre lag består af små isolerede sandlommer. Østligst i området, hvor terrænet er højst, findes et lokalt overfladenært sandlag. I overfladen dominerer moræneler.

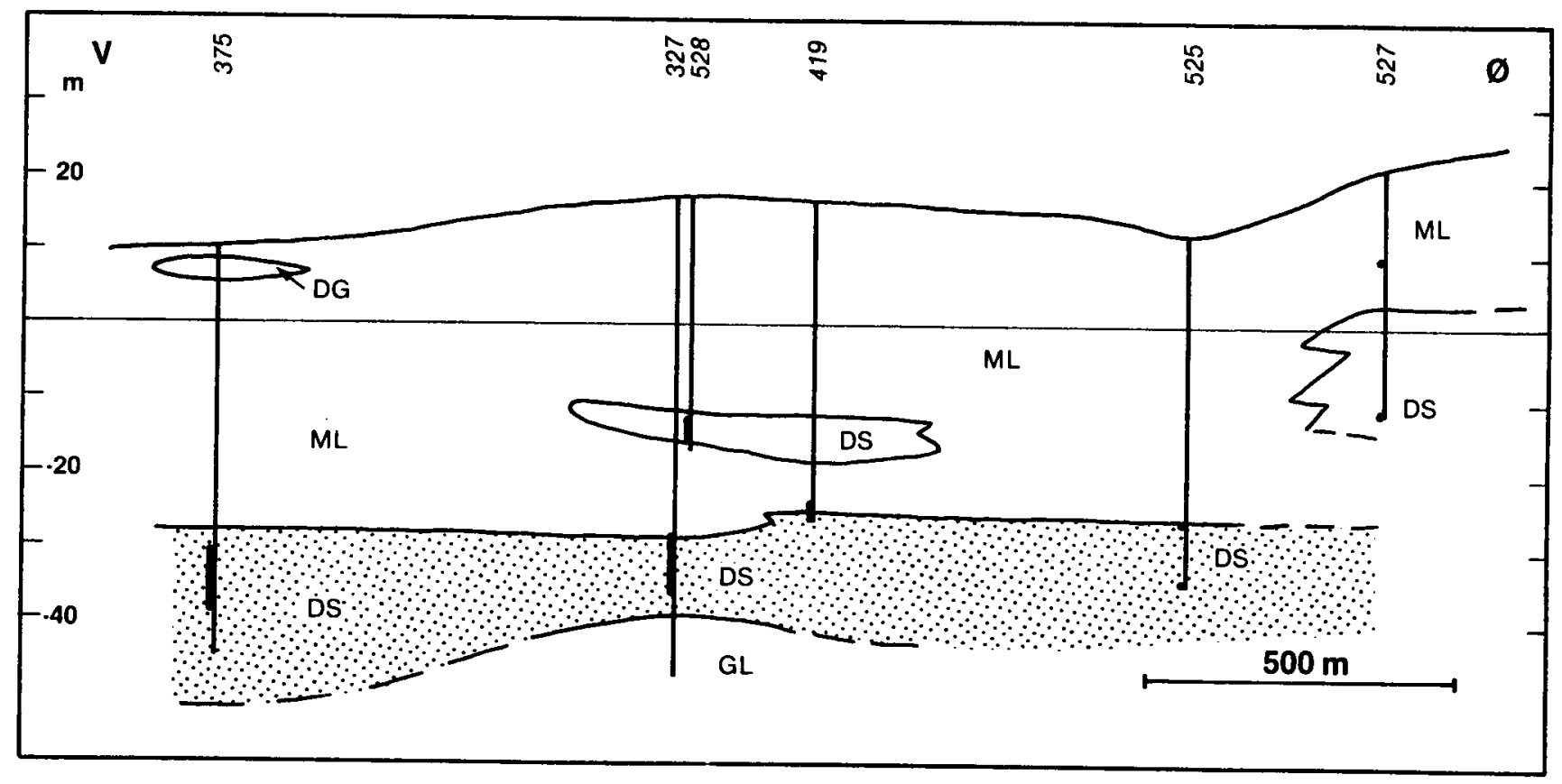


Hydrogeologi: Hovedreservoiret udgøres af det nedre lag af smeltevandssand kaldet Mjang Dam reservoiret. Dette reservoir er dækket af ikke-vandførende moræneler med dårlig vandføring. Det sekundære reservoir udgøres af det øvre sand/gruslag som er indlejret $\mathrm{i}$ moræneler. Der er lækage mellem det øvre og nedre reservoir. Begge reservoirer er artesiske. Områdets afgrænsning er anslået og antagelig for lille.

Grundvandskemi: Grundvandet $\mathrm{i}$ området er af calcium-bikarbonattypen. Den totale hårdhed er mellem 14 $22^{\circ} \mathrm{dH}$. Grundvandet indeholder under $2 \mathrm{mg}$ nitrat pr. liter og indholdet af opløst jern er ligeledes under 2 milligram pr. liter. Vandet $i$ hovedreservoiret har forhøjet kloridindhold, op til 160 milligram pr. liter.

Vandbalance $\mathbf{m m} / \mathbf{a ̊ r}$

Middelnedbor 650

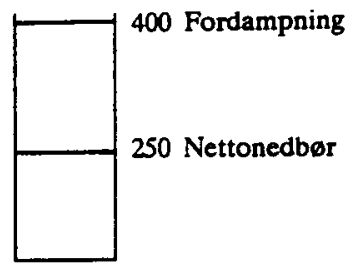

Kildeplads: Mjang Dam, 1 mill. m3/år
Arealanvendelse \%:

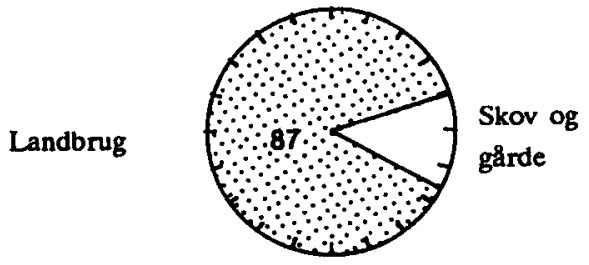

Registrerede depoter:

Koncentrationen af udvalgte stoffer i forhold til dybde under terræn.

\begin{tabular}{|c|c|c|}
\hline Nitrat/Dybde & Klorid/Dybde & Sulfat/Dybde \\
\hline $\begin{array}{l}\text { Data ikke } \\
\text { til rádighed }\end{array}$ & $\begin{array}{l}\text { Data ikke } \\
\text { til rådighed }\end{array}$ & $\begin{array}{l}\text { Data ikke } \\
\text { til rádighed }\end{array}$ \\
\hline
\end{tabular}




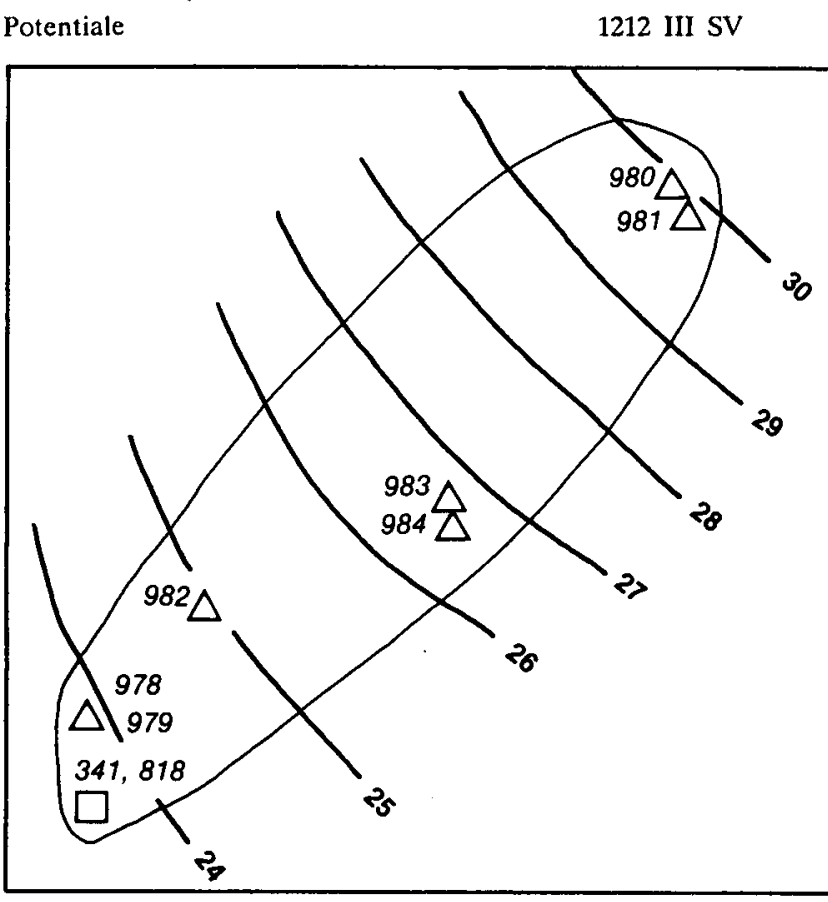

DGU nr. 159
Terræn

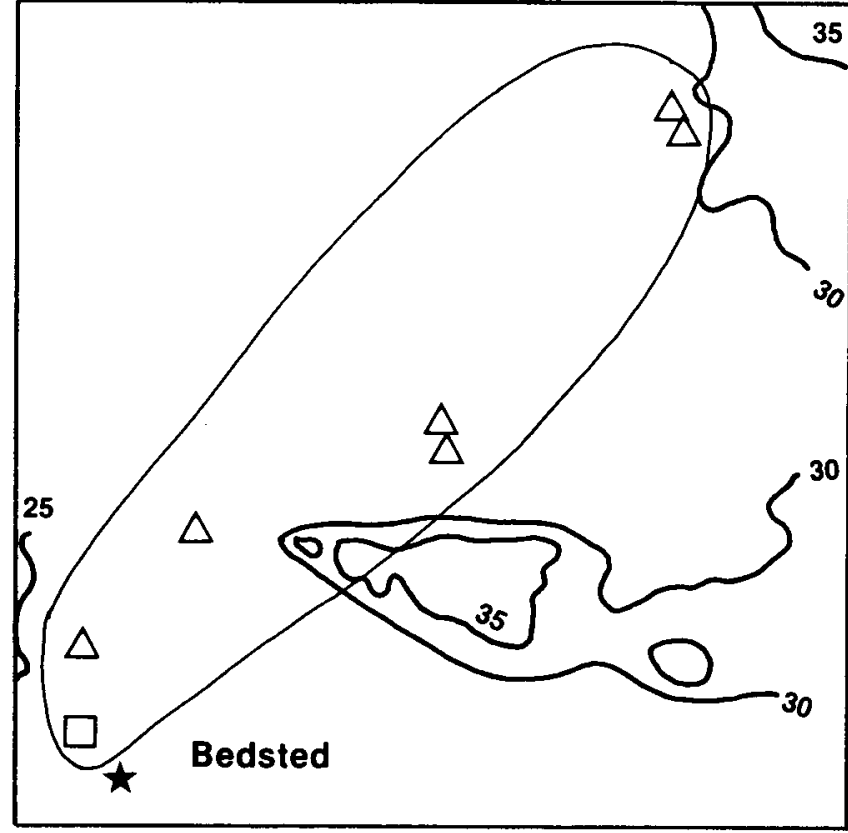

Areal $3 \mathrm{~km}^{2}$

Geologi: De kvartære aflejringer $\mathrm{i}$ området udgøres af to lagserier af smeltevandssand, som er adskilt af moræneler.

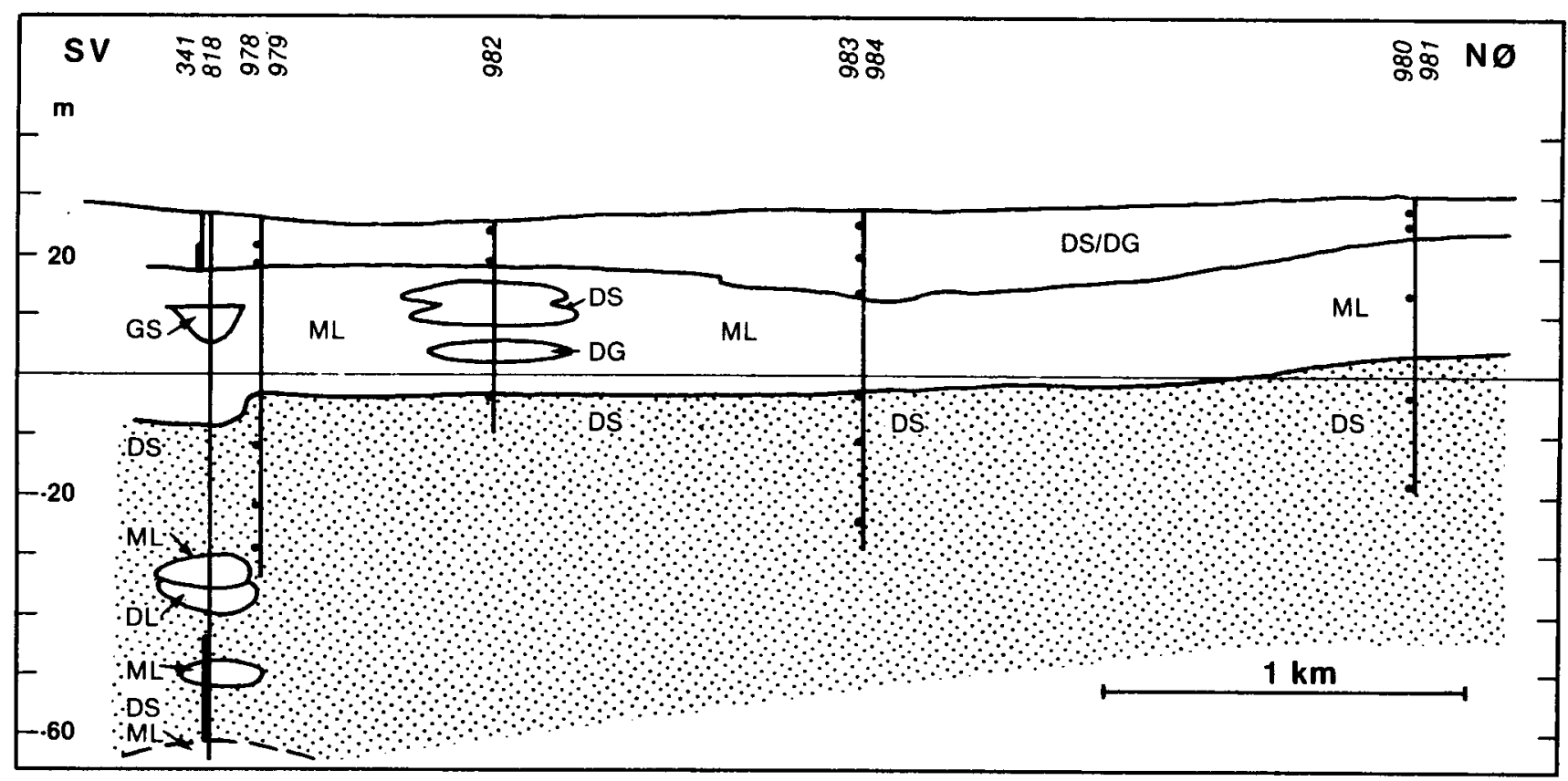


Hydrogeologi: Hovedreservoiret udgøres af det nedre lag af smeltevandssand og er artesisk. Det sekundære reservoir med frit grundvandsspejl findes $\mathrm{i}$ det $\emptyset v r e$ lag af smeltevandssand. Områdeafgræensningen gæider det sekundære reservoir.

Grundvandskemi: Grundvandet $\mathrm{i}$ området er middelhårdt til hårdt. Nitratindholdet er, antagelig som følge af nitratreduktion, generelt under 25 milligram pr. liter og sulfatindholdet er lavt. Enkelte steder er grundvandets nitratindhold dog væsentligt højere. $P a ̊$ Bedsted vandværk har der således $i$ en årrække været højt nitratindhold $\mathrm{i}$ vandet fra det sekundare reservoir, ligesom sulfatkoncentrationen her er relativ høj.

Vandbalance $\mathbf{m m} / \mathbf{a} r$ :

Middelnedbør 750

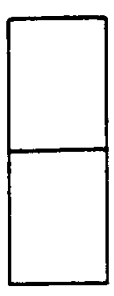

Kildeplads: Bedsted, 0,2 mill. m3/ar

\section{Arealanvendelse \%:}

360 Fordampning

390 Nettonedbør

Landbrug

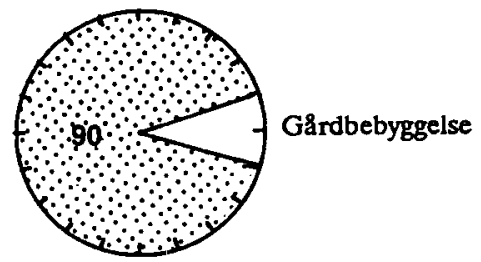

Registrerede depoter: ingen

Koncentrationen af udvalgte stoffer i forhold til dubde under terran.

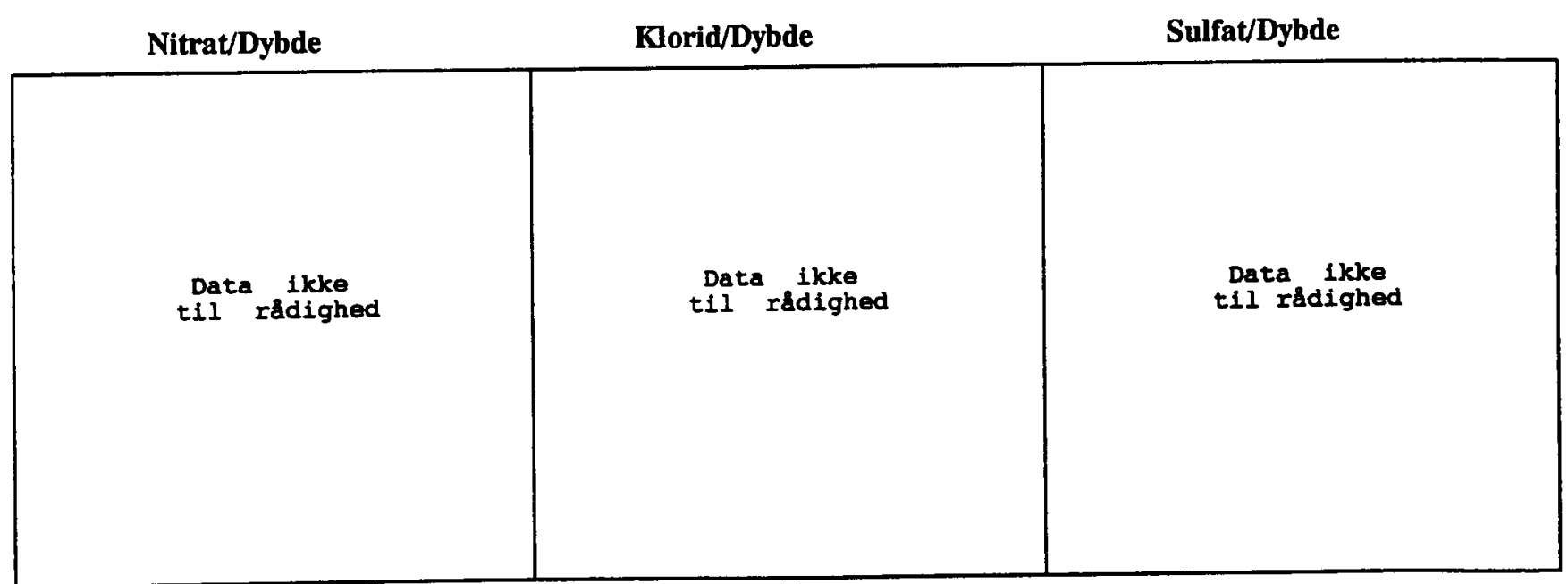




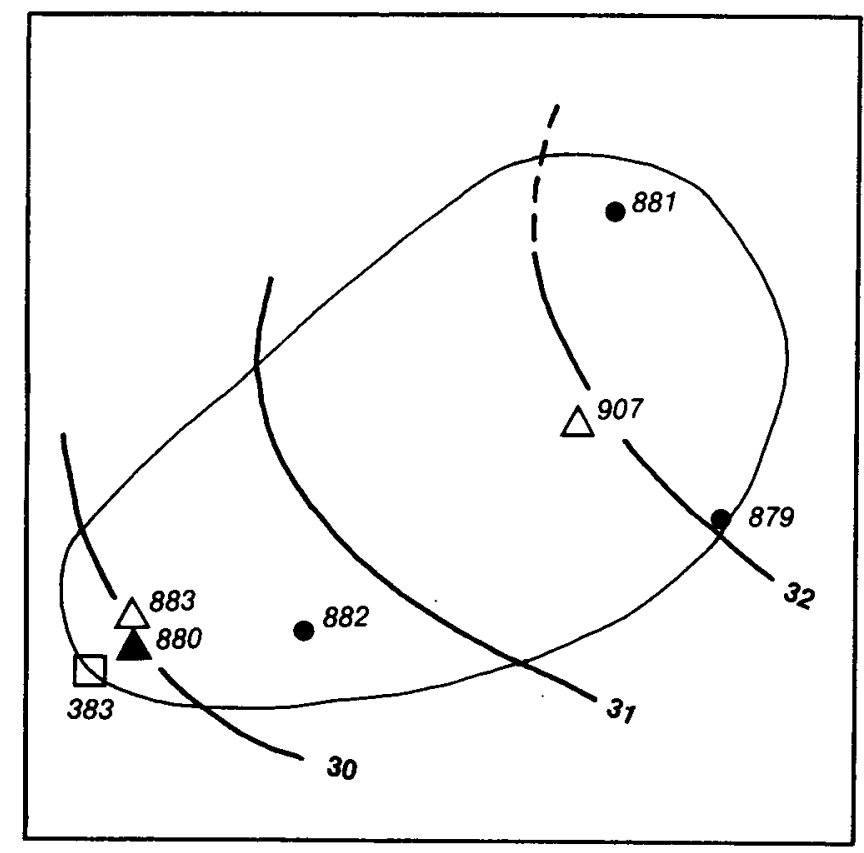

DGU nr. 141

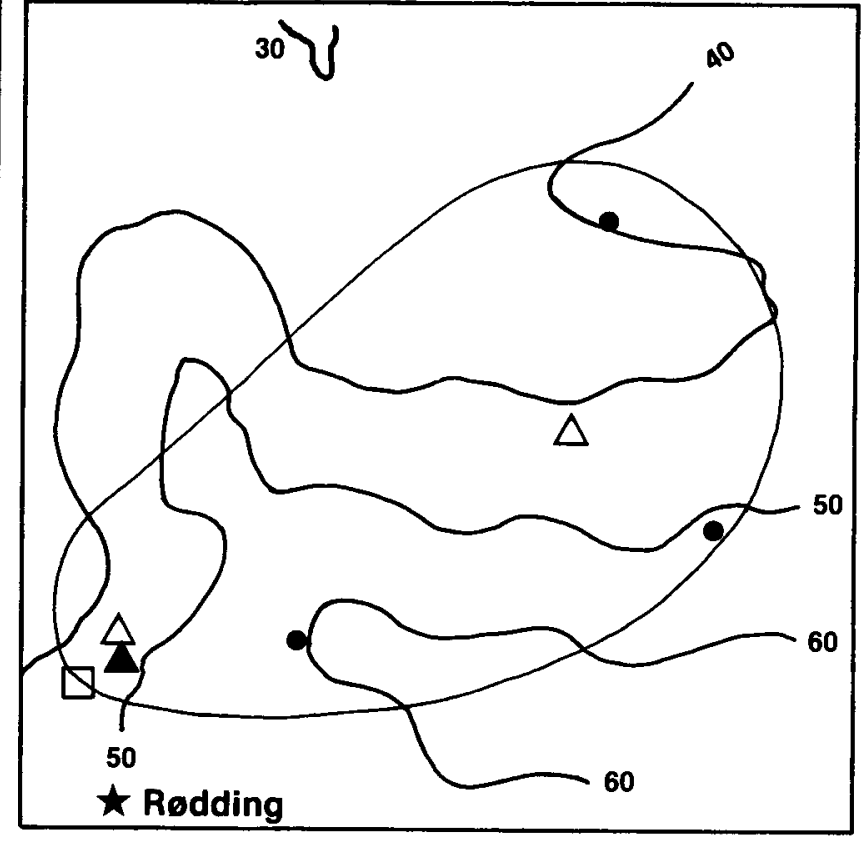

Areal $2,7 \mathrm{~km}^{2}$

Geologi: Den øverste prækvartære lagserie består af Miocænt sand, overlejret af glimmerler (ligeledes fra Miocæn). Den kvartære lagserie består af moræneler og smeltevand.

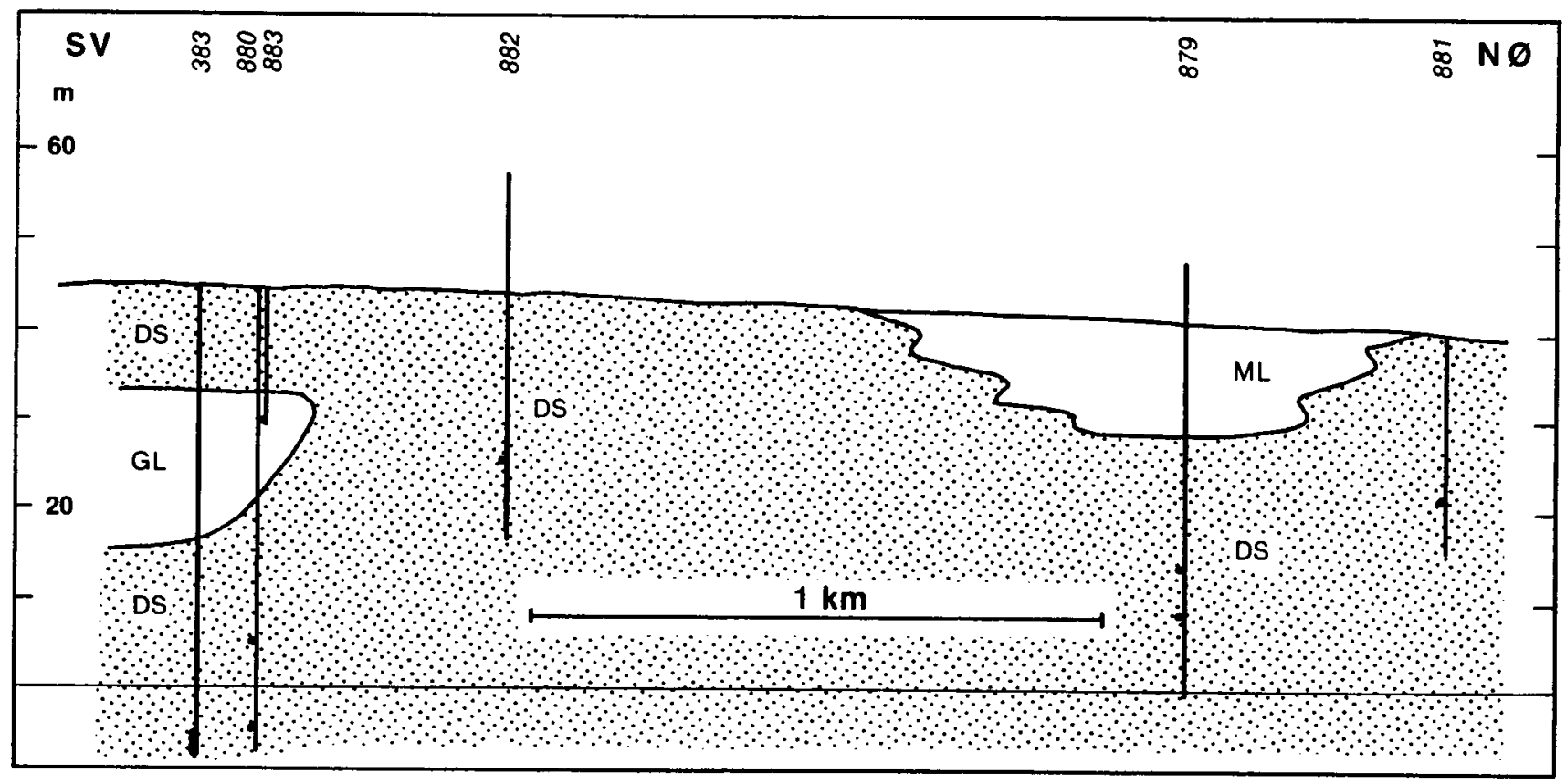


Hydrogeologi: Hovedreservoiret, der ikke indgår i overvågningen, er artesisk og består af den Miocæene sand, der formodes at være godt beskyttet af glimmerler. Der er frit grundvandsspejl i det sekundære reservoir. Områdeafgrænsningen gælder det sekundære reservoir.

Grundvandskemi: Grundvandet er kun svagt kalkholdigt og den stærkt varierende hårdhed er som helhed lav. Nitratindholdet er de fleste steder lavt. Enkelte steder, hvor også grundvandets iltindhold er højt, er nitratkoncentrationen dog $h ø j$.

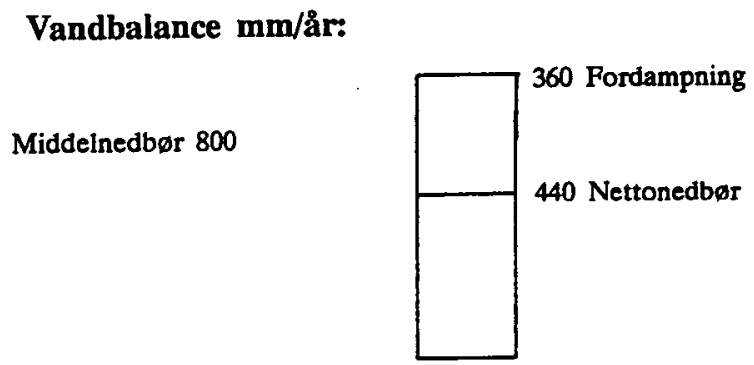

Kildeplads: Rødding w, 0,3 mill. m3/âr

\section{Arealanvendelse \%:}

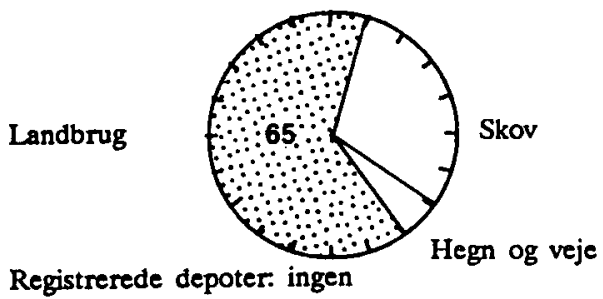

Koncentrationen af udvalgte stoffer $i$ forhold til dybde under terran.

\begin{tabular}{|l|c|c|}
\hline \multicolumn{2}{|c|}{ Klorid/Dybde } & Sulfat/Dybde \\
\hline $\begin{array}{c}\text { Data ikke } \\
\text { til rådighed }\end{array}$ & $\begin{array}{c}\text { Data ikke } \\
\text { til rådighed } \\
\text { tilde }\end{array}$ & $\begin{array}{c}\text { Data ikke } \\
\text { til rádighed }\end{array}$ \\
\hline
\end{tabular}



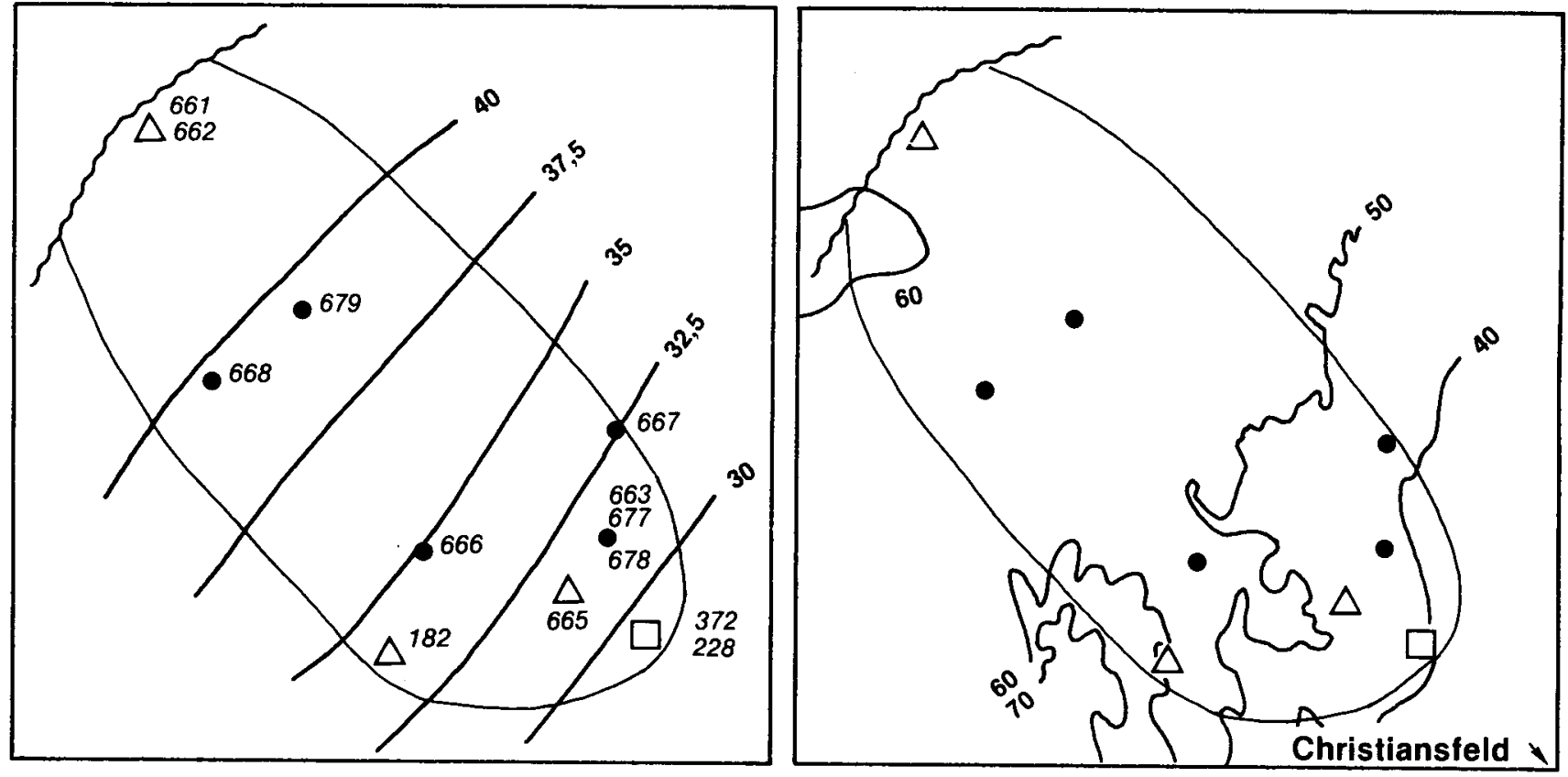

DGU nr. 142

Areal $3,5 \mathrm{~km}^{2}$

Geologi: Den kvartære lagserie består af en sekvens af smeltevandssand, ler/moræneler, endnu et lag af smeltevandssand og øverst af moræeneler.

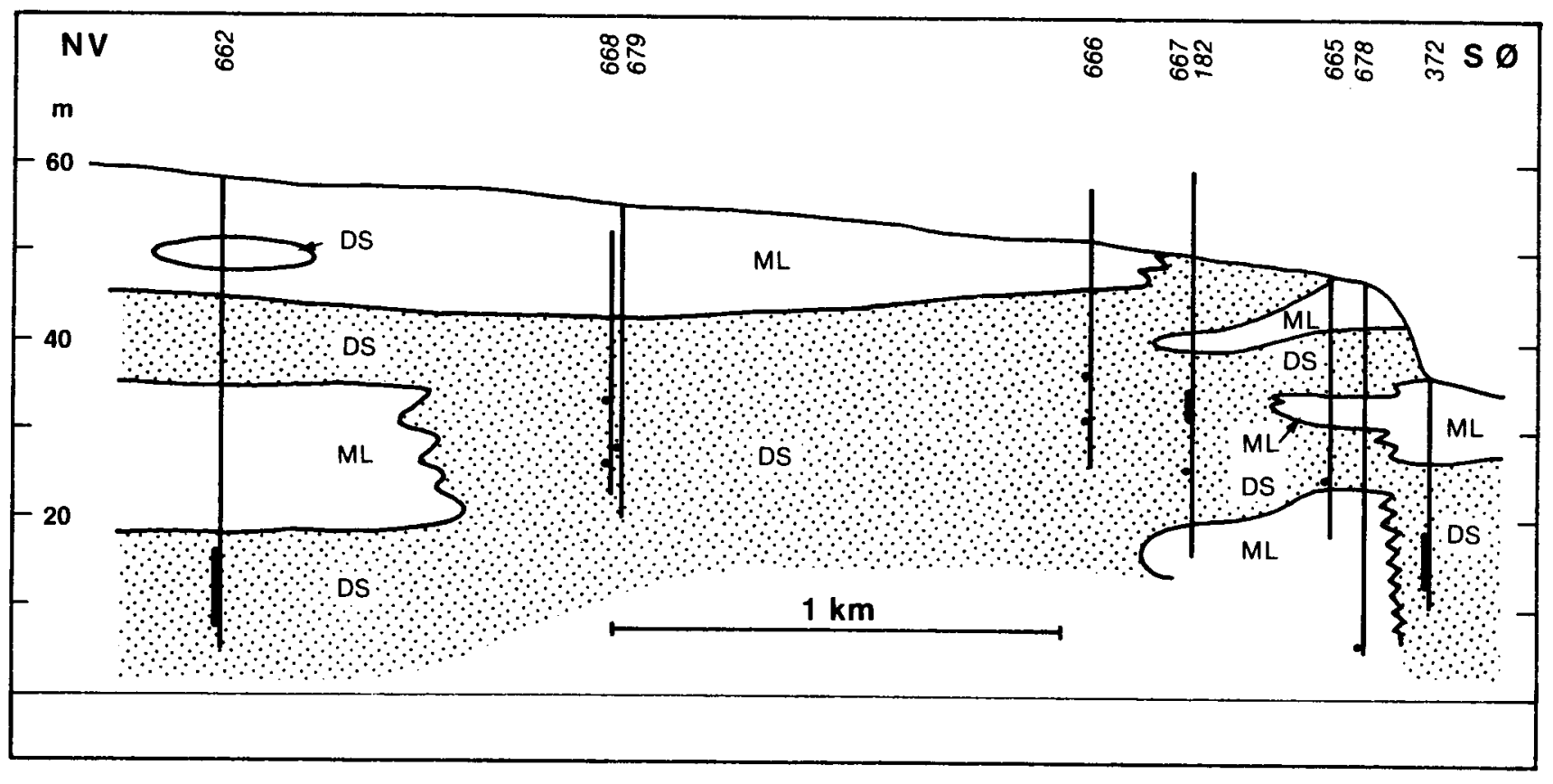


Hydrogeologi: Hovedreservoiret, der er artesisk, består af den nedre del af smeltevandssandet, der er velbeskyttet af de overlejrede morænelersbænke. Der er frit grundvandsspejl i det øvre smeltevandssand, som har frit grundvandsspejl. Områdeafgrænsningen gælder det øvre sandreservoir.

Grundvandskemi: Grundvandet $\mathrm{i}$ området er af calcium-bicarbonattypen. Hårdheden er ca. $20^{\circ} \mathrm{dH}$. Nitratindholdet er overalt under 5 milligram pr. liter. Grundvandet indeholder en del jern og mangan. Desuden er der en del aggressiv kulsyre.

Vandbalance $\mathbf{m m} / \mathbf{a} r:$

Middelnedbør 650

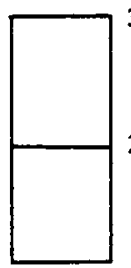

Kildeplads: Christiansfeld vv, 0,35 mill. m3/år

\section{Arealanvendelse \%:}

360 Fordampning

290 Nettonedbør

Landbrug

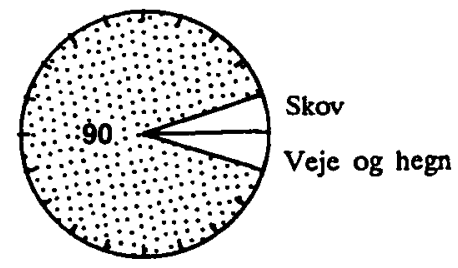

Registrerede depoter: et affaldsdepot er blevet fjernet

Koncentrationen af udvalgte stoffer i forhold til dybde under terræn.

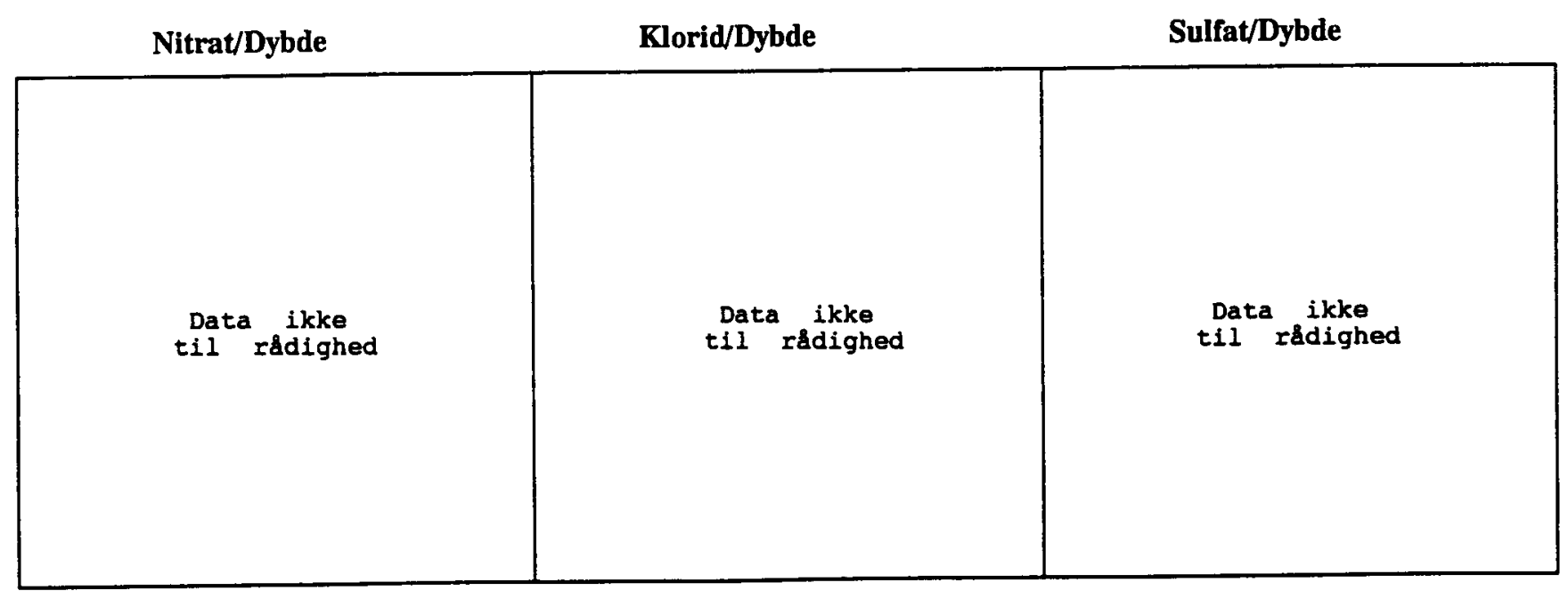



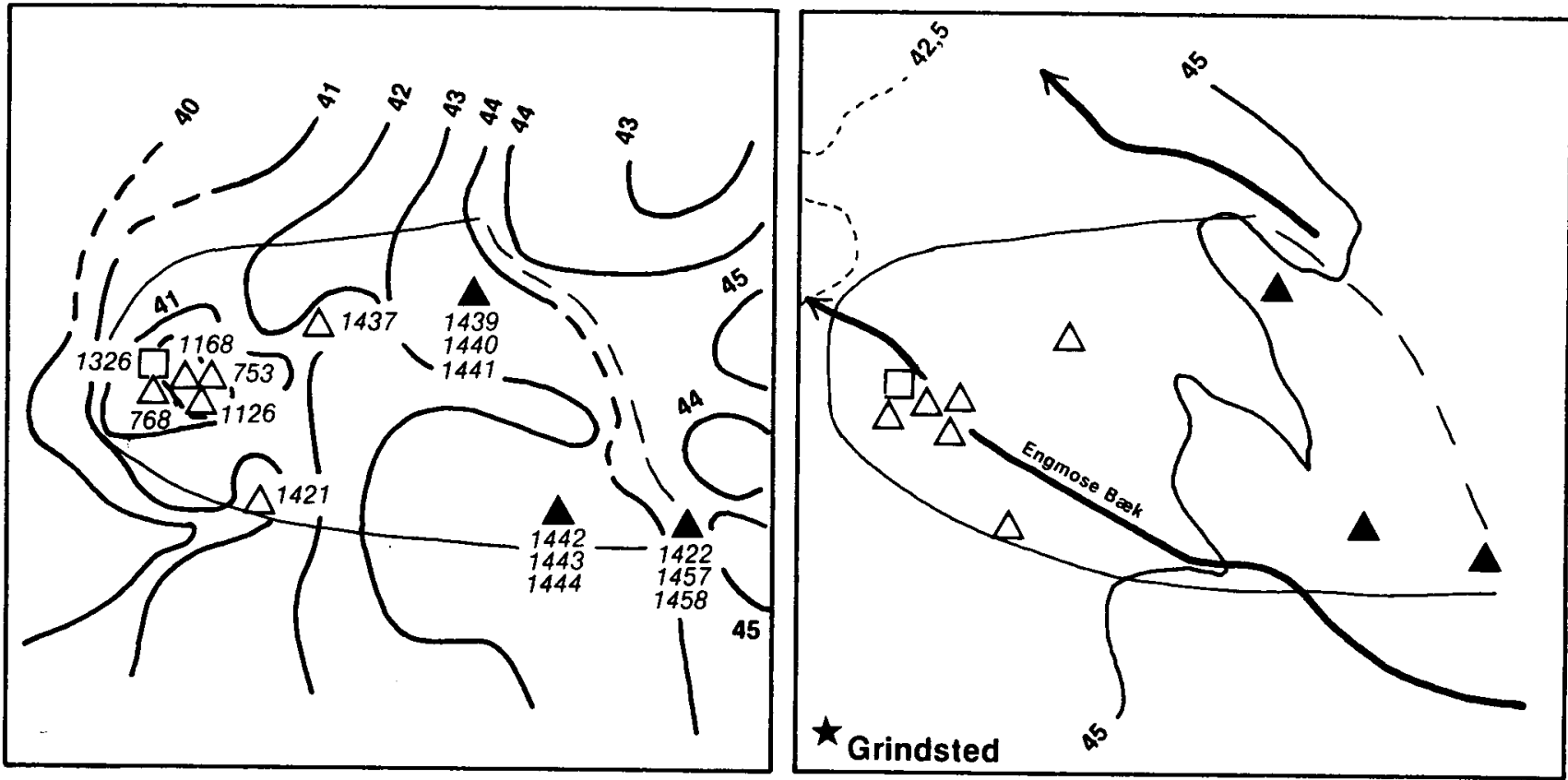

DGU nr. 114

Areal $3,5 \mathrm{~km}^{2}$

Geologi: De øverste prækvartære aflejringer i området består af Miocænt glimmerler, glimmersand og kvartssand. Kvartssand forekommer hyppigst $\mathrm{i}$ den øverste del af de Miocæne aflejringer. De kvartære aflejringer består af ekstramarginalt flodslettesand. Både kvartssandet og flodslettesandet findes $i$ hele området.

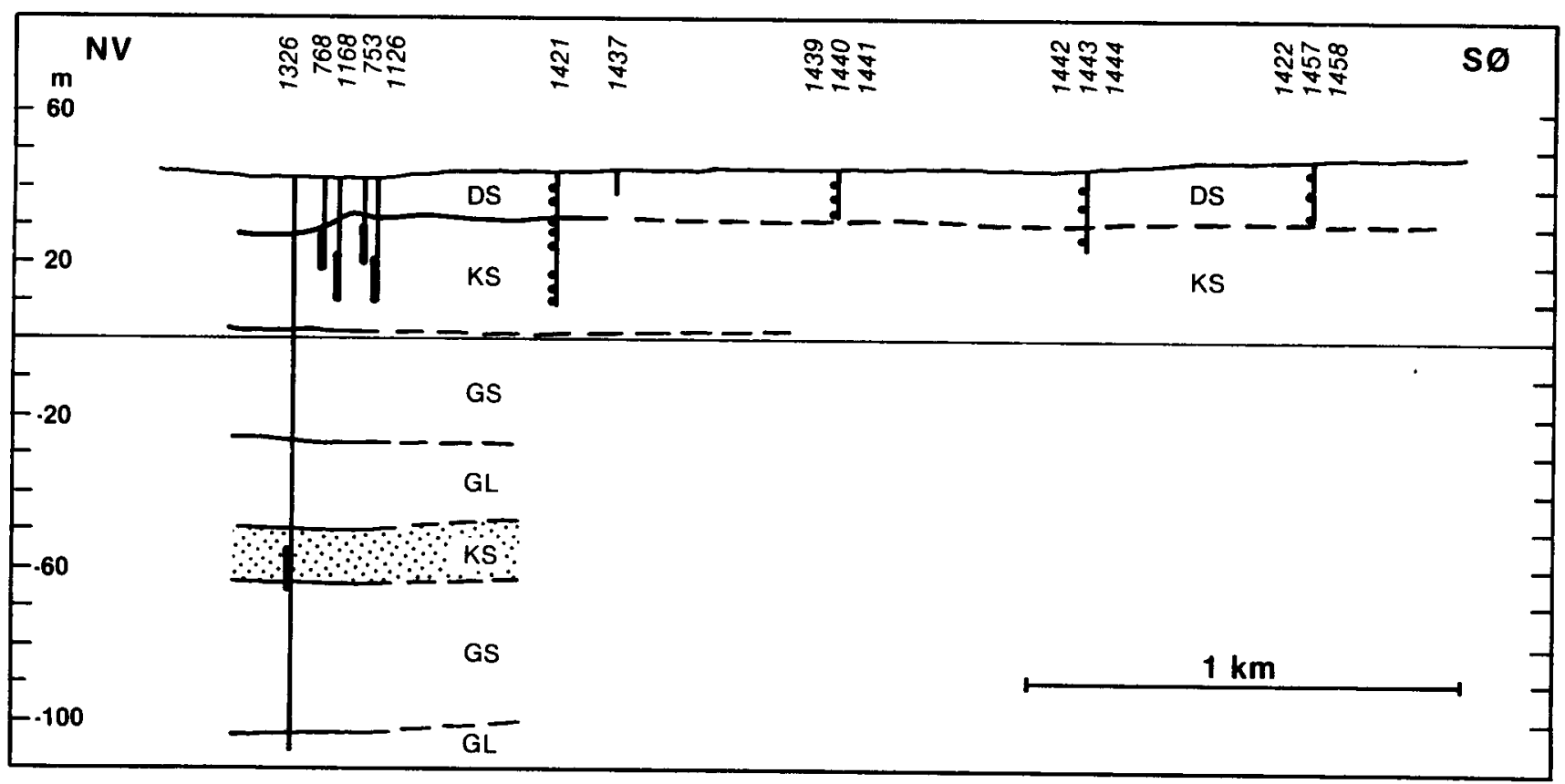


Hydrogeologi: Hovedreservoiret for grundvand er de Miocane sandaflejinger, hvor forholdene er artesiske. Det sekundære grundvandsreservoir, der findes $\mathrm{i}$ den øverste del af kvartssandet og i ferskvandssandet, har frit grundvandsspejl. Området er afgrænset på basis af det sekundære reservoir.

Grundvandskemi:Grundvandet $\mathrm{i}$ hovedreservoiret er af calcium-bikarbonattypen. Den totale hårdhed er 6-7 dH. Nitratindholdet er under 0,5 milligram pr. liter, mens jernindholdet er relativt højt, 3-5 milligram pr. liter, og manganindholdet er på 0,13-0,14 milligram pr. liter. Grundvandet $i$ det sekundære reservoir er af calcium-natrium-sulfat typen. Den totale hårdhed er 1,5-6 $\mathrm{dH}$. Nitratindholdet $\mathrm{i}$ det øvre reservoir er gennemgående højt (op til 155 milligram pr. liter).

Hvor nitratindholdet er højt er jernindholdet lavt og omvendt. Kaliumindholdet er højt $\mathrm{i}$ det sekundære reservoir. Vandkemien i overvågningsområdet er således præget af den intensive landbrugsdrift.

Vandbalance mm/år:

Middelnedbør 760

Kildeplads: Grindsted vv, kildefelt II, 1.4 mill. m /år

\section{Arealanvendelse \%:}

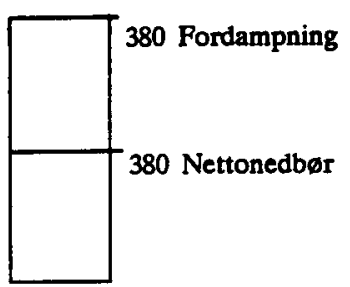

Landbrug

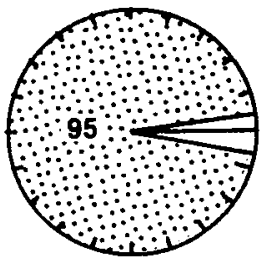

Skov og natur Gårdbebyggelse

Koncentrationen af udvalgte stoffer i forhold til dybde under terræn.

Graferne viser data fra 1989 og 1990.

Nitrat/Dybde

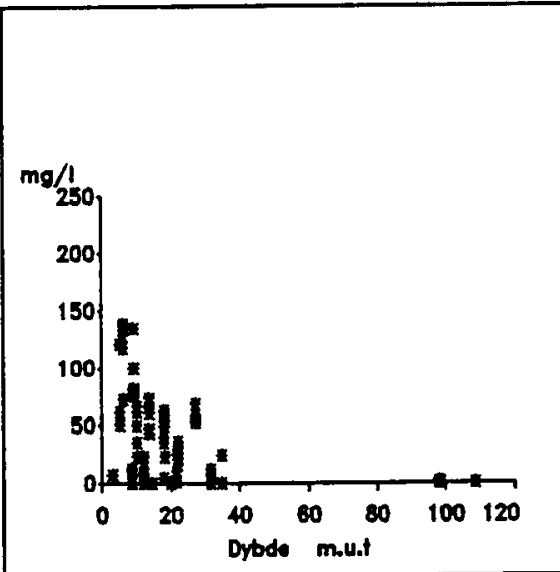

Sulfat/Dybde

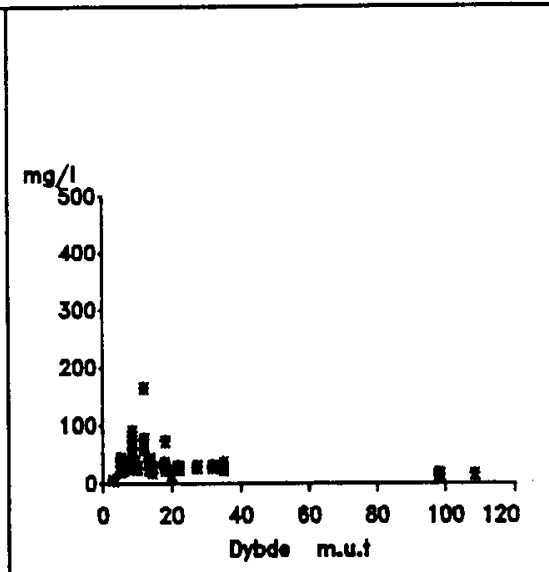

Registrerede depoter: ingen 

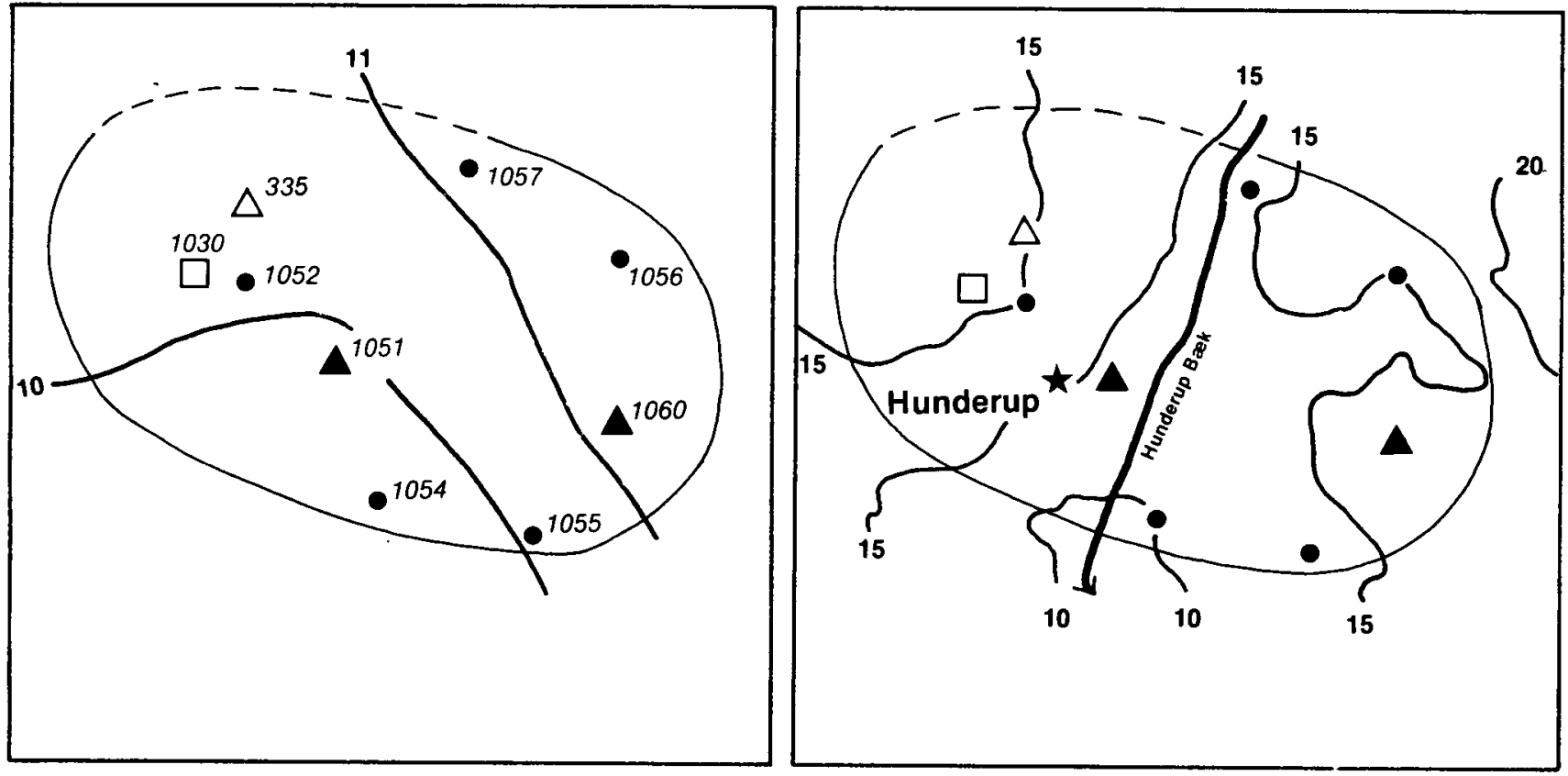

DGU nr. 131

Areal $4 \mathrm{~km}^{2}$

Geologi: De øverste prækvartære aflejringer består af Miocænt ler. Prækvartæroverfladen har et uroligt relief. I hele området er der herover en kvartær lagserie, der nederst består af 5-105 meter smeltevandssand og -grus med indlejrede lerlinser af varierende udstrækning og tykkelse. Den sandede sekvens overlejres i hele området af marint ler fra Holsteintiden, der igen overlejres af smeltevandssand. Endelig findes der $i$ områdets sydøstlige del et lokalt morænedække øverst i lagfølgen.

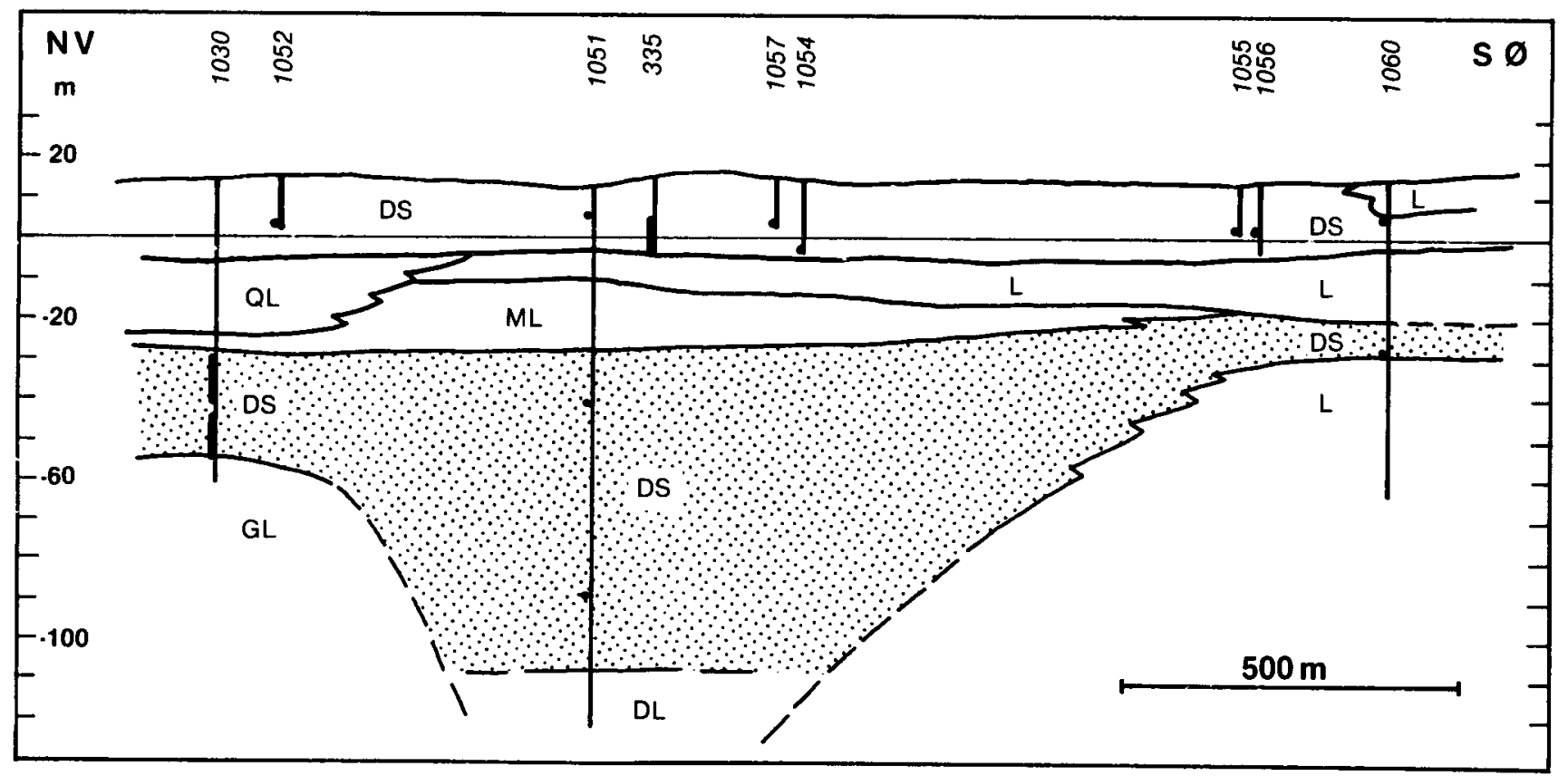


Hydrogeologi: Hovedreservoiret og det sekundære reservoir udgøres af de to sandaflejringer. Vandværket indvandt tidligere fra det sekundære reservoir, der har frit grundvandsspejl. I hovedreservoiret er der artesiske forhold. Den overordnede grundvandsstrømning går mod vest.

Grundvandskemi: Grundvandet i det sekundære reservoir karakteriseres ved indholdet af calcium og magnesium, samt sulfat, klorid og nitrat. Nitratindholdet har været stigende igennem en årrække og jernindholdet er meget højt.

Grundvandet $i$ hovedreservoiret er af calcium-bikarbonattypen, og indholdet af sulfat aftager med dybden grundet sulfatreduktion. Fra nogle af filtrene $i$ de nye indvindingsboringer produceres der brunt vand, som fjernes ved separationspumpning.

Vandbalance $\mathbf{m m} / \mathbf{a ̊ r}$

Ikke oplyst

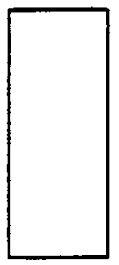

Kildeplads: Bramming-Hunderup vv, 0.6 mill. m3/ăr
Arealanvendelse \%:

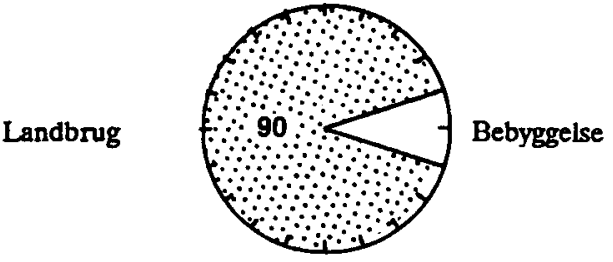

Registrerede depoter:

Risikoen for brunt vand syntes at være størst vest og nordvest for kildefeltet. Grundvandets fluoridindhold er generelt højere end $i$ resten af Ribe amt.

Koncentrationen af udvalgte stoffer $i$ forhold til dybde under terræen.

Graferne viser data fra 1989 og 1990.

Nitrat/Dybde

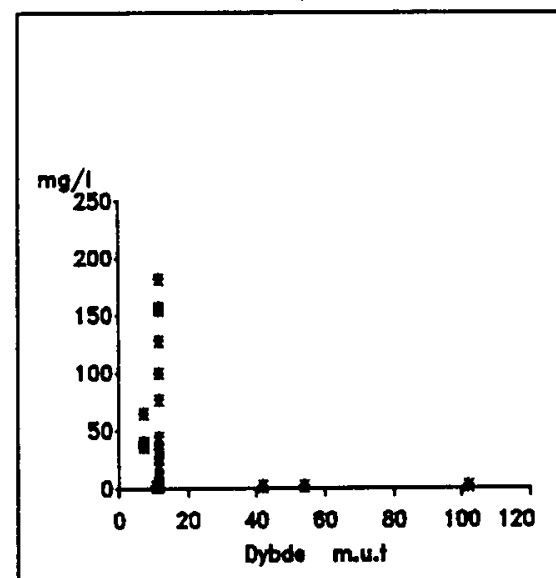

Klorid/Dybde

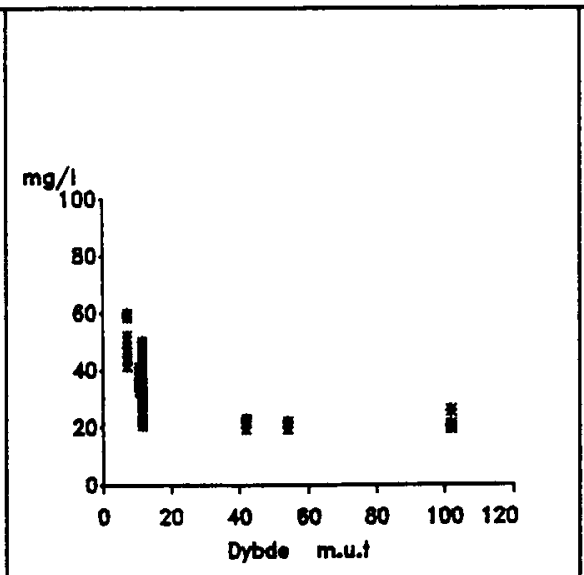

Sulfat/Dybde

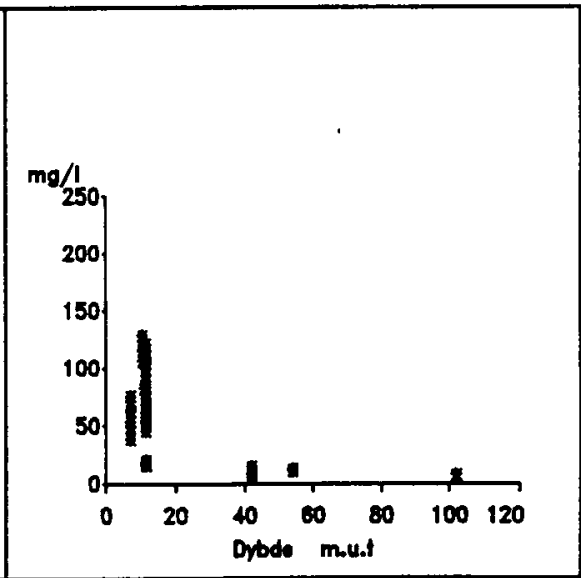


1114 III Sø og 1114 II SV

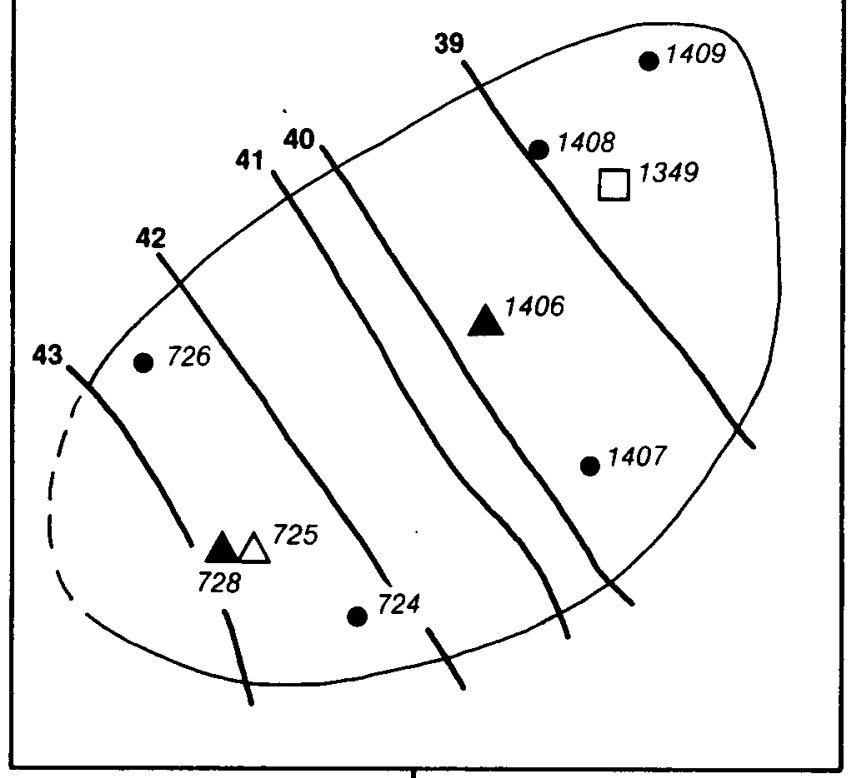

DGU nr.

$102 \mid 103$
Geologi: Under den kvartære lagserie af smeltevandssand og moræneler findes der Miocænt glimmerler- og sand. I hele områdets sydvestlige del er smeltevandssandet dækket af moræneler. Også mellem smeltevandssandet og de Miocæne lag findes der, i områdets nordlige del, et indslag af smeltevandsler.

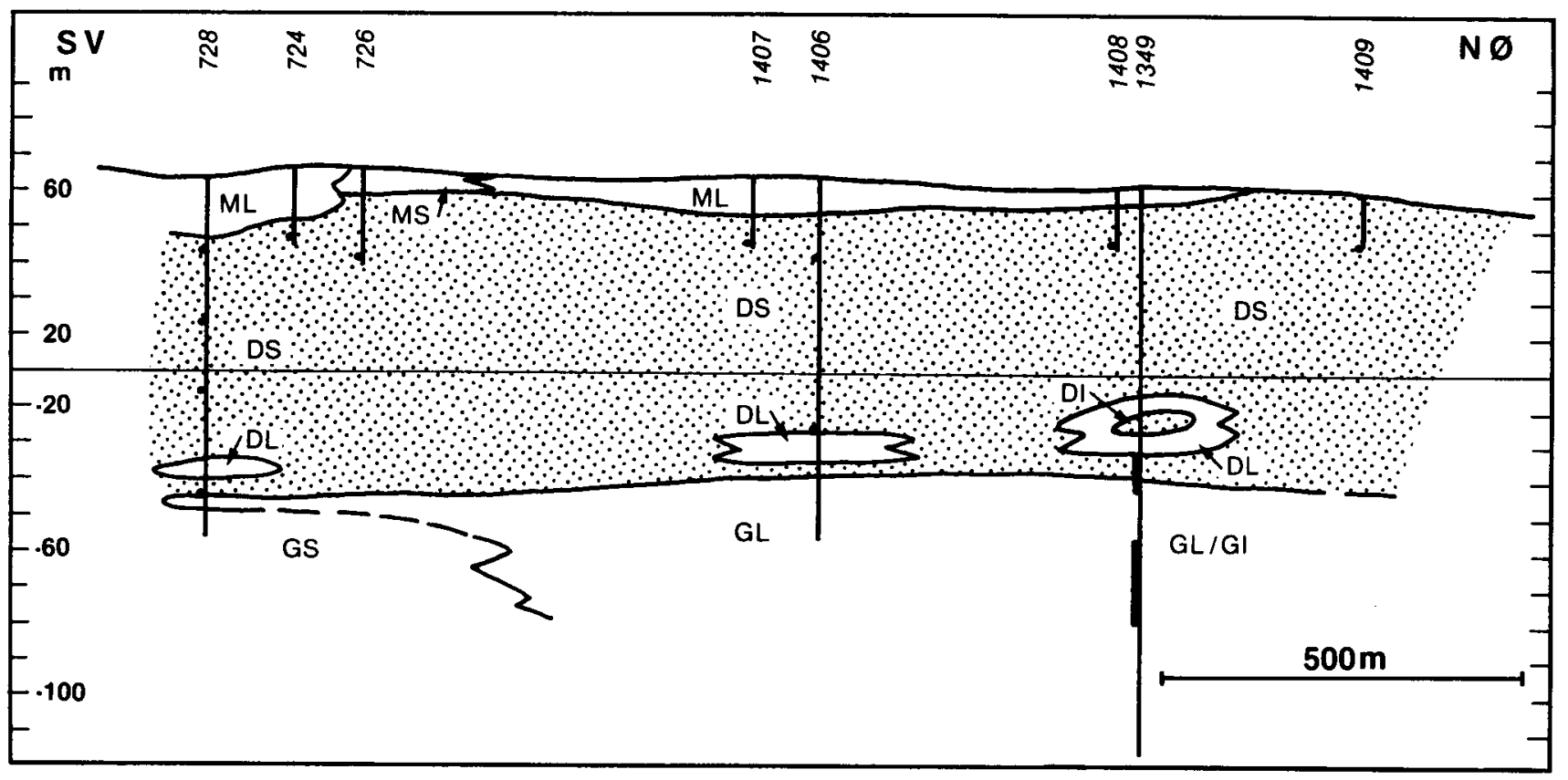


Hydrogeologi: Der er to hovedreservoirer i dette overvågningsområde. Det nederste består af Miocæent glimmersand, mens det øverste består af smeltevandssand.

Trods det udbredte morænelersdakke betragtes grundvandsreservoirerne med udgangspunkt $\mathrm{i}$ blandt andet nitratindholdet som frie og prægede næringssalte fra den intensive dyrkning.

Grundvandskemi: Grundvandet er af calcium-bikarbonattypen. I de øvre filtre har grundvandet relativt høj ionstyrke (3-6 milliækvivalenter pr. liter), indeholder nitrat (op til 130 milligram pr. liter), og variationen i koncentrationen gennem tiden er relativ høj. I størstedelen af overvågningsområdet er det øvre grundvand præget af den intensive dyrkning. Kun i områdets nordvestlige dele indeholder grundvandet intet eller kun lidt nitrat og ionstyrken er mellem 1,5-3 milliakvivalenter pr. liter.

Vandbalance $\mathbf{m m} / \mathbf{a} r$ :

Ikke oplyst

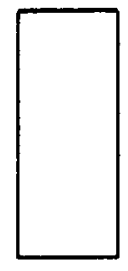

Kildeplads: Ølgod w, 0.5 mill. m3/ar

\section{Arealanvendelse \%:}

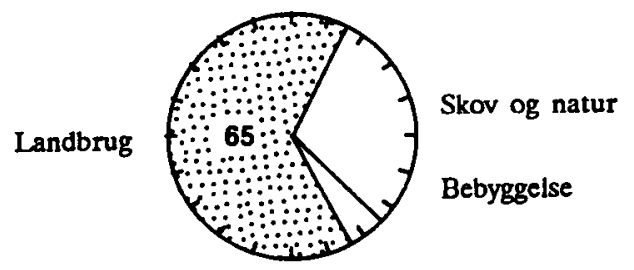

Registrerede depoter.

Koncentrationen af udvalgte stoffer $i$ forhold til dybde under terræen.

Graferne viser data fra 1989 og 1990.

Nitrat/Dybde

Klorid/Dybde

Sulfat/Dybde

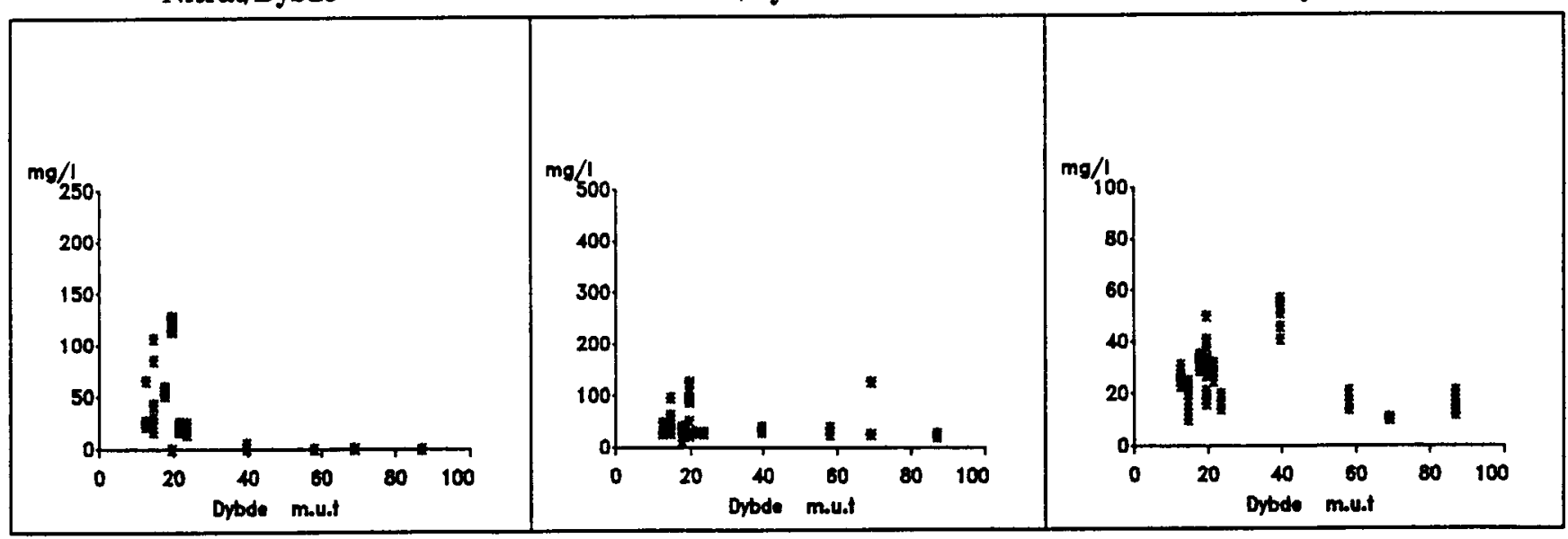


Potentialet

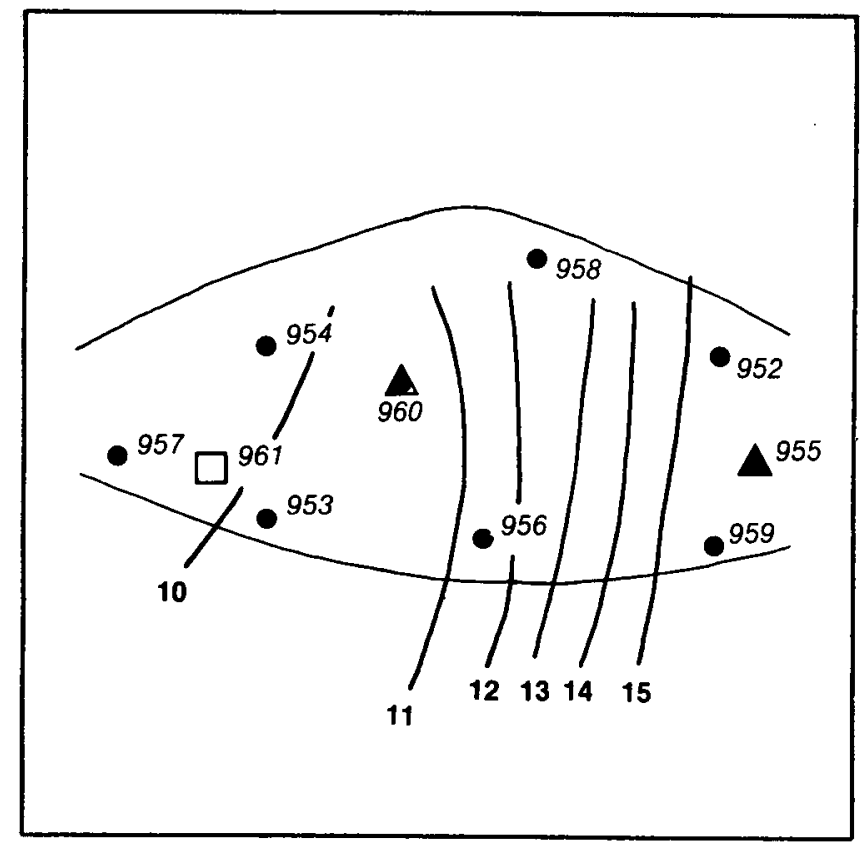

DGU nr. 121
Terræn

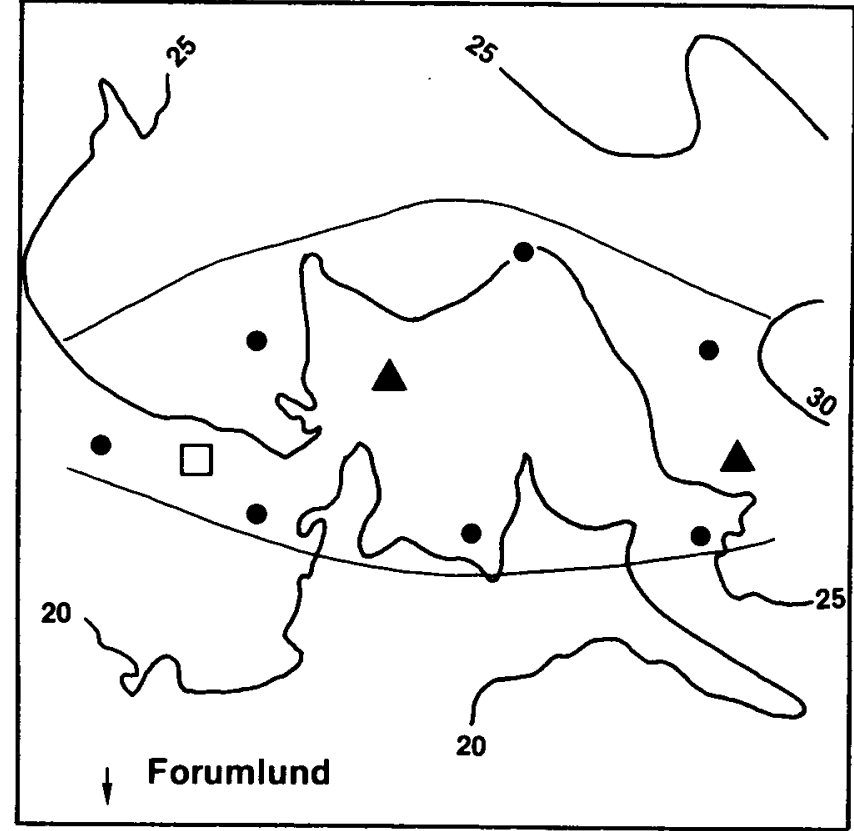

Areal $2 \mathrm{~km}^{2}$

Geologi: Det øverste prækvartære lag består af Miocænt glimmerler. Den kvartære lagserie består udover det dominerende smeltevandssand af moræneler, morænesand og marint interglacialt ler (Holstein).

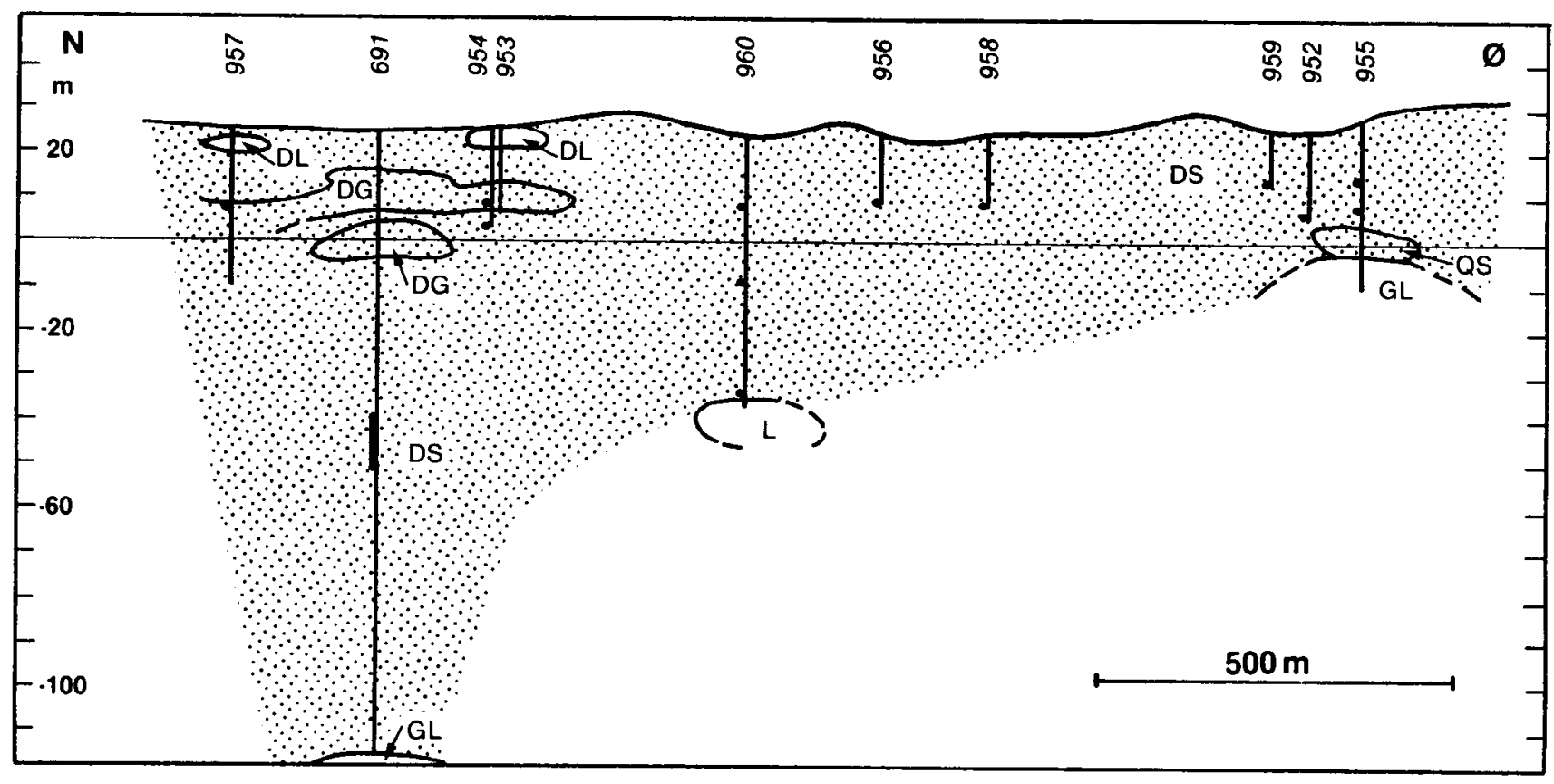


Hydrogeologi: Hovedreservoiret består af smeltevands- og morænesand. Der er lokale lag af moræneler $i$ flere dybdeintervaller, men da de ikke er forbundne udgør de sandede sedimenter, der omgiver dem, et sammenhangende reservoir. I dette reservoir er der hovedsagelig frit grundvandsspejl. Reservoiret, der centralt $i$ området er op mod 150 meter tykt, bliver gradvis tyndere mod sydøst (ned til 10 meter). Potentialekortet svarer til situationen ultimo 1989.

Grundvandskemi: Mængden af opløste stoffer $\mathrm{i}$ grundvandet er $\mathrm{i}$ de fleste tilfælde lavt. Ionstyrken ligger omkring 2 milliækvivalenter pr. liter, og der er ingen æendring $\mathrm{i}$ vandkvaliteten inden for den undersøgte periode. Grundvandskemien i reservoirets øvre dele afspejler arealanvendelsen. I det intensive dyrkningsfelt, der strækker sig som et bånd fra sydøststranden ind over midten af området og videre mod nordvest, er grundvandet relativt stærkt belastet med nitrat og næringssalte.

Vandbalance $\mathrm{mm} / \mathrm{år}$

Ikke oplyst

Kildeplads: Forum vv, ved Barbaras hule, 1.5 mill. m3/år

\section{Arealanvendelse \%:}

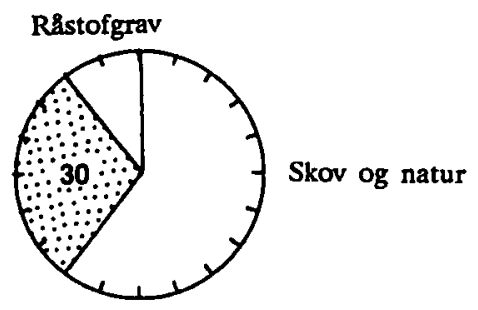

Registrerede rapporter.

Enkelte steder er der et ret højt saltindhold i det øverste grundvand. Magnesiumindholdet i grundvandet aftager med dybden.

Koncentrationen af udvalgte stoffer i forhold til dybde under terran.

Graferne viser data fra 1989 og 1990.

Nitrat/Dybde

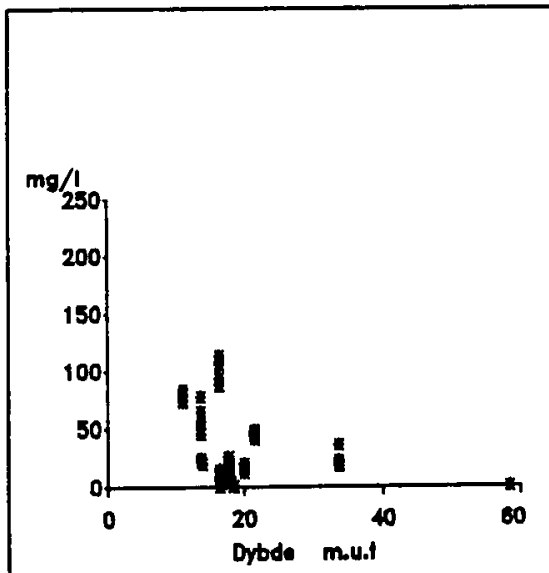

Sulfat/Dybde

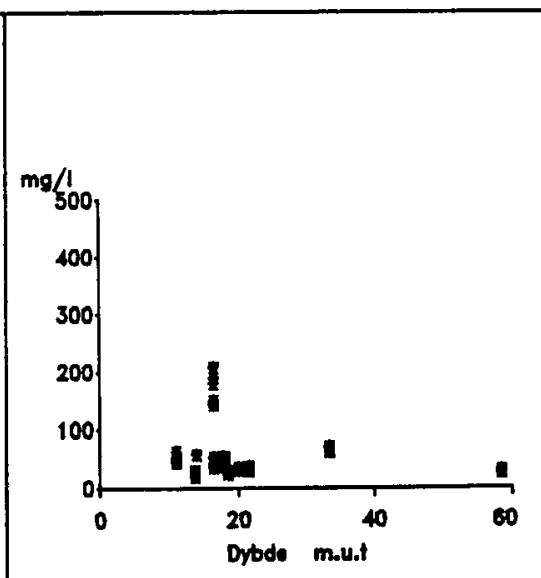

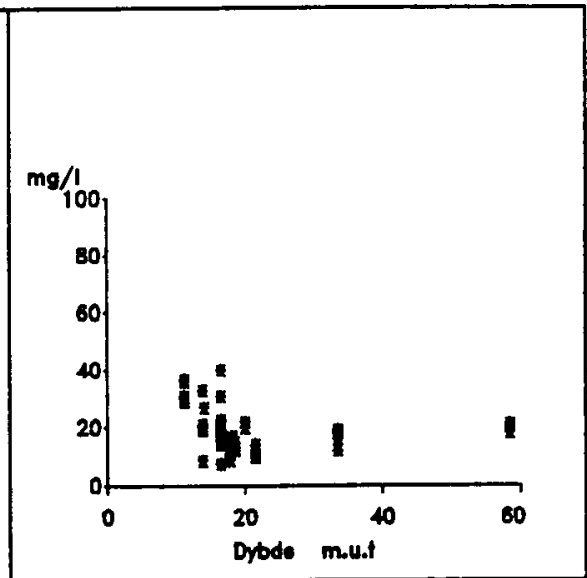


Potentiale

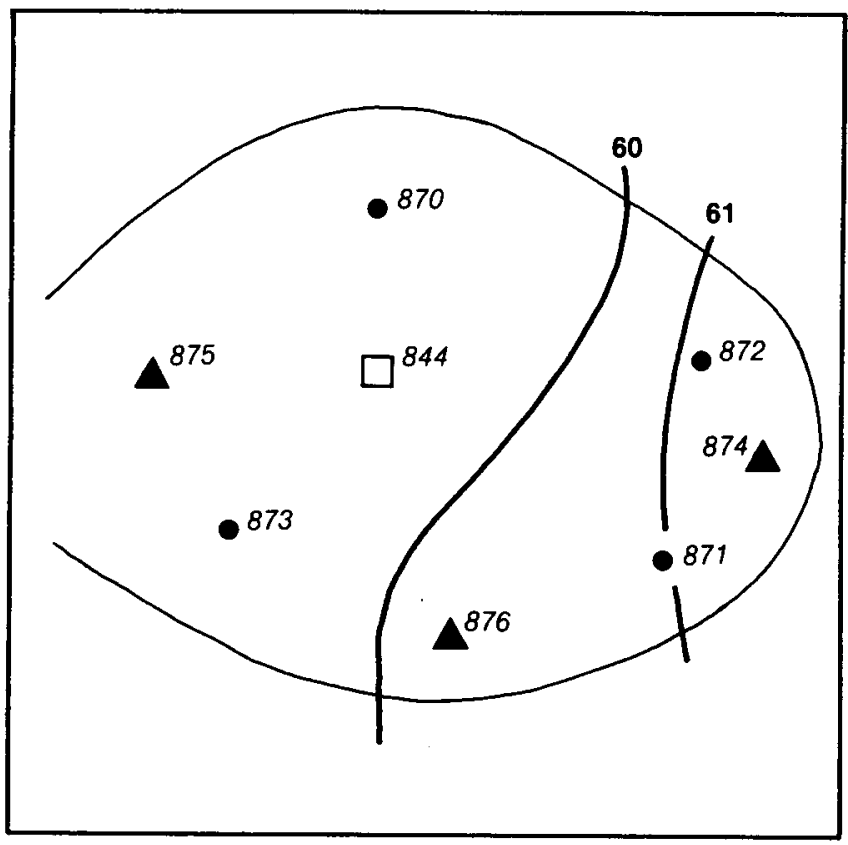

DGU nr. 143

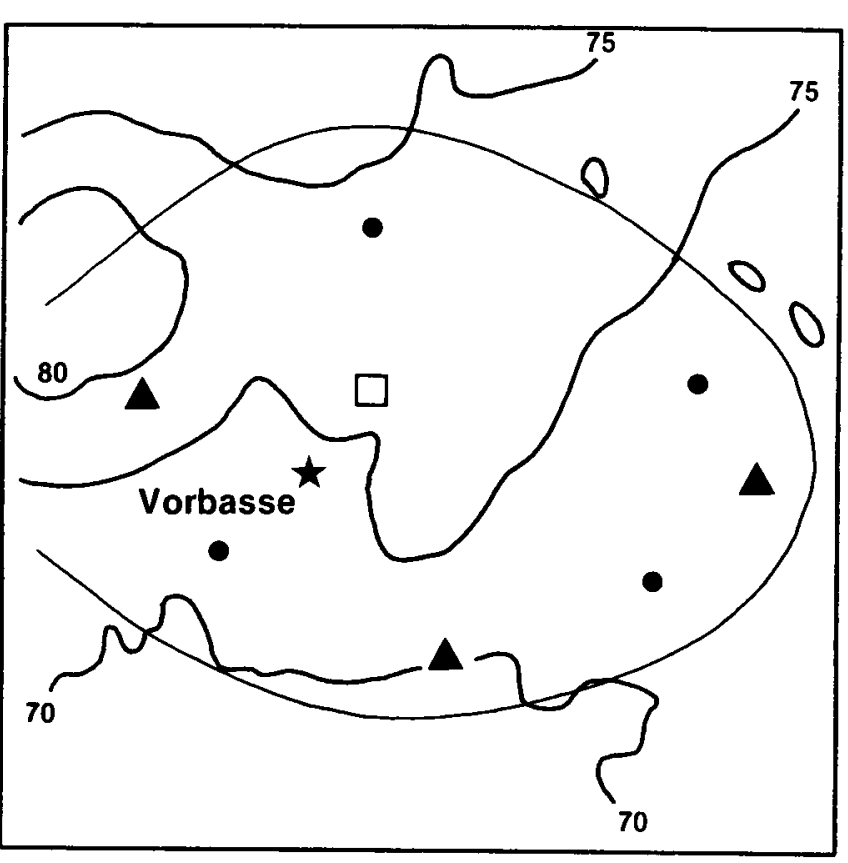

Areal $2 \mathrm{~km}^{2}$

Geologi: De øverste prækvartære lag består af glimmerler overlejret af Miocænt glimmer- og /eller kvartssand, der stedvis indeholder brunkulslag. Den kvartære lagserie består af smeltevandsaflejringer og moræneler. Området ligger på Hejnsvig Bakkeø, og i dets østlige del er de kvartære lag domineret af moræneler, mens de mod vest overvejende består af smeltevandssand.

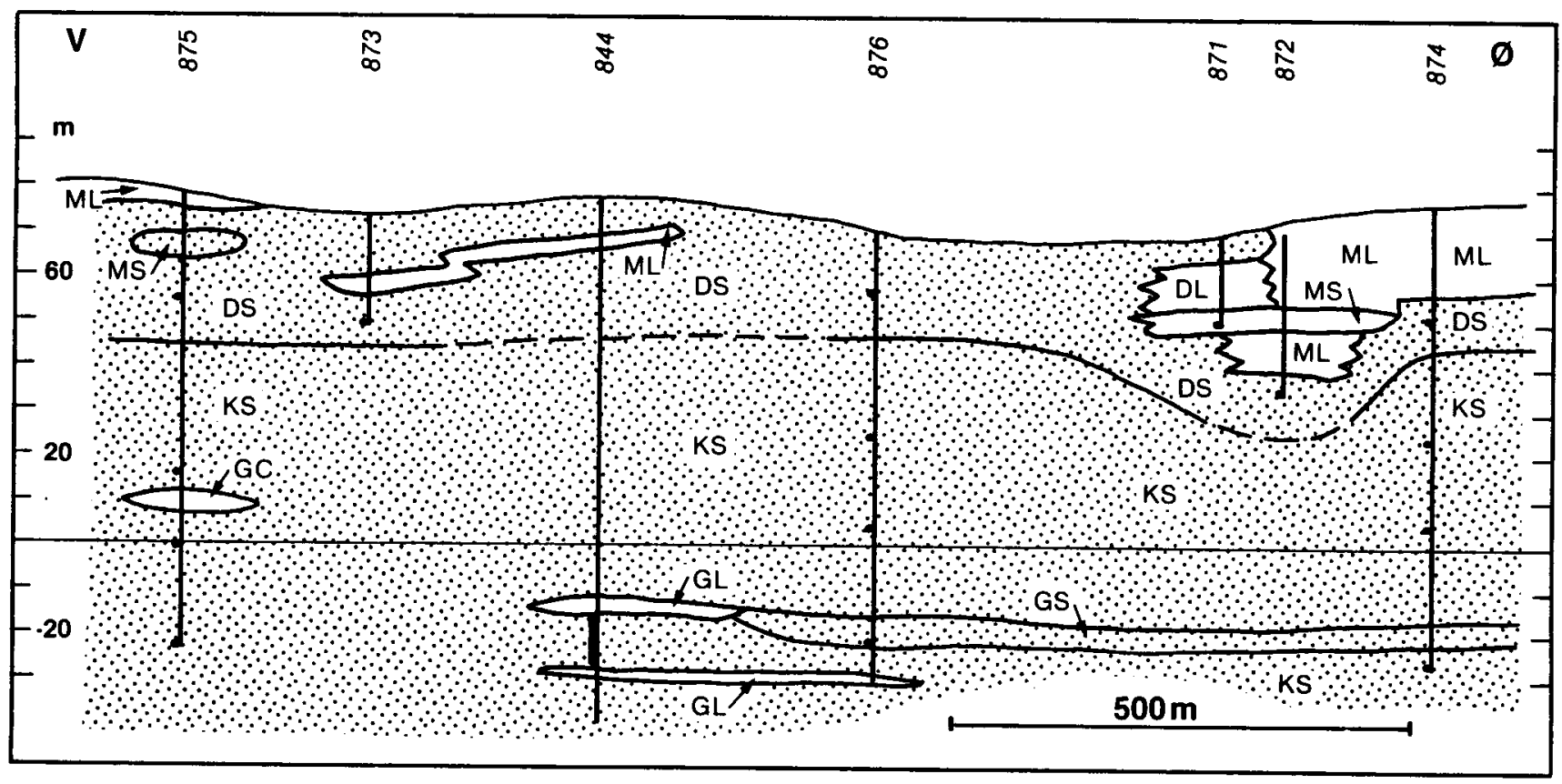


Hydrogeologi: Hovedreservoiret, der findes i hele området, består af såvel Miocænt kvartssand som kvartært smeltevandssand. Hovedreservoiret kan betragtes som artesisk, til trods for at der stedvis mangler tætte dæklag. Det er sandsynligt, at der er lækage fra overfladen.

Grundvandskemi: Især i områdets sydvestlige og nordøstlige dele er ionstyrken relativ høj (3-5 milliækvivalenter pr. liter) og koncentrationen varierer gennem tiden. I de øvre dele af reservoiret er der et nitratindhold på 15-40 milligram pr. liter, mens indholdet af aggressiv kulsyre er på 25-80 milligram pr. liter.

Vandbalance $\mathbf{m m} / \mathrm{år}:$

Ikke oplyst
Arealanvendelse \%:

Landbrug

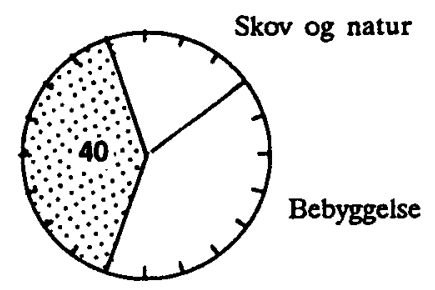

Registrerede depoter:

Koncentrationen af udvalgte stoffer i forhold til dybde under terran.

Graferne viser data fra 1989 og 1990.

Nitrat/Dybde

Klorid/Dybde

Sulfat/Dybde

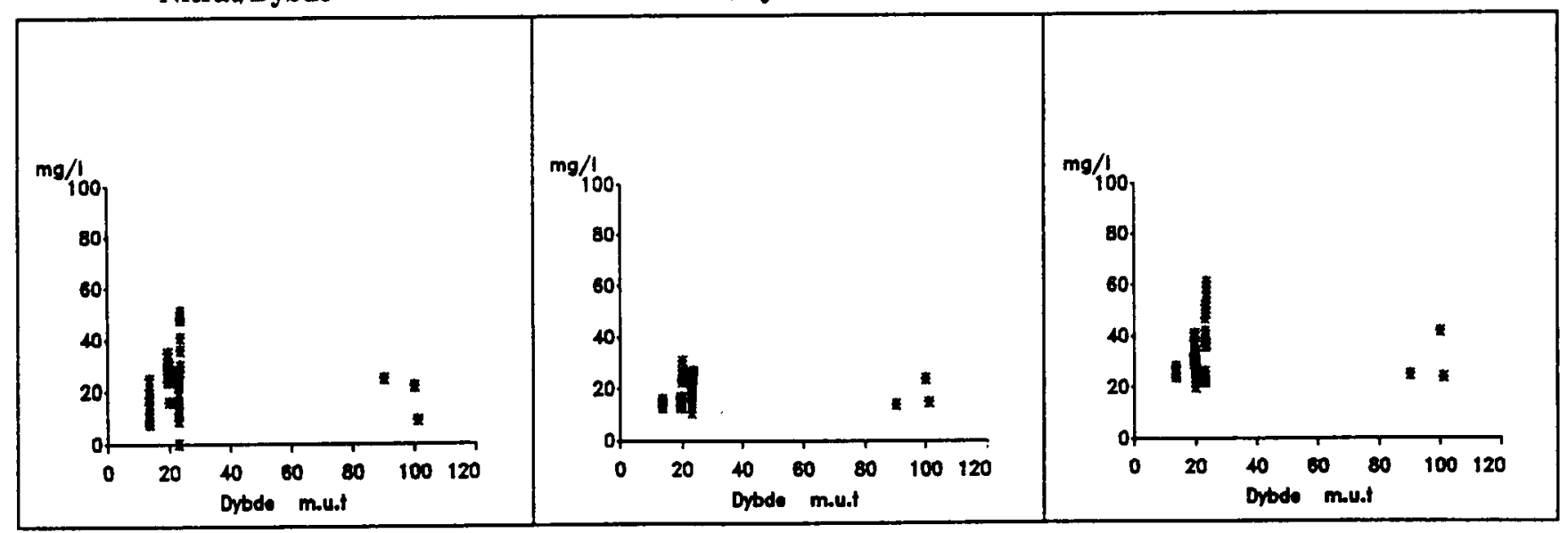




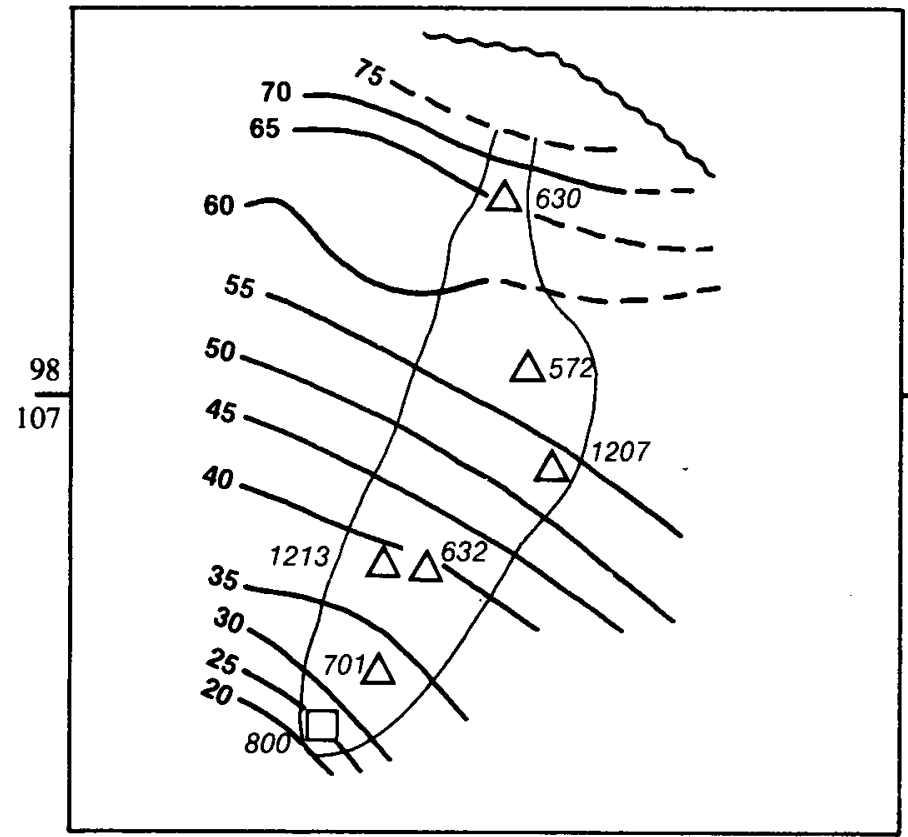

DGU nr. 98 og 107

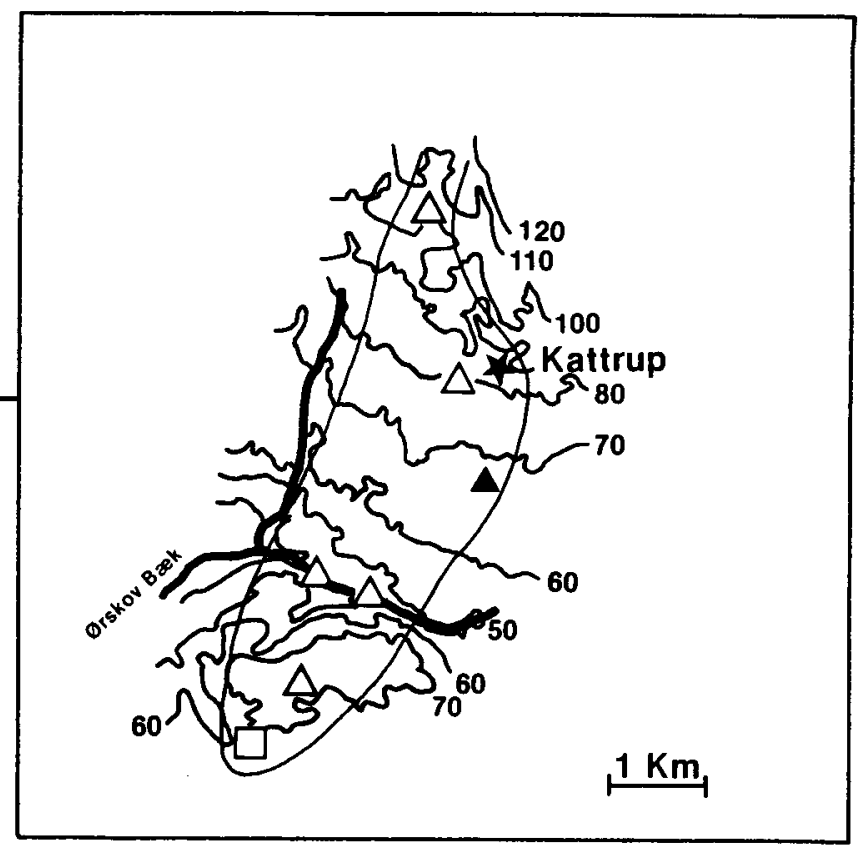

Areal $13 \mathrm{~km}^{2}$

Geologi: De øverste prækvartære aflejringer er tertiære og overlejres af ca. 150 meter kvartære aflejringer. Disse består af moræneler med sand og -gruslag i flere niveauer. De sandede lag er af glacial oprindelse bortset fra et af de midterste, der udgøres af interglacialt ferskvandssand.

Kun det øvre sandede lag findes $i$ hele området, mens de andre findes lokalt $i$ den sydlige del af området. Overfladelagene består overvejende af moræneler, men udgøres lokalt af morænegrus eller smeltevandssand og -grus.

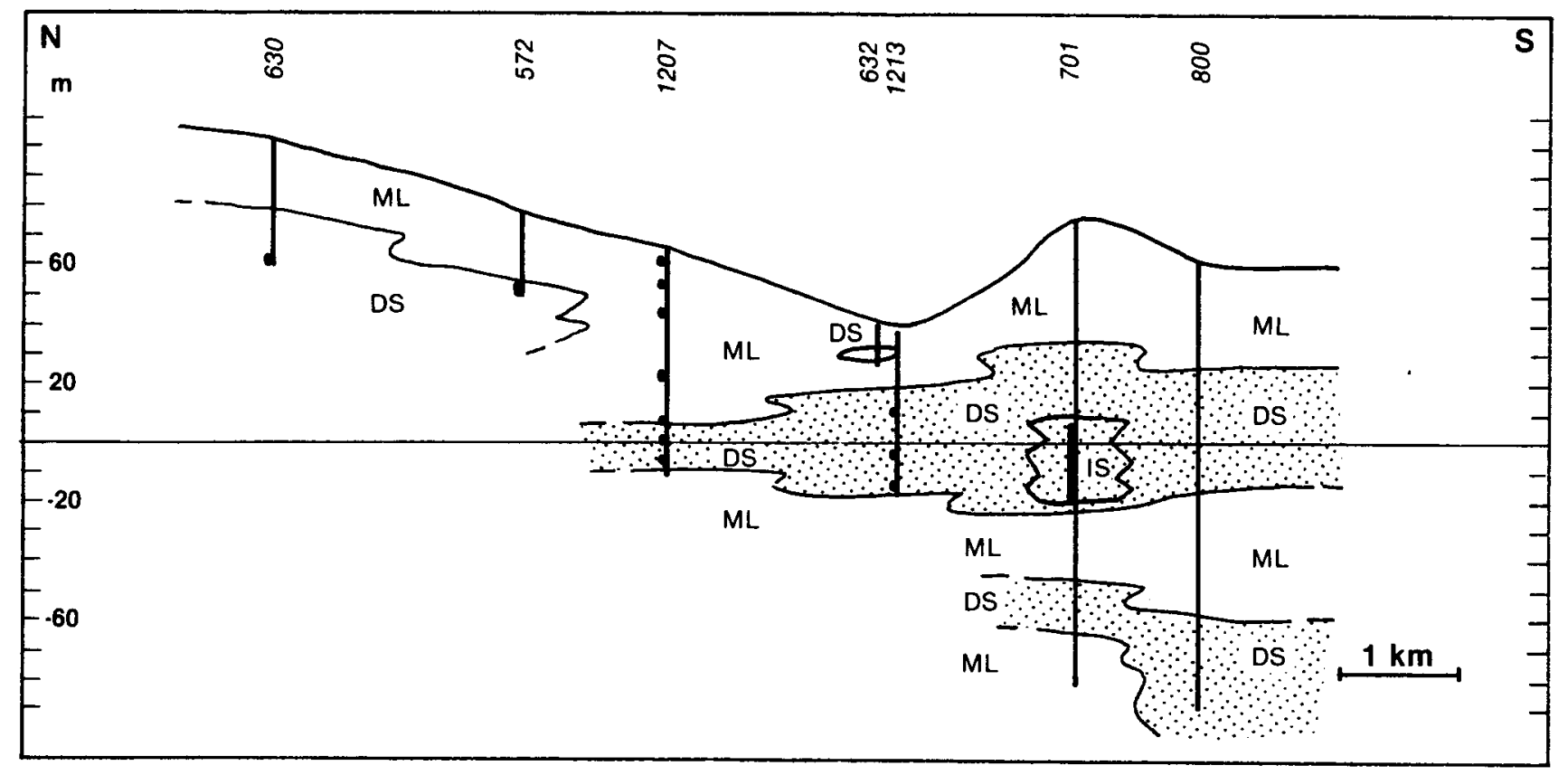


Hydrogeologi: Der er tre reservoirer med artesiske forhold i de kvartære aflejringer. På Højballegårdsværkets kildeplads indvindes der grundvand fra de to nedre reservoirer. De fleste private vandforsyninger udnytter de øverste reservoirer. Det afgrænsede område er mindre end, hvad der svarer til oppumpningen.

Grundvandskemi: Grundvandet er af calcium-bikarbonattypen med middelhårdt vand (omkring $12^{\circ} \mathrm{dH}$ ), moderat til stærkt reduceret og uden nitrat $i$ de to dybeste magasiner.

De øvre reservoirer indeholder op til 5 milligram nitrat pr. liter.

Der er et lavt indhold af sulfat på omkring 20 milligram pr. liter og kloridindholdet er mellem 17 og 40 milligram pr. liter. Fosfor-, ammonium- og kloridindholdet stiger med dybden fra reservoir til reservoir, mens sulfatindholdet falder. Analyseresultaterne viser, at grundvandets sammensætning er konstant med tiden.

Vandbalance mm/år:

Middelnedbør 670

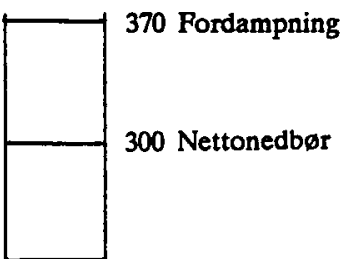

Kildeplads: Højballegårdsvarket, 3.4 mill. m3/âr

\section{Arealanvendelse \%:}

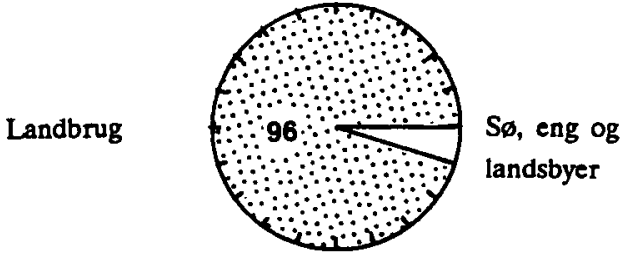

Registrerede depoter. ingen

Koncentrationen af udvalgte stoffer $\mathrm{i}$ forhold til dvbde under terran.

Graferne viser data fra 1989 og 1990.

Nitrat/Dybde

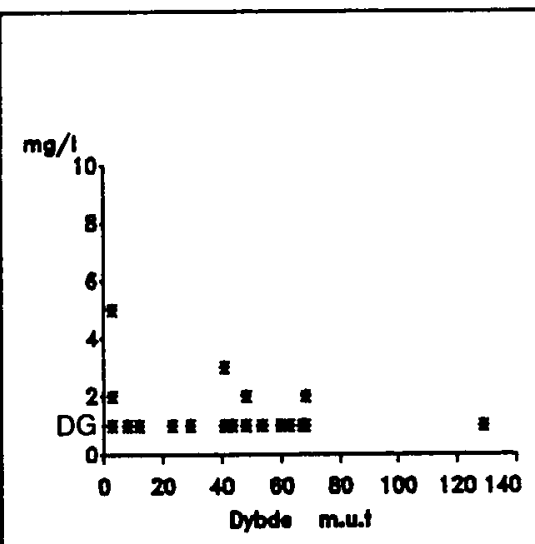

Klorid/Dybde

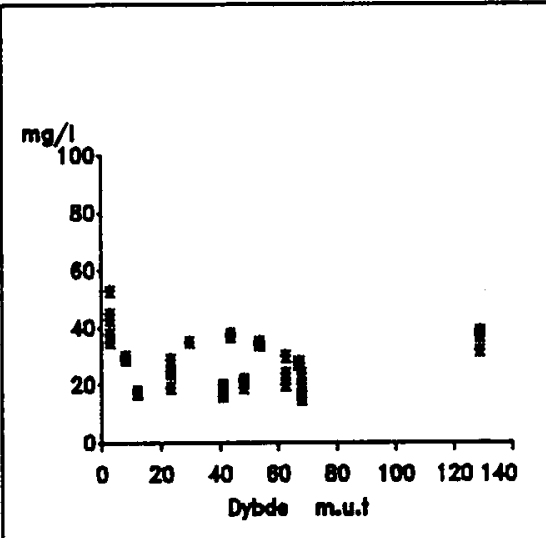

Sulfat/Dybde

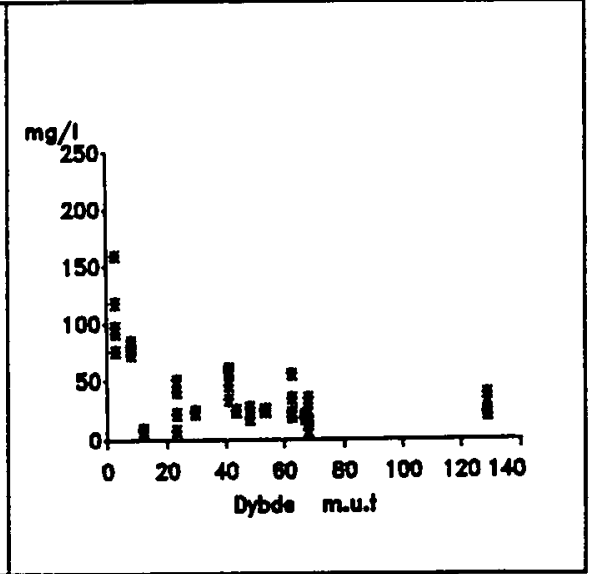


Potentiale

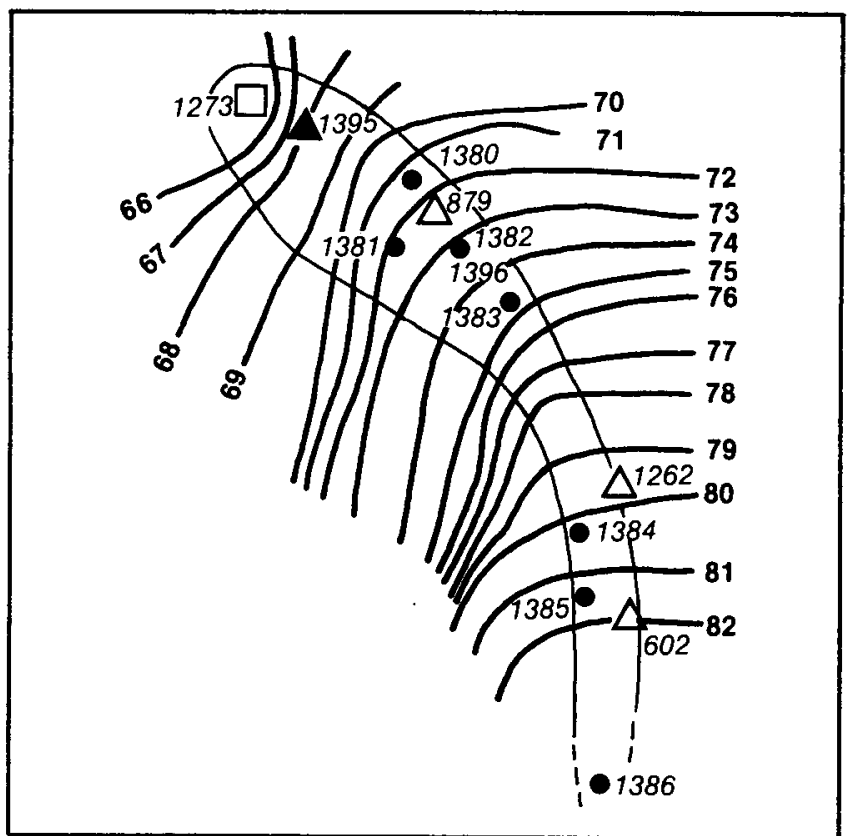

DGU nr. 105
Terræn

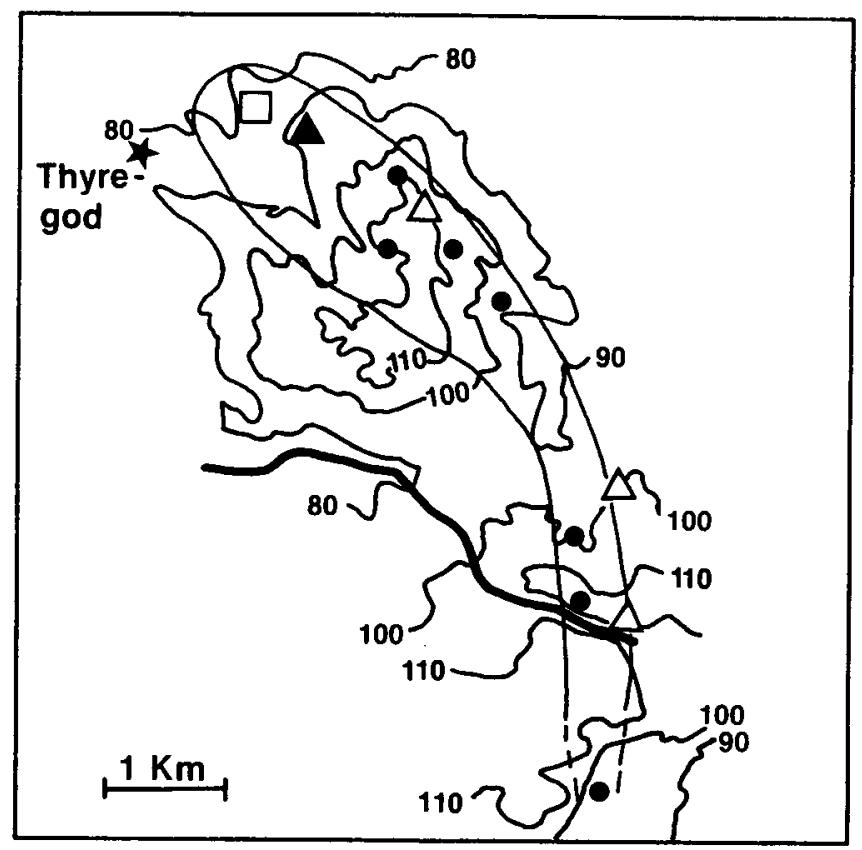

Areal $5 \mathrm{~km}^{2}$

Geologi: De øverste prækvartære aflejringer består af det vidt udbredte brunkulsholdige Miocæne kvartssand, ler og silt. Kvartæret består af moræneler og smeltevandssand.

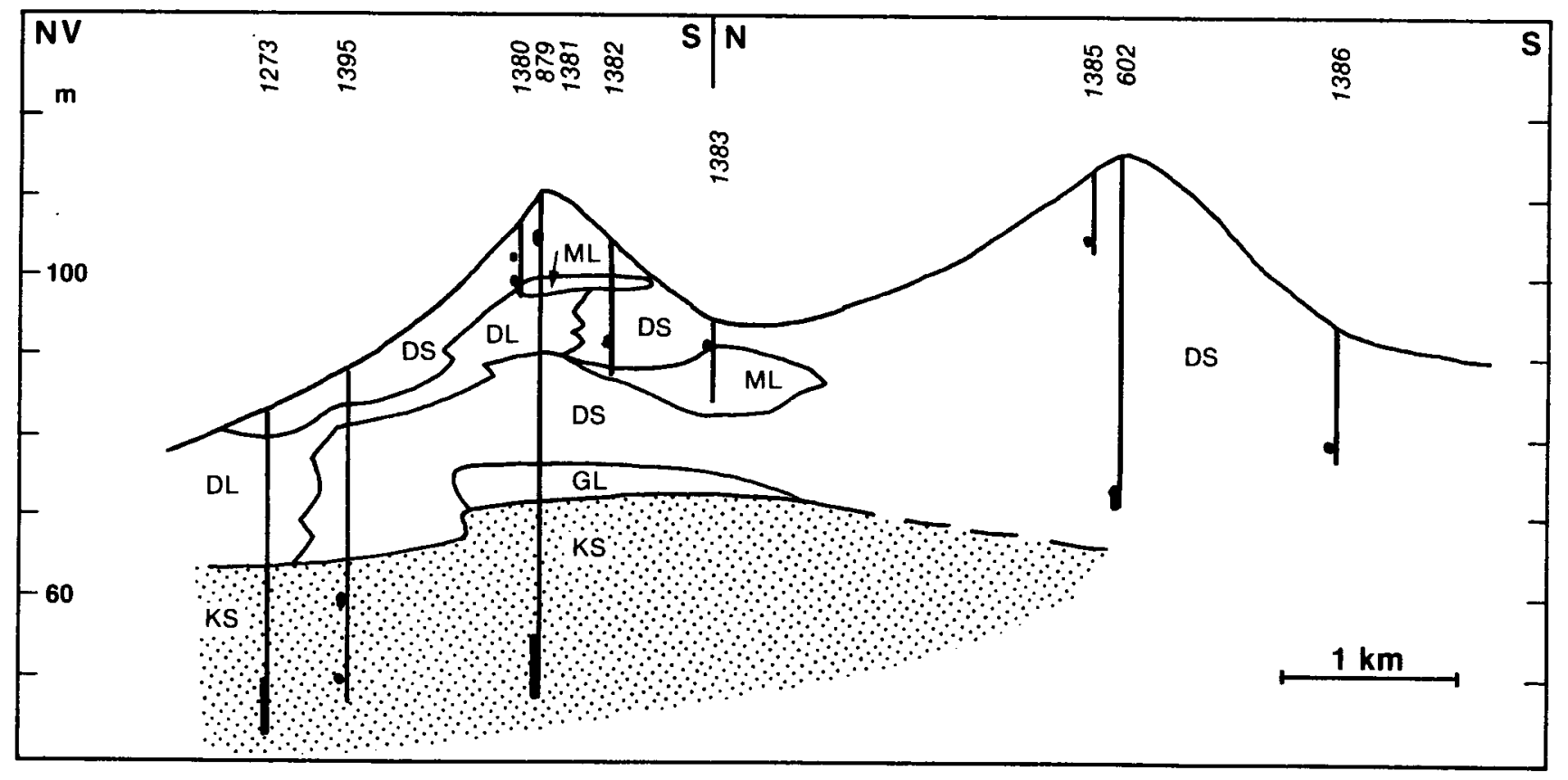


Hydrogeologi: Hovedreservoiret består af kvartssand, overlejret af op til 20 meter moræneler. Inden for oplandet findes der også et lokalt sammenhængende sekundært reservoir.

Ved Thyregod Vandværk, hvor oplandets hovedboring ligger, er der artesiske forhold i hovedreservoiret. I den sydlige del af oplandet, opstrøms i forhold til hovedboringen, er grundvandsspejlet frit.

Grundvandskemi: Det meste af grundvandet er nitratbelastet, har et beskedent indhold af calcium-bikarbonat, jern, fosfor, ammonium, sulfat og klorid. Vandet er blødt med en hårdhed mellem 3 og $8^{\circ} \mathrm{dH}$.

Fosfor- og nitratindholdet falder med dybden fra reservoir til reservoir, hvorimod sulfat- og ammoniumindholdene er lave og konstante. $\mathrm{pH}$ og hårdheden er yderst varierende $\mathrm{i}$ de sekundære reservoirer afhængig af de geologiske forhold, medens de $i$ de nederste filtre er ret ensartede.

Analyseresultaterne viser, at grundvandets sammensætning varierer betydeligt gennem tiden - især i de sekundære reservoirer.

Vandbalance $\mathbf{m m} / \mathbf{a ̊ r}$

Middelnedbør 760

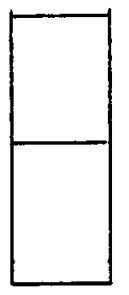

380 Fordampning

380 Nettonedbør

320 Afstrømning

60 Anden infiltration

Kildeplads: Thyregod vv, 0.16 mill. m3/år

\section{Arealanvendelse \%:}

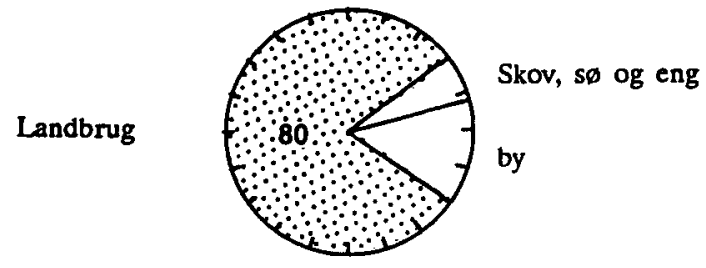

Registrerede depoter: ingen

Koncentrationen af udvalgte stoffer $i$ forhold til dybde under terræn.

Graferne viser data fra 1989 og 1990.

Nitrat/Dybde

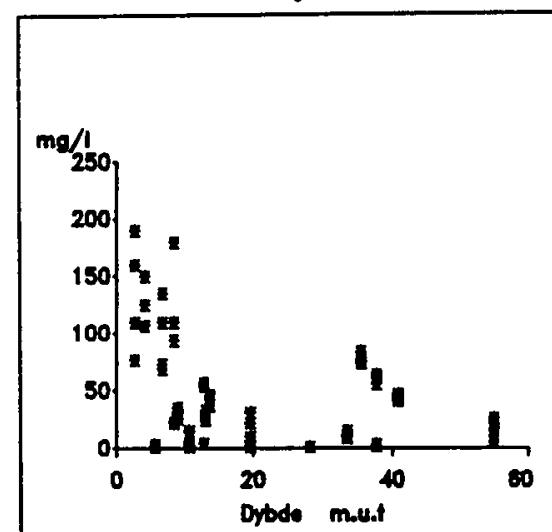

Klorid/Dybde

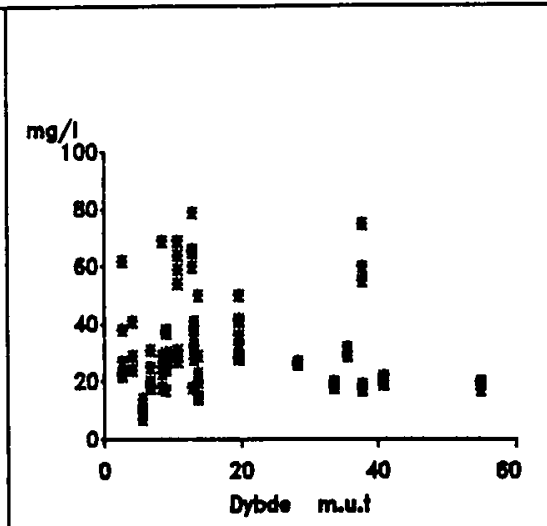

Sulfat/Dybde

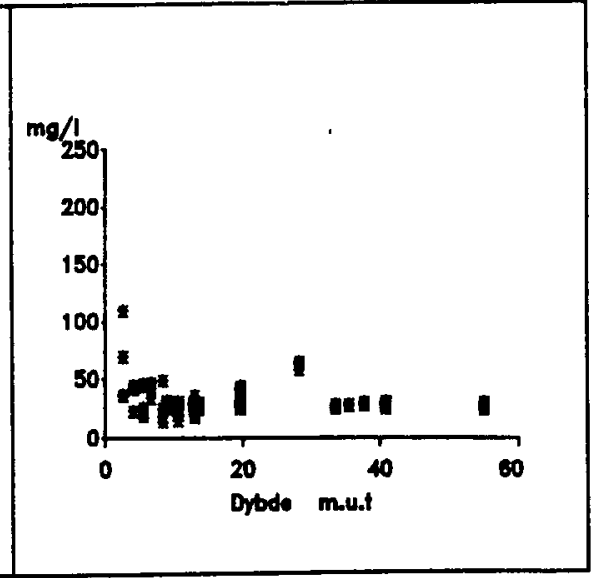


1213 III NØ

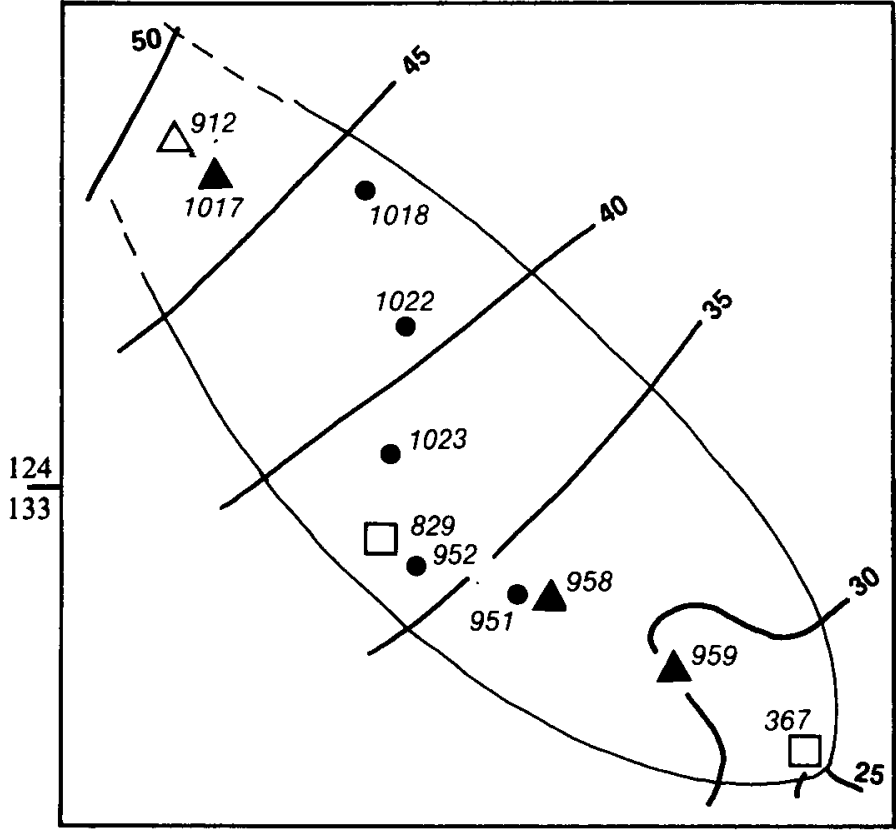

DGU nr. 124 og 133
Terræn

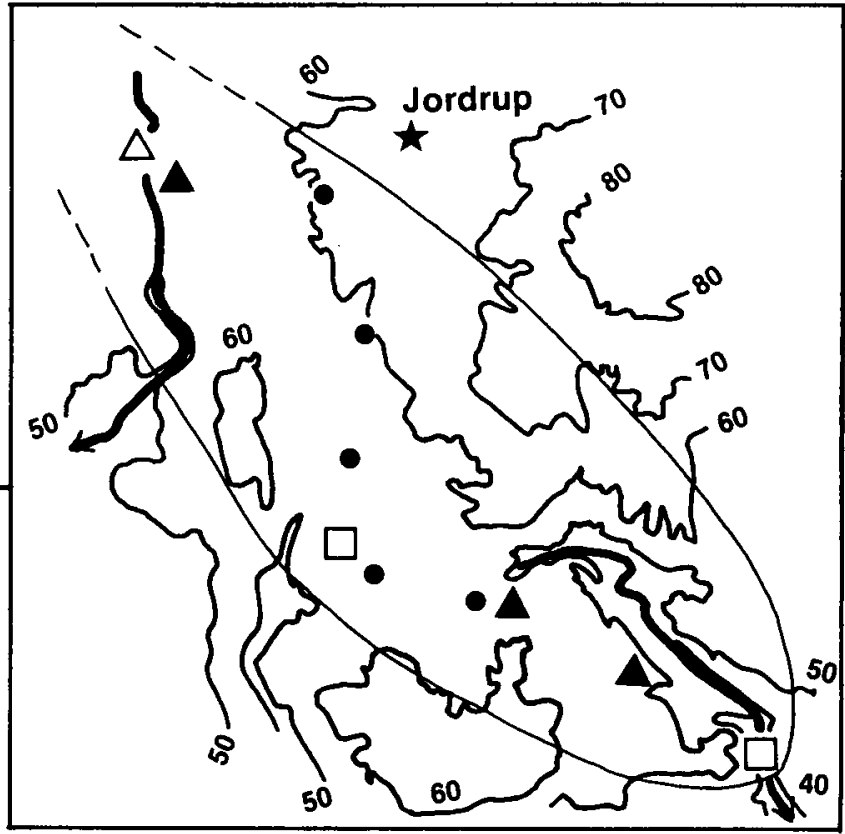

Areal $15 \mathrm{~km}^{2}$

Geologi: De øverste prækvartære lag består af Miocænt kvartssand. De kvartære aflejringer består af moræneler og smeltevandssand- og grus.

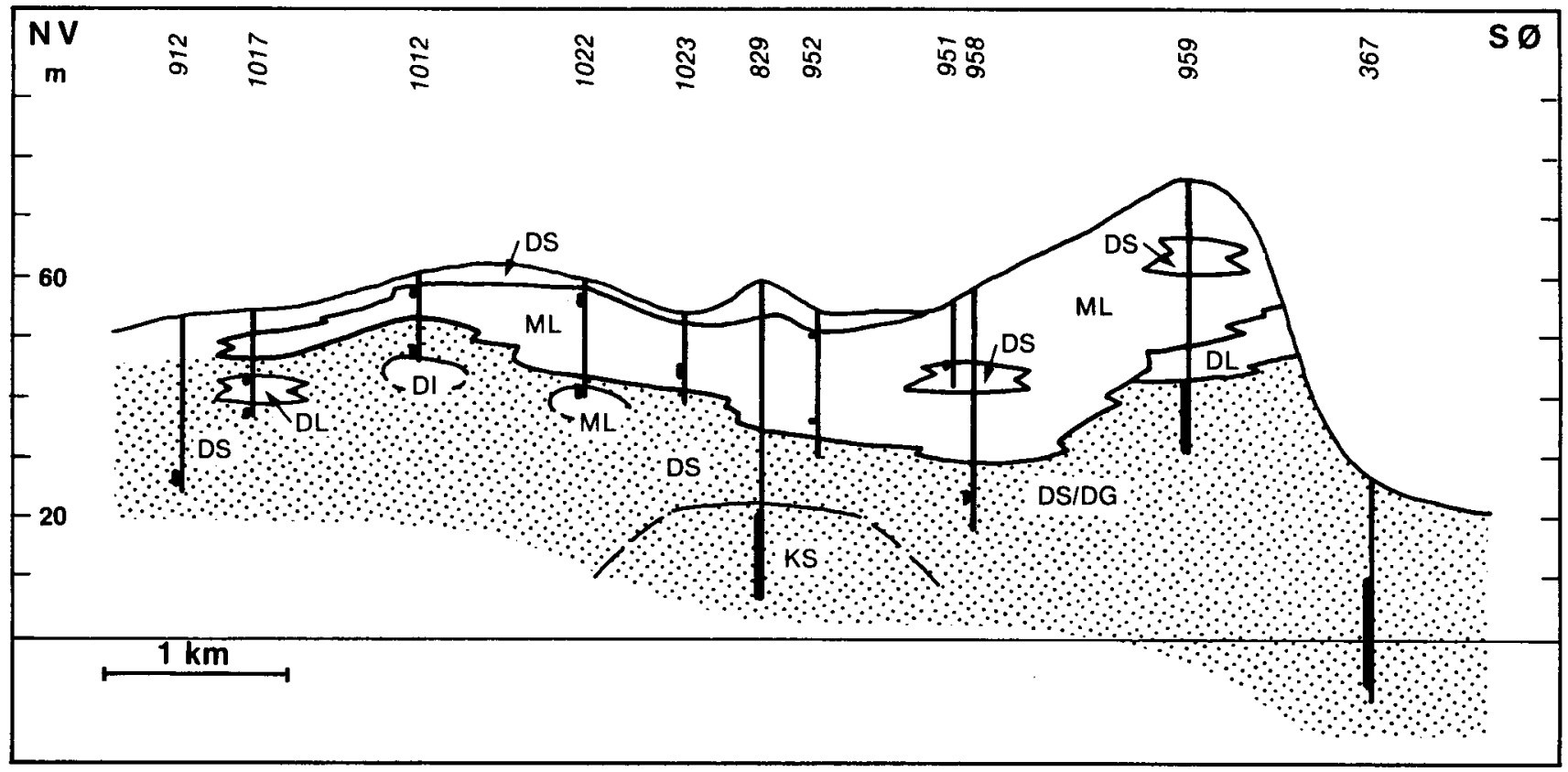


Hydrogeologi: Hovedreservoiret, der har artesiske forhold, består af Miocænt kvartssand og kvartært smeltevandssand og findes $\mathrm{i}$ hele området. Der er beskyttet af to tykke lag moræneler. Der er sekundære reservoirer i smeltevandsaflejringer over morænelerslagene.

Grundvandskemi: Grundvandet er af calcium-bicarbonattypen. Det har ringe hårdhed, og i hovedreservoiret er det stærkt reduceret, uden nitrat og kun med lidt sulfat og klorid. $\mathrm{pH}$ og hårdhed stiger med dybden. I de sekundære reservoirer indeholder grundvandet nitrat og relativt meget sulfat. Grundvandets sammensætning er uændret inden for måleperioden $i$ hovedreservoiret og ret stabil i de sekundære.

Vandbalance mm/år:

Middelnedbør 750

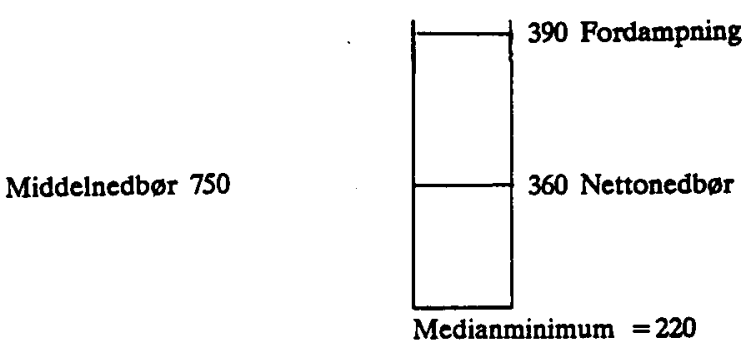

Kildeplads: Trudsbro vv, 2.5 mill. $\mathrm{m} 3 / \mathbf{a ̊ r}$

\section{Arealanvendelse \%:}

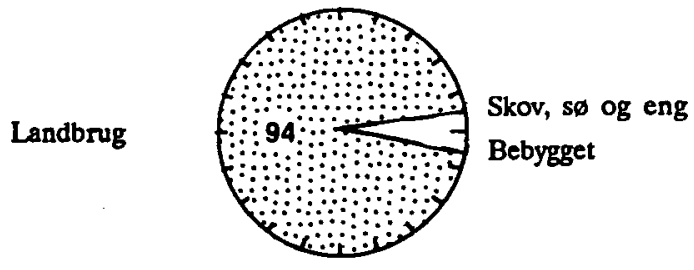

Registrerede depoter. et affaldsdepot

Koncentrationen af udvalgte stoffer i forhold til dybde under terræn.

Graferne viser data fra 1989 og 1990.

Nitrat/Dybde

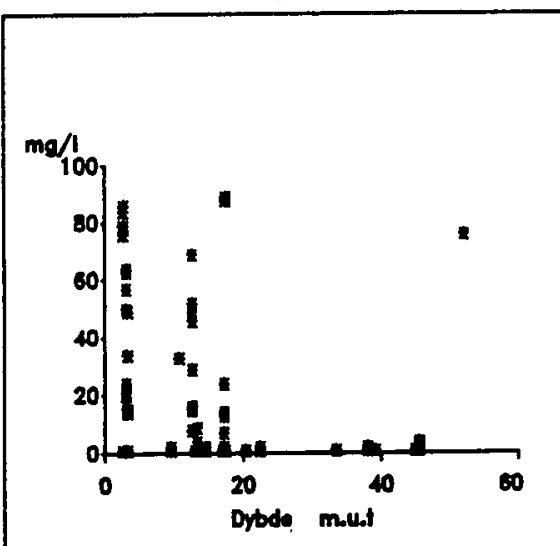

Klorid/Dybde

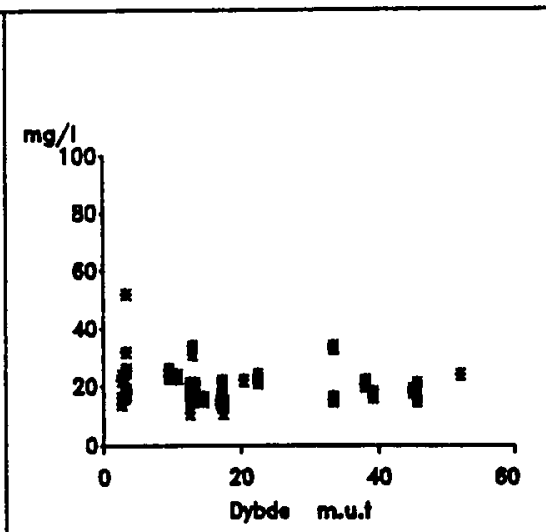

Sulfat/Dybde

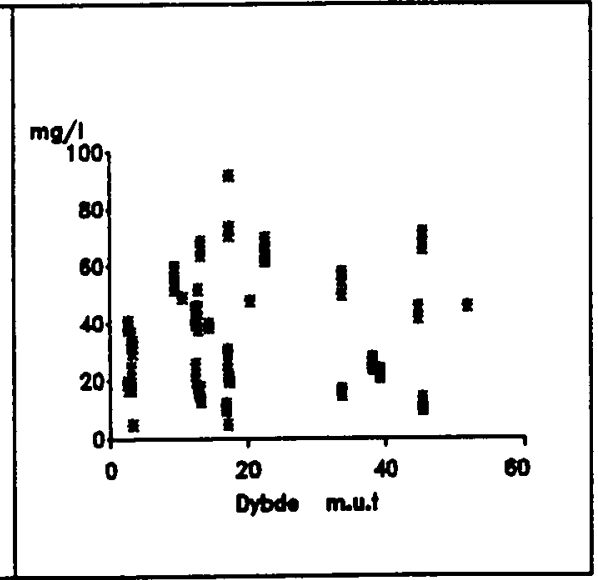



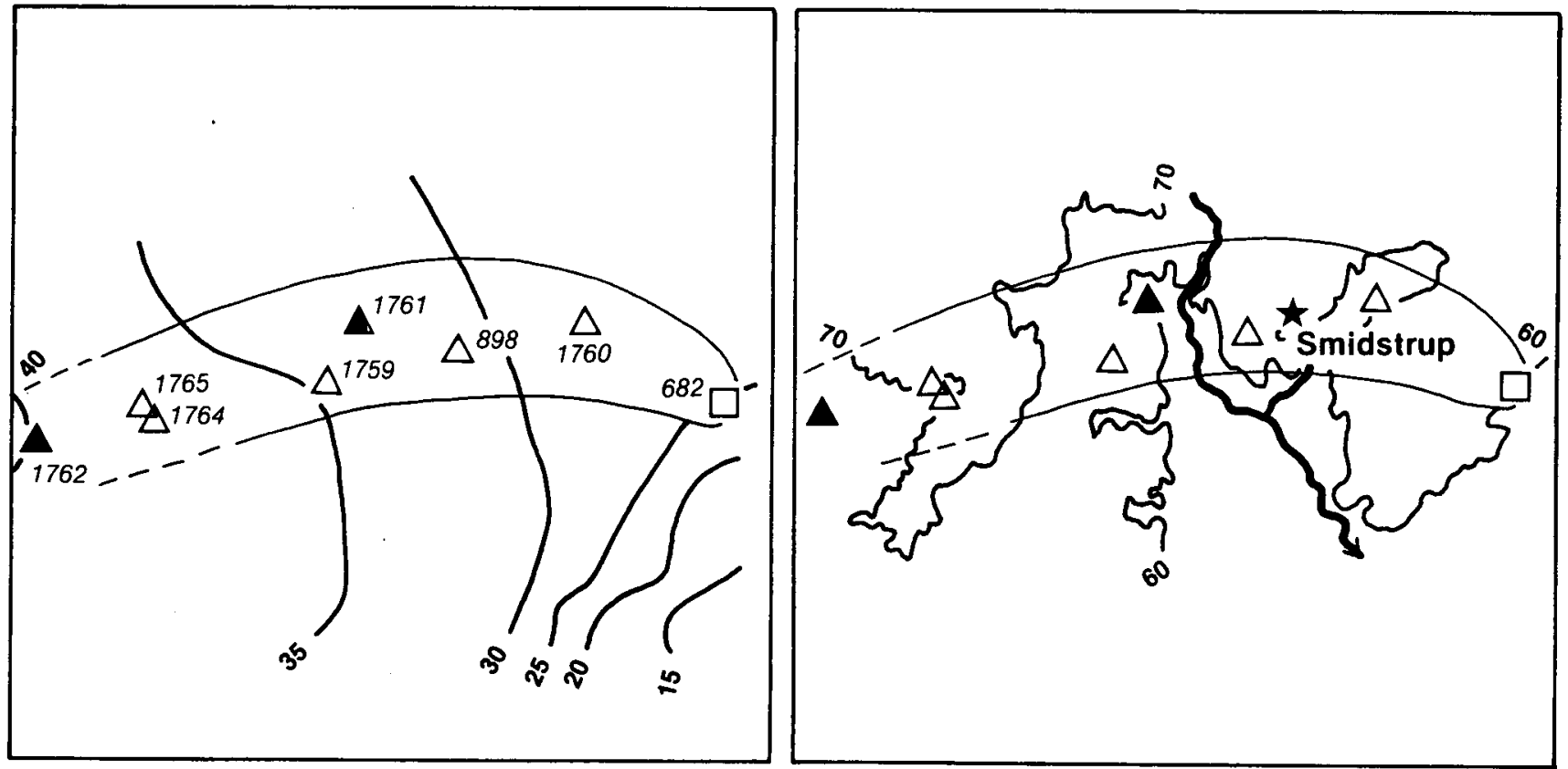

DGU nr. 125

Areal $11,5 \mathrm{~km}^{2}$

Geologi: Aflejringerne under de kvartære lag består af Miocænt glimmerler og glimmersand. Ved Follerup udfylder kvartære smeltevandssands og -gruslag en 50 meter dyb erosionsdal i de underliggende tertiære lag. Smeltevandssedimenterne er dækket af et lag af moræneler, som bliver gradvis tykkere væk fra hovedboringen.

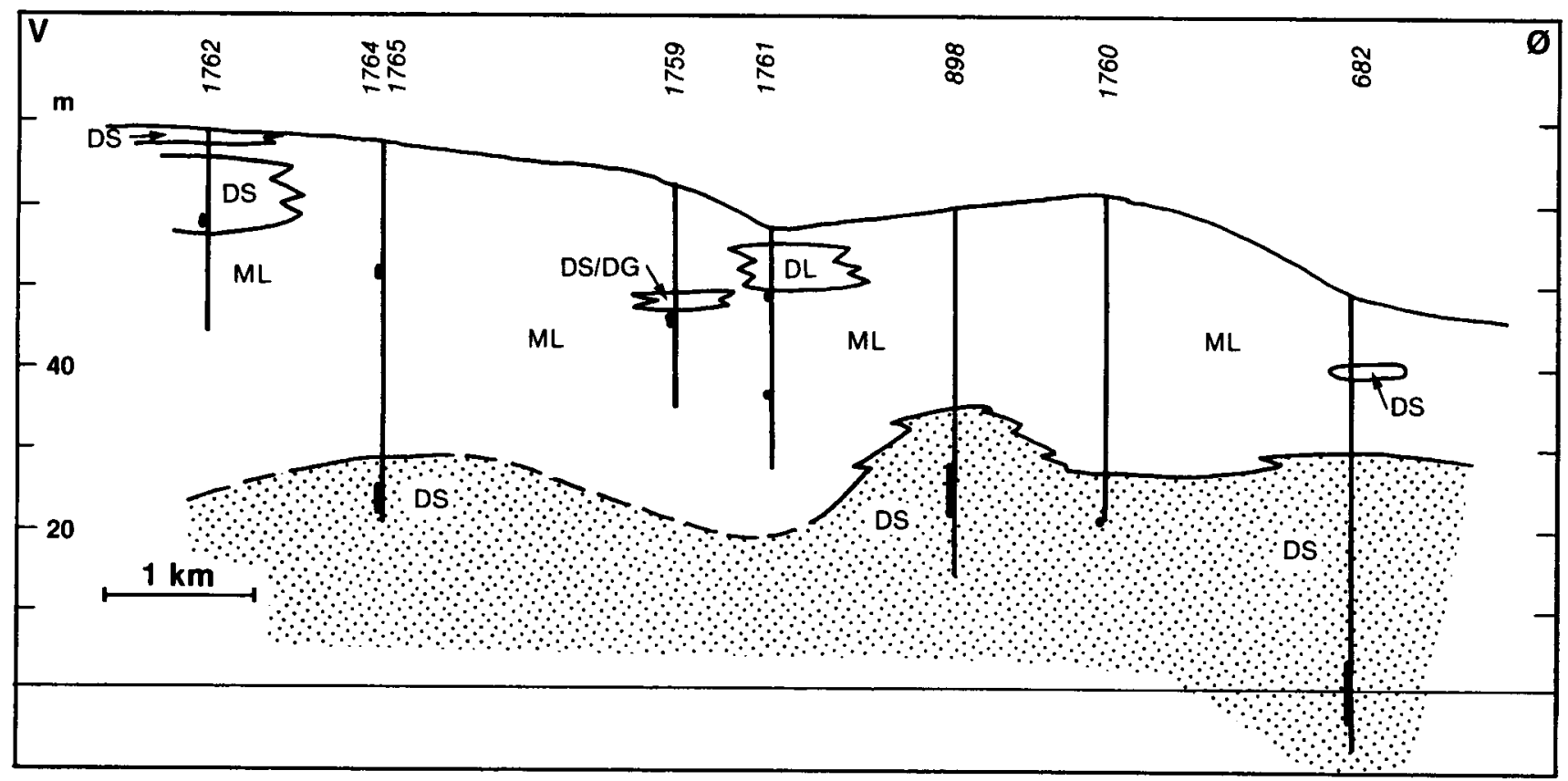


Hydrogeologi: Hovedreservoiret har artesiske forhold og består af smeltevandssand, der er beskyttet af moræneler. Der er kun små lokale sekundære reservoirer i området.

Grundvandskemi: Grundvandet $\mathrm{i}$ hovedreservoiret er af calcium-bikarbonattypen med hårdhed omkring $10^{\circ}$ $\mathrm{dH}$, det er stærkt reduceret og har et forholdsvis beskedent indhold af sulfat. Fosfor- og ammonium-indholdet stiger med dybden. Grundvandet i de sekundære reservoirer er nitratholdigt.

Vandbalance $\mathbf{m m} / \mathbf{a ̊ r}$

Arealanvendelse \%:

Middelnedbør 650

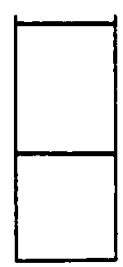

390 Fordampning

260 Nettonedbør

75 Afstromning

185 Anden infiltration

Kildeplads: Follerup vv, 3 mill. m3/ar

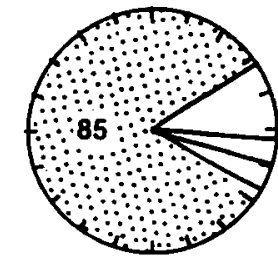

Skov

Sø og eng

Bymassig

Registrerede depoter: ingen

Koncentrationen af udvalgte stoffer i forhold til dybde under terræen.

Graferne viser data fra 1989 og 1990.

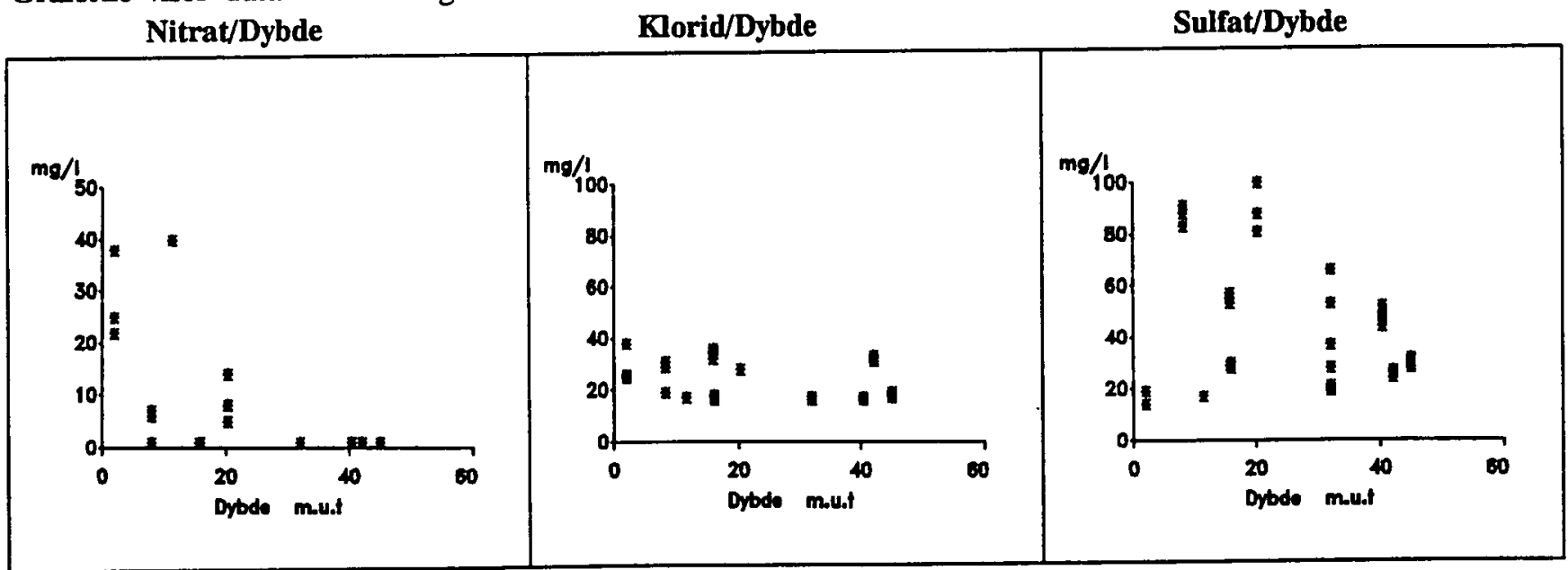



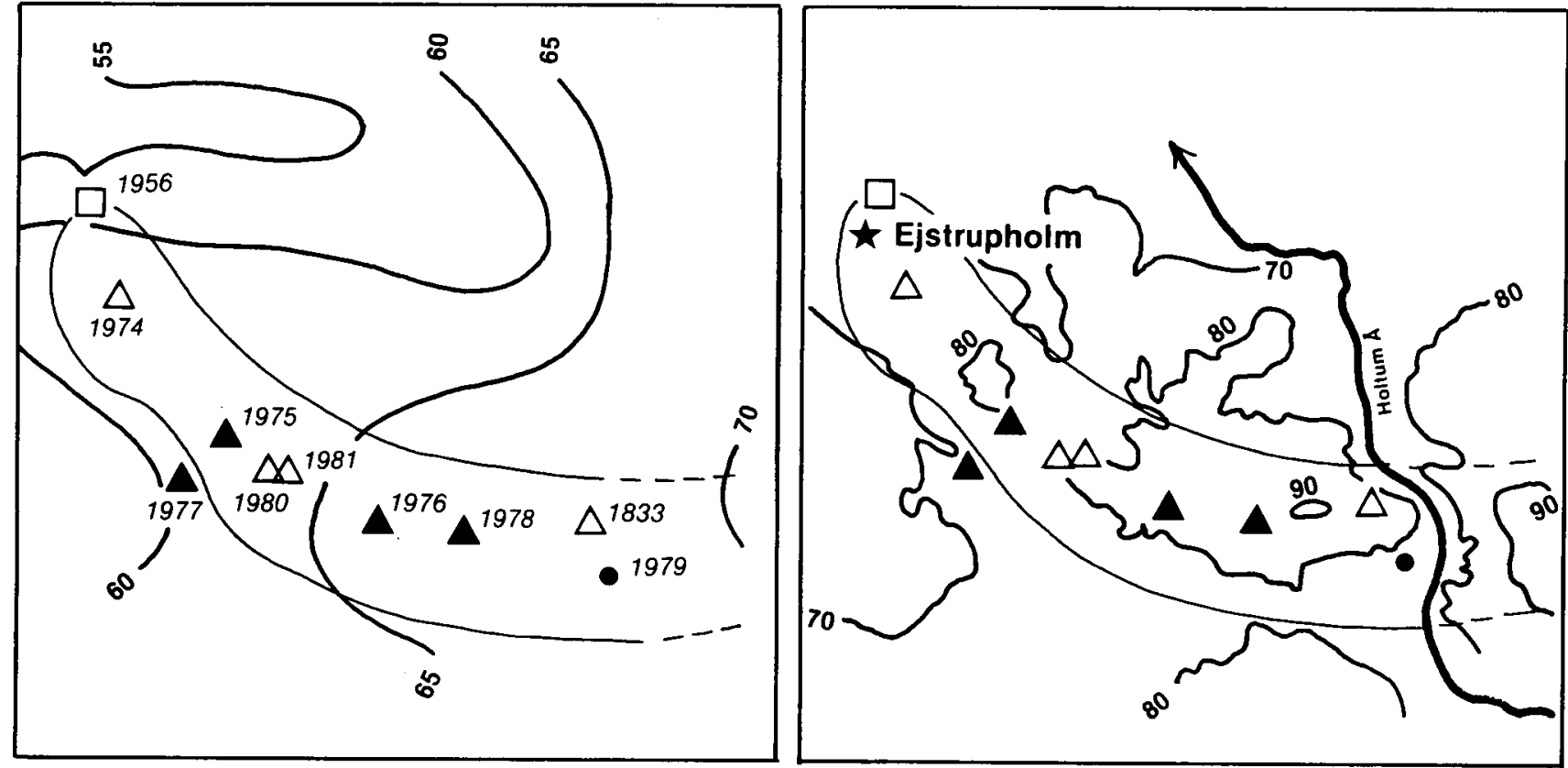

DGU nr. 96

Areal $6 \mathrm{~km}^{2}$

Geologi: De øverste prækvartære lag består af delvis brunkulsholdigt kvarts- og glimmersand af Miocæn alder. Den Miocæene lagserie afsluttes af to 1 meter tykke brunkulsholdige lerlag. Herover er der glaciale aflejringer, som består af smeltevandssand og moræneler.

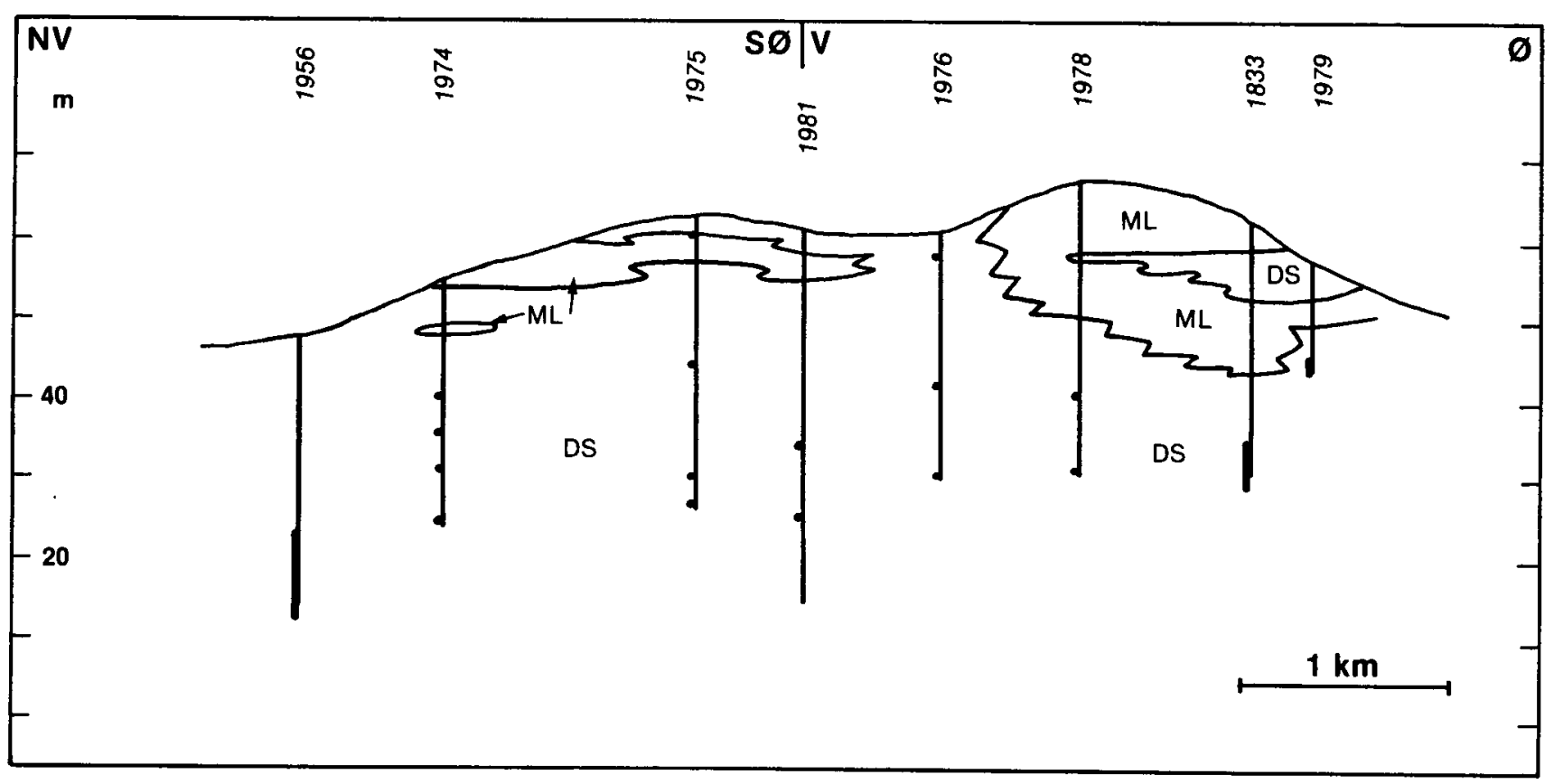


Hydrogeologi: Hovedreservoiret består af kvartssand, mens det sekundære består af smeltevandssand. Begge reservoirer har delvist frit grundvandsspejl.

Grundvandskemi: Grundvandet er overvejende af en iltet nitratbelastet type med et lavt indhold af calciumbikarbonat. Der er et beskedent indhold af fosfor, ammonium, sulfat og klorid. Vandet er blødt $\left(3-12^{\circ}\right.$ dH). Der er målt pH ned til 5. "Nitratfronten" falder sammen med brunkulslagene, og grundvandet under brunkulslagene er således nitratfrit. Nitratindholdet falder iøvrigt med dybden, mens fosfor-, ammoniumsulfatindholdet stiger med dybden. De hidtidige analyseresultater viser, at grundvandets sammensætning varierer betydeligt gennem tiden.

Vandbalance $\mathbf{m m} / \mathbf{a ̊ r}$

Middelnedbor

Kildeplads: Ejstrup w, 0.21 mill. m3/år

\section{Arealanvendelse: \%}

380 Fondampning

370 Nettonedbør

200 Afstromning

Lanđbrug

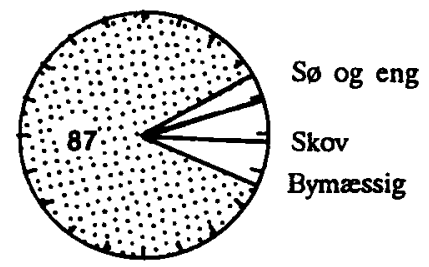

Registrerede depoter: ingen

Koncentrationen af udvalgte stoffer i forhold til dybde under terran.

Graferne viser data fra 1989 og 1990

Nitrat/Dybde

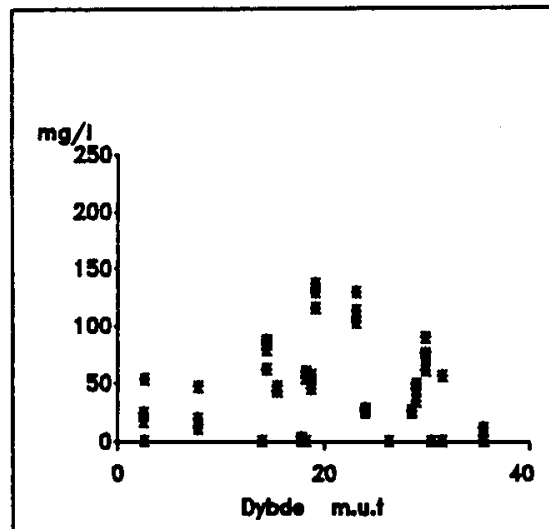

Klorid/Dybde

Sulfat/Dybde

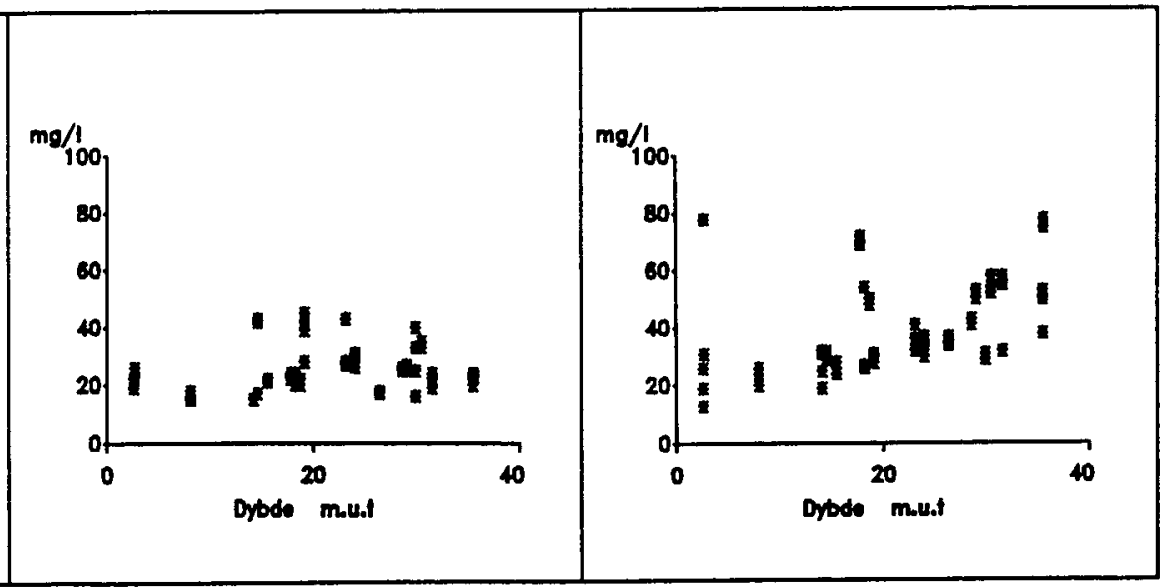




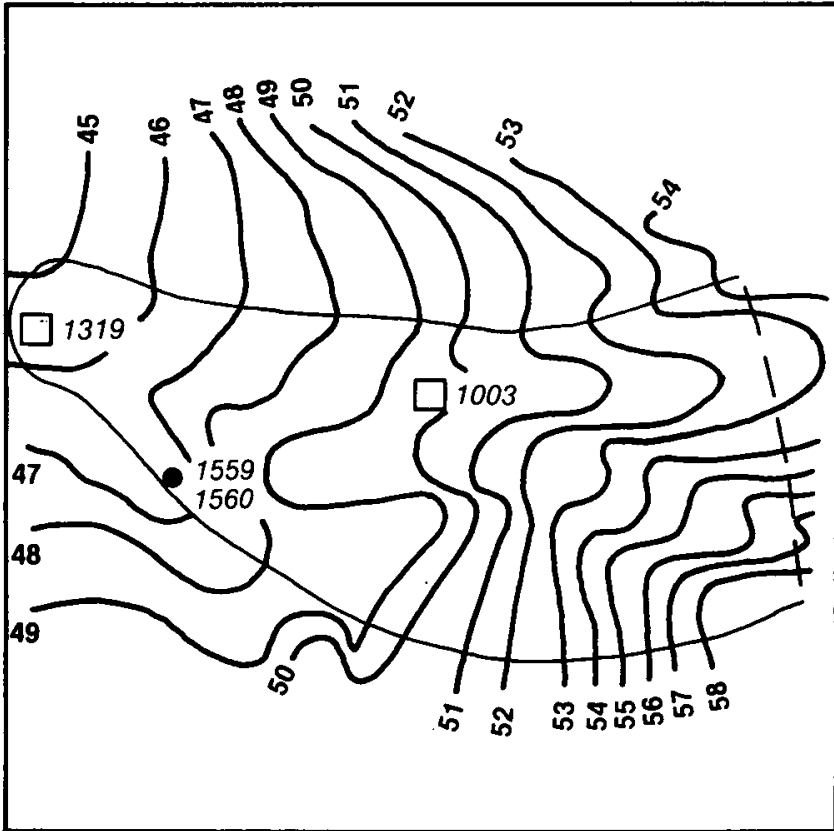

DGU nr. 85
Terræn

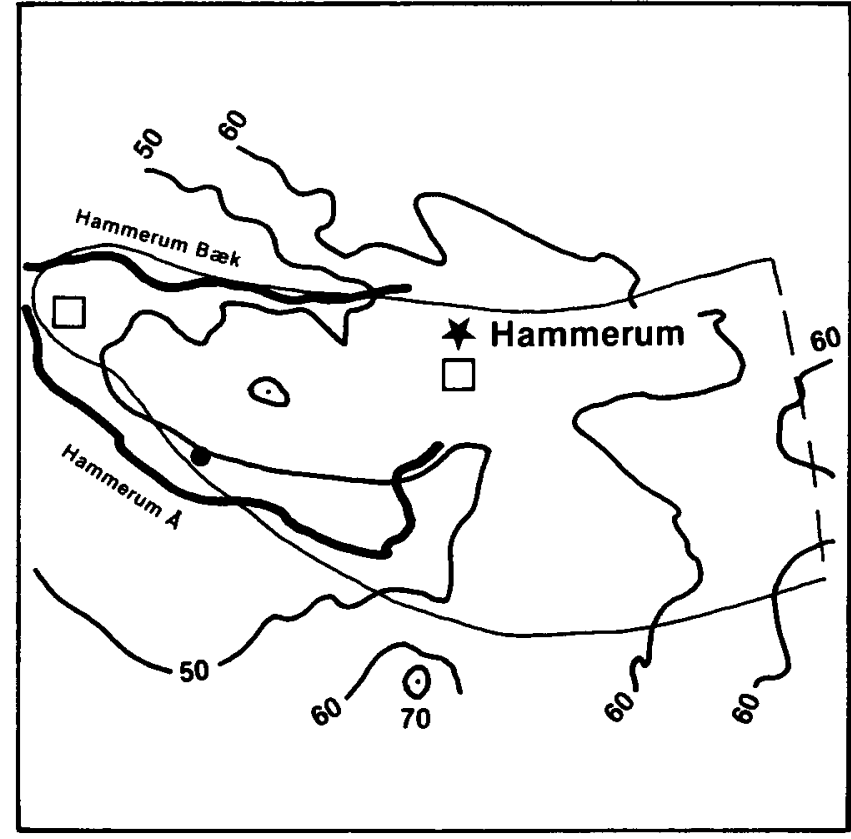

Areal $14 \mathrm{~km}^{2}$

Geologi: Det øverste prækvartære lag i området består af Miocænt kvartssand og -grus, som er under-, overog indlejret $\mathrm{i}$ glimmersand og -ler.

De Miocæne aflejringer er dækket af kvartært smeltevandssand og moræneler, som er de dominerende jordarter på overfladen. I dalene forekommer desuden postglacialt sand og dynd.

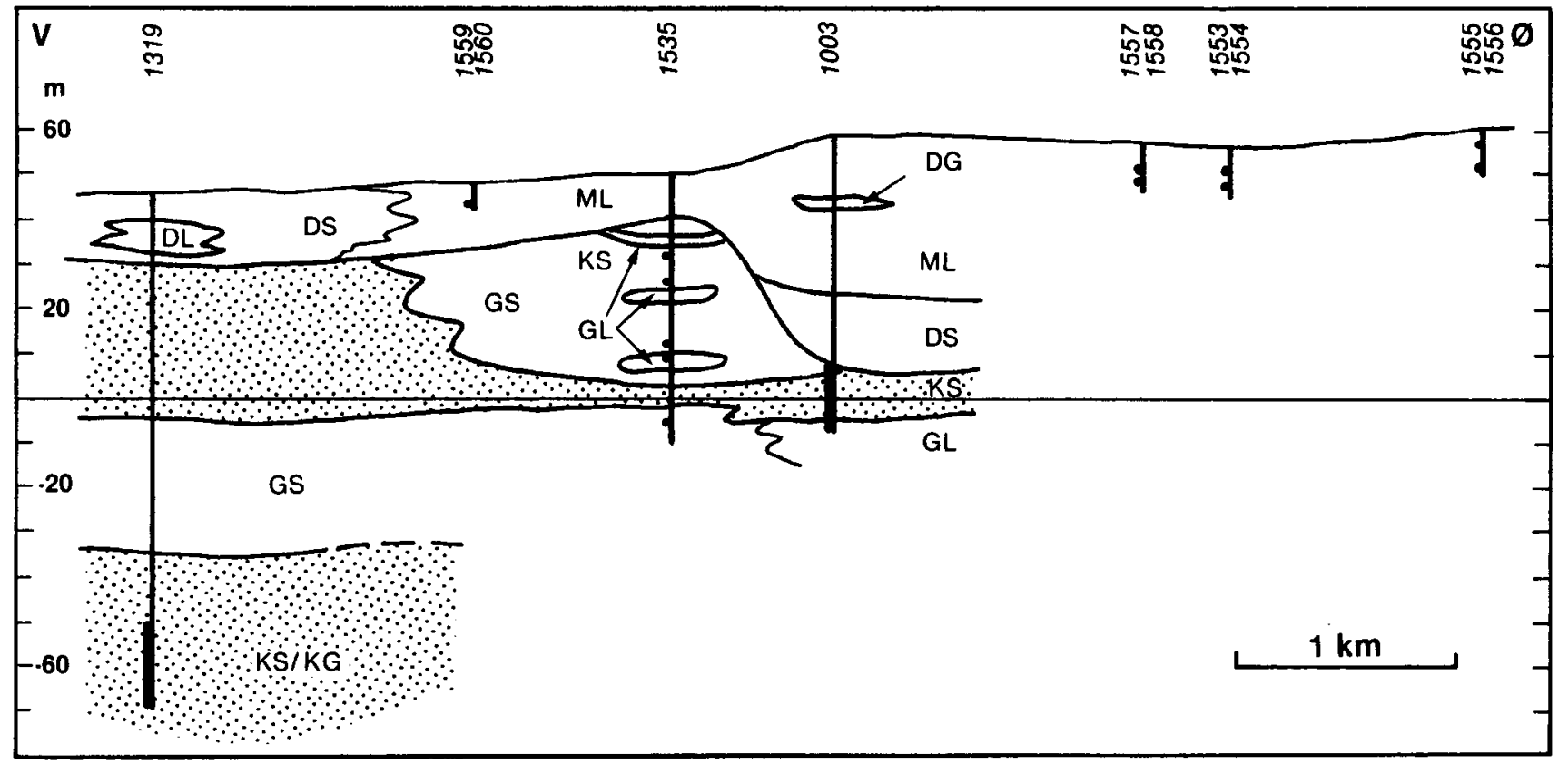


Hydrogeologi: Der er flere grundvandsreservoirer i området, hvoraf de tre vaesentligste (de artesiske hovedreservoirer) består af kvartssand og/eller -grus adskilt af glimmersandet og -leret. Der er i flere niveauer små lokale reservoirer med frit grundvandsspejl i det kvartære smeltevandssand. Herning østre vandværk indvinder vand fra det nedre Miocæne reservoir, mens Hammerum vandværk indvinder fra det øvere Miocæne reservoir. Områdeafgrænsningen gælder reservoirerne med frit grundvandsspejl. Potentialekortet viser det kvartære reservoir.

Grundvandskemi: Grundvandet i området er af calcium-natrium-bikarbonattypen. Den totale hårdhed er mellem 3 og $14^{\circ} \mathrm{dH}$. Nitratindholdet er generelt meget lavt, men enkelte steder er det højt. Hvor nitratindholdet er lavt er indholdet af opløst jern højt. Kaliumpermanganattallet er flere steder højt.

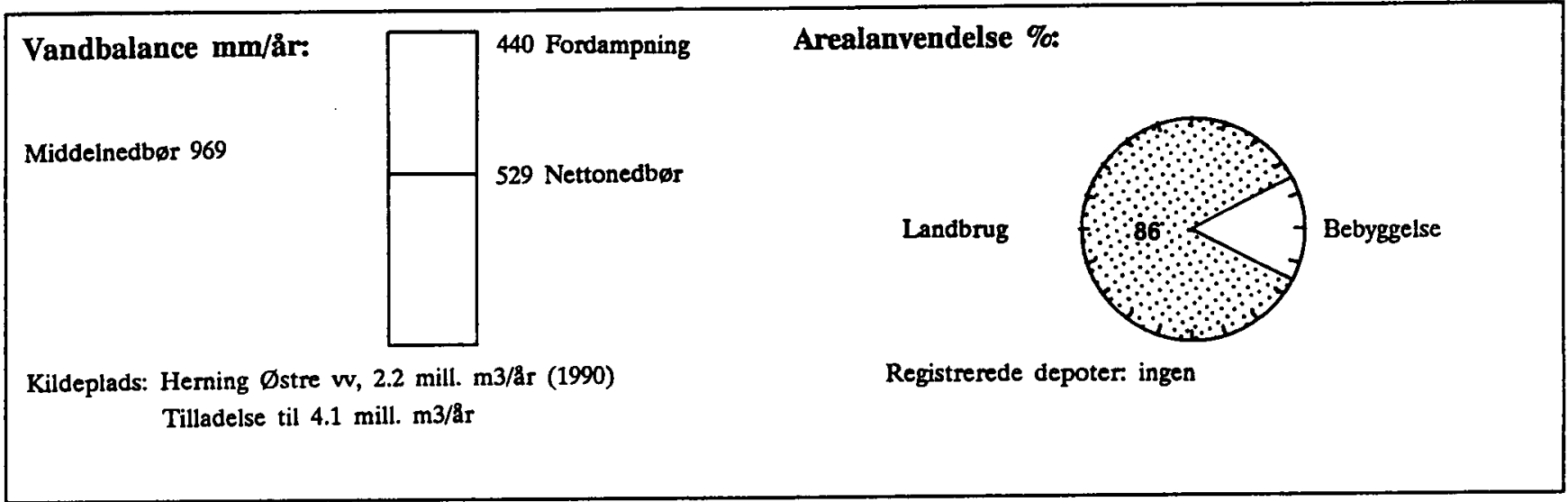

Koncentrationen af udvalgte stoffer i forhold til dybde under terræn.

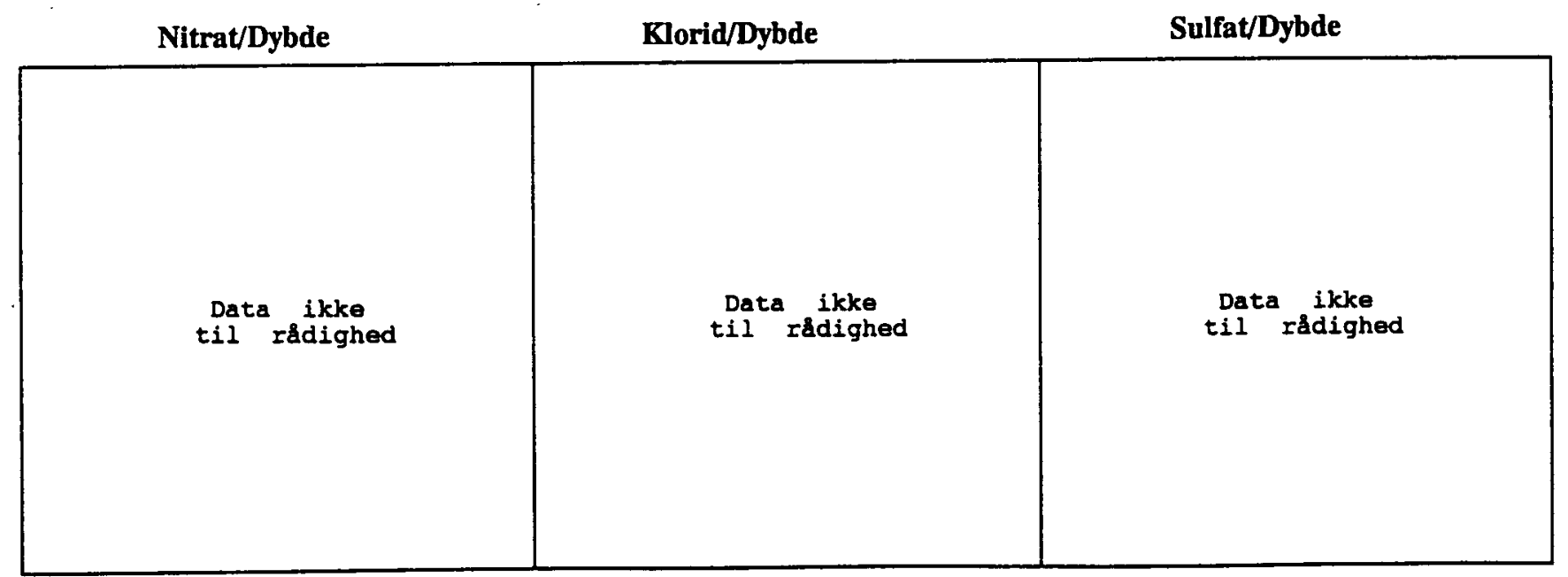




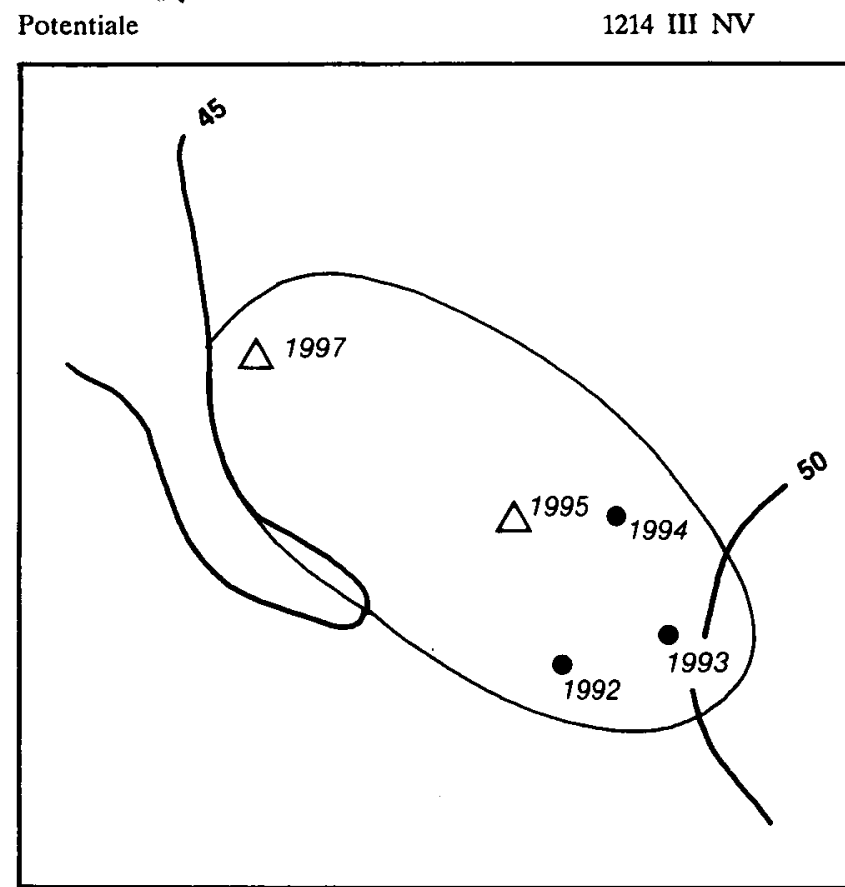

DGR nr. 104
Terræn

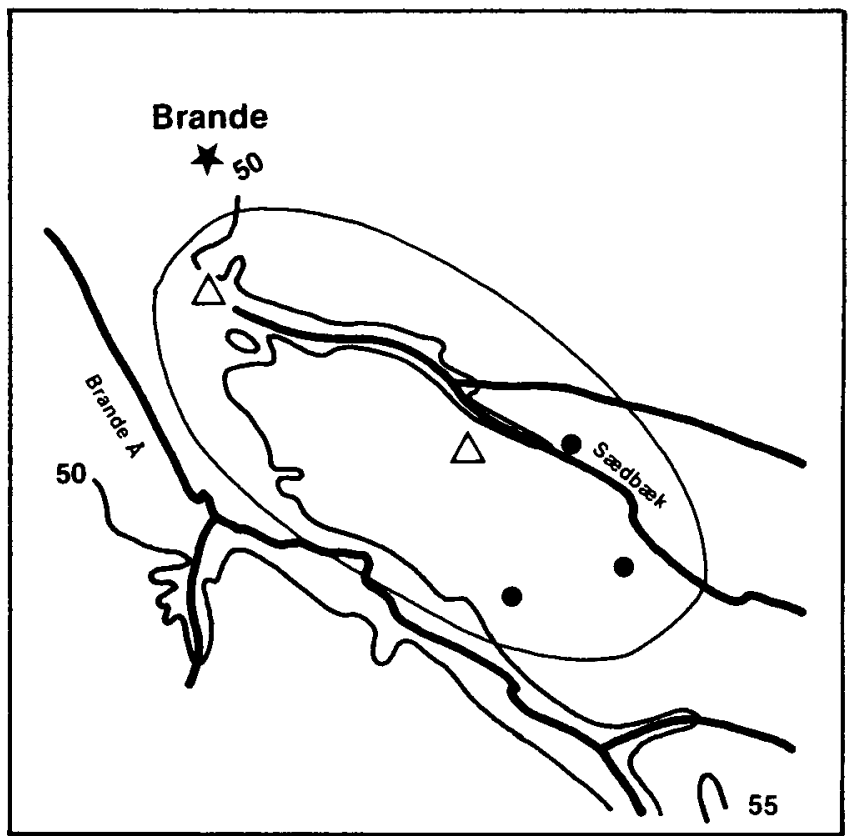

Areal $2 \mathrm{~km}^{2}$

Geologi: Den $\emptyset$ verste tertiære lagserie er fra Miocæn og består af vekslende sand- og lerlag. Heraf består sandlagene af kvarts- og glimmersand, og de lerede lag af glimmerler og -silt. I den kvartære lagserie dominerer smeltevandssand og smeltevandssilt og -ler, og der findes også et enkelt morænelerslag.

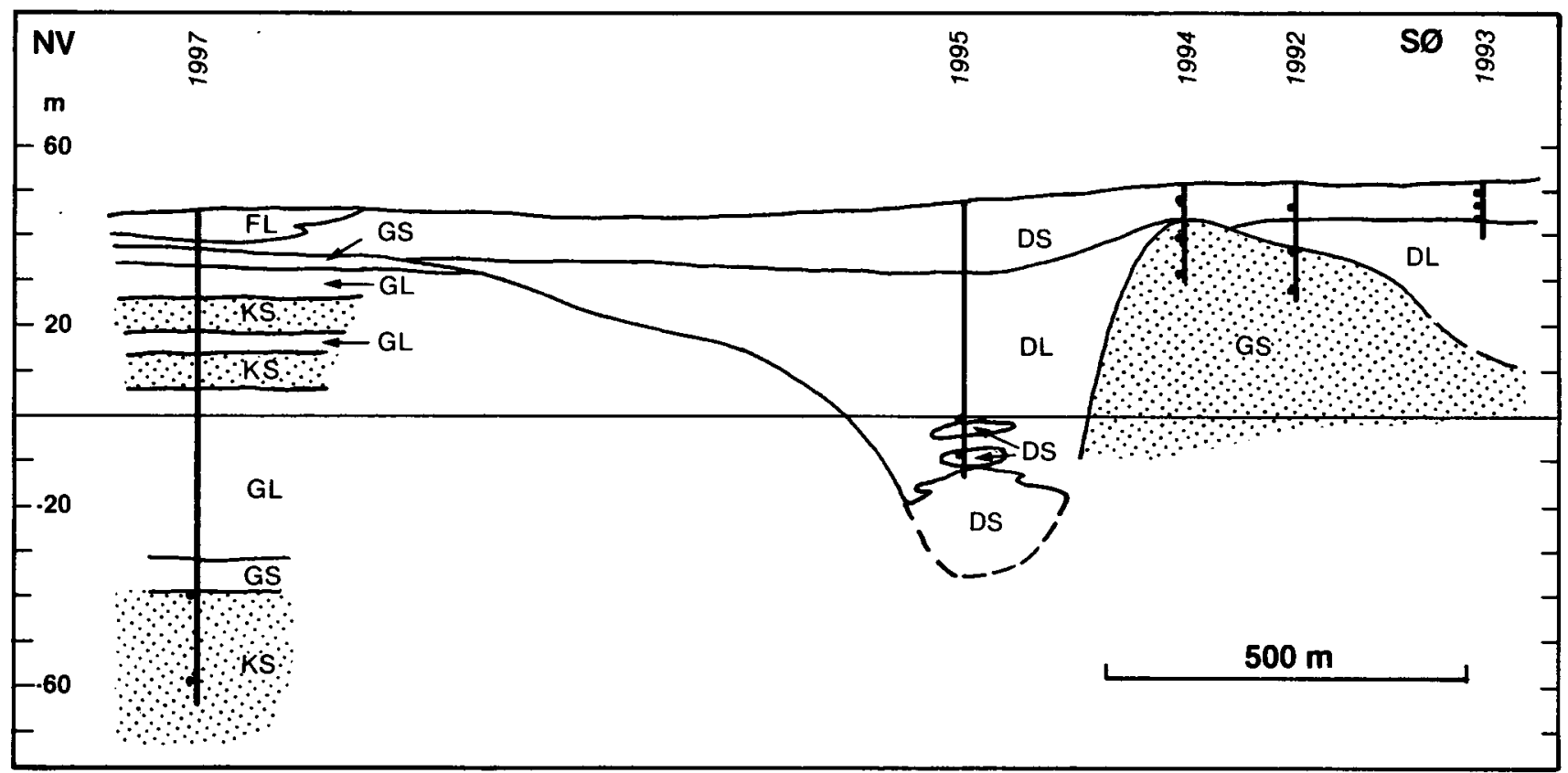


Hydrogeologi: Der indvindes grundvand fra tre reservoirer. Det nedre reservoir ligger $\mathrm{i}$ kvartssandlaget. Det mellemste reservoir består af kvarts- og glimmersand. $O g$ det øverste reservoir består af smeltevandssand. I de nedre reservoirer er der artesiske forhold, mens der $\mathrm{i}$ det øverste er frit grundvandsspejl. Områdeafgrænsningen gælder det øverste reservoir. Potentialekortet gælder det kvartære reservoir.

Grundvandskemi: Nitratindholdet i grundvandet ligger de fleste steder nær detektionsgrænsen, men enkelte steder $\mathrm{i}$ det øvre reservoir er nitratindholdet dog forholdsvis højt. Der er dog ikke konstateret nogen stigende tendens gennem tiden. $\mathrm{pH}$ er ret lavt, men stiger med dybden. Højt nitrat- og calciumindhold følges ad. Nogle steder er det naturlige fosfatindhold større end det højst tilladte indhold i drikkevand.

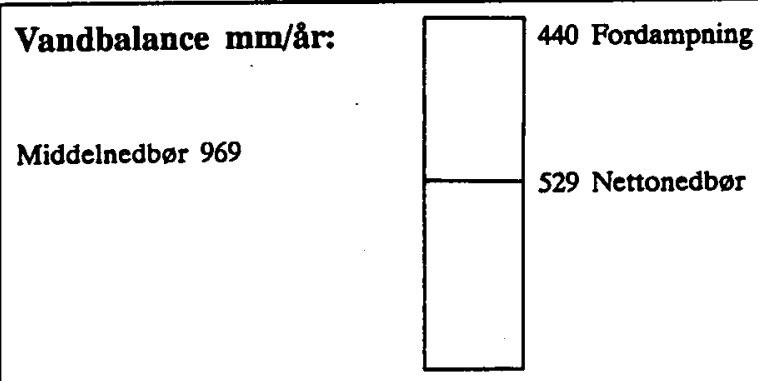

Kildeplads: Brande vv, 0.5 mill. m3/år (1990) Tilladelse til 0.6 mill. $\mathrm{m} 3 / \mathbf{a r}$.
Arealanvendelse \%:

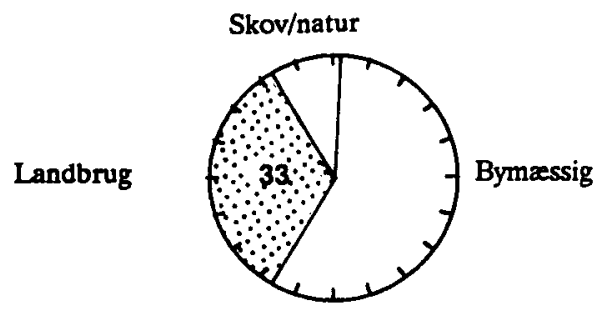

Registrerede depoter. et kemikaliedepot

Koncentrationen af udvalgte stoffer i forhold til dybde under terræn.

Graferne viser data fra 1989 og 1990.

. Nitrat/Dybde

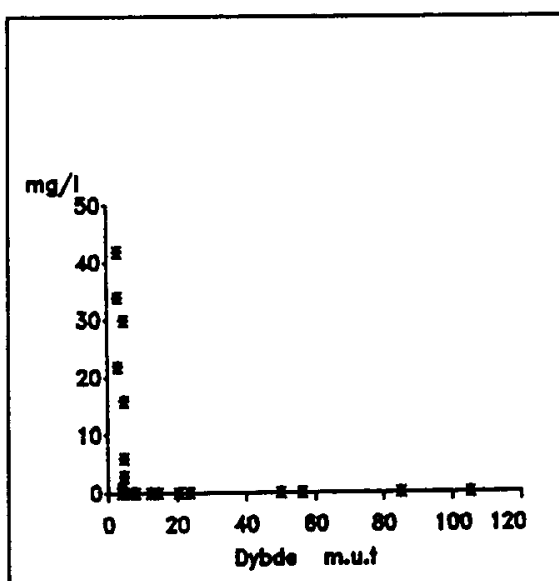

Klorid/Dybde

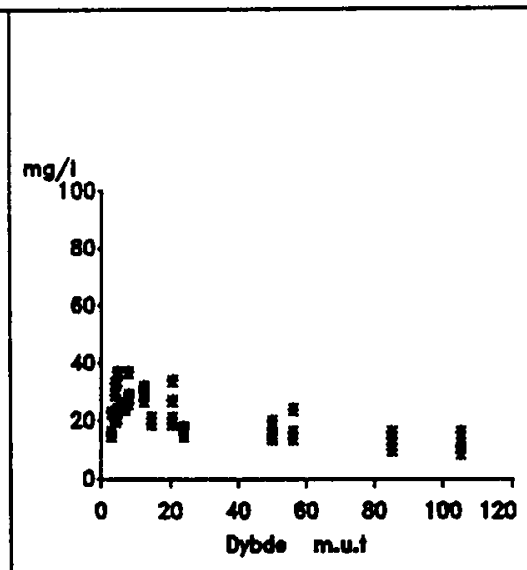

Sulfat/Dybde

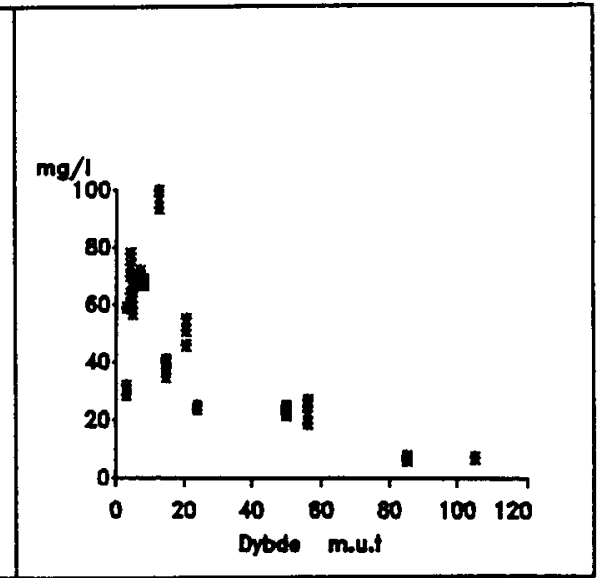




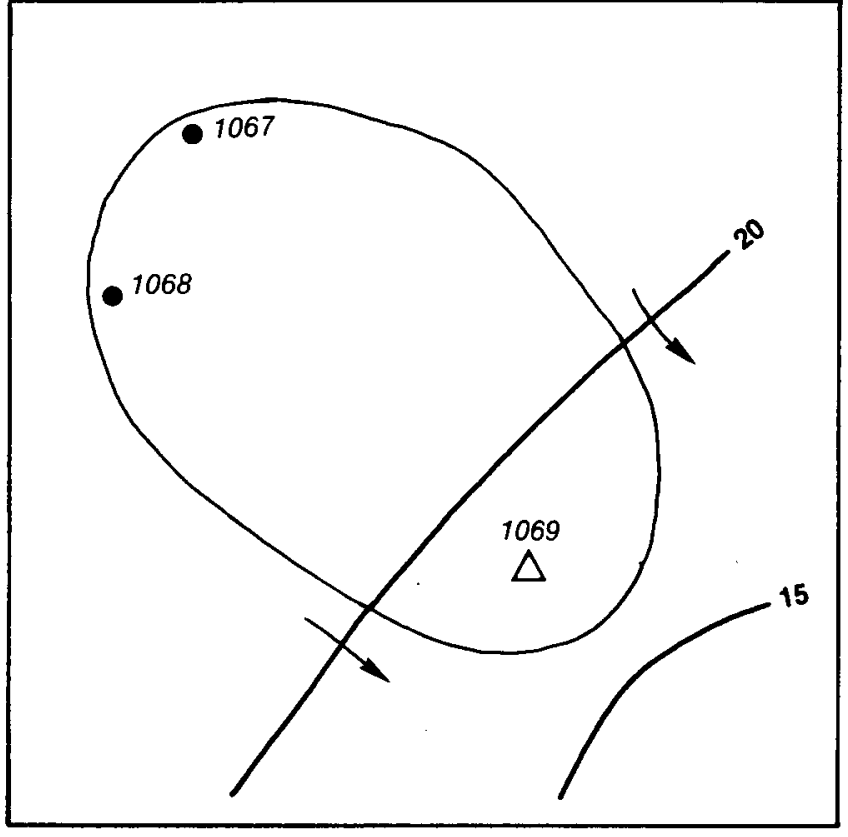

DGU nr. 65

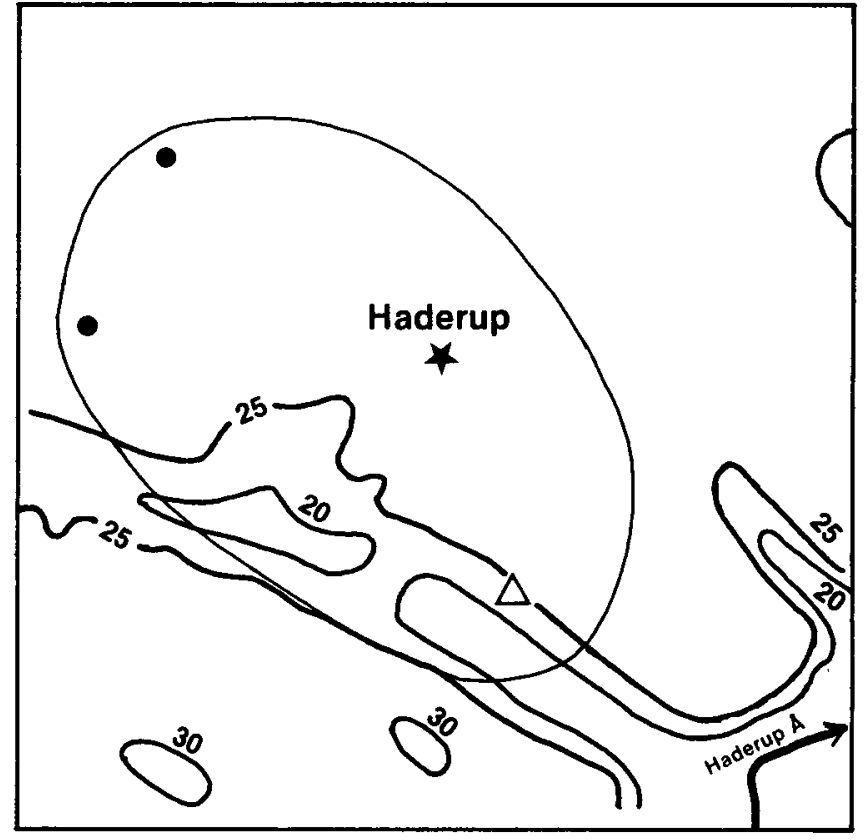

Areal $0,5 \mathrm{~km}^{2}$

Geologi: Den øverste tertiære lagserie består af vekslende lag af glimmersilt og -ler, samt kvarts- og glimmersand fra Miocæn. Den kvartære lagserie består af smeltevandssand og -ler.

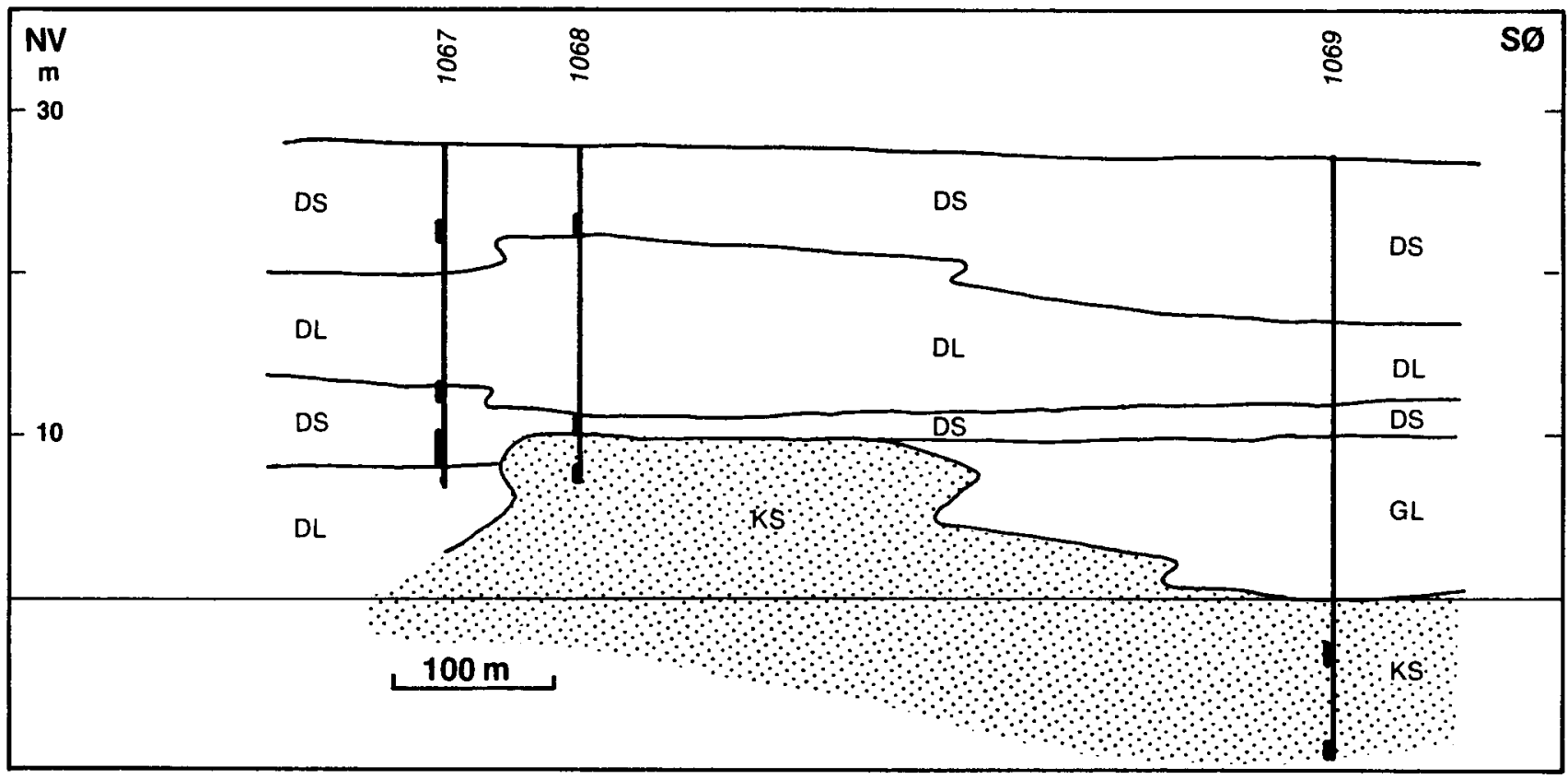


Hydrogeologi: Det nedre reservoir findes $\mathrm{i}$ de hydraulisk forbundne lag af glimmer- og kvartssand. Det $\emptyset v r e$ reservoir består af smeltevandssand, og står lokalt i forbindelse med det nedre reservoir. Der er artesiske forhold i det nedre reservoir, mens det øvre reservoir har frit grundvandsspejl. Områdeafgransningen og potentialekortet galder det øvre reservoir.

Grundvandskemi: Grundvandets nitratindhold i det nedre reservoir er meget lavt, mens det i det $\emptyset v r e$ reservoir, afhængig af arealanvendelsen, kan vare ganske højt. Nitratindholdet er konstant inden for måleperioden. Både pH og kaliumindholdet er højere i det øvre reservoir end i det nedre.

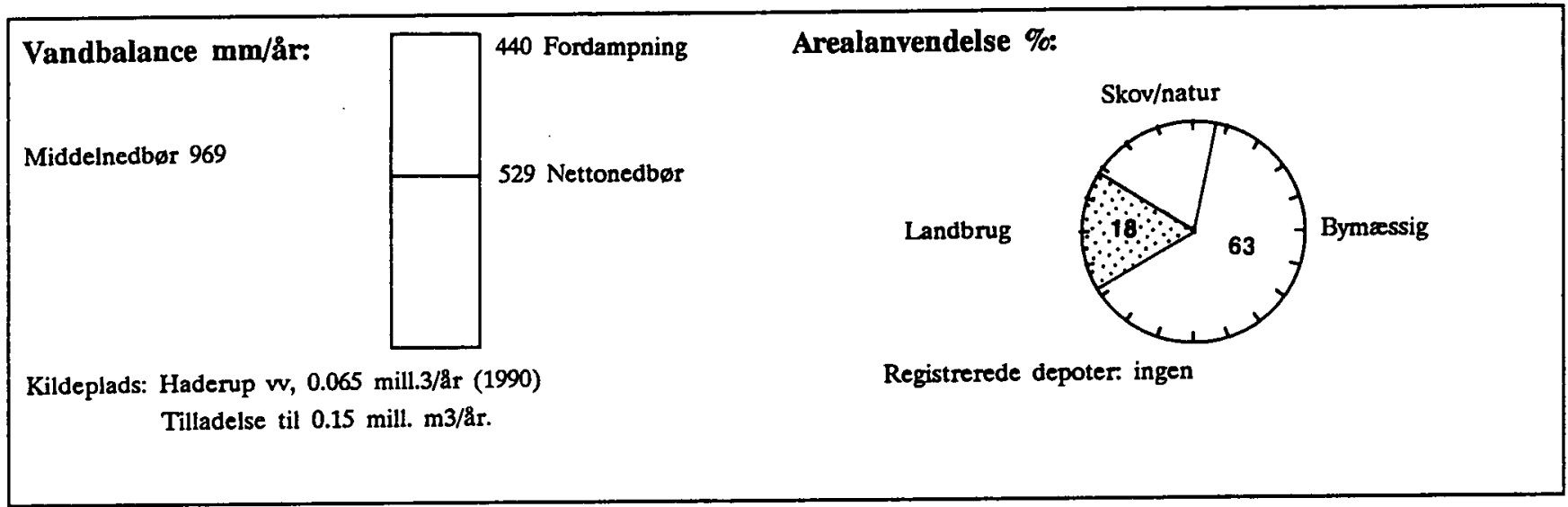

Koncentrationen af udvalgte stoffer i forhold til dybde under terran.

Graferne viser data fra 1989 og 1990.

Nitrat/Dybde

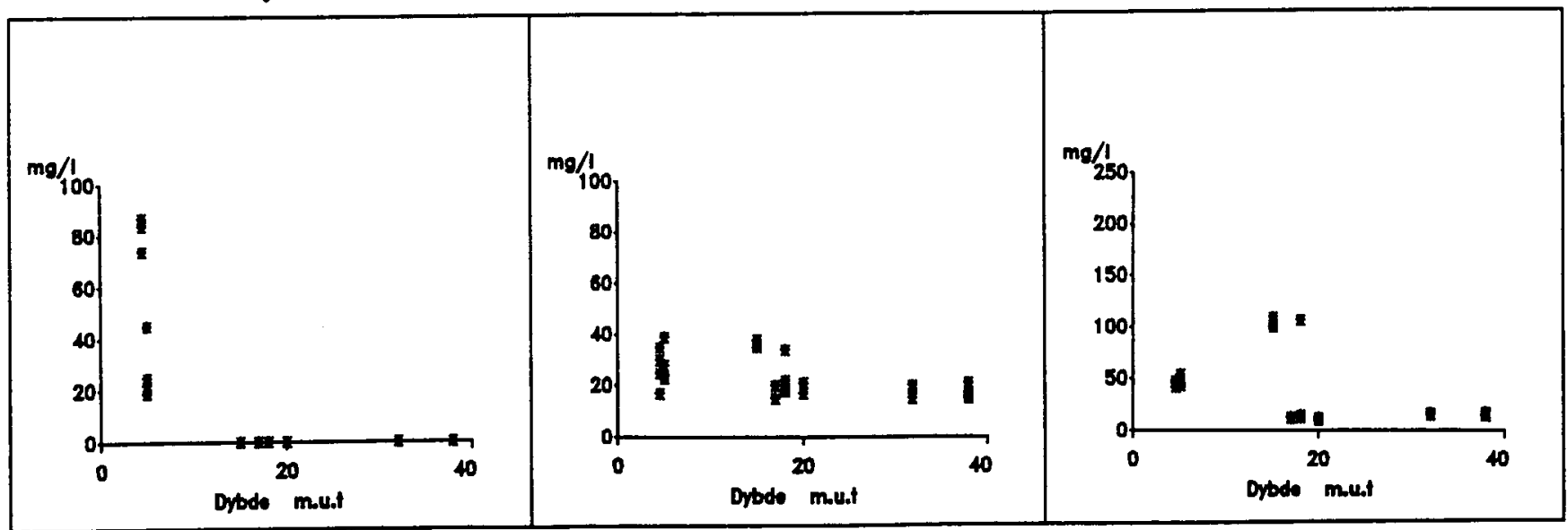


Potentiale

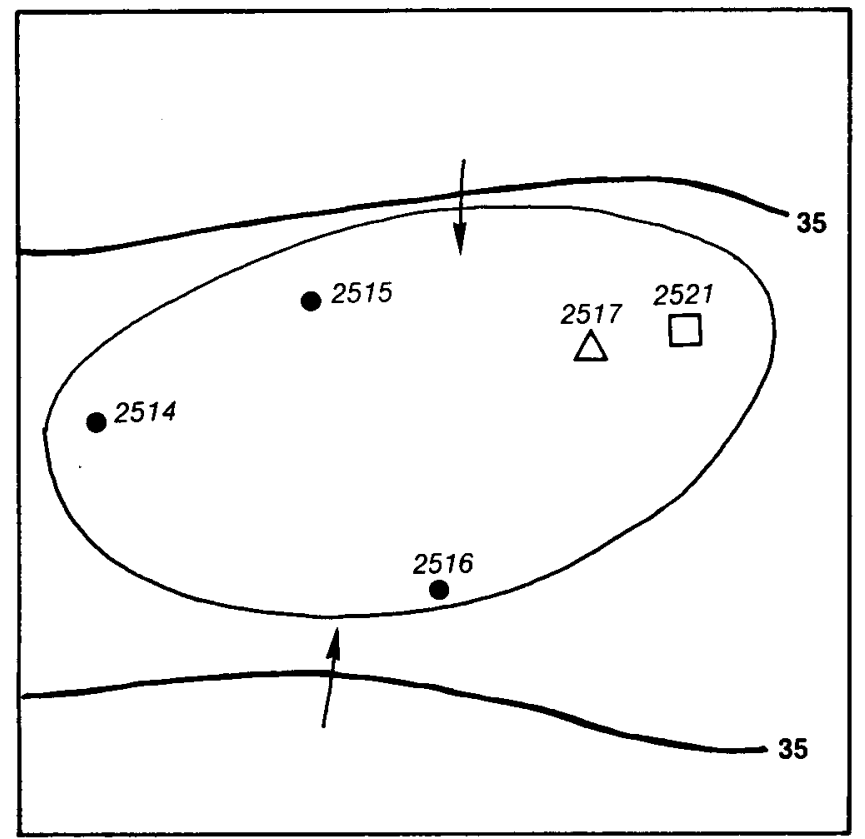

DGU nr. 94

1114 I SV

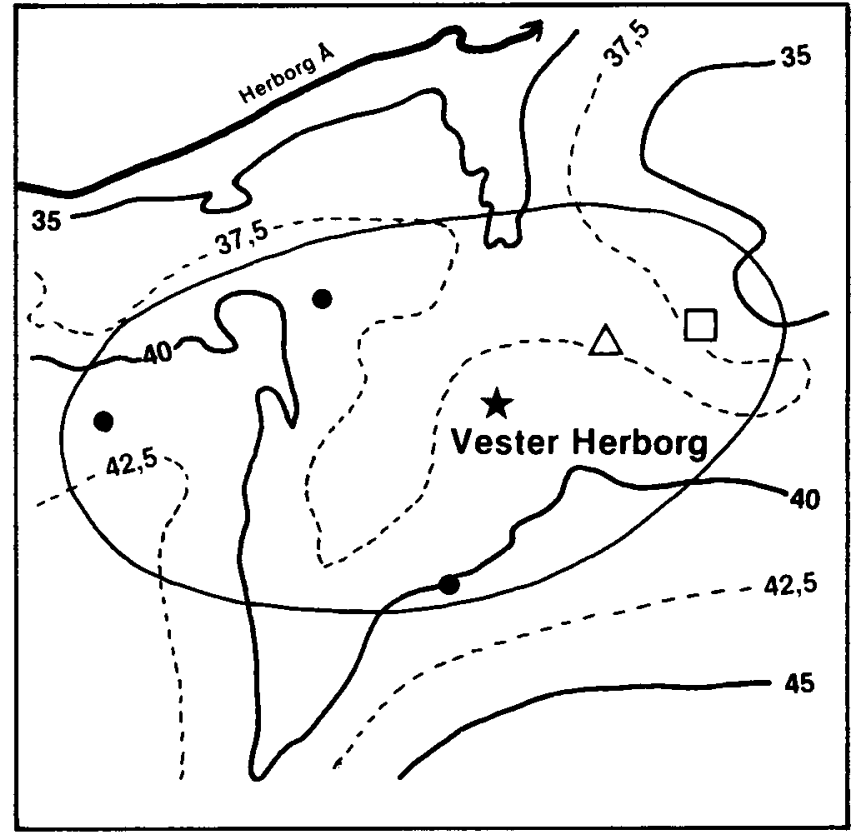

Areal $0,6 \mathrm{~km}^{2}$

Geologi: Overfladen af de tertiære lag er relativ jævn, idet den dog dykker mod syd. Kvartssand af Miocæn alder er den dominerende bjergart. Der forekommer ret tykke lokale lag af glimmerler. I den kvartære lagserie dominerer smeltevandssand, men mod vest og især mod syd er der massive indslag af moræneler. Mod øst findes der et tykt lag af smeltevandsler.

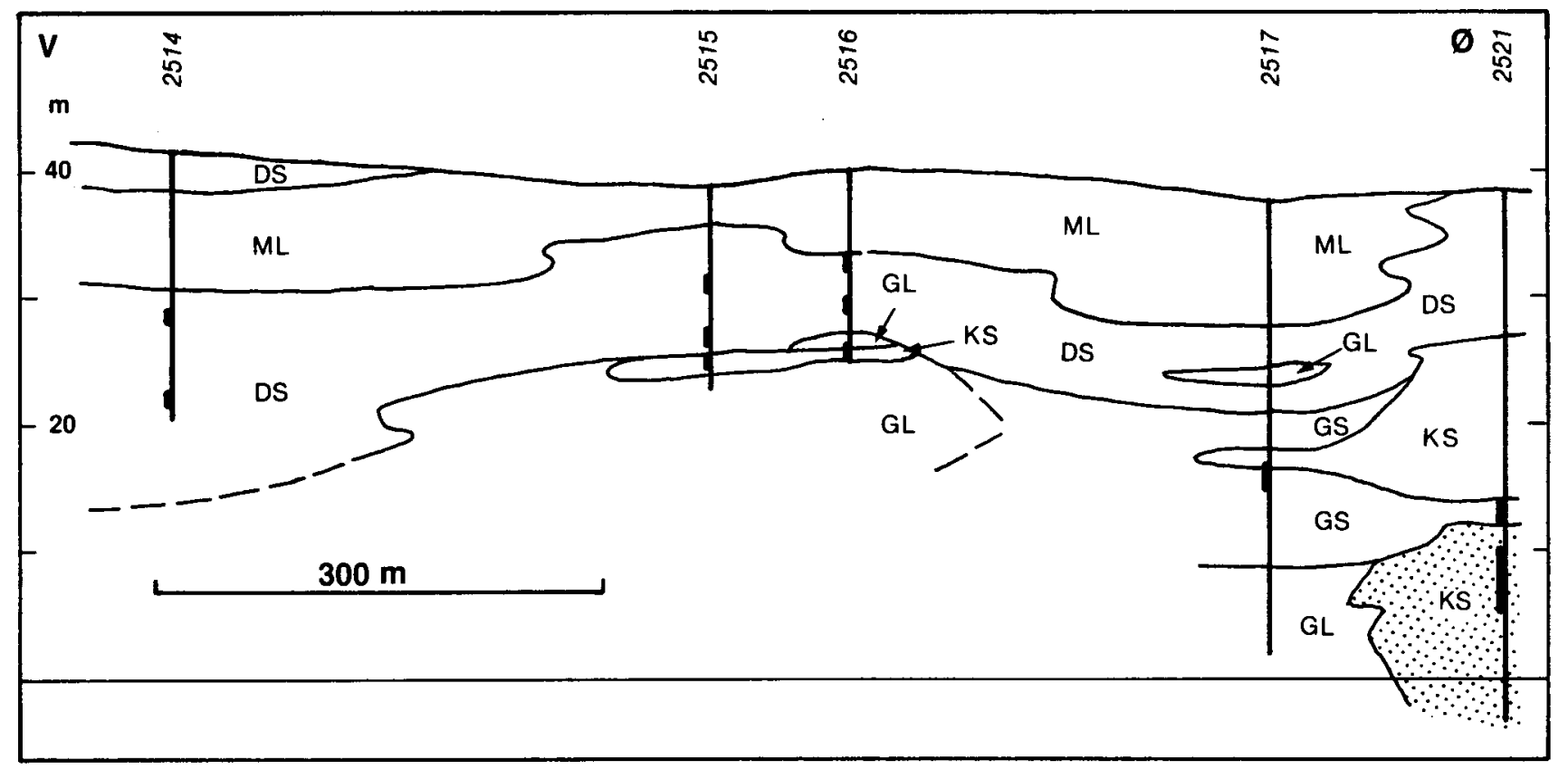


Hydrogeologi: Grundvandsreservoirerne er frie. I de sydlige og østlige dele af området består de vandførende lag af kvartssand. Disse reservoirer er hydraulisk forbundne og dermed ubeskyttede mod nedsivende forurening. I det nederste reservoir, hovedreservoiret, strømmer grundvandet mod sydøst, mens det $\mathrm{i}$ det øvre strømmer mod øst. Områdeafgrænsningen og potentialekortet gælder det øvre reservoir.

Grundvandskemi: Nitratindholdet $\mathrm{i}$ grundvandet $\mathrm{i}$ det $\emptyset v r e$ sandede og ubeskyttede reservoir er forholdsvis højt, mens det er væsentligt lavere umiddelbart under et lokalt overfladenært lerlag. I det dybtliggende, men ligeledes ubeskyttede, reservoir er nitratkoncentrationen også lav. Nitratindholdet varierer gennem året $i$ grundvandet fra de fleste filtre, men der er ikke konstateret nogen stigende tendens. $\mathrm{pH}$ er generelt omkring 5. Kaliumindholdet er en del steder temmelig højt.

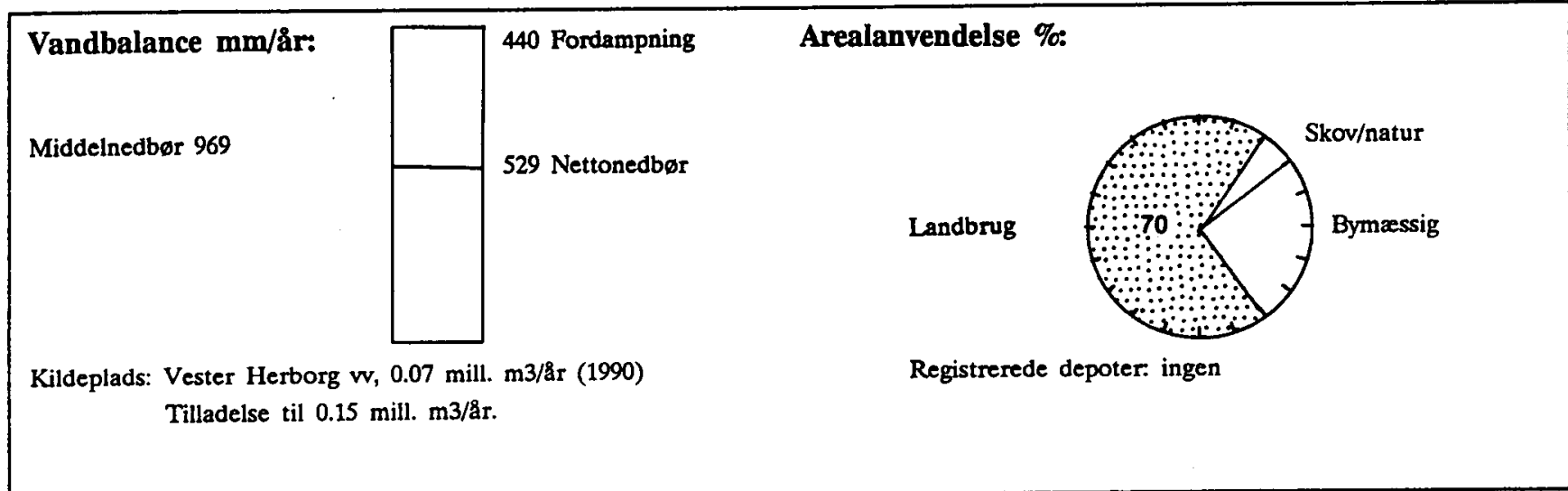

Koncentrationen af udvalgte stoffer i forhold til dybde under terran.

Graferne viser data fra 1989 og 1990.

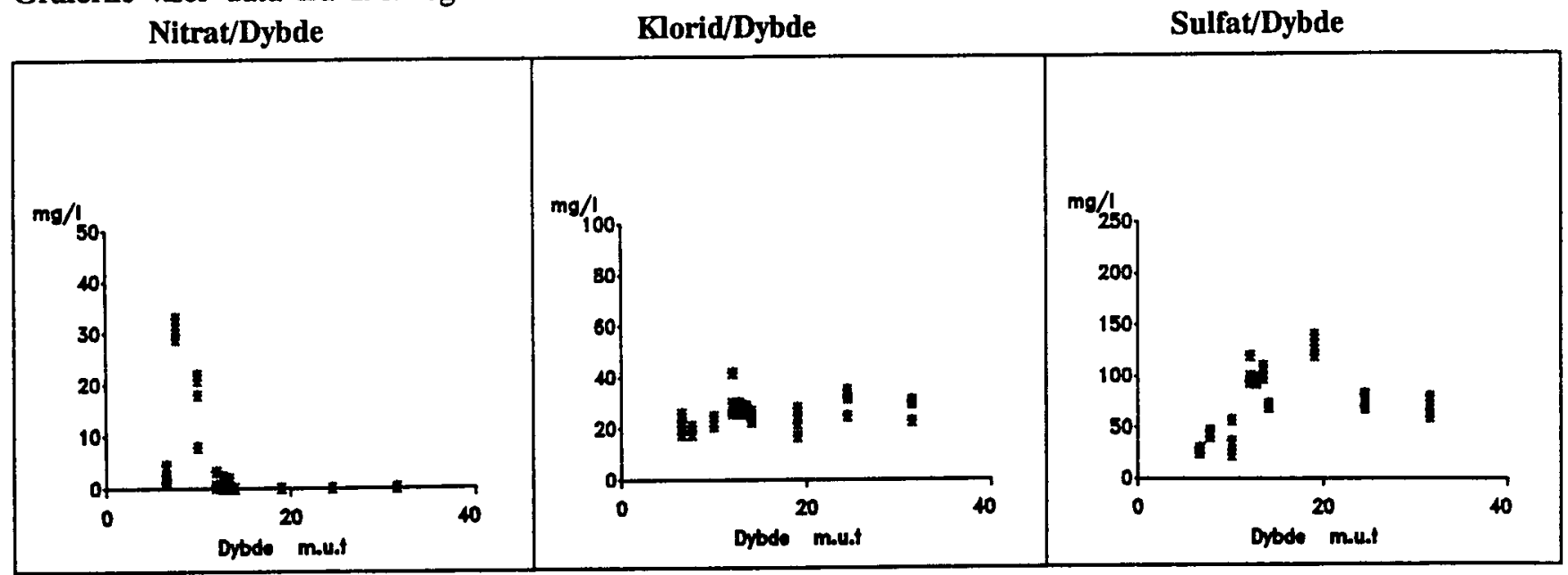


1114 IV S $\varnothing$

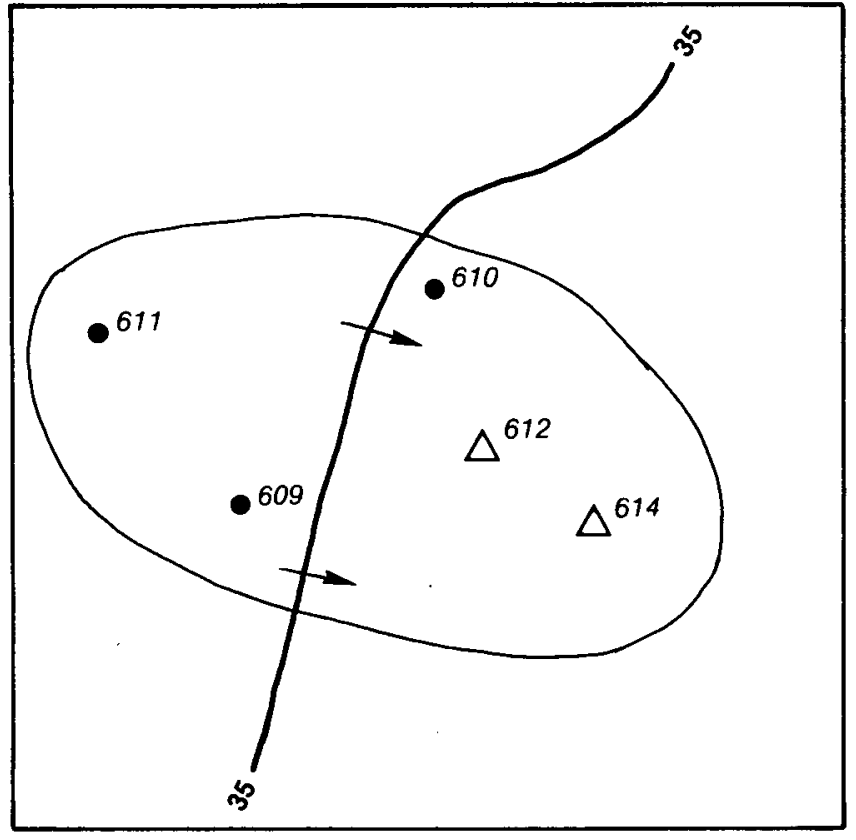

DGU nr. 93
Terræn

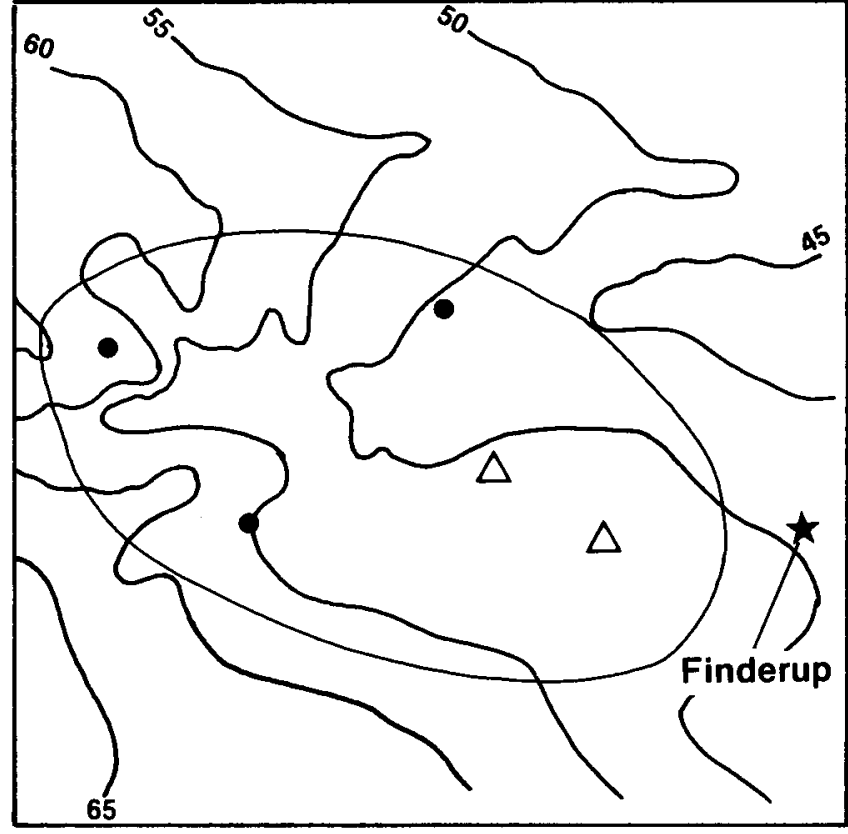

Areal $0,7 \mathrm{~km}^{2}$

Geologi: Kun mod nord er de dybtliggende øverste tertiære lag af glimmersilt og -sand fra Miocæn anboret. Den tykke kvartære lagserie består overvejende af smeltevandssand og -silt. Sydligt og østligt $\mathrm{i}$ området er der et overfladenært morænelerlag.

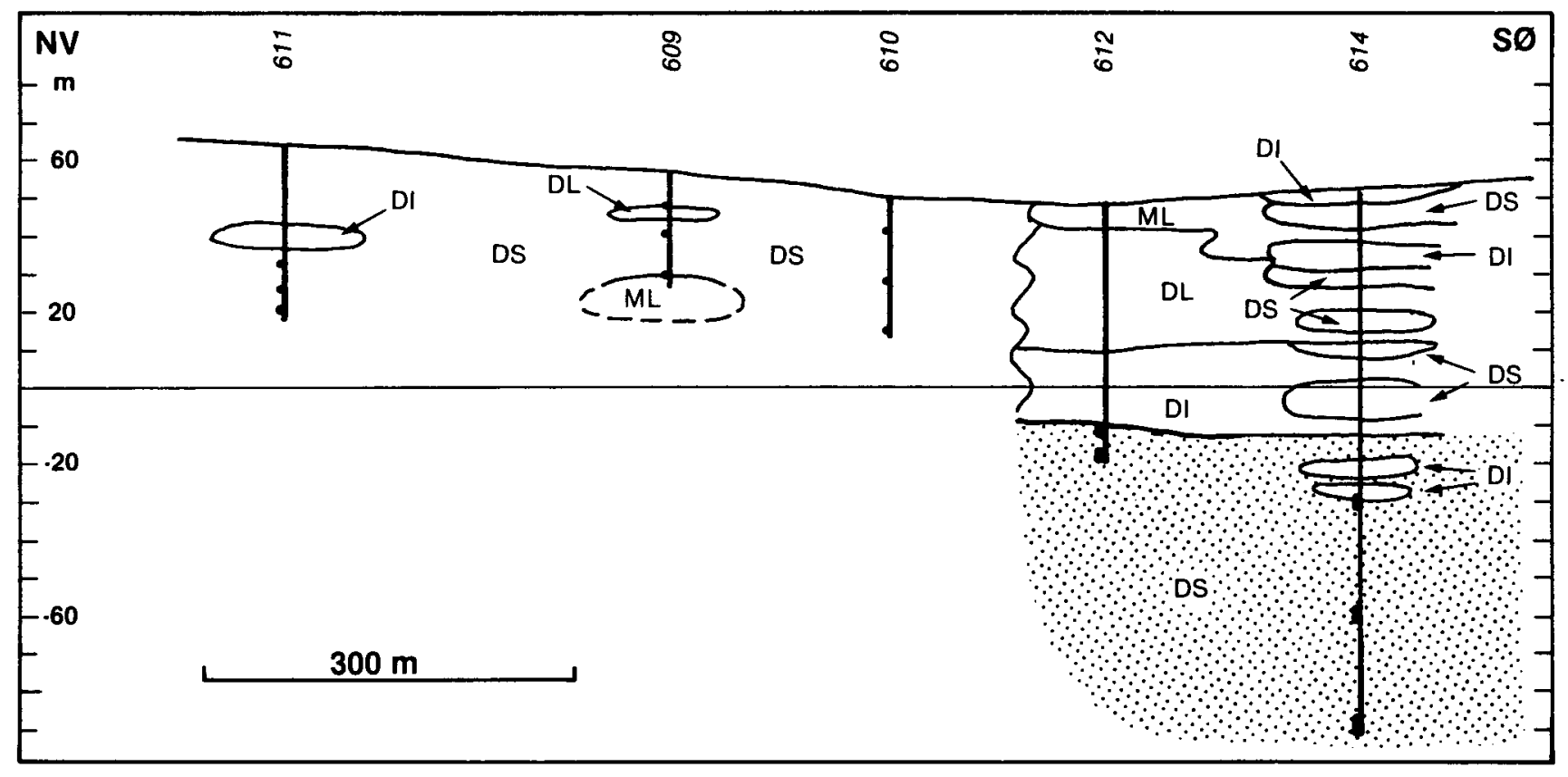


Hydrogeologi: Ved Finderup Vandværk er der et øvre og et nedre reservoir med samme trykniveau. Smeltevandssandet overlejres af flere lag af smeltevandssilt og -ler. Ved vandvarket er det nedre reservoir artesisk og velbeskyttet $\mathrm{i}$ kraft af de overliggende ler- og siltlag. Det øvre frie reservoir har direkte forbindelse til Ganer $\AA$. Områdeafgransningen gælder det øvre reservoir.

Grundvandskemi: Grundvandet fra de øverste filtre har fra relativt lavt til højt nitratindhold. I det nedre lerbeskyttede reservoir er nitratindholdet omkring detektionsgransen. Nitratindholdet har varet konstant gennem 1990. pH er generelt ret lavt, men i det lerbeskyttede reservoir er pH konstant nær neutralpunktet. Grundvandets kaliumindhold er højest i det øverste reservoir.

Vandbalance mm/år:

Middelnedbør 969

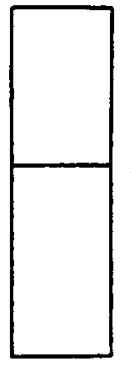

440 Fordampning

529 Nettonedbør

Kildeplads: Finderup vv,

Tilladt indvinding er $0.2 \mathrm{mill}$. m3/år

\section{Arealanvendelse \%:}

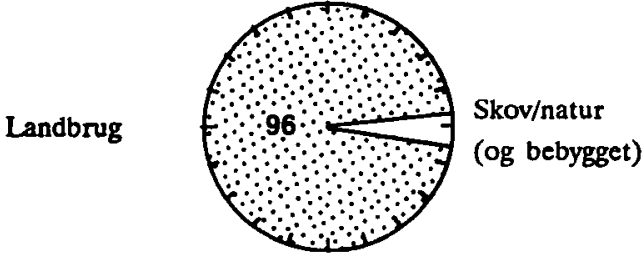

Registrerede depoter. ingen

Koncentrationen af udvalgte stoffer $\mathrm{i}$ forhold til dybde under terran.

Graferne viser data fra 1989 og 1990.

\section{Nitrat/Dybde}

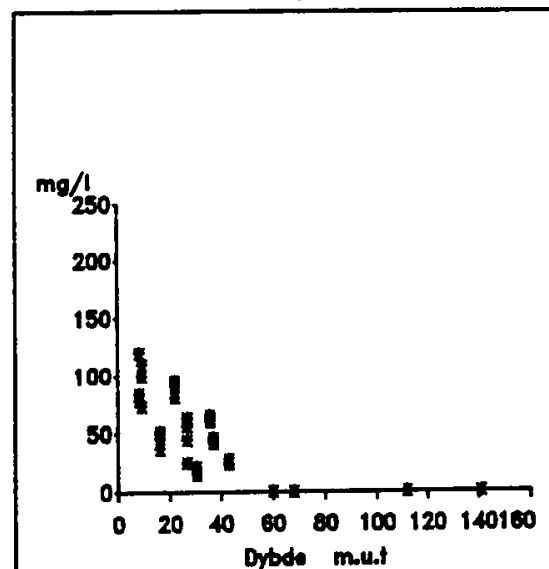

Klorid/Dybde

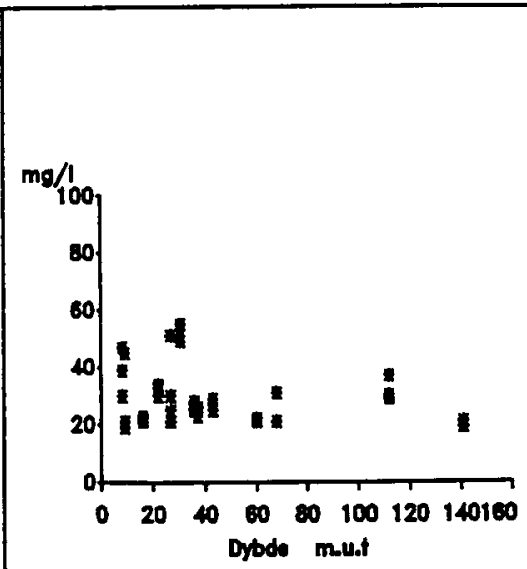

Sulfat/Dybde

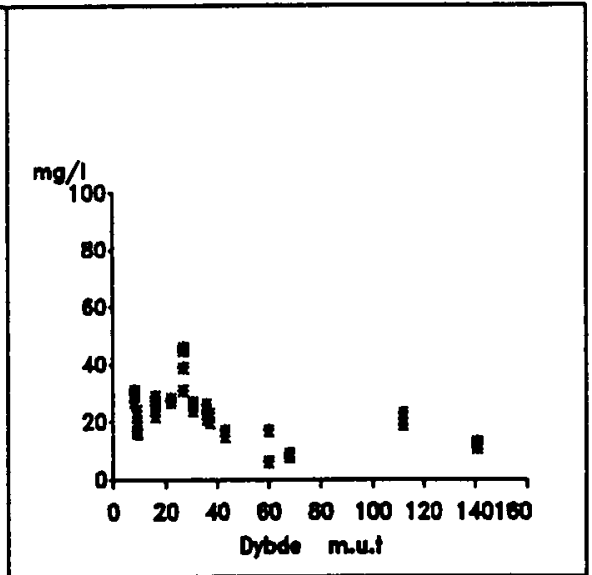




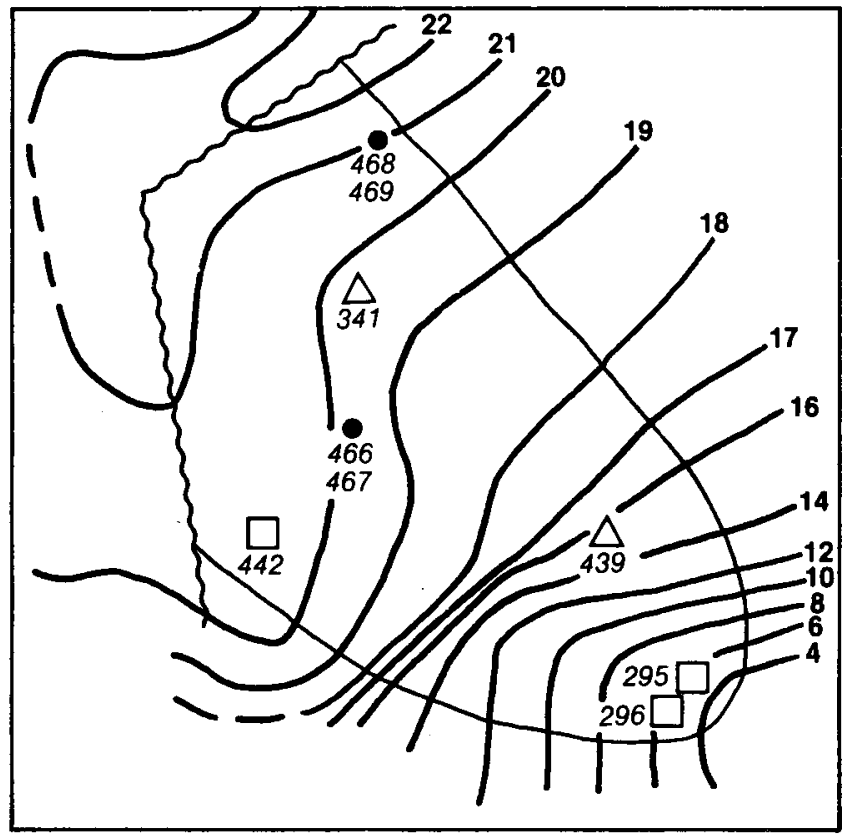

DGU nr. 71

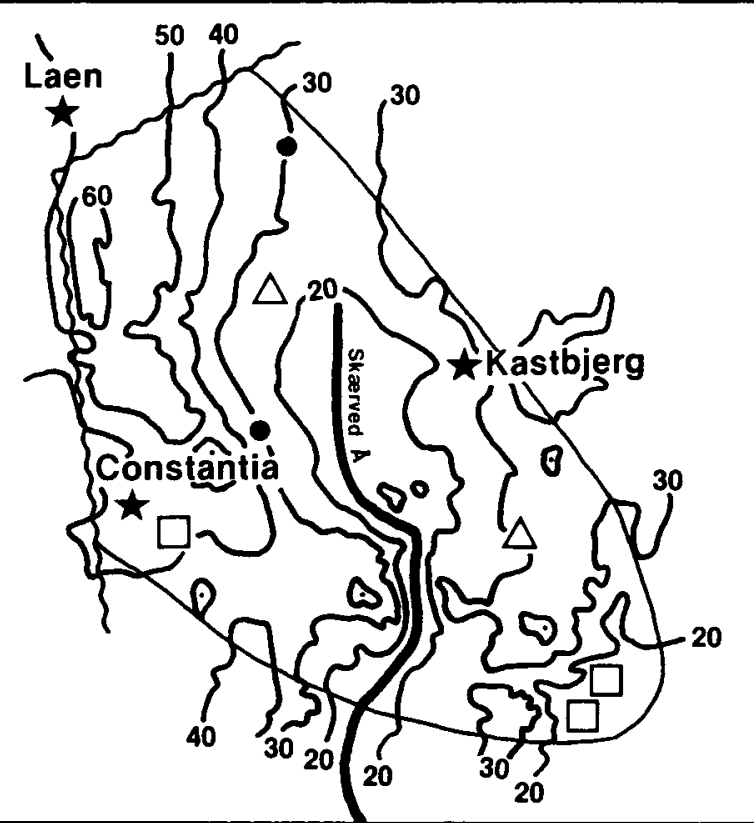

Areal $10 \mathrm{~km}^{2}$

Geologi: De øverste prækvartære lag i området består af kalk af Danien alder. Danienkalkens overflade er ujævn og dykker støt mod vest-nordvest. Kalklagene overlejres af moræneler, samt smeltevandssand og -grus. I den sydøstlige del af området overlejres kalkstenen direkte af moræneler, mens den nordvest herfor overlejres af smeltevandssand. I dette sand er der indlejret tynde lag af moræneler. Aflejringerne i terrænoverfladen domineres af smeltevandssand og -grus samt lokalt af moræneler. Langs Skærvad $\AA$ består de øverste lag af postglaciale tørv og gytje.

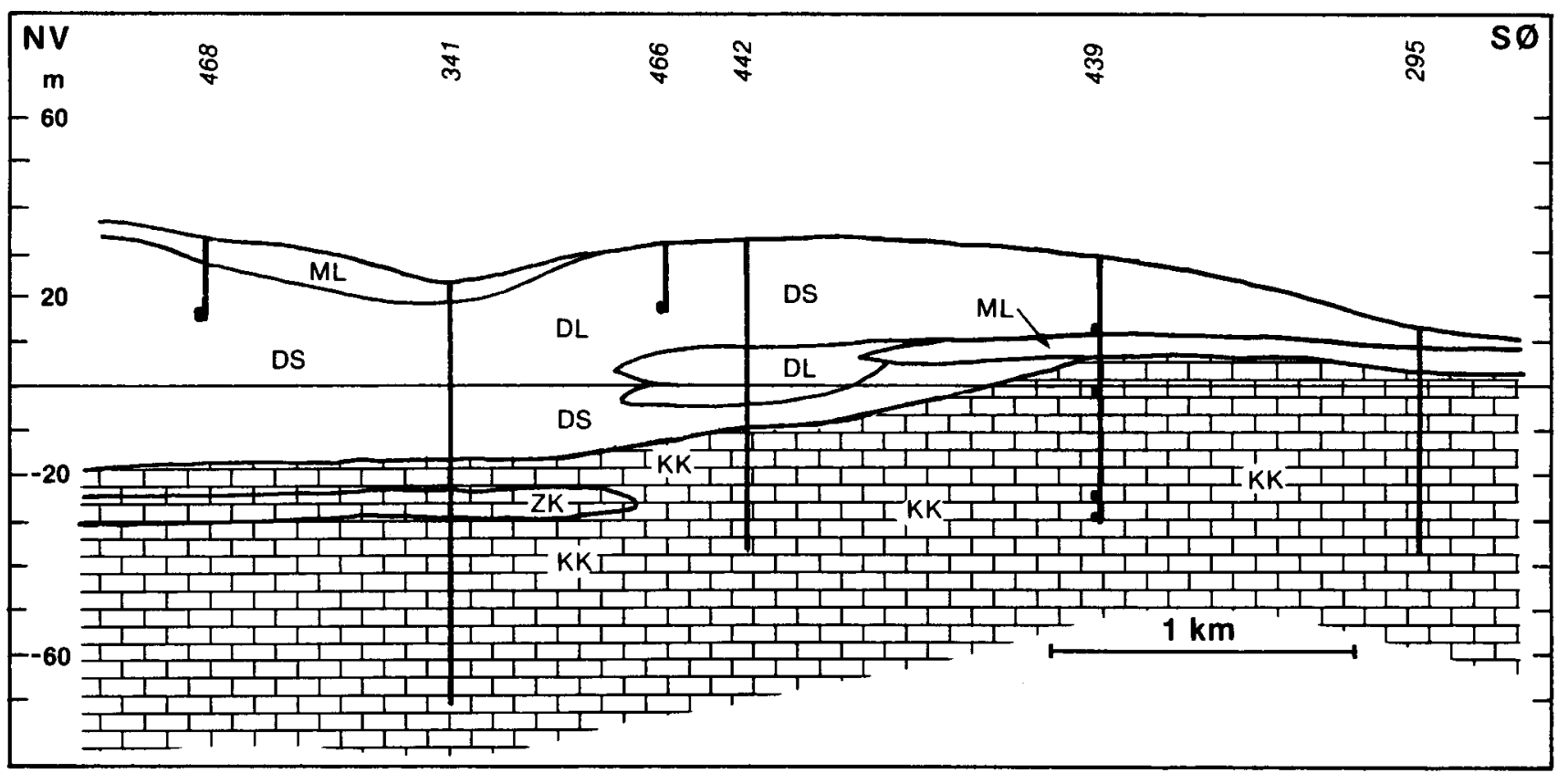


Hydrogeologi: Der er to grundvandsreservoirer i området. Hovedreservoiret består af Danienkalk og er delvis artesisk. Det øvre grundvandsreservoir består af smeltevandssand og -grus og har frit grundvandsspejl. I den nordvestlige del af området er der hydraulisk forbindelse mellem de to reservoirer. Området er antagelig angivet for lille $i$ forhold til oppumpningen.

Grundvandskemi: Grundvandet er overalt i området af calcium-bikarbonattypen. Hele området er nitratforurenet, men indholdet aftager generelt med dybden. Vandanalyser fra 1970 'erne og -80 'erne viser, at nitratindholdet $\mathrm{i}$ grundvandet er stigende. Vandværksvandet fra Constantia og Laen vandværker, der producerede fra sandreservoiret, indeholdt over 50 milligram nitrat pr. liter. Laen vandværk er nu lukket og Constantia vandværk har fået en ny boring, hvorfra der produceres vand uden nitrat.

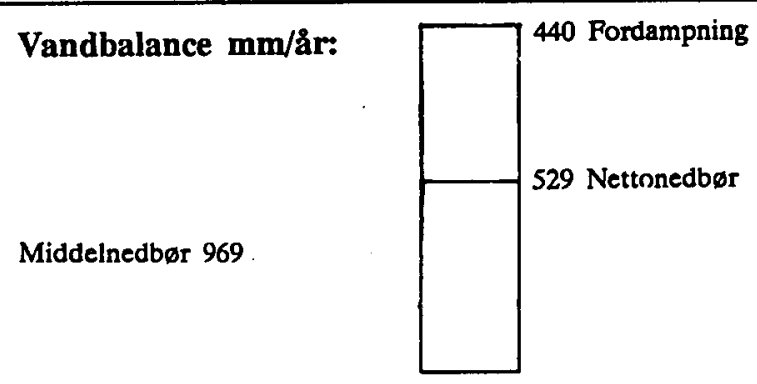

Kildeplads: Havdal, 1.4 mill. m3/år (i 1990)

\section{Arealanvendelse \%:}

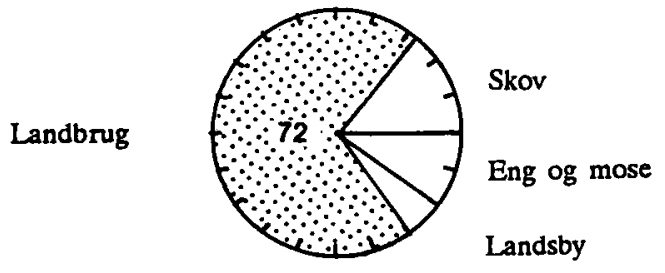

Registrerede depoter: to affaldsdepoter,

heraf et med kemikalieaffald nord for området.

Koncentrationen af udvalgte stoffer i forhold til dybde under terran.

Graferne viser data fra 1989 og 1990.

Nitrat/Dybde

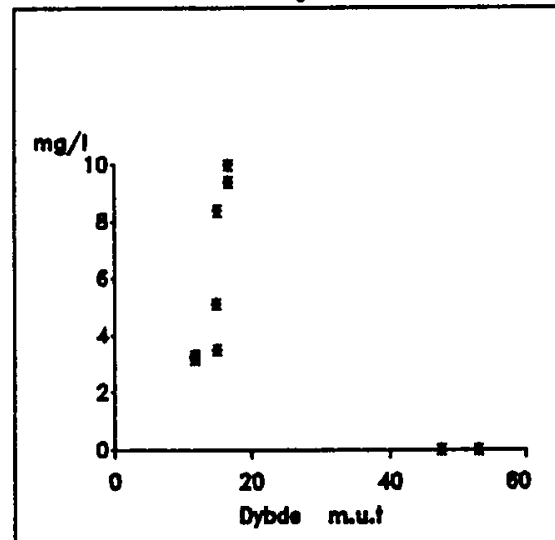

Klorid/Dybde

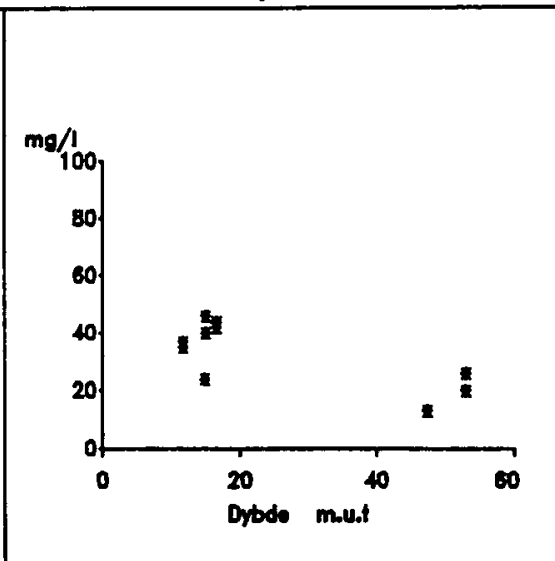

Sulfat/Dybde

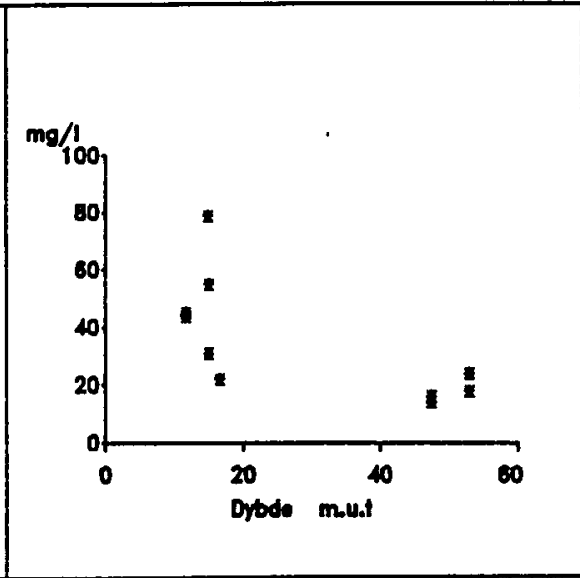


KASTED (70.02)

1314 IV NV og 1315 III SV

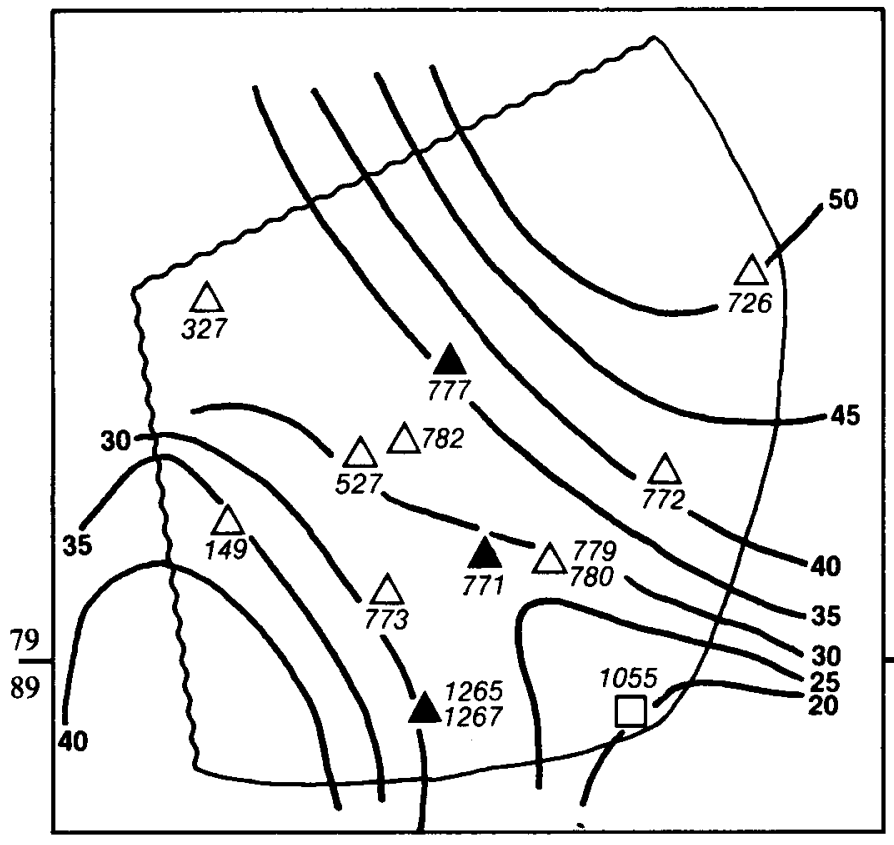

DGU nr. 79 og 89
Ref. Århus amt, 1990, 1991 og DGU 1990

Terræn

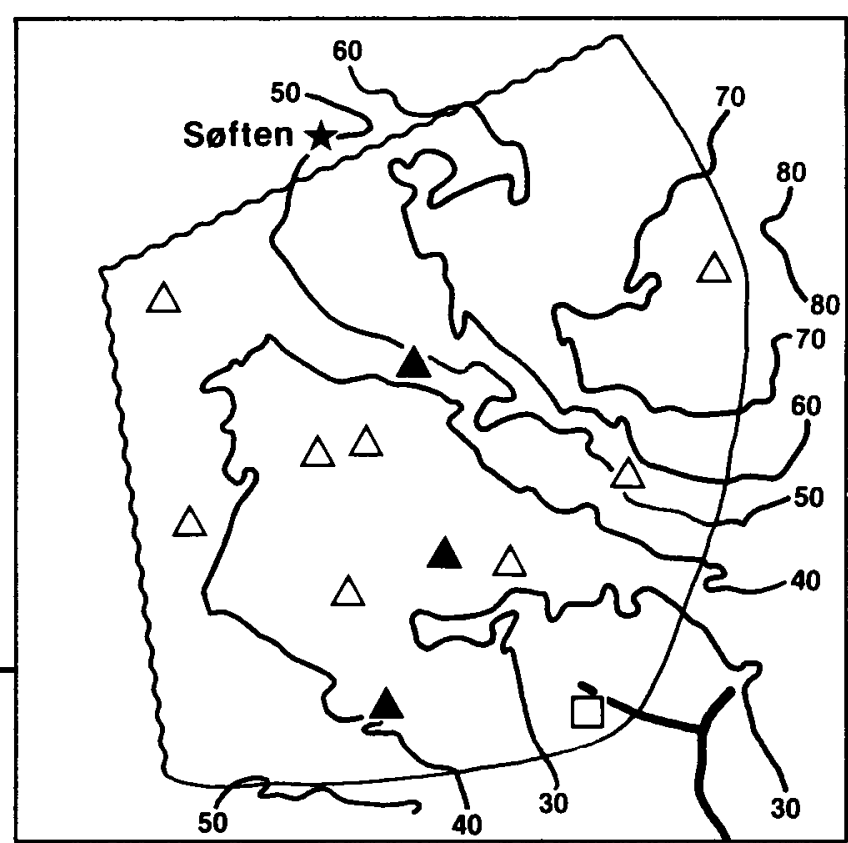

Areal $6 \mathrm{~km}^{2}$

Geologi: De øverste prækvartære lag i området består af ler af Oligocæn alder. Over det oligocæne ler er der moræneler, hvori der i tre niveauer er indlejret smeltevandssand. Det midterste sandlag har den største udbredelse. På overfladen dominerer moræneler.

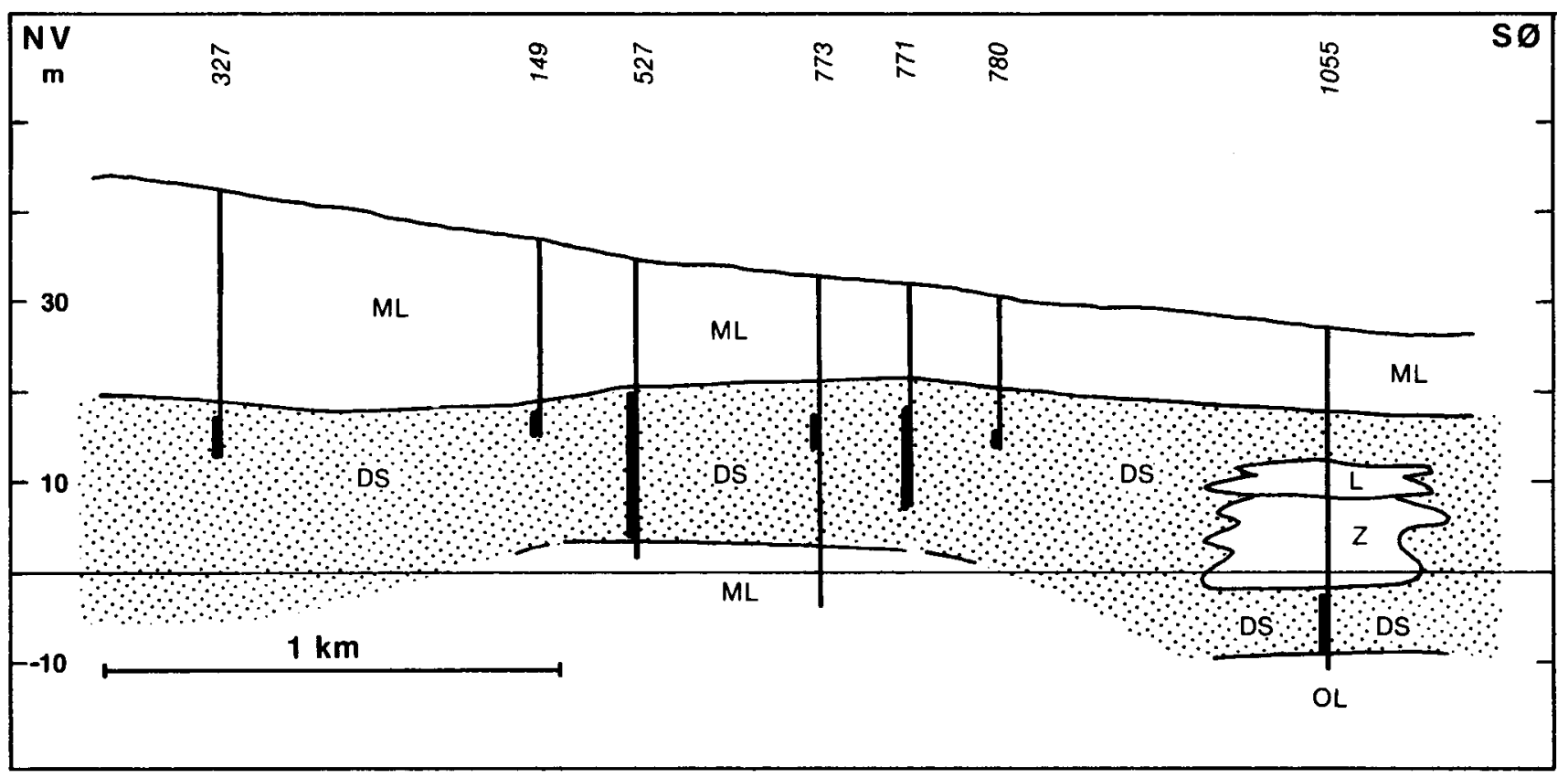


Hydrogeologi: Af de tre sandreservoirer $\mathrm{i}$ området udnyttes og kendes det nederste kun $\mathrm{i}$ hovedboringen. Den øvrige vandindvinding $\mathrm{i}$ området udnytter det mellemste og det øvre sandreservoir. Det mellemste reservoir findes $\mathrm{i}$ den syd- og sydvestlige del af området og det øvre i den nordøstlige del. Reservoirerne er adskilt og overlejret af moræneler. Reservoirerne er artesiske og grundvandet strømmer generelt mod sydøst. Området er angivet for lille $\mathrm{i}$ forhold til oppumpningen.

Grundvandskemi: Grundvandet $\mathrm{i}$ området er af calcium-bikarbonattypen. Indholdet af ilt og nitrat er generelt ubetydeligt, mens sulfatindholdet varierer noget. Den totale hårdhed er størst $\mathrm{i}$ det nederste reservoir. Grundvandet $i$ det nederste sandreservoir er beskyttet af lerlag med et stort indhold af jern og sulfat.

Størstedelen af grundvandet $\mathrm{i}$ det mellemste reservoir er iltfrit og nitratreduceret. Kun enkelte steder, hvor der er huller i de beskyttende lerlag, er der tegn på at det er nitratbelastet. Fosfatindholdet i grundvandet varierer meget indenfor området, men er gennemgående lavt.

Vandbalance mm/år:

Middelnedbør 650

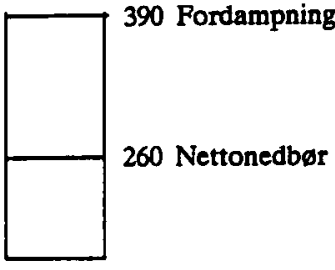

Kildeplads: Kasted, 3.4 mill. $\mathrm{m} 3 / a ̊ r$

\section{Arealanvendelse \%:}

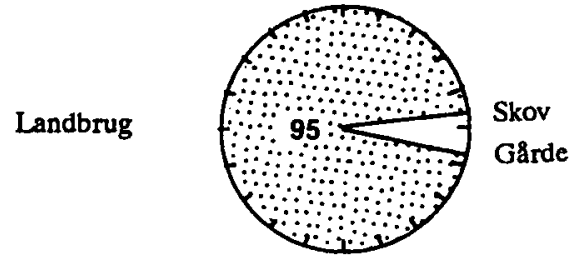

Registrerede depoter. 8 kemikalieaffaldsdepoter

Koncentrationen af udvalgte stoffer i forbold til dybde under terran.

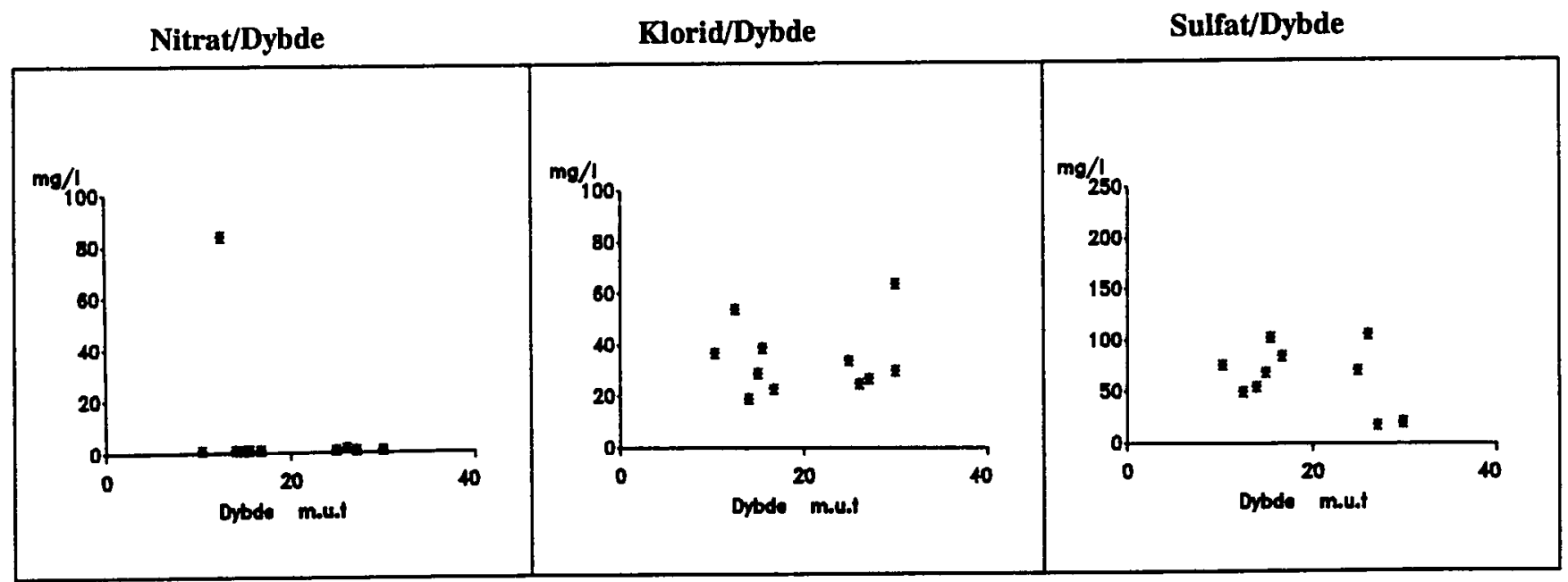



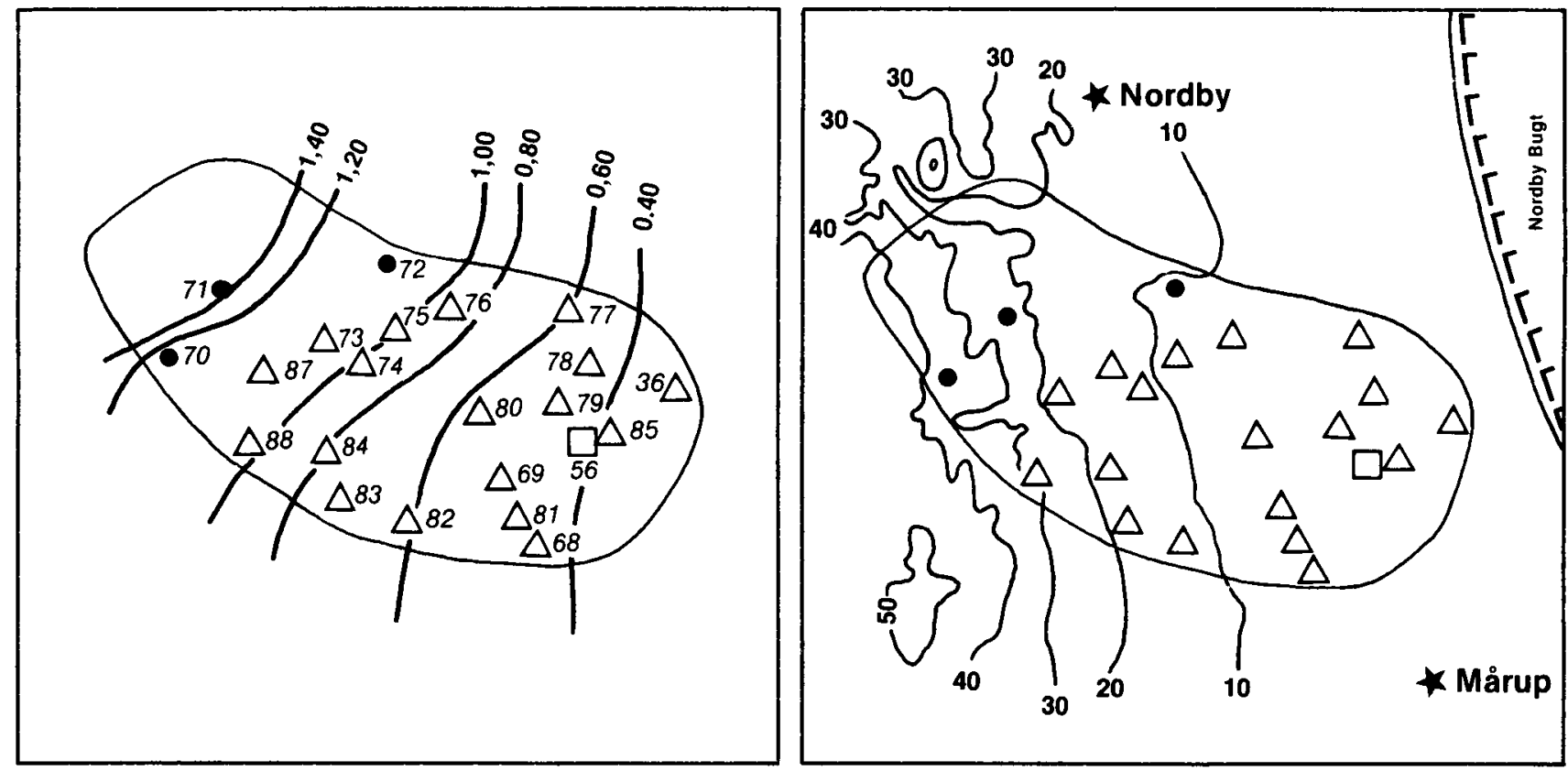

DGU nr. 100

Areal $5 \mathrm{~km}^{2}$

Geologi: Det øverste prækvartære lag består overalt af plastisk ler af Eocæn alder. Stedvis er der indlejret løsrevne flager af dette ler $\mathrm{i}$ de overlejrende kvartære aflejringer. Den kvartære lagfølge i området består af en vekslende serie af smeltevandsaflejringer, moræneler og til dels interglacialt materiale.

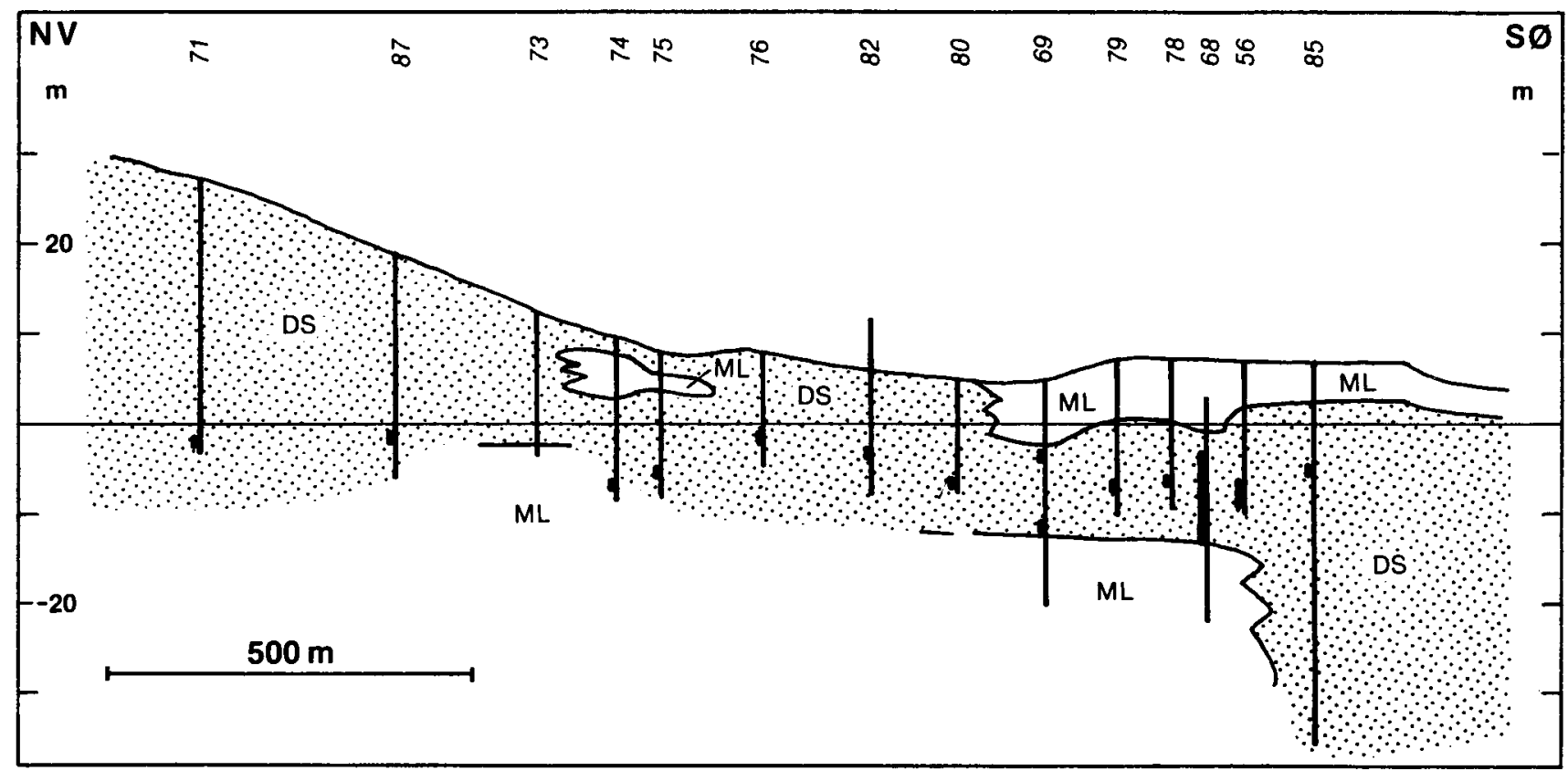


Hydrogeologi: De nedre, vandførende sand- og gruslag indeholder saltvand, hvorfor overvågningen er begrænset til det øvre reservoir, der består af sand- og grusaflejringer. Disse når helt op til terrænoverfladen i områdets vestlige del. Det $\emptyset$ vre reservoir har næsten overalt frit grundvandsspejl. Potentialet er påvirket af den relativt store indvinding på vandværket.

Grundvandskemi: Grundvandet i området er af calcium-bikarbonattypen. Vandet indeholder stedvist natriumklorid og dette tilskrives den kystnære beliggenhed. Vandet er dog generelt af fuldt tilfredsstillende drikkevandskvalitet. Generelt er der ikke sket nogen ændring af grundvandskemien inden for overvågningsperioden.

Vandbalance mm/år:

Middelnedbør 550

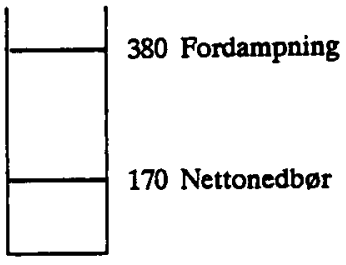

Kildeplads: Nordby kommunale vv, 0.2 mill. $\mathrm{m} 3 / \mathrm{ar}$

\section{Arealanvendelse \%:}

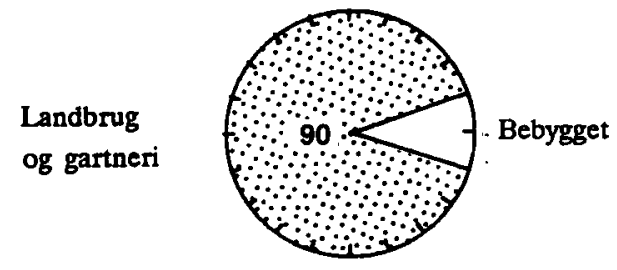

Registrerede depoter: ingen

Koncentrationen af udvalgte stoffer i forhold til dybde under terræn.

Graferne viser data fra 1989 og 1990.

Nitrat/Dybde

Klorid/Dybde

Sulfat/Dybde

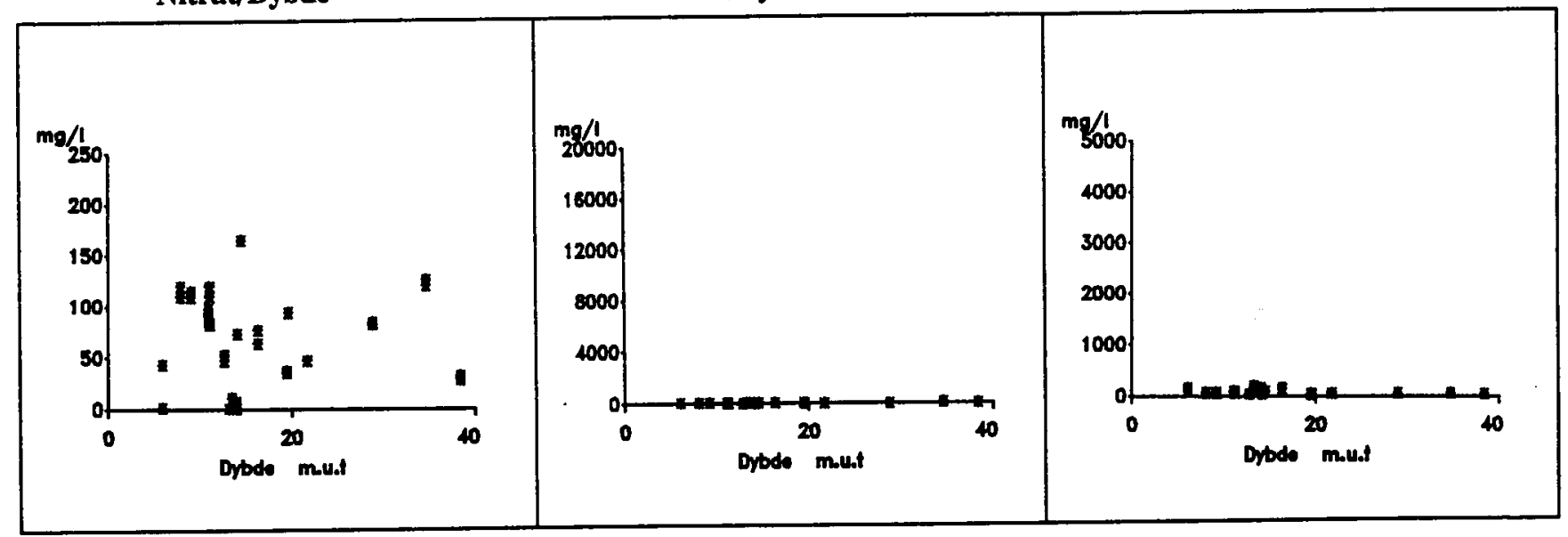




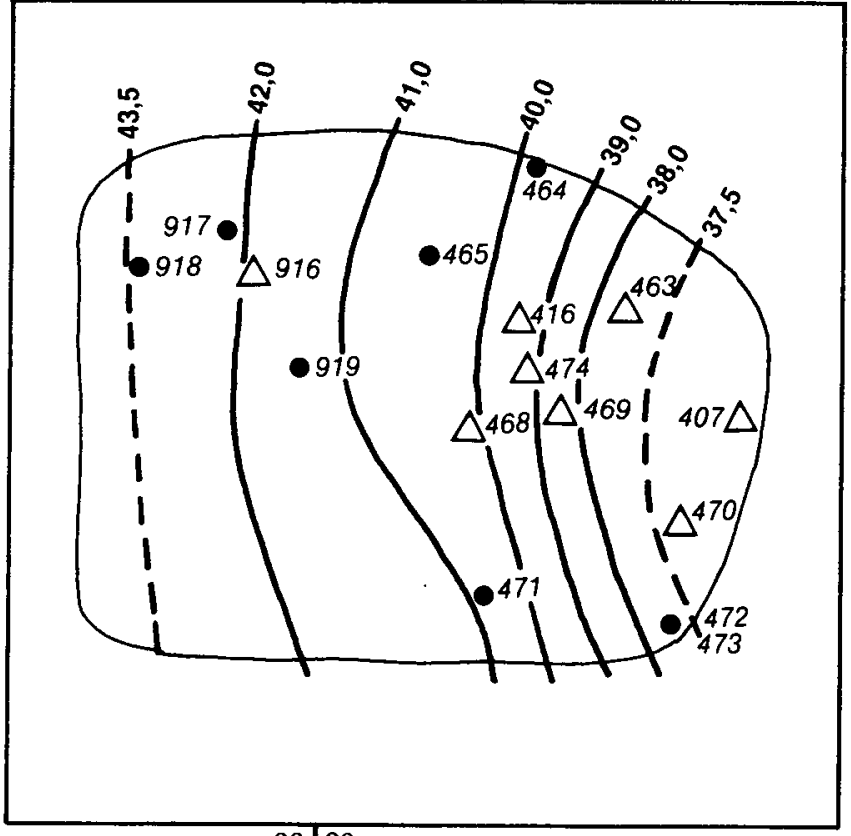

DGU nr.

$9 8 \longdiv { 9 9 }$

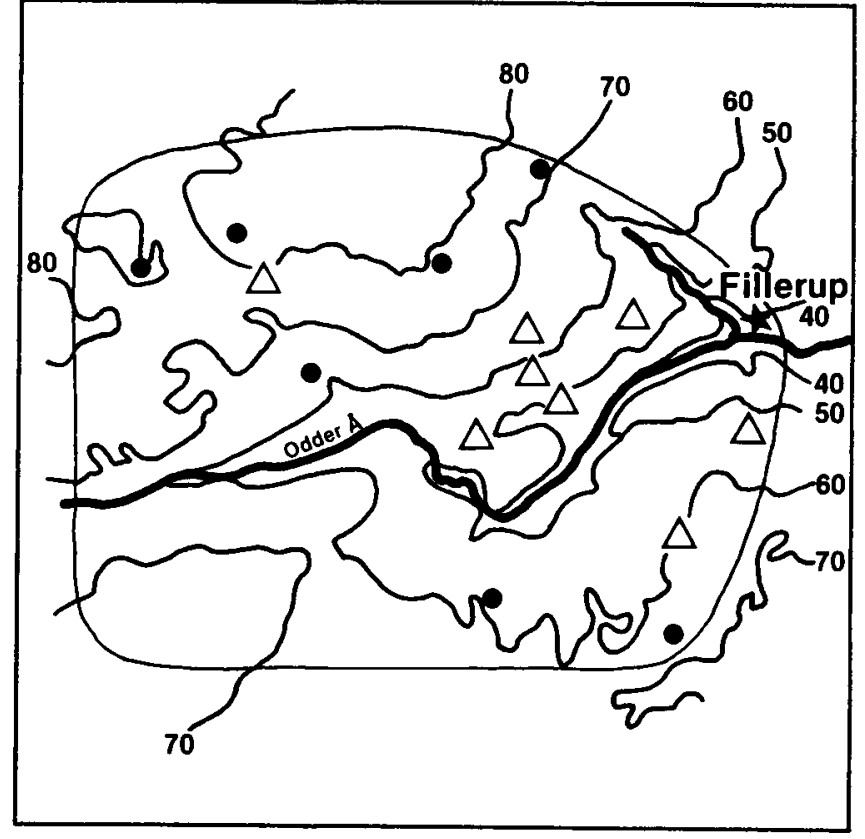

Areal $8 \mathrm{~km}^{2}$

Geologi: Den øverste prækvartære lagfølge er af Miocæn alder og består af glimmerler og -silt med horisonter af brunkul, overlejret af groft kvartssand. Den kvartære lagfølge består af en vekslende serie af moræneler og smeltevandsaflejringer.

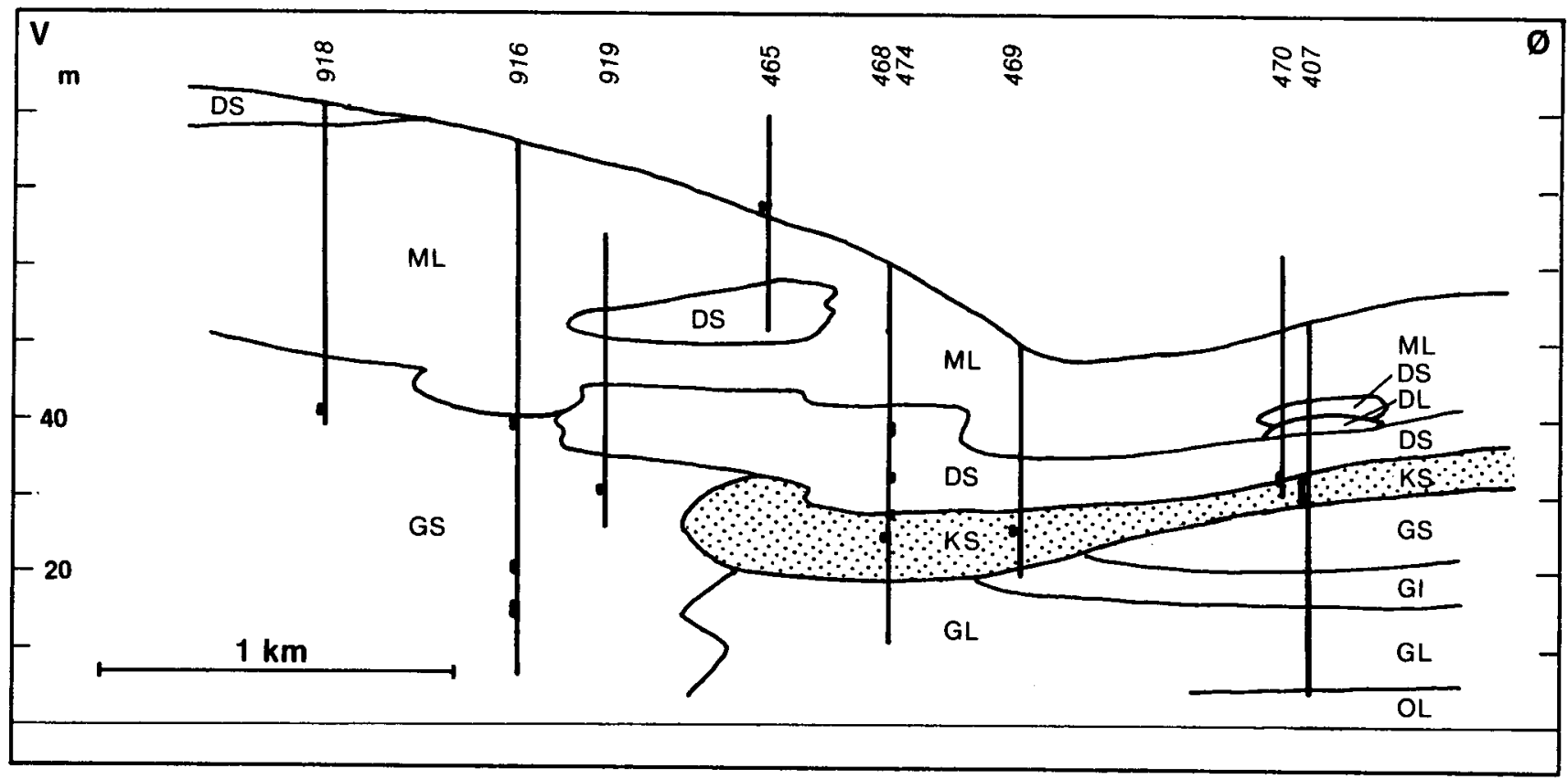


Hydrogeologi: Hovedreservoiret består af de udbredte og ret homogene lag af kvartssand og -grus og afgrænses nedad af det tertiære ler. Tykkelsen af det vandførende lag varierer meget. De sekundære reservoirer udgøres af smeltevandssand- og grus, der findes over kvartssandet og som lommer i morænelet. Hovedreservoiret er artesisk undtagen længst mod øst, hvor der er frit vandspejl.

Grundvandskemi: Grundvandet $\mathrm{i}$ området er af calcium-bikarbonattypen. Vandet fra hovedreservoiret har et lavt redoxpotentiale. Indholdet af ammonium, jern og mangan er relativt højt, mens indholdet af sulfat og klorid er relativt lavt. Både ilt- og nitratindholdet er ubetydeligt. Grundvandet fra det sekundære reservoir har højt sulfatindhold og lavt indhold af bikarbonat. Generelt er grundvandets kemiske sammensætning uændret inden for overvågningsperioden.

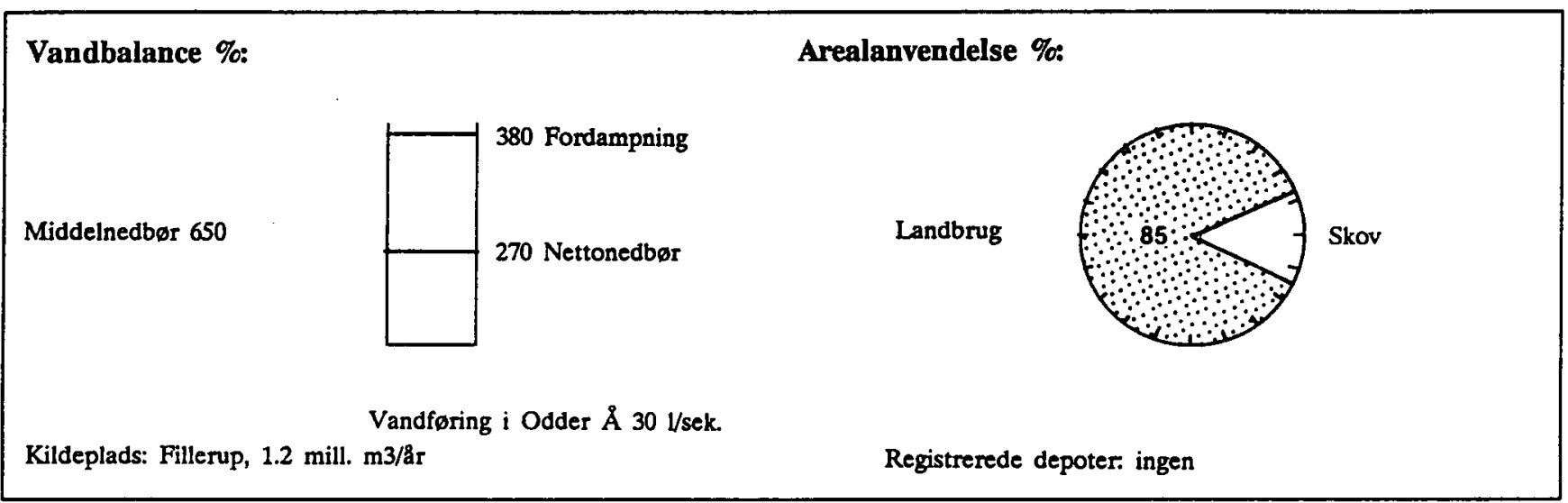

Koncentrationen af udvalgte stoffer i forhold til dybde under terræn.

Graferne viser data fra 1989 og 1990.

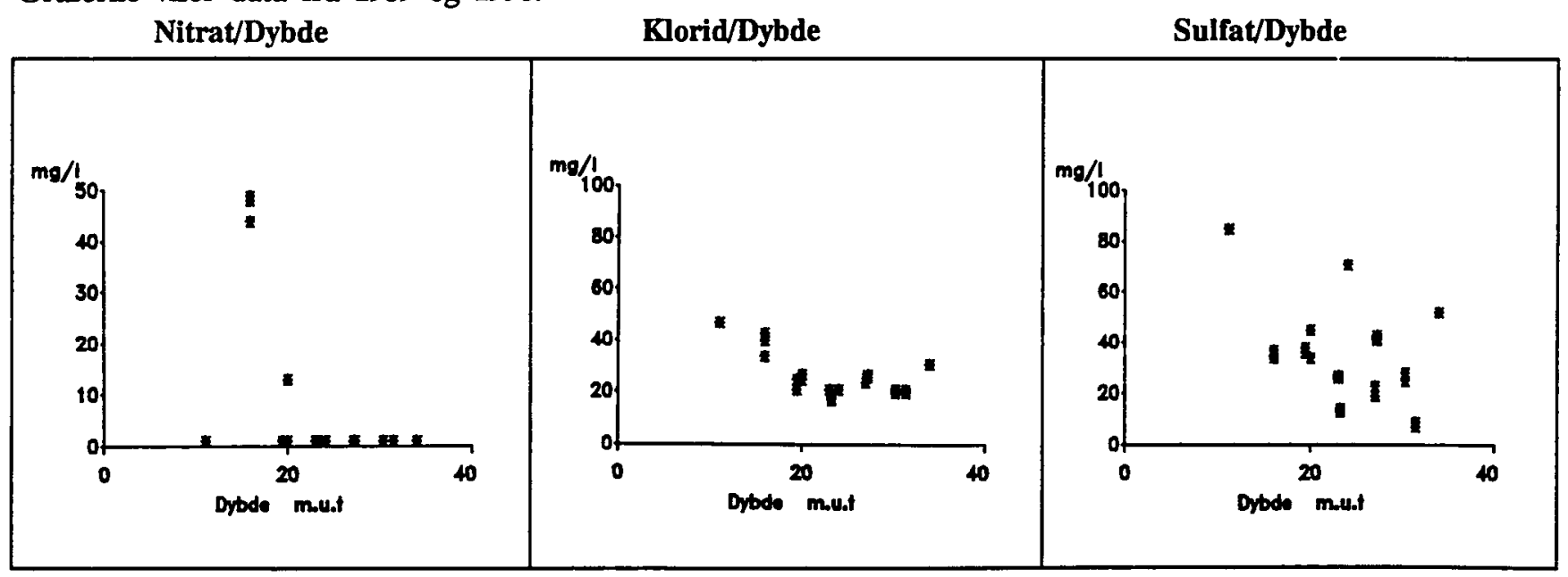




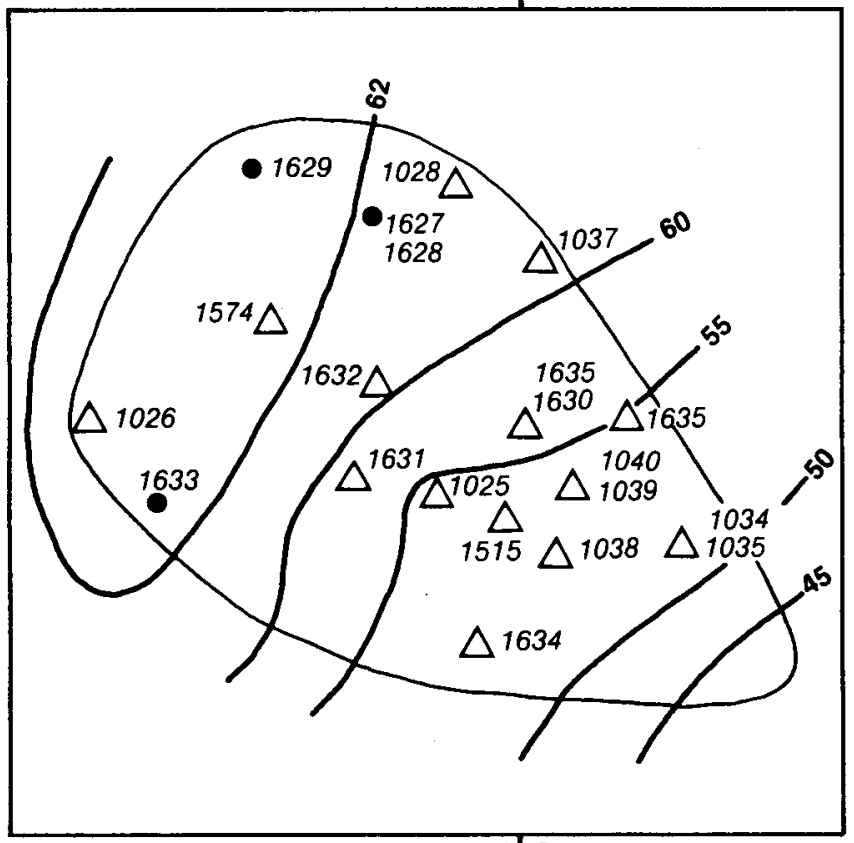

DGU nr.

$86 \mid 87$

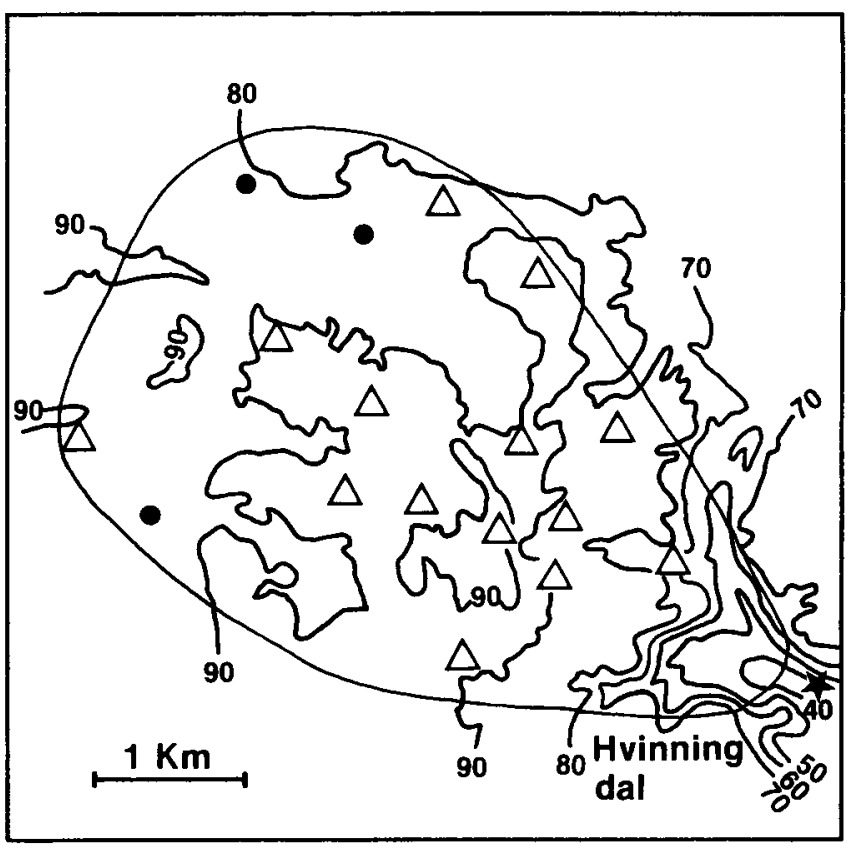

Areal $15 \mathrm{~km}^{2}$

Geologi: De $\emptyset$ verste prækvartære lag består af kvartssand samt glimmersand, -silt og -ler af Miocæn alder. Den prækvartære overflade har et jæunt relief. Den kvartære lagserie består af smeltevandssand og -grus med lokale indslag af moræneler.

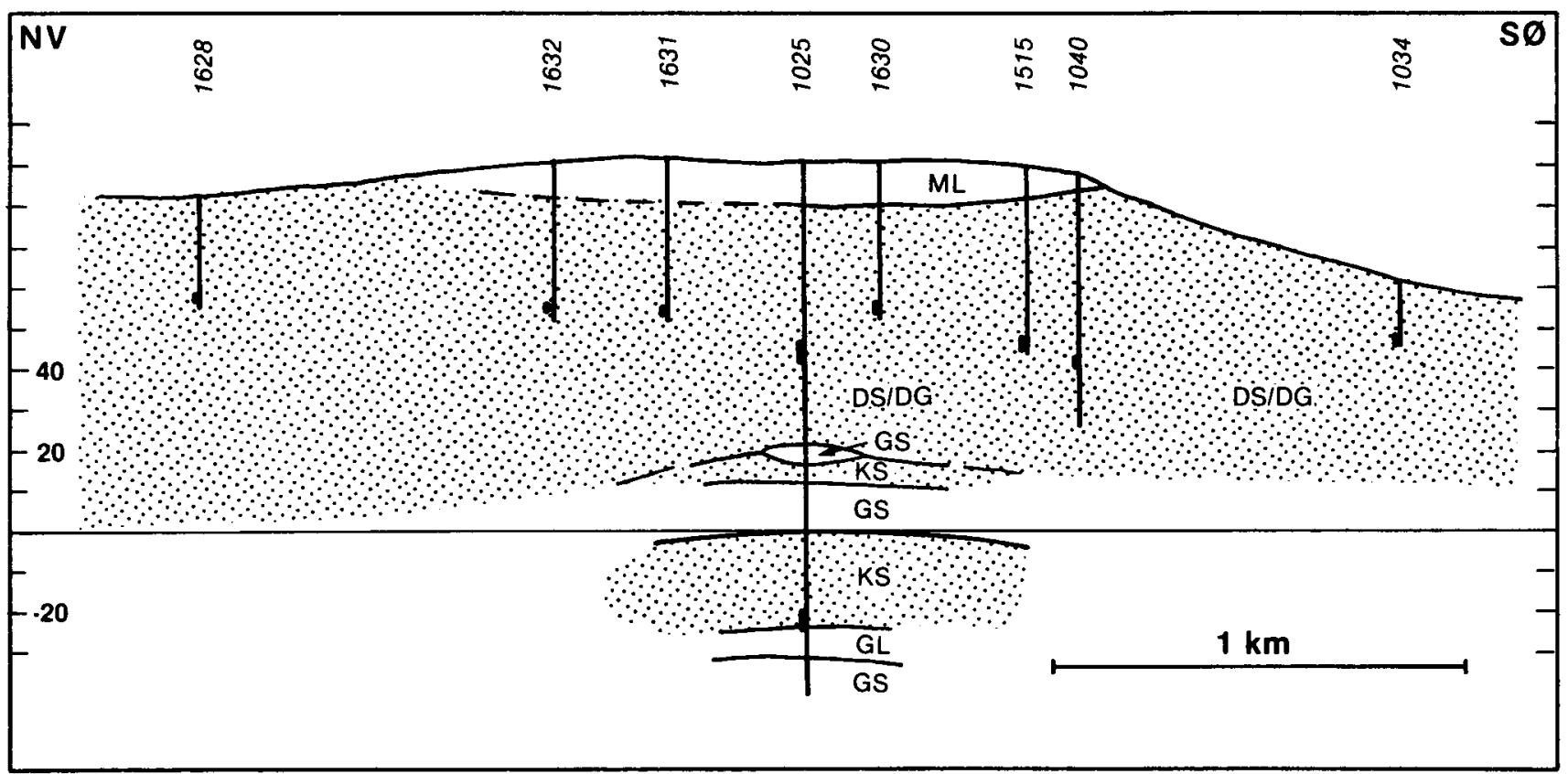


Hydrogeologi: Hovedreservoiret udgøres af de udbredte lag af kvartssand og smeltevandssand. Der er lokale sekundære reservoirer $\mathrm{i}$ de sandede kvartære lag. Både hovedreservoiret og de sekundære reservoirer har frit grundvandsspejl.

Grundvandskemi: De øverste ca. 10 meter af grundvandet er næsten mættet med ilt og nitrat trods den 40 meter tykke umættede zone. Vandet er surt med højt indhold af aggressiv kulsyre og en hårdhed på 2-6 $6^{\circ} \mathrm{H}$. Der er ikke sket nogen ændring i grundvandets sammensætning inden for undersøgelsesperioden.

Vandbalance $\mathrm{mm} / \mathrm{arr}$ :

Middelnedbør 750

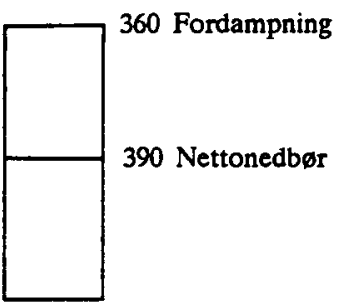

Kildeplads: Hvinningdal vv, 2.2 mill. m3/ăr
Arealanvendelse \%:

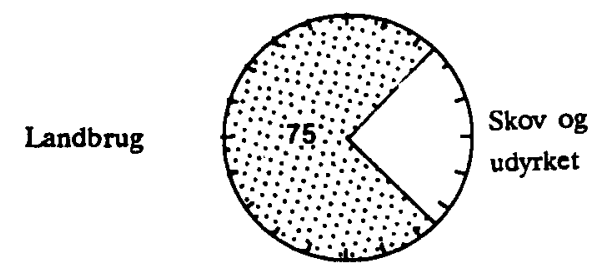

Registrerede depoter:

Koncentrationen af udvalgte stoffer $i$ forhold til dybde under terran.

Graferne viser data fra 1989 og 1990.

Nitrat/Dybde

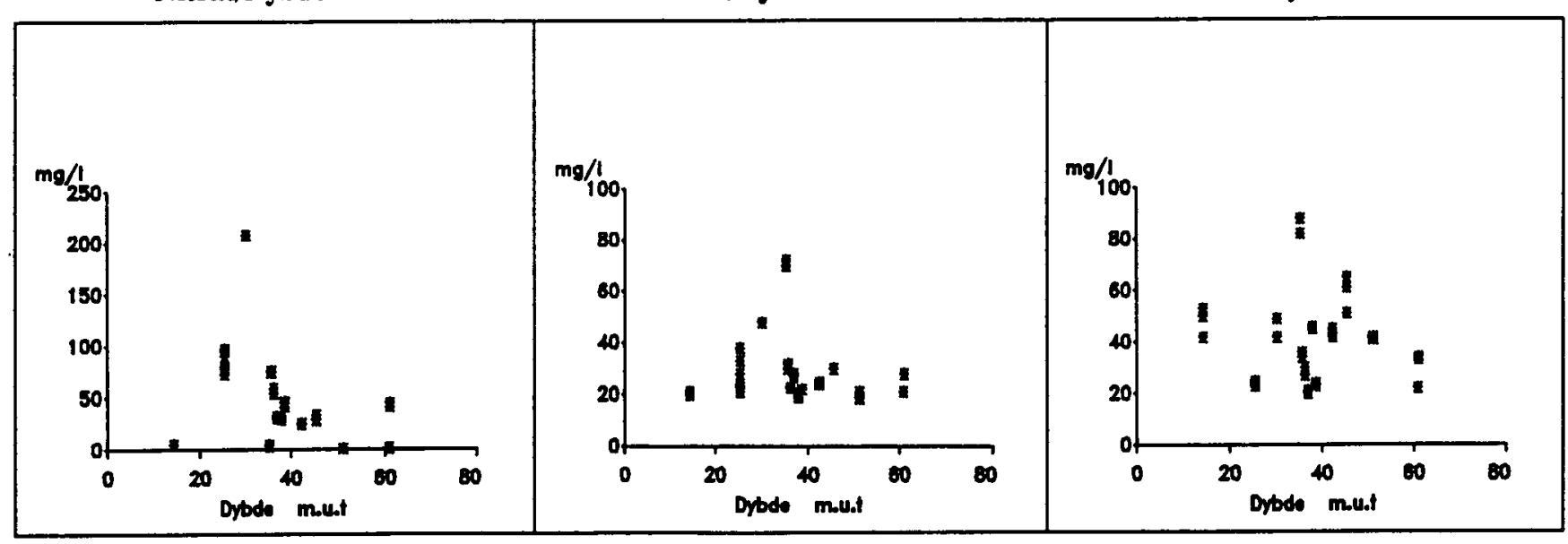



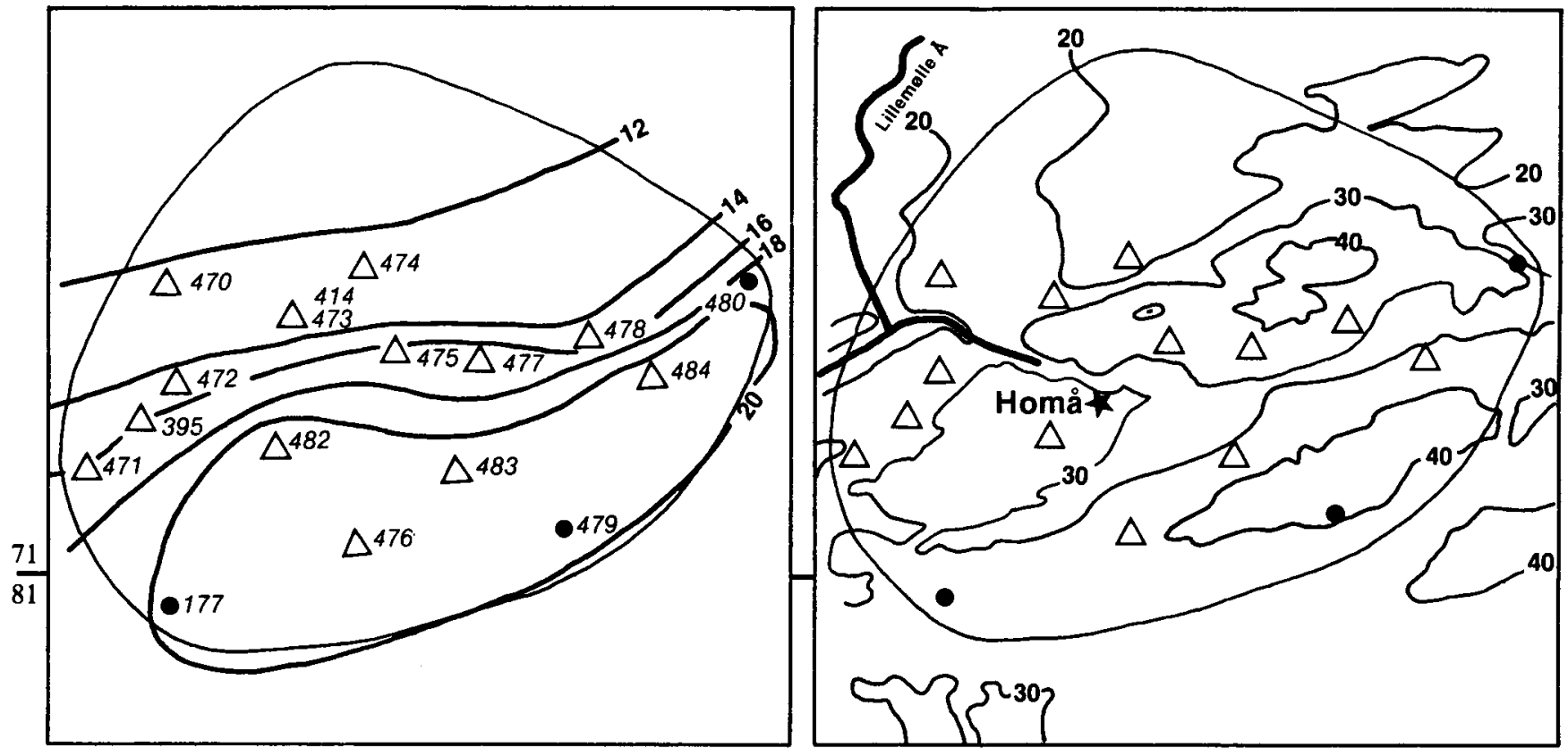

DGU nr. 71 og 81

Areal $15 \mathrm{~km}^{2}$

Geologi: Den øverste prækvartære lagserie består af hård og flintrig Danien kalksten i form af bryozokalk og kalksandskalk. Kalkstenene er mange steder opsprækket $\mathrm{i}$ forbindelse med forkastninger. Prækvartæroverfladen er ret ujævn, sandsynligvis som følge af en kombination af undergrundstektonik og isbevægelser. Områdets kvartære lagfølge består hovedsagelig af en vekslende serie af smeltevandsaflejringer med underordnede indslag af moræneler.

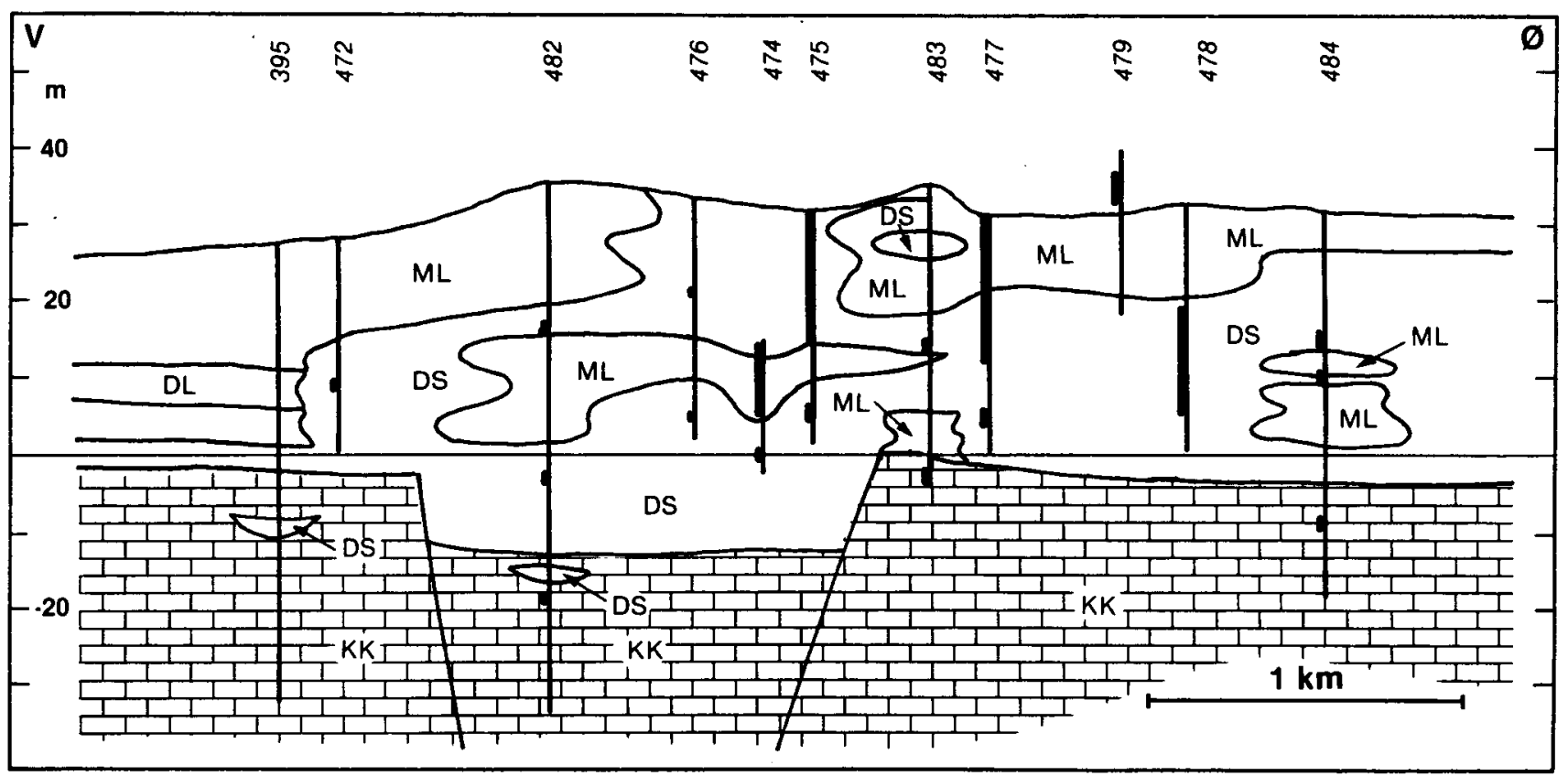


Hydrogeologi: Hovedreservoiret består hovedsagelig af Danienkalk. Den udnyttelige del af reservoiret er ca. 100 meter tyk. Dybere nede er der truffet saltholdigt grundvand. Den finkornede Danienkalk har i sig selv lav permeabilitet, som er knyttet til sprækkerne. Der er sekundære reservoirer i det kvartære smeltevandssand. Hovedreservoiret har artesiske forhold. På grund af den kvartære lagseries komplicerede opbygning kan vandudveksling mellem de sekundære reservoirer og kalkreservoiret dog ikke udelukkes.

Grundvandskemi: Grundvandets sammensæetning i kalkstensreservoiret varierer en del fra sted til sted men har iøvrigt ikke ændret sig inden for måleperioden. Sammensætningen af grundvandet $i$ kalkreservoiret og de sekundære reservoirer adskiller sig ikke systematisk fra hinanden. Dog er der mange steder et meget højt nitratindhold $\mathrm{i}$ grundvand $\mathrm{i}$ de sekundære reservoirer. Nitraten bevæger sig således dybt ned $\mathrm{i}$ kalkens

Vandbalance $\mathbf{m m} / \mathbf{a ̊ r}$ :

Middelnedbor 600

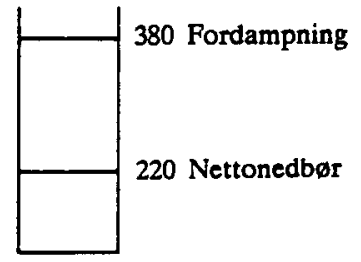

Kildeplads: Homå, 0.89 mill. m3/âr

\section{Arealanvendelse \%:}

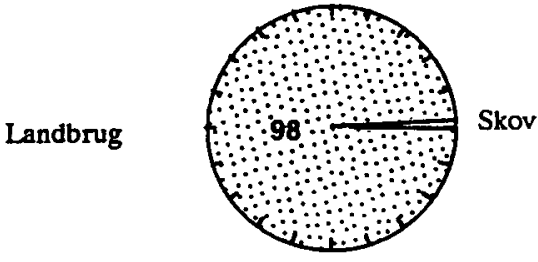

Registrerede depoter.

sprækkesystemer, når reduktionskapaciteten i dæklagene er opbrugt. Det er dette snarere end terrænformen eller en tyk umættet zone, der er årsag til nitratindholdet 35 meter under terræn.

Koncentrationen af udvalgte stoffer $i$ forhold til en dybde under terræn.

Graferne viser data fra 1989 og 1990.

Nitrat/Dybde

Klorid/Dybde

Sulfat/Dybde

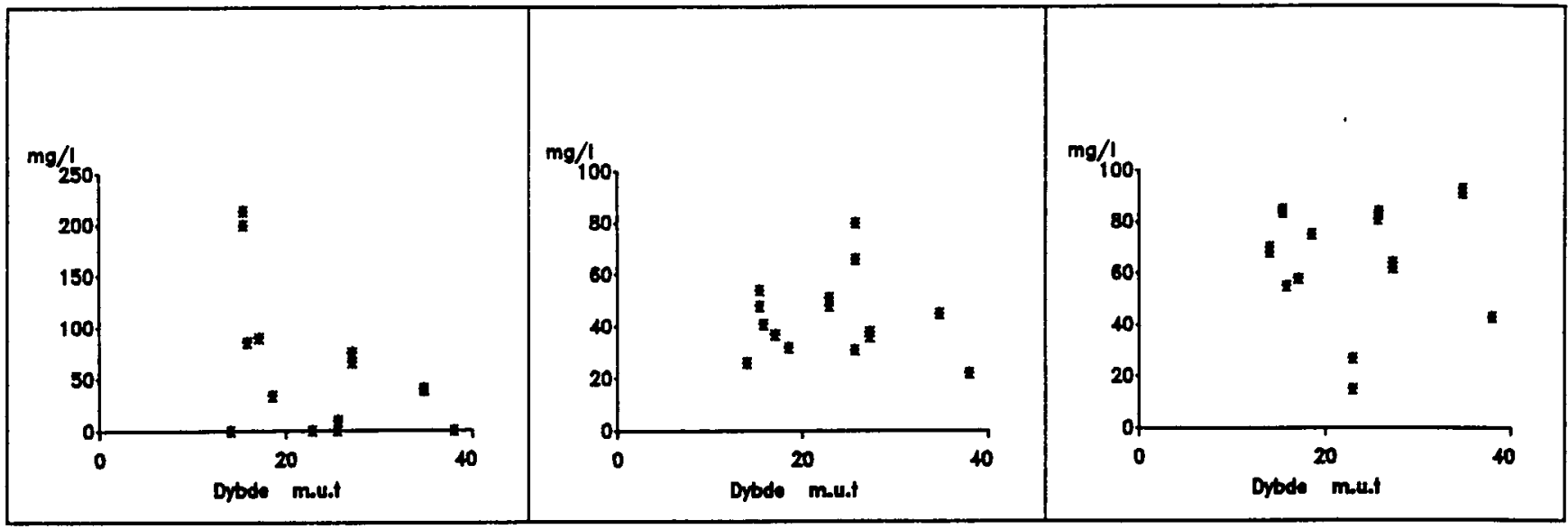




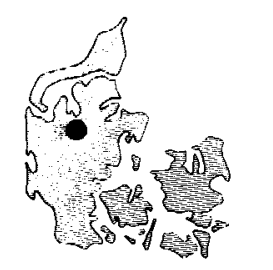

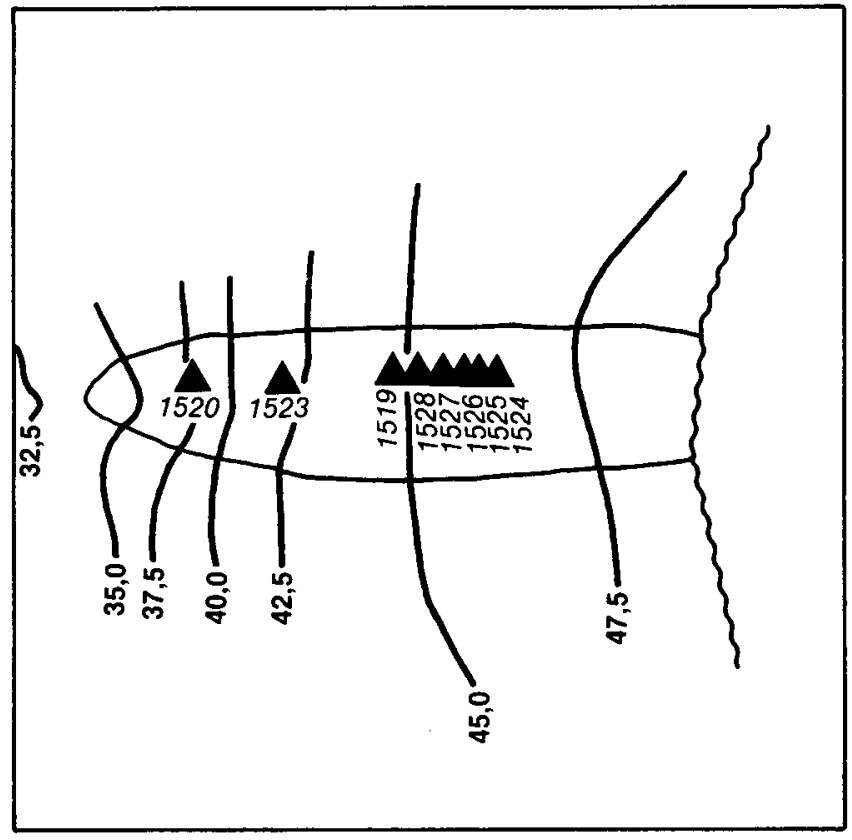

DGU nr. 66

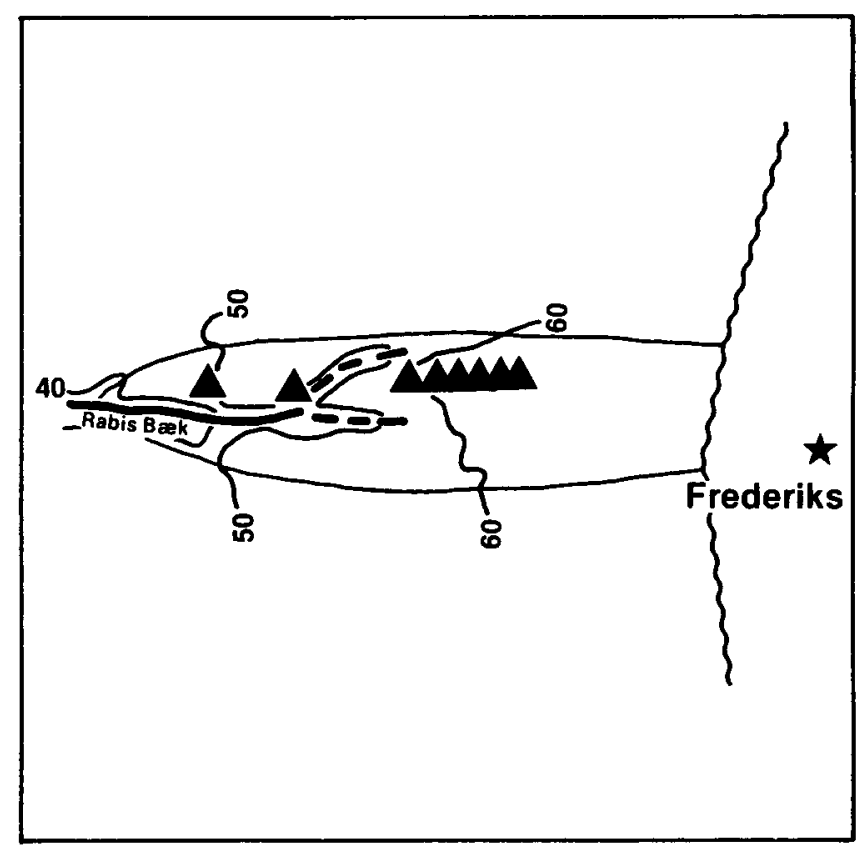

Areal $7 \mathrm{~km}^{2}$

Geologi: De øverste prækvartære lag består af Miocænt glimmersand, -silt og -ler, samt af kvartssand og underordnede lag af brunkul og lergytje. Den kvartære lagserie består hovedsagelig af sand- og gruslag, aflejret $\mathrm{i}$ store flettede smeltevandsfloder, der under afsmeltningsforløbet efter Weichsel istiden strømmede mod vest fra hovedopholdslinien.

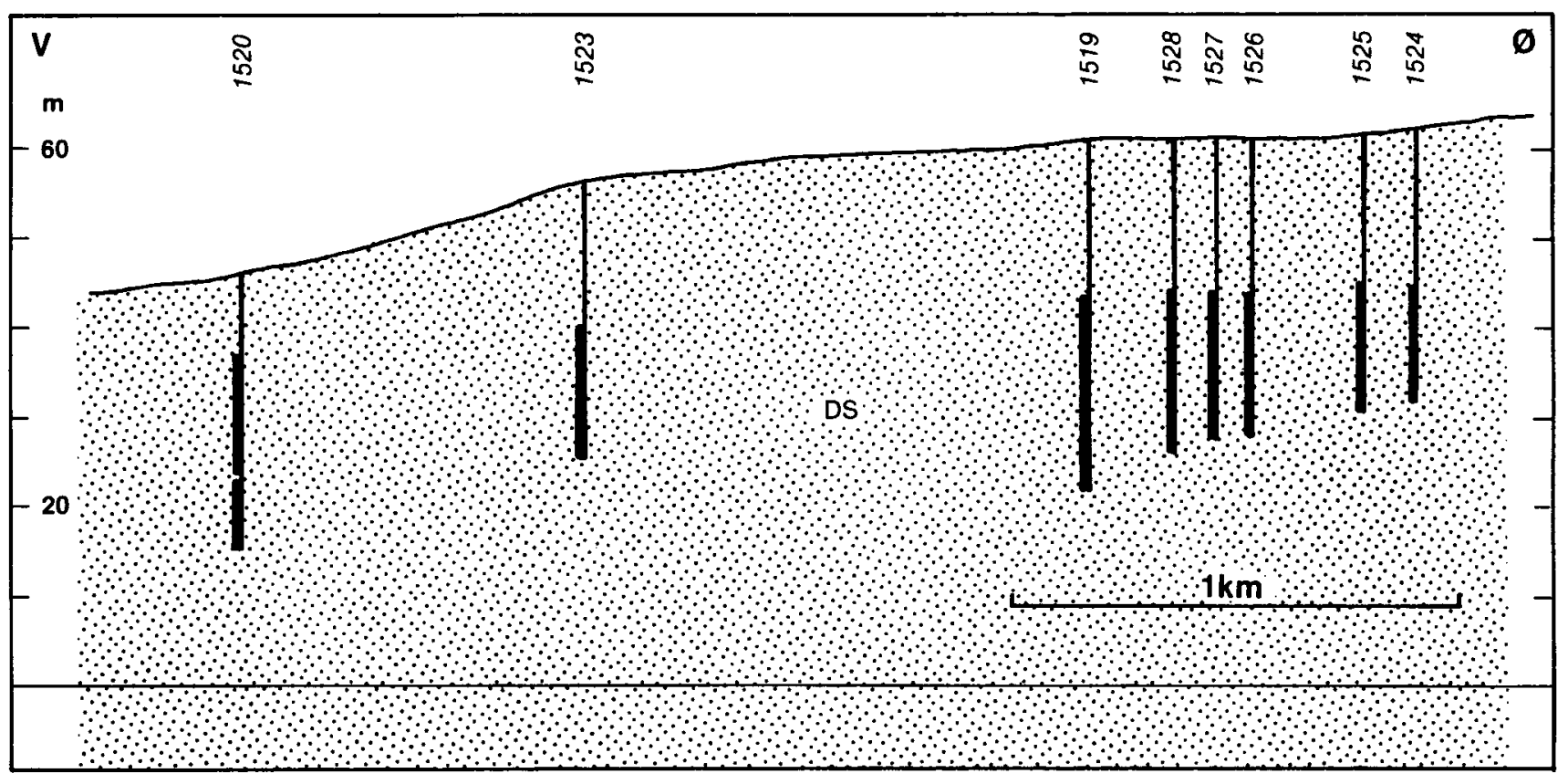


Hydrogeologi: I området er der et stort reservoir med frit grundvandsspejl i det kvartære smeltevandssand. De tertiare lag betragtes som svagt eller slet ikke vandførende. Dog udgør de tertiare og kvartare lag et fælles reservoir, hvor der forekommer kvartssand.

Grundvandskemi: Det nedre grundvand er af calcium-bikarbonattypen, det er nitratfrit og indeholder meget jern. Det øvre grundvand er overvejende af calciumsulfattypen. Det indeholder nitrat, særlig i den vestlige del af området, og jernindholdet er lavt.

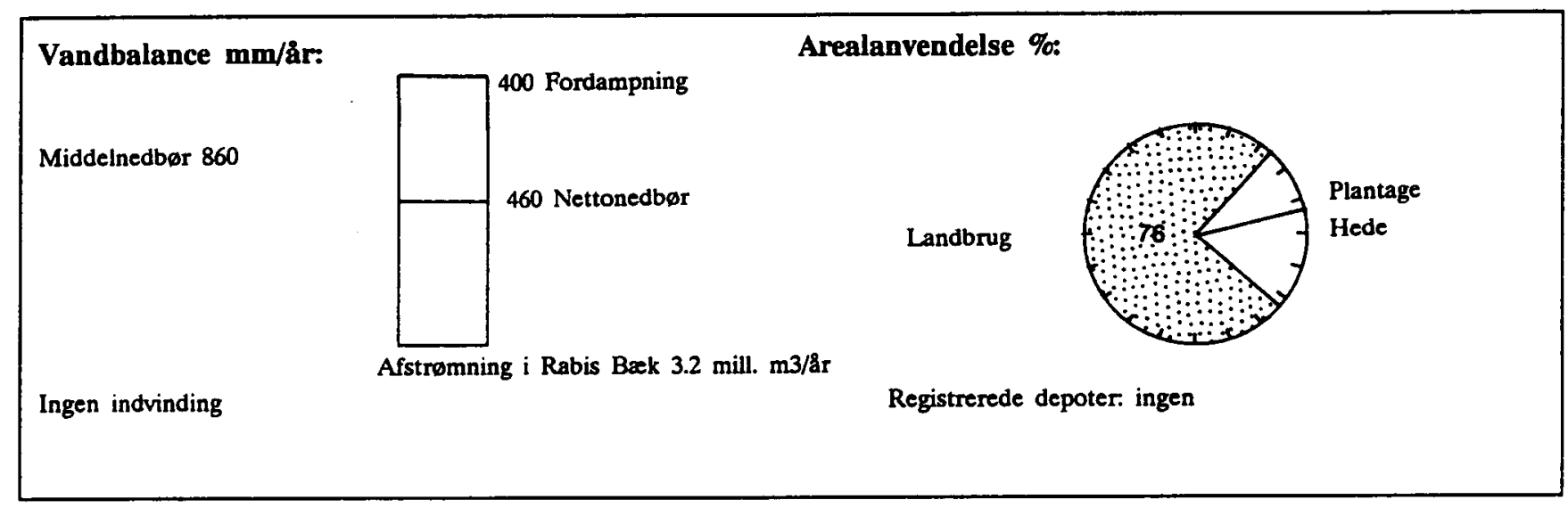

Koncentrationen af udvalgte stoffer $\mathrm{i}$ forhold til dybde under terræn.

Graferne viser data fra 1989 og 1990.

Nitrat/Dybde

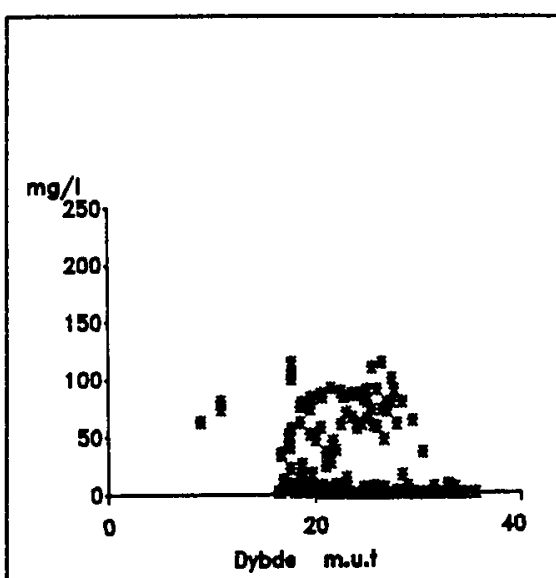

Klorid/Dybde

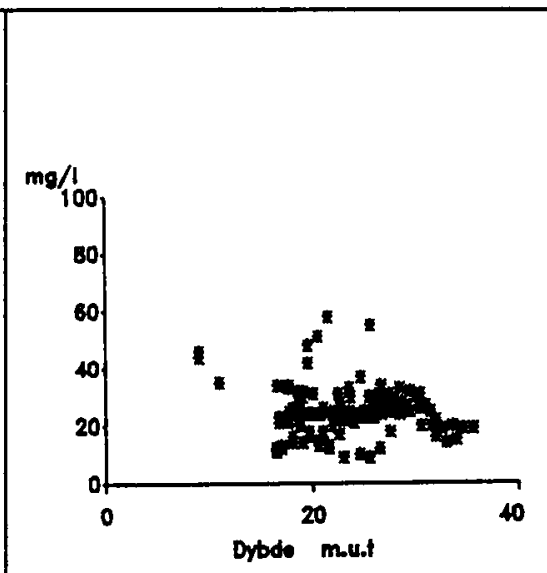

Sulfat/Dybde

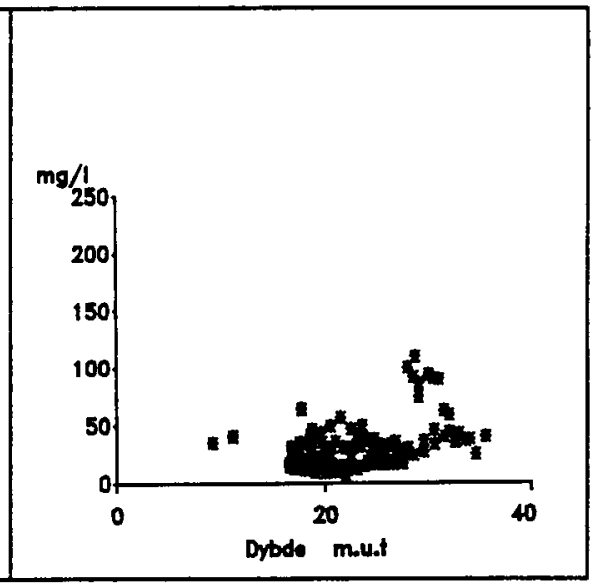


1214 IV S $\varnothing$

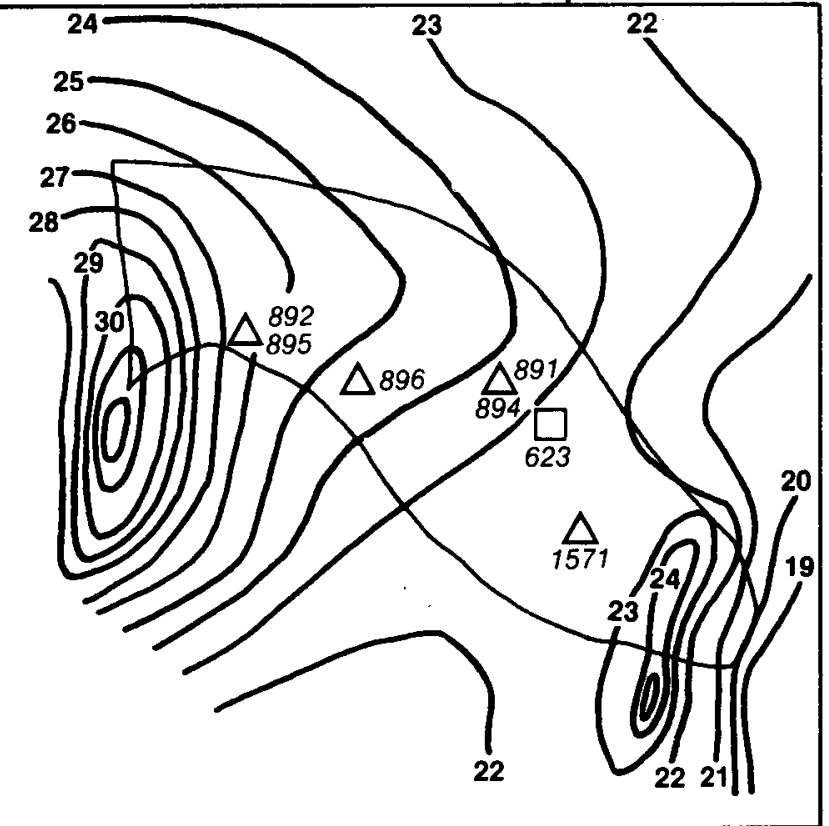

DGU nr.
$5 6 \longdiv { 6 6 }$
Terræn

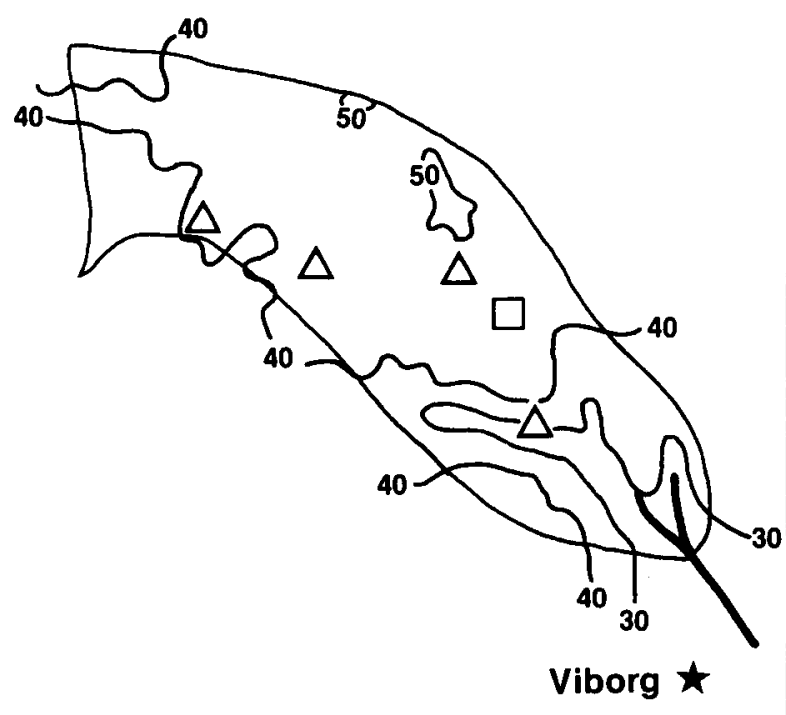

Areal $3,75 \mathrm{~km}^{2}$

Geologi: De øverste prækvartære lag i området består af tertiært ler og sand.

En begravet dal er nederoderet $\mathrm{i}$ de tertiære aflejringer. Dalen strækker sig fra Viborgsøerne mod nord nord-vest. Ved Viborg Nørresø findes der tertiære aflejringer op til kote 0 , mens dalen uddybes til mindst kote - 273 meter mod nord-vest. De dybestliggende kvartære aflejringer er dårligt kendt, men det formodes, at det sand vandværket indvinder fra er smeltevandssand og -grus af Elster alder. Herover er der smeltevandsler (Elster) og moræneler (Meldbjerghoved Formationen) af Saale alder. Øverst er der smeltevandssand og morænesand (St. Klinthøj Formationen) af Weichsel alder.

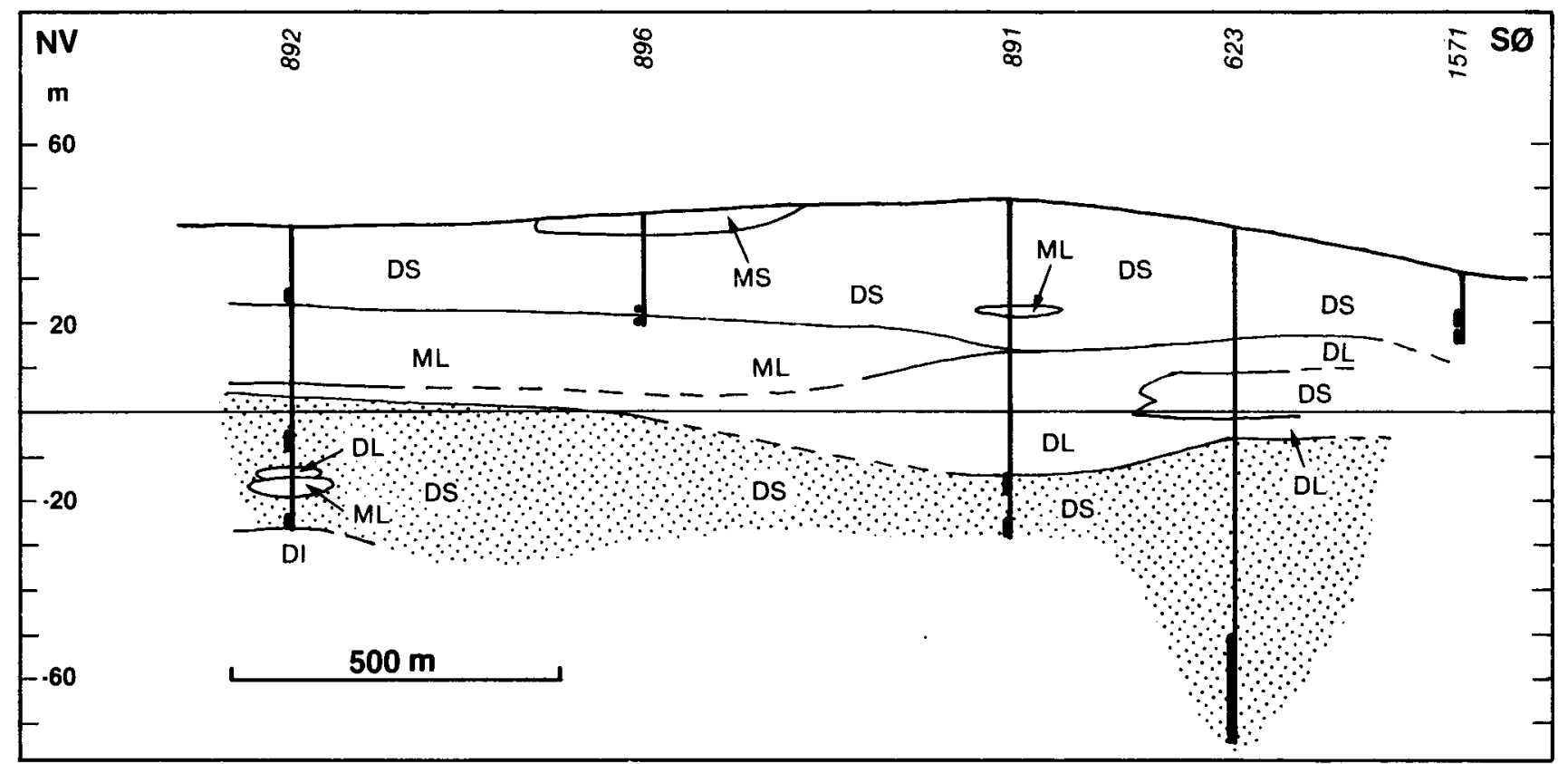


Hydrogeologi: Der kan groft set sondres mellem et $\emptyset$ vre og et nedre grundvandsreservoir, som adskilles af Melbjerghoved Formationen og det underliggende smeltevandsler. Hovedreservoiret består af smeltevandssand og grus fra Elster tid, iblandet ler- og siltdominerede lag. Reservoiret er overvejende artesisk. Det sekundære reservoir udgøres af smeltevandssand fra Weichsel, og har frit grundvandsspejl. I størstedelen af området foregår der nedsivning fra det øvre til det nedre reservoir. Potentialekortet og områdeafgrænsningen viser det $\emptyset$ vre reservoir. Grundet de artesiske forhold $\mathrm{i}$ hovedreservoiret er området antagelig meget større i dette niveau.

Grundvandskemi: Det $\emptyset$ vre grundvand indeholder ilt, aggressiv kulsyre og nitrat, men næsten intet jern. $\mathrm{pH}$ ligger mellem 6 og 7. Hårdhedsgraden er mellem 4 og 8.

Det nedre grundvand er helt eller næsten helt ilt- og nitrat-frit, mens indholdet af jern er højt. Det indeholder ikke aggressiv kulsyre og pH ligger mellem 7,5 og 8. Hårdhedsgraden er mellem 8 og 10.

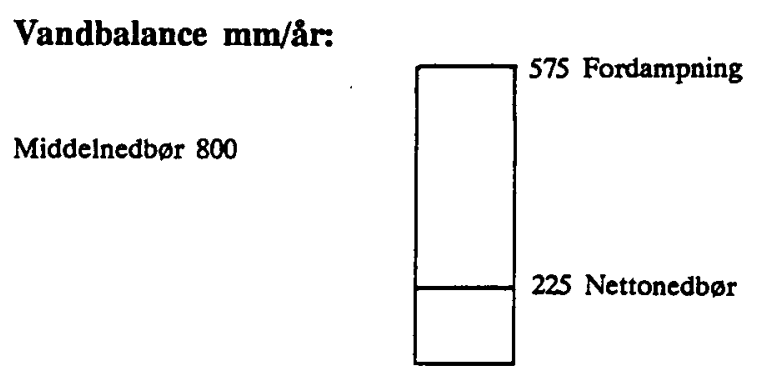

Kildeplads: Viborg Nord, 0.85 mill. $\mathrm{m} 3 / \mathrm{ar}$

\section{Arealanvendelse \%:}

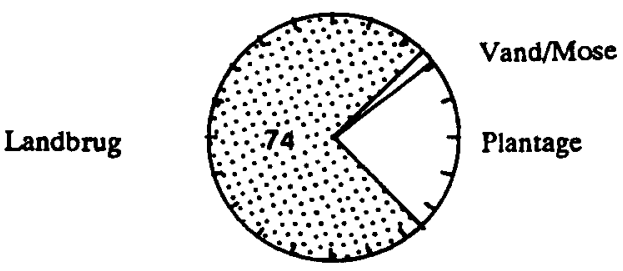

Registrerede depoter. ingen

Koncentrationen af udvalgte stoffer i forhold til dybde under terræn. Graferne viser data fra 1989 og 1990.

Nitrat/Dybde

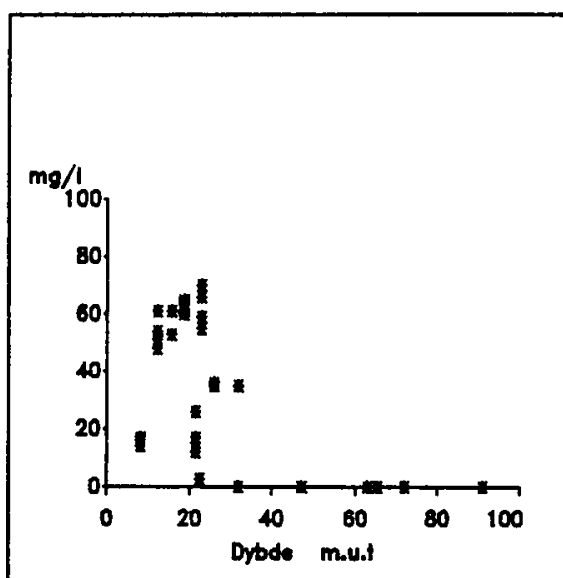

Sulfat/Dybde

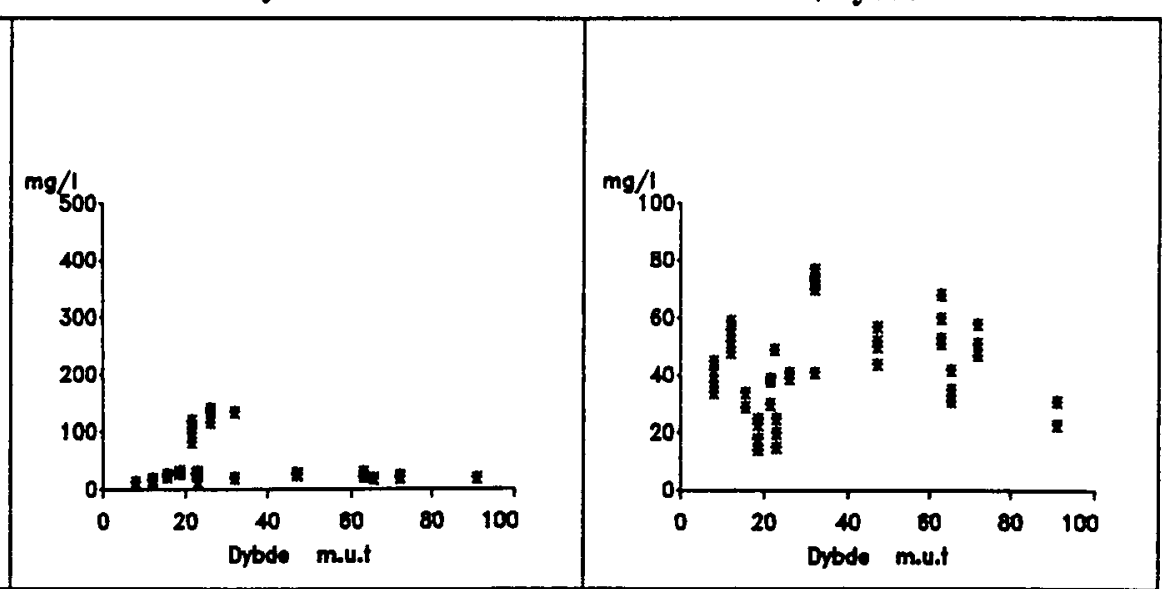



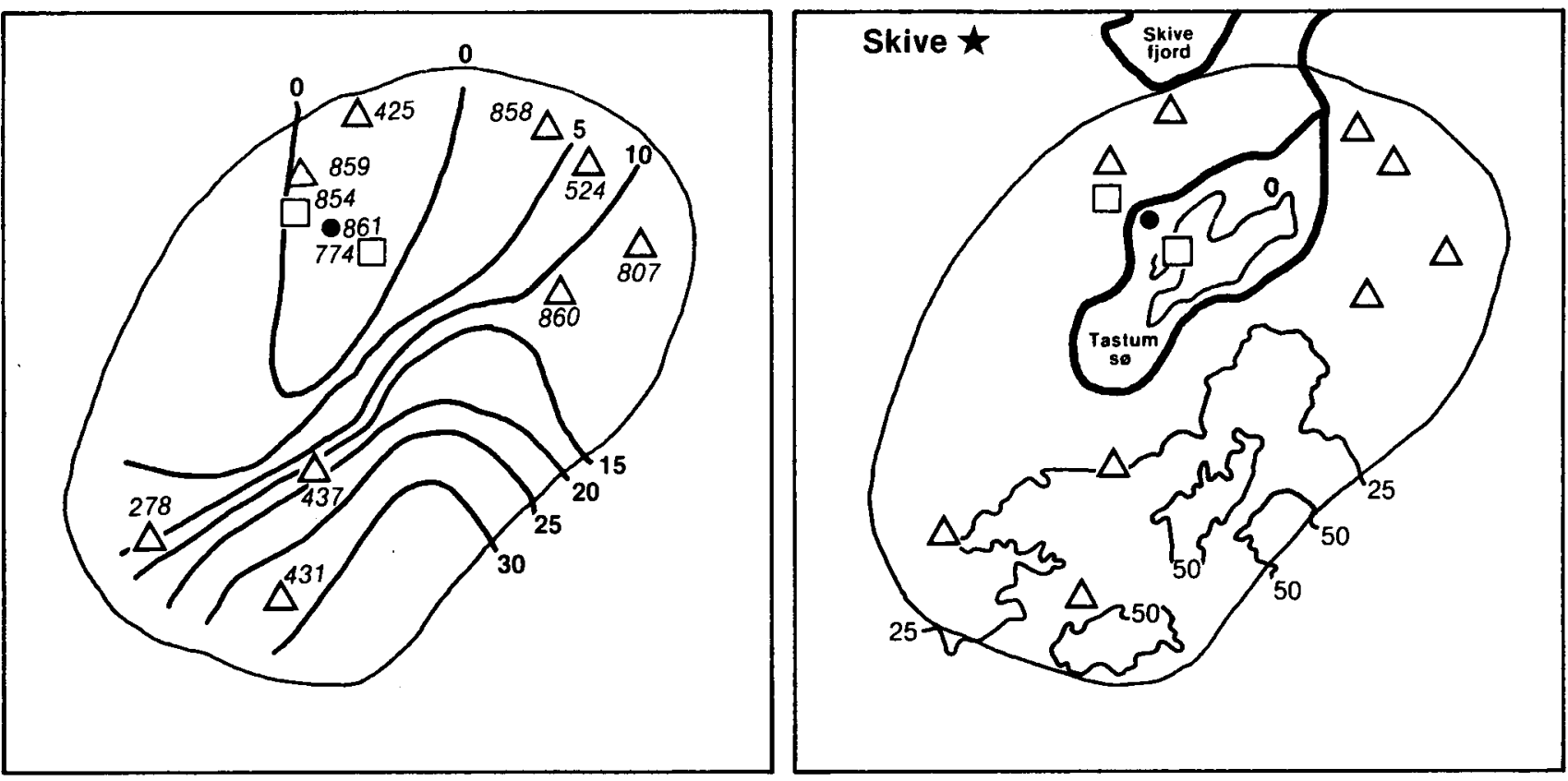

DGU nr. 55

Areal $50 \mathrm{~km}^{2}$

Geologi: De hydrogeologisk væsentligste aflejringer i området er smeltevandssedimenter fra forskellige glaciale perioder. Disse aflejringer er for en stor dels vedkommende blevet udsat for glacial deformation.

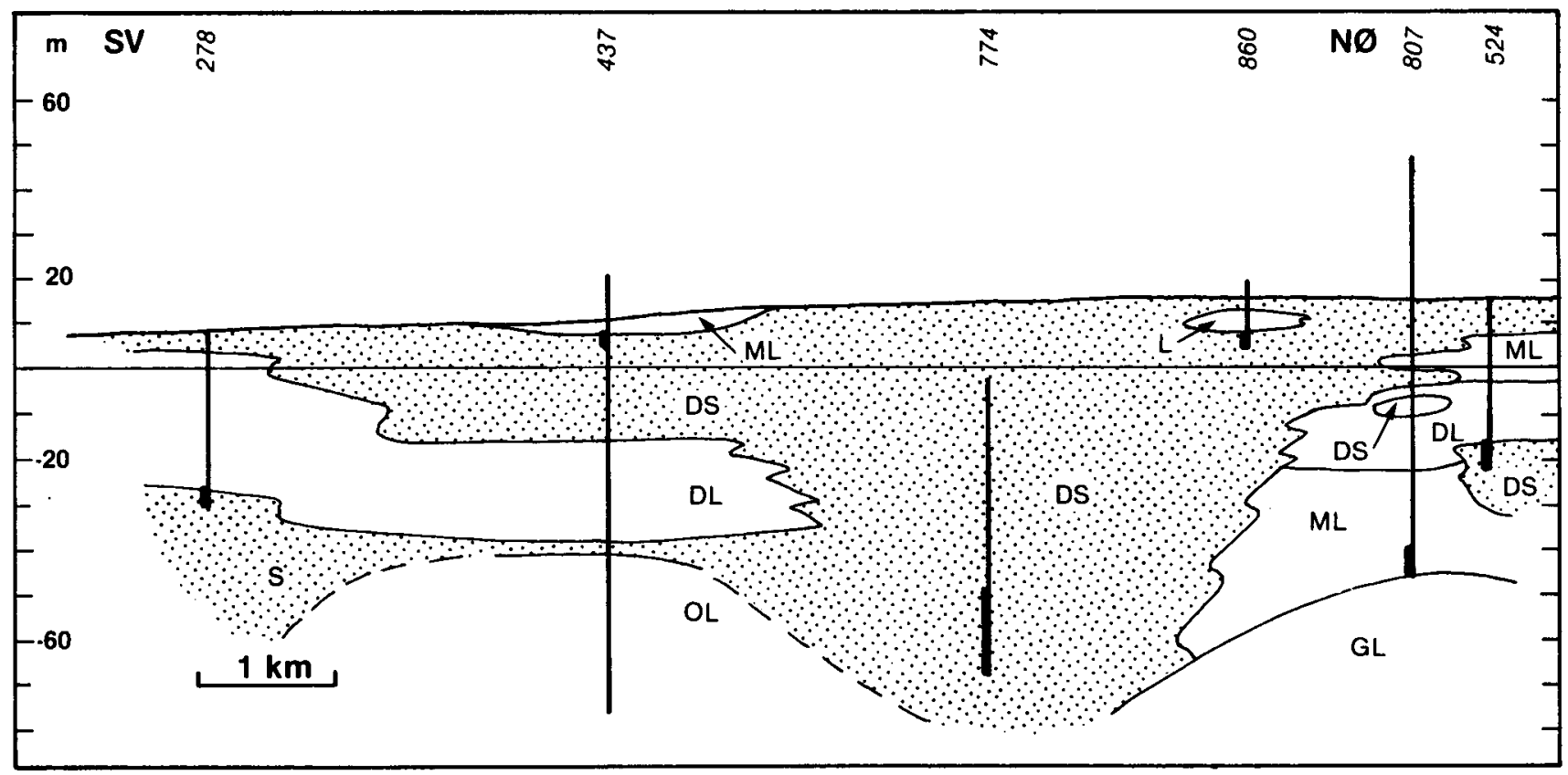


Hydrogeologi: Hovedreservoiret er artesisk, og består af smeltevandssand. Dette reservoir er antagelig aflangt i retningen nord-syd lige som hovedboringernes sænkningstragt. Der er flere steder overfladenære sekundære reservoirer med frit grundvandsspejl, bl.a. ved Dommerby Hede, ved Røgvad og omkring Kjeldbjerg. Grundet de artesiske forhold $\mathrm{i}$ hovedreservoiret er områdeafgrænsningen angivet "med rund hånd". Potentialekortet viser forholdene $\mathrm{i}$ hovedreservoiret.

Grundvandskemi: Grundvandet $\mathrm{i}$ hovedreservoiret er ilt- og nitratfrit, mens indholdet af jern er højt. Det indeholder ikke aggressiv kulsyre, $\mathrm{pH}$ ligger mellem 7,6 og 8 og hårdhedsgraden er mellem 5 og 12. Indholdet af natrium og klorid er steget støt gennem 80'erne og nåede i 1990 op på 140 milligram pr. liter. Grundvandet $i$ det sekundære reservoir er ilt- og nitratholdigt, og indeholder stedvis aggressiv kulsyre.

Vandbalance mm/år:

Middelnedbør 775

Middelnedoør 775

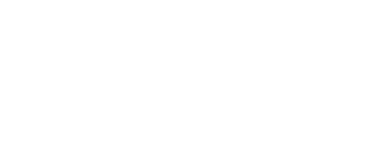

Kildeplads:Skive, 3 mill. m3/år

\section{Arealanvendelse \%:}

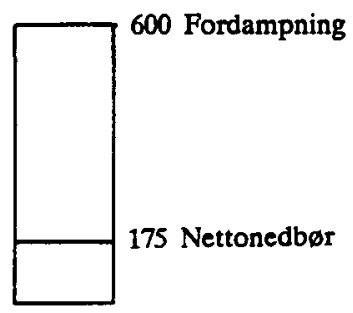

Landbrug

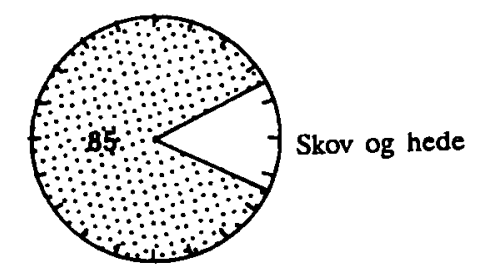

Registrerede depoter: ingen

Koncentrationen af udvalgte stoffer i forhold til dybde under terræn.

Graferne viser data fra 1989 og 1990.

Nitrat/Dybde

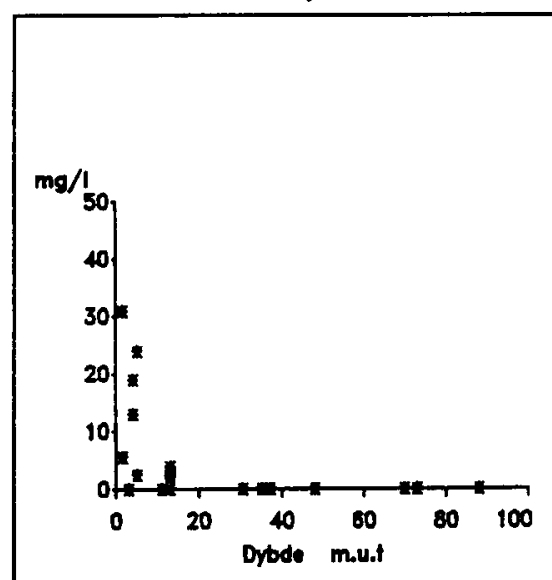

Sulfat/Dybde

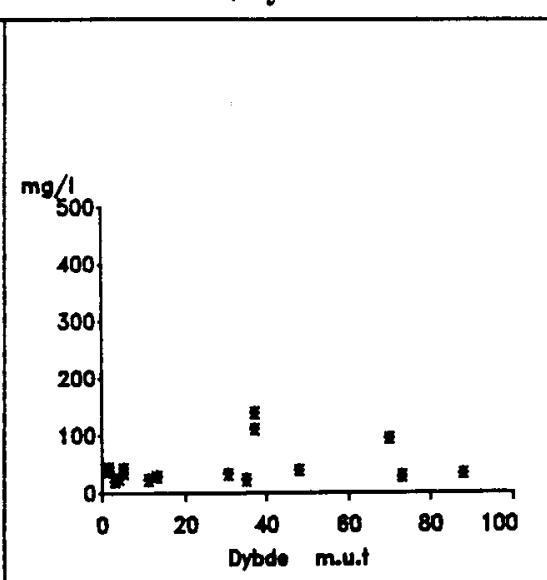

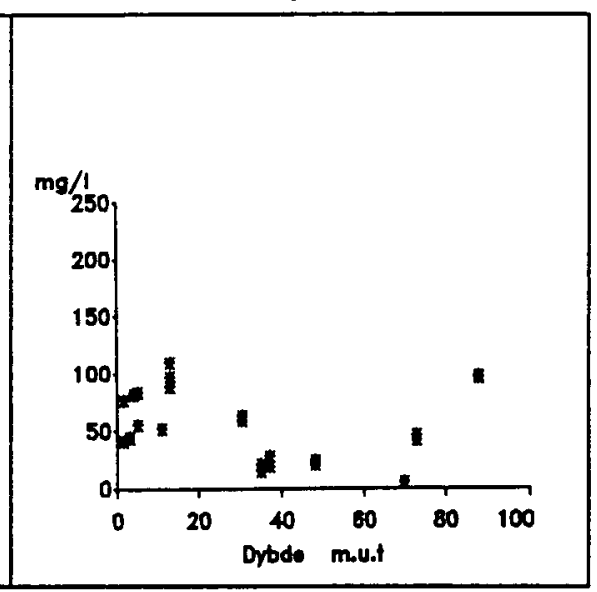



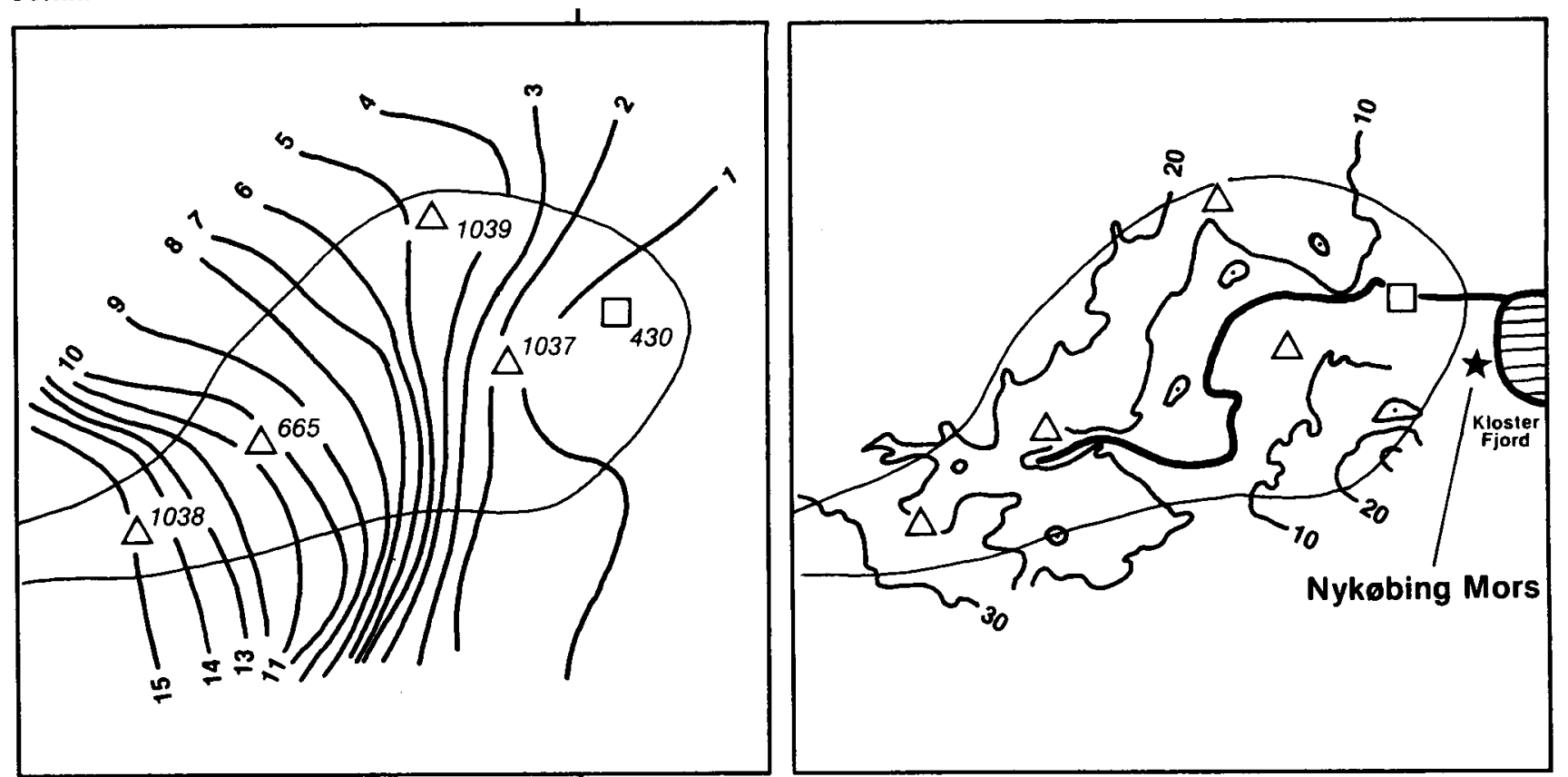

DGU nr.

$3 7 \longdiv { 3 8 }$

Areal $14 \mathrm{~km}^{2}$

Geologi: Den øverste prækvartære lagserie i området består af tertiære kalksten fra Danien overlejret af ler. Kalkoverfladen har kuppel-form. De kvartære aflejringer består af sandede og grusede smeltevandsaflejringer og moræneler, samt $\mathrm{i}$ den $\emptyset$ stlige del af området af stenalderhavets aflejringer.

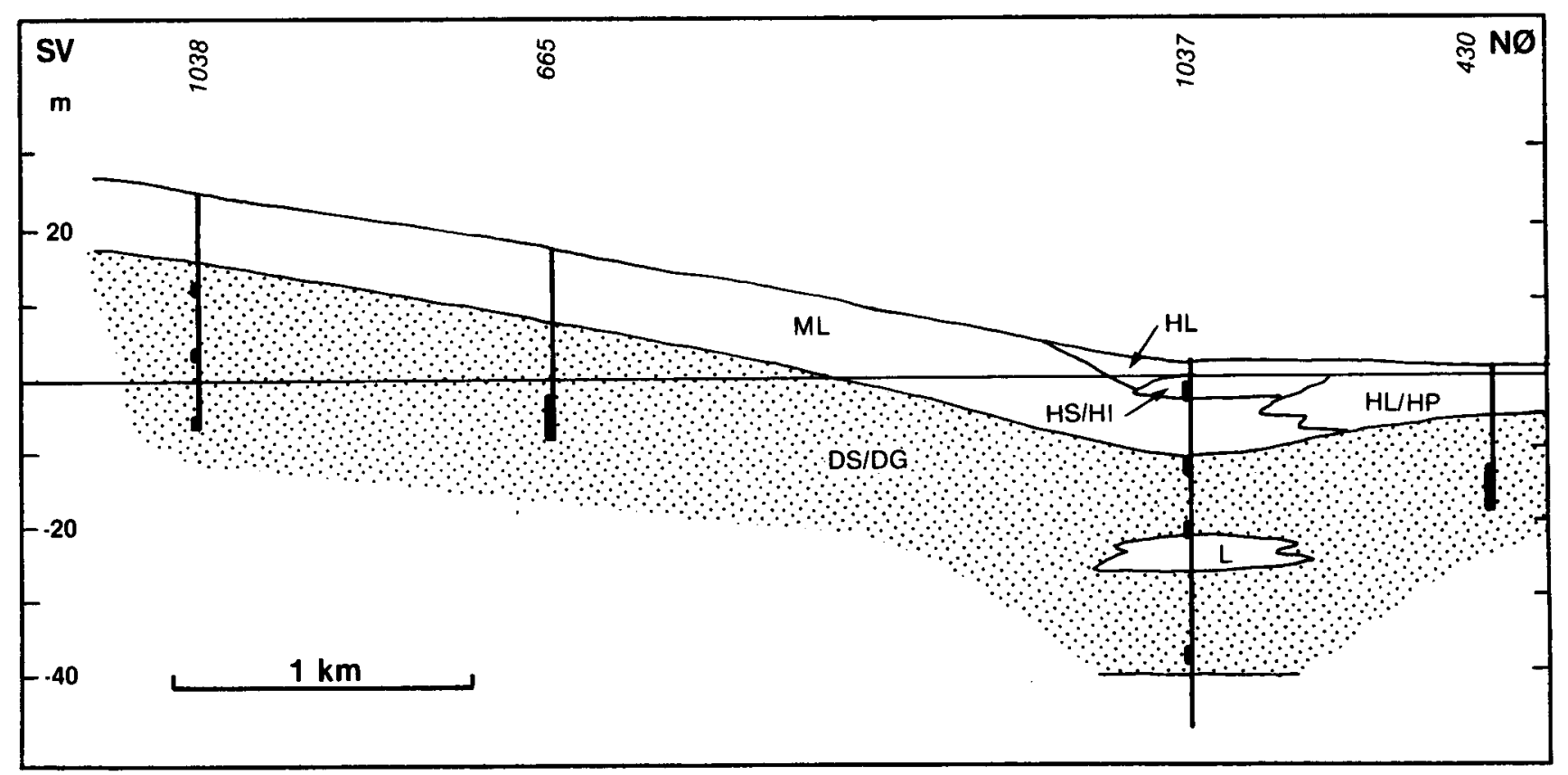


Hydrogeologi: Hovedreservoiret, der overvejende har frit grundvandsspejl, består af sandede smeltevandsaflejringer, samt i dele af området af kalksten. Herudover er der flere lokale sekundære grundvandsreservoirer.

Grundvandskemi: Grundvandet i hovedreservoiret er ilt- og nitratholdigt, mens indholdet af jern og mangan er lavt. pH er mellem 7 og 7,8 og hårdheden mellem 8 og $15^{\circ} \mathrm{dH}$. Kun det dybeste unders $\varnothing$ gte grundvand er ilt- og nitratfrit. Vandet fra hovedboringen har et forhøjet indhold af natriumklorid. Det øverste grundvand, i de sekundære reservoirer, analyseres kun et enkelt sted. Vandet har her et relativt højt indhold af jern, sulfat calcium og bikarbonat. $\mathrm{pH}$ er over 7 og vandet er iltfrit.

Vandbalance mm/år:

Middelnedbør 775

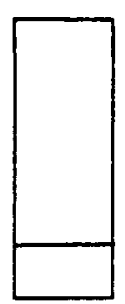

625 Fordampaing

150 Nettonedbør

Kildeplads: Nykøbing vv, 2.15 mill. $\mathrm{m} 3 / \mathrm{ar}$
Arealanvendelse \%:

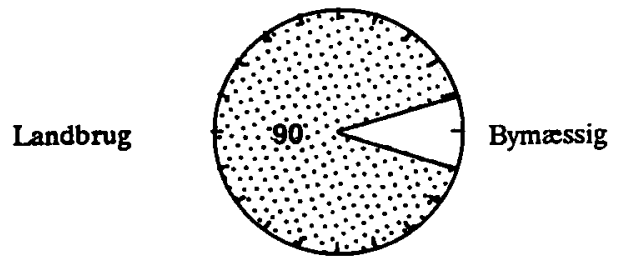

Registrerede depoter: ingen

Koncentrationen af udvalgte stoffer i forhold til dybde under terræn.

Graferne viser data fra 1989 og 1990.

Nitrat/Dybde

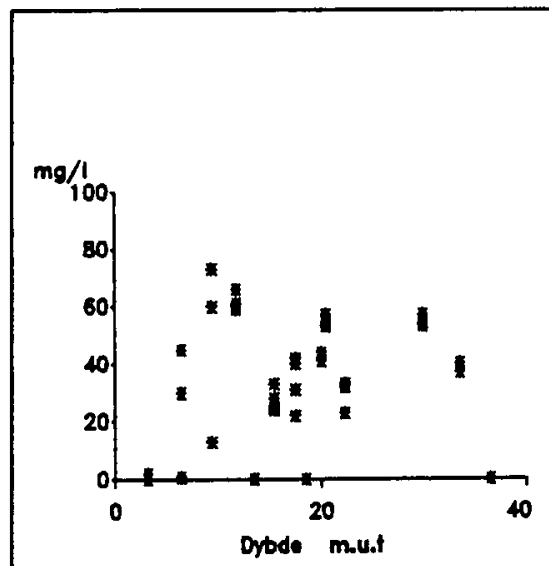

Klorid/Dybde

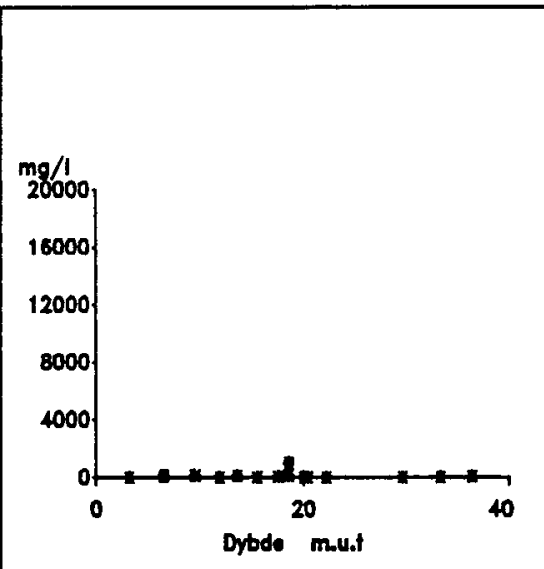

Sulfat/Dybde

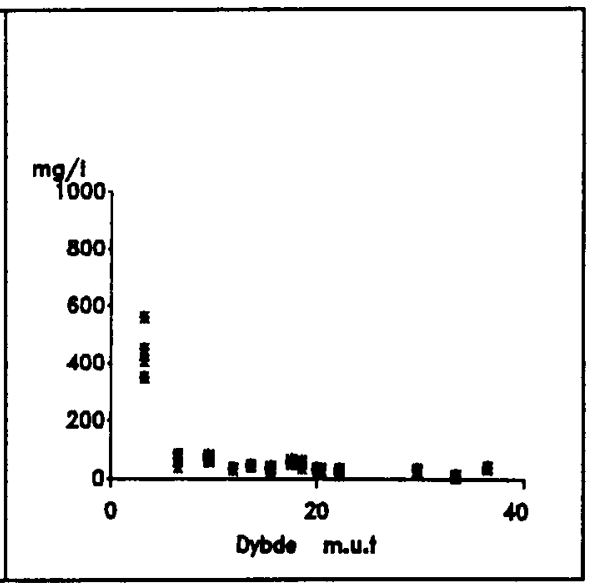




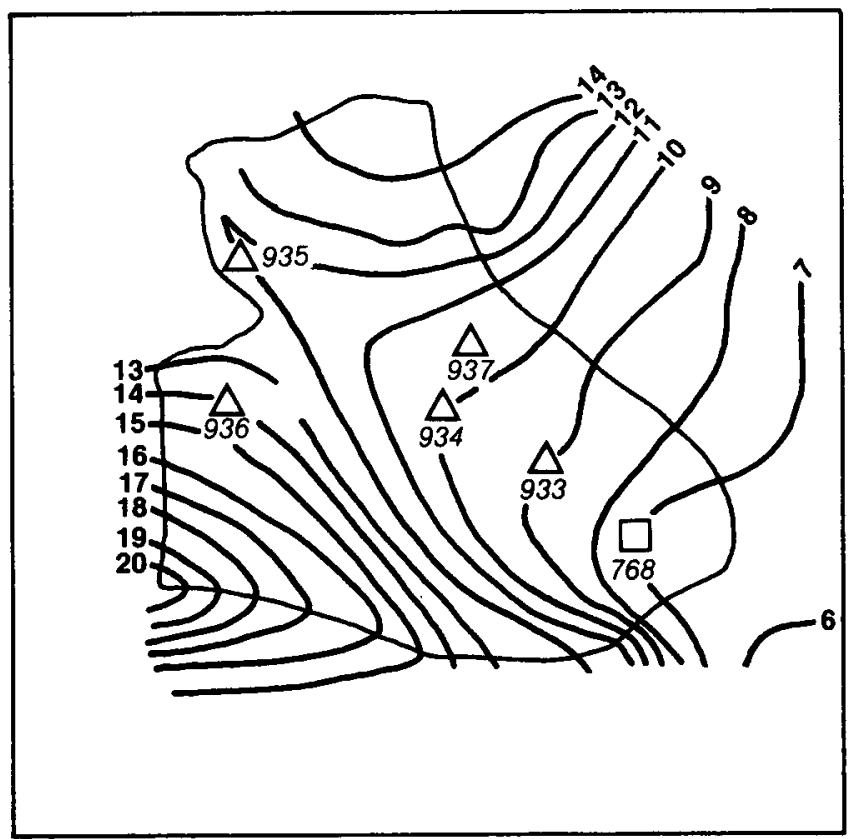

DGU nr. 30

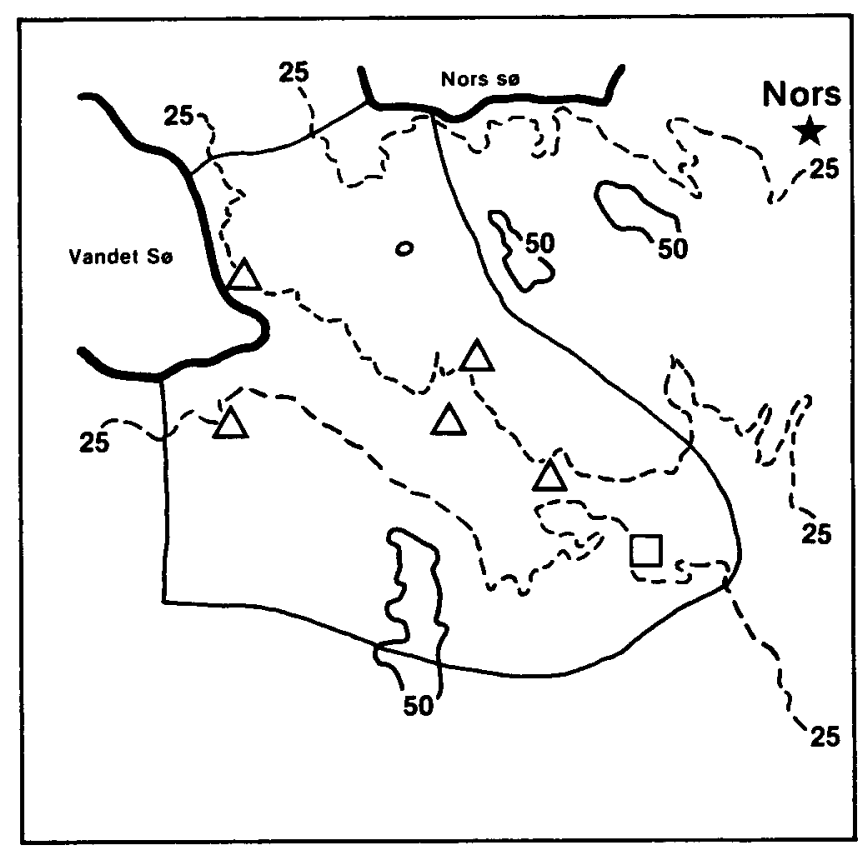

Areal $20 \mathrm{~km}^{2}$

Geologi: De øverste prækvartære aflejringer i området består af kalksten fra Senon og Danien perioderne. Kalkoverfladens markante topografi afspejles i landskabet. Over kalklagene er der et tyndt dække af morænesand og -ler.

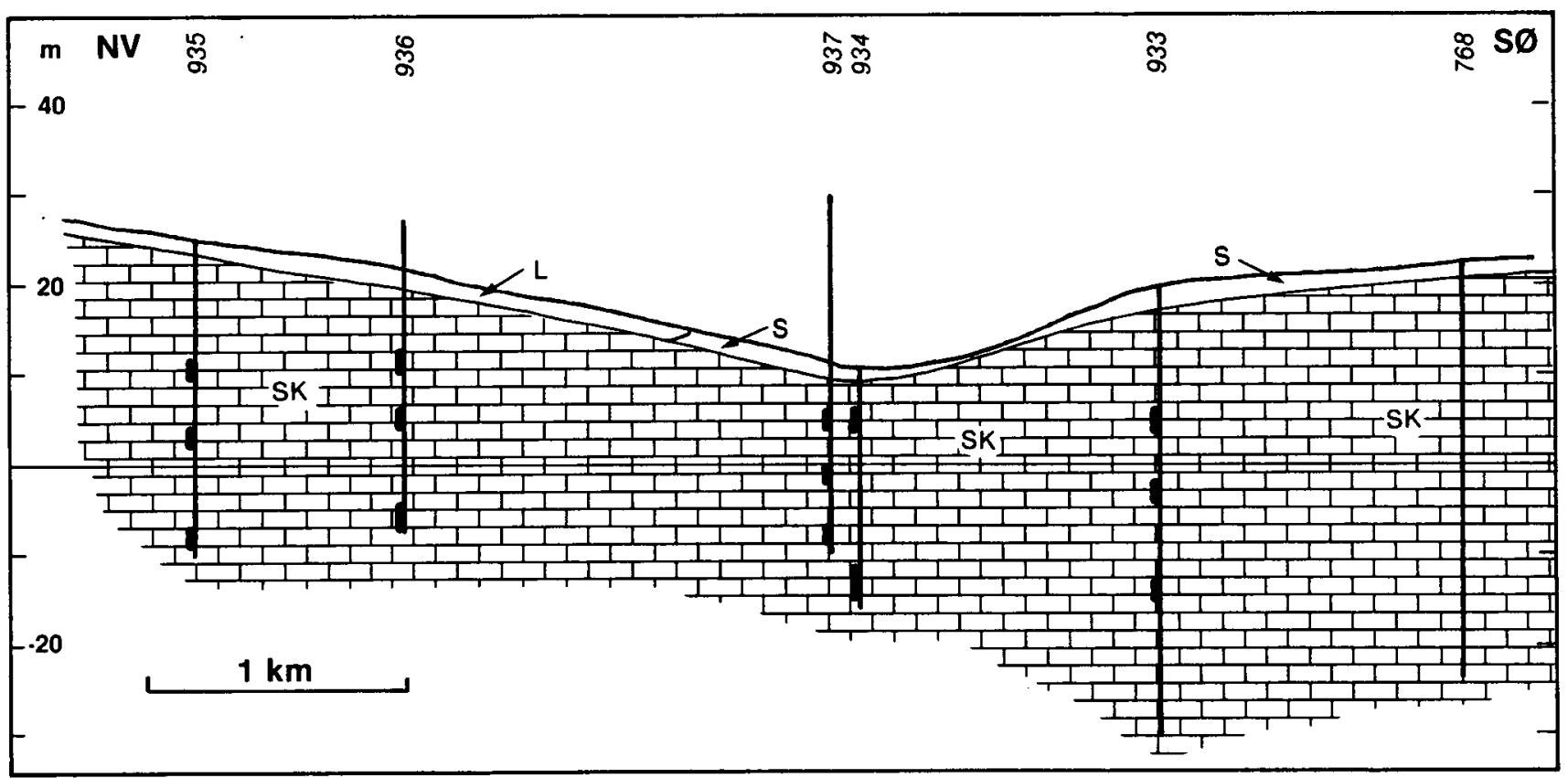


Hydrogeologi: Hovedreservoiret udgøres af kalkstenen, hvori det formodes, at grundvandet til dels bevæger sig gennem sprækkesystemer. Sprækkesystemerne strækker sig til stor dybde. Desuden formodes den øverste del af kalklagene at være meget opsprækket grundet glacial påvirkning og dermed stærkt vandførende. Hovedreservoiret har frit grundvandsspejl, undtagen $i$ et mindre område ved Skadekær, hvor forholdene en del af året er artesiske. Skadekær drænes kunstigt, og vandet pumpes til Vandet $s \emptyset$.

Grundvandskemi: Det øvre grundvand indeholder ilt og en del nitrat. Indholdet af jern er meget lavt og pH er mellem 7,2 og 7,9. Hårdheden i dette grundvand er mellem 8 og $15^{\circ} \mathrm{dH}$. Det nedre grundvand er helt eller næsten helt ilt- og nitratfrit, mens indholdet af jern er højt. $\mathrm{pH}$ er her mellem 7,3 og 7,7, og hårdheden mellem 9 og $15^{\circ} \mathrm{dH}$.

Vandbalance mm/år:

Middelnedbør 800

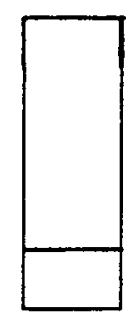

Kildeplads: Baun, 3.6 mill. m3/år
Arealanvendelse \%:

625 Pordampning

Landbrug

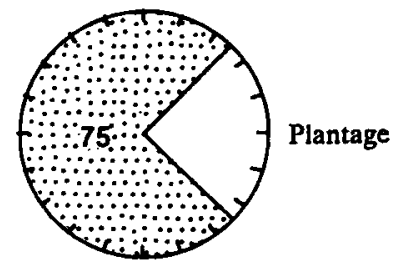

Registrerede depoter. ingen

Koncentrationen af udvalgte stoffer i forhold til dybde under terræn.

Graferne viser data fra 1989 og 1990.

Nitrat/Dybde

Klorid/Dybde

Sulfat/Dybde

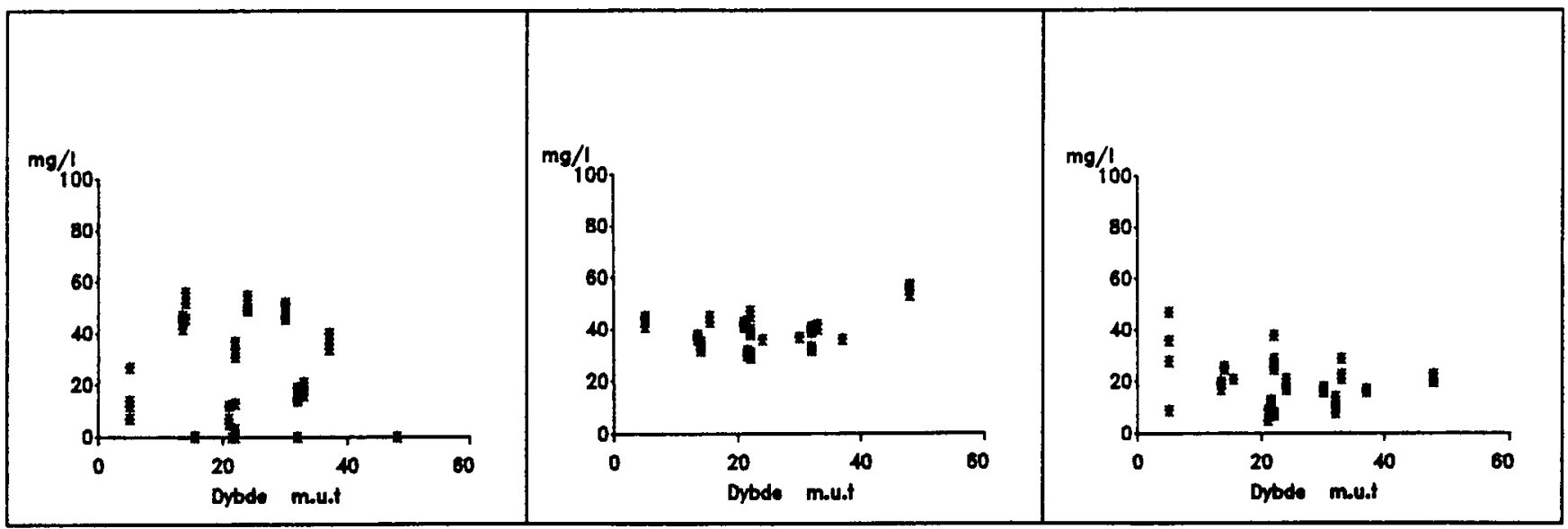




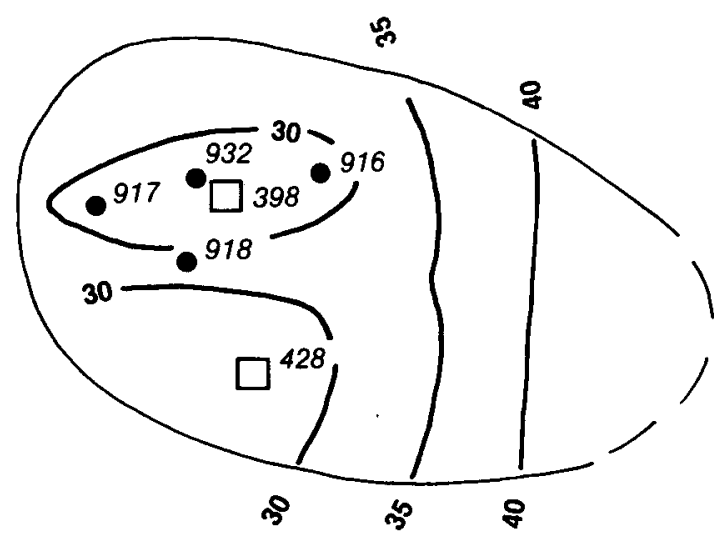

$0,5 \mathrm{Km}$

\section{Tornby}

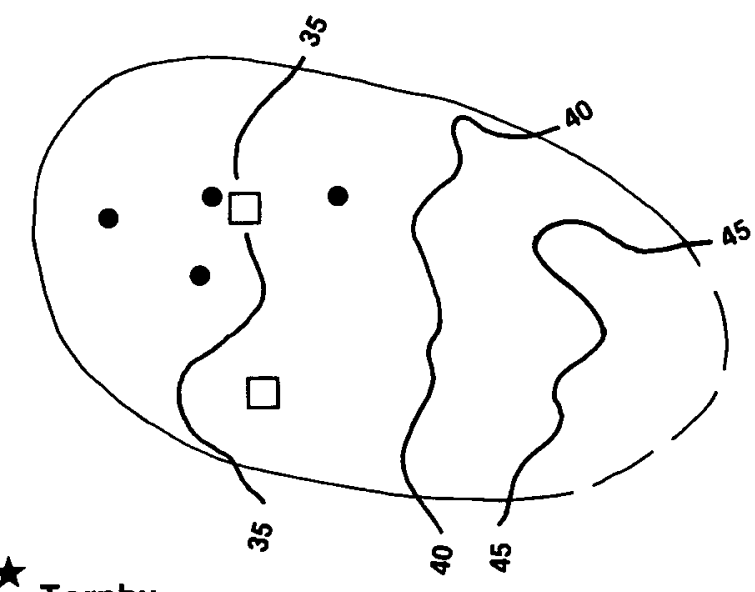

Areal $1 \mathrm{~km}^{2}$

Geologi: Den stærkt varierede kvartære lagfølge i området består af interglacialt saltvandsler og -sand, glacialt smeltevandssand, -silt og -ler, morænesand, senglacialt saltvandssand, -silt og -ler (Yoldia aflejringer) og postglacialt flyvesand.

Interglacialt saltvandssand, som der er mest af $\mathrm{i}$ området, er finkornet og findes $\mathrm{i}$ et stort område omkring Tornby.

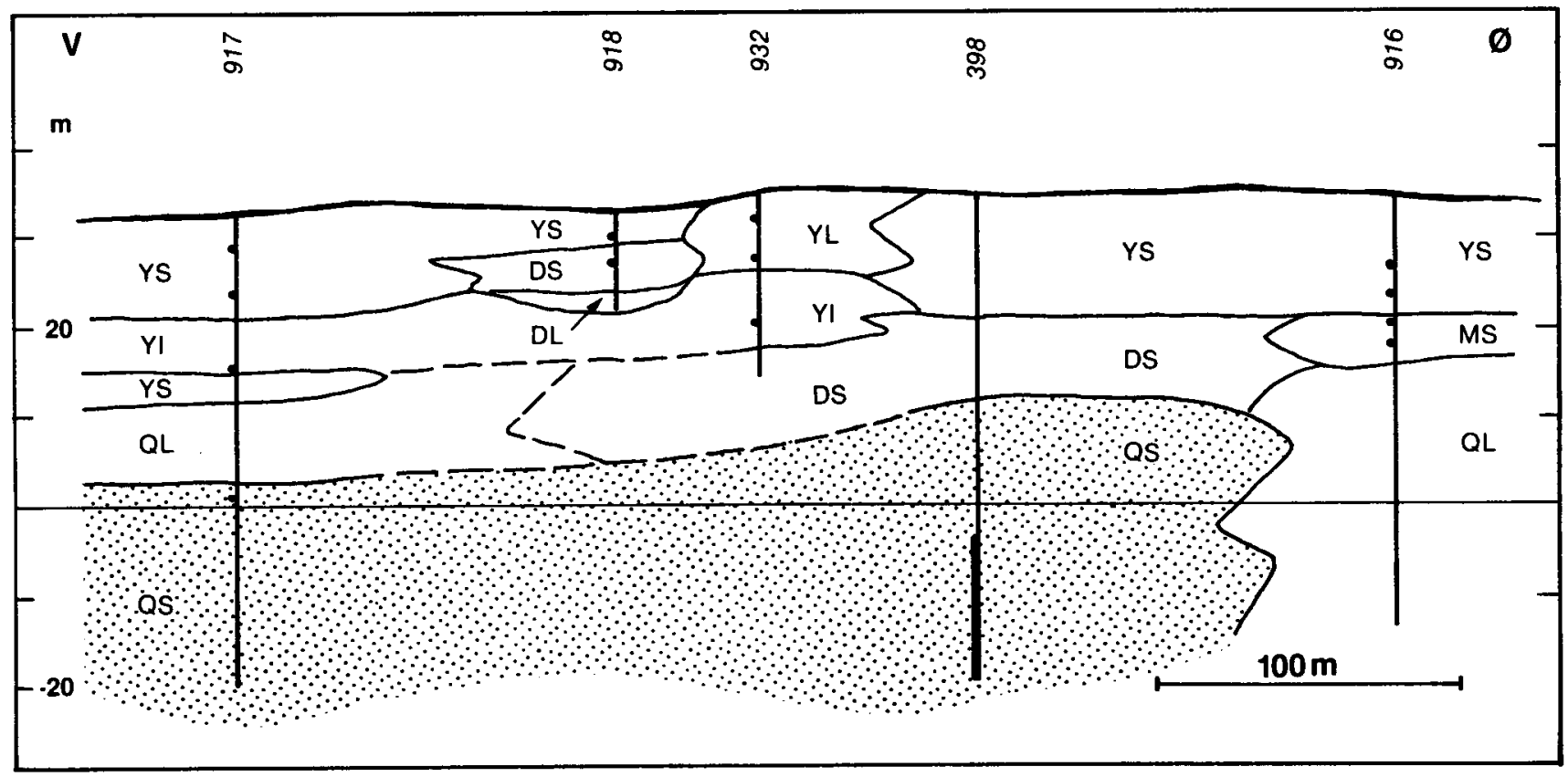


Hydrogeologi: I hovedreservoiret $\mathrm{i}$ det interglaciale saltvandssand er der artesiske forhold. Der foregår ingen indvinding fra "Yoldiasandet" $\mathrm{i}$ området. Områdeafgrænsningen er usikker.

Grundvandskemi: Grundvandet er af meget varierende sammensatning. Som hovedregel er grundvandet $i$ den øverste del af det senglaciale marine sand og i morænesandet iltholdigt og har stedvis et højt nitratindhold. Dybere nede er grundvandet både ilt- og nitratfrit eller -fattigt. Dette grundvand indeholder metan i varierende koncentrationer og har ofte høje kaliumpermanganattal. Endvidere er vandet sulfatreduceret og ionbyttet og indeholder natriumbikarbonat. Der foregår mikrobiologisk aktivitet $\mathrm{i}$ blandingszonen mellem de to vandtyper. Dette kan vare årsagen til de meget høje kimtal ved $21^{\circ} \mathrm{C}$, som forekommer i vandprøver fra Tornby.

Vandbalance mm/år:

Middelnedbør 650

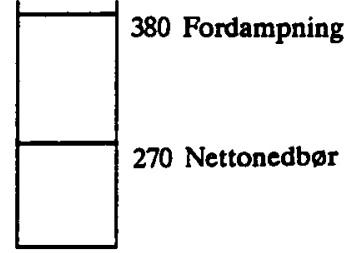

Kildeplads: Tornby, 0.16 mill. m3/år
Arealanvendelse \%:

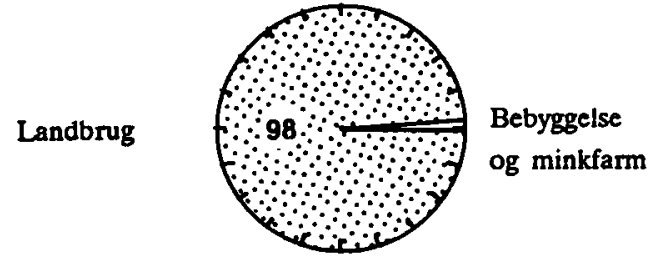

Registrerede depoter:

Koncentrationen af udvalgte stoffer i forhold til dybde under terræn.

Graferne viser data fra 1989 og 1990.

Nitrat/Dybde

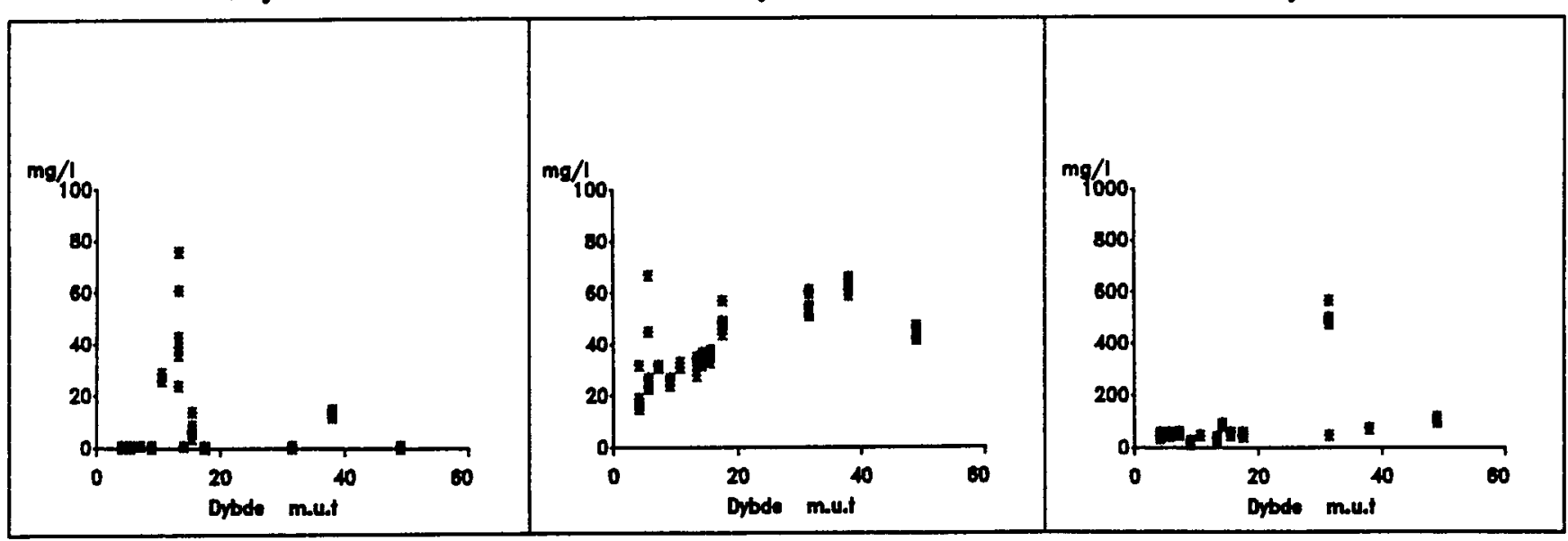




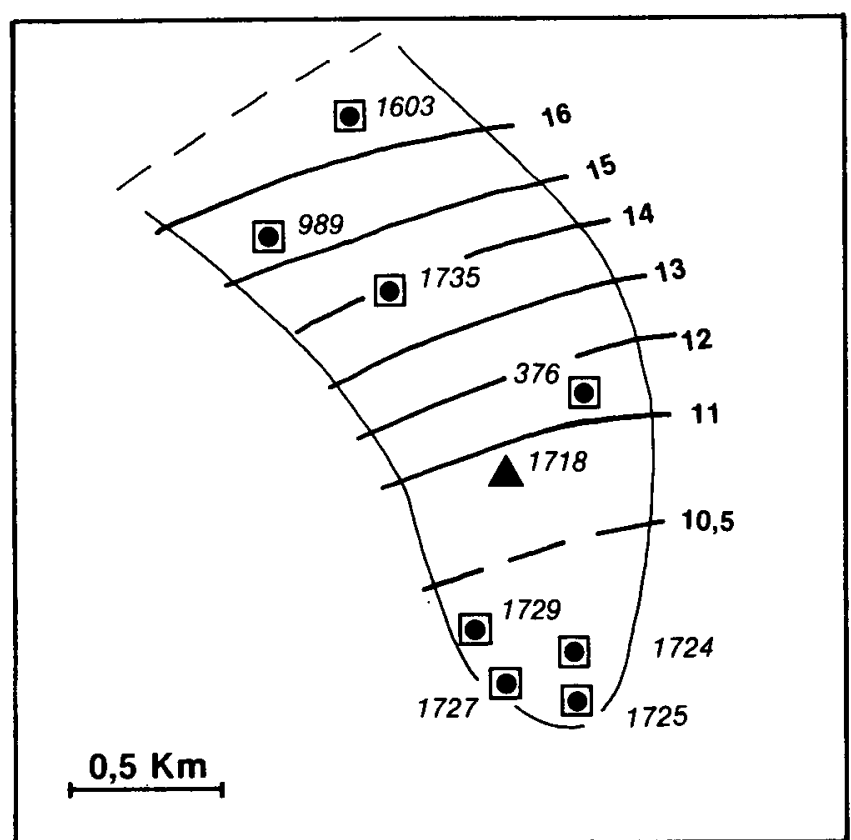

DGU nr. 34

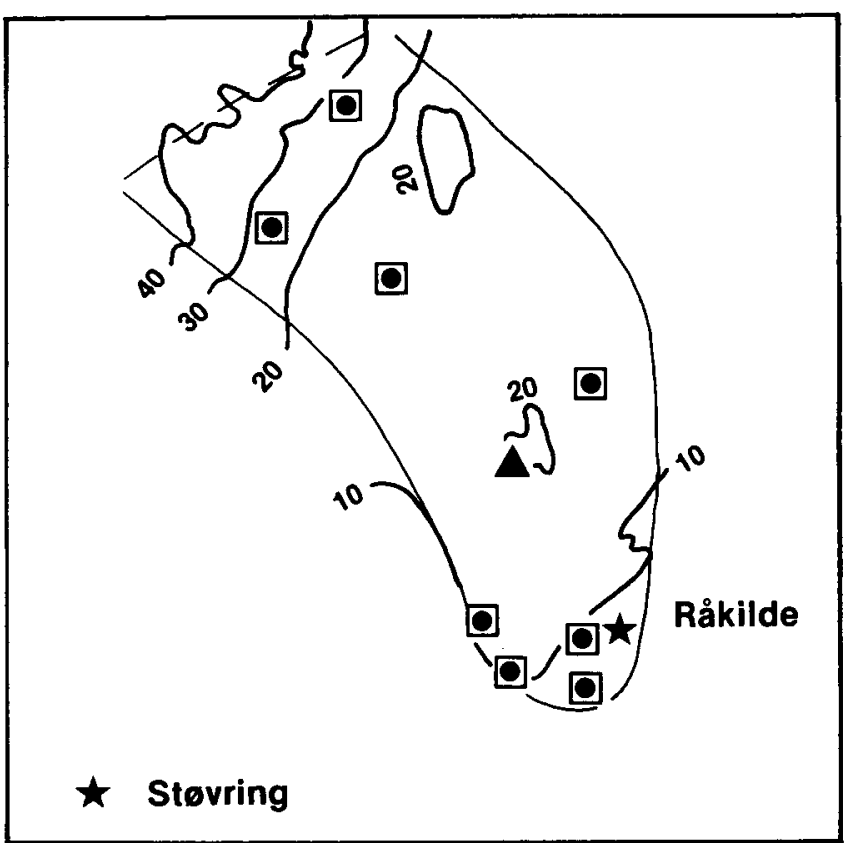

Areal $2 \mathrm{~km}^{2}$

Geologi: Skrivekridt af Senon alder findes umiddelbart under de kvartære aflejringer. Skrivekridtets overfladetopografi er uregelmæssig og influeret af forkastninger, karstfænomener og kvartærtidens isbevægelser. Den kvartære lagserie består af omlejret kridt, smeltevandssand og -grus, moræneler og -sand samt ferskvandsler. Overfladen består af moræne- og smeltevandssand.

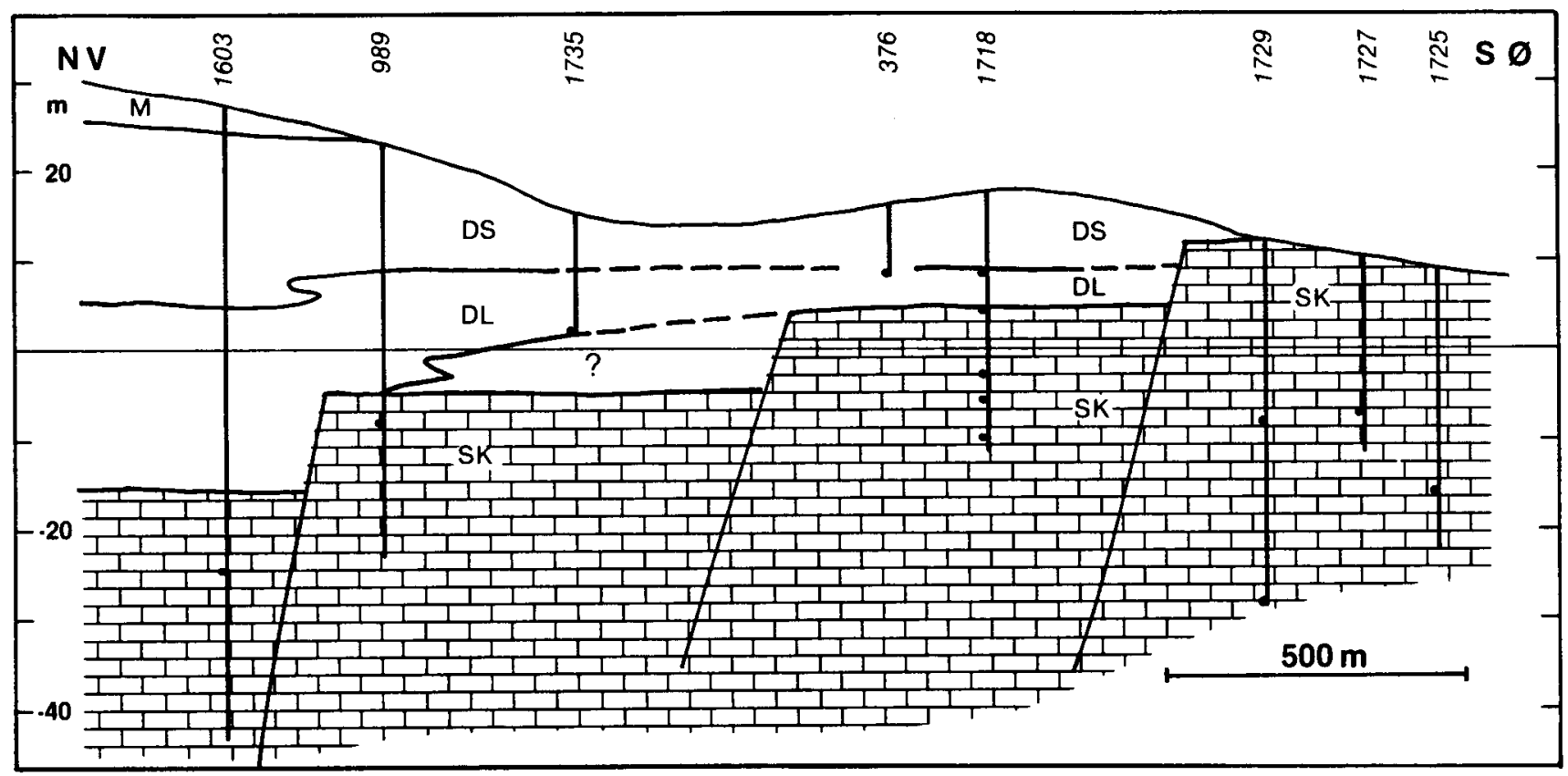


Hydrogeologi: Hovedreservoiret består af skrivekridt med mange sprakkezoner og et flere meter tykt, permeabelt lag af kvartært omlejret kridtmateriale. Forholdene er artesiske, med et grundvandspotentiale der ved Råkilde er op til $0,3 \mathrm{~m}$ over terran. Der foregår ikke vandindvinding fra smeltevandssedimenterne. Områdeafgrænsningen galder smeltevandssedimenterne.

Grundvandskemi: Indenfor området varierer vandkvaliteten betydeligt. Grundvandet er middelhårdt til hårdt $\left(9-21^{\circ} \mathrm{dH}\right)$, idet grundvand fra skrivekridtreservoiret har en hårdhed på 9-12 $\mathrm{dH}$. Vandet er iltholdigt og har lavt jernindhold. En del steder er nitratindholdet højt, men det oppumpede grundvand fra kildepladsboringerne indeholder dog kun ganske lidt nitrat.

Vandbalance mm/år:

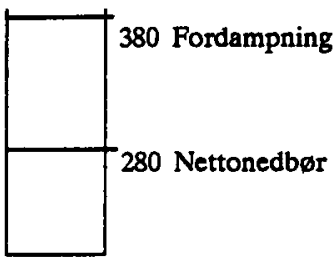

Kildeplads: Råkilde dambrug, 0.75 mill. m3/âr

\section{Arealanvendelse \%:}

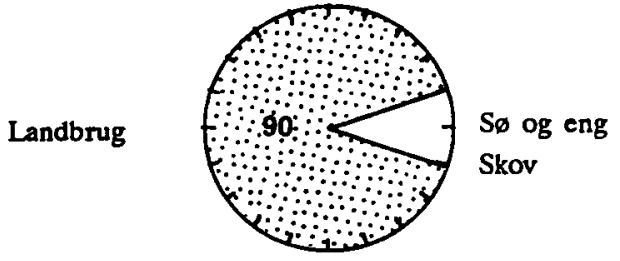

Registrerede depoter: ingen

Koncentrationen af udvalgte stoffer i forhold til dybde under terræen.

Graferne viser data fra 1989 og 1990.

Nitrat/Dybde

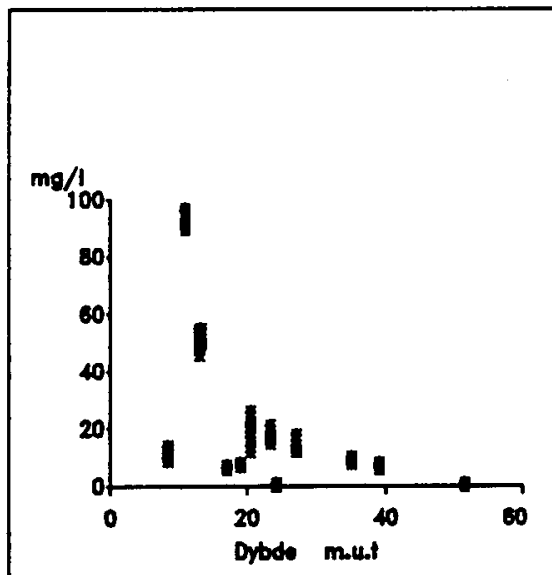

Klorid/Dybde

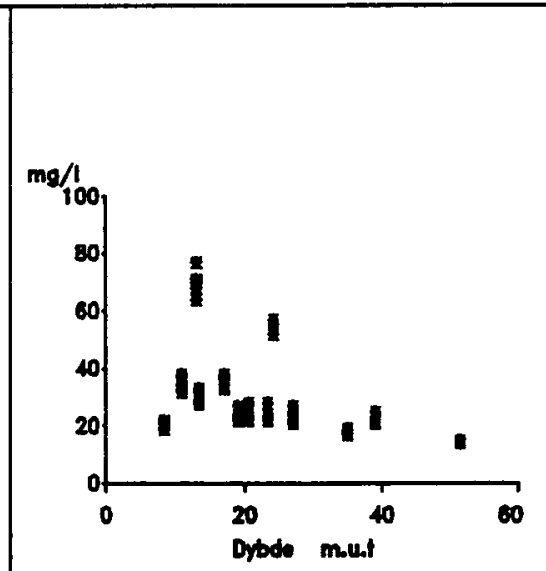

Sulfat/Dybde

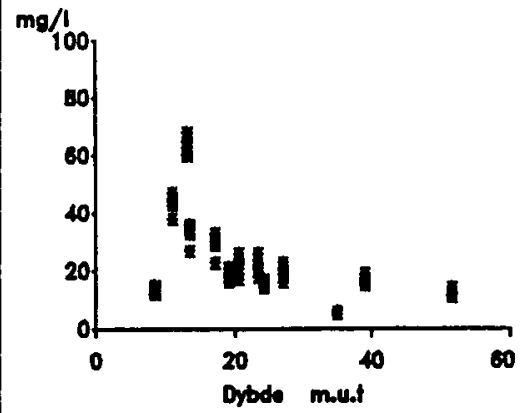




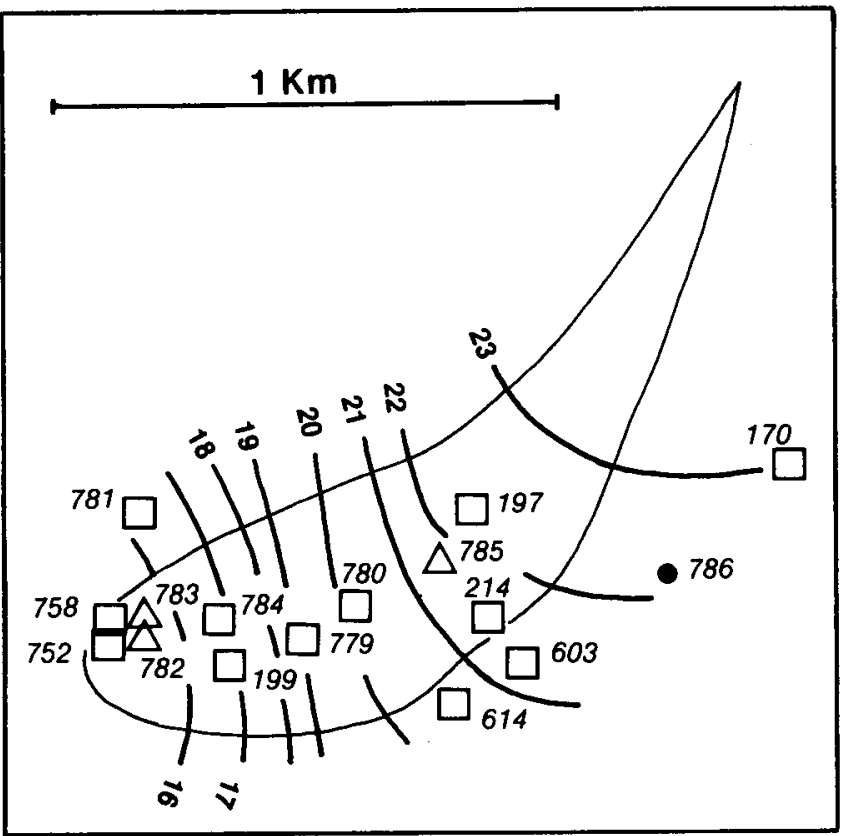

DGU nr. 24

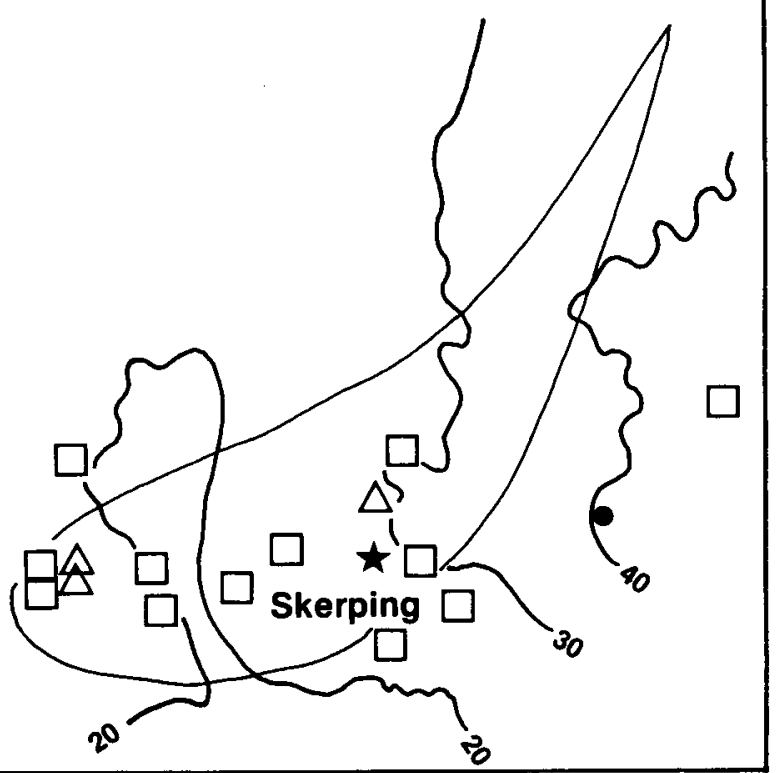

Areal $0,4 \mathrm{~km}^{2}$

Geologi: De øverste prækvartære lag består af skrivekridt fra Maastrichtien tid, der $\mathrm{i}$ den vestlige del af området er overlejret af kalksten fra Danien tiden. Prækvartæroverfladen er en erosionsflade, der i stor målestok danner et mønster af blokke ("øer") adskilt af dale. Dalene opfattes som uderoderede sprækkezoner. I overvågningsområdet er prækvartæroverfladen ret jævn. Skrivekridtet formodes at dykke svagt mod øst, da området ligger på østflanken af Fjerritslev saltpuden, som har bevæget sig opad siden Danien. Den kvartære lagserie er tynd i overvågningsområdet.

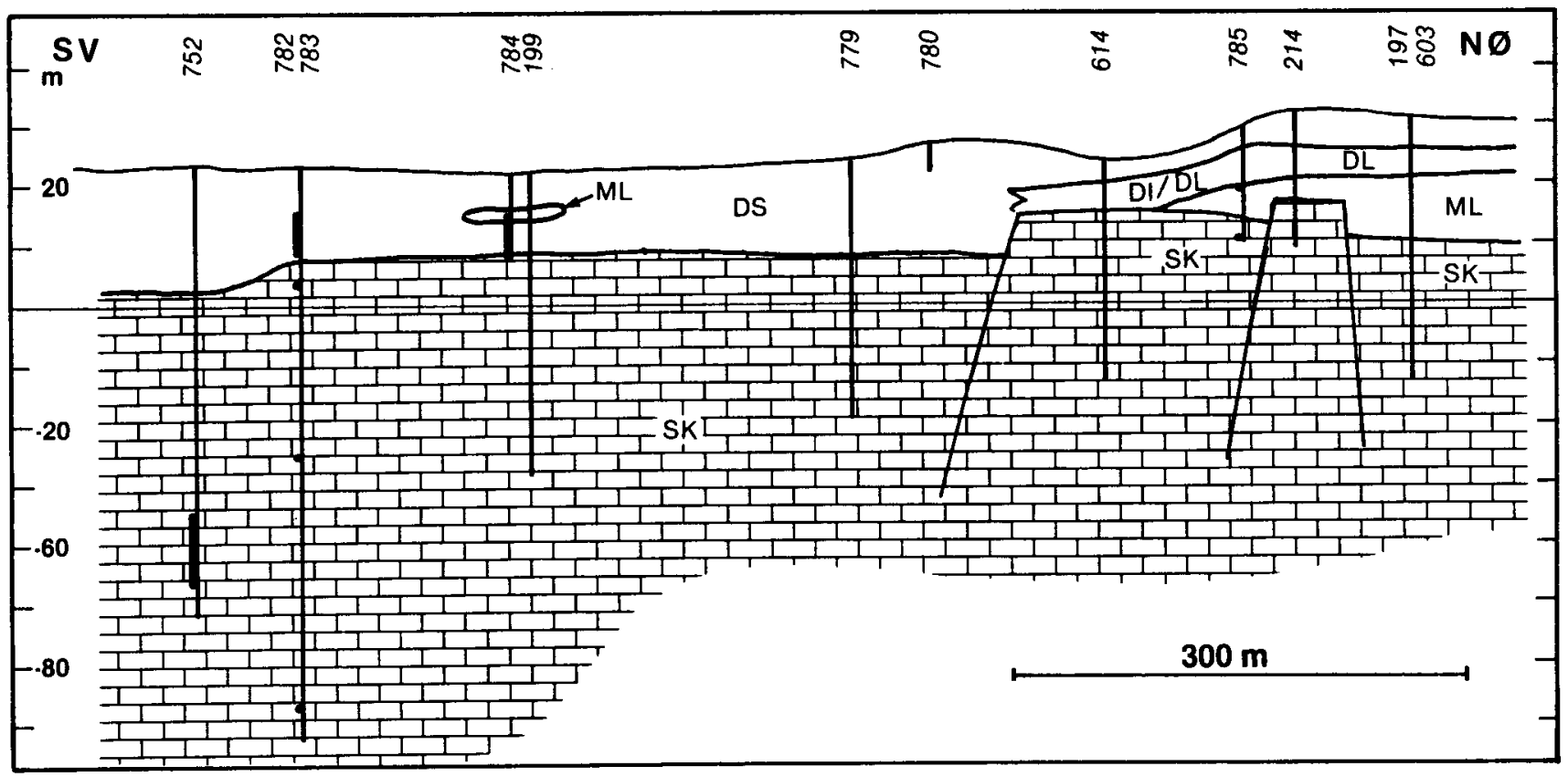


Hydrogeologi: Skrivekridt og smeltevandssand udgør et samlet reservoir. I den sydvestlige del af området er reservoiret artesisk eller frit, afhængig af tykkelsen og udbredelsen af de ovenliggende post/senglaciale lag. Ved Drastrup kildeplads er der frit grundvandsspejl. Områdegrænsningen gælder de øvre reservoirer.

Grundvandskemi: Grundvandet i området er af calcium-bikarbonattypen, men varierer i hårdhedsgrad, med hensyn til redoxpotentiale og i nitratindhold. Nitratkoncentrationen aftager med dybden. Der er eksempler på såvel stigende - som faldende nitratindhold gennem tiden.

Vandbalance mm/år:

Middelnedbor 580

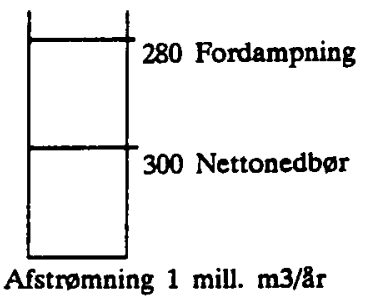

Kildeplads: Drastrup, 2 mill. m3/år

\section{Arealanvendelse \%:}

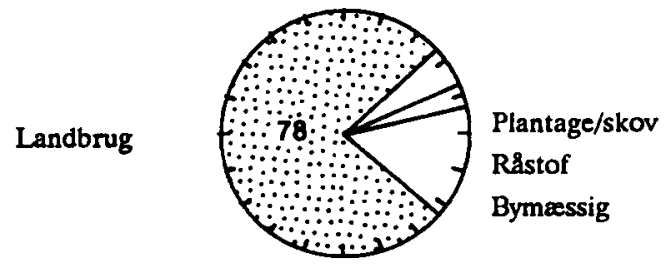

Registrerede depoter: ingen

Koncentrationen af udvalgte stoffer i forhold til dybde under terræn.

Graferne viser data fra 1989 og 1990.

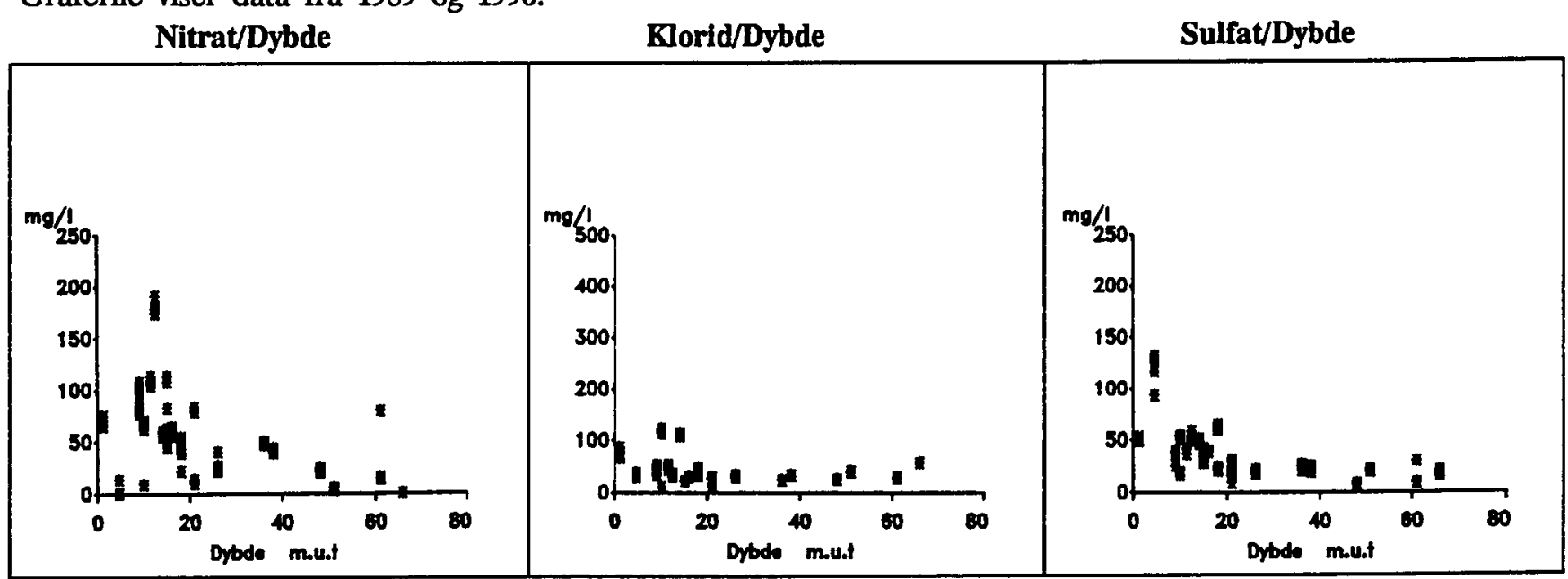




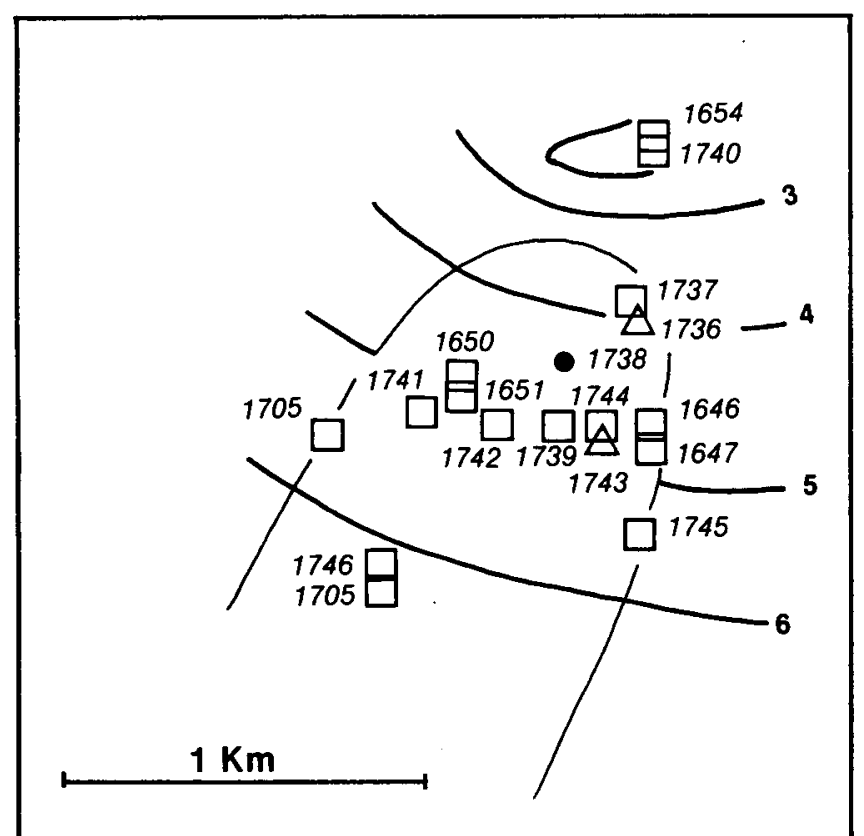

DGU nr. 34

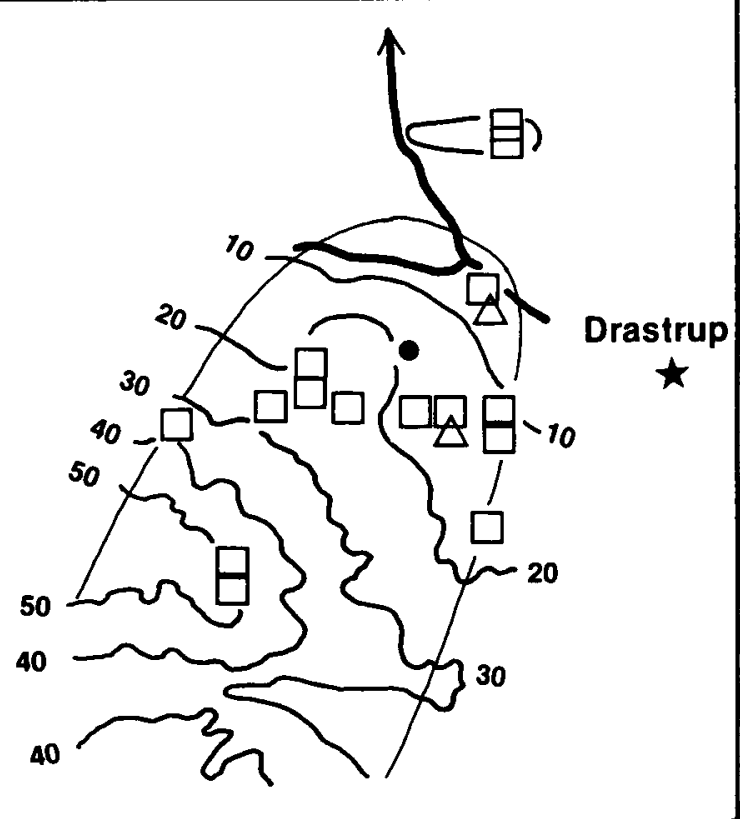

Areal $1,5 \mathbf{k m}^{2}$

Geologi: De øverste prækvartære lag består af kridt af Maastrichtien alder. Kalkoverfladen har et uregelmæssigt relief med bakker og dale. Dannelsen af dette relief skyldes, at kalken under hævningen af området er brudt op i blokke adskilt af brudzoner. Erosion og karstdannelse har været særlig koncentreret langs disse svaghedszoner, der er blevet uderoderet til dale. Den kvartære lagserie i området består i højlandet især af smeltevandssand og -grus. Sandet er stedvis dækket af moræneler. I en dal lige nordøst for Drastrup er moræneler dog dominerende $\mathrm{i}$ den dybeste del af kvartæret.

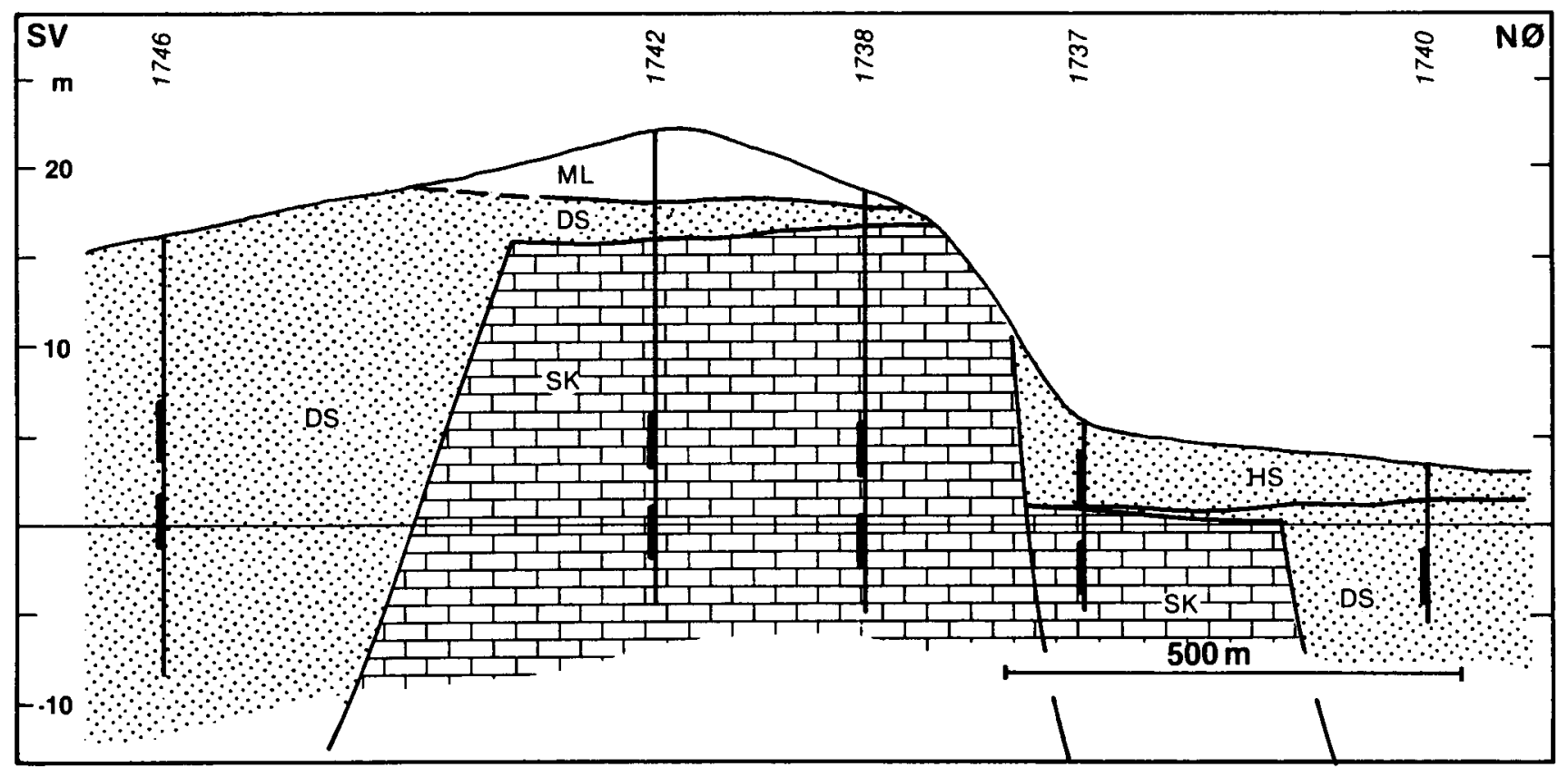


Hydrogeologi: Reservoiret består af skrivekridt og er frit eller artesisk afhængig af dybden til kalken og de overliggende kvartære lags sammensætning. Flere forhold antyder imidlertid, at den øvre del af skrivekridtet synes at have lav permeabilitet, således at den nedre del af kridtreservoiret må betegnes som semiartesisk, uanset om der er overliggende lerlag eller ej. Hvor kalken overlejres af moræneler er der ofte artesiske forhold og et øvre frit reservoir i det sand der findes ovenpå moræneleret.

Grundvandskemi: Grundvandet $\mathrm{i}$ området er blødt til middelhårdt, iltfattigt og $\mathrm{i}$ hovedsagen nitratfrit. Et enkelt sted er grundvandets kloridindhold forhøjet $\mathrm{i}$ det øverste grundvand, hvorfra det aftager med dybden. Det tynde dæklag til trods vurderer amtet at reservoirerne $\mathrm{i}$ området er godt beskyttede mod landbrugsforurening.

Vandbalance mm/år:

Middelnedbør

\section{Arealanvendelse \%:}
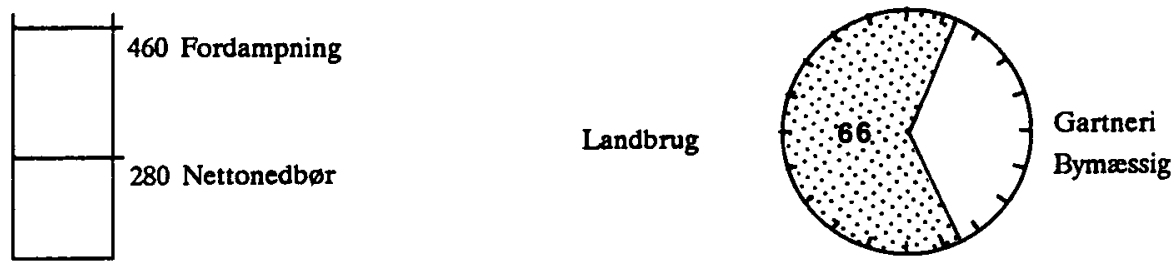

Registrerede depoter: ingen

Koncentrationen af udvalgte stoffer $i$ forhold til dybde under terran.

Graferne viser data fra 1989 og 1990.

Nitrat/Dybde

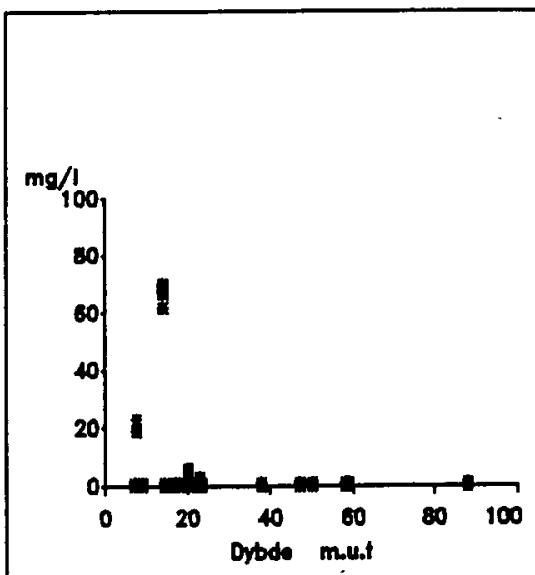

Klorid/Dybde

Sulfat/Dybde

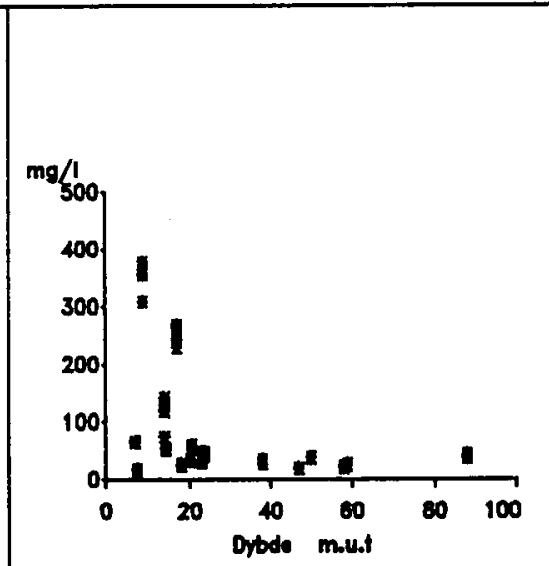

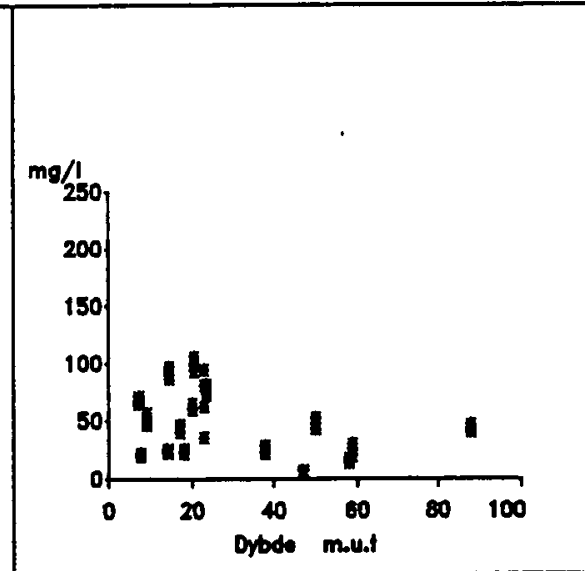


Hydrogeologi: Hovedreservoiret består af smeltevandssand, og findes fra omkring kildepladsen og et stykke mod nord. Den resterende del af overvågningsområdet er et moræneområde med et dække af smeltevandssand, der udgør et ubeskyttet sekundært reservoir. I denne "resterende" del af området er indvindingsmulighederne fra det dybereliggende smeltevandssandsreservoir usikre og varierende. Hovedreservoireret har frit grundvandsspejl omkring kildepladsen.

Grundvandskemi: Der er to hovedtyper af grundvand i området. Det overfladenære grundvand ved kildepladsen og i Albæk Kilde er blødt til middelhårdt og indeholder af og til aggressiv kulsyre. Vandet er iltholdigt og indeholder mere eller mindre nitrat. Grundvandet $i$ den dybe del af hovedreservoiret er blødt og indeholder af og til aggressiv kulsyre. Dette grundvand er endvidere iltfattigt, nitratfrit, indeholder metan og er svagt sulfatreduceret. Sammensætningen af dette grundvand tyder på, at det er influeret af marine sedimenter. Herudover tyder de høje kimtal ved $21^{\circ}$ (300-3000) på mikrobiologisk aktivitet i den dybe del af reservoiret.

Vandbalance mm/år:

Middelnedbør 660

Kildeplads: Albæk, 0.15 mill. m3/år
Arealanvendelse \%:

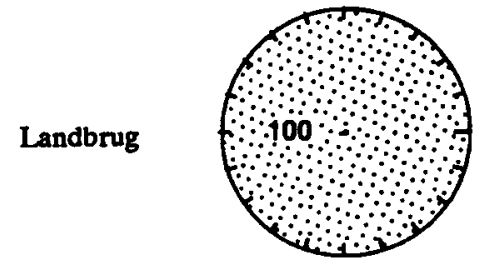

Registrerede depoter: ingen

Koncentrationen af udvalgte stoffer i forhold til dybde under terræen.

Graferne viser data fra 1989 og 1990.

Nitrat/Dybde

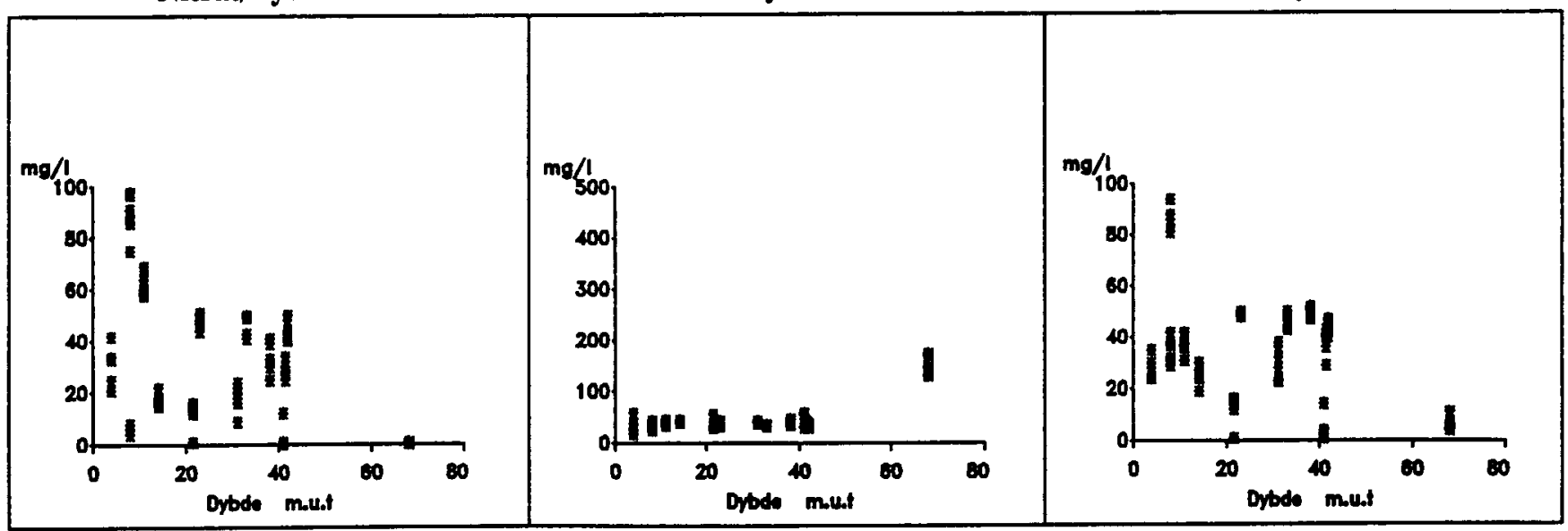




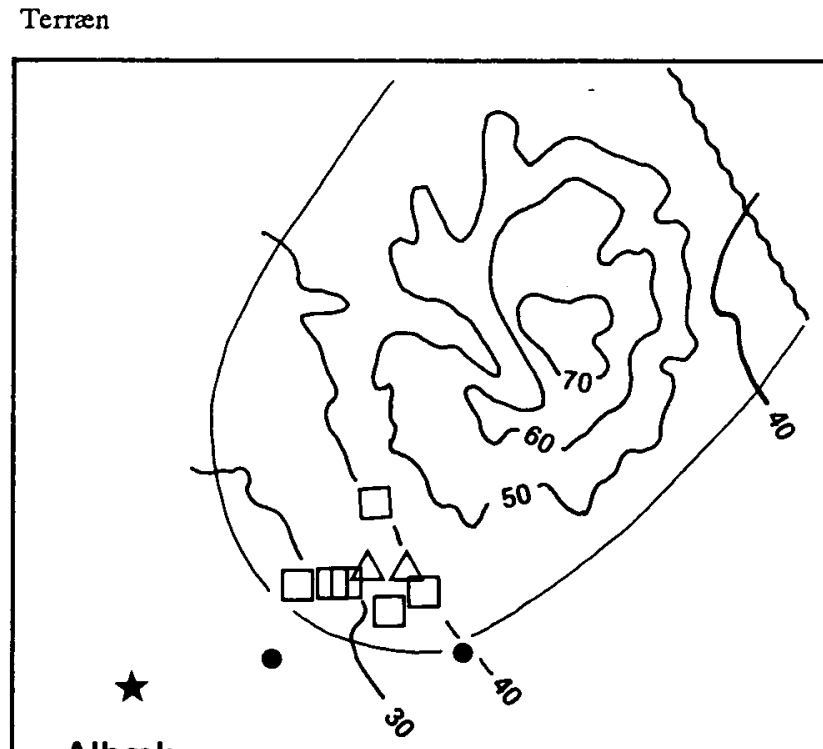

Albæk

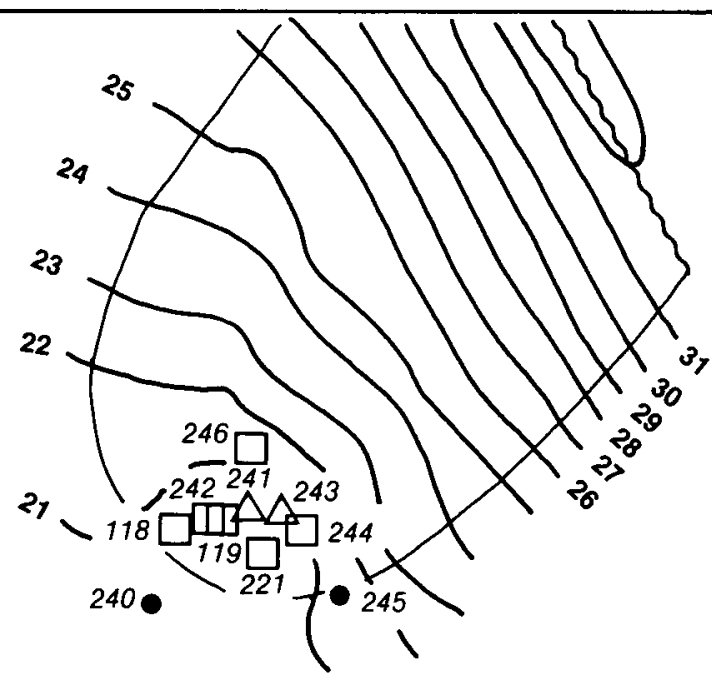

DGU nr. 18

Areal $1,2 \mathrm{~km}^{2}$

Geologi: Det øverste prækvartær består af skrivekridt fra Maastrichtien tid. Overvågningen foregår alene i den kvartære lagserie, som består af marint interglacialt ler og vekslende smeltevandsaflejringer fra Weichsel istiden.

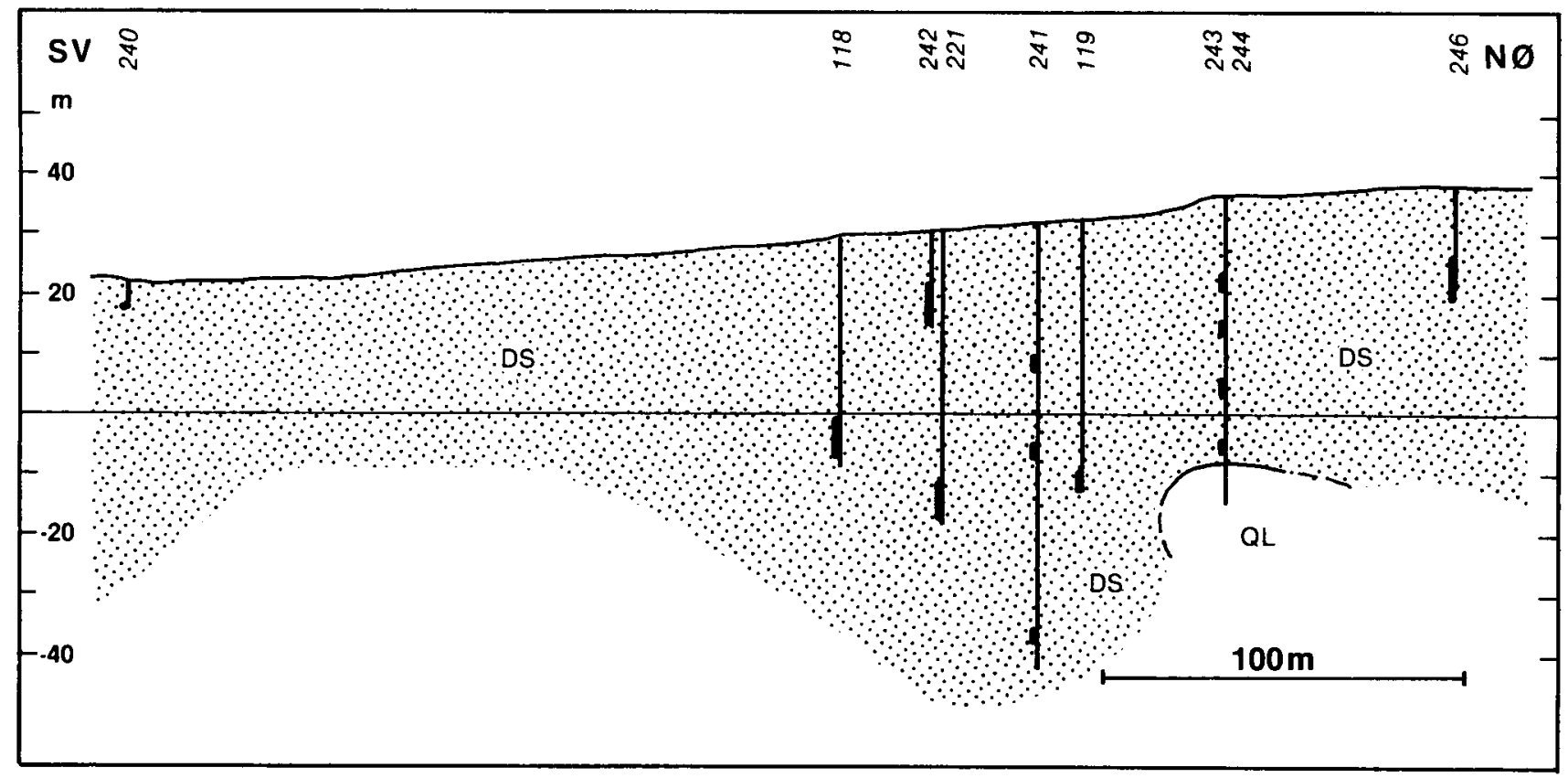



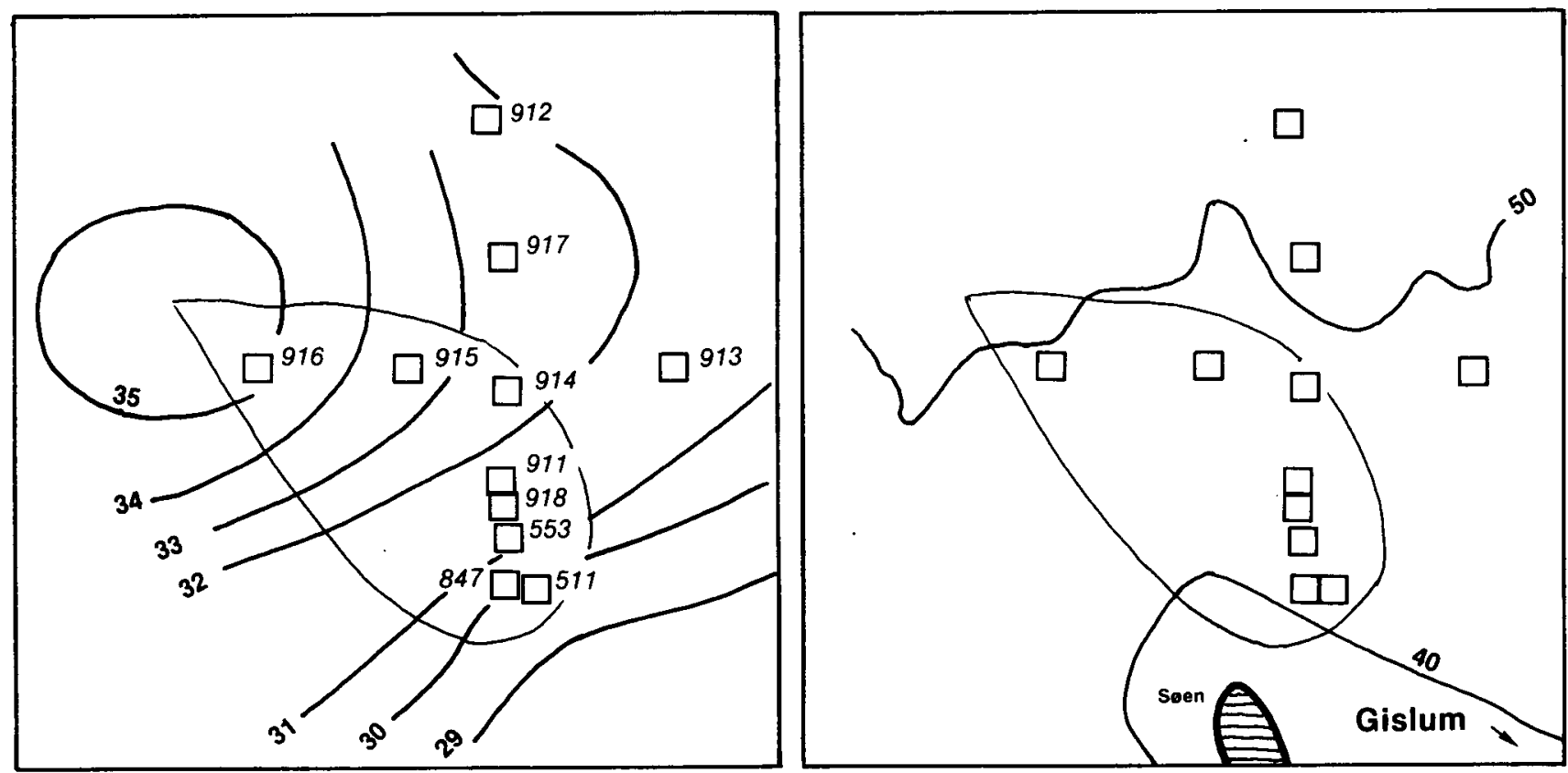

DGU nr. 40

Areal $0,15 \mathrm{~km}^{2}$

Geologi: Den øverste prækvartære lagserie består vest for Gislum af kalksten af Danien alder, mens den øst for byen består af Paleocænt, Eocænt og Oligocænt ler. Prækvartæroverfladen stiger mod øst. I den kvartære lagserie er der tre lag af smeltevandssand. Det dybeste sandlag overlejres af en tyk tertiærpræget lerserie, der tolkes til at være smeltevandsler fra sen-Elster. Lagserien under kote ca. $-10 \mathrm{~m}$ domineres af moræneler af formodet Saale alder. Det øverste lag af smeltevandssand er antagelig af Weichsel alder.

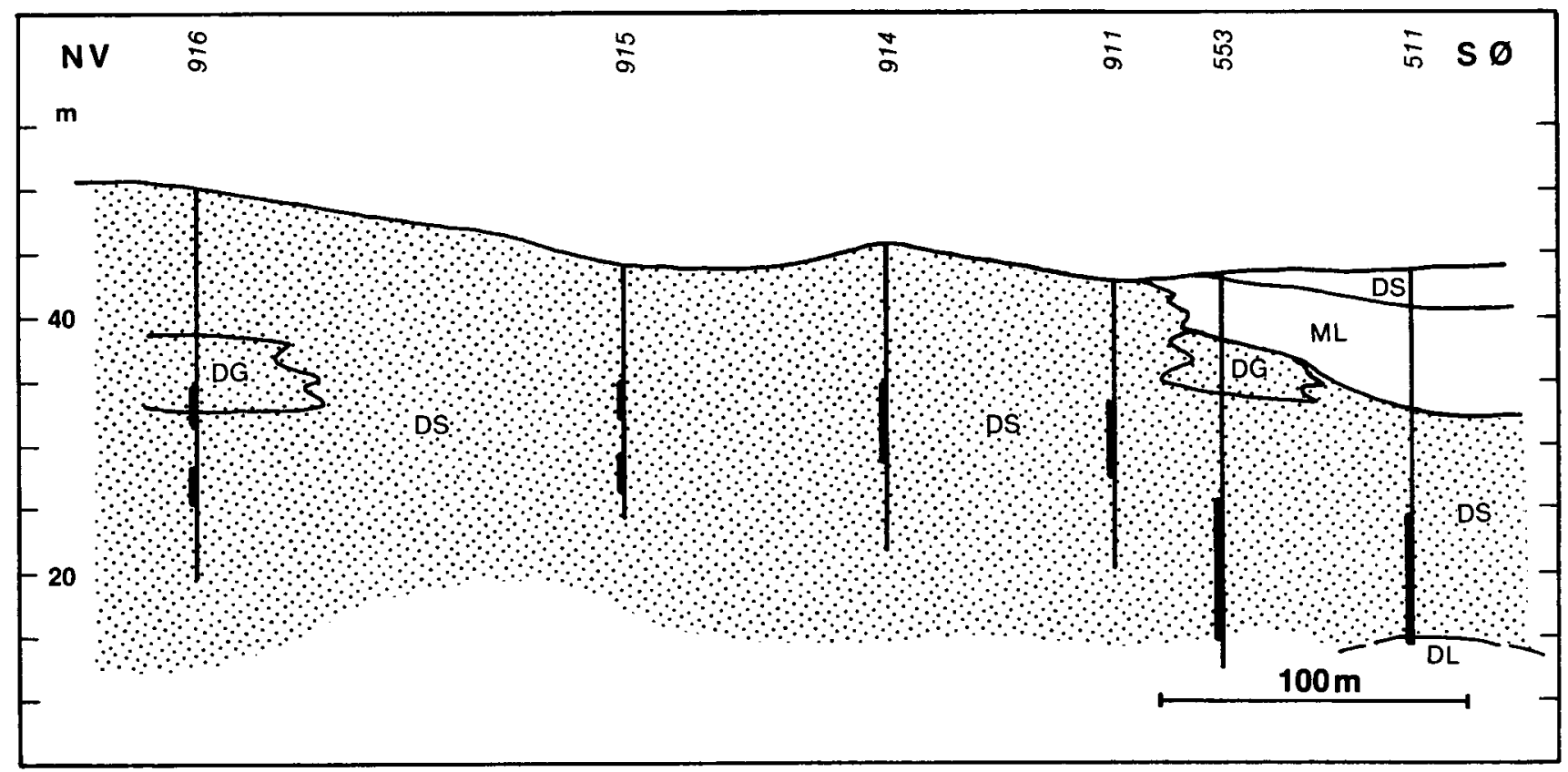


Hydrogeologi: Det øvre frie reservoir består af smeltevandssand og -grus og har stor udbredelse. Gislum ny vandværk indvinder vand fra dette reservoir. Det mellemste reservoir, der består af vekslende sand- og lerlag har stor udbredelse og er semiartesisk. Det nedre reservoir, der er artesisk, og består af smeltevandssand er kun truffet $\mathrm{i}$ en enkelt boring. Områdeafgrænsningen gælder de øvre reservoirer.

Grundvandskemi: Grundvandet i området er af calcium-bikarbonattypen. Vandkemien i det nederste reservoir adskiller sig fra de to øverste. Grundvandet har flere steder et svagt til jæunt stigende nitratindhold.

Vandbalance $\mathbf{m m} / \mathbf{a} \mathbf{r}:$

Middelnedbør 710

\section{Arealanvendelse \%:}

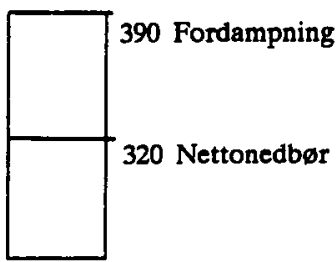

Landbrug

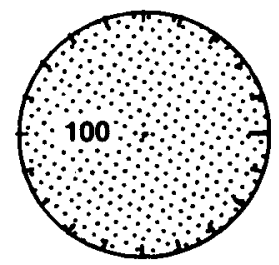

Registrerede depoter: ingen

Koncentrationen af udvalgte stoffer i forhold til dybde under terræen.

Graferne viser data fra 1989 og 1990.

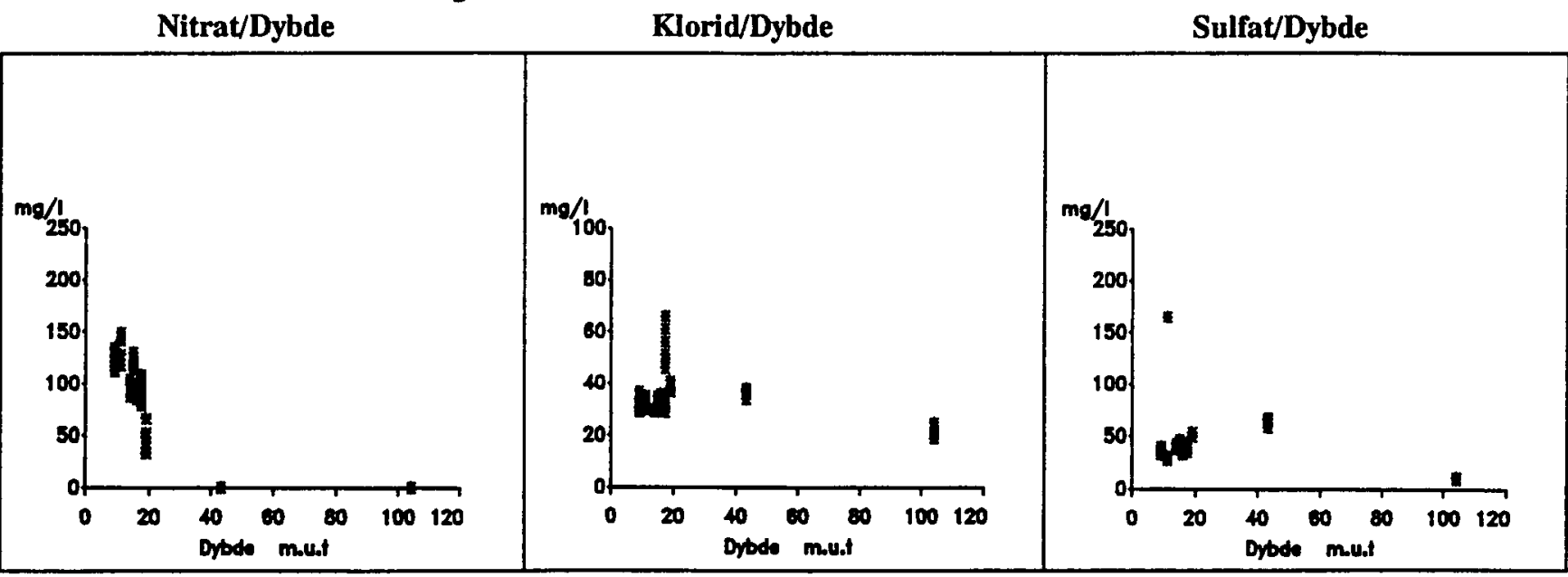




\section{SPECIALANALYSEPROGRAMMET}

Overvågningen af grundvandets sammensætning i overvågningsområderne omfatter ud over de hovedbestanddele, som der også normalt måles for i boringskontrollen, et antal mere specielle parametre. Udvalgte specialanalyser indgår dog også i boringskontrollen, hvis der er begrundet mistanke om at de forekommer i grundvandet. Det samlede analyseprogram er grupperet i analysepakker, således som det fremgår af tabel 3 (fra Miljøstyrelsen, 1990b).

Formålet med måleprogrammet er, dels at beskrive sammensætningen af det naturlige/upåvirkede grundvand, dels at registrere hvorvidt grundvandet skulle være påvirket af forurenende stoffer. Endelig er det formålet at blive opmærksom på en eventuel udvikling i grundvandets sammensætning så tidligt som muligt, således at eventuelle forholdsregier kan blive iværksat betids. Mens hovedbestanddelene måles kvartårligt gennemføres de meget omkostningstunge specielle analyser kun en gang på en prøve fra de analyseegnede prøvetagningssteder inden for overvågningsprogrammets første treårs periode.

For langt de fleste af måleprogrammets analyseparametre er der fastsat grænseværdier for hvor stor koncentration, der maksimalt må være i drikkevand. For mange komponenter, især de der kan forekomme naturligt, er der også fastsat en lavere "anbefalet" maksimalværdi.

De maksimalt accepterede koncentrationer af de specielle parametre er gennemgånde meget lave. Disse stoffer må altså i princippet overhovedet ikke være til stede, jæunfør bekendtgørelsen om vandkvalitet fra Miljøministeriet (1988). Da der ikke er fastlagt krav for grundvandets stofindhold, må det vurderes i de konkrete tilfælde. Da grundvandets stofindhold imidlertid i mange tilfælde vil kunne afspejles i det producerede drikkevand er grænseværdierne for drikkevand anført i den følgende gennemgang af analysepakkerne.

De store krav til analysenøjagtighed og sammenlignelighed har $\mathbf{n} ø$ dvendiggiort, at de benyttede laboratorier skulle igennem en interkalibrerings- og godkendelsesprocedure for at blive accepteret til de enkelte typer af analyser (Miljøstyrelsen, 1990d). For stoffer med krav om lave koncentrationer på eller nær detektionsgrænserne gælder der komplicerede kvalitetskrav til laboratoriernes analysenøjagtighed og gentageligheden af deres målinger, der indebærer at enkeltanalyser i praksis kan have en meget betragtelig usikkerhed. Foruroligende målinger bør derfor, som fremhævet af flere amter i dette års rapportering, kontrolanalyseres, omend også den gentagne måling kan have samme usikkerhed.

De store krav til laboratoriernes præcision og omhu skal nødvendigvis modsvares af analoge krav til prøvetagningen, -opbevaringen og -transporten. Der findes i praksis et stort antal kombinationer af boringstyper og prøvetagningsudstyr, der betinger hvilke indsamlingsprocedurer, der skal følges, og hvilke analyser, der kan udføres, (Miljøstyrelsen, 1990b). Enkeite amter har forsøgt alternative prøvetagningsprocedurer, heriblandt Nordjyllands amt, der har udtaget prøver til specialanalyser med en mobil dykpumpe og blot forpumpet rigeligt. Risikoen for krydskontamination er dog til stede, og amtet har da også siden installeret faste pumper (MP-1 og montejus) i alle boringer, hvor der ikke benyttes råvandshane.

I det føigende kommenteres analysepakkerne for de specielle komponenter: 
Bakteriologiske undersøgelser stiller ganske særlige krav til prøvetagningen, som kun anses $i$ øjeblikket at være opfyldt for $10 \%$ af filtrene (indvindingsboringerne) i overvågningsprogrammet. Disse analyser anses kun at give et summarisk indtryk af grundvandets mikrobiologi, idet de er identiske med de analyser, der udføres i drikkevandskontrollen. I takt med at der udvikles egnede metoder til løbende prøvetagning og indikatorprøver for oligotrophe bakterier i grundvandet kan det komme på tale at gennemføre disse analyser på linie med de øvrige specielle analyser. I forbindelse med den nuværende rapportering er der kun indberettet få bakteriologiske undersøgelser fra Fyns og Storstrøms amter.

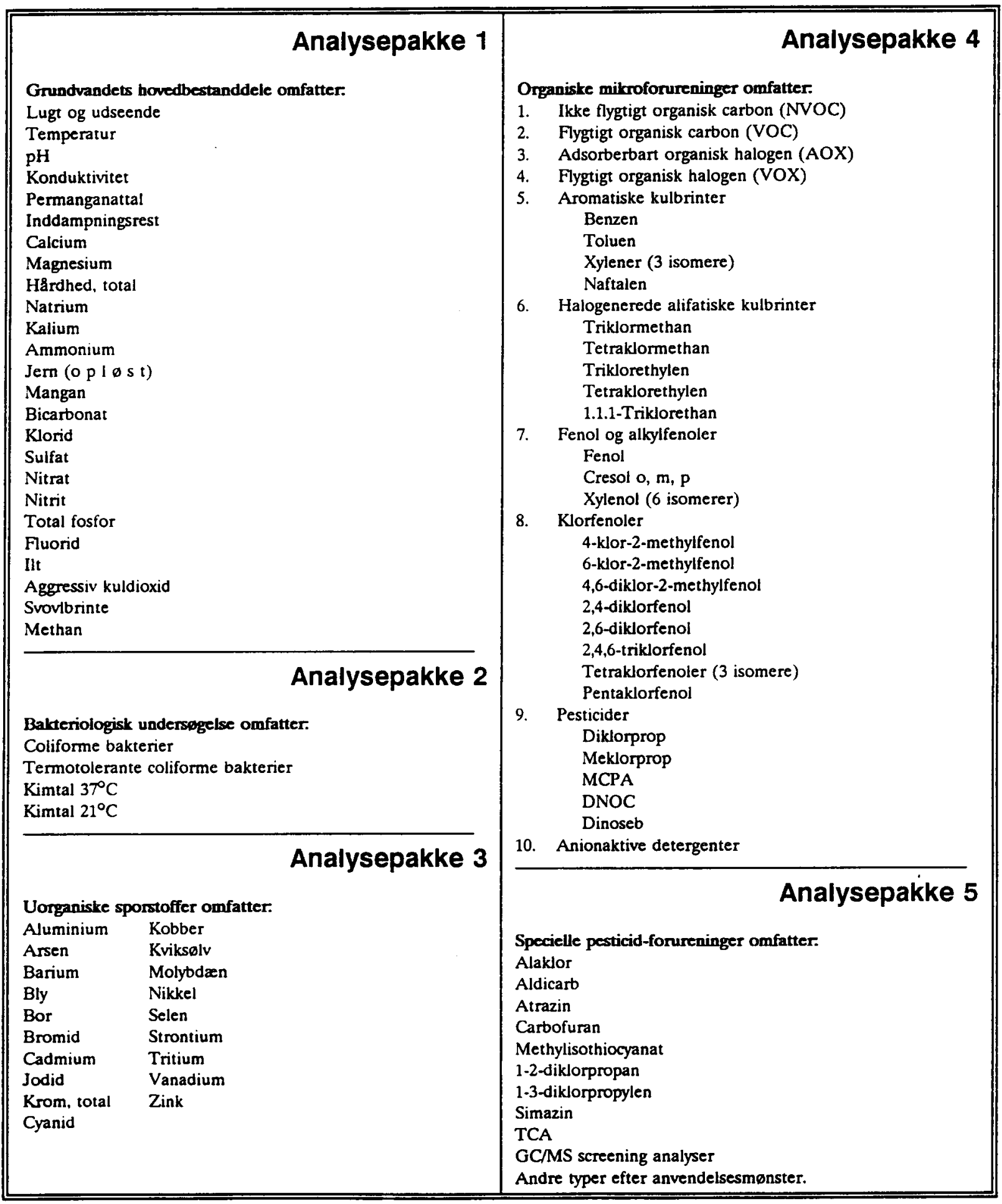


Uorganiske sporstoffer. En del af disse stoffer forekommer naturligt i reservoirbjergarterne og dermed i grundvandet, og de er således ikke miljøfremmede. Afhængig af metallernes opløselighed, evne til binding på jordens partikler og $\mathrm{pH}$-værdien kan sporstofferne findes i grundvandet, men normalt i små mængder, tabel 4 fra Helweg 1988. Kendskabet til det naturlige indhold af spormetaller i grundvandet er dog indtil i dag mangelfuldt. Højere koncentrationer i grundvandet kan skyldes særlige naturlige forhold, en ændret kemisk balance som følge af udnyttelsen af vandet eller forurening.

\begin{tabular}{|c|c|c|}
\hline Metal & $\begin{array}{c}\text { Median } \\
\text { vardi } \\
(\mathbf{m g} / \mathbf{k g})\end{array}$ & $\begin{array}{c}\text { Koncentrations- } \\
\text { interval } \\
(\mathbf{m g} / \mathbf{k g})\end{array}$ \\
\hline $\mathrm{Al}$ & 71.000 & $10.000-300.000$ \\
$\mathrm{As}$ & 6 & $0,1-40$ \\
$\mathrm{Be}$ & 0,3 & $0,01-40$ \\
$\mathrm{Cd}$ & 0,35 & $0,01-2$ \\
$\mathrm{Co}$ & 8 & $0,05-65$ \\
$\mathrm{Cr}$ & 70 & $5-1.500$ \\
$\mathrm{Cu}$ & 30 & $2-250$ \\
$\mathrm{Fe}$ & 40.000 & $2.000-550.000$ \\
$\mathrm{Hg}$ & 0,06 & $0,01-0,5$ \\
$\mathrm{Mn}$ & 1.000 & $20-10.000$ \\
$\mathrm{Mo}$ & 1,2 & $0,1-40$ \\
$\mathrm{Ni}$ & 50 & $2-750$ \\
$\mathrm{~Pb}$ & 35 & $2-300$ \\
$\mathrm{Se}$ & 0,4 & $0,01-12$ \\
$\mathrm{~V}$ & 90 & $3-500$ \\
$\mathrm{Za}$ & 90 & $1-900$ \\
\hline
\end{tabular}

Tabel 4: $\quad$ Oversigt over nogle vigtige spormetallers koncentration $i$ jord (fra Helweg, 1988).

Betydningen af filtreringen af vandprøverne forud for analyserne for at forhindre, at der sker afsmitning fra eventuelle partikler, er blevet undersøgt af Fyns amt. I prøver fra 5 boringer blev de dobbeltanalyseret for nogle stoffer med og uden filtrering. Krydsplot af de sammenhørende analyser viser, at de ufiltrerede prøver indeholder relativt meget krom, og at aluminiumindholdet varierer meget. Da der er relativt lidt aluminium i vandværksboringerne i forhold til de øvrige overvågningsboringer, mener Fyns amt, at der er sket afsmitning fra partikler i de boringer, der er udført specielt til grundvandsovervågningen.

Tritium indtager en særstilling blandt disse analyseparametre, idet koncentrationen af denne radioaktive brintisotop kan give et fingerpeg om grundvandets alder. Tritium opstår naturligt i meget små mængder ved kosmisk stråling, men dannes i stor mængde ved atombombesprængninger. Fra 1954 til 1962 udførte USA og Sovjetunionen adskillige atmosfæriske atomprøvesprængninger, hvorved nedbøren og dermed grundvandet fik tilført tritium. Især i årene 1963 og 1964 registreredes der et stort tritiumindhold i nedbøren. De atmosfæriske atomprøvesprængninger blev indstillet i 1962, og tritiumindholdet i nedbøren er siden aftaget, figur 3. Tritiumindholdet i grundvandet udgør idag ingen sundhedsmæssig risiko. Grundvand dannet før 1954 indeholder næsten intet tritium. Det er derfor muligt ved at måle den radioaktive stråling fra tritium i grundvandet at bestemme, om dette er dannet før eller efter 1954. På basis af disse målinger er det muligt at fastslå, hvor dybt regnvand, der er faldet efter 1954, siden er trængt ned i jorden. Tritiumanalyserne kan dermed vise, hvilke grundvandsmagasiner, der indeholder gammelt- og hvilke, der indeholder ungt vand. 
Koncentrationen af sporstoffer $\mathrm{i}$ grundvandet afhænger både af forvitringstilstanden $\mathrm{i}$ reservoirbjergarten, af adsorptionsprocesser og den eventuelle tilførsel på grund af forurening. De aktuelle koncentrationer vil således både afspejle den lokale geologi og de påvirkninger, der stammer fra det nedsivende grundvand.

Organiske mikroforureninger, omfatter 9 stofgrupper, tabel 3, med det fællespræg at de ikke optræder naturligt $i$ grundvandet. Et eventuelt indhold af disse stoffer $i$ grundvandet skyldes følgelig utilsigtet forurening fra punkt- eller arealmæssige kilder.

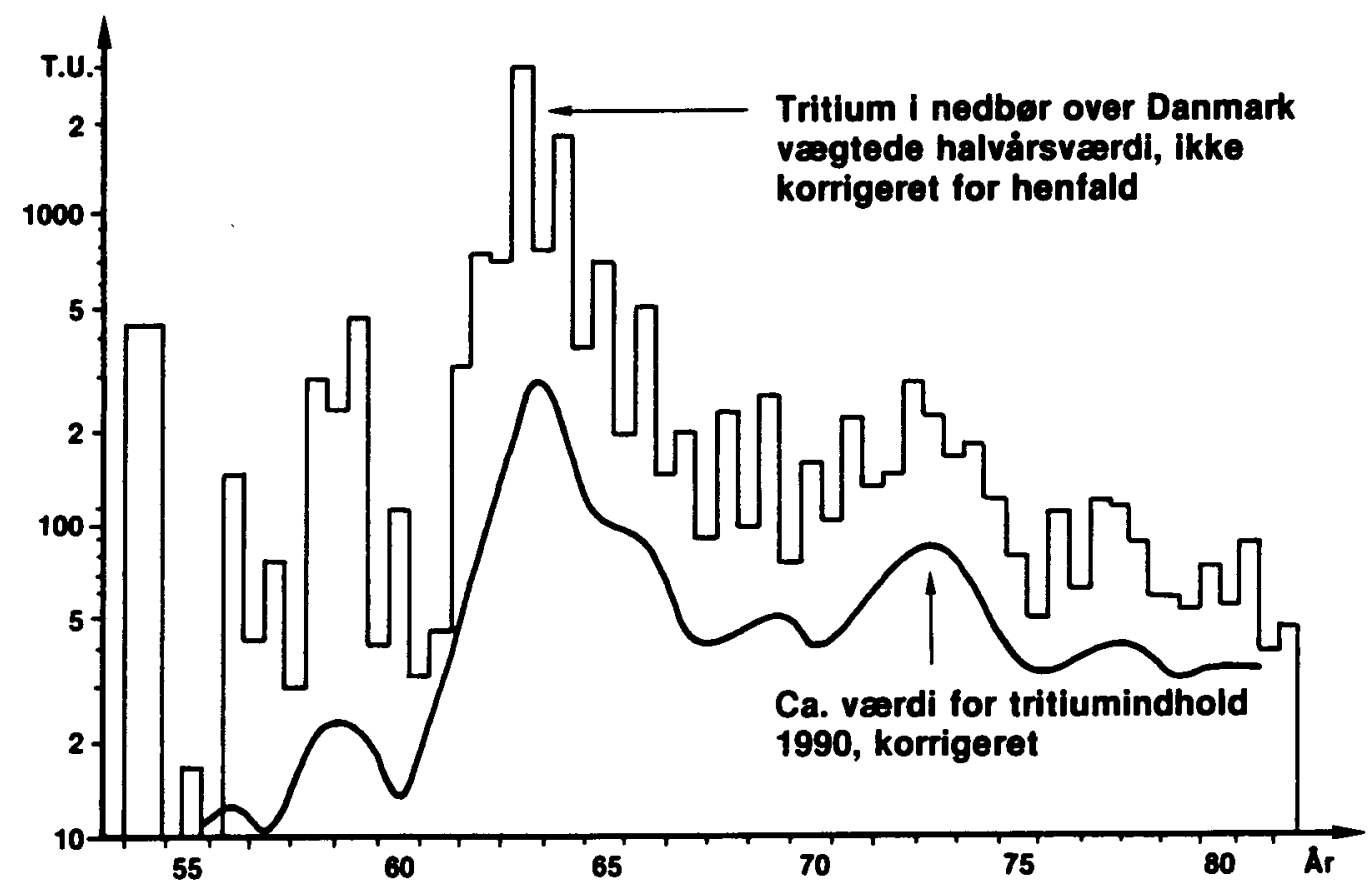

Figur 5: Tritiumindholdet $i$ det infiltrerede vand i perioden 1954 - 1982 (Information fra Isotopcentralen.)

Organiske samleparametre: NVOC, AOX og VOX omfatter talrige stofgrupper, hvoraf nogle også kan forekomme naturligt, tabel 5, og for hvilke nogle erfaringsværdier er anført i tabel 6 (begge tabeller er fra Grøn, 1988). Årsagerne til alle forøgelser af sædvanlige koncentrationer bør undersøges.

\begin{tabular}{|c|l|l|}
\hline FORKORTELSER & \multicolumn{1}{|c|}{ BETYDNING } & \multicolumn{1}{|c|}{ STOFGRUPPER OMFATTET AF ANALYSEN } \\
\hline NVOC & ikke-flygtigt organisk kulstof & $\begin{array}{l}\text { husmuslignende stoffer, phenoler, organiske syrer, detergenter, } \\
\text { vandopløselige opløsningsmidler, bekxmpelsesmidler. }\end{array}$ \\
\hline AOX & adsorberbart organisk halogen & $\begin{array}{l}\text { chlorerede opløsningsmidler, trihalomethaner, chlorerede } \\
\text { industrikemikalier, chlorphenoler, halogenerede bekampel- } \\
\text { sesmidler. }\end{array}$ \\
\hline VOX & flygtigt organisk halogen. & chlorerede oplosningsmidler, trihalomethaner. \\
\hline
\end{tabular}

Tabel 5: $\quad$ Eksempler på de mest betydende stofgrupper, der omfattes af samleparametrene (fra Grøn, 1988). 


\begin{tabular}{|l|c|c|c|}
\hline TYPE AF LOKALITET & $\begin{array}{c}\text { NVOC } \\
(\mathrm{mg} \mathrm{C} /)\end{array}$ & $\begin{array}{c}\text { AOX } \\
(\mu \mathrm{gCl} /)\end{array}$ & $\begin{array}{c}\text { VOX } \\
(\mu \mathrm{gCl})\end{array}$ \\
\hline \hline Uforurenet & $0,1-5$ & $1-15$ & $<0,5$ \\
\hline $\begin{array}{l}\text { Uforurenet under sarlige } \\
\text { geologiske forhold }\end{array}$ & 100 & 40 & $<0,5$ \\
\hline $\begin{array}{l}\text { Forurenet fra losseplads } \\
\text { Forurenet fra kemikalieaf- } \\
\text { faldsdepot }\end{array}$ & $10-1.000$ & $50-1.500$ & $<20$ \\
\hline \begin{tabular}{l} 
Forurenet fra industrigrund \\
\hline
\end{tabular} & $10-10.000$ & $50-10.000$ & $<10-10.000$ \\
\hline
\end{tabular}

Tabel 6: $\quad$ Erfaringsvcerdier for NVOC, AOX og VOX (fra Grøn, 1988).

Aromatiske kulbrinter: Disse stoffer er miljøfremmede og findes ikke i uforurenet grundvand. Påvisning af disse stoffer betyder derfor at grundvandet er forurenet. De mest almindelige forureningskilder er opløsningsmidler og olieprodukter, og det højst tilladte indhold i drikkevand er 10 mikrogram pr. liter.

Halogenerede alifatiske kulbrinter: Tilstedeværelsen af disse stoffer betyder at grundvandet er forurenet $\mathrm{f}$. eks. fra kilder som farve- og lakindustri (opløsningsmidler), plastindustri, kemisk rengøring eller metalaffedtning, og det vejledende største indhold er på 1 mikrogram pr. liter (drikkevandskrav).

Fenol og alkylfenoler: Et indhold af disse stoffer kan skyldes forurening fra for eksempel gasværker og tjæreindustrier, men de kan også stamme fra andre industrier, benzintanke og parcelhusområder. Det højest tilladelige indhold er 0,5 mikrogram pr. liter (drikkevandskrav).

Klorfenoler: Klorfenoler kan have deres oprindelse i nedbrudte pesticidprodukter. Det højst tilladelige indhold er 0,5 mikrogram pr. liter (drikkevandskrav).

Pesticider: De pesticider, der undersøges for i denne analyse-pakke, er blandt de mest anvendte ukrudtsbekæmpelsesmidler, både arealmæssigt og med hensyn til hvor lang en periode de har været anvendt. De benyttes især i forbindelse med korn. Pesticider i grundvandet kan altså, selv om de helt eller delvist er nedbrydelige, stamme fra arealbelastninger. I de tidligere undersøgte tilfælde har denne forurening ofte kunnet føres tilbage til punktformige kilder i nærheden af boringerne, Forslund 1987. Det må i denne forbindelse bemærkes, at det tidligere blev anbefalet landmændene at nedgrave den tomme emballage. Der må højest være 0,1 mikrogram pr. liter af et enkeit pesticid i vandet, og summen af alle pesticider må ikke overstige 0,5 mikrogram pr. liter (drikkevandskrav).

Anionaktive detergenter: Disse kan stamme fra vaske-, opvaske-og skuremidler samt fra landbruget (bl.a. nedbrudte pesticider). Et lavt indhold af anionaktive detergenter kan muligvis stamme fra humusstoffer og således være naturligt forekommende. Det højest tilladelige indhold i vandet svarer til 0,1 milligram LAS pr. liter (drikkevandskrav). LAS står for indikatorstoffet laurylsulfat. 
Specielle pesticid-forureninger. I modsætning til pesticiderne $i$ analysepakken for organiske mikroforureninger er de såkaldte "specielle pesticider" som hovedregel mindre anvendt, (de meget anvendte atrazin og simazin er dog rubriceret her), og der analyseres kun for disse stoffer i det omfang de vides at have været anvendt $\mathrm{i}$ området. Kun få af de pesticider, der bliver- eller har været anvendt $\mathrm{i}$ landbruget, indgår $\mathrm{i}$ analyseprogrammet, men de udvalgte pesticider er de mest anvendte. I konkrete tilfælde kan det derfor være nødvendigt at udvide programmet. Der må højest være 0,1 mikrogram pr. liter af et enkelt pesticid $i$ vandet, og summen af alle pesticider må ikke overstige 0,5 mikrogram pr. liter (drikkevandskrav). 


\section{AMTERNES VURDERING AF SPECIALANALYSERNE}

Dette afsnit indeholder et uddrag af de refererede rapporter, hvor der er lagt vægt på forklaringer på og fortolkninger af analyserne. Omtale af stoffer der ikke er konstateret ved målingerne, eller hvis koncentration og fordeling i overvågningsområderne ikke overrasker, er altovervejende udeladt.

\section{Københavns- og Frederiksberg kommuner, 1991}

Grundvandet $\mathrm{i}$ kommunernes overvågningsområde på Frederiksberg er fortrinsvis påvirket af industriel aktivitet og af perkolat fra affaldsdepoter. Vandet $\mathrm{i}$ indvindingsboringerne $\mathrm{i}$ overvågningsområdet har en anden og bedre kvalitet end $\mathrm{i}$ overvågningsboringerne. Der kan således ikke foretages nogen direkte interpolation mellem analyseresultaterne.

Der er fundet triklorethylen (23-29 mikrogram pr. liter) i en enkelt vandværksboring i overvågningsområdet. Boringen er forberedt til separationspumpning, så det forurenede vand kan sorteres fra, hvis det bliver nødvendigt. Derudover er der foretaget en kortlægning af kilder til forureningen med henblik på afværgeforanstaltninger ved kilderne. Boringens ydelse udgør for tiden ca. 90 kubikmeter i timen, som opblandes med 220 kubikmeter i timen uforurenet grundvand, og værkets samlede produktion indgår i ledningsnettet sammen med vand fra Københavns Vandforsyning.

I samtlige overvågningsboringer er der konstateret miljøfremmede stoffer, som stammer fra den industrielle aktivitet. Blandt andet organiske opløsningsmidler, herunder triklorethylen.

Der er fundet et højt indhold af opløste stoffer, blandt andet klorid og andre i øvrigt naturligt forekommende bestanddele i vandet i overvågningsboringerne. Der kan ikke være tale om påvirkning fra nyere lossepladser, men det er tænkeligt, at perkolat fra ældre måske mere spredt udlægning af affald, for eksempel i småsøer, kan have indflydelse på grundvandskvaliteten. 
Kobenhavns amt, 1991

Der er udført specialanalyse på grundvandsprøver fra 20 filtre alle i Søndersøområdet. Analyserne er endnu ikke verificerede og skal tolkes med forbehold. Der er konstateret meget lave niveauer af miljøfremmede stoffer i samtlige boringer, hvilket ikke umiddelbart kan forklares. Tritiumanalyser er udført for alle overvågningsområder. Grundvandet $\mathrm{i}$ kalkreservoiret nær kysten indeholder relativt ungt vand, hvilket tilskrives nedsivning som følge af vandindvindingen. Metalindholdene er meget lave, dog er det største indhold fundet $\mathrm{i}$ den af Københavns Vandforsynings indvindingsboringer, der indgår $\mathrm{i}$ overvågningsprogrammet. Drikkevandsbekendtgørelsens højst tilladelige værdi er overskredet for flere af metallerne.

Samtlige metaller, som det er valgt at analysere for, er fundet i grundvandsprøverne, bortset fra krom. De højeste indhold af metal findes $\mathrm{i}$ en indvindingsboring, og den højst tilladelige værdi er overskredet for bor, zink, aluminium og kobber.

$\mathrm{pH}$-værdierne i grundvandet ligger mellem 7,2 og 7,6 i overvågningsområdet. Ved prøvetagningen til specialanalyser var $\mathrm{pH} 7,6$.

Fundet af benzen i 4 filtre er på så lavt et niveau, at der kan være tale om en kontaminering i forbindelse med prøvetagningen. Af disse 4 filtre findes det ene i en af Københavns Vandforsynings indvindingsboringer. Fundet af klorerede forbindelser kan ikke umiddelbart forklares. Der er ikke noget i forbindelse med overvågningsoplandets arealanvendelse, der tyder på, at der har været anvendt større mængder klorerede opløsningsmidler.

Det målte meget høje VOX-indhold i det dybe kalkfilter i boringen ved Farum $s \emptyset$, virker højst besynderligt.

\section{$\underline{\text { Pesticider }}$}

Der er konstateret dinoseb $i$ en enkelt boring, 0,038 mikrogram pr. liter. Boringen ligger $i$ et område med landbrug og kan relateres hertil.

I samme filter, hvor der er konstateret dinoseb, er der detekteret klorfenol (0,03 mikrogram pr. liter). Da detektionsgrænsen er 0,02 mikrogram pr. liter er resultatet usikkert.

Tilsvarende usikkerhed gælder en anden prøve, hvor der er konstateret et lavt fenol indhold. Boringen er en af Københavns Vandforsynings indvindingsboringer.

Der er fundet et lavt cyanid indhold i grundvandsprøver fra 5 filtre. Der kan ikke gives nogen forklaring på det fundne indhold.

Fra andre grundvandsundersøgelser i Gladsaxe erhvervskvarter vides det at det sekundære grundvandsreservoir er forurenet med miljøfremmede stoffer. 
Af miljøfremmede stoffer er der i Søndersø-området konstateret: aromater: benzen, klorerede opløsningsmidler: 1,1,1 triklormetan og tetraklormetan, Samleparametre: VOX og AOX, pesticider: dinoseb, Alkylfenoler: fenol, klorfenoler: pentaklorfenol samt cyanid. Det skal bemærkes, at der er konstateret miljøfremmede stoffer i samtlige boringer i området. Der er ikke umiddelbart sammenhæng mellem fundet af de forskellige stoffer $i$ de respektive filtre.

\section{Frederiksborg amt, 1991}

Specialanalyseprogrammet i Frederiksborg amt i 1990 omfattede 57 prøver til analyse for organiske mikroforureninger og 26 prøver til analyse for pesticider. Der blev ikke konstateret pesticider i nogen af prøverne.

I måleprogrammet for de organiske mikroforureninger blev der fundet 4 prøver med spor af benzen (0,1-0,2 mikrogram pr. liter) og 2 prøver med triklorfenol (0,05 og 1,4 mikrogram pr. liter)

Endvidere blev der i 2 prøver fundet et ret højt indhold af triklormetan på 4,9 og 7,0 mikrogram pr. liter.

De enkelte prøver med indhold af organiske mikroforureninger skal tolkes med forbehold, idet der er endnu ikke er foretaget kontrolanalyser.

Resultaterne af specialanalyserne vil blive nærmere vurderet i amtets rapportering i 1992, når der foreligger resultater for det samlede specialanalyseprogram. 
Roskilde amt, 1991

Af bemærkningerne til analyseresultaterne for specialparametrene gengives følgende:

\section{Spormetaller.}

I amtet er der konstateret et forhøjet nikkelindhold, over 20 mikrogram pr. liter, i grundvandet flere steder langs med Køge bugt, figur 6 .

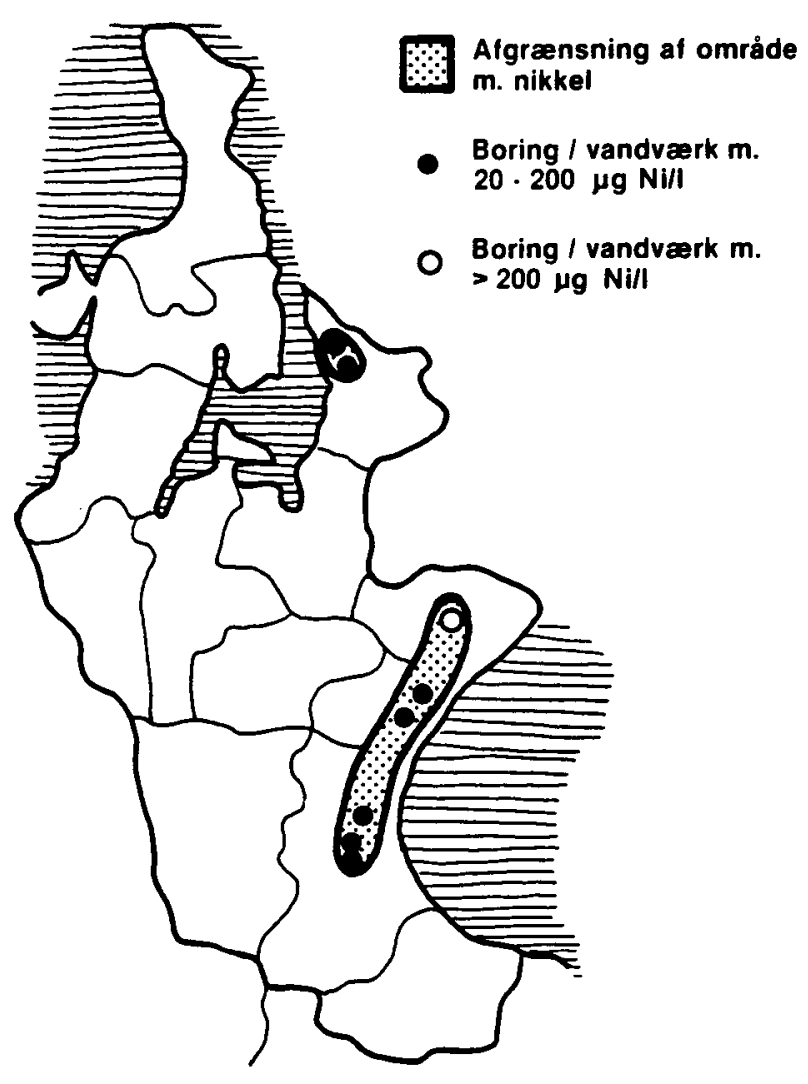

Figur 6: Afgrcensning af områder, hvor nikkelindholdet $i$ grundvandet overskrider den højst tilladelige voerdi for drikkevand.

Desuden er der i amtet konstateret et nikkelindhold på mellem 200 og 300 mikrogram pr. liter på Vardegårde kildeplads (en af Københavns Vandforsynings kildepladser) i Greve kommune. I Gundsø kommune er der en overskridelse på I/S Jyllinge Vandværk. Hvor stor udbredelsen af grundvand med højt nikkelindhold er, er endnu ikke fastlagt, da systematiske analyser for denne parameter først er påbegyndt $i$ forbindelse med den reviderede bekendtgørelse $\mathrm{nr}$. 515, om vandkvalitet og tilsyn med vandforsyningsanlæg. Nikkel kan udover forurening stamme blandt andet fra pyrit $\mathrm{i}$ kalken, som iltes/omsættes, når der sker grundvandssænkninger. Nylige undersøgelser tyder på, at nikkel også kommer i stor mængde fra de kvartære 
aflejringer, først og fremmest moræneleret, hvorfra det opkoncentreres i organiske aflejringer. Det høje nikkelindhold på I/S Jyllinge Vandværk bekræfter dette, da grundvandet her ikke indvindes fra kalk. Det høje nikkelindhold, som er konstateret flere steder $\mathrm{i}$ amtet, betragtes på nuværende tidspunkt som et problem, der bør undersøges nærmere.

\section{Pesticider.}

Der er ikke lavet nogen systematisk opgørelse over disse stoffers forekomst i grundvandet. I et internt amtsligt grundvandsovervågningsprogram er der foretaget screeninger af vandet fra 30 vandværksboringer fra 30 forskellige vandværker, som ligger spredt fordelt i amtet. Der blev ikke konstateret pesticider i nogen af boringerne.

Mikrobiologiske faktorer vurderes ikke at være genereile problemparametre på vandværkerne i amtet selv om overskridelser forekommer af og til.

\section{Vestsjællands amt. 1991}

I 1990 blev der udtaget vandprøver fra 20 filtre til analyse for specialparametre. Enkelte af disse prøver indeholdt enten pesticider eller opløsningsmidler (tabel 7).

\begin{tabular}{|l|c|c|c|l|l||}
\hline OMRÅDE & BORING & $\begin{array}{c}\text { FILTER- } \\
\text { DYBDE }\end{array}$ & $\begin{array}{c}\text { KONCENTRA- } \\
\text { TION } \\
\text { MIKROGRAM/1 }\end{array}$ & STOF & BEMARKNINGER \\
\hline Store Fuglede & $203.569^{\circ}$ & 13,5 & $\begin{array}{l}20,30 \\
1,04\end{array}$ & $\begin{array}{l}\text { Diklorprop } \\
\text { MCPA }\end{array}$ & Hovedreservoir \\
\cline { 2 - 6 } & 198.549 & 16,5 & $\begin{array}{l}7,16 \\
0,37\end{array}$ & $\begin{array}{l}\text { Diklorprop } \\
\text { MCPA }\end{array}$ & Hovedreservoir \\
\hline Holbæk & 16,0 & $\begin{array}{l}\text { svag } \\
\text { svag } \\
\text { svag } \\
\text { svag }\end{array}$ & $\begin{array}{l}\text { Benzen } \\
\text { 1,1,1-Trikloretan } \\
\text { Tetraklormetan } \\
\text { Triklormetan }\end{array}$ & Hovedreservoir \\
\hline
\end{tabular}

- I vandet fra et endnu dybere placeret filter i samme hovedreservoir, og fra en anden boring, er der ikke konstateret pesticider.

Tabel 7: $\quad$ Analyser med påvisning for pesticider og opløsningsmidler fra Vestsjoellands amt.

Resultaterne af specialanalyserne, herunder en årsag til det fundne pesticidindhold, vil blive nærmere analyseret $\mathrm{i}$ amtskommunernes afrapportering i 1992, når der foreligger resultater fra alle 60 filtre $\mathrm{i}$ overvågningsområderne. Som generel kommentar mener amtet, modsat DGU, at overvågningen af grundvandet $i$ overvågningsområderne ikke er en overvågning af grundvandet $i$ amtskommunen, og at overvågningsresultaterne således ikke kan generaliseres ud i større dele af amtskommunen. 
Udfra det begrænsede antal analyser, der er foretaget i 1990, er det ikke muligt at se en nærmere sammenhæng mellem arealanvendelsen $i$ grundvandsovervågningsområderne og de fundne resultater.

Analyser, hvor der er konstateret meget lave koncentrationer, bør altid verificeres ved en kontrolanalyse. De benzenværdier der er fundet i St. Heddinge-området virker upålidelige, og kunne skyldes kontaminering af prøven, evt. fra biler. Der er endnu ikke foretaget kontrolanalyser, men de planlagges gennemført.

Resultatet af specialanalyserne viser også at det er nødvendigt at analysere for organiske mikroforureninger i vandværkernes boringskontrol, idet mange punktkilder er ukendte.

Indholdet af uorganiske sporstoffer er generelt højst i centerboringen i Hjelmsølille-området. En tilsvarende tendens anes også $\mathrm{i}$ andre områder.

Omvendt er koncentrationen i de sekundære sandreservoirer generelt relativt lavere, specielt med hensyn til parametre som zink, nikkel og strontium.

I en grundvandsprøve fra Hjelmsølille-området er der, som det eneste eksempel i Storstrøms amt påvist cyanid (i koncentrationer lige over detektionsgrænsen).

Der er fundet benzen i enkelte filtre i Vesterborg-området, hvor også værdierne for AOX generelt er relativt bøje. Der er også fundet detergenter $\mathrm{i}$ enkelte af filtrene. Endelig er der $\mathrm{i}$ et filter, ud over de lave koncentrationer af benzen og detergenter, fundet bly, cadmium og krom, hvilket tyder på forurening. Der er dog ingen kendte forureningskilder i nærheden.

Det mest belastede overvågningsområde er Store Heddinge. Her er der fundet klorerede opløsningsmidler og andre organiske forbindelser i 7 filtre og yderligere detergenter i 2 filtre.

De analyserede stoffer er:

Detergenter

Benzen

Triklorethylen

Triklorethan

Tetraklorethylen

Triklormetan og

Atrazin.

Der er registreret en gammel gasværksgrund og flere industrigrundr indenfor St. Heddinge by. Herudover er mange filtre i St. Heddinge-området belastede med organiske forbindelser fra punktkilder. 
Resultatet af de bakteriologiske undersøgelser fremgår af tabel 8 .

\begin{tabular}{||l|c|c|c|}
\hline $\begin{array}{l}\text { OVERVÅGNINGS- } \\
\text { OMRÅDE }\end{array}$ & $\begin{array}{c}\text { KIMTAL 21 }{ }^{\circ} \mathrm{C} \\
\text { PR. ML } \\
\text { METODE: DS 2252 }\end{array}$ & $\begin{array}{c}\text { COLIFORME } \\
\text { BAKTERIER } \\
\text { PR. 100 ML } \\
\text { METODE: DS2255 }\end{array}$ & $\begin{array}{c}\text { KIMTAL 37 }{ }^{\circ} \mathrm{C} \\
\text { PR. ML } \\
\text { METODE: DS 2254 }\end{array}$ \\
\hline \hline Holeby & 8 & $<1$ & $<1$ \\
Vesterborg & 9 & $<1$ & $<1$ \\
Sibirien & 73 & $<1$ & $<1$ \\
St. Heddinge & $<1$ & $<1$ & $<1$ \\
\hline
\end{tabular}

Tabel 8: $\quad$ Resultaterne af de bakteriologiske undersøgelser $i$ hovedboringer $i$ Storstroms amt.

\section{Bornholms amt, 1991}

Der er foretaget specialanalyser på grundvandsprøver fra 8 filtre i 5 boringer. Prøverne er udtaget til analyse for forskellige uorganiske sporstoffer, organiske mikroforureninger og pesticider.

Resultaterne af specialanalyserne viser generelt, at grundvandets indhold af naturligt forekommende stoffer svarer til baggrundsværdier for rent grundvand, og at der ikke er fundet målelige mængder af naturfremmede stoffer.

Indholdet af det naturligt forekommende radioaktive stof strontium er generelt højt, hvilket skyldes at de geologiske lag (granit og skifer) i området indeholder en del strontium.

I en enkelt boring, er der konstateret et indhold af simazin (plantebekæmpelsesmiddel) på 0.36 mikrogram pr. liter i 29.27 meters dybde og 0.87 mikrogram i 14.27 meters dybde. Det forhøjede indhold af simazin skyldes uden tvivl brug af bekæmpelsesmidler i 1989 på en gårdsplads beliggende ca. 50 meter fra boringen. Da forbruget af bekæmpelsesmidlet er ophørt og omfanget begrænset, må det formodes at belastningen med simazin i grundvandet vil være begrænset til området omkring selve boringen. For en sikkerheds skyld vil en vandværksboring som ligger ca. 800 meter sydligere blive undersøgt en gang om året $\mathrm{i}$ de kommende år.

De resterende 8 prøvesteder i overvågningsområdet vil i 1991 blive undersøgt for specialstoffer, således at der i 1991-afrapporteringen kan foretages en samlet og mere detaljeret vurdering af resultaterne fra hele området. 


\section{Fyns amt, 1991}

Specialanalyseprogrammet omfattede i 1990 tredive prøver til analyse for uorganiske sporstoffer, organiske mikroforureninger og specielle pesticider. Prøverne blev hovedsageligt udtaget fra det dybere liggende, beskyttede grundvand. otteogtyve af prøverne er udtaget fra kvartære smeltevandsaflejringer, og to prøver er udtaget fra Danienkalk.

Resultaterne af de uorganiske sporstoffer viser, at alle disse sporstoffer findes naturligt $\mathrm{i}$ uforurenet grundvand, men at indholdet af specielt kviksølv, cadmium, krom, bly, nikkel og zink er meget lavt og ofte under detektionsniveau, tabel 9.

Der er fundet relativt store indhold af strontium, aluminium, bor, bromid og iodid men ingen af prøverne har et sporstofindhold, der overskrider den højst tilladelige værdi i drikkevand.

\begin{tabular}{||l|c|c||}
\hline PARAMETER & $\begin{array}{c}\text { MIDDEL } \\
\mu \mathrm{g} / \mathrm{l}\end{array}$ & $\begin{array}{c}\text { INTERVAL } \\
\mu \mathrm{g} / \mathrm{l}\end{array}$ \\
\hline \hline Aluminium & 30 & $0-280$ \\
Arsen & 4 & $0-20$ \\
Barium & 120 & $20-250$ \\
Bly & $<1$ & $0-5$ \\
Bor & 130 & $35-950$ \\
Bromid & 90 & $50-380$ \\
Cadmium & 0,004 & $0-0,04$ \\
Chrom & 0,1 & $0-0,2$ \\
Cyanid & 0,005 & $0-0,013$ \\
Jodid & 7 & $3-30$ \\
Kobber & 1 & $0-7$ \\
Kviksølv & 0,003 & $0-0,005$ \\
Lithium & 10 & $3-30$ \\
Molybdæn & 2 & $0-7$ \\
Nikkel & 0,5 & $0-2,5$ \\
Strontium & 700 & $225-4000$ \\
Zink & 4 & $0-20$ \\
\hline
\end{tabular}

Tabel 9: $\quad$ Resultateme af spormetalanalyseme på Fyn med angivelse af middelvardi og interval.

Bortset fra et stigende arsenindhold med dybden og et højere lithium- og strontiumindhold $i$ danienkalken ved Nyborg er der ikke fundet nogen sammenhæng mellem sporstofindholdet og geologi, henholdsvis dybde. Generelt gælder det, at sporstofindholdet ligger på nogenlunde samme niveau i de 6 overvågningsområder. Det er i overensstemmelse med, at hovedparten af prøverne er udtaget fra grundvandsreservoirer af samme bjergart (kvartære smeltevandsaflejringer).

Bortset fra en god korrelation mellem klorid- og bromidindholdet er der ikke fundet nogen sammenhæng mellem sporstofindholdet og grundvandets hovedbestanddele (jern, calcium, klorid) eller indbyrdes mellem sporstofferne.

Tritiumindholdet falder med dybden fra $20-60 \mathrm{TU}$ i det øverste grundvand til baggrundsniveauet på 0,1 1 TU i 40 - 50 meters dybde. Det betyder, at det grundvand, som ligger dybere end 40 - 50 meter, er dannet af nedbøren fra før 1950'erne. 
I måleprogrammet for organiske mikroforureninger er.der ikke fundet miljøfremmede stoffer i det undersøgte grundvand, tabel 10, det vil sige stofgrupperne: pesticider, aromatiske kulbrinter og halogenerede alifatiske kulbrinter.

\begin{tabular}{||c|c|c||}
\hline STOFGRUPPE & $\begin{array}{c}\text { MIDDELV FR- } \\
\text { DI } \\
\mu g / 1\end{array}$ & $\begin{array}{c}\text { INTERVAL } \\
\mu \mathrm{g} / \mathrm{l}\end{array}$ \\
\hline Samleparametre: & & \\
NVOC & 2000 & $600-6600$ \\
AOX & 2,9 & $1,5-6,9$ \\
VOX & $<0,5$ & \\
Aromatiske kulbrinter & $<0,1$ & \\
Halogenerede alifatiske kulbrinter & $<0,1$ & \\
Fenol og aikylfenoler & $*$ & $0-10$ \\
Klorfenoler & $*$ & \\
Anionaktive detergenter & $<4$ & \\
Pesticider & $<0,01$ & \\
\hline
\end{tabular}

- Resultater foreligger endnu ikke, men prøver er udtaget.

Tabel 10: $\quad$ Resultater af analyseme for organiske mikrofonureninger og samleparametre på Fyn.

I 4 boringer er der dog fundet forhøjet indhold af anionaktive detergenter. Det er uvist, om det skyldes forurening, eller om det er naturligt forekommende.

Af de organiske samleparametre er der fundet NVOC og AOX i alle prøver i koncentrationer svarende til baggrundskoncentration i uforurenet grundvand. Derimod er der ikke påvist VOX i prøverne. Endvidere er AOX-indholdet faldende med dybden. Det er uvist om det højere indhold af AOX i de kortere boringer er et udtryk for forurening, eller om det er naturligt betinget.

Resultaterne viser at indholdet af NVOC varierer fra 0.6-6.6 milligram kulstof pr. liter, med et gennemsnitligt indhold på 2 mikrogram pr. liter. Højeste værdi er fundet i boring 145.2087 i næstnederste filter (i 17 meters dybde) i overvågningsområdet i Borreby. Boringen har tillige et højt kaliumpermanganat-tal (15-20).

Generelt galder det, at der er en tydelig sammenhæng mellem NVOC og permanganat-tallet, figur 7.

NVOC analyserne svarer godt overens med erfaringsværdier for NVOC i grundvand, der oftest varierer mellem 0.1 og 5 milligram kulstof pr. liter, (Grøn, 1988).

Indholdet af AOX varierer mellem 1.5 og 6.9 mikrogram pr. liter, med et gennemsnitligt indhold på 2,9 mikrogram pr. liter. AOX indholdet svarer ifølge (Grøn, 1988) overens med indholdet $\mathrm{i}$ uforurenet grundvand.

Analyserne viser, at der er et tydeligt fald i AOX med dybden figur 8. Selv om AOX-indholdet $\mathrm{i}$ alle prøver ligger på baggrundsniveauet, kan det ikke afvises, at det forhøjede indhold $\mathrm{i}$ de korte boringer skyldes forurening, eventuelt fra nedbrydningsprodukter af pesticider. Der er ikke fundet nogen sammenhæng mellem NVOX og AOX. 
Fra tidligere unders $ø$ gelser vides at VOX ikke findes naturligt $\mathrm{i}$ grundvandet. I overensstemmelse hermed er der ikke påvist VOX i grundvandsprøverne fra overvågningsområdet. Alle analyser ligger under målegrænsen på 0.5 mikrogram kulstof pr. liter.

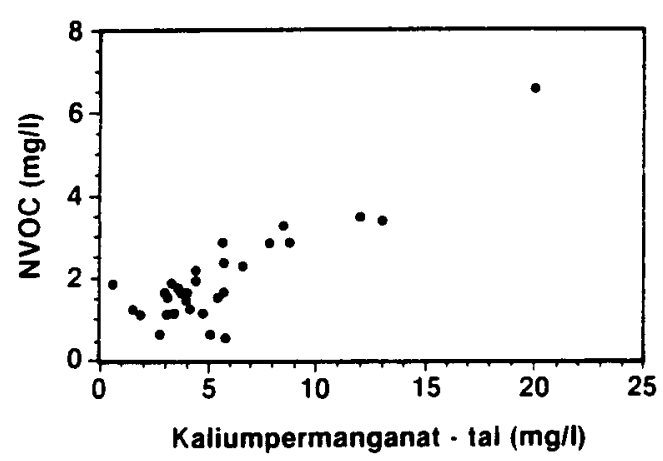

Figur 7: $\quad$ Sammenhaeng mellem NVOC og kaliumpermanganattallet på Fyn.

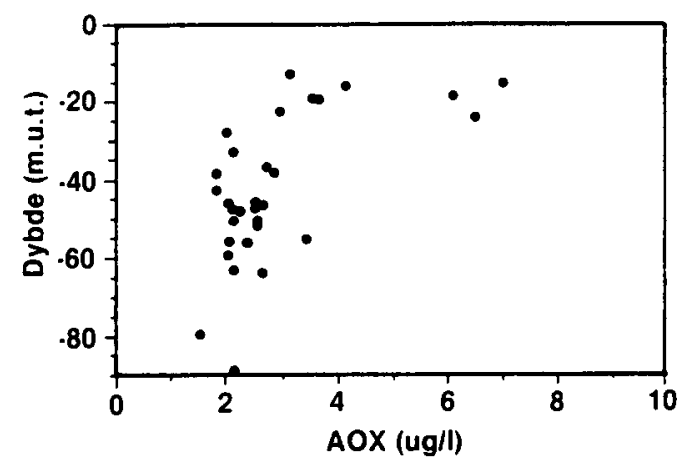

Figur 8: AOX-indholdets variation med dybden på Fyn.

I de 30 prøver fra overvågningsområderne er der hverken påvist aromatiske kulbrinter (detektionsgrænsen er 0.1 mikrogram pr. liter) eller halogenerede alifatiske kulbrinter (detektionsgrænsen er 0.1 mikrogram pr. liter).

Resultaterne for fenoler og klorfenoler foreligger ikke, fordi der er sket fejl under analyseringen. Der skal derfor udtages nye prøver.

De foreløbige resultater fra overvågningsprogrammet viser at indholdet af anionaktive detergenter normalt ligger under detektionsgrænsen på 4 mikrogram pr. liter. Der er dog konstateret detergenter i 4 prøver i koncentrationer mellem 6 og 10 mikrogram pr. liter. I to af de prøver, hvor der er fundet spor af detergenter (boring DGU nr. 155.763, nederste filter og 155.764, næstnederste filter, begge i Nr. Søby), blev der også fundet pesticider (Meklorprop). Der blev derfor udtaget nye prøver, hvori der ikke kunne påvises pesticider. Det første prøvesæt er derfor sandsynligvis forurenet ved udtagelsen eller på laboratoriet. Der vil blive udtaget nye prøver fra de boringer, hvor der er fundet forhøjet indhold af anionaktive detergenter.

\section{Pesticider}

Undersøgelsen i 1990 omfattede 8 pesticider: Simazin, MCPA, 2,4-D, meklorprop, diklorprop, atrazin, DNOC og dinoseb. Pesticiderne er udvalgt ud fra en eller flere af nedenstående kriterier:

\footnotetext{
- Stor anvendelse

- Stor mobilitet i jorden

- Stor nedbrydelighed
} 
Der er udtaget ialt 60 prøver fordelt på 30 prøver fra det dybereliggende grundvand i grundvandsovervågningsområderne og 30 prøver fra det øvre grundvand (1.5-7 meter under terræn) i landovervågningsoplandet ved Lillebæk. Landovervågningsområdet er et intensivt dyrket landbrugsområde (moræneler) med udbredt pesticidanvendelse. Bl.a. er der igennem en årrække anvendt atrazin i forbindelse med dyrkning af majs.

I de 30 prøver, der er udtaget fra det øverste grundvand i landovervågningsoplandet er der ikke fundet spor af pesticider. Alle prøver har et pesticidindhold under målegrænsen på 10 nannogram pr. liter.

I de prøver, der er udtaget fra grundvandsovervågningsområderne, er der som næunt fundet meklorprop dybere nede i to boringer i Nr. Søby med et indhold på henholdsvis 0,43 og 0,11 mikrogrampr. liter. Desuden er der fundet MCPA i boring DGU nr. 147.856 i det sekundære reservoir i Nyborg.

Nye prøver fra de 3 boringer viste dog ikke spor af pesticider. Det tyder derfor på, at der er sket forurening af prøverne ved prøveudtagningen eller på laboratoriet. 
I 1990 blev der foruden de fire prøvetagningsrunder til "almindelige analyser" også udtaget 27 prøver til analyse for uorganiske sporstoffer, 23 til organiske mikroforureninger samt 18 til pesticidanalyser.

Der er udtaget prøver til tritium- og kviksølvanalyser i næsten alle boringer. Der mangler at blive udtaget prøver fra tre filtre, som på det pågældende tidspunkt ikke gav vand, på grund af for lav grundvandsstand.

I overvågningsområderne varierer koncentrationen af de uorganiske sporstoffer fra boring til boring og fra filter til filter, men kun i Bedsted er der eksempler på at højst tilladte koncentration for et enkelt stof, nikkel, overskrides. Denne nikkel forekommer sammen med lave koncentrationer af kviksølv, der ikke er registreret andre steder i Bedsted-området. I Christiansfeld er der som det eneste sted fundet en lav cyanid koncentration i grundvandet, iøvrigt sammen med lidt kviksølv.

Der er påvist organiske mikroforureninger (på detektionsgrænseniveau).

I Bedsted-området er der konstateret et kontrolleret, men uforklarligt indhold af benzen på 0,1 mikrogram pr. liter $i$ en enkelt boring.

I Rødding-området er der et enkelt sted fundet en lav triklormetan koncentration og i Bedsted-området har enkelte højtliggende filtre et relativt stort indhold af de organiske samleparametre.

Pesticider er påvist i to boringers højtliggende filtre, et i Christiansfeld (meklorprop) og et i Bedsted-området (MCPA). Ingen af disse analyser er endnu blevet kontrolmålt.

I nærheden af den pågældende boring i Bedsted-området har DMU fundet MPCA i jordvandet $\mathrm{i}$ landovervågningsområdet Bolbro Bæk. Der er endnu ikke foretaget en nøjere vurdering af disse analyseresultaters hydrogeologiske betydning.

Ribe amt, 1991

I 1990 er de første specialanalyser udført på udvalgte boringer. Antallet af udtagne vandprøver til analyse for uorganiske sporstoffer, organiske mikroforureninger og pesticider er endnu så lavt, at det ikke er rimeligt at relatere disse analyseresultater til de observerede arealanvendelser og geologiske miljøer, hvorfor dette er udskudt til analyse i løbet af 1991.

En del ældre kildepladser er placeret i industriområder. I de senere år er kontrollen med opløsningsmidler og oliederivater derfor øget. Det er hidtil lykkedes at redde truede kildepladser fra ødelæggelse, men det må erkendes, at fremtidige kildepladser under ingen omstæandigheder må placeres $\mathrm{i}$ industriområder. Arbejdet med undersøgelser for kemisk forurening samarbejdes i øvrigt med affaldsdepotkortlægningen. 
Vejle amt, 1991

Specialanalyseprogrammet i 1990 omfattede 25 prøvesæt til analyse for uorganiske sporstoffer, organiske mikroforureninger og pesticider. Alle analyser blev foretaget på prøver fra de samme filtre. Prøverne blev udtaget i såvel primære- som sekundære reservoirer for derigennem at få både et indtryk af det naturlige indhold af uforurenet grundvand (baggrundskoncentration) samt af ungt påvirket grundvand. Af de specielle pesticider blev der analyseret for atrazin, simazin og 2,4-D.

I forbindelse med specialanalyserne blev der fundet to sprøjtemidler, an-ioniske detergenter, kloroform, fenol, forhøjet indhold af aluminium og zink. I øvrigt var det muligt at finde samtlige uorganiske sporstoffer. Der blev ikke fundet aromatiske kulbrinter, alkylfenoler og klorfenoler.

Tritium-analyser viser at grundvandets alder $\mathrm{i}$ Thyregod og Ejstrupholm områderne har ungt vand $\mathrm{i}$ det primære reservoir. Egebjerg, Follerup og Trudsbro har gammelt grundvand.

Tritium indholdet varierer således både med dybde og tid i Thyregod og Ejstrupholm områderne, mens variationen i forhold til tiden er ubetydelig i Egebjerg og Follerup områderne.

De foreløbige analyser viser, at alle sporstofferne er påvist i grundvand om end værdierne for cadmium, bly, nikkel og krom er lave og ofte under detektionsgrænsen, tabel 11.

\begin{tabular}{|c|c|c|c|c|}
\hline $\begin{array}{l}\text { PARAME- } \\
\text { TER }\end{array}$ & $\begin{array}{l}\text { KONCENTRATIONS. } \\
\text { INTERVAL } \\
\text { MIKROGRAM } \\
\text { PR LITER }\end{array}$ & $\begin{array}{l}\text { MEDIAN } \\
\text { MIKROGRAM } \\
\text { PR. LITER }\end{array}$ & $\begin{array}{l}\text { VEJL. VAERDI } \\
\text { MIKROGRAM } \\
\text { PR. LITER }\end{array}$ & $\begin{array}{l}\text { HØJST TILL. } \\
\text { VAERDI } \\
\text { MIKROGRAM } \\
\text { PR. LITER }\end{array}$ \\
\hline $\begin{array}{l}\text { Bly } \\
\text { Cadmium } \\
\text { Krom } \\
\text { Kobber } \\
\text { Nikkel } \\
\text { Arsen } \\
\text { Strontium } \\
\text { Zink } \\
\text { Molybdaen } \\
\text { Lithium } \\
\text { Aluminium } \\
\text { Barium } \\
\text { Kviksølv } \\
\text { Bor } \\
\text { Bromid } \\
\text { Iodid } \\
\text { Cranid }\end{array}$ & $\begin{array}{c}0-5 \\
0-0,12(0,35) \\
0-2 \\
0-1,4 \\
0-3,5 \\
0-24 \\
100-1000 \\
0-180 \\
0,3-4 \\
2-21 \\
0-500 \\
0-350 \\
0-0,058 \\
0-140 \\
50-140 \\
0-11 \\
0\end{array}$ & $\begin{array}{c}0,2 \\
0,03 \\
0,03 \\
0,03 \\
0,03 \\
3 \\
250 \\
5 \\
0,5 \\
5 \\
5 \\
120 \\
0,005 \\
80 \\
100 \\
7 \\
0\end{array}$ & $\begin{array}{l}\text { u.d. } \\
\text { u.d. } \\
\text { u.d. }\end{array}$ & $\begin{array}{c}50 \\
5 \\
50 \\
0,1 \\
20 \\
50 \\
\\
100\end{array}$ \\
\hline
\end{tabular}

Tabel 11: Oversigt over resultateme af sporstofanalyseme fra overvägningsprogrammet $i$ Vejle amt med angivelse af middelvaerdi og interval. Desuden fremgår vejledende og højst tilladelige vardi.

Det højeste indhold af sporstof er fundet for strontium, aluminium, bor, barium og zink. 
Der er et tilfælde af overskridelse, af det højst tilladelige indhold i drikkevand, for hvert af stofferne zink og aluminium. Andre analyser overskrider den tilsvarende vejledende grænseværdi. Den vejledende grænse er fastlagt ud fra det princip, at tungmetaller ikke må kunne påvises. Da de nye analyseapparater imidlertid måler så fint, at de fleste af tungmetallerne kan detekteres overalt, holder det nævnte princip ikke længere.

Der er en vis sammenhæng mellem indholdene af calcium, strontium og barium. Med stigende indhold af calcium kan der konstateres en stigning af strontium og bariumindholdet.Disse stoffer findes især $i$ tilknytning til de kalkholdige moræneaflejringer. Sporstoffer, så som cadmium, nikkel og aluminium, som er mobile i surt miljø findes mest i sandede områder uden kalkholdige bjergarter.

De største koncentrationer af arsen findes ved normale pH-forhold (mellem 7 og 8). Baseret på det nuværende beskedne datagrundlag synes arsen især at forekomme omkring $\mathrm{pH} 7,4$. Der er svag positiv korrelation mellem koncentrationerne af fosfor og arsen.

Resultaterne af de uorganiske sporstoffer viser, at disse stoffer findes naturligt $i$ uforurenet grundvand, men at indholdet for specielt kviksølv, cadmium, krom, bly og zink er på et meget lavt niveau og ofte under detektionsniveau. Der er en enkelt overskridelse af drikkevandskravene for aluminium og en for zink.

Kviksølvindholdet overskrider $\mathrm{i}$ ingen af de udførte analyser kravene til drikkevand.

Resultaterne viser foreløbig, at det overfladenære grundvand har et indhold på mellem 10 og 40 nannogram kviksølv pr. liter. I overvågningsområdet ved Ejstrupholm har der været målt op til 58 nannogram kviksølv pr. liter. Årsagen til dette noget højere indhold af kviksølv, kan skyldes de i området udbredte brunkulslag. Imidlertid er Ejstrupholm-området betydeligt mere sårbart overfor fladeforurening end de øvrige overvågningsområder, og antallet af analyser er for begrænset til, at fastslå om kullagene alene er årsagen.

\section{Organiske samleparametre.}

Resultaterne af analyserne er vist i tabel 13.

\begin{tabular}{||c|c|c||}
\hline & $\begin{array}{c}\text { MIDDELVARDI } \\
\text { mikrogram pr. liter }\end{array}$ & $\begin{array}{c}\text { KONCENTRATION } \\
\text { mikrogram pr. liter }\end{array}$ \\
\hline \hline Samleparametre: & 2000 & $320-2200$ \\
NVOC & 3 & $0,0-51$ \\
VOX & $<0,5$ & $<0,5$ \\
Aromatiske kulbrinter & $<0,1$ & $0,0-015$ \\
Halogenerede alifatiske kulbrinter & $<0,1$ & $0,0-0,22$ \\
Fenol og alkylfenoler & $<0,03$ & $0-50$ \\
Klorfenoler & $<0,01$ & $0-0,294$ \\
Anioniske detergenter & 10 & $<0,01$ \\
Pesticider & & \\
\hline
\end{tabular}

Tabel 13: Oversigt over resultaterne af analyseme for organiske mikroforureninger og samleparametre fra overvågningsprogrammet $i$ Vejle amt, med angivelse af middelvaerdi og koncentrationsinterval. 
Resultaterne fra måleprogrammet for de organiske mikroforureninger er vist i tabel 13. Det fremgår, at der af miljøfremmede stoffer er fundet halogenerede alifatiske kulbrinter (triklormetan), fenol og pesticider.

Triklormetan er påvist $\mathrm{i}$ en enkelt prøve med 0,15 mikrogram pr. liter, hvilket er under den vejledende grænse på 1 mikrogram pr. liter.

Fenol er påvist i en enkelt prøve med en værdi på 0,22 mikrogram pr. liter. Højst tilladelige indhold er 0,5 mikrogram pr. liter. Resultaterne fra overvågningsprogrammet viser, at indholdet af de Anioniske detergenter normalt ligger under detektionsgrænsen på 4 mikrogram pr. liter. Der er dog konstateret detergenter i 11 prøver i koncentrationer fra 10 mikrogram pr. liter og 4 prøver fra 30 mikrogram pr. liter.

\section{Pesticider.}

Der blev analyseret for følgende 8 pesticider: simazin, atrazin, MCPA, 2,4-D, meklorprop, DNOC og dinoseb. Pesticiderne er udvalgt ud fra en eller flere af følgende kriterier.

\section{- Stor anvendelse}

- Stor mobilitet $\mathrm{i}$ jorden

- Langsom nedbrydelighed

Af de 25 analyser blev der fundet MCPA i 5 af prøverne og DNOC i et tilfælde, som det fremgår af tabel 12. Grænseværdien er overskredet for analysen for DNOC. Skemaet indeholder oplysninger om de fysiske forhold. Det må konstateres at pesticiderne er fundet i dybder op til 68 meter under terræn. Pesticiderne er især fundet i Thyregod, som er kendetegnet ved at være et sandet område med intensiv dyrkning.

\begin{tabular}{|c|c|c|c|c|c|c|c|c|c|}
\hline STED/GRUMO nr. & $\begin{array}{c}\text { MIKRO. } \\
\text { GRAM } \\
\text { pr. liter }\end{array}$ & $\begin{array}{l}\text { DATO } \\
1990\end{array}$ & $\begin{array}{l}\text { GVS } \\
\text { m.u.t. }\end{array}$ & $\begin{array}{l}\text { FILTER- } \\
\text { DYBDE }\end{array}$ & BJERGART & $\begin{array}{l}\text { JORD- } \\
\text { BUND }\end{array}$ & $\begin{array}{l}\text { TOPO- } \\
\text { GRAFI }\end{array}$ & $\begin{array}{c}\text { NED- } \\
\text { BøR } \\
\text { mm }\end{array}$ & $\begin{array}{l}\text { VAN- } \\
\text { DING }\end{array}$ \\
\hline $\begin{array}{l}\text { MCPA: } \\
\text { Egebjerg } 60.01 .03 \\
\text { Thyregod } 60.11 .01 \\
\text { Thyregod } 60.11 .04 \\
\text { Thyregod } 60.11 .10-1 \\
\text { Thyregod } 60.11 .10-1\end{array}$ & $\begin{array}{c}0,03 \\
0,028 \\
0,02 \\
0,03 \\
0,045\end{array}$ & $\begin{array}{l}09 / 10 \\
15 / 10 \\
17 / 10 \\
15 / 10 \\
16 / 10 \\
\end{array}$ & $\begin{array}{c}0,5 \\
17 \\
34 \\
22 \\
5\end{array}$ & $\begin{array}{c}8-12 \\
33-39 \\
44-47 \\
38 \\
7\end{array}$ & $\begin{array}{l}\text { moranegrus } \\
\text { kvartssand } \\
\text { kvartssand } \\
\text { kvartssand } \\
\text { kvartssand }\end{array}$ & $\begin{array}{l}\text { leret } \\
\text { gr. sand } \\
\text { gr. sand } \\
\text { gr. sand } \\
\text { gr. sand }\end{array}$ & $\begin{array}{c}\text { sv. kup. } \\
\text { fladt } \\
\text { fladt } \\
\text { fladt } \\
\text { fladt }\end{array}$ & $\begin{array}{l}650 \\
700 \\
700 \\
700 \\
700\end{array}$ & $\begin{array}{l}\text { nej } \\
\text { ja } \\
\text { ja } \\
\text { ja } \\
\text { ja }\end{array}$ \\
\hline $\begin{array}{l}\text { DNOC: } \\
\text { Egebjerg 60.01.04-1 }\end{array}$ & 0,294 & $09 / 10$ & 16 & 68 & smeltev.sand & leret & sv. kup. & 650 & nej \\
\hline
\end{tabular}

Tabel 12.: $\quad$ Analyser med pesticider i Vejle amt. 
Ringkøbing amt, 1991

Størrelsen af analyseprogrammet $i$ amtet varierer fra stofgruppe til stofgruppe. Der er gennemført tritiumanalyser på vandprøver fra 45 ud af de 46 filtre amtet selv har etableret og fra 5 af de 14 filtre Danmarks Geologiske Undersøgelse har etableret.

Indholdet af uorganiske sporstoffer er undersøgt i vandprøver fra 17 filtre i de dybtliggende reservoirer, og indholdet af organiske mikroforureninger er analyseret $i$ vandprøver fra 20 filtre i de øverste frie reservoirer (der er ialt 60 overvågningsfiltre i amtet).

I en del af prøverne fra filtrene er der fundet et højt indhold af barium, i flere tilfælde over grænseværdien, hvilket kan skyldes påvirkning fra tætningsmidler (bentonit) og/eller boremudder. Disse målinger stammer fra såvel volumen- som linie- og punkt-overvågende filtre.

I nogle af de samme prøver er der yderligere et højt aluminium indhold, der $\mathrm{i}$ et enkelt tilfælde overskrider grænseværdien.

Der er ikke konstateret stofkoncentrationer, som kunne tyde på organisk forurening af grundvandet. 
Århus amt, 1991

Der blev i 1990 udført det fulde program for specialanalyser på grundvandsprøver fra 30 filtre i overvågningsområderne, Nordsamsø, Fillerup og Hvinningdal. Der er $\mathrm{i}$ disse analyser kun påvist miljøfremmede organiske forbindelser i é boring på Samsø.

Derudover er der i 5 filtre i hver af de tre områder udtaget prøver til kviksølvanalyse.

Prøverne er kun udtaget $\mathrm{i}$ boringer, som har udvist en stabil vandkemi, og de er fordelt på de enkelte oplande, således at forskellige vandtyper inden for hvert opland er blevet repræsenteret. Alle prøverne er udtaget uden efterfølgende filtrering. Dette indebærer for metalanalyserne en risiko for forhøjede værdier på grund af suspenderet stof, der ikke kunne ses med det blotte øje.

Analyserne for uorganiske sporstoffer viser, at der er store regionale forskelle på indholdet af disse i grundvandet. Dette skyldes formentlig forskellige sammensætninger af jordlagene i områderne. Kun for nikkel og aluminium kunne der påvises en sammenhæng med grundvandets surhedsgrad.

En vurdering af indholdet af uorganiske sporstoffer viser, at grundvandskemien i områderne har hver sit karakteristiske billede med karakteristiske niveauer for de forskellige stoffer for hvert område. Samtidig viser det indbyrdes forhold mellem en del af stofferne nogle fælles træk $i$ alle områderne, selv om de optræder i forskellige koncentrationsniveauer.

Bariumindholdet er ifølge flere forfattere afhængigt af sulfatindholdet, da bariumsulfat er uhyre tungtopløseligt. Denne sammenhæng kan dog ikke eftervises i det foreliggende datamateriale, figur 9.

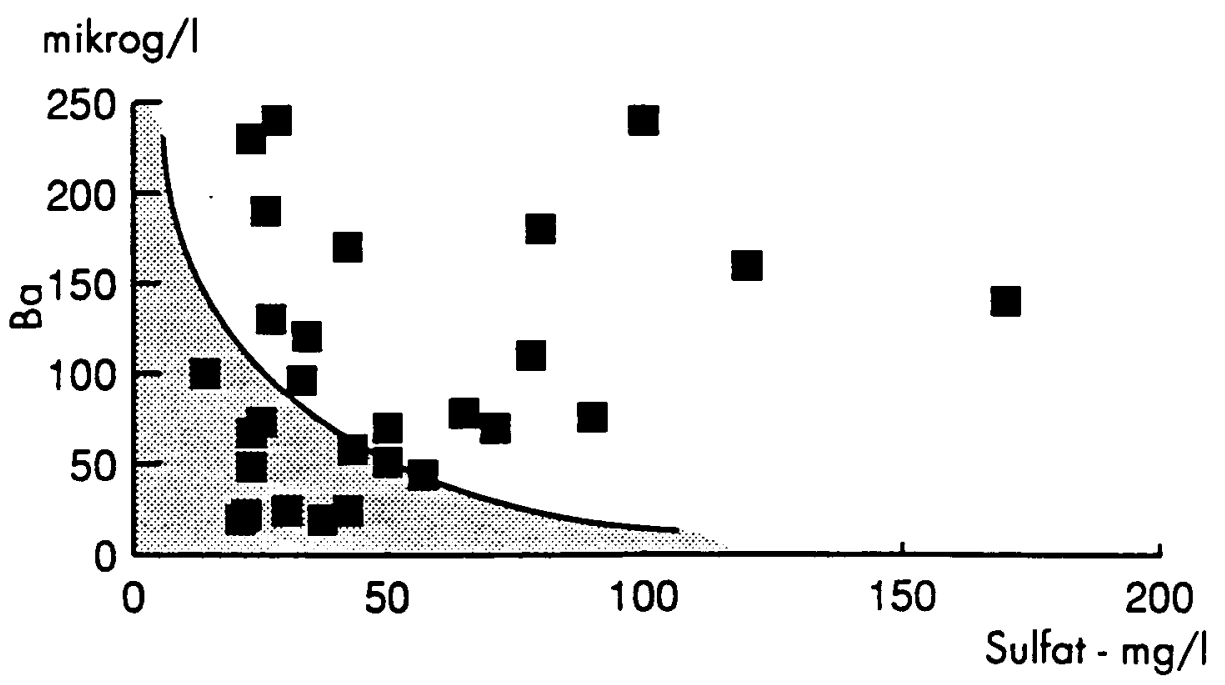

Figur 9.: Forholdet mellem barium og sulfat $i$ grundvandsovervagningsområdeme $i$ Ähus amt. Uden for det rastede felt er opløseligheden overskredet (op til en faktor 10). 
Overskridelse af opløseligheden for barium og sulfat kan muligvis forklares ud fra komplexdannelser, da sulfat bl.a. kan danne komplekser med for eksempel magnesium, natrium og calcium. Det kræver dog at $90 \%$ af den analyserede sulfat er på kompleksform, hvilket næppe er tilfældet ved de aktuelle ionsammensatninger.

Forholdet mellem de beslægtede stoffer barium og strontium er ens og lineært i alle overvågningsområderne. En tilsvarende relation mellem strontium- og calciumindholdet er tydelig, især ved lave calciumkoncentrationer i Hvinningdal-området.

Arsen- og fosfatkoncentrationerne er størst $\mathrm{i}$ lerjordene og da størst, hvor der er reducerede forhold og opløst ferrojern. De to forhold hænger sammen, da der under de reducerede forhold er en bedre opløselighed for såvel ferrojern som fosfat:

I de reducerede lag ved Fillerup er det gennemsnitlige arsenindhold på 3,5 mikrogram pr. liter med det typiske indhold på ca. 2,5 mikrogram pr. liter. I det oxiderede vand på Samsø er den typiske værdi ca. 0,5 mikrogram pr. liter, mens der ved Hvinningdal, hvor fosfatindholdet er meget lavt, findes typiske værdier på 0,2 mikrogram pr. liter $i$ den oxiderede zone.

Nikkelindholdet i grundvandet er $\mathrm{pH}$-afhængigt. Dette illustreres af analyserne fra Hvinningdal, figur 10, der viser at forhøjet nikkel-indhold ikke forekommer over $\mathrm{pH}$ på ca. 6,3. I de øvrige overvågningsområder er $\mathrm{pH}$ over 6,5. Det forhøjede nikkel-indhold er sammenfaldende med lavt ferrojern-indhold.

Borindholdet ser ud til at afhænge af det generelle saltindhold i jorden. Således er borindholdet på Samsø 4-5 gange større end i de to andre områder.

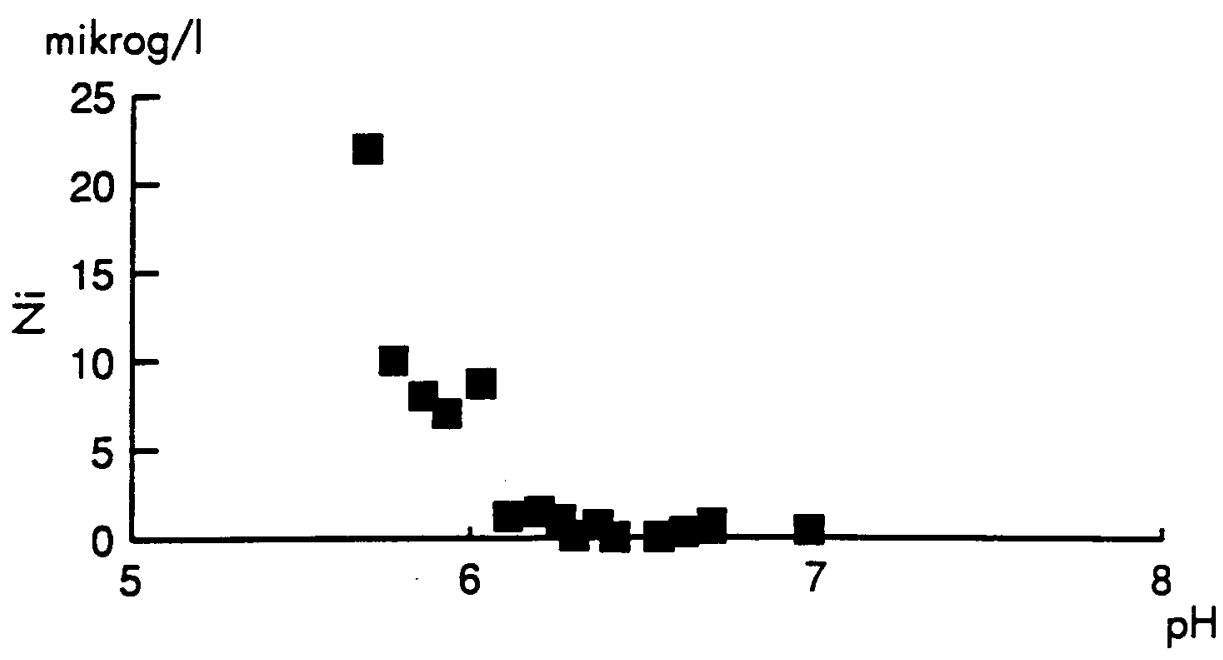

Figur 10: Forholdet mellem nikkel og pH i grundvandsovervågningsområdet Hvinningdal. 


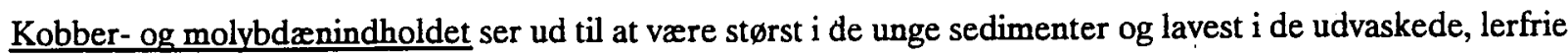
sedimenter ved Hvinningdal.

Aluminium er fundet $i$ det sure vand ved Hvinningdal, men overraskende nok også i det mere neutrale vand fra Fillerup. Disse værdier kan være udtryk for, at prøverne ikke var tilstrækkeligt renpumpede inden prøveudtagningen fandt sted. Da der ved alle boringer i Fillerup er anvendt pumpet bentonit til tætning af borehullet umiddelbart over filteret, er der en risiko for, at det påviste aluminium stammer herfra.

Alle prøver for organiske mikroforureninger viste, på nær en enkelt fra Nordsamsø, at der ikke kunne detekteres miljøfremmede organiske stoffer. I undtagelsen på Samsø er der fundet simazin, toluen, o-xylen og tetraklorethylen på niveau med detektionsgrænsen. Resultatet vil ikke blive tolket nærmere, før en omprøve foreligger. Boringens beliggenhed tæt ved en gård tyder dog på, at der kan være tale om en reel forurening, da prøven er udtaget i det øverste grundvand.

Af detergenter er der fundet mellem 4 og 7 mikrogram pr. liter i 5 boringer på Nordsams $\emptyset$ og i én boring ved Fillerup, hvor vandprøven stammer fra den nederste del af et meget velbeskyttet reservoir.

Det kan, trods risikoen for falske resultater, ikke udelukkes at en del af bidraget på Nordsamsø hænger sammen med brug af detergenter $\mathrm{i}$ sprøjtemidlerne, da der $\mathrm{i}$ området foregår en særlig intensiv grønsagsdyrkning.

Indholdet af AOX stiger med indholdet af klorid i grundvandet. Indholdet af klorid kan imidlertid ikke alene forklare AOX-værdierne, da der for høje kloridværdier også forekommer lave AOX, mens der for lave kloridværdier ikke forekommer høje AOX-værdier, figur 11.

En eventuel sammenhæng mellem AOX- og NVOC indholdet kan ikke anskueliggøres i nærværende datamateriale, idet NVOC-værdierne alle er næsten lige store.

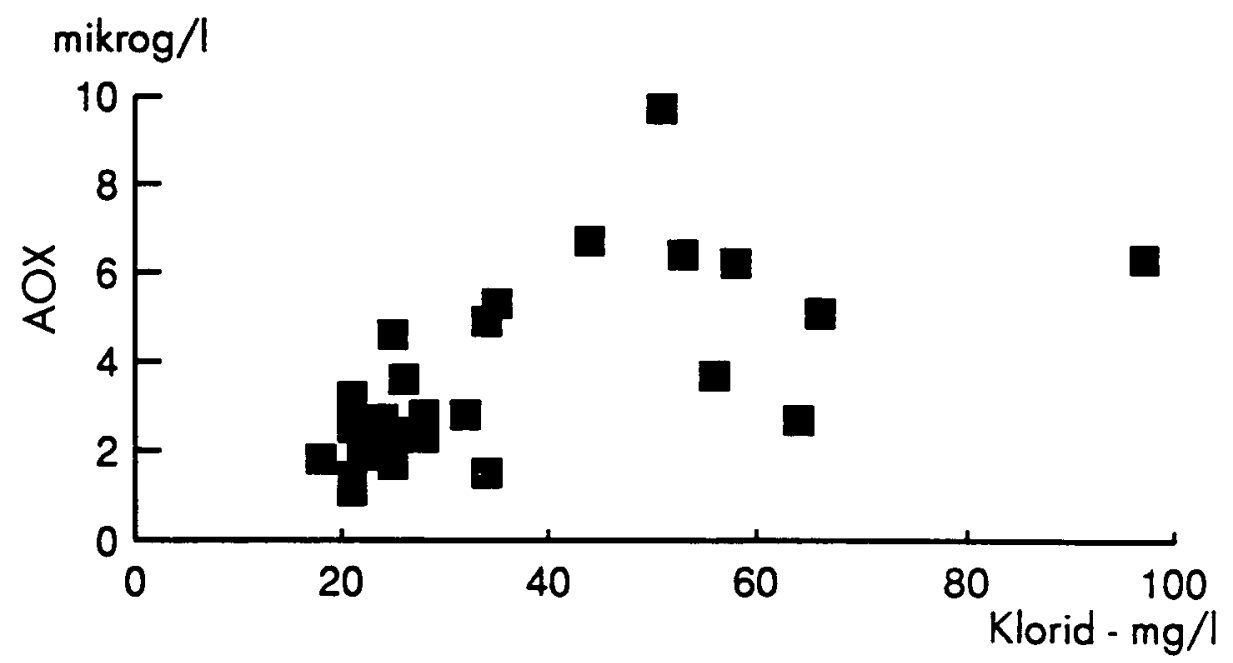

Figur 11: $\quad$ AOX som funktion af klorid $i$ grundvandet $i$ Arrhus amt. 
Der er foretaget 23 specialanalyser for bl.a. organiske mikroforureninger, tungmetaller og sprøjtemidler. Spormetaller, opløsningsmidler, pesticider og mikrobiologiske komponenter kendes kun som lokale punktforureninger. Bortset fra enkelte forhøjede værdier, der kan henføres til forurening i forbindelse med borearbejde, er der ingen af disse analyseresultater, der tyder på forurening af grundvandet.

Til specialanalyser er udvalgt filtre i vandværksboringer og overvågningsboringer med fast monteret pumpe, mens der ikke er taget prøver fra de overvågningsboringer, hvorfra prøvetagning sker med mobil pumpe. Fra 8 af filtrene i Thisted-området er der ikke analyseret efter pesticider, på grund af kapacitetsproblemer på laboratoriet.

I løbet af 1991 vil alle filtre blive forsynet med fast monteret pumpe, og de resterende sporstofanalyser vil blive udført.

Herefter vil analyseresultaterne blive vurderet samlet. Der vil i den forbindelse blive gjort forsøg på at lokalisere kilder til konstaterede forureninger, og det vil blive vurderet, i hvilket omfang, der skal udføres kontrolanaiyser.

Om de foreliggende analyser skal der bemærkes:

Der er overskridelse af den højst tilladelige værdi for zink i 3 tilfælde. De to af tilfældene er fra ibrugværende vandværksboringer. Begge vandværksboringer er for nylig blevet ombygget. Det kan derfor formodes, at de forhøjede zinkværdier stammer fra nyinstallerede galvaniserede rør eller fittings. Det tredie tilfæide kommer fra en boring ved et nedlagt vandværk.

I et filter i en nyetableret overvågningsboring ved Viborg er der fundet dinoseb, pentaklorfenol, og to isomerer af tetraklorfenol. Det er et filter, der sidder $i$ en dybde af 72-75 meter under terræn. Der er en stærk formodning om, at der er sket forurening i forbindelse med borearbejdet.

- I en nedlagt vandværksboring er der fundet spor af cresoler, dimethylfenoler, tetraklorfenol og pentaklorfenol. Det vides ikke, hvorfra forureningen stammer. Der er dog mistanke til forskellige kunststof-installationer på det gamle vandværk. 


\section{Nordjyllands amt, 1991}

I 1990 er der som en del af overvågningsprogrammet udtaget 30 specialanalyser til detektion af udvalgte stoffer på baggrundsniveau. Analyseværdierne er vurderet foreløbigt i nærværende rapport. Det er planen i løbet af 1991 at udtage endnu 30 af disse prøver, hvilket vil forøge tolkningsmulighederne væsentligt.

Hvad angår de fundne værdier ved specialanalyserne, giver disse generelt ikke anledning til bekymring, hvad angår forurening. Dog har enkelte resultater forårsaget udtagning af nye prøver for at be- eller afkræfte en uforklarlig forekomst af det pågældende stof.

Aluminium er kun fundet $i$ ca. halvdelen af boringerne og i meget lave koncentrationer. Dog overstiger en boring i Tornby området dette billede med en værdi på 85 mikrogram aluminium pr. liter. Boringen ligger ca. 50 meter fra en minkfarm. Endvidere er der i Råkilde området påvist den ekstremt høje værdi på 2230 mikrogram aluminium pr. liter, hvilket skyldes, at prøven ikke kunne filtreres i felten, og metallet derfor er knyttet til partiklerne.

Alle påviste bariumværdier ligger i området 3-100 mikrogram barium pr. liter med en enkelt undtagelse på 140 mikrogram barium pr. liter i Drastrup-området. Den vejledende værdi for Barium er 100 mikrogram pr. liter.

Bly er udover i Gislum-området kun konstateret i Råkilde-området, hvor til gengæld alle boringerne havde værdier fra 1.5 til 50 gange detektionsgrænsen på 0.18 mikrogram pr. liter. Overalt i Råkilde er boringerne forsynet med montejuspumper, og måske er forpumpningen utilstrakkelig jævnfør PVC's afgivelse af bly, jæunfør udredningsrapport U3 fra Lossepladsprojektet. Samme forhold gør sig måske gældende ved den forholdsvis lavtydende boring i Gislum.

I grundvandsprøver fra to boringer er der målt relativt høje cadmium-koncentrationer: I Råkilde-området skyides den høje koncentration antagelig, at det ikke var muligt at filtrere ved denne boring, hvilket yderligere har afstedkommet stærkt forhøjede koncentrationer af aluminium, bly, nikkel og zink. Derimod er det ikke umiddelbart muligt at forklare det relativt høje cadmiumindholdet i Gislum-området.

Strontiumindholdet er generelt meget højere end påvisningsgrænsen, og de typiske koncentrationer ligger mellem 100-400 mikrogram strontium pr. liter. Fordelingen er så jævn og ensartet $i$ alle områderne, at der må være tale om baggrundsværdier. Undtagelserne er to boringer i Råkilde-området, samt en vandværksboring i Skerping-området, der har værdier på henholdsvis ca. 1,2, 1,9 og 14,9 milligram strontium pr. liter. Der er dog ikke andre indikationer for forurening i disse boringer.

Der er påvist et lille indhold af cyanid i grundvandsprøver fra enkelte filtre i Råkilde- og Drastrup-områderne. De relativt højeste værdier er målt i Råkilde-området på vand fra en montejuspumpe installeret $i$ en husholdningsboring. Under installationen blev noget silikone suget ned i boringen i forbindelse med tætning af forerøret. Der vil blive foretaget en kontrolanalyse for at sikre mod målefejl.

VOX er kun påvist i én af de udtagne specialanalyser i Albæk-området med en værdi på 4 gange detektionsgrænsen på 0.5 mikrogram klorid pr. liter. Som en anerkendt indikatorparameter for forurening 
er fraværet af VOX særdeles positivt, og ligeledes er den fundne værdi så lav, at det sammenholdt med boringens øvrige parametre ikke giver grund til indgriben.

Den eneste påviste aromatiske kulbrinte er toluen, som er fundet en del steder i koncentrationer på 2-5 gange detektionsgrænsen på 0.1 mikrogram pr. liter. Det har vist sig, at en omdiskuteret mulig sammenhæng mellem målt toluen-indhold og pålimede kvartsfiltre på rørene ikke kan påvises. Den manglende efterviselighed af sammenhængen kan eventuelt skyldes fortynding ved forpumpning.

Fenol er den eneste påviste komponent i gruppen af fenoler og klorfenoler bortset fra enkelte "spor" af 2methylfenol og 4-methylfenol i en vandværksboring i Skerping.

Fenol er påvist en del steder i koncentrationer på 2-3 gange detektionsgrænsen på 0.03 mikrogram pr. liter.

MCPA er det eneste pesticid, der har kunnet påvises. I områderne Drastup, Skerping, Albæk og Gislum er det eventuelle MCPA-indhold overalt under detektionsgrænsen, mens der i områderne Tornby og Råkilde er MCPA $\mathrm{i}$ alle de undersøgte boringer, bortset fra en i Råkilde-området. Der er målt værdier på op til 15 gange påvisningsgrænsen på 0,01 mikrogram pr. liter, og den højest tilladelige værdi for et enkelt pesticid er således overskredet. Dette galder begge vandværksboringer i Tornby, og der er her udtaget nye prøver. Ligeledes er der foretaget omprøve i den boring i Råkilde-området, hvor der ikke blev påvist MPCA, for at sikre mod en evt. fejlmåling. Der er ikke påvist MPCA ved nogen af omprøverne. 


\section{PESTICIDER}

Næsten alle amter har i 1990 udtaget den første serie grundvandsprøver til specialanalyse, herunder prøver til analyse for bekæmpelsesmidler.

Pesticidanalyserne omfatter, ifølge analyseprogrammet, følgende stoffer:

Diklorprop, meklorprop, MCPA, DNOC, dinoseb, alaklor, aldicarb, atrazin, carbofuran, methylisothiocyanat, 1-2-diklorpropan, 1-3-diklorpropan, simazin og TCA. Pesticidanalyseprogrammet planlægges revurderet efter første analyserunde, når tilstedeværelsen af pesticider er nærmere belyst.

Amterne har $i$ den første del af specialanalyseprogrammet $i$ reglen valgt ikke at analysere for samtlige pesticider, men at koncentrere sig om de pesticider, der lokalt anvendes hyppigst og som er mest mobile. Special- og pesticidanalyserne fra de enkelte amter er beskrevet i afsnittet "Amternes vurdering af specialanalyser", side 169.

Af amternes afrapportering fremgår, at der i 1990 blev udtaget 264 vandprøver til analyse for pesticider. Da kun første del af specialanalyseprogrammet er gennemført, er det endnu ikke muligt at beskrive komplekse sammenhænge mellem for eksempel grundvandsreservoirernes geologiske/geokemiske miljøer og pesticidforekomsten.

Følgende generelle bemærkninger kan dog udledes af det samlede analysemateriale:

Ud af de 264 udtagne vandprøver blev der fundet pesticider i 28 , svarende til en hyppighed på $11 \%$. Atten af disse pesticidforekomster ligger under grænseværdien på 0,1 mikrogram pr. liter, og heraf 5 mellem 0,05 og 0,1 mikrogram pr. liter.ni pesticidanalyser, svarende til 3,5\%, ligger over grænseværdien. Blandt disse ni pesticidforekomster er der udført to ny prøvetagninger, hvor der i begge tilfælde ikke blev fundet pesticider ved ny analyse. Det kan ikke afvises at pesticidpåvisninger i visse tilfælde kan skyldes forurening under borearbejdet eller ved vandprøvetagningen. Tre ombestemmelser fra Nordjyllands amt, hvor der ved første analyse blev fundet 0,069-0,15 mikrogram MCPA pr. liter, men intet ved fornyet prøvetagning og analyse, indgår ikke i ovenstående.

I Vesttyskland viser en sammenstilling af analysedata, at grundvand indeholder en lang række pesticider. F.eks overskred atrazinindholdet i vandprøver udtaget fra 2264 lokaliteter grænseværdien i 4,9\% af tilfældene, mens simazin overskred grænseværdien i $1 \%$ af vandprøverne udtaget på 2254 lokaliteter. Meklorprop overskred grænseværdien i 4,5\% af vandprøver udtaget på 111 lokaliteter. Maksimalkoncentrationerne for de tre stoffer var henholdsvis $1,54,0,43$ og 0,60 mikrogram pr. liter (Deutsche Forschungsgemeinschaft ,1990). Undersøgelsen omfatter dog ikke en beskrivelse af lokaliteter og prøvekvalitet. 
Følgende 7 pesticider blev i 1990 fundet i dansk grundvand:

\begin{tabular}{|l|c|c||}
\hline STOF & $\begin{array}{c}\text { ANTAL } \\
\text { PRøVER }\end{array}$ & $\begin{array}{c}\text { KONCENTRATION } \\
\text { mikrogram pr. liter }\end{array}$ \\
\hline MCPA & 13 & $0,02-1,04$ \\
Dikjorprop & 4 & $1,33-20,3$ \\
Atrazin & 3 & $0,020-0,025$ \\
Meklorprop & 3 & $0,04-0,43$ \\
Dinoseb & 3 & $0,038-0,350$ \\
Simazin & 3 & $0,023-0,087$ \\
DNOC & 1 & 0,294 \\
\hline
\end{tabular}

Det er bemærkelsesværdigt, at næsten alle pesticider er påvist som enkeltstoffer, d.v.s. ikke forekommende sammen med andre pesticider. Kun i to tilfælde er MCPA og diklorprop fundet sammen. Pesticiderne findes dog ofte sammen med andre organiske mikroforurenende stoffer, som for eksempel detergenter.

I en undersøgelse omhandlende pesticidudvaskning fra to overvågningsoplande, Højvads Rende og Bolbro Bæk, blev der $\mathrm{i}$ vandprøver udtaget på samme lokaliteter fundet 4-10 forskellige pesticider både $\mathrm{i}$ jordvand, drænvand og vandløbsvand, (Mogensen og Spliid, 1991). De hyppigst forekommende pesticider var atrazin, simazin og 2,4 D, mens de største koncentrationer blev målt for følgende stoffer: MCPA, 2,4 D, meklorprop og diklorprop. Undersøgelsen viste også, at jordvandet i det sandede opland, Bolbro Bæk, indeholdt flere pesticider end jordvandet fra det lerede opland, Højvads Rende, mens det forholdt sig omvendt med vandløbsvandet fra de to oplande.

Hovedparten af de pesticider, der er påvist $\mathrm{i}$ amternes specialanalyser, stammer fra vandprøver udtaget $\mathrm{i}$ dybder ned til 20 meter under terræn, men der er dog også påvist pesticider (dinoseb og DNOC) i prøver fra ca. 70 meter under terræn. Et sted, hvor der blev fundet MCPA i en vandprøve fra et filter placeret 44-47 meter under terræn, består den 34 meter tykke umættede zone af sand.

En undersøgelse udført i Nebraska (Druliner, 1989) viste, at der blev fundet atrazin ned til ca 200 fod under terræn ( 75 meter), og at de største koncentrationer blev fundet i den øvre del af det sandede og grusede reservoir, fra en dybde af ca. 50 fod under terræn og opad ( 20 meter). Undersøgelsen viste, at der blev fundet atrazin i grundvandet under en umattet zone på ca. 95 fod (35 meter) og, at der var en tendens til en lineær sammenhæng mellem stigende nitratindhold og stigende atrazinindhold. Der blev også påvist en overhyppighed af atrazinforekomster $\mathrm{i}$ iltfrit reduceret grundvand, hvilket kan tolkes som at nedbrydningen af atrazin bliver dårligere under iltfattige forhold.

Pesticidindholdet $\mathrm{i}$ grundvandsprøverne som funktion af prøveudtagningsdybden for dette års indberettede analyser er vist på figur 12. Af figuren fremgår, at MCPA, diklorprop og DNOC forekommer i størst koncentration i de øvre dele af reservoirerne. Da amternes prøveudtagningsstrategi i de fleste tilfælde har været, at udtage disse prøver fra de øvre og mest sårbare grundvandsreservoirer, skal denne sammenhæng dog tages med forbehold. 
Nogle af amterne mener, at pesticidtilstedeværelsen i visse tilfælde kan forklares som analysefejl eller usikkerhed, prøveudtagningsusikkerhed, lokal forurening fra boregrej eller prøveudtagningsudstyr eller ved lokal punktmæssig "gårdforurening".

De næunte pesticider i prøver af det danske grundvand er fundet i reservoirer bestående af smeltevandssand, kvartssand, morænegrus, morænesand, bryozokalk, skrivekridt og kalk. Kun i et tilfælde blev der fundet atrazin i moræneler.

Hvis hovedparten af de indsendte pesticidanalyser, som forventet, er korrekt udført, og hvis vandprøverne ikke er sekundært forurenede, er de til dato indsamlede data bekymrende. Denne bekymring er så meget større, fordi der er grund til at formode, at grundvandet kan indeholde flere stoffer end det påviste de steder, hvor der $\mathrm{i}$ dag alene er påvist enkeltpesticider. Det er derfor vigtigt nøje at følge udbredelsesmønstrene for pesticider $i$ grundvandet $i$ de kommende år, og samtidig at vurdere den reelle pesticidudvasknings omfang.

Der er grund til at fremhæve, at langt den overvejende del af pesticidanalyserne viste indhold under grænseværdien for enkeltstoffer, og at det ikke kan afvises, at en del af pesticidpåvirkningerne over denne grænseværdi kan skyldes prøvetagningsmetoden. Påvisningerne af pesticider er dog så mange, at pesticidernes lokale tilstedeværelse i grundvandet må være reel.

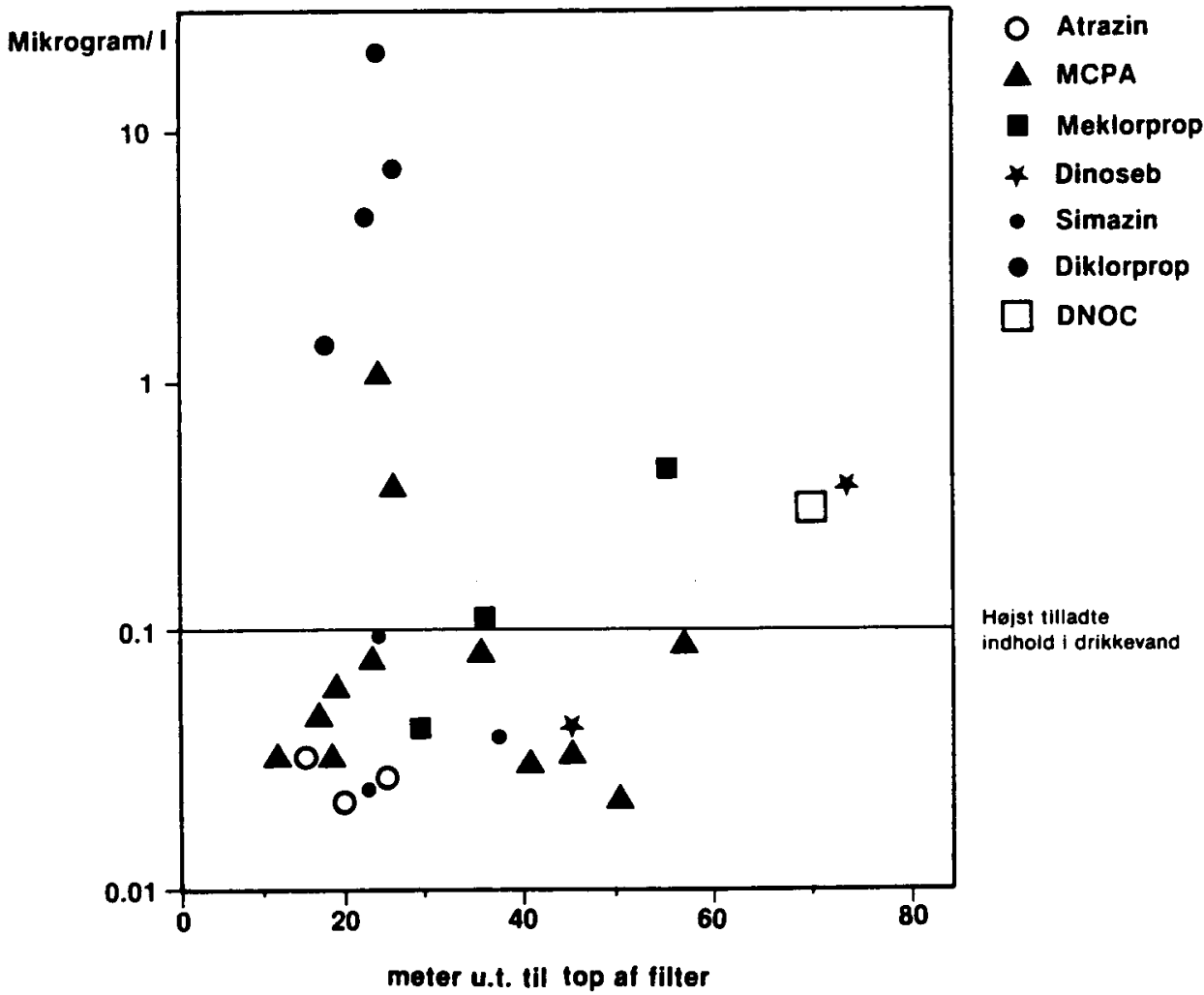

Figur 12: Pesticidholdige grundvandsprøver. 


\section{HYDROKEMISK KLASSIFIKATION AF GRUNDVAND}

Grundvandets kemiske sammensætning varierer fra sted til sted og med dybden. Denne variation er i mange henseender naturlig og skyldes samspillet mellem nedbør og fordampning samt geologi og hydrogeologi. Den rigelige nedbør i Danmark medfører en naturlig forvitring med udvaskning af kalk (forsuring og iltning af de øverste jordlag). Denne forvitringsprocess vil efterhånden påvirke de øverste grundvandsreservoirer, men det afhænger af de geologiske og hydrogeologiske forhold, hvor dybt påvirkningen trænger ned og hvor stærkt den præger grundvandet.

Udover naturlige faktorer er grundvandets kemiske sammensætning også præget af menneskelig påvirkning. Nogle af de menneskeskabte påvirkninger af grundvandet sker over så store områder og så kraftigt, at de helt kan ændre grundvandets sammensætning. Dette gælder for eksempel forurening med nitrat, der på opløst form i grundvandet er med til at fremme iltningen af blandt andet svovlkis, så grundvandets sulfatindhold stiger og redoxforholdet dermed falder.

Den medfølgende forvitringsprocess vil efterhånden påvirke de øverste grundvandsreservoirer, men det afhænger af de geologiske og hydrogeologiske forhold, hvor dybt påvirkningen kan spores.

Forvitringen foregår altså $i$ et samspil mellem naturlige processer og processer, der skyldes forurening.

Selv om fordelingen af alle forureningskomponenter ikke er lige afhængig af forvitringsgraden vil risiko for forurening fra terrænoverfladen være størst, hvor forvitringen er længst fremskreden. Det er derfor nødvendigt at have et overblik over disse grundlæggende forhold for at kunne fortolke en given forureningssituation.

Grundvandsovervågningsprogrammet i Danmark og kontrolprogrammet for vandværksboringer (boringskontrollen) medfører tilgang af et meget stort antal grundvandskemiske data. For at kunne fortolke disse på en sammenlignelig måde er der behov for et klassifikationssystem, som gør det muligt at håndtere og beskrive de mange analyser i naturligt sammenhørende grupper ved brug af EDB.

I det følgende er et sådant hydrokemisk klassifikationssystem beskrevet.

\section{Klassifikationssystemet}

Grundvandet klassificeres ved en nummerisk kode på fire cifre (for eksempel 3.1.2.1.), som på en forenklet måde angiver dets surhedsgrad, forvitringsgrad, indhold af aggressiv kulsyre og redoxforhold. Den nummeriske kode er et hjælpemiddel for den EDB-mæssige håndtering af klassifikationen. For at gøre klassifikationen anvendelig i tale og på skrift, er der også knyttet en verbal karakteristik til klassifikationens enkelte grupper og cifre.

Det første ciffer i klassifikationen inddeler grundvandsprøverne i grupper efter alkalinitet. Alkaliniteten er bestemt af jordlagenes indhold af kalciumkarbonat og partialtrykket af kuldioxid, og det udtrykkes ved 
koncentrationen af hydrogenkarbonat. Grundvand fra områder med kalkfattige eller kalkfrie jordlag, som for eksempel syd og vest for sidste istids hovedopholdslinie i Jylland, vil som hovedregel være surt og blødt med under 2,5 milliækvivalenter hydrogenkarbonat pr. liter. Dette grundvand vil derfor blive klassificeret i gruppe 1 som første ciffer.

Grundvand fra områder med kalkholdige jordlag vil afhængig af koncentrationen af hydrogenkarbonat høre til gruppe 2 eller 3. Som hovedregel vil grundvand fra de øverste lag i reservoirer med frit grundvandsspejl høre hjemme i gruppe 2, mens grundvand fra større dybde eller artesiske reservoirer vil høre til gruppe 3. Dette skyldes, at det høje partialtryk af kuldioxid forårsager en forholdsvis kraftigere opløsning af calciumhydrogenkarbonat.

De tre grupper under klassifikationens første ciffer benæunes: 1 lav, 2 middel og $3 \mathrm{~h} ø$.

\begin{tabular}{|c|c|}
\hline ALKALINITET & $\begin{array}{l}\text { KONCENTRATIONSINTERVAL } \\
\text { milliækvivalenter } \mathrm{HCO}_{3}^{-} \text {pr. liter }\end{array}$ \\
\hline lav & 0.2 .5 \\
\hline middel & $2,5-5$ \\
\hline 3. høj & over 5 \\
\hline
\end{tabular}

Det andet ciffer inddeler grundvandet efter forvitringsgrad ved forholdet mellem hårdhed og alkalinitet.

Under naturlige forhold vil det kuldioxidholdige vand udvaske kalk fra jordlagene, hvorved calcium og magnesium opløses som hydrogenkarbonat. Udsættes jordlagene ikke for anden syrepåvirkning end den, der skyldes vandets kuldioxidindhold, vil hovedparten af det nedsivende vands hårdhed være karbonathårdhed (forbigående hårdhed), og kun en mindre del vil være blivende hårdhed (blivende hårdhed skyldes kalkopløsning med andre syrer, for eksempel de naturlige organiske syrer som dannes $\mathrm{i}$ rodzonen). Grundvand, som er præget på denne måde, vil have et hårdheds/alkalinitetsforhold på mellem $1 \mathrm{og} 1,5 \mathrm{og}$ høre til gruppe 2 under andet ciffer.

\begin{tabular}{||cc|c|}
\hline \multicolumn{2}{|c|}{$\begin{array}{c}\text { FORVITRINGS- } \\
\text { GRAD }\end{array}$} & $\left(\mathrm{Ca}^{2+}+\mathrm{Mg}^{2+}\right) / \mathrm{HCO}_{3}{ }^{-}$ \\
\hline \hline 1. & høj & over 1,5 \\
\hline 2. & middel & over 1,5 \\
\hline 3. & lav & under 1 \\
\hline
\end{tabular}

Udsættes jordlagene for påvirkning af stærke mineralsyrer, for eksempel svovlsyre fra luftforurening eller salpetersyre fra forsuringsprocesser i dyrket jord, vil en større del af det infiltrerende vands indhold af calcium og magnesium udgøre en blivende hårdhed. Det samme vil være tilfældet, hvis der sker iltning af 
svovlkis i grundvandszonen som følge af sænkning af grundvandsspejlet, eller hvis der tilføres iltningsmidler, som for eksempel nitrat, til de svovlkisholdige jordlag. Grundvandsforekomster, som er så stærkt påvirkede af forvitring, falder i gruppe 1 som andet ciffer i klassifikationen. Ionbyttende grundvandsforekomster eller grundvand, hvori der er sket sulfatreduktion, vil som regel indeholde natriumbikarbonat, og grundvandet vil tilhøre gruppe 3.

I klassifikationssystemet benævnes grupperne under andet ciffer, der udtrykker forvitringsgraden, henholdsvis 1 høj, 2 middel og 3 lav.

Det tredie ciffer angiver den eventuelle tilstedeværelse af aggressiv kulsyre og tages som et udtryk for kalkunderskud.

\begin{tabular}{||c|c|}
\hline \multicolumn{2}{|c|}{ AGGRESSIV KULSYRE } \\
\hline 1. Underskud & Til stede \\
\hline 2. Overskud & Ikke til stede \\
\hline
\end{tabular}

Hvis naturlige og menneskeskabte forsuringspåvirkninger sker i områder med kalkfattige eller kalkfrie jordlag vil grundvandet komme til at indeholde aggressiv kulsyre, uanset om påvirkningen sker over eller under grundvandsspejlet.

Grundvand, der indeholder aggressiv kulsyre, tilhører gruppe 1 under klassifikationens tredie ciffer.

Er der kalk nok $\mathrm{i}$ jordlagene til at neutralisere syrepåvirkninger, vil grundvandet høre til gruppe 2 under tredie ciffer.

Grupperne under tredje ciffer benærnes som 1 underskud og 2 overskud.

Det fierde ciffer beskriver redoxforholdet i grundvandet.

\begin{tabular}{||ll|l||}
\hline \multicolumn{2}{|c|}{ REDOXFORHOLDET } \\
\hline 1. & Høj & Mere end et milligram nitrat pr. liter \\
\hline 2. & Middel & $\begin{array}{l}\text { Under et milligram nitrat pr. liter, og der er hverken } \\
\text { metan eller svovlbrinte tilstede }\end{array}$ \\
\hline 3. & Lav & $\begin{array}{l}\text { Under et milligram nitrat pr. liter, og der er metan } \\
\text { og/eller svovlbrinte tilstede }\end{array}$ \\
\hline
\end{tabular}

Den første gruppe svarer til forskellige nitratkoncentrationer afhængig af forureningens størrelse (arealanvendelsen) og har lav koncentration af opløst jern. Grundvandet $i$ den anden gruppe indeholder hverken nitrat, metan eller svovlbrinte, og har varierende koncentration af ferro - mangano- og ammoniumioner. Endelig kan koncentrationen af sulfat være forholdsvis høj som følge af iltning af svovlkis. I den tredje gruppe under fjerde ciffer indeholder grundvandet ikke nitrat, men metan og svovlbrinte, og vil som hovedregel have relativ lav koncentration af ferro, mangano- og især sulfationer. 
Det fjerde ciffer i klassifikationssystemet betegner redoxforholdet som henholdsvis 1 lav, 2 middel og 3 høj.

\begin{tabular}{|c|c|c|c|c|c|}
\hline $\begin{array}{l}\text { HYDRO. } \\
\text { KEMISK } \\
\text { KLASSE }\end{array}$ & $\begin{array}{c}\mathrm{HCO}_{3} \\
\text { mækv. pr. liter }\end{array}$ & $\frac{\mathrm{Ca}+\mathrm{Mg}}{\mathrm{HCO}_{3}}$ & $\begin{array}{l}\text { Aggressiv } \\
\text { kulsyre }\end{array}$ & Nitrat & $\begin{array}{l}\text { Metan og/eller } \\
\text { svovlbrinte }\end{array}$ \\
\hline 1.1 .1 .1 & $0-2.5$ & $<1,5$ & + & $>1$ & \\
\hline 1.1.1.2 & - & $\cdot$ & + & $<1$ & $\div$ \\
\hline 1.1.1.3 & - & - & + & $<1$ & + \\
\hline 1.1.2.1 & - & - & $\div$ & $>1$ & \\
\hline 1.1 .2 .2 & - & . & $\div$ & $<1$ & $\div$ \\
\hline 1.1 .2 .3 & - & $\therefore$ & $\div$ & $<1$ & + \\
\hline 1.2.1.1 & - & $1 \cdot 1,5$ & + & $>1$ & \\
\hline 1.2 .1 .2 & - & - & + & $<1$ & $\div$ \\
\hline 1.2 .1 .3 & - & - & + & $<1$ & + \\
\hline 1.2 .2 .1 & - & - & $\div$ & $>1$ & \\
\hline 1.2 .2 .2 & - & - & $\div$ & $<1$ & $\div$ \\
\hline 1.2 .2 .3 & - & - & $\div$ & $<1$ & + \\
\hline 1.3.1.1 & . & $<1$ & + & $>1$ & \\
\hline 1.3.1.2 & - & - & + & $<1$ & $\div$ \\
\hline 1.3 .1 .3 & - & - & + & $<1$ & + \\
\hline 1.3.2.1 & - & - & $\div$ & $>1$ & \\
\hline 1.3 .2 .2 & . & - & $\div$ & $<1$ & $\div$ \\
\hline 1.3 .2 .3 & . & - & $\div$ & $<1$ & + \\
\hline 2.1.1.1 & $2.5-5$ & $>1,5$ & + & $>1$ & \\
\hline 2.1 .1 .2 & & - & + & $<1$ & $\div$ \\
\hline 2.1 .1 .3 & - & - & + & $<1$ & + \\
\hline 2.1 .2 .1 & . & - & $\div$ & $>1$ & \\
\hline 2.1.2.2 & . & . & $\div$ & $<1$ & $\div$ \\
\hline 2.1 .2 .3 & . & - & $\div$ & $<1$ & + \\
\hline 2.2 .1 .1 & - & $1-1,5$ & + & $>1$ & \\
\hline 2.2.1.2 & - & - & + & $<1$ & $\div$ \\
\hline 2.2.1.3 & . & - & + & $<1$ & + \\
\hline 2.2 .2 .1 & - & $\cdot$ & $\div$ & $>1$ & \\
\hline 2.2.2.2.2 & - & - & $\div$ & $<1$ & $\div$ \\
\hline 2.2 .2 .3 & - & - & $\div$ & $<1$ & + \\
\hline 2.3 .1 .1 & - & $<1$ & + & $>1$ & \\
\hline 2.3.1.2 & - & - & + & $<1$ & $\div$ \\
\hline 2.3 .1 .3 & - & - & + & $<1$ & + \\
\hline 2.3.2.1 & - & - & $\div$ & $>1$ & \\
\hline 2.3.2.2 & - & - & $\div$ & $<1$ & $\div$ \\
\hline 2.3.2.3 & . & - & $\div$ & $<1$ & + \\
\hline 3.1.1.1 & $>5$ & $>1,5$ & + & $>1$ & \\
\hline 3.1 .1 .2 & $\cdot$ & $\cdot$ & + & $<1$ & $\div$ \\
\hline 3.1 .1 .3 & - & - & + & $<1$ & + \\
\hline 3.1.2.1 & - & - & $\div$ & $>1$ & \\
\hline 3.1.2.2 & - & - & $\div$ & $<1$ & $\div$ \\
\hline 3.1.2.3 & - & - & $\div$ & $<1$ & + \\
\hline 3.2.1.1 & - & $1-1,5$ & + & $>1$ & \\
\hline 3.2 .1 .2 & - & • & + & $<1$ & $\div$ \\
\hline 3.2 .1 .3 & - & - & + & $<1$ & + \\
\hline 3.2.2.1 & . & - & $\div$ & $>1$ & \\
\hline 3.2.2.2. & - & - & $\div$ & $<1$ & $\div$ \\
\hline 3.2.2.3 & - & - & $\div$ & $<1$ & + \\
\hline 3.3.1.1 & . & $<1$ & + & $>1$ & \\
\hline 3.3.1.2 & - & - & + & $<1$ & $\div$ \\
\hline 3.3.1.3 & - & - & + & $<1$ & + \\
\hline 3.3.2.1 & - & - & $\div$ & $>1$ & \\
\hline 3.3.2.2 & - & - & $\div$ & $<1$ & $\div$ \\
\hline 3.3.2.3 & . & . & $\div$ & $<1$ & + \\
\hline
\end{tabular}

Tabel 14: Hydrokemisk klassifikationssystem for grundvand i Danmark.

Klassifikationssystemet omfatter ialt 54 klasser (tabel 14), men langt fra alle vil forekomme inden for samme region. 
Klassifikationen tager ikke direkte hensyn til om grundvandet er salt eller indeholder "specielle" stoffer, der skyldes forurening, som for eksempel fluorid og organisk stof. Disse stoffer vil dog i de fleste tilfælde være knyttet til bestemte klasser i systemet.

\section{Anvendelse}

Den HydroKemiske klassifikation (forkortet HK-klassifikation) vil kunne anvendes i forbindelse med statistisk behandling af grundvandskemidata både indenfor lokale områder og for hele landet. Dette kan for eksempel ske ved en opgørelse af den relative fordeling af grundvand $i$ de klasser systemet omfatter. En sådan fordeling vil karakterisere de grundvandskemiske forhold så som surhed, hårdhedstype, forsuringsproblemer og nitratforurening.

Klassifikationen kan også anvendes til at sortere et datasæt forud for beregning af gennemsnitskoncentration og variationsbredde. For eksempel vil en sådan beregning for nitrat for grundvand tilhørende alle klasser i en region under ét være mindre anvendelig, fordi nitrat ikke forekommer $\mathrm{i}$ det reducerede grundvand. Sådanne beregninger vil hensigtsmæssigt kunne foretages på grundvand, som er karakteriseret med et ettal som tredje ciffer. Lignende forhold gælder for andre stoffer, som er knyttet til et specielt kemisk miljø.

HK-klassifikationen kan også anvendes som baggrund for vurdering af særlige forureningsforhold. For eksempel forekommer ammonium og fosfat ofte naturligt $i$ grundvand, hvis forholdene er stærkt anaerobe. Hvis disse stoffer derimod findes $\mathrm{i}$ iltede grundvandsforekomster (gruppe $1 \mathrm{i}$ fjerde ciffer), vil der højst sandsynligt være tale om forurening med spildevand, møddingsvand eller lignende.

Hvis en given grundvandsprøve indeholder stoffer, som normalt er karakteristiske for forskellige klasser, vil det vise, at prøven sandsynligvis er sammensat af forskelligt grundvand, der er blandet ved prøvetagningen. Dette er for eksempel tilfældet, hvis nitratholdigt grundvand indeholder ferrojern, methan og svovlbrinte. Grundvandsfordelingen på klasser indenfor et givet område vil afspejle de hydrogeologiske og geokemiske forhold $\mathrm{i}$ området og angiver således en "grundvandskemisk profil" for området. Udviklingstendenser $\mathrm{i}$ grundvandskemien indenfor området, for eksempel som følge af forsuringspåvirkninger eller påvirkning af redoxpotentialet, vil afspejle sig $i$ at grundvandet ændrer klasse.

Stigende kloridkoncentrationer eller stigninger i koncentrationerne af specielle stoffer, som ikke er omfattet af klassifikationen, vil dog ikke umiddelbart kunne ændre på fordelingen af klasser, men må efterfølgende tilføjes.

Denne enkle HK-klassifikation, der ligger i forlængelse af Ødum og Christensens (1936) beskrivelser af grundvandet, vil derfor $\mathrm{i}$ forbindelse med mere dybtgående vurderinger skulle suppleres for eksempel med Piper-diagrammer, Piper (1944). 


\section{Eksempler}

I det følgende er klassifikationen forsøgsvis anvendt til at beskrive overvågningsområderne Tornby og Råkilde i Nordjyllands amt.

\section{Tornby (80.01)}

Området omfatter en indvindingsboring med filter $\mathrm{i}$ et dybtliggende artesisk reservoir i smeltevandssand og overvågningsboringer med filtre i forskellige mere terrænnære reservoirer, der oftest består af senglacialt marint sand, se side 150 .

\begin{tabular}{|c|c|c|c|c|c|c|c|}
\hline $\begin{array}{l}\text { ALKA- } \\
\text { LINITET }\end{array}$ & $\%$ & $\begin{array}{l}\text { FOR- } \\
\text { VITRINGS- } \\
\text { GRAD }\end{array}$ & $\%$ & $\begin{array}{c}\text { AGGRESIV } \\
\mathrm{CO}_{2}\end{array}$ & $\%$ & $\begin{array}{l}\text { REDOX- } \\
\text { FORHOLD }\end{array}$ & $\%$ \\
\hline $\begin{array}{l}\text { Lav } \\
\text { Middel } \\
\text { Høj }\end{array}$ & $\begin{array}{l}20,8 \\
32,1 \\
47,1\end{array}$ & $\begin{array}{l}\text { høj } \\
\text { middel } \\
\text { lav }\end{array}$ & $\begin{array}{l}47,1 \\
39,6 \\
13,3\end{array}$ & $\begin{array}{l}\text { underskud } \\
\text { overskud }\end{array}$ & $\begin{array}{l}11,4 \\
88,6\end{array}$ & $\begin{array}{c}\text { højt } \\
\text { middel } \\
\text { lavt }\end{array}$ & $\begin{array}{l}32,1 \\
22,7 \\
45,2\end{array}$ \\
\hline
\end{tabular}

\section{Tabel 15: Klassifikation af grundvandet $i$ Tomby-området.}

Grundvandets fordeling på klasser viser de meget store variationer i grundvandskemien i området, idet der findes grundvand, der tilhører alle grupper med hensyn til alkalinitetsniveau, forvitringsgrad, aggressiv kuldioxid og redoxforhold.

Årsagen til dette er, at de øverste grundvandsreservoirer indeholder grundvand med stærkt præg af forvitring og høje redoxpotentialer, medens de dybe grundvandsreservoirer indeholder grundvand, der er ionbyttet, stærkt reduceret med methan og svovlbrinte, samt påvirket af marine sedimenter. Specielt viser fordelingen efter redoxforhold, at grundvandet fordeler sig i klasser, der indeholder henholdsvis nitrat og methan/svovlbrinte. Indvindingsboringen producerer blandingsvand, idet der forekommer prøver der både indeholder nitrat og methan/svovlbrinte, tabel 17.

\section{$\underline{\text { Råkilde (80.02) }}$}

Området omfatter såvel indvindingsboringer med filtre i et højtliggende skrivekridtreservoir, der inden for området stedvis er artesisk, stedvis har frit grundvandsspejl, som overvågningsboringer med filtre hovedsagelig i skrivekridt, se side 152 .

Fordelingen af grundvandet på klasser i tabel 18 er sammenfattet $i$ tabel 16.

\begin{tabular}{|l|c|c|c|c|c|c|c|}
\hline $\begin{array}{c}\text { ALKA- } \\
\text { LINITET }\end{array}$ & $\%$ & $\begin{array}{c}\text { FOR- } \\
\text { VITRINGS- } \\
\text { GRAD }\end{array}$ & $\%$ & $\begin{array}{c}\text { AGGRESIV } \\
\mathrm{CO}_{2}\end{array}$ & $\%$ & $\begin{array}{c}\text { REDOX- } \\
\text { FORHOLD }\end{array}$ & $\%$ \\
\hline Lav & 5,2 & $\begin{array}{c}\text { høj } \\
\text { middel } \\
\text { lav }\end{array}$ & $\begin{array}{c}24,7 \\
74,0 \\
1,3\end{array}$ & $\begin{array}{c}\text { underskud } \\
\text { overskud }\end{array}$ & $\begin{array}{c}0 \\
100\end{array}$ & $\begin{array}{c}\text { højt } \\
\text { middel }\end{array}$ & $\begin{array}{c}84,4 \\
15,6\end{array}$ \\
\hline
\end{tabular}




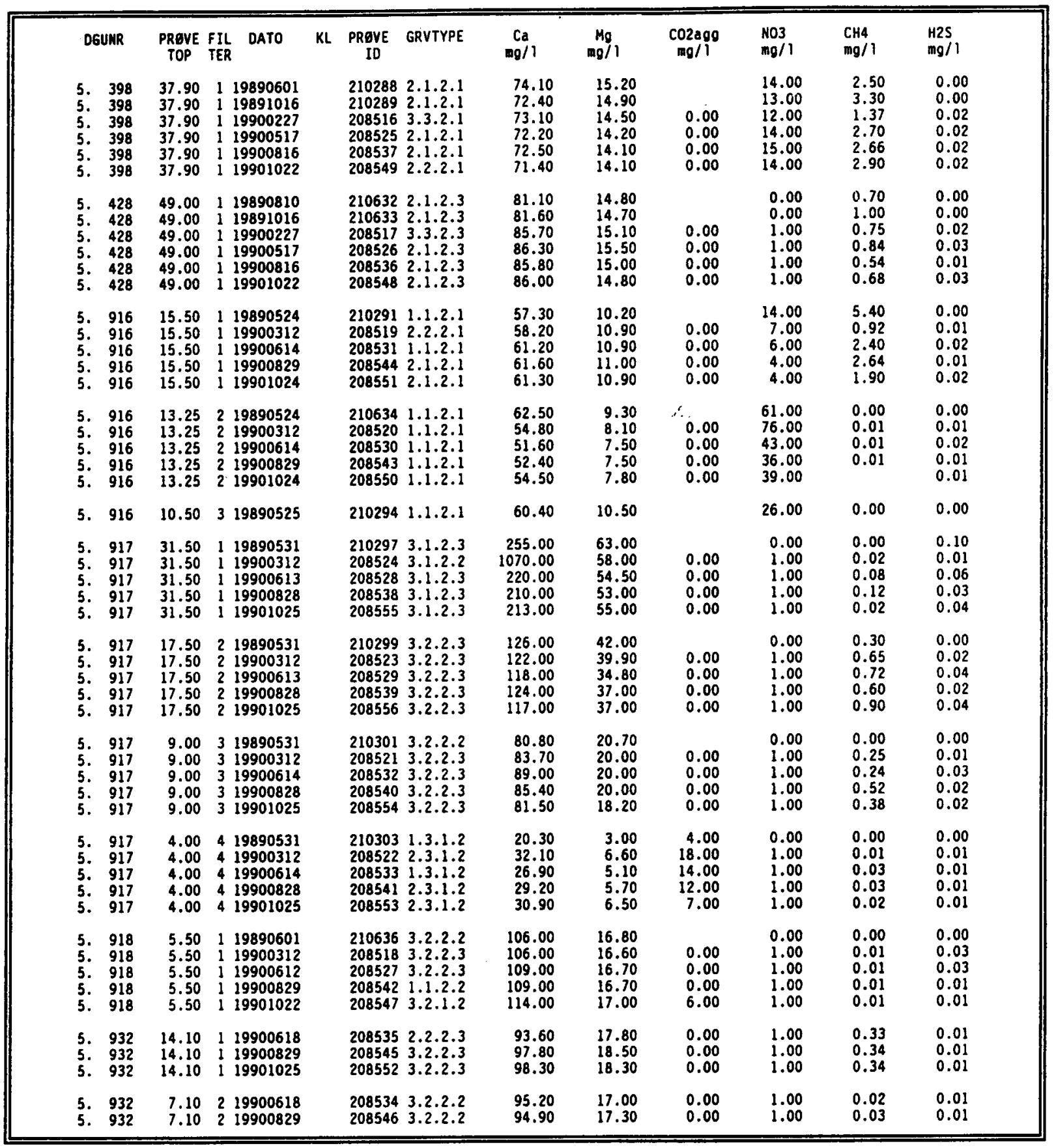

Tabel 17: Grundvandsanalyseme i Tomby-området fordelt efter HK-klassifikationen.

Fordelingen på klasser viser, at der er relativt ensartede grundvandskemiske forhold i området.

Alkalinitetsgraden er hovedsageligt middel, og forvitrings-graden høj til middel. Aggressiv kuldioxid forekommer ikke og redoxforholdene viser overvægt af prøver med højt redoxpotentiale og nitrat, medens der slet ikke forekommer prøver med lavt redoxpotentiale, methan og sulfat.

Årsagen til dette fordelingsmønster er, at reservoirerne består af kalkrige sedimenter med overvejende frit grundvandsspejl, som kommer til udtryk i de mange grundvandsvandprøver med middel surhed og uden aggressiv kuldioxid, der samtidigt oftest indholder nitrat. Modsat forekommer der ikke alkalisk grundvand med lavt redoxforhold i området. Til sammenligning er der i figur 13 vist Piper diagrammer for grundvandet i Tornby og Råkilde. Det er især HK-klassifikationens inddeling efter forvitringsgrad der også kan aflæses af disse diagrammer. 


\begin{tabular}{|c|c|c|c|c|c|c|c|c|c|c|}
\hline DGUMR & $\begin{array}{l}\text { PRQVE } \\
\text { TOP }\end{array}$ & $\begin{array}{l}\text { FIL } \\
\text { TER }\end{array}$ & KL & $\begin{array}{l}\text { PRGVE GRVTYPE } \\
\text { ID }\end{array}$ & $\begin{array}{c}C a \\
m g / 1\end{array}$ & $\stackrel{\mathrm{Mg}}{\mathrm{mg} / \mathrm{l}}$ & $\begin{array}{c}\text { c02agg } \\
m g / i\end{array}$ & $\begin{array}{l}\mathrm{NO3} \\
\mathrm{mg} / 1\end{array}$ & $\begin{array}{l}\mathrm{CH} 4 \\
\mathrm{mg} / 1\end{array}$ & $\begin{array}{l}\mathrm{H} 2 \mathrm{~S} \\
\mathrm{mg} / \mathrm{l}\end{array}$ \\
\hline $\begin{array}{ll}34 . & 376 \\
34 . & 376 \\
34 . & 376 \\
34 . & 376 \\
34 . & 376 \\
34 . & 376\end{array}$ & $\begin{array}{l}10.90 \\
10.90 \\
10.90 \\
10.90 \\
10.90 \\
10.90\end{array}$ & $\begin{array}{ll}1 & 19890615 \\
1 & 19891101 \\
1 & 19900219 \\
1 & 19900619 \\
1 & 19900903 \\
1 & 19901016\end{array}$ & & $\begin{array}{ll}210686 & 2.1 .2 .1 \\
210687 & 2.1 .2 .1 \\
208564 & 2.1 .2 .1 \\
208576 & 2.1 .2 .1 \\
208598 & 2.1 .2 .1 \\
208605 & 2.1 .2 .1\end{array}$ & $\begin{array}{l}114.00 \\
136.00 \\
111.00 \\
114.00 \\
110.00 \\
109.00\end{array}$ & $\begin{array}{l}4.40 \\
5.30 \\
4.20 \\
4.20 \\
4.20 \\
4.00\end{array}$ & $\begin{array}{l}0.00 \\
0.00 \\
0.00 \\
0.00\end{array}$ & $\begin{array}{l}93.00 \\
90.00 \\
92.00 \\
97.00 \\
96.00 \\
96.00\end{array}$ & $\begin{array}{l}0.00 \\
0.00\end{array}$ & $\begin{array}{l}0.00 \\
0.00\end{array}$ \\
\hline $\begin{array}{ll}\text { 34. } & 989 \\
34 . & 989 \\
34 . & 989 \\
34 . & 989 \\
34 . & 989 \\
34 . & 989\end{array}$ & $\begin{array}{l}34.90 \\
34.90 \\
34.90 \\
34.90 \\
34.90 \\
34.90\end{array}$ & $\begin{array}{ll}1 & 19890810 \\
1 & 19891101 \\
1 & 19900219 \\
1 & 19900620 \\
1 & 19900903 \\
1 & 19901016\end{array}$ & & $\begin{array}{ll}210688 & 2.2 .2 .1 \\
210689 & 2.2 .2 .1 \\
208561 & 2.2 .2 .1 \\
208585 & 2.2 .2 .1 \\
208597 & 2.2 .2 .1 \\
208604 & 2.2 .2 .1\end{array}$ & $\begin{array}{l}58.30 \\
72.60 \\
60.10 \\
60.50 \\
59.90 \\
59.50\end{array}$ & $\begin{array}{l}4.70 \\
5.70 \\
4.60 \\
4.50 \\
4.50 \\
4.50\end{array}$ & $\begin{array}{l}0.00 \\
0.00 \\
0.00 \\
0.00\end{array}$ & $\begin{array}{r}9.00 \\
9.00 \\
9.00 \\
8.00 \\
8.00 \\
10.00\end{array}$ & $\begin{array}{l}0.00 \\
0.00\end{array}$ & $\begin{array}{l}0.00 \\
0.00\end{array}$ \\
\hline $\begin{array}{l}\text { 34. } 1603 \\
\text { 34. } 1603 \\
\text { 34. } 1603 \\
\text { 34. } 1603 \\
\text { 34. } 1603 \\
\text { 34. } 1603\end{array}$ & $\begin{array}{l}51.54 \\
51.54 \\
51.54 \\
51.54 \\
51.54 \\
51.54\end{array}$ & $\begin{array}{ll}1 & 19890809 \\
1 & 19891101 \\
1 & 19900219 \\
1 & 19900620 \\
1 & 19900903 \\
1 & 19901023\end{array}$ & & $\begin{array}{ll}210690 & 2.2 .2 .2 \\
210691 & 2.2 .2 .2 \\
208560 & 2.2 .2 .2 \\
208581 & 2.2 .2 .2 \\
208596 & 2.2 .2 .2 \\
208611 & 2.2 .2 .2\end{array}$ & $\begin{array}{l}60.30 \\
76.30 \\
61.10 \\
61.00 \\
61.40 \\
61.10\end{array}$ & $\begin{array}{l}6.70 \\
8.40 \\
6.80 \\
6.70 \\
6.70 \\
6.50\end{array}$ & $\begin{array}{l}0.00 \\
0.00 \\
0.00 \\
0.00\end{array}$ & $\begin{array}{l}0.00 \\
0.00 \\
1.00 \\
1.00 \\
1.00 \\
1.00\end{array}$ & $\begin{array}{l}0.00 \\
0.00\end{array}$ & $\begin{array}{l}0.00 \\
0.00\end{array}$ \\
\hline $\begin{array}{l}\text { 34. } 1718 \\
\text { 34. } 1718 \\
\text { 34. } 1718 \\
34.1718 \\
\text { 34. } 1718 \\
\text { 34. } 1718\end{array}$ & $\begin{array}{l}27.00 \\
27.00 \\
27.00 \\
27.00 \\
27.00 \\
27.00\end{array}$ & $\begin{array}{ll}1 & 19890621 \\
1 & 19891011 \\
1 & 19900220 \\
1 & 19900620 \\
1 & 19900830 \\
1 & 19901023\end{array}$ & & $\begin{array}{ll}210705 & 2.2 .2 .1 \\
210706 & 2.2 .2 .1 \\
208566 & 2.2 .2 .1 \\
208583 & 2.2 .2 .1 \\
208590 & 2.2 .2 .1 \\
208607 & 2.2 .1 .1\end{array}$ & $\begin{array}{l}57.90 \\
58.40 \\
57.80 \\
61.90 \\
59.60 \\
61.20\end{array}$ & $\begin{array}{l}5.90 \\
6.00 \\
5.80 \\
6.00 \\
5.90 \\
5.90\end{array}$ & $\begin{array}{l}0.00 \\
0.00 \\
0.00 \\
6.00\end{array}$ & $\begin{array}{l}16.00 \\
13.00 \\
12.00 \\
18.00 \\
13.00 \\
14.00\end{array}$ & $\begin{array}{l}0.00 \\
0.00\end{array}$ & $\begin{array}{l}0.00 \\
0.00\end{array}$ \\
\hline $\begin{array}{l}\text { 34. } 1718 \\
\text { 34. } 1718 \\
\text { 34. } 1718 \\
34.1718 \\
34.1718 \\
\text { 34. } 1718\end{array}$ & $\begin{array}{l}23.40 \\
23.40 \\
23.40 \\
23.40 \\
23.40 \\
23.40\end{array}$ & $\begin{array}{ll}2 & 19890621 \\
2 & 19891011 \\
2 & 19900220 \\
2 & 19900620 \\
2 & 19900830 \\
2 & 19901016\end{array}$ & & $\begin{array}{ll}210707 & 2.2 .2 .1 \\
210708 & 2.2 .2 .1 \\
208565 & 2.2 .2 .1 \\
208579 & 2.2 .2 .1 \\
208591 & 2.2 .2 .1 \\
208606 & 2.2 .2 .1\end{array}$ & $\begin{array}{l}59.30 \\
59.00 \\
58.70 \\
59.80 \\
58.40 \\
58.80\end{array}$ & $\begin{array}{l}6.10 \\
6.00 \\
6.00 \\
6.00 \\
5.80 \\
5.70\end{array}$ & $\begin{array}{l}0.00 \\
0.00 \\
0.00 \\
0.00\end{array}$ & $\begin{array}{l}21.00 \\
17.00 \\
16.00 \\
15.00 \\
15.00 \\
18.00\end{array}$ & $\begin{array}{l}0.00 \\
0.00\end{array}$ & $\begin{array}{l}0.00 \\
0.00\end{array}$ \\
\hline $\begin{array}{l}\text { 34. } 1718 \\
\text { 34. } 1718 \\
34.1718 \\
34.1718 \\
\text { 34. } 1718 \\
\text { 34. } 1718\end{array}$ & $\begin{array}{l}20.50 \\
20.50 \\
20.50 \\
20.50 \\
20.50 \\
20.50\end{array}$ & $\begin{array}{ll}3 & 19890621 \\
3 & 19891011 \\
3 & 19900220 \\
3 & 19900620 \\
3 & 19900830 \\
3 & 19901016\end{array}$ & & $\begin{array}{ll}210709 & 2.2 .2 .1 \\
210710 & 2.2 .2 .1 \\
208570 & 2.2 .2 .1 \\
208582 & 2.2 .2 .1 \\
208593 & 2.2 .2 .1 \\
208603 & 2.2 .2 .1\end{array}$ & $\begin{array}{l}62.80 \\
62.50 \\
60.70 \\
58.90 \\
62.40 \\
62.00\end{array}$ & $\begin{array}{l}6.20 \\
6.30 \\
6.00 \\
5.80 \\
6.10 \\
6.00\end{array}$ & $\begin{array}{l}0.00 \\
0.00 \\
0.00 \\
0.00\end{array}$ & $\begin{array}{l}26.00 \\
21.00 \\
17.00 \\
12.00 \\
14.00 \\
19.00\end{array}$ & $\begin{array}{l}0.00 \\
0.00\end{array}$ & $\begin{array}{l}0.00 \\
0.00\end{array}$ \\
\hline $\begin{array}{l}\text { 34. } 1718 \\
\text { 34. } 1718 \\
34 \cdot 1718 \\
34 \cdot 1718 \\
\text { 34. } 1718 \\
\text { 34. } 1718\end{array}$ & $\begin{array}{l}13.40 \\
13.40 \\
13.40 \\
13.40 \\
13.40 \\
13.40\end{array}$ & $\begin{array}{ll}4 & 19890810 \\
4 & 19891011 \\
4 & 19900220 \\
4 & 19900620 \\
4 & 19900830 \\
4 & 19901023\end{array}$ & & $\begin{array}{ll}210711 & 1.1 .2 .1 \\
210712 & 1.1 .2 .1 \\
208567 & 1.1 .2 .1 \\
208580 & 1.1 .2 .1 \\
208592 & 2.1 .2 .1 \\
208609 & 2.1 .2 .1\end{array}$ & $\begin{array}{l}70.90 \\
73.20 \\
73.10 \\
74.40 \\
73.90 \\
77.00\end{array}$ & $\begin{array}{l}6.80 \\
6.80 \\
6.70 \\
6.70 \\
6.70 \\
6.70\end{array}$ & $\begin{array}{l}0.00 \\
0.00 \\
0.00 \\
0.00\end{array}$ & $\begin{array}{l}55.00 \\
51.00 \\
50.00 \\
51.00 \\
53.00 \\
51.00\end{array}$ & $\begin{array}{l}0.00 \\
0.00\end{array}$ & $\begin{array}{l}0.00 \\
0.00\end{array}$ \\
\hline $\begin{array}{l}\text { 34. } 1724 \\
\text { 34. } 1724 \\
34.1724 \\
\text { 34. } 1724 \\
\text { 34. } 1724 \\
\text { 34. } 1724 .\end{array}$ & $\begin{array}{l}8.40 \\
8.40 \\
8.40 \\
8.40 \\
8.40 \\
8.40\end{array}$ & $\begin{array}{ll}1 & 19890606 \\
1 & 19891009 \\
1 & 19900221 \\
1 & 19900619 \\
1 & 19900822 \\
1 & 19901023\end{array}$ & & $\begin{array}{ll}210713 & 2.2 .2 .1 \\
210714 & 2.2 .2 .1 \\
208572 & 2.2 .2 .1 \\
208577 & 2.2 .2 .1 \\
208586 & 2.2 .2 .1 \\
208608 & 2.2 .2 .1\end{array}$ & $\begin{array}{l}57.90 \\
60.10 \\
59.50 \\
59.50 \\
59.10 \\
59.60\end{array}$ & $\begin{array}{l}5.20 \\
5.30 \\
5.20 \\
5.30 \\
5.30 \\
5.20\end{array}$ & $\begin{array}{l}0.00 \\
0.00 \\
0.00 \\
0.00\end{array}$ & $\begin{array}{l}10.00 \\
11.00 \\
11.00 \\
12.00 \\
13.00 \\
14.00\end{array}$ & $\begin{array}{l}0.00 \\
0.00\end{array}$ & $\begin{array}{l}0.00 \\
0.00\end{array}$ \\
\hline $\begin{array}{l}\text { 34. } 1725 \\
\text { 34. } 1725 \\
\text { 34. } 1725 \\
\text { 34. } 1725 \\
\text { 34. } 1725 \\
\text { 34. } 1725\end{array}$ & $\begin{array}{l}24.20 \\
24.20 \\
24.20 \\
24.20 \\
24.20 \\
24.20\end{array}$ & $\begin{array}{ll}1 & 19890606 \\
1 & 19891011 \\
1 & 19900220 \\
1 & 19900619 \\
1 & 19900830 \\
1 & 19901015\end{array}$ & & $\begin{array}{ll}210715 & 2.3 .2 .2 \\
210716 & 2.2 .2 .2 \\
208569 & 2.2 .2 .2 \\
208578 & 2.2 .2 .2 \\
208594 & 2.2 .2 .2 \\
208602 & 2.2 .2 .2\end{array}$ & $\begin{array}{l}58.30 \\
58.60 \\
58.70 \\
59.90 \\
59.80 \\
57.60\end{array}$ & $\begin{array}{l}8.50 \\
8.50 \\
8.40 \\
8.50 \\
8.60 \\
8.40\end{array}$ & $\begin{array}{l}0.00 \\
0.00 \\
0.00 \\
0.00\end{array}$ & $\begin{array}{l}0.00 \\
0.00 \\
1.00 \\
1.00 \\
1.00 \\
1.00\end{array}$ & $\begin{array}{l}0.00 \\
0.00\end{array}$ & $\begin{array}{l}0.00 \\
0.00\end{array}$ \\
\hline $\begin{array}{l}\text { 34. } 1727 \\
34.1727 \\
34.1727 \\
34.1727 \\
34.1727 \\
\text { 34. } 1727\end{array}$ & $\begin{array}{l}17.10 \\
17.10 \\
17.10 \\
17.10 \\
17.10 \\
17.10\end{array}$ & $\begin{array}{ll}1 & 19890615 \\
1 & 19891009 \\
1 & 19900220 \\
1 & 19900619 \\
1 & 19900822 \\
1 & 19901015\end{array}$ & & $\begin{array}{ll}210369 & 2.2 .2 .1 \\
210370 & 2.2 .2 .1 \\
208568 & 2.2 .2 .1 \\
208575 & 2.1 .2 .1 \\
208587 & 2.2 .2 .1 \\
208599 & 2.2 .2 .1\end{array}$ & $\begin{array}{l}69.30 \\
71.10 \\
70.20 \\
72.00 \\
70.00 \\
70.70\end{array}$ & $\begin{array}{l}6.90 \\
7.10 \\
7.00 \\
6.90 \\
6.90 \\
6.80\end{array}$ & $\begin{array}{l}0.00 \\
0.00 \\
0.00 \\
0.00\end{array}$ & $\begin{array}{l}7.00 \\
7.00 \\
7.00 \\
7.00 \\
7.00 \\
7.00\end{array}$ & $\begin{array}{l}0.00 \\
0.00\end{array}$ & $\begin{array}{l}0.00 \\
0.00\end{array}$ \\
\hline $\begin{array}{l}\text { 34. } 1729 \\
\text { 34. } 1729 \\
\text { 34. } 1729 \\
\text { 34. } 1729 \\
\text { 34. } 1729 \\
\text { 34. } 1729\end{array}$ & $\begin{array}{l}39.05 \\
39.05 \\
39.05 \\
39.05 \\
39.05 \\
39.05\end{array}$ & $\begin{array}{ll}1 & 19890606 \\
1 & 19891009 \\
1 & 19900219 \\
1 & 19900618 \\
1 & 19900822 \\
1 & 19901015\end{array}$ & & $\begin{array}{ll}210717 & 2.2 .2 .1 \\
210718 & 2.2 .2 .1 \\
208562 & 2.2 .2 .1 \\
208574 & 2.2 .2 .1 \\
208589 & 2.2 .2 .1 \\
208601 & 2.2 .2 .1\end{array}$ & $\begin{array}{l}57.80 \\
59.80 \\
57.00 \\
58.50 \\
58.00 \\
57.70\end{array}$ & $\begin{array}{l}6.50 \\
6.60 \\
6.50 \\
6.40 \\
6.50 \\
6.40\end{array}$ & $\begin{array}{l}0.00 \\
0.00 \\
0.00 \\
0.00\end{array}$ & $\begin{array}{l}7.00 \\
7.00 \\
7.00 \\
7.00 \\
7.00 \\
8.00\end{array}$ & $\begin{array}{l}0.00 \\
0.00\end{array}$ & $\begin{array}{l}0.00 \\
0.00\end{array}$ \\
\hline $\begin{array}{l}\text { 34. } 1729 \\
\text { 34. } 1729 \\
\text { 34. } 1729 \\
\text { 34. } 1729 \\
\text { 34. } 1729 \\
\text { 34. } 1729\end{array}$ & $\begin{array}{l}19.05 \\
19.05 \\
19.05 \\
19.05 \\
19.05 \\
19.05\end{array}$ & $\begin{array}{ll}2 & 19890606 \\
2 & 19891009 \\
2 & 19900219 \\
2 & 19900618 \\
2 & 19900822 \\
2 & 19901015\end{array}$ & & $\begin{array}{ll}210719 & 2.2 .2 .1 \\
210720 & 2.2 .2 .1 \\
208563 & 2.2 .2 .1 \\
208573 & 2.2 .2 .1 \\
208588 & 2.2 .2 .1 \\
208600 & 2.2 .2 .1\end{array}$ & $\begin{array}{l}59.00 \\
60.20 \\
58.50 \\
60.10 \\
59.30 \\
59.00\end{array}$ & $\begin{array}{l}6.50 \\
6.60 \\
6.50 \\
6.50 \\
6.50 \\
6.40\end{array}$ & $\begin{array}{l}0.00 \\
0.00 \\
0.00 \\
0.00\end{array}$ & $\begin{array}{l}7.00 \\
7.00 \\
7.00 \\
7.00 \\
8.00 \\
8.00\end{array}$ & $\begin{array}{l}0.00 \\
0.00\end{array}$ & $\begin{array}{l}0.00 \\
0.00\end{array}$ \\
\hline $\begin{array}{l}\text { 34. } 1735 \\
34.1735 \\
34.1735 \\
34.1735 \\
34.1735 \\
34.1735\end{array}$ & $\begin{array}{l}13.08 \\
13.08 \\
13.08 \\
13.08 \\
13.08 \\
13.08\end{array}$ & $\begin{array}{ll}1 & 19890615 \\
1 & 19891101 \\
1 & 19900221 \\
1 & 19900620 \\
1 & 19900903 \\
1 & 19901023\end{array}$ & & $\begin{array}{ll}210374 & 2.1 .2 .1 \\
210375 & 2.1 .2 .1 \\
208571 & 2.1 .2 .1 \\
208584 & 2.1 .2 .1 \\
208595 & 2.1 .2 .1 \\
208610 & 2.1 .2 .1\end{array}$ & $\begin{array}{l}101.00 \\
123.00 \\
100.00 \\
98.90 \\
98.10 \\
99.60\end{array}$ & $\begin{array}{l}13.10 \\
16.00 \\
12.40 \\
12.20 \\
12.20 \\
12.30\end{array}$ & $\begin{array}{l}0.00 \\
0.00 \\
0.00 \\
0.00\end{array}$ & $\begin{array}{l}55.00 \\
52.00 \\
50.00 \\
46.00 \\
49.00 \\
49.00\end{array}$ & $\begin{array}{l}0.00 \\
0.00\end{array}$ & $\begin{array}{l}0.00 \\
0.00\end{array}$ \\
\hline
\end{tabular}

Tabel 18: Grundvandsanalyseme i R\&kilde-omrdet fordelt efter HK-klassifikationen. 

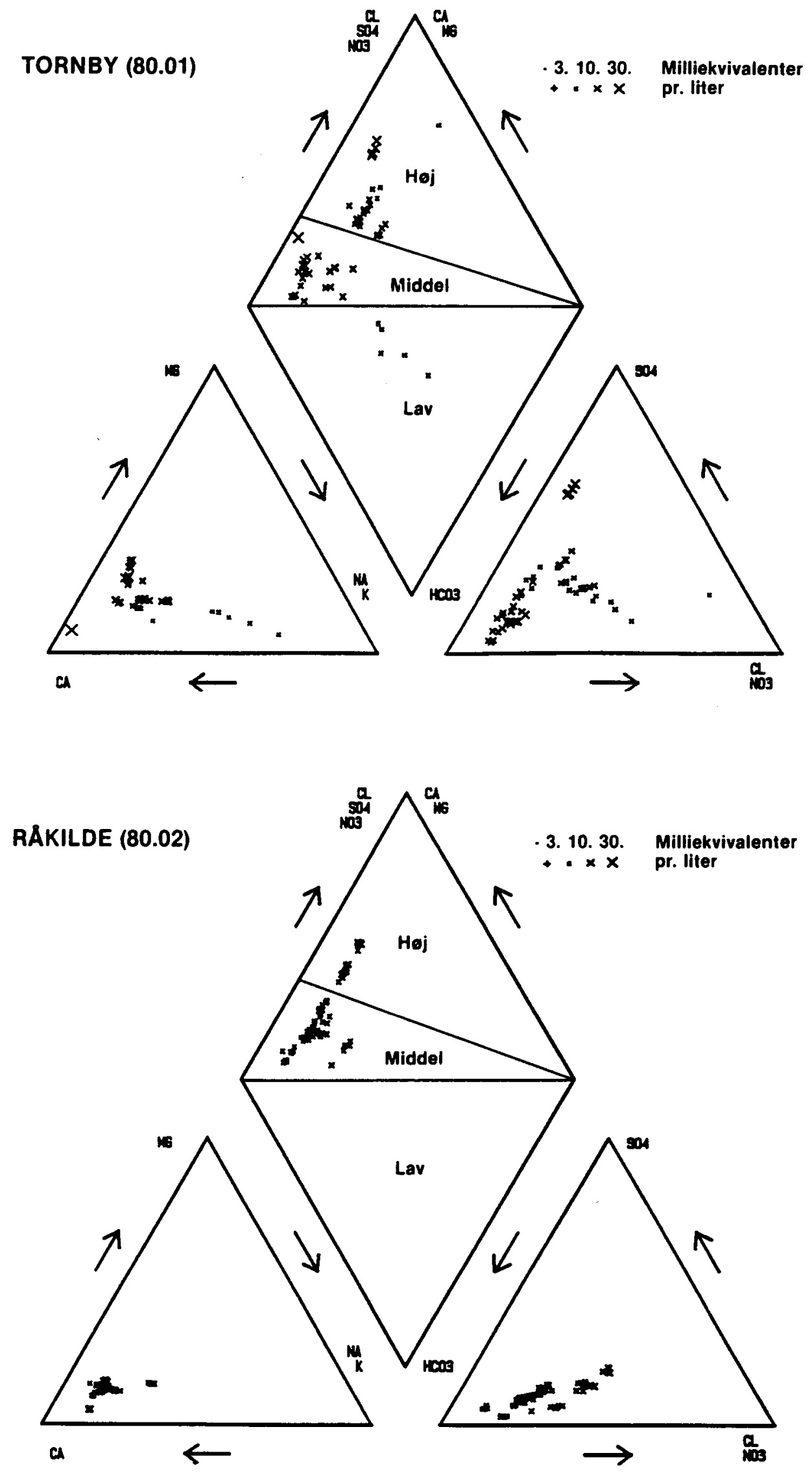

Figur 13:* $\quad$ Piper diagrammer for overvdgningsområdeme Tomby og Rdkalde. I det rhombeformede felt er der indtegnet delelinier, der afgrcenser felter med høj, middel og lav forvitringsgrad efter HKklassifikationen. 


\section{PROBLEMOMRÅDER}

Grundvandsproblemer, der vedrører kvalitet og ressource, er i dette afsnit beskrevet fortrinsvis ved hjalp af kort og kommentarer til disse. De geografisk afgrænsede "problemområder" er fastlagt udfra amternes indberetninger af hvor for eksempel indholdet af et givet stof er begrænsende for udnyttelsen af grundvandet. I disse områder er indholdet af for eksempel klorid, fluorid, natrium, nitrat, sulfat og spormetaller i det udnyttede grundvand for stort eller stigende. Steder, hvor grundvandet ikke udnyttes, hvor der er alternative og bedre grundvandsressourcer til rådighed, eller hvor kvalitetsproblemerne kan løses ved opblanding, er $\mathrm{i}$ princippet ikke anført som "problemområder".

I problemområderne beskrives regionale tendenser. Dette betyder at mindre, isolerede grundvandsforekomster med et problematisk stofindhold ikke repræsenteres på oversigtskortene. Omvendt kan der inden for de områder, der er udpeget som problemområderne lokalt findes grundvand af uproblematisk kvalitet. Formålet med "kortlægningen" er at etablere et grundlag for vurdering af de praktiske begrænsninger ved udnyttelsen af grundvandet i Danmark både nu og i fremtiden. Afsnittet er udarbejdet på grundlag af de amtslige indberetninger i 1990 og 1991 og DGU's samlerapport med status for grundvand og drikkevand i Danmark, 1990.

Grundlaget for de kvalitetskrav til råvand/drikkevand, der ligger bag afgrænsningen af problemområderne er "Bekendtgørelse om vandkvalitet og tilsyn med vandforsyningsanlæg", Miljøministeriet 1988, se tabel 19. Vurderingerne af grundvandsproblemerne varierer fra amt til amt. Således er det for eksempel ikke alle amter, der anser en overskridelse af den "vejledende grænseværdi" for problematisk.

De udarbejdede kort over problemområder er et første sammenstillingsforsøg. Hvor det er muligt, er kvalitetsproblemerne beskrevet i relation til reservoirtyperne. Dette galder for eksempel for Vestjylland, hvor grundvandet i de øvre frie reservoirer er stærkt belastet med nitrat, jern og aggressiv kulsyre, mens det i de dybereliggende og velbeskyttede grundvandsreservoirer er af god kvalitet. Kortene viser de faktorer, der er begrænsende for udnyttelsen af grundvandet. Derfor er nogle stoffer som mangan og jern, ikke illustreret, da disse stoffer kan fjernes rutinemæssigt ved traditionel vandbehandling.

Områder, hvor en for ringe grundvandsmængde er et problem, kan ikke afgrænses skarpt. Konstant faldende grundvandsstand $i$ en længere periode udgør således et problem, mens en kunstig lav og konstant grundvandsstand forårsaget af vandindvinding kan være acceptabel afhængig af recipienternes tilstand. Vurderingen bygger derfor både på holdningsmæssige og tekniske aspekter. 


\begin{tabular}{|c|c|c|c|}
\hline BESTANDDEL & $\begin{array}{c}\text { EVT. UNDERGRENSE } \\
\text { FOR } \\
\text { PROBLEMBESKRIVELSEN }\end{array}$ & $\begin{array}{l}\text { VEJLEDENDE } \\
\text { VAERI }\end{array}$ & $\begin{array}{l}\text { HØJST } \\
\text { TILLADELIGE } \\
\text { INDHOLD }\end{array}$ \\
\hline \multirow[t]{2}{*}{$\begin{array}{l}\mathrm{Na} \\
\mathrm{K} \\
\mathrm{NH}_{4} \\
\mathrm{Fe} \\
\mathrm{Mg} \\
\mathrm{Cl} \\
\mathrm{SO}_{4} \\
\mathrm{NO}_{3} \\
\mathrm{NO}_{2} \\
\mathrm{P} \text { tot. } \\
\mathrm{F} \\
\mathrm{H}_{2} \mathrm{~S} \\
\mathrm{CH}_{4}\end{array}$} & $\begin{array}{c}20 \\
0,05 \\
30 \\
50 \text { og stigende } \\
50 \text { og stigende } \\
25 \text { og stigende } \\
\text { u.d. } \\
\text { u.d. }\end{array}$ & $\begin{array}{c}20 \\
0,05 \\
0,05 \\
30 \\
50 \\
50 \\
25 \\
\text { u.d. } \\
\text { u.d. }\end{array}$ & $\begin{array}{c}175 \\
10 \\
0,5 \\
0,2^{*} \\
50 \\
300 \\
250 \\
50 \\
0,1 \\
0,15 \\
1,5 \\
\text { i.m. } \\
\text { i.m. }\end{array}$ \\
\hline & Andre & måleenheder & \\
\hline \multirow[t]{2}{*}{$\begin{array}{l}\text { Brunt vand } \\
\text { (Kaliumper- } \\
\text { mangantal) } \\
\text { pH } \\
\text { Agg. kulsyre }\end{array}$} & 6 & $\begin{array}{c}6 \\
7-8\end{array}$ & $\begin{array}{l}12 \\
8,5 \\
\text { i.m. }\end{array}$ \\
\hline & $\begin{array}{l}\text { Vandmangdeproblemer anføres } \\
\text { verstiger grundvandsdannelsen }\end{array}$ & $\begin{array}{l}\text { større områder } \\
\text { udnyttelig kvalite }\end{array}$ & or vandbehovet \\
\hline
\end{tabular}

Tabel 19: De krav til drikkevandets stofindhold, der danner udgangspunkt for den geografiske afgransning af problemområder.

i.m.: Ikke målelig ved den anviste metode, u.d.: under detektionsgraensen for den metode, der kan måle en tiendedel af den højst tilladelige vardi. ${ }^{*} D G U$ vurderer, at der skal vaere ca. 4 milligram jern pr. liter $i$ grundvandet, for dette stof udgør et problem ved vandindvindingen.

Ud over de i (tabel 19) næunte elementer har amtskommunerne også vurderet, at sporelementer, opløsningsmidler og oliederivater, pesticider, mikrobiologiske faktorer samt evt. kombinerede faktorer ikke udgør et kendt problem i større sammenhængende områder. Roskilde amt vurderer dog, at nikkelindholdet stedvist udgør et problem, se side 172, og Københavns amt finder, at hele amtet ville kunne opfattes som et problemareal for opløsningsmidler, se figur 23. 


\section{KVALITETSPROBLEMER}

\section{Natrium og klorid (saltvand)}

Natrium- og kloridioner $\mathrm{i}$ grundvandet stammer begge overvejende fra opløst natriumklorid. Derfor er områder, hvor indholdet af disse stoffer udgør et problem indtegnet på samme kort, figur 14.

Saltproblemerne findes fortrinsvis i de kystnære områder (indtrængende havvand) og i marine aflejringer, hvor porevandet ikke er udvasket (marint residualvand), samt i forbindelse med opstigende saltopløsninger fra den dybere undergrund (salt mineralvand). Grundvandet er som regel salt under 200 m's dybde; fra dette niveau kan det salte grundvand trænge op for eksempel i sprækkezoner over salthorste.

Et forhøjet natriumindhold uden et tilsvarende højt kloridindhold, kombineret med et lavt kalium- og magnesiumindhold kan skyldes ionbytning i marint ler. Ionbyttet grundvand af denne type træffes især på Vest- og Midtsjælland samt på Fyn (Paleocæne og Eocæne aflejringer) og i Vendsyssel (sen- og postglaciale aflejringer).

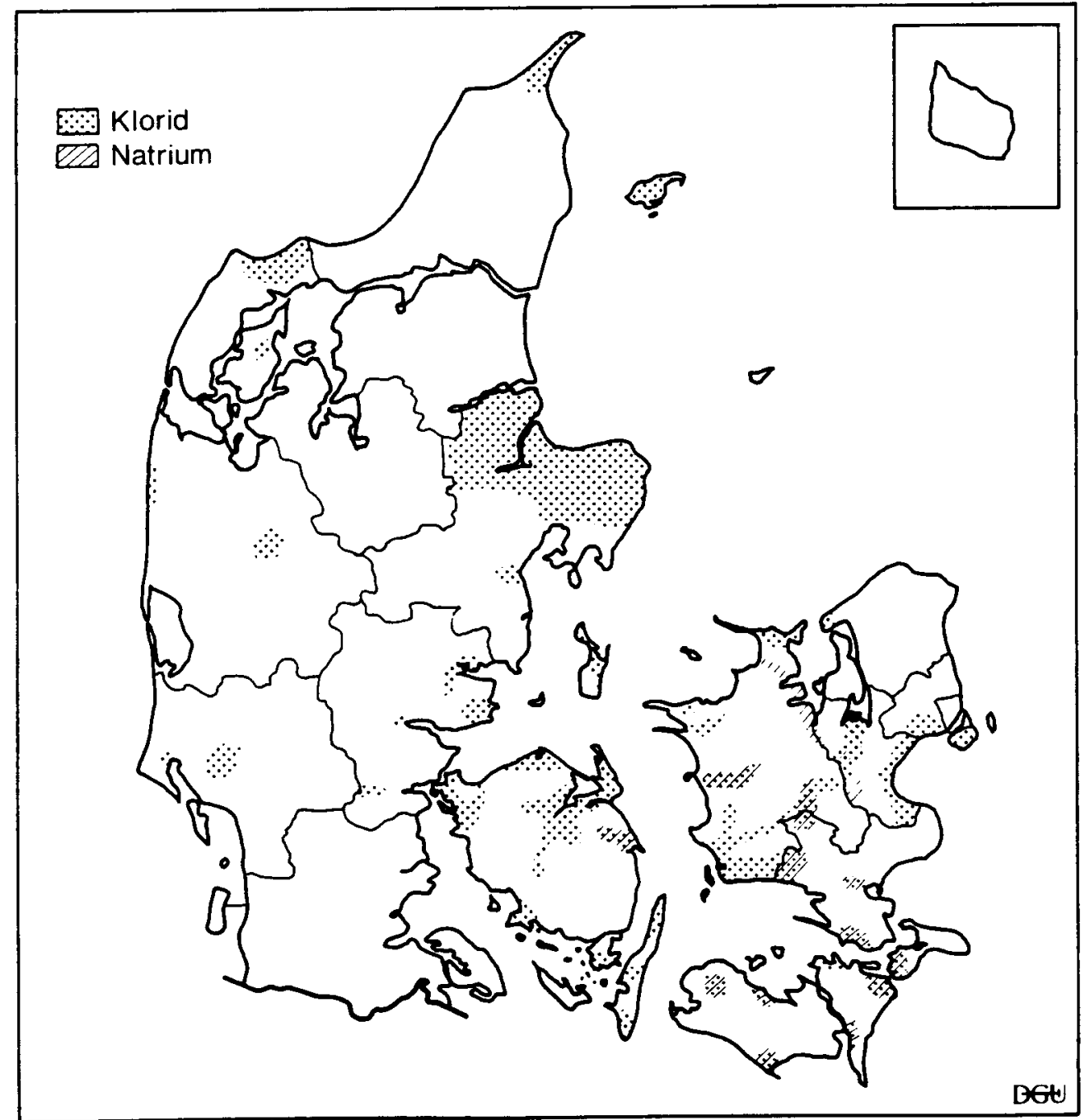

Figur 14: $\quad$ Problemområder for klorid og natrium. Sammenstillet efter oplysninger fra amterne.

I disse områder udgør klorid-og/eller natriumindholdet $i$ grundvandet en potentiel eller aktuel begransning for drikkevandsforsyningen. 
Københavns amt, Frederiksberg og Københavns kommuner:

Natrium er ikke et problem i grundvandet i amtet, men forhøjet indhold af klorid findes især i Køge Bugt området og på Amager.

Frederiksborg amt:

I området omkring Hundested på Halsnæs halvøen er der et stort indhold af natriumklorid i kalkreservoiret, hvilket skyldes overpumpning. I den nordlige del af amtet er natriumindholdet i grundvandet generelt lidt forhøjet på grund af ionbytning, men dette påvirker ikke vandforsyningen.

\section{Roskilde amt:}

I amtet findes områder med forhøjet natriumkloridindhold i grundvandet langs kysterne, især ved Køge Bugt området, men også i forbindelse med optrængning af salt mineralvand langs

sprækkesystemer. Amtet anser ikke, at natriumindholdet i grundvandet begrænser ressourcen. Derimod har grundvandet stedvist forhøjet natriumindhold i området fra Roskilde og mod syd i retning af Vestsjællands amt. Dette skyldes ionbytning i forbindelse med grønsandsaflejringer.

Vestsjællands amt:

Saltproblemer forekommer i den nordlige del af Odsherred, langs kysten ved Skælskør og videre i en zone over Ringsted. Natriumindhold i grundvand udgør et problem omkring Skælskør samt ved Holbæk og herfra mod nordvest.

\section{Storstrøms amt:}

Ionbyttet natriumholdigt grundvand findes i den nordlige del af amtet, medens der er problemer med forhøjet natriumkloridindhold i grundvandet fra kystnære indvindingsboringer. I Næstvedområdet findes generelt højtliggende salt grundvand.

Fyns amt:

Grundvandet i de kystnære områder er præget af indtrængende havvand og marint residualvand. Ved Nyborg, Odense og Middelfart skyldes natriumkloridproblemerne endvidere optrængning af saltholdigt vand fra prakvartære aflejringer. Kun i et område nord for Nyborg er der natriumproblemer, der skyldes ionbytning.

Ribe amt:

Enkelte steder i amtet er der salt grundvand, enten i form af residualvand eller som følge af den højtliggende saltvandsgrænse.

Vejle amt:

Der er risiko for indtrængning af havvand på Endelave og $\mathrm{i}$ kystegnene ved Juelsminde og Fredericia, medens marint residualvand findes ved ådalene omkring Horsens, Vejle og Kolding. 
Århus amt:

I den nordlige del af amtet er der overalt salt grundvand i de dybereliggende reservoirer, hvilket giver problemer ved for stor indvinding.

Ringkøbing amt:

Saltindholdet $\mathrm{i}$ grundvandet udgør et problem i de kystnære indvindingsboringer ved Holmsland Klit, Thorsminde Tangen og på Thyborøn Tangen. Herudover trænger der et enkelt sted salt mineralvand op fra en saltstruktur.

\section{Viborg amt:}

Salt grundvand findes $\mathrm{i}$ forbindelse med Mors salthorsten og som marint residualvand i stenalderhavets aflejringer i den nordøstlige del af Thy.

Nordjyllands amt:

Kloridindholdet i grundvandet udgør et problem, hvor der sker overpumpning fra postglaciale reservoirer i Skagen og på Læsø.

Bornholm og Sønderjyllands amter:

Der er ingen klorid- eller natriumproblemer. 
Nitrat

Grundvandets nitratindhold stammer overvejende fra landbrugsarealer, hvor planter og muld i dyrkningslaget ikke er i stand til at optage eller omsætte den tilførte handelsgødning og husdyrgødning eller, hvor der i efterårsperioden sker en mineralisering af organisk materiale. I lerede oplande bortledes en del af det nitratholdige infiltrationsvand til recipienterne via dræn, medens resten er grundvandsdannende. Nitrat kan $\mathrm{i}$ jorden omsættes til frit kvælstof ved denitrifikation under forbrug af let omsætteligt organisk stof eller ved reaktion med jernholdige mineraler. Det er især de dårligt beskyttede, øvre grundvandsreservoirer med frit vandspejl og en dårlig nitratreduktionskapacitet, der indeholder store mængder nitrat. Grundvandets nitratindhold er kun en potentiel trussel $\mathrm{i}$ områder, hvor der er alternative dybereliggende og nitratfrie grundvandsressourcer til rådighed. Således er de øvre grundvandsressourcer i de sandede hedesletter og bakkeøer i Vestjylland, hvor grundvandet er nitratholdigt, ikke i denne sammenhæng problemområder.

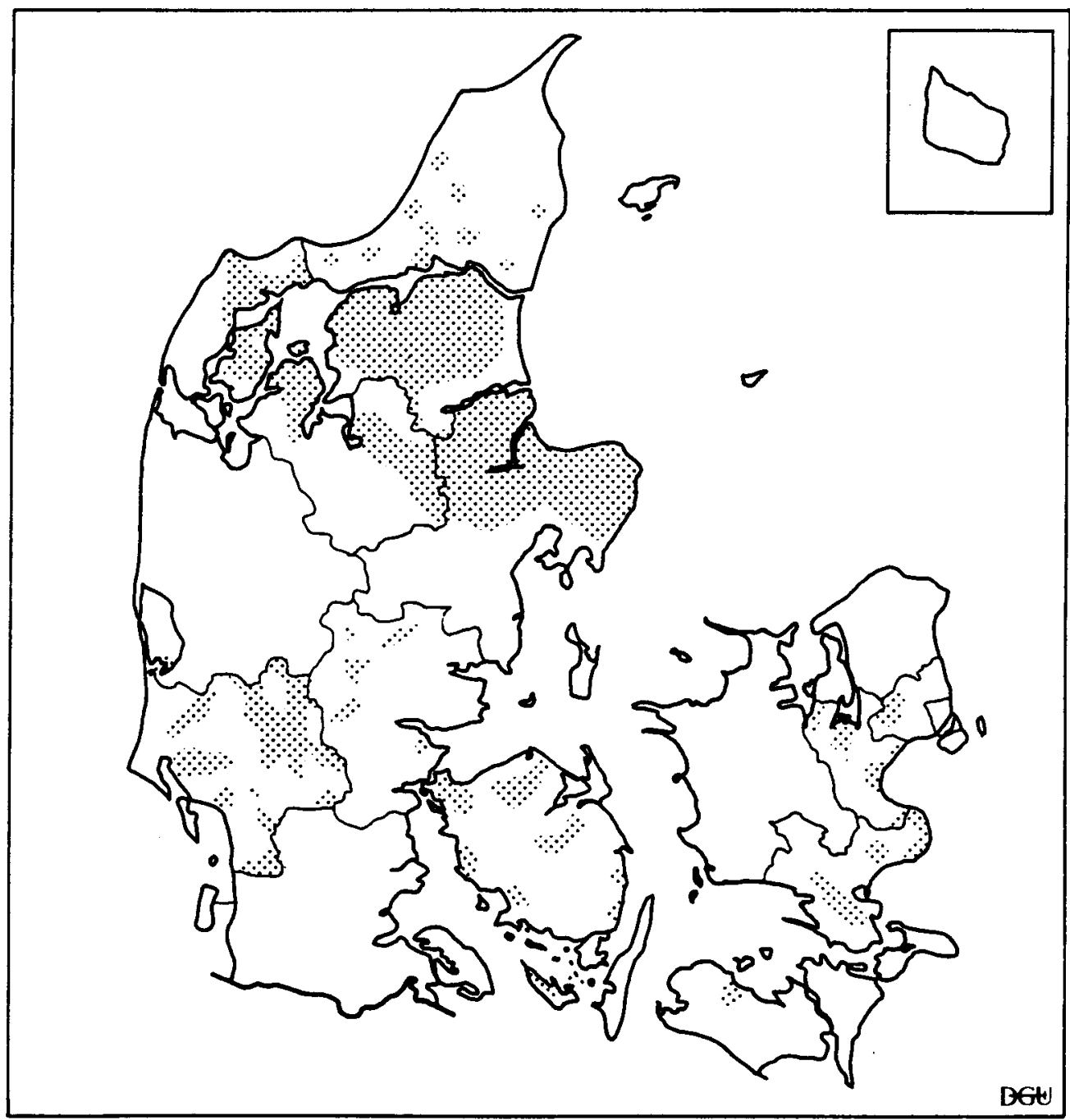

Figur 15: $\quad$ Problemområder for nitrat. Bemoerk at de nitratpdivirkede grundvandsressourcer $i$ Vestjylland ikke er vist på kortet. Sammenstillet efter oplysninger fra amterne.

I disse områder udgør nitrat-indholdet $i$ grundvandet en potentiel eller aktuel begraensning for drikkevandsforsyningen. 
Tilsvarende områder findes i det nordlige Jylland og på Stevns, hvor kalkreservoirerne kun er beskyttet af tynde lerlag. I Nordjyllands, Viborg og Århus amter er det ofte ikke muligt at finde grundvand med et acceptabelt lavt nitratindhold, da de øvre reservoirer indeholder nitrat og de dybereliggende salt, bl.a. som følge af overpumpning inden for disse områder. Grundvandet i de øvre dele af kalkreservoirerne er dog stedvis af god kvalitet. Kortet viser derfor ikke, at alt grundvand er nitratbelastet inden for de afgrænsede områder, men at nitratindholdet $i$ en del af grundvandet udgør et forsyningsmæssigt problem.

Områder med nitratproblemer er vist på figur 15.

Københavns amt, Frederiksberg og Københavns kommuner:

I København forekommer der nitratbelastet grundvand $\mathrm{i}$ den vestlige del af amtet, der domineres af gartneridrift og landbrugsområder.

Bornholms og Vestsjællands amter:

Der er ingen nitratproblemer i amtet.

Frederiksborg amt:

I amtet er grundvandet i et enkelt område vest for Arresø, hvor grundvandsspejlet er frit, belastet med nitrat ned til ca. 25 meter under terræn. Endvidere er grundvandet i den øvre del af hovedreservoiret i den centrale del af Horsherred stedvis nitratholdigt.

Roskilde amt:

Nitratholdigt grundvand findes langs Køge Bugt og i Hedeland

Formationen. Begge steder er reservoirerne kun beskyttet af tynde lerlag.

Storstrøms amt:

Nitratproblemområderne er knyttet til Stevns, hvor grundvandet indvindes fra et relativt dårligt beskyttet reservoir i Danienkalk, og fra Mogenstrup Ås's grus- og sandforekomster.

Fyns amt:

Generelt indeholder det øverste grundvand ned til ca. 5 meters dybde overalt nitrat. Derudover er der problemer, hvor der kun er en ringe beskyttelse med lerlag over de underliggende reservoirer.

De fleste udpegede problemområder ligger i nærheden af kysten, hvor det ikke er muligt at udnytte dyberebeliggende reservoirer på grund af saltvandsindtrængning fra havet.

Sønderjyllands amt:

Forhøjet nitratindhold i grundvandet forekommer $\mathrm{i}$ alle overfladenære ubeskyttede grundvandsreservoirer. Disse benyttes især til markvanding og enkeltforsyningsanlæg. I de dybereliggende reservoirer, der udnyttes til vandforsyningen, er grundvandet nitratfrit. 
Ribe amt:

Nitratholdigt grundvand findes i de øvre, ubeskyttede grundvandsreservoirer på hedesletterne og de mindre overfladenære grundvandsreservoirer på de sandede bakkeøer. Disse reservoirer udnyttes dog mest til enkeltindvindingsanlæg og markvanding, og vil antagelig ikke være anvendelig til vandværksformål indenfor en overskuelig fremtid.

Vejle amt:

I den vestlige del af amtet indeholder grundvandet i udsatte reservoirer med frit grundvandsspejl hyppigt mere nitrat end den vejledende værdi for drikkevand og hyppigt endda over det maksimalt tilladte indhold. Nitratindholdet i disse reservoirer er stigende.

Århus amt:

I den nordlige og nordøstlige del af amtet, hvor der indvindes

fra kalkreservoirer med tynde dæklag af ler, er grundvandet i almindelighed nitratholdigt. Grundvandet i de ydedygtige, øvre reservoirer $i$ amtets vestlige dele er ligeledes nitratholdigt. Problemet kan dog i sidstnævnte tilfælde løses ved at bore dybere.

\section{Ringkøbing amt:}

De øvre reservoirer med frit grundvandsspejl er overalt, hvor der er landbrugsdrift, belastet med nitrat til en dybde af 25 meter under terræn, mens de dybereliggende grundvandsforekomster er nitratfrie. Da hovedparten af vandforsyningen er baseret på indvinding fra dybe reservoirer, er nitrat i grundvandet ikke et problem for drikkevandsforsyningen. Det øvre nitratbelastede grundvand anvendes hovedsagelig til markvanding og enkeltvandforsyninger.

\section{Viborg amt:}

Det øverste grundvand er generelt nitratholdigt, men kun områder, hvor det ikke er muligt at indvinde nitratfrit grundvand fra større dybder, er problemområder. Disse områder ligger i Thy, Mors og på Salling samt i den nordøstlige del af amtet.

Nordjyllands amt:

Nitratholdigt grundvand findes især i Himmerland, men også spredt i Vendsyssel. Det er de øvre sandreservoirer med frit vandspejl og de dårligt beskyttede kalkstensreservoirer, der er nitratbelastede. Der er mange steder dybere grundvandsforekomster med godt vand. 
Sulfat

Sulfat i grundvand kan stamme fra nedbøren, sulfatholdig handelsgødning eller sulfat kan være dannet ved iltning af svovlkis og andre svovlforbindelser $i$ for eksempel tørv, dynd, brunkul og kalk. Især i områder, med stor afsænkning af grundvandsspejlet, kan der ske iltning af svovlkis med en markant stigning af sulfatindholdet i grundvandet til følge. Endelig kan forhøjet sulfatindhold i grundvandet forekomme, hvor der også er saltproblemer. Områder med sulfatproblemer er vist på figur 16.

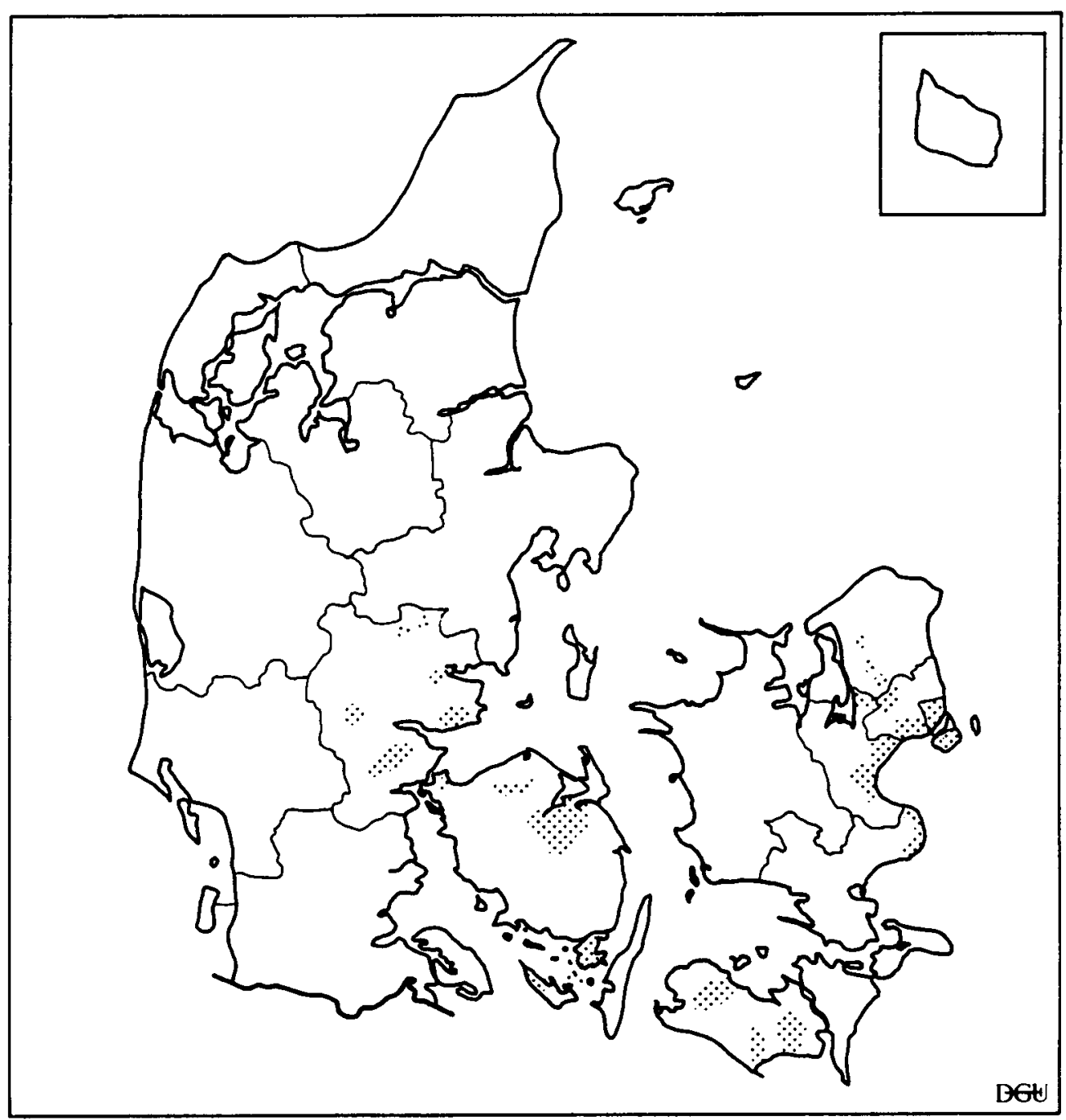

Figur 16: $\quad$ Problemområder for sulfat. Arhus amiskommune har ikke afgræenset sulfatproblemet geografisk. Sammenstillet efter oplysninger fra amteme.

I disse omrdder udgor sulfat-indholdet $i$ grundvandet en potentiel eller aktuel begraensning for drikkevandsforsyningen.

Kun enkelte vandværker leverer vand, der indeholder mere sulfat end højst tilladeligt, medens mange leverer vand, der har mellem det vejledende og det højst tilladelige indhold. På Bornholm er sulfatindholdet $\mathrm{i}$ 
grundvandet et problem ved Robbedale og Nyker (Nykerblokken) på grund af grusgravning og stigende vandindvinding. I og omkring København udgør sulfat et problem på grund af den kraftige afsænkning af grundvandet. Ved de store kildepladser i dette område er der sket en markant stigning i sulfatindholdet gennem de sidste 30-50 år. I Storstrøms amt er der problemer med højt sulfatindhold i kystegnene på Sydsjalland og Lolland. I Fyns og Vejle amter skyldes sulfatproblemerne iltning af svovlforbindelser i forbindelse med grundvandssænkning, eller at reservoirerne er dårligt beskyttede mod nedsivning af reaktivt nitrat- og iltholdigt vand. I Århus amt er udbredelsen af sulfatproblemet endnu ikke kortlagt. 
Fluorid

Et forhøjet indhold af fluorid $\mathrm{i}$ grundvandet skyldes opløsning af fluorholdige mineraler, særlig i kalkstensreservoirerne. Den geografiske udbredelse af grundvand med højt fluoridindhold følger på Sjælland udbredelsen af de udnyttede kalkstensreservoirer (Lolland-Falster, Sydsjælland, Stevns-Køge Bugt), figur 17. På Fyn udgør grundvandets fluoridindhold kun et problem i små områder ved Nyborg, mens der er fluoridproblemer i store dele af Djursland.

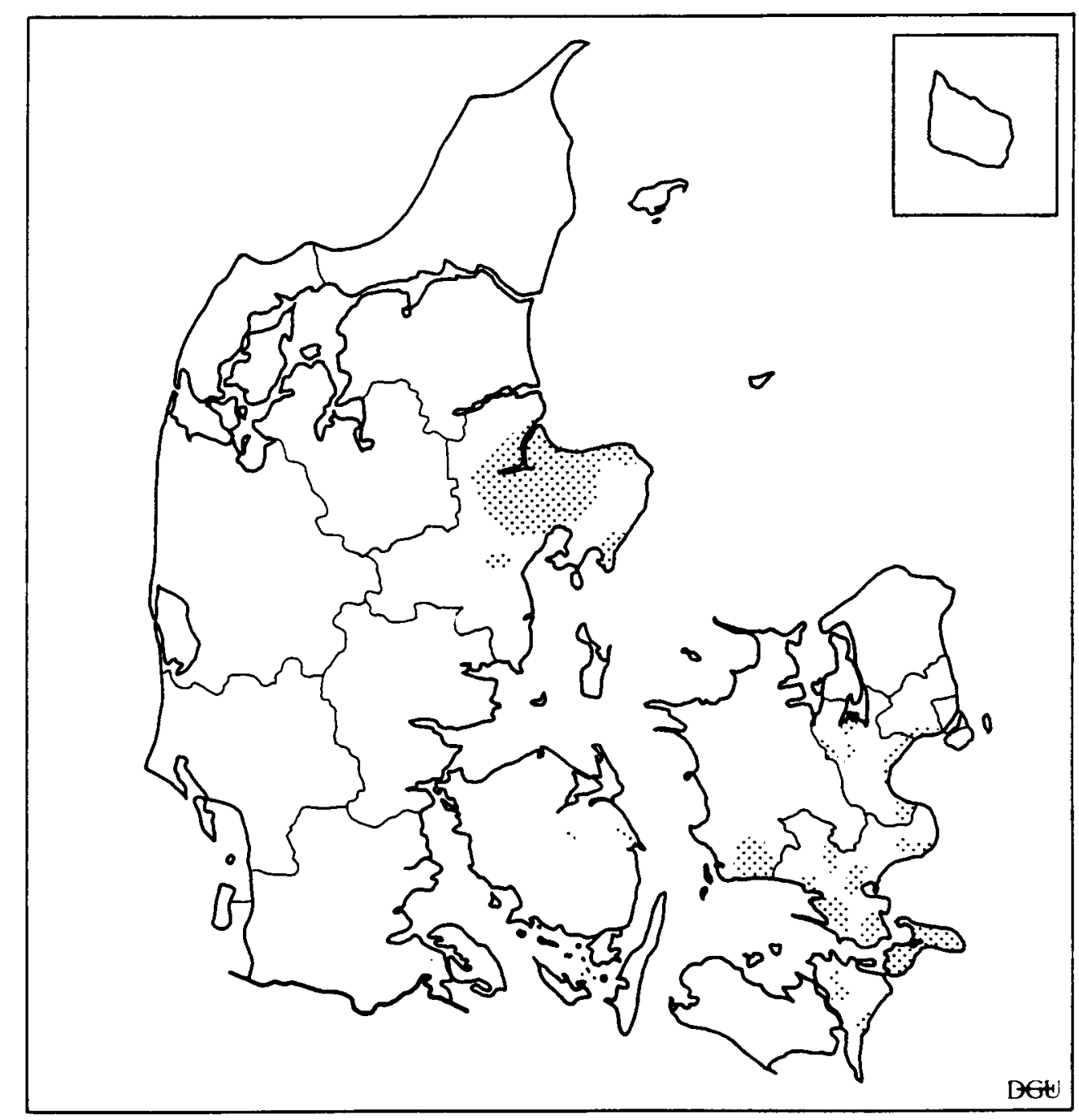

Figur 17: Problemområder for fluorid. Sammenstillet efter oplyșninger fra amterne.

I disse omrdder udgor fluor-indholdet $i$ grundvandet en potentiel eller aktuel begraensning for drikkevandsforsyningen. 
Kaliumpermanganattal (Organiske stoffer og brunt vand)

Med kaliumpermanganattallet udtrykkes grundvandets indhold af let omsætteligt organisk stof. Opløst organisk stof kan stamme fra nedsivning og fra udvaskning af humusholdige organiske sedimenter. Opløst organisk stof giver grundvandet en brun farve og en ubehagelig smag, det såkaldte brune vand. Grundvand af denne type kendes fra de dybe Miocæne reservoirer i Jylland, især fra den dybeste del af reservoirerne. Brunt vand kan også forekomme i forbindelse med for eksempel marine postglaciale aflejringer. Områder, hvor organisk stof $i$ grundvandet udgør et problem, er vist på figur 18.

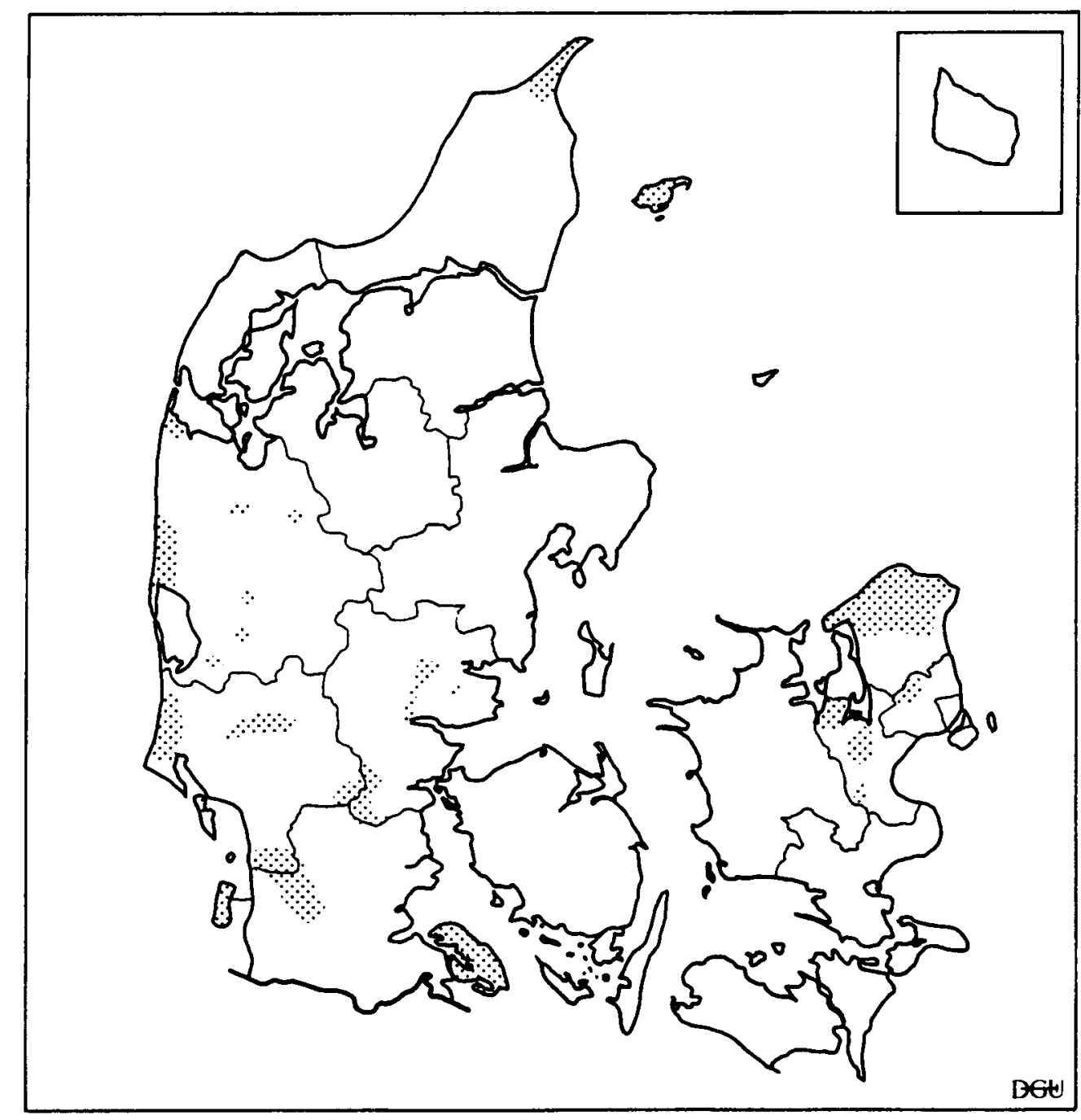

Figur 18: $\quad$ Problemområder for organisk stof (brunt vand). Sammenstillet efter oplysninger fra amteme. I disse områder udgør størrelsen af kaliumpermanganat-tallet (organisk stof/brunt vand) en potentiel eller aktuel begroensning for drikkevandsforsyningen. 
Københavns amt, Frederiksberg og Københavns kommuner:

I mindre områder i den vestlige del af amtet udgør grundvandets indhold af organisk stof et problem.

\section{Frederiksborg amt:}

Kaliumpermanganattallet for grundvandet $i$ de dybereliggende dele af kalkstens- og Alnarpsandreservoirerne samt $\mathrm{i}$ de samtidige sekundære reservoirer viser et varierende, men generelt højt, indhold af opløst organisk stof.

Roskilde amt:

I den centrale del af amtet, syd for Roskilde og i den sydlige del af Hornsherred, udgør grundvandets indhold af organisk stof et problem.

Sønderjyllands amt:

Grundvandets indhold af opløst organisk stof udgør et problem på Als (marine aflejringer fra Eem), Rømø (marine postglaciale aflejringer) og i den vestlige del af amtet (det dybtliggende tertiære grundvandsreservoir - Ribe formationen).

\section{Ribe amt:}

Brunt vand findes i de dybe boringer overalt i amtet. Det brune vand er knyttet til aflejringer fra Miocæn tid og Holstein interstadial. Brunt vand kan også forekomme i forbindelse med postglaciale marine aflejringer.

Vejle amt:

Der er kun fundet brunt vand i den vestlige del af Vejle $\AA$ dal i en dyb boring med aflejringer fra Holstein.

\section{Ringkøbing amt:}

Brunt vand findes flere steder $i$ amtet og begræenser indvindingsmulighederne fra den nedre del af de dybe reservoirer.

Mellem Nissum og Stadil Fjord findes det brune vand under ca. 150 metersdybde.

Nordjyllands amt:

Et indhold af humus i grundvandet er stedvist konstateret ved overpumpning af de postglaciale reservoirer i Skagen og på Læsø. 


\section{Ammonium}

Ammonium i små mængder forekommer ofte i grundvandet og kan være af naturlig oprindelse eller skyldes menneskelig påvirkning. Det tilføres grundvandet via regnvand, ved gødskning og ved omsætning af organisk materiale. Det meste ammonium i dyrkningslaget omsættes ved nitrifikation, hvor ammonium omdannes til nitrat. Ammonium kan desuden findes $\mathrm{i}$ dybere reservoirer under reducerende forhold. Ammonium $\mathrm{i}$ grundvand vanskeliggør vandbehandlingen, men hindrer ikke en udnyttelse af vandressourcen. Ammonium er således primært et teknisk problem. Et kort over forekomster af grundvand med et ammoniumindhold, som nødvendiggør en teknisk behandling, er vist i figur 19.

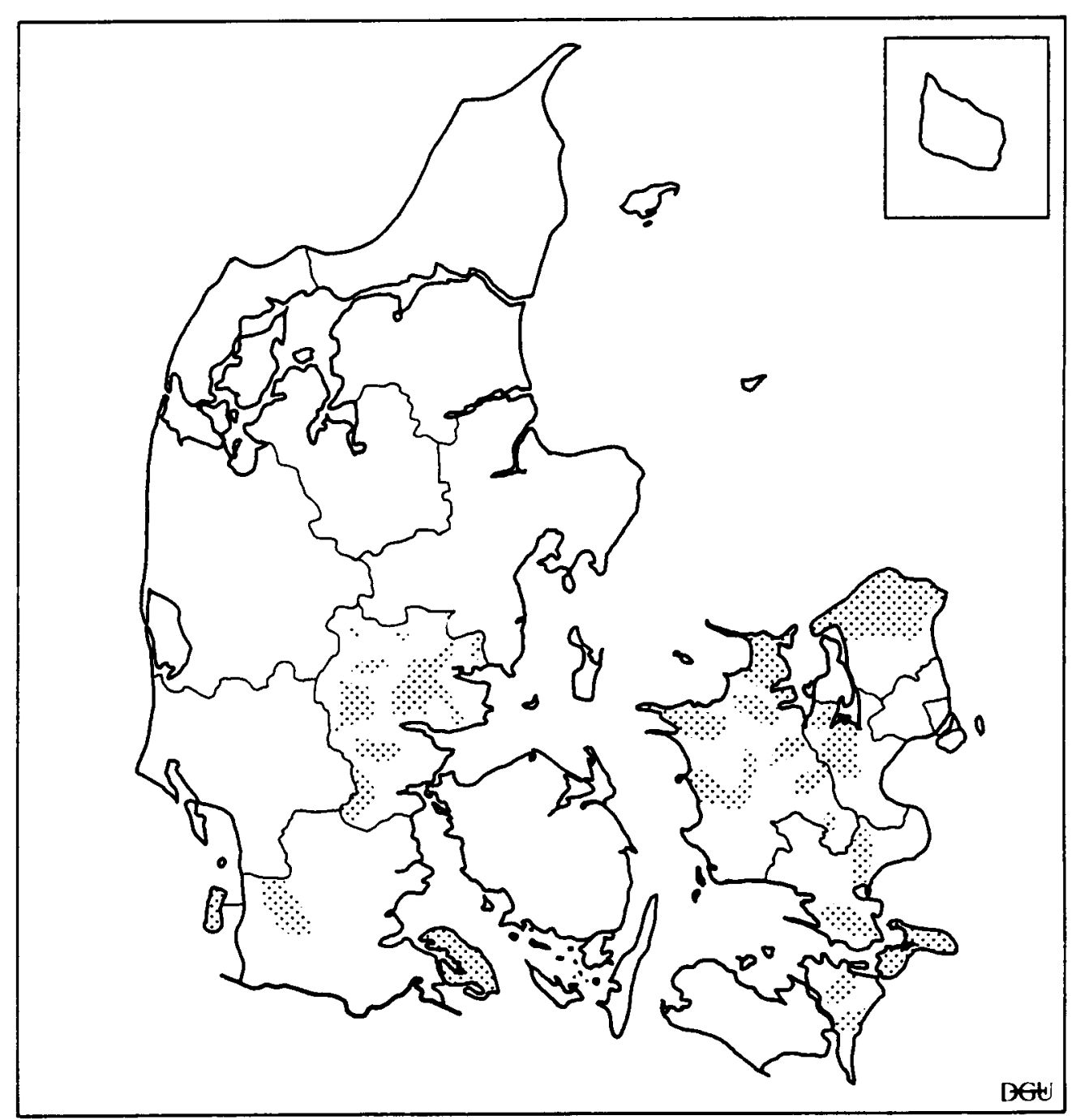

Figur 19: Problemområder for ammonium, hvor ammoniumindholdet nødvendiggør tekniske behandling af råvandet. Sammenstillet efter oplysninger fra amteme.

Eksempler på forekomster af forhøjet ammoniumindhold i grundvandet er nævat i det følgende, men også andre grundvandsreservoirer $\mathrm{i}$ andre amter kan, jævnfør figur 19, have et forhøjet indhold. I den østlige del af Danmark er der ofte et forhøjet ammoniumindhold i grundvandet $\mathrm{i}$ både kalkstensreservoirerne og de 
kvartære lag. Det relativt høje ammoniumindhold i grundvandet findes i områder, der strækker sig fra Lolland-Falster over Sydsjælland til Køge Bugt samt fra Odsherred til Ålborg. I den sydlige del af Jylland har grundvandet et forhøjet ammoniumindhold på Als i marine aflejringer fra Eem og på Rømø i marine postglaciale aflejringer. I den vestlige del af Jylland er der et naturligt forhøjet ammoniumindhold $\mathrm{i}$ de dybtliggende tertiære og kvartære grundvandsreservoirer.

\section{Svovlbrinte}

Grundvandets svovlbrinteindhold kan opstå ved forrådnelse af organiske stoffer og ved reduktion af sulfat i dybtliggende reservoirer. Da svovlbrinte let fjernes ved iltning, udgør stoffet alene et teknisk problem, figur 20.

Især hvor indvindingen foregår fra kalkstensreservoirer, er det nødvendigt at foretage en kraftig luftning af råvandet for at fjerne svovlbrinte.

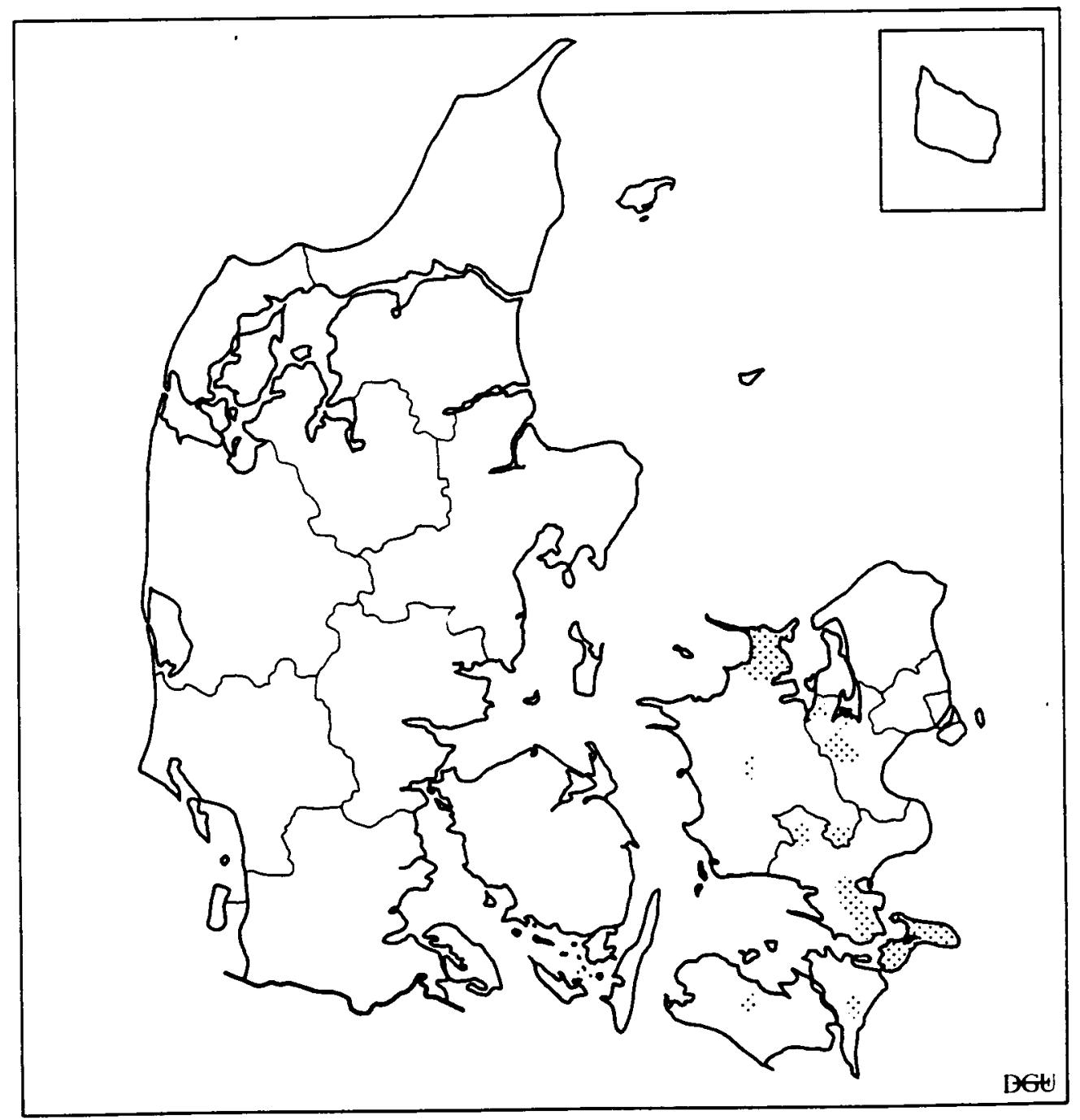

Figur 20: $\quad$ Problemområder for svovlbrinte, hvor svovlbrinteindholdet nødvendiggør teknisk behandling af råvandet. Sammenstillet efter oplysninger fra amterne. 
Metan

Metan kan dannes ved bakteriel omdannelse af organisk materiale i for eksempel kvartære marine aflejringer. Fra disse følger metanen med grundvandsstrømmen, og grundvand med et forhøjet metanindhold kan derfor have en større udbredelse end de aflejringer, hvori metanen er dannet.

Et kort over de steder, hvor grundvandets metanindhold fordrer en teknisk behandling af vandet, er vist $i$ figur 21.

Der forekommer metan i grundvandet i Nordsjælland og fra Odsherred mod Kalundborg. Kilden til metanen er her marine aflejringer fra sidste istid (for eksempel i bunden af Alnarp-dalen, DGU 1991). Et andet større område ligger i Vendsyssel, hvor metanen stammer fra den marine Skærumhede Formation. Metanen i grundvandet på Als og Ærø samt i Sydsjælland og på Møn stammer muligvis også fra interglaciale og glaciale marine aflejringer. Metan i grundvand vanskeliggør vandbehandlingen, men den hindrer ikke at grundvandet udnyttes.

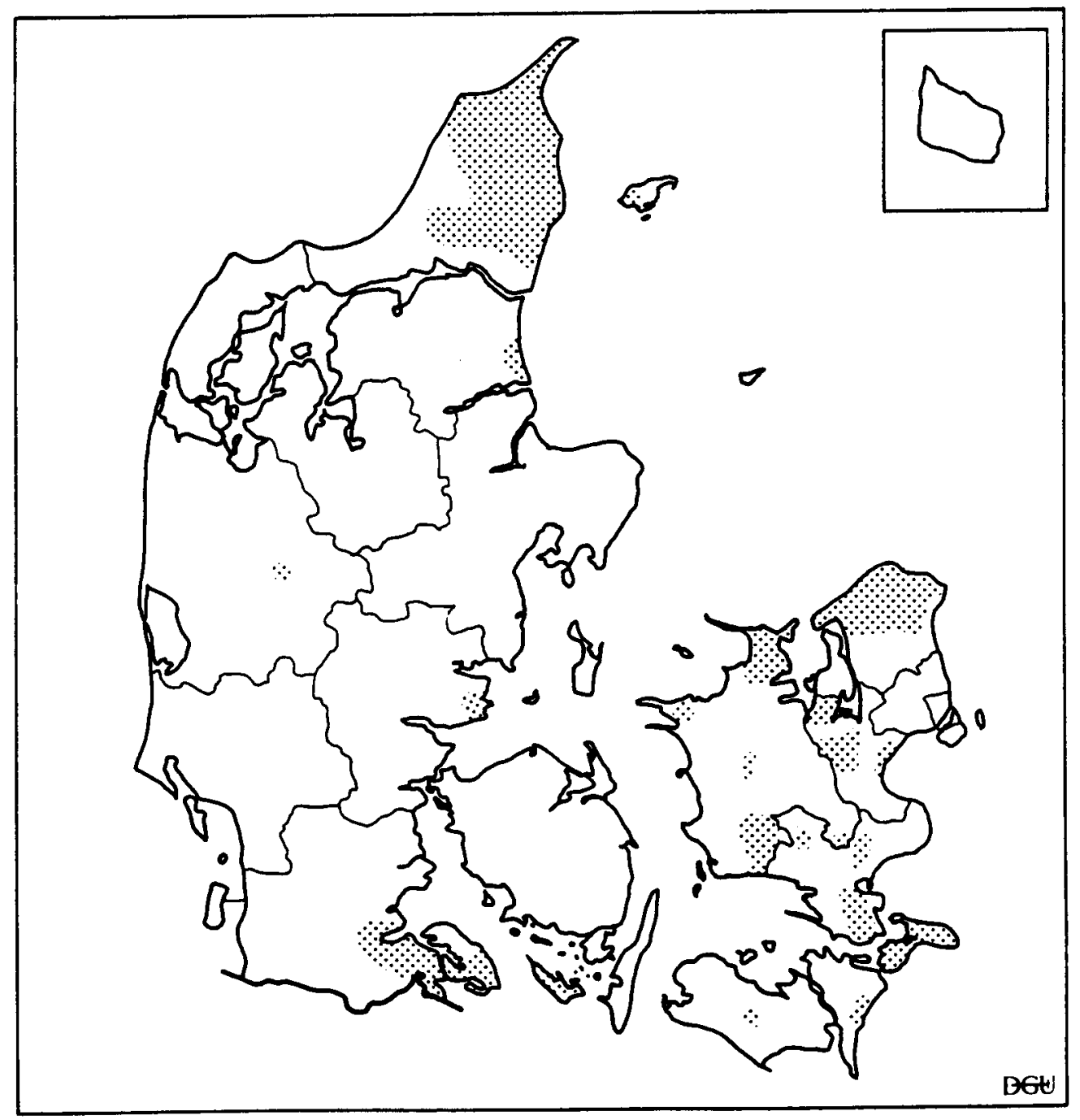

Figur 21: Problemomrdder for metan, hvor metanindholdet nødvendiggør teknisk behandling af råvandet. Sammenstillet efter oplysninger fra amteme. 
pH og aggressiv kulsyre

Der er ofte problemer med udnyttelsen af grundvandet som følge af lavt pH og aggressiv kulsyre i de samme grundvandsreservoirer. $\mathrm{pH}$ og aggressiv kulsyre omtales derfor under et.

I kalkholdige reservoirbjergarter har grundvandet typisk en pH-værdi mellem 7 og 8 , og det indeholder ikke aggressiv kulsyre. I Vestjylland er kalkudvaskningen fra de kvartære sandaflejringer ofte så fremskreden, at al opløselig kalk er udvasket. Som følge heraf indeholder grundvandet aggressiv kulsyre og har en pH-værdi mellem 5 og 7 .

Et kort over forekomster af oppumpet grundvand med et teknisk behandlingskrævende indhold af aggressiv kulsyre er vist på figur 22.

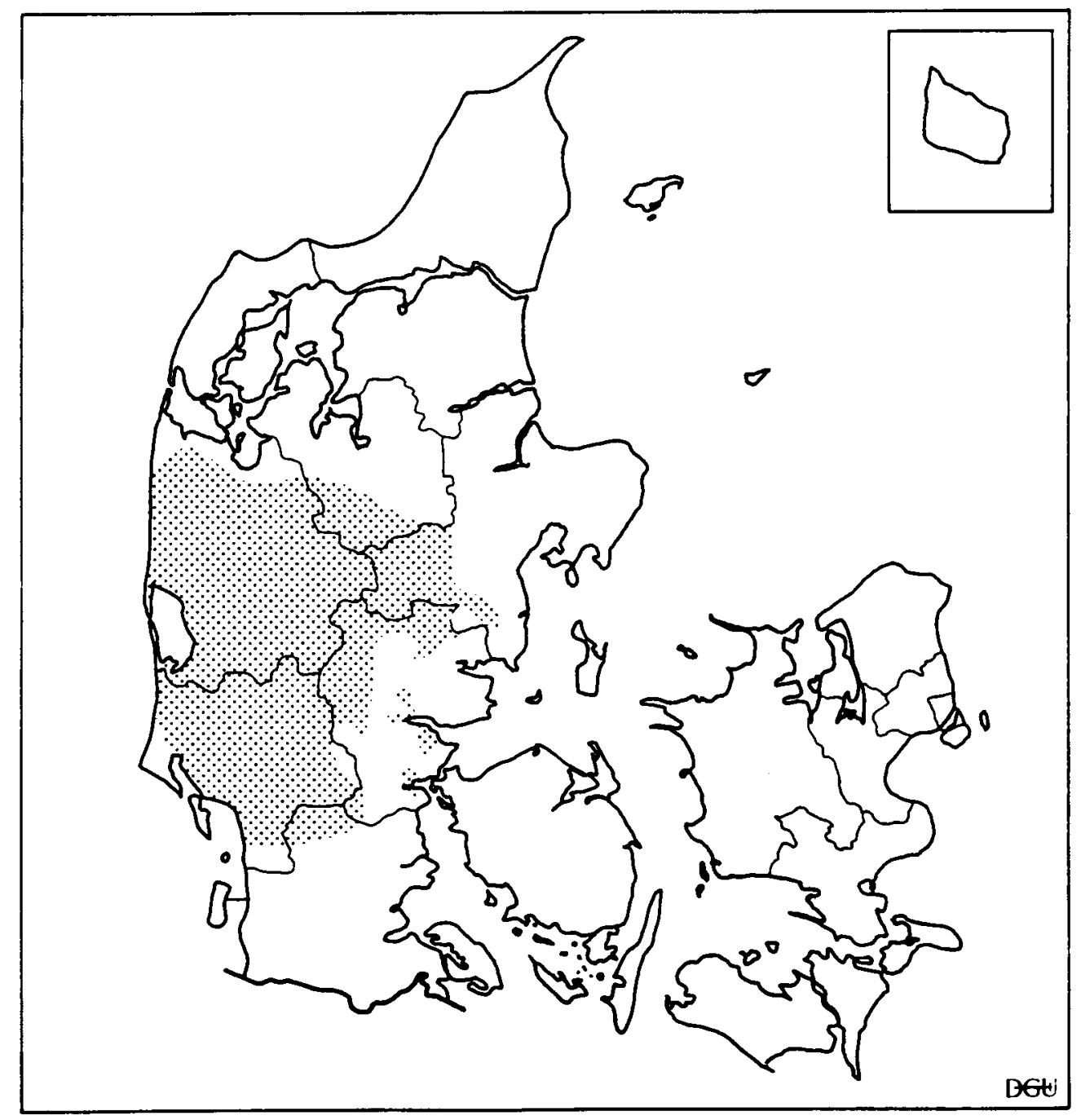

Figur 22: $\quad$ Problemområder for pH og aggressiv kulsyre, hvor indholdet af aggressiv kulsyre nødvendiggør teknisk behandling af råvandet. Sammenstillet efter oplysninger fra amteme. 
Ribe amt:

Generelt forekommer der grundvand, der indeholder aggressiv kulsyre og har lavt $\mathrm{pH}$ i de øvre reservoirer med frit grundvandsspejl. I de dybe miocæne og kvartære reservoirer kan $\mathrm{pH}$ til gengæld være forholdsvis højt.

Vejle amt:

Grundvand med aggressiv kulsyre findes i den vestlige og nordvestlige del af amtet samt $i$ mindre områder langs Lillebælt.

Århus amt:

Grundvand, hvis pH forhold udgør et problem, findes i den vestlige del af amtet, hvor grundvandet også indeholder aggressiv kulsyre.

Ringkøbing amt:

Grundvandet $\mathrm{i}$ de øvre reservoirer med frit vandspejl fordrer vandbehandling (grundet aggressiv kulsyre og lavt $\mathrm{pH}$ ) for at kunne udnyttes.

Viborg amt:

Der forekommmer surt terrænnært grundvand overalt i amtet, men kun i hedesletterne $\mathrm{i}$ den sydvestlige del af amtet udgør dette et sammenhængende problemområde. 


\section{Magnesium}

Grundvandets magnesiumindhold kan stamme fra jordlagenes indhold af magnesiumkarbonat som opløses af kulsyreholdigt infiltrationsvand og grundvand. Desuden kan magnesium i grundvandet stamme fra forvitring af silikater, udvaskning af marine sedimenter eller opblanding med havvand og salt mineralvand.

Grundvand med et magnesiumindhold mellem den vejledende og højst tilladelige værdi for drikkevand forekommer hyppigt øst for Storebalt, hvor indvindingen foregår fra kalkstensreservoirer.

Desuden er et øget magnesiumindhold et følgeproblem til klorid i forbindelse med indvinding i kystnære områder.

\section{Total fosfor}

Tilstedeværelsen af fosfor $i$ grundvandet kan skyldes frigivelse af fosfor fra organisk materiale eller metaloxider, for eksempel fra marine aflejringer. Et stærkt forhøjet fosforindhold skyldes oftest forurening med spildevand eller perkolat fra lossepladser. I forbindelse med beluftning af råvand vil fosfor helt eller delvis blive udfældet.

I Storstrøms amt findes et mindre areal ved Holeby, hvor grundvandets fosforindhold udgør et problem. I det sydlige Jylland har grundvandet stedvis et naturligt forhøjet fosforindhold. Dette er tilfældet på Als (marine aflejringer fra Eem), på Rømø (marine postglaciale aflejringer) og i de dybtliggende tertiære- (Ribe formationen) og kvartære grundvandsreservoirer $\mathrm{i}$ den vestlige del af området. I Ringkøbing amt er grundvandets fosforindhold forhøjet $\mathrm{i}$ et areal ved Struer. Drikkevandets fosforindhold er mellem den vejledende og højst tilladelige værdi, eller over den højst tilladelige værdi, på Mors og i Vendsyssel (DGU Status, 1990), hvor fosforindholdet skyldes frigivelse fra marine sedimenter. Disse områder er dog ikke af Nordjyllands og Viborg amter betegnet som "problemområder."

$\underline{\text { Jern }}$

Det er almindeligt, at der er jern i det oppumpede grundvand. Jernet kan i de fleste tilfælde fjernes ved filtrering og kan betragtes som et teknisk/økonomisk problem.

På Bornholm ved Robbedale og Nyker (Nykerblokken) er der forhøjet jernindhold i det oppumpede grundvand som følge af grusgravning i kombination med en for stor vandindvinding, der har medført iltning af svovlkis. I store dele af de vestjyske hedesletter og på de sandede bakkeøer har grundvandet både i den nedre del af de øvre grundvandsreservoirer og i de dybereliggende reservoirer et relativt højt jernindhold. I Nordjylland er der jernproblemer, hvor der er sket oppumpning fra postglaciale reservoirer i Skagen og på Lasø. 
$\underline{\text { Nitrit }}$

Nitrit i drikkevandet kan stamme fra nitrifikation af ammonium eller reduktion af nitrat. Nitrit omsættes under iltrige forhold til nitrat, der derefter under iltfattige forhold kan denitrificeres til frit kvælstof. Nitrit kan forekomme naturligt i grundvand og desuden i drikkevand, der er utilstrakkeligt behandlet. Nitrit kan fjernes fra det oppumpede grundvand, og udgør kun et teknisk problem.

\section{$\underline{\text { Kalium }}$}

Grænseværdien for drikkevand på 10 milligram pr. liter for kalium er ikke fastsat af sundhedsmæssige eller smagsmæssige grunde, men fordi kalium kan være en forureningsindikator for spildevand. På Lolland er grundvandets naturlige kaliumindhold lokalt højt. I Fyns amt, mellem Odense og Kerteminde, har grundvandet et højt kaliumindhold på grund af ionbytning og overfladebelastning.

Drikkevandsdata fra 1986-90 tyder på, at kaliumindholdet i grundvandet er forhøjet ved mange vandværker (DGU Status, 1990).

\section{Nikkel}

I Roskilde og Københavns amter er der konstateret et relativt højt nikkelindhold i grundvandet flere steder især langs $\mathrm{K} ø g e$ Bugt.

Det er muligt, at dette kan skyldes forvitring af nikkelholdig svovlkis eller er frigivet fra organiske aflejringer. Storstrøms amt mener, at nikkel kan blive et problem i fremtiden, men grundvandets nikkelindhold er her ikke tilstrækkeligt undersøgt. Fremtidige undersøgelser vil blive centreret om Stevnsområdet. 
Andre stoffer

Organiske opløsningsmidler, oliederivater og sporstoffer:

Disse stoffer er ofte fundet $i$ grundvandet $i$ forbindelse med forurening fra punktkilder såsom affaldsdepoter, $\mathrm{i}$ industrigrunde og benzintanke/anlæg. Derfor findes der rundt omkring $\mathrm{i}$ landet mange meget små områder, hvor disse stoffer begrænser muligheden for vandindvinding. I områder med stor befolkningskoncentration vil lokalt forurenede reservoirer kunne ligge så tæt, at hele byområder udgør problemområder. Dette gælder således med hensyn til klorerede opløsningsmidler i hele Københavns amt, figur 23.

I Københavns og Frederiksberg kommune er der trichlorethylen i dele af grundvandsreservoirerne.

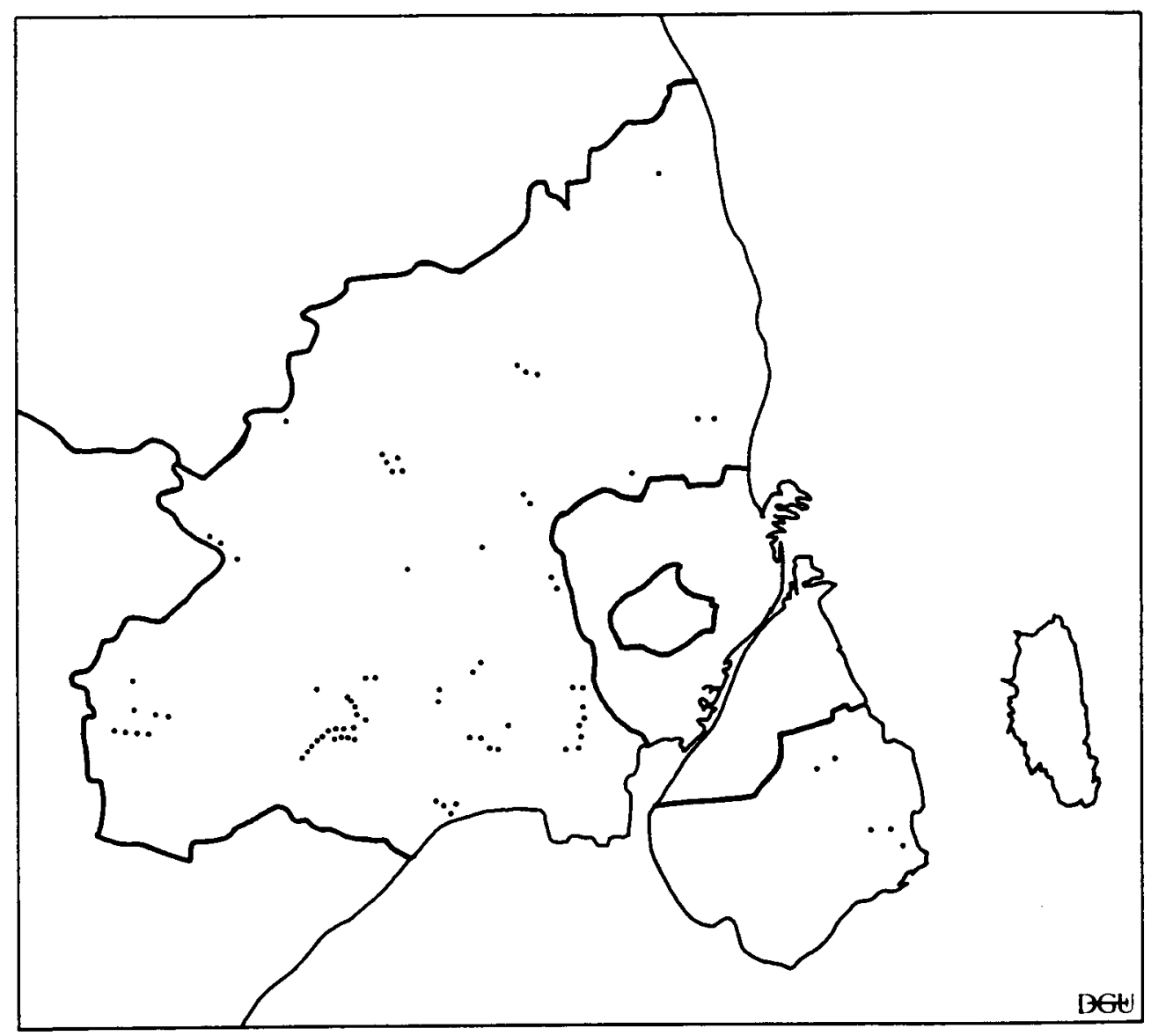

Figur 23: Fonurening fra punktkilder $i$ Københaws amt. 


\section{KVANTITETSPROBLEMER}

Hovedparten af drikkevandet i Danmark hentes fra grundvandsreservoirerne. Det er derfor relevant at sammenholde mængden af nedbør, fordampning og afstrømning med den oppumpede mængde vand inden for de enkelte landsdele. Herved fås et generelt billede af, hvor kraftigt grundvandet udnyttes, og hvor stor restressourcen er. På dette grundlag fremgår det at restressourcen generelt er størst i Jylland, dog således at områderne Esbjerg, Ålborg, Århus, Horsens, Vejle, Kolding og Als-området har begrænsede ressourcer. På øerne er restressourcen begrænset med undtagelse af mindre områder på Fyn og Lolland-Falster. Restressourcen kan derudover være begrænset af de tidligere nævnte kvalitetskrav til drikkevandet eller fordi det betragtes som en nødreserve.

Områder, hvor amterne vurderer, at der er ressource-problemer, er vist på figur 24.

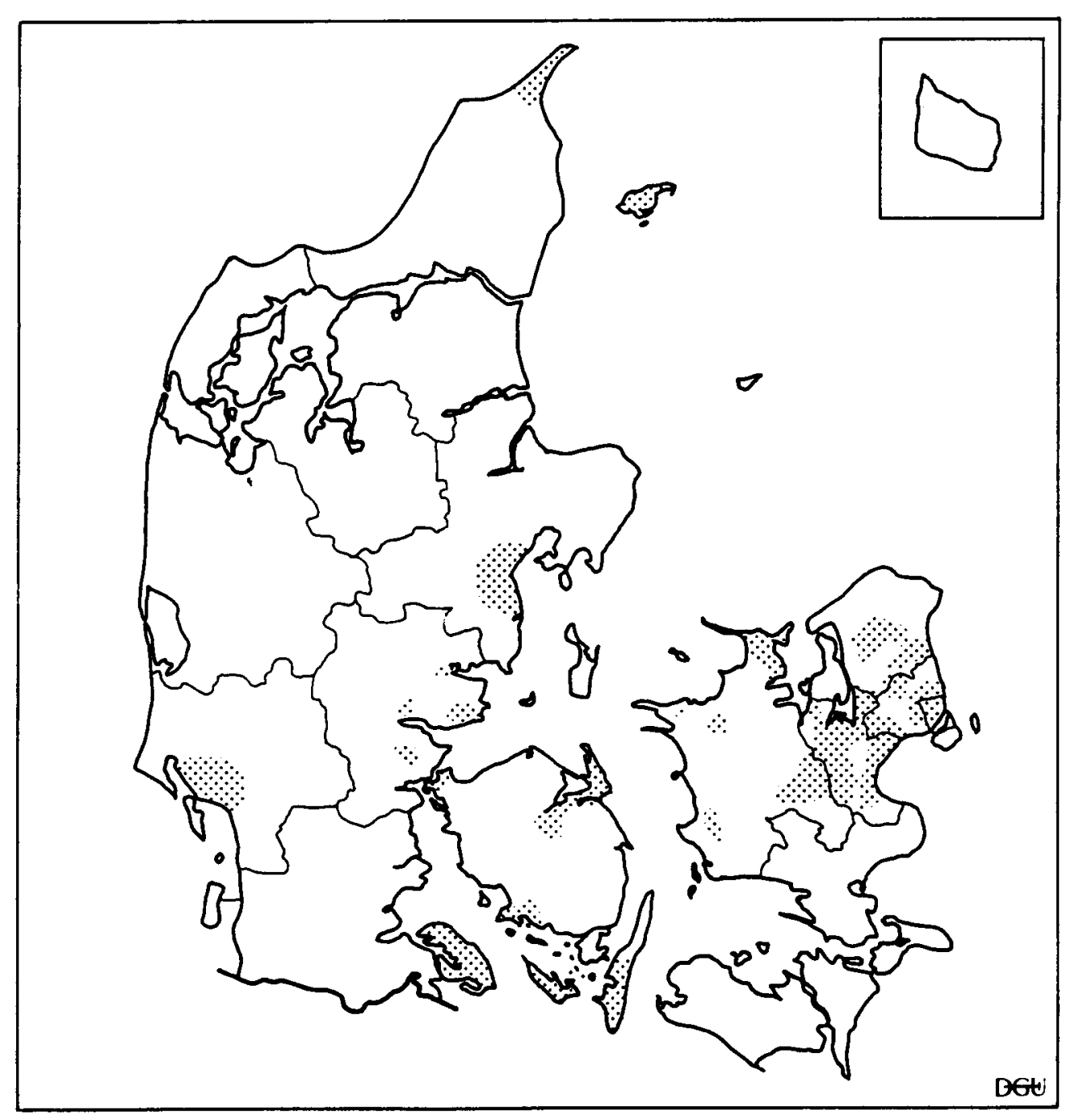

Figur 24: Problemområder hvor stor grundvandssankning udgør en potentiel eller aktuel begransning for drikkevandsforsyningen. Sammenstillet efter oplysninger fra amterne samt efter Hovedstadsrådet (1982). 
Københavns og Frederiksborg amter, Frederiksberg og Københavns kommuner:

Amterne og kommunerne har ikke angivet områder, hvor grundvandsressourcen er problematisk. Derfor er der $\mathrm{i}$ denne fremstilling anvendt et kort over grundvandssæenkninger i hovedstadsområdet 1900-1990 (Hovedstadsrådet, 1982), hvor $2.5 \mathrm{~m}$ sænkningskurven er benyttet til afgrænsning af problemområder.

I Frederiksberg kommune er der ubenyttede boringer, der vil kunne bidrage med en indvinding på ca. en million kubikmeter pr. år.

Bornholms amt:

Ifølge amtet er der ingen kvantitetsproblemer.

Roskilde amt:

Grundvandsressourcen overudnyttes flere steder i amtet, især syd for Roskilde, og det er på nuværernde tidspunkt vanskeligt at udpege nye lokaliteter til vandindvinding.

Vestsjællands amt:

Grundvandsressourcen overudnyttes $\mathrm{i}$ Odsherred og på Ringstedegnen samt $\mathrm{i}$ tre mindre områder $\mathrm{i}$ den vestlige del af amtet.

\section{Storstrøms amt:}

Amtet mener ikke, at der er overforbrug af grundvandsressourcen.

Fyns amt:

Der er ressourceproblemer i regioner med ringe grundvandsdannelse og små reservoirer. Desuden er der lokalt mangel på vand ved Odense og Middelfart.

Sønderjyllands amt:

Kun i Als-området er der ressourceproblemer, idet oppumpningen her svarer til grundvandsdannelsen.

Ribe amt:

Kun omkring Esbjerg og på Fanø er der ressourceproblemer, idet grundvandsressourcen er maksimalt udnyttet.

Vejle amt:

Ressourcemæssige grundvandsproblemer er begrænset til små dybereliggende og stærkt udnyttede reservoirer.

Århus amt:

Der er ressourceknaphed på grundvand omkring Århus, hvor den store oppumpning yderligere resulterer i forringet vandkvalitet. Desuden kan recipientkvalitetskravene ikke overholdes i disse områder. 
Ringkøbing, Viborg og Nordjyllands amter:

Ingen kvantitetsproblemer, når undtages Skagen og Læasø.

\section{TILTAG FOR AT BEVARE GRUNDVANDSRESSOURCEN}

Amterne arbejder med forskellige projekter for at afværge nogle af de grundvandsproblemer, som truer den fremtidige vandforsyning. I amternes vandindvindingsplaner udpeges områder med særlig betydning for drikkevandsproduktionen. Sådanne områder kan være kildepladser, hvor for eksempel den nuværende arealanvendelse som hovedregel ikke må ændres til en der øger truslen mod grundvandet, og aktiviteter, der ikke truer grundvandet, skal fremmes. Inden for disse kildepladsområder forsøges grundvandsressourcen beskyttet ved for eksempel en ændret dyrkning og markstyring (Drastrup projektet; Nordjyllands amtskommune. Tunø projektet; Århus amtskommune) eller ved braklægning og evt. skovrejsning. Tilsvarende hensyn skal tages ved placering af forurenende virksomheder.

Frederiksberg kommune anfører, at forsyningsproblematikken for de helt små vandforsyninger, hvis manglende behandligskapacitet udgør et problem kunne tænkes løst ved samarbejde mellem flere små vandforsyninger. Dette kunne være en kommunal, eller måske også en amtslig opgave.

Afværgepumpninger kan for eksempel benyttes til restaurering af vådområder og processvand, og en ændret indvindingsstrategi vil på længere sigt kunne øge grundvandsressourcen.

Den decentrale indvindingsstruktur bør opretholdes, idet selv mindre uforurenede grundvandsressourcer herved kan udnyttes fordelagtigt.

En anden løsning af kvalitetsproblemer er at nedlægge de små vandværker, hvor problemerne ofte er størst, og centrere vandforsyningen på store enheder, hvor det er økonomisk mere overkommeligt at behandle vandet teknisk. En kortlægning af vandressourcen med for eksempel lokalisering af nitratfronter og saltvandsgrænser kan i kombination med en tilpasset pumpestrategi reducere mængden af uønskede stoffer i drikkevandet og sikre en beddre udnyttelse af grundvandsressourcen.

Med dette formål har for eksempel Nordjyllands amt iværksat handlingsplaner for nitrattruede vandværker med henblik på at bevare en decentral vandforsyningsstruktur. Denne handlingsplan ligger på indiciduelt tilpassede løsninger.

For at reducere en overudnyttelse af grundvandsressourcen bør der igangsættes sparekampagner, samtidig med at tabet i ledningsnettet må søges begrænset. 


\section{GRUNDVAND I LANDOVERVÅGNINGSOPLANDENE}

Hovedformålet med de seks Landovervågningsoplande er at undersøge næringsstofudvaskningen på almindelige landbrugsarealer, DMU (1991). Som en del af denne overvågning undersøges det også, hvor stor en del af næringsstofudvaskningen, der føres med det infiltrerende vand ud af rodzonen til de mest terrænnære grundvandsforekomster. Tre af landovervågningsoplandene ligger $i$ umiddelbar tilknytning til grundvandsovervågningsområder, tabel 20. Den geografiske placering kan findes på figur 1.

\begin{tabular}{||c|c|l|l|l|l||}
\hline \multicolumn{2}{|c|}{ LANDOVERVAGNINGSOPLANDE } & \multicolumn{2}{c|}{ GRUNDVANDSOVERVÅGNINGSOMRÅDER } \\
\hline NAVN & NUMMER & JORDTYPER & NAVN & NUMMER & RESERVOIRTYPER \\
\hline Højvads Rende & 1 & lerjord & Vesterborg & 35.11 & $\begin{array}{l}\text { smeltevandssand/grus } \\
\text { og skrivekridt, artesisk }\end{array}$ \\
\hline Bolbro Bak & 6 & sandjord & Bedsted & 50.11 & smeitevandssand, frit \\
\hline Odderbak & 2 & sandjord & Gislum & 80.14 & $\begin{array}{l}\text { smeltevandssand, frit og } \\
\text { artesisk }\end{array}$ \\
\hline
\end{tabular}

Tabel 20: Geografisk sammenfaldende landovervågningsoplande og grundvandsovervågningsområder.

I dette afsnit sammenstilles data om grundvandets indhold af nitrat, klorid og sulfat fra de geografisk sammenfaldende landovervågningsoplande og grundvandsovervågningsområder Højvads Rende/Vesterborg og Odderbæk/Gislum (data fra Bolbro Bæk/Bedsted er ikke tilgængelige).

Der er installeret ca. 60 filtre til udtagning af grundvandsprøver $i$ hvert landovervågningsopland. Filtrene er alle placeret i faste dybder på 1,5,3 og 5 meter under terræn. Grundvandsspejlets beliggenhed varierer inden for landovervågningsoplandene mellem 2 og 3 meter under terræn. Beliggenheden så tæut under terræn medfører at klimatiske variationer, nedsivningsforhold og landbrugsdriften giver anledning til betydelige fluktuationer i grundvandskvaliteten fra mark til mark og i løbet af året. Med stigende dybde udjærnes årsvariationerne dog, DMU (1991).

Nitratindholdet $\mathrm{i}$ det grundvand, der er udtaget 1,5 meter under terræn, varierer fra næsten 0 til 300 milligram pr. liter i løbet af et år. Gennemsnitligt er der 46 milligram nitrat pr. liter grundvand i dette øverste grundvand i Højvads Rende, mens der i Odderbæk er 120 milligram. Dette viser, at det øverste grundvand er påvirket af landbrugsdrift, DMU (1991).

Denne forskel på de to områder kan også følges $i$ analyser af grundvand fra de dybere filtre, både de der hører til landovervågningen og grundvandsovervågningen, figur 25. Nitratkoncentrationerne er således generelt højere i de enkelte filterniveauer i Odderbæk/Gislum end i Højvads Rende/Vesterborg. 
Af figur 25 fremgår, at nitratindholdet $\mathrm{i}$ grundvandet falder jæunt med dybden. Sammenstillingen af de to datasæt illustrerer således, hvordan det høje nitratindhold i det infiltrerende vand gradvis, efterhånden som det trænger ned, omdannes ved reaktion med blandt andet jordlagenes svovlkis.

Hojvads Rende/Vesterborg

Dybode, $m$ ut

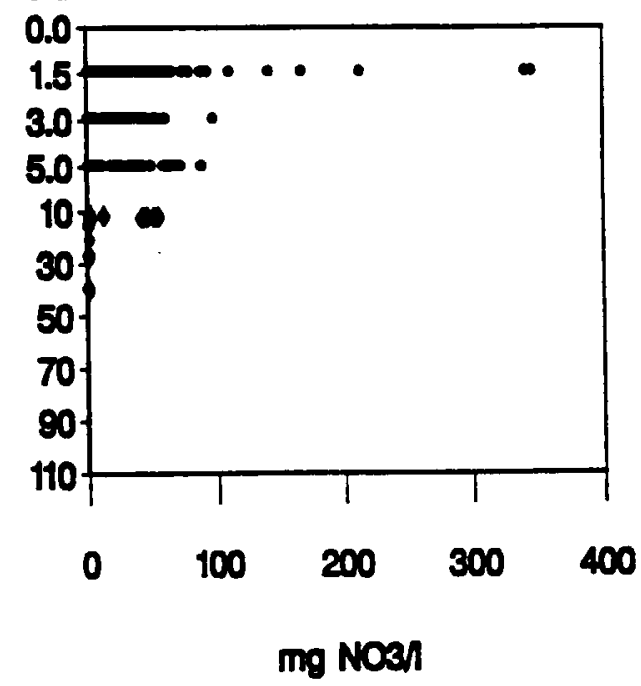

- Anatyser fra landovervigningsoplande
Odderbxt/Gislum

Dybde, in u.t.

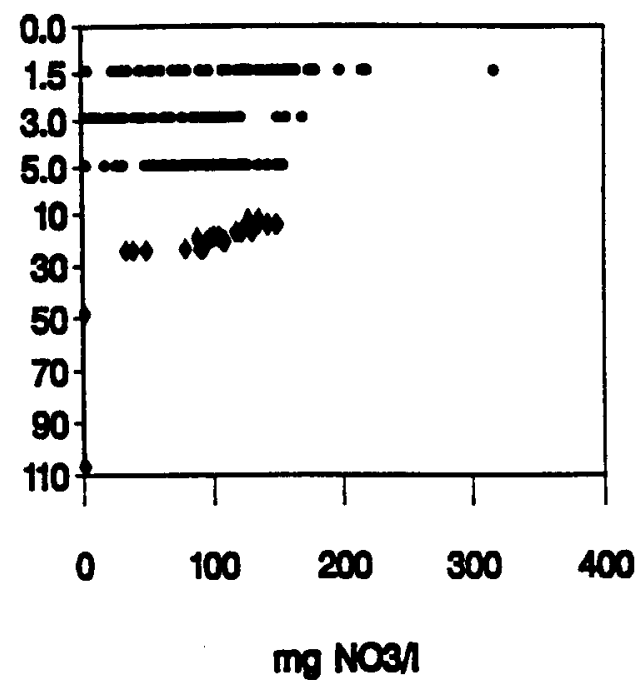

- Anayser fra grundvandsovervigningsområder

Figur 25: To eksempler på nitratkoncentrationeme i grundvand i sammenhrengende landovervågningsoplande og grundvandsovervågningsområder. Data stammer fra 1990. Bemaerk skiftet i dybdeskala ved 5 meter under terroen.

I Højvads Rende/Vesterborg er der nitrat i grundvandet ned til ca. 15 meter under terræn, mens det i Odderbæk/Gislum findes ned til ca. 25 meter under terræn.

Den forholdsvis høje nitratkoncentration, der er målt i grundvandet i 10-20 meters dybde under et lag moræneler i Højvads Rende/Vesterborg, skyldes sandsynligvis, at flere af filtrene i dette dybdeinterval er placeret i et reservoir (smeltevandssand), som opstrøms kun er dækket af nogle få meter moræneler, se side 68. I det dybere grundvand $\mathrm{i}$ det artesiske reservoir er der intet nitrat.

I Odderbæk/Gislum er det øvre grundvandsreservoir smeltevandssand og -grus med frit grundvandsspejl, dårligt beskyttet mod nedsivende nitrat, se side 160 . Dette afspejler sig i det gradvise fald i nitratindholdet ned til 25 meter under terræn.

Den forholdsvis stærkt og veldefineret stigende nitratkoncentration opad i grundvandsovervågningsområdets filtre (Gislum) synes at ændres til en omtrentlig konstant værdi ved overgangen til de terrænnære filtre i 
landovervågningsoplandet (Odderbæk). Reduktionspotentialet i reservoiret synes derfor at være opbrugt ned til ca. 25 meter under terræn.

Hojvads Rende/Vesterborg

Dytode, in ut

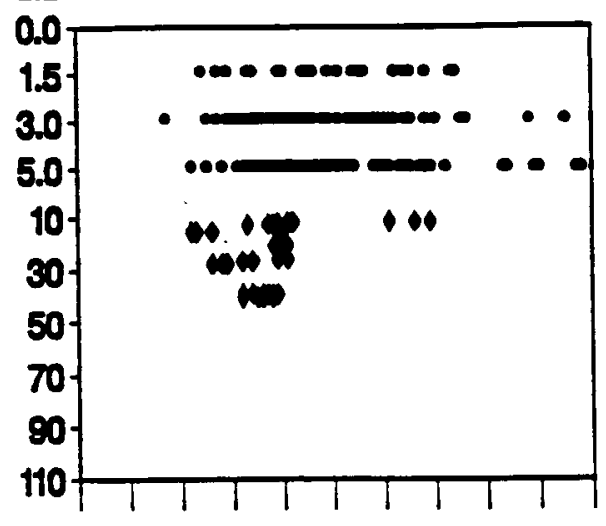

0102030405060708080100

$\mathrm{mg}$ an

- Analyser fra landovervigningsoplande
Odderbxk/Gislum

Dybde, $m$ ut

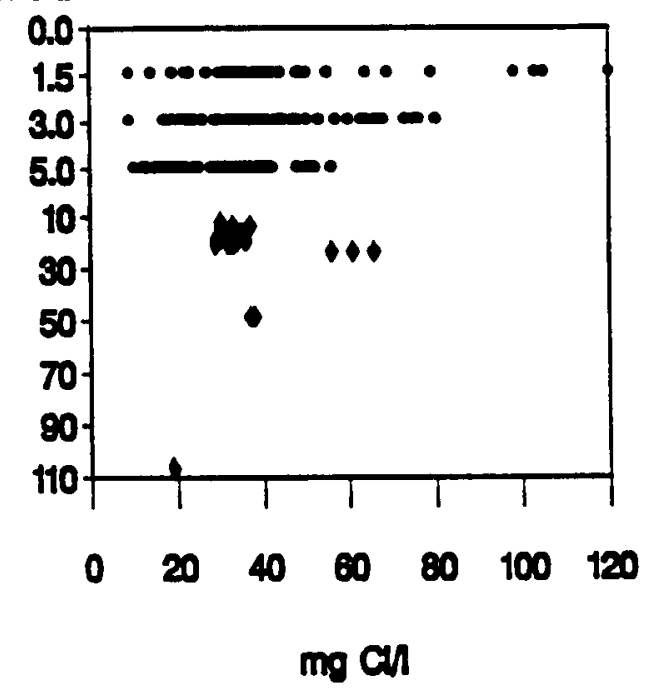

- Analyser fra grundvandsovervågningsiområder

Figur 26: To eksempler på kloridkoncentrationeme i grundvand $i$ sammenhoengende landovervågningsoplande og grundvandsovervågningsområder. Data stammer fra 1990. Bemaerk skiftet i dybdeskala ved 5 meter under terraen.

Kloridindholdets variation fra det allerøverste grundvand i de to landovervågningsområder til det dybeste $\mathrm{i}$ grundvandsovervågningsområderne er vist i figur 26. Spredningen i kloridkoncentration aftager med dybden.

I Højvads Rende/Vesterborg er der mindst ca. 20 milligram klorid i alt det øverste grundvand. Denne koncentration afspejler antagelig kloridindholdet $\mathrm{i}$ nedbøren, efter at det er opkoncentreret på grund af fordampningen fra jordoverfladen og vegetationen. De højere kloridkoncentrationer i det øverste grundvand i dette område skyldes antagelig fladepåvirkning. Den svage tendens til stigende kloridindhold i grundvandet i det artesiske kalkreservoir (under ca. 25 meters dybde), hvor kloridindholdet er lavt, kan skyldes, at der sker en svag tilstrømning af saltholdigt formationsvand nedenfra.

I Odderbæk/Gislum er det laveste kloridindhold ned til 5 meter under terræn kun lidt højere end nedbørens kloridindhold. Dette afspejler antagelig at nedbøren er større end ved Højvads Rende, hvorfor kloridindholdet ikke opkoncentreres så meget ved fordampning. Fordampningen er nemlig størst ved Højvads Rende. De mange målinger af højere kloridkoncentrationer i det øverste grundvand skyldes, ligesom i Højvads Rende, antagelig fladepåvirkning. 
I grundvandet i 15-20 meters dybde i Odderbæk/Guslum synes kloridindholdet at antage en middelværdi i forhold til det mere terrænnære grundvand. Dette kan skyldes at grundvandet i denne dybde strømmer horisontalt og forskelle i sammensætningen derfor udjævnes. De få spredte data fra større dybde kan ikke umiddelbart fortolkes.

Sulfat $\mathrm{i}$ lav koncentration er en naturlig bestanddel af grundvandet. Et større indhold på over ca. 100 milligram pr. liter kan skyldes, at der sker en kraftig reaktion mellem svovlkis $i$ jordlagene og opløste iltningsmidler som ilt og nitrat. Dette kan for eksempel skyldes, at grundvandsstanden er blevet sænket.

Højvads Rende/Vesterborg

Dyode, m ut

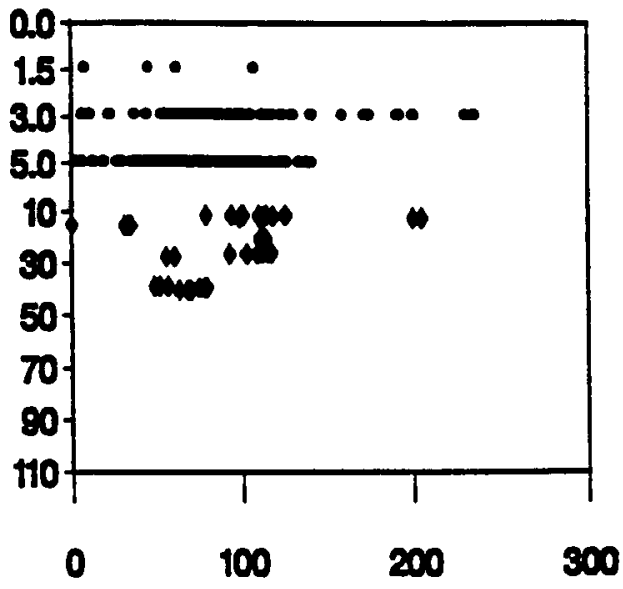

$\operatorname{mos} \operatorname{son}$
Odderbrk/Gishum

Dybode, $m$ ut

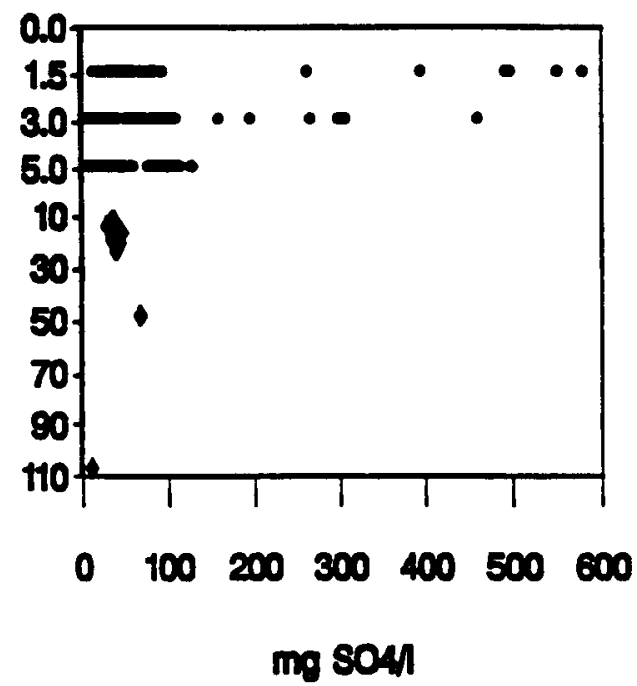

- Analyser fra landovervigningsoplande

- Analycer fra grundvandsovervigningsområder

Figur 27: To eksemplerpå sulfatkoncentrationeme ignundvand i sammenhaengende landovervagningsoplande og grundvandsovervågningsområder. Data stammer fra 1990. Bemark skiftet $i$ dybdeskala ved 5 meter under terran.

I Højvads Rende/Vesterborg, figur 27, er det gennemsnitlige sulfatindhold i de øverste filtre ret konstant eller svagt faldende med dybden, mens indholdet fra 10 meter under terræn synes at falde efter helt sin egen kurve. Dette afspejler antagelig, at grundvandet under denne dybde strømmer sideværts og er infiltreret uden for det overvågede område.

I Odderbæk/Gislum har det øverste grundvand i gennemsnit et næsten komstant sulfatindhold. Under 10 meter under terræn synes grundvandet at have det samme gennemsnitlige sulfatindhold, men med langt mindre spredning. Dette kan skyldes at grundvandet under 10 meters dybde er infiltreret direkte, men at en vis grundvandsopblanding udjævner koncentrationsforskellen. 
Koncentrationen af de tre her omtalte stoffer er, både i Højvads Rende/Vesterborg og Odderbæk/Gislum, en del højere $i$ det aller øverste grundvand, der registreres $\mathrm{i}$ forbindelse med landovervågningen, end $\mathrm{i}$ det der analyseres i grundvandsovervågningen. Trods den udjævnende effekt af strømning i det dybere grundvand synes dataene fra grundvandsdelen af landovervågningen at kunne bidrage væsentligt til billedet af stoffordelingen med dybden i grundvandet, og dermed til forståelsen af både stoftransporten og stofomsætningen. 


\section{SAMMENFATNING OG DISKUSSION}

Med denne rapport om grundvandsovervågningsområder og større områder, hvor der findes erkendte problemer med grundvandet, er det tilstrabt at skabe et grundlag for forståelsen af fremtidige lokale eller detaljerede tematiske undersøgelser. Sammen med den tilsvarende rapport fra sidste år (DGU Status, 1990) og de mange offentliggjorte indlæg og oversigter om emnet (blandt andre Vandmiljø-90, 1990, Miljøtilstanden, 1991, Miljøstyrelsen 1991, og Kristiansen og Stockmarr, 1991) er der tegnet et landsdækkende billede af nogle af de væsentligste parametre for vurderingen af grundvandet, og af de til dato udbyggede overvågningssystemer, som nu i altovervejende fungerer efter hensigten, samt de største datasamlinger om emnet. Rapporten er baseret på de oplysninger, der er indberettet af amterne. Der er foretaget mange lokale undersøgelser, der går videre end vi her har kunnet præsentere det. Som eksempler på dette kan nævnes lossepladsundersøgelserne i Skrydstrup (Strøbæk, 1989) og kortlægningen af problemet med organiske opløsningsmidler i grundvandet under det centrale København og Frederiksberg (Rambøll \& Hannemann, 1991). I en del tilfælde har praktiske vanskeligheder ved indberetningsformen foreløbigt hindret, at data har kunnet indlægges $i$ databasen. Dette gælder specialanalyserne fra halvdelen af amterne og alle data fra et enkelt amt.

\section{Overvågningsområderne}

Af den systematiske beskrivelse af overvågningsområderne (afsnit 2) fremgår, at der de fleste steder findes såvel lokale sekundære grundvandsreservoirer tæt under jordoverfladen som dybereliggende mere sammenhængende hovedreservoirer, hvorfra den største oppumpning af grundvand foregår. Hovedresevoirerne kan inddeles i fire hovedtyper efter fysiske forhold:

- Opsprækkede reservoirer med artesiske forhold (12 områder $=18 \%)$

- Sandreservoirer med artesiske forhold (33 områder $=49 \%$ )

- Opsprækkede reservoirer med frit grundvandsspejl (11 områder $=16 \%)$

- Sandreservoirer med frit grundvandsspejl (11 områder $=16 \%)$

Denne grove opdeling vil blive benyttet $i$ det følgende sammendrag til trods for, at der både findes overgangsformer mellem typerne, og at hydrokemien er betinget af blandt andet lagene over hovedresevoiret.

Grundvandet indeholder således naturligt en lang række opløste stoffer, der stammer enten fra nedbøren eller de geologiske lag vandet har bevæget sig igennem. Koncentrationen af nogle af disse stoffer kan stige som følge af udnyttelsen af grundvandet. I figur 28 er vist, hvilke af kvartærtidens jordarter der er dominerende ved terræn, og selv om den geografiske fordeling af jordarterne varierer meget ned gennem lagserien, giver kortet et godt fingerpeg om de sandsynlige påvirkninger af grundvandet inden for de geografiske regioner, blandt andet fordi hovedreservoiret i 48 af de 67 grundvandsovervågningsområder findes i kvartære lag. 


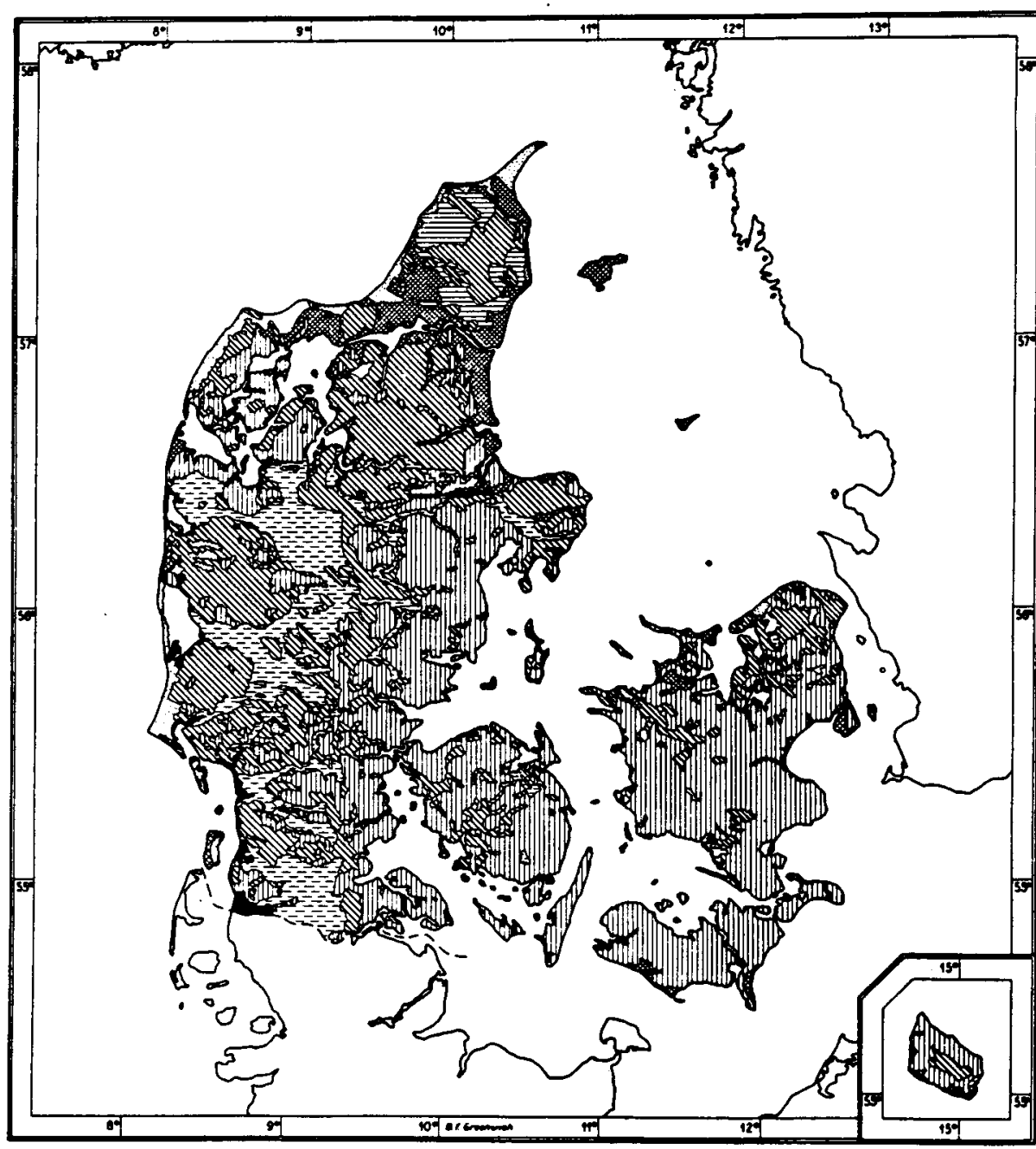

\section{GEOLOGISK KORT OVER DANMARK. JORDBUNDSKORT.}

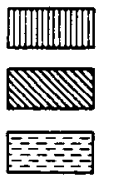

Qvervejende
moraneler

Overvejeno imelnevandssand og moranesand Smeitrevondssletter

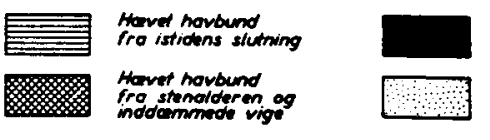

Marak -floddale, over.

Figur 28: Jordbundskort over Danmark. (Sorgenfrei og Berthelsen, 1970).

Reservoirer med frit grundvandsspejl er forholdsvis sårbare overfor fladepåvirkning, og de øverste dele af grundvandet er $\mathrm{i}$ disse reservoirer er $\mathrm{i}$ reglen iltet. De artesiske reservoirer er bedre beskyttede og grundvandet er ofte iltfattigt. Denne fysiske beskytteise kan også have en kemisk side da der især i de lerede lag også sker en nedbrydning og binding af nogle forurenende stoffer. I 19 af de 67 overvågningsområder findes hovedreservoiret $i$ lag fra før istiderne. Alderen og jordartstyperne fremgår af figur 29. I den følgende opsummering er det de høje stofkoncentrationer inden for måleværdiernes spredning, der er lagt vægt på. 


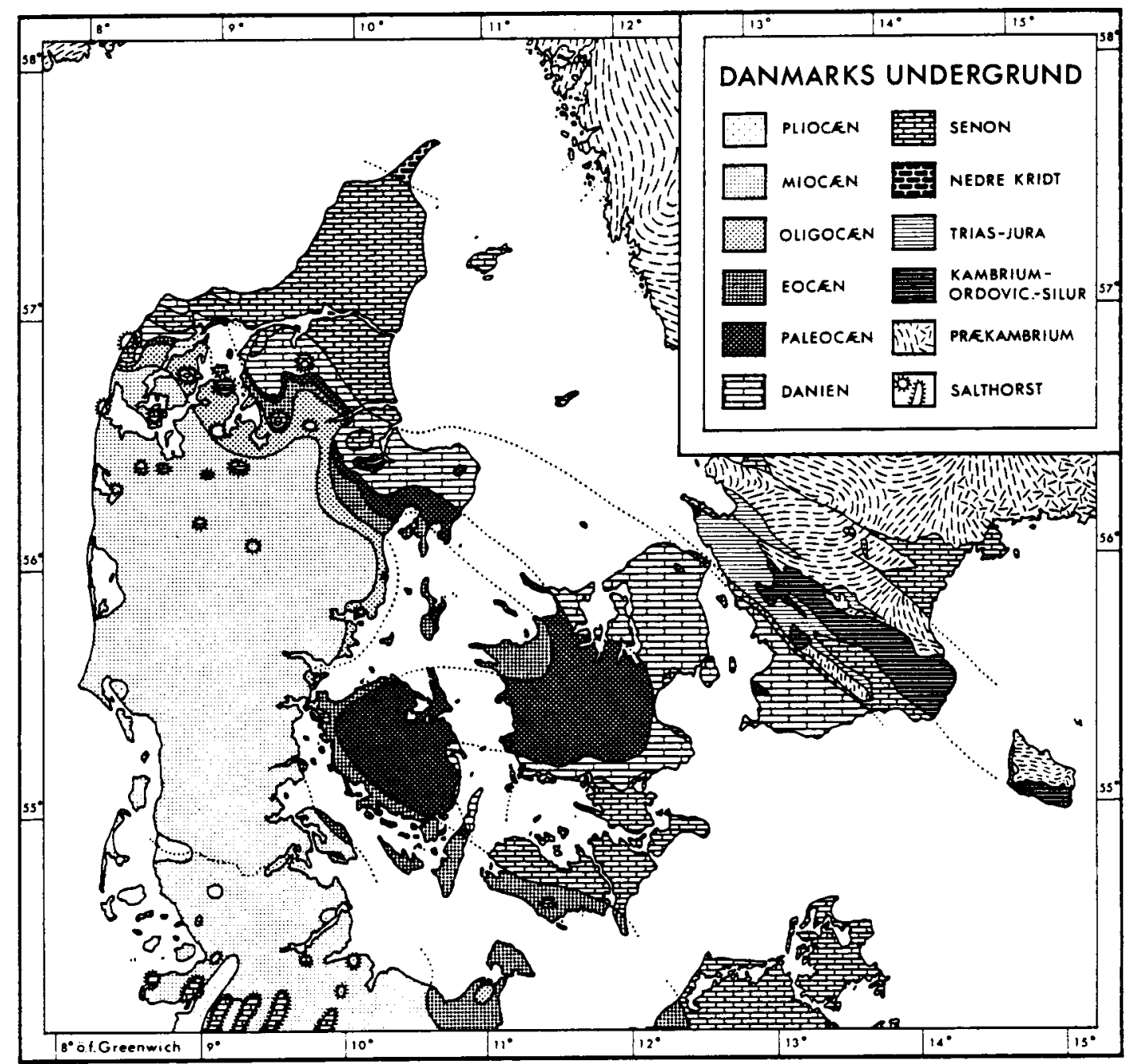

Figur 29: Danmarks undergnund (Wienberg Rasmussen, 1966).

\section{Opsprakkede hovedreservoirer med artesiske forhold}

Disse reservoirer består oftest af kalksten. Det dybe grundvand i hovedreservoiret er nitratfrit, mens grundvandet i de overliggende sekundære reservoirer, undtagen i Nyborg, indeholder nitrat (Lokalitetsnavne fremgår af figur 1). I fire af disse områder indeholder grundvandet i de sekundære reservoirer mere end 50 milligram nitrat pr. liter (det højest tilladte nitratindhold i drikkevand). Til trods for at disse hovedreservoirer er artesiske og nitratindholdet derfor kunne forventes at falde brat med dybden ligesom $\mathrm{i}$ artesiske sandreservoirer, er der en del eksempler på at det aftager javnt med dybden.

I Frederiksbergområdet stiger både klorid- og sulfatkoncentrationerne med dybden til meget høje værdier, hvilket antagelig skyldes, at der trakkes saltvand ind. En tilsvarende tendens for sulfatindholdet findes $i$ Homå. I de øvrige områder falder sulfatindholdet gradvist med dybden, og noget tilsvarende galder i reglen for kloridindholdet. Også de dele af reservoirerne, hvor forholdene er reducerende er således påvirkede. Dog er der i Nyborg og Hjelmsølille svagt stigende kloridkoncentration med dybden, hvilket antagelig skyldes indtrængende havvand og dybereliggende grundvand. I Frederiksberg overskrider klorid- og sulfatindholdet 
i hovedreservoirets grundvand de henholdsvis 300 og 250 milligram pr. liter, der højest må være i drikkevand, og noget tilsvarende gør sig i mindre grad gældende i det sekundære reservoir i Osted.

Den store variation i de hydrokemiske forhold i disse hovedreservoirer er et tegn på, at de opsprækkede kalkreservoirer er sårbare overfor påvirkninger nedenfra og sideværts indtrængning af saltvand, og at de kan påvirkes af forurening ovenfra gennem lækage i dæklagene.

\section{Sandreservoirer med artesiske forhold}

Disse hovedreservoirer består af kvartære og tertiære sandede sedimenter og overlejres af kvartære lag. Der er $\mathrm{i}$ disse overvågningsområder markant forskel på det tydeligt forhøjede nitratindhold $\mathrm{i}$ de øverste sekundære reservoirer og det oftest nitratfrie grundvand i hovedreservoiret. Både klorid- og sulfatindholdet i grundvandet falder i disse områder med dybden. Kun i få af de områder, hvor hovedreservoiret ligger lige over et opsprækket reservoir (Sibirien), og hvor der er indtrængen af salt mineralvand (Mjang Dam og Eggeslevmagle), er der konstateret relativt højt kloridindhold i hovedreservoiret. Sulfatindholdet når kun i Vesterborg i det sekundære reservoir op på 200 milligram pr. liter, mens et kloridindhold på ca. 300 milligram pr. liter forekommer i hovedreservoiret i Sibirien (de nævnte koncentrationer er de højest tilladte i drikkevand).

Som helhed udgør de mange overvågningsområder, hvor det artesiske hovedreservoir består af sand, en ret homogen gruppe med markant forskel mellem det påvirkede grundvand i de sekundære reservoirer og det upåvirkede grundvand af god kvalitet i hovedreservoirerne.

\section{Opsprakkede hovedreservoirer med frit grundvandsspejl}

Hovedreservoirerne består af kalksten samt i Smålyngområdet af sandsten, og reservoirerne er alle overlejret af kvartære sedimenter.

Der er $i$ alle tilfælde nitrat $i$ de sekundære reservoirer og indholdet aftager som hovedregel med dybden $i$ hovedreservoirerne. Der er dog flere eksempler på, at der er en relativ stor nitratkoncentration under de øverste filtre, og i Smålyng og Drastrup er der mellem 20 og 170 milligram nitrat pr. liter i hovedreservoiret.

Kloridindholdets fordeling afspejler som hovedregel de samme variationer og det generelle fald mod dybden som nitratindholdet, idet den modsatte situation med et maksimum øverst $i$ hovedreservoiret dog findes $i$ Skuldelev som følge af saltvand, der trækkes ind fra kystområdet. Det højeste kloridindhold på over 300 milligram pr. liter (højeste tilladte indhold i drikkevand) findes i de sekundære reservoirer i Skerping, bvor det antagelig skyldes fladepåvirkning, muligvis ved tørdeponering, og i Ishøj, hvor det skyldes indtrængende havvand.

Sulfatindholdet falder generelt med dybden ligesom nitratindholdet, men i reglen dog kun ganske svagt, og der er ingen steder, hvor indholdet overstiger 250 milligram pr. liter. 


\section{Sandreservoirer med frit grundvandsspejl}

Disse hovedreservoirer består af kvartære sandlag eller tertiære sandede aflejringer overlejret af kvartære lag. Nitratindholdets fordeling mod dybden i områder med denne type reservoir varierer meget. I halvdelen af områderne er der et betydeligt nitratindhold i størrelsesordenen 100 milligram pr. liter i den øverste del af grundvandet, samtidig med at der også er et mindre indhold af nitrat i det dybereliggende grundvand. I lige så mange tilfælde er der et tydeligt fald $\mathrm{i}$ nitratindholdet på overgangen fra det øverste til det dybereliggende grundvand. I Svendborg er der et beskedent nitratindhold i hovedreservoiret.

I de fleste af disse områder er der samme tendens $\mathrm{i}$ fordelingerne af grundvandets nitrat-, klorid- og sulfatindhold ned gennem reservoirerne. Albæk er dog en undtagelse. Dette varierende sulfatindhold, og den anden ved et stigende kloridindhold med dybden, mens nitrat- og sulfatindholdet varierer betydeligt med en tendens til aftagen med dybden.

Kun i vandet fra et enkelt filter i området på Samsø overskrider kloridindholdet 300 milligram pr. liter, mens sulfatindholdet overskrider 250 milligram pr. liter på Samsø og i Tornby. Disse forhold har geologisk årsag. Sammenfattende er det i områder, hvor hovedreservoiret har frit grundvandsspejl, der er den største variation $i$ koncentrationsfordelingen af de udvalgte stoffer.

\section{Udvalgte bestanddeles fordeling $\mathrm{i}$ hele landet}

De stoffer som i det foregående er blevet diskuteret er udvalgt, fordi de illustrerer den generelle påvirkelighed af grundvandet i områderne. Grundvandets kloridindhold kan skyldes vindaflejret salt, men hvor klorid- og sulfatindholdet stiger med dybden er det oftest tegn på påvirkning af havvand eller saltvand fra dybere lag. Denne tilstrømning kan kun mindskes eller standses ved en mindsket oppumpning eller i nogle tilfælde ved en særlig pumpestrategi. Højt kloridindhold i de øverste reservoirer er i de fleste af områderne en følge af arealpåvirkning gennem gødskning med naturgødning og med vindbåret salt. Det er dog kun undtagelsesvis, at disse forhøjede kloridkoncentrationer når op i nærheden af det, der højest må være i drikkevand (300 milligram pr. liter). Da sulfatindholdet i grundvandet stiger, når der trænger iltende vand ned gennem lag, hvor der før var iltfrie forhold, og svovlkis derfor iltes, kan dette antyde en kombineret effekt af sænkning ved pumpning og naturlige grundvandsfluktuationer.

\section{Nitrat}

Figur 30 viser at der $\mathrm{i}$ overvågningsområderne i praksis over hele landet er nitrat i det øverste grundvand, men at dette indhold varierer meget. Generelt er det størst og i størrelsesordenen 100 milligram pr. liter inden for de nordlige og vestlige to trediedele af Jylland. Denne karakteristik skal dog ses i lyset af, at der i disse overvågningsområder $\mathrm{i}$ reglen ikke indsamles prøver fra de øverste 10 meter under terræn. En antydning af at nitratindholdet $i$ dette dybdeinterval er endnu større end vist her fremgår af DMU (1991) på basis af data fra det aller øverste grundvand, indsamlet i Landovervågningsoplandende. Det omdiskuterede 
høje nitratindhold $\mathrm{i}$ det øverste grundvand især i Vestjylland er nu dokumenteret både med data fra overvågningsområderne og fra udvalgte vandværksboringer, se for eksempel Miljøindikatorer (1991).

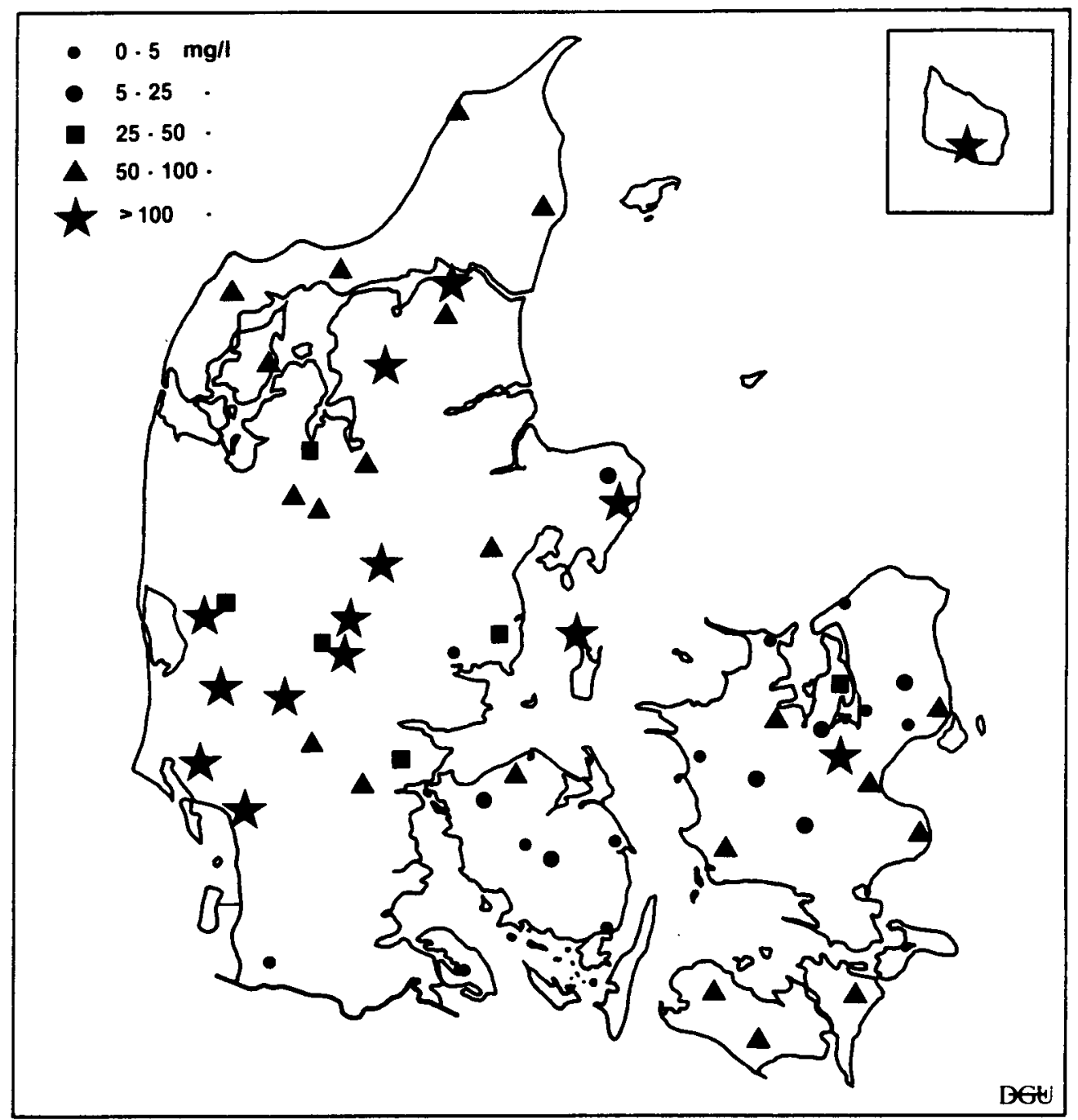

Figur 30: $\quad$ Nitrat i det фverste grundvand i overvågningsomrdideme.

Derimod er der kun i ca. 20\% af områderne nitrat i hovedreservoirerne, der enten er opsprækkede reservoirer eller sandreservoirer med frit grundvandsspejl. I lyset af den nuværende oversigt over nitratproblemets udbredelse, ikke bare i grundvandet i de frie men også i de opsprakkede artesiske reservoirer, er der, som fremhævet af Thorling og Hundahl (1991), alene for at håndtere dette problem behov for en indsats.

\section{Klorid}

I langt de fleste overvågningsområder indeholder det øverste grundvand mere klorid end hvad nedbøren betinger. Dette kan have flere årsager og kan illustrere, hvor udsat dette øverste grundvand er. Smagsgransen på 300 milligram pr. liter overskrides i Ishøj, Frederiksberg, Osted og Skerping. I hovedreservoirerne er der 
generelt mindre klorid i grundvandet end i de øverste. reservoirer, og i en fjerdedel af de vestdanske overvågningsområder er indholdet ikke forhøjet $\mathrm{i}$ forhold til den infiltrerende nedbør. De områder, hvor kloridindholdet stiger med dybden findes næsten alle i Midt- og Østsjælland. Smagsgrænsen er oversteget i Eggeslevmagle, Sibirien og Frederiksberg. Det bemarkes at der med kloridindholdet i grundvandet kan følge et natriumindhold, og at nogle grundvandstyper yderligere kan indeholde natrium på grund af ionbytning. Natriumindholdet i drikkevand må ikke overskride 175 milligram pr. liter på grund af dets blodtrykøgende virkning.

Sulfatindholdet $\mathrm{i}$ grundvandet er generelt relativt højt i det øverste grundvand i overvågningsområderne og aftager med dybden. Dette kan afspejle til hvilken dybde, der er foregået iltning af for eksempel svovlkis, og kan skyldes grundvandssænkning. I henholdsvis 12 og 6 områder er der konstant eller stigende sulfatkoncentration mod dybden som følge af overpumpning eller indtrængende vand af marin oprindelse. Kun i Frederiksberg-området og et enkelt prøvetagningssted i Tornby er sulfatindholdet $\mathrm{i}$ hovedreservoiret større end grænseværdien på 250 milligram pr. liter, der gælder for drikkevand. På Frederiksberg-området er sulfatindholdet en følge af den kraftige oppumpning, mens det i Tornby skyldes at vandindvindingen foregår fra lag af sand, der er aflejret $i$ havet.

\section{Hydrokemisk klassifikation}

Af hensyn til de fremtidige vurderinger af påvirkningen af grundvandet på basis af de mange overvågningsdata er der $i$ denne rapport foreslået et Hydro-Kemisk klassifikationssystem (HK-klassifikation) for grundvandet. Dette system er baseret på de væsentligste nøglekomponenter i grundvandet i Danmark. Der forventes herigennem at være muligt at karakterisere grundvandet på en måde, der er mere relevant for danske forhold end det kan opnås gennem eksisterende klassifikationer, som Piper Langlier (1954). Samtidig harmonerer karakteristikken med Ødum og Christensens (1936) gamle klassifikation. HK-klassifikationen er afprøvet på data fra Tornby og Råkilde og synes på dette grundlag velegnet til at give en grundlæggende karakteristik af grundvandets sammensætning mod dybden og gennem tiden.

\section{Specielle stoffer}

Med denne rapportering er der kun taget foreløbig stilling til grundvandets indhold af specielle stoffer, særlig fordi specialanalyserne kun er indberettet for ca. en trediedel af prøvetagningsstederne $i$ overvågningsprogrammet. Dette fremgår meget tydeligt af uddragene af amternes rapporteringer. Det har hidtil været kendt, at disse stoffer kan forekomme i grundvandet $\mathrm{i}$ byområderne og i nærheden af affaldsdepoter, og de er nu konstateret en del flere steder. Det skal dog bemærkes, at disse miljøfremmede stoffer ikke er fundet $\mathrm{i}$ langt hovedparten af det analyserede grundvand. Den bekymring, disse stoffer giver anledning til, finder blandt andet udtryk $i$, at flere amter betvivler analysernes kvalitet. De få genmålinger af pesticidindholdet som er foretaget har ikke kunnet bekræfte de første alarmerende resultater. Det er vigtigt i overvågningens begyndelsesfase at få bekræftet måleværdierne. Kun berigennem kan der sikres at analyseresultaterne ikke skyldes den måde grundvandsprøven indsamles eller håndteres på. 
Danmarks Geologiske Undersøgelse finder, at der er konstateret miljøfremmede stoffer, herunder pesticider, i så mange tilfælde, at det ikke alene kan bero på fejl. Overblikket over og forståelsen af disse stoffers fordeling i grundvandet er dog endnu for fragmentarisk til, at det kan forklares bortset fra konkrete enkelttilfælde. Det skal i fremtiden eftervises gennem den påbegyndte "Boringskontrol", at grundvandet er godt nok til at blive udnyttet til drikkevandsforsyning. Denne kontrol vil sammen med en fortsat måling af indholdet af de specielle stoffer $i$ overvågningsområderne, forbedre grundlaget for håndteringen af disse problemer.

\section{Geografiske problemområder}

Sammenstillingen af amternes afgrænsning af geografiske problemområder med hensyn til udnyttelsen af grundvandet omfatter de mest almindeligt kendte kvalitetsmæssige og mængdemæssige problemer. Hovedparten af disse problemer har vandværkerne hidtil kunnet administrere og behandle sig fra. Der er derfor ikke nødvendigvis noget bekymrende $i$, at der er anført problemer af en eller anden art i så at sige hele landet. Men der er et tydeligt faresignal for de dele af landet, hvor der er sammenfald af mange af disse problemer. Det er i høj grad tilfældet $\mathrm{i}$ områder, hvor der foregår intensiv udnyttelse af grundvandet: Storkøbenhavn, Odense, området nord for Århus. Disse områder er belastet med mange af de illustrerede problemer på en gang, mens noget tilsvarende i mindre udpræget grad gælder det meste af Vejle amt og Sydsjælland. På dette grundlag kan det være berettiget at revidere det kort over graden af overudnyttelse af grundvandet, som er vist i figur 5.3 i Vandmiljø-90 (Miljøstyrelsen, 1990c), til at omfatte dele af Århus, Vejle og Fyns amter samt Esbjergområdet, Als, Skagen og Læsø.

Da der er et tydeligt sammenfald mellem problemer for anvendelsen af grundvandet og kraftig udnyttelse af grundvandsressourcen er det nærliggende $i$ den fremtidige tolkning af de mange nye oplysninger om "specielle stoffer", at afklare om også disse især forekommer, hvor ressourcen overudnyttes.

\section{Behovet for fremtidig indsats}

Med dette års rapporteringer fra amterne er der samlet et billede af fordelingen af mange af de forurenende stoffer i grundvandet. Det er på denne baggrund nødvendigt fremover at skaffe mere klarhed over den videre udvikling gennem regelmæssigt gentagne målinger af indholdet af "specielle stoffer".

Det er derfor hensigtsmæssigt at specialanalyseprogrammet for overvågningsområderne er afstemt med programmet for den såkaldte Boringskontrol. Når begge disse datasæt fortolkes sammen, kan udbredelsen og fortolkningsmuligheden for disse stoffer bredes ud over de ialt ca. 500 kvadratkilometer, der er omfattet af overvågningsområderne. Derimod vil det være muligt at forøåge tidsintervallet mellem målinger af mere almindelige komponenter i grundvandet i tilfælde, hvor der ikke er konstateret koncentrationsændringer gennem tiden. 
Den udvidede indsats for beskyttelse af de mest sårbare områder for grundvandsdannelsen, er mange steder påbegyndt med individuelt tilpassede strategier. Denne indsats bør intensiveres og udstrækkes, således at kvaliteten af grundvandet sikres. 


\section{REFERENCER}

Amtsrapporterne er ordnet efter amternes numre. Herefter følger rapporter fra DGU og endelig de øvrige referencer $i$ alfabetisk orden.

Københavns og Frederiksberg Kommune (1990): Vandmiljøplanensgrundvandsovervågning.Grundvandsressourcens udnyttelse og tilstand. Grundvandsmoniteringsområder. Etablerings og statusrapport.

Københavns og Frederiksberg Kommune (1991): Vandmiljøplanensgrundvandsovervågning.Grundvandsmoniteringsområde og grundvandsproblemområder. Statusrapport.

Københavns Amtskommune (1990): Vandmiljøplanens grundvandsovervågning. Grundvandsressourcens udnyttelse og tilstand. Grundvandsmoniteringsområder. Etablerings og statusrapport.

Københavns Amtskommune (1991): Vandmiljøplanens grundvandsovervågning. Grundvandmoniteringsområder og grundvandsproblemområder. Statusrapport.

Frederiksborg Amtskommune (1990): Vandmiljøplanens grundvandsovervågning. Grundvandsressourcens udnyttelse og tilstand. Grundvandsmoniteringsområder. Etablerings og statusrapport.

Frederiksborg Amtskommune (1990): Vandmiljøplanens grundvandsovervågning. Tekniske data, Skuldelev 20.11.

Frederiksborg Amtskommune (1990): Vandmiljøplanens grundvandsovervågning. Tekniske data, Asserbo 20.12.

Frederiksborg Amtskommune (1990): Vandmiljøplanens grundvandsovervågning. Tekniske data, Attemose 20.13.

Frederiksborg Amtskommune (1990): Vandmiljøplanens grundvandsovervågning. Tekniske data, Espergærde 20.14.

Frderiksborg Amtskommune (1991): Vandmiljøplanensgrundvandsovervågning.Grundvandsmoniteringsområder og grundvandsproblemområder. Satusrapport.

Roskilde Amtskommune (1990): Vandmiljøplanens grundvandsovervågning. Grundvandsressourcensudnyttelse og tilstand. Statusrapport.
Roskilde Amtskommune (1990): Vandmiljøplanens grundvandsovervågning. Etablerings og statusrapport, Asemose 25.11.

Roskilde Amtskommune (1990): Vandmiljøplanens grundvandsovervågning. Etablerings og statusrapport, Osted 25.12.

Roskilde Amtskommune (1991): Vandmiljøplanens grundvandsovervågning. Grundvandsmoniteringsområder og grundvandsproblemområder. Statusrapport og bilag.

Vestsjællands Amtskommune (1990): Vandmil¡planens grundvandsovervågning. Grundvandsressourcens udnyttelse og tilstand. Statusrapport.

Vestsjallands Amtskommune (1990): Vandmiljøplanens grundvandsovervågning. Etablerings og statusrapport, Munke Bjergby 30.11 17. Vestsjællands Amtskommune (1990): Vandmiljøplanens grundvandsovervågning. Etablerings og statusrapport, Store Fuglede 30.12

Vestsjallands Amtskommune (1990): Vandmiljøplanens grundvandsovervågning. Etablerings og statusrapport, Nykøbing 30.13.

Vestsjallands Amtskommune (1990): Vandmiljøplanens grundvandsovervågning. Etablerings og statusrapport, Eggeslevmagle 30.14 .

Vestsjællands Amtskommune (1991): Vandmiljøplanensgrundvandsovervågning.Grundvandsmoniteringsområder og grundvandsproblemområder. Statusrapport.

Storstrøms Amtskommune (1990): Vandmiljøplanens grundvandsovervågning. Grundvandsressourcens udnyttelse og tilstand. Statusrapport.

Storstrøms Amtskommune (1990): Vandmiljøplanens grundvandsovervågning. Etablerings og statusrapport, Vesterborg 35.11.

Storstrøms Amtskommune (1990): Vandmiljøplanens grundvandsovervågning. Etablerings og statusrapport, Sibirien 35.12.

Storstrøms Amtskommune (1990): Vandmiljøplanens grundvandsovervågning. Etablerings og statusrapport, St.Heddinge 35.13. 
Storstrøms Amtskommune (1991): Vandmiljøplanens grundvandsovervågning. Grundvandsmoniteringsområder og grundvandsproblemområder. Statusrapport.

Bornholms Amtskommune (1990): Vandmiljøplanens grundvandsovervågning. Grundvandsressourcens udnyttelse og tilstand. Statusrapport.

Bornhoims Amtskommune (1991): Vandmiljøplanens grundvandsovervågning. Grundvandsmoniteringsområde og grundvandsproblemområder. Statusrapport

Fyns Amtskommune (1990): Vandmiljøplanens grundvandsovervågning. Grundvandsressourcens udnyttelse og tilstand. Etablerings og statusrapport.

Fyns Amtskommune (1990): Vandmiljøplanens grundvandsovervågning. Tekniske data, Svendborg 42.11.

Fyns Amtskommune (1990): Vandmiljøplanens grundvandsovervågning. Tekniske data, Nr.Søby 42.12 .

Fyns Amtskommune (1990): Vandmiljøplanens grundvandsovervågning. Tekniske data, Harndrup 42.13.

Fyns Amtskommune (1990): Vandmiljøplanens grundvandsovervågning. Tekniske data, Jullerup 42.14 .

Fyns Amtskommune (1991): Vandmiljøplanens grundvandsovervågning. Grundvandsmoniteringsområder og grundvandsproblemområder. Statusrapport.

Sønderjyllands Amtskommune (1990): Vandmiljøplanens grundvandsovervågning. Grundvandsressourcens udnyttelse og tilstand. Etablerings of statusrapport.

Sønderjyllands Amtskommune (1991): Vandmiljøplanensgrundvandsovervågning.Grundvandsmoniteringsområder og grundvandsproblemområder. Statusrapport.

Ribe Amtskommune (1990): Vandmiljøplanens grundvandsovervågning. Grundvandsressourcens udnyttelse og tilstand. Etablerings og statusrapport.

Ribe Amtskommune (1990): Vandmiljøplanens grundvandsovervågning. Tekniske data, Bramming 55.11 .
Ribe Amtskommune (1990): Vandmiljøplanens grundvandsovervågning. Tekniske data, Ølgod 55.12 .

Ribe Amtskommune (1990): Vandmiljøplanens grundvandsovervågning. Tekniskedata, Forumlund 55.13 .

Ribe Amtskommune (1990): Vandmiljøplanens grundvandsovervågning. Tekniske data, Vorbasse 55.14 .

Ribe Amtskommune (1991): Vandmiljøplanens grundvandsovervågning. Grundvandsmoniteringsområder og grundvandsproblemområder. Statusrapport.

Vejle Amtskommune (1990): Vandmiljøplanens grundvandsovervågning. Grundvandsressourcens udnyttelse og tilstand. Etablerings og statusrapport.

Vejle Amtskommune (1990): Vandmiljøplanens grundvandsovervågning. Tekniske data, Thyregod 60.11 .

Vejle Amtskommune (1990): Vandmiljøplanens grundvandsovervågning. Tekniske data, Trudsbro 60.12 .

Vejle Amtskommune (1990): Vandmiljøplanens grundvandsovervågning. Tekniske data, Follerup 60.13 .

Vejle Amtskommune (1990): Vandmiljøplanens grundvandsovervågning. Tekniske data, Ejstrupholm 60.14 .

Vejle Amtskommune (1991): Vandmiljøplanens grundvandsovervågning. Grundvandsmoniteringsområder og grundvandsproblemområder. Statusrapport.

Ringkøbing Amtskommune (1990): Vandmiljøplanens grundvandsovervågning. Grundvandsressourcens udnyttelse og tilstand. Etablerings og statusrapport.

Ringkøbing Amtskommune (1990): Vandmiljøplanens grundvandsovervågning. Tekniske data, Brande 65.11.

Ringkøbing Amtskommune (1990): Vandmiljøplanens grundvandsovervågning. Tekniske data, Haderup 65.12.

Ringkøbing Amtskommune (1990): Vandmiljøplanens grundvandsovervågning. Tekniske data, Herborg 65.13. 
Ringkøbing Amtskommune (1990): Vandmiljøplanens grundvandsovervågning. Tekniske data, Finderup 60.14

Ringkøbing Amtskommune (1991): Vandmiljøplanens grundvandsovervågning. Grundvandsmoniteringsområder og grundvandsproblemområder. Statusrapport.

Århus Amtskommune (1990): Vandmiljøplanens grundvandsovervågning. Grundvandsressourcens udnyttelse og tilstand. Etablerings- og statusrapport, Nordsams $\emptyset 70.11$.

Århus Amtskommune (1990): Vandmiljøplanens grundvandsovervågning. Grundvandsressourcens udnyttelse og tilstand. Etablerings og statusrapport, Fillerup 70.12.

Århus Amtskommune (1990): Vandmiljøplanens grundvandsovervågning. Grundvandsressourcens udnyttelse og tilstand. Etablerings og statusrapport, Hvinningdal 70.13.

Århus Amtskommune (1990): Vandmiljøplanens grundvandsovervågning. Grundvandsressourcens udnyttelse og tilstand. Etablerings og statusrapport, Homå 70.14 .

Århus Amtskommune (1991): Vandmiljøplanens grundvandsovervågning. Grundvandsmoniteringsområder og grundvandsproblemområder. Statusrapport.

Viborg Amtskommune (1990): Vandmiljøplanens grundvandsovervågning. Grundvandsressourcens udnyttelse og tilstand. Etablerings og statusrapport.

Viborg Amtskommune (1991): Vandmiljøplanens grundvandsovervågning. Grundvandsmoniteringsområder og grundvandsproblemområder. Statusrapport.

Nordjyllands Amtskommune (1990): Vandmiljøplanens grundvandsovervågning. Grundvandsressourcens udnyttelse og tilstand. Etablerings- og statusrapport.

Nordjyllands Amtskommune (1991): Vandmiljøplanensgrundvandsovervågning.Grundvandsmoniteringsområder og grundvandsproblemområder. Statusrapport.

DGU (1990): Vandmiljøplanens grundvandsovervågning. Baggrundsrapport, Fredensborg 20.01. DGU Intern rapport nr. 12-1990.

DGU (1990): Vandmiljøplanens grundvandsovervågning. Tekniske data, Fredensborg 20.01.
.DGU (1990): Vandmiljøplanens grundvandsovervågning. Baggrundsrapport, Torkilstrup 25.01. DGU Intern rapport nr. 13-1990.

DGU (1990): Vandmiljøplanens grundvandsovervågning. Tekniske data, Torkilstrup 25.01 .

DGU (1990): Vandmiljøplanens grundvandsovervågning. Baggrundsrapport, Brokilde 25.02 . DGU Intern rapport nr. 14-1990.

DGU (1990): Vandmiljøplanens grundvandsovervågning. Tekniske data, Brokilde 25.02 .

DGU (1990): Vandmiljøplanens grundvandsovervågning. Baggrundsrapport, Holbæk 30.01. DGU Intern rapport $\mathrm{nr}$. 15-1990.

DGU (1990): Vandmiljøplanens grundvandsovervågning. Tekniske data, Holbæk 30.01 .

DGU (1990): Vandmiljøplanens grundvandsovervågning. Baggrundsrapport, Holeby 35.01. DGU Intern rapport nr. 16-1990.

DGU (1990): Vandmiljøplanens grundvandsovervågning. Tekniske data, Holeby 35.01 .

DGU (1990): Vandmiljøplanens grundvandsovervågning. Baggrundsrapport, Hjelmsølille 35.02. DGU Intern rapport nr. 17-1990.

DGU (1990): Vandmiljøplanens grundvandsovervågning. Tekniskedata, Hjelmsølille 35.02.

DGU (1990): Vandmiljøplanens grundvandsovervågning. Baggrundsrapport, Smålyng 40.01. DGU Intern rapport nr. 18-1990.

DGU (1990): Vandmiljøplanens grundvandsovervågning. Tekniske data, Smålyng $\mathbf{4 0 . 0 1}$.

DGU (1990): Vandmiljøplanens grundvandsovervågning. Baggrundsrapport, Nyborg 42.01. DGU Intern rapport nr. 19-1990.

DGU (1990): Vandmiljøplanens grundvandsovervågning. Tekniske data, Nyborg 42.01 .

DGU (1990): Vandmiljøplanens grundvandsovervågning. Baggrundsrapport, Borreby 42.02. DGU Intern rapport nr. 20-1990.

DGU (1990): Vandmiljøplanens grundvandsovervågning. Tekniske data, Borreby 42.02 .

DGU (1990): Vandmiljøplanens grundvandsovervågning. Baggrundsrapport, Abild 50.01. DGU Intern rapport nr. 21-1990. 
DGU (1990): Vandmiljøplanens grundvandsovervågning. Tekniske data, Abild 50.01.

DGU (1990): Vandmiljøplanens grundvandsovervågning. Baggrundsrapport, Mjang Dam 50.02. DGU Intern rapport nr. 22-1990.

DGU (1990): Vandmiljøplanens grundvandsovervågning. Tekniske data, Mjang Dam 50.02.

DGU (1990): Vandmiljøplanens grundvandsovervågning. Baggrundsrapport, Grindsted 55.01 . DGU Intern rapport nr. 23-1990.

DGU (1990): Vandmiljøplanens grundvandsovervågning. Tekniske data, Grindsted 55.01.

DGU (1990): Vandmiljøplanens grundvandsovervågning. Baggrundsrapport, Egebjerg 60.01. DGU Intern rapport nr. 24-1990.

DGU (1990): Vandmiljøplanens grundvandsovervågning. Tekniske data, Egebjerg 60.01 .

DGU (1990): Vandmiljøplanens grundvandsovervågning. Baggrundsrapport, Herning 65.01. DGU Intern rapport nr. 25-1990.

DGU (1990): Vandmiljøplanens grundvandsovervågning. Tekniske data, Herning 65.01.

DGU (1990): Vandmiljøplanens grundvandsovervågning. Baggrundsrapport, Kastbjerg 70.01. DGU Intern rapport nr. 26-1990.

DGU (1990): Vandmiljøplanens grundvandsovervågning. Tekniske data, Kastbjerg 70.01.

DGU (1990): Vandmiljøplanens grundvandsovervågning. Baggrundsrapport, Kasted 70.02. DGU Intern rapport $\mathrm{nr}$. 27-1990.

DGU (1990): Vandmiljøplanens grundvandsovervåning. Tekniske data, Kasted 70.02 .

DGU (1990): Vandmiljøplanens grundvandsovervågning. Baggrundsrapport, Rabis Bæk 76.01. DGU Intern rapport $\mathrm{nr}$. 28-1990.

DGU (1990): Vandmiljøplanens grundvandsovervågning. Tekniske data, Rabis Bæk 76.01.

DGU (1990): Vandmiljøplanens grundvandsovervågning. Baggrundsrapport, Tornby 80.01. DGU Intern rapport nr. 29-1990.

DGU (1990): Vandmiljøplanens grundvandsovervågning. Tekniske data, Tornby 80.01 .
DGU (1990): Vandmiljøplanens grundvandsovervågning. Baggrundsrapport, Råkilde-Støvring 80.02. DGU Intern rapport nr. 30-1990.

DGU (1990): Vandmiljøplanens grundvandsovervågning. Tekniske data, Råkilde-Støvring 80.02.

DGU Status (1990): Status for grundvand og drikkevand i Danmark 1990. DGU Intern rapport nr. 45-1990.

Andersen,L.J. (1987): Grundvandsmoniteringsnet af 1.orden i Danmark. ATV-komiteen vedrørende grundvandsforurening, Vingstedcentret 5-6 oktober 1987, p 1-16.

Deutsche Forschungsgemeinschaft (1990): Pflanzenschutzmittel im Trinkwasser. Mitteilung XVI der Kommission fur Pflanzenschutz-, Pflanzenbehandlungs- und Vorratsschutzmittel, pp 82.

Druliner, A.D. (1989): Overview of the relations of nonpointsource agricultural chemical contamination to local hydrologic, soil, land-use, and hydrochemical characteristics of the high plains aquifer of Nebraska. U.S.Geological survey toxic substances hydrology program - Proceedings of the TechnicalMeeting, Phoenix, Arizona, Sept.2630,1988 , USGS Water Resources Investigations Report 88-4220, p 411-435.

Forslund,J. (1987): Pesticider i grundvand og drikkevand. Særtryk af Vand \& Miljø 4/1987.

Grøn, Ch. (1988): Informationsbrev fra Lossepladsprojektet, nr. 9.

Helweg, A. (1988): Kemiske stoffer i landbrugsmiljøer. Teknisk Forlag A/S.

Hovedstadsrådet (1982): Hydrogeologisk kortlægning, Teknisk baggrundsnotat, pp 63.

Isotopcentralen/ATV: Tritiumanalyser et hydrologisk værktøj, information fra Isotopcentralen.

Konradi,P. - Laier,T. (1991): Grundvandskemi. Årsberetning for 1990, DGU, p 47-49.

Kristiansen, H. \& Stockmarr, J. (1991): Hvordan påvirker nitrat- og fosfatkoncentrationerne $\mathrm{i}$ det nedsivende vand grundvandet i forskellige hovedreservoirtyper? Rapport fra konsensuskonference 31. jan., 1. og 4. febr. 1991. p. 8-1-8-28.

Maglekilde-Petersen,E. (1969): Grundvandets behandling. I. Vandforsyning. Teknisk forlag, København, p 153-196. 
Michalsen, A-S (1991): Personlig kommunikation

Miljøministeriet (1988): Bekendtgørelse om vandkvalitet og tilsyn med vandforsyningsanlæg. Miljøministeriets bekendtgørelse $\mathrm{nr} .515$ af 29.aug. 1988.

Miljøministeriet (1991a): Miljøindikatorer 1991.

Miljøministeriet (1991b): Miljøtilstanden i Danmark.

Miljøstyrelsen (1990a): STANDAT V 1.1. En standard for udveksling af miljødata. Vejledning fra Miljøstyrelsen $1990 \mathrm{nr} .1$.

Miljøstyrelsen (1990b): Vurdering af analyseprogrammet for udvalgte boringer $i$ vandmiljøplanensgrundvandsovervågning. Arbejdsrapport fra Miljøstyrrelsen $1990 \mathrm{nr} .11$.

Miljøstyrelsen (1990c): Vandmiljø-90. Redegørelse fra miljøstyrelsen nr. 1.

Miljøstyrelsen (1990d): Vurdering og udvælgelse af laboratorier, med henblik på deltagelse i Vandmiljøplanens Grundvandsovervågning. Janne Forslund, Christian Ammitsøe og Jens Stockmarr, Miljøstyrelsen 9. maj 1990.

Miljøstyrelsen (1991): Kvalstof og fosfor $\mathrm{i}$ jord og vand. NPO-forskning fra Miljøstyrelsen, Samlerapport.

Mogensen, B.B. og Spliid, N.H. (1991): Udvaskning af pesticider fra landbrugsjord. 8.Danske Planteværnskonference 1991, Pesticider/Miljø, pp 10.

Piper, A.M. (1944): A graphic procedure in the geochemical interpretation of water analysis. Trans. Am. Geophys. Union Hydrol. Pap., 6: 914 927.

Rambøll \& Hannemann (1991): Frederiksberg Kommune, Sikring af drikkevandsressourcen. R\&H Bulletin no. 27.

Rasmussen, H. Wienberg (1966): Danmarks Geologi, Gjellerup.

Sorgenfrei, T. og Berthelsen, O. (1970): Geologi og vandboring. Danmarks Geologiske Undersøgelse, III. række nr. 31.

Strøbæk, N. (1989): Skrydstrup Specialdepot. Udredningsrapport U7, lossepladsprojektet, dec. 1989.
Thorling, L. \& Hundahl, M., (1991): Nitratskjoldet på Djursland? Vandteknik nr. 9 p. 433-437.

Viborg Amtskommune (1991): Vandindvindingsplan, pp 101.

Ødum, H. \& Christensen, W. (1936): Danske grundvandstyper og deres geologiske optræden, DGU III Række nr. 26. 


\section{APPENDIX}

\section{De indrapporterede data}

Med de mange lister i dette Appendix over data fra 66 af de 67 overvågningsområder er omfanget af de data, der er leveret af amterne, og som indtil nu har kunnet indlægges i basen, dokumenteret. Der er dog endnu en del mangler i data, som er under afklaring. Fra listerne er de fejldata, der har kunnet lokaliseres ved testprocedurerne derfor udeladt, ligesom alle nul-værdier er udeladt.

Listerne er opdelt efter de to indberetningsrunder 1990 og 1989, og de omfatter hovedkomponenter samt $\mathrm{i}$ en del tilfælde specialanalyser. For hvert stof er der anført antallet af analyser, den gennemsnitlige måleværdi, medianværdien og spredningen, samt maksimum og minimum blandt måleværdierne. I tilfælde, hvor den tilsyneladende måleværdi er en detektionsgrænse, er dette anført med "DG", og særligt tvivlsomme angivelser er markeret med en fodnote.

Dataene er ordnet i følgende rækkefølge efter overvågningsområdets nummer og årstal.

\begin{tabular}{llll} 
Område & Navn & \multicolumn{2}{c}{ Årstal } \\
13.11 & Frederiksberg & 1990 & 1989 \\
15.11 & Søndersø & 1990 & 1989 \\
15.12 & Ishøj & 1990 & 1989 \\
15.13 & Gladsaxe & 1990 & 1989 \\
15.14 & Ishøj & 1990 & \\
20.01 & Endrup & 1990 & 1989 \\
20.11 & Skuldelev & 1990 & 1989 \\
20.12 & Asserbo & 1990 & 1989 \\
20.13 & Attemose & 1990 & 1989 \\
20.14 & Espergærde & 1990 & 1989 \\
25.01 & Torkilstrup & 1990 & 1989 \\
25.02 & Brokilde & 1990 & 1989 \\
25.11 & Asemose & 1990 & 1989 \\
25.12 & Osted & 1990 & 1989 \\
30.01 & Holbæk & 1990 & 1989 \\
30.11 & Munke Bjergby & 1990 & 1989 \\
30.12 & Store Fuglede & 1990 & 1989 \\
30.13 & Nykøbing S. & 1990 & 1989 \\
30.14 & Eggeslevmagle & 1990 & 1989 \\
35.01 & Holeby & 1990 & \\
35.02 & Hjelmsølille & 1990 & 1989 \\
35.11 & Vesterborg & 1990 & 1989 \\
35.12 & Sibirien & 1990 & \\
35.13 & St. Heddinge & 1990 & \\
40.01 & Smålyng & 1990 & 1989 \\
42.01 & Nyborg & 1990 & 1989 \\
42.02 & Borreby & 1990 & 1989 \\
42.11 & Svendborg & 1990 & 1989 \\
42.12 & Nr. Søby & 1990 & 1989 \\
42.13 & Harndrup & 1990 & 1989 \\
42.14 & Jullerup & 1990 & 1989 \\
50.01 & Abild & & 1989 \\
50.02 & Mjang Dam & & 1989 \\
50.11 & Bedsted & & 1989 \\
& & &
\end{tabular}

\begin{tabular}{llll} 
Område Navn & \multicolumn{2}{c}{ Årstal } \\
50.12 & Rødding nord & \multicolumn{2}{c}{1989} \\
50.13 & Christiansfeld & \multicolumn{2}{c}{1989} \\
55.01 & Grindsted & 1990 & 1989 \\
55.11 & Bramming & 1990 & 1989 \\
55.12 & Ølgod & 1990 & 1989 \\
55.13 & Forumlund & 1990 & 1989 \\
55.14 & Vorbasse & 1990 & 1989 \\
60.01 & Egebjerg & 1990 & 1989 \\
60.11 & Thyregod & 1990 & 1989 \\
60.12 & Trudsbro & 1990 & 1989 \\
60.13 & Follerup & 1990 & 1989 \\
60.14 & Ejstrupholm & 1990 & 1989 \\
65.01 & Herning & & \\
65.11 & Brande & 1990 & \\
65.12 & Haderup & 1990 & \\
65.13 & Herborg & 1990 & \\
65.14 & Finderup & 1990 & \\
70.01 & Kastbjerg & 1990 & \\
70.02 & Kasted & 1990 & \\
70.11 & Nordsams $\emptyset$ & 1990 & \\
70.12 & Fillerup & 1990 & \\
70.13 & Hvinningdal & 1990 & \\
70.14 & Homå & 1990 & \\
76.01 & Rabis Bæk & 1990 & \\
76.11 & Viborg N & 1990 & \\
76.12 & Skive & 1990 & \\
76.13 & Nykøbing M. & 1990 & \\
76.14 & Thisted-Baun & 1990 & \\
80.01 & Tornby & 1990 & 1989 \\
80.02 & Råkilde-Støvring & 1990 & 1989 \\
80.11 & Drastrup & 1990 & 1989 \\
80.12 & Skerping & 1990 & 1989 \\
80.13 & Albæk & 1990 & 1989 \\
80.14 & Gislum & 1990 & 1989
\end{tabular}


København og Frederiksberg Kommuner

\begin{tabular}{|c|c|}
\hline Stof navn & Enhed \\
\hline Konduktivitet & MSIEMENS/M \\
\hline $\mathrm{pH}$ & $\mathbf{P H}$ \\
\hline Inddampn ingsrest & $M G / L$ \\
\hline Carbondtox 1d, aggr. & $M G / L$ \\
\hline Hydrogencarbonat & MG/L \\
\hline Permanganatta $1 \mathrm{KMnO4}$ & $M G / L$ \\
\hline Ammon lak +ammon ium & MG/L \\
\hline Nitrit & $M G / L$ \\
\hline Nitrat & $M G / L$ \\
\hline Phosph.,tot.f11t P04 & $M G / L$ \\
\hline Calclum & $M G / L$ \\
\hline Chlorid & MG/L \\
\hline Fluor Id & $M G / L$ \\
\hline Jern & $M G / L$ \\
\hline Jern ferro & $M G / L$ \\
\hline Kalium & MG/L \\
\hline Magnes ium & $M G / L$ \\
\hline Mangan & $M G / L$ \\
\hline Natrium & $M G / L$ \\
\hline Ntkkel & MYGRAM/L \\
\hline Sulfat & $M G / L$ \\
\hline
\end{tabular}

\begin{tabular}{|c|c|c|c|c|c|}
\hline Anta 1 & Gens & Median & Spredning & Maximum & Mintmum \\
\hline 25 & 136.0280 & 107.6000 & 75.28 & 350.0000 & 62.3000 \\
\hline 25 & 7.0464 & 7.0600 & 0.18 & 7.3800 & 6.7400 \\
\hline 13 & 1226.6923 & 1129.0000 & 700.04 & 2897.0000 & 575.0000 \\
\hline 1 & 2.0000 & 2.0000 & - & 2.0000 & 2.0000 \\
\hline 13 & 465.7692 & 467.0000 & 114.09 & 635.0000 & 299.0000 \\
\hline 25 & 16.6040 & 17.1000 & 10.30 & 45.8000 & 4.0000 \\
\hline 24 & 0.7393 & 0.5411 & 0.80 & 3.9638 & 0.0182 \\
\hline 25 & 0.0354 & 0.0110 & 0.06 & 0.2400 & 0.0010 \\
\hline 25 & 2.9908 & 0.0500 & 13.31 & 66.6000 & 0.0120 \\
\hline 24 & 0.2657 & 0.1763 & 0.39 & 1.8704 & 0.0031 \\
\hline 25 & 271.1600 & 248.0000 & 131.48 & 589.0000 & 127.0000 \\
\hline 25 & 225.1200 & 146.0000 & 224.44 & 832.0000 & 32.0000 \\
\hline 24 & 0.3663 & 0.3450 & 0.09 & 0.5400 & 0.2600 \\
\hline 3 & 0.3773 & 0.3300 & 0.39 & 0.7900 & 0.0120 \\
\hline 22 & 14.1718 & 11.8000 & 10.00 & 37.0000 & 1.1200 \\
\hline 12 & 6.3583 & 6.3000 & 2.90 & 14.0000 & 3.3000 \\
\hline 13 & 35.3846 & 29.0000 & 17.10 & 76.0000 & 16.0000 \\
\hline 24 & 0.3551 & 0.2600 & 0.33 & 1.0800 & 0.0180 \\
\hline 13 & 66.1538 & 45.0000 & 45.11 & 147.0000 & 18.0000 \\
\hline 12 & 5.2500 & 3.5000 & 4.65 & 17.0000 & 1.0000 \\
\hline 25 & 281.5600 & 182.0000 & 206.14 & 756.0000 & 6.0000 \\
\hline
\end{tabular}


København og Frederiksberg Kommuner

\begin{tabular}{|c|c|c|c|c|c|c|c|}
\hline Stof navn & Enhed & Antal & Gens. & Median & Spredning & Maximun & Min Imum \\
\hline Kondukt ivitet & MSIEMEHS/M & 12 & 136.1583 & 106.2500 & 82.36 & 348.0000 & 61.0000 \\
\hline pH & $\mathrm{PH}$ & 12 & 7.0292 & 7.0150 & 0.17 & 7.2800 & 6.7400 \\
\hline Permanganattal $\mathrm{KHnO}$ & $M G / L$ & 12 & 15.2750 & 14.0500 & 6.82 & 29.0000 & 6.6000 \\
\hline Ammon 1 ak + amson fum & $M G / L$ & 12 & 0.5753 & 0.5338 & 0.36 & 1.3132 & 0.1277 \\
\hline Nitrit & $M G / L$ & 12 & 0.0272 & 0.0120 & 0.03 & 0.1020 & 0.0030 \\
\hline Nitrat & $\mathrm{MG} / \mathrm{L}$ & 12 & 0.7092 & 0.0310 & 2.35 & 8.1600 & 0.0090 \\
\hline Phosph.,tot.f1]t P04 & $M G / L$ & 12 & 1.4053 & 0.1257 & 3.02 & 9.0146 & 0.0061 \\
\hline Calc 1um & $M G / L$ & 12 & 279.0833 & 260.5000 & 144.71 & 632.0000 & 136.0000 \\
\hline Chlorid & $M G / L$ & 12 & 202.3333 & 99.0000 & 256.87 & 920.0000 & 41.0000 \\
\hline Fluor 1d & $M G / L$ & 12 & 0.3758 & 0.3600 & 0.10 & 0.5200 & 0.2400 \\
\hline Jern ferro & $M G / L$ & 12 & 7.9967 & 2.2100 & 10.17 & 32.4000 & 1.3200 \\
\hline Mangan & $M G / L$ & 12 & 0.7931 & 0.6390 & 0.67 & 2.4100 & 0.0750 \\
\hline Sulfat & $M G / L$ & 12 & 452.3333 & 242.0000 & 686.42 & 2563.0000 & 41.0000 \\
\hline
\end{tabular}


Søndersø (15.11)

\begin{tabular}{|c|c|}
\hline Stor navn & Enhed \\
\hline Kondukt ivitet & MSIEMENS/M \\
\hline $\mathrm{pH}$ & PH \\
\hline Torstof, total & $M G / L$ \\
\hline Oxygen indhold & $M G / L$ \\
\hline Hydrogencarbonat & $M G / L$ \\
\hline Permanganatta I KMnO4 & $M G / L$ \\
\hline Ammon tak taamon ium & $M G / L$ \\
\hline Nitrit & $M G / L$ \\
\hline Nitrat & $M G / L$ \\
\hline Phosph.,tot.f11t P04 & $M G / L$ \\
\hline Calcium & $M G / L$ \\
\hline Chlorid & $M G / L$ \\
\hline Fluorid & $M G / L$ \\
\hline Jern & $\mathrm{MG} / \mathrm{L}$ \\
\hline Ka lium & $M G / L$ \\
\hline Kobber & MYGRAM/L \\
\hline Kriksoiv & MANOGRAM/L \\
\hline Magnesium & $M G / L$ \\
\hline Mangan & $M G / L$ \\
\hline Natrium & $M G / L$ \\
\hline Sulfat & $M G / L$ \\
\hline Trit lum & T.U. \\
\hline Methan & $M G / L$ \\
\hline
\end{tabular}

Københavns Amt Grundvandsanalyser, 1990

\begin{tabular}{|c|c|c|c|c|c|}
\hline Antal & Gens & Median & Spredning & Max Imum & Minimum \\
\hline 75 & 61.3467 & 62.0000 & 5.00 & 72.0000 & 50.0000 \\
\hline 75 & 7.5413 & 7.5000 & 0.11 & 7.8000 & 7.3000 \\
\hline 74 & 381.5270 & 375.5000 & 65.26 & 730.0000 & 295.0000 \\
\hline 62 & 1.3339 & 0.7000 & 1.82 & 9.8000 & 0.1000 \\
\hline 75 & 315.3867 & 318.0000 & 26.12 & 398.0000 & 277.0000 \\
\hline 75 & 5.8933 & 6.0000 & 1.98 & 15.0000 & 3.0000 \\
\hline 75 & 0.4543 & 0.2300 & 0.61 & 3.2000 & 0.0100 \\
\hline 64 & 0.0183 & 0.0100 & 0.02 & 0.0900 & 0.0100 \\
\hline 75 & 0.6880 & 0.5000 & 0.72 & 6.5000 & 0.5000 \\
\hline 75 & 0.2424 & 0.2146 & 0.18 & 0.8892 & 0.0307 \\
\hline 74 & 97.6081 & 99.0000 & 10.93 & 120.0000 & 65.0000 \\
\hline 74 & 29.8311 & 26.5000 & 16.36 & 109.0000 & 9.0000 \\
\hline 75 & 0.3409 & 0.3400 & 0.08 & 0.6000 & 0.2000 \\
\hline 75 & 1.8865 & 1.8000 & 0.88 & 3.5000 & 0.2800 \\
\hline 75 & 2.2360 & 2.2000 & 0.88 & 7.3000 & 1.0000 \\
\hline 1 & 3.0000 & 3.0000 & $\cdot$ & 3.0000 & 3.0000 \\
\hline 20 & 3.5000 & 3.0000 & 1.40 & 8.0000 & 3.0000 \\
\hline 74 & 11.1662 & 11.0000 & 3.63 & 24.0000 & 1.0000 \\
\hline 75 & 0.1703 & 0.1900 & 0.10 & 0.4700 & 0.0100 \\
\hline 75 & 17.4800 & 16.0000 & 6.53 & 37.0000 & 8.0000 \\
\hline 75 & 23.1200 & 20.0000 & 13.04 & 74.0000 & 6.0000 \\
\hline 19 & 3.5053 & 1.2000 & 3.69 & 13.0000 & 1.0000 \\
\hline 17 & 0.8529 & 0.4000 & 1.02 & 3.3000 & 0.1000 \\
\hline
\end{tabular}




\section{Søndersø (15.11)}

\begin{tabular}{|c|c|c|c|c|c|c|c|}
\hline Stof navn & Enhed & Antal & Gens & Median & Spredning & Maximum & Mininum \\
\hline Kondukt iv itet & MSIEMENS/M & 39 & 61.7179 & 62.0000 & 6.72 & 89.0000 & 51.0000 \\
\hline pH & PH & 39 & 7.3821 & 7.3000 & 0.17 & 7.7000 & 7.1000 \\
\hline Terstof, total & $M G / L$ & 39 & 520.8974 & 400.0000 & 372.57 & 2150.0000 & 310.0000 \\
\hline Oxygen indhold & $M G / L$ & 20 & 3.4605 & 1.6450 & 4.83 & 20.0000 & 0.1900 \\
\hline Hydrogencarbonat & MG/L & 39 & 315.1795 & 323.0000 & 30.27 & 383.0000 & 265.0000 \\
\hline Perwanganatta $\mathrm{KMnO4}$ & $M G / L$ & 39 & 6.4359 & 5.0000 & 4.92 & 26.0000 & 2.0000 \\
\hline Anmon lak +asmon lum & $M G / L$ & 39 & 0.4997 & 0.2300 & 0.81 & 3.8000 & 0.0100 \\
\hline Nitrit & $M G / L$ & 39 & 0.0279 & 0.0100 & 0.08 & 0.5000 & 0.0100 \\
\hline Nitrat & $M G / L$ & 39 & 0.9282 & 0.5000 & 2.64 & 17.0000 & 0.5000 \\
\hline Phosph., tot.f1lt P04 & $M G / L$ & 39 & 0.3892 & 0.3066 & 0.34 & 1.6251 & 0.0307 \\
\hline Calc tum & $M G / L$ & 39 & 92.9231 & 93.0000 & 8.46 & 112.0000 & 72.0000 \\
\hline Chlorid & MG/L & 39 & 27.8462 & 27.0000 & 10.90 & 57.0000 & 16.0000 \\
\hline Fluorid & $M G / L$ & 39 & 0.3897 & 0.4000 & 0.11 & 0.7100 & 0.2200 \\
\hline Jern & $M G / L$ & 39 & 5.4669 & 1.7000 & 12.43 & 56.0000 & 0.4500 \\
\hline Kal1um & $M G / L$ & 39 & 4.4590 & 2.8000 & 5.85 & 30.0000 & 1.5000 \\
\hline Magnes fum & $M G / L$ & 39 & 11.0538 & 11.0000 & 4.04 & 23.0000 & 2.4000 \\
\hline Mangan & $M G / L$ & 39 & 0.2164 & 0.2000 & 0.13 & 0.5800 & 0.0100 \\
\hline Natrfum & $M G / L$ & 39 & 20.7128 & 19.0000 & 10.72 & 66.0000 & 9.8000 \\
\hline Sulfat & $M G / L$ & 39 & 30.0256 & 22.0000 & 20.34 & 83.0000 & 14.0000 \\
\hline Methan & $M G / L$ & 2 & 0.9000 & 0.9000 & 0.00 & 0.9000 & 0.9000 \\
\hline
\end{tabular}

\section{Københavns Amt Grundvandsanalyser, 1989}

0.00 


\section{Ishøj (15.12)}

\begin{tabular}{|c|c|}
\hline Stof navn & Enhed \\
\hline Kondukt fvitet & MSIEMENS/M \\
\hline $\mathrm{pH}$ & PH \\
\hline Torstof, total & $M G / L$ \\
\hline Oxygen indhold & $M G / L$ \\
\hline Hydrogencarbonat & $M G / L$ \\
\hline Permanganattal KMnO4 & $M G / L$ \\
\hline Ammon tak +ammon ium & $M G / L$ \\
\hline Witrit & $\mathrm{HG} / \mathrm{L}$ \\
\hline Nitrat & $M G / L$ \\
\hline Phosph., tot.f11t PO4 & MG/L \\
\hline Calctun & $M G / L$ \\
\hline Chlorid & $M G / L$ \\
\hline Fluorid & MG/L \\
\hline Jern & $M G / L$ \\
\hline Kalium & MG/L \\
\hline Magnesiun & $M G / L$ \\
\hline Mangan & $M G / L$ \\
\hline Matrium & $M G / L$ \\
\hline Sulfat & $M G / L$ \\
\hline Trit 1um & T.U. \\
\hline Methan & $M G / L$ \\
\hline
\end{tabular}

\section{Københavns Amt Grundvandsanalyser, 1990}

$\begin{array}{rrrrrrr}\text { Antal } & \text { Gens } & \text { Medtan } & \text { Spredning } & \text { Maximum } & \text { Minimum } \\ & & & & & & \\ 41 & 109.5610 & 85.0000 & 66.26 & 336.0000 & 68.0000 & \\ 41 & 7.5195 & 7.5000 & 0.16 & 7.9000 & 7.1000 & \\ 39 & 696.3333 & 473.0000 & 527.17 & 2520.0000 & 355.0000 & \\ 31 & 1.2677 & 0.7000 & 1.78 & 9.3000 & 0.2000 & \\ 41 & 390.6585 & 388.0000 & 55.85 & 467.0000 & 263.0000 & \\ 40 & 6.6750 & 7.0000 & 2.07 & 15.0000 & 3.0000 & \\ 41 & 0.6890 & 0.6200 & 0.41 & 1.5000 & 0.0100 & \text { DG } \\ 41 & 0.0322 & 0.0200 & 0.03 & 0.1200 & 0.0100 & 06 \\ 39 & 0.6718 & 0.5000 & 0.50 & 2.7000 & 0.5000 & \\ 41 & 0.2064 & 0.0920 & 0.24 & 1.0118 & 0.0307 & \\ 41 & 131.3415 & 100.0000 & 94.02 & 479.0000 & 59.0000 & \\ 41 & 127.6585 & 61.0000 & 204.79 & 970.0000 & 20.0000 & \\ 41 & 1.1895 & 0.8300 & 0.87 & 2.8000 & 0.3200 & \\ 41 & 1.9841 & 0.9000 & 3.01 & 15.1000 * & 0.0100 & \\ 41 & 4.9927 & 4.7000 & 2.05 & 10.0000 & 2.6000 & \\ 41 & 30.0390 & 25.0000 & 15.41 & 67.0000 & 6.8000 & \\ 40 & 0.1640 & 0.1200 & 0.17 & 0.6700 & 0.0100 & 06 \\ 41 & 49.3659 & 29.0000 & 46.95 & 223.0000 & 13.0000 & \\ 39 & 51.6667 & 41.0000 & 41.80 & 186.0000 & 10.0000 & \\ 13 & 12.7385 & 10.0000 & 11.13 & 33.0000 & 1.0000 & \\ 5 & 0.1400 & 0.1000 & 0.05 & 0.2000 & 0.1000 & \end{array}$


Ishøj (15.12)

\begin{tabular}{|c|c|}
\hline Stof navn & Enhed \\
\hline Kondukt Ivitet & MSIEMENS/ \\
\hline pH & PH \\
\hline Torstof, total & $M G / L$ \\
\hline Oxygen Indhold & $M G / L$ \\
\hline Hydrogencarbonat & $M G / L$ \\
\hline Permanganatta $1 \mathrm{KMnO4}$ & $\mathrm{MG} / \mathrm{L}$ \\
\hline 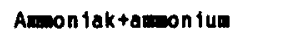 & $M G / L$ \\
\hline Nitrit & MG/L \\
\hline Nitrat & $M G / L$ \\
\hline Phosph., tot. fflt P04 & MG/L \\
\hline Calc ium & $\mathrm{MG} / \mathrm{L}$ \\
\hline Chlorid & $\mathrm{MG} / \mathrm{L}$ \\
\hline Fluorid & $M G / L$ \\
\hline Jern & $\mathrm{MG} / \mathrm{L}$ \\
\hline Kal ium & $M G / L$ \\
\hline Magnestum & $M G / L$ \\
\hline Mengan & $M G / L$ \\
\hline Natr lum & MG/L \\
\hline Sulfat & $M G / L$ \\
\hline Hydrogensu if 10 & MG/L \\
\hline Methan & $M G / L$ \\
\hline
\end{tabular}

Københavns Amt Grundvandsanalyser, 1989

\begin{tabular}{|c|c|c|c|c|c|}
\hline Anta 1 & Gens & Median & Spredning & Max Imum & MIn imum \\
\hline 34 & 101.9412 & 89.5000 & 50.98 & 246.0000 & 57.0000 \\
\hline 34 & 7.4412 & 7.4000 & 0.24 & 8.0000 & 7.0000 \\
\hline 34 & 1536.6176 & 955.0000 & 1344.54 & 5590.0000 & 350.0000 \\
\hline 20 & 3.2075 & 1.0000 & 4.65 & 17.0000 & 0.3800 \\
\hline 33 & 444.6364 & 408.0000 & 158.19 & 957.0000 & 310.0000 \\
\hline 34 & 10.5882 & 6.0000 & 14.94 & 85.0000 & 3.0000 \\
\hline 34 & 0.7715 & 0.7200 & 0.37 & 1.7000 & 0.1700 \\
\hline 33 & 0.0221 & 0.0100 & 0.02 & 0.1000 & 0.0100 \\
\hline 34 & 0.6265 & 0.5000 & 0.38 & 2.4000 & 0.5000 \\
\hline 34 & 0.9361 & 0.2300 & 2.87 & 16.8641 & 0.0307 \\
\hline 34 & 119.2059 & 93.0000 & 74.58 & 394.0000 & 49.0000 \\
\hline 34 & 111.0882 & 55.5000 & 162.44 & 597.0000 & 16.0000 \\
\hline 34 & 1.5350 & 0.9800 & 1.21 & 5.5000 & 0.4000 \\
\hline 34 & 3.8482 & 1.1500 & 6.96 & $29.0000^{*}$ & 0.0300 \\
\hline 34 & 8.1412 & 7.6000 & 4.20 & 25.0000 & 3.4000 \\
\hline 34 & 31.3500 & 30.5000 & 15.70 & 71.0000 & 1.0000 \\
\hline 34 & 0.5412 & 0.1300 & 1.87 & 11.0000 & 0.0100 \\
\hline 34 & 57.7941 & 37.5000 & 56.54 & 223.0000 & 13.0000 \\
\hline 34 & 62.3529 & 53.5000 & 53.89 & 229.0000 & 7.0000 \\
\hline 4 & 0.1000 & 0.1000 & 0.00 & 0.1000 & 0.1000 \\
\hline 3 & 0.1000 & 0.1000 & 0.00 & 0.1000 & 0.1000 \\
\hline
\end{tabular}

* Særlig usædvanlig værdi, der må kontrolleres. 
Gladsaxe (15.13)

\begin{tabular}{|c|c|}
\hline Stof navn & Enhed \\
\hline Kondukt Ivitet & MSIEMENS/M \\
\hline pH & PH \\
\hline Torstof, total & $M G / L$ \\
\hline Oxygen indmolo & $M G / L$ \\
\hline Hydrogencarbonat & MG/L \\
\hline Permanganatta 1 KMnO4 & $M G / L$ \\
\hline Armon laktanmon ium & $M G / L$ \\
\hline N1trit & $M G / L$ \\
\hline Nitrat & $M G / L$ \\
\hline Phosph.,tot.filt P04 & $M G / L$ \\
\hline Calcium & $M G / L$ \\
\hline Chlorid & $M G / L$ \\
\hline F luor id & $M G / L$ \\
\hline Jern & $M G / L$ \\
\hline Kalium & $M G / L$ \\
\hline Magnes ium & $M G / L$ \\
\hline Mangan & $M G / L$ \\
\hline Natrium & $M G / L$ \\
\hline Sulfat & $M G / L$ \\
\hline Trit fum & T.U. \\
\hline Methan & $M G / L$ \\
\hline
\end{tabular}

\section{Københavns Amt Grundvandsanalyser, 1990}

$\begin{array}{rrrrrrr}\text { Antal } & \text { Gens } & \text { Median } & \text { Spredning } & \text { Max 1mum } & \text { M1nimum } \\ 73 & 89.6712 & 74.0000 & 40.43 & 214.0000 & 59.0000 & \\ 73 & 7.5055 & 7.5000 & 0.20 & 7.9000 & 7.0000 & \\ 73 & 637.1233 & 502.0000 & 340.48 & 1649.0000 & 321.0000 & \\ 65 & 2.2492 & 1.2000 & 2.35 & 9.0000 & 0.1000 & \\ 73 & 330.8767 & 310.0000 & 90.07 & 631.0000 & 229.0000 & \\ 73 & 6.4247 & 4.0000 & 6.21 & 30.0000 & 1.0000 & \\ 73 & 0.1395 & 0.0500 & 0.19 & 0.6700 & 0.0100 & 06 \\ 66 & 0.0588 & 0.0100 & 0.19 & 1.4900 & 0.0100 & 06 \\ 73 & 6.1438 & 0.5000 & 13.46 & 54.0000 & 0.5000 & \\ 73 & 0.0979 & 0.0613 & 0.08 & 0.3679 & 0.0307 & \\ 73 & 160.1233 & 139.0000 & 75.26 & 372.0000 & 60.0000 & \\ 73 & 57.2877 & 27.0000 & 72.72 & 365.0000 & 13.0000 & \\ 73 & 0.3690 & 0.2500 & 0.45 & 2.4000 & 0.0100 * & \\ 73 & 1.5092 & 0.6600 & 2.07 & 8.2000 & 0.0100 & \\ 73 & 2.3260 & 2.3000 & 0.92 & 5.7000 & 0.8000 & \\ 73 & 15.7534 & 12.0000 & 10.83 & 76.0000 & 6.0000 & \\ 73 & 0.2370 & 0.1700 & 0.26 & 1.4000 & 0.0100 & 06 \\ 73 & 21.7603 & 14.0000 & 21.72 & 93.0000 & 6.0000 & \\ 73 & 126.5342 & 121.0000 & 90.74 & 383.0000 & 8.0000 & \\ 16 & 12.9000 & 7.0000 & 14.27 & 50.0000 & 1.0000 & \\ 3 & 0.3333 & 0.3000 & 0.06 & 0.4000 & 0.3000 & \end{array}$

* Særlig usædvanlig værdi, der må kontrolleres. 
Gladsaxe (15.13)

\begin{tabular}{|c|c|}
\hline Stof navn & Enhed \\
\hline Kondukt ivitet & MSIEMENS/M \\
\hline $\mathrm{pH}$ & PH \\
\hline Torstof, total & $M G / L$ \\
\hline Oxygen tndhold & $M G / L$ \\
\hline Hydrogencarbonat & $M G / L$ \\
\hline Permanganattal $\mathrm{KMnO4}$ & $M G / L$ \\
\hline Ammon iak +ammon fua & $M G / L$ \\
\hline Nitrit & MG/L \\
\hline Nitrat & $M G / L$ \\
\hline Phosph.,tot.f11t P04 & $M G / L$ \\
\hline Calc lum & $M G / L$ \\
\hline Chlorid & $M G / L$ \\
\hline F luorid & $\mathrm{MG} / \mathrm{L}$ \\
\hline Jern & MG/L \\
\hline Ka Ilum & $M G / L$ \\
\hline Magnesiun & $M G / L$ \\
\hline Mangan & $M G / L$ \\
\hline Natrium & $M G / L$ \\
\hline Sulfat & $M G / L$ \\
\hline Hydrogensulf id & $M G / L$ \\
\hline Methan & $M G / L$ \\
\hline
\end{tabular}

Københavns Amt Grundvandsanalyser, 1989

$\begin{array}{rrrrrrr}\text { Antal } & \text { Gens } & \text { Median } & \text { Spredning } & \text { Maximua } & \text { Min 1mum } \\ 31 & 94.1935 & 78.0000 & 43.20 & 200.0000 & 60.0000 & \\ 31 & 7.4032 & 7.4000 & 0.23 & 7.7000 & 6.7000 & \\ 31 & 1082.9032 & 730.0000 & 1148.16 & 5590.0000 & 390.0000 & \\ 24 & 4.2971 & 4.0000 & 3.33 & 12.1000 & 0.1000 & \\ 31 & 363.0323 & 334.0000 & 90.43 & 602.0000 & 234.0000 & \\ 31 & 7.7742 & 6.0000 & 6.52 & 24.0000 & 2.0000 & \\ 31 & 0.1603 & 0.0900 & 0.18 & 0.5800 & 0.0100 & 0 G \\ 31 & 0.0406 & 0.0100 & 0.06 & 0.2500 & 0.0100 & 0 G \\ 31 & 5.7968 & 0.5000 & 10.75 & 42.0000 & 0.5000 & \\ 31 & 0.2473 & 0.1226 & 0.27 & 1.0732 & 0.0307 & \\ 31 & 139.2903 & 114.0000 & 78.19 & 342.0000 & 46.0000 & \\ 31 & 57.4516 & 28.0000 & 73.01 & 292.0000 & 13.0000 & \\ 31 & 0.3587 & 0.2200 & 0.49 & 2.2500 & 0.1000 & \\ 31 & 2.8365 & 1.1000 & 3.42 & 14.0000 & 0.0400 & \\ 31 & 3.4903 & 2.9000 & 2.07 & 12.0000 & 1.2000 & \\ 31 & 14.7742 & 12.5000 & 7.13 & 37.0000 & 3.0000 & \\ 31 & 0.3087 & 0.3000 & 0.23 & 1.2000 & 0.0100 & 0 G \\ 31 & 33.4516 & 15.0000 & 45.08 & 213.0000 & 9.0000 & \\ 31 & 137.0968 & 126.0000 & 97.28 & 354.0000 & 12.0000 & \\ 2 & 0.1500 & 0.1500 & 0.07 & 0.2000 & 0.1000 & \\ 2 & 0.2500 & 0.2500 & 0.07 & 0.3000 & 0.2000 & \end{array}$


Ishøj (15.14)

$\begin{array}{ll}\text { Stof navn } & \text { Enhed } \\ \text { Kondukt ivitet } & M S I E M E M S / M \\ \text { pH } & P H \\ \text { Torstof, total } & M G / L \\ \text { Oxygen indnold } & M G / L \\ \text { Hydrogencaroonat } & M G / L \\ \text { Permanganattal KMnO4 } & M G / L \\ \text { Ammoniaktainonium } & M G / L \\ \text { Nitrit } & M G / L \\ \text { Nitrat } & M G / L \\ \text { Phosph..tot.filt PO4 } & M G / L \\ \text { Calcium } & M G / L \\ \text { Chlorid } & M G / L \\ \text { Fluorid } & M G / L \\ \text { Jern } & M G / L \\ \text { Kalium } & M G / L \\ \text { Magnesium } & M G / L \\ \text { Mangan } & M G / L \\ \text { Natrium } & M G / L \\ \text { Sulfat } & M G / L \\ & \end{array}$

Københavns Amt Grundvandsanalyser, 1990

$\begin{array}{rrrrrr}\text { Antal } & \text { Gens } & \text { Median } & \text { Spredning } & \text { Maximum } & \text { Minimum } \\ 3 & 89.3333 & 88.0000 & 11.06 & 101.0000 & 79.0000 \\ 3 & 7.3333 & 7.3000 & 0.06 & 7.4000 & 7.3000 \\ 1 & 579.0000 & 579.0000 & . & 579.0000 & 579.0000 \\ 2 & 0.2000 & 0.2000 & 0.00 & 0.2000 & 0.2000 \\ 3 & 369.0000 & 368.0000 & 21.52 & 391.0000 & 348.0000 \\ 3 & 6.3333 & 6.0000 & 0.58 & 7.0000 & 6.0000 \\ 3 & 0.8133 & 0.9600 & 0.29 & 1.0000 & 0.4800 \\ 3 & 0.0267 & 0.0300 & 0.02 & 0.0400 & 0.0100 \\ 3 & 0.5000 & 0.5000 & 0.00 & 0.5000 & 0.5000 \\ 3 & 0.5315 & 0.5213 & 0.51 & 1.0425 & 0.0307 \\ 3 & 109.3333 & 104.0000 & 23.46 & 135.0000 & 89.0000 \\ 3 & 56.6667 & 60.0000 & 8.50 & 63.0000 & 47.0000 \\ 3 & 0.5767 & 0.6000 & 0.07 & 0.6300 & 0.5000 \\ 3 & 5.1333 & 4.5000 & 2.51 & 7.9000 & 3.0000 \\ 3 & 4.5333 & 4.8000 & 0.64 & 5.0000 & 3.8000 \\ 3 & 21.3333 & 23.0000 & 4.73 & 25.0000 & 16.0000 \\ 3 & 0.1067 & 0.1100 & 0.06 & 0.1600 & 0.0500 \\ 3 & 25.3333 & 26.0000 & 2.08 & 27.0000 & 23.0000 \\ 3 & 57.6667 & 29.0000 & 51.39 & 117.0000 & 27.0000 \\ & & & & & \end{array}$


Endrup (20.01)

\begin{tabular}{|c|c|}
\hline Stof navn & Enhed \\
\hline Kondukt ivitet & MSIEMENS/M \\
\hline pH & PH \\
\hline Tarstof, total & $M G / 1$ \\
\hline Oxygen indhold & $M G / L$ \\
\hline Hydrogencarbonat & $M G / L$ \\
\hline Perwanganattal $\mathrm{KMnO} 4$ & $M G / L$ \\
\hline Amon tak tamaon fum & $M G / L$ \\
\hline N1trit & $M G / L$ \\
\hline Nitrat & $M G / L$ \\
\hline Orthophosphat -P04 & MG/L \\
\hline Phosph., tot.f11t P04 & $M G / L$ \\
\hline Calcium & $M G / L$ \\
\hline Chlorid & $M G / L$ \\
\hline Fluortd & $M G / L$ \\
\hline Jern & $H G / L$ \\
\hline Jern ferro & $M G / L$ \\
\hline Kallium & $M G / L$ \\
\hline Magnesiun & $M G / L$ \\
\hline Mangan & $M G / L$ \\
\hline Natrium & $M G / L$ \\
\hline Sulfat & $M G / L$ \\
\hline Methan & $M G / L$ \\
\hline
\end{tabular}

\section{Frederiksborg Amt Grundvandsanalyser, 1990}

\begin{tabular}{|c|c|c|c|c|c|}
\hline Antal & Gens & Medion & Spredning & Maxtmum & Mintmuta \\
\hline 32 & 69.6250 & 61.5000 & 14.42 & 114.0000 & 56.0000 \\
\hline 32 & 7.4938 & 7.4000 & 0.24 & 8.0000 & 7.1000 \\
\hline 33 & 414.5152 & 363.0000 & 97.10 & 775.0000 & 327.0000 \\
\hline 9 & 0.3444 & 0.1000 & 0.52 & 1.6000 & 0.1000 \\
\hline 33 & 374.6970 & 353.0000 & 63.65 & 519.0000 & 285.0000 \\
\hline 33 & 11.0667 & 11.0000 & 3.05 & 16.0000 & 2.1000 \\
\hline 33 & 0.8339 & 0.8100 & 0.37 & 1.6100 & 0.0300 \\
\hline 33 & 0.0124 & 0.0100 & 0.01 & 0.0300 & 0.0100 \\
\hline 33 & 2.8333 & 0.5000 & 13.31 & 77.0000 & 0.5000 \\
\hline 17 & 0.7500 & 0.8400 & 0.49 & 1.4400 & 0.0300 \\
\hline 33 & 0.7619 & 0.8279 & 0.47 & 1.5638 & 0.0613 \\
\hline 33 & 103.2121 & 96.0000 & 24.07 & 190.0000 & 68.0000 \\
\hline 33 & 29.0909 & 22.0000 & 13.79 & 51.0000 & 13.0000 \\
\hline 33 & 0.2697 & 0.3000 & 0.05 & 0.3000 & 0.2000 \\
\hline 33 & 3.7036 & 3.8000 & 2.03 & 12.0000 & 0.0200 \\
\hline 33 & 3.7036 & 3.8000 & 2.03 & 12.0000 & 0.0200 \\
\hline 33 & 2.6939 & 2.6000 & 0.74 & 4.9000 & 1.5000 \\
\hline 33 & 11.0303 & 11.0000 & 3.17 & 17.0000 & 6.0000 \\
\hline 33 & 0.2764 & 0.2200 & 0.14 & 0.7900 & 0.0800 \\
\hline 32 & 23.9688 & 23.0000 & 9.64 & 43.0000 & 12.0000 \\
\hline 33 & 18.5152 & 7.0000 & 26.68 & 110.0000 & 5.0000 \\
\hline 12 & 1.5417 & 0.8000 & 1.92 & 5.6000 & 0.1000 \\
\hline
\end{tabular}




\section{Endrup (20.01)}

\begin{tabular}{|c|c|}
\hline Stof navn & Enhed \\
\hline Kondukt ivitet & MSIEMENS/M \\
\hline $\mathrm{pH}$ & $\mathrm{PH}$ \\
\hline Torstof, total & $M G / L$ \\
\hline Oxygen indhold & MG/L \\
\hline Hydrogencarbonat & $M G / L$ \\
\hline Permanganatta $1 \mathrm{KMnO4}$ & $M G / L$ \\
\hline Ammon laktamon ium & MG/L \\
\hline Nitrit & $M G / L$ \\
\hline Nitrat & $M G / L$ \\
\hline Orthophosphat-P04 & $M G / L$ \\
\hline Phosph.,tot.f11t PO4 & $M G / L$ \\
\hline Calcium & $M G / L$ \\
\hline Ch lorid & $M G / L$ \\
\hline Fluor to & $M G / L$ \\
\hline Jern & $M G / L$ \\
\hline Jern ferro & $M G / L$ \\
\hline Kalluin & $M G / L$ \\
\hline Magnestum & $M G / L$ \\
\hline Mangan & $M G / L$ \\
\hline Natr fum & $M G / L$ \\
\hline Sulfat & $M G / L$ \\
\hline Hydrogensu if id & $M G / L$ \\
\hline Methan & $M G / L$ \\
\hline
\end{tabular}

Frederiksborg Amt Grundvandsanalyser, 1989

$\begin{array}{rrrrrr}\text { Antal } & \text { Gens } & \text { Median } & \text { Spredning } & \text { Max 1mum } & \text { Min Imum } \\ 11 & 72.0000 & 73.0000 & 14.84 & 95.0000 & 56.0000 \\ 10 & 7.3500 & 7.3500 & 0.20 & 7.8000 & 7.1000 \\ 11 & 416.0909 & 396.0000 & 85.59 & 548.0000 & 337.0000 \\ 5 & 1.2000 & 0.9000 & 0.88 & 2.1000 & 0.1000 \\ 11 & 392.0000 & 376.0000 & 81.20 & 537.0000 & 290.0000 \\ 11 & 12.3273 & 12.0000 & 2.35 & 16.0000 & 8.6000 \\ 11 & 0.8855 & 0.9400 & 0.40 & 1.5100 & 0.3800 \\ 11 & 0.0164 & 0.0100 & 0.01 & 0.0300 & 0.0100 \\ 11 & 0.6091 & 0.5000 & 0.24 & 1.3000 & 0.5000 \\ 10 & 0.3970 & 0.2750 & 0.45 & 1.4400 & 0.0300 \\ 10 & 0.5642 & 0.3986 & 0.54 & 1.5331 & 0.0307 \\ 11 & 107.3636 & 100.0000 & 21.50 & 150.0000 & 78.0000 \\ 11 & 31.0000 & 37.0000 & 14.31 & 47.0000 & 13.0000 \\ 11 & 0.2909 & 0.3000 & 0.03 & 0.3000 & 0.2000 \\ 11 & 2.7818 & 3.8000 & 1.93 & 4.9000 & 0.0200 \\ 11 & 2.7818 & 3.8000 & 1.93 & 4.9000 & 0.0200 \\ 11 & 2.9727 & 2.9000 & 0.93 & 4.0000 & 1.1000 \\ 11 & 11.7273 & 13.0000 & 4.03 & 17.0000 & 4.0000 \\ 11 & 0.3664 & 0.2500 & 0.32 & 1.3000 & 0.1500 \\ 11 & 27.0909 & 28.0000 & 9.41 & 41.0000 & 15.0000 \\ 11 & 14.7273 & 11.0000 & 11.36 & 34.0000 & 5.0000 \\ 1 & 0.1000 & 0.1000 & . & 0.1000 & 0.1000 \\ 8 & 1.9625 & 1.0500 & 1.98 & 5.2000 & 0.2000\end{array}$


Skuldelev (20.11)

\begin{tabular}{|c|c|}
\hline Stof navn & Enhed \\
\hline Kondukt Ivitet & MSIEMENS/M \\
\hline PH & PH \\
\hline Terstof, total & $M G / L$ \\
\hline Oxygen indhold & $M G / L$ \\
\hline Hydrogencarbonat & $M G / L$ \\
\hline Permanganatta $1 \mathrm{KMnO4}$ & $M G / L$ \\
\hline Ammo n fak tamenon fun & $M G / L$ \\
\hline Nitrtt & $M G / L$ \\
\hline Nitrat & $\mathrm{MG} / \mathrm{L}$ \\
\hline Orthophosphat-P04 & $M G / L$ \\
\hline Phosph., tot.f11t PO4 & $M G / L$ \\
\hline Calctum & $M G / L$ \\
\hline Chlorid & $M G / L$ \\
\hline Fluor id & $M G / L$ \\
\hline Jern & $M G / L$ \\
\hline Jern ferro & $M G / L$ \\
\hline Kaltua & $M G / L$ \\
\hline Magnes 1um & $M G / L$ \\
\hline Mangan & $M G / L$ \\
\hline Natrifue & $M G / L$ \\
\hline Sulf at & $M G / L$ \\
\hline Trit lum & T.U. \\
\hline
\end{tabular}

\section{Frederiksborg Amt Grundvandsanalyser, 1990}

\begin{tabular}{|c|c|c|c|c|c|}
\hline Antal & Gens & Median & Spredning & Max $\operatorname{man}$ & Mintmula \\
\hline 58 & 71.7172 & 68.0000 & 13.04 & 103.0000 & 53.0000 \\
\hline 44 & 7.5250 & 7.4000 & 0.20 & 7.9000 & 7.1000 \\
\hline 58 & 478.1034 & 456.5000 & 125.96 & 851.0000 & 291.0000 \\
\hline 35 & 1.4629 & 0.4000 & 2.54 & 8.2000 & 0.1000 \\
\hline 58 & 297.0000 & 301.0000 & 46.47 & 414.0000 & 178.0000 \\
\hline 59 & 3.3288 & 3.2000 & 0.95 & 5.6000 & 1.4000 \\
\hline 59 & 0.0571 & 0.0300 & 0.05 & 0.2400 & 0.0100 \\
\hline 58 & 0.0698 & 0.0100 & 0.12 & 0.4300 & 0.0100 \\
\hline 57 & 12.8298 & 3.7000 & 17.22 & 56.0000 & 0.5000 \\
\hline 30 & 0.0650 & 0.0600 & 0.05 & 0.2400 & 0.0300 \\
\hline 59 & 0.0717 & 0.0613 & 0.06 & 0.3986 & 0.0307 \\
\hline 59 & 118.1186 & 110.0000 & 23.45 & 160.0000 & 85.0000 \\
\hline 59 & 40.0847 & 27.0000 & 34.01 & 181.0000 & 11.0000 \\
\hline 59 & 0.1966 & 0.2000 & 0.06 & 0.3000 & 0.1000 \\
\hline 59 & 0.6819 & 0.2800 & 0.76 & 2.8000 & 0.0200 \\
\hline 59 & 0.6819 & 0.2800 & 0.76 & 2.8000 & 0.0200 \\
\hline 59 & 4.1424 & 1.7000 & 4.82 & 15.0000 & 0.9000 \\
\hline 59 & 9.0169 & 9.0000 & 2.50 & 13.0000 & 3.0000 \\
\hline 58 & 0.0879 & 0.0900 & 0.05 & 0.2000 & 0.0200 \\
\hline 59 & 15.7746 & 13.0000 & 12.98 & 69.0000 & 7.8000 \\
\hline 59 & 57.4576 & 53.0000 & 26.85 & 132.0000 & 22.0000 \\
\hline 13 & 15.6077 & 10.0000 & 15.52 & 54.0000 & 2.5000 \\
\hline
\end{tabular}


Skuldelev (20.11)

\begin{tabular}{|c|c|}
\hline Stof navn & Enhed \\
\hline Kondukt ivitet & MSIEMENS/M \\
\hline $\mathrm{PH}$ & PH \\
\hline Terstof, total & $M G / L$ \\
\hline Oxygen Indhold & $M G / L$ \\
\hline Hydrogencarbonat & $M G / L$ \\
\hline Permanganattal KMnO4 & $\mathrm{MG} / \mathrm{L}$ \\
\hline Amson faktalnon ium & $M G / L$ \\
\hline Nitrit & $M G / L$ \\
\hline Nitrat & $M G / L$ \\
\hline Orthophosphat-P04 & $M G / L$ \\
\hline Phosph., tot.P1lt P04 & $M G / L$ \\
\hline Calctum & $M G / L$ \\
\hline Chlorid & $M G / L$ \\
\hline Fluorid & $M G / L$ \\
\hline Jern & $M G / L$ \\
\hline Jern ferro & $M G / L$ \\
\hline Kalium & $M G / L$ \\
\hline Kriksolv & MANOGRAM/L \\
\hline Magnes ius & $M G / L$ \\
\hline Mangan & $M G / L$ \\
\hline Natr quil & $M G / L$ \\
\hline Sulfat & $M G / L$ \\
\hline
\end{tabular}

Frederiksborg Amt Grundvandsanalyser, 1989

$\begin{array}{rrrrrrr}\text { Antal } & \text { Gens } & \text { Medtan } & \text { Spredning } & \text { Maximum } & \text { Min 1mum } & \\ & & & & & & \\ 42 & 74.2429 & 72.8500 & 14.99 & 105.0000 & 54.1000 & \\ 41 & 7.4902 & 7.5000 & 0.19 & 7.8000 & 7.0000 & \\ 45 & 496.6222 & 486.0000 & 114.98 & 720.0000 & 324.0000 & \\ 35 & 1.7571 & 0.4000 & 2.50 & 7.4000 & 0.1000 & \text { DG } \\ 43 & 294.7442 & 299.0000 & 50.50 & 411.0000 & 179.0000 & \\ 43 & 4.0442 & 3.5000 & 2.23 & 13.0000 & 1.3000 & \\ 43 & 0.0533 & 0.0300 & 0.05 & 0.2100 & 0.0100 & \text { DG } \\ 45 & 0.1342 & 0.0100 & 0.21 & 0.7500 & 0.0100 & \text { DG } \\ 43 & 15.1512 & 11.0000 & 13.77 & 45.0000 & 0.5000 & \\ 26 & 0.0769 & 0.0600 & 0.08 & 0.3100 & 0.0300 & \\ 45 & 0.0831 & 0.0613 & 0.05 & 0.2146 & 0.0307 & \\ 43 & 126.3256 & 130.0000 & 24.03 & 162.0000 & 90.0000 & \\ 43 & 50.1860 & 32.0000 & 47.30 & 188.0000 & 11.0000 & \\ 43 & 0.1816 & 0.2000 & 0.07 & 0.3000 & 0.0100 & \\ 43 & 0.5012 & 0.2600 & 0.61 & 2.1200 & 0.0200 & \\ 27 & 0.4767 & 0.0900 & 0.65 & 2.1000 & 0.0200 & \\ 43 & 3.2953 & 1.8000 & 3.86 & 16.0000 & 1.0000 & \\ 5 & 3.4000 & 3.0000 & 0.55 & 4.0000 & 3.0000 & 0 G \\ 43 & 9.2326 & 9.0000 & 3.26 & 15.0000 & 1.0000 & \\ 43 & 0.1230 & 0.1000 & 0.13 & 0.8600 & 0.0200 & \\ 43 & 16.2419 & 14.0000 & 11.30 & 54.0000 & 7.7000 & \\ 43 & 57.0930 & 57.0000 & 24.14 & 114.0000 & 23.0000 & \end{array}$


Asserbo (20.12)

\begin{tabular}{|c|c|c|c|c|c|c|c|}
\hline Stof navn & Enhed & Anta 1 & Gens & Median & Spredning & Max imum & Min1mum \\
\hline Konduxtivitet & MSIEMENS/M & 37 & 55.0270 & 54.0000 & 9.98 & 71.0000 & 31.0000 \\
\hline pH & PH & 34 & 7.6765 & 7.7000 & 0.29 & 8.4000 & 7.1000 \\
\hline Terstof,total & MG/L & 37 & 351.1081 & 349.0000 & 74.58 & 540.0000 & 195.0000 \\
\hline Oxygen indhold & MG/L & 17 & 2.7412 & 2.0000 & 3.41 & 9.0000 & 0.1000 \\
\hline Carbond toxid, aggr. & MG/L & 4 & 6.5000 & 6.5000 & 2.89 & 10.0000 & 3.0000 \\
\hline Hydrogencaroonat & MG/L & 37 & 183.5135 & 179.0000 & 55.41 & 292.0000 & 92.0000 \\
\hline Permanganatta 1 KMnO4 & $M G / L$ & 37 & 5.9784 & 4.8000 & 5.08 & 22.0000 & 1.0000 \\
\hline Ammon tak tarson fum & MG/L & 35 & 0.1143 & 0.0500 & 0.14 & 0.5200 & 0.0100 \\
\hline Mitrit & $\mathrm{MG} / \mathrm{L}$ & 37 & 0.0127 & 0.0100 & 0.01 & 0.0500 & 0.0100 \\
\hline Nitrat & MG/L & 37 & 0.6108 & 0.5000 & 0.27 & 1.6000 & 0.5000 \\
\hline Orthophosphat-P04 & MG/L & 18 & 0.1483 & 0.1050 & 0.11 & 0.3600 & 0.0300 \\
\hline Phosph..tot.f1lt P04 & MG/L & 37 & 0.1558 & 0.1226 & 0.11 & 0.3986 & 0.0307 \\
\hline Calc tum & MG/L & 37 & 73.8649 & 71.0000 & 17.25 & 110.0000 & 27.0000 \\
\hline Chlorid & $M G / L$ & 37 & 50.9730 & 47.0000 & 21.05 & 107.0000 & 27.0000 \\
\hline Fluor 1d & MG/L & 37 & 0.1351 & 0.1000 & 0.05 & 0.2000 & 0.1000 \\
\hline Jern & $M G / L$ & 37 & 3.3386 & 0.3700 & 8.14 & 27.0000 & 0.0200 \\
\hline Jern ferro & MG/L & 37 & 3.3386 & 0.3700 & 8.14 & 27.0000 & 0.0200 \\
\hline Ka I Yum & MG/L & 37 & 1.4730 & 1.5000 & 0.31 & 1.9000 & 0.8000 \\
\hline Magnesium & $M G / L$ & 37 & 4.4324 & 4.0000 & 0.83 & 6.0000 & 3.0000 \\
\hline Mangan & $M G / L$ & 37 & 0.3559 & 0.2100 & 0.39 & 1.5000 & 0.0200 \\
\hline Matríum & $M G / L$ & 37 & 27.5676 & 25.0000 & 9.67 & 52.0000 & 14.0000 \\
\hline Sulfat & MG/L & 37 & 43.7838 & 42.0000 & 19.11 & 78.0000 & 6.0000 \\
\hline Trit fum & T.U. & 9 & 26.4778 & 25.0000 & 16.20 & 53.0000 & 10.0000 \\
\hline Methan & $M G / L$ & 3 & 0.6333 & 0.5000 & 0.51 & 1.2000 & 0.2000 \\
\hline
\end{tabular}

Frederiksborg Amt Grundvandsanalyser, 1990 
Asserbo (20.12)

\begin{tabular}{|c|c|}
\hline Stof navn & Enhed \\
\hline Kondukt ivitet & MSIEMENS/M \\
\hline pH & PH \\
\hline Terstof, total & MG/L \\
\hline Oxygen indhold & $M G / L$ \\
\hline Carbondioxid, aggr. & $M G / L$ \\
\hline Hydrogencarbonat & $M G / L$ \\
\hline Permanganatta 1 KMnO4 & MG/L \\
\hline Ammon lak tannon fum & $M G / L$ \\
\hline Nitrit & $M G / L$ \\
\hline Nitrat & $\mathrm{MG} / \mathrm{L}$ \\
\hline Orthophosphat-P04 & MG/L \\
\hline Phosph.,tot.ftlt PO4 & MG/L \\
\hline Calc tum & $M G / L$ \\
\hline Chlorid & MG/L \\
\hline Fluorid & $M G / L$ \\
\hline Jern & MG/L \\
\hline Jern ferro & MG/L \\
\hline Kalifum & $M G / L$ \\
\hline Krikselv & NANOGRAM/L \\
\hline Magnes iun & $M G / L$ \\
\hline Mangan & $M G / L$ \\
\hline Natrium & $M G / L$ \\
\hline Sulfat & MG/L \\
\hline Methan & $M G / L$ \\
\hline
\end{tabular}

Frederiksborg Amt Grundvandsanalyser, 1989

\begin{tabular}{|c|c|c|c|c|c|c|}
\hline Anta 1 & Gens & Medtan & Spredning & Maximum & Minfmum & \\
\hline 28 & 49.7107 & 50.3000 & 10.11 & 67.0000 & 28.6000 & \\
\hline 28 & 7.5214 & 7.6000 & 0.38 & 8.0000 & 6.8000 & \\
\hline 31 & 328.7419 & 332.0000 & 66.27 & 449.0000 & 218.0000 & \\
\hline 15 & 2.4067 & 0.7000 & 3.09 & 8.7000 & 0.1000 & \\
\hline 6 & 3.5000 & 1.5000 & 3.73 & 10.0000 & 1.0000 & \\
\hline 29 & 160.4138 & 164.0000 & 52.64 & 268.0000 & 64.0000 & \\
\hline 29 & 9.7069 & 5.8000 & 9.86 & 41.6000 & 1.0000 & \\
\hline 27 & 0.1311 & 0.1000 & 0.13 & 0.5100 & 0.0100 & $D G$ \\
\hline 31 & 0.0113 & 0.0100 & 0.00 & 0.0200 & 0.0100 & DG \\
\hline 29 & 0.6414 & 0.5000 & 0.45 & 2.3000 & 0.5000 & \\
\hline 17 & 0.1706 & 0.1500 & 0.12 & 0.3700 & 0.0300 & \\
\hline 31 & 0.1998 & 0.1533 & 0.12 & 0.4906 & 0.0307 & \\
\hline 28 & 65.8571 & 67.0000 & 21.43 & 110.0000 & 24.0000 & \\
\hline 29 & 47.8966 & 46.0000 & 13.89 & 89.0000 & 30.0000 & \\
\hline 29 & 0.1107 & 0.1000 & 0.04 & 0.2000 & $0.0100^{*}$ & \\
\hline 29 & 6.4541 & 0.7500 & 10.34 & 30.0000 & 0.0200 & \\
\hline 17 & 4.9112 & 0.5300 & 8.94 & 26.0000 & 0.0200 & \\
\hline 29 & 1.7552 & 1.8000 & 0.47 & 2.5000 & 0.8000 & \\
\hline 3 & & & & 3.0000 & 3.0000 & DG \\
\hline 29 & 4.0690 & 4.0000 & 1.22 & 7.0000 & 2.0000 & \\
\hline 29 & 0.8521 & 0.1800 & 1.96 & 10.5000 & 0.0200 & \\
\hline 29 & 25.6552 & 24.0000 & 6.85 & 42.0000 & 15.0000 & \\
\hline 29 & 37.5172 & 39.0000 & 15.35 & 63.0000 & 7.0000 & \\
\hline 3 & 0.7333 & 0.8000 & 0.50 & 1.2000 & 0.2000 & \\
\hline
\end{tabular}

* Særlig usædvanlig værdi, der må kontrolleres. 
Attemose (20.13)

\begin{tabular}{|c|c|}
\hline Stof navn & Enhed \\
\hline Konduxtivitet & MSIEMENS/ \\
\hline pH & PH \\
\hline Torstof, total & $M G / L$ \\
\hline Oxygen indhold & $M G / L$ \\
\hline Hydrogencarbonat & $\mathrm{MG} / \mathrm{L}$ \\
\hline Permanganatta $1 \mathrm{KMnO4}$ & MG/L \\
\hline Anmon lak +ammon lum & $M G / L$ \\
\hline Nitrit & $M G / L$ \\
\hline Nitrat & $M G / L$ \\
\hline Orthophosphat-P04 & $M G / L$ \\
\hline Phosph..tot.f1lt PO4 & $M G / L$ \\
\hline Calcium & $M G / L$ \\
\hline Chlorid & $M G / L$ \\
\hline Fluorid & $M G / L$ \\
\hline Jern & $M G / L$ \\
\hline Jern ferro & $M G / L$ \\
\hline Kalium & $M G / L$ \\
\hline Magnes ium & $M G / L$ \\
\hline Mangan & $M G / L$ \\
\hline Natrium & $M G / L$ \\
\hline Sulfat & $M G / L$ \\
\hline Tritium & T.U. \\
\hline Methan & $M G / L$ \\
\hline
\end{tabular}

Frederiksborg Amt Grundvandsanalyser, 1990

\begin{tabular}{|c|c|c|c|c|c|}
\hline Anta 1 & Gens & Median & Spredning & Max tmum & Min 1mum \\
\hline 48 & 49.7500 . & 49.0000 & 9.04 & 68.0000 & 37.0000 \\
\hline 38 & 7.6158 & 7.6500 & 0.19 & 8.0000 & 7.3000 \\
\hline 48 & 313.6250 & 310.0000 & 65.93 & 431.0000 & 136.0000 \\
\hline 18 & 0.2278 & 0.1000 & 0.21 & 0.8000 & 0.1000 \\
\hline 48 & 258.2083 & 251.5000 & 57.14 & 410.0000 & 196.0000 \\
\hline 48 & 4.4938 & 4.5000 & 1.52 & 7.6000 & 1.7000 \\
\hline 48 & 0.2052 & 0.1550 & 0.14 & 0.6600 & 0.1000 \\
\hline 48 & 0.0106 & 0.0100 & 0.00 & 0.0200 & 0.0100 \\
\hline 48 & 0.5396 & 0.5000 & 0.16 & 1.4000 & 0.5000 \\
\hline 24 & 0.3538 & 0.2250 & 0.29 & 1.1100 & 0.0600 \\
\hline 45 & 0.3584 & 0.2146 & 0.31 & 1.2571 & 0.0307 \\
\hline 48 & 83.1875 & 81.5000 & 14.92 & 110.0000 & 62.0000 \\
\hline 48 & 16.5625 & 17.0000 & 4.53 & 28.0000 & 10.0000 \\
\hline 48 & 0.2521 & 0.2500 & 0.05 & 0.4000 & 0.2000 \\
\hline 48 & 1.8263 & 1.7500 & 0.86 & 4.1000 & 0.4900 \\
\hline 48 & 1.8263 & 1.7500 & 0.86 & 4.1000 & 0.4900 \\
\hline 48 & 1.7958 & 1.8000 & 0.53 & 2.8000 & 1.0000 \\
\hline 48 & 6.2292 & 6.0000 & 2.43 & 14.0000 & 2.0000 \\
\hline 48 & 0.1321 & 0.1200 & 0.06 & 0.2900 & 0.0500 \\
\hline 48 & 12.0500 & 9.9500 & 6.76 & 36.0000 & 7.0000 \\
\hline 48 & 20.5417 & 15.5000 & 18.36 & 88.0000 & 5.0000 \\
\hline 6 & 16.8333 & 10.0000 & 16.74 & 51.0000 & 10.0000 \\
\hline 4 & 1.3500 & 1.3500 & 0.94 & 2.3000 & 0.4000 \\
\hline
\end{tabular}




\section{Attemose (20.13)}

\begin{tabular}{|c|c|}
\hline Stof navn & Enhed \\
\hline Kondukt ivitet & MSIEMENS/M \\
\hline pH & PH \\
\hline Torstof, total & $M 6 / L$ \\
\hline Oxygen indhold & MG/L \\
\hline Hydrogencarbonat & $M G / L$ \\
\hline Permanganattal $\mathrm{KMnO4}$ & $M G / L$ \\
\hline Ammon iak tammon ium & $M G / L$ \\
\hline Nitrit & $M G / L$ \\
\hline Nitrat & $M G / L$ \\
\hline Orthophosphat-P04 & $M G / L$ \\
\hline Phosph., tot.f1lt P04 & $M G / L$ \\
\hline Calclum & $M 6 / L$ \\
\hline Ch lor id & $M G / L$ \\
\hline Fluor id & $M G / L$ \\
\hline Jern & $M G / L$ \\
\hline Jern ferro & $M G / L$ \\
\hline Kalitum & $M G / L$ \\
\hline Kviksolv & MANOGRAM/L \\
\hline Magnes ium & MG/L \\
\hline Mangan & MG/L \\
\hline Natriuin & $M G / L$ \\
\hline Sulfat & $M G / L$ \\
\hline Hydrogensulf id & $M G / L$ \\
\hline Trittum & T.U. \\
\hline Methan & MG/L \\
\hline
\end{tabular}

Frederiksborg Amt Grundvandsanalyser, 1989

\begin{tabular}{|c|c|c|c|c|c|}
\hline Antal & Gens & Median & Spredning & Maximum & Minimum \\
\hline 36 & 47.9528. & 48.0000 & 8.79 & 65.0000 & 33.0000 \\
\hline 36 & 7.4500 & 7.5000 & 0.12 & 7.6000 & 7.2000 \\
\hline 41 & 314.1463 & 306.0000 & 59.17 & 425.0000 & 233.0000 \\
\hline 20 & 0.2700 & 0.2000 & 0.19 & 0.7000 & 0.1000 \\
\hline 36 & 252.1667 & 247.5000 & 44.25 & 379.0000 & 195.0000 \\
\hline 36 & 4.1889 & 3.9000 & 1.45 & 7.9000 & 1.3000 \\
\hline 36 & 0.1864 & 0.1500 & 0.10 & 0.5500 & 0.1000 \\
\hline 41 & 0.0122 & 0.0100 & 0.01 & 0.0500 & 0.0100 \\
\hline 35 & 0.6800 & 0.5000 & 0.63 & 3.4000 & 0.5000 \\
\hline 19 & 0.2874 & 0.1500 & 0.28 & 0.9200 & 0.0300 \\
\hline 41 & 0.3148 & 0.2146 & 0.25 & 0.9199 & 0.0613 \\
\hline 36 & 84.5000 & 81.5000 & 17.29 & 120.0000 & 52.0000 \\
\hline 36 & 17.3056 & 17.0000 & 5.53 & 30.0000 & 10.0000 \\
\hline 36 & 0.2417 & 0.2000 & 0.05 & 0.3000 & 0.2000 \\
\hline 36 & 1.8239 & 1.7000 & 0.77 & 4.1000 & 0.4900 \\
\hline 19 & 1.7453 & 1.7000 & 0.84 & 4.0000 & 0.4900 \\
\hline 36 & 1.6778 & 1.7000 & 0.54 & 2.9000 & 1.0000 \\
\hline 5 & 3.6000 & 3.0000 & 0.89 & 5.0000 & 3.0000 \\
\hline 36 & 5.6944 & 5.5000 & 2.96 & 15.0000 & 1.0000 \\
\hline 36 & 0.1356 & 0.1400 & 0.07 & 0.3200 & 0.0200 \\
\hline 36 & 10.4444 & 10.0000 & 2.32 & 19.0000 & 7.2000 \\
\hline 36 & 23.0556 & 15.0000 & 20.27 & 75.0000 & 5.0000 \\
\hline 1 & 0.1000 & 0.1000 & . & 0.1000 & 0.1000 \\
\hline 20 & 6.1000 & 1.5000 & 11.24 & 51.0000 & 1.0000 \\
\hline 6 & 0.7167 & 0.5500 & 0.43 & 1.5000 & 0.4000 \\
\hline
\end{tabular}




\section{Espergærde (20.14)}

\begin{tabular}{ll} 
Stof navn & Enhed \\
Kondukt ivitet & MSIEMENS/M \\
pH & $P H$ \\
Terstof, total & $M G / L$ \\
Oxygen indhold & $M G / L$ \\
Hydrogencarbonat & $M G / L$ \\
Permanganattal KMnO4 & $M G / L$ \\
Ammoniaktamaonium & $M G / L$ \\
Nitrit & $M G / L$ \\
Nitrat & $M G / L$ \\
Orthophosphat-P04 & $M G / L$ \\
Phosph., tot.f1it PO4 & $M G / L$ \\
Calcium & $M G / L$ \\
Chlorid & $M G / L$ \\
Fluorid & $M G / L$ \\
Jern & $M G / L$ \\
Jern ferro & $M G / L$ \\
Kalium & $M G / L$ \\
Magnesium & $M G / L$ \\
Mangan & $M G / L$ \\
Matrium & $M G / L$ \\
Sulfat & $M G / L$ \\
Methan & $M G / L$ \\
& \\
\hline
\end{tabular}

Frederiksborg Amt Grundvandsanalyser, 1990

\begin{tabular}{|c|c|c|c|c|c|}
\hline Anta 1 & Gens & Median & Spredning & Maximum & Mtnimum \\
\hline 63 & 96.4444 . & 71.0000 & 58.85 & 279.0000 & 52.0000 \\
\hline 54 & 7.5537 & 7.6000 & 0.18 & 7.9000 & 7.2000 \\
\hline 65 & 631.7385 & 435.0000 & 413.44 & 1910.0000 & 337.0000 \\
\hline 28 & 2.5464 & 2.1500 & 2.76 & 10.0000 & 0.1000 \\
\hline 65 & 297.7692 & 291.0000 & 53.42 & 433.0000 & 177.0000 \\
\hline 65 & 8.7492 & 4.7000 & 11.14 & 38.0000 & 1.2000 \\
\hline 64 & 0.2852 & 0.1250 & 0.62 & 4.8000 & 0.0100 \\
\hline 65 & 0.0200 & 0.0100 & 0.02 & 0.1300 & 0.0100 \\
\hline 65 & 8.7092 & 0.5000 & 16.96 & 61.0000 & 0.5000 \\
\hline 34 & 0.2224 & 0.0900 & 0.25 & 0.7200 & 0.0300 \\
\hline 65 & 0.2349 & 0.1226 & 0.26 & 0.7666 & 0.0307 \\
\hline 65 & 134.8615 & 110.0000 & 68.51 & 370.0000 & 66.0000 \\
\hline 65 & 136.4308 & 40.0000 & 205.58 & 786.0000 & 9.0000 \\
\hline 65 & 0.2215 & 0.2000 & 0.09 & 0.5000 & 0.1000 \\
\hline 65 & 2.6497 & 0.9700 & 2.94 & 10.0000 & 0.0200 \\
\hline 65 & 2.6497 & 0.9700 & 2.94 & 10.0000 & 0.0200 \\
\hline 65 & 1.5446 & 1.6000 & 0.44 & 2.8000 & 0.9000 \\
\hline 65 & 12.4769 & 11.0000 & 7.53 & 40.0000 & 4.0000 \\
\hline 65 & 0.2163 & 0.2000 & 0.15 & 0.6700 & 0.0200 \\
\hline 65 & 40.7231 & 20.0000 & 43.03 & 190.0000 & 11.0000 \\
\hline 65 & 40.6308 & 43.0000 & 16.05 & 73.0000 & 5.0000 \\
\hline 2 & 2.3000 & 2.3000 & 0.71 & 2.8000 & 1.8000 \\
\hline
\end{tabular}


Espergærde (20.14)

\begin{tabular}{ll} 
Stof navn & Enhed \\
Kondukt ivitet & $M S I E M E M S / M$ \\
\hline PH & $P H$ \\
Torstof, total & $M G / L$ \\
Oxygen indhold & $M G / L$ \\
Hydrogencarbonat & $M G / L$ \\
Permanganattal KMnO4 & $M G / L$ \\
Ammoniaktamonium & $M G / L$ \\
Nitrit & $M G / L$ \\
Nitrat & $M G / L$ \\
Orthophosphat-P04 & $M G / L$ \\
Phosph., tot.f $11 t ~ P O 4$ & $M G / L$ \\
Calc lum & $M G / L$ \\
Chlorid & $M G / L$ \\
Fluorid & $M G / L$ \\
Jern & $M G / L$ \\
Jern ferro & $M G / L$ \\
Kaltum & $M G / L$ \\
Magnesium & $M G / L$ \\
Mangan & $M G / L$ \\
Matrium & $M G / L$ \\
Sulfat & $M G / L$ \\
Methan & $M G / L$ \\
& \\
\hline
\end{tabular}

\section{Frederiksborg Amt Grundvandsanalyser, 1989}

$\begin{array}{rrrrrrr}\text { Anta } 1 & \text { Gens } & \text { Median } & \text { Spredning } & \text { Maximum } & \text { Mintmum } \\ 42 & 66.4286 & 64.5000 & 15.91 & 104.0000 & 7.2000 & \\ 35 & 7.4686 & 7.5000 & 0.22 & 8.0000 & 7.1000 & \\ 42 & 426.6190 & 398.0000 & 95.76 & 696.0000 & 280.0000 & \\ 17 & 0.4065 & 0.3000 & 0.34 & 1.4000 & 0.0100 & \text { DG } \\ 42 & 312.5000 & 305.0000 & 53.35 & 432.0000 & 252.0000 & \\ 42 & 8.4190 & 5.5500 & 8.07 & 30.0000 & 0.1000 * & \\ 42 & 0.2229 & 0.1700 & 0.20 & 0.7000 & 0.0100 & \text { DG } \\ 42 & 0.0112 & 0.0100 & 0.00 & 0.0200 & 0.0100 & 0 G \\ 37 & 0.6027 & 0.5000 & 0.27 & 2.0000 & 0.5000 & \\ 24 & 0.1913 & 0.1050 & 0.21 & 0.6800 & 0.0200 & \\ 42 & 0.2000 & 0.1226 & 0.18 & 0.7359 & 0.0307 & \\ 42 & 104.5476 & 101.5000 & 15.65 & 130.0000 & 67.0000 & \\ 42 & 44.5000 & 36.0000 & 40.03 & 170.0000 & 8.0000 & \\ 42 & 0.2500 & 0.2000 & 0.07 & 0.5000 & 0.2000 & \\ 42 & 3.4019 & 2.8000 & 3.07 & 13.0000 & 0.0300 & \\ 25 & 3.1616 & 3.5000 & 2.90 & 11.0000 & 0.0300 & \\ 42 & 1.6524 & 1.7000 & 0.41 & 2.3000 & 1.0000 & \\ 42 & 9.5952 & 9.0000 & 4.57 & 24.0000 & 3.0000 & \\ 42 & 0.2540 & 0.2300 & 0.13 & 0.5900 & 0.0300 & \\ 42 & 25.2381 & 20.5000 & 17.34 & 81.0000 & 11.0000 & \\ 42 & 36.3095 & 37.5000 & 15.33 & 73.0000 & 5.0000 & \\ 3 & 1.8667 & 2.5000 & 1.55 & 3.0000 & 0.1000 & \end{array}$


Torkildstrup (25.01)

\begin{tabular}{|c|c|c|c|c|c|c|c|}
\hline Stof navn & Enhed & Antal & Gens & Median & Spredning & Maximum & Minfaum \\
\hline Kondukt fvitet & MSIEMENS/M & 49 & 68.6622 & 66.1000 & 8.93 & 86.4000 & 38.6000 \\
\hline pH & PH & 49 & 7.3563 & 7.3500 & 0.14 & 8.0500 & 7.1600 \\
\hline Turbiditet & FTU & 5 & 8.2000 & 8.8000 & 5.21 & 16.0000 & 2.0000 \\
\hline Inddampn ingsrest & $M G / L$ & 48 & 471.6667 & 455.0000 & 75.41 & 780.0000 & 350.0000 \\
\hline Oxygen indhold & $M G / L$ & 4 & 0.9000 & 1.1000 & 0.55 & 1.3000 & 0.1000 \\
\hline Carbondioxid, aggr. & $M G / L$ & 1 & 2.0000 & 2.0000 & . & 2.0000 & 2.0000 \\
\hline Hydrogencarbonat & $M G / L$ & 49 & 340.1429 & 346.0000 & 33.98 & 386.0000 & 149.0000 \\
\hline Carbon, org, NVOC & $M G / L$ & 2 & 1.2950 & 1.2950 & 0.54 & 1.6800 & 0.9100 \\
\hline Permanganatta $7 \mathrm{KHnO4}$ & $M G / L$ & 49 & 4.4061 & 3.8000 & 1.99 & 8.4000 & 1.3000 \\
\hline Nitrit & $M G / L$ & 30 & 0.0244 & 0.0030 & 0.07 & 0.3300 & 0.0030 \\
\hline Nitrat & $M G / L$ & 29 & 2.3117 & 0.0200 & 4.63 & 15.0000 & 0.0200 \\
\hline Orthophosph. -P04, 111 & $M G / L$ & 13 & & & & 0.0307 & 0.0307 \\
\hline Phosph.,tot.f1lt PO4 & $M G / L$ & 5 & & & & 0.0307 & 0.0307 \\
\hline Alumin ium & MYGRAM/L & 2 & 1900.0000 & 1900.0000 & 141.42 & $2000.0000 *$ & 1800.0000 \\
\hline Arsen & MYGRAM/L & 2 & 0.9500 & 0.9500 & 0.49 & 1.3000 & 0.6000 \\
\hline Barium & MYGRAM/L & 2 & 55.5000 & 55.5000 & 2.12 & 57.0000 & 54.0000 \\
\hline Bly & MYGRAM/L & 2 & 0.2950 & 0.2950 & 0.16 & 0.4100 & 0.1800 \\
\hline Bor & MYGRAM/L & 2 & 26.5000 & 26.5000 & 4.95 & 30.0000 & 23.0000 \\
\hline Cadm fum & MYGRAM/L & 2 & 0.0160 & 0.0160 & 0.01 & 0.0200 & 0.0120 \\
\hline Calc ium & $M G / L$ & 49 & 126.9592 & 127.0000 & 14.21 & 165.0000 & 74.0000 \\
\hline Chlor, org, AOX & MYGRAM/L & 2 & 3.2500 & 3.2500 & 0.21 & 3.4000 & 3.1000 \\
\hline Ch lor, org, vox & MYGRAM/L & 2 & 2.6000 & 2.6000 & 0.00 & 2.6000 & 2.6000 \\
\hline Chlorid & $M G / L$ & 49 & 26.4286 & 25.0000 & 4.72 & 39.0000 & 20.0000 \\
\hline Chrom & MYGRAM/L & 2 & & & & 0.0700 & 0.0700 \\
\hline Cyanid & $M G / L$ & 2 & & & & 0.0020 & 0.0020 \\
\hline Jern ferro & $M 6 / L$ & 32 & 2.1378 & 1.8100 & 0.94 & 4.6300 & 1.0300 \\
\hline Jod & MYGRAM/L & 2 & & & & 1.0000 & 1.0000 \\
\hline Jodid & MYGRAM/L & 2 & 5.7500 & 5.7500 & 3.18 & 8.0000 & 3.5000 \\
\hline Kalium & $M G / L$ & 48 & 5.9521 & 3.0000 & 6.04 & 22.0000 & 2.2000 \\
\hline Kobber & MYGRAM/L & 2 & 0.4250 & 0.4250 & 0.35 & 0.6700 & 0.1800 \\
\hline Lith tum & MYGRAM/L & 2 & 10.0000 & 10.0000 & 0.00 & 10.0000 & 10.0000 \\
\hline Magnes Ium & $M G / L$ & 49 & 13.3265 & 11.0000 & 12.91 & 101.0000 & 3.0000 \\
\hline Molybdan & MYGRAM/L & 2 & 1.7050 & 1.7050 & 0.12 & 1.7900 & 1.6200 \\
\hline Natrium & $M G / L$ & 49 & 17.2612 & 13.0000 & 10.19 & 59.0000 & 5.8000 \\
\hline Nikke I & MYGRAM/L & 2 & 0.2750 & 0.2750 & 0.11 & 0.3500 & 0.2000 \\
\hline Stront fum & MYGRAM/L & 2 & 530.0000 & 530.0000 & 84.85 & 590.0000 & 470.0000 \\
\hline Sulfat & $M G / L$ & 49 & 73.0000 & 59.0000 & 39.81 & 170.0000 & 23.0000 \\
\hline Hydrogensulf id & $M G / L$ & 8 & & & & 0.0040 & 0.0040 \\
\hline Methan & $M G / L$ & 26 & 0.0208 & 0.0300 & 0.01 & 0.0300 & 0.0100 \\
\hline Kimtal 37Gr. PCA & ANTAL/ML & 1 & & & & 1.0000 & 1.0000 \\
\hline K1mtal 21Gr. KING B & ANTAL/ML & 1 & & & & 1.0000 & 1.0000 \\
\hline Colliforme bakt.37Gr. & ANTAL/100 ML & 1 & & & & 1.0000 & 1.0000 \\
\hline Faka le collbakter ter & ANTAL/10OML & 1 & & & & 1.0000 & 1.0000 \\
\hline Temperatur & GRADER C & 40 & 8.9600 & 8.8000 & 1.00 & 11.6000 & 7.3000 \\
\hline
\end{tabular}

\section{Roskilde Amt Grundvandsanalyser, 1990}

$G$




\section{Torkildstrup (25.01)}

\begin{tabular}{|c|c|}
\hline Stof navn & Enhed \\
\hline Kondukt ivitet & MSIEMENS/M \\
\hline pH & PH \\
\hline Turb 1ditet & FTU \\
\hline Inddanpn Ingsrest & $M G / L$ \\
\hline Oxygen indhold & MG/L \\
\hline Hydrogencarbonat & $M G / L$ \\
\hline Permanganattal KMnO4 & $M G / L$ \\
\hline Nitrit & $M G / L$ \\
\hline Nitrat & $M 6 / L$ \\
\hline Orthophosph. -P04, 111 & $M G / L$ \\
\hline Phosph.,tot.f1lt PO4 & $M G / L$ \\
\hline Calctum & $M 6 / L$ \\
\hline Chlorid & $M G / L$ \\
\hline Jern ferro & $M G / L$ \\
\hline Kalluw & $M G / L$ \\
\hline Magnes ium & $M 6 / L$ \\
\hline Mangan & $M G / L$ \\
\hline Matrium & $M G / L$ \\
\hline Sulfat & $M G / L$ \\
\hline Hydrogensu if id & $M G / L$ \\
\hline Metnan & $M G / L$ \\
\hline Temperatur & GRADER C \\
\hline
\end{tabular}

\section{Roskilde Amt}

Grundvandsanalyser, 1989

\begin{tabular}{|c|c|c|c|c|c|}
\hline Antal & Gens & Median & Spredning & Maximum & Min Imum \\
\hline 33 & 71.2788. & 65.5000 & 11.68 & 99.1000 & 54.1000 \\
\hline 32 & 7.4138 & 7.3950 & 0.15 & 7.8900 & 7.1300 \\
\hline 17 & 20.3412 & 12.5000 & 26.38 & 90.0000 & 3.9000 \\
\hline 31 & 470.5161 & 440.0000 & 79.86 & 630.0000 & 340.0000 \\
\hline 6 & 1.9400 & 1.3500 & 1.02 & 3.3000 & 1.2000 \\
\hline 31 & 337.8710 & 343.0000 & 29.71 & 389.0000 & 260.0000 \\
\hline 31 & 7.2903 & 5.6000 & 6.74 & 42.0000 & 2.7000 \\
\hline 2 & 0.0030 & 0.0030 & 0.00 & $0.0030 *$ & 0.0030 \\
\hline 15 & 2.4207 & 0.0200 & 5.58 & 21.0000 & 0.0200 \\
\hline 7 & 0.0307 & 0.0307 & 0.00 & 0.0307 & 0.0307 \\
\hline 6 & 1.4273 & 0.5826 & 1.82 & 4.9059 & 0.1932 \\
\hline 32 & 120.4688 & 120.0000 & 16.41 & 152.0000 & 84.0000 \\
\hline 32 & 27.3125 & 25.0000 & 5.44 & 40.0000 & 22.0000 \\
\hline 29 & 4.7439 & 2.2700 & 7.69 & 41.4000 & 0.0240 \\
\hline 32 & 7.0031 & 4.0500 & 6.50 & 27.0000 & 2.5000 \\
\hline 32 & 12.1500 & 11.5000 & 2.47 & 22.0000 & 9.0000 \\
\hline 2 & 1.6500 & 1.6500 & 0.78 & 2.2000 & 1.1000 \\
\hline 32 & 30.5938 & 17.0000 & 33.86 & 140.0000 & 14.0000 \\
\hline 31 & 80.5484 & 58.0000 & 45.43 & 180.0000 & 33.0000 \\
\hline 1 & 0.0040 & 0.0040 & . & 0.0040 & 0.0040 \\
\hline 13 & & & & 0.0300 & 0.0300 \\
\hline 29 & 8.6448 & 8.8000 & 0.88 & 10.8000 & 6.7000 \\
\hline
\end{tabular}

* Særlig usædvanlig værdi, der må kontrolleres. 
Brokilde (25.02)

\begin{tabular}{|c|c|c|c|c|c|c|c|}
\hline Stof navn & Enhed & Antal & Gens & Median & Sprednting & Maximum & Minimun \\
\hline Kondukt ivitet & MSIEMENS/M & 38 & 64.0974 & 60.7000 & 10.57 & 83.3000 & 49.6000 \\
\hline pH & PH & 38 & 7.4000 & 7.4050 & 0.13 & 7.6800 & 7.1400 \\
\hline Turblditet & FTU & 5 & 44.7600 & 27.0000 & 52.64 & 126.0000 & 1.6000 \\
\hline Inddanpn Ingsrest & $M G / L$ & 38 & 427.8947 & 410.0000 & 90.50 & 630.0000 & 280.0000 \\
\hline Oxygen indhold & $M G / L$ & 4 & 0.1000 & 0.1000 & 0.00 & 0.1000 & 0.1000 \\
\hline Hydrogencarbonat & $\mathrm{HG} / \mathrm{L}$ & 38 & 284.8947 & 283.5000 & 29.03 & 368.0000 & 230.0000 \\
\hline Carbon, org, NVOC & MG/L & 2 & 2.0950 & 2.0950 & 0.71 & 2.6000 & 1.5900 \\
\hline Permanganattal KMnO4 & $M G / L$ & 38 & 6.6105 & 6.2000 & 2.67 & 13.0000 & 2.7000 \\
\hline Nitrit & $M G / L$ & 21 & 0.0099 & 0.0030 & 0.02 & 0.0650 & 0.0030 \\
\hline Nitrat & $M G / L$ & 27 & 0.3348 & 0.0200 & 0.71 & 2.3000 & 0.0200 \\
\hline Orthophosph. .P04, $f 11$ & $M G / L$ & 3 & & & & 0.0307 & 0.0307 \\
\hline Phosph.,tot.f11t P04 & $M G / L$ & 1 & & & & 0.0307 & 0.0307 \\
\hline A lum in fua & MYGRAM/L & 2 & 1800.0000 & 1800.0000 & 0.00 & 1800.0000 & $1800.0000^{*}$ \\
\hline Arsen & MYGRAM/L & 2 & 2.1500 & 2.1500 & 2.62 & 4.0000 & 0.3000 \\
\hline Barium & MYGRAM/L & 2 & 49.5000 & 49.5000 & 7.78 & 55.0000 & 44.0000 \\
\hline $81 y$ & MYGRAM/L & 2 & 0.2250 & 0.2250 & 0.06 & 0.2700 & 0.1800 \\
\hline Bor & MYGRAM/L & 2 & 63.5000 & 63.5000 & 43.13 & 94.0000 & 33.0000 \\
\hline Cadm Ium & MYGRAM/L & 2 & & & & 0.0120 & 0.0120 \\
\hline Calc fuw & $M G / L$ & 38 & 110.3684 & 106.5000 & 24.26 & 164.0000 & 68.0000 \\
\hline Ch lor, oro, AOX & MYGRAM/L & 2 & 3.1000 & 3.1000 & 0.00 & 3.1000 & 3.1000 \\
\hline Ch lor, org, vox & MYGRAM/L & 2 & 2.6000 & 2.6000 & 0.00 & 2.6000 & 2.6000 \\
\hline Chlorid & $M G / L$ & 38 & 30.3158 & 24.5000 & 10.65 & 55.0000 & 18.0000 \\
\hline Chron & MYGRAM/L & 2 & & & & 0.0700 & 0.0700 \\
\hline Cyanto & $M G / L$ & 2 & & & & 0.0020 & 0.0020 \\
\hline Jern ferro & $M G / L$ & 35 & 3.0680 & 2.7000 & 1.15 & 6.7700 & 1.5700 \\
\hline Jod & MYGRAM/L & 2 & & & & 1.0000 & 1.0000 \\
\hline Jodid & MYGRAM/L & 2 & 9.8000 & 9.8000 & 4.53 & 13.0000 & 6.6000 \\
\hline Kal fum & $M G / L$ & 38 & 3.0842 & 2.2000 & 2.62 & 10.0000 & 1.4000 \\
\hline Kobber & MYGRAM/L & 2 & 0.2200 & 0.2200 & 0.06 & 0.2600 & 0.1800 \\
\hline Lithium & MYGRAM/L & 2 & 7.5000 & 7.5000 & 0.71 & 8.0000 & 7.0000 \\
\hline Magnes ium & $M G / L$ & 38 & 13.1579 & 13.0000 & 1.81 & 18.0000 & 10.0000 \\
\hline Mo lybden & MYGRAM/L & 2 & 1.0900 & 1.0900 & 1.12 & 1.8800 & 0.3000 \\
\hline Matrium & $M G / L$ & 38 & 15.1053 & 12.5000 & 6.41 & 40.0000 & 10.0000 \\
\hline N1kkel & MYGRAM/L & 2 & & & & 0.0700 & 0.0700 \\
\hline Stront ium & MYGRAM/L & 2 & 645.0000 & 645.0000 & 487.90 & 990.0000 & 300.0000 \\
\hline Sulfat & $\mathrm{MG} / \mathrm{L}$ & 38 & 82.3079 & 73.5000 & 54.68 & 190.0000 & 0.9000 \\
\hline Hydrogensulf id & $M G / L$ & 1 & & & & 0.0040 & 0.0040 \\
\hline Methan & $M G / L$ & 22 & 0.6450 & 0.0300 & 1.25 & 3.9000 & 0.0100 \\
\hline Temperatur & GRADER C & 29 & 8.5828 & 8.5000 & 0.81 & 10.1000 & 6.8000 \\
\hline
\end{tabular}

\section{Roskilde Amt \\ Grundvandsanalyser, 1990}

* Særlig usædvanlig værdi, der må kontrolleres. 


\section{Brokilde (25.02)}

Stof navn

Kondukt ivitet

pH

Turbiditet

Inddampningsrest

Oxygen indhold

Carbondioxid, aggr.

Hydrogencarbonat

Permanganattal KMnO4

Nitrit

Nitrat

Orthophosph.-P04,P11

Phosph., tot.f1lt P04

Calctue

Chlorid

Jern ferro

Kal1um

Magnestur

Mangan

Matrium

Ntkke 1

Sulfat

Hydrogensulf id

Methan

Temperatur
Enhed

MSIEMENS/M

PH

FTU

$M G / L$

$M G / L$

$M G / L$

$146 / L$

H6/L

H6/L

$M G / L$

MG/L

$M G / L$

$146 / 2$

$1 \% 6 / \mathrm{L}$

MG/L

NG/L

MG/L

HG/L

MG/L

MYGRAK/L

MG/L

$M G / L$

$M G / L$

GRADER C

\section{Roskilde Amt}

Antal Gens

19

64.4789 .

7.4600

13.2167

446.0000

1.1600

4.0000

287.8947

8.5263

0.0210

0.0210

3.4905

110.3333

29.4211

3.7926

3.8889

15.7222

1.2000

17.2222

4110.0000

90.8272

0.0040

0.3770

8.7067
Grundvandsanalyser, 1989

Median Spreoning Maximum Mintmum

\subsection{0}

12.71

91.8000

50.2000

7.4300

0.16

7.8800

7.2100

14.3500

5.40

18.2000

2.8000

406.0000

116.70

630.0000

280.0000

1.1600

0.08

1.2200

1.1000

4.0000

4.0000

4.0000

283.0000

33.24

366.0000

223.0000

8.4000

3.66

17.0000

3.4000

0.0030

0.0030

0.0200

0.0250

0.0307

0.0307

17.7840

0.0613

0.6746
110.5000

6.16

159.0000

72.0000

22.0000

25.22

58.0000

12.0000

3.7000

1.85

7.6100

1.4700

2.2500

3.49

11.0000

1.4000

14.0000

7.54

45.0000

11.0000

1.2000

.

1.2000

1.2000

15.5000

3.93

25.0000

12.0000

4110.0000

.

4110.0000

4110.0000 *

96.0000

64.85

210.0000

0.1900

0.0040

0.00

0.0040

0.0040

0.0300

1.10

3.5000

0.0300

8.8000

0.76

9.8000

7.4000 
Asemose (25.11)

\begin{tabular}{|c|c|c|c|c|c|c|c|}
\hline Stor navn & Enhed & Antal & Gens & Median & Spredning & Max 1muta & Min tmum \\
\hline Kondukt iv itet & MSIEMENS/M & 48 & 69.9104. & 68.5000 & 8.45 & 90.0000 & 56.4000 \\
\hline $\mathrm{pH}$ & PH & 48 & 7.2852 & 7.2800 & 0.16 & 7.6900 & 6.8100 \\
\hline Turbiditet & FTU & 7 & 9.8143 & 6.7000 & 7.98 & 22.0000 & 2.2000 \\
\hline Inddampn ingsrest & MG/L & 48 & 460.8333 & 445.0000 & 71.57 & 680.0000 & 340.0000 \\
\hline Oxygen indhold & $M G / L$ & 18 & 2.0278 & 1.4500 & 2.64 & 8.8000 & 0.1000 \\
\hline Hydrogencarbonat & $M G / L$ & 48 & 351.8750 & 353.0000 & 42.68 & 441.0000 & 262.0000 \\
\hline Carbon, org, nVOC & $\mathrm{MG} / \mathrm{L}$ & 3 & 1.3400 & 1.3500 & 0.10 & 1.4299 & 1.2400 \\
\hline Perwanganatta 1 KMnO4 & $M G / L$ & 48 & 4.8500 & 3.6000 & 3.85 & 16.0000 & 1.0000 \\
\hline Nitrit & MG/L & 16 & & & & 0.0300 & 0.0030 \\
\hline Nitrat & $\mathrm{MG} / \mathrm{L}$ & 45 & 8.3396 & 0.0200 & 17.89 & 85.0000 & 0.0200 \\
\hline Orthophosph. -P04, 111 & $M G / L$ & 14 & & & & 0.0307 & 0.0307 \\
\hline Phosph.,tot.filt P04 & $M G / L$ & 10 & 0.5997 & 0.0889 & 0.87 & 2.3303 & 0.0307 \\
\hline A lum in ium & MYGRAM/L & 3 & 4333.3333 & 1800.0000 & 4387.86 & $9400.0000^{*}$ & 1800.0000 \\
\hline Arsen & MYGRAM/L & 3 & 0.5333 & 0.5000 & 0.25 & 0.8000 & 0.3000 \\
\hline Barfum & MYG̣RAM/L & 3 & 23.7667 & 28.4000 & 8.55 & 29.0000 & 13.9000 \\
\hline Bly & MYGRAM/L & 3 & 0.4733 & 0.1800 & 0.51 & 1.0599 & 0.1800 \\
\hline Bor & MYGRAM/L & 3 & 51.3333 & 39.0000 & 33.26 & 89.0000 & 26.0000 \\
\hline Cadmium & MYGRAM/L & 3 & 0.0733 & 0.0460 & 0.05 & 0.1320 & 0.0420 \\
\hline Calc 1um & $M G / L$ & 48 & 110.6042 & 108.5000 & 20.64 & 162.0000 & 69.0000 \\
\hline Chlor,org, $A O X$ & MYGRAM/L & 3 & 4.8333 & 3.7000 & 2.50 & 7.7000 & 3.1000 \\
\hline chlor, org, vox & MYGRAM/L & 3 & 2.6000 & 2.6000 & 0.00 & 2.6000 & 2.6000 \\
\hline Chlorid & $M G / L$ & 48 & 33.0000 & 27.5000 & 13.68 & 84.0000 & 18.0000 \\
\hline Chrom & MYGRAM/L & 3 & & & & 0.0700 & 0.0700 \\
\hline Cyanid & $M G / L$ & 3 & 0.0106 & 0.0020 & 0.01 & 0.0278 & 0.0020 \\
\hline Fluor 1d & $M G / L$ & 1 & 0.4700 & 0.4700 & . & 0.4700 & 0.4700 \\
\hline Jern ferro & $M G / L$ & 26 & 2.0011 & 1.8750 & 1.83 & 7.6200 & 0.0050 \\
\hline Jod & MYGRAM/L & 3 & 49.8667 & 54.0000 & 27.43 & 75.0000 & 20.6000 \\
\hline Jodtd & MYGRAM/L & 3 & 3.7000 & 3.2000 & 0.87 & 4.7000 & 3.2000 \\
\hline Kaltum & $M G / L$ & 46 & 4.0196 & 3.5000 & 2.22 & 9.2000 & 1.2000 \\
\hline Kobber & MYGRAM/L & 3 & 1.5500 & 1.9100 & 0.78 & 2.0900 & 0.6500 \\
\hline Lith fum & MYGRAM/L & 3 & 12.6667 & 11.0000 & 2.89 & 16.0000 & 11.0000 \\
\hline Magnes Iua & $M G / L$ & 48 & 17.7500 & 17.0000 & 7.39 & 39.0000 & 5.0000 \\
\hline Mangan & $M G / L$ & 4 & 0.0050 & 0.0050 & 0.00 & 0.0050 & 0.0050 \\
\hline Mo lybdan & MYGRAM/L & 3 & 4.6333 & 3.8000 & 2.55 & 7.5000 & 2.6000 \\
\hline Matr 1um & $M G / L$ & 48 & 15.8750 & 14.5000 & 4.87 & 28.0000 & 9.2000 \\
\hline Nikke 1 & MYGRAM/L & 3 & 49.9333 & 32.1000 & 49.61 & 106.0000 & 11.7000 \\
\hline Stront fua & MYGRAM/L & 3 & 1706.6667 & 970.0000 & 1488.63 & 3420.0000 & 730.0000 \\
\hline Sulfat & $M G / L$ & 48 & 48.7917 & 44.5000 & 20.53 & 88.0000 & 12.0000 \\
\hline Hydrogensulf id & $M G / L$ & 5 & & & & 0.0040 & 0.0040 \\
\hline Metrian & $M G / L$ & 29 & 0.0203 & 0.0300 & 0.01 & 0.0300 & 0.0100 \\
\hline K1mta) 376r. PCA & ANTAL/ML & 3 & & & & 1.0000 & 1.0000 \\
\hline K1mtal 21Gr. KING 8 & ANTAL/ML & 3 & 126.0000 & 5.0000 & 211.31 & 370.0000 & 3.0000 \\
\hline Collforme bakt.376r. & AKTAL/100 ML & 3 & & & & 1.0000 & 1.0000 \\
\hline Fakale collbakter ler & ANTAL/100ML & 3 & & & & 1.0000 & 1.0000 \\
\hline Teaperatur & GRADER C & 45 & 9.3067 & 9.1000 & 0.97 & 13.7000 & 7.5000 \\
\hline
\end{tabular}

Roskilde Amt Grundvandsanalyser, 1990 
Asemose (25.11)

\begin{tabular}{|c|c|}
\hline Stof navn & Enhed \\
\hline Kondukt ivitet & MSIEMENS/M \\
\hline PH & PH \\
\hline Turb1ditet & FTU \\
\hline Inddampn ingsrest & $M G / L$ \\
\hline Oxygen inahold & $M G / L$ \\
\hline Hydrogencarbonat & $M G / L$ \\
\hline Permanganattal KMnO4 & $M G / L$ \\
\hline N1trit & $M G / L$ \\
\hline N1trat & $M G / L$ \\
\hline Orthophosph. -P04, f 11 & $M G / L$ \\
\hline Phosph., tot.f1]t PO4 & $M G / L$ \\
\hline Calcium & $M G / L$ \\
\hline Chlorio & $M G / L$ \\
\hline Jern ferro & $M G / L$ \\
\hline Kalium & $M G / L$ \\
\hline Magnes iun & $M G / L$ \\
\hline Mangan & $M G / L$ \\
\hline Natrium & $M G / L$ \\
\hline Sulfat & $M G / L$ \\
\hline Hydrogensu if 10 & $M G / L$ \\
\hline Methan & $M G / L$ \\
\hline Temperatur & GRADER C \\
\hline
\end{tabular}

\section{Roskilde Amt}

Grundvandsanalyser, 1989

\begin{tabular}{|c|c|c|c|c|c|c|}
\hline Antal & Gens & Median & Spredning & Maximum & Min Iaum & \\
\hline 24 & 66.1292 & 65.5000 & 9.60 & 84.7000 & 40.2000 & \\
\hline 23 & 7.3535 & 7.3300 & 0.29 & 8.4000 & 7.0100 & \\
\hline 11 & 10.4000 & 3.9000 & 16.23 & 55.0000 & 0.1000 & \\
\hline 23 & 462.0435 & 447.0000 & 63.15 & 602.0000 & 370.0000 & \\
\hline 10 & 4.9260 & 4.1000 & 3.07 & 9.4000 & 1.7000 & \\
\hline 24 & 334.7500 & 349.0000 & 73.08 & 454.0000 & 120.0000 & \\
\hline 23 & 9.9783 & 4.4000 & 17.23 & 76.0000 & 0.5000 & \\
\hline 6 & & & & 0.0030 & 0.0030 & DG \\
\hline 14 & 18.2557 & 11.7500 & 21.26 & 65.0000 & 0.0200 & DG \\
\hline 9 & 0.1056 & 0.0307 & 0.22 & 0.7052 & 0.0307 & DG \\
\hline 3 & 1.8908 & 1.3491 & 2.18 & 4.2927 & 0.0307 & DG \\
\hline 24 & 111.6667 & 105.5000 & 32.45 & 232.0000 & 64.0000 & \\
\hline 23 & 31.0870 & 29.0000 & 11.55 & 61.0000 & 19.0000 & \\
\hline 16 & 4.3644 & 2.8800 & 4.25 & $15.0000^{*}$ & 0.0050 & \\
\hline 24 & 4.0833 & 3.3000 & 5.62 & 30.0000 & 1.1000 & \\
\hline 24 & 15.6667 & 14.0000 & 8.33 & 31.0000 & 4.0000 & \\
\hline 4 & 0.7538 & 0.0050 & 1.50 & 3.0000 & 0.0050 & DG \\
\hline 24 & 17.8333 & 17.0000 & 4.47 & 29.0000 & 11.0000 & \\
\hline 24 & 47.8333 & 42.5000 & 17.86 & 75.0000 & 18.0000 & \\
\hline 6 & & & & 0.0040 & 0.0040 & DG \\
\hline 12 & & & & 0.0300 & 0.0300 & $D G$ \\
\hline 22 & 9.1818 & 9.0500 & 1.00 & 11.8000 & 7.8000 & \\
\hline
\end{tabular}

* Særlig usædvanlig værdi, der må kontrolleres. 
Osted (25.12)

Stof navn

Kondukt Ivitet

Turbidtet FTU

Inddampningsrest $\mathrm{MG} / \mathrm{L}$

Oxygen indhold MG/L

Hydrogencarbonat MG/L

Carbon,org, HVOC MG/L

Peraanganattal KMnO4 MG/L

Nitrit MG/L

Nitrat MG/L

Orthophosph.-P04,P11 MG/L

Phosph.,tot.f11t P04 MG/L

Aluminium

Arsen

Barium

Bly

Bor

Cadmitum

Calc tum

Chlor, org. AOX

Cnlor, org, vox

chlorto

Chrom

Cyantd

Fluorid

Jern ferro

Jod

Jodid

Kal1um

Kobber

Lith fum

Magnes Ium

Molybdan

Natrium

Nikkel

- Stront iun

, Sulfat

Hydrogensulf id

Methan

K1mtal 376r. PCA

Kintal 216r. KING B

Collforme bakt.37Gr.

Fakale collbakterier

Temperatur
Enhed

SIEMENS/M

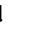

/L

L

L

/L

L

/L

MG/L

MYGRAM/L

MYGRAM/L

MYGRAM/L

MYGRAM/L

HYGRAM/L

MG/L

MYGRAM/L

MYGRAM/L

MG/L

MYGRAM/L

$M G / L$

MG/L

$M G / L$

MYGRAM/L

MYGRAM/L

MG/L

MYGRAM/L

MYGRAM/L

MG/L

MYGRAM/L

MG/L

MYGRAM/L

MYGRAM/L

$M G / L$

MG/L

MG/L

ANTAL/ML

ANTAL/ML

ANTAL/100 ML

ANTAL/100ML

GRADER C
Roskilde Amt

Antal Gens

$$
85.3900
$$

7.3970

6.8000

575.6000

1.0750

417.6000

1.9825

6.9060

0.0035

0.0313

0.1625

5600.0000

4.7475

145.2500

0.4075

0.0255

111.7600

3.1000

2.6000

61.7000

0.1123

1.3875

2.7207

1.5500

12.2750

4.6980

1.2375

25.7500

18.4540

1.9000

59.3400

1.5150

1577.5000

68.7953

1.5760

0.0195

16.1667

4.6000

0.0491

1800.0000

3.9950

100.0000

0.2650

215.0000

0.0180

100.5000

3.1000

2.6000

37.0000

0.0850

1.4000

2.4150

1.3500

12.6500

5.0500

1.1150

25.5000

16.0000

2.0000

51.5000

1.5100

1685.0000

17.0000

0.0100

0.0100

1.0000

1.0000

8.7659

8.8000

41
224.5000

36.01

5.15

306.79

0.70

71.96

0.37

4.86

0.00

0.07

7600.00

4.98

135.02

0.35

201.40

0.02

75.34

0.00

0.00

77.40

0.07

0.06

1.81

0.71

2.42

17.73

8.66

1.52

42.49

870.80

126.30

2.68

37.15
0.24

6.64

1.07

1.25

0.01

4.93

Max inun

206.0000

8.0900

16.0000

1680.0000

2.0000

501.0000

2.4200

34.0000

0.0120

0.4700

0.0307

0.5213

$17000.000 * 1800.0000$

10.7000

340.0000

0.9200

440.0000

0.0540

348.0000

3.1000

2.6000

330.0000

0.2090

0.0020

1.5000

9.8600

2.5000

18.0000

11.0000

2.5400

45.0000

41.0000

3.3000

140.0000

2.7000

2380.0000

470.0000

5.5000

0.0300

92.0000

10.0000

1.0000

1.0000

1.07

Mintaun

52.2000

6.9200

1.1000

300.0000

0.1000

270.0000

1.5500

1.0000

0.3000

41.0000

0.1800

28.0000

0.0120

38.0000

3.1000

2.6000

9.0000

1.3000

0.3400

5.8000

1.4000

0.1800

7.0000

8.0000

0.3000

12.0000

0.3400

560.0000

2.8000

$11.1000 \quad 6.3000$

$0.0030 \quad D G$

0.0200 DG

$0.0307 \quad 0 G$

$0.0307 \quad D G$

0.0700 DG

$0.0020 \quad O G$

1.0000 DG

$0.0040 \quad D G$

$0.0100 \quad 0 G$

$1.0000 \quad 0 G$

1.0000 DG

$1.0000 \quad D G$

$1.0000 \quad 06$ 
Osted (25.12)

\begin{tabular}{|c|c|}
\hline Stof navn & Enhed \\
\hline Kondukt iv itet & MSIEMENS/M \\
\hline pH & PH \\
\hline Turb tditet & FTU \\
\hline Inddampn ingsrest & $M G / L$ \\
\hline Oxygen Indhold & $M G / L$ \\
\hline Hydrogencarbonat & $M G / L$ \\
\hline Permanganatta $1 \mathrm{KMnO4}$ & $M G / L$ \\
\hline Nitrit & $M G / L$ \\
\hline Nitrat & $M G / L$ \\
\hline Orthophosph. -P04,f11 & MG/L \\
\hline Phosph..tot.f1lt P04 & MG/L \\
\hline Calc ium & $M G / L$ \\
\hline Chlorid & MG/L \\
\hline Fluorid & $M G / L$ \\
\hline Jern ferro & $M G / L$ \\
\hline Kalium & $M G / L$ \\
\hline Magnesfum & $M G / L$ \\
\hline Mangan & $M G / L$ \\
\hline Hatrifum & $M G / L$ \\
\hline Sulfat & $M G / L$ \\
\hline Hydrogensulf id & $M G / L$ \\
\hline Methan & MG/L \\
\hline Teaperatur & GRADER C \\
\hline
\end{tabular}

Roskilde Amt Grundvandsanalyser, 1989

$\begin{array}{rrrrrrr}\text { Antal } & \text { Gens } & \text { Median } & \text { Spredning } & \text { Maximud } & \text { Minimum } \\ & & & & & & \\ 34 & 92.9000 & 77.6000 & 42.11 & 221.0000 & 56.0000 & \\ 33 & 7.3927 & 7.3000 & 0.25 & 7.9000 & 6.9500 & \\ 16 & 55.5375 & 33.5000 & 94.97 & 400.0000 & 3.1000 & \\ 31 & 672.3871 & 504.0000 & 439.06 & 1960.0000 & 320.0000 & \\ 4 & 2.8750 & 2.8500 & 0.53 & 3.5000 & 2.3000 & \\ 34 & 389.5000 & 409.5000 & 101.41 & 498.0000 & 103.0000 & \\ 29 & 16.6138 & 11.0000 & 19.90 & 96.0000 & 1.9000 & \\ 6 & & & & 0.0030 & 0.0030 & \text { DG } \\ 19 & 25.6061 & 0.0200 & 75.63 & 250.0000 & 0.0200 & \text { DG } \\ 11 & 0.3877 & 0.0307 & 1.19 & 3.9861 & 0.0031 & \\ 8 & 3.2613 & 0.7972 & 4.39 & 11.3449 & 0.0307 & \text { OG } \\ 34 & 122.8529 & 105.5000 & 86.37 & 348.0000 & 37.0000 & \\ 34 & 75.0294 & 41.5000 & 103.08 & 415.0000 & 12.0000 & \\ 5 & 1.2760 & 1.3600 & 0.16 & 1.4200 & 1.1000 & \\ 30 & 8.7253 & 3.0250 & 14.32 & 67.7000 & 1.0800 & \\ 34 & 5.6118 & 5.6000 & 3.55 & 16.0000 & 1.5000 & \\ 34 & 19.4412 & 16.0000 & 9.89 & 44.0000 & 10.0000 & \\ 7 & 0.0050 & 0.0050 & 0.00 & 0.0050 & 0.0050 & \\ 34 & 69.5000 & 58.5000 & 45.95 & 150.0000 & 15.0000 & \\ 25 & 82.3188 & 41.0000 & 139.41 & 450.0000 & 0.0200 & \\ 5 & 0.0064 & 0.0040 & 0.00 & 0.0100 & 0.0040 & \text { DG } \\ 12 & & & & 0.0300 & 0.0300 & \text { DG } \\ 33 & 9.3242 & 9.4000 & 1.28 & 12.4000 & 7.2000 & \end{array}$




\section{Holbæk (30.01)}

Stof navn

Kondukt ivitet

MSIEMENS/M

pH

Oxygen Indhold

Carbondloxid, aggr. $\quad 146 / \mathrm{L}$

Calcluncarb, udfaldet MG/L

Carbon,org, HYOC MG/L

Permanganattal KMnO4 MG/L

Amontaktanmon tum $\quad M G / L$

Mitrit MG/L

Mitrat MG/L

Orthophosph.-PO4,f11 MG/L

Phosph..tot.filt PO4 MG/L

Phosph.,tot P04,1tit MG/L

Calcium

Chlorid

MG/L

Fluorid

Jern

Jern ferro

Kallum

Magnestun

Mangan

Natrlum

Sulfat

Hydrogensu if id

Methan

silikat
PH

MG/L

nhed

MG/L

MG/L

MG/L

MG/L

MG/L

MG/L

MG/L

MG/L

$M G / L$

$M G / L$

MG/L

$M G / L$
Vestsjæellands Amt Grundvandsanalyser, 1990

\begin{tabular}{|c|c|c|c|c|c|c|}
\hline Anta 1 & Gens & Median & Spredning & Max inum & Minfmun & \\
\hline 29 & 65.6552 & 63.0000 & 13.32 & 115.0000 & 56.0000 & \\
\hline 29 & 7.4241 & 7.4000 & 0.12 & 7.6000 & 7.0000 & \\
\hline 29 & 0.5679 & 0.5000 & 0.29 & 1.8000 & 0.0500 & \\
\hline 26 & 2.0000 & 2.0000 & 0.00 & 2.0000 & 2.0000 & \\
\hline 24 & 8.8542 & 6.7500 & 5.01 & 22.0000 & 5.0000 & \\
\hline 29 & 2.6828 & 2.3000 & 0.86 & 5.1000 & 1.8000 & \\
\hline 29 & 6.5931 & 5.6000 & 2.70 & 14.0000 & 2.6000 & \\
\hline 29 & 0.5511 & 0.5700 & 0.25 & 0.8876 & 0.0100 & DG \\
\hline 23 & 0.0174 & 0.0100 & 0.01 & 0.0400 & 0.0100 & $O G$ \\
\hline 29 & 6.5003 & 1.0000 & 20.23 & 81.0000 & 0.0100 & DG \\
\hline 29 & 0.5836 & 0.6132 & 0.27 & 0.9812 & 0.0613 & OG \\
\hline 23 & 0.7919 & 0.8279 & 0.32 & 1.3185 & 0.3679 & \\
\hline 6 & 0.5468 & 0.6439 & 0.31 & 0.7972 & 0.0613 & DG \\
\hline 29 & 115.4483 & 109.0000 & 27.62 & 218.0000 & 100.0000 & \\
\hline 29 & 26.4138 & 19.0000 & 21.36 & 108.0000 & 16.0000 & \\
\hline 29 & 0.2603 & 0.2600 & 0.04 & 0.3300 & 0.1500 & \\
\hline 23 & 4.1087 & 3.7000 & 1.35 & 6.9000 & 2.5000 & \\
\hline 29 & 3.2628 & 3.0000 & 1.33 & 5.5000 & 0.0200 & \\
\hline 29 & 2.9276 & 2.9000 & 0.42 & 3.9000 & 2.2000 & \\
\hline 29 & 10.9828 & 10.0000 & 2.01 & 16.0000 & 6.7000 & \\
\hline 29 & 0.1983 & 0.2000 & 0.06 & 0.3300 & 0.0900 & \\
\hline 29 & 17.3448 & 15.0000 & 5.87 & 36.0000 & 11.0000 & \\
\hline 29 & 27.3448 & 22.0000 & 20.14 & 87.0000 & 5.0000 & \\
\hline 23 & 0.0500 & 0.0500 & 0.00 & 0.0500 & 0.0500 & \\
\hline 29 & 0.1676 & 0.0500 & 0.25 & 1.2000 & 0.0500 & $D G$ \\
\hline 29 & 11.0448 & 11.0000 & 0.75 & 12.0000 & 9.3000 & \\
\hline
\end{tabular}


Holbæk (30.01)

\begin{tabular}{|c|c|}
\hline Stof navn & Enhed \\
\hline Kondukt ivitet & MSIEMENS/M \\
\hline $\mathrm{pH}$ & PH \\
\hline Oxygen indhold & MG/L \\
\hline Carbondtoxid, aogr. & $M G / L$ \\
\hline Ca lc tuncarb, udfaldet & $M G / L$ \\
\hline Carbon, org, NVOC & $M G / L$ \\
\hline Permanganatta $1 \mathrm{KMnO4}$ & $M G / L$ \\
\hline Alubon lak +abeseon lun & $M G / L$ \\
\hline Nitrtt & $M G / L$ \\
\hline N1trat & $M G / L$ \\
\hline Orthophosphat-P04 & $M G / L$ \\
\hline Phosph., tot PO4,f11t & $M G / L$ \\
\hline Calcium & $M G / L$ \\
\hline Chlorid & $M G / L$ \\
\hline Fluor id & $M G / L$ \\
\hline Jern & $M G / L$ \\
\hline Jern ferro & MG/L \\
\hline Ka l fum & $M G / L$ \\
\hline Magnes fum & $M G / L$ \\
\hline Mangan & $M G / L$ \\
\hline Natr lum & $M G / L$ \\
\hline Sulfat & $M G / L$ \\
\hline Hydrogensu if 10 & $M G / L$ \\
\hline Methan & $M G / L$ \\
\hline Siltkat & $M G / L$ \\
\hline
\end{tabular}

Vestsjællands Amt Grundvandsanalyser, 1989

$\begin{array}{rrrrrrr}\text { Anta1 } & \text { Gens } & \text { Median } & \text { Spredning } & \text { Maximum } & \text { Min Imum } \\ & & & & & & \\ 21 & 67.7143 & 66.0000 & 10.25 & 111.0000 & 61.0000 & \\ 21 & 7.3524 & 1.3000 & 0.14 & 7.7000 & 7.2000 & \\ 21 & 0.7714 & 0.5000 & 0.69 & 3.6000 & 0.5000 & \\ 20 & 4.1150 & 2.9500 & 4.11 & 20.0000 & 2.0000 & \\ 11 & 13.5455 & 5.0000 & 13.76 & 45.0000 & 5.0000 & \\ 21 & 2.8619 & 2.4000 & 1.29 & 6.7000 & 1.5000 & \\ 21 & 6.1143 & 5.3000 & 3.01 & 17.0000 & 3.2000 & \\ 21 & 0.1945 & 0.1945 & 0.10 & 0.3769 & 0.0122 & \text { DG } \\ 21 & 0.0286 & 0.0200 & 0.03 & 0.1600 & 0.0100 & 0 G \\ 21 & 3.6714 & 1.0000 & 11.31 & 53.0000 & 1.0000 & D G \\ 21 & 0.5037 & 0.4293 & 0.28 & 0.9199 & 0.0613 & D G \\ 21 & 0.5256 & 0.4599 & 0.29 & 0.9505 & 0.0613 & \text { DG } \\ 21 & 108.3333 & 106.0000 & 23.37 & 199.0000 & 75.0000 & \\ 21 & 22.8095 & 19.0000 & 14.63 & 84.0000 & 15.0000 & \\ 21 & 0.2929 & 0.2700 & 0.07 & 0.4700 & 0.1600 & \\ 13 & 4.8769 & 4.1000 & 2.21 & 8.6000 & 2.5000 & \\ 20 & 3.7425 & 3.3500 & 1.65 & 7.6000 & 0.8500 & \\ 21 & 3.3714 & 3.1000 & 1.18 & 7.2000 & 2.3000 & \\ 21 & 12.3810 & 11.0000 & 6.16 & 30.0000 & 6.4000 & \\ 21 & 0.2138 & 0.1900 & 0.07 & 0.3899 & 0.1100 & \\ 21 & 19.0952 & 16.0000 & 6.39 & 36.0000 & 13.0000 & \\ 21 & 23.8810 & 20.0000 & 17.72 & 81.0000 & 5.0000 & \\ 13 & 0.0515 & 0.0500 & 0.01 & 0.0700 & 0.0500 & \\ 18 & 0.1156 & 0.0700 & 0.16 & 0.5500 & 0.0500 & 0 G \\ 21 & 11.0429 & 11.0000 & 0.92 & 13.0000 & 9.2000 & \end{array}$


Munke Bjergby (30.11) Vestsjellands Amt Grundvandsanalyser, 1990

\begin{tabular}{|c|c|c|c|c|c|c|c|}
\hline Stof navn & Enhed & Anta 1 & Gens & Median & Spredning & Maximum & Min trum \\
\hline Kondukt ivitet & MSIEMENS/M & 28 & 77.8214 & 73.0000 & 20.24 & 114.0000 & 54.0000 \\
\hline pH & PH & 28 & 7.5250 & 7.5000 & 0.14 & 7.8000 & 7.2000 \\
\hline oxygen indhold & $M G / L$ & 28 & 1.2143 & 0.5000 & 1.77 & 8.8000 & 0.5000 \\
\hline Carbond10xid, aggr. & $M G / L$ & 28 & 2.4643 & 2.0000 & 2.10 & 13.0000 & 2.0000 \\
\hline Calc 1umcarb, udf zl det & $M G / L$ & 28 & 11.2857 & 7.5000 & 8.65 & 36.0000 & 5.0000 \\
\hline Carbon, org, AVOC & $M G / L$ & 28 & 3.1250 & 2.9000 & 1.76 & 9.6000 & 1.1000 \\
\hline Permanganattal KMnO4 & MG/L & 28 & 7.7321 & 6.5000 & 5.58 & 24.0000 & 1.1000 \\
\hline Ammon iak +ammon tum & $\mathrm{MG} / \mathrm{L}$ & 28 & 0.5346 & 0.4138 & 0.53 & 1.5807 & 0.0243 \\
\hline Nitrit & $M G / L$ & 24 & 0.0408 & 0.0100 & 0.05 & 0.1700 & 0.0100 \\
\hline Nitrat & $M G / L$ & 28 & 2.1250 & 1.0000 & 2.71 & 11.0000 & 1.0000 \\
\hline Orthophosph.-P04, $\mathrm{ftl}$ & $M G / L$ & 28 & 0.2354 & 0.1686 & 0.20 & 0.6132 & 0.0613 \\
\hline Phosph., tot.filt PO4 & $M G / L$ & 24 & 0.3616 & 0.3373 & 0.27 & 0.8892 & 0.0613 \\
\hline Phosph., tot P04,P1It & $M G / L$ & 4 & 0.0920 & 0.0613 & 0.06 & 0.1840 & 0.0613 \\
\hline Calcium & $M G / L$ & 28 & 134.2857 & 135.0000 & 42.41 & 202.0000 & 85.0000 \\
\hline Chlorid & $M G / L$ & 28 & 49.8214 & 33.0000 & 37.40 & 126.0000 & 16.0000 \\
\hline Fluorid & $\mathrm{MG} / \mathrm{L}$ & 28 & 0.1739 & 0.1750 & 0.05 & 0.2700 & 0.1000 \\
\hline Jern & $\mathrm{MG} / \mathrm{L}$ & 24 & 1.9263 & 1.9000 & 1.47 & 5.3000 & 0.0400 \\
\hline Jern ferro & $M G / L$ & 28 & 1.1971 & 1.1000 & 0.98 & 4.0000 & 0.0200 \\
\hline Kalium & $M G / L$ & 28 & 3.3179 & 3.2000 & 0.78 & 4.7000 & 1.8000 \\
\hline Magnes íum & $M G / L$ & 28 & 10.9964 & 11.5000 & 2.53 & 14.0000 & 6.5000 \\
\hline Mangan & $M G / L$ & 28 & 0.1846 & 0.1600 & 0.08 & 0.3500 & 0.0900 \\
\hline Natrifum & $M G / L$ & 28 & 21.7107 & 22.5000 & 8.68 & 43.0000 & 9.9000 \\
\hline Sulfat & $M G / L$ & 28 & 86.2857 & 106.5000 & 52.88 & 149.0000 & 5.0000 \\
\hline Hydrogensulf id & $M G / L$ & 24 & 0.0567 & 0.0500 & 0.02 & 0.1100 & 0.0500 \\
\hline Methan & $M G / L$ & 28 & 0.2239 & 0.0500 & 0.33 & 1.1000 & 0.0500 \\
\hline sirfkat & $M G / L$ & 28 & 10.2500 & 10.0000 & 2.55 & 15.0000 & 6.0000 \\
\hline
\end{tabular}


Munke Bjergby (30.11) Vestsjellands Amt Grundvandsanalyser, 1989

\begin{tabular}{|c|c|c|c|c|c|c|c|}
\hline Stof navn & Enhed & Antal & Gens & Median & Spredning & Max 1mua & Min imun \\
\hline Kondukt ivitet & MSIEMENS/M & 39 & 81.5641 & 77.0000 & 21.46 & 127.0000 & 53.0000 \\
\hline pH & PH & 39 & 7.3487 & 7.3000 & 0.26 & 8.1000 & 6.8000 \\
\hline Oxygen indhold & MG/L & 31 & 2.1068 & 0.6100 & 2.93 & 11.0000 & 0.0800 \\
\hline Carbondioxid, aggr. & $M G / L$ & 7 & 2.6571 & 2.0000 & 1.74 & 6.6000 & 2.0000 \\
\hline Calc luncarb, udfa l det & $M G / L$ & 38 & 9.4868 & 6.5000 & 8.88 & 57.0000 & 5.0000 \\
\hline Carbon, org, nYoC & $M G / L$ & 39 & 2.9103 & 2.8000 & 1.33 & 6.7000 & 1.3000 \\
\hline Permanganattal KMn04 & $M G / L$ & 39 & 7.1077 & 5.9000 & 4.04 & 17.0000 & 2.5000 \\
\hline Ammon lax $+a$ amen on tum & $M G / L$ & 32 & 0.2147 & 0.1945 & 0.19 & 0.6687 & 0.0122 \\
\hline Nitrit & $M G / L$ & 32 & 0.0491 & 0.0200 & 0.06 & 0.2000 & 0.0100 \\
\hline N1trat & MG/L & 30 & 3.0833 & 1.0000 & 4.07 & 14.0000 & 1.0000 \\
\hline Orthophosphat-P04 & $M 6 / L$ & 37 & 53.9842 & 0.3066 & 110.30 & 444.5990 & 0.0613 \\
\hline Phosph., tot P04,f1lt & $\mathrm{MG} / \mathrm{L}$ & 35 & 0.2672 & 0.2453 & 0.18 & 0.6439 & 0.0613 \\
\hline Calcium & $M G / L$ & 39 & 142.1795 & 139.0000 & 41.92 & 214.0000 & 87.0000 \\
\hline Chlorid & $M G / L$ & 39 & 51.5128 & 33.0000 & 36.27 & 121.0000 & 16.0000 \\
\hline Fluor id & $M G / L$ & 39 & 0.1879 & 0.2000 & 0.07 & $0.4300 *$ & 0.0100 \\
\hline Jern & $M G / L$ & 29 & 1.9165 & 2.0000 & 0.98 & 4.2000 & 0.3100 \\
\hline Jern ferro & $M G / L$ & 39 & 1.2110 & 1.3000 & 0.87 & 3.3000 & 0.0700 \\
\hline Kalfum & MG/L & 39 & 3.3769 & 3.3000 & 0.88 & 4.9000 & 1.8000 \\
\hline Magnes ium & $M G / L$ & 39 & 8.2205 & 8.3000 & 4.41 & 18.0000 & 0.4000 \\
\hline Mangan & $M G / L$ & 39 & 0.2236 & 0.1800 & 0.12 & 0.5200 & 0.0700 \\
\hline Natrium & $M G / L$ & 39 & 22.1538 & 20.0000 & 12.73 & 83.0000 & 10.0000 \\
\hline Sulfat & $M G / L$ & 38 & 91.5526 & 106.5000 & 48.44 & 165.0000 & 5.0000 \\
\hline Hydrogensu If id & MG/L & 29 & 0.0441 & 0.0500 & 0.02 & 0.1200 & 0.0100 \\
\hline Methan & $M G / L$ & 39 & 0.3095 & 0.0600 & 0.50 & 1.8000 & 0.0500 \\
\hline Silikat & $M G / L$ & 39 & 9.3974 & 9.4000 & 2.69 & 15.0000 & 5.5000 \\
\hline
\end{tabular}

* Særlig usædvanlig værdi, der må kontrolleres. 
Store Fuglede (30.12)

Vestsjællands Amt Grundvandsanalyser, 1990

\begin{tabular}{|c|c|c|c|c|c|c|c|}
\hline Stof navn & Enhed & Antal & Gens & Median & Spredning & Maxtaun & Min twu= \\
\hline Kondukt ivitet & MSIEMENS/M & 35 & 81.8000 . & 69.0000 & 31.65 & 187.0000 & 61.0000 \\
\hline pH & PH & 35 & 7.2686 & 7.4000 & 0.55 & 7.7000 & 4.3000 \\
\hline Oxygen indhold & $M G / L$ & 31 & 1.2581 & 0.5000 & 2.12 & 10.0000 & 0.0500 \\
\hline Carbondioxid, aggr. & $M G / L$ & 28 & 2.0000 & 2.0000 & 0.00 & 2.0000 & 2.0000 \\
\hline Ca lc 1uncarb, udf 2 ldet & $M G / L$ & 30 & 7.7500 & 5.5000 & 4.21 & 21.0000 & 5.0000 \\
\hline Carbon, org, nYoC & $M G / L$ & 35 & 2.0029 & 1.7000 & 0.91 & 5.5000 & 1.4000 \\
\hline Permanganatta $1 \mathrm{KMnO4}$ & $M G / L$ & 35 & 4.8286 & 4.1000 & 2.38 & 12.0000 & 2.3000 \\
\hline A weon fak +amaon lum & $M G / L$ & 35 & 0.5666 & 0.5836 & 0.27 & 1.1000 & 0.0122 \\
\hline Nitrit & $M G / L$ & 30 & 0.0197 & 0.0100 & 0.02 & 0.0800 & 0.0100 \\
\hline Nitrat & $M G / L$ & 35 & 1.4057 & 1.0000 & 0.75 & 3.5000 & 1.0000 \\
\hline Orthophosphat-P04 & $M G / L$ & 16 & 0.2817 & 0.3220 & 0.19 & 0.5519 & 0.0613 \\
\hline Orthophosph.,-P04, f1? & $M G / L$ & 19 & 0.2437 & 0.2453 & 0.13 & 0.4293 & 0.0613 \\
\hline Phosph.,tot.fllt PO4 & $M G / L$ & 16 & 0.4159 & 0.5213 & 0.18 & 0.6439 & 0.0920 \\
\hline Phosph., tot P04,f11t & $M G / L$ & 19 & 0.2760 & 0.2453 & 0.21 & 0.5826 & 0.0613 \\
\hline Calctun & $M G / L$ & 35 & 114.4000 & 103.0000 & 28.13 & 204.0000 & 94.0000 \\
\hline Chlorid & $M G / L$ & 35 & 53.6000 & 38.0000 & 37.71 & 176.0000 & 31.0000 \\
\hline Fluor to & $M G / L$ & 35 & 0.3648 & 0.3600 & 0.03 & 0.4200 & 0.3000 \\
\hline Jern & $M G / L$ & 25 & 4.0612 & 3.6000 & 2.20 & 10.0000 & 0.9000 \\
\hline Jern ferro & $M 6 / L$ & 32 & 3.3444 & 3.1500 & 1.98 & 9.4000 & 0.2000 \\
\hline Kallua & $M G / L$ & 35 & 4.0086 & 3.3000 & 1.88 & 8.4000 & 2.3000 \\
\hline Magnes tum & $M G / L$ & 35 & 19.6571 & 16.0000 & 11.20 & 53.0000 & 12.0000 \\
\hline Mangan & $M G / L$ & 32 & 0.1919 & 0.1800 & 0.05 & 0.3100 & 0.1300 \\
\hline Natrtum & $196 / L$ & 35 & 37.7429 & 23.0000 & 34.39 & 162.0000 & 19.0000 \\
\hline Sulfat & $M G / L$ & 35 & 49.2000 & 37.0000 & 34.58 & 190.0000 & 21.0000 \\
\hline Hydrogensulf id & $M G / L$ & 25 & 0.0500 & 0.0500 & 0.00 & 0.0500 & 0.0500 \\
\hline Methan & $M 6 / L$ & 34 & 0.0741 & 0.0500 & 0.06 & 0.2800 & 0.0500 \\
\hline Sllikat & $M G / L$ & 35 & 11.0057 & 11.0000 & 1.20 & 14.0000 & B. 0000 \\
\hline
\end{tabular}


Store Fuglede (30.12) Vestsjallands Amt Grundvandsanalyser, 1989

\begin{tabular}{|c|c|c|c|c|c|c|c|}
\hline Stof navn & Enhed & Antal & Gens & Median & Spredning & Maximuin & Min tmun \\
\hline Kondukt ivitet & MSIEMENS/M & 19 & 70.5263 . & 69.0000 & 5.95 & 92.0000 & 62.0000 \\
\hline $\mathrm{pH}$ & PH & 19 & 7.4947 & 7.5000 & 0.27 & 8.0000 & 7.2000 \\
\hline Oxygen indhold & $M 6 / L$ & 16 & 2.2688 & 1.4500 & 2.87 & 11.0000 & 0.4000 \\
\hline Carbond toxid, aggr. & $M G / L$ & 8 & 3.8625 & 3.4000 & 2.02 & 7.1000 & 2.0000 \\
\hline Calc iumcarb, udf eldet & $M G / L$ & 11 & 10.1818 & 10.0000 & 5.29 & 20.0000 & 5.0000 \\
\hline Carbon, org, HYOC & $M G / L$ & 13 & 1.5692 & 1.6000 & 0.31 & 2.2000 & 1.1000 \\
\hline Permanganattal KMnO4 & $M G / L$ & 19 & 3.4947 & 2.9000 & 1.57 & 8.0000 & 1.7000 \\
\hline Amson fak tamaon fum & MG/L & 19 & 0.2404 & 0.2553 & 0.10 & 0.4100 & 0.0365 \\
\hline Nitrit & $M G / L$ & 19 & 0.0184 & 0.0100 & 0.01 & 0.0500 & 0.0100 \\
\hline M1trat & HG/L & 19 & 1.2053 & 1.0000 & 0.34 & 2.0000 & 1.0000 \\
\hline Orthophosphat-PO4 & $M G / L$ & 19 & 35.2581 & 0.4906 & 112.67 & $484.4596 *$ & 0.0307 \\
\hline Phosph., tot P04,filt & $M G / L$ & 19 & 0.3066 & 0.3679 & 0.21 & 0.5826 & 0.0613 \\
\hline Calcium & HG/L & 19 & 108.6316 & 105.0000 & 17.90 & 180.0000 & 94.0000 \\
\hline Chlorid & $M G / L$ & 19 & 37.0000 & 34.0000 & 9.42 & 73.0000 & 30.0000 \\
\hline Fluorid & $M G / L$ & 19 & 0.3789 & 0.3800 & 0.03 & 0.4300 & 0.3300 \\
\hline Jern & $M G / L$ & 11 & 3.3809 & 3.4000 & 1.65 & 5.8000 & 0.0900 \\
\hline Jern ferro & $M G / L$ & 19 & 2.8800 & 2.9000 & 1.79 & 5.8000 & 0.0700 \\
\hline Ka l lum & $M 6 / L$ & 19 & 3.4526 & 3.3000 & 1.35 & 8.4000 & 2.3000 \\
\hline Magnes ium & $M G / L$ & 19 & 11.5947 & 12.0000 & 3.13 & 19.0000 & 6.6000 \\
\hline Mangan & $M G / L$ & 19 & 0.1737 & 0.1600 & 0.04 & 0.2700 & 0.1200 \\
\hline Natrium & $M G / L$ & 19 & 23.1579 & 21.0000 & 7.09 & 49.0000 & 18.0000 \\
\hline Sulfat & $M G / L$ & 19 & 31.8947 & 30.0000 & 14.44 & 81.0000 & 12.0000 \\
\hline Hydrogensulf Id & $\mathrm{MG} / \mathrm{L}$ & 8 & 0.0500 & 0.0500 & 0.00 & 0.0500 & 0.0500 \\
\hline Methan & $M G / L$ & 18 & 0.0594 & 0.0600 & 0.01 & 0.0700 & 0.0500 \\
\hline S1l1kat & $\mathrm{MG} / \mathrm{L}$ & 19 & 11.1211 & 11.0000 & 0.88 & 12.0000 & 8.3000 \\
\hline
\end{tabular}

\footnotetext{
* Særlig usædvanlig værdi, der må kontrolleres.
} 
Nykøbing S. (30.13)

\begin{tabular}{|c|c|}
\hline Stof navn & Enhed \\
\hline Konduktivitet & MSIEMENS/M \\
\hline PH & PH \\
\hline Oxygen indhold & $M G / L$ \\
\hline Carbondtoxtd, aggr. & $M G / L$ \\
\hline Calc Iumcarb, udfaldet & $M G / L$ \\
\hline Carbon, org, HYOC & $M G / L$ \\
\hline Permanganatta $1 \mathrm{KMnO4}$ & $M G / L$ \\
\hline Akmon $1 \mathrm{ak}+\mathrm{a}$ mon on tum & $M G / L$ \\
\hline Nitrit & $M G / L$ \\
\hline Nitrat & $M G / L$ \\
\hline Orthophosphat-PO4 & $M G / L$ \\
\hline Orthophosph.-P04, 111 & $M G / L$ \\
\hline Phosph..tot.P1lt P04 & $M G / L$ \\
\hline Phosph., tot P04,filt & $M G / L$ \\
\hline Bor & MYGRAM/L \\
\hline Calc tum & $M G / L$ \\
\hline Chlorid & $M G / L$ \\
\hline Fluorid & $M G / L$ \\
\hline Jern & $M G / L$ \\
\hline Jern ferro & $M G / L$ \\
\hline Kalfum & $M G / L$ \\
\hline Magnestun & $M G / L$ \\
\hline Mangan & $M G / L$ \\
\hline Natrium & $M G / L$ \\
\hline Sulfat & $M G / L$ \\
\hline Hydrogensulfid & $M G / L$ \\
\hline Methan & $M G / L$ \\
\hline Detergenter anton & $M G / L$ \\
\hline S111kat & $M G / L$ \\
\hline Kimtal 376r. PCA & ANTAL/ML \\
\hline Collforme bakt.30Gr. & ANTAL/100 ML \\
\hline Termotol.coll.bakt. & ANTAL/100 ML \\
\hline Cl.perfringens & ANTAL/100 ML \\
\hline
\end{tabular}

Vestsjæellands Amt Grundvandsanalyser, 1990

\begin{tabular}{|c|c|c|c|c|c|}
\hline Antal & Gens & Median & Spredning & Max tmum & Min inum \\
\hline 48 & 72.0417 & 73.0000 & 8.89 & 92.0000 & 60.0000 \\
\hline 48 & 7.5167 & 7.5000 & 0.12 & 7.7000 & 7.2000 \\
\hline 48 & 0.7688 & 0.5000 & 0.80 & 4.2000 & 0.5000 \\
\hline 40 & 2.0875 & 2.0000 & 0.24 & 3.0000 & 2.0000 \\
\hline 40 & 7.3375 & 5.0000 & 6.28 & 37.0000 & 5.0000 \\
\hline 52 & 9.7650 & 9.1500 & 4.39 & 20.0000 & 4.4000 \\
\hline 48 & 30.9375 & 29.5000 & 17.25 & 74.0000 & 11.0000 \\
\hline 52 & 0.9211 & 0.5472 & 1.72 & 8.0249 & 0.0122 \\
\hline 46 & 0.0198 & 0.0100 & 0.01 & 0.0700 & 0.0100 \\
\hline 48 & 1.1396 & 1.0000 & 0.37 & 3.0000 & 1.0000 \\
\hline 12 & 0.4804 & 0.1840 & 0.70 & 2.4836 & 0.0613 \\
\hline 36 & 0.4114 & 0.1840 & 0.57 & 2.2383 & 0.0613 \\
\hline 38 & 0.4583 & 0.2300 & 0.63 & 2.4530 & 0.0920 \\
\hline 14 & 0.4271 & 0.1073 & 0.65 & 2.3303 & 0.0307 \\
\hline 30 & 140.0000 & 135.0000 & 45.11 & 260.0000 & 80.0000 \\
\hline 49 & 97.2041 & 98.0000 & 15.68 & 126.0000 & 67.0000 \\
\hline 52 & 57.5192 & 54.0000 & 23.34 & 110.0000 & 27.0000 \\
\hline 48 & 0.2890 & 0.2350 & 0.16 & 0.7200 & 0.1300 \\
\hline 43 & 2.0714 & 1.8000 & 1.29 & 8.2000 & 0.5400 \\
\hline 48 & 1.6108 & 1.4000 & 0.84 & 3.5000 & 0.1000 \\
\hline 52 & 5.9923 & 5.0500 & 3.51 & 16.0000 & 2.2000 \\
\hline 49 & 12.8612 & 9.2000 & 5.51 & 23.0000 & 6.0000 \\
\hline 48 & 0.1383 & 0.1100 & 0.08 & 0.3200 & 0.0300 \\
\hline 50 & 36.0600 & 38.0000 & 7.78 & 52.0000 & 20.0000 \\
\hline 52 & 57.1346 & 68.0000 & 25.27 & 96.0000 & 9.0000 \\
\hline 42 & 0.0924 & 0.0500 & 0.13 & 0.8700 & 0.0500 \\
\hline 48 & 0.2674 & 0.0600 & 0.62 & $3.9000 *$ & 0.0050 \\
\hline 23 & 0.0117 & 0.0100 & 0.00 & 0.0200 & 0.0100 \\
\hline 48 & 8.9792 & 8.7000 & 2.48 & 15.0000 & 5.5000 \\
\hline 26 & 133.9231 & 11.0000 & 301.29 & 1300.0000 & 1.0000 \\
\hline 6 & 3.0000 & 2.0000 & 1.55 & 5.0000 & 2.0000 \\
\hline 6 & & & & 2.0000 & 2.0000 \\
\hline 6 & 4.6667 & 1.0000 & 6.22 & 16.0000 & 1.0000 \\
\hline
\end{tabular}

* Særlig usædvanlig værdi, der må kontrolleres. 
Nykøbing S. (30.13)

\begin{tabular}{|c|c|}
\hline Stof navn & Enhed \\
\hline Kondukt ivitet & MSIEMENS/M \\
\hline pH & PH \\
\hline Oxygen indhold & $M G / L$ \\
\hline Carbondioxid, aggr. & $M 6 / L$ \\
\hline Calc luncarb, udfaldet & MG/L \\
\hline Carbon, org, nvoc & $M G / L$ \\
\hline Permanganatta I KMn04 & $M G / L$ \\
\hline Amison taktamon fun & $M G / L$ \\
\hline Nitrit & $M G / L$ \\
\hline N1trat & $\boldsymbol{H S} / \mathrm{L}$ \\
\hline Orthophosphat-P04 & $M G / L$ \\
\hline Phosph., tot P04,f11t & $M G / L$ \\
\hline Bor & MYGRAM/L \\
\hline Calciun & $M G / L$ \\
\hline Chlor 1d & $M G / L$ \\
\hline Fluor id & $M G / L$ \\
\hline Jern & $M G / L$ \\
\hline Jern terro & $M G / L$ \\
\hline Kallua & $M G / L$ \\
\hline Magnes tur & MG/L \\
\hline Mangan & $M G / L$ \\
\hline Natrium & MG/L \\
\hline Sulfat & $M G / L$ \\
\hline Hydrogensulf id & $M G / L$ \\
\hline Methan & $M G / L$ \\
\hline Detergenter anton & $M G / L$ \\
\hline S1likat & $M G / L$ \\
\hline Ktmtal 376r. PCA & ANTAL/ML \\
\hline Collforme bakt.30Gr. & AKTAL/100 ML \\
\hline Termotol.colf.bakt. & ANTAL/100 ML \\
\hline Faka le collbakter ier & ANTAL/100ML \\
\hline Cl.perfringens & AMTAL/100 ML \\
\hline
\end{tabular}

\section{Vestsjællands Amt Grundvandsanalyser, 1989}

\begin{tabular}{|c|c|c|c|c|c|}
\hline Anta 1 & Gens & Medtan & Spredning & Maximun & Miniaum \\
\hline 42 & 73.9524. & 73.0000 & 10.41 & 97.0000 & 58.0000 \\
\hline 42 & 7.3071 & 7.3000 & 0.18 & 8.0000 & 6.9000 \\
\hline 32 & 0.8216 & 0.5000 & 0.94 & 4.2000 & 0.0500 \\
\hline 30 & 2.7233 & 2.0000 & 1.15 & 6.6000 & 2.0000 \\
\hline 30 & 10.6667 & 5.0000 & 8.93 & 35.0000 & 5.0000 \\
\hline 42 & 9.9333 & 9.0000 & 4.15 & 19.0000 & 4.2000 \\
\hline 42 & 34.4524 & 33.0000 & 17.95 & 72.0000 & 10.0000 \\
\hline 41 & 0.5113 & 0.2675 & 1.26 & 8.1465 & 0.0122 \\
\hline 39 & 0.0190 & 0.0200 & 0.01 & 0.0400 & 0.0100 \\
\hline 41 & 1.6244 & 1.2000 & 1.16 & 5.3000 & 1.0000 \\
\hline 42 & 96.9175 & 0.3066 & 342.62 & 2213.7964 & 0.0920 \\
\hline 35 & 0.4319 & 0.1840 & 0.62 & 2.3913 & 0.0920 \\
\hline 10 & 159.0000 & 160.0000 & 33.81 & 230.0000 & 120.0000 \\
\hline 42 & 101.5476 & 99.5000 & 17.54 & 136.0000 & 68.0000 \\
\hline 42 & 58.4762 & 56.5000 & 25.73 & 115.0000 & 26.0000 \\
\hline 42 & 0.2707 & 0.2200 & 0.16 & 0.7600 & 0.1300 \\
\hline 32 & 2.6759 & 2.4500 & 1.78 & 7.3000 & 0.1600 \\
\hline 37 & 1.7835 & 1.9000 & 0.96 & 4.3000 & 0.1500 \\
\hline 42 & 5.9167 & 5.0000 & 3.52 & 15.0000 & 2.2000 \\
\hline 42 & 10.9571 & 8.3500 & 5.30 & 22.0000 & 4.6000 \\
\hline 42 & 0.1640 & 0.1400 & 0.09 & 0.4000 & 0.0400 \\
\hline 42 & 33.6786 & 35.5000 & 8.07 & 47.0000 & 3.5000 \\
\hline 42 & 62.3571 & 69.5000 & 25.14 & 97.0000 & 12.0000 \\
\hline 31 & 0.1029 & 0.0500 & 0.19 & 0.9100 & 0.0100 \\
\hline 32 & 0.1809 & 0.0500 & 0.38 & 1.8000 & 0.0400 \\
\hline 11 & 0.0336 & 0.0300 & 0.02 & 0.0700 & 0.0100 \\
\hline 35 & 9.0543 & 8.3000 & 2.26 & 15.0000 & 5.9000 \\
\hline 14 & 448.9286 & 98.5000 & 623.90 & 2000.0000 & 2.0000 \\
\hline 17 & 3.0000 & 2.0000 & 3.02 & 13.0000 & 1.0000 \\
\hline 8 & & & & 2.0000 & 2.0000 \\
\hline 9 & & & & 1.0000 & 1.0000 \\
\hline 17 & 4.0588 & 1.0000 & 4.90 & 16.0000 & 1.0000 \\
\hline
\end{tabular}


Eggeslevmagle (30.14) Vestsjallands Amt Grundvandsanalyser, 1990

\begin{tabular}{|c|c|c|c|c|c|c|c|c|}
\hline Stof novn & Enhed & Antal & Gens & Median & Spredning & Max inum & Mintmue & \\
\hline Kondukt ivitet & MSIEMENS/M & 46 & 94.9130 . & 93.0000 & 20.85 & 183.0000 & 67.0000 & \\
\hline pH & $\mathbf{P H}$ & 47 & 7.4574 & 7.4000 & 0.16 & 7.8000 & 6.9000 & \\
\hline Oxygen tndhold & $M G / L$ & 47 & 1.0404 & 0.5000 & 1.19 & 5.8000 & 0.5000 & \\
\hline Carbondioxid, aggr. & $M G / L$ & 40 & 3.5625 & 2.0000 & 8.26 & 54.0000 & 2.0000 & \\
\hline Calc funcarb, udfaldet & $M G / L$ & 36 & 11.7639 & 8.0000 & 10.34 & 44.0000 & 5.0000 & \\
\hline Carbon,org, HVOC & MG/L & 47 & 1.9713 & 1.4000 & 1.04 & 4.6000 & 0.8500 & \\
\hline Permanganattal $\mathrm{KMnO4}$ & $M G / L$ & 47 & 5.5511 & 4.4000 & 5.10 & 32.0000 & 1.2000 & \\
\hline Amon n tak+asmontun & $M G / L$ & 43 & 0.4437 & 0.3405 & 0.65 & 4.2000 & 0.0100 & $D G$ \\
\hline Nitrit & $M G / L$ & 36 & 0.0200 & 0.0100 & 0.01 & 0.0600 & 0.0100 & DG \\
\hline Nitrat & $M G / L$ & 47 & 4.7936 & 1.0000 & 16.02 & 84.0000 & 1.0000 & \\
\hline Orthophosphat-PO4 & $M G / L$ & 23 & 0.1533 & 0.1226 & 0.11 & 0.4293 & 0.0613 & \\
\hline Orthophosph.-P04,111 & $M G / L$ & 22 & 0.1422 & 0.0767 & 0.12 & 0.4293 & 0.0307 & $D G$ \\
\hline Phosph.,tot.filt P04 & $M G / L$ & 14 & 0.2803 & 0.2453 & 0.16 & 0.6132 & 0.0613 & \\
\hline Phosph., tot P04,f11t & $M G / L$ & 33 & 0.1645 & 0.1226 & 0.13 & 0.5826 & 0.0307 & $O G$ \\
\hline Caletum & $\mathrm{MG} / \mathrm{L}$ & 47 & 118.8936 & 114.0000 & 28.04 & 184.0000 & 71.0000 & \\
\hline Chlorid & $M G / L$ & 47 & 185.6809 & 71.0000 & 658.39 & 4580.0000 & 31.0000 & \\
\hline F luortd & $M G / L$ & 47 & 0.3657 & 0.3600 & 0.11 & 0.6800 & 0.2000 & \\
\hline Jern & $M G / L$ & 31 & 2.4039 & 2.1000 & 1.22 & 4.8000 & 0.4700 & \\
\hline Jern ferro & $M G / L$ & 45 & 1.7191 & 1.5000 & 1.28 & 4.4000 & 0.0100 & \\
\hline Kalium & $M G / L$ & 47 & 5.6766 & 4.5000 & 5.38 & 33.0000 & 1.2000 & \\
\hline Magnes lun & $M G / L$ & 47 & 20.1489 & 19.0000 & 9.74 & 80.0000 & 11.0000 & \\
\hline Mangan & MG/L & 45 & 0.1824 & 0.1600 & 0.12 & 0.7000 & 0.0400 & \\
\hline Natrfum & $M G / L$ & 47 & 118.5957 & 45.0000 & 371.43 & 2590.0000 & 16.0000 & \\
\hline Sulfat & $M G / L$ & 47 & 97.8085 & 100.0000 & 35.59 & 187.0000 & 28.0000 & \\
\hline Hydrogensulf id & $M G / L$ & 32 & 0.0512 & 0.0500 & 0.00 & 0.0700 & 0.0500 & \\
\hline Methan & $M G / L$ & 47 & 0.0604 & 0.0500 & 0.01 & 0.0900 & 0.0500 & DG \\
\hline Sillkat & $M G / L$ & 47 & 10.9915 & 11.0000 & 1.45 & 14.0000 & 7.7000 & \\
\hline
\end{tabular}


Eggeslevmagle (30.14) Vestsjallands Amt Grundvandsanalyser, 1989

\begin{tabular}{|c|c|c|c|c|c|c|c|}
\hline Stof navn & Enhed & Antal & Gens & Median & Spredning & Maxinuin & Min inum \\
\hline Kondukt Ivitet & MSIEMENS/M & 29 & 97.4138. & 88.0000 & 19.58 & 126.0000 & 71.0000 \\
\hline pH & PH & 29 & 7.4690 & 7.5000 & 0.18 & 7.9000 & 7.2000 \\
\hline Oxygen indhold & $M G / L$ & 25 & 1.3176 & 0.5000 & 1.65 & 5.6000 & 0.2000 \\
\hline Carbond1oxid, aggr. & $M G / L$ & 19 & 2.3737 & 2.0000 & 1.06 & 6.6000 & 2.0000 \\
\hline Calc Iuncarb, udfaldet & MG/L & 19 & 9.2105 & 5.0000 & 6.07 & 25.0000 & 5.0000 \\
\hline Carbon, org, nVOC & $M G / L$ & 19 & 1.8737 & 1.4000 & 0.94 & 4.2000 & 1.1000 \\
\hline Permanganatta 1 KHnO4 & $M G / L$ & 29 & 4.3724 & 3.2000 & 2.68 & 10.0000 & 1.5000 \\
\hline A wan faktamen fula & HG/L & 27 & 0.1819 & 0.1702 & 0.13 & 0.5228 & 0.0122 \\
\hline N1trit & $M 6 / L$ & 25 & 0.0328 & 0.0200 & 0.03 & 0.1000 & 0.0100 \\
\hline Nitrat & $M G / L$ & 27 & 1.8444 & 1.0000 & 1.94 & 8.0000 & 0.8000 \\
\hline Orthophosphat-P04 & $M 6 / L$ & 29 & 44.6322 & 0.2146 & 99.68 & 429.2680 & 0.0307 \\
\hline Phosph., tot PO4,f11t & $M G / L$ & 29 & 0.1861 & 0.1226 & 0.12 & 0.4599 & 0.0307 \\
\hline Calcium & $146 / \mathrm{L}$ & 29 & 114.3103 & 110.0000 & 24.77 & 170.0000 & 63.0000 \\
\hline Cn lor 10 & $M G / L$ & 29 & 92.2414 & 62.0000 & 58.39 & 178.0000 & 30.0000 \\
\hline Fluor 1d & $\mathrm{HG} / \mathrm{L}$ & 29 & 0.3683 & 0.4000 & 0.08 & 0.5500 & 0.1900 \\
\hline Jern & $M 6 / L$ & 17 & 3.4041 & 3.7000 & 1.55 & 5.8000 & 0.1700 \\
\hline Jern ferro & $M G / L$ & 29 & 2.0924 & 1.6000 & 1.52 & 4.8000 & 0.0700 \\
\hline Kallua & $M 6 / L$ & 29 & 5.6621 & 5.1000 & 3.85 & 17.0000 & 1.2000 \\
\hline Magnes ium & MG/L & 29 & 15.5966 & 16.0000 & 5.22 & 29.0000 & 4.7000 \\
\hline Mangan & $M G / L$ & 29 & 0.1997 & 0.1900 & 0.07 & 0.4200 & 0.0800 \\
\hline Natrium & $M G / L$ & 29 & 67.3103 & 46.0000 & 44.24 & 146.0000 & 17.0000 \\
\hline Sulfat & $\mathrm{MG} / \mathrm{L}$ & 29 & 96.0690 & 103.0000 & 31.30 & 183.0000 & 34.0000 \\
\hline Hydrogensu if id & $M G / L$ & 17 & 0.0406 & 0.0500 & 0.02 & 0.0500 & 0.0100 \\
\hline Methan & MG/L & 29 & 0.0597 & 0.0600 & 0.01 & 0.0700 & 0.0500 \\
\hline Silikat & $M G / L$ & 29 & 9.7310 & 10.0000 & 2.04 & 13.0000 & 4.6000 \\
\hline
\end{tabular}




\section{Holeby (35.01)}

\begin{tabular}{|c|c|}
\hline Stof navn & Enhed \\
\hline Kondukt ivitet & HSIEMEMS/M \\
\hline pH & PH \\
\hline Inddanpn ingsrest & $\mathrm{MG} / \mathrm{L}$ \\
\hline Oxygen indhold & $M G / L$ \\
\hline Carbond10x1d, agor. & $M G / L$ \\
\hline Hydrogencarbonat & $M G / L$ \\
\hline Permanganattal KMnO4 & $M G / L$ \\
\hline Ammon tak tamon ium & $M G / L$ \\
\hline Nitrit & $M G / L$ \\
\hline Nitrat & $M G / L$ \\
\hline Orthophosphat-P04 & $M G / L$ \\
\hline Phosph.,tot.f1lt PO4 & MG/L \\
\hline Calciuan & $M G / L$ \\
\hline Chlorid & $M G / L$ \\
\hline Fluortd & $M G / L$ \\
\hline Jern ferro & $\mathrm{MG} / \mathrm{L}$ \\
\hline Kallum & MG/L \\
\hline Magnestun & $\mathrm{MG} / \mathrm{L}$ \\
\hline Mangan & $M G / L$ \\
\hline Matrfum & $M G / L$ \\
\hline Sulfat & $M G / L$ \\
\hline Hydrogensult id & $M G / L$ \\
\hline Methan & $M G / L$ \\
\hline Temperatur & GRADER C \\
\hline
\end{tabular}

Storstrøms Amt Grundvandsanalyser, 1990

\begin{tabular}{|c|c|c|c|c|c|}
\hline Antal & Gens & Median & Spredning & Max 1mun & Mintaum \\
\hline 60 & 75.7283 . & 75.0000 & 12.32 & 101.0000 & 49.0000 \\
\hline 60 & 7.3113 & 7.3100 & 0.22 & 7.7700 & 6.8300 \\
\hline 60 & 477.6667 & 460.0000 & 99.46 & 680.0000 & 270.0000 \\
\hline 57 & 1.0368 & 0.8000 & 0.88 & 4.1000 & 0.2000 \\
\hline 23 & 5.1587 & 3.0000 & 5.83 & 19.7000 & 0.0500 \\
\hline 59 & 372.6949 & 386.0000 & 47.65 & 439.0000 & 248.0000 \\
\hline 60 & 5.7217 & 4.5000 & 3.00 & 12.9000 & 1.0000 \\
\hline 59 & 0.5516 & 0.3520 & 0.50 & 1.9000 & 0.0070 \\
\hline 47 & 0.0346 & 0.0100 & 0.06 & 0.4100 & 0.0050 \\
\hline 59 & 7.3898 & 1.0000 & 17.63 & 75.0000 & 1.0000 \\
\hline 60 & 0.0393 & 0.0305 & 0.03 & 0.1200 & 0.0070 \\
\hline 60 & 0.2447 & 0.1962 & 0.16 & 0.9812 & 0.0276 \\
\hline 56 & 114.4821 & 110.0000 & 38.15 & 205.0000 & 30.0000 \\
\hline 60 & 43.5333 & 42.5000 & 19.92 & 103.0000 & 15.0000 \\
\hline 56 & 0.4679 & 0.5000 & 0.17 & 1.0000 & 0.2000 \\
\hline 59 & 3.3938 & 3.5800 & 2.72 & 11.3000 & 0.0300 \\
\hline 59 & 5.6119 & 5.0000 & 3.35 & 13.9000 & 2.2000 \\
\hline 56 & 17.5143 & 17.1500 & 5.52 & 28.0000 & 4.0000 \\
\hline 59 & 0.1139 & 0.1000 & 0.09 & 0.5000 & 0.0030 \\
\hline 59 & 35.6407 & 34.0000 & 10.84 & 60.0000 & 15.8000 \\
\hline 53 & 51.8894 & 48.0000 & 42.15 & 125.0000 & 0.3800 \\
\hline 59 & 0.0505 & 0.0500 & 0.00 & 0.0800 & 0.0500 \\
\hline 58 & 0.7136 & 0.0500 & 1.85 & 11.2000 & 0.0100 \\
\hline 60 & 10.5967 & 10.4000 & 1.87 & 16.5000 & 7.8000 \\
\hline
\end{tabular}


Hjelmsølille (35.02)

\begin{tabular}{|c|c|}
\hline Stof navn & Enhed \\
\hline Kondukt Ivitet & MSIEMENS/M \\
\hline pH & PH \\
\hline Inddaupn ingsrest & $M G / L$ \\
\hline Oxygen Indhold & MG/L \\
\hline Carbondtoxtd, aggr. & $M 6 / L$ \\
\hline Hydrogencarbonat & $M G / L$ \\
\hline Permanganatta 1 KMn04 & $M G / L$ \\
\hline Alimon lak tanmon fum & $M G / L$ \\
\hline Nitrit & $M G / L$ \\
\hline Nitrat & $M G / L$ \\
\hline Orthophosphat-P04 & MG/L \\
\hline Phosph., tot.filt PO4 & MG/L \\
\hline Calctun & MG/L \\
\hline Chlorid & $M G / L$ \\
\hline f luor id & $M G / L$ \\
\hline Jern ferro & $M G / L$ \\
\hline Kalium & MG/L \\
\hline Magnes luw & $M 6 / L$ \\
\hline Mongan & MG/L \\
\hline Natrium & $M G / L$ \\
\hline Sulfat & $M G / L$ \\
\hline Hydrogensu If id & $M G / L$ \\
\hline Methan & HG/L \\
\hline Temperatur & GRADER C \\
\hline
\end{tabular}

Storstrøms Amt Grundvandsanalyser, 1990

\begin{tabular}{|c|c|c|c|c|c|}
\hline Anta 1 & Gens & Modian & Spredning & Max tmu: & Minimum \\
\hline 40 & 68.8075. & 68.0000 & 14.02 & 98.0000 & 42.8000 \\
\hline 40 & 7.4465 & 7.4650 & 0.28 & 8.0100 & 7.0500 \\
\hline 45 & 451.7556 & 427.0000 & 107.36 & 675.0000 & 254.0000 \\
\hline 36 & 1.3611 & 0.9000 & 1.62 & 7.7000 & 0.1000 \\
\hline 11 & 3.2955 & 1.8000 & 2.65 & 8.2000 & 0.7000 \\
\hline 45 & 337.2000 & 344.0000 & 58.54 & 451.0000 & 236.0000 \\
\hline 45 & 5.5111 & 5.4000 & 2.22 & 11.0000 & 1.3000 \\
\hline 45 & 0.3949 & 0.4010 & 0.20 & 0.8230 & 0.0060 \\
\hline 44 & 0.0104 & 0.0055 & 0.01 & 0.0500 & 0.0050 \\
\hline 45 & 0.8647 & 0.4600 & 1.34 & 8.8900 & 0.0600 \\
\hline 45 & 0.0845 & 0.0100 & 0.13 & 0.4200 & 0.0010 \\
\hline 36 & 0.2606 & 0.0613 & 0.41 & 1.4411 & 0.0307 \\
\hline 45 & 103.4467 & 91.5000 & 26.64 & 162.0000 & 58.9000 \\
\hline 45 & 40.0956 & 35.6000 & 23.30 & 108.0000 & 14.5000 \\
\hline 45 & 0.4109 & 0.4200 & 0.25 & 1.9000 & 0.1800 \\
\hline 45 & 1.0927 & 0.4600 & 1.25 & 4.3100 & 0.0100 \\
\hline 45 & 3.4413 & 3.5300 & 1.23 & 5.5100 & 1.6400 \\
\hline 45 & 16.1440 & 15.5000 & 6.51 & 28.2000 & 0.8000 \\
\hline 45 & 0.0692 & 0.0220 & 0.08 & 0.2990 & 0.0050 \\
\hline 45 & 23.0844 & 20.0000 & 10.64 & 51.2000 & 10.0000 \\
\hline 45 & 43.8400 & 19.3000 & 47.92 & 137.0000 & 2.0000 \\
\hline 43 & 0.1191 & 0.0300 & 0.35 & 2.0900 & 0.0100 \\
\hline 44 & 0.3234 & 0.0500 & 0.50 & 1.8900 & 0.0100 \\
\hline 40 & 9.4675 & 9.4000 & 1.20 & 12.0000 & 6.3000 \\
\hline
\end{tabular}




\section{Hjelmsølille (35.02)}

\begin{tabular}{|c|c|}
\hline Stof navn & Enhed \\
\hline Kondukt Ivitet & MSIEHENS/M \\
\hline pH & PH \\
\hline Inddanpn ingsrest & $M G / L$ \\
\hline Oxygen indhold & M6/L \\
\hline Carbondioxid, aggr. & MG/L \\
\hline Hydrogencarbonat & MG/L \\
\hline Permanganattal KMnO4 & $M G / L$ \\
\hline Amon laktalmon fua & $M G / L$ \\
\hline Nitrit & MG/L \\
\hline Nitrat & $M G / L$ \\
\hline Orthophosphat-P04 & $M G / L$ \\
\hline Phosph.., tot.filt PO4 & $M G / L$ \\
\hline Calctum & $M G / L$ \\
\hline Chlorto & $M G / L$ \\
\hline F luor to & $H G / L$ \\
\hline Jern ferro & $M G / L$ \\
\hline Kalium & $M G / L$ \\
\hline Magnestum & $M G / L$ \\
\hline Mangan & $M G / L$ \\
\hline Natriun & $M 6 / L$ \\
\hline Sulfat & $M G / L$ \\
\hline Hydrogensulf id & $M 6 / L$ \\
\hline Methan & $M G / L$ \\
\hline Temperatur & GRADER C \\
\hline
\end{tabular}

\section{Storstrøms Amt}

\begin{tabular}{|c|c|c|c|c|c|c|}
\hline Antal & Gens & Median & Spredning & Maxinum & Min 1mum & - \\
\hline 12 & 72.8250 & 76.1500 & 14.95 & 99.0000 & 51.0000 & \\
\hline 3 & 7.4733 & 7.4400 & 0.07 & 7.5500 & 7.4300 & \\
\hline 12 & 475.4167 & 463.5000 & 82.31 & 646.0000 & 343.0000 & \\
\hline 5 & 2.4400 & 1.7000 & 1.97 & 5.7000 & 0.9000 & \\
\hline 7 & 3.5714 & 3.1000 & 1.92 & 6.6000 & 1.2000 & \\
\hline 12 & 380.3333 & 368.0000 & 136.81 & 780.0000 & 240.0000 & \\
\hline 12 & 7.8167 & 5.7000 & 10.91 & 42.0000 & 1.6000 & \\
\hline 12 & 0.3947 & 0.4325 & 0.25 & 0.8080 & 0.0300 & \\
\hline 12 & 0.0061 & 0.0050 & 0.00 & 0.0100 & 0.0050 & OG \\
\hline 12 & 0.4500 & 0.4550 & 0.21 & 0.7700 & 0.0800 & \\
\hline 12 & 0.2600 & 0.0200 & 0.52 & 1.8000 & 0.0100 & \\
\hline 12 & 0.3705 & 0.0613 & 0.56 & 1.9317 & 0.0307 & \\
\hline 12 & 109.4667 & 111.5000 & 25.48 & 168.0000 & 79.2000 & \\
\hline 12 & 42.0167 & 40.9500 & 21.43 & 102.0000 & 16.9000 & \\
\hline 12 & 0.5983 & 0.5400 & 0.23 & 0.9900 & 0.3600 & \\
\hline 12 & 1.8525 & 1.2700 & 2.13 & 7.5000 & 0.1100 & \\
\hline 12 & 3.4058 & 3.2650 & 1.23 & 5.2800 & 1.8700 & \\
\hline 12 & 15.1417 & 15.4500 & 4.38 & 22.4000 & 7.6000 & \\
\hline 12 & 0.1457 & 0.0965 & 0.17 & 0.5350 & 0.0070 & \\
\hline 12 & 23.9417 & 21.8500 & 9.94 & 47.7000 & 12.5000 & \\
\hline 12 & 47.0083 & 26.9500 & 46.63 & 136.0000 & 2.0000 & \\
\hline 12 & 0.0475 & 0.0400 & 0.05 & 0.1800 & 0.0100 & DG \\
\hline 12 & 0.2475 & 0.0550 & 0.38 & 1.2400 & 0.0200 & \\
\hline 11 & 9.3909 & 9.2000 & 0.66 & 10.6000 & 8.5000 & \\
\hline
\end{tabular}




\section{Vesterborg (35.11)}

\begin{tabular}{|c|c|}
\hline Stor navn & Enhed \\
\hline Kondukt ivitet & MSIEMENS/M \\
\hline pH & PH \\
\hline Inddanpn Ingsrest & MG/L \\
\hline Oxygen Indhold & $M 6 / L$ \\
\hline Carbondioxid, aggr. & $M G / L$ \\
\hline Hydrogencarbonat & $M G / L$ \\
\hline Permanganatta $1 \mathrm{KMnO4}$ & $M G / L$ \\
\hline Amontak+arenontum & $M G / L$ \\
\hline Mitrit & MG/L \\
\hline Mitrat & 116/L \\
\hline Orthophosphat-PO4 & $M G / L$ \\
\hline Phosph.,tot.f11t P04 & MG/L \\
\hline Calcium & MG/L \\
\hline Chlorid & $M G / L$ \\
\hline F luorid & $M G / L$ \\
\hline Jern ferro & $M G / L$ \\
\hline Kaltum & $M G / L$ \\
\hline Magnesiun & $M G / L$ \\
\hline Mangan & $M G / L$ \\
\hline Natriue & $M G / L$ \\
\hline Sulfat & $M G / L$ \\
\hline Hydrogensulfid & $1 \% 6 / L$ \\
\hline Methan & M6/L \\
\hline Terneratur & GRADER $C$ \\
\hline
\end{tabular}

Storstrøms Amt

44

45

44

44

44

45

41

45

4

45

33

45

45

45

0.7136
0.0405

0.1843

148.7111

38.0444

0.3485

2.1747

14.5489

\section{Grundvandsanalyser, 1990}

Medtan Spredning Maximur Minimua

$\begin{array}{rr}80.9000 & 82.0000 \\ 7.1755 & 7.1800 \\ 545.2222 & 560.0000 \\ 0.9289 & 0.6000 \\ 3.3500 & 2.6000 \\ 361.1591 & 367.0000 \\ 3.6578 & 3.3000 \\ 0.0805 & 0.0520 \\ 0.0414 & 0.0100\end{array}$

9.94

94.8000

58.0000

0.18

7.6100

6.7700

86.21

730.0000

340.0000

1.01

4.0000

0.1000

3.01

9.3000

0.0500

27.61

410.0000

296.0000

1.35

7.2000

1.6000

0.07

0.2000

0.0070

0.08

0.3899

0.0050

15.16

55.0000

1.0000

0.0260

0.05

0.2200

0.0070

0.1043

0.21

0.9505

0.0215

150.0000

26.05

220.0000

95.0000

38.0000

10.31

69.0000

22.0000

0.3000

0.07

0.5000

0.2000

2.0000

1.79

6.5700

0.0300

4.5756

4.7000

1.50

8.3000

2.2000

15.0000

2.73

20.0000

9.1000

0.1033

0.1000

0.07

0.3300

0.0200

45

21.6378

19.0000

8.55

55.0000

13.0000

$44 \quad 94.4773$

99.5000

40.17

205.0000

30.0000

$45 \quad 0.0538$

0.0500

0.02

0.1500

0.0500

$45 \quad 0.0320$

0.0200

0.04

0.1900

0.0100

10.6000

10.4000

1.90

16.2000

7.2000 
Vesterborg (35.11)

\begin{tabular}{|c|c|}
\hline Stof navn & Enhed \\
\hline Kondukt ivitet & MSIEMENS/M \\
\hline Inddaupn ingsrest & M6/L \\
\hline Hydrogencarbonat & $M G / L$ \\
\hline Perwanganatta $1 \mathrm{KMnO4}$ & MG/L \\
\hline Amon fax +ares on fun & MG/L \\
\hline Nitrit & MG/L \\
\hline Mitrat & $M G / L$ \\
\hline Orthophosphat-P04 & $M G / L$ \\
\hline Phosph.,tot.f11t PO4 & MG/L \\
\hline Calctum & $M G / L$ \\
\hline Chlorida & $M G / L$ \\
\hline Fluorid & $M G / L$ \\
\hline Jern ferro & $M G / L$ \\
\hline Kaltum & $M G / L$ \\
\hline Magnestur & $M G / L$ \\
\hline Mangan & $M G / L$ \\
\hline Natrium & $M G / L$ \\
\hline Sulfat & $M G / L$ \\
\hline Hydrogensu if id & $M G / L$ \\
\hline Methan & $M G / L$ \\
\hline Temperatur & GRADER C \\
\hline
\end{tabular}

\section{Storstrøms Amt Grundvandsanalyser, 1989}

\begin{tabular}{|c|c|c|c|c|c|}
\hline Antal & Gens & Median & Sprednting & Maximum & Minfmum \\
\hline 12 & 79.4167. & 79.5000 & 7.81 & 91.0000 & 67.0000 \\
\hline 11 & 897.2727 & 610.0000 & 719.01 & 2970.0000 & 500.0000 \\
\hline 13 & 607.3846 & 394.0000 & 528.80 & 2123.0000 & 343.0000 \\
\hline 13 & 11.7077 & 5.4000 & 11.22 & 34.0000 & 3.7000 \\
\hline 13 & 0.1138 & 0.0800 & 0.10 & 0.2900 & 0.0140 \\
\hline 13 & 0.0209 & 0.0100 & 0.03 & 0.1200 & 0.0050 \\
\hline 12 & 4.8833 & 1.1000 & 10.29 & 37.0000 & 1.0000 \\
\hline 13 & 0.4485 & 0.0680 & 1.03 & 3.8000 & 0.0150 \\
\hline 13 & 0.4696 & 0.1012 & 0.94 & 3.4648 & 0.0215 \\
\hline 13 & 162.3077 & 150.0000 & 42.54 & 280.0000 & 130.0000 \\
\hline 12 & 40.0833 & 38.5000 & 11.62 & 68.0000 & 25.0000 \\
\hline 13 & 0.3015 & 0.2300 & 0.14 & 0.5899 & 0.2100 \\
\hline 12 & 2.6775 & 2.0000 & 2.79 & 10.0000 & 0.0100 \\
\hline 13 & 4.8538 & 5.0000 & 1.84 & 8.2000 & 1.9000 \\
\hline 13 & 15.0769 & 15.0000 & 2.56 & 20.0000 & 11.0000 \\
\hline 13 & 0.3572 & 0.1600 & 0.58 & 2.2000 & 0.0240 \\
\hline 13 & 22.3231 & 19.0000 & 15.71 & 70.0000 & 4.2000 \\
\hline 13 & 120.4615 & 112.0000 & 56.79 & 275.0000 & 72.0000 \\
\hline 12 & 0.1092 & 0.0500 & 0.15 & 0.5500 & 0.0500 \\
\hline 12 & 0.0883 & 0.0500 & 0.09 & 0.3400 & 0.0500 \\
\hline 8 & 11.6625 & 11.4500 & 1.18 & 14.0000 & 10.4000 \\
\hline
\end{tabular}


Sibirien (35.12)

\begin{tabular}{|c|c|}
\hline Stof navn & Enhed \\
\hline Kondukt ivitet & MSIEMENS/M \\
\hline pH & PH \\
\hline Inddanpningsrest & $M G / L$ \\
\hline Oxygen indhold & $M G / L$ \\
\hline Carbondtoxid, aggr. & $M G / L$ \\
\hline Hydrogencarbonat & MG/L \\
\hline Permanganatta $1 \mathrm{KMnO4}$ & $M G / L$ \\
\hline Ammon taktamonfum & $M G / L$ \\
\hline Nitrit & $M G / L$ \\
\hline N1trat & $M G / L$ \\
\hline Orthophosphat-P04 & $M G / L$ \\
\hline Phosph., tot.filt P04 & $M G / L$ \\
\hline Calciun & $M G / L$ \\
\hline Chlorid & $M G / L$ \\
\hline F luor is & $M G / L$ \\
\hline Jern ferro & $M G / L$ \\
\hline Kaliun & $M 6 / L$ \\
\hline Magnesium & $M G / L$ \\
\hline Mangan & $M G / L$ \\
\hline Matriun & $M G / L$ \\
\hline Sulfat & $M G / L$ \\
\hline Hydrogensulfid & $M G / L$ \\
\hline Methan & $M G / L$ \\
\hline Teaperatur & GRADER C \\
\hline
\end{tabular}

\section{Storstrøms Amt Grundvandsanalyser, 1990}

\begin{tabular}{|c|c|c|c|c|c|}
\hline Anta 1 & Gens & Median & Spredning & Maxiaum & Min tanum \\
\hline 40 & 82.6000 . & 69.0000 & 28.21 & 184.0000 & 59.0000 \\
\hline 40 & 7.3310 & 7.3350 & 0.20 & 7.6700 & 6.8600 \\
\hline 40 & 490.2500 & 430.0000 & 154.63 & 970.0000 & 310.0000 \\
\hline 25 & 0.5920 & 0.4000 & 0.61 & 2.6000 & 0.1000 \\
\hline 19 & 4.7816 & 4.0000 & 2.98 & 12.0000 & 0.0500 \\
\hline 40 & 418.4000 & 405.0000 & 40.82 & 548.0000 & 375.0000 \\
\hline 40 & 6.7900 & 6.7500 & 3.95 & 24.0000 & 0.4000 \\
\hline 38 & 1.4877 & 1.7200 & 0.70 & 2.7200 & 0.0600 \\
\hline 40 & 0.0384 & 0.0100 & 0.10 & 0.6200 & 0.0050 \\
\hline 40 & 3.9250 & 1.0000 & 11.63 & 65.0000 & 1.0000 \\
\hline 40 & 0.1568 & 0.1250 & 0.13 & 0.4200 & 0.0070 \\
\hline 40 & 0.5147 & 0.4293 & 0.37 & 1.2878 & 0.0552 \\
\hline 40 & 107.1000 & 98.0000 & 31.10 & 210.0000 & 70.0000 \\
\hline 40 & 58.5500 & 24.0000 & 71.96 & 350.0000 & 10.0000 \\
\hline 37 & 0.6351 & 0.5000 & 0.46 & 1.7000 & 0.1000 \\
\hline 40 & 4.7077 & 5.3000 & 2.46 & 9.3000 & 0.1500 \\
\hline 40 & 5.2450 & 4.2000 & 3.16 & 13.5000 & 1.8000 \\
\hline 40 & 18.7000 & 15.5000 & 6.88 & 37.0000 & 12.0000 \\
\hline 39 & 0.2158 & 0.1600 & 0.18 & 0.7400 & 0.0200 \\
\hline 40 & 47.2725 & 22.0000 & 52.24 & 220.0000 & 9.7000 \\
\hline 40 & 23.6230 & 2.0000 & 34.34 & 111.0000 & 0.2300 \\
\hline 40 & 0.0505 & 0.0500 & 0.00 & 0.0700 & 0.0500 \\
\hline 40 & 1.4035 & 1.1100 & 1.34 & 4.2000 & 0.0100 \\
\hline 39 & 10.2436 & 9.9000 & 2.81 & 18.0000 & 6.0000 \\
\hline
\end{tabular}


St. Heddinge (35.13)

\begin{tabular}{|c|c|}
\hline Stof navn & Enhed \\
\hline Kondukt ivitet & MSIEMENS/H \\
\hline pH & PH \\
\hline Inddampn Ingsrest & $\omega G / L$ \\
\hline Oxygen Indhold & $M G / L$ \\
\hline Carbondtoxid, aggr. & $\mathrm{MG} / \mathrm{L}$ \\
\hline Hydrogencarbonat & $M G / L$ \\
\hline Permanganatta 1 KMnO4 & $M G / L$ \\
\hline Acusoniak+alnon fui & MG/L \\
\hline Nitrit & $1 \% 6 / L$ \\
\hline Nitrat & $M G / L$ \\
\hline Orthophosphat-P04 & $M G / L$ \\
\hline Phosph., tot.ftlt P04 & $M G / L$ \\
\hline Calclua & $M G / L$ \\
\hline Chlorto & $M G / L$ \\
\hline Fluor 10 & $M G / L$ \\
\hline Jern ferro & $M G / L$ \\
\hline Kaliun & $M G / L$ \\
\hline Magnes 1u: & $M G / L$ \\
\hline Mangan & $M G / L$ \\
\hline Natriun & $M G / L$ \\
\hline Sulfat & $M G / L$ \\
\hline Hydrogensulf id & Mo/L \\
\hline Methan & $M G / L$ \\
\hline Temperatur & GRADER C \\
\hline
\end{tabular}

\section{Storstrøms Amt}

Grundvandsanalyser, 1990

\begin{tabular}{|c|c|c|c|c|c|c|}
\hline Antal & Gens & Median & Spredn Ing & Maxtmun & Minimum & \\
\hline 69 & 71.2812 & 71.5000 & 7.44 & 91.3000 & 50.2000 & \\
\hline 63 & 7.2729 & 7.2800 & 0.16 & 7.5700 & 6.7900 & \\
\hline 69 & 548.9565 & 474.0000 & 352.51 & 2887.0000 & 290.0000 & \\
\hline 42 & 1.4143 & 0.6000 & 1.80 & 8.7000 & 0.2000 & \\
\hline 22 & 5.0855 & 4.4000 & 3.90 & 13.0000 & 0.4000 & \\
\hline 69 & 367.3913 & 315.0000 & 78.18 & 526.0000 & 272.0000 & \\
\hline 69 & 7.6754 & 5.8000 & 5.96 & 26.5000 & 0.3000 & \\
\hline 69 & 0.2281 & 0.2470 & 0.16 & 0.5510 & 0.0050 & DG \\
\hline 69 & 0.0439 & 0.0070 & 0.10 & 0.6710 & 0.0050 & $D G$ \\
\hline 69 & 10.4580 & 1.2100 & 17.71 & 57.4000 & 0.0800 & \\
\hline 69 & 0.1036 & 0.0200 & 0.37 & 3.0000 & 0.0100 & \\
\hline 69 & 0.1897 & 0.0920 & 0.29 & 1.7477 & 0.0307 & \\
\hline 69 & 100.4884 & 94.2000 & 21.86 & 138.0000 & 67.5000 & \\
\hline 69 & 27.5884 & 23.2000 & 12.36 & 53.5000 & 11.7000 & \\
\hline 69 & 0.9923 & 0.5899 & 0.67 & 2.3000 & 0.2000 & \\
\hline 69 & 1.1223 & 0.1800 & 1.92 & 8.0600 & 0.0100 & \\
\hline 69 & 2.9340 & 2.9000 & 0.98 & 4.8100 & 0.3490 & \\
\hline 69 & 26.1416 & 16.0000 & 15.80 & 56.8000 & 7.9100 & \\
\hline 69 & 0.0437 & 0.0240 & 0.04 & 0.1810 & 0.0050 & \\
\hline 69 & 17.0374 & 14.8000 & 9.72 & 74.0000 & 6.4899 & \\
\hline 69 & 46.6000 & 37.6000 & 35.58 & 118.0000 & 2.0000 & \\
\hline 68 & 0.0407 & 0.0200 & 0.05 & 0.2800 & 0.0100 & DG \\
\hline 69 & 0.0552 & 0.0300 & 0.06 & 0.2400 & 0.0100 & DG \\
\hline 69 & 9.5377 & 9.4000 & 1.20 & 11.8000 & 7.1000 & \\
\hline
\end{tabular}




\section{Smålyng (40.01)}

\begin{tabular}{|c|c|}
\hline Stof navn & Enhed \\
\hline Kondukt tv itet & MSIEMENS/M \\
\hline pH & PH \\
\hline Inddampn ingsrest & MG/L \\
\hline Oxygen indhold & $M G / L$ \\
\hline Carbonat & $M 6 / L$ \\
\hline Carbondioxid, aggr. & $M G / L$ \\
\hline Carbon, org, nvoc & $M G / L$ \\
\hline Permanganatta 1 KMnO4 & $M G / L$ \\
\hline Benzen & MYGRAM/L \\
\hline Toluen & MYGRAM/L \\
\hline Amon iak+amon ium & $M G / L$ \\
\hline Mitrit & $M G / L$ \\
\hline Mitrat & $M G / L$ \\
\hline Orthophosphat-P04 & $M G / L$ \\
\hline Phosph., tot.t1lt P04 & $\mathrm{MG} / \mathrm{L}$ \\
\hline Aluminium & MYGRAM/L \\
\hline Arsen & MYGRAM/L \\
\hline Bar ium & MYGRAM/L \\
\hline Bly & HYGRAM/L \\
\hline 8or & MYGRAM/L \\
\hline Brontd & MYGRAM/L \\
\hline Cadmiun & MYGRAM/L \\
\hline Calc 1um & MG/L \\
\hline Chlor,org, $A O X$ & MYGRAM/L \\
\hline Chlor, org. vox & MYGRAM/L \\
\hline Chlorid & $M G / L$ \\
\hline Chrow & MYGRAM/L \\
\hline Cyanid & $M G / L$ \\
\hline Fluor 1d & MG/L \\
\hline Jern & $\mathrm{MG} / \mathrm{L}$ \\
\hline Jern ferro & $M G / L$ \\
\hline Jod & MYGRAM/L \\
\hline Jodid & MYGRAM/L \\
\hline Kallum & $\mathrm{MG} / \mathrm{L}$ \\
\hline Kobber & MYGRAM/L \\
\hline Lith tum & MYGRAM/L \\
\hline Magnes tum & $m 6 / \mathrm{L}$ \\
\hline Mangan & $16 / \mathrm{h}$ \\
\hline Molybdan & MYGRAH/L \\
\hline Metrium & $M G / L$ \\
\hline N1kkel & MYGRAM/L \\
\hline Stront ium & MYGRAM/L \\
\hline Sulfat & H6/L \\
\hline Trit 1u= & T.U. \\
\hline Detergenter onton & MG/L \\
\hline Tetrach lorethy len & MYGRAM/L \\
\hline Trich lorethylen & MYGRAM/L \\
\hline 1,1,1-trichlorethan & MYGRAM/L \\
\hline P-xylen & MYGRAM/L \\
\hline M-xylen & MYGRAM/L \\
\hline
\end{tabular}

Bornholms Amt Grundvandsanalyser, 1990

Antal Gens Median Spredning Maximum Minimum.

\begin{tabular}{|c|c|c|c|c|c|}
\hline 59 & 64.9322 & 68.0000 & 20.05 & 103.0000 & 21.0000 \\
\hline 60 & 7.1227 & 7.1550 & 0.23 & 7.8000 & 6.6000 \\
\hline 60 & 450.7833 & 450.0000 & 142.73 & 740.0000 & 120.0000 \\
\hline 56 & 3.2467 & 1.8000 & 3.41 & 11.4000 & 0.0640 \\
\hline 59 & 233.6966 & 253.0000 & 90.34 & 358.0000 & 45.0000 \\
\hline 47 & 11.3830 & 10.0000 & 9.17 & 44.0000 & 2.0000 \\
\hline 7 & 0.8329 & 0.6500 & 0.44 & 1.8000 & 0.5400 \\
\hline 37 & 4.4865 & 4.0000 & 1.30 & 10.0000 & 4.0000 \\
\hline 6 & & & & 0.1000 & 0.1000 \\
\hline 6 & & & & 0.1000 & 0.1000 \\
\hline 47 & 0.0281 & 0.0090 & 0.07 & 0.3899 & 0.0050 \\
\hline 35 & 0.0070 & 0.0050 & 0.01 & 0.0300 & 0.0050 \\
\hline 60 & 29.9800 & 10.5000 & 44.94 & 170.0000 & 0.0200 \\
\hline 30 & 0.0207 & 0.0050 & 0.04 & 0.1830 & 0.0050 \\
\hline 97 & 0.0907 & 0.0153 & 0.37 & 3.0049 & 0.0050 \\
\hline 7 & 5.2429 & 0.4000 & 10.66 & 29.0000 & 0.4000 \\
\hline 7 & 0.0986 & 0.0500 & 0.08 & 0.2200 & 0.0500 \\
\hline 7 & 34.1429 & 30.0000 & 16.50 & 53.0000 & 15.0000 \\
\hline 7 & 3.9571 & 2.6000 & 3.59 & 9.2000 & 0.3000 \\
\hline 7 & 37.5714 & 44.0000 & 13.69 & 52.0000 & 17.0000 \\
\hline 7 & 83.7143 & 85.0000 & 21.92 & 116.0000 & 50.0000 \\
\hline 7 & 0.3580 & 0.1200 & 0.39 & 0.8100 & 0.0260 \\
\hline 59 & 102.2373 & 113.0000 & 33.28 & 160.0000 & 22.0000 \\
\hline 7 & 4.0429 & 3.4000 & 2.38 & 9.3000 & 2.5000 \\
\hline 5 & & & & 0.5000 & 0.5000 \\
\hline
\end{tabular}

$\begin{array}{lllll}39.9574 & 32.5000 & 27.17 & 130.0000 & 11.5000\end{array}$

$\begin{array}{lllll}0.1743 & 0.1000 & 0.17 & 0.5500 & 0.1000\end{array}$

$\begin{array}{lllll}0.0041 & 0.0040 & 0.00 & 0.0050 & 0.0040\end{array}$

$\begin{array}{lllll}0.5115 & 0.2800 & 0.62 & 2.7000 & 0.1200\end{array}$

$\begin{array}{lllll}1.7287 & 0.2300 & 4.35 & 22.0000 & 0.0200\end{array}$

$\begin{array}{lllll}0.3186 & 0.0200 & 0.96 & 5.2000 & 0.0020\end{array}$

$\begin{array}{lllll}15.0857 & 3.6000 & 18.34 & 50.0000 & 1.2000\end{array}$

$\begin{array}{llllll}3.2143 & 3.0000 & 0.95 & 5.0000 & 2.5000\end{array}$

$\begin{array}{lllll}4.9200 & 2.3000 & 5.10 & 18.0000 & 0.6000\end{array}$

$\begin{array}{lllll}7.0429 & 6.9000 & 4.72 & 13.1000 & 1.6000\end{array}$

$\begin{array}{lllll}7.7286 & 5.4000 & 4.87 & 13.9000 & 2.1000\end{array}$

$\begin{array}{lllll}11.3655 & 10.0000 & 4.92 & 23.0000 & 4.5000\end{array}$

$\begin{array}{lllll}0.2509 & 0.0630 & 0.48 & 2.3000 & 0.0200\end{array}$

$\begin{array}{lllll}1.3757 & 0.7700 & 1.67 & 5.0000 & 0.2000\end{array}$

$\begin{array}{lllll}19.7865 & 14.0000 & 13.02 & 56.0000 & 5.7000\end{array}$

$\begin{array}{lllll}2.9857 & 1.1000 & 3.13 & 9.2000 & 0.4000\end{array}$

$\begin{array}{lllll}210.2857 & 222.0000 & 90.37 & 328.0000 & 54.0000\end{array}$

$\begin{array}{lllll}60.2558 & 60.0000 & 25.24 & 109.0000 & 14.0000\end{array}$

$\begin{array}{lllll}26.4545 & 23.0000 & 10.60 & 46.0000 & 10.0000\end{array}$

$\begin{array}{lllll}0.0046 & 0.0040 & 0.00 & 0.0060 & 0.0040\end{array}$

$0.1000 \quad 0.1000 \quad 06$

$\begin{array}{llllll}0.0850 & 0.1000 & 0.04 & 0.1000 & 0.0100 & D G\end{array}$

$\begin{array}{llllll}0.0850 & 0.1000 & 0.04 & 0.1000 & 0.0100 & D 6\end{array}$

$0.1000 \quad 0.1000 \quad$ DG

$0.1000 \quad 0.1000 \quad D G$ 


\section{Smålyng (40.01)}

Stof navn

Enhed

0-xylen

MYGRAY/L

Maphthalen

Phenol

MYGRAY/L

MYGRAN/L

2-nethylphenol

MYGRAN/L

4-wethylphenol

3,4-d1sethylphenol

3,5-dtwethy lpheno 1

2,6-d twethylphenol

2,4-diwethy iphenol

4-clor, 2-methylpheno

6-c lor, 2-wethylpheno

2,4-dtc lorpheno 1

4,6-dic lor, 2-nethy ip

2,6-dtc lorpheno 1

2,4,6-triclorphenol

2,3,4,6-tetrac lorphe

2,3,5,6-tetrac lorphe

2,3,4,5-tetrac lorphe

Pentrac lorphenol

Dich lorprop

MCPA

Mechlorprop

DHOC

Dinoseb

Atrazin

simaz in
Bornholms Amt Grundvandsanalyser, 1990

\begin{tabular}{|c|c|c|c|c|c|}
\hline Antal & Gens & Median & Spredning & Maxtmun & Mintaum \\
\hline 6 & . & & & 0.1000 & 0.1000 \\
\hline 6 & & & & 0.1000 & 0.1000 \\
\hline 7 & & & & 0.0500 & 0.0500 \\
\hline 7 & & & & 0.0500 & 0.0500 \\
\hline 7 & & & & 0.0500 & 0.0500 \\
\hline 7 & & & & 0.0500 & 0.0500 \\
\hline 7 & & & & 0.0500 & 0.0500 \\
\hline 7 & & & & 0.0500 & 0.0500 \\
\hline 7 & & & & 0.0500 & 0.0500 \\
\hline 7 & & & & 0.0500 & 0.0500 \\
\hline 7 & & & & 0.0500 & 0.0500 \\
\hline 7 & & & & 0.0500 & 0.0500 \\
\hline 6 & & & & 0.0500 & 0.0500 \\
\hline 7 & & & & 0.0500 & 0.0500 \\
\hline 7 & & & & 0.0500 & 0.0500 \\
\hline 7 & & & & 0.0500 & 0.0500 \\
\hline 7 & & & & 0.0500 & 0.0500 \\
\hline 7 & & & & 0.0500 & 0.0500 \\
\hline 7 & & & & 0.0500 & 0.0500 \\
\hline 7 & & & & 0.0100 & 0.0100 \\
\hline 7 & & & & 0.0100 & 0.0100 \\
\hline 7 & 0.1514 & 0.0100 & 0.37 & 1.0000 & 0.0100 \\
\hline 7 & & & & 0.0100 & 0.0100 \\
\hline 6 & 0.0250 & 0.0100 & 0.04 & 0.1000 & 0.0100 \\
\hline 7 & & & & 0.0100 & 0.0100 \\
\hline 7 & 0.1214 & 0.0100 & 0.22 & 0.6000 & 0.0100 \\
\hline
\end{tabular}


Smålyng (40.01)

\begin{tabular}{|c|c|}
\hline Stor navn & Enhed \\
\hline Kondukt ivitet & MSIEMENS/M \\
\hline pH & PH \\
\hline Carbondioxid, aggr. & $M / L$ \\
\hline Hydrogencarbonat & $M G / L$ \\
\hline Permanganattal KMnO4 & $M G / L$ \\
\hline Almon laktasmon fua & $M G / L$ \\
\hline Nitrat & $M G / L$ \\
\hline Orthophosphat-PO4 & $M G / L$ \\
\hline Calc 1un & $\mathrm{HG} / \mathrm{L}$ \\
\hline Cnlorid & $M 6 / L$ \\
\hline Fluorid & $M 6 / \mathrm{L}$ \\
\hline Jern & $M G / L$ \\
\hline Jern ferro & MG/L \\
\hline Kalium & $M G / L$ \\
\hline Magnestum & $M G / L$ \\
\hline Mangan & $M G / L$ \\
\hline Matrfun & $M G / L$ \\
\hline Sulfat & $M G / L$ \\
\hline Temp. v. udtagning & GRADER C \\
\hline
\end{tabular}

Bornholms Amt Grundvandsanalyser, 1989

$\begin{array}{rrrrrr}\text { Anta } & \text { Gens } & \text { Modian } & \text { Spredning } & \text { Maximul } & \text { Minimum } \\ 60 & 61.6333 & 65.5000 & 19.75 & 99.0000 & 3.0000 \\ 57 & 7.2798 & 7.2500 & 0.52 & 8.4900 & 6.0500 \\ 19 & 1.5263 & 1.0000 & 0.84 & 4.0000 & 1.0000 \\ 53 & 235.1698 & 265.0000 & 92.17 & 368.0000 & 47.0000 \\ 60 & 5.2833 & 4.0000 & 2.95 & 18.0000 & 4.0000 \\ 60 & 0.0630 & 0.0250 & 0.12 & 0.5000 & 0.0100 \\ 59 & 25.5678 & 9.3000 & 39.84 & 134.0000 & 0.1000 \\ 45 & 0.0251 & 0.0200 & 0.02 & 0.0700 & 0.0100 \\ 60 & 99.5167 & 107.0000 & 31.95 & 143.0000 & 23.0000 \\ 60 & 38.0917 & 30.2500 & 27.22 & 135.0000 & 10.5000 \\ 60 & 0.4682 & 0.2700 & 0.55 & 2.7000 & 0.1300 \\ 59 & 4.0449 & 0.3700 & 9.63 & 41.3000 & 0.0100 \\ 60 & 0.2535 & 0.0200 & 0.61 & 3.3000 & 0.0200 \\ 57 & 5.1667 & 2.5000 & 4.76 & 18.0000 & 1.0000 \\ 60 & 10.8433 & 10.0000 & 4.72 & 24.0000 & 2.9000 \\ 59 & 0.3231 & 0.0500 & 0.93 & 6.7000 & 0.0200 \\ 60 & 18.8183 & 15.0000 & 10.07 & 49.0000 & 4.0000 \\ 60 & 63.1833 & 64.0000 & 25.23 & 107.00000 & 17.0000 \\ 58 & 8.4483 & 8.0000 & 1.20 & 12.0000 & 5.0000\end{array}$




\section{Nyborg (42.01)}

Stof navn Enhed

Kondukt ivite

MSIEMEMS/M

pH

Inddampn ingsrest

PH

Oxygen indhold

MG/L

Carbond toxid, aggr.

MG/L

Hydrogencarbonat

MG/L

Matr lumhydrogencarb

Carbon, org, NVOC

MG/L

Blok.11tforbr., BI5

MG/L

Peraanganatta 1 KMnO4

MG/L

Asmon lak tamonon lue

MG/L

Nitrit

MG/L

Nitrat

Phosph., tot.f1lt PO4

Phosph., tot P04,f $41 t$

Aluminium

Arsen

Barfun

Bly

Bor

Bronto

Cadmiun

Calctum

Chlor, org, AOX

chlor, org, vox

chlorido

chrom

Cyanto

Fluorid

Jern ferro

Jod

Jodid

Kallum

Kobber

Lith1um

Magnesiun

Mangan

Mo lybden

Natr ium

Mikke I

siliciund toxid

stront lue

Sulfat

Sulf 1d-S

Trit tum

Methan

Detergenter anton

K1mtal 376r. PCA

Kintal 21Gr.KING A
MG/L

MG/L

MG/L

MG/L

MYGRAM/L

MYGRAM/L

MYGRAM/L

MYGRAM/L

MYGRAM/L

MYGRAM/L

MYGRAM/L

MG/L

MYGRAM/L

MYGRAM/L

MG/L

MYGRAM/L

MG/L

MG/L

MG/L

MYGRAM/L

MYGRAM/L

MG/L

MYGRAM/L

MYGRAM/L

MG/L

$M G / L$

MYGRAM/L

MG/L

MYGRAM/L

MG/L

MYGRAM/L

MG/L

MG/L

T.U.

MG/L

MG/L

ANTAL/ML

ANTAL/ML
Fyns Amt

Antal Gens

123

88.2083

7.4137

594.2059

0.3898

3.8250

329.5161

52.0000

1.5200

0.7000

4.1758

0.4548

0.0667

0.1000

0.1037

0.1221

9.9600

0.6000

112.2000

0.1400

114.4000

195.4000

108.9677

3.7000

83.0161

0.7566

1.3792

2.4600

10.4000

5.1468

0.6980

10.6000

19.8758

0.1318

1.6600

50.1129

0.3440

26.6471

1293.0000

76.5000

0.0347

15.2250

0.0259

17

\section{Grundvandsanalyser, 1990}

Median Spredning Maximum

Min tmum .

90.3000

$12.47 \quad 121.0000$

62.6000

7.4300

0.23

8.0200

6.8600

586.5000

75.29

761.0000

437.0000

0.3000

0.37

2.0000

0.1000

$2.37 \quad 10.0000$

0.1000

$44.24 \quad 399.0000$

187.0000

335.0000

37.60

92.0000

17.0000

1.6000

0.20

1.7000

1.3000

0.7000

0.7000

0.7000

3.02

15.0000

1.5000

0.30

1.2700

0.0700

0.25

2.0035

0.0328

0.00

0.1000

0.1000

0.08

0.2900

0.0100

0.11

0.5213

0.0307

15.81

38.0000

0.8000

0.52

1.5000

0.2000

87.71

238.0000

19.0000

0.1000

0.05

0.2000

0.1000

109.0000

53.01

196.0000

51.0000

169.0000

113.10

384.0000

99.0000

0.0050

$0.0050 \quad D G$

104.0000

35.51

175.0000

56.0000

3.1000

1.87

6.9000

2.1000

0.5000

0.5000

DG

66.0000

42.62

192.0000

29.0000

0.1000

$0.1000 \quad$ OG

0.0050

$0.0050 \quad D G$

0.5600

0.53

1.7500

0.1400

0.9400

1.33

4.6200

0.0300

2.1000

1.69

5.0000

1.0000

11.10

30.0000

3.0000

5.6500

2.20

9.5000

1.3000

0.59

1.6900

0.2000

5.67

20.0000

4.8000

18.44

151.0000

2.6000

17.5000

0.12

0.4400

0.0100

1.4000

0.89

3.2000

0.9000

36.70

139.0000

13.0000

0.2000

0.20

0.6200

0.2000

1.37

29.0000

24.0000

641.0000

1530.19 


\section{Nyborg (42.01)}

Stof navn

Enhed

Collforme bakt.37Gr. ANTAL/100 ML

Termotol.coll.bakt. ANTAL/100 ML
Fyns Amt

Anta 1.

17

1

\section{Grundvandsanalyser, 1990}

Median Spredning Maximum Mintaum

$1.0000 \quad 1.0000 \quad 06$

$1.0000 \quad 1.0000 \quad 06$ 
Nyborg (42.01)

\begin{tabular}{|c|c|}
\hline Stof navn & Enhed \\
\hline Kondukt ivitet & MSIEMENS/M \\
\hline pH & PH \\
\hline Inddawpn ingsrest & MG/L \\
\hline Oxygen indhold & $M G / L$ \\
\hline Carbondtoxid, aggr. & $M G / L$ \\
\hline Hydrogencarbonat & $M G / L$ \\
\hline Natr iunhydrogencarb & $M G / L$ \\
\hline Permanganatta 1 KMnO4 & $M G / L$ \\
\hline Ammon 1aktannon 1 un & $M G / L$ \\
\hline Nitrit & $M G / L$ \\
\hline Nitrat & $M G / L$ \\
\hline Phosph., tot.f11t P04 & $M G / L$ \\
\hline Phosph., tot P04,f1lt & $\mathrm{MG} / \mathrm{L}$ \\
\hline Calctum & $M G / L$ \\
\hline Chlorid & $M 6 / L$ \\
\hline F luor id & MG/L \\
\hline Jern ferro & MG /L \\
\hline Kal1um & $M G / L$ \\
\hline Kutkse iv & MANOGRAM/L \\
\hline Magnes ium & $M G / L$ \\
\hline Mangan & $M G / L$ \\
\hline Natr 1uw & $M G / L$ \\
\hline S1lic fund lox id & $M G / L$ \\
\hline Sulfat & $M G / L$ \\
\hline Sulfid-s & $M G / L$ \\
\hline Tritium & T.U. \\
\hline Methan & $M G / L$ \\
\hline
\end{tabular}

Fyns Amt

\begin{tabular}{rrrrrr} 
Anta) & Gens & Modian & Spredning & Maximum & Mininum \\
\hline 41 & 84.8561 & 85.8000 & 12.15 & 115.0000 & 61.5000 \\
53 & 7.4464 & 7.4600 & 0.16 & 7.9300 & 7.0900 \\
20 & 564.0500 & 549.0000 & 70.48 & 681.0000 & 446.0000 \\
27 & 0.6815 & 0.5000 & 0.64 & 3.2000 & 0.1000 \\
17 & 8.1235 & 3.9000 & 10.39 & 38.0000 & 0.5000 \\
27 & 327.6667 & 335.0000 & 49.96 & 399.0000 & 202.0000 \\
2 & 50.0000 & 50.0000 & 36.77 & 76.0000 & 24.0000 \\
27 & 4.1963 & 3.2000 & 2.85 & 14.0000 & 2.2000 \\
27 & 0.4770 & 0.3400 & 0.27 & 0.9700 & 0.0700 \\
27 & 0.0474 & 0.0328 & 0.03 & 0.1314 & 0.0328 \\
27 & 1.3900 & 0.1000 & 1.47 & 3.0000 & 0.1000 \\
27 & 0.1533 & 0.0700 & 0.22 & 1.0599 & 0.0200 \\
27 & 0.1442 & 0.0920 & 0.20 & 1.0732 & 0.0307 \\
27 & 108.8889 & 105.0000 & 35.92 & 169.0000 & 54.0000 \\
27 & 78.0370 & 69.0000 & 41.38 & 180.0000 & 33.0000 \\
27 & 0.8430 & 0.4700 & 0.58 & 1.8200 & 0.1500 \\
27 & 1.4992 & 1.1100 & 1.42 & 5.1600 & 0.1000 \\
27 & 4.8852 & 4.1000 & 2.30 & 8.5000 & 1.1000 \\
7 & 3.2857 & 3.0000 & 0.49 & $4.0000 *$ & 3.0000 \\
27 & 14.3630 & 12.0000 & 8.28 & 30.0000 & 3.5000 \\
26 & 0.1354 & 0.1050 & 0.10 & 0.3600 & 0.0100 \\
27 & 47.9259 & 25.0000 & 38.04 & 140.0000 & 13.0000 \\
27 & 25.3704 & 26.0000 & 1.76 & 28.0000 & 22.0000 \\
27 & 78.4815 & 72.0000 & 51.81 & 166.0000 & 17.0000 \\
27 & 1.8059 & 0.0300 & 7.60 & 38.9000 & 0.0300 \\
6 & 12.8833 & 11.6000 & 9.93 & 25.0000 & 1.0000 \\
27 & 0.0157 & 0.0200 & 0.00 & 0.0200 & 0.0060 \\
& & & & & \\
\hline 76
\end{tabular}

0.0157

0.0200

0.00

0.0200

$0.0060 \quad D G$

Grundvandsanalyser, 1989

* Særlig usædvanlig værdi, der må kontrolleres. 
Borreby (42.02)

Stof navn

Kondukt iv itet

pH

Inddampningsrest

Oxygen indhold

Carbond toxid, aggr.

Hydrogencarbonat

Natr funhydrogencarb

Carbon, org, IVOC

Permanganattal KMnO4

Asmon lak tabmon ium

Nitrit

Nitrat

Phosph., tot.f1lt P04

Phosph., tot P04,f1lt

Aluarintua

Arsen

Bartum

Bly

Bor

Bromid

Cadurum

Calc tum

Chior, org, AOX

Chlor, org, vox

chlorid

Chrom

Cyan 10

Fluortd

Jern ferro

Jod

Jodid

Kallum

Kobber

Lith tum

Magnes tun

Mangan

Mo lybden

Metrium

Nikke 1

siliciund ioxid

Stront fus

Sulfat

Sulfid-s

Trit ium

Methan

Detergenter anion

MCPA

Kintal 376r. PCA

Kintal 216r.KING A
Enhed

MSIEMENS/M

PH

MG/L

MG/L

MG $/ \mathrm{L}$

MG/L

MG/L

MG/L

MG/L

MG/L

MG/L

MG/L

MG/L

MG/L

MYGRAM/L

MYGRAM/L

MYGRAM/L

MYGRAM/L

MYGRAM/L

MYGRAM/L

MYGRAM/L

MG/L

MYGRAM/L

MYGRAM/L

MG/L

MYGRAM/L

MG/L

MG/L

$M G / L$

MYGRAM/L

MYGRAM/L

MG/L

MYGRAM/L

MYGRAM/L

46/L

146/L

MYGRAM/L

$\mathrm{MG} / \mathrm{L}$

MYGRAM/L

MG/L

MYGRAM/L

MG/L

H6/L

T.U.

MG/L

MG/L

MYGRAM/L

ANTAL/ML

ANTAL/ML

Fyns Amt

Grundvandsanalyser, 1990

Antal Gens Median Spredning Maxiaum Minimu:

$\begin{array}{rrrrrr}63 & 66.3000 & 65.3000 & 9.64 & 84.9000 & 51.9000 \\ 63 & 7.4100 & 7.3700 & 0.26 & 8.1000 & 6.8000\end{array}$

18

463.3333

473.5000

94.77

601.0000

323.0000

0.4750

0.3000

0.56

2.4000

0.1000

3.0000

3.24

14.1000

0.8000

311.3103

304.0000

35.19

377.0000

268.0000

68.0000

68.25

134.0000

10.0000

3.5333

2.3000

2.67

6.6000

1.7000

4.9000

5.11

20.0000

1.9000

0.3400

0.46

1.9300

0.2000

0.0328

0.06

0.2299

0.0328

0.1000

0.60

3.3600

0.0100

0.2900

0.12

0.3800

0.0500

0.3066

0.17

1.0118

0.0920

19.6667

12.2000

22.55

45.0000

1.8000

0.3000

4.65

8. 3000

0.2000

108.6667

88.0000

55.94

172.0000

66.0000

0.2000

18.97

33.0000

0.1000

$115.3333 \quad 129.0000$

40.28

147.0000

70.0000

82.3333

80.0000

6.81

90.0000

77.0000

0.0050

0.0050

110.2903

113.0000

27.15

159.0000

66.0000

1.76

6.0000

2.6000

0.5000

DG

25.3226

26.0000

9.43

0.5000

13.0000

0.1000

0.06

48.0000

0.1000

0.0050

0.0050

0.1300

0.2390

0.2300

0.06

0.3800

2.7557

2.0600

2.18

9.4000

0.1200

5.1000

1.0000

7.10

13.3000

1.0000

4.0000

7.0000

7.0000

3.00

10.0000

1.2000

2.4000

0.92

4.2000

0.1000

2.4700

0.5100

3.76

6.8000

9.9667

8.6000

5.48

16.0000

5.3000

9.0323

8.4000

2.39

14.0000

5.4000

0.3300

0.12

0.6500

0.1800

1.0000

0.7000

0.89

2.0000

0.3000

14.0000

11.23

54.0000

12.0000

0.2000

0.2000 DG

25.1053

25.0000

2.35

30.0000

21.0000

444.0000

443.0000

112.50

557.0000

332.0000

59.4839

53.0000

38.99

142.0000

13.0000

0.0303

0.0300

0.00

0.0400

0.0300

13.4250

12.0500

12.75

33.0000

1.0000

0.0429

0.0200

0.06

0.2300 
Borreby (42.02)

Stof navn

Enhed

Collforme bakt.37Gr. ANTAL/100 ML

Termotol.col1.bakt. ANTAL/100 ML
Fyns Amt

Antal

2
Grundvandsanalyser, 1990

Median Spredning Maxinum Minimum

$\begin{array}{lllll}1.0000 & 1.33 & 5.0000 & 1.0000 & D G\end{array}$

$1.0000 \quad 1.0000 \quad D G$ 
Borreby (42.02)

\begin{tabular}{|c|c|c|c|c|}
\hline Stof navn & Enhed & Anta 1 & Gens & Modian \\
\hline Kondukt ivitet & MSIEMENS/M & 23 & 65.3957 . & 66.5000 \\
\hline pH & PH & 32 & 7.4322 & 7.3600 \\
\hline Inddanpn ingsrest & $M G / L$ & 14 & 470.3571 & 479.0000 \\
\hline Oxygen indhold & $M G / L$ & 15 & 1.2867 & 1.2000 \\
\hline Carbondioxid, aggr. & $M G / L$ & 13 & 3.7846 & 3.1000 \\
\hline Hydrogencarbonat & $M G / L$ & 17 & 311.0588 & 304.0000 \\
\hline Natr jumhydrogencarb & $M G / L$ & 1 & 55.0000 & 55.0000 \\
\hline Biok.11tforbr.. BI5 & $M G / L$ & 1 & 0.6000 & 0.6000 \\
\hline Perwanganattal KMnO4 & $M G / L$ & 16 & 7.6500 & 5.4000 \\
\hline Almon 1ak +amon fum & $M G / L$ & 16 & 0.5630 & 0.3330 \\
\hline Nitrit & $M G / L$ & 16 & 0.0801 & 0.0493 \\
\hline Nitrat & $M G / L$ & 16 & 1.7338 & 3.0000 \\
\hline Phosph., tot.flit PO4 & $M G / L$ & 17 & 0.2253 & 0.2700 \\
\hline Phosph., tot P04,P11t & $M G / L$ & 17 & 0.2399 & 0.2453 \\
\hline Calcium & $M G / L$ & 16 & 113.4375 & 116.0000 \\
\hline Chlortd & $M G / L$ & 16 & 27.0625 & 24.5000 \\
\hline Fluorid & $\mathrm{MG} / \mathrm{L}$ & 16 & 0.2300 & 0.2350 \\
\hline Jern ferro & $M G / L$ & 16 & 4.2106 & 2.1550 \\
\hline Kaltum & $M G / L$ & 16 & 2.4688 & 2.6500 \\
\hline Krikseiv & MANOGRAM/L & 1 & & \\
\hline Magnesium & $M G / L$ & 16 & 8.6250 & 8.1500 \\
\hline Mangan & $M G / L$ & 17 & 0.4717 & 0.3500 \\
\hline Natriun & $M G / L$ & 16 & 18.1250 & 14.5000 \\
\hline Siliciundioxid & $M G / L$ & 16 & 23.1250 & 24.0000 \\
\hline Sulfat & $M G / L$ & 16 & 70.1875 & 58.5000 \\
\hline Sulf id-s & $M G / L$ & 16 & 0.0819 & 0.0300 \\
\hline Trtetue & T.U. & 3 & 16.6000 & 15.4000 \\
\hline Methan & $M G / L$ & 15 & 0.0247 & 0.0200 \\
\hline Kintal 376r. PCA & ANTAL/ML & 2 & & \\
\hline K1ntal 21Gr.KING A & ANTAL/ML & 2 & & \\
\hline Collforme bakt. $37 \mathrm{Gr}$. & ANTAL $/ 100 \mathrm{ML}$ & 2 & & \\
\hline
\end{tabular}

Grundvandsanalyser, 1989

Spredning

Maximum

Mintoune.

$\begin{array}{rrr}10.40 & 84.5000 & 48.0000 \\ 0.18 & 7.9500 & 7.1300\end{array}$

$106.49 \quad 623.0000 \quad 325.0000$

0.91

3.1000

0.2000

1.96

7.0000

1.5000

35.74

371.0000

271.0000

-

55.0000

55.0000

$$
\text { - }
$$

0.6000

0.6000

5.62

20.0000

2.3000

0.57

2.0800

0.2000

0.08

0.2956

0.0328

1.48

3.0000

0.1000

0.12

0.3700

0.0100

0.12

0.3986

0.0307

32.71

158.0000

35.0000

11.22

48.0000

14.0000

0.05

0.3100

0.1400

4.63

16.6000 *

0.6700

0.81

4.2000

1.1000

3.0000

3.0000

1.93

14.0000

5.3000

0.34

1.5599

0.1000

10.98

55.0000

12.0000

2.36

26.0000

17.0000

42.70

152.0000

19.0000

0.21

0.8600

0.0300

15.83

33.0000

1.4000

0.1000

$0.0100 \quad D G$

1.0000

$1.0000 \quad D G$

1.0000

1.0000 DG

1.0000

$1.0000 \quad D G$

- Særlig usædvanlig værdi, der må kontrolleres. 
Svendborg (42.11)

\begin{tabular}{|c|c|}
\hline Stof navn & Enhed \\
\hline Konduktivitet & MSIEMENS/M \\
\hline pH & $\mathbf{P H}$ \\
\hline Inddanpningsrest & $M 6 / L$ \\
\hline Oxygen indhold & $M 6 / L$ \\
\hline Carbondtoxtd, aggr. & $M G / L$ \\
\hline Hydrogencarbonat & $M G / L$ \\
\hline Natr lumhydrogencarb & $M G / L$ \\
\hline Carbon,org, NVOC & $M G / L$ \\
\hline Blok.fltforbr., BI5 & $M G / L$ \\
\hline Permangonatta $1 \mathrm{KMnO4}$ & $m 6 / L$ \\
\hline Admon faktakmon fum & $M G / L$ \\
\hline Nitrit & $M G / L$ \\
\hline Nitrat & $M 6 / L$ \\
\hline Phosph..tot.filt P04 & $M G / L$ \\
\hline Phosph., tot P04,filt & $M G / L$ \\
\hline Aluminiug & MYGRAM/L \\
\hline Arsen & MYGRAM/L \\
\hline Bartum & MYGRAM/L \\
\hline Biy & MYGRAM/L \\
\hline Bor & MYGRAM/L \\
\hline Bromid & MYGRAM/L \\
\hline Cadiefun & MYGRAM/L \\
\hline Calcium & $M G / L$ \\
\hline Chlor,org, AOX & MYGRAH/L \\
\hline Chlor,org. vox & MYGRAM/L \\
\hline Chlorid & $M G / L$ \\
\hline Chrom & MYGRAM/L \\
\hline Cyan1d & $M G / L$ \\
\hline F luorid & $M G / L$ \\
\hline Jern ferro & $M G / L$ \\
\hline Jod & MYGRAM/L \\
\hline Jodtd & MYGRAM/L \\
\hline Kallum & $M G / L$ \\
\hline Kobber & MYGRAM/L \\
\hline Lithiun & MYGRAM/L \\
\hline Magnes iuu & $M G / L$ \\
\hline Mangan & MG/L \\
\hline Molyodan & MYGRAM/L \\
\hline Natriun & $\mathbf{M G} / \mathbf{L}$ \\
\hline Nikkel & MYGRAM/L \\
\hline silfe fund tox id & $M G / L$ \\
\hline Stront fua & MYGRAM/L \\
\hline Sulfat & $M G / L$ \\
\hline Sulfto-s & $M 6 / L$ \\
\hline Tritiun & T.U. \\
\hline Methan & $M G / L$ \\
\hline Detergenter anion & $M G / L$ \\
\hline Kintal 376r. PCA & ANTAL/ML \\
\hline Kimta] 216r.KING A & ANTAL/ML \\
\hline Collforme bakt.37Gr. & ANTAL/100 M \\
\hline
\end{tabular}

Fyns Amt

Grundvandsanalyser, 1990

Median Spredning Maxtaun

$\begin{array}{rrrrrr}85 & 66.3106 & 63.0000 & 11.50 & 101.0000 & 51.0000 \\ 80 & 7.3835 & 7.4200 & 0.29 & 8.0500 & 6.8000 \\ 7 & 434.5714 & 389.0000 & 82.21 & 567.0000 & 357.0000 \\ 34 & 0.2912 & 0.2000 & 0.26 & 1.3000 & 0.1000 \\ 22 & 3.3300 & 3.0000 & 2.87 & 12.0000 & 0.0600\end{array}$

$\begin{array}{llllll}43 & 330.6512 & 333.0000 & 35.14 & 401.0000 & 239.0000\end{array}$

$\begin{array}{llllll}9 & 76.1111 & 75.0000 & 39.13 & 121.0000 & 22.0000\end{array}$

$\begin{array}{lllllll}5 & 2.9000 & 2.9000 & 0.67 & 3.5000 & 1.8000\end{array}$

$\begin{array}{llllll}1 & 1.3000 & 1.3000 & . & 1.3000 & 1.3000\end{array}$

$\begin{array}{llllll}43 & 7.3558 & 7.5000 & 4.09 & 14.6000 & 1.0000\end{array}$

$\begin{array}{llllll}43 & 1.0809 & 0.9100 & 1.01 & 3.9900 & 0.1000\end{array}$

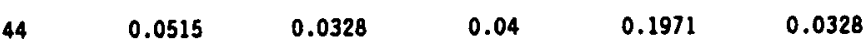

$\begin{array}{llllll}43 & 0.1002 & 0.1000 & 0.00 & 0.1100 & 0.1000\end{array}$

$\begin{array}{llllll}24 & 1.2279 & 0.7400 & 1.10 & 3.4700 & 0.1300\end{array}$

$\begin{array}{llllll}44 & 1.1819 & 0.7666 & 1.06 & 4.3844 & 0.1533\end{array}$

$\begin{array}{llllll}5 & 43.7200 & 25.0000 & 51.29 & 127.0000 & 0.8000\end{array}$

$\begin{array}{llllll}5 & 0.4800 & 0.4000 & 0.37 & 1.1000 & 0.2000\end{array}$

$\begin{array}{llllll}5 & 132.4000 & 131.0000 & 21.82 & 166.0000 & 106.0000\end{array}$

$\begin{array}{llllll}5 & 1.2520 & 0.3000 & 2.11 & 5.0000 & 0.1000\end{array}$

$\begin{array}{llllll}5 & 320.8000 & 152.0000 & 349.26 & 938.0000 & 118.0000\end{array}$

$\begin{array}{llllll}5 & 59.8000 & 60.0000 & 4.32 & 65.0000 & 55.0000\end{array}$

$\begin{array}{llllll}5 & 0.0088 & 0.0050 & 0.01 & 0.0200 & 0.0050\end{array}$

$\begin{array}{lllll}101.9070 & 100.0000 & 28.76 & 165.0000 & 46.0000\end{array}$

$\begin{array}{lllll}2.2600 & 2.2000 & 0.35 & 2.7000 & 1.8000\end{array}$

$0.5000 \quad 0.5000$

31.6047

23.0000

23.24

98.0000

7.6000

0.1000

3.35

0.0130

0.2300

0.08

0.6800

7.6200

1.9279

1.6000

1.39

19.6000

10.0000

7.2000

7.0000

1.64

33.0000

4.2000

16.0000

12.0000

1.2500

1.4000

128.0000

0.9040

0.6200

28.4348

596.0000

27.0000

533.0000

33.0000

0.0300

10.4000

0.0305

16.9667

0.4929

0.0750
$5000 \quad$ OG

15.0000

0.1000

0.0050

0.1500

0.0400

1.0000

DG

G

DG

6.0000

1.6000

0.1000

8.7000

4.8000

0.0600

0.3000

12.0000

0.2000

17.0000

448.0000

5.0000

0.0030

1.5000

0.0100

$0.0040 \quad D G$

1.0000 DG

$1.0000 \quad D G$

$1.0000 \quad D G$
2.5000

18.42

0.92

6.12

42.0000

152.91

821.0000

88.0000

0.0400

49.0000

5.3900

0.0040

1.0000

1.0000

1.0000 
Svendborg (42.11)

\begin{tabular}{|c|c|}
\hline Stof navn & Enhed \\
\hline Kondukt ivitet & MSIEMENS/M \\
\hline pH & PH \\
\hline Inddampn Ingsrest & $M G / L$ \\
\hline Oxygen indhold & MG/L \\
\hline Carbondioxid, aggr. & $M G / L$ \\
\hline Hydrogencarbonat & MG/L \\
\hline Matr iumhyorogencarb & $M G / L$ \\
\hline Permanganatta $1 \mathrm{KMnO4}$ & $M G / L$ \\
\hline Anmon fak+abmon fum & $M G / L$ \\
\hline Nitr1t & $M G / L$ \\
\hline Nitrat & $M G / L$ \\
\hline Phosph., tot.f1lt P04 & $M G / L$ \\
\hline Phosph., tot P04,P11t & $M G / L$ \\
\hline Calcium & $M G / L$ \\
\hline Chlorid & $M G / L$ \\
\hline Fluorid & $M G / L$ \\
\hline Jern ferro & $M G / L$ \\
\hline Kallum & $M G / L$ \\
\hline Kriksolv & MAMOGRAM/L \\
\hline Magnes iur & $M G / L$ \\
\hline Mangan & $M G / L$ \\
\hline Natr fuw & $M G / L$ \\
\hline silfe fundioxid & $M G / L$ \\
\hline Sulfat & $\mathrm{MG} / \mathrm{L}$ \\
\hline Sulfid-s & $M G / L$ \\
\hline Trit fum & T.U. \\
\hline Methan & $M G / L$ \\
\hline Kintal 376r. PCA & AKTAL/ML \\
\hline Kimtal 216r.KING A & ANTAL/ML \\
\hline Coliforme bakt.37Gr. & ANTAL $/ 100 \mathrm{ML}$ \\
\hline
\end{tabular}

Fyns Amt

Grundvandsanalyser, 1989

\begin{tabular}{|c|c|c|c|c|c|}
\hline Anta 1 & Gens & Madian & Spredning & Max 1mum & MIn1nue \\
\hline 56 & 65.0339 & 62.0000 & 11.27 & 98.0000 & 51.5000 \\
\hline 74 & 7.4539 & 7.4300 & 0.19 & 7.9900 & 7.1200 \\
\hline 3 & 380.6667 & 387.0000 & 28.04 & 405.0000 & 350.0000 \\
\hline 36 & 0.6611 & 0.4000 & 0.66 & 2.9000 & 0.1000 \\
\hline 23 & 3.4043 & 3.6000 & 1.72 & 6.1000 & 0.4000 \\
\hline 38 & 343.8158 & 336.0000 & 42.70 & 435.0000 & 242.0000 \\
\hline 17 & 97.5529 & 88.0000 & 65.46 & 246.0000 & 2.4000 \\
\hline 35 & 8.6086 & 8.0000 & 5.22 & 21.0000 & 1.6000 \\
\hline 38 & 0.7063 & 0.2850 & 1.04 & 4.7500 & 0.0100 \\
\hline 38 & 0.0527 & 0.0328 & 0.05 & 0.3285 & 0.0328 \\
\hline 37 & 0.1740 & 0.1000 & 0.48 & 3.0000 & 0.0010 \\
\hline 36 & 1.2761 & 0.6650 & 1.35 & 5.4000 & $0.0700 *$ \\
\hline 34 & 1.5133 & 0.7206 & 1.56 & 6.1017 & $0.0613 *$ \\
\hline 38 & 99.9474 & 93.5000 & 31.56 & 158.0000 & 43.0000 \\
\hline 38 & 29.2632 & 22.0000 & 18.67 & 83.0000 & 13.0000 \\
\hline 38 & 0.2600 & 0.2400 & 0.10 & 0.8000 & 0.1700 \\
\hline 35 & 2.0820 & 1.4100 & 1.48 & 6.2500 & 0.6400 \\
\hline 38 & 3.0763 & 2.8000 & 0.95 & 5.4000 & 2.0000 \\
\hline 4 & 3.0000 & 3.0000 & 0.00 & 3.0000 & 3.0000 \\
\hline 38 & 10.5316 & 8.9000 & 14.32 & 95.0000 & 2.2000 \\
\hline 36 & 0.2689 & 0.2550 & 0.10 & 0.4700 & 0.1200 \\
\hline 38 & 28.6579 & 24.5000 & 17.76 & 115.0000 & 12.0000 \\
\hline 38 & 28.5526 & 27.0000 & 6.21 & 42.0000 & 14.0000 \\
\hline 38 & 33.4184 & 34.5000 & 26.99 & 90.0000 & 0.1000 \\
\hline 36 & 0.0314 & 0.0300 & 0.01 & 0.0600 & 0.0300 \\
\hline 5 & 1.4200 & 1.3000 & 0.48 & 2.1000 & 1.0000 \\
\hline 35 & 0.9869 & 0.1000 & 2.27 & 10.0000 & 0.0100 \\
\hline 4 & & & & 1.0000 & 1.0000 \\
\hline 4 & 4.2500 & 2.0000 & 5.25 & 12.0000 & 1.0000 \\
\hline 4 & & & & 1.0000 & 1.0000 \\
\hline
\end{tabular}

* Særlig usædvanlig værdi, der må kontrolleres. 
Fyns Amt

Stof navn

Kondukt ivitet

pH

Inddampningsrest $\quad M G / L$

Oxygen indhold MG/L

Carbondtoxid, aggr. MG/L

Hydrogencarbonat MG/L

Natrifunhydrogencarb MG/L

Carbon,org, HvoC MG/L

Biok.1ltforbr., BI5 MG/L

Permanganattal KMn04 MG/L

Amson tak+amon fum $\quad M G / L$

Nitrit MG/L

Nitrat MG/L

Phosph.,tot.filt P04 MG/L

Phosph., tot PO4,filt MG/L

Alumininan

Arsen

Bar 1um

Bly

Bor

Bromid

Cada fus

calctum

Ch lor, org, AOX

Chlor, org, vox

chlorido

Chrom

Cyanid

Fluorid

Jern ferro

Jod

Jodtd

Kaltum

Kobber

Lithiue

Magnes tum

Mangan

Molybdan

Matriue

Nikke 1

siliclundioxid

Stront tue

Sulfat

Sulfid-s

Trit iun

Methan

Detergenter anion

Mech lorprop

Kintal 376r. PCA
Enhed

SIEMENS/M

(n)

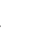

MG/L

MYGRAM/L

AKTAL/ML $\begin{array}{llllll}95 & 66.1821 & 62.5000 & 13.89 & 119.0000 & 44.0000\end{array}$

$\begin{array}{llllll}95 & 7.4292 & 7.4700 & 0.23 & 7.9800 & 6.9000\end{array}$

$\begin{array}{llllll}28 & 452.7500 & 437.0000 & 114.48 & 879.0000 & 323.0000\end{array}$

$\begin{array}{llllll}45 & 0.3311 & 0.2000 & 0.35 & 2.0000 & 0.1000\end{array}$

$\begin{array}{llllll}27 & 3.6963 & 3.6000 & 1.42 & 7.2000 & 1.1000\end{array}$

$\begin{array}{llllll}48 & 281.8333 & 259.0000 & 72.96 & 447.0000 & 117.0000\end{array}$

$\begin{array}{llllll}4 & 123.7500 & 127.0000 & 12.84 & 135.0000 & 106.0000\end{array}$

$\begin{array}{llllll}7 & 2.1286 & 2.0000 & 0.64 & 3.3000 & 1.2000\end{array}$

$\begin{array}{llllll}2 & 2.4000 & 2.4000 & 1.41 & 3.4000 & 1.4000\end{array}$

$\begin{array}{llllll}48 & 6.5979 & 4.5000 & 4.86 & 24.0000 & 2.0000\end{array}$

$\begin{array}{llllll}48 & 0.2721 & 0.1950 & 0.29 & 1.0500 & 0.0100\end{array}$

$\begin{array}{llllll}48 & 0.0753 & 0.0328 & 0.10 & 0.4927 & 0.0328\end{array}$

$\begin{array}{llllll}48 & 0.3517 & 0.1000 & 0.80 & 4.2000 & 0.0900\end{array}$

$\begin{array}{llllll}25 & 0.1988 & 0.1900 & 0.11 & 0.4300 & 0.0100\end{array}$

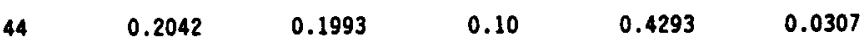

$\begin{array}{llllll}7 & 34.0143 & 33.0000 & 24.15 & 65.0000 & 0.8000\end{array}$

$\begin{array}{llllll}7 & 5.3714 & 5.1000 & 3.70 & 9.3000 & 1.0000\end{array}$

$\begin{array}{llllll}7 & 122.0000 & 116.0000 & 29.85 & 183.0000 & 96.0000\end{array}$

$\begin{array}{llllll}7 & 0.7357 & 0.4900 & 0.77 & 2.4000 & 0.1000\end{array}$

$\begin{array}{llllll}7 & 102.5714 & 79.0000 & 90.09 & 305.0000 & 53.0000\end{array}$

$68.5714 \quad 67.0000$

11.52

85.0000

0.0190

176.0000

4.1000

0.5000

160.0000

0.1000

0.0090

0.4700

7.3800

5.3000

8.0000

24.0000

1.1600

27.0000

19.0000

0.9800

6.4000

54.0000

1.2000

26.0000

1340.0000

113.0000

0.1300

43.0000

0.3000

0.0100

0.4300

28.0000

47.0000

0.0050

59.0000

2.0000

11.0000

0.1000

0.0050

0.1000

0.0100

1.5000

3.0000

0.8000

0.1000

3.5000

4.2000

0.1100

1.5000

9.0000

0.2000

16.0000

363.0000
$7 \quad 0.0056$

$2 \quad 0.2700$

$10 \quad 4.6000$
0.2700

1.0000
$0.5000 \quad D G$

9.0000

0.0300

1.0000

0.0100

OG

G

0.0040 DG

0.1100 DG

1.0000 DG 
Nr. Søby (42.12)

Stof navn

Enhed

K1mtal 216r.KING A

ANTAL/ML

Collforme bakt.376r. ANTAL/100 ML
Fyns Amt

Anta 1

Gens

10

108.3000

10
Grundvandsanalyser, 1990

Median Sprednino

Maximum

Minimum .

3.5000

190.24

480.0000

1.0000 
Nr. Søby (42.12)

\begin{tabular}{|c|c|}
\hline Stor navn & Enhed \\
\hline Kondukt ivitet & MSIERENS/H \\
\hline pH & PH \\
\hline Inddanpningsrest & $M G / L$ \\
\hline Oxygen Indhold & MG/L \\
\hline Carbondtoxtd, aggr. & $M G / L$ \\
\hline Hydrogencarbonat & $M G / L$ \\
\hline Natr funhydrogencarb & $M G / L$ \\
\hline Btok.11tforbr.. BI5 & $M G / L$ \\
\hline Permanganatta I $\mathrm{KMnO}_{4}$ & $M G / L$ \\
\hline Amon iak talmon fui & MG/L \\
\hline Nitrit & $M 6 / L$ \\
\hline Nitrat & $M G / L$ \\
\hline Phosph.,tot.f11t PO4 & $M G / L$ \\
\hline Phosph., tot P04,filt & $146 / L$ \\
\hline Calc Iua & $M G / L$ \\
\hline Chlorid & $M G / L$ \\
\hline Fluortd & $M G / L$ \\
\hline Jern terro & $M G / L$ \\
\hline Kallum & $M G / L$ \\
\hline Krikselv & MANOGRAM/L \\
\hline Magnesiun & $M G / L$ \\
\hline Mangan & $M G / L$ \\
\hline Matriun & $M G / L$ \\
\hline S111ctund tox id & $M G / L$ \\
\hline Sulfat & $M G / L$ \\
\hline Sulf id-s & $M G / L$ \\
\hline Trit fum & T.U. \\
\hline Methan & $M G / L$ \\
\hline Kintai 37Gr. PCA & ANTAL/ML \\
\hline K1mtal $216 r . K I N G$ A & ANTAL/ML \\
\hline
\end{tabular}

\section{Fyns Amt}

Anta 1 Gens

65.9591

7.5128

433.3810

0.4050

4.3895

296.9211

131.5000

2.1667

8.6716

0.2800

0.0971

0.5051

0.1212

0.1630

107.1951

30.6977

0.2730

2.4921

2.9070

4.0000

10.9488

0.4458

23.7500

22.2326

74.3023

0.0300

12.5667

0.0283

21.0000

230.5000

\section{Grundvandsanalyser, 1989}

Median

Spredning

Max 1mum

Min inus

61.4500

12.82

100.0000

42.5000

7.4800

0.21

8.1400

7.1300

410.0000

76.33

595.0000

339.0000

1.13

7.3000

0.1000

2.52

9.9000

1.2000

270.0000

78.34

463.0000

126.0000

131.5000

28.99

152.0000

111.0000

1.3000

1.59

4.0000

1.2000

5.58

25.0000

2.8000

0.31

1.1000

0.0100

0.0328

0.17

0.9854

0.0328

0.1000

1.44

5.7100

0.1000

0.1000

0.10

0.4000

0.0100

0.14

0.7666

0.0307

110.0000

25.52

156.0000

54.0000

27.83

123.0000

11.0000

0.2300

0.10

0.5100

0.1700

2.45

11.7000

0.1400

1.59

6.6000

0.9000

2.3000

1.00

5.0000

3.0000

8.49

44.0000

2.5000

0.3100

0.59

3.6000

0.1000

14.72

50.0000

10.0000

4.00

30.0000

14.0000

23.0000

31.09

116.0000

11.0000

0.0300

0.00

0.0300

0.0300

12.70

33.0000

1.0000

10.6000

0.03

0.1400

0.0100

21.0000

28.28

41.0000

1.0000

324.56

460.0000

$1.0000 \quad D G$

1.0000 
Harndrup (42.13)

\begin{tabular}{|c|c|c|c|c|c|c|c|}
\hline Stof navn & Enhed & Antal & Gens & Median & Spredning & Maximun & Minimum \\
\hline Kondukt iv ttet & MSIEMENS/M & 116 & 72.0405 & 64.3000 & 18.70 & 127.0000 & 56.0000 \\
\hline pH & PH & 118 & 7.3651 & 7.3900 & 0.20 & 7.8700 & 6.7900 \\
\hline Inddampn ingsrest & HG/L & 2 & 359.0000 & 359.0000 & 5.66 & 363.0000 & 355.0000 \\
\hline Oxyoen indhold & $M G / L$ & 59 & 0.2814 & 0.2000 & 0.22 & 0.9000 & 0.1000 \\
\hline Carbondtoxid, agar. & $M G / L$ & 29 & 3.8410 & 3.0000 & 2.58 & 13.4000 & 0.2900 \\
\hline Hydropencarbonat & MG/L & 57 & 332.3860 & 343.0000 & 35.06 & 433.0000 & 261.0000 \\
\hline Hatr fuahydrogencarb & $M G / L$ & 7 & 29.0857 & 26.0000 & 17.10 & 56.0000 & 7.6000 \\
\hline Carbon, org, HVOC & $M G / L$ & 7 & 1.7286 & 1.6000 & 0.58 & 2.9000 & 1.2000 \\
\hline Perwanganattal KMnO4 & HG/L & 59 & 3.8695 & 3.8000 & 1.51 & 9.9000 & 1.0000 \\
\hline Armon taktammon tum & $M G / L$ & 59 & 0.2805 & 0.2800 & 0.16 & 0.6500 & 0.0100 \\
\hline Nitrit & $M G / L$ & 59 & 0.0562 & 0.0328 & 0.06 & 0.3285 & 0.0328 \\
\hline Mitrat & $M G / L$ & 59 & 0.6075 & 0.1000 & 1.69 & 8.4000 & 0.0400 \\
\hline Phosph..tot.f11t P04 & $M G / L$ & 31 & 0.2003 & 0.1300 & 0.22 & 1.0800 & 0.0100 \\
\hline Phosph.,tot P04,Plit & $M G / L$ & 57 & 0.1959 & 0.1533 & 0.16 & 0.6132 & 0.0307 \\
\hline Alunintun & MYGRAM/L & 7 & 62.4429 & 30.0000 & 98.90 & 279.0000 & 0.8000 \\
\hline Arsen & MYGRAM/L & 7 & 8.1714 & 4.7000 & 5.79 & 18.2000 & 3.2000 \\
\hline Bartun & MYGRAM/L & 7 & 135.1429 & 127.0000 & 21.07 & 166.0000 & 112.0000 \\
\hline Bly & MYGRAM/L & 7 & 0.3771 & 0.1000 & 0.48 & 1.4000 & 0.1000 \\
\hline Bor & MYGRAM/L & 7 & 97.5714 & 84.0000 & 40.02 & 161.0000 & 51.0000 \\
\hline Brom1d & MYGRAY/L & 7 & 89.8571 & 78.0000 & 26.54 & 128.0000 & 62.0000 \\
\hline Cadiniun & MYGRAM/L & 7 & & & & 0.0050 & 0.0050 \\
\hline Calciun & $M G / L$ & 59 & 110.5763 & 101.0000 & 32.31 & 188.0000 & 71.0000 \\
\hline Chlor, org, AOX & MYGRAM/L & 7 & 2.7143 & 2.1000 & 1.68 & 6.4000 & 1.5000 \\
\hline Chlor, org, vox & MYGRAM/L & 7 & & & & 0.5000 & 0.5000 \\
\hline Chlorid & MG/L & 59 & 43.2034 & 27.0000 & 42.56 & 161.0000 & 14.0000 \\
\hline Chron & MYGRAM/L & 7 & 0.1143 & 0.1000 & 0.04 & 0.2000 & 0.1000 \\
\hline Cyanid & $M G / L$ & 7 & & & & 0.0050 & 0.0050 \\
\hline F luor 1d & $M G / L$ & 59 & 0.2678 & 0.2600 & 0.09 & 0.4800 & 0.1200 \\
\hline Jern & $M G / L$ & 7 & 2.7829 & 2.3400 & 1.54 & 5.2000 & 0.9900 \\
\hline Jern ferro & $M G / L$ & 52 & 1.5323 & 1.3000 & 1.44 & 6.8300 & 0.0100 \\
\hline Jod & MYGRAM/L & 7 & 4.0429 & 1.8000 & 4.68 & 12.0000 & 1.0000 \\
\hline Jodid & MYGRAM/L & 7 & 9.2857 & 7.0000 & 4.07 & 15.0000 & 5.0000 \\
\hline Kallun & $M 6 / L$ & 59 & 3.1017 & 2.8000 & 1.11 & 6.4000 & 1.6000 \\
\hline Kobber & MYGRAM/L & 7 & 0.8957 & 0.2000 & 1.68 & 4.7000 & 0.1000 \\
\hline Lith tum & MYGRAM/L & 7 & 11.7429 & 11.1000 & 3.09 & 17.8000 & 8.1000 \\
\hline Magnes 1un & $M G / L$ & 59 & 11.3949 & 11.0000 & 3.13 & 20.0000 & 6.7000 \\
\hline Mangan & $M G / L$ & 59 & 0.5330 & 0.3100 & 0.58 & 2.4000 & 0.1400 \\
\hline Molybden & MYGRAM/L & 7 & 3.2714 & 3.2000 & 1.72 & 6.7000 & 1.4000 \\
\hline Natr 1um & $\mathrm{MG} / \mathrm{L}$ & 59 & 23.8136 & 19.0000 & 12.26 & 64.0000 & 14.0000 \\
\hline M1kkel & MYGRAM/L & 7 & 0.7143 & 0.4000 & 0.60 & 1.6000 & 0.2000 \\
\hline stlictundtoxid & MG/L & 31 & 23.5161 & 25.0000 & 3.05 & 27.0000 & 16.0000 \\
\hline Stront iun & MYGRAM/L & 7 & 697.5714 & 605.0000 & 186.49 & 1040.0000 & 533.0000 \\
\hline Sulfat & MG/L & 59 & 41.3559 & 27.0000 & 34.79 & 171.0000 & 5.0000 \\
\hline Sulf 1d-S & $M G / L$ & 59 & 0.0305 & 0.0300 & 0.00 & 0.0500 & 0.0300 \\
\hline Tritiun & T.U. & 4 & 15.1500 & 12.2500 & 17.01 & 35.1000 & 1.0000 \\
\hline Methan & $M G / L$ & 59 & 0.0137 & 0.0100 & 0.01 & 0.0400 & 0.0100 \\
\hline Detergenter anion & $M G / L$ & 1 & & & & 0.0040 & 0.0040 \\
\hline Kintal 376r. PCA & ANTAL/ML & 18 & 20.0556 & 2.0000 & 52.75 & 210.0000 & 1.0000 \\
\hline Kimtal 216r.KING A & ANTAL/ML & 18 & 430.5556 & 48.5000 & 954.37 & 3000.0000 & 1.0000 \\
\hline
\end{tabular}

Fyns Amt

Grundvandsanalyser, 1990 
Harndrup (42.13)

Stof navn

Enhed

Collforme bakt.37Gr. ANTAL/100 ML

Terwotol.colf.bakt. ANTAL/100 ML
Fyns Amt

Antal Gens

18

1.1111

1

\section{Grundvandsanalyser, 1990}

Median Spredning Maximum Mintwum

1.0000

0.47

3.0000

1.0000

$1.0000 \quad 06$

$1.0000 \quad D G$ 


\section{Harndrup (42.13)}

\begin{tabular}{|c|c|}
\hline Stof navn & Enhed \\
\hline Kondukt iv itet & MSIEMENS/M \\
\hline pH & PH \\
\hline oxygen indhold & $\mathrm{MG} / \mathrm{L}$ \\
\hline Carbondtoxid, aggr. & $M G / L$ \\
\hline Hydrogencarbonat & $M G / L$ \\
\hline Matr Iuahydrogencarb & $M G / L$ \\
\hline Blok.11tforbr., 815 & $M G / L$ \\
\hline Permanganatta 1 KMnO4 & $M G / L$ \\
\hline Amon tak tasmon fum & $M G / L$ \\
\hline N1trit & $M G / L$ \\
\hline Nitrat & $M G / L$ \\
\hline Phosph., tot.f17t PO4 & $M G / L$ \\
\hline Phosph., tot PO4,f11t & $M G / L$ \\
\hline Calciun & $M G / L$ \\
\hline Chlorido & $M G / L$ \\
\hline Fluorida & $M G / L$ \\
\hline Jern ferro & $M G / L$ \\
\hline Kaliua & $M G / L$ \\
\hline Kviksolv & MAMOGRAM/L \\
\hline Magnesiue & $M G / L$ \\
\hline Mangan & $\mathrm{MG} / \mathrm{L}$ \\
\hline Natrium & $\mathrm{MG} / \mathrm{L}$ \\
\hline Stlle fuad iox id & MG/L \\
\hline Sulfat & $M G / L$ \\
\hline Sulf 1d-S & $M G / L$ \\
\hline Trit ium & T.U. \\
\hline Methan & $M G / L$ \\
\hline
\end{tabular}

\section{Fyns Amt}

Anta 1 Gens

82

105

68.0378

7.4396

0.5618

3.4786

14

52

7

340.7308

21.3714

1.2000

4.7455

0.3273

0.0457

0.6638

0.1815

0.2070

106.2679

41.8393

0.3173

2.0841

3.2893

3.0000

11.6786

0.4943

27.2143

23.3654

39.7143

0.0313

1.0000

0.0331

\section{Grundvandsanalyser, 1989}

Median Spredning

Maximum

Min imu

61.0000

7.4200

0.3000

3.1000

345.5000

14.0000

1.2000

4.0000

0.2150

0.0328

0.1000

0.1400

0.1533

96.5000

24.0000

0.3200

1.8000

3.3000

3.0000

11.0000

0.3100

19.0000

24.0000

25.0000

0.0300

1.0000

0.0200
18.55

0.20

0.63

1.80

66.96

20.97

.

3.34

0.39

0.05

1.27

0.14

0.13

26.13

45.08

0.09

1.48

0.92

0.92

0.00

2.98

0.57

22.50

3.54

31.32

0.01

0.00

0.03
126.7000

53.5000

8.1000

3.0000

7.0000

711.0000

59.0000

1.2000

20.0000

1.6400

0.2956

5.7100

0.6100

0.7052

179.0000

169.0000

0.5700

7.4000

6.1000

3.0000

20.0000

2.8900

106.0000

28.0000

138.0000

0.1000

1.0000

0.1000
6.6600

0.1000

0.4000

159.0000

1.3000

1.2000

0.5000

0.0100

0.0328

$0.0100 \quad D G$

0.0100

0.0307

69.0000

13.0000

0.1400

0.0400

1.8000

3.0000

5.4000

0.1200

14.0000

14.0000

14.0000

0.0300

1.0000

0.0100 


\section{Jullerup (42.14)}

Stof navn

Enhed

Kondukt ivitet

MSIEMENS/M

pH

Inddampningsrest $\quad M G / L$

Oxygen indhold MG/L

Carbondtoxid, ager. MG/L

Hydrogencarbonat MG/L

Carbon,org.KVOC MG/L

Permanganattal KMnO4 MG/L

Amon taktamon fum $\quad M G / L$

Nitrit MG/L

Nitrat MG/L

Phosph.,tot.filt PO4 MG/L

Phosph., tot P04,f11t M6/L

Aluminius

MYGRAM/L

Arsen

Barium

Bly

Bor

Bromid

Cadintum

Calciua

Chlor,org, $A O X$

Chlor, org, vox

Chlorid

Chrow

Cyanid

Fluor id

Jern

Jern ferro

Jod

Jodid

Kallum

Kobber

Lithium

Magnestum

Mangan

Mo lybden

Natriug

Nikke 1

stiletund toxid

Stront lun

Sulfat

Sulfto-s

Trittun

Methan

Kistal $376 r$. PCA

Kinta 2 2IGr.KING A

Coltforne bakt.37Gr.

Ternotol.col1.bakt.

MYGRAM/L

MYGRAM/L

MYGRAM/L

MYGRAM/L

MYGRAM/L

MYGRAM/L

MG/L

MYGRAM/L

MYGRAM/L

MG/L

MYGRAM/L

MG/L

MG/L

$M G / L$

MG/L

MYGRAM/L

MYGRAM/L

MG/L

MYGRAM/L

MYGRAM/L

MG/L

MG/L

MYGRAM/L

MG/L

MYGRAM/L

MG/L

MYGRAM/L

$M G / L$

MG/L

T.U.

MG/L

ANTAL/ML

ARTAL/ML
Fyns Amt

32

4

$$
12
$$

12

4

45

45

45

45

45

45

4

ANTAL/100 ML

ANTAL/100 ML

$4 \quad 0.9875$

86.5000

43.5000

66.5000

0.0138

129.7111

58.8444

0.2156

1.5349

1.9956

.2000

$4 \quad 0.3000$

$22 \quad 24.0909$

$42 \quad 0.0305$

Antal Gens Medtan Spredning Maximum Minimua .

Grundvandsanalyser, 1990

$\begin{array}{rrrrrr}90 & 74.7656 & 63.7500 & 30.18 & 153.0000 & 14.3000 \\ 90 & 7.4329 & 7.4200 & 0.28 & 8.1400 & 6.8100 \\ 32 & 514.0938 & 432.0000 & 224.27 & 1020.0000 & 286.0000 \\ 45 & 1.1644 & 0.4000 & 1.88 & 7.2000 & 0.1000 \\ 12 & 2.6667 & 2.4000 & 0.69 & 3.8000 & 2.0000\end{array}$

$\begin{array}{llllll}45 & 319.8222 & 284.0000 & 107.55 & 586.0000 & 222.0000\end{array}$

0.7150

0.61

1.9000

8.5000

0.6200

1.8000

2.03

0.7600

0.4000

0.0700

0.12

0.9525

0.0100

0.0328

0.1000

15.16

65.0000

0.0100

0.0750

0.09

0.4400

0.0200

0.0920

0.10

0.5519

0.0307

2.6500

4.83

11.5000

0.8000

1.4500

1.02

2.3000

0.3000

92.0000

18.36

102.0000

60.0000

0.1000

0.17

0.4400

0.1000

40.0000

9.43

57.0000

37.0000

63.5000

14.75

87.0000

52.0000

0.0050

0.02

0.0400

0.0050

110.0000

54.26

260.0000

83.0000

$2.1000 \quad 2.0500$

0.29

2.5000

1.8000

0.5000

0.5000

14.0000

27.0000

58.67

167.0000

0.1000

0.1000

0.00

0.1000

0.0050

DG

0.2100

0.0050

0.1100

1.0800

0.06

0.3400

0.0400

1.0300

3.38

11.0000

0.0200

2.0500

11.7000

1.0000

4.5000

1.25

4.0000

1.0000

1.8000

1.41

7.0000

4.0000

0.1000

3.5000

1.1000

0.1000

0.1000

7.3000

7.8000

6.4000

11.0000

0.59

27.0000

5.1000

0.1800

0.22

0.9900

0.0300

2.0000

0.13

2.1000

1.8000

15.0000

12.14

57.0000

9.0000

0.2000

0.2500

0.5000

19.0000

24.0000

3.21

31.0000

224.0000

314.5000

54.65

350.0000

11.0000

0.0300

30.07

105.0000

0.0300

12.3000

21.80

1.0000

0.0100

0.05

48.8000

0.0100

9.0000

$95.54 \quad 310.0000$

$1.0000 \quad D G$

$13 \quad 1536.4615 \quad 140.0000$

3796.5

14000.000

$1.0000 \quad D G$

$\begin{array}{lll}13 & 2.6923 \quad 1.0000\end{array}$

6.10

23.0000

$1.0000 \quad 0 G$

$\begin{array}{lll}3 & 8.3333 & 1.0000\end{array}$

12.70

23.0000

$1.0000 \quad D G$ 


\section{Jullerup (42.14)}

Stof navn

Kondukt ivitet

Enhed

pH

Inddampningsrest $M G / L$

Oxygen indhold MG/L

Carbondloxid, aggr. $\mathrm{MG} / \mathrm{L}$

Hydrogencarbonat MG/L

Permanganattal KMnO4 MG/L

Ameon laktalcon fum $\quad M G / L$

Nitrit

MG/L

Nitrat

Phosph., tot.f17t PO4

Phosph.., tot P04,filt

Calclua

Chlortd

Fluor id

Jern

Jern ferro

Kal1um

Kvikso iv

Magnestum

Mangan

Natrium

silic tumdioxid

Sulfat

Sulftd-s

Trit lum

Methan

Kintal 376r. PCA

Kimtal 21Gr.KING A

ANTAL/ML

ANTAL/ML

Collforme bakt.37Gr. ANTAL/100 ML
Fyns Amt

Anta 1 Gens

5

64

66.5283

7.4692

512.4375

0.8771

2.7200

296.0000

3.2714

0.0809

0.0668

4.9849

0.0871

0.1516

117.9143

51.9143

0.2571

590.0350

1.5554

2.0629

14.3714

0.2176

16.5143

23.9429

58.4457

0.0314

1.3000

0.0471
Grundvandsanalyser, 1989

Madian Spredning

Maxiaun

Miniaun

57.8000

22.73

118.0000

0.7150

7.5050

0.26

7.9900

6.2100

449.0000

209.03

952.0000

312.0000

0.4000

1.16

4.7000

0.1000

2.7500

0.95

4.0000

1.2000

286.0000

72.28

588.0000

219.0000

2.4000

2.40

12.0000

0.7000

0.0800

0.06

0.2700

0.0100

0.0328

0.05

0.2299

0.0328

0.1000

11.61

41.5000

0.0100

0.0800

0.06

0.2700

0.0100

0.0920

0.19

0.9199

0.0307

93.0000

46.60

295.0000

82.0000

20.0000

60.55

206.0000

13.0000

0.2600

0.06

0.3500

0.1600

834.34

1180.0000

0.0700

1.2400

1.69

10.2000

0.0900

2.0000

0.62

4.0000

1.4000

3.0000

3.0000

10.0000

19.66

125.0000

6.7000

0.1850

0.14

0.8000

0.0600

14.0000

8.18

44.0000

9.0000

24.0000

2.93

33.0000

16.0000

51.0000

31.54

111.0000

8.6000

0.0300

0.01

0.0600

0.0300

1.0000

0.52

1.9000

1.0000

0.04

0.1300

0.0100

1.0000

$1.0000 \quad D G$

1.0000

$1.0000 \quad D G$

1.0000

$1.0000 \quad D$ 
Abild (50.01)

\begin{tabular}{|c|c|}
\hline Stof navn & Enhed \\
\hline Kondukt Ivitet & MSIEMENS/M \\
\hline pH & $\mathbf{P H}$ \\
\hline Oxygen indhold & MG/L \\
\hline Carbond loxid, aggr. & $M G / L$ \\
\hline Hydrogencarbonat & $M G / L$ \\
\hline Permanganattal KMnO4 & $M G / L$ \\
\hline Ammon lak+ancon lum & $M G / L$ \\
\hline Nitrit & $M G / L$ \\
\hline Nitrat & $M G / L$ \\
\hline Phosph..tot.f1lt PO4 & $M G / L$ \\
\hline Calcium & $M G / L$ \\
\hline Chlorid & $M G / L$ \\
\hline Fluor td & $M G / L$ \\
\hline Jern & $M 6 / L$ \\
\hline Kaltum & $M G / L$ \\
\hline Magnes fulw & $M 6 / L$ \\
\hline Mangan & $M G / L$ \\
\hline Natrium & $M G / L$ \\
\hline Sulfat & $M G / L$ \\
\hline Hydrogensulf id & MG/L \\
\hline
\end{tabular}

\section{Sønderjyllands Amt Grundvandsanalyser, 1989}

\begin{tabular}{|c|c|c|c|c|c|}
\hline Anta 1 & Gens & Median & Spredn1ng & Maximus & Min imum \\
\hline 16 & 51.4375 . & 47.8000 & 12.43 & 71.3000 & 33.3000 \\
\hline 16 & 7.2581 & 7.2100 & 0.37 & 7.9400 & 6.5000 \\
\hline 6 & 0.3817 & 0.2800 & 0.33 & 0.7900 & 0.1000 \\
\hline 10 & 20.2000 & 17.0000 & 16.59 & 60.0000 & 1.0000 \\
\hline 16 & 186.3125 & 183.5000 & 61.10 & 318.0000 & 88.0000 \\
\hline 16 & 84.5000 & 10.0000 & 199.98 & 816.0000 & 2.0000 \\
\hline 16 & 0.1250 & 0.1300 & 0.06 & 0.2600 & 0.0400 \\
\hline 16 & 0.0100 & 0.0100 & 0.00 & 0.0100 & 0.0100 \\
\hline 16 & & & & 1.2000 & 1.0000 \\
\hline 16 & 1.3875 & 0.2300 & 2.76 & 11.3449 & 0.0307 \\
\hline 16 & 74.6250 & 75.5000 & 23.87 & 108.0000 & 38.0000 \\
\hline 16 & 42.9375 & 34.5000 & 18.04 & 76.0000 & 25.0000 \\
\hline 16 & 0.0563 & 0.0250 & 0.06 & $0.2000 *$ & 0.0100 \\
\hline 16 & 27.7063 & 28.0000 & 28.50 & 90.0000 & 1.5000 \\
\hline 16 & 3.2125 & 3.5500 & 1.73 & 7.0000 & 0.7000 \\
\hline 16 & 6.3375 & 6.0500 & 2.42 & 10.0000 & 1.8000 \\
\hline 16 & 1.0800 & 0.8950 & 1.13 & 4.4000 & 0.1100 \\
\hline 16 & 23.5625 & 21.0000 & 8.57 & 42.0000 & 15.0000 \\
\hline 16 & 61.5000 & 60.0000 & 26.00 & 100.0000 & 21.0000 \\
\hline 1 & 0.4000 & 0.4000 & . & 0.4000 & 0.4000 \\
\hline
\end{tabular}

* Særlig usædvanlig værdi, der må kontrolleres. 
Mjang Dam (50.02)

\begin{tabular}{|c|c|}
\hline Stof navn & Enhed \\
\hline Kondukt Ivitet & MSIEMENS/M \\
\hline pH & PH \\
\hline Carbondtoxid, aggr. & $M 6 / L$ \\
\hline Hydrogencarbonat & MG/L \\
\hline Permanganatta 1 KMnO4 & $M 6 / L$ \\
\hline Almon taktasmontun & $M G / L$ \\
\hline Nitrit & $M G / L$ \\
\hline Nitrat & $M G / L$ \\
\hline Phosph..tot.filt P04 & $M G / L$ \\
\hline Calctum & MG/L \\
\hline Chlortd & $M G / L$ \\
\hline Fluortd & MG/L \\
\hline Jern & $M G / L$ \\
\hline Kallum & $M G / L$ \\
\hline Magnes fur & $M G / L$ \\
\hline Mangan & Mo/L \\
\hline Natriun & $M G / L$ \\
\hline Sulfat & $M G / L$ \\
\hline Methan & $M G / L$ \\
\hline
\end{tabular}

Sønderjyllands Amt Grundvandsanalyser, 1989

\begin{tabular}{|c|c|c|c|c|c|}
\hline Antal & Gens & Median & Spredning & Max fnum & Minimum \\
\hline 6 & 110.9000 & 111.9000 & 42.03 & 158.3000 & 63.3000 \\
\hline 6 & 7.4850 & 1.4450 & 0.15 & 7.7700 & 7.3500 \\
\hline 2 & 4.0000 & 4.0000 & 0.00 & 4.0000 & 4.0000 \\
\hline 6 & 572.3333 & 572.0000 & 185.54 & 769.0000 & 373.0000 \\
\hline 6 & 144.1667 & 42.5000 & 179.26 & 404.0000 & 17.0000 \\
\hline 6 & 12.9667 & 2.5750 & 16.76 & 37.0000 & 1.8000 \\
\hline 6 & 0.0200 & 0.0150 & 0.01 & 0.0400 & 0.0100 \\
\hline 6 & 1.2167 & 1.0000 & 0.53 & 2.3000 & 1.0000 \\
\hline 6 & 3.7357 & 0.8739 & 6.67 & 17.1707 & 0.2146 \\
\hline 6 & 118.3333 & 102.0000 & 50.73 & 204.0000 & 72.0000 \\
\hline 6 & 69.5000 & 31.5000 & 62.73 & 160.0000 & 25.0000 \\
\hline 6 & 0.1933 & 0.1450 & 0.12 & 0.3900 & 0.0800 \\
\hline 6 & 17.7000 & 10.4500 & 16.25 & 48.0000 & 4.1000 \\
\hline 6 & 27.0333 & 7.8500 & 31.29 & 74.0000 & 5.7000 \\
\hline 6 & 18.5000 & 19.0000 & 1.22 & 20.0000 & 17.0000 \\
\hline 6 & 0.6267 & 0.4450 & 0.66 & 1.8000 & 0.0900 \\
\hline 6 & 107.3333 & 141.0000 & 60.14 & 154.0000 & 28.0000 \\
\hline 4 & 96.7000 & 94.0000 & 107.95 & 198.0000 & 0.8000 \\
\hline 2 & 6.0000 & 6.0000 & 6.36 & 10.5000 & 1.5000 \\
\hline
\end{tabular}




\section{Bedsted (50.11)}

\begin{tabular}{|c|c|}
\hline Stof navn & Enhed \\
\hline Kondukt ivitet & MSIEMENS/M \\
\hline pH & PH \\
\hline Oxygen indhold & $M G / L$ \\
\hline Carbondioxid, aggr. & MG/L \\
\hline Hydrogencarbonat & $M G / L$ \\
\hline Permanganattal KMnO4 & $M G / L$ \\
\hline Ammon 1aktamen iua & $M G / L$ \\
\hline Nitrit & MG/L \\
\hline N1trat & $M G / L$ \\
\hline Phosph.,tot.f11t P04 & $M G / L$ \\
\hline Calctum & $M G / L$ \\
\hline Cnlorid & $M G / L$ \\
\hline Fluoridd & $M 6 / L$ \\
\hline Jern & $M G / L$ \\
\hline Kaltun & $M G / L$ \\
\hline Magnes fun & $M G / L$ \\
\hline Mangan & $M G / L$ \\
\hline Matrium & $M G / L$ \\
\hline Sulfat & $M G / L$ \\
\hline
\end{tabular}

Sønderjyllands Amt Grundvandsanalyser, 1989

$\begin{array}{rrrrrrr}\text { Antal } & \text { Gens } & \text { Median } & \text { Spredning } & \text { Max 1mum } & \text { Minimum } \\ & & & & & & \\ 42 & 49.8976 . & 44.1000 & 15.42 & 107.6000 & 33.8000 & \\ 42 & 7.4352 & 7.5600 & 0.46 & 8.2300 & 6.1000 & \\ 37 & 0.8068 & 0.1000 & 1.73 & 6.2000 & 0.0500 & \\ 26 & 15.7308 & 10.0000 & 15.78 & 70.0000 & 2.0000 & \\ 42 & 192.5952 & 193.0000 & 47.07 & 354.0000 & 91.0000 & \\ 42 & 8.0238 & 4.0000 & 13.23 & 75.0000 & 1.0000 & \\ 42 & 0.4514 & 0.1450 & 1.34 & 6.7000 & 0.0100 & 06 \\ 33 & 0.0318 & 0.0100 & 0.07 & 0.4300 & 0.0100 & 06 \\ 42 & 9.6619 & 1.1000 & 25.21 & 119.0000 & 1.0000 & 06 \\ 42 & 0.2431 & 0.2146 & 0.13 & 0.5826 & 0.0307 & \\ 42 & 79.7619 & 69.0000 & 25.73 & 145.0000 & 44.0000 & \\ 42 & 22.0238 & 22.0000 & 6.48 & 46.0000 & 15.0000 & \\ 42 & 0.0674 & 0.0400 & 0.08 & 0.4500 & 0.0100 & \\ 42 & 1.3598 & 0.7050 & 1.75 & 6.8000 & 0.0100 & \\ 42 & 6.1310 & 2.1500 & 12.86 & 70.0000 & 1.3000 & \\ 42 & 6.0190 & 5.0000 & 3.17 & 15.0000 & 2.1000 & \\ 42 & 0.8695 & 0.2600 & 1.88 & 12.0000 & 0.0600 & \\ 42 & 16.2857 & 15.0000 & 5.45 & 38.0000 & 10.0000 & \\ 42 & 65.3048 & 47.0000 & 65.93 & 342.0000 & 5.4000 & \end{array}$


Rødding nord (50.12)

\begin{tabular}{|c|c|}
\hline Stof navn & Enhed \\
\hline Kondukt ivitet & MSIEMENS/M \\
\hline pH & PH \\
\hline Oxygen indhold & $M G / L$ \\
\hline Carbondioxid, agar. & $M 6 / L$ \\
\hline Hydrogencarbonat & $M 6 / L$ \\
\hline Permanganatta I KMnO4 & $\mathrm{MG} / \mathrm{L}$ \\
\hline 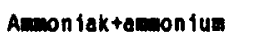 & $16 / \mathrm{L}$ \\
\hline N1trit & $m / L$ \\
\hline N1trat & $m / L$ \\
\hline Phosph., tot.f11t P04 & $M G / L$ \\
\hline Calc lus & $M G / L$ \\
\hline Cnlorid & $M G / L$ \\
\hline Fluorid & $M G / L$ \\
\hline Jern & $M G / L$ \\
\hline Kaliua & $M G / L$ \\
\hline Magnes Iun & $M G / L$ \\
\hline Mangan & $M G / L$ \\
\hline Matriun & $M G / L$ \\
\hline Sulfat & $M G / L$ \\
\hline Hydrogensulf to & $M G / L$ \\
\hline
\end{tabular}

Sønderjyllands Amt Grundvandsanalyser, 1989

$\begin{array}{rrrrrrr}\text { Antal } & \text { Gens } & \text { Median } & \text { Spredning } & \text { Max1mum } & \text { Min 1mum } \\ 11 & 43.9909 & 38.7000 & 14.45 & 66.5000 & 26.6000 & \\ 11 & 6.7918 & 6.7500 & 0.74 & 7.6500 & 5.5100 \\ 8 & 2.8075 & 2.0000 & 3.05 & 8.3000 & 0.1000 & \\ 7 & 29.4286 & 31.0000 & 15.96 & 56.0000 & 4.0000 & \\ 11 & 131.3636 & 66.0000 & 126.66 & 323.0000 & 8.0000 & \\ 11 & 7.4545 & 4.0000 & 12.61 & 45.0000 & 1.0000 & \\ 11 & 0.0850 & 0.0300 & 0.12 & 0.4000 & 0.0100 & \text { DG } \\ 9 & 0.0133 & 0.0100 & 0.01 & 0.0400 & 0.0100 & \text { DG } \\ 11 & 20.7818 & 4.0000 & 26.21 & 61.0000 & 1.0000 & 0 G \\ 11 & 0.2564 & 0.2453 & 0.12 & 0.4599 & 0.0920 & \\ 11 & 63.2727 & 41.0000 & 33.78 & 116.0000 & 31.0000 & \\ 11 & 33.6364 & 27.0000 & 13.82 & 61.0000 & 19.0000 & \\ 11 & 0.0955 & 0.1000 & 0.07 & 0.1800 * & 0.0100 & \\ 11 & 1.4991 & 0.3900 & 2.24 & 5.9000 & 0.0100 & \\ 11 & 2.4545 & 2.7000 & 1.20 & 4.1000 & 0.8000 & \\ 11 & 5.9364 & 4.7000 & 2.67 & 11.0000 & 3.0000 & \\ 11 & 0.1064 & 0.1700 & 0.09 & 0.2000 & 0.0100 & \\ 11 & 16.3636 & 16.0000 & 4.90 & 26.0000 & 10.0000 & \\ 11 & 47.4545 & 35.0000 & 23.36 & 87.0000 & 24.0000 & \\ 1 & 0.4000 & 0.4000 & . & 0.4000 & 0.4000 & \end{array}$

* Særlig usædvanlig værdi, der må kontrolleres. 
Christiansfeld (50.13) Sønderjyllands Amt Grundvandsanalyser, 1989

\begin{tabular}{|c|c|c|c|c|c|c|c|c|}
\hline Stof navn & Enhed & Antal & Gens & Median & Spredning & Max Ieun & Mininum & \\
\hline Kondukt Ivitet & MSIEMENS/M & 18 & 67.6889 & 62.4500 & 14.15 & 95.1000 & 52.0000 & \\
\hline pH & PH & 17 & 7.3841 & 7.4300 & 0.16 & 7.6300 & 7.0000 & \\
\hline Oxygen indhold & MG/L & 14 & 0.2550 & 0.1300 & 0.31 & 1.2000 & 0.0100 & \\
\hline Carbond10xid, aggr. & $M G / L$ & 10 & 6.4000 & 4.0000 & 5.64 & 20.0000 & 2.0000 & \\
\hline Hydrogencarbonat & $M G / L$ & 18 & 273.2222 & 259.0000 & 50.51 & 369.0000 & 208.0000 & \\
\hline Permanganattal $\mathrm{KMnO4}$ & $M G / L$ & 18 & 3.2222 & 2.5000 & 2.80 & 13.0000 & 1.0000 & \\
\hline Amwon taktanmon fun & $M G / L$ & 18 & 0.0939 & 0.0750 & 0.07 & 0.2400 & 0.0200 & \\
\hline Nitrit & $M G / L$ & 18 & 0.0111 & 0.0100 & 0.00 & 0.0300 & 0.0100 & DG \\
\hline Nitrat & $M G / L$ & 18 & 1.0222 & 1.0000 & 0.04 & 1.1000 & 1.0000 & DG \\
\hline Phosph..tot.ftlt P04 & HG/L & 18 & 0.1261 & 0.0920 & 0.11 & 0.3679 & 0.0307 & \\
\hline Calcius & $\mathrm{MG} / \mathrm{L}$ & 18 & 128.9444 & 113.0000 & 36.89 & 196.0000 & 92.0000 & \\
\hline Chlorid & $M G / L$ & 18 & 24.6111 & 23.5000 & 6.79 & 42.0000 & 16.0000 & \\
\hline Fluorid & MG/L & 18 & 0.0750 & 0.0650 & 0.06 & $0.2300 *$ & 0.0100 & \\
\hline Jern & $M G / L$ & 18 & 1.3489 & 1.2500 & 0.85 & 3.1000 & 0.0100 & \\
\hline Kallua & $M G / L$ & 18 & 1.9500 & 1.9500 & 0.54 & 3.0000 & 1.2000 & \\
\hline Magnes fun & $M G / L$ & 18 & 7.7222 & 6.9000 & 2.66 & 14.0000 & 4.5000 & \\
\hline Mangan & $M G / L$ & 18 & 0.5606 & 0.5200 & 0.15 & 0.8700 & 0.3500 & \\
\hline Natrium & $M G / L$ & 18 & 15.5000 & 15.0000 & 2.20 & 20.0000 & 12.0000 & \\
\hline Sulfat & $196 / \mathrm{L}$ & 18 & 114.3889 & 98.0000 & 57.50 & 215.0000 & 48.0000 & \\
\hline Hydrogensulf id & MG/L & 1 & 0.1000 & 0.1000 & - & 0.1000 & 0.1000 & \\
\hline Methan & $M 6 / L$ & 1 & 0.3000 & 0.3000 & - & 0.3000 & 0.3000 & \\
\hline
\end{tabular}

* Særlig usædvanlig værdi, der må kontrolleres. 


\section{Grindsted (55.01)}

\begin{tabular}{|c|c|}
\hline Stor navn & Enhed \\
\hline Kondukt ivitet & MSIEMENS/M \\
\hline $\mathrm{pH}$ & PH \\
\hline Inddampn ingsrest & $M G / L$ \\
\hline Oxygen indhold & $M G / L$ \\
\hline Carbond toxid, aggr. & $M G / L$ \\
\hline Hydrogencarbonat & $M G / L$ \\
\hline Carbon,org, nVOC & MG/L \\
\hline Permanganattal KMnO4 & $M G / L$ \\
\hline Benzen & MYGRAM/L \\
\hline Toluen & MYGRAM/L \\
\hline Ammon lak +ammon fum & $M G / L$ \\
\hline Nitrit & $M G / L$ \\
\hline Nitrat & $M G / L$ \\
\hline Orthophosph._P04.P11 & $M G / L$ \\
\hline Phosph., tot.filt PO4 & $\mathrm{MG} / \mathrm{L}$ \\
\hline Phosph., tot P04,filt & $M G / L$ \\
\hline Aluminiun & MYGRAM/L \\
\hline Arsen & MYGRAM/L \\
\hline Bartum & MYGRAM/L \\
\hline Biy & MYGRAM/L \\
\hline Bor & MYGRAM/L \\
\hline Browid & MYGRAM/L \\
\hline Cadn Iun & MYGRAM/L \\
\hline Calctum & $M G / L$ \\
\hline Chlor,org,AOX & MYGRAM/L \\
\hline Chlor.org.vox & MYGRAM/L \\
\hline Chlortd & $M G / L$ \\
\hline Chrom & MYGRAM/L \\
\hline Cyanid & $M G / L$ \\
\hline Fluorid & $M G / L$ \\
\hline Jern & $M G / L$ \\
\hline Jern ferro & $M G / L$ \\
\hline Jod & MYGRAM/L \\
\hline Jodtd & MYGRAM/L \\
\hline Kallum & $M G / L$ \\
\hline Kobber & MYGRAM/L \\
\hline Lithium & MYGRAM/L \\
\hline Magnes lum & $M G / L$ \\
\hline Mangan & $M G / L$ \\
\hline Molybdan & MYGRAM/L \\
\hline Natrium & $M G / L$ \\
\hline N\{kke\} & MYGRAM/L \\
\hline stlic lum & $M G / L$ \\
\hline S1I Ic tund tox id & $M G / L$ \\
\hline Stront fum & MYGRAM/L \\
\hline Sulfat & $M G / L$ \\
\hline Hydrogensulf 1d & HG/L \\
\hline Methan & $M G / L$ \\
\hline Detergenter anion & $M G / L$ \\
\hline Tetrach lorethylen & MYGRAM/L \\
\hline
\end{tabular}

Ribe Amt

Anta 1 Gens

\section{Grundvandsanalyser, 1990}

$78 \quad 31.8487$

5.5144

235.3947

26.8224

3450.0000

8.1423

0.3000

0.1073

0.0304

34.7829

0.1052

0.1597

0.1490

611.8314

0.2400

34.0000

0.1800

74.2000

48.0000

0.0120

24.3526

18000.000

18000.000

\subsection{8}

0.0400

0.1000

3.4676

2.6246

30.0000

3.2000

6.6904

0.2300

5.2000

5.3949

0.5299

0.2000

18.7282

1.1500

7.6024

8.0342

689.0000

38.6410

0.0204

0.1981

0.0090

0.0500
33.3000

5.5000

254.5000

1.0750

54.5000

14.0000

3450.0000

6.1500

0.3000

0.0170

0.0190

25.5000

0.0445

0.0981

0.0859

98.5000

0.2400

34.0000

0.1800

74.2000

48.0000

0.0120

24.0000

29.0000

0.0400

0.1000

1.2000

0.1960

Spredning

Maxtmum

Min Imua

$\begin{array}{rrr}9.09 & 56.5000 & 10.0000 \\ 0.75 & 8.4000 & 4.1900 \\ 79.15 & 418.0000 & 55.0000 \\ 2.29 & 9.1100 & 0.2300 \\ 45.04 & 249.0000 & 1.0000 \\ 45.09 & 210.0000 & 0.8000\end{array}$

$3450.0000 \quad 3450.0000$

$\begin{array}{lll}6.64 & 44.0000 & 1.0000\end{array}$

$0.3000 \quad 0.3000$

0.1000

1.1800

0.1660

0.03

35.68

139.0000

0.12

0.4262

0.6347

0.6347

0.15

$1322.88 \quad 8770.0000$

0.2400

34.0000

0.1800

74.2000

48.0000

0.0120

0.1000

0.0100

0.0050

0.5000

0.0092

0.0153

0.0153

1.9000

0.2400

34.0000

0.1800

74.2000

48.0000

0.0120

0.2000

15.0000

1.1500

7.3000

7.4500

689.0000

42.5000

0.0100

0.1000

0.0090

0.0500
48.0000

11.23

18000.000

500.0000

21.14

165.0000

0.0400

0.0020

0.1000

19.8000

5.43

17.9000

30.0000

3.2000

64.0000

0.2300

5.2000

20.0000

6.1400

0.2000

2.1000

18000.000

$500.0000 \quad D G$

15.0000

0.0400

$0.0020 \quad D G$

0.1000

0.0340

0.0100

30.0000

$3.2000^{*}$

0.3500

0.2300

5.2000

0.5000

0.0100

0.2000

$9.55 \quad 51.0000$

8.8000

1.1500

1.1500

2.60

17.0000

3.9000

2.84

17.0000

4.5000

689.0000

689.0000

19.30

78.0000

2.3000

0.03

0.1900

0.0100

0.22

1.1000

0.1000

0.0090

0.0090

0.0500
DG

DG

$O G$

* Særlig usædvanlig værdi, der må kontrolleres. 
Grindsted (55.01)

Stof navn
Trtchlorethylen
$1,1,1-$ trich lorethan
Maphthalen
Phenol

2,3 dimethy lphenol

2-methylpheno?

4-methylphenol

3,4-diwethylphenol

3,5-dimethylphenol

2,6-dimethy 1phenol

2,4-dimethylphenol

4-clor, 2-methylpheno

6-clor, 2-wethyipheno

2,4-dic lorphenol

4,6-diclor, 2-methylp

2,6-diclorphenol

2,4,6-tric lorphenol

2,3,4,6-tetrac lorphe

2,3,5,6-tetrac lorphe

2,3,4,5-tetrac lorphe

Pentrac lorphenol

Dich lorprop

MCPA

Mech lorprop

DNOC

Dinoseb

\begin{tabular}{|c|c|}
\hline Enhed & Antal \\
\hline MYGRAM/L & 1 \\
\hline MYGRAM/L & 1 \\
\hline MYGRAM/L & 1 \\
\hline MYGRAM/L & 1 \\
\hline MYGRAM/L & 1 \\
\hline MYGRAM/L & 1 \\
\hline MYGRAM/L & 1 \\
\hline MYGRAM/L & 1 \\
\hline MYGRAY/L & 1 \\
\hline MYGRAM/L & 1 \\
\hline MYGRAM/L & 1 \\
\hline MYGRAM/L & 1 \\
\hline MYGRAM/L & 1 \\
\hline MYGRAM/L & 1 \\
\hline MYGRAM/L & 1 \\
\hline MYGRAM/L & 1 \\
\hline MYGRAM/L & 1 \\
\hline MYGRAM/L & 1 \\
\hline MYGRAM/L & 1 \\
\hline MYGRAM/L & 1 \\
\hline MYGRAM/L & 1 \\
\hline MYGRAM/L & 1 \\
\hline MYGRAM/L & 1 \\
\hline MYGRAM/L & 1 \\
\hline MYGRAM/L & 1 \\
\hline MYGRAM/L & 1 \\
\hline
\end{tabular}

\section{Ribe Amt}

Grundvandsanalyser, 1990

\begin{tabular}{|c|c|}
\hline 0.0500 & 0.0500 \\
\hline 0.0500 & 0.0500 \\
\hline 0.1000 & 0.1000 \\
\hline 0.0300 & 0.0300 \\
\hline 0.0300 & 0.0300 \\
\hline 0.0300 & 0.0300 \\
\hline 0.0300 & 0.0300 \\
\hline 0.0300 & 0.0300 \\
\hline 0.0300 & 0.0300 \\
\hline 0.0300 & 0.0300 \\
\hline 0.0300 & 0.0300 \\
\hline 0.0500 & 0.0500 \\
\hline 0.0500 & 0.0500 \\
\hline 0.0300 & 0.0300 \\
\hline 0.0300 & 0.0300 \\
\hline 0.0300 & 0.0300 \\
\hline 0.0100 & 0.0100 \\
\hline 0.0100 & 0.0100 \\
\hline 0.0100 & 0.0100 \\
\hline 0.0100 & 0.0100 \\
\hline 0.0200 & 0.0200 \\
\hline $0.1000 *$ & 0.1000 \\
\hline $0.1000 *$ & 0.1000 \\
\hline $0.1000 *$ & 0.1000 \\
\hline $0.0500 *$ & 0.0500 \\
\hline $0.0500 *$ & 0.0500 \\
\hline
\end{tabular}

$\begin{array}{lllll}0.1000 & 0.1000 & . & 0.1000 * & 0.1000 \\ 0.1000 & 0.1000 & . & 0.1000 * & 0.1000 \\ 0.1000 & 0.1000 & . & 0.1000 * & 0.1000 \\ 0.0500 & 0.0500 & . & 0.0500 * & 0.0500 \\ 0.0500 & 0.0500 & . & 0.0500 * & 0.0500\end{array}$

* Særlig usædvanlig værdi, der må kontrolleres. 


\section{Grindsted (55.01)}

\begin{tabular}{|c|c|}
\hline Stof navn & Enhed \\
\hline Kondukt ivitet & MSIEMEMS/N \\
\hline pH & PH \\
\hline Inddampn Ingsrest & $M G / L$ \\
\hline oxygen indhold & $M G / L$ \\
\hline Carbonat & $M G / L$ \\
\hline Carbondioxid, aggr. & $M G / L$ \\
\hline Hydrogencarbonat & $M G / L$ \\
\hline Permanganatta 1 KMnO4 & $M G / L$ \\
\hline Asmon iaktamon ium & $M G / L$ \\
\hline Nitrit & $M G / L$ \\
\hline Nitrat & $M G / L$ \\
\hline Orthophosph.-P04, 111 & $M G / L$ \\
\hline Phosph., tot.filt P04 & MG/L \\
\hline Phosph., tot P04,filt & $M G / L$ \\
\hline Alumin iun & MYGRAM/L \\
\hline Calc 1um & $M G / L$ \\
\hline Chlorid & $M G / L$ \\
\hline Fluorid & $M G / L$ \\
\hline Jern & $M G / L$ \\
\hline Jern Perro & $M G / L$ \\
\hline Kalfum & $M G / L$ \\
\hline Magnestun & $M G / L$ \\
\hline Mangan & $M G / L$ \\
\hline Natrium & $M G / L$ \\
\hline Stlicium & $M G / L$ \\
\hline Silic fund tox td & $\mathrm{MG} / \mathrm{L}$ \\
\hline Sulfat & $M G / L$ \\
\hline Hydrogensulf id & $M G / L$ \\
\hline Methan & $M G / L$ \\
\hline
\end{tabular}

\section{Ribe Amt}

\section{Grundvandsanalyser, 1989}

\begin{tabular}{|c|c|c|c|c|c|}
\hline Antal & Gens & Median & Spredning & Maximum & Min fmum \\
\hline 22 & 30.9727 & 30.4500 & 8.98 & 45.5000 & 10.6000 \\
\hline 28 & $5.4414^{\circ}$ & 5.4950 & 0.44 & 6.7400 & 4.6000 \\
\hline 10 & 357.6000 & 285.5000 & 281.16 & 855.0000 & 84.0000 \\
\hline 17 & 1.9106 & 1.0000 & 2.12 & 9.0000 & 0.4000 \\
\hline 1 & 0.1000 & 0.1000 & . & 0.1000 & 0.1000 \\
\hline 21 & 58.0000 & 55.0000 & 23.85 & 107.0000 & 23.0000 \\
\hline 28 & 17.2786 & 13.0000 & 20.79 & 101.0000 & 1.8000 \\
\hline 22 & 22.6091 & 7.6500 & 43.67 & 156.0000 & 1.0000 \\
\hline 24 & 0.1000 & 0.0235 & 0.20 & 0.9880 & 0.0100 \\
\hline 19 & 0.0372 & 0.0140 & 0.05 & 0.1980 & 0.0050 \\
\hline 27 & 34.7296 & 30.0000 & 35.14 & 135.0000 & 0.5000 \\
\hline 19 & 0.0760 & 0.0491 & 0.09 & 0.4078 & 0.0153 \\
\hline 16 & 0.1127 & 0.0721 & 0.12 & 0.5642 & 0.0399 \\
\hline 18 & 0.1213 & 0.0859 & 0.12 & 0.5642 & 0.0276 \\
\hline 7 & 401.7143 & 318.0000 & 338.19 & 798.0000 & 28.0000 \\
\hline 28 & 24.1179 & 24.2000 & 11.50 & 49.0000 & 2.3000 \\
\hline 28 & 36.1071 & 29.0000 & 19.07 & 91.0000 & 7.0000 \\
\hline 22 & 0.1000 & 0.1000 & 0.00 & 0.1000 & 0.1000 \\
\hline 22 & 3.0524 & 1.3200 & 4.38 & 17.2000 & 0.1980 \\
\hline 34 & 2.8761 & 1.1150 & 3.84 & 15.2000 & 0.0080 \\
\hline 28 & 6.4821 & 4.5000 & 7.28 & 39.0000 & 0.5000 \\
\hline 28 & 4.3107 & 4.0500 & 2.50 & 11.0000 & 0.6000 \\
\hline 37 & 0.4204 & 0.2730 & 0.66 & 4.0900 & 0.0110 \\
\hline 28 & 16.0929 & 15.0000 & 5.55 & 30.0000 & 8.2000 \\
\hline 17 & 6.8176 & 6.7000 & 3.25 & 13.0000 & 1.2000 \\
\hline 18 & 7.7056 & 6.9000 & 3.31 & 14.0000 & 1.2000 \\
\hline 28 & 40.6143 & 43.5000 & 15.92 & 76.0000 & 0.1000 \\
\hline 19 & 0.0226 & 0.0100 & 0.03 & 0.1000 & 0.0100 \\
\hline 17 & 0.1076 & 0.1000 & 0.03 & 0.2300 & 0.1000 \\
\hline
\end{tabular}




\section{Bramming (55.11)}

\begin{tabular}{|c|c|}
\hline Stof navn & Enhed \\
\hline Konduktivitet & MSIEMENS/M \\
\hline $\mathrm{pH}$ & PH \\
\hline Inddampningsrest & $M G / L$ \\
\hline Oxygen indhold & $\mathrm{MG} / \mathrm{L}$ \\
\hline Carbond 10x 1d, aggr. & $M G / L$ \\
\hline Hydrogencarbonat & $M G / L$ \\
\hline Carbon, org, NVOC & $M G / L$ \\
\hline Permanganatta 1 KMnO4 & $M G / L$ \\
\hline Benzen & MYGRAM/L \\
\hline Toluen & MYGRAM/L \\
\hline Ammon ia $k$ tamen fum & $M G / L$ \\
\hline Nitrit & MG/L \\
\hline Nitrat & $M G / L$ \\
\hline Orthophosph..P04, 111 & MG/L \\
\hline Phosph., tot PO4,f11t & $M G / L$ \\
\hline Aluminfum & MYGRAM/L \\
\hline Arsen & MYGRAM/L \\
\hline Barium & MYGRAM/L \\
\hline $81 y$ & MYGRAM/L \\
\hline Bromid & MYGRAM/L \\
\hline Cadmiun & MYGRAM/L \\
\hline Calcium & $M G / L$ \\
\hline $\mathrm{Chlor}$,org, $\mathrm{AOX}$ & MYGRAM/L \\
\hline Chlor, org, vox & MYGRAM/L \\
\hline Chlorid & $M G / L$ \\
\hline Chrom & MYGRAM/L \\
\hline Cyantd & $M G / L$ \\
\hline F luorto & $M G / L$ \\
\hline Jern & $M G / L$ \\
\hline Jern ferro & $M G / L$ \\
\hline Jod & MYGRAM/L \\
\hline Jodid & MYGRAM/L \\
\hline Kalium & $M G / L$ \\
\hline Kobber & MYGRAM/L \\
\hline Kr $1 \mathrm{ks} 8 \mathrm{IV}$ & MAMOGRAM/L \\
\hline Litn tum & MYGRAM/L \\
\hline Magnesium & $\mathrm{MG} / \mathrm{L}$ \\
\hline Mangan & $M G / L$ \\
\hline Molybden & MYGRAM/L \\
\hline Natrium & $M G / L$ \\
\hline NIkke1 & MYGRAM/L \\
\hline Stliciun & $\mathrm{MG} / \mathrm{L}$ \\
\hline Stlic luad tox 10 & MG/L \\
\hline Stront ium & MYGRAM/L \\
\hline Sulfat & $M G / L$ \\
\hline Hydrogensu lf id & $M G / L$ \\
\hline Tritium & T.U. \\
\hline Methan & $M G / L$ \\
\hline Detergenter anion & $M G / L$ \\
\hline Tetrach lorethy len & MYGRAM/L \\
\hline
\end{tabular}

Ribe Amt

Grundvandsanalyser, 1990

\begin{tabular}{|c|c|c|c|c|c|c|}
\hline Anta 1 & Gens & Median & Spredning & Max inum & Min inum & \\
\hline 41 & 43.4390 & 42.0000 & 6.88 & 65.0000 & 32.0000 & \\
\hline 41 & $6.2707^{\circ}$ & 6.4000 & 1.06 & 7.6000 & 4.5000 & \\
\hline 30 & 314.0000 & 280.0000 & 157.01 & 1050.0000 & 190.0000 & \\
\hline 40 & 2.1275 & 0.9000 & 2.75 & 8.5000 & 0.2000 & \\
\hline 29 & 40.7586 & 52.0000 & 25.89 & 80.0000 & 2.0000 & \\
\hline 39 & 104.5256 & 130.0000 & 87.65 & 225.0000 & 1.0000 & \\
\hline 1 & 1400.0000 & 1400.0000 & . & 1400.0000 & 1400.0000 & \\
\hline 41 & 10.6341 & 4.0000 & 29.07 & 190.0000 & 1.0000 & \\
\hline 1 & 0.3000 & 0.3000 & . & 0.3000 & 0.3000 & \\
\hline 1 & & & & 0.1000 & 0.1000 & 06 \\
\hline 41 & 0.1239 & 0.0500 & 0.21 & 0.8300 & 0.0100 & $D G$ \\
\hline 41 & 0.0146 & 0.0100 & 0.01 & 0.0800 & 0.0100 & $D G$ \\
\hline 41 & 22.7805 & 2.0000 & 47.25 & 182.0000 & 2.0000 & \\
\hline 41 & 0.5280 & 0.2453 & 0.47 & 1.3798 & 0.0307 & \\
\hline 41 & 0.5758 & 0.4906 & 0.47 & 1.4411 & 0.0307 & \\
\hline 21 & 187.1333 & 44.0000 & 324.42 & 1520.0000 & 3.9000 & \\
\hline 3 & 0.5367 & 0.5300 & 0.46 & 1.0000 & 0.0800 & \\
\hline 3 & 194.0000 & 230.0000 & 118.19 & 290.0000 & 62.0000 & \\
\hline 3 & 0.2433 & 0.1800 & 0.11 & 0.3700 & 0.1800 & \\
\hline 3 & 58.3333 & 56.0000 & 8.74 & 68.0000 & 51.0000 & \\
\hline 3 & 0.0120 & 0.0120 & 0.00 & 0.0120 & 0.0120 & \\
\hline 41 & 43.5610 & 52.0000 & 14.74 & 64.0000 & 16.0000 & \\
\hline 1 & 14.0000 & 14.0000 & . & 14.0000 & 14.0000 & \\
\hline 1 & & & & 0.5000 & 0.5000 & DG \\
\hline 41 & 32.3415 & 31.0000 & 10.60 & 60.0000 & 20.0000 & \\
\hline 3 & 0.1600 & 0.1600 & 0.12 & 0.2800 & 0.0400 & \\
\hline 3 & & & & 0.0020 & 0.0020 & DG \\
\hline 41 & 0.1432 & 0.1200 & 0.05 & 0.2700 & 0.1000 & \\
\hline 41 & 7.5032 & 6.1100 & 9.82 & 46.2000 & 0.0300 & \\
\hline 41 & 6.0312 & 5.9000 & 6.31 & 23.2000 & 0.0200 & \\
\hline 3 & 10.0667 & 1.6000 & 14.66 & 27.0000 & 1.6000 & \\
\hline 3 & 5.4667 & 4.0000 & 3.44 & 9.4000 & 3.0000 & \\
\hline 41 & 3.7024 & 3.1000 & 2.21 & 11.0000 & 1.4000 & \\
\hline 3 & 0.6467 & 0.2900 & 0.72 & 1.4700 & 0.1800 & \\
\hline 1 & 3.0000 & 3.0000 & . & 3.0000 & 3.0000 & \\
\hline 3 & 7.5667 & 7.9000 & 0.67 & 8.0000 & 6.8000 & \\
\hline 41 & 9.2829 & 9.5000 & 4.49 & 19.0000 & 2.5000 & \\
\hline 41 & 0.4361 & 0.4300 & 0.20 & 0.7600 & 0.0200 & \\
\hline 3 & 0.6633 & 0.5700 & 0.30 & 1.0000 & 0.4200 & \\
\hline 41 & 19.5366 & 18.0000 & 4.81 & 34.0000 & 14.0000 & \\
\hline 3 & 3.7200 & 0.1800 & 6.22 & 10.9000 & 0.0800 & \\
\hline 30 & 9.8467 & 9.7500 & 2.85 & 16.0000 & 5.5000 & \\
\hline 11 & 9.1545 & 9.2000 & 2.44 & 13.0000 & 5.4000 & \\
\hline 3 & 289.3333 & 303.0000 & 87.31 & 369.0000 & 196.0000 & \\
\hline 41 & 54.1707 & 58.0000 & 40.04 & 129.0000 & 7.0000 & \\
\hline 22 & 0.0268 & 0.0100 & 0.04 & 0.1900 & 0.0100 & \\
\hline 4 & 6.7500 & 6.9500 & 4.68 & 11.4000 & 1.7000 & \\
\hline \multirow[t]{3}{*}{17} & 0.1588 & 0.1000 & 0.13 & 0.4500 & 0.1000 & \\
\hline & & & & 0.0070 & 0.0070 & \\
\hline & & & & 0.0500 & 0.0500 & DG \\
\hline
\end{tabular}




\section{Bramming (55.11)}

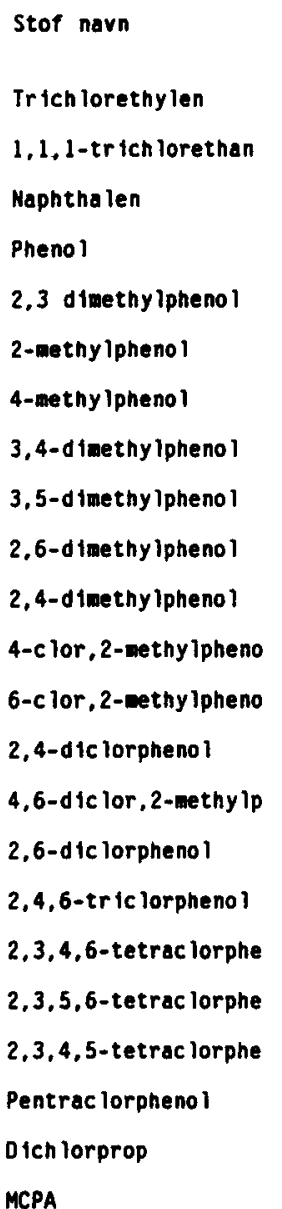

MCPA

Mech lorprop

DNOC

Dinoseb

Atraz in

Simaz in
Enhed

MYGRAM/L

MYGRAM/L

MYGRAM/L

MYGRAM/L

MYGRAM/L

MYGRAM/L

MYGRAM/L

MYGRAM/L

MYGRAM/L

MYGRAM/L

MYGRAM/L

MYGRAM/L

MYGRAM/L

MYGRAM/L

MYGRAM/L

MYGRAM/L

MYGRAM/L

MYGRAM/L

MYGRAM/L

MYGRAM/L

MYGRAM/L

MYGRAM/L

MYGRAM/L

MYGRAM/L

MYGRAM/L

MYGRAM/L

MYGRAM/L

MYGRAM/L
Ribe Amt

Grundvandsanalyser, 1990

Antal Gens Median Spredning Maximum Mintaug

$0.0500 \quad 0.0500 \quad D G$

$0.0500 \quad 0.0500 \quad 06$

$0.1000 \quad 0.1000 \quad D G$

$0.0300 \quad 0.0300 \quad D G$

$0.0300 \quad 0.0300$ DG

0.0300 . 0.0300 DG

$0.0300 \quad 0.0300 \quad D G$

$0.0300 \quad 0.0300 \quad$ DG

$0.0300 \quad 0.0300 \quad D G$

$0.0300 \quad 0.0300 \quad 06$

$0.0300 \quad 0.0300 \quad D G$

$\begin{array}{lll}0.0500 & 0.0500 \quad 06\end{array}$

$0.0500 \quad 0.0500 \quad 0 G$

$0.0300 \quad 0.0300 \quad D G$

$\begin{array}{ll}0.0300 & 0.0300 \quad D G\end{array}$

$0.0300 \quad 0.0300 \quad$ DG

$0.0100 \quad 0.0100 \quad O G$

$0.0100 \quad 0.0100 \quad D G$

$0.0100 \quad 0.0100 \quad O G$

$0.0100 \quad 0.0100 \quad D G$

$0.0200 \quad 0.0200 \quad$ DG

$0.0130 \quad 0.0130 \quad O G$

$0.0100 \quad 0.0100 \quad$ DG

$0.0110 \quad 0.0110$ DG

$0.0100 \quad 0.0100 \quad$ DG

$0.0100 \quad 0.0100 \quad D G$

$0.0100 \quad 0.0100 \quad$ DG

$0.0100 \quad 0.0100 \quad 06$ 
Bramming (55.11)

\begin{tabular}{|c|c|}
\hline Stof navn & Enhed \\
\hline Kondukt ivitet & MSIEMENS/M \\
\hline $\mathrm{pH}$ & PH \\
\hline Inddampn ingsrest & $M G / L$ \\
\hline Oxygen indhold & $M G / L$ \\
\hline Carbond toxtd, agar. & $M G / L$ \\
\hline Hydrogencarbonat & MG/L \\
\hline Permangonatta $1 \mathrm{KMnO4}$ & $\mathrm{MG} / \mathrm{L}$ \\
\hline Ammon lak +amen fum & $M G / L$ \\
\hline N1trit & $M G / L$ \\
\hline Nitrat & $M G / L$ \\
\hline Orthophosph.-PO4.f11 & $M G / L$ \\
\hline Phosph., tot P04,fift & $M G / L$ \\
\hline Calc fum & $M G / L$ \\
\hline Chlorid & $M G / L$ \\
\hline Fiuorid & $M G / L$ \\
\hline Jern & MG/L \\
\hline Jern ferro & $M G / L$ \\
\hline Kallum & $M G / L$ \\
\hline Krikselv & NAMOGRAM/L \\
\hline Magnes ium & $M G / L$ \\
\hline Mangan & $M G / L$ \\
\hline Natrium & $M G / L$ \\
\hline stiletum & $M G / L$ \\
\hline Silic fumdioxid & $M G / L$ \\
\hline Sulfat & $M G / L$ \\
\hline Hydrogensulf id & $M G / L$ \\
\hline Tritium & T.U. \\
\hline Methan & $M G / L$ \\
\hline
\end{tabular}

$M G / L$

\section{Ribe Amt}

\begin{tabular}{|c|c|c|c|c|c|c|}
\hline Antal & Gens & Median & Spredning & Maximun & Minimum & \\
\hline 28 & 41.5714 & 40.0000 & 5.77 & 53.0000 & 31.0000 & \\
\hline 28 & 6.1214 & 6.2500 & 1.12 & 7.6000 & 4.3000 & \\
\hline 1 & 280.0000 & 280.0000 & - & 280.0000 & 280.0000 & \\
\hline 28 & 1.4036 & 0.4000 & 1.92 & 6.7000 & 0.1000 & \\
\hline 27 & 32.4444 & 38.0000 & 29.75 & 92.0000 & 2.0000 & \\
\hline 25 & 104.8640 & 103.0000 & 85.99 & 235.0000 & 1.0000 & \\
\hline 28 & 5.5000 & 4.0000 & 4.48 & 19.0000 & 1.0000 & \\
\hline 28 & 0.1154 & 0.0400 & 0.28 & 1.4000 & 0.0100 & $D G$ \\
\hline 28 & 0.0171 & 0.0100 & 0.02 & 0.0800 & 0.0100 & $D G$ \\
\hline 28 & 16.2857 & 2.0000 & 25.29 & 100.0000 & 2.0000 & \\
\hline 28 & 0.3548 & 0.2146 & 0.36 & 0.9505 & 0.0307 & \\
\hline 28 & 0.3833 & 0.2453 & 0.37 & 1.0425 & 0.0307 & \\
\hline 28 & 40.1071 & 40.5000 & 15.87 & 64.0000 & 19.0000 & \\
\hline 28 & 31.7857 & 32.0000 & 10.07 & 59.0000 & 20.0000 & \\
\hline 28 & 0.1796 & 0.1750 & 0.07 & 0.3800 & 0.0800 & \\
\hline 28 & 5.6904 & 5.9500 & 5.77 & 21.5000 & 0.0200 & \\
\hline 28 & 5.5325 & 5.0000 & 5.98 & 21.5000 & 0.0200 & \\
\hline 28 & 3.6500 & 2.9500 & 2.10 & 8.9000 & 1.4000 & \\
\hline 2 & 3.5000 & 3.5000 & 0.71 & 4.0000 & 3.0000 & DG \\
\hline 28 & 9.8750 & 10.9000 & 4.72 & 18.0000 & 3.2000 & \\
\hline 28 & 0.5189 & 0.4600 & 0.19 & 0.8800 & 0.1600 & \\
\hline 28 & 20.6071 & 18.5000 & 6.07 & 43.0000 & 14.0000 & \\
\hline 1 & 9.3000 & 9.3000 & • & 9.3000 & 9.3000 & \\
\hline 27 & 8.9370 & 8.9000 & 2.61 & 14.0000 & 5.0000 & \\
\hline 28 & 58.3214 & 60.5000 & 39.27 & 124.0000 & 5.0000 & \\
\hline 28 & 0.0121 & 0.0100 & 0.00 & 0.0300 & 0.0100 & \\
\hline 1 & 1.0000 & 1.0000 & $\cdot$ & 1.0000 & 1.0000 & \\
\hline 28 & 0.2329 & 0.1000 & 0.64 & 3.5000 & 0.1000 & \\
\hline
\end{tabular}

\section{Grundvandsanalyser, 1989}

0.2329

0.1000

3.5000

0.1000 
Ølgod (55.12)

Kondukt ivitet

MSIEMENS/M

$\mathrm{pH}$

$\mathrm{PH}$

Inddampn Ingsrest

MG/L

Oxygen indhold

$M G / L$

Carbondioxid, aggr.

MG/L

Hyorogencorbonat

MG/L

Carbon, org, HVOC

MG/L

Permanganatta 1 KMnO4

MG/L

Benzen

Toluen

Ammon tak tackon ium

Nitrit

Nitrat

Orthophosph.-P04,f11

Phosph., tot.filt PO4

Phosph., tot P04.Pllt

Aluniniun

Arsen

Barium

Bly

Bor

Bromid

Cadm 1um

Calcium

Ch lor, org, AOX

Ch lor,org, vox

chlorio

Chrom

Cyonido

Fluorid

Jern

Jern ferro

Jod

Jodid

Kallum

Kobber

Lith tum

Magnesiur

Mangan

Molybdan

Natr Ium

Nikke?

silictue

sille iund fox id

Stront ium

Sulfat

Hydrogensulf id

Methan

Detergenter anton

Chloroform

MYGRAM/L

MYGRAM/L

MG/L

MG/L

MG/L

MG/L

$M 6 / L$

$M G / L$

MYGRAM/L

MYGRAM/L

MYGRAM/L

MYGRAM/L

MYGRAM/L

MYGRAM/L

MYGRAM/L

MG/L

MYGRAM/L

MYGRAM/L

MG/L

MYGRAM/L

MG/L

MG/L

MG/L

MG/L

MYGRAM/L

MYGRAM/L

MG/L

MYGRAM/L

MYGRAM/L

H6/L

MG/L

MYGRAM/L

MG/L

MYGRAM/L

MG/L

MG/L

MYGRAM/L

$M G / L$

MG/L

MG/L

$\mathrm{MG} / \mathrm{L}$

MYGRAM/L
Ribe Amt

Grundvandsanalyser, 1990
Gens

Median

43.8024

43.6000

6.5795

6.8100

268.2813

260.0000

3.3703

1.2150

22.6158

17.0000

124.7439

127.0000

770.0000

770.0000

3.0293

2.4000

Spredning

Maximum

20.3000

5.1500

$65.92 \quad 449.0000$

$3.53 \quad 13.1000$

$23.81 \quad 90.0000$

$91.50 \quad 278.0000$

770.0000

9.0000

0.3000

0.1000

0.1520

4.9000

$0.2700 \quad 0.0080$

0.03

0.98

127.0000

40.44

0.6623

0.2053

0.0889

0.22

0.7390

0.7298

0.3782

0.24

0.26

131.0000

4.5000

0.81

4.5000

136.6667

4.5000

120.0000

56.86

0.1800

0.1800

0.1800

0.00

45.2000

14.14

78.0000

0.0120

88.0000

49.6293

47.0000

23.55

4.2000

0.5000

28.0000

29.30

128.0000

0.1100

0.0020

0.2600

0.06

13.8000

3.83

3.74

11.5000

1.6000

7.8000

2.74

3.02

20.0000

2.1780

1.3000

0.1967

0.1800

7.3333

7.2000

5.2927

2.9000

0.2028

0.1880

0.4700

0.4900

23.3171

20.0000

0.6167

0.1300

17.2531

17.0000

19.1412

19.0000

284.0000

277.0000

26.6098

25.0000

0.0151

0.0100

0.1123

0.1000

0.0060

0.0060

147.0000

0.3000

1.0000

4.4000

770.0000

1.0000

0.5000

0.0061

0.0153

0.0399

1.8000

3.1000

90.0000

0.1800

25.2000

43.0000

7.6000

4.2000

13.0000

0.0400

0.0020

0.0100

0.0200

0.0180

1.6000

3.0000

0.6000

0.1800

5.8000

0.7000

0.0020

0.4000

13.0000

0.0800
$11.61 \quad 77.0000$

$0.78 \quad 7.8200$
0.03

0.2300

1.60

6.98

0.16

0.06

8.30

0.89

6.17

5.24

114.66

12.31

0.01

0.02

9.0000

27.0000

0.5400

0.5200

52.0000

1.6400

33.0000

27.0000

402.0000

55.0000

0.0400

0.1700

0.0060

0.0500
0.3000 DG

$0.1000 \quad D G$

0.0100 DG

$0.0050 \quad D G$

0.0120 DG

$0.5000 \quad D G$ 
Ølgod (55.12)

Stof navn

Enhed

Tetrach lorku Istof

MYGRAM/L

Tetrach lorethylen

Trich lorethylen

1,1,1-trich lorethan

Maphtha len

Phenol

2-wethy lphenol

3,4-d tmethylpheno 1

3,5-dimethy Iphenol

2,6-d 1 methy Iphenol

2,4-dimethyipheno I

4-clor, 2-methy ipheno

6-clor, 2-methy lpheno

2,4-dic lorphenol

4,6-dtc lor, 2-methylp

2,6-dic lorpheno 1

2,4,6-tric lorpheno 1

2,3,4,6-tetrac lorphe

2,3,5,6-te troc lorphe

2,3,4,5-tetrac lorphe

Pentrac lorphenol

D tch lorprop

MCPA

Mech lorprop

DNOC

Dinoseb

Atrazin

Simazin

MYGRAM/L

MYGRAM/L

MYGRAM/L

MYGRAM/L

MYGRAM/L

MYGRAM/L

MYGRAM/L

MYGRAM/L

MYGRAM/L

MYGRAM/L

MYGRAM/L

MYGRAM/L

MYGRAM/L

MYGRAM/L

MYGRAM/L

MYGRAM/L

MYGRAM/L

MYGRAM/L

MYGRAM/L

MYGRAM/L

MYGRAM/L

MYGRAM/L

MYGRAM/L

MYGRAM/L

MYGRAM/L

MYGRAM/L

MYGRAM/L
Ribe Amt

Antal Gens
Grundvandsanalyser, 1990

Median Spredning

Maximum

Min imum.

$0.0500 \quad 0.0500 \quad 06$

$0.0500 \quad 0.0500 \quad$ DG

$0.0500 \quad 0.0500 \quad D G$

$0.0500 \quad 0.0500 \quad D G$

$0.1000 \quad 0.1000 \quad D G$

$0.0300 \quad 0.0300 \quad D G$

$0.0300 \quad 0.0300 \quad O G$

$0.0300 \quad 0.0300 \quad D G$

$0.0300 \quad 0.0300 \quad D G$

$0.0300 \quad 0.0300 \quad D G$

$0.0300 \quad 0.0300 \quad 06$

$0.0500 \quad 0.0500 \quad D G$

$0.0500 \quad 0.0500 \quad D G$

$0.0300 \quad 0.0300 \quad D G$

$0.0300 \quad 0.0300 \quad D G$

$0.0300 \quad 0.0300 \quad D G$

$0.0100 \quad 0.0100 \quad D G$

$0.0100 \quad 0.0100 \quad 0 G$

$0.0100 \quad 0.0100 \quad 06$

$0.0100 \quad 0.0100 \quad 06$

$0.0200 \quad 0.0200 \quad D G$

$0.0130 \quad 0.0130 \quad D G$

$0.0100 \quad 0.0100 \quad D G$

$0.0110 \quad 0.0110 \quad D G$

$0.0100 \quad 0.0100 \quad D G$

$0.0100 \quad 0.0100 \quad D G$

$0.0100 \quad 0.0100 \quad D G$

$0.0100 \quad 0.0100 \quad D G$ 
Ølgod (55.12)

\begin{tabular}{|c|c|}
\hline Stof navn & Enhed \\
\hline Kondukt Ivitet & MSIEMENS/M \\
\hline pH & PH \\
\hline Inddampn ingsrest & $M G / L$ \\
\hline Oxygen indhold & $M G / L$ \\
\hline Carbond loxid, agor. & $M G / L$ \\
\hline Hydrogencarbonat & $M G / L$ \\
\hline Permanganatta $1 \mathrm{KMnO4}$ & $M G / L$ \\
\hline Amanon 1ak+areon 1um & $M G / L$ \\
\hline Nitrit & $M G / L$ \\
\hline Nitrat & $M G / L$ \\
\hline Orthophosph. -P04, ft1 & $M G / L$ \\
\hline Phosph., tot.filt P04 & $M G / L$ \\
\hline Phosph., tot PO4, filt & $M G / L$ \\
\hline Alumin in tue & MYGRAM/L \\
\hline Calc tua & $M G / L$ \\
\hline Chlor1d & $\mathrm{MG} / \mathrm{L}$ \\
\hline Fluor 10 & $M G / L$ \\
\hline Jern & $M G / L$ \\
\hline Jern ferro & $M G / L$ \\
\hline Karlium & $M G / L$ \\
\hline Kvikselv & MAMOGRAM/L \\
\hline Magnes lum & $M G / L$ \\
\hline Mangan & $M G / L$ \\
\hline Natrium & $M G / L$ \\
\hline silfeium & $\mathbf{M G} / \mathbf{L}$ \\
\hline Silfe iuad tox id & $M G / L$ \\
\hline Sulfat & $M G / L$ \\
\hline Hydrogensulf id & $M G / L$ \\
\hline Tritium & T.U. \\
\hline Methan & $M G / L$ \\
\hline
\end{tabular}

Ribe Amt

\begin{tabular}{|c|c|c|c|c|c|}
\hline Anta 1 & Gens & Median & Spredning & Maxinum & Min 1mum \\
\hline 28 & 40.8214 & 41.6500 & 12.37 & 74.0000 & 18.7000 \\
\hline 28 & $6.4507^{\circ}$ & 6.5100 & 0.73 & 7.5000 & 5.1200 \\
\hline 6 & 276.0000 & 312.5000 & 81.80 & 328.0000 & 117.0000 \\
\hline 28 & 3.6082 & 2.7000 & 3.50 & 11.2000 & 0.3000 \\
\hline 26 & 24.6923 & 21.0000 & 22.76 & 79.0000 & 1.0000 \\
\hline 28 & 109.3357 & 91.0000 & 87.43 & 277.0000 & 5.5000 \\
\hline 28 & 3.6500 & 2.6500 & 2.80 & 9.4000 & 0.1000 \\
\hline 28 & 0.0329 & 0.0205 & 0.03 & 0.0970 & 0.0100 \\
\hline 28 & 0.2020 & 0.0085 & 0.56 & 2.3300 & 0.0050 \\
\hline 28 & 28.5821 & 17.5000 & 37.60 & 129.0000 & 0.5000 \\
\hline 28 & 0.1741 & 0.0383 & 0.24 & 0.7911 & 0.0153 \\
\hline 6 & 0.3879 & 0.3526 & 0.27 & 0.7543 & 0.1012 \\
\hline 28 & 0.2589 & 0.0981 & 0.30 & 0.9260 & 0.0153 \\
\hline 2 & 101.0000 & 101.0000 & 76.37 & 155.0000 & 47.0000 \\
\hline 28 & 44.0429 & 42.0000 & 25.37 & 84.0000 & 8.0000 \\
\hline 28 & 38.0714 & 28.5000 & 22.41 & 125.0000 & 22.0000 \\
\hline 28 & 0.1361 & 0.1100 & 0.05 & 0.2600 & 0.1000 \\
\hline 28 & 3.8110 & 1.9750 & 4.33 & 13.2000 & 0.0200 \\
\hline 32 & 2.1521 & 0.3190 & 3.43 & 11.0000 & 0.0050 \\
\hline 28 & 1.6857 & 1.2500 & 0.81 & 3.2000 & 0.7000 \\
\hline 3 & 4.0000 & 3.0000 & 1.73 & 6.0000 & 3.0000 \\
\hline 28 & 5.2750 & 2.4500 & 7.23 & 30.0000 & 0.6000 \\
\hline 33 & 0.1618 & 0.1540 & 0.14 & 0.4450 & 0.0050 \\
\hline 28 & 21.3571 & 19.5000 & 5.32 & 39.0000 & 15.0000 \\
\hline 6 & 18.8833 & 18.0000 & 7.08 & 28.0000 & 8.3000 \\
\hline 28 & 17.8464 & 18.5000 & 5.98 & 28.0000 & 7.9000 \\
\hline 28 & 26.3571 & 25.0000 & 11.84 & 57.0000 & 11.0000 \\
\hline 27 & 0.0407 & 0.0100 & 0.07 & 0.2000 & 0.0100 \\
\hline 3 & 4.5333 & 4.6000 & 3.20 & 7.7000 & 1.3000 \\
\hline 27 & 0.1178 & 0.1000 & 0.04 & 0.2000 & 0.1000 \\
\hline
\end{tabular}

\section{Grundvandsanalyser, 1989}

G

DG


Forumlund (55.13)

\begin{tabular}{|c|c|}
\hline Stof navn & Enhed \\
\hline Kondukt ivitet & MSIEMENS/M \\
\hline PH & PH \\
\hline oxygen indhold & $M G / L$ \\
\hline Carbond $10 \times 1 d$, aggr. & $M G / L$ \\
\hline Hydrogencarbonat & $M G / L$ \\
\hline Carbon, org, nvoC & $M G / L$ \\
\hline Perwanganatta $1 \mathrm{KMnO4}$ & $M G / L$ \\
\hline Benzen & MYGRAM/L \\
\hline Toluen & MYGRAM/L \\
\hline Ammon lak taminon fum & MG/L \\
\hline Nitrit & $M G / L$ \\
\hline Nitrat & $M G / L$ \\
\hline Orthophosph.-P04,fil & $M G / L$ \\
\hline Phosph., tot P04.f11t & $M G / L$ \\
\hline Aluminium & MYGRAM/L \\
\hline Arsen & MYGRAM/L \\
\hline Barium & MYGRAM/L \\
\hline $81 y$ & MYGRAM/L \\
\hline Bor & MYGRAM/L \\
\hline Bromid & MYGRAM/L \\
\hline Cadm Ium & MYGRAM/L \\
\hline Calcium & $M G / L$ \\
\hline Chlor,org, AOX & MYGRAM/L \\
\hline Chlor, org, vox & MYGRAM/L \\
\hline Chlorid & $M G / L$ \\
\hline Chrom & MYGRAM/L \\
\hline Cyanid & $M G / L$ \\
\hline Fluorta & $M G / L$ \\
\hline Jern & $M G / L$ \\
\hline Jern Perro & $M G / L$ \\
\hline Jod & MYGRAM/L \\
\hline Jodtd & MYGRAM/L \\
\hline Kal lum & $M G / L$ \\
\hline Kobber & MYGRAM/L \\
\hline Kriksolv & MANOGRAM/L \\
\hline Lith fum & MYGRAM/L \\
\hline Magnes Ium & $M G / L$ \\
\hline Mangan & $M G / L$ \\
\hline Molybdan & MYGRAM/L \\
\hline Matrium & $M G / L$ \\
\hline Nikke I & MYGRAM/L \\
\hline Stlic tumd tox td & $M G / L$ \\
\hline Stront fum & MYGRAM/L \\
\hline Sulfat & $M G / L$ \\
\hline Hydrogensulf to & $M G / L$ \\
\hline Tritiun & T.U. \\
\hline Methan & $M G / L$ \\
\hline Detergenter anion & $M G / L$ \\
\hline Chlorof orm & MYGRAM/L \\
\hline Tetrach lorethylen & MYGRAM/L \\
\hline
\end{tabular}

Ribe Amt

\section{Grundvandsanalyser, 1990}

\begin{tabular}{|c|c|c|c|c|c|}
\hline Anta 1 & Gens & Median & Spredning & Maximum & Mtn imum \\
\hline 44 & 27.8977 & 22.7500 & 12.07 & 68.4000 & 12.7000 \\
\hline 44 & $5.3714^{\circ}$ & 5.3450 & 0.42 & 6.4700 & 4.6700 \\
\hline 41 & 7.8420 & 8.8500 & 3.28 & 11.6000 & 0.4000 \\
\hline 44 & 46.4773 & 38.0000 & 21.91 & 97.0000 & 20.0000 \\
\hline 44 & 10.3568 & 6.0000 & 10.71 & 45.0000 & 1.2000 \\
\hline 2 & 680.0000 & 680.0000 & 98.99 & 750.0000 & 610.0000 \\
\hline 44 & 2.2818 & 2.0300 & 1.37 & 6.4000 & 0.2800 \\
\hline 2 & & & & 0.3000 & 0.3000 \\
\hline 2 & & & & 0.1000 & 0.1000 \\
\hline 44 & 0.0154 & 0.0085 & 0.01 & 0.0470 & 0.0050 \\
\hline 44 & 0.0056 & 0.0050 & 0.00 & 0.0320 & 0.0050 \\
\hline 44 & 29.5150 & 17.0000 & 32.40 & 107.0000 & 0.0700 \\
\hline 44 & 0.0817 & 0.0092 & 0.21 & 0.7666 & 0.0061 \\
\hline 44 & 0.1088 & 0.0353 & 0.23 & 0.8892 & 0.0061 \\
\hline 39 & 192.9995 & 83.0000 & 303.55 & 1270.0000 & 1.8000 \\
\hline 4 & 0.3500 & 0.1100 & 0.50 & 1.1000 & 0.0800 \\
\hline 4 & 205.0000 & 156.5000 & 194.90 & 470.0000 & 37.0000 \\
\hline 4 & 0.2550 & 0.1800 & 0.15 & 0.4800 & 0.1800 \\
\hline 1 & 25.0000 & 25.0000 & . & 25.0000 & 25.0000 \\
\hline 4 & 151.5000 & 146.5000 & 45.51 & 207.0000 & 106.0000 \\
\hline 4 & 0.1578 & 0.1355 & 0.15 & 0.3480 & 0.0120 \\
\hline 44 & 8.6523 & 7.9500 & 5.08 & 18.0000 & 1.5000 \\
\hline 2 & 6.5500 & 6.5500 & 1.91 & 7.9000 & 5.2000 \\
\hline 2 & 0.7500 & 0.7500 & 0.35 & 1.0000 & 0.5000 \\
\hline 44 & 49.0682 & 36.5000 & 39.52 & 208.0000 & 19.0000 \\
\hline 4 & 0.6975 & 0.5850 & 0.64 & 1.5800 & 0.0400 \\
\hline 4 & & & & 0.0020 & 0.0020 \\
\hline 20 & 0.1000 & 0.1000 & 0.00 & 0.1000 & 0.1000 \\
\hline 44 & 0.6753 & 0.2740 & 1.30 & 7.9000 & 0.0180 \\
\hline 44 & 0.2646 & 0.0240 & 1.15 & 7.5000 & 0.0010 \\
\hline 4 & 57.0000 & 33.5000 & 66.02 & 151.0000 & 10.0000 \\
\hline 4 & 5.0500 & 4.2500 & 2.53 & 8.7000 & 3.0000 \\
\hline 44 & 2.5500 & 1.9000 & 1.55 & 6.5000 & 1.1000 \\
\hline 4 & 0.3075 & 0.2300 & 0.19 & 0.5900 & 0.1800 \\
\hline 4 & 44.7500 & 31.0000 & 53.18 & 114.0000 & 3.0000 \\
\hline 4 & 2.4000 & 1.8000 & 1.57 & 4.7000 & 1.3000 \\
\hline 44 & 8.5500 & 5.8000 & 6.02 & 22.0000 & 1.8000 \\
\hline 44 & 0.0475 & 0.0340 & 0.05 & 0.2370 & 0.0050 \\
\hline 4 & 0.2300 & 0.2000 & 0.06 & 0.3200 & 0.2000 \\
\hline 44 & 27.2045 & 23.0000 & 20.53 & 104.0000 & 10.0000 \\
\hline 4 & 4.1600 & 4.6450 & 2.96 & 7.1600 & 0.1900 \\
\hline 33 & 8.6152 & 8.4000 & 1.98 & 14.0000 & 5.7000 \\
\hline 4 & 99.5000 & 68.5000 & 77.13 & 214.0000 & 47.0000 \\
\hline 44 & 18.7841 & 18.0000 & 7.63 & 40.0000 & 8.6000 \\
\hline 18 & 0.0283 & 0.0200 & 0.02 & 0.1200 & 0.0200 \\
\hline 3 & 15.2333 & 20.1000 & 12.44 & 24.5000 & 1.1000 \\
\hline 18 & 0.0422 & 0.0200 & 0.08 & 0.3800 & 0.0200 \\
\hline 2 & 0.0040 & 0.0040 & 0.00 & 0.0050 & 0.0030 \\
\hline 22 & 0.3736 & 0.1650 & 0.40 & 1.2800 & 0.0500 \\
\hline 2 & & & & 0.0500 & 0.0500 \\
\hline
\end{tabular}




\section{Forumlund (55.13)}

Ribe Amt

Stof navn
Trich lorethylen
$1,1,1-$ trich lorethan
Naphthalen
Phenol

2,3 dimethy lphenol

2-methy lpheno 1

4-wethy lphenol

3,4-diwethy lpheno 1

3,5-dimethy ipheno 1

2,6-diwe thy lpheno 1

2,4-dimethy ipheno 1

4-clor, 2-wethy lpheno

6-clor, 2-sethy lpheno

2,4-dic lorpheno 1

4,6-dic lor, 2-methylp

2,6-diclorphenol

2,4,6-tric lorphenol

2,3,4,6-tetrac lorphe

$2,3,5,6$-tetrac lorphe

2,3,4,5-tetrac lorphe

Pentrac lorpheno 1

Dich lorprop

MCPA

Mech lorprop

DNOC

Oinoseb

Atrazin

Simaz in

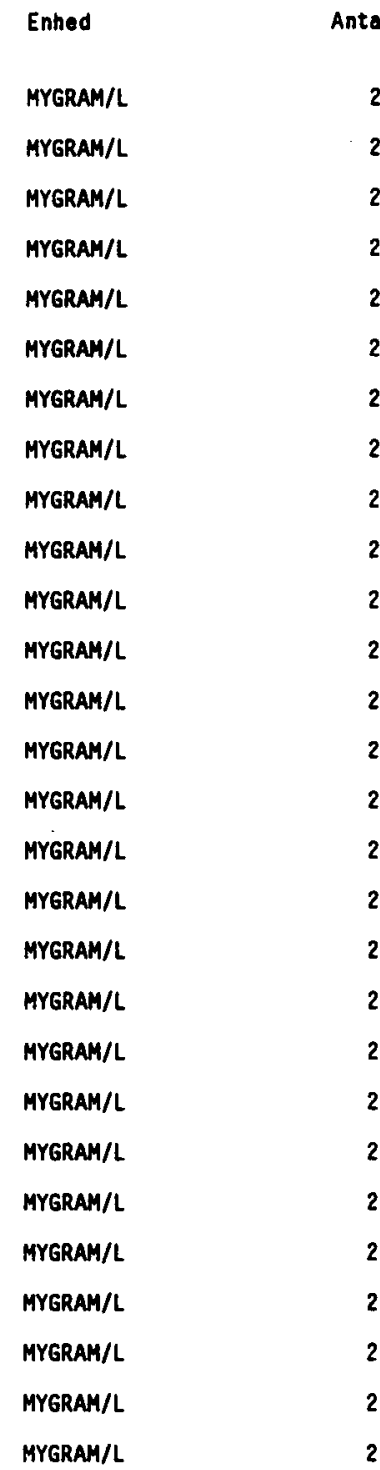

\section{Grundvandsanalyser, 1990}

\begin{tabular}{|c|c|c|}
\hline Median Spredning & Maxinum & Min 1mua \\
\hline & 0.0500 & 0.0500 \\
\hline & 0.0500 & 0.0500 \\
\hline & 0.1000 & 0.1000 \\
\hline & 0.0300 & 0.0300 \\
\hline & 0.0300 & 0.0300 \\
\hline & 0.0300 & 0.0300 \\
\hline & 0.0300 & 0.0300 \\
\hline & 0.0300 & 0.0300 \\
\hline & 0.0300 & 0.0300 \\
\hline & 0.0300 & 0.0300 \\
\hline & 0.0300 & 0.0300 \\
\hline & 0.0500 & 0.0500 \\
\hline & 0.0500 & 0.0500 \\
\hline & 0.0300 & 0.0300 \\
\hline & 0.0300 & 0.0300 \\
\hline & 0.0300 & 0.0300 \\
\hline & 0.0100 & 0.0100 \\
\hline & 0.0100 & 0.0100 \\
\hline & 0.0100 & 0.0100 \\
\hline & 0.0100 & 0.0100 \\
\hline & 0.0200 & 0.0200 \\
\hline & 0.0130 & 0.0130 \\
\hline & 0.0100 & 0.0100 \\
\hline & 0.0110 & 0.0110 \\
\hline & 0.0100 & 0.0100 \\
\hline & 0.0100 & 0.0100 \\
\hline & 0.0100 & 0.0100 \\
\hline & 0.0100 & 0.0100 \\
\hline
\end{tabular}


Forumlund (55.13)

Ribe Amt

\begin{tabular}{|c|c|}
\hline Stof navn & Enhed \\
\hline Kondukt ivitet & MSIEMENS/M \\
\hline pH & PH \\
\hline Oxygen Indhold & $M G / L$ \\
\hline Carbondioxid, aggr. & $M G / L$ \\
\hline Hydrogencarbonat & $M G / L$ \\
\hline Permenganattal KMnO4 & $M G / L$ \\
\hline Ammon iak tabenon ium & $M G / L$ \\
\hline Nitrit & $M G / L$ \\
\hline Nitrat & $M G / L$ \\
\hline Orthophosph. -PO4, $\mathrm{f} 11$ & $M G / L$ \\
\hline Phosph., tot P04,f1\}t & $M G / L$ \\
\hline A lumin fum & MYGRAM/L \\
\hline Calcium & $M G / L$ \\
\hline Chlorid & $M G / L$ \\
\hline Fluorid & $M G / L$ \\
\hline Jern & $M G / L$ \\
\hline Jern ferro & $M G / L$ \\
\hline Kallum & $M G / L$ \\
\hline Magnes ium & $M G / L$ \\
\hline Mangan & $M G / L$ \\
\hline Natriun & $\mathrm{HG} / \mathrm{L}$ \\
\hline Stiliciund toxid & $M G / L$ \\
\hline Sulfot & $M G / L$ \\
\hline Hydrogensulf id & MG $/ \mathrm{L}$ \\
\hline Trittum & T.U. \\
\hline Methan & $M G / L$ \\
\hline
\end{tabular}

Grundvandsanalyser, 1989

\begin{tabular}{|c|c|c|c|c|c|}
\hline Anta 1 & Gens & Median & Spredning & Maxinum & Min 1mum \\
\hline 23 & 30.0565 & 24.0000 & 14.95 & 73.0000 & 13.0000 \\
\hline 23 & 5.1813 & 5.1700 & 0.27 & 5.6700 & 4.7400 \\
\hline 24 & 9.1646 & 9.6000 & 1.65 & 11.6000 & 5.5800 \\
\hline 22 & 45.1364 & 36.5000 & 22.03 & 106.0000 & 26.0000 \\
\hline 24 & 5.2854 & 5.2000 & 1.50 & 8.5000 & 3.0000 \\
\hline 24 & 2.6879 & 2.2000 & 1.60 & 6.0000 . & 0.5400 \\
\hline 24 & 0.0121 & 0.0080 & 0.01 & 0.0430 & 0.0050 \\
\hline 24 & 0.0048 & 0.0050 & 0.00 & 0.0050 & 0.0030 \\
\hline 24 & 41.8058 & 32.0000 & 36.23 & 114.0000 & 0.6400 \\
\hline 24 & 0.0519 & 0.0307 & 0.12 & 0.6132 & 0.0153 \\
\hline 24 & 0.0525 & 0.0092 & 0.08 & 0.3679 & 0.0092 \\
\hline 1 & 1400.0000 & 1400.0000 & . & 1400.0000 & 1400.0000 \\
\hline 24 & 10.9833 & 12.5000 & 6.72 & 24.0000 & 2.7000 \\
\hline 24 & 56.4583 & 40.0000 & 48.71 & 210.0000 & 23.0000 \\
\hline 24 & 0.1000 & 0.1000 & 0.00 & 0.1000 & 0.1000 \\
\hline 24 & 0.8258 & 0.4000 & 1.10 & 4.1000 & 0.0100 \\
\hline 24 & 0.0437 & 0.0200 & 0.07 & 0.3300 & 0.0050 \\
\hline 24 & 3.1500 & 2.4500 & 1.90 & 8.1000 & 1.1000 \\
\hline 24 & 10.5208 & 8.6500 & 5.24 & 22.0000 & 4.6000 \\
\hline 24 & 0.0492 & 0.0370 & 0.04 & 0.1700 & 0.0030 \\
\hline 24 & 29.1667 & 25.0000 & 22.11 & 98.0000 & 11.0000 \\
\hline 24 & 8.6917 & 8.1000 & 2.04 & 14.0000 & 5.6000 \\
\hline 24 & 18.0917 & 16.5000 & 8.37 & 37.0000 & 7.4000 \\
\hline 22 & 0.0380 & 0.0200 & 0.09 & 0.4300 & 0.0020 \\
\hline 7 & 18.5714 & 18.0000 & 2.88 & 23.0000 & 14.0000 \\
\hline 23 & 0.0177 & 0.0200 & 0.01 & 0.0200 & 0.0020 \\
\hline 12 & 161.4575 & 0.5150 & 366.04 & $1270.0000 *$ & 0.0200 \\
\hline
\end{tabular}

* Særlig usædvanlig værdi, der må kontrolleres. 
Vorbasse (55.14)

\begin{tabular}{|c|c|c|c|c|c|c|c|c|}
\hline Stof navn & Enhed & Antal & Gens & Median & Spredning & Maximum & Min faum & \\
\hline Kondukt Ivitet & MSIEMENS/M & 24 & 28.2417 & 25.0500 & 12.18 & 51.0000 & 13.9000 & \\
\hline pH & PH & 24 & 6.3288 & 6.4300 & 0.68 & 7.1300 & 4.8900 & \\
\hline Inddampn ingsrest & $M G / L$ & 19 & 204.3158 & 210.0000 & 69.22 & 330.0000 & 114.0000 & \\
\hline Oxygen tndhold & $M G / L$ & 24 & 8.3800 & 9.1450 & 3.08 & 12.2000 & 1.2800 & \\
\hline Carbondioxid, agar. & $M G / L$ & 24 & 34.8750 & 25.0000 & 35.41 & 129.0000 & 1.0000 & \\
\hline Hydrogencarbonat & $M G / L$ & 24 & 52.5417 & 34.0000 & 45.78 & 142.0000 & 5.7000 & \\
\hline Carbon, org, nVOC & $M G / L$ & 1 & 290.0000 & 290.0000 & . & 290.0000 & 290.0000 & \\
\hline Permanganattal KMnO4 & $M G / L$ & 24 & 2.0125 & 1.3500 & 1.22 & 4.8000 & 1.0000 & \\
\hline Benzen & MYGRAM/L & 1 & 0.3000 & 0.3000 & . & 0.3000 & 0.3000 & \\
\hline Toluen & MYGRAM/L & 1 & 0.1000 & 0.1000 & . & 0.1000 & 0.1000 & \\
\hline Ammon tak +aman fum & $M G / L$ & 24 & 0.0272 & 0.0120 & 0.04 & 0.1790 & 0.0100 & \\
\hline Nitrit & $M G / L$ & 24 & 0.0380 & 0.0050 & 0.08 & 0.2850 & 0.0050 & \\
\hline Nitrat & $M G / L$ & 24 & 24.8458 & 25.5000 & 12.20 & 51.0000 & 8.0000 & \\
\hline Orthophosph..P04, 111 & $M G / L$ & 24 & 0.0703 & 0.0613 & 0.04 & 0.1502 & 0.0153 & \\
\hline Phosph.,tot.f11t P04 & $M G / L$ & 21 & 0.1355 & 0.1349 & 0.08 & 0.3434 & 0.0307 & \\
\hline Phosph., tot P04, f 11t & $M G / L$ & 6 & 0.1410 & 0.1395 & 0.04 & 0.1993 & 0.0797 & \\
\hline Alumintua & MYGRAM/L & 13 & 501.0769 & 10.0000 & 1237.92 & 4180.0000 & 4.0000 & \\
\hline Calcium & MG/L & 24 & 31.8792 & 25.0000 & 18.49 & 64.0000 & 7.7000 & \\
\hline Chlor, org, AOX & MYGRAM/L & 1 & 2.8000 & 2.8000 & . & 2.8000 & 2.8000 & \\
\hline Chlor, org, vox & MYGRAM/L & 1 & & & & 0.5000 & 0.5000 & DG \\
\hline Chlorid & $M 6 / L$ & 24 & 20.3333 & 19.0000 & 5.24 & 31.0000 & 13.0000 & \\
\hline Fluor 1d & $M G / L$ & 12 & 0.0947 & 0.1000 & 0.03 & 0.1160 & 0.0100 & \\
\hline Jern & $M G / L$ & 24 & 1.0712 & 0.3625 & 1.49 & 6.6000 & 0.0620 & \\
\hline Jern ferro & $M G / L$ & 27 & 0.0941 & 0.0200 & 0.36 & 1.9100 & 0.0200 & \\
\hline Kallium & $M G / L$ & 24 & 2.0917 & 1.6000 & 1.23 & 5.0000 & 1.2000 & \\
\hline Magnesium & $M G / L$ & 24 & 4.2917 & 4.3000 & 0.92 & 5.9000 & 2.5000 & \\
\hline Mangan & $M G / L$ & 26 & 0.1499 & 0.0170 & 0.33 & 1.1670 & 0.0020 & \\
\hline Natrium & $M G / L$ & 24 & 14.3333 & 11.0000 & 8.61 & 35.0000 & 6.6000 & \\
\hline Silicium & $M G / L$ & 19 & 10.5000 & 11.0000 & 1.09 & 12.0000 & 7.9000 & \\
\hline silfciund tox to & $M G / L$ & 6 & 10.4000 & 10.5000 & 1.19 & 12.0000 & 8.6000 & \\
\hline Sulfat & $M G / L$ & 24 & 34.5000 & 29.0000 & 11.80 & 61.0000 & 22.0000 & \\
\hline Hydrogensulf id & $M G / L$ & 12 & 0.0145 & 0.0100 & 0.01 & 0.0400 & 0.0010 & \\
\hline Methan & MG/L & 6 & 0.1000 & 0.1000 & 0.00 & 0.1000 & 0.1000 & \\
\hline Tetrach lorethy len & MYGRAM/L & 1 & & & & 0.0500 & 0.0500 & OG \\
\hline Trien lorethylen & MYGRAM/L & 1 & & & & 0.0500 & 0.0500 & DG \\
\hline 1,1,1-trich lorethan & MYGRAM/L & 1 & & & & 0.0500 & 0.0500 & DG \\
\hline Maphthalen & MYGRAM/L & 1 & & & & 0.1000 & 0.1000 & DG \\
\hline Atrazin & MYGRAM/L & 2 & 0.0120 & 0.0120 & 0.00 & 0.0140 & 0.0100 & DG \\
\hline
\end{tabular}

Ribe Amt

Grundvandsanalyser, 1990 
Vorbasse (55.14)

\begin{tabular}{|c|c|}
\hline Stof navn & Enhed \\
\hline Kondukt ivitet & MSIEMENS/M \\
\hline PH & PH \\
\hline Inddampn ingsrest & $M G / L$ \\
\hline oxygen indhold & $M G / L$ \\
\hline Carbondtoxid, aggr. & $M G / L$ \\
\hline Hydrogencarbonat & $M G / L$ \\
\hline Permanganattal $\mathrm{KMnO4}$ & $M G / L$ \\
\hline Ammon iak +amon fum & $M G / L$ \\
\hline Nitrit & $M G / L$ \\
\hline Nitrat & $M G / L$ \\
\hline Orthophosph. $-\mathrm{PO4}, \mathrm{f}+1$ & $\mathrm{MG} / \mathrm{L}$ \\
\hline Phosph., tot.f11t P04 & $M G / L$ \\
\hline Phosph., tot P04,P11t & $M G / L$ \\
\hline A lumininium & MYGRAM/L \\
\hline Calc tum & $M G / L$ \\
\hline Chiorid & $M G / L$ \\
\hline fluorida & $M G / L$ \\
\hline Jern & $M G / L$ \\
\hline Jern ferro & $M G / L$ \\
\hline Kallum & $M G / L$ \\
\hline Magnes Ium & $M G / L$ \\
\hline Mangan & $M G / L$ \\
\hline Natrium & $M G / L$ \\
\hline Stlicium & $M G / L$ \\
\hline Silic fund iox id & $M G / L$ \\
\hline Sulfat & $M G / L$ \\
\hline Hydrogensulfid & $M G / L$ \\
\hline Methan & $M G / L$ \\
\hline
\end{tabular}

\section{Ribe Amt}

\begin{tabular}{|c|c|c|c|c|c|}
\hline Anta ? & Gens & Median & Spredning & Max Imun & Minimum \\
\hline 21 & 29.4095 & 25.0000 & 13.22 & 52.0000 & 15.5000 \\
\hline 21 & $6.3171^{\circ}$ & 6.1300 & 0.84 & 7.7700 & 5.0000 \\
\hline 2 & 103.0000 & 103.0000 & 7.07 & 108.0000 & 98.0000 \\
\hline 18 & 9.3000 & 10.7000 & 3.85 & 13.8000 & 0.8000 \\
\hline 20 & 32.8800 & 31.5000 & 26.25 & 80.0000 & 1.0000 \\
\hline 21 & 63.7190 & 38.0000 & 57.86 & 186.0000 & 5.1000 \\
\hline 21 & 2.3619 & 2.0000 & 1.32 & 5.3000 & 1.0000 \\
\hline 20 & 0.0456 & 0.0130 & 0.07 & 0.2330 & 0.0100 \\
\hline 21 & 0.0590 & 0.0130 & 0.09 & 0.3910 & 0.0050 \\
\hline 21 & 22.6386 & 25.0000 & 9.79 & 41.0000 & 0.0100 \\
\hline 21 & 0.0429 & 0.0307 & 0.03 & 0.1349 & 0.0153 \\
\hline 5 & 0.0693 & 0.0951 & 0.04 & 0.0981 & 0.0153 \\
\hline 18 & 0.0666 & 0.0567 & 0.05 & 0.1809 & 0.0153 \\
\hline 1 & 63.0000 & 63.0000 & $\cdot$ & 63.0000 & 63.0000 \\
\hline 21 & 29.5714 & 21.0000 & 21.29 & 71.0000 & 7.9000 \\
\hline 21 & 19.2857 & 18.0000 & 5.36 & 27.0000 & 11.0000 \\
\hline 21 & 0.1048 & 0.1000 & 0.01 & 0.1400 & 0.1000 \\
\hline 21 & 2.4317 & 1.3000 & 2.28 & 7.1500 & 0.0310 \\
\hline 21 & 0.1169 & 0.0370 & 0.17 & 0.6200 & 0.0200 \\
\hline 21 & 1.9714 & 1.5000 & 1.19 & 5.0000 & 1.2000 \\
\hline 21 & 4.1857 & 4.2000 & 0.89 & 5.8000 & 2.6000 \\
\hline 21 & 0.4303 & 0.0220 & 0.87 & 2.8800 & 0.0040 \\
\hline 21 & 15.1714 & 13.0000 & 9.37 & 48.0000 & 7.9000 \\
\hline 3 & 10.1333 & 11.0000 & 1.50 & 11.0000 & 8.4000 \\
\hline 18 & 10.7222 & 11.0000 & 1.25 & 13.0000 & 8.4000 \\
\hline 21 & 33.1905 & 32.0000 & 10.41 & 57.0000 & 20.0000 \\
\hline 21 & 0.0133 & 0.0100 & 0.01 & 0.0700 & 0.0090 \\
\hline 21 & 0.1000 & 0.1000 & 0.00 & 0.1000 & 0.1000 \\
\hline
\end{tabular}

\section{Grundvandsanalyser, 1989}

G

DG

G




\section{Egebjerg (60.01)}

Stof navn

Kondukt Ivite

$\mathrm{pH}$

Inddampningsrest MG/

Oxygen indhold MG/L

Carbondioxid, sggr. MG/L

Hydrogencarbonat MG/L

Carbon,org, MVOC, P1It MG/L

Permanganattal KMnO4 MG/L

Benzen

Toluen

Amonon faktamen tum

Nitrit

Nitrat

Orthophosph.-PO4,f11

Phosph.,tot.filt PO4

Arsen

Bly

Bor

Bromid

Cadm ium

Calcium

Chlor, org, AOX

chlor, org, vox

Chlorid

Chrom

Cyanto

Fluorid

Jern

Jern ferro

Jod

Jod1d

Kalium

Kobber

Lith ium

Magnes Ium

Mangan

Mo lybden

Matrium

Nikke I

silic ium, flit

Stront Ium

Sulfat

Sulf 1d-s

Methan

Detergenter anton

Chloroform

Tetraen lorku lstof

Tetrach jorethylen

Trichlorethylen

1,1,1-trich lorethan

G/L

MYGRAM/L

MYGRAM/L

MG/L

MG/L

MG/L

MG/L

MG/L

MYGRAM/L

MYGRAM/L

MYGRAM/L

MYGRAM/L

MYGRAM/L

MG/L

MYGRAM/L

MYGRAM/L

MG/L

MYGRAM/L

$M G / L$

MG/L

MG/L

MG/L

MYGRAM/L

MYGRAM/L

MG/L

MYGRAM/L

MYGRAM/L

MG/L

NG/L

MYGRAM/L

NG/L

MYGRAM/L

MG/L

MYGRAM/L

MG/L

MG/L

MG/L

$M G / L$

MYGRAM/L

MYGRAM/L

MYGRAM/L

MYGRAM/L

MYGRAM/L
Enhed

MSIEMENS/M

$/ L$

Vejle Amt

Grundvandsanalyser, 1990

Antal Gens Median Spredning Maxtmum Minimum

$\begin{array}{rrrrrr}52 & 62.7692 & 59.0000 & 13.67 & 120.0000 & 48.0000 \\ 52 & 7.5481 & 7.5000 & 0.22 & 8.2000 & 7.2000\end{array}$

$\begin{array}{lllll}7.5481 & 7.5000 & 0.22 & 8.2000 & 7.2000\end{array}$

$\begin{array}{llllll}52 & 386.1538 & 355.0000 & 89.36 & 710.0000 & 290.0000\end{array}$

440.2023

0.2000

2.0000

0.02

0.3000

0.2000

3.0923

295.0000

313.2115

1.4000

61.47

37.0000

2.0000

1.4600

7.1000

0.33

2.0000

220.0000

39.42

188.0000

1.2000

0.3000

0.1000

0.00

0.3000

2.0000

0.1000

0.4550

0.00

0.1000

0.3000

0.5229

0.0115

0.32

0.1000

0.0173

1.0000

0.3833

0.4906

12.4000

0.2000

0.5400

114.0000

103.6000

130.0000

112.0000

69.8077

67.0000

2.2800

1.8000

28. 1538

28.5000

0.3000

8.95

0.00

0.2500

0.12

1.6000

1.0500

5.7000

9.0000

3.6000

0.3000

15.2000

11.0000

0.2600

3.1000

37.0000

0.4000

25.0000

840.0000

24.0000

0.0200

0.0500

0.0100

0.0120

37.2154

0.0208
1.5000

0.02

0.1200

5.0000

0.8892

0.7666

23.7000

1.9000

140.0000

120.0000

0.0200

124.0000

4.9000

0.5000

53.0000

0.3000

0.0020

0.6200

5.2000

5.1000

11.1000

11.0000

6.4000

0.3000

20.9000

18.0000

0.4300

5.2000

170.0000

0.4000

34.0000

1000.0000

160.0000

0.0350

0.0829

0.0200 *

0.1000

0.0500

0.0500

0.0500

0.0500

0.0300

0.0050

1.0000

0.0399

0.1533

2.3000

0.2000

40.0000

82.0000

0.0200

33.0000

1.1000

0.5000

15.0000

0.3000

0.0020

0.1800

0.0740

0.0110

2.0000

3.4000

1.4000

0.3000

7.2000

7.6000

0.0800

1.3000

11.0000

0.4000

9.6000

370.0000

8.0000

0.0200

0.0050

0.0100

$0.1000 \quad D G$

0.0500 OG

0.0500 DG

$0.0500 \quad O G$

$0.0500 \quad O G$

* Særlig usædvanlig værdi, der må kontrolleres. 
Egebjerg (60.01)

P-xylen

M-xylen

0-xylen

Naphthaien

Phenol

3-wethylphenol

2,3 diwethylphenol

2-methylphenol

4-methylphenol

3,4-dimethylpheno 1

2,6-dimethylpheno 1

2,4-diwethy lphenol

6-clor, 2-methy lpheno

2,4-diclorphenol

4,6-dic lor, 2-methylp

2,6-dic lorphenol

2,4,6-tric lorpheno?

2,3,4,6-tetrac lorphe

2,3,5,6-tetrac lorphe

2,3,4,5-tetrac lorphe

Pentrac lorphenol

oichlorprop

MCPA

Mech lorprop

DNOC

Dinoseb

Atraz in

Simaz in

Kinta 1 376r. PCA

Kimtal 216r. KIMG $B$

--Collforme Bakt. MP
Enhed

MYGRAM/L

MYGRAM/L

MYGRAM/L

MYGRAM/L

MYGRAM/L

MYGRAM/L

MYGRAM/L

MYGRAM/L

MYGRAM/L

MYGRAM/L

MYGRAM/L

MYGRAM/L

MYGRAM/L

MYGRAM/L

MYGRAM/L

MYGRAM/L

MYGRAH/L

MYGRAM/L

MYGRAM/L

MYGRAM/L

MYGRAM/L

MYGRAM/L

MYGRAM/L

MYGRAM/L

MYGRAM/L

MYGRAM/L

MYGRAM/L

MYGRAM/L

ANTAL/ML

ANTAL/ML

ANTAL/100 ML
Vejle Amt

Grundvandsanalyser, 1990

5

5

5

5

5

5

5

5

5

5

5

5

5

5

5

5

5

5

5

5

5

5

5

5

12

12

12

Gens

Median Spredning

Maxtmum

0.1000

0.1000

$0.1000 \quad D G$

0.1000

$0.1000 \quad 06$

0.1000

$0.1000 \quad D G$

0.1000 DG

0.0300

0.0300

0.0300

$0.0300 \quad D G$

$0.0300 \quad D G$

$0.0300 \quad O G$

0.0300

$0.0300 \quad D G$

0.0300

0.0300 DG

0.0300

0.0300 DG

0.0300

$0.0300 \quad D G$

0.0300

0.0300 DG

0.0500

0.0500 DG

0.0300

0.0300 DG

0.0300

0.0300 DG

0.0300

0.0300 DG

0.0100

0.0100 DG

0.0100

$0.0100 \quad O G$

0.0100

$0.0100 \quad D G$

0.0100

0.0100 DG

0.0200

0.0200 DG

0.0100

$\mathbf{0 . 0 1 0 0} D G$

0.0140

0.0100

0.01

0.0300

0.0100 DG

0.0100

$0.0100 \quad D G$

0.0668

0.0100

0.13

0.2940

$0.0100 \quad D G$

0.0100

$0.0100 \quad D G$

0.0100

$0.0100 \quad D G$

0.0100

0.0100 DG

1.0000

$1.0000 \quad$ DG

1.5833

1.0000

1.38

5.0000

1.0000

$1.0000 \quad 06$

$1.0000 \quad 06$ 
Egebjerg (60.01)

\begin{tabular}{|c|c|}
\hline Stof navn & Enhed \\
\hline Kondukt ivitet & MSIEMENS/M \\
\hline pH & PH \\
\hline Torstof, total 1 & $M G / L$ \\
\hline Oxygen indhold & $M G / L$ \\
\hline Carbondioxid, aggr. & $M G / L$ \\
\hline Hydrogencarbonat & $M G / L$ \\
\hline Permanganattal KHnO4 & $M G / L$ \\
\hline Anon 1aktamon fum & $M 6 / L$ \\
\hline Nitrit & $M G / L$ \\
\hline Nitrat & $M G / L$ \\
\hline Orthophosphat-P04 & $M G / L$ \\
\hline Phosph., tot.filt P04 & $M G / L$ \\
\hline Calcium & $M G / L$ \\
\hline Chlorid & MG/L \\
\hline Fluorito & $M G / L$ \\
\hline Jern & $M 6 / L$ \\
\hline Jern ferro & MG/L \\
\hline Kollum & $M G / L$ \\
\hline Magnes ful & $\mathrm{HG} / \mathrm{L}$ \\
\hline Mangan & $M 6 / L$ \\
\hline Natrium & $M 6 / L$ \\
\hline Stlic fund tox td & $M G / L$ \\
\hline Sulfat & MG/L \\
\hline
\end{tabular}

Vejle Amt

Grundvandsanalyser, 1989

Antal Gens Median Spredning Maxtmum Mintmus

$\begin{array}{cc}8 & 60.0000 . \\ 8 & 7.5125\end{array}$

59.5000

10.78

80.0000

48.0000

0.20

7.9000

7.3000

$8 \quad 375.0000$

360.0000

72.90

510.0000

290.0000

0.2000

0.2000

0.00

0.2000

0.2000

$8 \quad 2.2500$

2.0000

0.71

4.0000

2.0000

$305.0000 \quad 295.0000$

45.98

360.0000

230.0000

49.51

120.0000

3.5000

0.5788

1.80

5.5968

0.1994

1.1626

0.0125

0.00

0.0170

0.0050

0.35

2.0000

1.0000

1.1250

1.0000

0.1145

0.07

0.2000

0.0150

$6 \quad 0.5826$

0.5979

0.26

0.9199

0.1533

70.1250

70.0000

27.73

128.0000

40.0000

25.3750

23.5000

8.83

38.0000

15.0000

0.2500

0.12

0.5600

0.2100

1.1050

0.73

2.3000

0.7400

1.3900

0.8750

0.91

3.1000

0.4000

4.6250

4.5000

1.61

7.4000

2.0000

9.7125

10.5000

3.34

13.0000

3.3000

$8 \quad 0.2463$

0.2350

0.07

0.3700

0.1400

46.8750

31.5000

41.16

130.0000

11.0000

$8 \quad 22.0000$

23.5000

7.05

32.0000

12.0000

$8 \quad 37.5000$

30.0000

85.0000

8.0000 
Thyregod (60.11)

\begin{tabular}{|c|c|c|c|c|}
\hline Stof navn & Enhed & Anta 1 & Gens & Median \\
\hline Kondukt Ivitet & MSIEMENS/M & 61 & 34.3443 & 31.0000 \\
\hline $\mathrm{pH}$ & PH & 61 & 6.2541 & 6.3000 \\
\hline Inddaupn 1ngsrest & $M G / L$ & 61 & 226.7213 & 190.0000 \\
\hline Oxygen indhold & $M G / L$ & 52 & 4.8775 & 4.7500 \\
\hline Carbondioxid, aggr. & $M G / L$ & 59 & 33.4068 & 27.0000 \\
\hline Hydrogencarbonat & $M G / L$ & 62 & 63.3871 & 39.0000 \\
\hline Carbon, org, HVOC, $111 t$ & $M G / L$ & 6 & 0.6317 & 0.4250 \\
\hline Permanganattal KMnO4 & $M G / L$ & 62 & 22.6032 & 2.1500 \\
\hline Benzen & MYGRAM/L & 6 & & \\
\hline Toluen & MYGRAM/L & 6 & & \\
\hline Amon laktaman Iun & $\mathrm{MG} / \mathrm{L}$ & 62 & 0.0638 & 0.0200 \\
\hline Mitrit & $M G / L$ & 61 & 0.0155 & 0.0050 \\
\hline Nitrat & $M G / L$ & 62 & 40.0806 & 27.5000 \\
\hline Orthophosph. $-\mathrm{PO4}, \mathrm{f} 11$ & $M G / L$ & 61 & 0.0747 & 0.0460 \\
\hline Phosph.,tot.f1lt P04 & $\mathrm{MG} / \mathrm{L}$ & 48 & 0.1140 & 0.0797 \\
\hline Alua infun & MYGRAM/L & 6 & 21.0333 & 0.3000 \\
\hline Arsen & MYGRAM/L & 6 & 0.3000 & 0.3000 \\
\hline Bartum & MYGRAM/L & 6 & 69.1667 & 52.5000 \\
\hline Bly & MYGRAM/L & 3 & 0.6333 & 0.2000 \\
\hline Bor & MYGRAM/L & 6 & 15.1667 & 13.5000 \\
\hline Bromid & MYGRAM/L & 6 & 70.1667 & 82.0000 \\
\hline Cadmina & MYGRAM/L & 6 & 0.0450 & 0.0300 \\
\hline Calcium & $M G / L$ & 61 & 39.1311 & 35.0000 \\
\hline Chlor, org, AOX & MYGRAM/L & 6 & 1.9667 & 1.8000 \\
\hline Chlor, org, vox & MYGRAM/L & 6 & & \\
\hline Chlorid & $M G / L$ & 62 & 30.7710 & 26.0000 \\
\hline Chros & MYGRAM/L & 6 & 0.5500 & 0.3000 \\
\hline Cyanid & $\mathrm{MG} / \mathrm{L}$ & 6 & & \\
\hline Fluorid & $M G / L$ & 61 & 0.1031 & 0.1000 \\
\hline Jern & $M 6 / L$ & 48 & 0.3162 & 0.1100 \\
\hline Jern ferro & MG/L & 61 & 1.9298 & 0.0330 \\
\hline Jod & MYGRAM/L * & 6 & 55.8667 & 10.1000 \\
\hline Jodid & MYGRAM/L & 6 & 3.6000 & 3.4500 \\
\hline Kallum & $M G / L$ & 61 & 5.6234 & 1.8000 \\
\hline Kobber & MYGRAM/L & 6 & 0.5167 & 0.3000 \\
\hline Magnes fun & $M G / L$ & 61 & 4.8770 & 4.3000 \\
\hline Mangan & $M 6 / L$ & 62 & 2.2611 & 0.0450 \\
\hline Mo lybden & MYGRAM/L & 3 & 0.4333 & 0.4000 \\
\hline Natrium & $M G / L$ & 61 & 14.5541 & 11.0000 \\
\hline M1kkel & MYGRAM/L & 6 & 4.2833 & 0.4500 \\
\hline silic tum, fllt & $M 6 / L$ & 61 & 13.0213 & 13.0000 \\
\hline Stront tum & MYGRAM/L & 6 & 126.8833 & 125.0000 \\
\hline Sulfat & $M G / L$ & 61 & 29.4426 & 27.0000 \\
\hline Sulfid-s & $\mathbf{M G} / \mathbf{L}$ & 21 & 0.0201 & 0.0200 \\
\hline Methan & $M G / L$ & 20 & 0.5150 & 0.0500 \\
\hline Detergenter anion & $M G / L$ & 6 & 0.0233 & 0.0200 \\
\hline Chloroform & MYGRAM/L & 6 & & \\
\hline Tetrach lorku lstof & MYGRAH/L & 6 & & \\
\hline Tetrach lorethylen & MYGRAM/L & 6 & & \\
\hline Trich lorethylen & MYGRAM/L & 6 & & \\
\hline
\end{tabular}

Grundvandsanalyser, 1990

Vejle Amt

Spredning

$0.82 \quad 7.9000$

$115.86 \quad 780.0000$

3.87

$21.94 \quad 93.0000$

$85.52 \quad 410.0000$

0.45

53.07

240.0000

0.21

0.04

56.75

370.0000

0.11

40.69

117.0000

7.14

27.12

0.04

17.06

0.56

0.01

0.62

10.82

77.88

0.70

14.94

0.44

2.63

8.88

0.15

8.12

8.70

4.60

28.90

10.73

0.00

1.11

0.01
11.0000

1.5000

0.3000

0.1000

1.4000

0.2500

0.3679

0.5213

102.0000

0.3000

1.5000

29.0000

95.0000

0.1200

125.0000

2.9000

0.5000

79.0000

1.7000

0.0020

0.1300

Mininum

15.0000

5.2000

100.0000

0.2000

2.0000

4.0000

0.3300

2.0000

$0.3000 \quad D G$

0.1000 DG

0.0100

$0.0050 \quad D G$

1.0000

0.0460

0.0460

0.3000

0.3000

36.0000

0.2000

10.0000

25.0000

$0.0200 \quad D G$

9.0000

$1.0000 \quad D G$

$0.5000 \quad D G$

9.8000

0.3000

$0.0020 \quad D G$

0.1000

0.0050

3.8000

0.0050

180.0000

3.4000

$4.6000 \quad 3.0000$

100.0000

0.4500

1.4000

0.3000

12.0000

1.2000

49.0000

0.0100

0.6000

0.3000

40.0000

4.8000

22.0000

0.4000

24.0000

3.8000

$178.0000 \quad 97.3000$

$65.0000 \quad 14.0000$

$0.0230 \quad 0.0200$

4.2000

0.0500

$0.0400 \quad 0.0100$

0.1000

$0.1000 \quad D G$

0.0500

$0.0500 \quad D G$

0.0500

$0.0500 \quad D G$

0.0500

$0.0500 \quad 06$

* Særlig usædvanlig værdi, der må kontrolleres. 
Thyregod (60.11)

Stof navn
1,1,1-trich lorethan
P-xylen
M-xylen
0-xylen
Maphthalen
Phenol
3-wethylphenol

2,3 dimethylphenol

2-methylphenol

4-wethylphenol

3,4-d dimethy Iphenol

3.5-d trethy Iphenol

2,6-d iwe thy ipheno I

2,4-d inethylphenol

4-c lor. 2-methy lpheno

6-c lor, 2-methy lpheno

4,6-dic lor, 2-wethylp

2,6-dic lorpheno I

2,4,6-tric lorphenol

2,3,4,6-tetrac lorphe

2,3,5,6-tetrac lorphe

2,3,4,5-tetrac lorphe

Pentrac lorpheno 1

oich lorprop

MCPA

Mech lorprop

DNOC

Dinoseb

Atrazin

Stmoz in

Kintal 376 r. PCA

Kintal 216r. KING B

--Collforme Bakt. MP

--Termo.col1f .MPN
Enhed

MYGRAM/L

MYGRAM/L

MYGRAM/L

MYGRAM/L

MYGRAM/L

MYGRAM/L

MYGRAM/L

MYGRAM/L

MYGRAM/L

MYGRAM/L

MYGRAM/L

MYGRAM/L

MYGRAM/L

MYGRAM/L

MYGRAM/L

MYGRAM/L

MYGRAM/L

MYGRAM/L

MYGRAM/L

MYGRAM/L

MYGRAM/L

MYGRAM/L

MYGRAM/L

MYGRAM/L

MYGRAM/L

MYGRAM/L

MYGRAM/L

MYGRAM/L

MYGRAM/L

MYGRAM/L

ANTAL/ML

ANTAL/ML

ANTAL/100 ML

ANTAL/100 ML

Vejle Amt

Grundvandsanalyser, 1990

Anta 1

6

6

6

6

6

6

6

6

6

6

6

6

6

6

6

3

6

3

6

6

6

6

6

6

6

6

6

6

6

6

8

8

8

8

1
Median Spredning

Max 1mu:

Mininum .

$0.0500 \quad 0.0500 \quad D G$

$0.1000 \quad 0.1000 \quad D G$

$0.1000 \quad 0.1000 \quad D G$

$0.1000 \quad 0.1000 \quad D G$

$0.1000 \quad 0.1000 \quad$ DG

$\begin{array}{lll}0.0300 & 0.0300 \quad 06\end{array}$

$0.0300 \quad 0.0300 \quad D G$

$\begin{array}{lll}0.0300 & 0.0300 \quad D G\end{array}$

$0.0300 \quad 0.0300 \quad D G$

$0.0300 \quad 0.0300 \quad D G$

$0.0300 \quad 0.0300 \quad D G$

$0.0300 \quad 0.0300 \quad D G$

$0.0300 \quad 0.0300 \quad$ DG

$0.0300 \quad 0.0300 \quad 06$

$0.0500 \quad 0.0500 \quad 06$

$0.0500 \quad 0.0500 \quad D G$

$0.0300 \quad 0.0300 \quad 0 G$

$0.0300 \quad 0.0300 \quad 06$

$\begin{array}{lll}0.0100 & 0.0100 \quad 06\end{array}$

$0.0100 \quad 0.0100 \quad 06$

$0.0100 \quad 0.0100 \quad 06$

$0.0100 \quad 0.0100 \quad 06$

$0.0200 \quad 0.0200 \quad 06$

$\begin{array}{lll}0.0140 & 0.0140 \quad 06\end{array}$

$0.0450 \quad 0.0100 \quad 06$

$\begin{array}{lll}0.0120 & 0.0120 \quad 06\end{array}$

$\begin{array}{lll}0.0150 & 0.0150 & 06\end{array}$

$0.0100 \quad 0.0100 \quad D G$

$0.0100 \quad 0.0100 \quad D G$

$0.0100 \quad 0.0100 \quad D G$

388.7500

1.0000

1095.51

3100.0000

$1.0000 \quad D G$

57.1250

1.0000

146.97

420.0000

$1.0000 \quad D G$

1.0000

$1.0000 \quad D G$

1.0000

1.0000

DG 
Thyregod (60.11)

\begin{tabular}{|c|c|}
\hline Stof navn & Enhed \\
\hline Kondukt IvItet & MSIEMERS/M \\
\hline PH & PH \\
\hline Torstof, total 1 & $M G / L$ \\
\hline oxygen indhold & $M G / L$ \\
\hline Carbondioxid, agar. & $146 / \mathrm{L}$ \\
\hline Hydrogencarbonat & $M G / L$ \\
\hline Permonganattal KMnO4 & $M G / L$ \\
\hline Ammon lak +amon ium & $M G / L$ \\
\hline Nitrit & $M G / L$ \\
\hline Nitrot & $M G / L$ \\
\hline Orthophosphat-p04 & $M G / L$ \\
\hline Phosph., tot.f1]t P04 & $M G / L$ \\
\hline Calcium & $M G / L$ \\
\hline Chlorid & $M G / L$ \\
\hline F luorid & $M G / L$ \\
\hline Jern & $M G / L$ \\
\hline Jern ferro & $\mathrm{MG} / \mathrm{L}$ \\
\hline Kallum & $\mathrm{MG} / \mathrm{L}$ \\
\hline Magnes 1um & $M G / L$ \\
\hline Mangen & $M G / L$ \\
\hline Natrium & $M G / L$ \\
\hline Sill te fund tox id & $M G / L$ \\
\hline Sulfat & $M G / L$ \\
\hline Hydrogensu lf 1d & $M G / L$ \\
\hline Methan & $M G / L$ \\
\hline
\end{tabular}

\section{Vejle Amt}

\begin{tabular}{|c|c|c|c|c|c|}
\hline Anta 1 & Gens & Median & Spredning & Maxtmun & Min 1mum \\
\hline 49 & 36.0612 & 31.0000 & 12.84 & 68.0000 & 20.0000 \\
\hline 49 & 6.5429 & 6.7000 & 0.73 & 7.9000 & 5.3000 \\
\hline 39 & 214.8718 & 190.0000 & 77.08 & 450.0000 & 90.0000 \\
\hline 39 & 5.0308 & 4.1000 & 4.28 & 17.1000 & 0.2000 \\
\hline 40 & 38.0750 & 35.0000 & 23.86 & 97.0000 & 2.0000 \\
\hline 49 & 69.7755 & 41.0000 & 70.85 & 270.0000 & 6.0000 \\
\hline 48 & 45.5667 & 2.9000 & 98.00 & 420.0000 & 2.0000 \\
\hline 49 & 0.1404 & 0.0250 & 0.52 & 3.0800 & 0.0097 \\
\hline 39 & 0.0285 & 0.0060 & 0.07 & 0.3700 & 0.0050 \\
\hline 49 & 43.4490 & 31.0000 & 43.38 & 180.0000 & 1.0000 \\
\hline 49 & 0.0224 & 0.0150 & 0.02 & 0.1300 & 0.0150 \\
\hline 35 & 2.5607 & 0.0920 & 13.44 & 79.7212 & 0.0307 \\
\hline 49 & 42.6327 & 37.0000 & 21.59 & 110.0000 & 18.0000 \\
\hline 49 & 28.3878 & 27.0000 & 12.57 & 75.0000 & 7.0000 \\
\hline 49 & 0.1016 & 0.1000 & 0.02 & 0.1400 & 0.0100 \\
\hline 44 & 17.3011 & 1.1100 & 72.08 & 470.0000 & 0.0200 \\
\hline 45 & 0.9320 & 0.0900 & 4.19 & 28.0000 & 0.0100 \\
\hline 37 & 5.8757 & 2.9000 & 6.18 & 23.0000 & 1.0000 \\
\hline 49 & 5.3408 & 4.3000 & 3.65 & 15.0000 & 1.2000 \\
\hline 47 & 1.7794 & 0.1000 & 6.71 & 34.3000 & 0.0100 \\
\hline 49 & 16.1102 & 12.0000 & 10.77 & 68.0000 & 6.0000 \\
\hline 25 & 13.5600 & 12.0000 & 3.84 & 23.0000 & 5.0000 \\
\hline 49 & 33.6735 & 29.0000 & 14.92 & 110.0000 & 18.0000 \\
\hline 1 & 0.3000 & 0.3000 & $\cdot$ & 0.3000 & 0.3000 \\
\hline 2 & 1.1500 & 1.1500 & 0.49 & 1.5000 & 0.8000 \\
\hline
\end{tabular}

Grundvandsanalyser, 1989

DG
1.1500

1.5000

0.8000 
Trudsbro (60.12)

\begin{tabular}{|c|c|c|c|c|c|c|c|}
\hline Stof novn & Enhed & Antal & Gens & Median & Spredning & Maximum & Min imula \\
\hline Kondukt ivitet & MSIEMENS/M & 66 & 42.3333 & 39.0000 & 11.13 & 70.0000 & 22.0000 \\
\hline PH & PH & 65 & 7.1385 & 7.4000 & 0.68 & 7.9000 & 5.3000 \\
\hline Inddaapn I Ingsrest & MG/L & 65 & 278.4615 & 260.0000 & 72.74 & 460.0000 & 150.0000 \\
\hline Oxygen indhold & $M G / L$ & 62 & 0.5087 & 0.2000 & 1.21 & 6.8000 & 0.2000 \\
\hline Carbond 10x1d, aggr. & MG/L & 65 & 12.3385 & 2.7000 & 22.51 & 81.0000 & 2.0000 \\
\hline Hydrogencarbonat & $M G / L$ & 66 & 172.4697 & 180.0000 & 94.34 & 350.0000 & 15.0000 \\
\hline Carbon, org, NVOC, ptlt & $M G / L$ & 6 & 0.8550 & 0.6450 & 0.54 & 1.9000 & 0.4000 \\
\hline Permanganattal $\mathrm{KMnO4}$ & $M G / L$ & 65 & 13.5446 & 6.4000 & 15.68 & 80.0000 & 2.0000 \\
\hline Benzen & MYGRAM/L & 6 & & & & 0.3000 & 0.3000 \\
\hline Toluen & MYGRAM/L & 6 & & & & 0.1000 & 0.1000 \\
\hline Ammon 1ak+amen ium & $M G / L$ & 66 & 0.1227 & 0.1250 & 0.09 & 0.3300 & 0.0100 \\
\hline Nitrit & $M G / L$ & 65 & 0.0249 & 0.0180 & 0.03 & 0.1700 & 0.0050 \\
\hline Nitrat & $M G / L$ & 65 & 12.8462 & 1.0000 & 23.77 & 86.0000 & 1.0000 \\
\hline Orthophosph.-p04,f11 & $M G / L$ & 65 & 0.2639 & 0.3066 & 0.19 & 0.7052 & 0.0460 \\
\hline Phosph.,tot.f 17t P04 & MG/L & 47 & 0.3587 & 0.3986 & 0.17 & 0.9505 & 0.0460 \\
\hline A lum in tum & MYGRAM/L & 6 & 83.5333 & 0.3000 & 197.24 & 486.0000 & 0.3000 \\
\hline Arsen & MYGRAM/L & 6 & 2.8833 & 2.7000 & 1.62 & 4.9000 & 0.6000 \\
\hline Bor tum & MYGRAM/L & 5 & 195.0000 & 128.0000 & 114.86 & 352.0000 & 101.0000 \\
\hline Bor & MYGRAM/L & 6 & 47.8333 & 52.0000 & 24.61 & 76.0000 & 10.0000 \\
\hline Bromid & MYGRAM/L & 6 & 71.1667 & 70.5000 & 25.36 & 116.0000 & 41.0000 \\
\hline Cadmiun & MYGRAM/L & 6 & 0.0217 & 0.0200 & 0.00 & 0.0300 & 0.0200 \\
\hline Calciun & $M G / L$ & 66 & 68.7424 & 65.5000 & 25.47 & 133.0000 & 23.0000 \\
\hline Chlor, org, AOX & MYGRAM/L & 6 & 2.1167 & 1.9500 & 0.53 & 2.9000 & 1.6000 \\
\hline Chlor, org, vox & MYGRAM/L & 6 & & & & 0.5000 & 0.5000 \\
\hline Chlortd & $M G / L$ & 66 & 20.6061 & 19.0000 & 6.30 & 52.0000 & 14.0000 \\
\hline Chrom & MYGRAM/L & 6 & 0.3000 & 0.3000 & 0.00 & 0.3000 & 0.3000 \\
\hline Cyanid & $M G / L$ & 6 & & & & 0.0020 & 0.0020 \\
\hline F luorid & $M G / L$ & 66 & 0.1444 & 0.1450 & 0.04 & 0.2900 & 0.1000 \\
\hline Jern & $M G / L$ & 47 & 2.0365 & 1.6000 & 1.99 & 11.0000 & 0.0500 \\
\hline Jern ferro & $M G / L$ & 65 & 1.6862 & 1.4000 & 1.86 & 7.3000 & 0.0100 \\
\hline Jod & MYGRAM/L * & 6 & 10.0167 & 7.7500 & 10.25 & 28.9000 & 2.0000 \\
\hline Jodid & MYGRAM/L & 6 & 3.3000 & 3.0000 & 0.53 & 4.3000 & 3.0000 \\
\hline Kallum & $M G / L$ & 65 & 2.3949 & 1.5000 & 1.80 & 8.1000 & 0.6500 \\
\hline Kobber & MYGRAM/L & 6 & 0.3000 & 0.3000 & 0.00 & 0.3000 & 0.3000 \\
\hline Lith tum & MYGRAM/L & 1 & 3.5000 & 3.5000 & $\cdot$ & 3.5000 & 3.5000 \\
\hline Magnes fum & MG/L & 66 & 4.6409 & 4.4500 & 1.76 & 8.7000 & 2.0000 \\
\hline Mangan & $M G / L$ & 65 & 0.3735 & 0.2800 & 0.27 & 1.0300 & 0.0100 \\
\hline Molybdan & MYGRAM/L & 6 & 0.9000 & 0.8500 & 0.24 & 1.3000 & 0.6000 \\
\hline Natriun & $M G / L$ & 65 & 11.1308 & 11.0000 & 2.21 & 19.0000 & 7.0000 \\
\hline N1kke I & MYGRAM/L & 6 & 0.4000 & 0.4000 & 0.00 & 0.4000 & 0.4000 \\
\hline S111c tum, f11t & $M G / L$ & 65 & 21.0462 & 24.0000 & 8.19 & 31.0000 & 4.0000 \\
\hline Stront fun & MYGRAM/L & 6 & 233.8333 & 239.0000 & 69.24 & 309.0000 & 124.0000 \\
\hline Sulfat & MG/L & 65 & 34.4923 & 30.0000 & 21.57 & 92.0000 & 5.0000 \\
\hline Sulf 1d-s & MG/L & 21 & 0.0257 & 0.0200 & 0.01 & 0.0600 & 0.0200 \\
\hline Methan & $M G / L$ & 26 & 0.0512 & 0.0500 & 0.01 & 0.0810 & 0.0500 \\
\hline Detergenter anton & $M G / L$ & 6 & 0.0100 & 0.0100 & 0.00 & 0.0100 & 0.0100 \\
\hline Chloroform & MYGRAM/L & 6 & 0.0833 & 0.1000 & 0.03 & 0.1000 & 0.0500 \\
\hline Tetrach lorku lstof & MYGRAM/L & 6 & & & & 0.0500 & 0.0500 \\
\hline Tetrach lorethy len & MYGRAM/L & 6 & & & & 0.0500 & 0.0500 \\
\hline Trichlorethylen & MYGRAM/L & 6 & & & & 0.0500 & 0.0500 \\
\hline
\end{tabular}

* Særlig usædvanlig værdi, der må kontrolleres. 
Trudsbro (60.12)

\begin{tabular}{|c|c|}
\hline Stof navn & Enhed \\
\hline 1,1,1-trichlorethan & MYGRAM/L \\
\hline P-xylen & MYGRAM/L \\
\hline M-xylen & MYGRAM/L \\
\hline $0-x y l e n$ & MYGRAM/L \\
\hline Maphthalen & MYGRAM/L \\
\hline Phenol & MYGRAM/L \\
\hline 3-methylphenol & MYGRAM/L \\
\hline 2,3 dimethy lpheno 1 & MYGRAM/L \\
\hline 2-methylphenol & MYGRAM/L \\
\hline 4-methy (phenol & MYGRAM/L \\
\hline 3,4-d 1methy iphenol & MYGRAM/L \\
\hline 3.5-d twethylpheno 1 & MYGRAM/L \\
\hline 2.6-d imethy lphenol & MYGRAM/L \\
\hline 2,4-d dmethylphenol & MYGRAM/L \\
\hline 4-c lor, 2-wethy Ipheno & MYGRAM/L \\
\hline 2,4-d1c lorphenol & MYGRAM/L \\
\hline 4,6-dic lor, 2-wethy ip & HYGRAM/L \\
\hline 2,6-diclorphenol & MYGRAM/L \\
\hline 2,4,6-tric lorphenol & MYGRAM/L \\
\hline 2,3,4,6-tetrac lorphe & MYGRAM/L \\
\hline 2,3,5,6-tetrac lorphe & MYGRAM/L \\
\hline 2,3,4,5-tetrac lorphe & MYGRAM/L \\
\hline Pentrac lorphenol & MYGRAM/L \\
\hline Dtch lorprop & MYGRAM/L \\
\hline MCPA & MYGRAM/L \\
\hline Mech lorprop & MYGRAM/L \\
\hline DNOC & MYGRAM/L \\
\hline Dinoseb & MYGRAM/L \\
\hline Atrazin & MYGRAM/L \\
\hline Sigazin & MYGRAM/L \\
\hline Kimtal 37Gr. PCA & ANTAL/ML \\
\hline Kimtal 216r. KING B & ANTAL/ML \\
\hline - Collforme Bakt. MP & ANTAL/100 ML \\
\hline
\end{tabular}

Vejle Amt Grundvandsanalyser, 1990

6

6

6

6

6

6

6

5

1

6

6

6

6

6

6

6

6

6

6

6

6

6

6

6

6

6

Gens

Median Sprednting

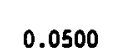

0.0500 DG

$0.1000 \quad 0.1000 \quad D G$

$\begin{array}{lll}0.1000 & 0.1000 \quad 06\end{array}$

$0.1000 \quad 0.1000 \quad O G$

$0.1000 \quad 0.1000 \quad$ OG

0.0617

0.0300

0.08

0.2200

0.0300

0.0300

0.0300

0.0300

0.0300

0.0300

0.0300

0.0300

0.0500

0.0300

0.0300

0.0300

0.0100

0.0100

0.0100

0.0100

0.0200

$0.0300 \quad D G$

$0.0300 \quad O G$

0.0300 DG

0.0300 DG

0.0300 OG

$0.0300 \quad D G$

$0.0300 \quad D G$

$0.0300 \quad 06$

$0.0300 \quad D G$

$0.0500 \quad D G$

0.0300 DG

0.0300 DG

0.0300 DG

0.0100 DG

0.0100 DG

0.0100 DG

$0.0100 \quad O G$

0.0135

0.0135

0.00

0.0150

$0.0200 \quad 0 G$

0.0105

0.0105

0.00

0.0110

$0.0120 \quad D G$

0.0115

0.0115

0.00

0.0130

$0.0100 \quad D G$

0.0100

$0.0100 \quad$ DG

0.0100

0.0100 DG

0.0100

$0.0100 \quad D G$

0.0100

$0.0100 \quad D G$

0.0100

$0.0100 \quad D G$

1.6667

1.0000

1.63

5.0000

1.0000 DG

347.1667

1.5000

810.30

2000.0000

1.0000

1.0000 DG

1.0000 DG 
Trudsbro (60.12)

\begin{tabular}{|c|c|}
\hline Stof navn & Enhed \\
\hline Kondukt ivitet & MSIEMENS/M \\
\hline pH & PH \\
\hline Terstof, total & MG/L \\
\hline Oxygen indhold & $M G / L$ \\
\hline Carbondioxid, aggr. & $M G / L$ \\
\hline Hydrogencarbonat & $M G / L$ \\
\hline Permanganattal KMnO4 & $M G / L$ \\
\hline Ammon tak tammon fum & $M G / L$ \\
\hline N1trit & $M G / L$ \\
\hline Nitrat & $M G / L$ \\
\hline Orthophosphat-PO4 & $M G / L$ \\
\hline Phosph.,tot.filt P04 & $M G / L$ \\
\hline Calciun & $\mathbf{M G} / \mathbf{L}$ \\
\hline Chlor 1d & $H G / L$ \\
\hline Fluor 1d & $M G / L$ \\
\hline Jern & $M G / L$ \\
\hline Jern ferro & MG/L \\
\hline Kollum & $M G / L$ \\
\hline Magnes ium & $M G / L$ \\
\hline Mangan & HG/L \\
\hline Natriun & $M G / L$ \\
\hline Stlic fund tox id & $\mathrm{MG} / \mathrm{L}$ \\
\hline Sulfat & $M G / L$ \\
\hline Hydrogensulf id & $M G / L$ \\
\hline Methan & $M G / L$ \\
\hline
\end{tabular}

Vejle Amt

Grundvandsanalyser, 1989

\begin{tabular}{|c|c|c|c|c|c|}
\hline Anta 1 & Gens & Median & Spredning & Max taum & Min 1num \\
\hline 57 & 43.7895. & 40.0000 & 11.04 & 72.0000 & 22.0000 \\
\hline 57 & 7.3228 & 7.4000 & 0.49 & 8.0000 & 5.6000 \\
\hline 51 & 295.4902 & 280.0000 & 77.18 & 460.0000 & 140.0000 \\
\hline 51 & 0.8686 & 0.2000 & 2.55 & 16.2000 & 0.2000 \\
\hline 55 & 8.8909 & 2.0000 & 18.01 & 80.0000 & 2.0000 \\
\hline 57 & 194.6140 & 190.0000 & 83.61 & 370.0000 & 25.0000 \\
\hline 57 & 52.5158 & 8.0000 & 117.68 & 570.0000 & 2.0000 \\
\hline 53 & 0.1443 & 0.1398 & 0.10 & 0.4300 & 0.0100 \\
\hline 51 & 0.0499 & 0.0180 & 0.15 & 1.1000 & 0.0050 \\
\hline 57 & 11.3333 & 1.0000 & 22.59 & 89.0000 & 1.0000 \\
\hline 56 & 0.0784 & 0.0755 & 0.05 & 0.2200 & 0.0150 \\
\hline 45 & 1.6074 & 0.3986 & 3.37 & 15.0244 & 0.0920 \\
\hline 57 & 72.9474 & 66.0000 & 23.00 & 130.0000 & 27.0000 \\
\hline 57 & 18.5614 & 17.0000 & 4.85 & 34.0000 & 11.0000 \\
\hline 57 & 0.1414 & 0.1500 & 0.03 & 0.2000 & 0.1000 \\
\hline 50 & 16.1104 & 3.0500 & 38.30 & 168.0000 & 0.1800 \\
\hline 57 & 1.8811 & 1.4000 & 1.90 & 7.1000 & 0.0100 \\
\hline 51 & 2.4137 & 1.7000 & 1.45 & 7.2000 & 1.1000 \\
\hline 57 & 4.9281 & 4.6000 & 1.87 & 10.0000 & 1.8000 \\
\hline 57 & 0.6307 & 0.4200 & 0.85 & 4.8000 & 0.0200 \\
\hline 57 & 11.5544 & 11.0000 & 1.90 & 15.0000 & 7.4000 \\
\hline 37 & 22.2973 & 26.0000 & 8.79 & 36.0000 & 4.0000 \\
\hline 57 & 33.4211 & 27.0000 & 19.29 & 72.0000 & 5.0000 \\
\hline 2 & 0.2500 & 0.2500 & 0.07 & 0.3000 & 0.2000 \\
\hline 17 & 0.1000 & 0.1000 & 0.00 & 0.1000 & 0.1000 \\
\hline
\end{tabular}


Follerup (60.13)

\begin{tabular}{|c|c|}
\hline Stof navn & Enhed \\
\hline Trich lore thy len & MYGRAM/L \\
\hline 1,1,1-tr tch lorethan & MYGRAK/L \\
\hline$P=x y$ len & MYGRAM/L \\
\hline M-xylen & MYGRAM/L \\
\hline $0-x y$ len & MYGRAM/L \\
\hline Maphthalen & MYGRAM/L \\
\hline Phenol & MYGRAM/L \\
\hline 3-methylphenol & MYGRAM/L \\
\hline 2,3 dimethylphenol & MYGRAM/L \\
\hline 2-methylphenol & MYGRAM/L \\
\hline 4-methylphenol & MYGRAM/L \\
\hline 3,4-d 1methylphenol & MYGRAM/L \\
\hline 3,5-d Imethylphenol & MYGRAM/L \\
\hline 2,6-d inethylphenol & MYGRAM/L \\
\hline 2,4-d fmethylphenol & MYGRAM/L \\
\hline 4-c lor, 2-methy Ipheno & MYGRAM/L \\
\hline 6-c lor, 2-methylpheno & MYGRAM/L \\
\hline 2,4-dic lorpheno i & MYGRAM/L \\
\hline 4,6-dic lor, 2-wethy ip & MYGRAM/L \\
\hline 2,6-dic lorphenol & MYGRAM/L \\
\hline 2,4,6-tric lorphenol & MYGRAM/L \\
\hline $2,3,4,6$-tetrac lorphe & MYGRAM/L \\
\hline 2,3,5,6-tetrac lorphe & MYGRAM/L \\
\hline 2,3,4,5-tetrac lorphe & MYGRAM/L \\
\hline Pentrac lorpheno 1 & MYGRAM/L \\
\hline Dich lorprop & MYGRAM/L \\
\hline MCPA & MYGRAM/L \\
\hline Mech lorprop & MYGRAM/L \\
\hline DNOC & MYGRAM/L \\
\hline Dinoseb & MYGRAM/L \\
\hline Atrazin & MYGRAM/L \\
\hline Simaz in & MYGRAM/L \\
\hline Kintal 37Gr. PCA & ANTAL/ML \\
\hline XImtal 2lGr. KIMG 8 & ANTAL/ML \\
\hline -Collforme 8akt. MP & ANTAL/100 ML \\
\hline --Termo.col1f .MPN & ANTAL $/ 100 \mathrm{ML}$ \\
\hline
\end{tabular}

Vejle Amt

Grundvandsanalyser, 1990

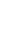

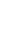

7.6667

4.0000

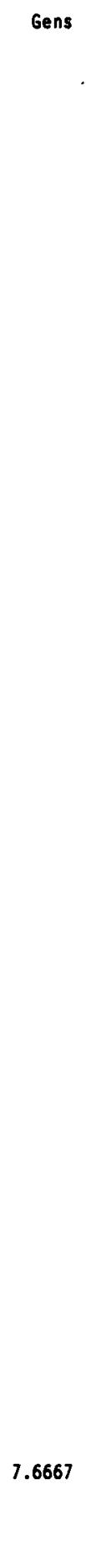

Median Spredning

Maxinum

Minimua .

$0.0500 \quad 0.0500 \quad D G$

$0.0500 \quad 0.0500 \quad D G$

$0.1000 \quad 0.1000 \quad D G$

$0.1000 \quad 0.1000 \quad D G$

$0.1000 \quad 0.1000 \quad D G$

$0.1000 \quad 0.1000 \quad D G$

$0.0300 \quad 0.0300 \quad D G$

$0.0300 \quad 0.0300 \quad O G$

$0.0300 \quad 0.0300 \quad$ DG

$0.0300 \quad 0.0300 \quad D G$

$0.0300 \quad 0.0300 \quad D G$

$\begin{array}{lll}0.0300 & 0.0300 \quad D G\end{array}$

$0.0300 \quad 0.0300 \quad D G$

$0.0300 \quad 0.0300 \quad D G$

$0.0300 \quad 0.0300 \quad D G$

$0.0500 \quad 0.0500 \quad D G$

$0.0500 \quad 0.0500 \quad D G$

$0.0300 \quad 0.0300 \quad D G$

$0.0300 \quad 0.0300 \quad D G$

$\begin{array}{lll}0.0300 & 0.0300 \quad D G\end{array}$

$0.0100 \quad 0.0100 \quad D G$

$0.0100 \quad 0.0100 \quad D G$

$0.0100 \quad 0.0100 \quad 06$

$0.0100 \quad 0.0100 \quad 0 G$

$0.0130 \quad 0.0130 \quad D G$

$0.0100 \quad 0.0100 \quad D G$

$0.0110 \quad 0.0110 \quad D G$

$0.0100 \quad 0.0100 \quad 06$

$0.0100 \quad 0.0100 \quad O G$

$0.0100 \quad 0.0100 \quad D G$

$1.0000 \quad 1.0000 \quad$ OG

$18.0000 \quad 1.0000 \quad$ OG

$1.0000 \quad 1.0000 \quad D G$

$1.0000 \quad 1.0000 \quad D G$
$0.0200 \quad 0.0200 \quad D G$

$0.0100 \quad 0.0100 \quad D G$ 
Follerup (60.13)

Kondukt iv itet

$\mathrm{pH} \quad \mathrm{PH}$

Inddampningsrest MG/L

Oxygen indhold $\mathrm{M6} / \mathrm{L}$

Carbondtoxid, aggr. M6/L

Hydrogencarbonat MG/L

Carbon,org, HYOC, filt MG/L

Permanganatta 1 KMnO4

Benzen

Toluen

Ameon iaktagon fum

Nitrit

Nitrat

Orthophosph.-P04, P11

Phosph., tot.pilt PO4

Aluminfun

Arsen

Bartum

Biy

Bor

Bromid

Cadulun

Calc lua

Chlor, org, AOX

Chlor,org, vox

Chlortd

Chrom

Cyanid

Fluorid

Jern

Jern ferro

Jod

Jodid

Kallum

Kobber

Lith tum

Magnestur

Mangan

Molybden

Natriun

Nikkel

sillefun, flit

Strontiun

Sulfat

Sulfid-s

Methan

Detergenter anion

Chloroform

Tetrach lorku Istof

Tetrach lorethylen
Enhed

MSIEMENS/M

G/L

$/ L$

$M G / L$

$\mathrm{MG} / \mathrm{L}$

MYGRAM/L

MYGRAM/L

MG/L

MG/L

MG/L

Mo/L

mo/L

MYGRAM/L

MYGRAM/L

MYGRAM/L

MYGRAM/L

MYGRAM/L

MYGRAM/L

MYGRAM/L

M6/L

MYGRAM/L

MYGRAM/L

MG/L

MYGRAM/L

MG/L

M6/L

M6/L

MG/L

MYGRAM/L

MYGRAM/L

MG/L

MYGRAM/L

MYGRAM/L

M6/L

MG/L

MYGRAM/L

MG/L

MYGRAM/L

MG/L

MYGRAM/L

MG/L

MG/L

MG/L

MG/L

MYGRAM/L

MYGRAM/L

MYGRAM/L
Vejle Amt

Grundvandsanalyser, 1990

Antal Gens Median Spredning Maximum Mintwum

$\begin{array}{rrrrrr}31 & 50.4194 & 51.0000 & 11.33 & 67.0000 & 18.0000 \\ 31 & 7.2742 & 7.4000 & 0.50 & 7.7000 & 5.6000\end{array}$

323.5484

330.0000

73.24

450.0000

120.0000

0.4414

0.2000

1.30

7.2000

0.2000

2.7500

6.24

24.0000

2.0000

226.1613

250.0000

78.76

320.0000

9.0000

1.0400

0.33

1.4000

0.7700

$276.45 \quad 1260.0000$

2.0000

0.3000

$0.3000 \quad$ DG

0.1000

0.1000 DG

0.2313

0.2000

0.19

0.8000

0.0100

0.0050 DG

$4.0000 \quad 1.0000$

0.01

0.0430

1.0000

0.2450

0.2269

8.50

38.0000

0.0460

0.3066

0.15

0.4906

0.1012

2.1000

0.12

0.5213

0.3000

3.6250

5.6000

4.58

10.0000

2.1000

169.5000

170.0000

3.34

10.0000

130.0000

0.2000

0.2000

208.0000

0.2000

79.2500

78.5000

.

0.2000

40.0000

88.5000

78.5000

35.34

120.0000

57.0000

0.0200

0.0200

19.0000

82.5161

79.0000

24.26

122.0000

1.4000

4.0000

0.5000

0.5000

16.0000

24.0645

19.0000

7.94

38.0000

0.3000

0.0020

0.0020

DG

0.2000

0.10

0.6400

0.1000

2.0000

0.69

3.4000

0.7600

1.6000

0.87

3.2000

0.0150

2.0000

2.35

6.7000

2.0000

4.1000

3.1000

2.07

7.2000

3.0000

2.2000

0.84

3.5000

1.0000

0.3500

0.14

0.6000

0.3000

10.6000

10.6000

7.7000

2.17

11.0000

2.5000

0.2900

0.11

0.4200

0.0100

1.4500

0.50

2.2000

1.0000

13.0000

2.88

18.0000

6.9000

0.4000

0.25

0.9000

0.4000

25.1355

28.0000

6.96

31.0000

4.3000

574.0000

638.0000

240.76

783.0000

237.0000

41.1613

30.0000

22.22

91.0000

14.0000

0.0200

0.01

0.0420

0.0180

0.0500

0.1200

0.0500

0.0100

0.0100

0.0100

0.0500

0.00

0.1500

0.0500

0.0500

0.0500

0.0500

0.0500 DG 
Follerup (60.13)

\begin{tabular}{|c|c|}
\hline Stof navn & Enhed \\
\hline Kondukt fvitet & MSIEMENS/M \\
\hline pH & PH \\
\hline Torstof, total & $M 6 / L$ \\
\hline Oxygen indhold & $M G / L$ \\
\hline Carbond 1oxid, aggr. & $M G / L$ \\
\hline Hydrogencarbonat & $M G / L$ \\
\hline Permanganatta I KMnO4 & $M G / L$ \\
\hline A & $M G / L$ \\
\hline Nitrit & $M G / L$ \\
\hline Nitrat & $M G / L$ \\
\hline Orthophosphat-P04 & $M G / L$ \\
\hline Phosph.,tot.filt P04 & $M G / L$ \\
\hline Calc tum & $M G / L$ \\
\hline Chlortd & $M G / L$ \\
\hline F luorid & MG/L \\
\hline Jern & $M G / L$ \\
\hline Jern ferro & $M G / L$ \\
\hline Ka H lum & $M G / L$ \\
\hline Magnes 1um & MG/L \\
\hline Mangan & $M G / L$ \\
\hline Matriua & $M G / L$ \\
\hline Stife luand toxid & $M G / L$ \\
\hline Sulfat & $M G / L$ \\
\hline Methan & $M G / L$ \\
\hline
\end{tabular}

Vejle Amt

Grundvandsanalyser, 1989

\begin{tabular}{|c|c|c|c|c|c|}
\hline Antal & Gens & Median & Spredning & Maximu: & M1nimum \\
\hline 19 & 51.9474 . & 50.0000 & 10.22 & 67.0000 & 20.0000 \\
\hline 19 & 7.2895 & 7.3000 & 0.30 & 7.5000 & 6.1000 \\
\hline 19 & 320.0000 & 310.0000 & 72.72 & 450.0000 & 110.0000 \\
\hline 19 & 0.5158 & 0.2000 & 1.28 & 5.8000 & 0.2000 \\
\hline 19 & 4.2632 & 2.0000 & 7.96 & 37.0000 & 2.0000 \\
\hline 19 & 244.5263 & 250.0000 & 65.01 & 330.0000 & 20.0000 \\
\hline 19 & 8.4632 & 6.2000 & 7.01 & 30.0000 & 2.0000 \\
\hline 19 & 0.3565 & 0.2200 & 0.49 & 2.3000 & 0.0270 \\
\hline 19 & 0.0245 & 0.0200 & 0.02 & 0.0620 & 0.0050 \\
\hline 19 & 4.3158 & 1.0000 & 9.27 & 40.0000 & 1.0000 \\
\hline 19 & 0.0864 & 0.0760 & 0.06 & 0.1800 & 0.0150 \\
\hline 17 & 0.5104 & 0.4293 & 0.45 & 2.0544 & 0.1840 \\
\hline 19 & 86.8421 & 81.0000 & 22.67 & 124.0000 & 23.0000 \\
\hline 19 & 21.8421 & 17.0000 & 6.91 & 34.0000 & 16.0000 \\
\hline 19 & 0.2121 & 0.2100 & 0.06 & 0.3500 & 0.1000 \\
\hline 17 & 5.0482 & 2.7000 & 5.54 & $20.7000^{*}$ & 1.7000 \\
\hline 19 & 1.9958 & 2.0000 & 1.22 & 4.8000 & 0.0200 \\
\hline 19 & 2.2316 & 2.4000 & 0.79 & 3.3000 & 1.0000 \\
\hline 19 & 7.8842 & 8.3000 & 2.19 & 12.0000 & 2.4000 \\
\hline 19 & 0.3132 & 0.3200 & 0.07 & 0.4000 & 0.2000 \\
\hline 19 & 13.5737 & 13.0000 & 2.56 & 18.1000 & 7.8000 \\
\hline 19 & 25.5789 & 28.0000 & 5.52 & 30.0000 & 7.0000 \\
\hline 19 & 42.7895 & 31.0000 & 24.50 & 100.0000 & 17.0000 \\
\hline 5 & 0.1000 & 0.1000 & 0.00 & 0.1000 & 0.1000 \\
\hline
\end{tabular}

* Særlig usædvanlig værdi, der må kontrolleres. 
Ejstrupholm (60.14)

\begin{tabular}{|c|c|c|c|c|}
\hline Stof navn & Enhed & Antal & Gens & Median \\
\hline Kondukt Ivitet & MSIERENS/M & 62 & 31.2419 & 30.5000 \\
\hline $\mathrm{pH}$ & PH & 62 & 6.1468 & 6.1000 \\
\hline Inddampn ingsrest & $M G / L$ & 62 & 219.3548 & 200.0000 \\
\hline Oxygen indhold & $M G / L$ & 61 & 4.4908 & 4.1000 \\
\hline Carbondioxid, aggr. & $M G / L$ & 58 & 27.2638 & 26.0000 \\
\hline Hydrogencarbonat & MG/L & 62 & 43.4694 & 24.5000 \\
\hline Carbon,org, NYoC, pllt & MG/L & 4 & 1.0550 & 0.8500 \\
\hline Permanganattal KMnO4 & $M G / L$ & 62 & 43.5435 & 8.5500 \\
\hline Benzen & MYGRAM/L & 4 & & \\
\hline Toluen & MYGRAM/L & 4 & & \\
\hline Almon faktabnon fua & $M G / L$ & 62 & 0.0414 & 0.0250 \\
\hline Nitrit & $M G / L$ & 62 & 0.0119 & 0.0050 \\
\hline Nitrat & $M G / L$ & 62 & 36.9516 & 26.5000 \\
\hline Orthophosph.-P04,f11 & MG/L & 62 & 0.0758 & 0.0460 \\
\hline Phosph., tot.filt P04 & $M G / L$ & 30 & 0.0854 & 0.0705 \\
\hline Alumintum & MYGRAM/L & 3 & 208.3333 & 135.0000 \\
\hline Arsen & MYGRAM/L & 4 & 1.4500 & 1.1500 \\
\hline Bartum & MYGRAM/L & 3 & 101.6667 & 74.0000 \\
\hline Bly & MYGRAM/L & 4 & 0.2925 & 0.2000 \\
\hline Bor & MYERAM/L & 4 & 50.2500 & 48.0000 \\
\hline Bromid & MYGRAM/L & 4 & 90.5000 & 86.5000 \\
\hline Cadintum & MYGRAM/L & 4 & 0.1125 & 0.0400 \\
\hline Calc lum & $M G / L$ & 62 & 35.1290 & 34.5000 \\
\hline Chlor, org, AOX & MYGRAM/L & 4 & 14.1750 & 2.2000 \\
\hline Ch lor,org, vox & MYGRAM/L & 4 & & \\
\hline Chlortd & $M G / L$ & 62 & 25.1774 & 23.5000 \\
\hline Chron & MYGRAM/L & 4 & 1.0750 & 1.0000 \\
\hline Cyanid & $M G / L$ & 4 & & \\
\hline Fluorid & $M G / L$ & 62 & 0.1092 & 0.1000 \\
\hline Jern & $M G / L$ & 30 & 0.3419 & 0.2850 \\
\hline Jern ferro & $M G / L$ & 62 & 0.5210 & 0.1250 \\
\hline Jod & MYGRAM/L* & 4 & 5.2250 & 2.8000 \\
\hline Jodid & MYGRAM/L & 4 & 3.0750 & 3.0500 \\
\hline Kallun & $M G / L$ & 62 & 2.3302 & 1.4000 \\
\hline Kobber & MYGRAM/L & 4 & 0.3000 & 0.3000 \\
\hline Lith 1um & MYGRAM/L & 3 & 3.4667 & 3.1000 \\
\hline Magnes fun & $M G / L$ & 62 & 5.9387 & 5.0500 \\
\hline Mangan & $M 6 / L$ & 62 & 0.0721 & 0.0400 \\
\hline Mo lybdzen & MYGRAM/L & 3 & 0.4000 & 0.3000 \\
\hline Matr ium & $M G / L$ & 62 & 12.0419 & 11.0000 \\
\hline N1kke\} & MYGRAM/L & 4 & 2.2000 & 2.4500 \\
\hline Silictua,flit & MG/L & 62 & 12.0548 & 10.0000 \\
\hline Stront fun & MYGRAM/L & 4 & 177.5000 & .170 .0000 \\
\hline Sulfat & $M G / L$ & 62 & 39.9677 & 34.5000 \\
\hline Sulf 1d-s & $M 6 / L$ & 30 & 0.0270 & 0.0200 \\
\hline Methan & $M G / L$ & 60 & 0.0490 & 0.0500 \\
\hline Detergenter anton & $146 / \mathrm{L}$ & 4 & 0.0275 & 0.0250 \\
\hline Chloroform & MYGRAM/L & 4 & & \\
\hline Tetrach lorku lstof & MYGRAM/L & 4 & & \\
\hline Tetrach lorethylen & MYGRAM/L & 4 & & \\
\hline
\end{tabular}

Grundvandsanalyser, 1990

Vejle Amt

Spredning

8.25

0.73

124.96

4.02

12.40

46.73

0.81

100.51

$$
\text { 100. }
$$

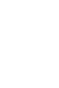

Maxinum

Mininum

$$
49.0000
$$

14.0000

$$
7.2000
$$

* Særlig usædvanlig værdi, der må kontrolleres. 


\section{Ejstrupholm (60.14)}

\begin{tabular}{|c|c|}
\hline Stof navn & Enhed \\
\hline Trich lorethylen & MYGRAM/L \\
\hline $1,1,1-\operatorname{tr}$ ich lorethan & MYGRAM/L \\
\hline P-xylen & MYGRAM/L \\
\hline$M-x y l e n$ & MYGRAM/L \\
\hline 0 -xylen & MYGRAM/L \\
\hline Naphtha len & MYGRAM/L \\
\hline Phenol & MYGRAM/L \\
\hline 3-methylphenol & MYGRAM/L \\
\hline 2.3 diwethylphenol & MYGRAM/L \\
\hline 2-wethylphenol & MYGRAM/L \\
\hline 4-methylphenol & MYGRAM/L \\
\hline 3,4-d imethylphenol & MYGRAM/L \\
\hline 3,5-diwethylphenol & MYGRAM/L \\
\hline 2,6-d imethylphenol & MYGRAM/L \\
\hline 2,4-d twethylphenol & MYGRAM/L \\
\hline 4-c lor, 2-methy lpheno & MYGRAM/L \\
\hline 6-clor, 2-methy lpheno & MYGRAM/L \\
\hline 2,4-d1c lorphenol & MYGRAM/L \\
\hline 4,6-dic lor, 2-methy lp & MYGRAM/L \\
\hline 2,6-dic lorphenol & MYGRAM/L \\
\hline 2,4,6-tric lorpheno & MYGRAH/L \\
\hline 2.3.4,6-tetrac lorphe & MYGRAM/L. \\
\hline 2,3,5,6-tetrac lorphe & MYGRAM/L \\
\hline $2,3,4,5$-tetrac lorphe & MYGRAM/L \\
\hline Pentrac lorphenol & MYGRAM/L \\
\hline Dich lorprop & MYGRAM/L \\
\hline MCPA & MYGRAM/L \\
\hline Mech lorprop & MYGRAM/L \\
\hline OHOC & MYGRAM/L \\
\hline Oinoseb & MYGRAM/L \\
\hline Atraz in & MYGRAM/L \\
\hline Simazin & MYGRAM/L \\
\hline Kintal 376r. PCA & ANTAL/ML \\
\hline Kintal 27Gr. KING B & ANTAL/ML \\
\hline --Coliforme Bakt. MP & AMTAL $/ 100$ \\
\hline
\end{tabular}

Vejle Amt

$\begin{array}{ll}\text { Antal } & \text { Gens } \\ & \\ 4 & \\ 4 & \\ 4 & \\ 4 & \\ 4 \\ 4 \\ 4 \\ 2 \\ 4 \\ 4 \\ 2 \\ 4 \\ 3 \\ 4 \\ 7 \\ 4 \\ 3 \\ 3 \\ 4 \\ 4 \\ 3 \\ 4 \\ 4 \\ 4 \\ 4 \\ 4 \\ 4 \\ 4 \\ 4 \\ 4 \\ 4 \\ 4 \\ 4 \\ 4 \\ 4 \\ 4 \\ 4 \\ 4 \\ 4 \\ 4 \\ 4 \\ 4 \\ 4\end{array}$

Grundvandsanalyser, 1990

Median Spredning Maximum Mininum.

\begin{tabular}{lll}
0.0500 & 0.0500 & $D G$ \\
0.0500 & 0.0500 & $D G$ \\
0.1000 & 0.1000 & $D G$ \\
0.1000 & 0.1000 & $O G$ \\
0.1000 & 0.1000 & $D G$ \\
0.1000 & 0.1000 & $D G$ \\
0.0300 & 0.0300 & $D G$ \\
0.0300 & 0.0300 & $O G$ \\
0.0300 & 0.0300 & $D G$ \\
0.0300 & 0.0300 & $D G$ \\
0.0300 & 0.0300 & $D G$ \\
0.0300 & 0.0300 & $D G$ \\
0.0300 & 0.0300 & $O G$ \\
0.0300 & 0.0300 & $D G$ \\
0.0300 & 0.0300 & $D G$ \\
0.0500 & 0.0500 & $O G$ \\
0.0500 & 0.0500 & $D G$ \\
0.0300 & 0.0300 & $D G$ \\
0.0300 & 0.0300 & $D G$ \\
0.0300 & 0.0300 & $D G$ \\
0.0100 & 0.0100 & $D G$ \\
0.0100 & 0.0100 & $D G$ \\
0.0100 & 0.0100 & $D G$ \\
0.0100 & 0.0100 & $D G$ \\
0.0200 & 0.0200 & $O G$ \\
0.0100 & 0.0100 & $D G$ \\
0.0100 & 0.0100 & $D G$ \\
0.0100 & 0.0100 & $D G$ \\
0.0100 & 0.0100 & $D G$ \\
0.0100 & 0.0100 & $D G$ \\
0.0100 & 0.0100 & $D G$ \\
0.0100 & 0.0100 & $D G$ \\
2.0000 & 1.0000 & $D G$ \\
\hline 00.0000 & 1.0000 & $D G$ \\
& 1.0000 & $D G$ \\
\hline
\end{tabular}


Ejstrupholm (60.14)

\begin{tabular}{|c|c|}
\hline Stof navn & Enhed \\
\hline Kondukt ivitet & MSIEMENS/M \\
\hline pH & PH \\
\hline Torstof, total & $116 / L$ \\
\hline Oxygen indhold & $M G / L$ \\
\hline Carbondtoxtd, agor. & $M G / L$ \\
\hline Hydrogencarbonat & $M G / L$ \\
\hline Permanganatta $1 \mathrm{KMnO4}$ & $M G / L$ \\
\hline Amson taktamen tua & $M 6 / L$ \\
\hline NAtrit & $M G / L$ \\
\hline Mitrat & $M G / L$ \\
\hline Orthophosphat-P04 & $M G / L$ \\
\hline Phosph.,tot.f11t PO4 & $M G / L$ \\
\hline Calctun & $M G / L$ \\
\hline Chlorid & $M G / L$ \\
\hline Fluortd & $\mathrm{MG} / \mathrm{L}$ \\
\hline Jern & $M G / L$ \\
\hline Jern ferro & MG/L \\
\hline Kalium & $M G / L$ \\
\hline Magnesfum & $M G / L$ \\
\hline Mangan & $M G / L$ \\
\hline Natr fu= & $M G / L$ \\
\hline Siltciund toxtd & $M G / L$ \\
\hline Sulfat & $M G / L$ \\
\hline
\end{tabular}

\section{Vejle Amt}

Grundvandsanalyser, 1989

\begin{tabular}{|c|c|c|c|c|c|}
\hline Antal & Gens & Median & Spredning & Maximum & Minimum \\
\hline 11 & 35.0000 . & 34.0000 & 9.40 & 48.0000 & 23.0000 \\
\hline 11 & 6.4455 & 6.3000 & 0.56 & 7.3000 & 5.8000 \\
\hline 11 & 223.6364 & 220.0000 & 56.79 & 310.0000 & 150.0000 \\
\hline 11 & 4.5636 & 4.0000 & 4.52 & 11.0000 & 0.2000 \\
\hline 11 & 24.8182 & 21.0000 & 13.14 & 52.0000 & 5.0000 \\
\hline 11 & 60.4545 & 40.0000 & 54.92 & 180.0000 & 9.0000 \\
\hline 11 & 43.3364 & 7.3000 & 63.10 & 190.0000 & 2.0000 \\
\hline 11 & 0.1566 & 0.0596 & 0.28 & 0.9691 & 0.0097 \\
\hline 11 & 0.2191 & 0.0120 & 0.63 & 2.1000 & 0.0050 \\
\hline 11 & 45.1818 & 46.0000 & 45.49 & 130.0000 & 1.0000 \\
\hline 11 & 0.0174 & 0.0150 & 0.00 & 0.0250 & 0.0150 \\
\hline 5 & 0.0675 & 0.0613 & 0.03 & 0.0920 & 0.0307 \\
\hline 11 & 40.3636 & 36.0000 & 15.84 & 73.0000 & 17.0000 \\
\hline 11 & 25.4545 & 24.0000 & 8.81 & 43.0000 & 15.0000 \\
\hline 11 & 0.1100 & 0.1000 & 0.02 & 0.1700 & 0.1000 \\
\hline 5 & 0.4500 & 0.5100 & 0.37 & 0.8100 & 0.0400 \\
\hline 8 & 0.9213 & 0.6600 & 1.04 & 3.2000 & 0.0200 \\
\hline 7 & 2.2286 & 2.6000 & 0.92 & 3.2000 & 1.2000 \\
\hline 11 & 8.0273 & 6.9000 & 4.99 & 17.0000 & 2.1000 \\
\hline 11 & 0.1900 & 0.1000 & 0.21 & 0.6700 & 0.0100 \\
\hline 11 & 13.1727 & 12.2000 & 5.06 & 24.6000 & 9.3000 \\
\hline 11 & 12.9091 & 12.0000 & 4.06 & 20.0000 & 8.0000 \\
\hline 11 & 41.4545 & 32.0000 & 15.71 & 78.0000 & 25.0000 \\
\hline
\end{tabular}


Brande (65.11)

\begin{tabular}{|c|c|}
\hline Stof navn & Enhed \\
\hline Kondukt ivitet & MSIEMENS/M \\
\hline $\mathrm{pH}$ & PH \\
\hline Torstof, tota 1 & MG/L \\
\hline Oxygen indhold & MG/L \\
\hline Carbonat & $M G / L$ \\
\hline Carbondioxto, aggr. & MG/L \\
\hline Hydrogencarbonat & MG/L \\
\hline Kem.fltf. KIF,total & MG/L \\
\hline Permanganattal KMnO4 & $M G / L$ \\
\hline Amwon fak tarmon fum & $M G / L$ \\
\hline Nitrit & $M G / L$ \\
\hline Nitrat & MG/L \\
\hline Orthophosphat-PO4 & $M G / L$ \\
\hline Phosph., tot.f 11 PO4 & MG/L \\
\hline Calctum & $M G / L$ \\
\hline Chlorid & $M G / L$ \\
\hline Fluor 1d & $M G / L$ \\
\hline Jern & $M G / L$ \\
\hline Jern ferro & $M G / L$ \\
\hline Ka l tum & $M G / L$ \\
\hline Magnes ium & $M G / L$ \\
\hline Mangan & $M G / L$ \\
\hline Matrium & $M G / L$ \\
\hline Stliciumdioxtd & $M G / L$ \\
\hline Sulfat & $M G / L$ \\
\hline Sulfid-s & $M G / L$ \\
\hline Methan & $M G / L$ \\
\hline
\end{tabular}

Ringkøbing Amt Grundvandsanalyser, 1990

\begin{tabular}{|c|c|c|c|c|c|}
\hline Anta 1 & Gens & Median & Spredning & Max Imun & Min 1mum \\
\hline 51 & 25.6667 & 25.0000 & 4.87 & 36.0000 & 19.0000 \\
\hline 51 & 6.3241 & 6.6000 & 0.86 & 7.5000 & 4.4000 \\
\hline 51 & 178.7451 & 170.0000 & 43.56 & 290.0000 & 107.0000 \\
\hline 51 & 0.7518 & 0.1900 & 2.17 & 9.8000 & 0.0700 \\
\hline 51 & 0.1000 & 0.1000 & 0.00 & 0.1000 & 0.1000 \\
\hline 51 & 29.4098 & 29.0000 & 14.65 & 60.0000 & 3.7000 \\
\hline 50 & 55.1224 & 63.5000 & 38.29 & 110.0000 & 0.0100 \\
\hline 51 & 2.7608 & 2.1000 & 2.35 & 13.0000 & 1.0000 \\
\hline 51 & 10.8647 & 8.3000 & 9.22 & 50.0000 & 4.0000 \\
\hline 51 & 0.0794 & 0.0600 & 0.06 & 0.2500 & 0.0100 \\
\hline 51 & 0.0129 & 0.0100 & 0.01 & 0.1000 & 0.0100 \\
\hline 51 & 3.0300 & 0.0100 & 9.10 & 42.0000 & 0.0100 \\
\hline 51 & 0.1251 & 0.0800 & 0.11 & 0.4900 & 0.0100 \\
\hline 51 & 0.2249 & 0.2146 & 0.16 & 0.5826 & 0.0307 \\
\hline 51 & 28.5490 & 29.0000 & 6.12 & 40.0000 & 16.0000 \\
\hline 51 & 21.4863 & 21.0000 & 7.29 & 37.0000 & 8.9000 \\
\hline 51 & 0.1096 & 0.1000 & 0.02 & 0.1800 & 0.1000 \\
\hline 51 & 5.3535 & 2.8000 & 5.47 & 20.0000 & 0.1600 \\
\hline 47 & 4.9334 & 2.5000 & 5.19 & 19.0000 & 0.0300 \\
\hline 51 & 2.4725 & 1.6000 & 2.57 & 9.5000 & 1.0000 \\
\hline 51 & 3.2804 & 2.7000 & 1.57 & 7.8000 & 1.4000 \\
\hline 51 & 0.2708 & 0.2100 & 0.20 & 0.7700 & 0.0300 \\
\hline 51 & 10.6529 & 11.0000 & 2.15 & 18.0000 & 7.2000 \\
\hline 3 & 7.0667 & 7.3000 & 0.78 & 7.7000 & 6.2000 \\
\hline 51 & 44.9745 & 41.0000 & 27.58 & 100.0000 & 6.3000 \\
\hline 41 & 0.2000 & 0.2000 & 0.00 & 0.2000 & 0.2000 \\
\hline 44 & 0.1000 & 0.1000 & 0.00 & 0.1000 & 0.1000 \\
\hline
\end{tabular}




\section{Haderup (65.12)}

\begin{tabular}{|c|c|}
\hline Stof navn & Enhed \\
\hline Kondukt iv itet & MSIEMENS/M \\
\hline pH & PH \\
\hline Terstof, total & $46 / L$ \\
\hline Oxygen indhold & $M G / L$ \\
\hline Carbonat & $M G / L$ \\
\hline Carbondtoxid, aggr. & $M G / L$ \\
\hline Hydrogencarbonat & $M G / L$ \\
\hline Kem.11tf. KIF, tota? & $M G / L$ \\
\hline Permanganatta 1 KMnO4 & $M G / L$ \\
\hline Amson tak +amenon fum & MG/L \\
\hline Nitrit & $M G / L$ \\
\hline Nitrat & $M G / L$ \\
\hline Ortnophosphat-P04 & M6/L \\
\hline Phosph., tot.ftlt POA & MG/L \\
\hline Calcitum & MG/L \\
\hline Cnlorid & $M G / L$ \\
\hline Fluorid & $M G / L$ \\
\hline Jern & $M G / L$ \\
\hline Jern ferro & $M G / L$ \\
\hline Kalium & $M G / L$ \\
\hline Magnes full & $M G / L$ \\
\hline Mangan & MG/L \\
\hline Natrium & MG/L \\
\hline Sulfat & $M G / L$ \\
\hline Sulf 1d-s & $M G / L$ \\
\hline Methan & $M G / L$ \\
\hline
\end{tabular}

\section{Ringkøbing Amt}

Anta 1

32

31

32

32

26$$
32
$$

32$$
3
$$

3

3

\begin{tabular}{|c|c|c|c|c|}
\hline Gens & Median & Spredning & Maximum & MIn Imum \\
\hline 37.1250 & 37.0000 & 7.29 & 53.0000 & 25.0000 \\
\hline 6.9484 & 7.4000 & 0.95 & 7.6000 & 4.6000 \\
\hline 276.0625 & 265.0000 & 53.43 & 426.0000 & 190.0000 \\
\hline 0.9188 & 0.1500 & 1.50 & 4.7000 & 0.0800 \\
\hline 0.0931 & 0.1000 & 0.02 & 0.1000 & 0.0100 \\
\hline 9.1125 & 4.4500 & 9.29 & 28.0000 & 2.0000 \\
\hline 143.1603 & 160.0000 & 82.69 & 230.0000 & 0.1000 \\
\hline 2.2188 & 1.2000 & 1.93 & 8.1000 & 1.0000 \\
\hline 8.7563 & 4.7500 & 7.68 & 32.0000 & 4.0000 \\
\hline 0.0969 & 0.1000 & 0.07 & 0.2400 & 0.0100 \\
\hline 0.0231 & 0.0100 & 0.04 & 0.1600 & 0.0100 \\
\hline 13.8584 & 0.0200 & 28.41 & 87.0000 & 0.0100 \\
\hline 0.0791 & 0.0450 & 0.08 & 0.3200 & 0.0100 \\
\hline 0.6046 & 0.7359 & 0.33 & 1.0118 & 0.0307 \\
\hline 56.3750 & 57.5000 & 16.87 & 86.0000 & 27.0000 \\
\hline 22.3438 & 19.5000 & 7.74 & 39.0000 & 15.0000 \\
\hline 0.1203 & 0.1200 & 0.02 & 0.2000 & 0.1000 \\
\hline 2.8616 & 3.0000 & 1.62 & 5.5000 & 0.3000 \\
\hline 2.2138 & 2.5500 & 1.54 & 5.4000 & 0.0300 \\
\hline 3.9344 & 1.2500 & 4.85 & 14.0000 & 1.0000 \\
\hline 4.3031 & 4.4000 & 0.78 & 5.6000 & 2.6000 \\
\hline 0.6556 & 0.6000 & 0.40 & 1.6000 & 0.1800 \\
\hline 11.8000 & 12.0000 & 2.09 & 17.0000 & 7.2000 \\
\hline 33.4281 & 16.0000 & 30.99 & 110.0000 & 9.7000 \\
\hline 0.2000 & 0.2000 & 0.00 & 0.2000 & 0.2000 \\
\hline 0.0972 & 0.1000 & 0.01 & 0.1000 & 0.0200 \\
\hline
\end{tabular}




\section{Herborg (65.13)}

Kondukt ivitet

Enhed

MSIEMENS/M

pH

Torstor, total

PH

Oxygen indhold

MG/L

Carbonat

MG/L

Carbondioxid, aggr. MG/L

Hydrogencarbonat MG/L

Kem.11tf . KIF,total MG/L

Peraanganattal KMnO4 MG/L

Amon faktamon fum $\quad \mathrm{MG} / \mathrm{L}$

Nitrit MG/L

Nitrat MG/L

Orthophosphat-P04 MG/L

Phosph., tot.filt PO4 MG/L

Calctum MG/L

Chlorid

fluorid

Jern

Jern ferro

kaltum

Magnes tua

Mangan

Notrium

Sulfat

Sulfid-s

Methan

\section{Ringkøbing Amt}

Anta 1

Gens

31.7500 .

5.3900

228.1000

1.2621

0.0910

62.7625

29.2200

2.0500

8.0625

0.0525

0.0105

5.2795

0.0353

0.0828

24.8575

25.9250

0.1007

2.9358

2.6245

10.1125

5.6850

0.1203

18.4000

76.0500

0.2000

0.1000
Grundvandsanalyser, 1990

Median Spredning

Maxinun

Mtntaun

32.5000

10.61

57.0000

15.0000

5.1000

0.85

7.5000

4.0000

225.0000

69.37

390.0000

112.0000

0.3150

2.25

9.6000

0.1100

0.1000

0.03

0.1000

0.0100

68.5000

22.12

88.0000

2.0000

4.5500

57.66

197.0000

1.0000

1.7500

1.11

5.1000

1.0000

6.7500

4.37

20.0000

4.0000

0.0500

0.04

0.1800

$0.0100 \quad D G$

0.0100

0.00

0.0300

$0.0100 \quad 0 G$

0.2550

10.10

33.0000

$0.0100 \quad D G$

0.0200

0.04

0.2200

$0.0100 \quad D G$

0.0307

0.08

0.2760

0.0307

21.0000

23.78

95.0000

3.2000

26.0000

5.08

42.0000

17.0000

0.1000

0.00

0.1200

0.1000

2.4000

2.50

8.8000

0.0500

2.1500

2.47

8.8000

0.0300

8.8500

8.19

24.0000

1.0000

4.6000

2.48

12.0000

2.8000

0.1100

0.05

0.2400

0.0500

17.0000

5.98

32.0000

8.0000

74.5000

32.36

140.0000

23.0000

0.2000

0.00

0.2000

0.2000

0.1000

0.00

0.1000

0.1000 
Finderup (65.14)

\begin{tabular}{|c|c|}
\hline Stof navn & Enhed \\
\hline Kondukt ivitet & MSIEMENS/M \\
\hline pH & PH \\
\hline Terstof, total & $M G / L$ \\
\hline oxygen indhold & $M 6 / L$ \\
\hline Carbonat & $M G / L$ \\
\hline Carbond10xid, aggr. & $M G / L$ \\
\hline Hydrogencarbonat & $M G / L$ \\
\hline Kem.11t\}. XIF,total & $M G / L$ \\
\hline Permanganatta) KMnO4 & $M G / L$ \\
\hline Amonon fak tamon ium & $M G / L$ \\
\hline N1trit & $M G / L$ \\
\hline Nitrat & $M G / L$ \\
\hline Orthophosphat-P04 & $M G / L$ \\
\hline Phosph..tot.filt PO4 & $M G / L$ \\
\hline Calc lus & $M G / L$ \\
\hline chlorita & $M G / L$ \\
\hline F luor id & $M G / L$ \\
\hline Jern & 146/L \\
\hline Jern ferro & $M G / L$ \\
\hline Kalluw & MG/L \\
\hline Magnes fum & $M G / L$ \\
\hline Mangan & $M G / L$ \\
\hline Natr fum & $M G / L$ \\
\hline Sulfat & $M G / L$ \\
\hline Sulfid-s & $M G / L$ \\
\hline Methan & $M G / L$ \\
\hline
\end{tabular}

\section{Ringkøbing Amt Grundvandsanalyser, 1990}

\begin{tabular}{|c|c|c|c|c|c|}
\hline Antal & Gens & Median & Spredntng & Max tmum & M4n imum \\
\hline 42 & 34.7143 . & 33.0000 & 9.55 & 54.0000 & 21.0000 \\
\hline 42 & 6.2810 & 6.3000 & 0.94 & 8.0000 & 4.8000 \\
\hline 42 & 253.8333 & 265.0000 & 84.97 & 530.0000 & 150.0000 \\
\hline 40 & 7.4175 & 7.7500 & 3.89 & 13.0000 & 0.0700 \\
\hline 42 & 0.0979 & 0.1000 & 0.01 & 0.1000 & 0.0100 \\
\hline 41 & 29.7822 & 32.0000 & 20.85 & 65.0000 & 0.5500 \\
\hline 41 & 80.0073 & 28.0000 & 91.85 & 260.0000 & 1.9000 \\
\hline 42 & 1.1024 & 1.0000 & 0.27 & 2.2000 & 1.0000 \\
\hline 42 & 4.3905 & 4.0000 & 1.03 & 8.5000 & 4.0000 \\
\hline 42 & 0.0379 & 0.0100 & 0.05 & 0.1800 & 0.0100 \\
\hline 42 & 0.0124 & 0.0100 & 0.01 & 0.0800 & 0.0100 \\
\hline 42 & 46.0505 & 45.5000 & 36.68 & 120.0000 & 0.0100 \\
\hline 39 & 0.0479 & 0.0200 & 0.08 & 0.3400 & 0.0100 \\
\hline 42 & 0.2051 & 0.0613 & 0.52 & 3.3728 & 0.0307 \\
\hline 42 & 35.4667 & 31.0000 & 23.78 & 82.0000 & 2.6000 \\
\hline 42 & 29.3333 & 26.5000 & 9.86 & 55.0000 & 19.0000 \\
\hline 42 & 0.1055 & 0.1000 & 0.02 & 0.1700 & 0.1000 \\
\hline 42 & 0.8864 & 0.3200 & 1.33 & 7.5000 & 0.0300 \\
\hline 41 & 0.2732 & 0.0300 & 0.55 & 2.0000 & 0.0200 \\
\hline 42 & 3.5048 & 2.2000 & 2.88 & 11.0000 & 1.3000 \\
\hline 42 & 6.8890 & 6.2000 & 3.51 & 14.0000 & 0.2400 \\
\hline 42 & 0.2170 & 0.0500 & 0.69 & 4.5000 & 0.0100 \\
\hline 42 & 18.6119 & 16.0000 & 7.39 & 41.0000 & 8.6000 \\
\hline 42 & 23.0095 & 23.0000 & 8.57 & 46.0000 & 6.3000 \\
\hline 37 & 0.2000 & 0.2000 & 0.00 & 0.2000 & 0.2000 \\
\hline 37 & 0.1000 & 0.1000 & 0.00 & 0.1000 & 0.1000 \\
\hline
\end{tabular}


Kastbjerg (70.01)

\begin{tabular}{|c|c|}
\hline Stof navn & Enhed \\
\hline Kondukt ivitet & MSIEMENS/M \\
\hline $\mathrm{pH}$ & PH \\
\hline Torstof, flitrat & $G / L$ \\
\hline Oxygen indhold & $M G / L$ \\
\hline Carbondioxid, aggr. & $M G / L$ \\
\hline Hydrogencarbonat & $M G / L$ \\
\hline Carbon,org, HVOC & $M G / L$ \\
\hline Permanganatta $1 \mathrm{KMnO4}$ & $M G / L$ \\
\hline Ammon tak tamanon 1 um & $M G / L$ \\
\hline Nitrit & $M G / L$ \\
\hline N1trat & $M G / L$ \\
\hline Phosph., tot.filt P04 & $M G / L$ \\
\hline Calctum & $M G / L$ \\
\hline Chlorido & $\mathrm{MG} / \mathrm{L}$ \\
\hline Fluorid & $M G / L$ \\
\hline Jern & $M G / L$ \\
\hline Kalfum & $M G / L$ \\
\hline Magnesium & $M G / L$ \\
\hline Mangan & $M G / L$ \\
\hline Natrium & $M G / L$ \\
\hline Nikkel & MYGRAM/L \\
\hline Sulfat & $M G / L$ \\
\hline
\end{tabular}

\section{Århus Amt}

Grundvandsanalyser, 1990

\begin{tabular}{|c|c|c|c|c|c|}
\hline Antal & Gens & Median & Spredning & Maximug & Min 1mum \\
\hline 13 & 47.4231 & 42.2000 & 8.69 & 65.8000 & 39.3000 \\
\hline 13 & 7.9692 & 8.1000 & 0.21 & 8.2000 & 7.6000 \\
\hline 13 & 0.3115 & 0.2900 & 0.06 & 0.4300 & 0.2400 \\
\hline 12 & 3.7333 & 1.5500 & 4.62 & 12.9000 & 0.1000 \\
\hline 11 & 2.0000 & 2.0000 & 0.00 & 2.0000 & 2.0000 \\
\hline 12 & 192.4167 & 210.0000 & 58.97 & 322.0000 & 122.0000 \\
\hline 12 & 0.7817 & 0.8450 & 0.29 & 1.2300 & 0.3200 \\
\hline 13 & 4.7692 & 4.0000 & 2.49 & 13.0000 & 4.0000 \\
\hline 13 & 0.0723 & 0.0400 & 0.07 & 0.1700 & 0.0100 \\
\hline 13 & 0.0238 & 0.0100 & 0.04 & 0.1700 & 0.0100 \\
\hline 13 & 4.8423 & 3.3000 & 5.87 & 20.0000 & 0.0100 \\
\hline 13 & 0.1958 & 0.1441 & 0.24 & 0.8923 & 0.0184 \\
\hline 12 & 78.3333 & 69.0000 & 27.27 & 160.0000 & 61.0000 \\
\hline 13 & 34.1538 & 35.0000 & 16.14 & 73.0000 & 13.0000 \\
\hline 13 & 0.1562 & 0.1400 & 0.09 & 0.4000 & 0.0500 \\
\hline 12 & 0.4200 & 0.2500 & 0.47 & 1.5000 & 0.0200 \\
\hline 12 & 1.4883 & 1.4000 & 0.68 & 2.9000 & 0.6300 \\
\hline 12 & 6.6417 & 5.8500 & 3.40 & 15.0000 & 3.6000 \\
\hline 12 & 0.0317 & 0.0250 & 0.02 & 0.0700 & 0.0200 \\
\hline 12 & 11.5750 & 11.0000 & 3.57 & 21.0000 & 8.1000 \\
\hline 13 & 2.1538 & 2.0000 & 0.55 & 4.0000 & 2.0000 \\
\hline 13 & 39.0769 & 31.0000 & 23.06 & 79.0000 & 14.0000 \\
\hline
\end{tabular}


Kasted (70.02)

Stof navn

Kondukt ivitet

Enhed

pH

Turbiditet

Farvetal-Pt

Inddampningsrest

Oxygen indhold

Hydrogencarbonat

Carbon, org, NVOC

Peraanganattal KMnO4

Amson tak takmon ium

Nitrit

Nitrat

Phosph..tot.f11t P04

Calc tua

chlorid

Fluorid

Jern

Jern ferro

Ka lium

Magnesium

Mangan

Natr 1um

Nikkel

Sulfat

K imtal $1376 \mathrm{r}$. PCA

Ktmtal $216 r$. KING B

Collforme bakt. $37 \mathrm{Gr}$.
MSIEMENS/M

PH

FTU

PPH

MG/L

MG/L

MG/L

MG/L

$M G / L$

MG/L

MG/L

MG/L

MG/L

MG/L

MG/L

MG/L

MG/L

MG/L

MG/L

MG/L

MG/L

M6/L

MYGRAM/L

MG/L

ANTAL/ML

ANTAL/ML

ANTAL/100 ML
Århus Amt

\section{Grundvandsanalyser, 1990}

\begin{tabular}{|c|c|c|c|c|c|}
\hline Antal & Gens & Median & Spredning & Maximug & Minimum \\
\hline 15 & 62.6667 & 62.0000 & 8.52 & 81.0000 & 46.0000 \\
\hline 15 & 7.6600 & 7.6000 & 0.13 & 8.0000 & 7.5000 \\
\hline 15 & 13.9600 & 2.5000 & 24.02 & 78.0000 & 1.2000 \\
\hline 15 & 8.4000 & 7.0000 & 3.91 & 20.0000 & 5.0000 \\
\hline 15 & 412.2000 & 425.0000 & 73.02 & 540.0000 & 297.0000 \\
\hline 12 & 1.0000 & 0.4500 & 2.21 & 8.0000 & 0.1000 \\
\hline 15 & 267.2000 & 262.0000 & 28.32 & 335.0000 & 214.0000 \\
\hline 13 & 1.4969 & 1.2100 & 0.86 & 4.0000 & 0.8100 \\
\hline 15 & 9.0733 & 8.7000 & 5.63 & 19.0000 & 4.0000 \\
\hline 15 & 0.1387 & 0.1000 & 0.17 & 0.6100 & 0.0100 \\
\hline 15 & 0.0780 & 0.0100 & 0.20 & 0.7600 & 0.0100 \\
\hline 15 & 10.1067 & 1.0000 & 21.92 & 84.0000 & 1.0000 \\
\hline 15 & 0.3620 & 0.3066 & 0.29 & 1.1345 & 0.0429 \\
\hline 15 & 100.3333 & 104.0000 & 21.25 & 130.0000 & 55.0000 \\
\hline 15 & 34.0667 & 32.0000 & 11.54 & 64.0000 & 19.0000 \\
\hline 15 & 0.1587 & 0.1400 & 0.04 & 0.2700 & 0.1200 \\
\hline 15 & 1.1227 & 1.0000 & 0.76 & 2.7000 & 0.0500 \\
\hline 15 & 0.7433 & 0.3200 & 0.76 & 2.0000 & 0.0100 \\
\hline 15 & 2.6467 & 3.0000 & 0.88 & 4.0000 & 1.4000 \\
\hline 15 & 8.5933 & 9.6000 & 1.91 & 11.0000 & 5.2000 \\
\hline 18 & 0.1900 & 0.1800 & 0.11 & 0.5000 & 0.0100 \\
\hline 15 & 23.3333 & 18.0000 & 15.07 & 71.0000 & 13.0000 \\
\hline 15 & 3.0267 & 3.0000 & 0.10 & 3.4000 & 3.0000 \\
\hline 15 & 76.0000 & 76.0000 & 37.16 & 127.0000 & 18.0000 \\
\hline 8 & 3.1250 & 1.0000 & 5.22 & 16.0000 & 1.0000 \\
\hline 8 & 110.8750 & 80.0000 & 116.47 & 370.0000 & 14.0000 \\
\hline 2 & 3.0000 & 3.0000 & 2.83 & 5.0000 & 1.0000 \\
\hline
\end{tabular}


Nordsamsø (70.11)

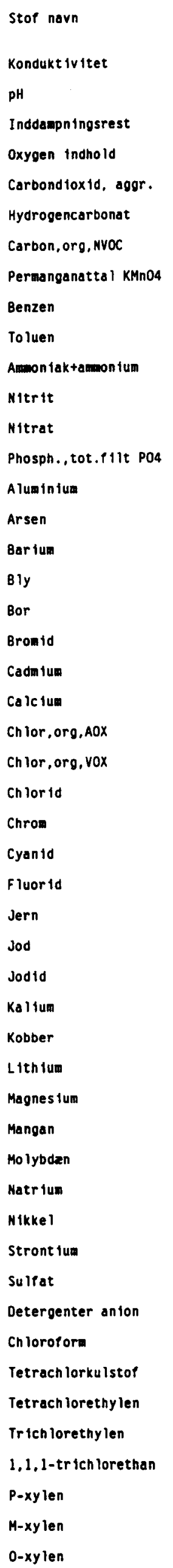

MSIEMENS/M

$\mathrm{PH}$

MG/L

MG/L

$M G / L$

$M G / L$

$M G / L$

$M G / L$

MYGRAM/L

MYGRAM/L

MG/L

MG/L

MG/L

MG/L

MYGRAM/L

MYGRAM/L

MYGRAM/L

MYGRAM/L

MYGRAM/L

MYGRAM/L

MYGRAM/L

MG/L

MYGRAM/L

MYGRAM/L

MG/L

MYGRAM/L

$M G / L$

$M G / L$

MG/L

MYGRAM/L

MYGRAM/L

MG/L

MYGRAM/L

MYGRAM/L

MG/L

MG/L

MYGRAM/L

MG/L

MYGRAM/L

MYGRAM/L

MG/L

MG/L

MYGRAM/L

MYGRAM/L

MYGRAM/L

MYGRAM/L

MYGRAM/L

MYGRAM/L

MYGRAM/L

MYGRAM/L
Århus Amt

Grundvandsanalyser, 1990
Antal

87.4870

89.7000

7.4009

1313.8182

3.2189

2.1818

254.5636

1.2927

4.3927

0.1050

0.3276

0.0438

59.5982

0.1690

5.0000

0.6210

123.0000

0.1030

301.6000

221.5000

0.0135

132.2545

5.4900

309.9909

0.2860

0.1482

0.6271

2.4900

8.2000

5.0145

0.4840

7.1800

26.9273

0.1844

2.5000

165.7091

2.7215

325.0000

125.9273

0.0045

0.0910

7.3900

620.0000

2.2000

2.0000

253.0000

1.2200

2.1000

0.1000

0.0010

0.0100

64.0000

0.0153

5.0000

0.3150

125.0000

0.1000

285.0000

213.0000

0.0110

130.0000

5.7500

56.0000

0.1650

0.1500

0.0400

1.6000

6.0000

2.9000

0.5600

5.9500

11.0000

0.0200

1.8000

37.0000

2.0000

320.0000

78.0000

0.0041

0.1000
Median

Spredning

Maximun

Min 1西保

18.38

128.0000

47.0000

0.16

7.7600

6.8800

5451.55

41000.000

380.0000

2.91

9.9000

0.1000

0.80

7.0000

2.0000

41.20

0.58

390.0000

170.0000

14.52

3.5000

0.4300

$110.0000^{*}$

2.0000

$0.3000 \quad 0.3000 \quad O G$

0.02

0.1500

2.29

17.0000

0.08

0.3600

44.41

165.0000

1.0000

0.45

2.2383

0.0153

0.00

5.0000

5.0000

0.74

2.6000

0.1700

60.66

240.0000

44.0000

0.01

0.1300

0.1000

165.93

550.0000

96.0000

104.19

379.0000

96.0000

0.01

0.0290

0.0010

80.52

700.0000

67.0000

2.10

9.7000

2.7000

0.5000

0.5000

1880.24

14000.000

31.0000

0.24

0.7000

0.1000

0.0040

0.0040

0.04

0.2800

0.1000

3.65

27.2000

0.0100

1.51

5.2000

1.6000

6.56

26.0000

4.0000

10.38

77.0000

1.0000

0.27

0.9300

0.0800

3.15

12.3000

3.0000

119.94

900.0000

5.1000

0.26

1.2600

0.0100

1.69

6.1000

1.1000

952.41

7100.0000

19.0000

2.51

14.0000

0.2800

73.97

460.0000

230.0000

234.64

1800.0000

32.0000

0.00

0.0071

0.0040

0.03

0.1000

0.0100

0.1000 DG

$0.0010 \quad D G$

$0.0100 \quad O G$

OG

DG

0.1000

$0.1000 \quad 06$

0.1000

$0.1000 \quad 06$

0.1000

$0.1000 \quad 06$

0.1000

$0.1000 \quad 06$

0.1000

$0.1000 \quad 06$

$0.1000 \quad 0.1000 \quad D G$

0.1000

$0.1000 \quad 06$

* Særlig usædvanlig værdi, der må kontrolleres. 
Nordsamsø (70.11)

\begin{tabular}{ll} 
Stof navn & Enhed \\
Naphthalen & MYGRAM/L \\
Phenol & MYGRAM/L \\
2-methylphenol & MYGRAM/L \\
4-methylphenol & MYGRAM/L \\
3,4-dimethylphenol & MYGRAM/L \\
3,5-dimethylphenol & MYGRAM/L \\
2,6-dimethylphenol & MYGRAM/L \\
2,4-dimethyiphenol & MYGRAM/L \\
4-clor,2-methylpheno & MYGRAM/L \\
6-clor,2-methyipheno & MYGRAM/L \\
2,4-diclorphenol & MYGRAM/L \\
4,6-diclor,2-methylp & MYGRAM/L \\
2,6-diclorphenol & MYGRAM/L \\
2,4,6-triclorphenol & MYGRAM/L \\
2,3,4,6-tetraclorphe & MYGRAM/L \\
2,3,5,6-tetraclorphe & MYGRAM/L \\
2,3,4,5-tetraclorphe & MYGRAM/L \\
Pentrac lorphenol & MYGRAM/L \\
Dich lorprop & MYGRAM/L \\
MCPA & MYGRAM/L \\
Mechlorprop & MYGRAM/L \\
DMOC & MYGRAM/L \\
Dinoseb & MYGRAM/L \\
Atrazin & MYGRAM/L \\
Simazin & MYGRAM/L \\
\hline
\end{tabular}

Århus Amt

Grundvandsanalyser, 1990

\begin{tabular}{|c|c|c|c|c|c|}
\hline nta 1 & Gens & Median & Spredning & Maximum & Min 1mum \\
\hline 10 & & & & 0.1000 & 0.1000 \\
\hline 10 & & & & 0.0300 & 0.0300 \\
\hline 10 & & & & 0.0300 & 0.0300 \\
\hline 10 & & & & 0.0300 & 0.0300 \\
\hline 10 & & & & 0.0300 & 0.0300 \\
\hline 10 & & & & 0.0300 & 0.0300 \\
\hline 10 & & & & 0.0300 & 0.0300 \\
\hline 10 & & & & 0.0300 & 0.0300 \\
\hline 10 & & & & 0.0500 & 0.0500 \\
\hline 10 & & & & 0.0500 & 0.0500 \\
\hline 10 & & & & 0.0300 & 0.0300 \\
\hline 10 & & & & 0.0300 & 0.0300 \\
\hline 10 & & & & 0.0300 & 0.0300 \\
\hline 10 & & & & 0.0100 & 0.0100 \\
\hline 10 & & & & 0.0100 & 0.0100 \\
\hline 10 & & & & 0.0100 & 0.0100 \\
\hline 10 & & & & 0.0100 & 0.0100 \\
\hline 10 & & & & 0.0200 & 0.0200 \\
\hline 10 & 0.0146 & 0.0150 & 0.00 & 0.0150 & 0.0130 \\
\hline 10 & 0.0108 & 0.0110 & 0.00 & 0.0110 & 0.0100 \\
\hline 10 & 0.0126 & 0.0130 & 0.00 & 0.0130 & 0.0110 \\
\hline 10 & & & & 0.0100 & 0.0100 \\
\hline 10 & & & & 0.0100 & 0.0100 \\
\hline 10 & & & & 0.0100 & 0.0100 \\
\hline 10 & 0.0113 & 0.0100 & 0.00 & 0.0230 & 0.0100 \\
\hline
\end{tabular}




\section{Fillerup (70.12)}

\begin{tabular}{|c|c|}
\hline Stof navn & Enhed \\
\hline Kondukt ivitet & MSIEMENS/M \\
\hline $\mathrm{pH}$ & $\mathbf{P H}$ \\
\hline Inddampn ingsrest & $M G / L$ \\
\hline Oxygen indhold & $M G / L$ \\
\hline Carbondioxid, aggr. & $M G / L$ \\
\hline Hydrogencarbonat & $M G / L$ \\
\hline Carbon,org, NVOC & $M G / L$ \\
\hline Permanganattal $\mathrm{KMnO} 4$ & $M G / L$ \\
\hline Benzen & MYGRAM/L \\
\hline Toluen & MYGRAM/L \\
\hline Anmon laktammon 1um & $M G / L$ \\
\hline Nitrit & $M G / L$ \\
\hline Nitrat & $M G / L$ \\
\hline Phosph.,tot.f1lt PO4 & $M G / L$ \\
\hline Alumintum & MYGRAM/L \\
\hline Arsen & MYGRAM/L \\
\hline Barfum & MYGRAM/L \\
\hline Bly & MYGRAM/L \\
\hline Bor & MYGRAM/L \\
\hline Bromid & MYGRAM/L \\
\hline Cadm fum & MYGRAM/L \\
\hline Calc lum & $M G / L$ \\
\hline $\mathrm{Ch}$ lor,org, $\mathrm{AOX}$ & MYGRAM/L \\
\hline Chlor,org, vox & MYGRAM/L \\
\hline Chlorid & $M G / L$ \\
\hline Chrom & MYGRAM/L \\
\hline Cyantd & $\mathrm{MG} / \mathrm{L}$ \\
\hline Fluorid & $M G / L$ \\
\hline Jern & MG/L \\
\hline Jern ferro & $M G / L$ \\
\hline Jod & MYGRAM/L \\
\hline Jodid & MYGRAM/L \\
\hline Kalium & $M G / L$ \\
\hline Kobber & MYGRAM/L \\
\hline Lith ium & MYGRAM/L \\
\hline Magnesium & $M G / L$ \\
\hline Mangon & $M G / L$ \\
\hline Molybdzn & MYGRAM/L \\
\hline Natrium & $M G / L$ \\
\hline Nikkel & MYGRAM/L \\
\hline Stront 1ua & MYGRAM/L \\
\hline Sulfat & $M G / L$ \\
\hline Detergenter anion & MG/L \\
\hline Chloroform & MYGRAM/L \\
\hline Tetrach lorkulstof & MYGRAM/L \\
\hline Tetrach lorethylen & MYGRAM/L \\
\hline Trtchlorethylen & MYGRAM/L \\
\hline $1,1,1-\operatorname{tr} 1 \mathrm{ch}$ lorethan & MYGRAM/L \\
\hline P-xylen & MYGRAM/L \\
\hline M-xylen & HYGRAM/L \\
\hline
\end{tabular}

Århus Amt

Grundvandsanalyser, 1990

Antal Gens Median Spredning Maximum Minimum

53.6829

54.0000

7.4291

7.4200

336.8571

0.6906

3.5143

246.8857

1.4151

3.5771

350.0000

0.5000

2.0000

251.0000

1.4900

3.6000

0.1230

0.1428

0.1000

0.0950

0.0174

0.0100

5.2857

1.0000

0.1953

0.2116

10.8250

3.2375

149.8750

7.5500

2.5000

150.0000

40.7500

86.0000

0.0101

82.8571

2.9300

25.2857

0.1750

43.0000

84.0000

0.0100

84.0000

2.6000

24.0000

0.1600

0.2346

0.8700

0.4600

2.0125

4.3000

2.2143

0.4688

7.4625

7.2743

0.1329

1.1188

16.8000

1.7679

407.5000

35.4257

0.2200

0.8700

0.4600

1.6500

4.0000

2.0000

0.2800

7.6000

6.6000

0.1300

1.2000

16.0000

2.0000

400.0000

33.0000
8.29

$0.13 \times 7.7500$

$41.07 \quad 390.0000$

0.63

3.60

42.98

0.42

1.32

0.08

0.08

0.21

0.03

13.13

0.19

7.48

2.96

73.15

4

13.44

25.17

0.01

11.64

1.14

7.67

0.08

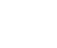

0.08

0.58

.

0.73

0.82

1.05

0.52

2.52

2.70

0.06

0.44

4.00

1.00

158.72

18.59

$$
2.7000
$$

18.0000

332.0000

2.3599

7.0000

0.3000

0.3500

1.1900

0.1500

49.0000

0.8279

23.0000

9.9000

240.0000

0.1000

57.0000

128.0000

0.0200

99.0000

4.9000

0.5000

47.0000

0.2900

0.0040

0.4600

1.9400

0.4600

3.5000

6.0000

6.4000

1.7000

10.6000

16.0000

0.3700

1.6000

32.0000

6.0000

670.0000

85.0000

0.0040

0.1000

0.1000

0.1000

0.1000

0.1000

0.1000

0.03

0.2000
38.1000

7.1400

250.0000

0.1000

2.0000

152.0000

0.7300

2.0000

$0.3000 \quad D G$

$0.0800 \quad D G$

$0.0010 \quad D G$

0.0100 DG

1.0000

0.0153

5.0000

0.8600

19.0000

0.1000 DG

12.0000

35.0000

0.0010

60.0000

1.5000

$0.5000 \quad D G$

14.0000

0.1000

0.0040

0.1000

0.0100

0.4600

1.6000

3.0000

0.9000

0.0800

3.3000

3.9000

0.0400

0.4000

12.0000

0.0500

150.0000

7.0000

0.0040 DG

$0.1000 \quad D G$

0.1000 DG

0.1000 DG

$0.1000 \quad D G$

0.1000 DG

0.1000 DG

$0.1100 \quad 0.1000$

0.1000 DG 
Fillerup (70.12)

\begin{tabular}{|c|c|c|c|}
\hline Stof navn & Enhed & Antal & Gens \\
\hline 0 -xylen & MYGRAM/L & 10 & 0.1010 \\
\hline Naphtha len & MYGRAM/L & 10 & 0.0950 \\
\hline Phenol & MYGRAM/L & 9 & \\
\hline 2-methy lphenol & MYGRAM/L & 9 & \\
\hline 4-methy lphenol & MYGRAM/L & 9 & \\
\hline 3,4-d imethy Iphenol & MYGRAM/L & 9 & \\
\hline 3,5-d tmethy lphenol & MYGRAM/L & 9 & \\
\hline 2,6-dimethy lphenol & MYGRAM/L & 9 & \\
\hline 2,4-dime thy lpheno 1 & MYGRAM/L & 9 & \\
\hline 4-clor, 2-wethy lpheno & MYGRAM/L & 9 & \\
\hline 6-clor, 2-methy lpheno & MYGRAM/L & 9 & \\
\hline 2,4-dic lorphenol & MYGRAM/L & 9 & \\
\hline 4,6-dic lor, 2-methylp & MYGRAM/L & 9 & \\
\hline 2,6-dic lorphenol & MYGRAM/L & 9 & \\
\hline 2,4,6-tric lorphenol & MYGRAM/L & 9 & \\
\hline 2,3,4,6-tetrac lorphe & MYGRAM/L & 9 & \\
\hline 2,3,5,6-tetrac lorphe & MYGRAM/L & 9 & \\
\hline 2,3,4,5-tetrac lorphe & MYGRAM/L & 9 & \\
\hline Pentrac lorphenol & MYGRAM/L & 9 & \\
\hline Dieh lorprop & MYGRAM/L & 10 & 0.0135 \\
\hline MCPA & MYGRAM/L & 10 & 0.0105 \\
\hline Mech lorprop & MYGRAM/L & 10 & 0.0115 \\
\hline DNOC & MYGRAM/L & 10 & 0.0224 \\
\hline Dinoseb & MYGRAM/L & 10 & 0.0238 \\
\hline Atrazin & MYGRAM/L & 10 & \\
\hline S1mazin & MYGRAM/L & 10 & \\
\hline
\end{tabular}

Grundvandsanalyser, 1990

Median Spredning Maximum Minfmus.

$\begin{array}{lllll}0.1000 & 0.00 & 0.1100 & 0.1000 & D G\end{array}$

$\begin{array}{lllll}0.1000 & 0.02 & 0.1000 & 0.0500 & \text { OG }\end{array}$

$0.0300 \quad 0.0300 \quad 06$

$0.0300 \quad 0.0300 \quad D G$

$0.0300 \quad 0.0300 \quad 06$

$0.0300 \quad 0.0300 \quad D G$

$0.0300 \quad 0.0300 \quad D G$

$0.0300 \quad 0.0300 \quad 06$

$0.0300 \quad 0.0300 \quad D G$

$0.0500 \quad 0.0500 \quad D G$

$0.0500 \quad 0.0500 \quad D G$

$0.0300 \quad 0.0300 \quad 0 G$

$0.0300 \quad 0.0300 \quad D G$

$0.0300 \quad 0.0300 \quad D G$

$0.0100 \quad 0.0100 \quad D G$

$0.0100 \quad 0.0100 \quad 0 G$

$0.0100 \quad 0.0100 \quad 06$

$0.0100 \quad 0.0100 \quad 06$

$0.0200 \quad 0.0200 \quad 06$

$0.0150 \quad 0.0120 \quad D G$

$0.0110 \quad 0.0100 \quad 06$

$0.0130 \quad 0.0100 \quad D G$

$0.1000 \quad 0.0100 \quad D G$

$0.1000 \quad 0.0100 \quad D G$

$0.0100 \quad 0.0100 \quad D G$

$0.0100 \quad 0.0100 \quad D G$ 
Hvinningdal (70.13)

\begin{tabular}{|c|c|}
\hline Stof navn & Enhed \\
\hline Kondukt ivitet & MSIEMENS/M \\
\hline $\mathrm{pH}$ & PH \\
\hline Inddampn Ingsrest & $M G / L$ \\
\hline Oxygen indhold & $M G / L$ \\
\hline Carbondtoxid, aggr. & $M G / L$ \\
\hline Hydrogencarbonat & $M G / L$ \\
\hline Carbon, org, HVOC & $M G / L$ \\
\hline Permanganatta I KMnO4 & $M G / L$ \\
\hline Benzen & MYGRAM/L \\
\hline Toluen & MYGRAM/L \\
\hline Ammon tak +ammon ium & MG/L \\
\hline Nitrit & $M G / L$ \\
\hline Nitrat & $M G / L$ \\
\hline Phosph., tot.f11t P04 & $M G / L$ \\
\hline Aluminfum & MYGRAM/L \\
\hline Arsen & MYGRAM/L \\
\hline Bartum & MYGRAM/L \\
\hline $81 y$ & MYGRAM/L \\
\hline Bor & MYGRAM/L \\
\hline Browid & MYGRAM/L \\
\hline Cadmi ium & MYGRAM/L \\
\hline Calc lum & $M G / L$ \\
\hline Chlor,org, AOX & MYGRAM/L \\
\hline Ch lor, org, vox & MYGRAM/L \\
\hline Chlorid & $M G / L$ \\
\hline Chrom & MYGRAM/L \\
\hline Cyanid & $M G / L$ \\
\hline Fluortd & $M G / L$ \\
\hline Jern & $M G / L$ \\
\hline Jern ferro & $M G / L$ \\
\hline Jod & MYGRAM/L \\
\hline Jodid & MYGRAM/L \\
\hline Kaltum & $M G / L$ \\
\hline Kobber & MYGRAM/L \\
\hline Kriksolv & KANOGRAM/L \\
\hline Lith fum & MYGRAM/L \\
\hline Magnestum & $M G / L$ \\
\hline Mangan & $\mathrm{HG} / \mathrm{L}$ \\
\hline Molybdan & MYGRAM/L \\
\hline Natrium & MG/L \\
\hline N1kke 1 & MYGRAM/L \\
\hline Stront tum & MYGRAM/L \\
\hline Sulfat & MG/L \\
\hline Detergenter anion & $M G / L$ \\
\hline Chloroform & MYGRAM/L \\
\hline Tetrach lorkulstof & MYGRAM/L \\
\hline Tetrach lorethy len & MYGRAM/L \\
\hline Tr ichlorethy len & MYGRAM/L \\
\hline 1,1,1-trichlorethan & MYGRAM/L \\
\hline p-xylen & MYGRAM/L \\
\hline
\end{tabular}

Århus Amt

Grundvandsanalyser, 1990

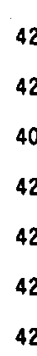

34.1262

6.3176

225.5000

6.1825

30.7619

36.1190

0.5098

2.6833

11

11

42

42

42

42

11

11

11

11

11

11

11

42

11

42

11

11

42

40

2

11

11

42

11

5

42

11

42

42

11

42

11

11

11

11

11

11

0.0083

0.0143

46.7452

0.0954

12.7727

0.2855

50.9091

24.3636

82.7273

0.0373

34.2143

1.6273

27.9405

0.2573

0.1019

0.3725

3.9650

5.2636

2.5000

1.3619

0.1355

4.0000

1.9545

5.7810

0.0310

0.2455

14.1619

4.0131

126.0000

37.3095

0.0918

0.0836

0.0918

0.0918

0.0918
Median

31.3500
6.3650
215.0000
7.4000
27.5000
28.5000
0.3700
2.0000

0.0010

0.0100

32.0000

0.0153

11.0000

0.1500

51.0000

25.0000

84.0000

0.0100

32.0000

1.4000

24.0000

0.2500

0.1000

0.0350

3.9650

1.6000

2.5000

1.2000

0.0800

3.0000

1.7000

1.7000

0.0100

0.1500

13.0000

2.0000

140.0000

34.0000

0.1000

0.1000

0.1000

0.1000

0.1000
14.94

104.0000

15.7000

$0.37 \quad 7.0900$

5.5300

$100.36 \quad 700.0000$

$4.23 \quad 11.0000$

$16.87 \quad 85.0000$

23.32

97.9000

0.56

2.30

3.2500

13.0000

0.3000

0.1000

0.1610

0.1000

0.02

56.93

0.11

308.0000

0.3679

25.0000

1.7000

0.47

26.22

96.0000

0.1000

6.92

35.0000

20.81

0.04

12.36

0.64

11.86

0.16

0.01

0.01

1.39

5.59

10.89

0.00

0.65

0.10

1.41

0.86

5.33

0.11

0.29

5.33

4.63

33.88

16.01

0.1100

76.0000

2.8000

0.5000

72.5000

0.6800

0.0040

0.1300

8.8200

7.9200

38.0000

2.5000

3.5000

0.3500

6.0000

3.6000

31.0000

0.7200

1.1000

37.0000

22.0000

170.0000

88.0000

0.0040

0.1000

0.1000

0.1000

0.1000

0.1000

0.1000
12.0000

14.6000

0.2000

2.0000

0.3000

$0.1000 \quad D G$

$0.0010 \quad D G$

0.0100

1.0000

0.0153

5.0000

0.0800

19.0000

$0.1000 \quad 06$

13.0000

50.0000

$0.0100 \quad D G$

17.0000

1.0000

$0.5000 \quad D G$

18.5000

0.1000

$0.0040 \quad D G$

0.1000

0.0100

0.0100

1.6000

2.5000

0.6000

0.0800

3.0000 DG

0.9000

1.3000

0.0100

0.1500

9.8000

0.1000 DG

60.0000

20.0000

$0.0040 \quad O G$

$0.0100 \quad D G$

$0.0100 \quad O G$

0.0100 DG

$0.0100 \quad D G$

0.0100 DG

0.1000 DG 
Hvinningdal (70.13)

\begin{tabular}{|c|c|}
\hline Stof navn & Enhed \\
\hline M-xylen & MYGRAM/L \\
\hline $0-x y$ len & MYGRAM/L \\
\hline Naphtha len & MYGRAM/L \\
\hline Phenol & MYGRAM/L \\
\hline 2-methy lphenol & MYGRAM/L \\
\hline 4-methylphenol & MYGRAM/L \\
\hline 3,4-d tmethy Iphenol & MYGRAM/L \\
\hline 3,5-d ime thy Iphenol & MYGRAM/L \\
\hline 2,6-dimethy Iphenol & MYGRAM/L \\
\hline 2,4-d finethylphenol & MYGRAM/L \\
\hline 4-c lor, 2-methylpheno & MYGRAM/L \\
\hline 6-clor, 2-methylpheno & MYGRAM/L \\
\hline 2,4-dic lorphenol & MYGRAM/L \\
\hline 4,6-dic lor, 2-methy ip & MYGRAM/L \\
\hline 2.6-dic lorphenol & MYGRAM/L \\
\hline 2,4,6-tric lorphenol & MYGRAM/L \\
\hline $2,3,4,6$-tetrac lorphe & MYGRAH/L \\
\hline 2,3,5,6-tetrac lorphe & MYGRAM/L \\
\hline 2.3,4.5-tetrac lorphe & MYGRAM/L \\
\hline Pentrac lorphenol & MYGRAM/L \\
\hline Dich lorprop & MYGRAM/L \\
\hline MCPA & MYGRAM/L \\
\hline Mech lorprop & MYGRAM/L \\
\hline DNOC & MYGRAM/L \\
\hline Dinoseb & MYGRAM/L \\
\hline Atrazin & MYGRAM/L \\
\hline Simazin & MYGRAM/L \\
\hline
\end{tabular}

Århus Amt

Grundvandsanalyser, 1990

\begin{tabular}{|c|c|c|c|c|c|c|}
\hline Antal & Gens & Median & Spredning & Maximum & Mintmum & . \\
\hline 11 & & & & 0.1000 & 0.1000 & $D G$ \\
\hline 11 & , & & & 0.1000 & 0.1000 & DG \\
\hline 11 & & & & 0.1000 & 0.1000 & $D G$ \\
\hline 11 & & & & 0.0300 & 0.0300 & DG \\
\hline 11 & & & & 0.0300 & 0.0300 & $D G$ \\
\hline 11 & & & & 0.0300 & 0.0300 & $\mathbf{D G}$ \\
\hline 11 & & & & 0.0300 & 0.0300 & $D G$ \\
\hline 11 & & & & 0.0300 & 0.0300 & DG \\
\hline 11 & & & & 0.0300 & 0.0300 & $D G$ \\
\hline 11 & & & & 0.0300 & 0.0300 & DG \\
\hline 11 & & & & 0.0500 & 0.0500 & DG \\
\hline 11 & & & & 0.0500 & 0.0500 & DG \\
\hline 11 & & & & 0.0300 & 0.0300 & DG \\
\hline 11 & & & & 0.0300 & 0.0300 & DG \\
\hline 11 & & & & 0.0300 & 0.0300 & $D G$ \\
\hline 11 & & & & 0.0100 & 0.0100 & DG \\
\hline 11 & & & & 0.0100 & 0.0100 & DG \\
\hline 11 & & & & 0.0100 & 0.0100 & DG \\
\hline 11 & & & & 0.0100 & 0.0100 & DG \\
\hline 11 & & & & 0.0200 & 0.0200 & $D G$ \\
\hline 11 & & & & 0.0140 & 0.0140 & $D G$ \\
\hline 11 & 0.0103 & 0.0100 & 0.00 & 0.0110 & 0.0100 & DG \\
\hline 11 & & & & 0.0120 & 0.0120 & $D G$ \\
\hline 11 & 0.0114 & 0.0100 & 0.00 & 0.0150 & 0.0100 & $D G$ \\
\hline 11 & & & & 0.0100 & 0.0100 & DG \\
\hline 11 & & & & 0.0100 & 0.0100 & DG \\
\hline 11 & & & & 0.0100 & 0.0100 & DG \\
\hline
\end{tabular}




\section{Homå (70.14)}

\begin{tabular}{|c|c|}
\hline Stof navn & Enhed \\
\hline Konduxt ivitet & MSIEMENS/M \\
\hline pH & $\mathrm{PH}$ \\
\hline Terstor, filtrat & $G / L$ \\
\hline Oxygen indhold & $M G / L$ \\
\hline Carbondioxid, aggr. & $M G / L$ \\
\hline Hydrogencarbonat & MG/L \\
\hline Carbon, oro, NVOC & $M G / L$ \\
\hline Permanganatta $1 \mathrm{KMnO4}$ & $M G / L$ \\
\hline Ammon taktamison fum & MG/L \\
\hline Nitrit & $M G / L$ \\
\hline Nitrat & $M G / L$ \\
\hline Phosph., tot.filt P04 & $M G / L$ \\
\hline Calctum & $M G / L$ \\
\hline Chlor id & MG/L \\
\hline Fluorid & MG/L \\
\hline Jern & MG/L \\
\hline Ka l fum & MG/L \\
\hline Magnes tua & MG/L \\
\hline Mangan & MG/L \\
\hline Natrium & $M G / L$ \\
\hline Nikkel & MYGRAM/L \\
\hline Sulfat & MG/L \\
\hline
\end{tabular}

Århus Amt

36

36

36

31

34

36

36

36

36

36

36

36

36

36

36

36

36

36

36

36

34

36
Grundvandsanalyser, 1990

Median Spredning

Max 1mu:

Min imun

72.7389

64.7500

30.72

208.0000

44.7000

7.7444

7.7500

0.24

8.3000

7.3000

0.4689

0.4200

0.18

1.1700

0.2600

4.0774

1.4000

4.35

11.2000

0.1000

2.0000

2.0000

0.00

2.0000

2.0000

227.3333

231.5000

74.79

423.0000

112.0000

1.1928

0.8900

1.10

6.1400

0.5100

4.4722

4.0000

1.21

8.0000

4.0000

0.0696

0.0200

0.18

1.0500

0.0100

0.0570

0.0100

0.09

0.3400

0.0100

0.0100

38.2086

19.5000

52.13

213.0000

0.9996

0.0061

99.5000

89.0000

0.17

180.0000

61.0000

60.0000

39.0000

494.0000

19.0000

0.2072

0.1600

0.29

1.9000

0.0800

0.7317

0.1100

1.20

5.7000

0.0200

1.5464

1.3000

1.32

8.5000

0.5700

13.6111

13.5000

0.0650

5.60

29.0000

0.1400

5.5000

30.0278

2.1765

17.0000

0.04

52.15

325.0000

0.0200

64.3889

0.63

5.0000

25.73

122.0000
2.0000

15.0000 
Rabis Bæk (76.01)

\begin{tabular}{|c|c|}
\hline Stof navn & Enhed \\
\hline Kondukt ivitet & MSIEMENS/M \\
\hline pH & PH \\
\hline Inddompn ingsrest & $M G / L$ \\
\hline Carbondioxid, aggr. & $M G / L$ \\
\hline Hydrogencarbonat & $M G / L$ \\
\hline Permanganattal KMnO4 & $M G / L$ \\
\hline Afmen iak+asmon fun & $M G / L$ \\
\hline N1trit & $M G / L$ \\
\hline Nitrat & $M G / L$ \\
\hline Phosph., tot.f11t P04 & $M G / L$ \\
\hline Calciun & $M G / L$ \\
\hline Chlorid & $M G / L$ \\
\hline Fluor id & $M G / L$ \\
\hline Jern ferro & $M G / L$ \\
\hline Kallun & $M G / L$ \\
\hline Magnes iun & $M G / L$ \\
\hline Mangan & $M G / L$ \\
\hline Matrium & $M G / L$ \\
\hline Sulf at & $M G / L$ \\
\hline Hydrogensulf to & $M G / L$ \\
\hline Methan & $M G / L$ \\
\hline
\end{tabular}

Viborg Amt

\begin{tabular}{|c|c|c|c|c|c|}
\hline Antal & Gens & Median & Spredning & Maximun & Minimum \\
\hline 117 & 24.3954 . & 25.5000 & 9.59 & 45.5000 & 8.1000 \\
\hline 117 & 5.5598 & 5.4500 & 0.53 & 7.5500 & 4.2000 \\
\hline 115 & 204.6957 & 200.0000 & 93.54 & 540.0000 & 70.0000 \\
\hline 111 & 22.5577 & 22.0000 & 6.20 & 42.0000 & 8.3000 \\
\hline 121 & 11.6860 & 10.0000 & 11.67 & 87.0000 & 0.1000 \\
\hline 114 & 5.3684 & 4.0000 & 5.32 & 48.0000 & 4.0000 \\
\hline 121 & 0.0290 & 0.0100 & 0.05 & 0.4300 & 0.0100 \\
\hline 121 & 0.0117 & 0.0050 & 0.02 & 0.2300 & 0.0050 \\
\hline 141 & 34.4987 & 15.0000 & 35.98 & 115.0000 & 0.1000 \\
\hline 121 & 0.2020 & 0.1073 & 0.31 & 2.2690 & 0.0307 \\
\hline 121 & 14.7000 & 16.0000 & 8.70 & 34.0000 & 2.6000 \\
\hline 119 & 24.9244 & 24.0000 & 8.84 & 58.0000 & 9.0000 \\
\hline 121 & 0.1004 & 0.1000 & 0.00 & 0.1300 & 0.1000 \\
\hline 114 & 0.6464 & 0.0200 & 1.49 & 6.5100 & 0.0200 \\
\hline 121 & 2.4919 & 1.4000 & 5.81 & 50.0000 & 0.6300 \\
\hline 121 & 8.2397 & 9.0000 & 4.97 & 23.0000 & 1.4000 \\
\hline 114 & 0.0850 & 0.0600 & 0.08 & 0.4900 & 0.0250 \\
\hline 121 & 12.4347 & 12.0000 & 2.91 & 24.0000 & 6.8000 \\
\hline 120 & 32.5217 & 29.5000 & 20.57 & 110.0000 & 6.6000 \\
\hline 97 & 0.0205 & 0.0200 & 0.00 & 0.0500 & 0.0200 \\
\hline 96 & 0.0547 & 0.0500 & 0.05 & 0.5000 & 0.0500 \\
\hline
\end{tabular}

Grundvandsanalyser, 1990

DG


Viborg N. (76.11)

\begin{tabular}{|c|c|}
\hline Stor navn & Enhed \\
\hline Kondukt iv itet & MSIEMENS/M \\
\hline pH & PH \\
\hline Inddampningsrest & $M G / L$ \\
\hline Torstof, total & $M G / L$ \\
\hline Oxygen indhold & $M G / L$ \\
\hline Carbondtoxid, aggr. & $M G / L$ \\
\hline Hydrogencarbonat & $M G / L$ \\
\hline Carbon, org, NVOC & MG/L \\
\hline Perwanganatta $1 \mathrm{KMnO4}$ & $M G / L$ \\
\hline Benzen & MYGRAM/L \\
\hline Toluen & MYGRAM/L \\
\hline Ammon fak +ammon fum & $M G / L$ \\
\hline Nitrit & $M G / L$ \\
\hline Nitrat & $M G / L$ \\
\hline Phosph.,tot.f11t P04 & $M G / L$ \\
\hline Alumintum & MYGRAM/L \\
\hline Arsen & MYGRAM/L \\
\hline Bartum & MYGRAM/L \\
\hline Bly & MYGRAM/L \\
\hline Bor & MYGRAM/L \\
\hline Bromid & MYGRAM/L \\
\hline Cadelua & MYGRAM/L \\
\hline Calctura & $M G / L$ \\
\hline Chlor,org, AOX & MYGRAM/L \\
\hline Ch lor, org, vox & MYGRAM/L \\
\hline Chlorid & $M G / L$ \\
\hline Chrom & MYGRAM/L \\
\hline Cyanid & $M G / L$ \\
\hline Fluorid & $M G / L$ \\
\hline Jern & $M G / L$ \\
\hline Jern ferro & $M G / L$ \\
\hline Jern (<450na) & $M G / L$ \\
\hline Jod & MYGRAM/L \\
\hline Jodid & MYGRAM/L \\
\hline Kallum & $M G / L$ \\
\hline Kobber & MYGRAM/L \\
\hline Lith 1uw & MYGRAM/L \\
\hline Magnes tur & $M G / L$ \\
\hline Mangan & MG/L \\
\hline Molybdzn & MYGRAM/L \\
\hline Natr tun & $M G / L$ \\
\hline N1kkel & MYGRAM/L * \\
\hline Stront fum & MYGRAM/L \\
\hline Sulfat & $M G / L$ \\
\hline Hydrogensulf id & $M G / L$ \\
\hline Detergenter anion & $M G / L$ \\
\hline Chloroform & MYGRAM/L \\
\hline Tetrach lorkulstof & MYGRAM/L \\
\hline Tetrach lorethylen & MYGRAM/L \\
\hline Trtehlorethylen & MYGRAM/L \\
\hline
\end{tabular}

Viborg Amt

Grundvandsanalyser, 1990

Anta 1

$46 \quad 38.8565$.

Median

Spredning

Maxtmum

Mininum

$17 \quad 7.0353$

37.1500

11.80

74.4000

16.7000

7.3000

259.1304

282.9630

4.6933

8.9283

89.2240

0.6450

4.2000

2

\section{2}

45

0.0182

0.0828

24.5667

0.1588

5500.0000

5.7500

45.5000

0.7200

58000.000

72.0000

0.0215

48.6200

1.1500

37.4200

0.1000

0.0000

0.3278

0.4938

0.4192

0.6350

7.8000

3.0000

1.2882

8.5850

5.9000

4.2160

0.1438

4.9000

22.2700

100.0000

0.1750

41.8600

0.0258

0.0045
250.0000

260.0000

2.7000

4.1500

91.0000

0.6450

4.0000

0.0100

0.0050

15.0000

0.1533

5500.0000

5.7500

45.5000

0.7200

58000.000

72.0000

0.0215

53.0000

1.1500

23.0000

0.1000

0.0000

0.1100

0.3100

0.1500

0.6350

7.8000

3.0000

1.2500

8.5850

5.9000

3.9500

0.1250

4.9000

16.0000

100.0000

0.1750

41.0000

0.0200

0.0045
0.67

57.12

88.09

4.69

8.40

47.04

0.06

1.01

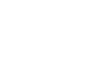

0.01

0.22

25.95

0.08

707.11

6.01

17.68

0.74

36769.6

4.24

0.02

15.28

0.21

36.29

0.00

0.00

1.46

0.51

0.50

0.26

8.77

0.00

0.48

11.90

2.69

1.56

0.12

0.99

13.94

0.00

0.05

15.90

0.02

0.00
7.9500

5.9500

430.0000

500.0000

11.8000

26.0000

156.0000

0.7000

11.0000

0.3000

0.1000

0.0600

1.1000

70.0000

0.3373

150.0000

160.0000

0.1000

2.0000

8.1000

0.5900

4.0000

0.3000 DG

0.1000 DG

0.0100

$0.0050 \quad D G$

0.1000

0.0307

$6000.0000 * 5000.0000$

$58.0000 \quad 33.0000$

$1.2400 \quad 0.2000$

$84000.000 * 32000.000$

0.0330

0.0100

72.0000

10.0000

1.3000

0.5000

1.0000

141.0000

0.5000

13.0000

0.1000

0.1000

0.0000

0.0000

10.0000

0.0100

1.4300

0.0400

1.8200

0.0200

0.8200

0.4500

14.0000 *

1.6000

3.0000

3.0000

3.0000

0.6500

17.0000

0.1700

7.8000

4.0000

8.0000

2.0000

0.6700

0.0250

5.6000

4.2000

63.0000

9.1000

100.0000

100.0000

0.2100

0.1400

77.0000

14.0000

0.0900

0.0200

0.0050

0.0040 DG

0.1000

$0.1000 \quad D G$

0.1000

0.1000 DG

0.1000

$0.1000 \quad 0 G$

0.1000

$0.1000 \quad O G$
$10.0000 \quad 1.5000$

$75.0000 \quad 69.0000$

* Særlig usædvanlig værdi, der må kontrolleres. 
Viborg N. (76.11)

\begin{tabular}{|c|c|c|c|}
\hline Stof navn & Enhed & Antal & Gens \\
\hline $1,1,1-\operatorname{tr} 1 \mathrm{ch}$ lorethan & MYGRAM/L & 2 & \\
\hline$P-x y l e n$ & MYGRAM/L & 2 & \\
\hline M-xylen & MYGRAM/L & 2 & \\
\hline $0-x y$ len & MYGRAM/L & 2 & \\
\hline Maphthalen & MYGRAM/L & 2 & \\
\hline Phenol & MYGRAM/L & 2 & \\
\hline 3-methylphenol & MYGRAM/L & 2 & \\
\hline 2,3 dime thy lphenol & MYGRAM/L & 2 & \\
\hline 2-wethy Iphenol & MYGRAM/L & 2 & \\
\hline 4-wethylphenol & MYGRAM/L & 2 & \\
\hline 3,4-dimethylphenol & MYGRAM/L & 2 & \\
\hline 3,5-d twethylphenol & MYGRAM/L & 2 & \\
\hline 2,6-dinethy lphenol & MYGRAM/L & 2 & \\
\hline 2,4-d1wethy lphenol & MYGRAM/L & 2 & \\
\hline 4-c lor, 2-wethy lpheno & MYGRAM/L & 2 & \\
\hline 6-clor, 2-wethy lpheno & MYGRAM/L & 2 & \\
\hline 2,4-dic lorpheno 1 & MYGRAM/L & 2 & \\
\hline 4,6-dtc lor, 2-nethylp & MYGRAM/L & 2 & \\
\hline 2.6-diclorphenol & MYGRAM/L & 2 & \\
\hline 2,4,6-trtc lorpheno 1 & MYGRAM/L & 2 & \\
\hline $2,3,4,6$-tetrac lorphe & MYGRAM/L & 2 & 0.0130 \\
\hline $2,3,5,6$-tetrac lorphe & MYGRAM/L & 2 & \\
\hline $2,3,4,5$-tetrac lorphe & MYGRAM/L & 2 & 0.0125 \\
\hline Pentrac lorphenol & MYGRAM/L & 2 & 0.1500 \\
\hline Dtch lorprop & MYGRAM/L & 2 & \\
\hline MCPA & MYGRAM/L & 2 & \\
\hline Mech lorprop & MYGRAM/L & 2 & \\
\hline onoc & MYGRAM/L & 2 & \\
\hline Dinoseb & MYGRAM/L & 2 & 0.1800 \\
\hline Atrazin & MYGRAM/L & 2 & \\
\hline Staaz in & MYGRAM/L & 2 & \\
\hline
\end{tabular}

Grundvandsanalyser, 1990

Median Spredning Maximum Mininum

\begin{tabular}{|c|c|c|}
\hline 0.1000 & 0.1000 & DG \\
\hline 0.1000 & 0.1000 & $D G$ \\
\hline 0.1000 & 0.1000 & $D G$ \\
\hline 0.1000 & 0.1000 & DG \\
\hline 0.1000 & 0.1000 & DG \\
\hline 0.0300 & 0.0300 & DG \\
\hline 0.0300 & 0.0300 & $O G$ \\
\hline 0.0300 & 0.0300 & DG \\
\hline 0.0300 & 0.0300 & DG \\
\hline 0.0300 & 0.0300 & $D G$ \\
\hline 0.0300 & 0.0300 & DG \\
\hline 0.0300 & 0.0300 & DG \\
\hline 0.0300 & 0.0300 & DG \\
\hline 0.0300 & 0.0300 & DG \\
\hline 0.0500 & 0.0500 & OG \\
\hline 0.0500 & 0.0500 & DG \\
\hline 0.0300 & 0.0300 & DG \\
\hline 0.0300 & 0.0300 & DG \\
\hline 0.0300 & 0.0300 & DG \\
\hline 0.0100 & 0.0100 & DG \\
\hline 0.0160 & 0.0100 & DG \\
\hline 0.0100 & 0.0100 & DG \\
\hline 0.0150 & 0.0100 & $D G$ \\
\hline 0.2800 & 0.0200 & OG \\
\hline 0.0130 & 0.0130 & $D G$ \\
\hline 0.0100 & 0.0100 & DG \\
\hline 0.0110 & 0.0110 & DG \\
\hline 0.0100 & 0.0100 & DG \\
\hline 0.3500 & 0.0100 & DG \\
\hline 0.0100 & 0.0100 & DG \\
\hline 0.0100 & 0.0100 & \\
\hline
\end{tabular}


Skive (76.12)

\begin{tabular}{|c|c|c|c|c|}
\hline Stof navn & Enhed & Antal & Gens & Media \\
\hline Kondukt ivitet & MSIEMENS/M & 30 & 45.2867 . & 46.150 \\
\hline pH & PH & 30 & 7.3913 & 7.47 \\
\hline Inddampn ingsrest & MG/L & 22 & 320.4545 & 315.0 \\
\hline Tarstof, total & $\mathrm{HG} / \mathrm{L}$ & 11 & 297.2727 & 300.00 \\
\hline Oxygen indhold & $\mathrm{MG} / \mathrm{L}$ & 11 & 0.5100 & 0.10 \\
\hline Carbondioxtd, agor. & $M G / L$ & 33 & 4.2303 & 2.00 \\
\hline Hydrogencarbonat & $M G / L$ & 33 & 139.4848 & 158.00 \\
\hline Carbon,org, NVOC & $M G / L$ & 13 & 0.7862 & 0.7 \\
\hline Permanganattal KMnO4 & $M G / L$ & 33 & 4.2424 & 4.00 \\
\hline Benzen & MYGRAM/L & 8 & & \\
\hline Toluen & MYGRAM/L & 8 & 0.1088 & 0.10 \\
\hline Ameon iak +amon ium & $M G / L$ & 33 & 0.1500 & 0.11 \\
\hline Nitrit & $M G / L$ & 33 & 0.0294 & 0.00 \\
\hline M1trat & $M G / L$ & 33 & 3.2879 & 0.16 \\
\hline Phosph., tot.f11t PO4 & $M G / L$ & 33 & 0.3526 & 0.23 \\
\hline Alum in ium & MYGRAM/L & 8 & 5037.5000 & 5000.00 \\
\hline Arsen & MYGRAM/L & 8 & 3.1900 & 2.45 \\
\hline Bar 1un & MYGRAM/L & 8 & 58.0000 & 47.50 \\
\hline Bly & MYGRAM/L & 8 & 0.7000 & 0.20 \\
\hline Bor & MYGRAM/L & 8 & 74625.000 & 69500.0 \\
\hline Bromid & MYGRAM/L & 5 & 141.8000 & 128.00 \\
\hline Cadmium & MYGRAM/L & 8 & 0.0113 & 0.01 \\
\hline Calc lum & $M G / L$ & 33 & 64.4848 & 68.0 \\
\hline Ch lor, ord, AOX & MYGRAM/L & 8 & 2.2000 & 2.20 \\
\hline Chlor, org, vox & MYGRAM/L & 8 & & \\
\hline Chlortd & $M G / L$ & 33 & 40.0303 & 30.00 \\
\hline Chrom & MYGRAM/L & 8 & 0.1313 & 0.10 \\
\hline Cyanid & $M G / L$ & 8 & 0.0000 & 0.00 \\
\hline F luor id & $M G / L$ & 33 & 0.1079 & 0.11 \\
\hline Jern & $M G / L$ & 2 & 1.2450 & 1.2 \\
\hline Jern ferro & $M G / L$ & 28 & 0.6620 & \\
\hline Jern ( $<450 \mathrm{~nm})$ & $M G / L$ & 5 & 0.8900 & 0.5 \\
\hline Jod & MYGRAM/L & 8 & 55.7625 & 26.00 \\
\hline Jodid & MYGRAM/L & 8 & 5.8750 & 5.50 \\
\hline Kalium & MG/L & 33 & 2.5333 & \\
\hline Kobber & MYGRAM/L & 8 & 0.6063 & \\
\hline Lith fur & MYGRAM/L & 8 & 6.6125 & 4.95 \\
\hline Magnes tur & MG/L & 33 & 5.7394 & \\
\hline Mangan & $M G / L$ & 33 & 0.1475 & \\
\hline Molybden & MYGRAM/L & 8 & 3.9750 & \\
\hline Matriua & $M G / L$ & 33 & 20.9697 & 17.0 \\
\hline Nikkel & MYGRAM/L & 8 & 395.0000 & 180.0 \\
\hline Stront fum & MYGRAM/L & 8 & 0.4700 & 0.3 \\
\hline Sulfat & $M G / L$ & 33 & 56.6545 & 52.0 \\
\hline Hydrogensulf id & $M G / L$ & 6 & 0.0200 & 0.0 \\
\hline Methen & $M G / L$ & 6 & 0.0425 & 0.0 \\
\hline Detergenter anion & MG/L & 8 & 0.0049 & \\
\hline Chloroform & MYGRAM/L & 8 & & \\
\hline Tetrach lorku lstof & MYGRAM/L & 8 & & \\
\hline Tetrach lorethylen & MYGRAM/L & 8 & & \\
\hline
\end{tabular}

Grundvandsanalyser, 1990

Spredning Maximum Minimum

$\begin{array}{rrrr}10.54 & 66.2000 & 30.0000 & \\ 0.46 & 8.0700 & 6.0500 & \\ 77.06 & 480.0000 & 210.0000 & \\ 83.92 & 460.0000 & 210.0000 & \\ 1.03 & 3.5000 & 0.1000 & \\ 4.93 & 22.0000 & 2.0000 & \\ 62.31 & 274.0000 & 18.0000 & \\ 0.14 & 0.9700 & 0.6100 & \\ 0.44 & 5.0000 & 4.0000 & \\ & 0.3000 & 0.3000 & D G \\ 0.02 & 0.1700 & 0.1000 & D G \\ 0.12 & 0.3600 & 0.0100 & \\ 0.05 & 0.2100 & 0.0050 & D G \\ 7.46 & 31.0000 & 0.1000 & \\ 0.27 & 0.8892 & 0.0307 & \end{array}$

$2468.059200 .0000 * 100.0000$

$\begin{array}{lll}3.29 & 11.0000 & 0.4200\end{array}$

$\begin{array}{lll}26.39 & 120.0000 \quad 41.0000\end{array}$

$\begin{array}{lll}1.41 & 4.2000 & 0.2000\end{array}$

$48550.2 \quad 150000.00 * 23000.000$

$\begin{array}{lll}38.43 & 199.0000 \quad 99.0000\end{array}$

$\begin{array}{lll}0.00 & 0.0200 & 0.0100\end{array}$

$\begin{array}{lll}21.07 & 115.0000 \quad 30.0000\end{array}$

$\begin{array}{lll}0.62 & 2.8000 \quad 1.1000\end{array}$

$0.5000 \quad 0.5000$

DG

$28.14 \quad 140.0000 \quad 21.0000$

$\begin{array}{lll}0.09 & 0.3500 & 0.1000\end{array}$

$\begin{array}{lll}0.00 & 0.0000 & 0.0000\end{array}$

$\begin{array}{lll}0.02 & 0.1400 & 0.0100\end{array}$

$\begin{array}{lll}0.30 & 1.4600 & 1.0300\end{array}$

$\begin{array}{lll}0.58 & 2.0800 & 0.0200\end{array}$

$\begin{array}{lll}0.67 & 1.9800 & 0.3900\end{array}$

$87.58264 .0000^{*} \quad 1.6000$

$2.36 \quad 10.0000 \quad 3.0000$

$1.48 \quad 6.6000 \quad 1.3000$

$\begin{array}{lll}0.97 & 2.5000 & 0.0800\end{array}$

$3.27 \quad 11.6000 \quad 3.5000$

$\begin{array}{lll}1.60 & 9.2000 & 2.4000\end{array}$

$\begin{array}{lll}0.06 & 0.2400 & 0.0250\end{array}$

$5.40 \quad 17.0000 \quad 1.1000$

$\begin{array}{lll}10.39 & 52.0000 \quad 12.0000\end{array}$

$417.48 \quad 1110.0000 * 100.0000$

$0.34 \quad 1.1000 \quad 0.2100$

$\begin{array}{lll}31.88 & 110.0000 \quad 5.0000\end{array}$

$\begin{array}{lll}0.00 & 0.0200 & 0.0200\end{array}$

$\begin{array}{lll}0.02 & 0.0500 & 0.0050\end{array}$

$\begin{array}{lll}0.00 & 0.0060 & 0.0040 \quad D G\end{array}$

$0.1000 \quad 0.1000 \quad D G$

$0.1000 \quad 0.1000 \quad D G$

$0.1000 \quad 0.1000 \quad D G$

- Særlig usædvanlig værdi, der må kontrolleres. 
Skive (76.12)

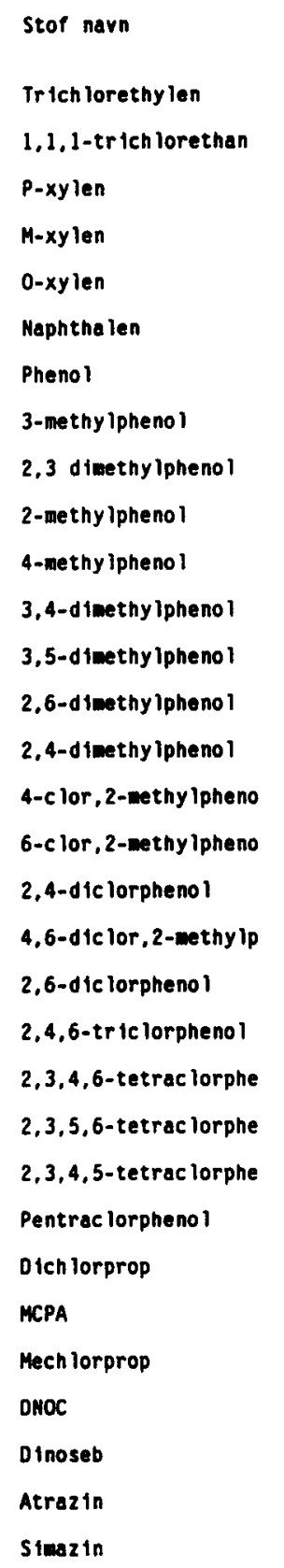

Viborg Amt

Enhed

MYGRAY/L

MYGRAM/L

MYGRAM/L

MYGRAM/L

MYGRAM/L

MYGRAM/L

MYGRAM/L

MYGRAM/L

MYGRAM/L

MYGRAM/L

MYGRAM/L

MYGRAM/L

MYGRAM/L

MYGRAM/L

MYGRAM/L

MYGRAM/L

MYGRAM/L

MYGRAM/L

MYGRAM/L

MYGRAM/L

MYGRAM/L

MYGRAM/L

MYGRAM/L

MYGRAM/L

MYGRAM/L

MYGRAM/L

MYGRAM/L

MYGRAM/L

MYGRAM/L

MYGRAM/L

MYGRAM/L

MYGRAM/L

Anta 1 Gens

Grundvandsanalyser, 1990

Median Spredning Maximum Minimun

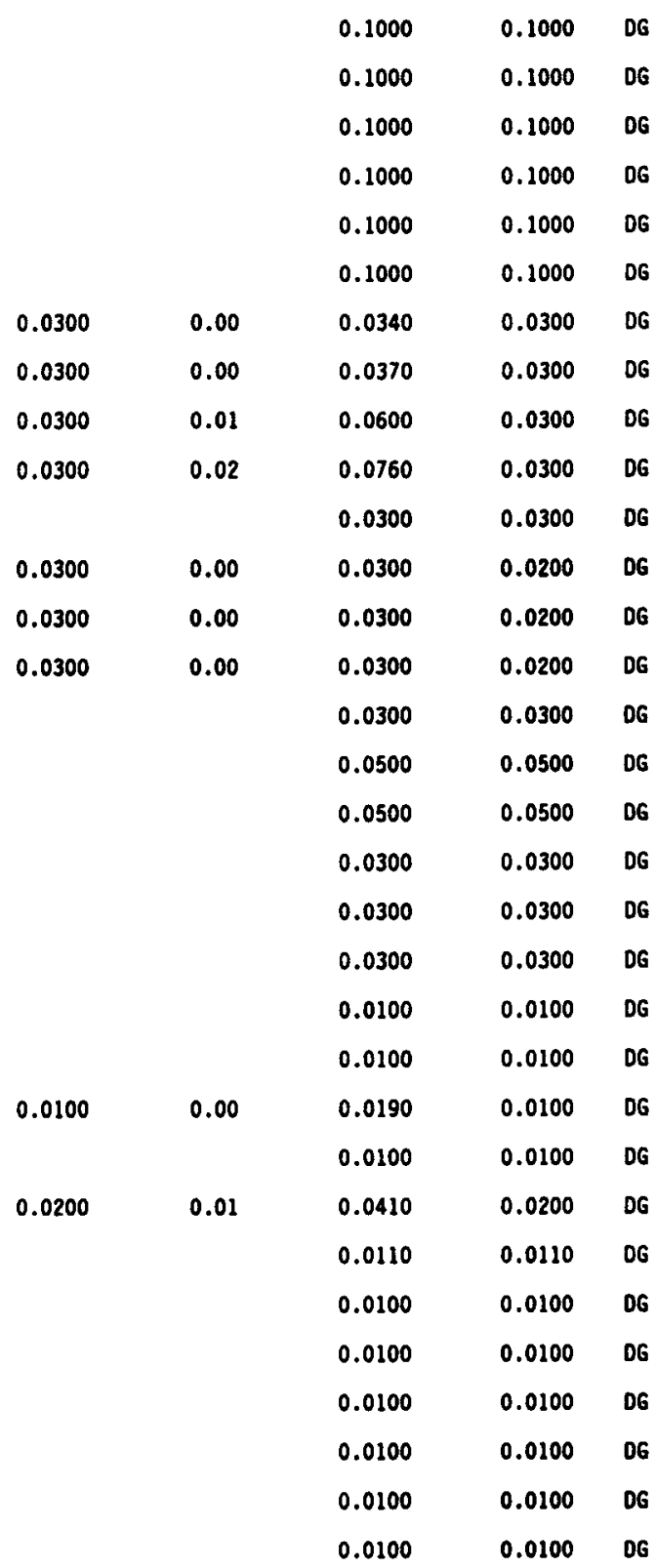


Nykøbing M. (76.13)

stof navn

Kondukt ivitet

pH

Inddampningsrest $\quad M G / L$

Torstof, totel MG/L

Oxygen indhold MG/L

Carbondtoxid, aggr. MG/L

Hydrogencarbonat MG/L

Calctumcarb, udfeldet MG/L

Carbon,org, HVOC MG/L

Permanganattal KMnO4 MG/L

Benzen

Toluen

Anmon laktamon fum $\quad M G / L$

Nitrit MG/L

Nitrat MG/L

Phosph., tot.f1?t P04 MG/L

A luminiue

Arsen

Barium

Biy

Bor

Bromid

Cadming

Calctun

Ch lor,org, $A 0 X$

Chlor,org, vox

Chlorid

Chrom

Cyantd

Fluor id

Jern

Jern ferro

Jern (<450nm)

Jod

Jodid

Kallue

Kobber

Lith tua

Magnestum

Mangan

Mo lybden

Matr tum

Nikkel

Stront ium

Sulfat

Hydrogensu lf id

Methan

Detergenter onion

Ch loroform

Tetrach lorkulstof
MYGRAM/L

MYGRAM/L

Enhed

SSIEMENS/M

L

G/L

G/L

/L

L

G/L

MYGRAM/L

MYGRAM/L

MYGRAM/L

MYGRAM/L

MYGRAK/L

MYGRAM/L

MYGRAM/L

MG/L

MYGRAM/L

MYGRAM/L

MG/L

MYGRAM/L

MG/L

MG/L

MG/L

MG/L

MG/L

MYGRAM/L

MYGRAM/L

MG/L

MYGRAM/L

MYGRAM/L

MG/L

MG/L

HYGRAM/L

MG/L

MYGRAM/L

MYGRAM/L

$\mathrm{MG} / \mathrm{L}$

HG/L

MG/L

MG/L

MYGRAM/L

MYGRAM/L
Viborg Amt

Grundvandsanalyser, 1990

Median

Spredning

Maxinum

Minimun

54.8000

46.94

0.49

39.2000

$7.2600 \quad 7.3900$

$589.6296 \quad 360.0000$

531.0714

350.0000

4.5357

4.3500

12.1558

3.4000

164.6545

184.0000

35.0000

35.0000

0.5267

0.5100

8.5636

4.0000

0.3000

0.3000

0.1000

0.1000

0.0985

0.0100

0.0101

0.0050

31.9724

33.0000

0.2110

0.1840

3366.6667

5000.0000

0.9133

1.1000

195.3333

130.0000

5.5967

1.3500

120666.67

68000.000

202.0000

202.0000

0.0340

0.0100

80.2364

67.0000

3.1000

1.7000

122.1091

44.0000

0.2600

0.1000

0.0000

0.0000

0.1631

0.1400

3.8592

0.2400

4.1706

0.0375

0.3967

0.5300

51.4333

4.3000

22.0000

2.2107

10.0000

2.1000

4.2467

0.4400

7.0000

9.0667

7.2000

9.9800

0.3063

0.0530

6.1333

7.6000

69.6364

23.0000

100.0000

600.0000

0.6600

0.9400

71.4527

39.0000

0.0215

0.0200

0.0500

0.0047

0.0050

$456.61 \quad 2100.0000 \quad 290.0000$

$\begin{array}{lll}387.70 & 2100.0000 & 290.0000\end{array}$

$\begin{array}{lll}3.50 & 9.7000 & 0.1000\end{array}$

$\begin{array}{lll}18.28 & 71.0000 & 2.0000\end{array}$

$\begin{array}{lll}63.85 & 344.0000 \quad 52.0000\end{array}$

. $\quad 35.0000 \quad 35.0000$

$\begin{array}{lll}0.05 & 0.5900 & 0.4800\end{array}$

$\begin{array}{lll}15.37 & 82.0000 & 4.0000\end{array}$

$\begin{array}{lll}0.00 & 0.3000 & 0.3000\end{array}$

$\begin{array}{lll}0.00 & 0.1000 & 0.1000\end{array}$

$0.22 \quad 1.0000$

0.0100

$0.01 \quad 0.0750$

0.0050

$23.33 \quad 73.0000$

0.1000

0.11

0.5519

0.0307

$2829.025000 .0000 * 100.0000$

$0.70 \quad 1.5000 \quad 0.1400$

$209.77 \quad 430.0000 \quad 26.0000$

8.34

15.2000

0.2400

121858

$260000.00 * 34000.000$

132.94

296.0000

108.0000

0.04

0.0820

0.0100

43.37

230.0000

34.0000

3.05

6.6000

1.0000

0.5000

0.5000

DG

$226.79 \quad 1082.0000$

22.0000

0.28

0.5800

0.1000

0.00

0.0000

0.0000

0.07

0.3500

0.1000

12.93

46.9000

0.0200

15.69

65.0000

0.0200

0.5500

0.1100

81.90

$146.0000 *$

4.0000

27.07

53.0000

3.0000

1.16

6.2000

0.9000

6.71

12.0000

0.3000

6.07

15.9000

4.3000

7.42

26.0000

2.1000

0.85

5.5000

0.0250

4.77

10.0000

0.8000

135.14

660.0000

12.0000

866.03 
Nykøbing M. (76.13)

Viborg Amt

\begin{tabular}{|c|c|}
\hline Stof navn & Enhed \\
\hline Tetrach lorethylen & MYGRAM/L \\
\hline Trichlorethylen & MYGRAM/L \\
\hline $1,1,1-\operatorname{tr}$ ichlorethan & MYGRAM/L \\
\hline P-xylen & MYGRAM/L \\
\hline M-xylen & MYGRAM/L \\
\hline $0-x y l e n$ & MYGRAM/L \\
\hline Maphthalen & MYGRAM/L \\
\hline Phenol & MYGRAM/L \\
\hline 3-methy lphenol & MYGRAM/L \\
\hline 2,3 diwethylphenol & MYGRAM/L \\
\hline 2-methy Iphenol & MYGRAY/L \\
\hline 4-methylphenol & MYGRAM/L \\
\hline 3,4-dimethy lphenol & MYGRAM/L \\
\hline 3,5-d twethy Iphenol & MYGRAM/L \\
\hline 2,6-d twe thy lphenol & MYGRAM/L \\
\hline 2,4-d twe thy Iphenol & MYGRAM/L \\
\hline 4-clor, 2-methy lpheno & MYGRAM/L \\
\hline 6-c lor, 2-Eethy lpheno & MYGRAM/L \\
\hline 2,4-dic lorphenol & MYGRAM/L \\
\hline $4,6-d 1 c$ lor, 2-methy lp & MYGRAM/L \\
\hline 2,6-d fc lorphenol & MYGRAM/L \\
\hline 2,4,6-triclorphenol & MYGRAM/L \\
\hline 2,3,4,6-tetrac lorphe & MYGRAM/L \\
\hline $2,3,5,6$-tetrac lorphe & MYGRAM/L \\
\hline 2,3,4,5-tetrac lorphe & MYGRAM/L \\
\hline Pentrac lorphenol & MYGRAM/L \\
\hline O1ch lorprop & MYGRAM/L \\
\hline MCPA & MYGRAM/L \\
\hline Mech lorprop & MYGRAM/L \\
\hline DMOC & MYGRAM/L \\
\hline Dinoseb & MYGRAM/L \\
\hline Atrazin & MYGRAM/L \\
\hline Simazin & MYGRAM/L \\
\hline
\end{tabular}

Grundvandsanalyser, 1990

Gens

Median Spredning

Max Imum

Minfaum.

$\begin{array}{lll}0.1000 & 0.1000 & D G \\ 0.1000 & 0.1000 & D G \\ 0.1000 & 0.1000 & D G \\ 0.1000 & 0.1000 & D G \\ 0.1000 & 0.1000 & D G \\ 0.1000 & 0.1000 & D G \\ 0.1000 & 0.1000 & D G \\ 0.0300 & 0.0300 & D G \\ 0.0300 & 0.0300 & D G \\ 0.0300 & 0.0300 & D G \\ 0.0300 & 0.0300 & D G \\ 0.0300 & 0.0300 & D G \\ 0.0300 & 0.0300 & D G \\ 0.0300 & 0.0300 & D G \\ 0.0300 & 0.0300 & D G \\ 0.0300 & 0.0300 & D G \\ 0.0500 & 0.0500 & D G \\ 0.0500 & 0.0500 & D G \\ 0.0300 & 0.0300 & D G \\ 0.0300 & 0.0300 & D G \\ 0.0300 & 0.0300 & D G \\ 0.0100 & 0.0100 & D G \\ 0.0100 & 0.0100 & D G \\ 0.0100 & 0.0100 & D G \\ 0.0100 & 0.0100 & D G \\ 0.0200 & 0.0200 & D G \\ 0.0130 & 0.0130 & D G \\ 0.0100 & 0.0100 & D G \\ 0.0110 & 0.0110 & D G \\ 0.0100 & 0.0100 & D G \\ 0.0100 & 0.0100 & D G \\ 0.0100 & 0.0100 & D G \\ 0.0100 & 0.0100 & D G \\ & & \end{array}$


Thisted - Baun (76.14) Viborg Amt

\begin{tabular}{|c|c|c|c|c|}
\hline Stor navn & Enhed & Anta 1 & Gens & Media \\
\hline Kondukt ivitet & MSIEMEMS/M & 57 & 50.8582 . & 55.100 \\
\hline pH & PH & 58 & 7.4459 & 7.40 \\
\hline Torstof, total & $M G / L$ & 66 & 352.1212 & 380.00 \\
\hline oxygen indhold & $N G / L$ & 66 & 4.1802 & 2.40 \\
\hline Carbondioxid, aggr. & $M G / L$ & 66 & 1.9744 & 2.00 \\
\hline Hydrogencarbonat & $M G / L$ & 66 & 219.0305 & 223.500 \\
\hline Carbon, org, NVOC & $M G / L$ & 9 & 0.8256 & 0.71 \\
\hline Permanganatta $1 \mathrm{KMnO4}$ & $M G / L$ & 66 & 4.5500 & 4.00 \\
\hline Benzen & MYGRAM/L & 9 & & \\
\hline Toluen & MYGRAM/L & 9 & & \\
\hline Ameon fak +amon ium & $M G / L$ & 66 & 0.0248 & 0.00 \\
\hline Nitrit & $M G / L$ & 66 & 0.0045 & 0.00 \\
\hline Nitrat & $M G / L$ & 66 & 21.7657 & 15.50 \\
\hline Orthophosphat-PO4 & $M G / L$ & 49 & 0.0537 & 0.030 \\
\hline Orthophosph.-P04,f11 & $M G / L$ & 15 & 0.0570 & 0.03 \\
\hline Phosph., tot.flit P04 & $M G / L$ & 66 & 0.0585 & 0.042 \\
\hline Aluminfum & MYGRAM/L & 9 & 5000.0000 & 5000.000 \\
\hline Arsen & MYGRAM/L & 9 & 1.5389 & 0.950 \\
\hline Bartum & MYGRAH/L & 9 & 62.4444 & 59.00 \\
\hline Bly & MYGRAM/L & 9 & 0.4000 & 0.200 \\
\hline 8or & MYGRAM/L & 9 & 75777.778 & 25000.00 \\
\hline Bromid & MYGRAM/L & 9 & 112.4444 & 108.000 \\
\hline Cadm 1um & MYGRAM/L & 9 & 0.0449 & \\
\hline Calc fum & $M G / L$ & 66 & 87.0455 & 93.50 \\
\hline Chlor, org, AOX & MYGRAM/L & 9 & 3.3111 & 3.100 \\
\hline Chlor, oro, vox & MYGRAM/L & 9 & 0.6556 & 0.500 \\
\hline Chlorld & $M G / L$ & 66 & 39.1061 & 38.00 \\
\hline Chrow & MYGRAM/L & 9 & 0.1978 & 0.130 \\
\hline Cyanid & $M G / L$ & 9 & 0.0000 & 0.000 \\
\hline Fluorid & $M G / L$ & 66 & 0.1353 & 0.11 \\
\hline Jern & $M G / L$ & 65 & 0.4117 & \\
\hline Jern ferro & $M G / L$ & 41 & 0.3345 & \\
\hline Jern $(<450 \mathrm{~nm})$ & $M G / L$ & 9 & 0.5944 & \\
\hline Jod & MYGRAM/L & 9 & 11.8222 & \\
\hline Jodid & MYGRAM/L & 9 & 4.0000 & 4.00 \\
\hline Kal fum & $M G / L$ & 66 & 1.4250 & 1.30 \\
\hline Kobber & MYGRAM/L & 9 & 0.4789 & 0.61 \\
\hline Lith fum & MYGRAM/L & 9 & 2.0667 & \\
\hline Magnes tum & $M G / L$ & 66 & 3.3727 & \\
\hline Mangan & MG/L & 65 & 0.0630 & 0.02 \\
\hline Molybdzen & MYGRAM/L & 9 & 0.9333 & 0.70 \\
\hline Natrfun & $M G / L$ & 66 & 19.6061 & 20.00 \\
\hline N1kke I & MYGRAM/L & 9 & 3352.2222 & 2050.00 \\
\hline Stront lun & MYGRAH/L & 9 & 1.4300 & 1.00 \\
\hline Sulfat & MG/L & 66 & 18.9091 & 19.00 \\
\hline Hydrogensulfid & $M G / L$ & 1 & 0.0200 & 0.02 \\
\hline Detergenter anton & $M G / L$ & 9 & 0.0046 & \\
\hline Cnloroform & MYGRAM/L & 9 & & \\
\hline Tetrach lorkulstof & MYGRAM/L & 9 & & \\
\hline Tetrach lorethylen & MYGRAM/L & 9 & & \\
\hline
\end{tabular}

Grundvandsanalyser, 1990

Median Spredning Maxtmum Minimum

$\begin{array}{lll}10.19 & 62.9000 & 7.4200\end{array}$

$\begin{array}{lll}0.17 & 7.8400 & 7.2100\end{array}$

$59.03 \quad 430.0000 \quad 240.0000$

$\begin{array}{lll}4.21 & 11.8000 & 0.1000\end{array}$

$\begin{array}{lll}0.25 & 2.3000 & 0.0100\end{array}$

$48.67 \quad 296.0000 \quad 0.0100$

$\begin{array}{lll}0.42 & 1.9000 & 0.4700\end{array}$

$\begin{array}{lll}1.54 & 12.0000 \quad 4.0000\end{array}$

$0.3000 \quad 0.3000 \quad D G$

$0.1000 \quad 0.1000 \quad D G$

$0.04 \quad 0.1700 \quad 0.0060$

$\begin{array}{lll}0.01 & 0.0580 & 0.0030 \quad D G\end{array}$

$\begin{array}{lll}19.87 & 56.0000 & 0.0220\end{array}$

$\begin{array}{lll}0.06 & 0.3066 & 0.0307\end{array}$

$\begin{array}{lll}0.07 & 0.3066 & 0.0307\end{array}$

$\begin{array}{lll}0.04 & 0.2760 & 0.0061\end{array}$

$0.00 \quad 5000.0000 * 5000.0000$

$1.59 \quad 5.3000 \quad 0.2200$

$\begin{array}{lll}14.35 & 85.0000 \quad 45.0000\end{array}$

$\begin{array}{lll}0.60 & 2.0000 & 0.2000\end{array}$

$76024.3220000 .00 * 18000.000$

$28.17 \quad 162.0000 \quad 75.0000$

$\begin{array}{lll}0.07 & 0.2330 & 0.0100\end{array}$

$15.95 \quad 108.0000 \quad 53.0000$

$\begin{array}{lll}1.43 \quad 6.0000 & 1.4000\end{array}$

$\begin{array}{lll}0.31 & 1.3000 & 0.5000\end{array}$

$\begin{array}{lll}6.09 & 57.0000 \quad 29.0000\end{array}$

$\begin{array}{lll}0.12 & 0.4300 & 0.1000\end{array}$

$\begin{array}{lll}0.00 & 0.0000 & 0.0000\end{array}$

$\begin{array}{lll}0.07 & 0.4500 & 0.1000\end{array}$

$\begin{array}{lll}0.70 & 2.3000 & 0.0200\end{array}$

$\begin{array}{lll}0.63 & 2.3000 & 0.0250\end{array}$

$\begin{array}{lll}0.89 & 2.3000 & 0.0250\end{array}$

$18.71 \quad 61.0000 * \quad 2.1000$

$1.32 \quad 7.0000 \quad 3.0000$

$\begin{array}{lll}0.56 & 2.4000 & 0.7500\end{array}$

$\begin{array}{lll}0.33 & 0.8700 & 0.0800\end{array}$

$\begin{array}{lll}0.75 & 3.7000 & 0.9000\end{array}$

$\begin{array}{lll}0.15 & 7.3000 \quad 1.7000\end{array}$

$\begin{array}{lll}0.27 & 2.2000 & 0.0200\end{array}$

$\begin{array}{lll}0.81 & 2.7000 & 0.1500\end{array}$

$\begin{array}{lll}3.95 & 31.0000 \quad 13.0000\end{array}$

$2368.257570 .0000 * 1590.0000$

$\begin{array}{lll}2.07 & 6.8000 & 0.2100\end{array}$

$8.95 \quad 47.0000 \quad 5.0000$

$0.0200 \quad 0.0200$

0.00

0.0070

$0.0040 \quad D G$

$0.1000 \quad 0.1000 \quad 0 G$

$0.1000 \quad 0.1000 \quad D G$

$0.1000 \quad 0.1000 \quad D G$

* Særlig usædvanlig værdi, der må kontrolleres. 
Thisted - Baun (76.14) Viborg Amt $\quad$ Grundvandsanalyser, 1990

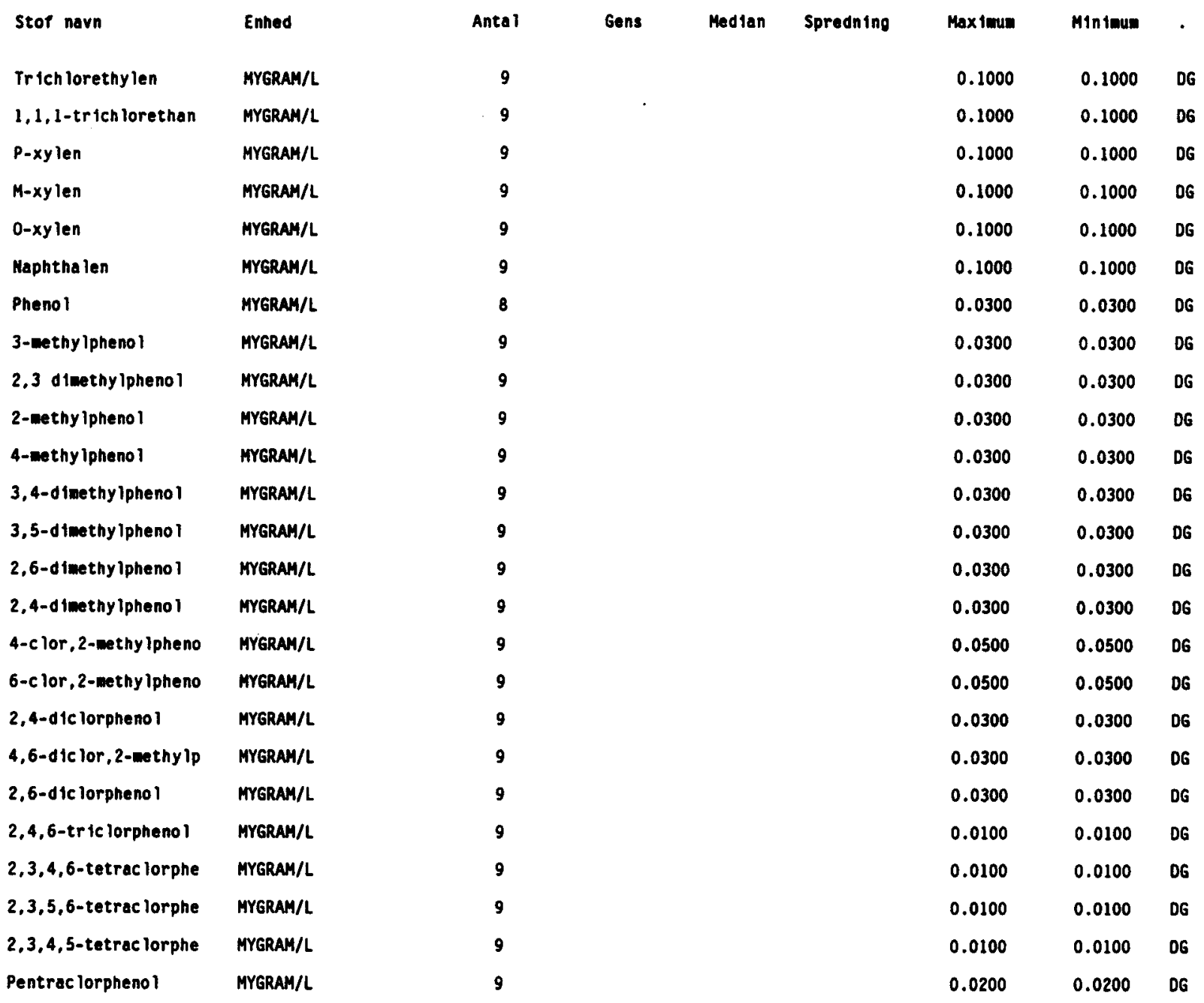




\section{Tornby (80.01)}

Stor navn Enhed

$\begin{array}{ll}\text { Kondukt ivitet } & \text { MSIE } \\ \text { PH } & \text { PH } \\ \text { Inddanpningsrest } & M G / L \\ \text { Carbondtoxid, aggr. } & M G / L \\ \text { Hydrogencarbonat } & M G / L \\ \text { Carbon, org, NVOC } & M G / L\end{array}$

Cyanid, total

Benzen

Toluen

Ammon lak +anmon ium

Nitrit

Nitrat

Phosph., tot.f11t PO4

Aluminiua

Arsen

Barium

Bly

Bor

Browido

Cadalum

Calc lum

Chlor,org, AOX

Chlor,org, vox

chlorio

Chrom

Fluortd

Jern

Jod

Jodid

Kallum

Kobber

Litnium

Magnes ium

Mangan

Molybden

Matr lus

Mikke I

stront fua

Sulfat

Hydrogensulf id

Trit fum

Methan

Detergenter anion

Chlorofor:

Tetrach lorkulstof

Tetrach lorethylen

Trtchlorethylen

1,1,1-trichloretnan

P-xylen
MSIEMENS/M

PH

M6/L

HG/L

HG/L

$M G / L$

MG/L

MYGRAM/L

MYGRAM/L

MYGRAM/L

MG/L

MG/L

MG/L

MG/L

MYGRAM/L

MYGRAM/L

MYGRAM/L

MYGRAM/L

MYGRAM/L

MYGRAM/L

MYGRAM/L

MG/L

MYGRAM/L

MYGRAM/L

MG/L

MYGRAM/L

MG/L

$M G / L$

MYGRAM/L

MYGRAM/L

MG/L

MYGRAM/L

MYGRAM/L

$M G / L$

$M G / L$

MYGRAM/L

MG/L

MYGRAM/L

MYGRAM/L

MG/L

MG/L

T.U.

146/L

MG/L

MYGRAM/L

MYGRAM/L

MYGRAM/L

MYGRAY/L

MYGRAH/L

MYGRAM/L
Nordjyllands Amt

Ant

$41 \quad 70.7805$

64.0000

7.3976

7.4000

455.3659

400.0000

11.4000

12.0000

280.2927

1.3667

326.0000

1.6000

15.8956

7.6000

29.95

152.0000

7.9000

$237.50 \quad 1150.0000$

$4.98 \quad 18.0000$

128.29

493.0000

0.59

1.8000

$17.55 \quad 73.0000$

2.0000

0.3000

0.1000

3.7693

0.1200

0.9872

0.5472

1.13

0.0200

0.03

76.0000

1.0000

15.14

0.7359

85.0000

3.4000

94.0000

0.1800

153.0000

113.6667

94.0000

145.0000

34.06

43.31

197.0000

0.0120

85.8000

159.23

1070.0000

3.7000

0.64

3.7000

0.5000

66.0000

0.1000

0.2800

12.4000

5.9000

22.0000

7.2800

0.3000

10.0000

58.0000

0.4900

1.1000

48.2000

0.4000

0.3600

10.39

0.4000

165.0000

0.16

218.0000

34.22

500.0000

0.0600

29.0000

2.9000

0.0200

0.1000

0.1000

0.1000

0.1000

0.1000

0.1000

38.0000

6.7000

250.0000

6.0000

99.0000

0.7000

0.3000

2.0000

0.3000

0.1000

0.0122

0.0100

1.0000

0.0613

1.8000

0.0800

16.0000

0.1800

94.0000

111.0000

0.0120

26.9000

2.6000

0.3000

15.0000

0.1000

0.1000

0.0100

1.6000

3.0000

1.8000

0.1000

3.0000

5.1000

0.0100

0.5000

13.2000

0.1000

154.0000

13.0000

0.0100

15.0000

0.0100

0.0100

0.1000

0.1000

0.1000

0.1000

0.1000

0.1000 


\section{Tornby (80.01)}

M-xylen

0-xylen

Naphthalen

Phenol

3-wethylpheno ?

2,3 diwethy lphenol

2-methy Iphenol

4-wethy iphenol

3,4-d ine thylphenol

3,5-dine thylphenol

2,6-d twe thy lphenol

2,4-d twe thy lpheno 1

4-c Jor, 2-methy ipheno

6-clor, 2-nethy ipheno

2,4-dic lorphenol

4,6-dic lor, 2-methy lp

2,6-dtc lorphenol

2,4,6-tric lorpheno 1

2,3,4,6-tetrac lorphe

2,3,5,6-tetrac lorphe

$2,3,4,5$-tetrac lorphe

Pentrac lorphenol

Otch lorprop

MCPA

Mech lorprop

DNOC

Dinoseb

Atraz in

Simaz in

Temp. v. udtagning

Kintal 376r. PCA

Kimta) 216r.KING A

Iltindhold
Enhed

MYGRAH/L

MYGRAM/L

MYGRAN/L

MYGRAM/L

MYGRAM/L

MYGRAM/L

MYGRAM/L

MYGRAM/L

MYGRAM/L

MYGRAM/L

MYGRAM/L

MYGRAM/L

MYGRAM/L

MYGRAM/L

MYGRAM/L

MYGRAH/L

MYGRAM/L

MYGRAM/L

MYGRAM/L

MYGRAM/L

MYGRAM/L

MYGRAM/L

MYGRAM/L

MYGRAM/L

MYGRAM/L

MYGRAM/L

MYGRAM/L

MYGRAM/L

MYGRAM/L

GRADER C

ANTAL/ML

AHTAL/ML

MG/L
Nordjyllands Amt

Grundvandsanalyser, 1990

3

3

3

3

3

3

3

3

3

3

3

3

3

3

3

3

3

3

3

3

3

3

3

3

3

3

3

3

42

8.5286

0.1097

0.1100

8.4500 $\begin{array}{rr}41 \quad 1178.4878 \\ 41 & 1.0183\end{array}$

$\begin{array}{rr}41 & 1178.4878 \\ 41 & 1.0183\end{array}$

210.0000

0.3400
0.04

0.1000

0.1000

0.1000

0.0300

0.0300

0.0300

0.0300

0.0300

0.0300

0.0300

0.0300

0.0300

0.0500

0.0500

0.0300

0.0300

0.0300

0.0100

0.0100

0.0100

0.0100

0.0200

0.0240

0.1500

0.0120

0.0150

0.0100

0.0100

$0.0100 \quad 0.0100$

0.91

Mininum

0.1000

0.1000

0.1000

0.0300

0.0300

0.0300

0.0300

0.0300

0.0300

0.0300

0.0300

0.0300

0.0500

0.0500

0.0300

0.0300

0.0300

0.0100

0.0100

0.0100

0.0100

0.0200

0.0140

0.0690

0.0120

0.0150

0.0100

0.0100

10.8000

6.4000

$1.0000 \quad 1.0000$

$2144.60 \quad 9000.0000$

1.0000

1.52

5.9000

0.0500 
Tornby (80.01)

\begin{tabular}{|c|c|}
\hline Stof navn & Enhed \\
\hline Kondukt ivitet & MSIEMENS/ \\
\hline pH & PH \\
\hline Terst of, total & $M G / L$ \\
\hline Oxygen indhold & $M G / L$ \\
\hline Carbond toxid, aggr. & $M G / L$ \\
\hline Hydrogencarbonet & $M G / L$ \\
\hline Permanganattal KMnO4 & $M G / L$ \\
\hline Ammon 1aktarmon fum & $M G / L$ \\
\hline Nitrat & $M G / L$ \\
\hline Phosph., tot.f1lt PO4 & $M G / L$ \\
\hline Calc tum & $M G / L$ \\
\hline Chlorid & $M G / L$ \\
\hline Fiuorid & $M G / L$ \\
\hline Jern & $M G / L$ \\
\hline Kalfum & $M G / L$ \\
\hline Magnesium & $M G / L$ \\
\hline Mangan & $M G / L$ \\
\hline Natrium & $M G / L$ \\
\hline Sulfat & $M G / L$ \\
\hline Hydrogensulfid & $M G / L$ \\
\hline Tritium & T.U. \\
\hline Methan & $M G / L$ \\
\hline
\end{tabular}

Nordjyllands Amt Grundvandsanalyser, 1989

$\begin{array}{rrrrrr}\text { Antal } & \text { Gens } & \text { Median } & \text { Spredning } & \text { Maximum } & \text { Minimum } \\ & & & & & \\ 23 & 69.6957 & 63.0000 & 34.59 & 171.0000 & 38.0000 \\ 23 & 7.3152 & 7.3500 & 0.49 & 8.1000 & 6.1500 \\ 5 & 352.0000 & 390.0000 & 54.95 & 390.0000 & 270.0000 \\ 5 & 4.2200 & 0.8000 & 5.19 & 10.1000 & 0.1000 \\ 2 & 3.0000 & 3.0000 & 1.41 & 4.0000 & 2.0000 \\ 13 & 229.7692 & 198.0000 & 131.19 & 487.0000 & 23.0000 \\ 13 & 18.0692 & 8.4000 & 27.43 & 106.0000 & 5.4000 \\ 13 & 0.6938 & 0.2400 & 0.95 & 2.9000 & 0.0300 \\ 11 & 35.4545 & 26.0000 & 26.09 & 84.0000 & 9.0000 \\ 5 & 0.1778 & 0.2146 & 0.10 & 0.2760 & 0.0307 \\ 13 & 86.1538 & 74.1000 & 57.15 & 255.0000 & 20.3000 \\ 23 & 40.2609 & 35.0000 & 14.34 & 67.0000 & 19.0000 \\ 6 & 0.2000 & 0.1000 & 0.20 & 0.6000 & 0.1000 \\ 23 & 27.7948 & 7.3200 & 55.48 & 234.0000 & 0.0100 \\ 13 & 4.1154 & 3.4000 & 2.18 & 8.8000 & 1.6000 \\ 13 & 18.4385 & 14.8000 & 16.44 & 63.0000 & 3.0000 \\ 13 & 0.1985 & 0.1600 & 0.17 & 0.5300 & 0.0100 \\ 13 & 27.6846 & 21.0000 & 12.30 & 55.1000 & 16.6000 \\ 13 & 96.5385 & 58.0000 & 143.16 & 567.0000 & 26.0000 \\ 1 & 0.1000 & 0.1000 & . & 0.1000 & 0.1000 \\ 2 & 27.5000 & 27.5000 & 0.71 & 28.0000 & 27.0000 \\ 6 & 2.2000 & 1.7500 & 1.94 & 5.4000 & 0.3000\end{array}$


Råkilde-Støvring (80.02) Nordjyllands Amt

Grundvandsanalyser, 1990

\begin{tabular}{|c|c|c|c|c|c|c|c|}
\hline Stof navn & Enhed & Antal & Gens & Modian & Spredning & Maxtmuin & Minimum \\
\hline Kondukt Ivitet & MSIEMENS/M & 52 & 45.3462 . & 40.0000 & 10.46 & 71.0000 & 35.0000 \\
\hline PH & PH & 52 & 7.7212 & 7.7000 & 0.15 & 8.0000 & 7.3500 \\
\hline Inddampn ingsrest & $\mathrm{MG} / \mathrm{L}$ & 52 & 280.9615 & 245.0000 & 78.32 & 490.0000 & 200.0000 \\
\hline Carbondioxid, aggr. & $M G / L$ & 1 & 6.0000 & 6.0000 & $\cdot$ & 6.0000 & 6.0000 \\
\hline Hydrogencarbonat & $M G / L$ & 52 & 174.1923 & 173.0000 & 15.68 & 210.0000 & 138.0000 \\
\hline Carbon, org, MYOC & $M G / L$ & 5 & 0.8440 & 0.6500 & 0.44 & 1.3000 & 0.3200 \\
\hline Permanganattal KMnO4 & $M G / L$ & 52 & 2.5315 & 1.9000 & 2.26 & 10.0000 & 0.3000 \\
\hline Cyanid, total & MYGRAM/L & 5 & 2.9600 & 2.0000 & 2.15 & 6.8000 & 2.0000 \\
\hline Benzen & MYGRAM/L & 5 & & & & 0.3000 & 0.3000 \\
\hline Toluen & MYGRAM/L & 5 & & & & 0.1000 & 0.1000 \\
\hline Amonon faktammon fum & MG/L & 52 & 0.0192 & 0.0122 & 0.02 & 0.0973 & 0.0122 \\
\hline N1trit & $M G / L$ & 52 & 0.0252 & 0.0100 & 0.05 & 0.1800 & 0.0100 \\
\hline Nitrat & $M G / L$ & 52 & 21.9808 & 12.0000 & 26.40 & 97.0000 & 1.0000 \\
\hline Phosph., tot.filt PO4 & $M G / L$ & 52 & 0.0855 & 0.0613 & 0.05 & 0.2760 & 0.0307 \\
\hline A luan in 1um & MYGRAM/L & 5 & 448.7400 & 4.4000 & 995.76 & $2230.0000 *$ & 1.8000 \\
\hline Arsen & MYGRAM/L & 5 & 1.3200 & 1.1000 & 0.49 & 2.2000 & 1.1000 \\
\hline Barium & MYGRAM/L & 5 & 34.1600 & 17.0000 & 31.09 & 73.0000 & 3.8000 \\
\hline Bly & MYGRAM/L & 5 & 3.9000 & 3.5000 & 3.83 & 10.2000 & 0.3000 \\
\hline Bor & MYGRAM/L & 5 & 48.2000 & 20.0000 & 58.69 & 153.0000 & 20.0000 \\
\hline Brow id & MYGRAM/L & 5 & 79.2000 & 74.0000 & 40.37 & 145.0000 & 36.0000 \\
\hline Codm tum & MYGRAM/L & 5 & 0.0676 & 0.0120 & 0.12 & 0.2900 & 0.0120 \\
\hline Calcium & $M G / L$ & 52 & 68.6250 & 60.3000 & 16.61 & 114.0000 & 57.0000 \\
\hline Chlor,org. AOX & MYGRAM/L & 5 & 2.6400 & 2.1000 & 1.54 & 5.2000 & 1.4000 \\
\hline Chlor,org, vox & MYGRAM/L & 5 & & & & 0.5000 & 0.5000 \\
\hline Chlortd & $M G / L$ & 52 & 30.4423 & 24.0000 & 15.00 & 71.0000 & 14.0000 \\
\hline Chrow & MYGRAM/L & 5 & 1.5000 & 0.2000 & 2.91 & 6.7000 & 0.1000 \\
\hline Fluorid & $M G / L$ & 52 & 0.1113 & 0.1000 & 0.03 & 0.2400 & 0.1000 \\
\hline Jern & $M G / L$ & 41 & 0.0666 & 0.0200 & 0.12 & 0.4300 & 0.0100 \\
\hline Jod & MYGRAM/L & 5 & 13.6600 & 1.6000 & 27.02 & $62.0000 *$ & 1.2000 \\
\hline Jodid & MYGRAM/L & 5 & 5.4000 & 3.0000 & 5.37 & 15.0000 & 3.0000 \\
\hline Kalfun & $M G / L$ & 52 & 1.2229 & 1.1300 & 0.32 & 1.9100 & 0.8400 \\
\hline Kobber & MYGRAM/L & 5 & 2.1400 & 0.4000 & 3.90 & 9.1000 & 0.2000 \\
\hline Lith1un & MYGRAM/L & 5 & 3.8000 & 3.0000 & 2.77 & 8.0000 & 1.0000 \\
\hline Magnes tum & $M G / L$ & 52 & 6.5865 & 6.4000 & 1.97 & 12.4000 & 4.0000 \\
\hline Mangan & $M G / L$ & 34 & 0.0194 & 0.0100 & 0.02 & 0.0900 & 0.0100 \\
\hline Mo lybdan & MYGRAM/L & 5 & 0.9800 & 0.9000 & 0.49 & 1.8000 & 0.6000 \\
\hline Natrium & $M G / L$ & 52 & 13.5558 & 11.5000 & 5.39 & 29.5000 & 8.2000 \\
\hline Nikke 1 & MYGRAM/L & 5 & 1.7980 & 1.0100 & 2.31 & 5.8900 & 0.4400 \\
\hline Stront ium & MYGRAM/L & 5 & 866.4000 & 489.0000 & 689.27 & 1947.0000 & 276.0000 \\
\hline Sulfat & $M G / L$ & 52 & 23.8077 & 19.0000 & 14.97 & 68.0000 & 5.0000 \\
\hline Trit ium & T.U. & 8 & 32.1250 & 22.5000 & 28.77 & 98.0000 & 10.0000 \\
\hline Detergenter anton & MG/L & 5 & 0.0220 & 0.0200 & 0.01 & 0.0400 & 0.0100 \\
\hline Chloroform & MYGRAM/L & 5 & & & & 0.1000 & 0.1000 \\
\hline Tetrach lorku lstof & MYGRAK/L & 5 & & & & 0.1000 & 0.1000 \\
\hline Tetrachlorethylen - & MYGRAM/L & 5 & & & & 0.1000 & 0.1000 \\
\hline Trich lorethylen & MYGRAM/L & 5 & & & & 0.1000 & 0.1000 \\
\hline 1,1,1-tr teh lorethan & MYGRAM/L & 5 & & & & 0.1000 & 0.1000 \\
\hline P-xylen & MYGRAM/L & 5 & & & & 0.1000 & 0.1000 \\
\hline H-xy len & MYGRAM/L & 5 & & & & 0.1000 & 0.1000 \\
\hline $0-x y$ len & MYGRAM/L & 5 & & & & 0.1000 & 0.1000 \\
\hline
\end{tabular}

* Særlig usædvanlig værdi, der må kontrolleres. 
Råkilde-Støvring (80.02) Nordjyllands Amt

Grundvandsanalyser, 1990

\begin{tabular}{|c|c|c|c|c|c|c|c|c|}
\hline Stof navn & Enhed & Antal & Gens & Median & Spredning & Max Tmum & Min imum & . \\
\hline Naphthalen & MYGRAM/L & 5 & . & & & 0.1000 & 0.1000 & $D G$ \\
\hline Phenol & MYGRAM/L & 4 & 0.0363 & 0.0300 & 0.01 & 0.0550 & 0.0300 & DG \\
\hline 3-methylphenol & MYGRAM/L & 5 & & & & 0.0300 & 0.0300 & DG \\
\hline 2,3 diwe thy lphenol & MYGRAM/L & 5 & & & & 0.0300 & 0.0300 & OG \\
\hline 2-methy lphenol & MYGRAM/L & 5 & & & & 0.0300 & 0.0300 & DG \\
\hline 4-methyiphenol & MYGRAM/L & 5 & & & & 0.0300 & 0.0300 & DG \\
\hline 3,4-d 1methy Ipheno I & MYGRAM/L & 5 & & & & 0.0300 & 0.0300 & OG \\
\hline 3,5-dimethylphenol & MYGRAM/L & 5 & & & & 0.0300 & 0.0300 & DG \\
\hline 2,6-d dmethylphenol & MYGRAM/L & 5 & & & & 0.0300 & 0.0300 & $D G$ \\
\hline 2,4-diwethylphenol & MYGRAM/L & 5 & & & & 0.0300 & 0.0300 & DG \\
\hline 4-c lor, 2-methy lpheno & MYGRAM/L & 5 & & & & 0.0500 & 0.0500 & OG \\
\hline 6-clor, 2-methylpheno & MYGRAM/L & 5 & & & & 0.0500 & 0.0500 & OG \\
\hline 2,4-dic lorphenol & MYGRAM/L & 5 & & & & 0.0300 & 0.0300 & $D G$ \\
\hline 4,6-dtclor, 2-methy ip & MYGRAM/L & 5 & & & & 0.0300 & 0.0300 & $D G$ \\
\hline 2,6-dic lorphenol & MYGRAM/L & 5 & & & & 0.0300 & 0.0300 & OG \\
\hline 2,4,6-tric lorphenol & MYGRAM/L & 5 & & & & 0.0100 & 0.0100 & $D G$ \\
\hline $2,3,4,6$-tetrac lorphe & MYGRAM/L & 5 & & & & 0.0100 & 0.0100 & DG \\
\hline 2,3,5,6-tetrac lorphe & MYGRAM/L & 5 & & & & 0.0100 & 0.0100 & $D G$ \\
\hline 2,3,4,5-tetrac lorphe & MYGRAM/L & 5 & & & & 0.0100 & 0.0100 & DG \\
\hline Pentrac lorphenol & MYGRAM/L & 5 & & & & 0.0200 & 0.0200 & DG \\
\hline Dich lorprop & MYGRAM/L & 5 & & & & 0.0140 & 0.0140 & OG \\
\hline MCPA & MYGRAM/L & 5 & 0.0614 & 0.0780 & 0.03 & 0.0840 & 0.0110 & $D G$ \\
\hline Mech lorprop & MYGRAM/L & 5 & & & & 0.0120 & 0.0120 & DG \\
\hline DNOC & MYGRAM/L & 5 & & & & 0.0150 & 0.0150 & DG \\
\hline Dinoseb & MYGRAM/L & 5 & & & & 0.0100 & 0.0100 & $D G$ \\
\hline Atrazin & MYGRAM/L & 5 & & & & 0.0100 & 0.0100 & DG \\
\hline Simazin & MYGRAM/L & 5 & & & & 0.0100 & 0.0100 & OG \\
\hline Temp. v. udtagning & GRADER C & 52 & 8.6192 & 8.6000 & 0.62 & 10.6000 & 7.6000 & \\
\hline Kimtel 21Gr.KIHG A & ANTAL/ML & 48 & 366.5625 & 150.0000 & 635.58 & 3200.0000 & 1.0000 & \\
\hline It indhold & MG/L & 52 & 2.1085 & 1.9000 & 1.74 & 6.6000 & 0.1100 & \\
\hline
\end{tabular}


Råkilde-Støvring (80.02) Nordjyllands Amt Grundvandsanalyser, 1989

\begin{tabular}{|c|c|c|c|c|c|c|c|}
\hline Stof navn & Enhed & Anta 1 & Gens & Median & Spredning & Maximum & Min 1mum \\
\hline Kondukt ivitet & MSIEMENS/M & 39 & 45.9487 & 40.0000 & 10.81 & 72.0000 & 36.0000 \\
\hline pH & PH & 39 & 7.5308 & 7.6000 & 0.22 & 8.0000 & 7.1500 \\
\hline Torstof, total & $M G / L$ & 22 & 267.9545 & 255.0000 & 72.98 & 450.0000 & 190.0000 \\
\hline Oxygen indhold & $M G / L$ & 22 & 6.6045 & 6.4000 & 3.74 & 13.5000 & 1.6000 \\
\hline Hydrogencarbonat & $M G / L$ & 26 & 181.5769 & 174.5000 & 22.44 & 253.0000 & 142.0000 \\
\hline Permanganattal KMnO4 & $M G / L$ & 25 & 1.9760 & 1.9000 & 1.23 & 5.1000 & 0.3000 \\
\hline Amon taktarmon tum & $M G / L$ & 10 & 0.0230 & 0.0100 & 0.02 & 0.0700 & 0.0100 \\
\hline N1trat & $M G / L$ & 33 & 26.6970 & 14.0000 & 26.82 & 93.0000 & 6.0000 \\
\hline Phosph., tot.f11t PO4 & $M G / L$ & 21 & 0.0818 & 0.0613 & 0.04 & 0.1533 & 0.0307 \\
\hline Calcium & HG/L & 26 & 71.4462 & 60.2500 & 21.82 & 136.0000 & 57.8000 \\
\hline Chlor 10 & $M G / L$ & 39 & 29.7949 & 23.0000 & 15.67 & 77.0000 & 14.0000 \\
\hline F luor id & $M G / L$ & 10 & 0.1600 & 0.1000 & 0.10 & 0.4000 & 0.1000 \\
\hline Jern & $M G / L$ & 35 & 2.1203 & 0.0300 & 7.35 & 41.1000 & 0.0100 \\
\hline Kaliue & $M G / L$ & 26 & 1.2000 & 1.2000 & 0.33 & 1.8000 & 0.8000 \\
\hline Magnesiun & MG/L & 26 & 7.0038 & 6.5000 & 2.48 & 16.0000 & 4.4000 \\
\hline Mangan & $M G / L$ & 9 & 0.0300 & 0.0100 & 0.03 & 0.1000 & 0.0100 \\
\hline Natrfun & M6/L & 26 & 14.0538 & 12.0500 & 5.44 & 28.7000 & 6.1000 \\
\hline Sulfat & MG/L & 26 & 24.8077 & 20.5000 & 15.24 & 65.0000 & 5.0000 \\
\hline
\end{tabular}




\section{Drastrup (80.11)}

\begin{tabular}{|c|c|}
\hline Stor navn & Enhed \\
\hline Kondukt ivitet & MSIEMEMS/M \\
\hline pH & PH \\
\hline Inddampn ingsrest & $M G / L$ \\
\hline Hydrogencarbonat & $M G / L$ \\
\hline Carbon, org, nYOC & $M G / L$ \\
\hline Peraanganatta $1 \mathrm{KMnO4}$ & $M G / L$ \\
\hline Cyanid, total & MYGRAM/L \\
\hline Benzen & MYGRAM/L \\
\hline Toluen & MYGRAM/L \\
\hline Ama on tak +akswon fum & MG/L \\
\hline N1trit & $M G / L$ \\
\hline Nitrat & $M G / L$ \\
\hline Phosph.,tot.filt PO4 & $M G / L$ \\
\hline Aluminius & MYGRAM/L \\
\hline Arsen & MYGRAM/L \\
\hline Bartua & MYGRAM/L \\
\hline Bly & MYGRAM/L \\
\hline Bor & MYGRAM/L \\
\hline Brom 1d & MYGRAM/L \\
\hline Cadmintum & MYGRAM/L \\
\hline Calctum & $M G / L$ \\
\hline Chlor, org, AOX & MYGRAM/L \\
\hline Chlor, org, vox & MYGRAM/L \\
\hline Chlorid & MG/L \\
\hline Chrow & MYGRAM/L \\
\hline Fluor 1d & $M G / L$ \\
\hline Jern & $M G / L$ \\
\hline Jod & MYGRAM/L \\
\hline Jodid & MYGRAM/L \\
\hline Kallua & MG/L \\
\hline Kobber & MYGRAM/L \\
\hline Lith fum & MYGRAM/L \\
\hline Magnes ium & MG/L \\
\hline Mangan & $M G / L$ \\
\hline Mo lybdan & MYGRAM/L \\
\hline Natrium & $M G / L$ \\
\hline N1kke I & MYGRAM/L \\
\hline Stront iun & MYGRAM/L \\
\hline Sulfat & $M G / L$ \\
\hline Hydrogensulf id & $M G / L$ \\
\hline Trittun & T.U. \\
\hline Methan & MG/L \\
\hline Detergenter anton & $M G / L$ \\
\hline Ch loroform & MYGRAM/L \\
\hline Tetrach lorkulstof & MYGRAM/L \\
\hline Tetrach lorethy len & MYGRAM/L \\
\hline Trich lorethylen & MYGRAM/L \\
\hline 1,1,1-trich lorethan & MYGRAM/L \\
\hline P-xylen & MYGRAM/L \\
\hline A-xylen & MYGRAM/L \\
\hline
\end{tabular}

Nordjyllands Amt Grundvandsanalyser, 1990

\begin{tabular}{|c|c|c|c|c|c|}
\hline Antal & Gens & Medtan & Spredning & Maximum & Min inum \\
\hline 91 & 60.8791 & 56.0000 & 18.49 & 103.0000 & 35.0000 \\
\hline 91 & 7.4868 & 7.5500 & 0.23 & 7.8000 & 6.8000 \\
\hline 90 & 394.8889 & 360.0000 & 133.86 & 700.0000 & 200.0000 \\
\hline 90 & 198.4333 & 187.0000 & 48.96 & 344.0000 & 133.0000 \\
\hline 8 & 1.0988 & 0.9450 & 0.51 & 2.0000 & 0.5700 \\
\hline 90 & 6.9082 & 2.8000 & 16.67 & 92.0000 & 0.3000 \\
\hline 8 & 2.1125 & 2.0000 & 0.25 & 2.7000 & 2.0000 \\
\hline 8 & & & & 0.3000 & 0.3000 \\
\hline 8 & & & & 0.1000 & 0.1000 \\
\hline 90 & 0.0404 & 0.0122 & 0.11 & 0.7052 & 0.0122 \\
\hline 90 & 0.0212 & 0.0100 & 0.04 & 0.2100 & 0.0100 \\
\hline 90 & 51.9333 & 47.0000 & 42.67 & 191.0000 & 1.0000 \\
\hline 91 & 0.1658 & 0.0920 & 0.19 & 0.8279 & 0.0307 \\
\hline 8 & 2.2000 & 2.0500 & 0.47 & 3.0000 & 1.8000 \\
\hline 8 & 1.0637 & 1.0050 & 0.61 & 2.0000 & 0.3100 \\
\hline 8 & 28.3375 & 14.5000 & 45.26 & 140.0000 & 7.3000 \\
\hline 8 & 0.1800 & 0.1800 & 0.00 & 0.1800 & 0.1800 \\
\hline 8 & 21.2500 & 20.0000 & 2.31 & 25.0000 & 20.0000 \\
\hline 8 & 92.5000 & 79.5000 & 44.38 & 184.0000 & 49.0000 \\
\hline 8 & & & & 0.0120 & 0.0120 \\
\hline 90 & 95.9656 & 88.7500 & 32.11 & 177.0000 & 57.4000 \\
\hline 8 & 5.7750 & 4.7000 & 2.43 & 9.2000 & 3.4000 \\
\hline 8 & & & & 0.5000 & 0.5000 \\
\hline 90 & 42.8556 & 35.0000 & 27.05 & 124.0000 & 11.0000 \\
\hline 8 & 0.6625 & 0.6500 & 0.20 & 1.0000 & 0.3000 \\
\hline 90 & 0.1040 & 0.1000 & 0.02 & $0.2300 *$ & 0.0100 \\
\hline 52 & 0.4485 & 0.0150 & 1.48 & 5.7000 & 0.0100 \\
\hline 8 & 3.8250 & 2.7000 & 3.19 & 11.0000 & 1.6000 \\
\hline 8 & 4.0250 & 3.8000 & 0.68 & 5.3000 & 3.3000 \\
\hline 90 & 2.0691 & 1.0599 & 3.43 & 18.6400 & 0.6800 \\
\hline 8 & 0.8375 & 0.7000 & 0.51 & 2.0000 & 0.4000 \\
\hline 8 & 2.3750 & 2.5000 & 1.30 & 4.0000 & 1.0000 \\
\hline 90 & 5.2100 & 4.6500 & 2.13 & 9.8000 & 2.1000 \\
\hline 65 & 0.0355 & 0.0100 & 0.06 & 0.3500 & 0.0100 \\
\hline 8 & 1.3125 & 1.3000 & 0.60 & 2.5000 & 0.6000 \\
\hline 90 & 18.7411 & 15.9500 & 7.05 & 38.0000 & 9.4000 \\
\hline 8 & 0.8875 & 0.3500 & 1.48 & 4.5200 & 0.1800 \\
\hline 8 & 264.6250 & 260.5000 & 95.40 & 461.0000 & 131.0000 \\
\hline 90 & 35.0222 & 30.0000 & 24.03 & 133.0000 & 7.0000 \\
\hline 4 & 0.0275 & 0.0150 & 0.03 & 0.0700 & 0.0100 \\
\hline 17 & 20.4588 & 17.5000 & 13.55 & 50.0000 & 1.9000 \\
\hline 5 & 0.0340 & 0.0100 & 0.04 & 0.0900 & 0.0100 \\
\hline 8 & 0.0125 & 0.0100 & 0.00 & 0.0200 & 0.0100 \\
\hline 8 & & & & 0.1000 & 0.1000 \\
\hline 8 & & & & 0.1000 & 0.1000 \\
\hline 8 & & & & 0.1000 & 0.1000 \\
\hline 8 & & & & 0.1000 & 0.1000 \\
\hline 8 & & & & 0.1000 & 0.1000 \\
\hline 8 & & & & 0.1000 & 0.1000 \\
\hline 8 & & & & 0.1000 & 0.1000 \\
\hline
\end{tabular}

* Særlig usædvanlig værdi, der må kontrolleres. 
Drastrup (80.11)

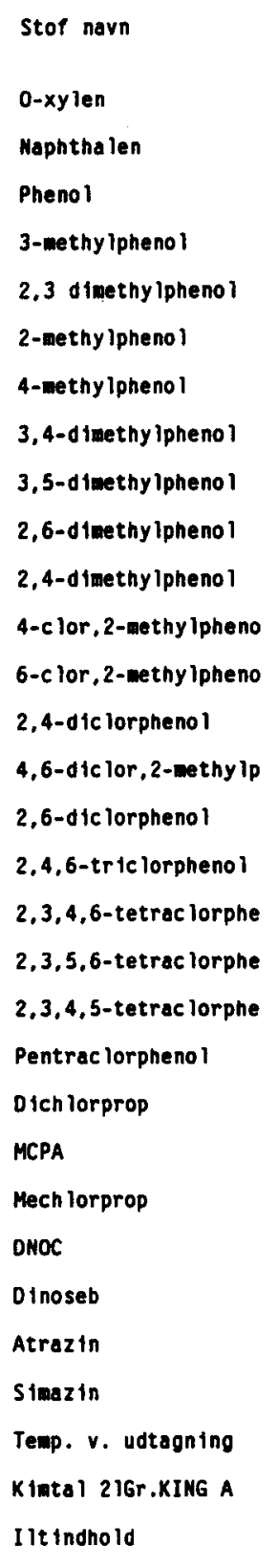

MYGRAM/L

MYGRAM/L

MYGRAM/L

MYGRAM/L

MYGRAM/L

MYGRAM/L

MYGRAM/L

MYGRAM/L

MYGRAM/L

MYGRAM/L

MYGRAM/L

MYGRAM/L

MYGRAM/L

MYGRAM/L

MYGRAM/L

MYGRAM/L

MYGRAM/L

MYGRAM/L

MYGRAM/L

MYGRAM/L

MYGRAM/L

MYGRAM/L

MYGRAM/L

MYGRAM/L

MYGRAM/L

GRADER C

ANTAL/ML

MG/L
Nordjyllands Amt

MYGRAM/L

MYGRAM/L

MYGRAM/L

\begin{tabular}{|c|c|c|c|c|c|}
\hline Antal & Gens & Median & Spredning & Max 1mum & Min inum \\
\hline 8 & . & & & 0.1000 & 0.1000 \\
\hline 8 & & & & 0.1000 & 0.1000 \\
\hline 8 & 0.0405 & 0.0300 & 0.02 & 0.0870 & 0.0300 \\
\hline 8 & & & & 0.0300 & 0.0300 \\
\hline 8 & & & & 0.0300 & 0.0300 \\
\hline 8 & & & & 0.0300 & 0.0300 \\
\hline 8 & & & & 0.0300 & 0.0300 \\
\hline 8 & & & & 0.0300 & 0.0300 \\
\hline 8 & & & & 0.0300 & 0.0300 \\
\hline 8 & & & & 0.0300 & 0.0300 \\
\hline 8 & & & & 0.0300 & 0.0300 \\
\hline 8 & & & & 0.0500 & 0.0500 \\
\hline 8 & & & & 0.0500 & 0.0500 \\
\hline 8 & & & & 0.0300 & 0.0300 \\
\hline 8 & & & & 0.0300 & 0.0300 \\
\hline 8 & & & & 0.0300 & 0.0300 \\
\hline 8 & & & & 0.0100 & 0.0100 \\
\hline 8 & & & & 0.0100 & 0.0100 \\
\hline 8 & & & & 0.0100 & 0.0100 \\
\hline 8 & & & & 0.0100 & 0.0100 \\
\hline 8 & & & & 0.0200 & 0.0200 \\
\hline 8 & & & & 0.0140 & 0.0140 \\
\hline 8 & 0.0103 & 0.0100 & 0.00 & 0.0110 & 0.0100 \\
\hline 8 & & & & 0.0120 & 0.0120 \\
\hline 8 & 0.0124 & 0.0130 & 0.00 & 0.0150 & 0.0100 \\
\hline 8 & & & & 0.0100 & 0.0100 \\
\hline 8 & & & & 0.0100 & 0.0100 \\
\hline 8 & & & & 0.0100 & 0.0100 \\
\hline 88 & 8.6932 & 8.5500 & 1.14 & 14.2000 & 5.6000 \\
\hline 90 & 457.6444 & 125.0000 & 1022.45 & 8000.0000 & 8.0000 \\
\hline 90 & 5.2587 & 5.5500 & 3.26 & 10.4000 & 0.0400 \\
\hline
\end{tabular}




\section{Drastrup (80.11)}

Stof navn

Enned

Kondukt iv itet

MSIEMENS/M

$\mathrm{pH}$

Turbiditet

Tarstof , total

$\mathrm{PH}$

FTU

oxygen Indhold

HG/L

Carbond loxid, aggr.

Hydrogencarbonat

Permanganattal KMnO4

Aumon iaktamen fum

Nitrat

Phosph., tot.f11t P04

Calcium

Chlorid

Fluorto

Jern

Kal ium

Magnesium

Mangan

Natr fum

Sulfat

Methan

MG/L

MG/L

MG/L

MG/L

MG/L

MG/L

MG/L

MG/L

MG/L

MG/L

$M G / L$

MG/L

MG/L

MG/L

MG/L

$M G / L$

MG/L
Nordjyllands Amt

Ante

1

3

6.0462

1.0000

200.8085

0.3750

56.3833

0.1295

0.1111

60.0412

$47 \quad 35.5319$

Antal Gens Median Spredning Maximum Minimum

$61.4000 \cdot 56.0000$

18.98

106.0000

34.0000

$\begin{array}{ll}7.3877 & 7.4500\end{array}$

0.24

7.7500

6.5500

$0.4500 \quad 0.4500$

-

0.4500

0.4500

$370.7692 \quad 360.0000$

116.04

670.0000

190.0000

6.4000

3.35

13.1000

1.0000

0.2000

1.0000

.

1.0000

188.0000

49.07

345.0000

137.0000

20.02

96.0000

0.3000

0.1000

0.83

2.7000

0.0100

55.5000

40.12

182.0000

3.0000

0.0920

0.11

0.4293

0.0307

$47 \quad 94.1064$

87.2000

37.44

214.0000

35.9000

43.1538

34.0000

28.84

119.0000

10.0000

0.1000

0.03

0.2000

0.1000

0.0400

1.93

10.4000

0.0100

1.0000

3.85

23.2000

0.6000

4.8000

2.28

12.2000

2.1000

0.0100

0.07

0.2300

0.0100

14.5000

6.91

38.5000

8.0000

31.0000

23.95

129.0000

7.0000

0.1000

0.00

0.1000

0.1000 
Skerping (80.12)

\begin{tabular}{|c|c|}
\hline Stof navn & Enhed \\
\hline Kondukt ivitet & MSIEMENS/M \\
\hline $\mathrm{pH}$ & PH \\
\hline Inddampn ingsrest & $\mathrm{HG} / \mathrm{L}$ \\
\hline Carbondloxid, aggr. & $M G / L$ \\
\hline Hydrogencarbonat & $M G / L$ \\
\hline Carbon,org, NVOC & $M 6 / L$ \\
\hline Permanganattal KMnO4 & $M G / L$ \\
\hline Cyanid, total & MYGRAM/L \\
\hline Benzen & MYGRAM/L \\
\hline Toluen & MYGRAM/L \\
\hline Anmon lak+akno on fua & MG/L \\
\hline N1trit & MG/L \\
\hline Nitrat & $M G / L$ \\
\hline Phosph., tot.filt PO4 & $M G / L$ \\
\hline Alumintue & MYGRAM/L \\
\hline Arsen & MYGRAM/L \\
\hline Bar tu= & MYGRAM/L \\
\hline Bly & MYGRAM/L \\
\hline Bor & MYGRAM/L \\
\hline Bronld & MYGRAM/L \\
\hline Cadmitur & MYGRAM/L \\
\hline Calc tum & $M G / L$ \\
\hline$C h$ lor, org, AOX & MYGRAM/L \\
\hline Chlor, org, vox & MYGRAM/L \\
\hline Chlorid & $M G / L$ \\
\hline Chron & MYGRAM/L \\
\hline F luor id & $M G / L$ \\
\hline Jern & $M G / L$ \\
\hline Jod & MYGRAH/L \\
\hline Jodid & MYGRAM/L \\
\hline Kaltua & $M G / L$ \\
\hline Kobber & MYGRAM/L \\
\hline Lith tur & MYGRAM/L \\
\hline Magnes fum & $M G / L$ \\
\hline Mangan & $M G / L$ \\
\hline Mo lybdan & MYGRAM/L \\
\hline Matriun & $M G / L$ \\
\hline Nikkel & MYGRAM/L \\
\hline Stront fue & MYGRAM/L \\
\hline Sulfat & $M G / L$ \\
\hline Hyorogensu if 10 & $M G / L$ \\
\hline Methan & $M 6 / L$ \\
\hline Detergenter anion & $M G / L$ \\
\hline Ch loroform & MYGRAM/L \\
\hline Tetrach lorku Istof & MYGRAM/L \\
\hline Tetrach lorethy len & MYGRAM/L \\
\hline Trich lorethylen & MYGRAM/L \\
\hline $1,1,1-\operatorname{tr} 1 \mathrm{ch}$ lorethan & MYGRAM/L \\
\hline P-xylen & MYGRAH/L \\
\hline M-xylen & MYGRAY/L \\
\hline
\end{tabular}

Nordjyllands Amt Grundvandsanalyser, 1990

$\begin{array}{rrrrrrr}\text { Antal } & \text { Gens } & \text { Median } & \text { Spredning } & \text { Maximum } & \text { Minimum } & \\ 48 & 64.2500 & 59.0000 & 33.20 & 160.0000 & 29.0000 & \\ 48 & 7.5490 & 7.5250 & 0.20 & 7.9000 & 7.2000 & \\ 48 & 404.3750 & 345.0000 & 232.39 & 1110.0000 & 170.0000 & \\ 3 & 4.6667 & 5.0000 & 0.58 & 5.0000 & 4.0000 & \\ 48 & 203.3750 & 193.5000 & 78.38 & 474.0000 & 96.0000 & \\ 5 & 1.3480 & 0.9500 & 0.61 & 2.2000 & 0.8600 & \\ 48 & 3.6969 & 3.5500 & 2.15 & 9.5000 & 0.3000 & \\ 5 & & & & 2.0000 & 2.0000 & \text { DG } \\ 5 & & & & 0.3000 & 0.3000 & \text { DG } \\ 5 & 0.1100 & 0.1000 & 0.02 & 0.1500 & 0.1000 & D G \\ 48 & 0.1031 & 0.0730 & 0.09 & 0.2918 & 0.0122 & \text { DG } \\ 48 & 0.0175 & 0.0100 & 0.02 & 0.0900 & 0.0100 & \text { DG } \\ 48 & 0.9375 & 1.0000 & 16.62 & 09.0000 & 1.0000 & \end{array}$

$48 \quad 6.9375 \quad 1.0000$

16.62

69.0000

1.0000

$0.0837 \quad 0.0613$

$2.3600 \quad 1.8000$

0.06

0.2760

0.0307

1.14

4.4000

1.8000

1.2900

0.6000

1.39

3.5000

0.2700

29.3000

36.0000

19.95

51.0000

7.0000

0.1800

0.1800

0.1800

0.1800

$68.2000 \quad 73.0000$

132.8000

150.0000

40.40

108.0000

20.0000

67.73

203.0000

53.0000

0.0136

0.0120

0.00

0.0200

0.0120

82.5354

74.6000

39.96

167.0000

36.5000

$3.8600 \quad 4.4000$

1.93

5.8000

1.0000

0.5000

0.5000

$95.95 \quad 379.0000$

16.0000

0.19

0.6000

0.1000

0.3600

0.3000

0.33

1.7000

0.0300

0.6109

0.5700

0.51

1.6900

0.0100

3.7600

1.8000

3.44

9.6000

1.6000

5.8400

3.5000

4.66

14.0000

3.0000

2.0719

1.4750

1.48

6.7700

0.8500

0.2200

0.2000

0.16

0.5000

0.1000

4.0000

1.92

6.0000

1.0000

12.3333

8.7500

8.20

31.0000

4.0000

0.0300

0.14

0.5100

0.0100

1.9000

1.2000

2.10

5.6000

0.4000

20.1500

20.61

104.0000

10.1000

$$
1.5940
$$

0.3400

2.88

6.7400

0.1500

230.2500

220.5000

101.92

362.0000

118.0000

48.2708

47.0000

26.92

100.0000

7.0000

0.0200

0.01

0.0500

0.0100

0.0180

0.0100

0.01

0.0600

0.0100

0.0100

0.0100

0.00

0.0100

0.0100

0.1000

$0.1000 \quad 0 G$

0.1000

0.1000 DG

0.1000

$0.1000 \quad 06$

0.1000

0.1000 DG

0.1000

0.1000 DG

0.1000

0.1000 DG

0.1000

0.1000 OG 
Skerping (80.12)

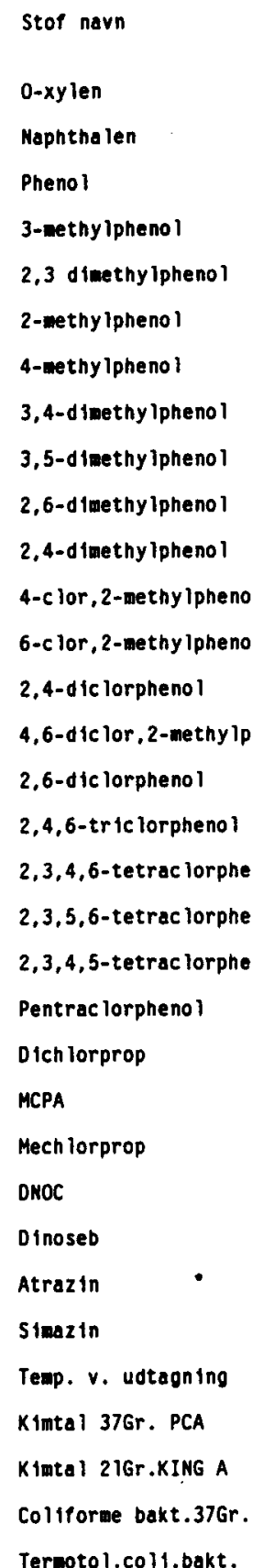

Ilt indhold
Enhed

MYGRAM/L

MYGRAM/L

MYGRAH/L

MYGRAM/L

MYGRAM/L

MYGRAM/L

MYGRAM/L

MYGRAM/L

MYGRAM/L

MYGRAM/L

MYGRAM/L

MYGRAM/L

MYGRAM/L

HYGRAK/L

MYGRAM/L

MYGRAM/L

MYGRAM/L

MYGRAM/L

MYGRAM/L

MYGRAM/L

MYGRAM/L

MYGRAM/L

MYGRAM/L

MYGRAM/L

MYGRAM/L

MYGRAM/L

MYGRAM/L

MYGRAM/L

GRADER C

ANTAL/ML

ANTAL/ML

ANTAL/100 ML

ANTAL/100 ML

MG/L
Nordjyllands Amt

Anta 1

5

5

5

5

5

5

5

\section{5}

5

\section{5}

\section{5}

5

\section{5}

5

5

5

\section{5}

\section{5}

5

\section{5}

5

\section{5}

\section{5}

5

5

5

\section{5}

\section{5}

5

76

$1 \quad 160.0000$

$47 \quad 400.2979$

$1 \quad 160.0000$

$1 \quad 92.0000$

$48 \quad 1.6623$
Grundvandsanalyser, 1990

Maximua Minfmum.

\begin{tabular}{|c|c|}
\hline 0.1000 & 0.1000 \\
\hline 0.1000 & 0.1000 \\
\hline 0.0300 & 0.0300 \\
\hline 0.0300 & 0.0300 \\
\hline 0.0300 & 0.0300 \\
\hline 0.0300 & 0.0300 \\
\hline 0.0300 & 0.0300 \\
\hline 0.0300 & 0.0300 \\
\hline 0.0300 & 0.0300 \\
\hline 0.0300 & 0.0300 \\
\hline 0.0300 & 0.0300 \\
\hline 0.0500 & 0.0500 \\
\hline 0.0500 & 0.0500 \\
\hline 0.0300 & 0.0300 \\
\hline 0.0300 & 0.0300 \\
\hline 0.0300 & 0.0300 \\
\hline 0.0100 & 0.0100 \\
\hline 0.0100 & 0.0100 \\
\hline 0.0100 & 0.0100 \\
\hline 0.0100 & 0.0100 \\
\hline 0.0200 & 0.0200 \\
\hline 0.0120 & 0.0120 \\
\hline 0.0100 & 0.0100 \\
\hline 0.0100 & 0.0100 \\
\hline 0.0100 & 0.0100 \\
\hline 0.0100 & 0.0100 \\
\hline 0.0100 & 0.0100 \\
\hline 0.0100 & 0.0100 \\
\hline 12.5000 & 8.1000 \\
\hline 160.0000 & 160.0000 \\
\hline 000.0000 & 1.0000 \\
\hline 160.0000 & 160.0000 \\
\hline 92.0000 & 92.0000 \\
\hline 11.2000 & 0.0700 \\
\hline
\end{tabular}




\section{Skerping (80.12)}

\begin{tabular}{|c|c|}
\hline Stof navn & Enhed \\
\hline Kondukt ivitet & MSIEMENS/M \\
\hline pH & PH \\
\hline Torstof, total & $M G / L$ \\
\hline Oxygen indhold & $M G / L$ \\
\hline Carbond tox 1d, aggr. & $\mathrm{MG} / \mathrm{L}$ \\
\hline Hydrogencarbonat & MG/L \\
\hline Perwanganatta $1 \mathrm{KMnO4}$ & $M G / L$ \\
\hline Amaon faktaturon fua & MG/L \\
\hline Nitrat & $M G / L$ \\
\hline Phosph..tot.f11t P04 & $M G / L$ \\
\hline Caictum & $M G / L$ \\
\hline Chlorid & $M G / L$ \\
\hline fluor 1d & $M G / L$ \\
\hline Jern & $M G / L$ \\
\hline Kallum & $M G / L$ \\
\hline Magnes tur & $\mathbf{M G} / \mathbf{L}$ \\
\hline Mangan & $M G / L$ \\
\hline Natr fum & MG/L \\
\hline Sulfat & $M G / L$ \\
\hline Trit 1un & T.U. \\
\hline
\end{tabular}

Nordjyllands Amt Grundvandsanalyser, 1989

$\begin{array}{rrrrrr}\text { Antal } & \text { Gens } & \text { Median } & \text { Spredning } & \text { Max 1mun } & \text { Min 1mum } \\ & & & & & \\ 38 & 58.9737 & 50.0000 & 29.00 & 163.0000 & 30.0000 \\ 38 & 7.2711 & 7.3000 & 0.28 & 7.7500 & 6.7000 \\ 29 & 347.9310 & 300.0000 & 171.51 & 980.0000 & 180.0000 \\ 28 & 1.2786 & 0.4500 & 2.17 & 9.7000 & 0.1000 \\ 1 & 1.0000 & 1.0000 & . & 1.0000 & 1.0000 \\ 38 & 191.4211 & 192.0000 & 41.45 & 275.0000 & 94.0000 \\ 37 & 4.1108 & 4.0000 & 2.25 & 11.4000 & 0.3000 \\ 35 & 0.1054 & 0.0800 & 0.06 & 0.2200 & 0.0100 \\ 8 & 25.6250 & 15.0000 & 25.83 & 70.0000 & 4.0000 \\ 21 & 0.0891 & 0.0920 & 0.06 & 0.2146 & 0.0307 \\ 38 & 76.5158 & 68.9000 & 35.95 & 166.8000 & 36.1000 \\ 38 & 65.2368 & 37.0000 & 80.53 & 356.0000 & 16.0000 \\ 16 & 0.5000 & 0.2000 & 0.56 & 1.8000 & 0.1000 \\ 36 & 0.5969 & 0.5550 & 0.53 & 1.8500 & 0.0100 \\ 38 & 1.9342 & 1.3000 & 1.43 & 6.5000 & 0.7000 \\ 38 & 11.8658 & 8.7500 & 7.36 & 30.8000 & 3.9000 \\ 26 & 0.0800 & 0.0200 & 0.13 & 0.4900 & 0.0100 \\ 38 & 24.8026 & 20.6000 & 18.75 & 101.1000 & 9.9000 \\ 38 & 47.3947 & 43.0000 & 26.60 & 106.0000 & 7.0000 \\ 15 & 23.9333 & 26.0000 & 12.71 & 45.0000 & 1.0000\end{array}$


Albæk (80.13)

Stof navn

Kondukt ivitet

pH

Inddaupningsrest

Carbondioxid, aggr. MG/

Hydrogencarbonat MG/L

Carbon,org.NVOC MG/L

Permanganattal KMnO4 MG/L

Cyanid, total

MYGRAM/L

Benzen

Toluen

Alimon laktasison ful

Nitrit

Nitrat

Phosph., tot.filt P04

Aluming iuw

Arsen

Barlun

Bly

Bor

Bromid

Cadmiun

Calc lum

Chlor, org, AOX

Ch lor,org, vox

Chlorid

Chrow

Fluorid

Jern

Jod

Jodid

Karifum

Kobber

Lith fum

Magnestum

Mangan

Molybden

Natr 1un

Mikkel

Strontiue

Sulfat

Hydrogensulf to

Trit fun

Methan

Detergenter anion

Chlorofora

Tetrach lorkulstof

Tetrach lorethylen

Trich lore thy len

1,1,1-trich lorethan

P-xylen
Enhed

MSIENENS/M

PH

MG/L

MYGRAM/L

MYGRAM/L

MG/L

MG/L

$M G / L$

MG/L

MYGRAM/L

MYGRAM/L

MYGRAM/L

MYGRAM/L

MYGRAM/L

MYGRAM/L

MYGRAM/L

$M G / L$

MYGRAM/L

MYGRAM/L

H6/L

MYGRAM/L

MG/L

MG/L

MYGRAH/L

MYGRAM/L

MG/L

MYGRAM/L

MYGRAM/L

MG/L

MG/L

MYGRAM/L

HG/L

MYGRAM/L

MYGRAM/L

MG/L

HG/L

T.U.

MG/L

MG/L

MYGRAM/L

MYGRAM/L

MYGRAM/L

MYGRAM/L

HYGRAM/L

MYGRAM/L
Nordjyllands Amt Grundvandsanalyser, 1990

$\begin{array}{rrrrrrr}\text { Antal } & \text { Gens } & \text { Median } & \text { Spredning } & \text { Maximum } & \text { Mininum } \\ 59 & 47.9153 & 42.0000 & 18.78 & 115.0000 & 23.0000 & \\ 59 & 7.6000 & 7.8500 & 0.63 & 8.2500 & 5.9500 & \\ 59 & 292.0339 & 270.0000 & 109.93 & 640.0000 & 120.0000 & \\ 19 & 15.2632 & 11.0000 & 22.22 & 106.0000 & 4.0000 & \\ 59 & 148.6271 & 92.0000 & 139.87 & 491.0000 & 7.0000 & \\ 5 & 0.7540 & 0.9000 & 0.42 & 1.2000 & 0.1000 & \\ 59 & 0.9688 & 3.2000 & 11.69 & 40.0000 & 0.3000 & \\ 5 & & & & 2.0000 & 2.0000 & 06 \\ 5 & & & & 0.3000 & 0.3000 & 06 \\ 5 & 0.1980 & 0.1500 & 0.13 & 0.4200 & 0.1000 & \\ 59 & 0.6001 & 0.0122 & 1.34 & 4.1341 & 0.0122 & \\ 59 & 0.0154 & 0.0100 & 0.02 & 0.1000 & 0.0100 & 06 \\ 59 & 30.8983 & 27.0000 & 24.75 & 97.0000 & 1.0000 & \end{array}$

0.1533

1.29

5.2125

0.0307

4.7000

6.74

18.0000

1.8000

0.3600

0.63

1.4000

0.0800

23.8000

20.0000

13.48

47.0000

14.0000

0.1800

0.04

0.1800

0.0800

22.8000

20.0000

6.26

34.0000

20.0000

81.0000

36.51

154.0000

62.0000

0.0138

0.0120

0.00

0.0210

0.0120

57.1000

11.1000

4.9400

4.9000

6.6000

3.6000

0.8000

0.5000

0.67

2.0000

0.5000

39.0000

30.06

174.0000

25.0000

0.3000

0.05

0.3000

0.2000

0.1000

0.04

0.3899

0.1000

0.0250

0.81

2.5100

0.0100

1.9000

4.46

12.0000

1.6000

4.5000

3.0000

1.18

5.5500

1.1100

1.4700

0.19

0.7000

0.2000

1.0000

0.00

1.0000

1.0000

10.5000

3.2000

0.2100

0.0100

0.0100

0.06

3.1000

0.1500

0.8500

0.1500

1.28

217.0000

9.2000

0.1500

0.5400

0.1000

0.2600

131.0000

30.34

191.0000

124.0000

32.4576

32.0000

20.77

94.0000

1.0000

0.0226

0.0200

0.01

0.0500

0.0100

21.6000

20.0000

8.06

35.0000

7.0000

6.9949

0.0200

12.89

36.6000

0.0100

0.0100

0.00

0.0100

0.0100

0.1000

0.1000

0.1000

0.1000

0.1000

$0.1000 \quad O G$

0.1000

0.1000 DG

0.1000

0.1000 DG

0.1000

0.1000

DG 


\section{Albæk (80.13)}

\begin{tabular}{|c|c|}
\hline Stof navn & Enhed \\
\hline M-xylen & MYGRAM/L \\
\hline $0-x y$ len & MYGRAM/L \\
\hline Naphthalen & MYGRAM/L \\
\hline Phenol & MYGRAM/L \\
\hline 3-wethy lphenol & MYGRAM/L \\
\hline 2,3 d twe thy lphenol & MYGRAM/L \\
\hline 2-methy lphenol & MYGRAM/L \\
\hline 4-methylphenol & MYGRAM/L \\
\hline 3,4-d diethy iphenol & MYGRAM/L \\
\hline 3,5-dinethylpheno 1 & MYGRAM/L \\
\hline 2,6-diwethy lpheno 1 & MYGRAM/L \\
\hline 2,4-dimethylpheno 1 & MYGRAM/L \\
\hline 4-c lor, 2-methy lpheno & MYGRAM/L \\
\hline 6-clor, 2-Eethylpheno & MYGRAM/L \\
\hline 2,4-dic lorphenol & MYGRAM/L \\
\hline 4,6-dic lor, 2-methylp & MYGRAM/L \\
\hline 2.6-dIc Jorphenol & MYGRAM/L \\
\hline 2,4,6-tric lorphenol & MYGRAM/L \\
\hline 2,3,4,6-tetrac lorphe & MYGRAM/L \\
\hline $2,3,5,6$-tetrac lorphe & MYGRAM/L \\
\hline 2,3,4,5-tetrac lorphe & MYGRAM/L \\
\hline Pentraclorphenol & MYGRAM/L \\
\hline Dich lorprop & MYGRAM/L \\
\hline MCPA & MYGRAM/L \\
\hline Mech lorprop & MYGRAM/L \\
\hline DMOC & MYGRAM/L \\
\hline Dinoseb & MYGRAM/L \\
\hline Atrazin & MYGRAM/L \\
\hline Sinazin & MYGRAM/L \\
\hline Teap. v. udtagning & GRADER C \\
\hline Kintal $376 r$. PCA & ANTAL/ML \\
\hline Kintal 2IGr.KING A & ANTAL/ML \\
\hline Ilt indhold & $M G / L$ \\
\hline
\end{tabular}

Nordjyllands Amt Grundvandsanalyser, 1990

\begin{tabular}{|c|c|c|c|c|c|}
\hline Antal & Gens & Median & Spredning & Maxtmum & Min 1mua \\
\hline 5 & . & & & 0.1000 & 0.1000 \\
\hline 5 & & & & 0.1000 & 0.1000 \\
\hline 5 & & & & 0.1000 & 0.1000 \\
\hline 5 & 0.0440 & 0.0400 & 0.02 & 0.0700 & 0.0300 \\
\hline 5 & & & & 0.0300 & 0.0300 \\
\hline 5 & & & & 0.0300 & 0.0300 \\
\hline 5 & & & & 0.0300 & 0.0300 \\
\hline 5 & & & & 0.0300 & 0.0300 \\
\hline 5 & & & & 0.0300 & 0.0300 \\
\hline 5 & & & & 0.0300 & 0.0300 \\
\hline 5 & & & & 0.0300 & 0.0300 \\
\hline 5 & & & & 0.0300 & 0.0300 \\
\hline 5 & & & & 0.0500 & 0.0500 \\
\hline 5 & & & & 0.0500 & 0.0500 \\
\hline 5 & & & & 0.0300 & 0.0300 \\
\hline 5 & & & & 0.0300 & 0.0300 \\
\hline 5 & & & & 0.0300 & 0.0300 \\
\hline 5 & & & & 0.0100 & 0.0100 \\
\hline 5 & & & & 0.0100 & 0.0100 \\
\hline 5 & & & & 0.0100 & 0.0100 \\
\hline 5 & & & & 0.0100 & 0.0100 \\
\hline 5 & & & & 0.0200 & 0.0200 \\
\hline 5 & & & & 0.0130 & 0.0130 \\
\hline 5 & & & & 0.0100 & 0.0100 \\
\hline 5 & & & & 0.0110 & 0.0110 \\
\hline 5 & & & & 0.0100 & 0.0100 \\
\hline 5 & & & & 0.0100 & 0.0100 \\
\hline 5 & & & & 0.0100 & 0.0100 \\
\hline 5 & & & & 0.0100 & 0.0100 \\
\hline 55 & 8.3855 & 8.2000 & 0.84 & 13.1000 & 7.7000 \\
\hline 3 & 38.6667 & 5.0000 & 61.81 & 110.0000 & 1.0000 \\
\hline 59 & 649.3220 & 250.0000 & 1778.26 & 12000.000 & 2.0000 \\
\hline 59 & 7.2044 & 7.6000 & 4.12 & 15.5000 & 0.0800 \\
\hline
\end{tabular}




\section{Albæk (80.13)}

Stof navn

Enhed

Kondukt ivitet

pH

Terstof, total

Oxygen indhold

Carbondtoxid, aggr.

Hydrogencarbonat

Permanganattal KMnO4

Amson faktamon fum

Nitrat

Phosph., tot.filt P04

Calcium

chlorid

Fluortd

Jern

Kallum

Magnesfun

Mangan

Natriun

Sulfat

Trit lum

Methan
MSIEMENS/M

PH

MG/L

$M 6 / L$

MG/L

MG/L

MG/L

MG/L

$M G / L$

$M G / L$

MG/L

MG/L

MG/L

MG/L

MG/L

MG/L

MG/L

MG/L

$M G / L$

T.U.

$M G / L$
Nordjyllands Amt Grundvandsanalyser, 1989

$\begin{array}{rrrrrr}\text { Anta1 } & \text { Gens } & \text { Median } & \text { Spredning } & \text { Maximum } & \text { Min1mun } \\ 31 & 46.6065 & 41.0000 & 17.71 & 102.0000 & 21.0000 \\ 31 & 7.4055 & 7.6500 & 0.60 & 8.0500 & 5.9500 \\ 17 & 270.0000 & 260.0000 & 89.02 & 560.0000 & 130.0000 \\ 17 & 9.3706 & 10.3000 & 2.95 & 14.0000 & 0.2000 \\ 7 & 1.4286 & 1.0000 & 1.13 & 4.0000 & 1.0000 \\ 28 & 124.0000 & 94.0000 & 115.63 & 416.0000 & 6.0000 \\ 27 & 7.2519 & 2.8000 & 11.84 & 47.0000 & 0.6000 \\ 12 & 1.0408 & 0.0500 & 1.49 & 3.3000 & 0.0100 \\ 27 & 38.7407 & 39.0000 & 23.26 & 98.0000 & 4.0000 \\ 15 & 0.4190 & 0.1226 & 1.16 & 4.5993 & 0.0613 \\ 28 & 42.6893 & 44.0000 & 10.88 & 57.5000 & 11.6000 \\ 31 & 44.3548 & 37.0000 & 28.70 & 148.0000 & 18.0000 \\ 11 & 0.1636 & 0.2000 & 0.07 & 0.3000 & 0.1000 \\ 25 & 0.2516 & 0.0300 & 0.56 & 2.1600 & 0.0100 \\ 28 & 2.2071 & 1.5000 & 1.27 & 4.9000 & 1.1000 \\ 28 & 7.0607 & 6.7000 & 1.79 & 11.3000 & 3.7000 \\ 16 & 0.0638 & 0.0250 & 0.07 & 0.2600 & 0.0100 \\ 28 & 39.3250 & 20.2000 & 49.16 & 193.0000 & 12.0000 \\ 28 & 33.0357 & 36.0000 & 17.39 & 86.0000 & 2.0000 \\ 3 & 40.0000 & 38.0000 & 3.46 & 44.0000 & 38.0000 \\ 8 & 11.9000 & 9.5000 & 12.71 & 28.9000 & 0.1000\end{array}$


Gislum (80.14)

Stor nayn

Kondukt ivitet

MSIEMENS/M

pH

Inddaupn ingsrest

Hydrogencarbonat

MG/L

Carbon, org. HYOC

MG/L

Permanganattal KMnO4

Cyanid, total

MG/L

Benzen

Toluen

Ameon taktacon 1ut

Nitrit

Nitrat

Phosph., tot.f11t P04

A lumintum

Arsen

Bortum

Bly

Bor

Bromido

Cadintum

Calc tum

Chlor, org, AOX

Chlor, org, vox

Chlorid

Chrow

Fluorid

Jern

Jod

Jodid

Kalium

Kobber

Lithium

Magnes tum

Mangan

Mo lybden

Matrium

Nikkel

stront fum

Sulfat

Hydrogensulf id

Methan

Detergenter anton

$\mathrm{Ch}$ loroform

Tetrach lorku lstof

Tetrach lorethylen

Trich lorethylen

1,1,1-trichlorethan

P-xylen

M-xylen

o-xylen

M6/L

MYGRAM/L

MYGRAM/L

MG/L

HYGRAM/L

MG/L

MG/L

MYGRAM/L

MYGRAM/L

MG/L

MYGRAM/L

MYGRAM/L

MG/L

MG/L

MYGRAM/L

MG/L

MYGRAM/L

MYGRAM/L

MG/L

MG/L

MG/L

MG/L

MYGRAM/L

MYGRAM/L

IYGRAM/L

MTGRAM/L

MYGRAM/L
Nordjyllands Amt Grundvandsanalyser, 1990

\begin{tabular}{|c|c|c|c|c|c|c|}
\hline Anta 1 & Gens & Median & Spredning & Max imum & Minimum & \\
\hline 29 & 60.2759 & 61.0000 & 10.16 & 84.0000 & 34.0000 & \\
\hline 29 & 7.6207 & 7.6500 & 0.17 & 7.9500 & 7.2000 & \\
\hline 26 & 402.3077 & 420.0000 & 81.50 & 550.0000 & 200.0000 & \\
\hline 26 & 257.2308 & 148.5000 & 44.05 & 276.0000 & 112.0000 & \\
\hline 4 & 30.0300 & 0.8600 & 58.65 & 118.0000 & 0.4000 & \\
\hline 26 & 3.0750 & 3.5000 & 1.23 & 5.4000 & 0.3200 & \\
\hline 4 & 2.0000 & 2.0000 & 0.00 & 2.0000 & 2.0000 & \\
\hline 4 & & & & 0.3000 & 0.3000 & OG \\
\hline 4 & 0.3075 & 0.2750 & 0.13 & 0.4900 & 0.1900 & \\
\hline 26 & 0.0444 & 0.0122 & 0.08 & 0.2797 & 0.0122 & \\
\hline 26 & 0.0104 & 0.0100 & 0.00 & 0.0200 & 0.0100 & DG \\
\hline 29 & 86.4138 & 98.0000 & 48.61 & 149.0000 & 1.0000 & \\
\hline 26 & 0.2760 & 0.2453 & 0.11 & 0.6439 & 0.1840 & \\
\hline 4 & 2.1750 & 1.9000 & 0.62 & 3.1000 & 1.8000 & \\
\hline 4 & 1.3375 & 1.1000 & 0.80 & 2.5000 & 0.6500 & \\
\hline 4 & 41.0000 & 38.5000 & 8.04 & 52.0000 & 35.0000 & \\
\hline 4 & 0.4700 & 0.1800 & 0.58 & 1.3400 & 0.1800 & \\
\hline 4 & 44.7500 & 22.0000 & 46.87 & 115.0000 & 20.0000 & \\
\hline 4 & 80.5000 & 80.5000 & 29.13 & 111.0000 & 50.0000 & \\
\hline 4 & 0.0665 & 0.0155 & 0.10 & 0.2230 & 0.0120 & $D G$ \\
\hline
\end{tabular}

MYGRAM/L

MYGRAM/L

87.5577

90.9000

22.88

128.0000

23.7000

4.2250

4.9000

2.00

5.8000

1.3000

0.5000

0.5000

35.1154

32.5000

10.70

66.0000

19.0000

0.8250

0.9000

0.39

1.2000

0.3000

0.1042

0.1000

0.02

0.1700

0.1000

0.0856

0.0100

0.19

0.6300

0.0100

2.8500

2.4000

1.56

5.0000

1.6000

6.6500

6.1000

2.36

9.8000

4.6000

2.0919

1.2950

2.16

8.1700

0.7500

1.4000

1.4000

1.21

2.7000

0.1000

2.5000

2.5000

1.73

4.0000

1.0000

6.0923

6.4500

1.55

8.7000

2.3000

0.0318

0.0100

0.04

0.1400

0.0100

0.9250

0.9500

0.57

1.6000

0.2000

20.6962

18.9500

7.25

44.7000

14.6000

0.6825

0.6650

0.25

1.0000

0.4000

254.2500

231.0000

66.67

352.0000

203.0000

13.21

68.0000

10.0000

0.0100

0.0100

0.00

0.0100

0.0100

0.0100

0.0100

0.00

0.0100

0.0100

0.0150

0.0150

0.0200

$0.0100 \quad D G$

$0.1000 \quad 0.1000 \quad 06$

$0.1000 \quad 0.1000 \quad 06$

$0.1000 \quad 0.1000 \quad D G$

$0.1000 \quad 0.1000 \quad 06$

$\begin{array}{lll}0.1000 & 0.1000 \quad 06\end{array}$

$0.1000 \quad 0.1000 \quad 06$

$0.1000 \quad 0.1000 \quad 06$

$0.1000 \quad 0.1000 \quad 06$ 
Gislum (80.14)

Stof navn

Enhed

Naphthalen

Phenol

3-methylphenol

2,3 diwethylpheno 1

2-wethylphenol

4-methylpheno

3,4-dine thy ipheno ?

3,5-dinethylphenol

2,6-dimethylphenol

2,4-dine thy lphenol

4-c lor, 2-methy lpheno

6-clor, 2-wethy lpheno

2,4-diclorphenol

4,6-dic lor. 2-methy ip

2,6-diclorphenol

2,4,6-trtc lorphenol

2,3,4,6-tetrac lorphe

2,3,5,6-tetraclorphe

2,3,4,5-tetrac lorphe

Pentrac lorphenol

D1ch lorprop

MCPA

Mech lorprop

DHOC

Dinoseb

Atraz in

Simaz in

Temp. v. udtagning

Kintal 37Gr. PCA

Kimtal $21 \mathrm{Gr}$.KING A

It indhold
MYGRAN/L

MYGRAM/L

MYGRAM/L

MYGRAM/L

MYGRAM/L

MYGRAM/L

MYGRAM/L

MYGRAM/L

MYGRAM/L

MYGRAM/L

MYGRAM/L

MYGRAM/L

MYGRAM/L

MYGRAM/L

MYGRAM/L

MYGRAM/L

MYGRAM/L

MYGRAM/L

MYGRAM/L

MYGRAM/L

MYGRAM/L

MYGRAM/L

MYGRAM/L

MYGRAM/L

MYGRAM/L

MYGRAM/L

MYGRAM/L

GRAOER C

ANTAL/ML

ANTAL/ML

$M G / L$
Nordjyllands Amt

Grundvandsanalyser, 1990

4

4

4

4

4

4

4

4

4

4

4

4

4

4

4

4

4

4

4

4

4

4

4

4

4

4

4

4

4

40

3

28

26
Gens

Median

Spredning

Maximu:

0.1000

0.0300

0.0300

0.0300

0.0300

0.0300

0.0300

0.0300

0.0300

0.0300

0.0500

0.0500

0.0300

0.0300

0.0300

0.0100

0.0100

0.0100

0.0100

0.0200

0.0150

0.0110

0.0130

0.0100

0.0100

0.0100

0.0100

11.4000

7.0000

3.6667

8.5500

0.68

3.0000

214.1786

175.0000

8.1938

10.2500

3.06

850.0000

4.02

11.5000
Min inum

$0.1000 \quad 06$

$0.0300 \quad D G$

$0.0300 \quad D G$

$0.0300 \quad O G$

0.0300 DG

0.0300 DG

$0.0300 \quad D G$

$0.0300 \quad D G$

$0.0300 \quad D G$

0.0300 DG

$0.0500 \quad D G$

$0.0500 \quad O G$

$0.0300 \quad D G$

$0.0300 \quad D G$

0.0300 DG

$0.0100 \quad D G$

$0.0100 \quad D G$

$0.0100 \quad D G$

0.0100 DG

$0.0200 \quad D G$

0.0150 DG

$0.0110 \quad D G$

$0.0130 \quad D G$

$0.0100 \quad 0 G$

$0.0100 \quad D G$

$0.0100 \quad D G$

$0.0100 \quad O G$

7.8000

$1.0000 \quad D G$

$1.0000 \quad D G$

0.2000 DG 
Gislum (80.14)

\begin{tabular}{|c|c|}
\hline Stof navn & Enhed \\
\hline Kondukt ivitet & MSIEMENS/M \\
\hline pH & PH \\
\hline Torstof, total & $M G / L$ \\
\hline Oxygen indhold & $M G / L$ \\
\hline Carbond tox 1d, aggr. & $M G / L$ \\
\hline Hydrogencarbonat & $M G / L$ \\
\hline Permanganatta $1 \mathrm{KMnO4}$ & $M G / L$ \\
\hline Almon tak tocmon fum & $M G / L$ \\
\hline Nitrat & $M G / L$ \\
\hline Phosph..tot.f11t PO4 & $M G / L$ \\
\hline Calcium & MG/L \\
\hline Chlor 1d & $M 6 / L$ \\
\hline F luor $1 d$ & $M G / L$ \\
\hline Jern & $M G / L$ \\
\hline Kal1un & $M G / L$ \\
\hline Magnes 1ua & $M G / L$ \\
\hline Mangan & $M G / L$ \\
\hline Natriun & $M G / L$ \\
\hline Sulfat & $M G / L$ \\
\hline Hydrogensu if Id & M6/L \\
\hline Tritfun & T.U. \\
\hline
\end{tabular}

Nordjyllands Amt Grundvandsanalyser, 1989

$\begin{array}{rrrrrr}\text { Antal } & \text { Gens } & \text { Median } & \text { Spredning } & \text { Maximum } & \text { Mintmum } \\ 31 & 60.5000 & 61.0000 & 12.45 & 93.0000 & 34.0000 \\ 30 & 7.5650 & 7.5750 & 0.16 & 7.8500 & 7.1500 \\ 21 & 379.5238 & 390.0000 & 83.99 & 520.0000 & 200.0000 \\ 20 & 9.8050 & 10.8500 & 6.84 & 33.0000 & 0.1000 \\ 3 & 4.0000 & 2.0000 & 4.36 & 9.0000 & 1.0000 \\ 20 & 152.9500 & 143.0000 & 39.01 & 246.0000 & 103.0000 \\ 18 & 4.4722 & 4.0500 & 2.63 & 10.1000 & 0.6000 \\ 4 & 0.1875 & 0.2100 & 0.07 & 0.2400 & 0.0900 \\ 26 & 101.5385 & 108.0000 & 25.46 & 144.0000 & 33.0000 \\ 21 & 0.3008 & 0.2760 & 0.13 & 0.6439 & 0.0920 \\ 22 & 82.9364 & 89.0000 & 22.82 & 117.0000 & 27.2000 \\ 30 & 33.4667 & 32.5000 & 6.56 & 51.0000 & 21.0000 \\ 2 & 0.1000 & 0.1000 & 0.00 & 0.1000 & 0.1000 \\ 21 & 0.4848 & 0.0300 & 1.81 & 8.3700 & 0.0100 \\ 22 & 2.0136 & 1.4500 & 1.61 & 6.8000 & 0.6000 \\ 22 & 5.7591 & 6.0000 & 1.58 & 8.2000 & 2.6000 \\ 7 & 0.0657 & 0.0900 & 0.05 & 0.1400 & 0.0100 \\ 22 & 20.6591 & 18.8000 & 6.93 & 44.7000 & 13.9000 \\ 22 & 43.0909 & 39.5000 & 29.93 & 165.0000 & 12.0000 \\ 1 & 10.0000 & 10.0000 & . & 10.0000 & 10.0000 \\ 10 & 22.8000 & 22.0000 & 7.47 & 35.0000 & 12.0000\end{array}$


Denne rapport indeholder den første samlede præsentation af de 67 grundvands-overvågningsområder i Danmark. Det vises i hvilket omfang områderne repræsenterer de varierende geologiske, hydrogeologiske og geokemiske forhold især i landbrugsområderne. Den lokale detaljerede viden om bl.a. forurenende stoffer, der herigennem er skabt, kan ses i sammenhæng med problemerne for udnyttelsen af grundvandet. Kemiske analyser danner grundlaget for at vurdere både den naturlige sammensæetning af grundvandet og den af mennesker skabte påvirkning. Resultaterne af disse analyser fra overvågningsområderne er, som det fremgår af de vedføjede eksempler, meget omfattende. Der foreslås derfor etableret et klassifikationssystem, der både giver overblik over variationerne i grundvandets sammensætning og hvor sårbart det er for forurening.

This report includes the first complete presentation of the 67 groundwater monitoring areas in Denmark. The areas are described to give an overwiew over, to what degree they represent the varying geological, hydrogeological and hydrochemical conditions particularly in the agricultural areas. The detailed local knowledge about a.o. pollutants, which is hereby established, may be considered in conjunction with the presented actual problems for the utilisation of groundwater.

The basis for evaluation of both the natural and the human influence on constituents in the groundwater is chemical analyses. The analyses from the monitoring areas are so numerous that a well defined classification of "groundwater types« is needed. Such af classification is suggested and the data are exemplified. 